


Digitized by the Internet Archive in 2007 with funding from Microsoft Corporation 

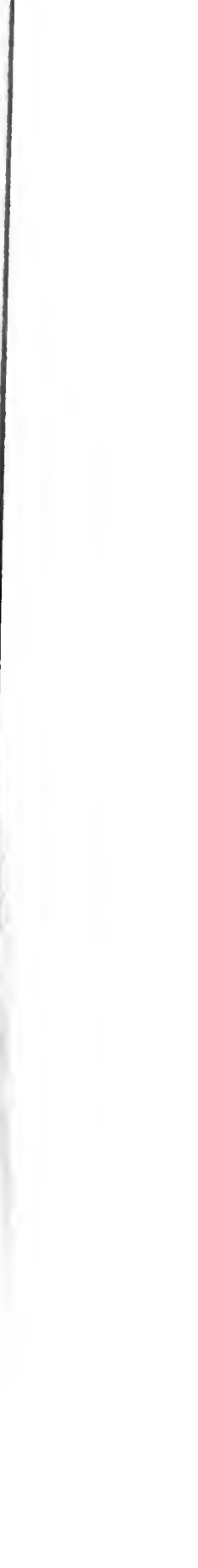

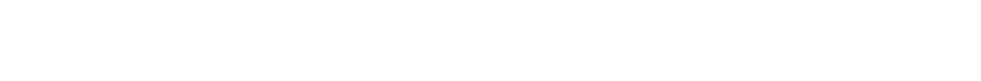

(1) 



\section{Law

ON THE LAW OF

\section{9}

\section{MASTER \\ AND \\ SERVANT}

INCLUIING THEREIN

\section{MASTERS ANJ) WORKMEN}

IN EVERY DESCRIPTION OF TRADE AND OCCUPATION;

Whith an Appendiz of Statuteg.

\section{BY}

\section{CHARLES MANLEY SMITH, EsQ.,}

OF THE INNER TEMPLE, BARRISTER-AT-LAW, ONE OF THE MASTERS OF THE SUPREME COURT OF JUDICATURF.

"Masters, give unto your servants that which is just and equal, knowing that ye aiso have a Master in Heaven." $-\mathrm{Col}$. iv, 1.

"Servants, obey in all things your masters according to the flesh; not with eye-service, as men pleasers; but in singleness of heart, fearing (rop."-Col. iil, 22.

"Servi sunt, imo hominco: servi sunt, imo contubernales: servi sunt, imo humiles amici: cervi sunt, imo conservi." -Senec. Ep. xivii.

From the Fourth Englisb EDition.

PHILADELPHIA:

THE BLACKSTONE I'UBLISHING COMPANY.

1886. 
Entered according to the acts of Congress, in the year 1856, BY THE BLACKSTONE PUBLISHING COMPANY, In the office of the Librarian of Congress at Washington, D. C. 


\section{PREFACE}

TO THE FOURTH EDITION.

In this Edition (in which a larger type than was used on former occasions has been adopted) the Cases and Statutes have been brought down to the end of 1884 . The increased size of the Work is accounted for by the fact that, in addition to the numerous decisions of courts of Law and Equity upon subjects discussed in the following pages which have taken place, a great number of Statutes bearing upon the Law of Master and Servant have been passed since the last Edition of this Work was published, most of which it is absoIutely necessary to print in extenso to render the Work complete. These Statutes are adverted to in the Introduction as well as discussed in the body of the Work: It is to be regretted, however, that nothing appears to have been done by the Legislature towards consolidating the Statute Law relating to Masters and Servants $(a)$. Great care has been taken in the preparation of this Edition, (in which the Author has been assisted by his son, Ernest Manley Smith, M. A., of the Inner Temple and Midland Circuit, Barristerat-law,) and it is believed that no Statute or Case of importance has been omitted.

Faster Term, 1885.

(a) See further on this subject, post, p. Ixiii. 



\section{PREFACE}

TO THE FIRST EDITION.

There are so few persons not interested in the law applicable to the relationship of Master and Servant, either in one capacity or the other, that the publication of a Treatise upon that subject may seem to most people to require but little apology. With professional men, however, the case is somewhat different. They have been so long accustomed, when any question of law arising out of the relationship of Master and Servant has been brought before them, to refer, if necessary, to works of general application, such as treatises on contracts, agency, or criminal law, or to digests, indices, and abridgments; that they may perhaps hardly have felt the want of a separate Work upon the Law of Master and Servant. But it is conceived that even professional men may be more truly said to have become used to the want of such a Work, than not to have felt it. It is, at least, to the existence of a strong impression upon the mind of the Author that such was the case, and that a Book exclusively devoted to the subject he has attempted to elucidate was wanted, combined with a desire on his part to supply what he considered a deficiency in the list of legal publications, that the present Work owes its origin. In it he has attempted to concentrate all $(a)$ that information upon the subject treated of which has hitherto been diffused through many books. How far he has succeeded in his object it is not for himself to determine. Whilst, however, on the one hand, he is well aware that many defects may, and not improbably will, be discovered in the following Work, on the other hand, he ventures to express his hopes that it will not be found altogether useless, even to the members of his own Profession; who, he trusts, will receive it with that indulgence which they are ever wont to accord to the efforts of their younger brethren. And if it shall be found by experience that the Author has so far succeeded in his undertaking as to have acted the part of a pioneer only upon a path hitherto, if not altogether untrodden, at least but imperfectly explored, he will be sufficiently compensated for his labours by the reflection that his leisure hours, which the present abnormal condition of his Profession has rendered more than usually numerous, have not been altogether misspent, whilst devoted to the preparation of this Work.

MIIDDLE TEMPLe,

Trinity Term, 1852.

(a) A Chapter on the Law of Settlement by Hiring and Service was partially prepared, but the addition of it would necessarily add much both to the size and price of this Volume. Upon further refleetion, therefore, the Author has determined to omit it, and this, the rather, as the suhject daily decreases in importance, and questions upon it now seldom arise. See post, p. 1, n. (b). 



\section{CONTENTS.}

[The paging refere to the [*] pages.]

trable of Cases Citen,

PAGE. xiii

Table of Statutes Citen, . . . . . . . . . . . . . . . . . . . . xli

Alphatetical Table, sirowing the various Statetes applica Hee To WORKMEN, \&C., iN PARTICUlar TraDES, \&C., UNDER MANY OF WIICH JURISDICTION IS GIVES TO MAGISTRATES, . . . . . xlvii

Intronuction, ..................... . . . . li

\section{CHAPTER I.}

The Parties to tile Contract-who may contract tie RelationShIP of Master anil Servant, . . . . . . . . . . . . . . 1-36

Generally,. . . . . . . . . . . . . . . . . . . . . 1

Married Women, . . . . . . . . . . . . . . . . 4

Infants, . . . . . . . . . . . . . . . . . . . . . . . . . 11

Lunatics, . . . . . . . . . . . . . . . . . . . . . . . . 15

Partners, . . . . . . . . . . . . . . . . . 16

Corporations, . . . . . . . . . . . . . . . . . 22

Bankrupts and Insolvents, . . . . . . . . . . . . . . 35

\section{CHAPTER II.}

The Contract of fliring ani Service, . . . . . . . . . . . . $37-1: 29$

1. The Requisites of the Contract.

When Writing necessary-Statute of Frauds, . . . . . . . :

The Stamp, . . . . . . . . . . . . . . . . . . . 49

2. The Interpretation of the Contract.

Admissibility of Parol Evidence, . . . . . . . . . . . . . 54

The Relationship created by the Contract.

Partner or Servant, . . . . . . . . . . . . . 59

Apprentice or Servant, . . . . . . . . . . . . 78

Tenant or Servant. . . . . . . . . . . . . . . 30

General Hiring-Yearly Hiring, \&e., . . . . . . . . . . 84

How far Master bound to find work for Servant, . . . . . . . 98

Agreements in restraint of Trade contained in Contracts in

Hiring and Service, . . . . . . . . . . . . . 103 
[The paging refers to the [*] pages.]

\section{CHAPTER III.}

The Duties of the Servaxt to The MASTER, AND THE Rights AND REMEDIES OF THE MASTER TO ENFORCE THE PERFORMANCE OF THEM,

1. As between the Master and Servant, . . . . . . . . . . . . 130

Duties of Servant to Master, and actions by Master against Servant for breach thereof, . . . . . . . . . . . . 131

Chastisement of Serrant, . . . . . . . . . . . . . . . . 133

Discharge of Servant-what causes will justify his Discharge. 139

2. As between the Master and Third Persons, . . . . . . . . . . . 15\%

Of the action for enticing away a Servant, . . . . . . . . 156

harboring a Servant after notice, . . . . . 160

by a Master for the earnings of a Serrant, . . . 161

personal injuries to a Servant, . 170

Of the common action for Seduction, . . . . . . . . 174

\section{CHAPTER IV.}

The Duties of the Master to the Servaxt, AxD the Rights aND REMEDIES OF THE SERVANT TO ENFORCE THE PERFORMANCE OF THEXr,

Of the Master's duty to receive the Servant into his serrice and retain him, and the Servant's remedies for breach of such duties, . 18:

Remedies for Servant wrongfully discharged, . . . . . . . . . . 1es

Of the Master's duty to pay the Serrant's wages, and the Servant's remedies to recover then-Master's Default, . . . . . . . . 197

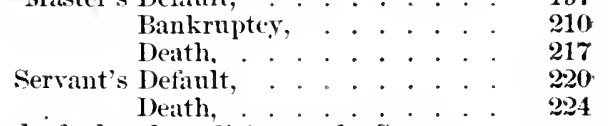

Of the Master's duty to supply food and medicine to the ServantStatutes 14 \& 15 Vict. e. $11 ; 24 \& 25$ Vict. c. 100 , s. 26, . . . .

of the Master's duty to indemnify the Serrant from the consequences of obeying his orders: and herein of the Master's liability for injuries to Servant, .............

\section{CHAPTER $Y$.}

THE Liability of A MASTER to THIRI PERSOA FOR THE ACTS OF hIS SerVant, . . . . . . . . . . . . . . 271-38?

In cases of Contract, . . . . . . . . . . . . . . . . . . . . . 271

Tort-Criminaliter, .306

Civiliter, . . . . . . . . . . 30?

\section{CHAPTER VI.}

The Liability of a Servant to Thiro Persoxs for Acts done ox BEHALF OF HIS MASTER, . . . . . . . . . . . . . . . . . 32:?-425

In cases of Contract,

Tort-Criminaliter. Civiliter, . . . . . . . . . . . . . . . 415 
[The paging refers to the [*] pages.]

CHAPTER VII.

The Servant's Character, . . . $426^{\text {Page. }}$

The Character-Defamation, . . . . . . . . . . . . . 426

False and Forged Characters-Statute 32 Geo. 3, c. 56, . . . . . . 467

CHAPTER VIII.

OfFences by Servants Against their Masters, . . . . . . .471-541

Murder of Master by Servant, . . . . . . . . . . . . . . . . . 471

Assault on Master by Servant, . . . . . . . . . . . . . . . . 472

Burglary by Servant in Master's House, . . . . . . . . . . . . 472

Servant negligently firing Master's House, . . . . . . . . . . . 474

Stealing in a Shop, Warehouse or Counting-house, . . . . . . . . 475

Stealing in a Dwelling-house to the value of $51 .$, . . . . . . . . . 476

Stealing Goods in process of Manufacture, . . . . . . . . . . . . . 478

Destroying Goods in process of Manufieture, . . . . . . . . . . . 478

Larceny and Embezzlement by Clerks and Servants, . . . . . . . 479

Who is a Clerk or Servant, . . . . . . . . . . . . . . . . 502

What is a Reeeipt on aecount of his Master, . . . . . . . . . 511

What is an Embezzlement, . . . . . . . . . . . . . . . 519

Indietment, . . . . . . . . . . . . . . . . . . 526

Falsification of Aecounts, . . . . . . . . . . . . . . . . . . . 531

Offenees by Publie Servants or Police, . . . . . . . . . . . . . . . . . $\quad 532$

Embezzlement of Officers of the Bank of England or Ireland, . . $\quad 534$

Offenees by Servants in the Post Office, . . . . . . . . . . . . 535

Clerks of Courts uttering false Copies or Certificates of Reeords, . . 541

CHAPTER IX.

JURISDICTION OF JUSTICES IN DISPUTES BETWEEN MASTER AND SER-

VANTS, . . . . . . . . . . . . . . . . . .542-555

Generally, . . . . . . . . . . . . . . . . . . . 542

Arbitration of Disputes between Masters and Workmen, . . . . : 544

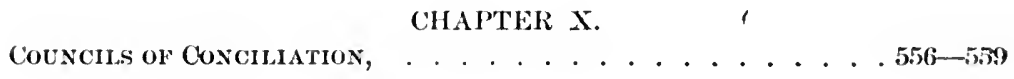

CHAPTER XI.

Combination amongst Masters and Workmen, . . . . . . . 560-564

The Conspiraey and Protection of Property Act, 1875, . . . . . . 560

CHAL'TER XII.

LeqaCins to Servants, . . . . . . . . . . . . 565-578 


\section{APPENDIX.}

[The paging refers to the [*] pages.]

CONTAINING THE FOLLOWING STATUTES.

22 Geo. 2, c. 27, . . . . . . . . . . . . . . . . . . . . . . . . 579

17 Geo. 3 , c. 56 , . . . . . . . . . . . . 588

(32 Geo. 3, e. 56, will be found at p. 468.)

The Schedule to 5 Geo. 4, c. 96 , . . . . . . . . . . . . . . . . . 600

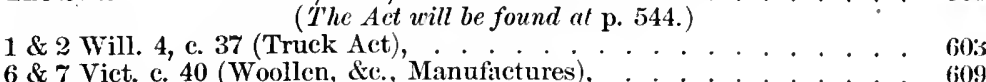

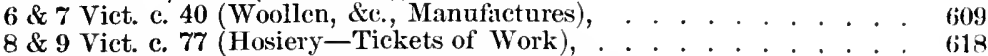

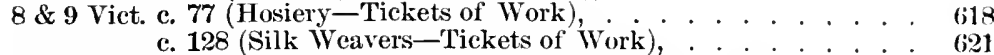

14 \& 15 Vict. c. 11 (Protection of Young Servants), . . . . . . . . . . . $\quad 623$

$24 \& 25$ Vict. c. 100, ss. 26, 73, 77 (Food to Young Servants, \&c.), . . . $\quad 623$

26 \& 27 Vict. c. 103 (Misappropriation by Servants), . . . . . . . . . .625

30 \& 31 Vict. c. 105 (Councils of Conciliation), . . . . . . . . . . . . 627

(The Aet will be found at p.556.)

c. 130 (Agricultural Gangs), . . . . . . . . . . . . . . 630

32 \& 33 Vict. c. 14 (Taxes on Male Servants), . . . . . . . . . . . . 632

$33 \& 34$ Vict. c. 30 (Wages Attachment Abolition Act), . . . . . . . . . . . $\quad$ 6i33

34 \& 35 Vict. c. 31 (The Trade Union Act, 1871), . . . . . . . . . . . . $\quad 634$

$35 \& 36$ Vict. c. 46 (Arbitration (Masters and Workmen) Act, 1872), . . 553

c. 61 (Factories (Steam Whistles) Act), . . . . . . . . . 641

c. 76 (The Coal Hines Regulation Act, $1 \times \gamma 2)$, . . . . . . 641

c. 77 (The Metalliferous Mines Regulation Act, 1872), . . $\quad$ 673

$37 \& 38$ Vict. c. 48 (Hosiery Manufacture (Wages) Act, 1874), . . . . . 689

38 \& 39 Vict. c. 39 (The Metalliferous Mines Regulation Act, 187\%, Amendment Act), . . . . . . . . . . . . . . 690

c. 86 (The Conspiracy and Protection of Property Act, 1975, (691

c. 90 (The Employers and Workmen Act, $1 \times 7 \%$ ). . . . . . 698 Rules therennder, . . . . . . . . . . . 704

39 \& 40 Vict. c. 22 (Trade Union Act Amendment Act, 1876), . . . . . . 715

$41 \& 42$ Vict. c. 16 (The Factory and Workshop Act, 1878), . . . . . . 718

$42 \& 43$ Vict. c. 34 (The Children's Dangerous Performances Act, 1879 ), 762

43 \& 44 Vict. c. 42 (The Employers Liability Act, 1880), . . . . . . . 763

County Court Rules thereunder, . . . . . . . . . . . 766

45 Vict. c. 2 (Slate Mines Gunpowder Act, 1882), . . . . . . . . . . . . . 770

$46 \& 47$ Vict. c. 31 (Payment of Wages in Pnblic Houses Prohibition A $A \cdot$, 1883), . . . . . . 771

c. 53 (The Factory and Workshop Act, 1883), . . . . . . . . 772 


\section{TABLE OF CASES.}

A.

Abbott v. Bates v. Hendricks v. M'Fie

Albotts $v$. Barry

Aliraham $v$. Reynolds

Abraliat's case

A eey $v$. Fernie

Acland $x$. Buller

Adamison $r$. Jervis

Addison $v$. Gandessequi $r$. Mayor of Preston.

Agar v. Athenaeum Life Assurance Co.

Aggs $v$. Nicholson

Aishcombe $r$. Hundred of Snelholme

Alkro v. Agawam Camal Co. $244,245,251 ;, 268$ ข. Jaquith . $240,244,268$

Alderson 1: Maddison . . . 20:2, 565 Aldridge $r$. Great Western Railway Co. 49,324 $v$ Johnson 482

Alexander $\%$. Gibson . . . . 283, 284

— ฯ. Mackenzie . . . . . 298 $v$ Sizer 391

- $r$ Sonthey . . . . 419, 420

Alfred $v$. Fitzjames . . . . . . 197

Allan v. Barelay . . . . . . . . 171

Allen v. Dnnstone . . . . . . . . 286

— $v$. Hayward . . . . 354, 378, 380

- $v$. London and Sonth Western Railway Co.

v. New Gas Co.

- $v$. Rawson

v. Taylor

$12: 3$

Allsopp $v$. Wheateroft . . . 116, 117

Alsop w. Yates . . . . . . . 2(30, 261

Alton $v$. Midland Railway Co. $17 \%, 416$

Anıann $v$. Damm . . . . . 45:2, 458

American, The . . . . . . . 355

Amor v. Fearon . . . . 140, 141, 146

Ancona $v$. Marks . . . . . . . . 274

Andrews $v$. Askey . . . . . . . 181

$\longrightarrow$. Garstin . . . . . 141

— v. Pngli . . . . . . . 67

Angus $r$ Dalton . . . . . . . . . 3\%
Annapolis, The . . . . . . . 36:

Applebee $v$. Percy . . . . . 27,324

A ppleby $v$. Dods . . . . . . . 221

- v. Myers . . . . . . . . 227

Appleton $v$. Binks . . . . . . . . . 389

Araminta, The . . . . . . . . 199

Archard $\varepsilon$. Horner . . . . . 188, 196

Archer $v$. James . . . . . . 205, 603

- $v$ Marsh . . . . . . . 46, 119

Alkwright's ease . . . . . . . . 464

Arlington (Lord) $x$. Merrick . . 19

Armitage $r$. Insoles . . . . . . 19:

Armory ‘. Delamire . . . . . . 324

Armstrong $r$ Lancashire and

Torkshire Ratilway Co. . . . 348

Arnold r. llamel . . . . . 379

r. Mayor of Poole. . . . 22

Ashby $v$. White . . . . . . . . 423

Ashersmitl $r$. Drury . . . . 604,605

Ashley $r$. Harrison . . . . . 156, 464

Ashworth $r$. Stanwix . . . . 17, 258

Aspdin r. Austin . . . . . . 99, 100

Association of Iancl Financiers,

Re..........216

Assop) r. Yates . . . . . 2(00, 261

Aste r. Montague . . . . . . . 305

Astley r. Weldon . . . . . . 13I

Atcheson r. Everitt . . . . . . . 31:2

Athenaem Life Assurance Co., Re . . . 32, 27!

-v. Pooley . . 33

Atkin r. Acton . . . . . 143, 22\%

Atkins $v$. Banwell . . . . . . . 2:3:3

Atkinson $r$. Denlyy

$r$. Newcastle, Se., Wuter

Co. . . . . . . . . . . :30, 245

Atkyns $x$ Kinnier . . . . 114, 123

1. Pearee . 301

Atlas, The . . . . . . 361, 366

Atlee 4 Batcklouse . . . 1:37, :39:, :396

Attorney-General $v$. Allen . . . 31:3 $v$. Bowman $31 \%$

r. Gaskill . . :

v. Le Marelant $: 31 \%$ v. Riallofr . . $31 \%$ r. Ridale. . . 314

[\%xiv] Attwood r. Munnings 272,298 
[The paging refers to the [*] pages.]

Atwood $v$. FaGnest

Austen $v$. Manchester, \&c., Railway Company

Austin $v$. Board of Guardians of St. Mattlew, Bethnal Green

Avery v. Bowden

Ayre $r$. Craven

B.

Backhouse $r$. Hall

Bailey, Re . . . . . 45, 101, 543 r. Macaulay

Baillie $v$. Sell . .

Baines $v$ Swainson $143,150,200,203$

Baker, Ex parte 544

- $v$. Carter . . . . . . 662, 663

Bakewell's case . . . . . . . . 535

Baldwin $v$. Casella . . . . . . . . 324

Balfour $\boldsymbol{v}$. Ernest . . . . . . . 298

Ball, Ex parte . . . . . . . . . 217

Bamfield $r$. Massey . . . . 179, 180

Bamford $r$. Shuttleworth . . . . 394

Bank of Ireland $v$. Trustees of Evans' Charities . 330, 331

-New South Wales $v$. Owston 2\%,

328, 342

-_United States $v$. Dunn . . 303

Banks v. Crossland . . . . . . . 42

Barber v. Dennis . . . . . 158, 163

- v. Gingell . . . . . . . 280

Baring $v$. Corrie . . . . . . . . 2 26

Barker $v$, Parker . . . . . . . . 218

$v$. Stead . . . . . . . . 302

Barnes $v$. Akroyd . . . . . . . 309

Barnett $v$. Lambert . . . . . . 293,302

Barnsley $v$. Taylor . . . . 188, 195

Baron $x$. Husband . . . . . 136, 402

Barret $v$. Blagrave . . . . . . . 128

Barrett $v$ : Deare . . . . . 280,512

Barrow $v$. Arnaud . . . . . . 424

Barry $v$. Arnaud . . . . . . . . 424

— v. Croskey . . . . . . . . . 329

-v. Nesham ....... . 72

Bartlet $v$. Baker . . . . . . . . 357

Bartley $v$. Richtmyer . . 174, 175, 176

Barton's Hill Coal Co. r. M'Guire 251

253

v. Reid 236, 251, 252, 258,

Barwick $v$ : Buba . 261, 262, 263

- $r$. English Joint Stock

Bank . . . 283, 294, 327, 329, 330
PAGE 482,519

Bate $v$. Hill . . . . . . . . . . . 179

Bateman $r$. Mayor of Ashtonunder-Lyne . . . . . . . . . 33

Bathe $i$. Bank of England . . . 10

Bather $r$. Day . . . . . . . . . 324

Batterbury $r$. Vyse . . . . . . 204

Baxter v. Burfield . . . . . . . 218

_. Earl of Portsmouth . . 16

—. Gray . : . . . . . . . 203 r. Nurse . . . 58, 85, 86,90

Bayley r. Ashton . . . . . . 272

r. Manchester, Sheffield \&

Lincolnshire Railway

Co. . . . 328, 33\%, 369

ı. Rimmell . . . . . . . 85

r. Wilkins . . . . . . . 234

Bayliffe $r$. Butterworth . . . . . 234

Baylis $r$. Lawrence . . . . . . . . 450

Bazeley's case . . . . . . . . . 498

Beale $v$. Thompson . . . . . . . . 221

Bealey $v$. Stuart . . . . . . . . 44

Beard $r$. Webh .. . . . . . . 4, 12

Beaulieu r. Fiuglanı . . . . . . 324

Bearau r. M'Donnell . . . . . . 16

Beattie $r$. Ebury (Lord) . . . . 392

Becher $v$. Great Eastern Railway

Co. . . . . . . . . . 172

Beckham r. Drake 35, 36, 37, 175, 188 ,

$$
190,194
$$

Beddall $v$. Maitland $\cdot \cdot \cdot \cdot 59$

Bedford $r$. Bagshawe . . . . . . . . . 421

- $r$. M'kowl . . . . . . . 181

Beeching $r$. Westbrook . . . . . 50

Beeston $r$. Collyer . . . 41, 85, 91, 92

Bell v. Carey . . . . . . . . . . 36 $r$. Drummond . . . . . . 198 r. Hyde 8

Benjamin $x$. Porteous. . . . 60, 74

Bennet $r$. Deacon . . . . . . . 451

$\imath$. Moita . . . 362

Bennett $r$. Alcot . . . 1 4 , iz6, 178

- $v$. Bayes . . . . . . . 415

-

- $r$. P. \& O. Steam Co. . . 328

- Whitehouse . . . . . 309

Bent $v$. Baker . . . . . . . . . 13;

Benwell $\imath$ Inns . . . . . . 117, 127

Benyon $v$. Grieve . . . . . . . .574

Berringer $r$. Great Eastern Railway Co. . . . . . . . . . 172, 416

Berry $v$. Da Costa . . . . . 174, 181

Berthold $t$. Goldsmith . . . . . 70

Bertie $v$. Beaumont . . . . . . 80

Berwick $v$. Horsfall

19 
[The paging refers to the [*] pages.]

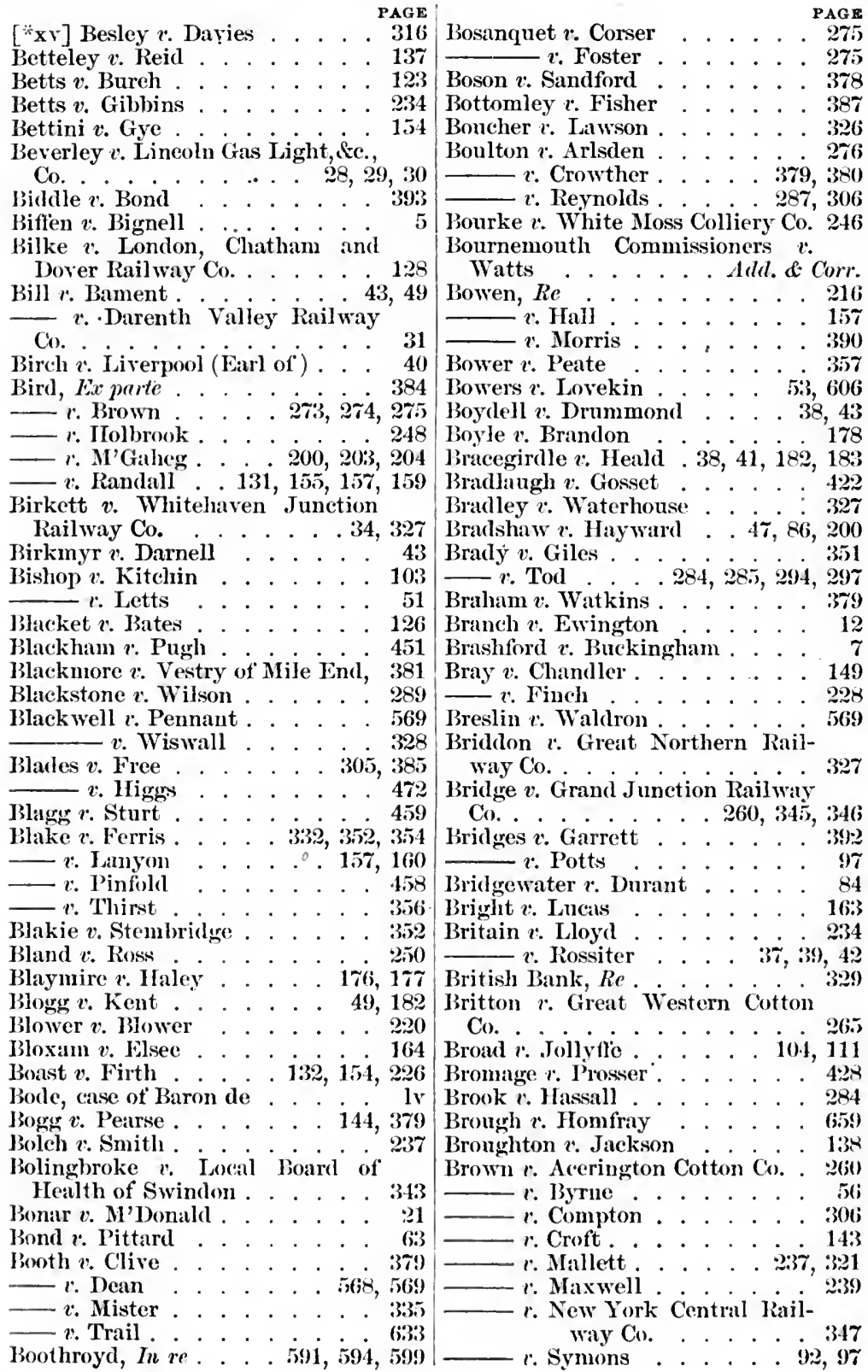


[The paging refers to the [*] pages.]

Brown $v$. Wilkinson ${ }^{*}$ xvi] Browning $v$. Great Centra

Mining Co.

Broxham v. Wagstaffe . . . . 85

Brunsden v. Humphrey ... . . . . 371

Bryant $t$. Flight .. . . . . . . 203

Brydon 2 . Stewart . . . . . . . 263

Bryson $r$. Whitehead . . . . 121, 122

Buckland $v$. Johnson . . . . . . . 159

Buckley $v$. Collier Ex parte

- $v$. Wood

Bull's case,

Buller $v$. Harrison . . . 396, 400, 401

Bnlling $v$ Ellice . . . . . 567

Bnllock $v$. Jenkins . . . . . . . . 179

Bnnker $v$. Midland Railway Co. 235, 763

Bunn v. Guy

117

Burbidge $v$. Morris . . . . . . . 302

Burehall $v$. Hickisson . . . . . 237

Burdick $v$. Garriek . . . . . . . 530

Burgess $v$. Beaumont . . . . . . . 143

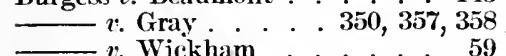

Burling $v$. Harley . . . . . . . . . 379

Burnard $v$. Aaron . . . . . . . 17

Burns v. Poulson . . . . . . . . 341

Burnside $v$. Dayrell

302

Buron $v$. Denman . 274, 378, 415, 422

Burrell $v$. Jones . . . . . . . 383, 389

Burton $r$. Great Northern Railway Co. v. Le Gras

100

306

Bush $v$. Beavan

379

379

$v$. Martin

317,350

Butcher $v$. South-Western Railway

Co.

Butler $v$. Basing . . . . . . . . 326

v. Hunter . . . . . . 356

$r$. Wigge

Butt $\imath$. Great Western Railway Co. 325

Butterfield $v$. Forester . 260, 345, 346

Button $v$. Thompson . . . . 223, 228

Buxton $v$. Rust . . . . . . . . 43

Byrne, Ex parte . . . . . . . 392

\section{C.}

Cahill v. Dawson

Caine $v$. Horsfall .

Calder $v$. Dobell

385 Chatfield
PAGE

Callo v. Brouncker|. 140, 141, 143, 144

Calye's case . . . . . . . . . . 359

Cameron $v$. Reynolds . . . . . 423

Campbell $x$. Campbell . . . . 135

v. Hall . . . . . . . 395

Candler $v$. Candler . . . . . . 69

Capes v. Hutton . . . . . . . 12

Capp v. Kemp . . . . . . . . . 357

Capron v. Balmond . . . . . . . 180

Carden $v$. The General Cemetery

Co. . . . . . . . . . . 25

Carnes $v$. Nisbitt . . . . . . . . . 128

Carpenter $\imath$ Wall . . . . . . . 181

Carr $v$. Clarke . . . . . . . . 178

Co. Laneashire, \&c., Railway

Carrol $u$. Birrl . . . . . . . . 426

Carsan $v$. Watts . . . . . . . 162

Carter $v$. Cooper . . . . . . . . 467

v. Drysdale . . . . . . 765

- $v$. Hall . . . . . . . 3, 199

Cartmell's case . . . . . . . . . 301

Cartwright $v$. Hateley . . . . 136

Cary v. Cary . . . . . . . . 576

— v. Mathews . . . . . . 26

— $v$. Webster . . . . 324, 396, 400

Cast Plate Glass Manufacturers $\boldsymbol{r}$. Neredith

Caswell $r$. Worth $263,265,266,345$

Caton $v$. Caton . . . . . . . . . 48

Cattell v. Ireson . . . . . . . . 312

Catterall $v$. Kenyon . . . 420, 421

Cave $v$. Hastings . . . . . . . . . 43

Cavenagh $v$. Such . . . . . 327,416

Cawthorn $t$. Cordrey . . . . . 38, 42

Center $v$. Finney . . . . . . . . . 345

Central Diseount Co. $v$ Glegg . . 123

Chamberlain v. Hazlewood $\cdot 172,176$

Chanberline $v$. Harvey . . . . . 155

Chambers v. Bernaseoni . . . . . 290

Champion $v$. Bostwick $\cdot . \cdot . \quad 175,181$

Chancey's case . . . . . . . . . . . 574

Chandler $v$. Broughton . . . . . 370

Chapleo $v$. Brunswick Benefit Building Society . . . . . 329, 392

Chaplin $v$. North-lWestern Railway

Co. . . . . . . . . . . 186

Chappell $v$. Bray . . . . . . . . 304

r. Poles . . . . . . . 398

Chapple $v$. Cooper . . . . . . . 12

Charles $v$. Blackwell . . . . 279, 385 $v$. Taylor . . . . . . . 255

Chartered Bank of India $v$. Rich .132

Chater $v$. Beckett . . . . . . . 47

52 
[The paging refers to the [*] pages.]

Chawner $x$. Cummings . 205, 603, 608 [*xvii] Cheap v. Cramond

Cheesman $r$ Exall ... 136, 13 7,393

Cherry $v$. Bank of Australasia, . 392

- $v$. Heming . . . . 38, 41

Chesman $i$. Nainby . . 111, 112, 122

Chicago and Eastern Railway Co. v. Flaxman

Chilcot $v$. Bromley . 323, 350, 566, 567

Child $v$. Affleck . . . . 429, 439, 460

Childers $v$. Wouler . . . . . . 234

Chilton $v$. London and Croydon

Railway Co. . . . . . 327, 328

Chinn $v$. Bullen.... .208

Chinnock $v$. Sainsbury . . 132, 185

Chipchase's case . . . . . . . . 482

Chippendall $v$. Tomlinson . . . 35

Chowne $x$. Baylis . . . . . . . 530

Christiana, The . . . . . 364

Chuck, Ex parte . . . . . . . 71

Cluarch $v$. Imperial Gas Co. . . . 30

Churchward $v$. Chambers . . . 34, 142

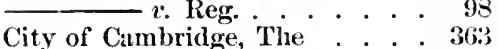

Clark $x$. Chambers. . . . . . 339

- $\bullet$ Inperial Gas Light, \&e, Co.

MLolynenx . . . . . 428

— shee . . . . . . 397

Clarke ¿. Allatt . . . 182, 183

$\longrightarrow$. Bury St. EInunds . 84

$-r$. Cucktield Union . . . 29

—. Earnshiaw . . . . . 360

$r$ Lord Rivers . . . . . 389

r. Midland Railway Co. . 327

— $v$. Roe. Watkins . . . . . . 193, 127

C. Watson . . . . . 204

Clarkson $r$ Edge . . . . . . . . 127

$-x$. Musrrave \& $\cdot 965$

Clayards $x$. Dethick 345, 3\%4, 3\%8, 3\%9

Claygate v. Bachelor . . 104, 109, 111

Cleaver $v$. Sarrande . . . . . . 450

Clegg $v$. Laffer . . . . . . . . 461

Clemson $r$. Ifubbard . . . . . . 699

Clerk $v$. Lanrie . . . . . . . . 8

C Tailors of Exeter : . . 103

Cleveland $x$. Spiers. . . . . . 247

Cleworth r. Pickford . . . . . . 209

Clifford $v$. Laton . . . . . . . . 6

Clutterbuck $x$. Coflin . . . . . . 3, 199

Colb $\approx$. Becke . . . . . . 136

Cock $r$. Worthan . . . . . 172, 179

Cockayne $v$. Hodgkinson . . . . 450

Cockerell r. Anicompte . . . . . 273

Cocking r. Ward

273

Coe $r$. Platt
PAGR

Coc $v$. Wise . . . . . . 381

Colbarn $x$ Patmorc . . . 135, 310

Cole $v$. North Western Bank . 288

Coleman $x$. Riches . . . 283, 329, 344

Coles $v$. Barrow . . . . . . . . 35

C. Wright . . . . 396, 415

Colgate $i$. Bachelor . . . . . 109, 111

Collen $x$ Wright . . . . . . . 392

Collett $\therefore$ Foster . . . . 323, 352

Co. $v$. North-lWestern Iitilway

Co. . . . . . . 416

Collier, $R e$. . . . . . . . . . 101

Collinet, Ex parte . . . . . . . 214

Collins $x$. Blantern . . . . . 47, 531

$-r$ Brook . . . . . . . . 393

- $v$ Evans . . . . . . . 234

— $v$ Locke . . . . . 103, 117

—. Price . . . . . . 188

Colmer $v$. Clarke. . . . . . . . 112

Colvin $x$. Holbrook . . . . . . . . 393

Colyer, Esc parte . . . . . . 213, 214

- $v$. Mayne . . . . . . . 179

Commissioners of Works $v$ Angus, 35:2

Connors $v$. Jnstice _. . 143, 463

Conservators of River Thames $x$. IIall . . . . . . . . . 365

Conway $v$ Belfust and Northern Counties Railway Co. . . 25i, 766

Conybeare $r$. New Brunswick and

Canada Railway and Land Co. $\quad 329$

Cooch $v$. Goodman . . . . . . . 41

Cook v. Bell . . . . . . . . . . 260

— $x$. Duncan . . . . . . 261

- $x$. Wriglit . . . . . . 387

Cooke $v$. Calcraft . . . . . . . 122

- $x$. Paxton . . . . . . . 91

- $v$. Tonkin . . . . . . 302

- $r$. Wildes. . . . 42\%, 43\%, 442

-r. Wilson . . . . . 389

Coombs e. Briştol and Exeter Rail-

waty Co. . . . . . . . . . . 289

Coon $v$. Syracuse and Utiea Railroad Co. . . . . . . . . . . 239

Cooper, Ex parte . . . . . . . . 608

- $r$ Phillips . . . . . . 23:2

$\checkmark$ Shepherd . . . . . 159

- $r$ Simnons. . . . 12, 218

- $r$ Wellington $* .306,311$

- Whitehonse . 194, 200,206

Cope $v$ Doherty . . . . . . . 325

$r$ Rowlands . . . . . . $\$ 6$

$v$. Thames Haven Dock, Se.,

Corby $v$. Hill

265 Core $v$. James . . . . . . . 315

(15) 
[The paging refers to the [*] pages.]

Corking $v$. Jarrard . PAGE

Cormick $v$. Digby . . . . . . . 341

[*xviii] Cornfoot $x$. Fowke . 282, 294 ,

Cornforth $v$. Danube \& Black Sea

Railway Co. .

Cornwall's case $\quad \cdots \cdot \cdot \quad \cdot \quad 51$

Cornwall $v$. Hawkins . . . . 125, 126

Cotes $v$. Sadler . . . . . . . . . . . . 131

Cotton $v$. Wood

Couch $v$. Steel . . 230, 245, 423

Countess of Plymouth r. Throgmorton . . . . . 218 Rutland's case 50 Salop $v$. Crompton : 133

Cowan $v$. Milbourn

Coward, $R e$

$-v$. Wellington.

Cowles $v$. Potts . 438, $45 \dot{4}, 45 \overline{5}, 456$

Cowley $v$. Mayor of Sunderland . 27

$\operatorname{Cox} v$. Feeney

- v. Great Western Railway Co. $v$ Hickman . . . . 62,75

- $v$. Midland Counties Railway Co. . . . . . 34, 282, 290 $v$ Prentice . . 401

Coxhead $x$. Richards . . . . . 451

Cranch $v$. White . . . . . . . . 418

Crane $v$. Powell . . . . . . . 42, 43

Crawfoot, Ex parte . . . 211, 214

Crawshay $v$. Thornton . . . . 136

Cripps $v$. Judge . . . . . . . . . 763

Crisp $v$. Bunbury . . . . . . . . 544

Crispin $x$. Babbett . . . . . . . 257

Critchley, Ex parte. . . .. . . . 531

Croaker $v$. Chicago and North-

Western Railway Co. . . . . 328

Crocker $v$. Molyneux . . . . . . . 189

Croft $v$. Alison . . . . . . 335, 339

Crofton $v$. Poole . . . . . . . . . 36

Crofts $r$. Waterhouse . . . 323, 327

Crookewit $v$. Fletcher . . . . 184

Crosby $v$. Leng . . . . . 173, 530

Cross, Ex parte . . . . . . . . 543

Crosskey $v$. Mills . . . . . . . 137

Crouch's case . . . . . . . lvi

Crouch $v$. Great Western Railway Co. $v$. London and North-West-

ern Railway Co. . . . . . . 327

Crow's case . . . . . . . . . 515

Cuckson $v$. Stones . . . . . . 153, 192

Cullen $v$. Morris . . . . . . . 424

— $v$. Thompson . . . . . . 421

Cuming $v$. Hill . . . . . . . 12

Cunningham $v$. Fonblanque $.86,143$
Curtis $v$ Williamson

Curtis 0 . Wis 140

Cuthbert $x$. Cumming . . . 56

Cuthbertson $r$. Parsons . . . . . 353

Cutler $v$. Dixon . . . . . . . . 444

Cutter $v$. Powell . 188, 196, 219, 221,

Cutts $v$. Ward . . . . . . 205, 608

Czech $v$. General Steam Navigation Co. . . . . . . . . . . 338

D.

Dain $x$. Wycoff $\quad$. . . 174, 176, 181

Dalyell $r$. Tyrer . . . . . 351, 416

Dansey $v$. Richardson . . . . 360, 361

Danube and Black Sea Railway, \&c., Co. $r$. Xenos . . . . . 183

Darlow $v$. Edwards . . . . . . 572

Dartmouth, Mayor of, $v$. Silly . . 20

Dangars $x$. Rivaz . . . . . . 185

Davey $r$. Shamnon . . . . . 38, 40

Davidson $x$. Stanley . . . . . 301

Davies $v$. Berwick . . . . . . . 701

- $v$. Davies 197

- $v$. England . . . . . . 264

- $v$. Harrey . . . . . . 316

— Mann . . . . . . 346

$v$. Snead . . . . . . . . 451

—. Vernon . . . . 398, 418

- v. Williams . . 173, 178, 180

Davis $x$. Clarke . . . . . . . . 386

— $v$. Curling . . . . . . 379

- $r$. Jones . . . . . . . 54

—. Marshall . . . . . 91

- $v$ Mason . . . . . . 112

$v$. Yest . . . . . . 594, 595

$r$ Reeres . . . . . 452

$v$ Williams

Dawkins $v$. Lord Rokeby . . 444, 458

— $v$. Paulet . . . . 444, 458

Day $v$. Bream . . . . . . . . . 419

- $v$. Robinson . . . . . . . 461

Dean \& Gilbert's claim, $R e$. . 217

-v. Branthwaite . . . . . 350

- $v$. Hogg ....... . 351

Debenham $v$. Mellon . . . . . . 5

Degg $r$. Midland Railway Co. 247, 248

249

Delaney $v$. Fox . . . . . . . . 83

De Mattos v. Gibson . . . . . . 126

De Medina $v$. Norman $: 192$

Dendy $v$. Henderson . . 116, 118, 119

Dennis $v$. Tovell . . . . . . 362, 414 
[The paging refers to the [*] pages.]

\begin{tabular}{|c|c|c|}
\hline & & \\
\hline Cenny $v$. Cabot . . & ... . & Dudley and West Bromwich Lank \\
\hline Deslandes $v$. Gregory & . 291 & $v$. Spittle . . . . . . . \\
\hline Je Wahl $x$. Braune & . 4 & Duel $v$. Harding \\
\hline Dickinson $v$. Fletcher & . 659 & Dugdale $r$. Lovering . \\
\hline Jickson $v$. Cooper. & 60 & Duignan $x$. Walker \\
\hline Vilton & 455 & Duke $v$. Littleboy \\
\hline$-v$. Hilliar & 455 & Duke of Beaufort $r$. Necld . \\
\hline triclisen $v$. Cabburn & 126 & — Devonshire $x$. Latforest . . 304 \\
\hline & and Black- & — Norfolk $\imath$. Worthy . . 393, 394 \\
\hline & . . . 22, 34 & Duncan $x$. Findlater . . \\
\hline & . 283 & Dunkley $v$. Ferris . \\
\hline ldie $r$. Bailey & 530 & Dunn $v$. Murray . \\
\hline Blackburn & 163 & — $v$. Sales. \\
\hline ond. & . . $17: 176$ & Dunne $v$. Anderson. . \\
\hline .171 & $1,172,173,181$ & Dunsford $r$ Ridgwick . \\
\hline & & Dunston $v$. Imperial Gas Light, \&e. \\
\hline lond & 136 & Durell $v$. Pritchiard \\
\hline is. & 439 & Durrell $c$. Evans . \\
\hline$v$. Rankin . & 262 & Dutton $v$. Marsh . \\
\hline iter's Te & graph Co. 3: & 293 \\
\hline $\begin{array}{l}\text { obbin } v \text {. Foster . . } \\
\text { obson } v \text {. Collis . }\end{array}$ & $\begin{array}{l}.18,19,207 \\
. \quad .38,40\end{array}$ & Dynen $v$. Leach \\
\hline
\end{tabular}

Jodd $x$. Norris . . . . . 17i, iz9, 180

Doe $v$. Baytup . . . . . . . . . 83

— $v$. Hirehmore . . . . . . 83

- $v$. Bold . . . . . . . . . . 26

- $v$. Glover . . . . . . . 544

- $v$. Gollwin . . . . . . . 274

- $x$.Jones . . . . . . . . 80

— $v$. I'Kaeg . . . . . . . . 80

- $v$. Pierce . . . . . . . 26

— $\imath$ Walters ....... $2 \pi 4$

— $v$. Willis ........ . 185

Doel $v$. Sheppard . . . . . . . . 265

Donaldson $c$. Williams . . 16, 17, 140

Donnell $r$. Bennett . . . . . 126, 182

Donnellan $v$. Read . . . . . . . 41

boogood $r$. Rose . . . . . . . . 192

Doswell $v$. Inıpey . . . . . 423, 424

Doughty $r$. Firbank . . . . . . 764

Douglas $r$. Watson . . . . . . . 12

Dowell $v$. General Steam Naviga-

tion $\mathrm{Co}$.

346

Eades $\imath$. Vandeput . . . . 163

Eager $v$. Grim wool 155, 173, 174, 178,

180

Earl of Auckland, The . . . 362, 364

— Hardwicke $v$. Vernon . . 530

- Stamford $v$. Dawson . . . 422

Earle $x$. Roweroft . . . . . . 344

East Anglian Railway Co. $v$. Lyth-

goe . . . . 145, 146, 187, 208

Easterbrook $v$. Barker . . . 301

East London Waterworks Co. $v$.

Bailey . . . . . . . . 34

Lastern Counties Railway Co. $v$.

Broom . . 26, 327, 328, 369

Eastmead $r$ Witt . . . . 442

Down $v$. Pinto . . . . . . . 91 Laton $v$. Basker........ 24

Dowman $r$. Williams . . 282, 329, 389, $\longrightarrow$. Swansea Waterworks . 306

Doyley $v$. Roberts . ... . . . . 463 Merrall . . . . . . . . . 26

Drike $x$. leekham . . . . . . 206 Elden $r$ Read . . . . . . . 394

Drury $v$. Drury . . . . . . . . 12 Eden, Ex partc . . . . . . 12

Iry $v$. Boswell . . . . . . . 70,74 Elgell $v$ Day . . . . . . . 394

T. Davy . . . . . . 20 Edmond's case . . . . . 474

Juberley $r$ Gunning . . . . 174 Elmondson $v$. Fachell . 173, 174, 175

Dublin and Wicklow Railway Co. r. Stevenson . . . 429

$v$. Black . . . . . 12 Edward $v$. Trevellick . . . . 138

v. Slattery . . . . . 346 Edwards $v$. Holding . . . . 399

B MAS. \& SER.

(17) 
[The paging refers to the [*] pages.]

Edwards $v$. London \& North-Western Railway Co. . . 342 r. Lowndes . . . . . . 379 $v$. Midland Railway Co. 27 , 327,344

Elborough $v$. Ayres . . 155

Elderton $v$. Emmens 84, 100, 188, 190,

Eley $v$. The Positive, \&c., Assurance Co. . . . . . 23, 24, 40

Ellen $v$. Topp . . . . . . . . . 13

Elliot v. Clayton . . . . . . . . 36

Elliott $v$. Nicklin . . . . . 174, 180

[* $\mathrm{xx}$ ] Ellis $x$. Sheffield Gas Co, . 356

- $v$. South-Western Railway Co.

Ellwood v. Liverpool Victoria Legal Friendly Society . . . . 164

Elves v. Croft . . . . . . . . . 120

Emden v. Carte . . . . . . . . 35,36

Emerson v. Blonden . . . . . . 271

Emery v. Day . . . . . . . . 33

Energy, The ....... . . 348

Engell $v$. Fitch . . . . . . . . 392

English and Scottish Marine Insurance Co., Re

Ernest v. Nicholls . . . . 16, 32, 279

Erskine v. Adeane . . . . . . . 38

Estcourt v. Estcourt Hop Co. . . 128

Etherington $v$. Parrott . . . . . 6

Evans v. Birch . . . . . . . . . 137

— v. Harper . . . . . . . 22

— v. Lady Mostyn . . . . 654, 676

- v. Roe ...... . . . 56,90

- v. Walter . . . . . . . 159

- v. Walton $155,156,158,159,171$,

F.

Fairlie v. Hastings . . . . . 289

Fairman $v$. Ives . . . . . . 457 v. Oakford

Farebrother $v$. Ansley

Farmer $v$. Joseph .. . . . . . . .

Farrant $v$. Barnes . . . . . . . 416

Farrar v. Close . . . . . . . . . . 107

$v$. Justices of Bradford, . 107

Farren $v$. Lancashire and Yorkshire Railway Co. . . . . . . 328

Farrow $v$. Wilson . . . . . . . 218

Farwell $v$. Boston and Worcester

Railroad Corporation . . . 239, 244

Faulkner $v$. Erie Railway Co. . . 239
Faviell v. Eastern Connties Rail-

way Co. . . . . . . . . . 25

Fawcett $v$. Bearres . . . . . 160 $r$. Cash . . . . . 84, 92

Feather $v$. Reg. . . . . . . . . 415

Fell $v$. Knight . . . . . . . . . 319

Feltham $v$. England . . . . 255, 257

Fenn $v$. Harrison . 283, 284, 294, 297

Fenton $v$. City of Dublin Steam

Packet Co. . . . . 328, 351

v. Emblers . . . . . . 41

Ferguson $v$. Carrington . . . . . 275

Fewings $v$. Tisdal . . . 188, 194, 196

Field $v$. Lelean . . . . . . . . 56

Filleul $v$. Armstrongr . . . . . . 146

Filliter $v$. Phippard . . . . 324, 474

Finlay $x$. Bristol and Exeter Rail-

way Co. . . . . . . . . . 26

Finucane $v$. Small . . . . . . . 359

Fischer $v$. Aide . . . . . . . . . . . 140

Fisher $v$. Jones . . . . . . . . 605

-v. Marsh . . . . . . . . 384

Fishmongers' Co. $v$. Robertson . 29

Fitzgerald $v$. Dressler . . . . 273

Fitzherbert $v$. Mather . . . . . 276

Flemington $v$. Smithers . . . . 171

Flemyng $v$. Hector . . . . . 273, 299

Fletcher $v$. Krell . . . . . . . . 37

Florence, The . . . . . . . . 199

Flower $v$. Bradley . . . . . . . 363

Foley $v$. Parry . . . . . . . . . $\mathbf{5 7 6}$

Foord $v$. Morley . . . . . . . . 197

Forbes $v$. Cochrane . . . . . . . . 161

- $v$. Lce Conservancy Board 381

r. Marshall . . . . . . . 279

Fores $v$. Wilson . . . . 158, 174, 175

Forgan $x$. Burke . . . . . . . 91, 97

Forman $v$. Mayor of Canterbury 332 ,

Fossett $v$. Breer

Foster $v$. Green . . . . . . . . . . 329

$\longrightarrow v$. Essex Bank . 343, 344, 359 v. Smith . . . . . . 275

$\checkmark$. Stewart . . . . . 163

Fonlger $v$. Newcomb . . . . . . 462

Fountain $v$. Boodle 427, 433, 434, 435

Fowler $v$. Lock . . . . . . . 327

Fowles $v$. Great Western Railway

Co. . . . . . . . . . 326

Fox $v$. Broderick . . . . . . . . 462

Frankleton v. Sherlock . . . . 381

Franklyn $v$. Lamond . . . . . . 384

Franks, Ex parte . . . . . . . 8

Fraser $v$. Hatton . . . . . . . . 198

Frazer $v$. Bunn . . . . . . . . 51

Freeman $v$. Cook . . . . . . . . 275

(18). 
[The paging refers to the [*] pages.]

Freemantle $r$. London and Nortli-

Western Railway Co. . . . . . 324

French $v$. Brooke . . . . . 194, 195

- $v$. Macale . . . . . 124, 128

Friend's "Styring . . . . . . 73, 75

Frith $v$. Rotherham . . . . . . 20

Frost $v$. Knight . . . . . . 183, 184

Fryer $v$. Kinnersly . . . . . 438, 439

Fuentes $v$. Montis . . . . . . . 288

Fuller, $R e$. . . . . . . . . . . 574

-v. Wilson . . . . . 282, 329

Fyler $v$. Fyler . . . . . . . . . . . 136

G.

[*xxi] Gadd $v$. Houghton

389

Gallagher v. Piper . . . . . 255, 257

Galsworthy $v$. Strutt . . . . 117, 12:3

Gandell $v$. Pontigny . . . . . . 188

Gannon v. Housatonic Railroad Co. 239

Gantret $v$. Egerton . . . . . . . 237

Garlner v. Moult . . . . . . 288

๖ $v$. Slade . . . . . 427,440

Garrard v. Cottrell . . . . . . . 234

Garth v. Howard . . . . . . 288, 339

Gartside $v$. Outram . . . . . . . 444

Gas Liglit and Coke Co. $v$. Turner 47

Gassett $v$. Gilbert . . 438, 442, 452

Gauntlett $v$. King . . . . . . 322

Gayford $v$. Nicholls . . . . . . 353

Geakes $v$. Jackson . . . . . . . 279

Geddes $v$. Wallace . . . . . . . 62

Gee, Ex parte . . . . . . . . . 216

General Steam Navigation Co. $v$.

British Colonial Steam Naviga-

tion Co.

Gent $v$ Tounpkins $\cdot \bullet^{*} \cdot \bullet^{*} \quad 362$

George v George ${ }^{\circ} \cdot \bullet^{\cdot} \cdot{ }^{\circ}$

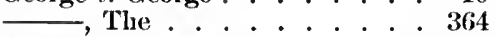

Gerard v. O'Reilly . . . . . . . 124

Germaı Mining Co., Re . . . . 290

Geswood, Ex parte . . . . . . 543

Gibbon $v$. Wilcox . . . . . . . . 70

Giblos v. Liverpool Dock Trustees

$v$. Great Western Railway

Co. . . . . . . . . . . 764

Giblin v. M'Mullen . . . . 344, 35)

Gibson v. East India Co. . . . 22, 30

$\longrightarrow v$. Holland . . . . . . . 43

Gidley v. Lord Palmerston - 402,416

Gilbert $v$. Fletcher

12

$v$. Sehwenck . . 13, 156, 171

Gilbertson $v$. Richardson . . . . 370
PAGT

Giles $v$. Taff Vale Railway Co. 27, 34, 327

Gilman $v$. Robinson . . . . 276, 293

Gilpin $v$. Fowler . . . . . . 437, 442

Gilshamnon $v$. Stomy Brook Railroad Corporation . . . . . 239, 256

Girảude $v$. Richmond . . . . . 39,56

Gladman $x$. Johnson . . . . . . 324

Glenn $v$. Feith . . . . . . . . . 204

Glover, Ex parte . . . . . . . . 213 $v$. London and North-Western Railway Co. . . . . . . . 354

Godsall $v$. Boldero . . . . . . . 159

Godwin v. Francis . . . . . . . . 392

Goff $v$. Great Northern Railway Co. . . . . . . . . 34, 328, 375

Gogarty $v$. Great Southern and Western Railway Co. . . . . 325

Goodall v. Lowndes . . . . . . 397

Goodman $v$. Kennell . . . . . . 340

$v$. Pocoek . 188, 190, 192, 196

Groodyear $v$. Mayor of Weymouth 205

Gordon $v$. Jennings . . . . . . 633

- v. Potter . . . . . . 92

$v$. Rolt . . . . . . 372, 373

Gorgier v. Morris . . . . . . . 198

Gorley, Ex parte . . . . . . . 474

Gorris $v$. Scott . . . . . . . 245, 267

Gosden v. Elphiek . . . . . . . . 379

Goslin v. Agrieultural Hall Co. . 352

Gosling $r$. Birnic . . . . . . . 136

Goss $v$. Lord Nugent . . . . . . . 56

Gough, Ex parte . . . . . . . . 214

$v$. Bryan . . . . 171, 345

- v. Findon . . . . . 209, 573

Gould $v$. Webb . . . . . . . . 149

Goupy $v$. Iarden . . . . . . . . . 388

Grace $v$. Smith . . . . . . . 73

- v. Newman . . . . . . . 169

Græme $v$. Wroughton . . . . . . 46

Grafton v. Eastern Counties Railway Co. . . . . . . . . . 204

Grainger $v$. Aynsley . . . . 699, 701

Grammar v. Nixon . . . . . . 329

Granger $v$. Dacre . .* . . . . 192

Grant $v$. Maddox . . . . . . . 59

$\longrightarrow v$ Norway . . . . . . . 344

Gratland v. Freeman . . . . . 304

Gravely v. Barnard . . . . . . 112

Gray v. Bransey . . . . . . . . 262

$v$. Pullen . . . . . . . 357

Great Eastern, The . . . . . . 195

Great Northern Railway Co. $v$. Shepherd . . . . . . . . . 327

Great Western Insurance Co. (New York) v. Cunliff . . . . . . 136

Great Western Railway Co. v. Goodman . . . 327 
[The paging refers to the $\left[{ }^{*}\right]$ pages.]

Great Western Railway Co. $v$ mell Rimr. Tucker . . . 136 r. Willis . . 289

Green $x$. Beesley . . . . . . . . 63 $r$ Button. . . . . . . . . 465 $r$. Kopke . . . . . . . . . 391 v. London General Omnibus Co. . . . . . . . 27,328

v. Marsden . . . . . . $5 \pi 5$

v. New River Co. . . . . . 135

r. Roberts . . . . . . . . 198

$v$ Sarldington

41

$v$. Wright .

96

Greenham $r$. Gray . . 63, 64, 65, 146

Greenland $r$. Chaplin . . . . 339, $34 \pi$

[*xxii] Greenway $v$. Fisher . . 417

[*. . . 393, 395, 396

Greenwood, Ex parte . . . . . . 279

Gregory $v$. Cotterell . . . . 280, 306

r. Piper . . 368, 369, 3\%4, 3\%5

_ $v$. Slowman West Midland Railway 418

Gregson $v$ Watson . . . . . 220, 702

Grellier, Ex parte . . . . . . 216

Griftith $v$. Selby . . . . . . . . 19:2

Griffiths $r$ Earl of Dudley . . . 2\%0

- Gidlow . . 249, 251, 261, 263

$\longrightarrow$ Jones . . . . . . . . 2\%8

— $v$. Lewis . . . . . . . . 461

$\longrightarrow v$. London and St. Katherine's Dock Co. . . . 264

$r$. Teetgen . . . . . . . 177

Grigby $r \cdot \operatorname{Cox}$

Grill $r$ General Screw Co. . . 326

Grinnell $r$. Wells . 155, 174, 175, 176

Grizzle $v$. Frost . . . . . . . . 257

Groenvelt $\imath$ Burwell . . . . . . 423

Grundon $v$. Master . . Add. \& Corr.

Grylls $v$. Davies . . . . . . 235, 419

Guardians of Halifax Union $v$. Wheelwright . . 330

Graham Union $r$ 21

Gunmakers' Co. $r$. Fell . . . . . 110

Guy Mannering, The . . . . . . 364

Gye $v$. Felton . . . . . . . . . 158

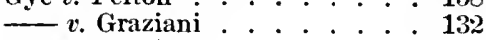

Gylbert $v$. Fletcher . . . . . . . 12

H.

Haigh v. North Brierley Union
Hale $v$. Wright

PAGE

. 225

Hall's case . . . . . . . . . . . 31

Hall $r$. Ashurst . . . . . . . . 389

- $\bullet$. Hill . . . . . . . . 7

—. Hollander . . . . . 1.5.5, 171

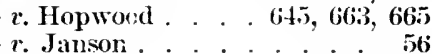

—. Jolinson . . . . . . . 2.5.5, 25\%

- $r$. Lewis . . . . . . . . . 84

$r$. Mayor of Śwansea . . . . 22

— Smith . . . . 322, 3ir, 3\%0

- . Taylor . . . . . . 33, 37!

Halley, The . . . . . . . . . 362

Hambleton 2 : Veere . . . . . . . $15 \pi$

Hambirgh $r$. Hull and London

Fire Insurance Co. . . . . . . 302

Hamilton $r$. Outranı . . . . . . 80

Hammack $r$. White . . . . . . . $3: 27$

Hammond $\imath$. Rogers . . . . . . 363

$r$. The Vestry of St. Pan-

eras . . . . . . . . . 381

Hamper, Ex parte . . . . . . 71,74

Hampson, E.r parte . . . . . 213, 21

Hanbury $r$. Ireland . . . . . . . 15i;

Hancock $r$. The Tork, Sc. Rail-

way Co. . . . . . . . . . . . 321

Hands $r$ Slaney . . . . . . . . 12

Hanna, The . . . . . . . . . . 364

Hanson $r$ Roberdean. . . . . . 384

—. Royden . . . . . . . 19!)

Hardie $v$. Addie . . . . . . . . 25

Hardman $v$. Wilcocks, . . . 136, 393

Hardy $r$. Martin . . . . . . 128

-r. Ryle. . . . . . . 701

Hargrave $v$. Le Breton . . . . . 701

Haruer r. Cornelius . . 151, 152, 15:,

Harmis $v$ Parsons

Harper $v$. Luffkin . . . . . . $7,17(\mathbf{f}$

Harrington $r$. Churchward . $62, \pi 1, \pi$ $76,7 \tau, 196$

เ. Victoria Graving Co. 60)

Harris, Ex parte . . . . . . . 215

— Re . . . . . . . . . . 530

r. Baker . . . . . . $3 \tau \alpha$

$r$ Butler . . . . . 176, 17x

r. Carter . . . . . . 3, 199

r. Montgomery . . . $60,191 \mathrm{i}$

r. Thompson . . 42\%, 428, 430,

441,442

r. Watson . . . . . 198

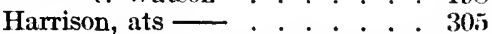

$\longrightarrow$. Bush . . . . 45j, 458, 459

r. Great Northern Railway Co. . . . . 339 r. Leaper . . . . . . 317

$30 \longrightarrow r$ Varty . . . . . . 379 
[The paging refers to the [*] pages.]

Hart $v$. Aldridge . . . . . . . 157

— $v$ Denny . . . . . . . 193

Hartley's Trusts, Re . . . . . 572

Hartley $v$. Cummings . $4 \overline{5}, 46,101$, $103,116,158$

v. Harman . . . 190, 194

$\longrightarrow$ - Ponsonby .

Hartopp, Ex parte . . . . . . 383

Harvey, Re

Haseler $v$. Lemoyne

Hastings $v$, Whitley

Hatfield $v$. Plillips . . . . . . . 535

Hatton $v$. Kean . . . . . . 169, 170

- M. Macready . . . . . 188

Hawken $v$. Bourne . . . . . . . 292

["xxii] Hawkins, Re . . . . . . 530 $v$. Twizell . . . . 2:26

Hawtayne $v$. Bourne . . 290, 301

Hayes $v$. Western Railroad Corporation . . . . . . . 239, 256

Hayman $v$. Flewker . . . . . 288 $r$. The Governing Bolly

of Rugby School . . . . . . 185

Hay ward $v$. Young . . . . . . . 112

llazard $v$. Treadwell . . . . . . $2 \tau 6$

I Ieald $v$. Kenworthy . . . . . . 277

Healey $v$. Story . . . . . . . . 386

Heane $v$. Rogers . . . . . . . . 275

Hearne v. Garton . . . . . . . 317

Heath, Re . . . . . . . 216

$\longrightarrow v$. Wilson . . . . . . 336

Heaven $v$. Pender . . . . . . . 237

Hedges $v$. Tagg . . . . . . . . 177

Herlgely $v$. Holt . . . . . . . 208

Helyer $v$. Hawke . . . 283, 284, 286

Hemming $v$. Hale . . . . . . . 393

Hemmingway $v$. Hamilton . . . 183

Henderson $v$. Australian Roval Mail Steam Navigation Co. . . . .

I Ienkel $v$. Pape . . . . . . . . . . . 297

lleraud $v$. Leafe . . . . . . . . 273

Herbert $v$. Reid . . . . . . . . 571

Hercules Insurance Co., lie . . . 32

IIermann Loog, (Limited) $r$. lican Add. \& Corr.

- $v$. Seneschal . . . . . 379

Hern $v$. Nicholls . . . . . $276,282,329$

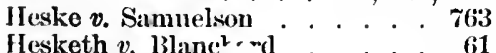

Hesse $v$. Steph

Hewett $v$. Swif . . . . . . . 398

Heyhoe $r$ Burge. . . . . . . 72

Hiblert $v$. Hibbert . . . . . . . 577

Hiblos $x$ Ross . . . . . . . . 350

Hickin, Ei parte....... 215
Hickman $r \cdot \operatorname{Cox}$

Higgins $x$. Pitt . . . . . . . 397

1. Senior . . 291, 385, 388

Higgs $v$. Maynard . . . . . . . 367

Ifill $v$. Allen . . . . . . . . . 162

— $v$. Campbell . . . . . . 427

r. Hawker . . . . . . . 381

— $v$. Royds . . . . . . . 40:2

- $v$. Thompson . . . . . . 16-4

Hilliard $v$. Richardson . . . . . 354

Hills $v$. Croll . . . . . . . . . 126

Hilton $v$. Eckersley 104,105, 106,107,108

Hinde $v$. Gray . . . . . . . 104, 120

Hindley $r$ Haslam . . . . . . 699

Hingeston $v$. Kelly $\quad . \quad . \quad . \quad . \quad . \quad 202$

Hinton $x$. Dibbin . . . . . . . 325

Hirst $x$. Tolson . . . . . . . 218

Hiscox $v$. Greenwood $296,300,301,304$

Hitchcock $x$. Coker . 46, 110, 116, 119

Hitchins $v$. The Kilkenny Rail way

Co. . . . . . . 25

Hobson $x$ Cowley $. .18,146,20 \%$

Hochster $v$. De La Tour . . . 18:3

Hodgkinson $v$. Fernie . . . . . 425

Hodgson $x$. Jolunson . . . . . . 41

․ Searlett . . . . . . 428

L. Sidney . . . . . . . 176

Hodsoll $v$. Stallebrass . . . 171, 173

Hoey $v$. Felton . . . . . . . . 466

一 $v$. M'Ewan . . . . . . . . 217

Hoffman $v$. New York Central, \&e.

Railroad Co. . . . . . . 343

Hogarth $v$. Wherley . . . . . . 301

Hoggartl $v$. Taylor . . . . . . 194

Holeroft $v$. Barber $\ldots \quad \ldots \quad \ldots \quad 58,86$

- $r$. Higgins . . . . . 206

Holder $x$. Cope . . . . . . . . . $\quad$ 6

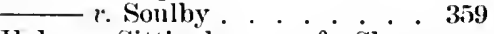

Hole $v$. Sittinglourne \& Sheer-

ness Railway Co. . . . 352, 35\%

Holl $v$. Griftin . . . . . . . . . 136;

Folland $v$. Russcll . . . . . . . . 399

Hollings $v$. Robinson . . . . . . $9(;$

Hollingworth $v$. Palmer . . . . 227

Hollowiy $r$. Abel . . . 173, 178, 180

Holman $v$. Johnson . . . . . . 47

Holme $v$. Brunskill . . . . . . 21

Holmes case . . . . . . 67, 68

Holmes $v$ Clirk . . . . 238, 265, 719

$-v$ Higgrins.. .206

$-r$ Onion . . . . . 350

Holt $v$. Brien . . . . . . . . . 6

Homberg, Fx parte. . . . . . 214

Home $v$. Bentinck . . . . . 45R

Homer $v$. Ashford . . . 109, 112, 115

Homersham $v$. Wolverhampton

Waterworks Co. . . . . 31 
[The paging refers to the [*] pages.]

PAGE

Hookham $v$. Pottage . . . . . 134

Hooper $v$. Truscott . . . . . . . 429

Hopkins $v$. Crowe . . . . . . . 379

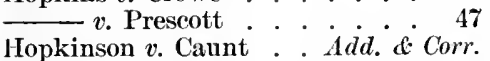

Hopwood $v$. Thorn . . . . . . . 463

Hornby $v$. Close . . . . . . . . 107

Horne $v$. Chandler : . . . . . . 12

— $v$. Ivy . . . . . . . . . . 28

— $v$. Thornborough . . . . 379

Horner $v$. Flintoff . . . . . . . 123 $v$. Graves . . . . 110, 116

Horsfall $v$. Handley . . . . . . 396

Horton $v$. M'Murtry 139, 140, 149, 193

Hough $v$. Manzanos . . . . . . . . 389

Hounsell $v$. Smytl . . . . . . . 237

Howard $v$. Baillie . . 273, 282, 298

[*xxiv] Howard v. Braithwaite . 296 $v$. Chapman . . . . . 287

v. Crowther. . . . . . . 175

$v$. Sheward . . . . 283, 294

v. Wilson . . . . . 566

$v$. Woodward . . . . . 125

Howell $v$. Batt . . . . . . 402, 403

Howells $v$. Landore Siemens Steel Co.

257,649 v. Wynne $: 306,663$

Hubbersty $v$. Warl . . . . . . 344

Hubert $v$. Treherne . . . . . 49

Hudson $v$. Footte . . . . . . . 405

Huffell $v$. Armitstead . . . . . 89

Huggins $v$. Waydey . . . . . . 379

Hughes $v$. Buckland . . . . . . 379

- - v. Budd ...... 48, 52

$-v$. Chatham . . . . . 84

- $v$. Græme . . . . . . 392

- $v$. Humphreys . . . . 12

— $v$. M'Fie . . . . . . . . . 349

Hulle $v$. Heightman . . . . . . 221

Hulse $v$. Hulse . . . . . . . 203, 573

Humble $v$. Hunter . . . . . . . 385

Humfrey $v$. Dale . . . . . . . . 56

Humphreys, Ex parte . . . 210, 214

Hunlock $v$. Blacklowe . . . . 122

Hunt $v$. Goodlake . . . . . . . 459

- $v$. Maniere . . . . . . . . 136

- $v$. Wimbledon Local Board 24, 29

Hunter $v$. Berkely (Dowager Coun-

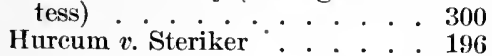

Hurley $v$. Baker . . . . . . . . 394

Hurrell v. Ellis . . . . . . . . 466

Hussey $v$. Pacey . . . . . . . . . . 133

Hutchinson $v$. Tatham $.56,389$

\&c. Railway Co. $240,241,242,244$,
.
Hutman $r$ Bulnois

PAGE

$85,131,222$

Hutton $v$. Parker . . . 104, 109, 115

$v$. Warren 56

Huzzey $v$. Field . . . . . . . 328

Hyams $v$. Webster . . . . . . 357

Hyde $v$. Deă cf Windsor . . . 225

- v. Johnson ...... 27:3

\section{I.}

Illidge $v$. Goodwin . . . . . . . 339

Inchbald $v$. Western Neilgherry

Coffee, \&c. Co. . . . . . . . 202

Indermaur $v$. Dames . . . . . . 237

Inderwick $v$. Snell . . . . . . 186

Ingerson $v$. Miller . . . . . 174, 178

Ingram $v$. Barues . . 53, 205, 607, 701

Innocent $v$. Peto . . . . . 243

Iona, The . . . . . . . . 364

Ipswich Tailors' case . . . . . . 104

Ireland $v$. Thompson . . . . 136, 396

Irwin $v$. Brand wood . . . . . 46?

- v. Dearman . . . . . . 175

Ireson $v$. Coningtoll $\quad . \quad . \quad . \quad . \quad .389$

J.

Jacklin, Ex parte . . . . 543

-In re........ . 699

Jackson, In re . . . . . . 69

$-v$. Bridge . . . . . . 218

Jacquot $v$. Boura . . . . . 143, 195

James $v$. Brook . . . . . . . . 463

Jardine $v$. Leathley . . . . . . 274

Jelliott $x$. Broarl . . . . . . . 111

Jenkins $v$. Betham . . . . . . . 152

$v$. Hutchinson . . . . . . 392

- $v$. Morris . . . . . . 386

Jenner $v$. Turner . . . . . . . 565

Jenness $v$ Emerson . . . . . 13

Jesse $v$. Roy . . . . . . . . . . 221

Jewel $v$. Stead . . . . . . . . . 115

Jewsbury $v$. Newbold . . . . 6

Joel $v$. Morrison . . . . 335, 336

Johnson Ex parte . . . . . . 701

v. Applehy . . . . . . 56

$v$ Blenkinsopp : $57,93,95$

$v$. Dodgson . . . . . 49

$r$ Evans . . . 445, 446

r. Gallagher . . . 8

- v. Lucas . . . . . 7

Raylton . . . . . 56

$246-v$. Reid .... 701 
[The paging refers to the [*] pages.]

Johnson t: Shrewsbury and Pir- PAaE mingham Railway Co. 13:, 185,186

$v$. Snmner

$\overline{\text { Jollifle } r} r$. Wallatey Local Board .381

Jolly $r$. Rees

Jones $v$. Bedlington . . . . . 181

— $v$. Birl . . . . . . . . 378, 379

- $r$. Brown ....... . 172, 178

- $r$. Downman . . . . . 282, 329

— $v$. Festiniog Railway Co. 324, 325

- $v$. Hart. . . . . . 289, 324

- $v$. Jenley $. . . . .571,572$

- $r$. Littledale . . . . . . . 388

[* $\mathrm{xxv}$ ] Jones $\iota$. Mills . . . . . 89

[ $v$. Wiite. . . . . . . 47

Jordan $c$ Norton . . . . . 296, 298

Joseph $x$. Cavander . . . . . . . 178

Josephs $v$. Pebrer $\quad . \quad . \quad . \quad . \quad . \quad . \quad .446$

Josslyn $r$ Parson : . . . . . . 123

Jung $r$. Phosplate of Lime Co. . 391

Juno, The . . . . . . . 362

K.

Kaye $v$. Brett

Keane $v$. Boyeott $\quad . \quad . \quad . \quad 158,159$

Keegan $v$. Western Railroad Co. . 264

Keen $v$. Millwall Dock Co. . . . 765

Keir $v$. Leeman . . . . . . . . 531

Kelly $v$. Nayor, \&c. of New York 323,

$r$. Partington . 429, 432, 447, 464

Kelner $r$. Baxter . . . . 388, 389

Kemble $v$. Farren . . . . 123, 131 r. Kean . . . . . 126

Kendall $x$. King . ........ .33, 379

Kendillon $v$ Malthy . . . . . 444

Kent $v$. Great Western Rail way Co. 379

Ke. Worthing Local Board . . 381

Keon $r$. Iart . . . . . . .91, 97

Kershaw $v$ Bailey . . . . . . 456

Keys $v$. Balfist Railway Co. . . . 325

Kieran $v$. Sanders . . . . . . . 136

Killarney, The . . . . . . 362

Kimberley $r$ Jennings . . . . 126

Kine $v$. Evershed . . . . . . . 379

King $c$. Soston and woreester Rail-

roild Corporation . . . . . 239

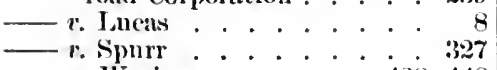

— $v$ Waring $\therefore$ 428, 448
King's Norton $v$ Cambden PAGE

Kinnitz $v$. Surry

Kirkin $v$. Jenkins

Kirkstall Brewery Co. $v$. Furness

Railway Co. . . . . . . . 28?

Kitson $v$. Julian . . . . . . 19

Klinitz $v$. Surry . . . . . . . 4 4!

Knight $v$. Barber . . . . . . 51)

- v. Crockford . . . . 48

v. Fox . . . $354,358,367$

$v$ Gibbs . . . 450,465

v. Knight . . . 575, 577

Knowles $r$. Compigne : . . . 180)

$v$. Diekinson . . . . 659

v. Inaughton . . . . 62

Knowlman $v$. Bluett . . . . . . 38

L.

Labouchere $r$. Dawson . . . . 125

Lacon $v$. Hooper . . . . . . . 424

Laey $v$. Osbaldiston . . . . 145

Lake $x$. Butler . . . . . . . . 115

— $x$. Canphell . . . 58, 80, 202

- $v$. King . . . . . . 444, 457

Lakeman $x$. Stephenson . Ald. \& Corr.

Lamb $r$. Attenborough . . . . . 288

- - Bunce . . . . . . . 2333

- $v$. Bumett . . . . . . 138

— $v$. Palk . . . . 338, 339, 340

Lamburn v: Cruden 189, 199, 200, 213

Lampleigh : Braithwaite . . . 135

Lancaster $r$. Greaves . . . . 701

Lane $r$. Cotton . . . 313, 376, 377, 416 i. Ironmonger

- $v$ Pratt . . . . . . 289

Langan $r$. Great Western lailway

Co. . . . . . . 290

Langlale, Ex parte. . . . 71

Langton $r$. Carleton . . . . . . 92

lammen $v$ : Albany Gas Light Co. 347

latham $x$. Elinburgl and Glissow Railway Co. . . . . . 198

Latter $v$ Bratdell . . . . . 138

Lamglier $v$. Pointer 332, 350, 351, 353

Laughton $v$. Bishop of Solor and Man . . . . . . . 430

Lavell $x$ Howell . . . . . . . 25

Lavender's case . . . . . 482

Law v. 'Thompson . . . . . 208

Lawler r. Linden . . . . . . 95

Lawless $v$. Anglo-Egyptian Cotton and Oil Co. . . . 453, 454 
[The paging refers to the [*] pages.]

Lawrence $x$. Todd . . . . . $\begin{gathered}\quad 53 \\ \text { PAGR }\end{gathered}$

Lawson $v$. Dumlin . . . . . . . 363

Lay $v$. Midland Railway Co. . . 349

Laycock's case . . . . . . . . 306

Laythroap $v$. Bryant . . . . . 43, to

Leadbitter $\boldsymbol{r}$. Farrow . . . . . . 388

Leader $v$. Moxton . . . . . . . 378

Leake $x$. Loveday . . . . . . . 137

Leame $v$. Bray . . . . . . . . . . 367

Leather Cloth Co. $v$. Lorsont 104, 117

[*XXVI] Lee $v$. Bayes . . . . . 419

— $v$. Haley ......... . 134

- $v$. Robinson . . . . . 419

—v. Whitaker . . . . . . 123

Leeds Banking Co., Re. ' · 8

Lees $v$. Whitcomb . . . 44, 98, 131

Leetch $v$. Gartside . . . Add. \& Cor.

Lefevre $v$. Lloyd . . . . . . . . 386

Legg $v$. Pardoe . . . . . . . . 312

Leigh $v$. Hind . . . . . . . . . 114

Leighton $r$. Wales . . . . . . . 119

Leloir $v$. Bristow . . . . . . . 208

Le Maitre $r$. Davis . . . . . . . . 357

Lennard $v$. Robinson . . . . . . . 359

Leroux $v$. Brown . . . . . 38, 39, 40

Le Sage $v$. Coussmaker . . . . . 574

Leslie $v$. Fitzpatrick . . . . . . . 699

Levey $v$. Hill . . . . . . . . . 108

Levy $v$. Lord Herbert . . . . 192 $v$. Rutley . . . . . . . . 166

Lewis $v$. Campbell . . . . . 234

- $v$. Fog . . . . . . . 171, 172

— $v$. Nicholson . . . . . 390, 392

— $v$. Peacey . . . . . . . 12

— $v$. Reed . . . . . . 337

— $v$. Taylor. . . . . . . 405

Lewson $v$. Kirk . . . . . . . . 134

Ley $v$. Peter . . . . . . . . . . 289

Leycester $v$. Logan . . . . . . . 324

Lightly $\boldsymbol{v}$. Clouston

Lilley $v$. Elwin . 84, 91, 141, 188, 222

Lilly $v$. Hays . . . . . . 402

Limland $v$. Stephens . . . . . 133

Limpus $v$. General Omnibus Co. 337, 340

Lindley $v$. Lacey _. . . . . . 54

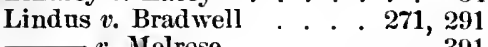

Lion, The

Lipson $v$. Harrison . . . . . . . . . 198

Lismore $v$. Beadle . . . . . . . 195

Lister $v$. Smith . . . . . . . . 54

Liverpool Brazil and River Plate Steam Navigation Co. $v$. Benham (Corporation of) $v$. Wright

Llewellyn $v$. Winckworth
Lloyd $v$. Blackburn

PAGE

18 . Genew Collier Co. . . . . . 338

- $x$. Harper. . . . . . . . 20

Lobb $r$. Stanley . . . . . . . . 48

Lockett $v$. Nicklin . . . . . . . 56

Loftus $v$. Maw . . . . . . . . . 204

Lomax $v$. Arding . . . . 139, 148

London Assurace Co. $r$ Bold . 19

$\longrightarrow$ and Birmingham Railway Co. $v$. Winter . . . . 28: Chartered Bank of Australia $v$. Lemprière . . . 8 Doek Co. $v$. Sinott . . . . 31

Bailey . . Tramways Company $v_{0}, 201$

Longfellow $v$. Williams . . . . 42

Longmeid $v$. Holloway . . . . . 416

Louth $x$. Drummond . . . . . . 9.5

Lovegrove $v$. London Brighton and

South Coast Railway Co. . . . 255

Lowe $v$. North-Western Railway

Co. . . . . . 26, 34

Lowell $v$. Boston and Lowell Rail-

road Corporation . . 234, 334, 354

Lowndes $v$. Earl of Stamforl . . 219

Lowry $v$. Aikenheal . . . . . . 429

Lucas $v$. Beach . . . . . . . 51, 207

- $v$. Beal . . . . . . . . 391

$-v$. Bristow . . . . . . 56

—r. Novosilieski . . . . . . 209

Lucy $v$. Ingram . . . . . . . . 362

Ludbrook $v$. Barrett . . . . . . 204

Ludlow (Mayor of ) $v$. Charlton 22, 28,

Lumby $v$ Allday . . . . . . . 463

Lumley $v$. Gye . . . . . . 156, 157

$r$. Wagner . . 126, 131, 132

Lyste $x^{2}$. 140, 189, 193

Lygo $x$. Newbold : . . . . . . 349

Lynch $v$. Knight . . . 464, 465, 466;

Iyon $v$. Nurdin . . . . . . . 349

Lyons $v$. Hyman . . . . . 208

工 $v$ Martin $.340,368,369$

\section{M.}

M'Anley $v$. Brownlie . . . . . 25r

Macbeath $v$. Haldinuand . . . . 383

48 M'Carthy $v$. British Shipowner's Co. 2is 280 r. Colvin . . . 39r 
[Tho paging refers to the [*] pages.]

Macdonald $r$. Longbottom

M'Dougal $v$. Claridge

$v$ Paterson

M'Elveney $v$. Connellan

M'Eniry $x$. Waterford and Kilken-

ny Railway Co.

Marfarlane $c$. Giannacopnlo

M'Giffen $v$. P'almers ship Building $\mathrm{Co}$.

I'Gowan $x$ Dyer

M'Gregor $x$ lowe $: 397$

[*xxvii] Machu $r$. South-IVestern

R. Co.

M'Intyre 2 Belcher $\cdot \cdot 100,326$

Mackay $v$. Commercial Bank of New Brunswick . 328, 329 $r$ Ford .

M'kean $x$ Cowley

140

Mackenzie $v$. Macleod

194

M'Keon $v$. Bolton . . . . . . . . 353

N'Kinney $v$. Irish North Western

Railway Co.

M'Kone $r$. Wood . . . . . . . 450

Maclaughlin $v$. Pryor. . 350, 351, 367,

Maclean $v$. Dmm, . . . . . 49, 27:3

Maclure, Re . . . . . . . . . . 217

M'Mahon $x$ Lennard

1

I'Manus $v$. Crickett $339,343,368,370$,

way Co. . . . 326

M'Millan $r$. M'Millan . . . . 257

ton Railroasl Co.

M'Naughton 2 . Caledonian Rail-

way Co. . . . . 239, 253, 254

I'Queen $v$. Great Western Rail-

way Co.

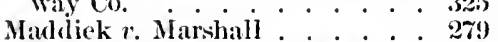

Maddlison $r$. Alderson Adll \& Corr. 204

Maddon $v$. White

12

Magee $v$. Atkinson . . . . . . 388

$-r$ Lavell . . . . . . . . 1233

Mahony $r$ Kekule . . . . 390, 391

Mainwaring $r$. Leslie . . . . 6

Mair $r$. Glennie . . . . . . ( $(2,71$

Makepeace $r$. Jackson . . . . . 164

Mallan $x$. May . 104, 109, 110, 111, 11:,

Malling Union $x$. Graham

Manloy $r$. Iong . . . . . . . . 26

- Seott . . . 5

$-r$ Witt . . . . 442, 449

Mangan $e$. Atherton . . . . . . 34!

Manley $r$. Fichl . . . . . . . 17\%

Naun $v$. Barrett . . . . . 177
PAGE

Mansell $r$. Thompson . . . . 178

Mansfield $r$ Baddeley . . . . 236

Manzoni $t$. Douglikss . . . . . . 327

Marehant $r$. Lee Conservaney Board . . . . . . . . . 26

Mare $r$. Charles . . . . . . . 387

Maria, case of The . . . . . . 362

Marsls $r$. keating . . . . . . 530

Narsliall $r$. Broadluurst . . . . 2:5

56

50

(6)

Railway Co.

Martinez $c$. Gerber . . . . 171, 173

Martin $r$. Strong . . . . . . . . 456

$r$ Temperly . . 353, 365, 366

Martins, Ex parte . . . . . . . 543

Mary, The . . . . . . . . 35.

Mason $r$ Mitchell . . . . . . . 10

$v$. Birkenhead Improvement

Commissioners . . . . . . 379

Masters $v$. Lowther . . . . . . 407

Mattliews $v$. Macdonald . . . . 262

$r$. Natthews 574

Maund $v$. Aommouthshire Canal

Co. . . . . . . . . 328,374

Maunder $v$. Conyers . . . . . . 300

- Venn . . . . 1\%2, 1\%

May $v$. O'Neile . . . . . . . . 117

Mayhew $v$. Suttle . . . . . . 80, 81

Mayor of Berwick $r$. Oswald . . 19 Jartmouth \&. Silly . . 20

Dublin $r$. llayes . . . 48 Kidilerminster $v$. Iariwicke . . . 29 Ludlow v. Charlton, 22,28 ,

$$
\text { Thetford's case ... } 29
$$

Maythorn $x$ Palmer . . . . . 128

Mead $v$. Lamond . . . . . . 32.1

Meakin $v$ Morris . . . . . 13, 14

Mellors $v$. Shaw . . . 17, 258, 661

Mercer $x$. Irving . . . . . . 1:3

— r.sparks . . . . . . 4:8 $r$ Whall . 139, 146, 150, 183

Nerryweather $r$. Nixon. . 234, 418

Mersey Iocks and thurbour Board r. Gilbus . . . 378, 38I

- $r$. P'enhallow . . . 381

Meswiter r. loose. . . . . . . 131

Metealt $r$ liruin . . . . . . . 20

Metcalfe, tx pate . . . . . . 202

_ lletherington . . . 3:21

$r$. Iondon, firighton and

South Coast linilway Co. . . . 325

Metzner 2 . Bolton . . 56, 92, 96,193 
[The paging refers to the $\left[{ }^{*}\right]$ pages.]

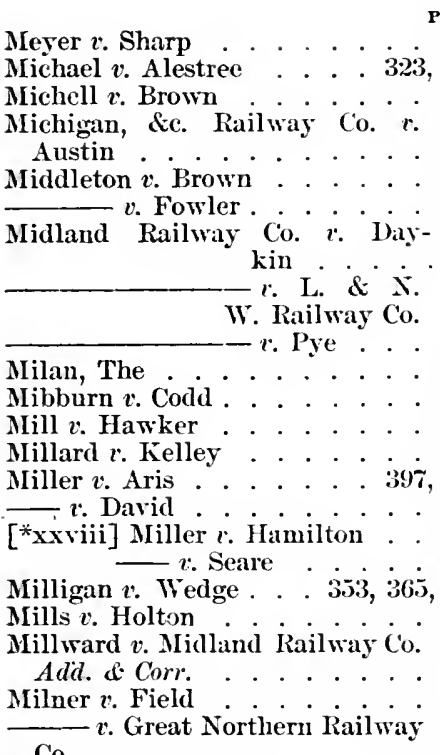
Co.

Mires $r$ Solebay . . . . . . 419, 420

Mitchell $v$. Crassweller . . . 341, 342 $-v$. Reynolds . . 104, 108, 110

Mitcheson $v$. Oliver . . . . . 280

Mizen $v$. Peck . . . . . . . . . 5, 6

Mobile, The . . . . . . . . 363

Moffatt $r$. Parsons . . . . . . . 280

Moflatt $r$. Dixon . . . . . . . . 201

- $v$. Laurie . . . . . 201, 202

MIolton $v$. Camroux $\quad$. . . . . . . 16

Sonk $v$, Clayton . . . . . . . . 305

Monkman $v$. Shepherdson . . . . 200

Montague $v$. Benedict . . . . 5

$\bar{c} r$ Flockton . . . . . . 126

Montefiore $x$. Lloyd . . . . . . 20

Moon $v$. Towers . . . . . . . . . . 369

Moore $v$. Bushell . . . . . . . . 402

- v. Fitchbourg Railroad Corporation

. Metropolitan Railway

Moreton $v$ Hardern $:$. . . .

Morgan $v$. Birnie

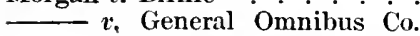
Add. \& Corr.

323

328

17

204

763 $25 \pi$

Morison $v$. Thompson . . . 136, 164

Morley $r$. Graisford . . . 368, 371, 374

Morris, $R e$
Iorris $x$. Coleman PAGE

465

Morrison $v$. Baird . . . . . 763

$-\imath$. General Steam Savigation Co. . . . . 346 v. Glover . . . . . . 544

Mortimer $v$. Prowett . . . . . . 90

Moss $v$. Hall . . . . . . . . . 119

Monfllet $v$. Cole . . . . . . . . 11i

Mounsey $r$. Stephenson . . . . . 53

Moxham, The . . . . . . . 356

Moyle $x$. Jenkins . . . . . . 765

Inllins $v$ Collins . . . . . . . 316

Iulvehall $x$. Nillward . . . . 175

Inmorol $r$. Gething . 54, 5i, 113, 114

Innday $r$. Stublos . . . . . 379

$-\imath$ Thimes Iron Works. . 765

Innro $r$. Butt . . . . . . . 204

IIurphy $x$. Boese . . . . . . 4 48

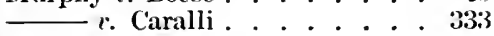

c. Kellett . . . . . 446

r. Phillips . . . . . 262

—

- . Wilson . . . . . 764

Murray $v$. Currie . . . . . 246, 352

¿. East India Co. . . . . 273 $r$ Mann - 137, 28., 401, 402 $r$. Montrie . . . . . 138

Muschamp $t$. Lincaster, \&c. Rail-

way $\mathrm{Co}$. . . . . . . . 327

Myers $r$. Sarl . . . . . . . . . 59

Myler $v$. Fitzpatrick . . . . . . 136

Iytton $v$. The Midland Railway

Co. . . . . . . . 327

N.

National Exchange Co. of Glasgow

r. Drew . . . . . 329

Niylor $x$. IIortimore . . . . . . 26

Seale, Ex parte . . . . . . . 214

$-r$. Turton . . . . . 298, 301

Neate $r$. Harding . . . . . 163, 399

Newby $x$. Wiltshire . . . . 231,233

Newling $v$. Dobell . . . . . . . 123

Newman, $R e$. . . . . . . 123

- Walters . . . . 199

Sewnham $r$. Stevenson . . . . 13?

Newsome $v$. Coles . . . . . . . 305

Newton $v$. Belcher . . . . 275

$r$ Ellis. . . . . . . 37!

r. Holford . . . . 122, I74

$v$ Liddiard . . . . . . . 275 
[The paging refers to the [*] pages.]

Nias $\%$ PAGE

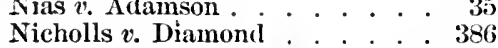
$-v$ Stretton . 47, 117, 121, 122,

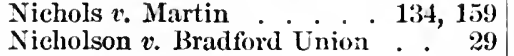
- v. Gooch . . . . . . 397 $v$. Knowles . . . . . 136 - v. Mouncey . . . . 37\%, 378

Nickson v. Brohan . 133, 276, 293, 305

Nicoll $v$. Graves . . . . . . . . 93, 94

Noblesville and Eagletown Gravel

Road Co. $v$. Gause

334

Noden $v$. Johnson . . . 138

North River Bank $v$. Aymar . . 298

North's case . . . . . . . . . 378

North-Western Railway Co. $r$.

Whinray

Norton v. Herron . . . . . . . 389

— v. Powell . . . . . . . . 48

- $v$. Turvill $\cdot \cdot \cdot \cdot \cdot{ }^{\circ}$

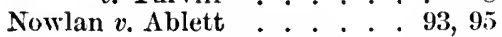

[*xxrx] Nunn's Will, Re . . . 573

Nurse v. Wills.

o.

Oakley v. Portsmouth and Ryde

Steam Packet Co. . . . . . . 355

Oates $v$. Hudson . . . . . . 398

O'Byrne $v$. Burn . . . . . 257, 258

(oflley $v$. Clay . . . . . . 7

Ogden $v$. Fossick . . 126, 186, 187

Ogle $v$. Atkinson : . . . . . 137

- v. Morgan . . . . . . 568

Ulding $v$. Snith . . . 289, 317, 604

O'Neill $v$. Wilson . . . . . . 260

Ormond $v$. Holland . . . . . . 261

Usborn. $v$. Gillett . . . . . 173, 529

Osborne $v$. Jackson . . . . . . 763

$-v$. Jullion . . . . 66

- v. Morgan . . 240, 244, 26id

Overton $v$. Freeman . . . 355, 367

Ovington $\approx$. M'Keane . . . . 260

Owen v. Bowen . . . . . . . 20i

- v. Gooch . . . . . . . 383

Owens $r$. Dickinson

Ozard $v$. Durnford
Padmore $v$. Lawrence . . . . 459

Padwick $\imath$. King . . . . . . . 405

Pagani v. Gandolfi . . . . . . . 188

Page $r$. Defries . . . . 337, 338, 340

Paice $v$. Walker . . . . . . . . 339

Paine $v$. Strand Union . . . . . 29

Palethrop $v$. Furnish . . . . . . . 271

Palmer $v$. Evans . . . . . . . . 280

Paradice's case . . . . . . . 481, 482

Pardington $v$. Sunth Wales Railway Co. . . . . . . . 344, 345

Pardoe $v$. Price . . . . . . . . 25

Parker $v$. Bristol and Exeter Railway Co. . . . . . . 398 r. Green . . . . . . . 312

$\longrightarrow v$. Ibbetson . . 58, 96, 193, 202

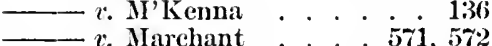

—. Winlow . . . . . . . 389

Parkes $v$. Preseott . . . . . . 310, 324

Parnaby $\%$ Lancaster Canal Co. 321,380

Parry 1. Smith . . . . . . . 353

Parsons $x$. Winchell . . . . . . 323

Parton v. Willians . . . . . . 379

Pasley $v$. Freeman . . . . . . . 467

Patent Floor Cloth Co., Re . . . 217

Paterson $v$. Gandassequi . . 303, 383

—. Wallace . . . . . 262

Patten v. Rea . . . . . . . . . 338

Pattison $v$. Jones . . . . . . . . 431

Pauling $r$ Isondon and North-

Western Railway Co.· 275, 278, 304

Pawlet $v$. Burnham . . . . . . 37

Pawsey $v$. Armstrong . . . . . 59

Paxton v. Popham . . . . . . . 46

Payne, Ex parte . . . . . . . . 544

- $v$. Mayor of Brecon . . . 33

- New South Wales Coal

Co. . . . . . . . . . . . . 44

l'aynter $v$. Williams . . . . . . 233

leachey $v$. Rowland . . 306, 344, 356

Peacock $r$. Peacock . . . 61, 203

Pearce $v$. Rogers . . . . . . 300, 304

Pearson $x$ Grahain . . . . . 415, 416

- r. Pearson . . . Add. ce Cor.

Pease $r$ Hirst . . . . . . . . 20

Pechell $v$. Layton . . . . . . . 306

lecrless, The . . . . . . . . . 362

Penhallow $v$. Mersey Doeks and

440 Harbour Board . . . . . . . 27

6 Penrose 2 . Martyn . . . . . . . 387

Pereival $r$. Huglues . . . . . 356, 357

l'crkins $v$. Smitl $\quad$. . . \$16, 117,418 
[The paging refers to the [*] pages.]

Perring $v$. Harris

Perry v. Shipway

Peter. $v$. Compton

$v$. Kendal

Peters $v$. Fleming

P. Opic.

Peto $v$. Brighton, Eekfield and Tunbridge Wells Railway Co. . . . . . 126, 12\% r. Hague

Phelps $v$. Wincheomb

Philadelphia, Wilmington and Baltimore Railroad Corporation $r$. Qnigley . . . . . . 27, 328, 453 Philadelphia \& Reading Railroad

Corporation $v$. Jerby

Phillins $v$. Clark . 326

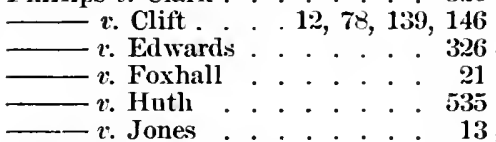

Phillipson $v$. Hayter . . . . . . . 5

Pickard $v$. Sears . . . . . . . . 27j

v Snith . . . . . . 352, 357

Piekering $v$. Busk

- $r$. James . . . . . . . 424

[*xxx] Piekwell v. Spencer . . 565

Pierce $v$. Jersey Waterworks Co. .

Piggott $v$. Eastern Counties Rail-

way Co. . . . . . . . . . . 324

32

Pike v. Fitzgibbon . . . . . . . 8

Pilgrim $v$. Southampton, \&e. Rail-

way Co.

Pilkington $v$. Scott . $45,46,101,102$, $103,119,158$

Pillar $v$. Llynvi Coal and Iron Co. 5艹3, $604,608,701$

Pinto $v$. Santos . . 136

Planche $v$. Colburn $\quad . \quad$ 188, 189, 196

Plate Glass Co. $v$. Meredith . . . 378

Playfair $v$. United Kingdom Elee-

tric Co.

$3: 31$

Pointer $v$. Hill .

Pole $v$. Harrobin . . . . . . . . . 46

v. Leask . . . . . . . . . 287

Poley $v$. Osborn . . . . . . . . . 155

Polhill $v$. Walter

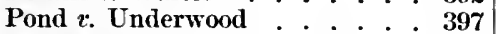

Popham $v$. Jones . . . . . . . .

Pott $v$. Eyton . . . . . . $\tau_{1,}, 2,73$

Potter $v$. Faulkner . . . . . 248, 249

Potts $v$. Plunkett

v. Port Carlisie Dock and Railway Co. . . . . . .

Poulson $v$. Thirsk
Poulton $r$. London and South Western Railway Co. . 342 . 375 52

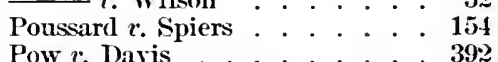
Powell r. Bradbury . . . . 140, 193

- $v$. Hoyland . . . . . . 419

- r. Rees . . . . . . . 164

Powers $r$. Fowler . . . . . . 44, 48

Powis, Ex parte . . . . . . . . 216

Powles $v$. Hider . . . . . . . . 327

Precious $v$. Abel . . . . . . . . . . . . . 295

Prescott $v$. Flinn . . . . . . . . 280

Preskitt $v$. Balger . . . . . . . 196

Prestwick $v$. Marshall . . . . . 271

Price $r$. Green . . . 47, 11\%, 122, 123

- $r$. Marsl . . . . . . . . 289

r. Taylor . . . . . . . . . 387

$r$ Torrington (Earl of) $\quad . \quad 290$

Priestley $v$. Fernie . . . . . 303, 391

— $v$. Fowler . 237, 238, 239, 240, $244,245,246,251,254$, 255,258

Prinee of Wales Assnrance Society $v$. Athenaum Assurance Soci-

ety . . . . . . . . . . 32, 279

Princeton, The . . . . . . . : 362

Pritchard $v$. Hitcheock . . . . . 135

Practor $v$. Sargent . . . 116, 117, 120

Prudential Assurance Co. $v$. Knott 467

Prugnell $v$. Gosse . . . 104, 109, 111

Pryce $v$. Beleher . . . . . . . . 424

Pulling $v$. Great Fastern Railway

Co. . . . . . . . . . . . 416

Purcell v. Sowler . . . . . . . 454

Pnttock $v$. Warr . . . . . . . . . . . . 287

Pybus $v$. Gibb . . . . . . . . . 20, 21

Pym $v$. Canupbell . . . . . . . 54

Q.

Quarman r. Bnrnett 347, 351, 352, 3\%8, $365,366,376,494,566$

Queen, The .......... 363

R.

Radley $r$ London and North Western Railway Co. . . . . . . 346 
[The paging refers to the [*] pages.]

Pamazotti $v$. Bowring

PAGE

PAGF

2\%5, 303 R. ?. Beacall

502,525

Ramsden $v$. Brearley

$11-r$. Beaman

Randal $v$. Trimen .

$392-r$. Beanlieu

516, $51 \stackrel{2}{7}$

Randleson $x$. Murray .

$333-r$. Beanmont

488

Rannie $x$. Irvine . . . .

Raphael $r$. Goodman

122 $-x$. Beechey

$51: 3$

Rapson $v$. Cuhitt .

$329-r$. Bennett

309

Rawlings $r$. Bell

$347,353-r$ Betts

$409,486,520$

$234-v$ Bickerstaft . . . . . . 539, 540

$v$. Chandler

$204-v$ Bigg . . . . . . . . 22

Rawlinson $v$. Clarke

$65-r$ Bilborough

79

Rayment $v$. Minton

$139-x$. Billinghay

57,79

Rayner $v$. Mitchell .

$341-v$. Bilton

156

lead $v$. Coker . .

$17,3 \% 9$

- $r$. Birchall

408,415

$145-r$ Birdbrooke . . . . . . 90

$v$ Legard . . . . . . $16-r$ Birmingham . . . . . 87,89

Reade $r$. Lamb

38 -r. Bishop's Hatfield . . . . . 88

Reavely $x$. Nainwaring. . . . . $156-v$ Bishopton . . . . . . 81

Redgate $v$. Haynes . . . . . $316-v$ Bleasdale . . . 309, 332, 404

Redpatl $x$. Wigg . . . . . . . $306-v$ Bolton . . . . . . . . . . 598

Reed $v$. Moore . . . . . . . . . $6-x$. Bootyman . . . . . . . . 527

Reedie $r$. London and North West-

ern Railway Co. $317,323,333,354$

367

- $r$ Borrett

532,537

- $r$. Bowers

509,510

Reeve $v$. Conyham (Marquis of)

Reid $v$. Dreaper

$r$ Bracket

162

71

- $x$. Bradley

315

$-r$. Hollinshed

- $v$. Bren .

504,505

- $v$ Brown . . . . . . . 665

[* $\mathrm{*} \times \mathrm{x}$ ] Reignald's case

Reindel $v$. Schell

124

- $v$. Buckland Denlanı

88,89

$302-v$ Bunkall . . . . . 482

Rennie $v$. Wynn

140

Renno $v$. Bennett

43,48

- $x$. Bunn

lxvi, 560

Reuter $x$. Eleetric Telegrapli Co.

481

$30-r$ Burton . . . . . . . . 507

Revis $v$. Smith

128 - $x$. Bury St. Elmund's . . . . 233

$444-r$ Butcher . . . . . . . 307

Rex aut Reg. $v$ Adey . . . . $506-r$ Butler . . . . 518, 519, 520

$-r$. Allen

$-r$ Almon

$408,409-v$. Button . xlviii, $588,597,61 \%$

- r. Althorne

310,31

- $r$. Ardington

88 - $r$. Byker

86,89

$-r$. Arlington

503

- $r$ Arnesby

- r. Arnndel

12 - $v$ Carter . . . . . . . . . 475

505

- r. Ashley

12 - $r$. Chapmian

523

$80,481-r$. Charlesworth . . . . . . . 409

- r. Aslett

535

409

- $v$ Aston

511,512

- v. Atkinson

504,519

- $r$. Cheeseman

$485,496 i$

-r. Balls

526,564

- $r$. Cheshunt

- v. Bannen

- v. Christopher

487

- r. Barnes

489.390 - 1 . Clapton

509

- $v$. Barrett

321, $408-v$. Cleworth

- $v$. Batt .

564 - " Clifford

701

- v. Batty

$505-r$. Coggeshali

- $v$. Baxter

$507-v$. Cook

- v. Bayley $457,504-v$. Cooper 
[The paging refers to the [*] pages.]

R. v. Cowpen

- v. Crawley

- v. Crediton

- v. Creed

- v. Creevy

$-v$. Cromford

- v. Cross

- v. Cullum

-v. Daniel

- v. Dean

- v. Dedham

- v. Delaval

- v. Deny

- $v$ Dixon

- v. Dodderhill

- v. Dolan

- $v$. Druitt

- v. Duffield

-v. Dukinfield

-v. Duuton

- v. Eceleston

- v. Edgmond

- v. Edingale

- v. Edmundson

- v. Edwards

- $v$. Egrinton

- $v$. Elmley Cast

- $v$. Empingham

- v. Essex

- v. Evans

[*XXXII] R. v. Field

R. v. Firth

- v. Foulkes . . . . . . . . 504

- v. Frampton . . . . 525, 526

一 v. Frankland . . . . . . 503

- v. Freeman . . . . . . 505

- v. Frome Selwood . . . . . 89

- v. Gale

- v. Gardner

- v. Garrett

- v. Gateshead

- v. Gibbs

- $v$. Giles

-v. Gillyard • • • • • $\cdot \dot{320}^{\circ} 321$

- $v$. Gilroy . . . . . . . . . 317

一v. Glass . . . . . . 493, 540

- v. Glover . . . . 508

- v. Glyde . . . . . . . . . 487

-v. Goodbody . . . . 492, 503, 505

- $v$. Goode

- v. Goodenough $\cdot . \cdot$. . . . 4

- $v$. Goodfellow

- v. Goodwin

- v. Gorbutt

-v. Gouche
R. v. Gray

PAGR

473,478

12 - v. Great Bowden

$79-v$. Great North of England Rail

$428-v$. Great Wishford * • • 318, 319

12 - v. Great Yarmouth . . . . . 91

317 - v. Green . . . . . . . 408, 492

- v. Gregory . . . . . . . . . 480

-v. Grey . . . . . . . . . . 408

- $v$. Grove . . . $519,521,522,534$

- v. Gruncell . . . . . . . . 488

- $v$. Guelder . . . . . . . . 521

- $v$. Guildtord . . . . • • . 4

- $v$. Gutch . . . . . . . 310, 314

- $v$. Haines . . . . . . 408, 415

- $v$. Hall . 81, 488, 489, 503, 524, 525

- $v$. Hampreston

91

- $x$. Hanbury

- $v$. Handley

487

$9-v$. Harding

484

472,540

$79-v$. Harris

512,513

- v. Hartley

$6 \%, 506$

- $v$. Harvey

493

- $v$. Hassal

3 - v. Hastic . . . . . . . . 515

88 - $v$. Hawkins . . . . . 485, 517

503 - v. Hawtin . . . . . . . 512, 514

93 - v. Haydon . . . . . . . 351, 497

81 - $v$. Hayward . . . . . . . . 500

- $v$. Headge . . . . . . . 497, 518

- v. Hebb . . . . . . . . . . 519

- $v$. Hedges . . . . . . . . 518

- $v$. Herstmoneeaux . . . . . . 86

- $v$. Hey . . 353, 485, 493, 494, 503

-v. Heywood . . . . . . 495

- $v$. Higgins . . . . . . . . 480

- $v$. Hindringham . . . . . 2

- v. Hipswell . . . . . . . . 15

310 - $v$. Hoare . . . . . . . . 510

- v. Hobson . . . . . . . . 519

一 $v$. Hodgson . . . . . . . 519, 527

- v. Holbeek . . . . . . . . 89

一 $v$. Holbrook . . . . . 311

- v. Holloway $. \cdot . \cdot .47 \%, 479,489$

一 v. Holsworthy . . . . . . . 3

- $v$. Hornby . . . . . . . . 486

- $v$. Hoseason . . . . . . . . 332

一 $v$. Houseman . . . . . . . . 518

- v. Huggins . . . . . . . 306,506

- $v$. Hughes . 408, 494, 503, 505, 513

$492-v$. Hunt . . . . . . . . . 525

594 - $v$. Ightham . . . . . . . . . 79

409 - $v$. Iken . . . . . . . . . . 80

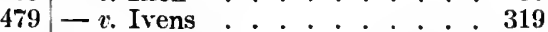

Ix - v. Jackson . . . . 494, 519, 520 
[The paging refers to the [*] pages.]

R. v. James ..... 404, 405

— v. Jarvis . . . . 308, 309, 482

- $v$. Jennings

- $v$. Jenson

- $v$. Jeyes

- v. Jolnson

- v. Jones

- $v$. Jones . . 427, 476, 493, 519, 522

- $v$. Justices of Cumberland . . 24

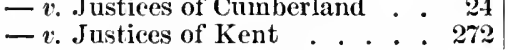

$-v$. Justices of West Riding of

- v. Keena Yorkshire

- v. Kerr

- v. Killingholme

- $v$. King's Lynn

$-v$. Kingswinford

- v. Latlock

- $v$. Iaindon

- $v$. Lamade

- $x$. Lambert

$-v$. Lambeth

- v. Lambton

- v. Ledger .

- $v$. Leeeh

- $v$. Ieggett

[*xxxiii] $v$. Leonar

- $v$. Lichfield

- $v$. Iister

- v. Little Bolton

$-v$. Longnor

$-v$. Long Whatton

- $v$. Lord

$-v$. Lovelass

- $v$. Lovell

$-v$. Lowrie

$-v$. Ludlow

$-v$. Iydd

-v. Lynn

- v. Lyons

- v. Iyth

- $v$. Macelesficid

- $x$. Macdonald

- v. M'Gill

- $v$. M'Gregor

$-v$. M'Knight

- $v$. M'Namee

$-v$. Mainwaring

$-v$ 'Manning

- $v$. Marshall

- v. Martham

- v. Martin .

- $v$. Masters

- v. May

- $v$. Mayor of Norwich 24 Add, and

$485,496,501$ $517,519,526$

598 527 487

R. $v$. Mazeau

PAGE

- Mears

- $v$. Medley 318

- $v$ Mellish . . . . . . 502, 511

— v. Hence . . . . . . . 539

- $v$. Metcalf . . . 482, 485, 505

- $v$. Michael . . . . . . 307

-v. Middleton . . . . . . 302

— $v$. Mills . . . . . . . . . 491

- $v$. Minster . . . . . . . . 80

- $v$. Miteham . . . . . . . . 90

- $v$ Moah . . 468, 523, 526, 527, 533,

- $v$. Moore $\quad 487$

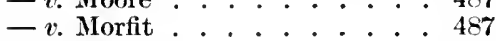

— $v$ Murdock . . . . . . . 519

- v. Murphy . . . . . . . 505

- $v$. Murray . . . . . 498, 517

— v. Mursley . . . . . . . . 87

— $v$. Mutters . . . . . . 482

- v. Negus . . . . . . . . . 509

- $v$. Nether Knutsford . . . . . 79

- v. Nettleton . . . . . . 507

— v. Newey . . . . . . . 539

- $v$. Newton . . . . . . 79, 86

— $v$. Newton Toney . . . . . 90

- $v$. Noake . . . . . . . . 528

- $v$. Norman . . . . . . . 521

- v. North Nibley . . . . . 88

- $r$. Northowram . . . . 79,88

一 $v$. Northwingfield $: . .4 \dot{7}, 57,86$

- v. Norton .. . . . . . . 2

- v. Norton Bavant . . . . . 89

- $v$. Norval . . . . . . 484

- $r$. Oates . . . . . . . 490

- $v$. Odillam . . . . . . . 90

- v. Oldland . . . . . . . . 233

- $v$. Ossett eum Gawthorpe . . 86, 89

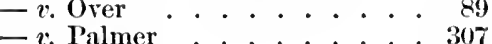

- v. Parr . . . . . 308, 404

- v. Partridge . . . . . 156

- v. Pearson . . . . . . . $5: 37$

— v. Pease . . . . . . . 318, 409

- v. Peck . . . . . . . . 218

- v. Pedly . . . . . . . 318

- $v$. Pendleton . . . . . . 86

- v. Pershore . . . . . . . . . 91

- $x$. Phetheon . . . . . 4 47

- $v$. Pitminster . . . . . 86

- v. Pocock . . . . . . 378, 408

— \begin{tabular}{l}
. Polesworth . . . . 87 \\
\hline
\end{tabular}

- v. Pool ........... 489

and $-v$. Potter . . . . . . . 475

Corr. - v. Poynton . . . . . 536

- v. Mayor of Staniford . . . 23 - 2 Poyser . . . . . . . 485 
[The paging refers to the [*] pages.]

R. v. Prest

PAGF

- $v$. Preston

2.) R. $x$. Squire

PAGE

- $v$. Prince

$89,4-7-v$. Stainer

503

$30: 2-x$ Stanbury

- $v$. Prould

$4-r-r$. Standon Massey

513

- $x$. Puckington

$505-x$. Steplens.

— $v$ Pucklechurch

$2-r$. Stock 318

- $r$. Purchase

$90-x$. Stokesley $\quad 80,48$

- v. Rainham

$528-r$ Stoke-upon-Trent . . . 57, 89

- $r$ Rathbone . . . . 538, 53

$79-r$. Stownarket

- $r$ Ravenstor

418

- $v$. Reason

53

- $r$. Reed

- $v$. Swindall

- 2 Rees . . . 80, 537

$-v$ Registrar of Friendly Societies

$6: 3$

- $v$. Tiunton

- r. Taylor

$405,408,519$

- $x$. Terrott

80

$-v$ Reynolds

$518-\imath$. Thomas

518

- $v$. Richards

$-v$. Riekinghall $48 \%, 488,54$

$-r$. Ridley

- $r$. Ripon

- $x$. Roherts

512,514

$228-v$. Thorpe

517

$-r$ Robins

$500-r$. Threckin

487

$-v$. Rogers

$180-v$ Tibble

406

$-v$ Rowlands

$526,599-v$. Tite

$50 ; 5,509$

- $v$. Rudick

$150-x$. Tiverton

$8(1)$

- $v$ Saffron Walden

$498-r$. Tongue

505,514

[*raiv] St Helen's

$115-v$ Townsend . . . 506,533, 537

Aurkland $86,-v$. Train . . . . . . 31

— v. St. John, Devizes . . . . $89-\imath$ Threadgold. . . . . . . . 526

— St. Martin, Lcicester . . $86-x$ Trebilcock . . . . . . 47\%

- $\imath$. St. Mary-at-the-IValls, Colchester

- $v$ St Paul Bedtiord ' * •

- $x$. St. l'etrox .......

$-i$. Salisbury

$-x$. Trenwyth

5.37

$3-r$ Trevenner . . . . . 489

51 - $x$. Truman

$12-r$ Turner $: .2406$

- $x$. Sandhurst

- $v$. Saunders

86

- $v$ Turve

88

$-x$ Saward

$-x$. Schlesinger

2:29, 4 (4)

75

598

- $x$. Trnemouth 81

- r. Schmidt

$423-r$. U1verston

505

$-r$ Scott

$484-r$. Waite

87

$-r$. Seacroft

$31 \dot{8}$

$409-r$. Walbottle

504

$-r$. Selsby .

$80-r$. Walker

$-8,89$

- v. Sharman

$156-r$. Walsh

68,508

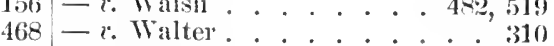

- v. Sharpe

$409-r$. Wantage

- $v$. Shaw

395

538

- $r$. Shintield

12. 197

- $x$. Smith $229,230,462,502,513,515$,

$-v$. Snowley

502,512

497

- $v$. Somerton

86

$-v$. Sow

505,513

- $v$. Spon Lane Colliery Co. 655,659

- $r$. Ward

162

— varminster . . . . . 90

- $x$. Warren

$23: 3$

- $x$. Watts . . . 321, 499, 504, 51 7

- $x$. Webb . . . . . 488, 489

- v. Welch

$45,101,103,503,523$

143

- $v$. Wenmoutl

474

- v. Spurrell

$81-v$. White .

86

$412,486,505$ 
[The paging refers to the [*] pages.]

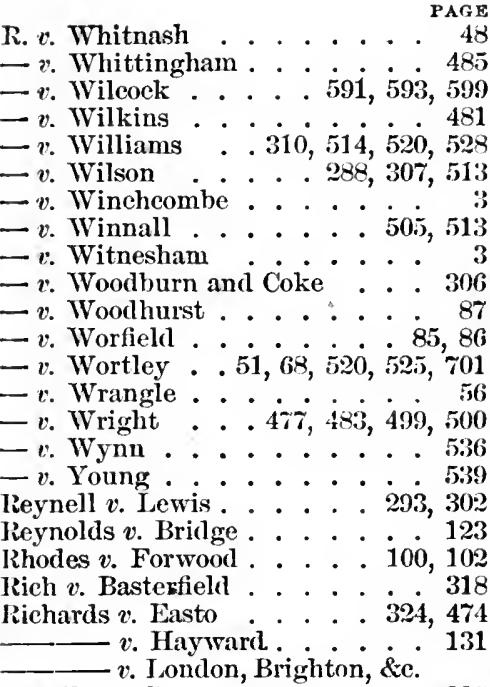

Railway Co. . . . . . . . . 327

[* ${ }^{*} \times x v$ ] Richardson $v$. Cartwright $2 \pi 8$ $v$ Coreoran . . . . 379 v. Dunn . . . . 392 $v$. Greese . . . . . 574

Riche $v$. The Ashbury Railway, \&c. Co.

Ricketts $v$. Benuett $\ldots 290,301$ Ridgway $v$. Hungerford Market

Co. . . . $11,145,150,222$ v. Ward . Add. \& Corr. 315

- $v$. Wharton ..... 43

Righy $v$. Connol . . . . . . . 634 $v$. Hewitt $\ldots . . .399,347$ Riley $v$. Baxendale . . . . . 235 — v. Packington . . . . . . . 279 $r$ Warden 53, 205, 604, 607, 608,

Rinıl $v$. Sampayo . . . . 245, 304 Risbourg $v$. Bruckner . . . . 138 Rist $v$. Faux . . . . . . . . 17 River Wear Commissioners $v$.

Adanıson . . . . 362, 414

Robbins $v$ Fennell . . . . 136

Robert Mary's case . . . . 155, 171

Roberts $v$. Brett . . . . . 184

- v. Ogilby ...... 136

- v. Shaw . . . . . 352

- v. Smith . . 201, 203, 261

- $v$. Tueker . . . . . 40,42, 43

- v. Walker . . . . . . 205

Rohins v. Cubitt . . . . . . . . 763 c Mas. \& SEr.
PAGR

196

Robinson's ease..
Robinson $v$. Pickering

315

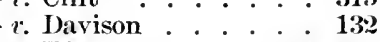

Robson $v$. Drummond

Roch $v$. Callen . . . . . . . $5 \sigma_{4}$

Rodrigues $x$. Melhuish . . . . 363

Roe $v$. Birkenhead, \&c. Railway

Co. . . 26, 369, 375,

Rogers $v$ Clifton . . . . . 429, 431

— v. Maenamara . . . . 466

Roper $v . J o h n s o n$. . . . . . . 183

Rosiere $v$. Sawkins . . . . . . 171

Ross $v$. Borer . . . . . . . 5 $\tilde{7} 4$

- $v$. Hill . . . . . . . . 327

Rossiter $v$. Trafalgar Life Assur-

ance Association . . . . . . 299

Rousillon $v$. Rousillon . . . . 109

Rontledge $v$. Hislop . . . . . 208

Rowe $r$. Roach . . . . . . 428

Rowlandson, Ex parte . . . 71

Rowning $v$. Goodehild . . . 376, 42:3

Ruckley $v$. Kiernan . . . . 438

Ruddock $v$ Marsh . . . . . 5

Rumsey $v$. Webh . . . . . 436

Rusby $v$. Scarlett . . . . . 277

Russell's Patent, Re . . . . 165

Rust $v$. Nottilge . . . . . . 100

Ryan v. Fowler . . . . . . 243

$v$. Jenkinson.... .997

Jyrler $v$. Nills . . . . . . . . lxii

- $v$. Wombwell ..... 12

\section{S.}

Sack $v$. Ford . . . . . . . 352

Saller $r$ Erans . . . . . . 393

- $v$ Henlock . . . 353, 35 (

- $r$ Johnson ....... 52

St. Anne $v$ Linnacan Society .. 80

St. Nicholas, Rocliester $v$. St. Bo-

tolph, Bishopsgate . . . . 12

Sainter $v$. Ferguson $46,113,119,120$,

Sammell $v$. Wright . . . . 350

Sanderson $v$ Aston ......20, 21

—_ Baker . . . . . 306

- $v$ Bell . . . . . 287

Sands v. Child . . . . . . 415

Santos $v$. Illidge . . . . li

Siunders, Ex parte . . . . 215 
[The paging refers to the [*] pages.]

\begin{tabular}{|c|c|}
\hline Whittle & \\
\hline unders $v$. Whittle & Simmons $v$. Wilmot \\
\hline riffiths... . 273 & Simonds $v$. Atkinson \\
\hline vage $v$. Walthew . . . . 133 & Simons $v$. Monier . \\
\hline$\therefore 173$ & $-v$. Patchett \\
\hline . . 230,231 & Simpson $v$. Cooke . \\
\hline .. . 424 & $-v$ Egginton \\
\hline . . 265 & — v. Robinson \\
\hline . . 363 & - $v$. Wells . . \\
\hline 204 & Sims $v$. Bond . . . \\
\hline rnogl $>$ ( & -v. Britain \\
\hline & asi, The . \\
\hline Rail- & Scallan. \\
\hline . . 346 & $v$. Fletcher \\
\hline n $\operatorname{Corr}$ & er, Ex parte $\dot{\text {. }}$ \\
\hline & $\begin{array}{l}\text { Eastern Counties Ra } \\
\text {. . . . . . 259, } 2\end{array}$ \\
\hline . . 389 & Slater $v$. Jewett . . . . . \\
\hline . . 530 & ath $v$. Wilson. \\
\hline IIanchester & Sleeman $v$. Barrett . $53,205,607,701$ \\
\hline . . . . . & eat Northern Railway \\
\hline . 367 & \\
\hline . . . 462 & case \\
\hline . . 254 & $v$. West Ham Union \\
\hline 309 & . 299 \\
\hline 5 & \\
\hline 327 & ingham Gas Co. \\
\hline . 136 & -v. Blakey. . \\
\hline [xxxvi] Sellen $v$. Norman $.208,209$, & $\begin{array}{r}397 \\
. \quad 23\end{array}$ \\
\hline . . 260,266 & $-v$. Cator \\
\hline . . 324,353 & $-v$. Gould \\
\hline . . 572 & - v. Great Eastern $\mathrm{I}$ \\
\hline & . 324,327 \\
\hline nwood . . . . 3 & . 188,196 \\
\hline $\operatorname{dox} \cdot \cdot \cdot 237,2$ & - . 445 \\
\hline . . . 47,135 & per. \\
\hline Naviga- & Glass Co. 2 \\
\hline 763 & 280,304 \\
\hline 162 & . 298 \\
\hline . 3978 & 32 \\
\hline lers $\dot{53}, \dot{205}, 607,701$ & $\begin{array}{l}\text {-v. Leveaux . } \\
v \text { v. London and }\end{array}$ \\
\hline .... 100 & Railway Co. . . . \\
\hline & - v. London and St. Kather- \\
\hline 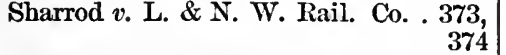 & ine's Dock Co. \\
\hline lip Colonial Gold & - v. Neale \\
\hline$\therefore \quad \therefore 330$ & -v. Smith \\
\hline $166,167,170$ & - v. Steele . \\
\hline . . . IX & $\therefore 429$ \\
\hline 36, 137, & $\begin{array}{l}.58,59,147,194 \\
. \quad .205,317,605\end{array}$ \\
\hline$\cdot$ & - v. Watson $\because$ \\
\hline ase $\cdot \cdot \cdot \cdot \cdot$ & 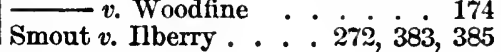 \\
\hline
\end{tabular}


[The paging refers to the [*] pages.]

Smyly $v$. Glasgow and Londonderry Steam Packet Co.

Snead $v$. Watkins

Snelling $v$. Lord Huntingfield .

Snowdon $v$. Davis

Somerset $v$. Hart .

Somersett's case . . liv, lvi, 161, 162

Somervill $v$. Hawkins . . . 430, 449

Somerville $v$. Gray : . . . . 257, 258

Sotilichos $v$. Kemp . . . . . . . 58

Souch $v$. Strawbridge . . . . . 38, 41

Soutlicote $r$. Stanley . . . . 237, 268

Southee $v$. Denny . . . . . . . . 463

Southern $v$. How . . 234, 235, 282, 329

Southerwood $v$. Ramsden . . 175, 181

Soutl, of Ircland Colliery Co. $v$. Waddle

Soutliwell v. Bowditch

Soutl Torkshire Railway Co. $v$. G. N. Railway Co.

Sowclon $v$. Mills

Sowerby $v$. Butcher

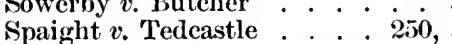

Spain v. Arnott . . 91, 140, 141, 221

Sparrow v. Paris . . . . . . . 123

Spartali v. Benecke . . . . . . 56

Spcar's case . . . . . . . . . . 482

Speck $v$. Phillips . . . 144, 194, 200

Spedding $v$. Nevell . . . . . . . 392

Speiglit $w$. Oliveira . . . . . 176, 177

[*xxxvii] Spencer's case . . . . 513

Spicer $v$. Barnard . . . . . . 319, 405

Spill v. Maule . . . . . . . 430

Spittle v. Lavender . . . . . . . . . 390

Spotswood $v$. Barrow 143, 150, 151, 192

Springhead Spinning Co. $v$. Riley 563

Sproul $v$. Hemingway . . . . 355, 356

Stables v. Eley . . . . . . . . 350

Stadhart $v$. Lee . . . . . . . . 204

Stagr v. Elliott . . . . . . . . . 298

Stinley (Lady) $v$. Earl of Slirews-

bury . . . . . . . . 127

Stanway $v$. Perry . . . . . . . 306

Stapleton $v$. Foreign Vineyard Association

Stead $v$. Dawber . . . . . . . 56

Steele $v$. Lester ... 327

-v. South-Eastern Railway $\mathrm{Co}, 354$

Stecle $v$. Williams . . . . . . 398

Stephens $v$. Badeock . . . . 394, 399

- $v$. Elwall . . . 416, 417, 418

Sterry $v$. Clifton ...... 47

Stettin, The . . . . . . . . 364

Stevens v. Armstrong . . . . . 333

$v$. Benning . . . . . . . 169 $v$. Gourley . . . . . . 355 Stevens v. Midland Railway Co. 27, 323, $32 \%, 344$

v. Woodward . . . . . . 342

Stevenson $v$. Mortimer . : . . . . 3933

Stewart $v$. Beaumont . . . . 28.5, 286

Stiles $v$. Cardiff Steam Navigation

Co. . . . . . . . . . . 27, 324

- $v$. Granville . . . . . . 13

Stilk $v$. Meyrick . . . . . . . . 198

Stimson $v$. Hall . . . . . . . . 208

Stirling $v$. Maitland . . . . . 102, 189

Stoek r. Harris . . . . . . . 376, 4थ3

Stocker $v$. Brocklebank $62,66,71,132$,

$\tau$. Wedderburn . . . . 126

Stokes $v$. Eastern Counties Riail-

way Co. . . . . . . . . . . . 325

- v. Grissell . . . . . . 115

Stone v. Cartwright . . . . . . . . 332

$v$. Cheshire Railroad Corpora-

tion . . . . . . . . 262, 334, 354

—.Hyde . . . . . . . . . 765

— $\because$ Marsh . . . . . . 173,530

Storey $v$. Ashton . . . . . 336, 341

Stowell $v$. Robinson . . . . . . . 56

Strange $v$. Lee . . . . . . . . . 20

Strode v. Dyson . . . . . . . 286

Stroud $v$. Watts . . . . . . . . 423

Stuart v. Evans . . . . . . . 763

- . Welch . . . . . . 136

Stubbing $v$. Heintz . . . . . . . 299

Stublos $v$. Holywell Railway Co. 22:3,

224,223

Sturmy $v$. Sheriff of Middlesex . 306

Sullivall $v$. Waters . . . . . . 237

Sumniers $v$. Solomon . . 277, 280, 287

$v$. The City Bank. . 10

Sutton $v$. Clark . . . . . . . \%3, 379

Swaine $v$. Great Northem Railway

Co. . . . . . . 127

Swainson $v$. Nortl-listern liail-

way Co. . . . . . . 247, 255

Swan, Re . . . . . . . . . 276,330

v. Australasian Co. . . . 330

Swect $v$. Benning . . . . . . 169

—v. Lee . . . . . . . 44, 48

Sweeting $v$. Pearce . . . . . . 287

Swift $v$. Winterbotham . $2 \% 2,329,421$

— v. Jewsbury . . . . 27\%, 329, 421

Swire v. Franeis . . . . . . 330

Sword v. Cameron . . . . . . 262

Syers $x$. Jonas . . . . . . . . . 56

Sykes $v$. Dixon . . . . 44, 98, 158

一 $v$ Giles . . . . . . . . 287

—. North-Eastern Railway Co. 173

-v. Sykes . . . . . . 397 
[The paging refers to the [*] pages.]

Sylvester, Ex parte

Symmons $v$. Want

Syria, The

\section{T.}

Tall $v$. Ryland .

Tallis $v$. Tallis $115,117,118,119,122$

Tanner $v$. Christian . . . . . . . 389

Tarrant $v$. Webb . . . . . , 259

'Tarry $v$. Ashton . . . . . . . . 352

Tasker $v$. Shepherd . . - 19, 217, 218

Tassell v. Coopar . . . . . 136, 30ј

Tatton $v$. Wade . . . . . . . . . 468

Taylor $v$. Brewer . . . . . . . 201

- $v$. Caldwell 218, 224, 225, 226,

228

v. Carr

$2: 0$

$\checkmark r$. Greenhalgh . . . . 332, 352

$-v$. Hawkins 429, 430, 442, 448,

459

$-v$. Laird . . 190, 191, 223, 228

-v. Neri . . . . . . 156, 464

$v$. Rowan...... 467

Teed $v$. Beere . . . . . . . . . 530

Templeman $v$. Trafford . . . . . 317

Ten Tailors of Exeter $x$. Clarke . 111

Teneh $v$. Roberts

69

Terry $v$. Hutchinson . . . . . . 177

Thames Conservators $v$. Hall . . $36 \overrightarrow{5}$

[*xxxviii] Thetford's, Mayor of, case

Thetis, The . . . . . . . . . 329

Thomas $v$. Bisliop . . . . . 386, 387

$-v$. Churton . . . . . . 444

— ¿. Edwards . . . . . . 303

- . Hopkins . . . . . . . 211

$v$ Williams $2,36,47,189,211$,

Thompson v. Bell . . . . . . . $\begin{array}{r}278 \\ 278\end{array}$

- $v$ Gibson . . . . . . . 409

- r. Havelock . . . .. . . 163

$\longrightarrow v$. Hervey .. . . . $\cdot \cdot$

v. North-Eastern Railway Co. . . . . . 347

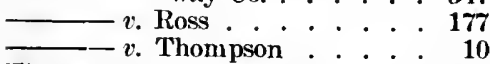

Thompson $x$. Davenport 291, 303, 383,

Thorncroft $\imath$. Lashmar . . . . . 575

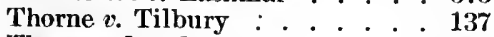

Thorogood v. Bryan . . . . 347, 348

Thorold $v$. Snith . . . . . . . . . 293

Thrupp $v$. Collett . . . . . . . . . . 570

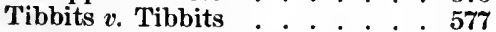

Tilson $v$. Warwick Gaslight Co. . 25
Timothy $v$ Pimpson

370

Tobin $v$. Crawford . . . . . . . . 282

— $v$. Reg . . . . . . . . . 415

Todd $v$. Emly . . . . . . . . . 302

Todd $x$. Kerrich . . . . . . . . 95

๑. Robinson . . . . . . 276, 293

Tomlinson $x$. Bentall . . . . . . 233

Tonnet $v$. Cripps . . . . . . . . 42

Toogood $r$. Spyring 44:3, 45i, 459, 460,

461

Tope $v$. Hockin . . . . . . . . 396

Toplis $x$. Grane . . . . . . . . 234

Torrence $v$. Gibbins 17:, 173, 178, 180

Totterdell $v$. Fareham Blne Brick

and Tile Co . . . . . . . 279

Towne $v$. Campbell . . . . . . 89

Townsend $r$. Windham . . . 566, 570

Townson $v$. Wilson . . . . . . . . . 398

Trent $x$. Hunt . . . . . . . . . 151

Trimmer $v$. Danby . . . . . . . 573

Trinity $v$. St. Peter's in Dorchester $8 \boldsymbol{7}$

Trottman $v$. Dunn . . . . . . 445

Trueman $v$. Loder . . . . . 291, 305

Tuff $\varkappa$. Warman . . . . . . . . 346

Tugman $x$. Hopkins . . . . . . 399

Tullidge $x$. Wade . . 174, 176, 179, 180

Tunney $v$. Midland Railway Co. . 255

Turberville $\imath$. Stamp . . 217, 324, 325

Turner $v$. Evans . . . . . . . . 127 $\longrightarrow$ Great Eastern Railway

Co. . . . . . . . . . . 353

$r$. Mason . . . . . 141

Turner $\imath$. Robinson $91,134,144,145$,

Turney v. Bayley .. . . . . 78

Tuson $v$ Evans . . . . . . . . . . 442

Tyne Improvement Commissioners

$v$. General Steam Navigation Co. 362

U.

Udell $v$. Atherton . 283, 294, 329, 330

Underhill $x$. Longridge . . . 653

United Service Co. $v$. Johnson, Re. 359

- States $v$. City Bank of

Columbus . . . . . . . 30?

Unwin $v$. Leaper . . . . . . 312

\section{V.}

Valpy $v$. Manley . . . . . . . . 398

Vanderburg $v$. Hnll . . . . 70

Vaughan $v$. Booth : . . . . 568

$v$. Cork and Youghal Railway Co. . . . . . . 346 
[The paging refers to the ["] pages.]

Vaughan v. Moffatt . PAGR

- $v$. Taff Vale Railway Co. 354 $v$. Walker

Vaughton $v$. Brine

$v$ London and Nortl-

Western Railway Co. . . . 325

Veal $v$. Veal . . . . . . . . . 573

Velasquez, The . . . . 363

Venables $v$. Smith . . . 327, 341, 350

Venes $v$. Marriott . . . . . . . 572

Vere $v$. Ashby . . . . . 273

Verrall $v$. Robinson . . . . . 420, 421

Verry $v$. Watkins . . . . . . 180

Vesta, The . . . . . . . . 362

Vibert $v$. Eastern Telegraph Co. 96

Vicars $v$. Wileocks . . . 464, 465, 466

Vollans $v$. Fleteher . . . . . . 50

Vose $v$. Lancashire, \&c., Railway

Co. . . . . . . 249, 250,261

Vrede, The ........ 199

W.

Walling $v$. Oliphant . . . . . 36

Wagstaff $v$. Wilson . . . . . . . 289

Wain $v$. Warlters . . . . . . . 43

Waite's case . . . . . . . . . . . 497

Waite $v$. North Eastern Railway

Co. . . . . . . . . . 348, 349

Wake $v$. Harrop . . . . . . 389

[*xxxix] Wakefield $v$ Newbon . 398

Walker, Ex parte . . . . . . 216

— v. Goe Great Western Railway

Co. . . . . . . . 290

v. Guarantee Association . 133

ב v. Hirseh . . . Add. and Cor.

v. Hunter . . . . . . 274

$v$. Mills . . . . . . . . 405

$v$. South Eastern Railway Co. . . . . . . 27, 342

Waller $v$. Loeh . . . . . . . . . 451

- $v$ South Eastern Railway Co. . . . . . . 239, 240

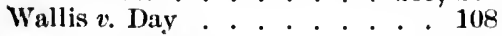

— Litteli . . . . . . . . 5 5

v. Snith . . . . . . . . 123

Wallwork, Ex parte . . . . . . 605

Walrond $v$. Walrond . . . . . . . $\quad 8$

Walsh $v$. Sontliworth . . . . . . . 4

Walters, Ex purte.

Walther $v$. Mess
Walton $r$. Lonclon, Brighton and

S. C. Railway Co. . . . 346

Wanstall $v$. Pooley . . . . . . . 334

Warburton $v$. Great Western Railway Co. . . . $.96,250$
Byrne . . . . . $116,120,121$ way Co. $v$ Heyworth $. .4 .90,702$
Ward $v$. Byrne . . . . $116,120,121$

L Evans . . . . 293, 296

$v$ General Omnibas Co. . . 3:3

$v$ Lee . . . . . 424, 425 ^. Lloyd . . . . . . . . 5:31

Warkworth, The . . . . . . 364

Warner $x$. Willington . . . . 43

Warren $x$. Warren . . . . . . 442

Warwick $v$. Fonlkes . . . 437

Waters $v$. Brogden . . 296, 297, 301

Watkins $\because$ : Great Western Rail-

way Co. . . . . . 237

- $v$. Wince . . . . . 282

Watling $r$. Oaster . . . . . 264

- $r$ Walters . . . . . 233

Watson, Exparte . . . . . 71,74

- v. Christie . . . . . . 138

$v$ Earl Charlemont . . . 32!

$v$. Murrel . . . . . . 389

$v$. Threlkeld . . . . 6

Wangh $v$. Carver . . . 61, 62, 7:3

Way $v$. Great Eastern Railroad

Co. . . . . . 325

Wayland's case . . . . 27t, 277

Wayland $v$ Elkins . . . . . . 332

Weatherston $v$. Hawkins . . 429, 447

Weaver $r$. Floyd . . 53, 604, 607, 645

Webb $\varepsilon$. England . . . . . 139, 185

T. Eatst . . . . . . 427

Webster $v$. Dillon . . . . . . . 132

Weedon $r$. Woodh

Weeks $v$ Macnamara. . . . . . 323

we Propert . . . . . . 392

Weir v. Bell . . . . . . . . . . 329

Welchman v. Sturgis . . . . . 219

Wellock $v$. Constantine . . . . . 529)

Wells $v$. Abraham . . . . . 173, 529

Welsh v. Iawrence . . . . . . . 33i5

Wenman $r$ Ash $\ldots . . .442,457$

Wennall $r$ Adney . 230, 231, 232, 2333

Wentworth v. Cook . . . . 225

West London Commercial Bank $r$. Tubb

Kitson . . . . . . . 392

West Riding and Grimsly Railway Co. $r$ Wakefield Local

Board of Health . . . . . . . 357

West r. Smallwood . . . . . . . 701

Westropp $x$. Solomons . . . . . 234

Westwick $\iota$. Thoodor . . . . 78, 1399

196 Wharton $x$. Mackenzie . . . 12

(37) 
[The paging refers to the [*] pages.]

Whatman $v$. Pearson . . . . . $\begin{array}{r}\text { PAGE } \\ 379\end{array}$

Wheatley $v$. Patrick . . . . . . 336

Wheeler $v$. Haynes . . . . . . 461

Whincup $v$. Hughes . . . . . . 218

Whitaker $v$. Howe . . . 117, 121, 124

Whitamore $v$. Waterhouse . . 135, 323

Whitbrcad v. Brooksbank . . . 395

Whitcomb $v$. Whiting . . . . . 49

White v. Bailey . . . . . . 80, 82

$\longrightarrow v$. Bartlett . . . . . . 136,396

- v. Boulton . . . . . . . 327

- v. Crisp . . . . . . . . 321

- v. Cuyler . . . . . . 5

$\longrightarrow v$. France. . . . . . . . 237

—_ $v$. Hindley Local Board . 381 v. Jameson . . . . . . 367

v. Spettigue . . . . . 173, 530

Wlitehead $v$. Tuckett . . . . 272, 292

Whitehouse $v$. Birmingham Canal Co.

Whitley $v$. Adams Fellowes * * * 380

$-v$. Armitage . . . . $\quad .53,701$

¿ v. Pepper, . . . . 325, 357

Whitfield $v$. Lord le Despencer, 377, 422 v. S. E. Railway Co. 27,327 ,

Whitman $v$. Pearson . . . 336, 337

Whittle $v$. Frankland . . . . 44, 102

Wickham v. Gattrell . . . . . 530

Wicks, Ex parte . . . . . . . . 210

Wiems $v$. Mathieson . . . . . . 251

Wiggett $v$. Fox. . . . . . . 246, 248

Wigmore $v$. Jay . . . . 243, 244, 257

Wildes $v$. Norris . . . . . . . . 378

Wilds $v$. Hudson River Railroad

Co.

$\left.{ }^{*} \mathrm{xl}\right]$ Wiles $v$. Cooper . . . . . . 701

Wilkin $v$. Read ......... . 467

Wilkinson $v$. Evans . . . . . . 43

- v. Fairrie ....... . 237

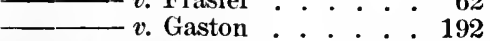

Willett $v$. Boote . . . . . . 333, 334

Willetts $v$. Green . . . . . . . . 151

Williams $v$. Birne . . . . . . 87, 92

${ }^{v} v$. Chambers . . . . . 35,211

v. Clough . . . . . 263, 264

$v$. Corbet . . . . . . 577

v. Cranston . . . . 327, 416

v. Everett . . . . . 402

$v$. Gardiner . . . . . . 461

$v$. Great Western Railway Co. . . . . 327 v. Hedley . . . . . . 397 v. Jones . . . . . . . 325 v. Piggott . . . . . 293,302
PAGE

Willianıs $v$. Stott . . . . . . . 502, 508

Williamson $v$. Barton . . . . 384

- $v$. Frere . . . . . . 439

$v$ Taylor . . . . 45, 98

Willis $v$. Child . . . . . . . . 185

Wills $v$. Nurse . . . . . . . . . 7

Wilmot $v$. Smith . . . . . . . . 280

Wilson $v$. Anderton . . . . . . 420

$v$. Cookson . . . . . . 605

$v$. Glasgow Tramways and Omnibus Co. . . . . 763

v. Lancashire and York shire Railway Co. . . 328

- $v$. Merry . . . . . . 257

v. Newport Dock Co. . . . 355

v. O'Leary . . . . . . 574

— $v$. Peto . . . . . . . . 409

v. Rankin . . . 339,344

$v$. Robinson . . . . 437, 456

— $v$. Stewart . . . . . . 306,407

- $v$. Tumman . . . . . 49, 274

v. Viscount Curzon . . 206

r. West Hartlepool Railway

Co. . . . . . 22, 282, 287

- $v$. Zulueta . . . . . . . 51

Wilton $v$. Royal Alantic Mail Steam

Navigation Co. . . . . . . . . 326

Winch $v$. Conservators of River

Thames .. . . . . . . . 381

Windsor, Re. . . . . . . . . 519

Winkfield $v$. Packington . . . . 278

Winsmore $v$. Greenbank . . . 158, 175

Winstone $v$. Linn . . . . . . . . 78,139

Winterbottom $v$. Wright . . 237, 376

Wise $v$. Wilson . . . 78, 139, 144, 146

Wish $v$. Small ......... . . 70

Withington $v$. Herring . . . . . 273

Woburn Abbey, The . . . . . . 364

Wolfe $v$. Mathews . . . . . . . 634

Wolley $v$. Pole . . . . . . . . . 132

Wood $v$. Benson . . . . . . . . 47

-v. Fenwick ........ 13

v. Smith . . . . . . . . 363

Woodgate $v$. Knatchbull . . . . 306

Woodin $v$. Burford . . . . 283, 286

Woodley $v$. Coventry . . . . . . 278

$v$. Metropolitan Railway

Co. . . . . . . . . . . 237

Woodward $v$. Lander . . . . . 458

Woolt $v$. Beard . . . . . . . . 348

Woollen $v$. Wright . . . . . . . . 274

Wolverhampton and iValsall Railway Co. $v$. London and Nortl-

Western Railway Co. . . . . . 132

Wormell $v$. Hailstone . . . . . 33

Worthington $v$. Sudlow . . . . . 100 
[The paging refers to the [*] pages.]

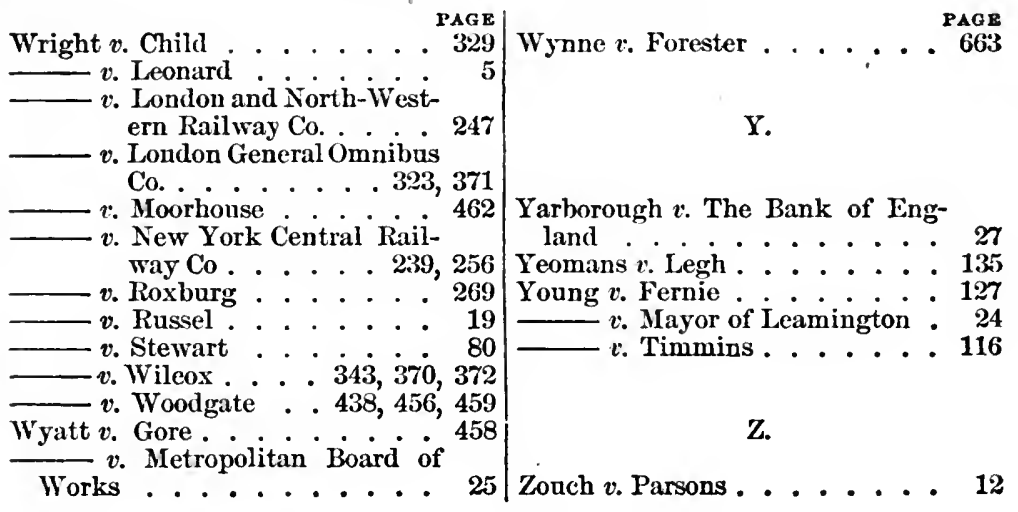





\section{TABLE OF STATUTES.}

[The paging refers to the [*] pages.]

PAGE

[*xli] 23 Edw. 3, c. 8 . Ivi, Ivii, lviii 25 - st. 1 . . . l lvii, lviii, lix $34-$ st. 5 ec. $9,10,11 \cdots 171,471$

36 - c. 8 . . . . . . . lvi

37 ce. $8,9,11,14$. . . lix

1 Ricl. 2, c. 7 . . . . . . . . lix

2 - c. 8 . . . . lvi, lix

$12-$ cc. $4,6,8$. . . . lix

16 - c. 4 ...... . . lix, 93

20 - c. 1,2 . . . . . lix, 93

1 Hen. 4, c. $\tau$. . . . . . lix, 93

2 - c. 21 . . . . . . . . lix, 93

$7 \longrightarrow$ c. 14 ....... . lix

$11-$ c. 4. . . . . . . $\operatorname{lix}$

13 с. 3. . . . . . . . lix

4 Hen. 5, c. 4 . . . . . . . lix

2 Hen. 6, c. 14 . . . . . . . . lix

6 - c. 3 . . . . . . . . lix

8 - ce. 4,8 . . . . . . $\operatorname{lix}$

$23-$ c. 13 . . . . . . . . . lix

3 Edw. 4 , c. 5 . . . . . . . lix

$4-$ c. 1 . . . . . . . lix

8 - c. 2 . . . . . . . lix

12 - c. $4 \ldots . . . . \operatorname{lix}$

17 - е. 3 . . . . . . $\operatorname{lix}$

$22-$ c. 1 . . . . . . . lix

11 Hen. 7, c. 2 . . . . . . . lix

21 Hen. 8, c. 7 . . . . . . 480

$22-$ c. 9 ........ 471

$24-$ c. 13 . . . . . . . . lix

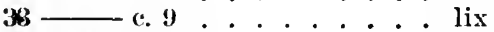

$34 \& 35$ Hen. 8 , e. 1 . . . . . . lix

1 Elw. 6, c. 12 . . . . . . lix, 471

1 Mary, c. 1 . . . . 471,480

1 Eliz. c. 12 . . . . . 313

5 - 4 . Iviii, lx, 157, 472, 696

с. 10 . . . . . . . . . 480

43 c. 2 .. . . . . . . . . 15

3 Car. 1, c. 4 . . . . . lix

1 Jac. 1, c. 6. . . . . . lix, lx

$22 \& 23$ Car. 2, c. 1 . . . . 306

29 Car. 2, c. 3 . . . . . . . 33

7will e. 7 . . . . . 48

8 \& 9 Will. 3 , c. $36 ;. .0609$

$9 \& 10$

309) 5!

1 Ann. st. 2, c. $18 \ldots . .579,609$

5 - c. 14 . . . . . 4 405

6 - е.31 . . . . . . 324

$9-$ c. 30 . 609

12 Geo. 1 , e. 341 xi, $585,599,609,696$

13 Gco. 2. c. 8 . . 579, 580, 581, 601

15 - c. 13 . . . . 497, 535

20 - c. 19 ... lxi, 542, 701

— c. 43 . . . . . . 639

$22-$ c. 27 . . 579, 588, 589, 592,

_ c. 46 . . . 599,610

27 - c. 6 ....... lxi

29 - c. 33 . . . . . $1 \mathrm{l}$

$31-$ c. 11

5 Geo. 3, c.51 . . . . . . 696

6 - e. 25 . . . . lxi, 54:

12 - с. 73 ...... 324

14 _ с 44 ...... 58:

$15-(678 \cdots$

$17-$ c. $56.582,583,584,585$,

583,610

$18 \longrightarrow$ c. 47 ...... 15

19 - c. 49 - . . . . . $6 ! 96$

$32-$ c. 44 . . . . . 610

- c. 56 . . . 4 467, 468

$33-$ c. 55 . . . . lxi, 695

36 - c. 22 . . . . . 315

$37-$ c. 123 . . . . . . 564

$39-$ c. 56 . . . . . $1 \mathrm{r}, \mathrm{lx}$

с. 79 . . . . . 525,564 $497,501,50 \%, 503$

$506,518,53 \%$

41 - e. lxxxvi . . . . 360

42 - с $46 \ldots . . .15,624$

—— c. $73 . . . .1 \times 1 \mathrm{xii}, 760$

$50-$ с. 59 . . . . . . . 532

$52-$ c. 104 . . . . . . . . 564

—— 143 ...... . 537

53 - c. $40^{\circ}$. . . . . . $1 \mathrm{x}$

56 - c. $1399 . . . . .15$

[*xlii] 57 (reo. 3, (. 1!) . . 525, 564

— c. 68 . . . . . 423

- c. $1 \mathrm{x}$. . . . . . . 407

$58-$ c. 51 . . . 582, 591, 605

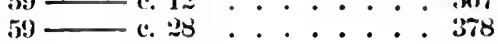


The paging refers to the [*] pages.]

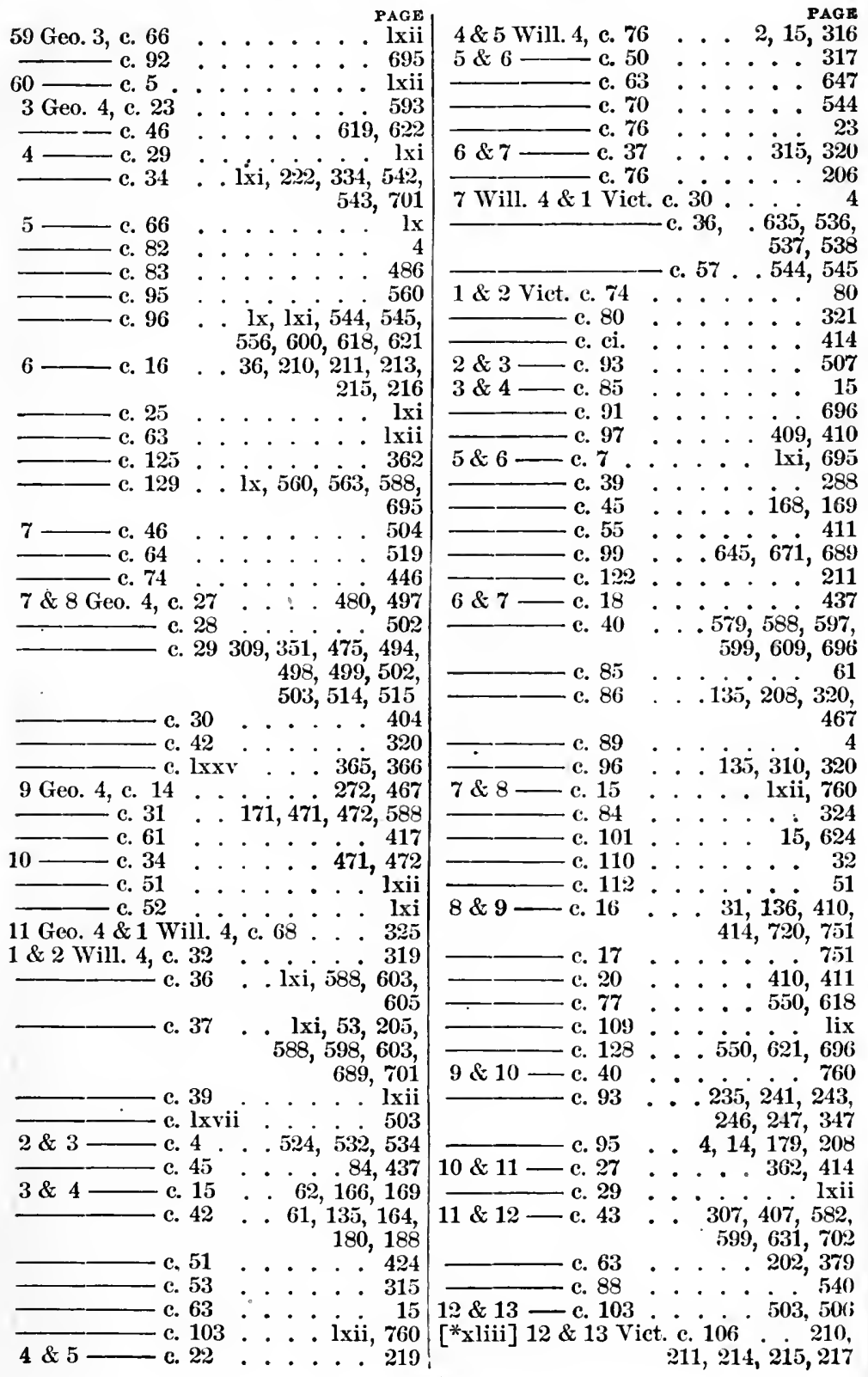


[The paging refers to the $\left[{ }^{*}\right]$ pages.]

$13 \& 14$ Vict. c. 21

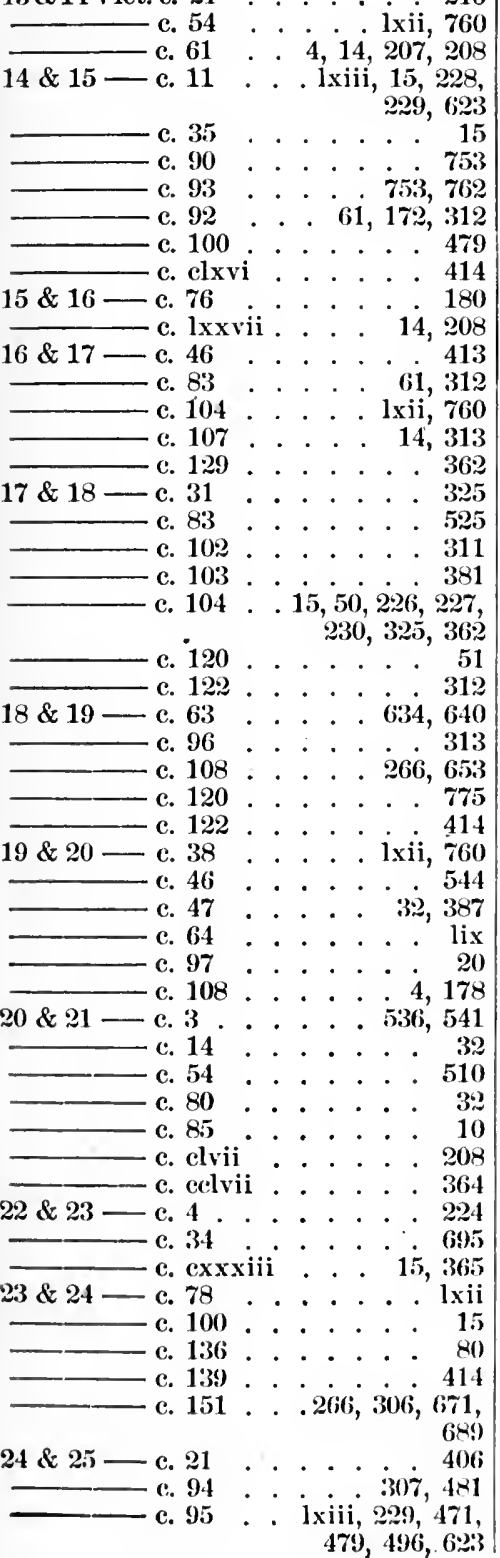

24 \& 25 Vict. c. 96 PAGF $412,475,476,478$ $479,488,491,495$, $496,497,498,500$, $502,505,506,510$, $515,524,526,527$, $528,532,534,537$.

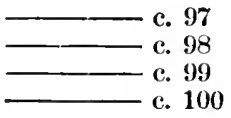

541

474,478

-. $\dot{308}, 412,535$

. . . . 308 lxiii, 171,228 , $229,413,471$, $472,495,496$, $623,624,695$ c. 101 . . . $315,597,599$
c. 117 . . $1 \times 1 \times, 760$ $25 \& 26-$ c. 8 . . . . . . lxii

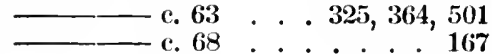
c. 79 . . . . . . . 671 - c. 89 . . . $31,278,6: 34$

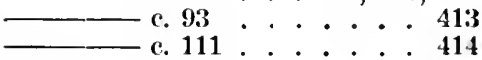

$26 \& 27-$ c. 38 . . . . . . . Ixiii c. 40 . . . . . 1xiii, 760 — c. 41 . . . . . . . 103 . . . . . $487,6 \% 5$ c. 112 . . . . . . 414 c. 124 . . . . 125 . . . lviii, lix, 157 $27 \& 28-$ c. 37 . . . . . . 15 - 44 . . . . . . . 11 c. 47 . . . 412, 478, 5i35 c. 48 . . . . 1xii, 761 c. 53 . . . . . 751,762

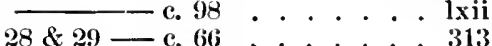
c. 86 . . . . . . 60 — c. 90 . . . . 320,475 29\&30- c. 104 . . . - . 90313 $30 \& 31-$ c. 8 . . . . . . $1 \times v$ — c. 59 . . . . . . $1 \mathrm{x}$ c. $7.4 . \circ . \cdot . \cdot . \cdot 1 \times v$ c. 94 . . . • $\bullet 617$ c. 103 . . lxii, lxiv, 761 c. 105 . . . 1xi, lxiv, 15 , $554,5.51,5.56$

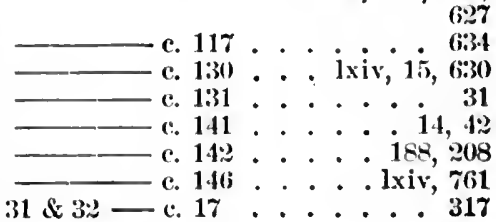
(43) 
[The paging refers to the [*] pages.]

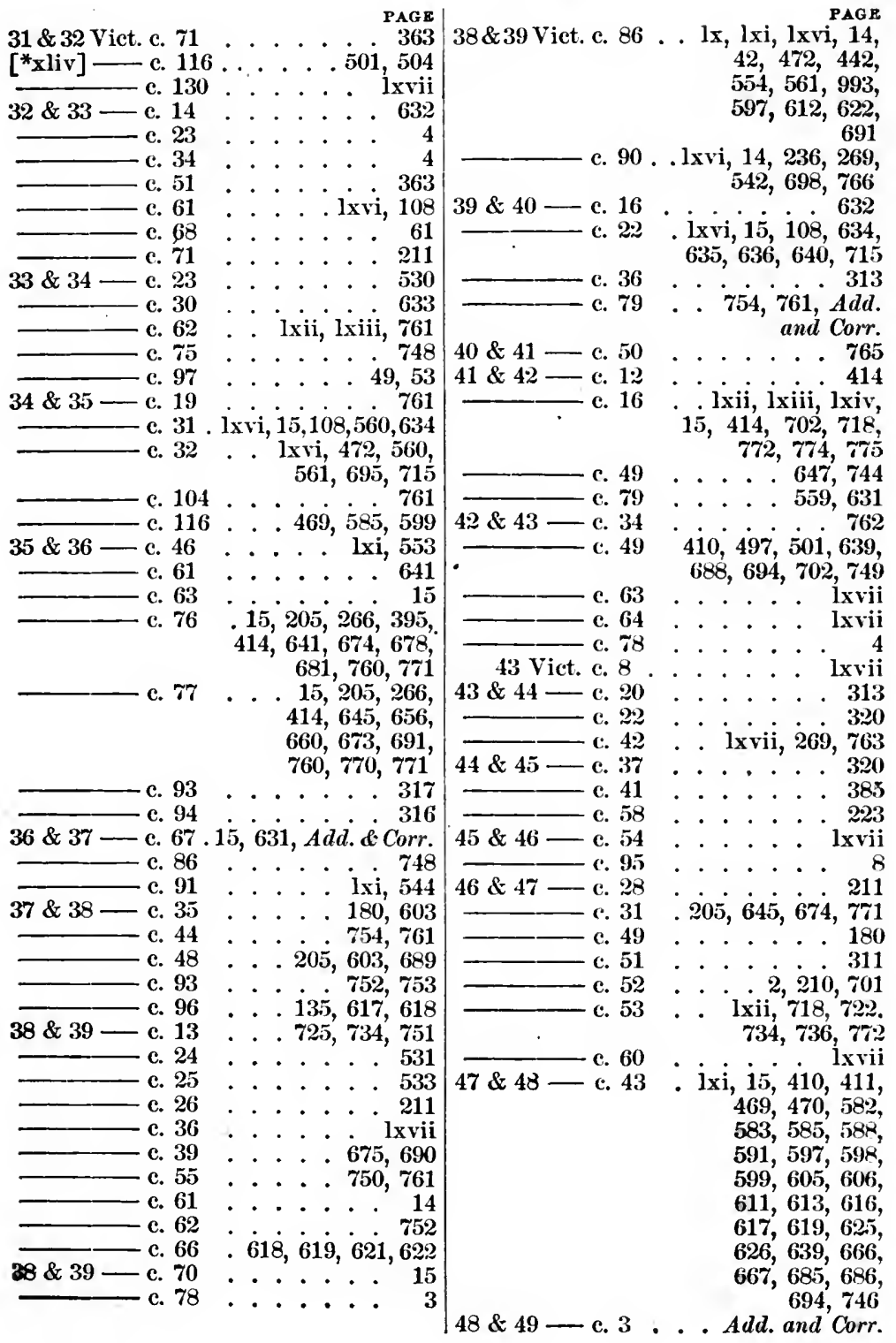




\section{ALPHABETICAL TABLE.}

Showing the various Statutes applicable to Workmen, \&c., in particular Trades, \&c.; under many of uhich Jurisdiction is given to Magistrates (a).

Agriculturat, Gaxgs.

30 \& 31 Viet. c. 130, post, p. 630.

Agricultural, SErviNts, misippropriation of eorn, \&e. by. $26 \& 27$ Viet. c. 103, post, p. 625 .

BAKEITOUSES.

$41 \& 42$ Vict. c. 16, post, p. 759.

B.allastuex (except Trinity Ballastmen). See Bargemen.

Bargeyen, Ligmtermex, Watermex, BAllastuex (except Trinity Ballastmen), Coalwhippers, Coal Porters, Sailors, Lumpers, Riggers, SimpWRIGHTS, CAULKEks or other labourers who work for hire in and npon the River Thames, or the docks, creeks, wharres, quays or places adjacent, not heing in the City of London or the liberties thereof, and the Owners, Masters or Commanders of Vessels, or their Agents, on the said river, or the docks or creeks therennto adjoining, or the Owners, Wharfingers or Occupiers of sucle wharves or quays, or their Agents or other Employers; respecting wages or money dne to sueh labourers for work or loss of time, whether the same persons be emploved for any certain time or in any other manner.

$2 \& 3$ vict. e. 71, s. 37.

BoOt And SHOLMAKers. See Leather and Shoemakers.

Breecues Makens. See Leather.

C.IPankms. See Hatmakers.

C.aulkers. See Bargemen.

Ćnildrey's Daxgerous Performaxces ACt, 1879.

$42 \& 43$ Vict. e. 34 post, p. 762 .

Chimeysweeps.

$3 \& 4$ Vict. c. 85, post, p. 15 , note (b).

$27 \& 28$ Vict. c. 37.

38 \& 39 Vict. c. 70.

$47 \& 48$ Vict. e. 43.

(a) The Truck Act, $1 \& 2$ Will. 4, c. 37 , post, p. 60: ; the Summary Jurisrliction Acts, $11 \& 12$ Vict. c. 43 , and $42 \& 43$ Vict. c. 49 ; the Employers and Workmen Act, 1875 , 38 \& 39 Vict. c. 90 , post, p. 698 , the Factory and Workshop Act, 1878, 41 \& 42 Vict. c. 16 , post, p. 718. and the Pavment of Wages in Public Houses Prohibition Act, 1883,46 \& 47 Vict. c. 31, post, p. 771, apply to most trades. 
[*xlvi] Clock axd Watchumakes.

27 Geo. 2, c. 7. See $47 \& 48$ Vict. c. 43.

Crothiers. See Woollen Manufacturers.

5 Geo. 3, c. 51 . See $47 \& 48$ Vict. c. 43 .

14 Geo. 3, c. 25.

Coal Mines. See Mines.

Conl Porters. See Bargemen.

COALWHIPPERs. See Bargemen.

ColduERs. See Mines.

$39 \& 40$ Geo. 3 , c. 77 (except sects. 1 and 5 , which were repealed by 7 $\& 8$ Geo. 4 , c. 27 ; sect. 8 and part of sect. 10 were repealed by $47 \&$ 48 Vict. c. 43$)$.

$24 \& 25$ Vict. c. 96, ss. $38,39$.

$24 \& 25$ Vict. c. 97 , ss. $1112,26-29$.

Cotron Manufactories. See Factories, Hosiery.

1 Ann. st. 2, c. 18 (made perpetual 9 Ann. c. 30).

13 Geo. 2, c. 8.

22 Geo. 2 , c. 27, post, p. 579.

14 Geo. 3, c. 44 . (Sect. 1 was repealed $34 \& 35$ Vict. c. 116).

17 Greo. 3 , c. 56, post, p. 588 .

DYERS AND HoTPRESSERS.

22 Geo. 2 , c. 27 , post, p. 579.

17 Geo. 3, c. 56. See sect. 17, post, p. 597. (This Act was not repealed as to Dyers by $6 \& 7$ Vict. c. 40, post, p. 609 . See R.v. Button, 11 Q. B. 941).

EMPloyers AND WorkMeN ACT, 1875, 698.

\section{Factories.}

The exemption of factories from $11 \& 12$ Vict. c. 43 (by sect. 35 of that act) was repealed by $34 \& 35$ Vict. c. 104.

See now-

$41 \& 42$ Vict. c. 16, post, p. 718 .

$46 \& 47$ Vict. c. 53, post, p. 772 .

FELT. See Hatmakers.

Fuax. See Factories, Hosiery.

22 Geo. 2, c. 27 , post, p. 579.

14 Geo. 3, c. 44 . (Sect. 1 was repealed by 34 \& 35 Vict. c. 116).

17 Geo. 3, c. 56, post, p. 588.

Framework KNITTERS.

28 Geo. 3, c. 55 . (Sect. 4 was repealed by $34 \& 35$ Vict. c. 116).

Fur. $\quad 22$ Geo. 2, c. 27 , post, p. 579.

Fustian. 17 Geo. 3, c. 56, post, p. 588.

Glass Works.

$41 \& 42$ Vict. c. 16, post, p. 759.

Glovemakers. See Hosiery and Leather.

Hackney Carriages. Disputes between Proprietors and Drivers.

$1 \& 2$ Will. 4 , c. 22, s. 29.

$6 \& 7$ Vict. c. 86 , s. 22 .

$16 \& 17$ Vict. c. 33. 
[The paging refors to the [*] pages.]

HAIr. See Mohair.

HATMAKERS.

22 Geo. 2, c. 27 , post, p. 579.

17 Geo. 3, c. 11. (Partly repealed by $24 \& 25$ Viet. e. 101.)

17 Geo. 3, e. 55 ; and see also $47 \& 48$ Vict. e. 43.

17 Geo. 3 , c. 56 , post, p. 588.

Hemp, Maxufacturers of Hexp, or Hemp mixed witi WoOI, Fur, Flax, - Mohatr or Sirk. See Factories, Hosicry. 22 Geo. 2, c. 27 , post, p. 579.

14 Geo. 3, c. 44 . (Sect. 1 was repealed by $34 \& 35$ Vict. c. 116).

- 17 Geo. 3 , c. 56 , post, p. 588.

Hosiery. See Factories.

Persons engaged in the manufacture of woollen, worsted, linen, cotton, flax, mohair or silk materials in, on, or by the stoeking frame warp machine, or any other machine employed in the manufacture of framework, knitted or looped fabrics, and every trade, occupation, operation or employment whatsoever eonnected with or ineidental to the manufacture of stockings, gloves and other articles of hosiery.

Framework knitters.

28 Geo. 3, c. 55 . (Sect. 4 was repealed by $34 \& 35$ Vict. c. 116) $6 \& 7$ Viet. c. 40 , post, p. 609.

Ticket; of work (pursuant to 5 Geo. 4, c. 96, s. 18). $8 \& 9$ Vict. c. 77 , post, p. 618.

Payment of wages without stoppages.

$37 \& 38$ Vict. c. 48 , post, p. 689.

Hotpressers. See Dyers.

Husbaniny, Servants iv. See Agricultural Gangs; Agricultural Scrvants.

Note.-1 \& 2 Will. 4, e. 37 , does not apply to servants in husbandry ; see sect. 20, post, p. 607. But the Employers and Workmen Act, $1875,38 \& 39$ Vict. c. 90 , does, see sect. 10 , post, p. 701.

Irow. 22 Geo. 2, c. 27 , post, p. 579.

17 Geo. 3 , c. 56, post, p. 588.

JAPANNED GOODS.

$1 \& 2$ Will. 4, c. 37 , post, p. 603.

$\left.\begin{array}{l}\text { Kenlamen. } \\ \text { LABOURERs. }\end{array}\right\}$ See Bargemen.

Leatirer-Manufacturkrs of Leather Breeches, Gloves, \&c.

1 Ann. stat. 2, c. 18, made perpetual 9 Ann. c. 30.

13 Geo. 2 , c. 8 , s. 4 .

22 Geo. 2 , c. 26 , post, p. 579.

17 Geo. 3 , c. 56 , post, p. 588 .

Lightermex. See Bargemen.

Thames, $22 \& 23$ Vict. e. exxxiii.

Linen. See Factories; Hosiery.

22 Geo. 2, c. 27 , post, p. 579.

14 Geo. 3 , c. 44 . (Seet. 1 was repcaled by $34 \& 35$ Vict. c. 116).

15 Geo. 3 , c. 14.

17 Geo. 3 , c. 56 , post, p. 588 .

6 \& 7 Vict. c. 40 , post, p. 609. 
[The paging refers to the $[*]$ pages.]

[*xlviii] LINEN-continued.

IN IRELAND.

$3 \& 4$ Vict. c. 91 (partly repealed by $37 \& 38$ Vict. c. 96 . Sects. 18 and 23 repealed by $38 \& 39$ Vict. c. 86 ).

$5 \& 6$ Vict. c. 68 (partly repealed by $37 \& 38$ Vict. c. 96 ).

LuMPERs. See Bargemen.

Muls. See Factories; Silk.

Mines. See Colliers.

Coal Mines.

$35 \& 36$ Vict. c. 76, post, p. 641.

Metalliferous Mines.

35 \& 36 Vict. c. 77, post, p. 673.

38 \& 39 Vict. c. 39 , post, p. 690.

Slate Mincs (Gunpowder Act, 1882.)

45 Vict. c. 3 , post, p. 770.

Moftir. See Hemp, Hosiery, Linen.

I'ITyEn. See Collicrs, Mines.

RigGers. See Bargemen.

$\left.\begin{array}{l}\text { SAILORS. } \\ \text { SHIPWRIGHTS. }\end{array}\right\}$ See Bargemen.

Seaman or Apprentice.

$17 \& 18$ Vict. c. 104, s. 188 ; and see 43 \& 44 Vict. c. 16 , and $46 \&$ 47 Vict. c. 41 .

SHOEMAKERS, JoURNeYMEN.

9 Geo. 1, c. 27.

$47 \& 48$ Vict. c. 43.

Sulk. See Factories, Hosiery, Linen.

$\left.\begin{array}{l}14 \& 15 \text { Car. } 2 \text {, c. } 15, \\ 20 \text { Car. } 2 \text { c. } 6 \text {, }\end{array}\right\}$ as to Throwers, Winders and Doublers.

22 Geo. 2, c. 27 , post, p. 579.

14 Geo. 3, c. 44 . (Sect. 1 was repealed by $34 \& 35$ Vict. c. 116).

17 Geo. 3 , c. 56 , post, p. 588 .

10 Geo. 4 , c. 52 .

-Weaver's Tick ETS of Work (pursuant to 5 Geo. 4 , c. 96, s. 18).

$8 \& 9$ Vict. c. 128 , post, p. 621 .

STEEL. See Iron.

Stockings. See Hosiery, Factories.

Trade Union ACTS, 1871 and 1876.

$34 \& 35$ Vict. c. 31 , post, p. 634 .

$39 \& 40$ Vict. c. 22, post, p. 715.

WATĆHMAKERS. See Clockmakers.

Watermen, Thames. See Bargemen.

22 \& 23 Vict. c. cxxxiii.

We.Avers (In Ireland). See Lincn. 
TABLE OF STATUTES APPLICABLE TO WORKMEN. Xlix

[The paging refers to the [*] pages.]

Woolen and Worsted Maxufacturens. See Clothiers, Factories, [*xlix] Hosiery.

1 Ann. stat. 2, c. 22 . See $47 \& 48$ Vict. c. 43.

12 Geo. 1 , c. 34 , ss. 2 and 5. See $47 \& 48$ Vict. c. 43.

13 Geo. 2 , c. 8 . See $47 \& 48$ Vict. c. 43 .

15 Geo. 2 , c. 27 , as to stealing wool in the night-time; and see $47 \& 48$ Vict. c 43.

22 Geo. 2, c. 27, post, p. 579.

14 Geo. 3 , c. 25 . See $47 \& 48$ Vict. c. 43.

14 Geo. 3 , c. 44 . Sect. 1 was repealed by $34 \& 35$ Vict. c. 116 . See also $47 \& 48$ Vict. c. 43.

15 Geo. 3 , c. 14 . See also $47 \& 48$ Vict. c 43 .

17 Geo. 3, c. 11. In the counties of York, Lancaster and Chester (partly repealed by $24 \& 25$ Vict. c. 101 , and $47 \& 48$ Vict. c. 43 ).

17 Geo. 3 , c. 56 , post, p. 588 .

24 Geo. 3, st. 2, c. 3. In Suffolk (partly repealed by 24 \& 25 Vict. c. 101 , and $47 \& 48$ Vict. c. 43 ).

25 Geo. 3, c. 40 . In eounties of Bedford, Huntingdon, Northampton, Leicester, Rutland and Lincoln and Isle of Ely (partly repealed by 24 $\& 25$ Vict. c. 101 , and $47 \& 48$ Vict. c. 43 ).

31 Geo. 3, c. 56. In county of Norfolk and city of Norwich and county of the said city (partly repealed by $47 \& 48$ Vict. c. 43 ).

D Mas. \& Ser. 



\section{INTRODUCTION.}

IN treating of the Law applicable to the relationship of Master and Servant as it exists in England at the present day, it seems to be unnecessary to enter into any discussion of the varions opinions which have been expressed by different authors as to the first origin of that relationship $(a)$; for since it is obvious that, in the complicated intercourse of modern society, a great proportion of the business of human life must be carried on through the instrumentality of others, and it is also clear that slavery does not now (b) exist, in any shape, in England, where every man is, and (accoräing to that memoriable sentiment expressed in the will of Alfred the Great) it is fit that every Englishman should ever remain, as free as his own thoughts, it seems to follow inevitably, not only that the relationship of master and servant must exist, but also that wherever it does exist in this country it must be by virtue of some agreement, either express or implied, * between the parties. Puffendorf $(c),[*] i i]$ too, refers its first origin to contract: he says, "the first rise of servitude is owing to the voluntary consent of the poorer and more helpless persons, and is founded upon that common form of contract-Do, ut facias."

But whatever its origin, servitude, in some shape or other, has clearly existed from the remotest antiquity; and without inquiring into the condition of the slave amongst the ancient Grecians and Romans, which might be considered irrelevant to the object more

(a) The curious on this sulject may consult Puff. de Jure Nat. ac Gent., lib. 6 , cap. 3, where various opinions are diseussed; and see Co. Litt. $116(b) ; B l$. Com. vol. i. ch. 14 ; Encyc. Brit. tit. "Slavery," Grotius divides servitude into perfect and imperfect, and, amongst the latter, classes mereruarii;-“" Inter qnos," he says, "ii qui in Anglia apprentisii dicunter durante disciplinx sno tempore, proxime ad servilem conditionem accedunt," lih. 2, eap. 5, sec. $: 0$; and M. Barbeyrac, in his notes, refers to Thom. Smith de Republ. Anglie lib. 3, cap. 10.

(b) During the Anglo-Saxon times, slaves were one of the principal English exports. Strabo, 1. 4, p. 199 (ed. Paris, 1620); Barr on Stat. 274; Rnss. MIod. Eur., note to P.S. to Letter xx. Santos v. Illidlye, $29 \mathrm{I}$. J., C. P. 348 , it was held by the majority of the Court of Excherguer Chamber, reversing the judgment of the Conrt of Common Pleas, 2S L. J., C. P. 317, that an action might. be brought in England for the noncompletien of a contract for the purchase of slaves in Braxil.

(c) Puff. lib. 6, eap. 3, sect. 4. Blackstone (vol. i. ch. 14), says "The relationship of master and servant is foundel in convenicnce," and he evidently mestns, that convenience induces men to enter into the conivact, whence the relationship arises. 
immediately in view in the following pages, it may be convenient to offer a few remarks upon the state of the slave, or vilein, in this country, whose condition had most of the incidents of slavery; and to trace the progress of English legislation with reference to that class of persons, commonly called servants and labourers, who in most respects supply the places formerly occupied by vileins, though their condition is far superior.

Both among the German Saxons and among the Anglo-Saxons slaves or vileins were divided into two classes, - household slaves $(d)$, after the manner of the ancients, and predial, or rustic, who were transferred like cattle with the soil $(e)$; though there does not appear to have been much difference between the two as to their condition. The power of a master over his slaves appears not to have been unlimited among the Anglo-Saxons as it was among their an[*liii] cestors. If a man beat out his slave's *eye or teeth, the slave recovered his liberty; if he killed him, he paid a fine to the King, provided the slave died within a day after the wound or blow, otherwise it passed unpunished $(f)$.

Whether or not the feudal law had place at all among AngloSaxons is a doubtful question $(g)$; but its introduction does not appear to have ameliorated the condition of the slaves or vileins, except in so far as it tended to promote the civilization of their masters, who, as long as villenage lasted, had an almost absolute power over them. Their service was uncertain and indeterminate, such as their lord thought fit to require, or, as some old writers express it, they knew not in the evening what they were to do in the morning $(h)$; they were bound to do whatever they were commanded. They were liable to beating, imprisonment, and every other chastisement which their lord might prescribe, except killing and maiming. They were incapable of acquiring property for their own benefit, except by their lord's sufferance or permission,- - the rule being, quicquid acquiritur servo acquiritur domino (i). They

(d) In Kent's Comm., Lec. 32, vol. ii. p. 204, it is said, that domestie slavery existed throughout the United States when they were colonies of Great Britain. "But," adds the learned author (p. 206), "after the area of our Independence the principles of natural right and civil liberty were better known and obeyed, and domestic slavery speedily and sensibly felt the genial influence of the Revolution."

(e) See Hume's Hist. Engl. vol. i, chap. 3, App. 1; Spell. Gloss. Verb. Servus; Russ. Mod. Eur. part 1, Letter viii.

( $f$ ) Leges Alf. 8. 17. This seems to be borrowed from the Jewish law, Exod. xxi. $20,21,26,27$.

(g) See Hume's Hist. Engl. vol. i. App. 2 to ch. 11; Hall. Mid. Ages, vol. i. ch. 2 , p. 2 ; Encyc. Brit. tit. "Feodal System."

(h) Co. Lit. 116 b.

(i) "Non potest aliquis" (says Glanvil) "in villenagio positus libertatem suam propriis denariis suis quærere, quia omnia eatalla eujuslibet nativi intelliguntur esse in potestate domini sui." Lib. 5, cap. 5. The benevolence of lords, however, in many cases, allowed their vileins to acquire property (like the peeulium of the Roman law), with which they purchased their enfranchisement. As to the rresent applicability of the maxim in the text, see post, p. 162 . 
were themselves the subject of property; as such, saleable and transmissible. If vileins regardant, they passed with the manor or land to which they were annexed, but they might be severed at the pleasure of the lord. If vileins in gross, they were hereditaments or chattels real according to their lord's interest, being descendible to the heir when the lord was absolute owner, *and trans- [*liv] missible to the executor when he had only a term of years in him. Lastly, the slavery extended to the issue if both parents were vileins, or if the father only was a vilein; our law deriving the condition of the child from that of the father, contrary to the Roman law, in which the rule was, partus sequitur ventrem $(k$.) Larceny could not be committed by taking and carrying away a vilein; "because," said Lord Coke, "they are in the reality" (l). It was, however, only in respect of his lord that the vilein, at least in England, was without rights $(m)$. He might inherit, purchase, suo in the courts of law, if his lord did not interfere, and when sued as a defendant in a real action or suit wherein land was claimed, he might shelter himself under the plea of villenage. If left executor, his lord could not take from him what belonged to the testator, but the vilein might have an action against him for the same, and might recover both the goods and damages, which would, however, of course be part of the testator's estate $(n)$. And he seems to have been admissible as a witness in England in all cases, except as against his lord, though this point is rather obscure (o).

Such being the abject condition of the vilein, it is not to be wondered at that as Christianity $(p)$, civilization, and commerce advanced, villenage should have gradually become extinct. It is not, however, necessary here to *follow it in the several stages [*lv] of its decline, or to trace the causes which led to its ultimate extinction. It will be sufficient to mention, that the period of its final extinetion in England (which was effected without any actual interposition of the Legislature) $(q)$, is generally fixed about *the [*]vi]

(k) See Lit. sect. $172 \mathrm{cl} s e q$. , and Hargrave's famous argument in Somerset's Case, 20 How. St. Tr. 1.

(l) 3 Inst. 109.

(m) Lit. seet. 189.

(n) Swinb. p. 2, sect. 9, ?. 15 .

(o) See Hall. Mid. Ages, vol. i. el. 2, p. 2.

(p) 'The doetrine that slavery was contrary to the principles of the Christian religion, is said to have been originally inculcated by Wyelift" and his followers. Barr. on Stat. 280. Paley, Polit. Philos. c. iii., says, "Christianity can only operate as an alterative. By the mild diffusion of its light and influence the minds of men are insensibly prepared to perceive and correct the enomities which folly or wickedness or aceident have introduced into their public establishments. In this way the Greek and lioman slavery, and since then the feudil tyranny, has declined before it."

(q) See Barr. on Stat. 272-4. The ease appears to have been otherwise in France, where Louis Hutin, in 1315, and l'hilip the Jong, three years later, issued ordinances, decluring "that as all mon were by wature free liom, and as their kingdom was ealled the kingdom of lranks, they determined that it should be so in reality as well as in name; therefore they aplointed that en- 
latter end of Queen Elizabeth's reign, or soon after the accession of James I. $(r)$.

As villenage gradually declined, the interposition of the Legislature appears to have become necessary for the regulation of labourers and servants, who seem to have been inclined to avail themselves of their freedom by remaining totally idle unless induced to work by high wages. But the first trace of any interposition on the part of the Government with a view of regulating the labour market is to be found in the Ordinance, Proclamation, or Statute, whichever it is, which is commonly called the Statute of Labourers,

franchisements should be granted throughout the whole kingdom upon just and reasonable conditions." See Roberts. Introd. to Hist. Chas. V., sects. 1 and 4 , and note xx. ib. He cites Ordon. tom. 1, pp. 583, 653. Hallam, however, mentions as a fact not generally known, that predial servitude was not abolished in all parts of France till the Revolution, at the close of the last century. Mid. Ages, eh. 2, p. 2, note, p. 150, 9th edit. The feudal law was abolished in France by a decree of the National Assembly, 4th August, 1789. See the Baron de Bode's Casc, 8 Q. B. 246. It is remarkable, that till about the same period, or even later, there were in Scotland many colliers, coal-bearers and salters in a state of slavery or bondage, bonnd to the collieries and salt works, where they worked for life, and transferable with the collieries and salt works wilen their original masters had no further use for them. These men were not all free till an Act of Parliament was passed (39 Geo. 3, c. 56), declaring them to be so, for they appear to have neglected to avail themselves of an act which had been passed nearly a quarter of a century before (15 Geo. 3, c. 28$)$, which enabled them to obtain their freedom, by going through certain forms. Lord Brougham, Polit. Philos. c. viii., ad fin., says, they complained of the act as a trick of the owners to evade certain payments. However this may be, the poet might well write-

"Such dupes are men to custom, and so prone

To rev'rence what is ancient, and can plead

A course of long observance for its use,

That even servitude, the worst of ills,

Because delivered down from sire to son,

Is kept and guarded as a sacred thing."-Cowp. The Task, B. 5.

In the Life of Hugh Miller, by Brown, 1858, it is said, p. 71, that "so late as 1842, when Parliament issued a Commission to inquire into the results of female labour in the coal pits of Scotland, there was a collier still living that had never been twenty miles from the metropolis; who conld state to the Commissioners that his father, his grandfather, and himself were slaves, and that he had wrought for years in a pit in the neighbourhood of Musselburgh, where the majority of the miners were also serfs." And the author adds, p. 72, "the colliers carried in their faces the too certain index at once of their social and intellectual condition, being mostly of that type to which a rery strong resemblance is found in the prints of savage tribes. The effect of the emancipation of these poor creatures has been, that in less than a quarter of a century this type of face has disappeared throughont Scotland." May, Constit. Hist. vol. ii. p. 287, well remarks, "The last vestige of slavery was now effaced fiom the soil of Britain, but not until the land had been resounding for years with outcries against the African slave trade."

$(r)$ One of the last instances in which villenage was insisted on was Crouch's Case, which happened $10 \& 11$ Eliz., and is reported in Dyer, 266, pl. 11, and 282, pl. 32. Mr. Hargrave, however, in his argument in Somerset's Case, 20 How. St. Tr. 40, mentions several later cases-one so late as IIil. T., 15 Jac. 1, since which, he says, the claim of villenage has not been heard of in our courts of justice. 
and which occurred $23 \mathrm{Edw} .3$, A. D. 1349 . In that year, when the plague, sométimes called "The Black Death," or "The Great Mortality," which is said to have destroyed one-third of the population of Europe $(s)$, had extended its ravages to England, where it was equally destructive $(t)$, so that servants and labourers of all sorts became excessively scarce, and demanded exorbitant wages (u), Edward III. (as *Parliament was not sitting, having [*]vii] been prorogued on account of the plague $(v)$, by the assent of the Prelates, \&c., and others of his Council (de quorum unanimi consilio duximus ordinandum quod, \&c.), issued an ordinance, writ, or proclamation, directed to the Sheriffs of the various Counties in England, with a view of compelling workmen and labourers to serve for reasonable wages. This ordinance recites that "because a great part of the people, and especially of workmen and servants, late died of the pestilence, many seeing the necessity of masters will not serve unless they may receive excessive wages, and some rather willing to beg in idleness, than by labour to get their living ;" and then proceeds to direct what wages shall be paid, and to make other regulations for the control of workmen and servants. It is printed at length in the Statutes at Large, as though it were an Act of Parliament, and is commonly referred to as "The

(s) Various aceounts of this plague are eollected in Barnes, Hist. Edw. 3, B. 2, Ch. 8, p. 428. Sec also Knighton, p. 2599. There is also an account of its ravages in Florence in the Introduction to the Decameron of lioccaceio. He, too, speaks, of the great "scarsita di serventi" in Florenee caused by it. See his account charmingly elaborated by Lord Lytton in his Ricnzi. It is remarkable that so little notice of this plague is taken by most historians of England, who appear to be absorbed in the recital of the French wars of Edw. 1II. Froissart says but little of it in his Chronieles, vol. i. p. 200 (John's edit.). Hume and Goldsmith searely mention it. Iingard speaks more fully of it in his Hist. Eng. vol. iv. p. 86. There is only a short account in Carte's Hist. Engl. vol. ii. p. 475.

( $t$ ) Rogers in his History of Prices, vol. i. p. 60, thinks that it really destroyed not much less than half the population, and doubled the rate of wages, ib. 265 .

(u) This effect of the plague was not confined to servants, for parish priests also, having become "very scant after the pestilence," an Art of Parliament was passed to regulate their wages, $36 \mathrm{Edw}$. 3, c. 8. See also $23 \mathrm{Ldw} .3$, e. 8, ad fin.

(v) Barnes, p. 437, says, "all suits and pleadings in the King's Beneh and other places ceased, and all Sessions of Parliament for the space of more than two years were hindred." The writs for the prorogation are set out at length in Rymer's Fodera, vol. iii. part 1 , and show the prourress of the plague in England. See pl. 180, 182, 191. At p. 198 is a writ dated 18th June, 1350, 24 Edw. 3, direeted to the Sheriff of Kent (and a note stating that consinitia brevia diriguntur singulis vicecomitibus per Angliam), quia magna pars populi et maxime operciorum et servientum in ultima pestilentiâ defuneta est, with a view of compelling such to work for reasonable wages. This last appears to be the same as what is eommonly called The Statute of Labourers. At p. 210 there are two other writs directed to individuals in Suffolk and lincolnshire, dated 12 and 18 Nov. 1350 , from whieh it would appear that the former writs to the sherifts latd not been much regarded. 
Statute of Labourers" $(x)$. But it would appear to be at least very [*Iviii] *doubtful, if it ever had the authority of an Act of Parliament. Moreover, its provisions appear to have been eluded by the ingenuity and avarice of the labourers. Knighton says, "Operarii tamen adeo elati et contrariosi non advertebant regis mandatum, set si quis eos habere vellet, oportuit eum eis dare secundum suum velle, et aut fructus suos et segetes perdere, aut operariorum elatam et cupidam voluntatem ad vota implere." The King seems to have endeavoured to enforce his mandate, and enrich his own treasury, by fining the givers, and imprisoning the receivers, of exorbitant wages, though with little effect. For as soon as Parliament met after the plague had ceased, it was found necessary to pass an Act of Parliament having the same object, but of more extended operation. This act, $25 \mathrm{Edw} .3$, stat. 1, is, it is conceived, more properly entitled to the appellation of the "Statue of Labourers." It recites the "said ordinance" of $23 \mathrm{Edw}$. 3, and that "the said servants having no regard to the said ordinance, but to their ease and singular covetise, do withdraw themselves to serve great men and other, unless they have livery and wages to the double or treble of that they were wont to take the said 20th year of Edw. 3, and before, to the great damage of the great men, and impoverishing of all the said Conmonality, whereof the said Commonality prayeth remedy." It then proceeds to enact, in order "to refrain the malice of the said servants," various provisions more extensive than those contained in the ordinance of $23 \mathrm{Edw}$. 3. Among them is one, "That all workmen bring openly in their bands to the merchant towns their instruments, and there shall be hired in a common place and not privy." This regulation, which was probably intended to prevent secret contracts of hiring at exorbitant wages, but which was repealed 5 Eliz. c. 4 (and again by $26 \& 27$ Vict. c. 125 ), ap[*lix] pears to be the origin of those "Statutes," "Mops," *or Fairs $(y)$, for the hiring of servants still kept up in various parts of England, but which are now found to be productive of so mnch demoralization and harm to servants and labourers themselves, that great efforts are being made by clergymen and other philanthropic individuals to put them down.

(x) Barrington on Stat. calls it a supposed statute, because the intervention of the Commons is not mentioned, and adds in a note that it appears from Dugdale that no Parliament was held $23 \mathrm{Edw}$. 3, because of the plague. Knighton, p. 2600, says, "Interim rex misit in singulos eomitatus regni quod messores et alii operarii non plus eaperent quam capere solcbant, seb pana in statuto timitata, ct ex hoe innovavit statutum" Barnes, p. 441, calls it a "King's Ordinance." See also 2 Rich. 2, e. 8 . But $23 \mathrm{Edw} .3$, appears to have been treated as a statute, F. N. B. 167 B. See note to Co. Litt. $42 b, 159 b$; and also 4 Inst. 26. The trine solution of the point would seem to be that the "King's Ordinance" of 23 Edw. 3 was made a Statute, 25 Edw. 3. See Hall. Mid. Ages, vol. ii. p. 181 (9th edit.). The point, however, is now more curious than important.

(y) As to the obstruetion of highways by stalls ereeted at these fairs, see Simpson v. Welle, 41 L. J. M. C. $10 \tilde{5}$. 
Various statutes were also afterwards passed with a view to compel labourers and servants to work, and regulating their wages $(z)$, diet $(a)$, apparel $(b)$, and games $(c)$. And some to prevent people of small means making a great retinue of people, and giving them hats and other liveries $(d)$, a custom which appears to have grown up, having for its object the mutual maintenance in quarrels, and which was not confined to noblemen (e).

At the commencement of the reign of Queen Elizabeth, however, all former acts regulating wages were repealed, "chiefly for that the wages and allowances limited and *rated in many of the [*]x] said statutes were in divers places too small, and not answerable to that time respecting the advancement of prices of all things belonging to the said servants and labourers," and power was given to justices of the peace and magistrates of cities and burghs to rate wages and fix prices of work $(f)$. Acts of Parliament conferring similar powers were also passed in Scotland $(g)$ where their provisions were found so beneficial that they were afterwards extended to colliers $(h)$. But so much of those acts as authorized and empowered justices of the peace and magistrates of cities and burghs to rate wages and fix prices of work for artificers, labourers, and craftsmen, has since been altogether repealed $(i)$; and it is remark-

(z) 25 Edw. 3, s. 1; 34 Edw. 3, ec. 9, 10, 11; 2 Rich. 2, c. 8 ; 12 Rich. 2 , c. 4 ; 4 Hen. 5 , c. 4 ; 2 Hen. 6 , c. $14 ; 6$ Hen. 6 , c. 3 ; 8 Hen. 6 , c. 8 ; 23 Hen. 6 , c. 13.

(a) 37 Elw. 3, c. 8. See 3. Inst. 201.

(b) $37 \mathrm{Edw} .3$, ce. 8, 9, 11, 14 ; 3 Edw. 4, c. 5 ; $22 \mathrm{Edw}$ 4, c. 1 . These two, however, were not confined to servants, and they were repealed 24 IIen. 8, c. 13 and 1, Jac. c. $25 . \quad$ See 3 Inst. 199.

(c) 12 liich. 2 , c. $6 ; 16$ Rich. 2 , c. $4 ; 11$ Hen. 4, c. 4 (see 17 ldw. 4, c. 3); 11 Hen. 7 , e. $2 ; 33$ Hen. 8 , c. 9 . See now 8 \& 9 Vict. c. 109.

(d) 1 Rieh. 2, c. 7 ; 20 Rich. 2 , ce. 1,$2 ; 1$ Hen. 4 , c. 7 ; 2 Hen. 4, e. $21 ; 7$ Hen. 4 , c $14 ; 13$ Hen. 4 , c. $3 ; 8$ Hen. 6 , c. $4 ; 8$ Edw. 4, e. 2 . In 12 lalw. 4 , it was found necessary to pass an act of parliament for enabling the Prince of Wales to give liveries to other than menial servants, $12 \mathrm{Edw}$. 4, c. 4. These acts were repealed by 3 Car. 1 , c. 4 . See also $19 \& 20$ Vict. c. $64 ;: 2 ; \&: 27$ Vict. 125. Lord Coke (3 Inst. 200) says, "William of Malmesbury, comparing Englishnen and Normans together, satith, that in his time the English manner was to sit bibbing whole houres after dinner; and that the Norman fashion was to walk the streets with great troops witle idle aud loose serving men following them, botl which were causes of many disorders and outrages."

(c) By the statute $34 \& 35$ Hen. 8, c. 1 (A. 1). 1542-3), it was enaeted, not only that the Bible should not be read in English in any church, but also that no women or artificers, prentices, journeymen, servingmen of the dewree of yeomen or under, husbandmen, nor labourers should read the New Testament in English. This act, however, which was chiefly directed against 'Tindal's translation of the Bible, was repealed about four years afterwarrls, 1 liw. 6, c. 12.

$(f) 5$ Eliz. c. 4 . See 1 Jac. 1, c. 6, explaining this act. The 5 Eliz. e. 4 was repealed by 38 \& 39 Vict. c. 86 , post, Appendix.

(g) 2:2 Parl. Jac. 6, c. 8; 1 Parl. Car. 1, c. 38.

h) 39 Geo. 3 , e. 56 ; see 34 \& 35 Vict. e. 116.

(i) 53 Geo. 3 , c. $40 ; 30 \& 37$ Vict. c. 91 . Several aets which had heen passed in the reign of Geo. 3, for empowering justices to regulate the wages of persons employed in the manufacture of silk, were repealed, 5 Geo. 4 , c. 66 ; the provi- 
able as showing the entire change of public opinion upon this subject, that in the act for the arbitration of disputes between masters and workmen, which was passed in $1824(k)$, there is a special provision, that nothing therein contained shall authorize justices, acting in execution of that act, to estabilish a rate of wages without the mutual consent of both master and workmen.

The statute of 5 Eliz. c. 4 only gave power to the magistrates "to limit, rate, and appoint" wages, and gave no power to order payment of them. That power was, however, assumed by the magistrates, and their assumption of it was, by construction of law, [*]xi] held to be legal (l). * But the statute being deficient, as it extended only to such wages as should be rated, and to servants in husbandry, and contained no power to admit the servant's oath in evidence, another act was passed in 20 Geo. 2, c. 19, giving more extensive powers to magistrates, and extending those powers to disputes between masters and various other descriptions of servants than those mentioned in the statute of Elizabeth. And this act was found so beneficial in some respects, that although, as we have seen, repealed as to rating wages, several other acts were subsequently passed extending the powers conferred by it in other respects $(m)$. But these acts were all repealed in $18 \% 5(n)$.

The Statute Book also contains (in addition to the acts relating to the arbitration of disputes between masters and workmen (o); "The Councils of Conciliation Act, 1867" $(p)$; the act prohibiting the payment of wages in goods or otherwise than in the current coin of the realm, commonly called the Truck Act $(q)$; and the payment of wages in Public Houses Prohibition Act, $1883(r)$; which are applicable to most trades) a large number of statutes applicable to masters and servants in particulr trades $(s)$, which it is not thought necessary in this place to refer to at greater length, as they are not

sions contained in them "having been found rexations and injurions in their operation." The 29 Geo. 2, c. 33, s. 1, which empowered justices to make rates for the payment of wages to weavers and others employed in the woollen manufactures, was repeiled, 6 Geo. 4 , c. $1: 99 ; 30 \& 31$ Vict. c. 59.

(k) 5 Geo. 4 , c. 96 post. p. 544.

(l) R. r. Gouche, 2 Salk. 441; 2 Lord Raym. 820; Shcrgold v. Hallowny, 2 Str. $100 \%$.

(m) As to masters and workmen, see 27 Geo. 2 , c. $6 ; 31$ Geo. 2 , c. 11, s. $2: 6$ Geo. 3, c. $25 ; 4$ Geo. 4, c. $34 ; 10$ Geo. 4, c. 52. As to masters and apprentices, see 33 Geo. 3 , c. $55 ; 47 \& 43$ Vict. c. $43 ; 4$ Geo. 4 , c. $29 ; 4$ Geo. 4, e. $34 ; 5 \& 6$ Vict. c. 7 .

(n) By $38 \& 39$ Vict. c. 86 , s. 17, post, Appendix, p. 695.

(o) 5 Geo. 4 , e. 96 , and 35 \& 36 Vict. e. 46 post, p. 553.

(p) 30 and 31 Vict. c. 37 , post, p. 556.

(q) 1 \& 2 Will. 4, c. 37, post, p. 603 . All previous acts on this subject were repealed by $1 \& 2$ Will. 4 , c. 36 . The first, $4 \mathrm{Edw}$. 4, c. 1 , s. .13 , war passed in 1464. The first that nses the word "truck," as applied to the payment of wages otherwise than in money, is 12 Geo. 1 , c. $34(17 \% 5)$.

(r) $46 \& 47$ Vict. c. 31 , post, p. 771.

(s) See the Alphabetical Table, ante, p. xlvii. 
of general interest ; the principal of those now in existence will be found in the Appendix.

Acts of Parliament have also been passed at various *times [*1xii] for the regulation of the enployment of children and young persons in cotton and other factories, and for the preservation of their health and morals, which are commonly called "The Factory Acts."

The first act for this purpose was passed in $1802(s)$, and was amended in $1819(t)$. Further enactments on the subject were made in 1825, $(u)$, the provisions of which having been defeated for want of form, it was found necessary again to amend the law in $1829(v)$. At the commencement of the reign of Will. 4, however, all these acts (except the first) were repealed, and other regulations enacted in lieu thereof $(x)$. But a few years afterwards those regulations were in their turn also repealed, and other acts passed $(y)$, which, however, were all repealed in 1878 . The acts now in force upon the subject are the Factory and Workshop Acts, 1878 and $1883(z)$.

The provisions contained in the repealed acts, which were applicable to young persons (that is, persons above thirteen and under eighteen years of age $(a)$ ), were first extended to females above that age in $1844(b)$. In 1860, the powers and provisions of the Factory Acts were applied to bleaching works and dyeing works $(c)$ : in 1861 , to lace factories $(d)$ : in 1862, to bleach fields or works in which the operation of bleaching by the open air process is carried on $(e)$ : in 1863 , to calendaring works and *finishing [*1xiii] works $(f)$; and in 1867 their application was still further extended as will be noticed presently. In 1863 an act was passed for limiting the hours of labour of persons under eighteen years of age in bakehouses, and containing regulations as to the cleanliness of bakehouses, called "The Bakehouse Regulation Act, 1863" $(g)$. But that act has also been repealed $(h)$.

In 1851, an Act of Parliament was passed for the protection of

(s) 42 Geo. 3, c. 73 .

(t) 59 Geo. 3, c. 66 ; 60 Geo. 3 , c. 5 .

(u) 6 Geo. 4 , c. 63.

(v) 10 Geo. 4 , c. 51 .

(x) 1 \& 2 Will. 4 , c. 39 .

(y) $3 \& 4$ Will. 4 , c. 103 , amended by $7 \& 8$ Vict. c. $15 ; 10 \& 11$ Vict. c. 29 (see Ryder v. Mills, 3 Exc. 853 ) ; 13 \& 14 Vict. c. $54 ; 16 \& 17$ Vict. c. $104 ; 19$ $\& 20$ Vict. c. $38 ; 27 \& 28$ Vict. c. $48 ; 30$ \& 31 Vict. c. 103.

(z) 41 \& 42 Vict. c. 16, post, Appendix, p. $718 ; 46 \& 47$ Vic. c. 53, post, Appendix, p. 772.

(a) $7 \& 8$ Vict. c. 15, s. 73.

(b) $7 \& 8$ Vict. c. 15, s. 32 , and see 13 \& 14 Virt. c. 54.

(c) $13 y 23$ \& 24 Vict. c. 78 , extended by $27 \& 28$ Vict. e. 98 [both repealed 33 and 34 Vict. c. 62, s. 5.]

(d) By 24 \& 25 Vict. c. 117 [repealed $41 \& 42$ Vict. c. 16, s. 107].

(e) By 25 \& 26 Vict. c. 8 [repealed 33 \& 34 Vict. c. 62, s. 5].

(f) By $26 \& 27$ Vict. c. 38 [repealed 33 \& 34 Vict. c. 62, s. 5$]$.

(g) 26 \& 27 Vict. c. 40.

(h) $41 \& 42$ Vict. c. 16 s. 107. 
strike of gas stokers took place $(y)$. And the Acts of 1871 not proving sufficient or satisfactory another Royal Commission was appointed 19th March, 1874, to inquire into the working of "The Master and Servant Act, 1867," and of "The Criminal Law Amendment Act, 1871." Their final report was made on 17th February, 1875, and in that year "The Master and Servant Act, 1867," and "The Criminal Law Amendment Act, 1871," were repealed, and "Conspiracy and Protection of Property Act, 1875" (z) and "The Employers and Workmen Act, 1870" (a), were passed ; and in the following year "The Trade Union Act, 1871," was amended by "The Trade Union Act (1871) Amendment Act, 1876" (b).

In 1877 a Select Committee, which had been appointed in the previous Session, was re-appointed to inquire into the liability of Employers for injuries to their Servants. Their report, which was made on 25th June, 1877, resulted, after several bills had been in[*]xvii] troduced into the ${ }^{*}$ House of Commons, in the passing of "The Employers' Liability Act, 1880 " (c) which came into operation on 1st January, 1SS1, and is to continue in force till the 31st December, 1887, and to the end of the then next Session of Parliament and no longer, unless Parliament shall otherwise determine $(d)$.

It may, perhaps, be not out of place to remark here, that in 1868 "The Artizans and Labourers' Dwellings Act, 1868" (e), was passed for the purpose of providing better dwellings for that class of persons ; and that several other acts have also been subsequently passed having the same object $(f)$.

In 1883 an act was passed to better the condition of labourers in Ireland $(g)$.

A Royal Commission on the Housing of the Working Classes is now sitting, and their report is shortly expected.

(y) R. v. Bunn, 12 Cox, C. C. 316 . In Pointon v. Hill, 53 L. J. M. C. 62, it was held that workmen on strike begging could not be convicted as "idle and disorderly" persons.

(z) 38 \& 39 Vict. c. 86 , post, Appendix, p. 691.

(a) 38 \& 39 Vict. c. 90 , post, Appendix, p. 698.

(b) $39 \& 40$ Vict. c. 22 , post, Appendix, p. 715.

(c) 43 \& 44 Vict. c. 42 , post, Appendix, p. 763 . Sce further as to this Act, post, p. 269.

(d) Sect. 10.

(c) 31 \& 32 Vict. c. 130 , amended by $42 \& 43$ Vict. c. 64 , and 43 Vict. c. 8.

(f) See "The Artizans and Labourers' Dwellings Improvement Act, 1875," $38 \& 39$ Vict. c. 36 , as amended by 42 \& 43 Vict. c. 63 ; and "The Artizans' Dwellings Act, 1882," $45 \& 46$ Vict. c. 54. As to Ireland, see "The Labourers' (Ireland) Act, 1883 ," $46 \& 47$ Vict. c. 60.

(g) $46 \& 47$ Vict. c. 60. 


\section{A TREATISE}

ox

\section{THE LaW OF MasTER AND SERVANT.}

CHAPTER I.

THE PARTIES TO THE CONTRACT.-WHO MAY CONTRACT THE RELATIONSHIP OF MASTER . AND SERVANT.

[This paging refers to the $[*]$ pages.]

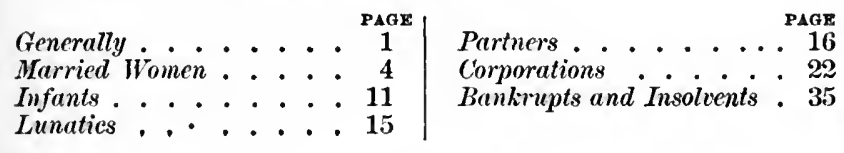

\section{Generally.}

$\Lambda$ s a general rule, every person of the full age of Parties to the twenty-one years, and not under any legal disability, is contract gencapable of becoming either a master or a servant. But erally. in order that a contract of hiring and service may be Servant must legally. binding $(a)$, it is necessary, that, at the time be sui juris such a contract is entered into, the party about to be in order to hired should bo free from any other engagement in-binding concompatible with that into which he is about to enter; tract of in other words, he must be sui juris.

*Thus, whilst a settlement could be gained by [*2] hiring and service $(b)$, it was held that the party who

(a) It is not always necessary to prove a legally binding contract of hiring : a service de facto is, as we shall hereafter see, sufficient for many purposes. Even in an action for disturbance of a freehold office, it is not necessary to show an appointment by deed, proof of having acted in the office for several years is sufficient. IF' Mahon v. Lennard, 6 Ho. Lords Cases, 970, et cas. cit. $i b$. 984. See also the Customs Consolidation Act, $1876,39 \&$ 40 Viet. c. 36 , s. 261 .

(b) By $4 \& 5$ Will. 4 , c. 76 , s. 64 , no settlement can be gained by hiring and service, or by residence under the same, since 14 August, 1834.

1 MAS. \& SER. 
As in cases of hired himself as a servant must, in order to acquire a settlementby settlement by service under that hiring, have been, at hiring and the time of hiring, disencumbered from any other relaservice. tion which might interfere with or defeat the performance of his engagement; for, unless he were so, he was not free to contract, and, if not free to contract, he could not be lawfully hired.

Contracts of

Therefore an apprentice $(c)$ could not, whilst his inhiring by ap- dentures remained in force, (and they were not then prentices. dissolved by the bankruptcy (d) of the master,) lawfully hire himself to another master so as to gain a settle. Soldiers. ment by service under such hiring. So a deserter from the king's marine forces $(e)$; and an invalided soldier in the king's service, who had leave of absence upon agreeing to relinquish his pay for the time, which leave was renewed from time to time; were also beld incapable of making a valid contract of hiring and service, so as to gain a settlement thereunder, since they were not sui juris so as to be able to contract, being under a legal disability in consequence of having entered into a different obligation $(f)$.

Militiamen and others.

And similar principles were held to be applicable to militiamen and their substitutes, and members of volunteer corps, such persons being held to be incapable of entering into a valid contract of hiring and service; unless, at the time they did so, they informed their master, or he knew of their liability to be called on to [*3] serve, and *agreed, in such case, to dispense with their personal services $(g)$.

(c) $R$. v. Hindringham, 6 T. R. 557. And see $R$. v. Stowmarket, 9 East, $211 ; R$. v. Dunton, 15 East, 352, which, althongh not cases of apprenticeship, illustrate the text.

(d) R. v. Puckington, 1. Str. 582; and see Thomas v. Williams, 1 A. \&. E. 485 . The statute 32 \& 33 Vict. c. 71 , s. 33 , under which an order of adjudication in bankruptey, if either the bankrupt or the apprentice or clerk gave notice in writing to the trustee to that effect, operated as a complete discharge of the indenture of apprenticeship or articles of agreement, was repealed by the Bankruptcy Act, 1883 , (46 \& 47 Vict. c. 52).

(e) $R$. v. Norton, 9 East, 206.

(f) $R$. v. Beaulieu, 3 M. \& S. 229.

(g) R. v. Westerleigh, Burr. 753; R. v. Winchcombe, 1 Doug. 391 ; $R$. v. Holsworthy 6 B. \& C. $283 ; R$. v. Taunton St. James, 9 B. \& C. $831 ; R$. v. Elmley Castle, 3 B. \& Ad. $826 ; R$. v. St. Mary-at-theWalls, Colchester, 5 B. \& Ad. $1023 ; R$. v. Witmesham, 2 A. \& E. 648. By the Malitia (Voluntary Establishment) Act, 1875 (38 \& 39 Vict. c. 69 . Vict. c. 69), s. 78 , "If any servant whatever, hired by the year or otherwise, be enlisted as a militiaman by virtue of this Act, such enlistment shall not vacate or recind the contract or alter the engagement between such servant and his master or employer, unless the militia of the county for which 
Upon similar principals it has been held $(h)$, that a Purser's purser's steward on board one of her Majesty's ships, steward, who who could not be appointed by the purser without the is servant of assent of the commander, and was entitled to the pay Crown, canof an able seaman from the Crown, could not recover purser. additional wages from the purser, although it was proved to be usual for pursers to allow their steward a salary at the rate of 11 . per gun.

But where (i) the commander of one of her Majesty's But eook hirships engaged the plaintiff, who was then cook on board. ed from ana steamer, to serve in that capacity on board the ship other vessel, he commanded, promising to give him $12 l$. a year beyond on promise of his rating as an able seaman; it was held that the extra pay, plaintiff might recover that amount in an action against the commander, Maule, J., observing, "Here the plaintiff, instead of contracting to do the work which he was already bound to perform, was a free agent, perfectly sui juris, when he entered into the engagement."

For all ministerial acts, which require no exercise of Ministerial judgment or discretion, every public officer may appoint publie officer *a deputy or servant $(k)$, unless required by the [*4] may appoint statute under which they are appointed to execute their a deputy. duties in person, as in case of clerks in the Master's Office $(l)$, clerks of the Parliament $(m)$, \&c. Thus a sheriff, or churchwarden or, overseer may depute the execution of warrants to others. But an officer whose Jndge duties are of a judicial character cannot act by deputy cannot. (n), unless empowered to do so by Act of Parliament;

such servant is enlisted be embodied under this Act, or unless such person so enlisted leave the service of his master or employer for the purpose of preliminary training or training and exereise in pursuance of this Act, and do not return again to the same service at the end of the period of preliminary training, or training and exercise, or as soon after as reasonably may be, but his master or employer shall be entitled to an abatement from his wages in proportion to the duration of his absence from his said serviecs." And, by the same section, disputes respecting wages under 20l. may be decided in England or Ireland by a justice, and in Scotland by the sheriff of the county or two justices, in a summary way.

(h) Carter v. Hall, 2 Stark. 361.

(i) Clutterbuck v. Coffin, 3 M. \& G. 842 ; and see Harris v. Carter, 3 E. \& B. 559 ; Hartley v. Ponsonby, 26 I.. J., Q. B. 322.

(k) Phelps v. Winchcombe, 3 Bulstr. 77; Walsh v. Southuorth, 6 Exc. $150 ; 2$ L. M. \& P. 91.

(l) 7 W. 4 \& 1 Viet. e. 30, s. 13 , which was not repealed by "The Supreme Court of Judieature (Officers) Act, 1879," 42 \& 43 Vict. c. 78. See the Second Sehedule.

(m) 5 Geo. 4 , c. 82 , s. 2.

(n) Roll. Abr. 591, tit. "Deputie." Bac. Abr. "Offices and Officers" (L.). 
as County Court judges (o), recorders $(p)$, and stipendiary magistrates $(q)$ are empowered to do so in certain - cases.

\section{Married Women.}

Married women.

Liability of husband,

White v. Cuyler.

depends on wife's agency.
A married woman is, in general, incapable of entering into any contract which will be binding upon her at law, and cannot, therefore, take an apprentice, as she cannot legally bind herself to instruct him $(r)$. And she cannot (except in cases within the Married Woman's Property Act, 1882) (s) sue alone on a contract made with her before or after marriage, even though her husband is an alien enemy $(t)$. In entering into contracts she is generally regarded as the agent of her husband, and he will, in general, be bound by such contracts. When, therefore, a married woman hires servants, her husband will, in most cases, be liable to pay the wages. And it makes no difference in his liability that the wife has [*5] entered into *and signed an agreement under seal, where he has not authorized her to do so.

In a case $(t)$, therefore, where the defendant's wife, by an agreement under seal to which he was no party, and which he had not given her any uritten authority to enter into, agreed to take the plaintiff with her to Barbadoes in the capacity of a waiting-maid, to pay her 21l. per annum as long as she continues in her service, and to pay for her passage to Barbadoes, and other incidental expenses, and also her passage home to Eng. land in case she should be dismissed from her situation; it was held that the defendant was liable to an action of assumpsit for the amount of the plaintiff's wages and her passage-money home to England, which had not been paid, although it was objected on the part of the defendant, that the form of action was misconceived, and that it should have been on the deed.

The liability of the husband, however, upon contracts of hiring entered into by the wife, depends entirely upon

(o) $9 \& 10$ Vict. c. 95 , s. 20 ; see $13 \& 14$ Vict. c. 61 , s. 3 ; $19 \&$ 20 Vict. c. $108, \mathrm{~s} 6$.

(p) 6 \& 7 Vict c. 89, s. 8 ; $32 \& 33$ Vict. c. 23.

(q) 32 \& 33 Vict. c. $34, \mathrm{~s} 2$.

(r) R. v. Guildford, $2 \mathrm{Ch}$. 284 . As to how far a married woman may act as a feme sole in the city of London, see Beard v. Webb, 2 Bos. \& P. 93.

(s) Post, p. 9.

(t) De Whal v. Braune. 1 H. \& N. 178.

(t) White v. Cuyler, 1 Esp. $200 ; 6$ T. R. 176. As to whether an action will lie against husband and wife for false representation by the wife, see Wright v. Leonard, 30 L. J., C. P. 365. 
the principle that the wife was his agent and had authority from him to enter into the contract $(u)$. But it is not necessary, in order to render him liable, to show that such authority was expressly given to the wife. It is sufficient if it can be implied from circumstances. In all cases the question whether or not she had authority to bind him is one proper for the consideration of a jury $(x)$; and, so long as the husband and wife cohabit, it will bo presumed that she had authority to hire such servants as were necessary *or suita- [*6] ble to the condition in life of her husband, and he will be liable to pay their wages $(y)$. When they do not cohabit the presumption is rather the other way, viz., against the husband's liability upon his wife's contracts (z). But in both cases the presumption may be rebutted: Presumption in the former case, by evidence that the husband had of lusband's expressly forbidden his wife to hire the servant, and liability may the servant knew that he had done so $(a)$; or by show. ing that, during his temporary absence, he allowed and paid his wife an adequate sum for the payment of all necessary expenses, and that the servant knew that he did so $(b)$; in the latter case, by showing that the wife was not reasonably provided for, considering the circumstances of the husband $(c)$. For if, when husband and wife are separated, she receive, eitber from her husband or any other source $(d)$, an adequate sum for her sepa-

(u) Manby v. Scott, Montagne v. Benediet, Seaton v. Bewedict, 2 Smith's L. C. 396 ; Mizen v. Piek, 3 M. \& W. 481 ; Chit. on Contr. 152 ; Reid v. Teakle, 13 C. B. 627 ; Ruddoek v. Marsh, 1 H. \& N. (601; Johnson v. Sumner, 3 H. \& N. 261 ; 27 L. J., Exc. 341 ; Biffen ․ Bignell, 31 L. J., Exc. 189 ; Jolly v. Rees, 32 L. J.. C. P. 177 ; Debenham v. Mellon, 49 L. J., Q. B. 497 ; 5 Q. B. D. $394 ; 6$ App. Cas. 24 ; 50 L. J., C. L. 155.

$(x)$ Lane v. Ironmonger, $13 \mathrm{M} . \&$ W. 368. But if there is no reasonable evidence upon which the jury can act, the judge is instified in withdrawing the case from the jury, and nonsuiting the plaintiff, Phillipson v. IIayter, L. R., 6 C. P. 38.

(y) See Etherington v. Parrolt, 1 Salk. 118; Jcwsbury v. Newbold, 26 I. J., Exc. 247 ; and cas. cit. 2 Snitl's L. C. 441 . This presumption of agency arising from cohabitation is not confined to the case of a lawful wife; it extends to the case of a woman with whom the defendant cohahits, and whom he allows to assume his nams, although not his wife, Watson v. Threlkeld, 2 Esp. (337.

(z) Reed v. Moore, 5 C. \& P. 200; Ozurd v. Darnford, 1 S. N. P. 298; Mainwaring v. Leslie, M. \& M. 18; Clifford v. Laton, M. \& M. 101.

(a) Wtherington v. Parrolt, 1 Salk. 118.

(b) Holt v. Brien, 4 B. \& Ald. 252.

(e) Clifford v. Laton, M. \& M. 101.

(d) Ihid. But a pension revocable at pleasure is not a sufficiently stable fund for the purpose, Thompson v. Hertey, 4 Burr. 2177 . 
rate maintenance she has no implied anthority to pledge her husband's credit, and in such case it is not necessary to prove that the party trusting the wife had notice of her separate maintenance, in order to exempt the husband from liability $(e)$. But when a married woman is separated from her husband, she does not thereby regain the capacity to enter into contracts which will be binding upon her as a feme sole, even though the separation be by deed, and therefore, although, in some such cases, the husband is not liable, yet no more is she ; parties entering into contracts with her, under such circumstances, trust to her honour $(f)$.

Power of husband to take advantage of wife's contracts of hiring.

Payment to

And an admission by the wife that her wages have een paid would not be evidence against her husband tion by husband for her wages.

Harper $\mathrm{v}$. Luffkin.

[*7] *So, on the other hand, the husband may take advantage of any contract of service entered into by his wife ; and therefore where a married woman enters into service her husband is the person to whom her wages should be paid, as he is entitled to the profits resulting from her work and labour, and she cannot, in goneral, even join him in an action upon a contract made during the marriage for her work and labour $(g)$, though it is said she may do so where she is in the meritorious cause of action, as where cause arises from her personal labour and skill $(h)$. - in action by him for her wages (i). Nor, indeed, would the fact of actual payment to the wife be any answer to such an action, unless she was authorized by him to receive it $(k)$.

There is, however, one case $(l)$ in which it was held that a married woman, who was residing with her father, having been seduced, the father might bring an action against her seducer, although it was objected that the action was founded on loss of service, and the daughter being a married woman, she could not enter

(e) Mizen v. Piek, 3 M. \& W. 481; Holder v. Cope, 2 C. \& K. 437 ; Reeve v. Marquis of Conyngham, 2 C. K. 444.

(f) Marshall v Rutton, 8 T. R. 545.

(g) Buckley v. Collier, 1 Salk. 114. And see Cooper v. Wellington, 7 C. \& P. 531, which was an action brought by a husband alone, who was separated from his wife, for special damage sustained by him in consequence of a libel on his wife, whereby she lost a situation which enabled her to maintain herself.

(h) Brashford v. Buekingham, Cro. Jac. 77, 205: and see Nurse v. Wills, 4 B. \& Ad. 743 ; in error, 1 A. \& E. 65 ; Johnson v. Lueas, 1 E. \& B. 659 ; Selw. Nisi Prius, tit. "Baron and Feme," III.

(i) Hall v. Hill, 2 Str. 1094.

(k) Offey v. Clay, 2 M. \& G. 172.

(l) Harper v. Luffkin, 7 B. \& C. 387. 
into a valid contract of service, and therefore the father was not legally entitled to her services; but it was held that a service in fact was sufficicnt to support the action, especially as the husband had not interfered. $y$

Where the husband is civilly dead, as in the case of his being transported for life, or a limited term, the bance wife may contract as a feme sole, and sue or be sued victed. upon her *contracts $(m)$; and it makes no differ- [*8] ence in this respect that he is at the hulks in this country and not actually sent abroad $(n)$.

In equity a married woman having separate property power of is, for many purposes, regarded as a feme sole, and her married contracts (o) are held to bind her separate estate, women in though she is incapable at law of making a contract in Equity. respect of her separate property $(p)$. And it appears to be the better opinion, that it is not necessary that a contract should be in writing, in order to bind her separate estate in equity, where that is not rendered necessary by any statute $(q)$; nor, where it is in writing, is it necessary that it should refer to the separate property in order to bind it $(r)$. Where, however, there is a restraint upon her power of anticipation, she cannot deal with her property as a feme sole. And a married woman is not rendered competent to contract as a feme sole, by the possibility that she may afterwards acquire separate property $(s)$.

By the Married Women's Property Act, $1882(t)$, Married which came into force on 1st January, 1883, and re- Women's Property Act, 1882 .

(m) Chit. on Contr. 169; or make a will, Re Coward, 34 L. J., P. M. \& Adm. 120.

(n) Ex parte Frank: 7 Bing. 762.

(o) Bell v. Hyde, Prec. Cha. 328; Norlon v. Turvill, 2 P. Wms. 144: Grigby v. Cox, 1 Ves. 517.

(p) Clerk v. Laurie, 1 H. \& N. 432.

(q) Owcns v. Dickinson, Cr. \& Ph. 5i). See Wright v. Chard, 29 L. J., Ch. 82; 4 Drew. 673; Juhnson v. Gallagher, 30 I. J., Ch. 293; 3 Do G., F. \& J. 494; Shattock v. Shattock, 35 L. J., Ch. 509; L. R., 2 Eq. 182; Re Leeds Bauking Co., 36 L. J., Ch. 90; London Charlered Bank of Australia v. Lempriere, 42 I. J., Pr. C. 49; I. R., 4 Pr. C. App. 57: at p. 594, James, L. J., says:-"It would be very ineonvenient that a married woman with a large separate property should not be able to employ a solieitor, or a surveyor, or a builder, or tradesman, or hire labourer or servants, and very unjust if she did that they should have no remedy against such separate property." And see Re Harvey, 49 I. J., Ch. 3; I'ike v. Filzgibbon, 50 L. J., Ch. 394; 17 Ch. Div. 454; Robinson v. Pickering, 50 L. J., Ch. 527; King v. Lueas, 53 I.. J., Ch. 64.

(r) Ibid., and see Vaughan v. Walker, 6 Ir. Ch. Rep. 471.

(s) Per Wood, V. C., in Walroul v. Walrond, 28 I. J., Ch. 97.

( $t) 45$ \& 46 Vict. c. 75 . By sect. 26 this Act does not extend to Scotland.

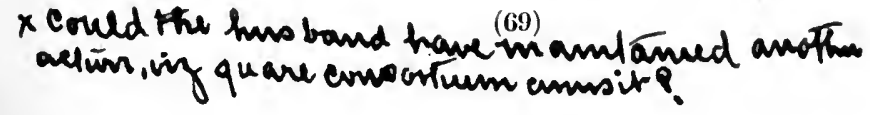


pealed the Acts of 1870 and 1874 (provided that such repeal should not affect any act done or right acquired while either of such Acts was in force, or any right or [*9] liability of any *husband or wife married before the commencement of this Act) (u), it is enacted:

Sec. 1. (1) A married woman shall, in accordance

Married woman to be capable of holding property and of contracting as a feme sole. with the provisions of this Act, be capable of acquiring, holding and disposing by will or otherwise of any real or personal property as her separate property in the same manner as if she were a feme sole, without the intervention of any trustee.

(2) A married woman shall be capable of entering into and rendering herself liable in respect of and to the extent of her separate property on any contract, and of suing and being sued either in contract or in tort or otherwise, in all respects as if she were a feme sole, and her husband need not be joined with her as plaintiff or defendant or be made a party to any action or legal proceeding brought by or taken against her; and any damages or costs recovered by her in any such action or proceeding shall be her separate property; and any damages or costs recovered against her in any such action or proceeding shall be payable out of her separate property and not otherwise $(v)$.

(3) Every contract entered into by a married woman shall be deemed to be a contract entered into by her with respect to and to bind her separate property, unless the contrary be shown.

(4) Every contract entered into by a married woman with respect to and to bind her separate property shall bind not only the separate property which she is possessed or entitled to at the date of the contract, but also all separate property which she may, thereafter acquire.

Property of a 2. Every woman who marries after the commencewoman mar- ment of this Act (1st January, 1883) shall be entitled ried after the to have and to hold as her separate property and to disAct to be held by her as a feme sole. pose of in manner aforesaid [i. e., by will or otherwise] all real and personal property which shall belong to her at the time of marriage, or shall be acquired by or devolve upon her after marriage, including any wages, earnings, money and property gained or acquired by [*10] her in any employment, trade *or occupation in which she is engaged or which she carries on separately from her husband, or by the exercise of any literary, artistic or scientific skill.

(u) . Sect. 22.

(v) See Weldon v. Winslor, 53 L. J., C. L. 528. 
5. Every woman married before the commencement Property acof this Act (supra) shall be entitled to have and to hold quired after and to dispose of in manner aforesaid as her separate the Act by a property all real and personal property her title to woman marwhich, whether vested or contingent, and whether in the Act to be possession, reversion or remainder, shall accrue after held by her the commencement of this Act, including any wages, as a feme sole. earnings, money and property so gained or acquired by her as aforesaid $(x)$.

And $(y)$ where a wife is deserted $(z)$ by her husband where wife she may at any time after such desertion, if resident deserted by within the metropolitan district, apply to a police magistrate, or if resident in the country to justices in husband hass petty sessions; or, in either case, to the Court for $\mathrm{Di}$ obtained vorce and Matrimonial Causes $(a)$, for an order to pro- earnings. tect any money or property she may acquire by her own lawful industry (b), and property which she may become possessed of after such desertion, against her husband or his creditors, or any person claiming under him; and such magistrate or justices or court, if satisfied of the fact of such desertion, and that the same was without reasonable cause, and that the wife is maintaining herself by her own industry or property, may make and give to the wife an order protecting her earnings and property acquired since the commencement of such desertion, from her husband and all creditors and *persons claiming under him; and such [*11] earnings and property shall belong to the wife as if she were a feme sole: Provided always, that every such order, if made by a police magistrate or justices at petty sessions, shall, within ten days after the making thereof, be entered with the registrar of the county court within whose jurisdiction the wife is resident; and that it shall be lawful for the husband, and any creditor or

(x) Under the Act of $18 \% 0$ it was held that a married woman who deposited her earnings at a bank could in her own name only sue the bank for dishonouring her checue, Summers v. The Gily Bank, 43 L. J., C. P. 261.

(y) $20 \& 21$ Vict. c. 85, s. 21 . The affidavit in support of the application for such an order should be very precise, to satisly the Court of the fact of desertion, Ex parle sewcll, 28 L. J., Prob. \& Mat. C. 8 . On the construction of this section generally, see Bathe v. Bank of England, 27 J. J., Ch. 630; Millland Railway Company v. Pye, 30 L. J., C. P. 314.

(z) As to what amounts to desertion, see Thompson v. Thompsou, 27 J. J., Prob. \& Mat. C. 35.

(a) Alimony pendente lite was refused to a wife in service at 14l. a year, George v. Georye, 37 I.. J., Mat. 17.

(b) This does not apply to earnings alcpuired as keeper of a brothel, Mason v. Mitcheil, 34 L. J., Exe. 68. 
other person claiming under him, to apply to the court or to the magistrates or justices by whom such order was made $(c)$ for the discharge thereof: Provided also, that if the husband, or any creditor of or person claiming under the husband, shall seize or continue to hold any property of the wife after notice of any such order, he shall be liable at the suit of the wife (which she is thereby empowered to bring) to restore the specific property, and also for a sum equal to double the value of the property so seized or held after sucb notice as aforesaid: if any such order of protection be made the. wife shall, during the continuance thereof, be and be deemed to have been during such desertion of her in the like position in all respects with regard to property and contracts, and suing $(d)$ and being sued, as she would be under this Act if she obtained a decree of judicial separation.

\section{INFANTS.}

Infants.

Although infants labour under a general incapacity to enter into absolutely binding contracts with other persons $(e)$, yet they may make some contracts which will be binding upon them until avoided by them $(f)$; such as [*12] * contracts for their benefit $(f)$. Infants may also make contracts for necessaries, which will be absolutely binding upon them $(g)$.

What are

What are necessaries is a mixed question of law and necessaries. fact $(h)$, and will be decided by the Court and jury

(c) Or "to the magistrates for the time being acting as the successor or in the place of the magistrate who made the order of protection for the discharge of it, who shall have authority to make an order discharging the same;" and an order for discharge of an order for protection may be applied for to and be granted by the Court, altlougl the order for protection was not made by the Court; and an order for protection made at one petty sessions may be discharged by the justices of any later petty sessions or by the Court; $27 \& 28$ Vict. c. 44 , which was passed in consequence of Ex parte Sharpe, 33 L. J., M. C. 152.

(d) See Ramsden v. Brearley, 44 L. J., Q. B. 46.

(e) Bac. Abr. tit. "Infancy," I.

(f) Third persons cannot aroid contracts entered into by infants, on the ground that they are not for the infant's benefit, Douglas v. Watson, 17 C. B. 685 . When an infant can avoid a contract he must do it within a reasonable time of coming of age, Dublin and IFicklow Railway Company v. Black, 8 Exe. 181

(f) Maddon v. White, 2 T. R. $161 ; R$. v. Shinfield, 14 East, 541.

(g) Bac. Abr. tit. "Infancy," I. 1; and see Zouch v. Parsons, 3

Burr. 1801 ; Drury v. Drury, 5 Bro. Parl. Cas. 570.

(h) Wharton v. M'Kenzic, 5 Q. B. 612. 
taking into consideration the station in life of the infant $(i)$.

Livery for the servants of an infant, who was a cap- Livery for tain in the army, has been held to come within the de- servants of scription of necessaries, and the infant was held liable captain in to pay for it $(k)$. Similar principles would apply to a the army. claim for wages.

A contract of apprenticeship is generally to be re-Contracts garded as for the benefit of an infant, and, therefore, heneficial to he may make a legal binding contract of apprentice- infint. ship $(l)$. If he could not do so, he could not be bound contract of at all, for a father has no common law authority to bind apprenticehis infant son an apprentice without his consent $(m)$. ship.

*So a contract of hiring and service may be [*13] Contracts of beneficial to an infant, and would, generally speaking, hiring and be binding upon him, and may be made even with his service. own fatber $(n)$ or mother (o). Such a contract would subject him to the statutable regulations applicable to masters and servants, although he might not be liable

(i) Peters v. Fleming, 6 M. \& W. 46 ; Wharton v. M'Kenzie ubi supra; Chapple v. Cooper, 13 M. \& W. 252; Ryder v. Hombwell, 38 L. J., Exc. 8.

(k) Hands v. Slancy, 8 T. R. 578 ; Chapple v. Cooper, 13 M. \& W. 258.

(l) R. v. St. Petrox, 4 T. R. 196 ; R. v. Arundel, 5 M. \& S. 257 ; Cooper v. Simmons, 31 L. J., M. C. 138. In order to make it binding however, he must execute the contract (as an adnlt must also, $R$. v. Ripon, 9 East, 295). It is not sufficient for the fiather and master to execute, $R$. v. Cromford, 8 East, $25 ; R$. v. Arm'sby, 3 B. \& Ald. 584 ; St. Nicholas, Rochester v. St. Botolph, Bishopsgate, 31 L. J., M. C. 258. But he may execute by the hand of a third party, $R$. v. Longnor, 4. B. \& Ad. 647.

(m) R. v. Amesby, 3 B. \& Ald. 584. The reason, why the father or friend generally joins in a contract of apprenticeship, is because an action of eovenant will not lie against an infant apprentice for not serving; see Y. B., 21 Hen. 6, 31; Gilbert v. Fleteher, Cro. Car. 179; and see Capes v. Hutton, 2 Russ. 357. Though it appears to be otherwise by the custom of Iondon, Horn v. Chandler, 1 Mod. 271 ; and see Ex parte Eden, 2 MI. \& S. 226; Com.' Dig. "Justices of the Peace;" 13. 59 ; Beard v. Webb, 2 B. \& P. 99. Any action for breach of the contract on the part of the infant should be against the father where he joins, Branch v. Evington, 2 Dong. 518. Where the deed is still in force the master can only recover damages up to the time of issuing the writ, not prospective damages; Levis v. Peacey, 31 I. J., Exc. 496. To such an action it is no answer that it was the master's duty to compel service, Mughes v. Humphreys, 6 B. \& C. 687 ; nor that the son avoided the indenture after he came of age, Cuming v. Hill, 3 B. \& Ald, 59; see also Ellen v. Topp, 6 Exc. 424; Phillips v. Clift, 4 H. \& N. 168.

(n) R. v Chillesford, 4 B. \& C. 94.

(o) Gilbert v. Schwench, 14 M. \& W. 488. 
to any action upon the contract $(p)$. And it would give him a right of action for wages earned $(q)$. For if an infant of five years of age, or other person who is non potens in corpore, be retained and serve in the best manner he can, his master must pay him his wages $(r)$.

Wood $\mathrm{v}$. A contract of hiring and service for wages would be Fenwick. considered beneficial to, and binding upon, an infant, although it contains clauses for referring disputes to arbitration, and for the imposition of forfeitures in case of neglect of duty, to be deducted from the wages $(s)$ $R$. v. Lord. But it has been held that a contract by an infant binding himself to serve during a certain time for wages, but enabling the master to stop the work whenever he chose, and retain the wages during the stoppage, is wholly void, as not being beneficial to the infant $(t)$.

Contract of apprenticeship not beneficial to infant roid. Meakin $\mathrm{r}$. Morris.

And on a summons before the magistrate under the Employers and Workmen Act, $187 \overline{5}$, taken out by a master to enforce performance of his duties by an apprentice under his indentures, where the indentures, dated May, 1882, contained a clause providing that the master should not be liable to pay the apprentice wages [*14] so long as *business might be interrupted by turn-outs or strikes, the apprentice being authorized and allowed during such period to employ himself in any other manner ur with any other person for his own benefit, it was held that such a clause was illegal, as not being beneficial to the infant, and the indentures void. A strike had occurred on November 24th, 1883, and a turn-out. The apprentice got employment at other works at the same wages he had been earning, but at the conclusion of the turn.out refused to return to his master $(u)$.

Infants may - By the County Courts Act it is provided $(x)$, "that it in County Court;

(p) R. v. Chillesford, ubi supra, Wood v. Fentick, 10 M. \& W. 204.

(q) Ibid. In America a minor cannot sue for wages unless his father has given him his time, or emancipated him Stiles v. Granville, 6 Cush. Rep. 458 . But where the father has dead and the mother was insane, a minor was regarded as emancipated, and allowed to recover, Jenness v. Emerson, 15 New Hampsh. Rep. 486.

(r) Dalt. Just. Ch. 58; Bro. tit. "Labour," 46; Bac. Ab. tit. "Master and Servant," and see Phillips v. Jones, 1 A. \& E. 333.

(s) Wood v. Fenwich, 10 M. \& W. 195.

(t) R. v. Lord, 12 Q. B. 757 .

(u) Meakin v. Morris, 53 L. J. M. C.72.

(x) $9 \& 10$ Vict. c. 95 , s. $64 ; 13$ \& 14 Vict. c. 61 , s. 1 ; C. C. Ord. 1875, Ord. V. 7. 
one years to prosecute any suits in any court holden under that act for any sum of money, not greater than fifty pounds, which may be due to him for wages, or piecework, or for work as a servant, in the same manner as if he were of full age."

There is a similar provision in the City of London Snall Debts Act $(y)$.

And by the Interpretation Clause of the Employers are within and Workmen Act, 1875, (z) (which enlarged the powers Employers of County Courts in respect of disputes between em- and Workployers and workmen, and gave other courts a limited men Act, civil jurisdiction in respect of such disputes) it is enacted that-

"In this Act the expression 'workman' does not include a domestic or menial servant, but, save as aforesaid, means any person who, being a labourer, servant in husbandry, journeyman, artificer, handicraftsman, miner, or otherwise engaged in manual labour, whether under the age of twenty-one years or above that age, has entered into or works under a contract with an employer, whether the contract be made before or after the passing of this Act, be express or implied, oral or in writing and be *a contract of service or a con- [*15] tract personally to execute any work or labour."

But an infant cannot be registered as a voter under not within the Councils of Conciliation Act, $1867(\alpha)$.

Women and children, however, being considered to require legislative protection and control whilst entering into contracts of hiring and service, various Acts of Parliament have at different times, been passed for this Councils of Conciliation Act, 1867 . purpose, which are referred to in note $(b)$, and some Statutes for protection and control and children.

(y) 15 \& 16 Vict. c. Ixxvii, s. 46. In the Customs Regulation Act, there is also a provision that bonds given under that aet by minors shall be valid $16 \& 17$ Vict. c. 107 , s. 195 .

(z) 38 and 39 Vict. c. 90, s. 10. "The Master and Servant Act, $1867, " 30 \& 31$ Vict. c. 141 , was repealed by "The Conspiracy and Protection of P'roperty Act, 1875," 38 \& 39 Vict. c. 86, s. 17.

(a) 30 \& 31 Vict. c. 105 , s. 9, post, Chap. X.

(b) See as to Parish Apprentices, 43 Eliz. c. 2, s. 5; 18 Geo. 3, c. 47 ; 42 Geo. 3 c. 46 [scct. 8 repealed, 35 \& 36 , Vict. c. 63 , and see 47 $\& 48$ Vict. c. 43 ] ; 56 Geo. 3 , c. 139 [sect. 1 repealed, $39 \& 40$ Vict. c. 61, s. 27 , and see $47 \& 48$ Vict. c. 43 ] ; $3 \& 4$ Will. 4, c. $63 ; 4 \& 5$ Will. 4 , c. 76 , ss. 15,$61 ; 7 \& 8$ Vict. c. 101, s. 12 ; as to Apprentices to Sea Service, $17 \& 18$ Vict, c. 104, s. 141 et seq. ; 14 \& 15 Vict. c. 35, s. 10 (the rest of that Act being repenled); as to Apprentices to Watermen, \&c., on the Thames, $22 \& 2: 3$ Vict. $c$. cxxxiii, s 48 et seq.; as to Chimney Sweeps, 3 \& 4 Vict. c, 8.5 (see R. v. Hipswell, 8 B. \& C. 466), 27 \& 28 Vict. c. $37 ; 38$ \& 39 Vict. c. $70 ; 47 \& 48$ Vict. c. 43 ; as to employment of Women and Children in Mines and Collieries, $35 \& 36$ Vict. c. 76 (post, Appendix); in Metalliferous Mines, $35 \& 36$ Vict. c. 77 (post, $\Lambda_{1}$ - 
of which will be found printed at length in the Appendix.

\section{LUNATICS.}

Lanatics.

Partners generally.

The position of a lunatic or person of unsound mind is considered in general to bear some analogy to that of an infant in regard to his liability upon contracts $(c)$. For although, strictly speaking, a person of unsound mind is incompetent to contract $(d)$, yet there can be no doubt that a lunatic would be held liable to pay for any services which had been rendered to him, provided they were such as might reasonably be considered necessary for a person in his station in life. In such a case the law [*16] would imply *a promise to pay for them (e). And modern cases show that when a party entering into a contract is a lunatic, but the state of his mind is unknown to the other party, who has taken no advantage of the lunatic, he would not be allowed to set up his - lunacy as a defence to an action on the contract, especially in a case where the contract was not merely executory, but executed in the whole or in part, and the parties could not be restored altogether to their original position $(f)$.

\section{Partiners.}

Every partner may in general be regarded as the agent of the partnership firm, and as such endowed with authority to do all acts within the scope of the partnership business, so as to bind the firm. A partner, indeed, virtually embraces the character of both principal and agent. So far as he acts for himself and his own interest in the common concerns of the partnership, he may properly be deemed a principal, and so far

pendix); in Factories, 41 \& 42 Vict. c. 16 (post, Appendix); in Husbandry (Agricultural Gangs), 30 \& 31 Vict. c. 130 (post, Appendix); "Agricultnral Children Act, 1873 ," 36 \& 37 Vict. c. 67 (post,Appendix). And see the General Act for the better protection of Apprentices and Servants, 14 \& 15 Vict. c. 11, amended by $24 \& 25$ Vict. c. 100 , ss. 26 , 73, and 77 (post, Appendix); and "The Trade Union Acts, 1871 and 1876," 34 \& 35 Vict. c. $31 ; 39 \& 40$ Vict. c. 22 (post, Appendix). The Stat. $36 \&$ 37 Vict. c. 67, was repealed by the Elementary Education Act, 1876 , (39 \& 40 Vict. c. 79), s. 52 see post $P .631$.

(c) Wentworth v. Tubb, 1 Y. \& C. N. C. 171.

(d) See Chit. on Contr. 129, et esq. The maxim of the Roman law was-" Furiosus nullum negotium gerere potest, quia non incclligit quod agit." Inst. lib. 3 , tit. 20 , s. 8.

(e) See Baxter v. Earl Portsmouth, 5 B. \& C. 170.

(f) Molton v. Camroux, 2 Exc. 487 ; 4 Exc. 17; Read v. Legard, 6 Exc. 636 ; Beavan v. M' Donnell, 9 Exc. 309. 
as he acts for bis partners he may as properly be deemed an agent $(g)$.

With regard to hiring and dismissing clerks and Power of servants, each partner would, generally speaking, have hiring and authority to hire and discharge such servants as might dismissing be necessary for the purpose of carrying on the business of the partnership.

Where, therefore, one partner gave a weekly servant Donaldson v. due notice to quit, but the other partner afterwards Williams. authorized him to remain in the house where the partnership business was carried on, and of which the partners were joint tenants, it was held that such remaining was lawful, and that the partner who gave the notice to quit was not justified in turning the * servant out by force on his refusing to go peace- [*17] ably, as the rights of the partners were co-extensive $(h)$.

And where the purser of a mine, who was also one of Atrood $\mathrm{r}$. the adventurers, in pursuance of a resolution of share- Ernest. holders, deposited the account-books of the mine with an accountant to examine the accounts, it was held that the purser could not alone bring an action for the recovery of the books which the accountant detained by the license, as he alleged, of the other adventurers (i).

We shall hereafter, when treating of the liability of Liability of a master for the negligence of his servants, see that a partners for master is not generally liable to one servant for injuries negligence of master is not caused through the negligence of a fellow servant $(k)$. causing inBut that principle does not apply where the fellow jury to serservant is also the master, or one of several partners vant of firm. who are the masters of the injured servant.

In a case $(l)$, therefore, where two men were lessees Ashcorth v. of a coal-pit, and one of them acted as banksman at Stanxix. the mouth of the shaft, and whilst so acting was guilty of negligence whereby the plaintiff, a pitman, was injured, it was held that both the lessees were liable for the injury; Crompton, J., saying-

(g) Story on Partn. 1 ; Ernest v. Nicholls, 6 Ho. Lords Cases, 417. As to embezzlement by one partner of money, \&e. belonging to the partnership, see 31 \& 32 Vict. e. 116.

(h) Donaldson v. Williams, 1 Cr. \& M. 345, See also Read v. Coker, 13 C. B. 850; where two partners quarrelled, and one, with the aid of his servants, turned the other out.

(i) Atwood v. Ernest, 12 C. B. 881.

(k) Post, Chap. IV.

(l) Ashworth v. Stanwix, 30 L. J., Q. B. 183; Mellors v. Shaw, 30 L. J., Q. B. 333; 1 Best \& S. 437. See Burnard v. Aaron, 31 L. J., C. P. 334, where one of two joint owners of a ship was held not liable for the negligence of the other, who, under the circumstances, was held to have hircd the whole ship, and so to be solely liable. 
"The relation of master and servant does not the less subsist because by some arrangement between the joint masters one of them takes upon himself the functions of a workman. It is fallacy to suppose that on that account the character of master is converted into that of a fellow labourer. Though engaged with the plaintiff in a common employment W. did not the less re. main the master of the plaintiff and the partner of the defendant $S$. This being so, it follows that $S$. must be liable in respect of the negligence through which injury has arisen to the plaintiff, as the relation of partner subsisted between W. and $S$. ; and as the negligence was in a matter within the scope of a common undertak[*18] ing, *we think that $\mathbf{S}$. is equally liable with W. That a partner is liable for the negligence of his copartner when engaged in the business of the partnership is not only clear in principle but is established by the case of Moreton v. Hardern $(m)$ in this court, where two proprietors of a stage coach were held liable with a third for the negligence of the latter by whom the coach had been driven. Now it has never been doubted that for personal negligence of the master, whereby injury is occasioned to the servant, the master will be liable. Personal negligence is clearly established against $W$., and it being admitted that the defendant S. was his co-proprietor and partner the latter must be held to be jointly responsible in respect of such negligence, and is therefore liable in this action."

Effect of dissolution of partnership or change of firm on contracts of hiring. Hobson r. Couley.

Whether or not a dissolution of partnership would be a breach of a contract by a firm to retain a person in their service for a lengthened period at an increasing salary may be doubted $(n)$ : but a dismissal by one of the remaining partners would clearly be so. And where a person entered into the service of a firm as manager for seven years at a salary increasing every year up to $190 l$. per annnm, but shortly afterwards, upon a change in the tirm, signed a memorandum, "In consideration that a new agreement is entered into with the new firm at a salary of $180 l$. a year, I am willing to cancel the present agreement with C. \& M." (the old firm), and afterwards continued in the service of the new firm from August to April, at a salary of 180l. a year, and the jury found that there was a new

(m) 4 B. \& C. 223.

(n) See Lloyd v. Blackburn, 9 M. \& W. 363, where the question arose on dissolution of partnership between masters of an apprentice; and Popham v. Jones, 13 C. B. 225, where A. was bound apprentice to two masters not in partnership. 
agreement with the new firm, it was held, in an action against C. \& M. for wrongful dismissal, that the new agreement was an implied surrender of the first, and was good evidence in support of a plea of exoneration before breach $(o)$.

A., B. and C. were partners in trade, and in July, Dobbin v. 1838 , by an agreement in writing, engaged to employ Foster. the plaintiff, and he to serve them, as their foreman for twelve *years at two guineas a week, with perqui-[*19] sites. In 1843 , the firm got into difficulties, and the concern was closed. A fiat in bankruptcy was sued out against them, and notice was given to the plaintiff by the assignees not to come again upon the premises. In November, 1838 , C. had retired from the firm, and the business was carried on by $\mathrm{A}$. and B., and the plaintiff had continued to serve them. The plaintiff sued A., B. and C., upon the original agreement, which, on their behalf, was contended to have been rescinded, but Coltman, J., held the defence not to be made out, and said, "C.'s going out of the concern did not per se put an end to the agreement; and as by that agreement the plaintiff had engaged to serve for a certain period, it appears to me that he was bound to continue in the service of A. and B., and that therefore it cannot be implied from this circumstance that the original contract was rescinded" $(p)$.

Where, however, one of two partners, who had ap- Tasker $\mathrm{v}$. pointed the plaintiff as their sole London agent for a Shepherd. period of four and a half years upon certain terms died, it was held that the survivor was not liable to an action for not employing the plaintiff as his sole agent; the contract being subject to an implied condition that all the parties so long lived $(q)$.

It may be convenient to mention in this place that Effect of where bonds are given by sureties to partners, for the change of fidelity and good conduct of clerks and other officers firm, or alterand agents in the service of a partnership, the uniform ation of salrule of construction of the bond, unless some clear lan- ity bonds. guage to the contrary is inserted, is, that the bond does not apply as a security after any change of the mem. bers of the firm by death or otherwise $(r)$, or, after any

(o) Hobson v. Couley, 37 L. J., Exc. 205; and see Robson v. Drummond, 2 B. \& Ad. 303.

(p) Dobbin v. Foster, 1 C. \& K. 323.

(q) Tasker v. Shepherd, 20 L. J., Exc. 207; 6 H. \& N. 575.

(r) Story on Partn. 350; Wright v. Russel, $2 \mathrm{~W}$. Bl. 934; Lord Arlington v. Merrick, 2 Wms. Saund. 411, and notes; Mayor of Bervick v. Oswald, 1 E. \& B. $295 ; 3$ E. \& B. $653 ; 5$ Ho. Lords 2 MAS. \& SEI. 
[*20] alteration of the *servant's salary $(s)$. But language may of course be used in a bond which shall clearly import a continuing liability, notwithstanding any change of firm or salary; and if such language is used, there can be no question that it will, both at law and in equity, have the most complete operation $(t)$.

By the Mercantile Law Amendment Act, 1856, $(u)$, it is enacted that-

"No promise to answer for the debt, default or mis-

Guarantee to carriage of another made to a firm consisting of two or to cease upon more persons or to a single person trading under the a change in name of a firm, and no promise to answer for the debt, the firm, except in default or miscarriage of a firm consisting of two or special cases. more persons or of a single person trading under the name of a firm, shall be binding on the person making such promise in respect of anything done or omitted to be done after a change shall have taken place in any one or more of the persons constituting the firm or in the person trading under the name of a firm, unless the intention of the parties that such promise shall continue to be binding notwithstanding such change shall appear either by express stipulation or by necesary implication from the nature of the firm or otherwise."

This provision, however, does not apparently alter the English law as previously settled by decided cases, but was intended to make the law of Great Britain uniform; the Scotch law, if it differed, being assimilated to the English by c. 60 of the same session, s. $7(x)$.

Under this statute it was held, where three persons Backhouse v. trading under the name of "G., W. \& W. J. Hall,"
Hall. gave to a banker the following guarantee-" In consideration that you have at my instance and request con[*21] sented to *open an account with the firm of G.,

Cas. 856 ; Kitson v. Julian, 4 E. \& B. 854 . So, e converso, a fidelity bond for $\mathrm{A}$. would not render the surety liable for the acts of A.'s partner B., London Assurance Company v. Bold, 6 Q. B. 514; Montefiore v. Lloyd, 33 L. J., C. P. 49. As to the effect of the death of the surety, see Lloyd v. Harper, 50 L. J., Ch. 140, 146.

(8) North Western Railway Company v. Whinray, 10 Exe. 77. See Sanderson v. Aston, post, p. 21.

(t) Strange v. Lee, East, 484 ; Metcalfe v. Bruin, 12 East, 400 ; Pease v. Hirst, 10 B. \& C. 122 ; Dry v. Davy, 10 A. \& E. 30 ; Simpson v. Cooke, 1 Bing. 452 ; Frith v. Rotherham, 16 M. \& W. 39 ; Pybus v. Gibb, 6 E. \& B. 902; Mayor of Dartmouth v. Silly, 7 E. \& B. 97. See London Tramtays Company v. Bailey, 37 L. T., N. S. 499, where $5 l$. deposited with plaintiff's manager as a guarantee for fidelity was held to be forfeited.

(u) $19 \& 20$ Vict. c. 97 , s. 4.

(x) Per Blackburn, J., in Backhouse v. Hall, 34 L. J., Q. B. 141 ; 6 Best \& S. 507 . 
W. \& W. J. Hall, shipbuilders, I hereby guarantee the payment to you of the monies that at any time may become due, not exceeding $5,000 l$," and one of them afterwards died, that the guarantee ceased on his death, as a contrary intention did not appear by express stipulation or by necessary implication from the nature of the firm or otherwise $(y)$.

And it may be considered settled law that where there Alteration of is a bond of suretyship for an officer, and by the act of duties, the parties, or by Act of Parliament, the nature of the avoids bond. office is so changed that the duties are materially altered, so as to affect the peril of the sureties, the bond is avoided. Even if the sureties were consenting par. ties by parol to such a change, it could hardly affect their liability under the bond." The question is whether the nature and functions of the office or employment are changed, for if they are, it is not the same office within the meaning of the bond $(z)$

But a mere addition to the duties of the principal But mere would not affect the liability of the surety; as where a addition to collector of poor and other rates was appointed to col- duties does lect a main drainage rate; or a collector of rents in one not. county was appointed to collect rents in another county $(a)$. Nor would an alteration of the length of notice determining the service, as from one month to three months, discharge the surety $(b)$.

If, however, a master retain a servant after notice that he has been guilty of embezzlement, the surety. would be discharged (c).

\section{* Corporations $(d)$.}

[*22]

Contracts in general, in order to be binding upon a Corporations. corporation, must be under the common seal of the

(y) Backhouse v. Hall, ubi supra.

z) Pybus v. Gibl, 6 E. \& B. 902 ; Bonar v. Mactonald, 3 Ho. Lords Cas. 226. See also Guardians of Malling Union v. Graham, 39 I. J., C. P. 54.

(it) Skillett v. Fletcher, 35 I. J., C. P. 154 ; 36 I. J., C. P. 206;

1 Harr. \& Ruth. 197.

(b) Sanderson v. Aslon, 42 I. J., Exe. 64; I. R., 8 Exe. 73. But see Holme v. Brunskill, 47 I. J., C. I. 81,610 ; I. R., 3 Q. B. Div. 405 .

(c) Phillips v. Foxhall, 41 L. J., Q. B. 293 ; I. R., 7 Q. B. 666 ; Sanilerson v. Aston, suprit.

(d) See Evans v. Harper, 45 I. J., C. I. 206. An attempt by a manager of a mutual insurance assoeiation, having no Parliamentary power to sue on behalf of the members, to sue upon a contriet on behalf of the members, which fitled. 
corporate body (e). This rule is to be found in all tho authorities $(f)$, beginning with those collected from the Year Books in Brooke's Abridgment, tit. " Corporations and Capacities," down to the latest of the present day, the ground of the rule being, that, as a corporation is a body politic and invisible, it can only act and speak by its common seal ; or, as it is said arguendo in Reg. v. Bigg $(g)$, "the conmon seal is the hand mouth of the corporation."

Attorney to a Accordingly no municipal corporation (except Loncorporation don) (h) can appoint an attorney, except under the must be appointed by corporate seal.

deed.

Arnold v.

Mayor of

Poole.

And, therefore, where (i) an attorney, who was town clerk and clerk of the peace, received instructions from the mayor and other members of the town council to take all necessary steps to oppose certain measures in Parliament, and to conduct certain suits in Chancery relating to the borough, but no authority was given to him under the seal of the corporation, it was held, that he could not sustain an action against the corporation for his costs.

Town clerk [*23] *So where $(k)$ a person, who, previously to the and clerk of passing of the statute $5 \& 6$ Will. 4 , c. 76 , had held the the peace.

Reg. v. Mayor of Stanford. offices of town clerk and clerk of the peace, and also clerk to the justices, was, after the passing of that statute, re-appointed to the offices of town clerk and clerk of the peace at an increased salary, by a resolution passed at a meeting, and entered upon the minutes of the town council; but there was no agreement under - the seal of the corporation: it was beld, upon issue

(e) Bac. Abr. "Corporations," E. 3 ; Com. Dig. "Franchise," F. 13. In The Mayor of Ludlow v. Charlton, 6 M. \& W. 815 , it is shown that the doctrine is not, as it might appear, a mere relic of ignorant times. And see Diggle v. The London and Blackvall Railway Company, 5 Exc. 451. Where the corporation have acted on a contract entered into by an agent on thcir behalf (as by entering into possession of land and making a railroad upon it), they could not afterwards take advantage of the fact that the agent was not appointed under seal. Wilson v. West Hartlepool Railway Company, 34 L. J., Ch. 241 ; 11 L. T., N. S. 327.

(f) See Gibson v. East India Company, 5 Bing. N. C. 269.

(g) 3 P. Wms. 423.

(h) In London the appointment is matter of record; see The Mayor of Thetford's case, 1 Salk. 192 ; 3 Salk. 103; Lord Raym. 848; Holt, 171.

(i) Arnold v. Mayor of Poole, 4 M. \& G. 860. In Hall v. Mayor of Stcansea, 5 Q. B. 544, Patterson, J., said, "The only difference I see between Arnold's case and that of servant employed at small wages is the comparitive inconvenience of insisting on a contract under seal in the latter case."

(k) R. v. Mayor of Stamford, 6 Q. B. 433. 
joined on a return to a mandamus for compensation under 5 \& 6 Will. 4 , c. 76 , s. 66 , bringing in question the fact of the re-appointment, that it could not be proved by an entry in the minutes of the town council; and, therefore, although there was no doubt that an agreement to the effect contended for had been made, yet that it could not bind the corporation without being sealed.

And so it has been held $(l)$ that a corn and coal meter Corn and coal to a corporation, who was entitled to receive for his meter. own use certain fees for weighing coals from ships Smith v. arriving at a port, must be appointed under seal, as he Cartwright. was an officer, and not a mere servant; and it was also held, that the tenure of his office, which was said to be during the pleasure of the corporation, did not make it unnecessary that he should have such an appointment, or convert him from an officer into a mere servant.

Upon similar principles where, in the articles of as- Solicitor to sociation of a company (afterwards incorporated), there company. was a clause providing that the plaintiff should be the Eley v. The solicitor for the company and should transact all the Positive, \&ic. legal business of the company for the usual fees and Assurance Co. charges, and should not be removed from his office unless for misconduct, which articles were signed by seven persons who became directors, but there was no appointment of the plaintiff *ander the seal of the [*24] company, it was held that the plaintiff could not sue the company for discontinuing to employ him and employing other solicitors $(m)$.

Again, in the following case a local board were held Arehitect to not liable to pay an architect for plans which he had local hoard. prepared under the directions of the defendants' sur- Hunt v. Wimveyor, although the defendants knew of and sanctioned bledon Local the employment of the plaintiff, as there was no contract under seal $(n)$. By s. 85 of the Public Health Act, $1348(11 \& 12$ Vict. c. 63$)$ every contract by the Local Board of Health whereof the value exceeds $10 l$; and by s. 174 of the Public Health Act, 1875 (38 \& 39 Vict. c. 55) every contract by an urban authority where-

(l) Smith v. Cartwright, 6 Exc. 927; quare, whether a corporation, by prescription, might preseribe to do certain corporate aets withont seal, which acts by the general law would require the use of a seal. Ilid. 939.

(m) Eley v. The Positive Government Security Life Assurance Company (Limitcl), 45 I. J., C. L. 58, 451.

(n) Hunt v. Wimbledon Local Board, 47 I. J., C. I. 540 ; 48 I. J., C. L.' 207. And see Enton v. Basker, 50 J. J., C. I. 194, 4.14; Young v. Mayor, \&e. of Royal Leamington Spa, 51 L. J., C. L. 29:; 52 L. J., C. L. 713; Attorney-General v. Gaskill, 52 L. J., Ch. 163. 
of the value exceeds $50 l$, shall be in writing and sealed with the seal of such board or authority as the case may be. The defendants, who were a local board within s. 85 and an urban authority within s. 174, authorized their surveyor to employ the plaintiff, an architect, to prepare plans for intended necessary offices, which were not afterwards erected. But as there was no contract under seal they were held not liable to pay the plaintiff.

Reg.v. Mayor, de. of Norwich.

Attorney to railway company under their Act.

R. v. Lichificld.

Cases in which solicitors recovered against corporations, though not appointed under seal, explained.

And where a corporation made payments which were justly due for work actually done, it was held that they were justified in so doing, although there was no contract under seal binding them to make such payments (o).

And where the Act of Parliament constituting a railway company enacted that the directors should have the management and superintendence of the affairs of the company, and might appoint 'and displace any of the officers of the company, it was held by Wightman, J., to be clear, that under that section the directors might appoint the officers of the company by parol, and if so, that they might appoint an attorney in the same way $(p)$.

[*25]*And where an attorney had been retained generally under the common seal of the borough, and had also been authorized and retained by resolution of the town council, to take proceedings in opposition to a rule nisi for a mandamus, it was held that this was a sufficient retainer to warrant the payment to him of the costs of so doing $(q)$.

There are, moreover, some cases $(r)$ in which it has been held, that the solicitors employed in obtaining the Acts of Parliament, incorporating certain companies, had a legal claim against them when incorporated, in respect of their services in obtaining the act of incorporation, although they were not, and, from the nature

(o) R. v. Mayor, \&c. of Norwich, Times, May 6, 1882, R. v. Mayor of Norwich is reported 30 W. R. 752 and see Bournemouth Commissioners v. Watts, 54 L. J., C. L. 93.

(p) R. v. Justices of Cumberland, 5 D. \& I. 431, note. And see Faviell v. Eastern Counties Railway Company, 2 Exc. $344 ; 6$ D. \& L. 54, where it was held that defendant's attorney might consent to a judge's order to refer, although he had no authority under seal to defend or refer the cause. 32.

(q) R. v. Lichfield, 10 Q. B. 534; and see R. v. Prest, 16 Q. I3.

(r) Tilson v. The Warwick. Gas Light Company, 4 B. \& C. 962; and Carden v. The General Cemetery Company, 5 Bing. N. C. 253; Hitchins v. The Kilkenny Railway Company, 9 C. B. 536; sce Wyatt v. The Metropolitan Board of Works, 31 L. J., C. P. 217. 
of the case, could not be, appointed under the seal of the corporate body. But $n$ each of those cases there was a clause in the act directing that the costs of obtaining the act should be paid, in preference to all other claims, out of the first money received by the defendants; and those cases were decided on the ground, that the meaning of the legislature was to make the incorporated companies, as soon as they had obtained funds, debtors to the solicitors who had obtained the acts, for all the costs which they had incurred $(s)$. Those cases do not, therefore, as at first might appear, from any exception to the general rule above stated.

There are, nevertheless, some exceptions to that rule, Execptions probably coeval with the rule itself, in those matters to general which, form their very nature or necessarily frequent rule. occurrence, it would be difficult or, perhaps, impossible to execute with the formality of a seal. Those are mat- Appointment ters of trifling importance and of frequent occurrence, of servants. such as the appointment of a servant, cook or butler, or such as from their *nature do not admit of [*26] delay, such as the appointment of a bailiff to distrain cattle damage feasant $(t)$. And it has been held, that a corporation was liable to an action for an illegal distress, though not damage feasant, by one who acted as their bailiff, although he was not appointed under seal $(u)$. And that a corporation might maintain an action of ejectment after notice to quit, given by a steward who was not appointed under seal $(x)$.

So it has been held, that the manager of an unincor- Naylor $\mathrm{v}$. porated banking company, although not authorized by Mortimore. any instrument under seal, might appoint an attorney to assent to and accept a proposal by a debtor under

(s) See Pardoe v. Price, 16 M. \& W. 460.

(t) Manby v. Long, 3 Lev. 107; Cary v. Mathews, 1 Salk. 191; see per Alderson, B., in Finlay v. Bristol and Excter Railway Company, 7 Ech. 411 . But it has been held that a clerk to the master of a workhonse at a salary of $52 l$. a year with board and lokging, whose duties were to keep the beoks of the master, was not within the exception, and, not having been appointed under seal, could not maintain an action for wrongful dismissal, Austin $\mathrm{v}$. Board of Guarditins of St Matthew, Bethnal Green, 43 I. J., C. P. 100; L. R., 9 C. P. 91. And sce Marehant v. The Lee Conssrrancy Board, 43 I. J., Exe. 54, where it was held (reversing a decision of the Court of Exchequer), that a clerk to trustees of a river navigation conld not sue for a pension grauted him by a resolution of the trustees not under seal.

(u) Smith v. The Birmingham Gas Company, 1 A. \& E. 526.

(x) lare v. P'icrec, 2 Campb. 96; and see Doc v. Bold, 11 Q. B. 127; Lowe v. The North-Wrstern Railway Compan!, 18 Q. B. 632; Ecclesinstical Commissioners v. Mervall, 38 L. J., Exe. 93. 
the Bankruptcy Act, 1861 , so as to make up the re. quisite majority of assenting creditors $(y)$.

Railway eom- So, also, it has been held $(z)$, that a railway company panies liable may be liable to an action of trespass for assault and for torts of false imprisonment, in consequence of their servant servants. having given a person into custody on an unfounded charge, although the directions to the servant were not False impri- under seal. In that case, indeed, it does not appear sonment. whether the original appointment of the servant was by deed, though most probably he was not so appointed, as he was only an inspector. It is clear, however, that a corporation may be liable to an action for a wrong done by their servant, although his appointment be not

Malicions prosecution.

Jibel. [*27] under seal $(\alpha)$. And it *would seem to be clear also that an action for malicious prosecution may, in a fit case, be brought against a corporation for the acts of its officers and servants (b). And it has been held, both in England (c) and America.(d), that a railway company is responsible, in its corporate capacity, for a libel published by its agents in the course of its business and of their employment.

In fact the whole tenour of authorities, from Yar-

(y) Naylor v. Mortimore, 33 L. J., C. P. 273.

(z) Eastern Conntics Rail Co. v. Broom, 6 Exe. 314.

(a) Ibid. And see Roe v. The Birkenhead, Lancashire and Cheshire Junetion Railuay Company, 7 Exc. 36; 21 L. J., Exc 9; Giles v. Taff Vale Railway Company, 2 E. \& B. 822; Watker v. South Eastern Railway Company, 39 L. J., C. P. 346. Whether or not the servant was autliorized by the corporation to do the particular aet eomplained of is, of course, a different question. As to which, see-cas. eit. infra. note $(b)$.

(b) Bank of New South Wales v. Owston, L. R., 4 App. Cas. 2\%0, 282; 48 L. J., Pr. C. C. 25; Edwards v. Midland Railway Company, 50 L. J., C. I,, 281; Stenens v. Midland Counties Railuay Company, 10 Exe. 352; Whitficld v. South Eastern Railuay Company, 27 I. J., Q. B, 229.

(e) Whitfield v. South Eastern Railway Company, ubi supra,

(d) The Philadelphia, Wilmington and Baltimore Raitroad Corporation v. Quigley, 21 Howard's Rep. 202. In that case Daniel, $J$., dissented fiom the judgmnnt of the rest of the Court, and speaks of Whitfield v. South Eastern Railway Company as "a solitary preeedent most eertainly contravening the eourse of decision for eenturies;" and of the judgment in that case as "in its arguments and eonelusions eonfused and obsenre; and incongruous and contradietory, both in its reasoning and its eonclusions. In the line of English adjudications it presents itself," says he "as solitary and eecentric, and in opposition to the most inveterate, the clearest and reiterated distinetions announeed by the sages of the law-distinctions having their foundation in reason and in the essential eharacter of the subjects to which those distinctions have been applied." The author, however, ventures to think there is little doubt but that it will be upheld, should the question ever be earried to a Ccurt of Appeal. 
borough v. The Bank of England (e) down to the case of Other cases Whitfield v. South Eastern Railway Company $(f)$, of tort. shows that.an action for a wrong lies against a corporation where the thing done is within the purpose of the incorporation, and it has been done in such a manner as to constitute what would be an actionable wrong if done by a private individual $(g)$. And as was observed by Blackburn, J. (h), *on one occasion, "If a cor- [*28] poration cannot know anything except by its servants, or do anything except by its servants, it would seem that the corporation must be liable for the knowledge of its servants, and the acts of its servants, or not liable at at all."

But the above exceptions do not apply to cases in Exceptions which an interest is vested in or divested out of a corpora- do not apply tion ; and therefore, a corporation cannot, without deed, appoint a bailiff to seize goods as forfeited to the use corporation. of the corporation $(i)$.

The cases, however, in which it has been held that a Foundation cook or butler, or other inferior servant to a corpora- of exceptions. tiun, need not be appointed under the common seal, are said to rest on a fiction that some individual has been duly authorized to make contracts of that nature on behalf of the corporation $(k)$. And it has not yet been settled whether the exceptions introduced by them, apply to the case of a corporation where no individual member is appointed head of the corporate body $(l)$. When, however, the case shall arise, there can, it is conceived, be little or no doubt that the further development of the principles, founded on expediency and convenience, amounting almost to necessity, which have led, in England, to the engrafting of exceptions on the ancient rule of the common law, and, in Awerica, to its total abolition $(m)$, will lead to the conclusion that

(e) 16 East, 6 .

(f) Ubi supra.

(g) Per Erle, C. J., in Geen v. London General Omnibus Company, 29 L. J., C. P. 13. See also Cowley v. Mayor of Sunderland. 30 L. J., Exc. 127.

(h) In Penhallow v. Mersey Docks and Harbour Board, 30 L. J., Exc. 331. See also, as to providling the scicuter against a eorporation by the knowledge of its servants, Stiles v. Cardiff steam Nurigation Company, 33 L. J., Q. B. 310 ; Applebee v. Perry, 43 L. J., C. P. 365.

(i) Horn v. Ivy, 1 Mod. 18.

(k) See per Iord Cranworth in Mayor of Ludlow v. Charllon, 6 M. \& W. 819, 821.

(l) Per Lord Wensteydate in Cope Thames Hacen Dock and Railway Company, 8 Exe. 844.

(m) See Story on Agency, s. 53; 2 Kent's Comm. 288, 291 
the exceptions above mentioned apply equally to the case of all companies, whether with or without a head. Exception in There is another class of cases which may perhaps cases of part be regarded as forming an exception to the rule that performance : corporations can only be bound by contracts under seal ; not applicable to contracts of hiring and serrice.

Exception in cases of trading corporations.

Contracts necessarily incident to purposes of corporation.

[*29] those *ases, namely, in which, by reason of part performance of contract, the objection that the contract was not under seal cannot be set up. But, as the equitable doctrine of part performance is not applicable to contracts of hiring and service $(m)$, it is thought sufficient to refer to some of those cases in a note $(n)$.

There is also another class of exceptions to the rule, that corporations can only be bound by contracts under seal, which has arisen in modern times. Corporations have, of late, been established sometimes by Royal Charter, more frequently by Act of Parliament, for the purpose of carrying on trading speculations; and where the nature of their constitution has been such as to render the drawing of bills, or the constant making of any particular sort of contracts necessary for the purposes of the corporation, there the Courts have held, that they would imply in those who are, according to the provisions of the Charter or Act of Parliament, carrying on the corporation concerns, an authority to do those acts without which the corporation could not subsist $(o)$.

Accordingly, in a variety of cases, corporations have been held bound by, and able to take advantage of, contracts necessarily incident to the purposes and objects for which the corporation was created, although such contracts have neither been under the corporate seal, nor entered into by an agent or servant authorized in that manner to act for the corporation. The exception

(Part 4, Lect. 33); and see Beverley v. Lincoln Gas Light and Coke Company, 6 A. \& E. 837, where Patteson, J. says, "There are obvious circumstances which justify their adrancing with a somewhat freer step to the discussion of ancient rules of our common law than would be proper for ourselves."

(m) Britain v. Rossiter, 48 L. J., C. L. 362 ; 11 Q. B. Div. 123.

(n) The Fishmongers' Company v. Robertson, 5 M. \& Gr. 131; The Mayor, \&c. of Kidderminster v. Hardwicke, 43 L. J. Exc. 9, et cas. ib. cit.; Hunt v. Wimbledon Local Boarl, 48 L. J., C. L. 207, ante, p. 24,

(o) Per Lord Cranworth in The Mayor of Ludlow v. Charlton, 6 M. \& W. 821; and see Beverly v. Lincoln Gas Light and Coke Company, 6 A. \& E. 829 ; Paine v. Strand Union, 8 Q. B. 326 ; Clarke v. Cuckfield Union, Bail. C. C. 81 ; Smart v. West Ham Union, 10 Exc. 867; 11 Exc. 867; Nicholson v. Bralforl Union, 35 L. J., Q. B. 176. "See also Scott v. Great and Little Clifton School Board, 52 L. T., N. S. 105. 
established by these cases $(p)$ depends upon the principle, before adverted to, of expediency and convenience, amounting almost to necessity, -- a principle, however, which, although in many *ases equally [*30] applicable to contracts of hiring and service as to contracts of other descriptions, yet it is conceived wonld only apply to contracts for services of an ordinary description, and such as might be necessary for carrying on the business of the corporation $(q)$.

Thus, a contract made by the directors of a steam navigation company, incorporated for the purpose of trading as shipowners, to pay for services in bringing home a disabled vessel, has been held to be binding upon the company, though not under seal, as one of the most ordinary incidents to the ownership of trading vessels is the necessity of employing persons to bring home such vessels as may have been accidentally disabled at a distance from home $(r)$.

Upon similar principles in a case $(s)$ in which the by poor law guardians of a Poor Law Union, having reason to be- guardians to lieve that their clerk had been guilty of fraud, and that sums of money had been misappropriated, employed the plaintiff, who was an accountant, to audit their accounts, investigate them generally, and make up the books; and resolutions to this effect were from time to time entered in the rough minute book; but there was no contract under the seal of the guardians; it was held by Erle, J. (though Crompton, J., doubted), that the plaintiff having dove the work agreed upon was entitled to recover, although the contract was not under seal.

(p) Mr. Justice Story says truly "that this exception affords a beantiful illustration of the expansive power of the common law, which accunires flexibility and moulds itself from time to time, so as to accomplish the various ends of modem society." Story on Agency, s. 53.

(q) Iunston v. The Imperial Gas Light and Coke Company, $3 \mathrm{~B}$. \& Ad. 125; see Clark v. The Imperial Gas Light and Coke Company, 4 B. \& Ad. 315, where it was held that the directors were justified in anlixing the corporate seal to a deed granting a retiring pension to the plaintiff, who had been elerk to the company ; and see Gibson v. Easl India Compermy, 5 Bing. N. C. 271 ; Beverly v. Lincoln Gas Company, 6 A. \& E. 829 ; Chureh v. Imperial Gas Company, 6 A. \& E. 853.

(r) IItraterson v. The Australian Royal Mail Steam Narigation Company, 5 E. \& B. 409; 24 L. J., Q. B. 322 ; and see Reiter v. The Electrie Telegraph Company, i E. \& 13. $341 ; 26$ L. J., Q. B. 46 ; Soulh of Ireland Colliery Company w. Waddle, 37 I. J., C. 1'. 211, where the company wore allowed to sne upm a contrat not under seal, part of the consideration for which had been received by the defendant.

(s) Haigh v. North Bierley Union, 28 L. J., Q. B. 6:2. 
And Erle, J., said, "Here the work which was done by the plaintiff was incidental and necessary to the purposes for which the corporation was created, and was [*31] done at the request of the *corporation. They had appointed proper officers to do the work, and they had reason to believe that there had been fraud, embezzlement, and a system of false accounting. Then, by the first resolution, they employ the plaintiff as an accountant to audit the accounts of the union. These services were quite essential to the purposes for which the guardians were created, and the first of them would probably be of short duration and not very difficult. It seems to have been highly important that the investigation should be made, and the subsequent employment was of much the same description, arising upon subsequent inquiries being made, and it was ordered by the guardians. The question of fact is, was this done by the plaintiff for the effecting of the purposes for which the guardians were appointed? It seems to me that it was." Crompton, J., however, thought otherwise, and was unable to distinguish the case from The London Dock Company v. Sinott $(t)$.

but not con- That was an action by the dock company against the tract by dock defendant for not performing a contract into which he company to had entered for scavenging the docks. But it was held pay for cleau- by the Court of Queen's Bench that. it could not be
ing docks. ing docks. maintained, as the contract was not under the seal of the company; and the plaintiffs did not bring themselves within any of the exceptions to the general rule, that a corporation aggregate can only be bound by contracts under seal.

Contracts by Contracts of this nature are, in many cases, regulated joint stock by the Companies Acts, 1862 and $1867(u)$, and the companies. Companies Clauses Consolidation Act, $1845(x)$, which last applies to all joint stock companies incorporated by Act of Parliament for the purpose of carrying on any undertaking, so far as the same are applicable thereto, except so far as expressly varied by the special Act.

Contracts by By the 91st section of the Companies Clauses Conjoint stock companies binding if within scope of company, solidation Act, 1845 , the determination as to the remu[*32] *neration of the secretary of a company is to be exercised only at a general meeting. But it is no answer to an action by a secretary for his salary, that

(t) 27 L. J., Q. B. 129.

(u) $25 \& 26$ Vict. c. $89 ; 30 \& 31$ Vict. c. 131, s. 37 .

(x) 8 \& 9 Vict. c. 16: see Homersham The Wolverhampton Waterworks Company, 6 Exc. 137. 
no determination as to such salary has ever been exer. cised at any general meeting of the company $(y)$. It may be a breach of trust as between the directors and the shareholders to agree to give the secretary a salary without the authority of a genereral meeting, but yet the company may be bound to pay it.

The principal of this decision is an important one, though not in and is in conformity with the cases in which it has conformity been held, that a joint stock company registered under with deed of $7 \& 8$ Vict. c. $110(z)$ was liable upon a contract within the scope and objects of the company bona fide entered settlement, into by the directors under seal, but not in conformity with the provisions of the deed of settlement of the company. If such a contract were illegal, of course it would not be biuding $(\alpha)$.

And although, generally speaking, where the seal is affixed to a contract made by a corporation in a manner binding upon them, the contract is the contract of the corporation, to be governed by the same rules of law as the contracts of private persons; yet, where a corporation is created by an Act of Parliament for particular purposes, with special powers, the contract does not bind them if it *appear by the express pro- [*33] visions of the statute creating the corporation, or by necessary and reasonable inference from its enactment, or ultra vires. that the contract was ultra vires, that is, that the Legislature meant that such a contract should not be made (b).

(y) Bill v. Darenth Valley Railroad Company, 1 H. \& N. 305; 26 L. J., Exe. 81.

(z) This Act is repealed by $19 \& 20$ Vict. e. 47, s. $10 \% ; 20 \&$ 21 Vict. c. 14 , s. $2:$, exeept as to insurance companies, $20 \& 21$ Vict. e. 80 .

(a) Agar v. Atheapum Life Assuranee Society, :3 C. B., N. S. 72:; 27 L. J., C. P. 95; Prince of Wales Assuranec Socioty v. Athensum Assurance Socicly, 27 I. J., Q. 13. 297, and cases there eited; Re Atheneum Life Assurance Company, 27 L. J., Ch. 829. In these cases dissent from a dictum of Lord Wensleydale in Ermest v. Nieholls, 6 Ho. Lords Cas. 418, is expressed. See also Atheneum Life Assurance Commeny v. Prooly, $28 \mathrm{~L}$. J., Ch. 119; Re IIcreules Insurance Company, 41 1. J., Ch. 450, where articles of assoeiation provided that, when 3,000 shases shonld have been allotted, the members should he assoeiated for the objects of the company, it was held that the allotment of the 3,000 shares was a condition precelent to the company being associated, and that the eompany were not riable for the salary of an engineer emploved by the direetors before the allotment of 3,000 shares. Pierce v. The Jersey Waterworks Company, $39 \mathrm{~L}$. J., lixe. 156.

(b) South Yorkshire Railuay Company v. Great Northern Railway Company, 9 Exc. 55; Bateman v. Mayor of Ashton-under-Lyne, 
Public trus- In modern times, also, another anomaly has been intees, \&c. may troduced into the law, which may not improperly be be sued in adverted to in this place, viz., that persons acting as name of trustees for public purposes, visiting justices and the
clerk. like, may contract, though not bodies corporate, without rendering themselves personally liable, and may sue and be sued in the name of their clerk or secretary. This, no doubt, leads to difficulties: but it has become familiar, and it is perfectly well settled, that judgments so recovered are not to be enforced otherwise than by mandamus, or bill in equity $(c)$.

Hall $\mathrm{v}$. And accordingly, in a case $(d)$, where commissionTaylor. Local commissioners may be sued for salary of clerk. ers, who were elected annually under a local act, and were authorized to carry out its provisions for the internal management of a town, were empowered to employ a clerk and other necessary officers, and to pay them reasonable salaries out of the monies to be raised by rates and tolls; they were to sue and be sued in the name of their clerk, who was to be reimbursed all costs and expenses out of the same fund, and not to be personally liable for them; power was given to them to enter into certain specified contracts; no power was expressly given to them to retain an attorney; but the nature of their powers would render legal assistance necessary, and the plaintiff was appointed clerk by one set of commissioners, no salary being mentioned, and re-appointed next year by the succeeding commis[*34] *sioners at a fixed salary, and he also did business within the scope of the Act for the same commissioners on their retainer; it was held, that he might maintain an action of contract against the commissioners for the time being, in the name of their clerk, for the services thus rendered to former commissioners.

Power to ap- It has been decided, that where the special Act of point ser- Parliament gave power to the directors of a company to rants with- appoint servants and workmen, \&c., without using the out seal only corporate seal, they could only exercise that power with
applies to ordinary servants. regard to the appointment of ordinary servants; and that it did not extend to enable them to enter into a contract for extraordinary services, which would be

3 H. \& N. 323; 27 L. J., Exe. 458; Payne v. Mayor of Breeon, 3 H. \& N. 572.

(e) Kendall v. King, 17 C. B. 510. The mere fact that they have no funds would not prevent the plaintiff recovering judgment in the action. Ibid. Wormell v. Hailstone, 6 Bing. 668; Emery v. Day, 1 C. M. \& R. 245.

(d) Hall v. Taylor, 1 E. B. \& E. 107 ; 27 L. J., Q. B. 311. 
binding npon the company, without affixing the corporate seal $(e)$.

The question as to how far the directors of a railway company had power, under their special act, to appoint servants otherwise than by deed was raised in the case of Cox v. The Midland Counties Railuay Company $(f)$, Cox r. Mitand the Court, in giving judgment $(g)$, intimated an lanl Counties opinion that, under their Act, they probably did possess Railuay the power; but it became unnecessary to decide the Company. point on that occasion, as it was held that, assuming the servant in that case to have been properly appointed, yet that he had not power to bind the company by entering into the contract on which the action was brought.

With regard to the liability of a corporation for wages for services rendered, there can be no doubt that at the present day they would be held to be liable to pay for them, although there was no contract under seal $(h)$.

It has been laid down by all the judges in the Ex-Trading chequer Chamber ( $i)$, that it is the duty of a company company * carrying on trade to have on the spot an officer [*:35] hound to with authority to do for the company all that in the or- rized officer dinary exigencies of their business may require to be on the spot. done promptly, and in this respect there is no difference between an ordinary partnership and a corporation; and that it was not necessary to show any authority under seal to the general superintendent of the company to render the company liable for acts which he was authorized to do.

\section{Bankrupts and Ixsolvents.}

An uncertificated bankrupt or an insolvent may him- Bankrupt or self maintain an action for the profits of his personal insolvent labour and skill after his bankruptey or insolveney, and mily sue for his assignees have no right to interfere $(k)$; indeed, in wages in re-

(c) Cope r. The Thames Ifacen Doek and Railway Company, 3 labour. Exe. 841 ; see Iniggle $\checkmark$. The London and Bladkull Railuay Company, 5 Exc. 42 ; East London Wateruorks Company v. Bailey, 4 Bing. 283.

(f) 3 Exe. 268.

(i) l'age $27 \%$.

(h) See Love v. London and North Western Railwny Compan!, 18 Q. 13. 63:?.

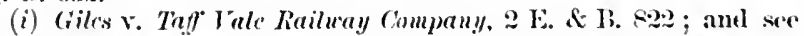
Birkettr. The White Haren Junction Retilnay Company, $28 \mathrm{I}$. .J., Exc. 318; Goff v. Great Northern Railuay Company, 30 I. J., Q. I3. 148 .

(k) Chippendall v. Tomlinson, 4 1)ong. 318; 1 Co. Bankr. Law; 
Materials one case, it was held that he might even sue them where blended with they had employed him to carry on the business $(l)$. work.

And where materials furnished are necessary to the bankrupt's labour, the work and materials may become so blended together as to form one joint cause of action, upon which the bankrupt himself may sue and be entitled to recover, his assignees not interfering $(m)$.

Furniture But a furniture broker, who was employed in moving broker. goods, in the course of which employment he procured vans, supplied packing-cases, \&c, and employed tive or six men, and likewise cleaned and repaired furniture, was held not to be a man using merely his personal labour, and therefore that he could not recover the [*36] amount of his bill *for so doing if the assignees thought proper to put in their claim $(n)$.

Surgeon and And so it was held, that a man carrying on business apothecary. as a medical practitioner, who was in possession of his original stock of medicines on credit, and procured more on credit, and with these and his personal skill pursued his occupation for profit, conld not sue for bis work and labour as a surgeon and apothecary, and for medicines, after he had become bankrupt and his assignees had ciaimed the debt $(o)$.

Assignees en- And where A. agreed to serve B. and C., who were titled to stip- type-founders, as their foreman, for seren years, at ulated dam- fixed wages, at the rate of three guineas a week, "the ages for breach of contract to employ workman who has become bankrupt. party making default to pay to the other the sum of $500 l$. by way or in the nature of specific damages." A. was dismissed, then became bankrupt, and after the bankruptcy brought an action upon the agreement for the amount of the penalty, to which the defendants pleaded his bankruptcy: it was held by the Honse of

432; see 7 East, 57, note 6; Beekham v. Drake, 2 Ho. Lords Cases, 579, 643; Williams v. Chambers, 10 Q. B. 337; and eas. cit. Ex parte Walters, 2 Mont. D. \& DeGex, 635. But any margin over what is necessary to support life is a protit which wonld pass to the trustees. See por Lush, L. J., in Emden v. Carte, 51 L. J., Ch. 42.

(l) Coles v. Barrove, 4 Taunt. 754 ; but see Nias v. Adamson, 3 B. \& Ald. 232, where Best, J., said of Coles v. Barrow, "If" Mr. Justice Lawrence had continued in the Court of Common l'leas that decision would probably not have been pronouneed. It is not, therefore, entitled to any great weight." The authority of that case is much broken in upon by Hesse v. Stevenson, 3 B. \& P. 578.

(m) Sitk v. Osborn, 1 Esp. 140.

(n) Crofton v. Ponle, 1 B. \& Ad. 568.

(o) Ellint v. Clayton, 16 Q. B. 581. And see Emilen v. Carte, $50 \mathrm{~L}$. J., Ch. $492 ; 51 \mathrm{~L}$. J., Ch. 41, where the trustee in bankruptcy was added as a co-plaintiff. 
Lords that the action could not be maintained, as the right of action passed to his assignees $(p)$, on the ground that the contract contained a clause imposing a penalty for the breach thereof, for which penalty the action was substantially brought $(q)$.

Under the old Bankrupt Act $(r)$ it was held that a Bankrupt commission of bankrupt did not operate as a dissolu- master. tion of a contract of hiring between the bankrupt and his clerk, and the bankrupt was held liable to pay his clerk's wages due from the expiration of the year last before the commission up to the time of rescinding the contract of hiring, notwithstanding the bankruptcy $(s)$.

(p) Beckkam v. Drake, 2 Ho. Lords Cases, 579; see also Wadling v. Oliphant, 45 L. J., C. L. 173; Emden v. Carte, ante, p. 35, note $(k)$.

(q) See per Maule, J., in Bell v. Carey, 8 C. B. 894.

(r) 6 Geo. 4 , c. 16.

s) Thomas v.Williams, 1 A. \& E. 685; see further on this point, post, Ch. IV. 
[The paging refers to the [*] pages.]
1. The Requisites of the ${ }^{\text {Page. }}$ Partner or Serrant, . . $\quad$ Page. CoNTRACT.
When Writing necessary- Statute of Frauds, . . The Stamp, . . . . . 49
2. THE INTERPRETATION OF the Contract. Admissibility of Parol Evi- dence, . . . . . . . The Relationship ereuted by the Contract Apprentice or Sercant, . . 78 T'enant or Screant, . . . 80 37 General Hiring - Yearly 49 Hiring, \&c., . . . . 84 How far Master bound to find Work for Scrvant, 98 Agrecments in restraint of 54 Trade eontained in Con- tracts of Hiring and Ser- vice, . . . . . 103

\section{THE REQUISITES OF A CONTRACT OF HIR- ING AND SERVICE.}

\section{When Writing Necessarp.-The Statute of Fradds.}

By common

By the Common Law a servant might be hired, either law might be by deed or by a parol contract $(a)$; but when hired or either by retained by deed, could only be discharged by an equaldeed or parol. ly formal instrument $(b)$. When hired by parol, he Since the Statute of Frauds, writing necessary in some cases. might also be discharged by parol $(c)$. Since the passing of the Statute of Frands, however, it has become necessary, in many cases, that contracts of hiring should be in writing, or they cannot be enforced. But contracts not in writing are not altogether void $(d)$.

(a) A contract is called a Parol Contract, when either verbal, or in writing, but not under seal ; see Beckham v. Drake, 9 MI. \& W. 79. In Fletcher v. Krell, 42 L. J., C. L. 55, it was held that the mere concealment of a material fact would not, in the absence of fraud, vitiate a contract of hiring and service. In that case a governess was described as "spinster" when she was really a divorced wife.

(b) $i$. $e$., from the contract, for he night be discharged from the service, so as to prevent his gaining a settlement, by parol agreement ; Paulet v. Burnham, 1 Sess. Ca. $61 ; 2$ Bott, 424.

(c) Dalt. Just. c. $58 ; R$. v. Daniel, 6 Miod. 182.

(d) See also Madison v. Alderson, (in Dom. Proc.), I. R., 8 app. Cas. $474 . \quad$ Britain v. Rossiter, 48 L. J., C. L. 362 ; 11 Q. B. Div. 123 ; overruling on this point Carrington v. Roots, 2 II. \& W. 248 ; and Reede v. Lamb, 2 L., M. \& P. 67, 69; 6 Exc. 130 . See also Leroux v. Brown, 12 C. B. 801. 
*By the fourth section of that statute $(e)$ it is [*38] The Statute enacted, "that no action shall be brought $(f)$ upon any of Frauds. agreement that is not to be performed within the space of one year from the making thereof, unless the agreement upon which such action shall be brought, or some memorandum or note thereof, shall be in writing, and signed by the party to be charged therewith, or some other person by him thereunto lawfully authorized."

In this enactment the word "performed," means a Construction complete and not a mere inchoate or partial perform- of statutes. ance; and, therefore, where an agreement distinctly shows upon the face of it that the parties contemplated. its performance to extend over a greater space of time than one year, it is within the statute; but where the contract is such that the whole may be performed within a year, and there is no stipulation to the contrary, the statute does not apply $(g)$.

Accoritingly, where $(h)$ the defendant verbally agreed Bracegirdle $\mathbf{v}$. on the 27th of May to take the plaintiff into his service Heald.

as groom and gardener for a year, to cummence on the 30 th of June following, but afterwards refused to receive him, it was held that the plaintiff could not sustain any action for such breach of contract, as there was no written agreement, Lord Ellenborough, C. J., say . ing, "If we were to hold that a case which extended one minute beyond the time pointed out by the statute did not fall within its prohibition, I do not see where we should stop ; for, in point of reason, an excess of twenty years will equally not be within the act."

*So, where $(i)$ the defendant on 20th July pro-[*39] Suclling r. posed to hire the plaintiff as bailiff for one year, to com. Lorl Huntmence on the 24th of July, and the defendant at that time ingfield. wrote a menorandum (but which was signed by neither of the parties), which was delivered to the plaintiff, and by him taken away, stating the terms on which the plaintiff was to serve, and the plaintiff entered the defend-

(e) 29 Car. 2, c. 3. The corresponding Irish Act is 7 Will. 3, c. 12 .

(f) See ante $(d)$.

(y) Per Tindal, C. J., Souch v. Strawbrilge, 2 C. B. 815; Boydell v. Drummond, 11 East, 142 . The cases on this subject will be found collected in 1 Smith's I. C. 296 , note to Peter $\mathrm{r}$. Compton; and see Cherry v. Heming. 4 Exc. 631; 19 L. J., Exe. 63; Erskine v. Adcane, 42 L. J., Ch. 395 ; Kuovlman v. Bluett, 43 L. J., Exc. 29 ; Davey v. Shannon, 48 I. J., C. I. 459

(h) Bracegirille v. Heald, 1 B. \& Ald. 722; Dobson v. Collis, 1

H. \& N. 81, post, p. 40 . But see Ciuthorn v. Cordrey, post, p. 42.

(i) Suelling v. Lord Muntingficld, 1 C. M. \& R. 20. See also Britain v. Rossiter, 48 L. J., C. L. $362 ; 11$ Q. B. Div. 128. 
Giraud v. Richmond.

No action lies here on contract made abroad it within statute.

Lerou $x$ v. Brown.

Defeasible contract within the statute. ant's service on the 24th, but before tho expiration of the year the defendant, being displeased with the plaintiff, gave him a month's warning to quit his service, and the plaintiff left before the expiration of the year. It was held that he could not maintain an action against the defendant for not continuing the plaintiff for the year, as there was no agreement in writing, in conformity with the Statute of Frauds.

And where $(j)$ the plaintiff entered into the service of the defendant under the following agreement: "I agree to receive you as clerk or bookkeeper in my establishment, in consideration of your paying me a premium of $300 l$, and to pay you a salary at the follouing rates, viz., for the first year $70 l$.; for the second, $90 l$; for the third, 110l.; for the fourth, 130l.; and 150l. for the fifth and following years that you may remain in my employment; and also agree in case of death of either of us to return 150l.:" it was held that the agreement was one that, by the Statute of Frauds, was required to be in writing; and that, there being a precise stipulation for yearly payments, evidence was not admissible to show a verbal agreement for quarterly paymants.

No action can be brought in the courts of this country to enforce an oral agreement made abroad (and valid there), which, if made here, could not, by reason of the Statute of Frauds, have been sued upon.

Where, therefore, an oral agreement was entered into at Calais between the plaintiff and the defendant, [*40] under * which the latter, who resided in England, contracted to employ the former, who was a British subject resident at Calais, at a salary of $100 l$. per annum, to collect poultry and eggs in that neighborhood for transmission to England, the employment to commence at a future day, and to continue for one year certain; it was held that no action could be maintained in this country for breach of the agreement, although, by the law of France, such an agreement is capable of being enforced, although not in writing $(k)$.

The mere circumstance that a contract is defeasible, and may be put an end to within a year, does not take it out of operation of the Statute of Frauds, if, by its terms, it is to continue for more than a year, in case it is not put an end to $(l)$.

(j) Giraud v. Richmond, 2 C. B. 835.

(k) Leroux v. Brown, 12 C. B. 801.

1. (l) Birch v. Earl of Liverpool, 9 B. \& C. 392 ; and see Roberts v. Tucher, 3 Exe. 632 ; Eley v. Positive Government Security Life Assurance Co., 45 L. J., C. L. 58 ; Darcy v. Shannon 48 L. J., C. L. 459. 
Therefore, where $(m)$ the defendants on the 2 nd of Dolson v. October, 1854, verbally agreed to employ the plaintiff Collis. .as a traveller until the first of September, 1855, and for a year thereafter, unless the employment were deter. mined by three months' notice given by the plaintiffs or defendants respectively, it was held that no action could be maintained by the plaintiff for wrongful dismissal before the 1st of September, as the contract was not in writing, and it was not the less a contract not to be performed within the year, because it might be put an ond to within that period. And Alderson, B, added, "See the absurdity of holding otherwise; at the end of two years and a half one of the parties might claim a right to put an end to a parol contract for five years, by giving three months' notice, but the very subject of dispute might be whether or no he had a right to give such notice. That shows this is a contract within the statute."

But a contract to serve for an indefinite period, subject $*$ to be put an end to at any time upon a reason- [*41] able notice, is not within the statute, though it may.extend beyond the year $(n)$. A contingency is not within the statute, nor any case that depends upon a contingency $(o)$.

The words of the statute, "not to be performed," Statute loes mean, not to be performed on one side or the other $(p)$. Where, therefore, the contract has been, or is capable of being, completely performed on one side, the statute does not apply $(q)$. The consideration, when entire, side.

cannot be split: where, therefore, any part of it is not But does, if executed, the statute has been beld to apply $(r)$. Cases, not comhowever, may arise, in which there may be two separate pletcly exepromises on separate considerations in one agreement, to cutcd on one one of which the Statute of Frauds may apply, whilst the other is not within that statute. In such cases an action may be brought upon the promise to which the statue does not apply, although not in writing $(s)$.

(m) Dobson v. Collis, 1 H. \& N. 81 ; 25 I. J., Exc. $26 \%$.

(u) Por Tindal, C. J., in Souch v. Straubridge, 2 C. B. 815.

o) Per Denison, J., in Fenton v. Emblers, 3 Burr. 1278.

(p) Donnellen v. Read, 3 B. \& Ad. 899; Smith v. Neale, 26 I. J., C. P. $144 ; 2$ C. B., N. S. 67 .

(q) Cherry v. Heming, 4 Exe. 631; 19 I. .J., Exe. 63; Souch v. Straubridge, and Smith v. Neale, nbi supra. But sce 1 Byth. Conv. (3rd cd.) 310, 311; 1 Smith's I. C. 296, note to Pcter v. Compton.

(r) Cocking v. Ward, 1 C. B. 858; Irodgson v. Johnson, 28 L. J., Q. B. 88 .

(s) Grecn v. Saddington, 7 E. B. 583; Hodgson v. Johnson, ubi supra. 
Statute does not apply to an implied hiring ;

or a hiring deed;

or affect cases of settlement by hiring and service;

- or action for wages for services pertormed; except as to amount of wages;

nor certain cases under 4 Geo. 4, c. 34 .

Fresh contract may be implied when service entered upon.

Cawthorn v. Cordrey.

But the statute does not apply where an agreement for a yearly hiring is merely implied from circumstances $(t)$. And it would seem to be the better opinion, that it does not apply where the agreement is by deed $(u)$, as the object of the statnte would be satisfied where the terms of the agreement were reduced into writing and authenticated by a seal or mark. Nor does the statute, or the decisions upon it, affect the question of what is a sufficient hiring to confer a settlement by service under it $(v)$. And the absence of an agree[*12] ment, in compliance with the Statute *of Frands, would not defeat an action for wages in respect of services actually performed, though the amount which a plaintiff in such could recover, would depend upon what his services were worth, irrespectively of any agreement.

And in the case of a dispute between master and servant, within the meaning of the statute 4 Geo. 4 , c. 34 , the absence of a contract in writing would not take the case out of the jurisdiction of a magistrate where the service had been entered into $(x)$.

Where the service has been actually entered upon, a fresh contract for a year commencing on the day on which the service was entered upon may sometimes be inferred.

Where, therefore, in a conversation which took place on Sunday, 23rd March, it was arnanged that the plaintiff should become clerk to the defendant at $100 \mathrm{l}$. a year, and on the following day the plaintiff accordingly attended at the defendant's place of business and commenced the service, and received $20 l$. on account, and gave the following receipt: "March 24, 1862 . Received of $\mathrm{C}$. the sum of $20 \mathrm{l}$, on account for my assistance in keeping books from Lady-day, 1862 to 1863:" it was held in action for wrongful dismissal that the jury were justified in inferring a fresh contract on the 24 th $(y)$.

Where an agreement in writing is necessary, under

(t) Beeston v. Collyer, 4 Bing. 309.

(u) Cherry v. Heming, 4 Exc. 631; 19 L. J., Exc. 63; Cooch v. Goodman, 2 Q. B. 580.

(v) See per Bayley, J., in Bracegirdle v. Heald, 1 B. \& Ald. 722.

$(x)$ See s. 3, and $R$. v. Lord, 12 Q. B. 762 . As to the effect of the Master and Servant Act, 1867, 30 \& 31 Vict. c. 141, on this point, see Crane v. Poncell, 38 L. J., M. C. 43; Banks v. Crossland, 44 L. J., M. C. 8 . But 30 \& 31 Vict. c. 144 , was repealed by 38 \& 39 Vict. c. 86 , s. 17 .

(v) Cawthorn v. Cordery, 32 L. J., C. P. 152. See also Britain v. Rossiter, 11 Q. B. Div. 123. 
the terms of the Statute of Frauds, it is not necessary Formal that there should be a formal agreement, signed by the agreement party to be charged; any acknowledgment in writing, not necesthat he had entered into such an agreement, would be a sufficient memorandum within the statute $(z)$, if made a suffliont memowledgbefore action *brought. An acknowledgment [*43] ment suffimade afterwards would not do $(\alpha)$. But it has been cient. held, that the mere nomination to the bishop of the dio- Roberts $v$. cese, of the plaintiff as the defendant's curate, is not Tucker. a sufficient acknowledgment $(b)$.

It would seem, however, that a note or letter written Note to third to a third person $(c)$, even the party's own agent $(d)$, person. would be sufficient to satisfy the statute. A letter repudiating the agreement has been held sufficient where it contained all the essential terms of the bargain $(e)$. And even a note addressed to the other contracting party, attempting to withdraw from the agreement, may supply the name if not mentioned in the agreement $(f)$.

It matters not from how many different papers the Agreement agreement be collected, provided they are connected in may be colsense $(g)$, for the writing is merely evidence of the lected from contract which is made before any signature thereof by numerous the parties $(h)$. If they refer to one another, they papers. may be connected by parol evidence $(i)$.

The statute enacts, that "the agreement, or some what is rememorandum or note thereof," shall be in writing, \&c. quired to be This word "agreement" includes the consideration in writing in upon which the agreement of the party to be charged is founded, as well as his promise $(k)$. cases within Statutes of Frauds.

(z) Roberts v. Tucker, 3 Exc. 632, 641; Lougfellow v. Williams, Peake's Add. Cas. 225. "Memorandum from A. B." printed was held sufficient in Tonnet v. Cripps, 48 L. J., Ch. 567.

(a) Bill v. Bament, 9 M. \& W. 36; Gibson v. Holland, L. R. 1 C.

P. 1; 1 Harr. \& R. 1 .

(b) Roberts v. Tucker, ubi supra.

c) See 12 C. 13. 818,822 .

(d) Gibson v. Hollund, uli supra.

(c) Bailiy v. Sweeting, 30 L, J., C. P. 150; 9 C. B., N. S. 843. See also Wilkinson v. Exams, 35 L. J., C. P. 224; Buxton v. Rust, 41 L. J., Exc. 175.

( $f$ ) Warner v. Willington, 25 L. .J., Cl. 662; 3 Drew. 523. See Reuss v. Pieksley, 35 L. J., Exe. 218.

(g) Boydlll v. Drummond, 11 East, 152; 1 Smith's I. C. 274, note to Birkmyr v. Darnell. See per Maule, J., in Wecton v. Woolbrilge, 13 Q. B. 475. See also Crane v. Powell, 38 L. J., M. C. 43 ; Cave v. Hastings, 50 I. J., C. I. 575.

(h) Laythaorp v. Bryant, 2 Bing. N. C. 744.

(i) Riilgway v. Wharton, 6 Ho. Iords Cas. 238; 27 I.. J., Ch. 46.

(k) Wain v. Warlters, 5 East, 10; Seunders r. Wakefielu, \& 13.

\& A. 596 ; and cases cited in 1 Smith's I. C. 274 , note to Birk- 
Consideration must appear either expressly, Lees v. Whitcomb;

Sykes v. Dixon;

Payne v. New South Wales Coal Company;

or by implication.

Pilkington $\mathrm{v}$. Scott.
In every written contract of hiring and service, there[*44] fore, *the consideration must appear, either expressly or by necessary implication, or the contract cannot be enforced $(l)$. Thus, where $(m)$ the defendant signed the following agreement, "I hereby agree to remain with $\mathrm{L}$. for two years from the date hereof, for the purpose of learning the business of a dressmaker;" it was held that $L$. could not maintain an action against the defendant for leaving her service before the expiration of the two years, as the agreement did not show any obligation on $L$. to teach the defendant, and was, therefore, void for want of $\mathrm{mu}$ tuality.

And where $(n)$ B. signed an agreement to "work for and with S., manufacturer of powder-flasks and other articles, at and in such work as he shall order and direct, and no other person whatsoever, from this day henceforth during and until the expiration of twelve months; and so on from twelve months end to twelve months end, until I shall give the said S. twelve months' notice in writing that I shall quit his service:" the agreemen: was held void for want of mutuality, as S. was not bound to employ B.; and, therefore, it was also held that $\mathrm{S}$. could not maintain an action against the defendant for harbouring $B$.

So, upon similar principles, an agreement by the defendants, that the plaintiffs should have the defendants' shipbroking business at the port of Sydney, upon certain terms, and that the defendants would provide the plaintiffs with a free passage to that colony, was held void, as not disclosing any consideration, the plaintiffs not being bound to work for the defend. ants $(o)$.

All the cases, however, agree that it is enough if the consideration can fairly be collected from the terms of the writing $(p)$.

$[* 45] *$ Therefore, where $(q)$ the plaintiffs agreed in writing with L., that he would at all times, during the

myr v. Darnell. See also 1 Wms. Saund. 211; Puff. lib. 5, c. 2, 8. 2 ; Grot. lib. 2 , c. 11 , s. iv. 2.

(l) 1 Wms. Saund. 211 , note $d$.

(m) Lees v. Whitcomb, 5 Bing. 34; and see Sweet v. Lee, $3 \mathrm{Mr}$. \& G. 466 .

(n) Sykes v. Dixon, 9 A. \& E. 693. See Bealey v. Stuart, 31 L. J., Exc. 281; Whittle v. Frankland 31 L. J., M. C. 84. 283.

(o) Payne v. The New South Wales Coal, de. Company, 10 Exc.

(p) Per Wightman, J., in Powers v. Fowler, 4 E. \& B. 518.

(q) Pilkington v. Scott, 15 M. \& W. 657.

(102) 
term of seven years, serve them as a crown-glass maker; that he would not, duting the said term, work for any other person at any other glass-house or place of business, without the licence of the plaintiffs; that it should be lawful for the plaintiffs to deduct from his wages any fine that he might incur for breach of their rules; that during any depression of trade he should be paid a moiety of his wages; that if he should be sick or lame the plaintiffs should be at liberty to employ any other person in his stead without paying him any wages; that the plaintiffs should pay him when and so long as he should continue to be employed and work as a crown-glass maker, wages by the piece, (stating them,) and $8 l$. per annum in lieu of houserent and firing; and that the plaintiffs should have the option of dismissing him from their service on giving him a month's wages or a month's notice; it was held that, looking at the agreement altogether, it sufficiently appeared that the plaintiffs were bound to employ $\mathbf{L}$. for the seven years subject to the notice, and that $L$. was bound to serve them for that period on the same terms; and therefore that the contract was binding on the parties, and might be made the foundation of an action against the defendants for harbouring and employing the plaintiffs' servant.

And so, where $(r)$ P. contracted to serve the plaintiff Hartley $\mathrm{v}$. and his partners, for the time being, for seven years, Cummings. in the business of a glass and alkali manufacturer, and at all times, during the term, to do his best endeavours and use his utmost care and diligence in the works, and further, that he would not at any time during the term neglect or absent himself from the said service without the consent in writing of the plaintiff or his partners for the time*being, or either or such of [*46] them as should carry on the business, nor would work for or serve any other person without such consent; in consideration of which service the plaintiff agreed to pay P. 24s. per week for a certain amount of work, and to find him some other description of work, provided he should not require that quantity of the specified work, so that P.'s wages should not be less than $24 s$. per week, except when a furnace should be ont, when P. agreed to work for 21s. per week; and it was agreed, that if $P$. should be sick or incapacitated from

(r) Hartley v. Cummings, 5 C. B. 247; and see Williamson v. Taylor, 5 Q. B. 175; R. v. Welch, 2 E. \& B. 357 ; Re Bailey, 3 E. \& B. 607 . 
performing the service, or in case of misconduct, or if the plaintiff or his partners for the time being, or either or such of them as should carry on the trade, should discontinue the trade during the term-in ejther of such cases the plaintiff or his partners should be at liberty to retain or employ any other person in the room or stead of $\mathbf{P}$., without being obliged to pay him any wages or satisfaction: it was held, that there was no want of mutuality in the contract, and that the plaintiffs were bound to employ P., and might maintain an action against the defendant for seducing P. from their service and harbouring him after notice.

Courts will not inquire into adequacy of consideration ;

but it must not be illegal.

-

Contract for service and cohabitation void.

If there sufficiently appear to have been $a$ consideration, the Courts will not inquire into the adequacy of it, for that were, in truth, to inquire whether the parties have or not made a good bargain, which must be left to the parties themselves to settle $(s)$.

But if the consideration appear to be illegal $(t)$, either on the ground of fraud or immorality, or as being contrary to public policy, or the enastments of any [*47] statute, the * whole agreement will be vitiated, and cannot be made the foundation of any action $(u)$.

Thus a contract for service and cohabitation would be void and could not be enforced in a Court of law, and parol evidence would be admissible to show whether the consideration for the hiring was wholly or in part cohabitation $(x)$.

And where a contract is made on several considera-

(s) Hitcheock v. Coker, 6 A. \& E. 438; Areher v. Marsh, 6 A. \& E. 659; Pilkington v. Scott, 15 M. \& W. 657; Hartley v. Cummings, 5 C. B. 247; Sainter v. Ferguson, 7 C. B. 716.

(t) In Paxton v. Popham, 9 East, 421, Lord Ellenborough said, "Since the case of Pole v. Harrobin, in 178\%, it has been generally understood that an obligor is not tied up from pleading any matter which shows that the bond was given upon an illegal consideration, whether consistent or or not with the condition of the bond." And see Josephs v. Pebrer, 3 B. \& C. 639; Cope v. Rowlands, 2 M. \& W. 157; Grame v. Wroughton, 11 Exc. 146.

(u) Parol evidence to show that the consideration is illegal, if such be the case, is held to be admissable on the grounds of public policy, and not for the sake of the defendant; bnt because Courts of law will not lend their aid to a plaintiff who seeks to enforce an illegal or immoral contract. See Collins v. Blantern, 2 Wils. 350; 1 Smith's L. C. 325; Holman v. Johnson, Cowp. 341; Ch. on Contr. 570; Abbott v. Hendricks, 1 M. \& G. 791; Gas Light and Coke Company v. Turner, 6 Bing. N. C. 327.

(x) R. v. Northwingfield, 1 B. \& Ad. 912. This was a case of settlement, it is true, and not between the parties to the contract; but it illustrates the rule above given. See Bradshaw v. Hayward, Carr. \& M. 591, where the defendant was allowed to prove an agreement for cohabitation without pleading it, in answer to an action for wages. 
tions, any one of which is illegal, the whole contract is If one of servoid $(y)$. If, however, the consideration be good, and eral considerthe contract be partly good and partly bad, and that ationsillegal, part which is good can be separated from that which is the whole bad the good part may be sustained, provided the de- contract roid. bad, the good part may bo sustained, provided the de- If consideraclaration be framed so as to meet the proof of that part tion good, of the contract which is $\operatorname{good}(z)$. A distinction, how- and contract ever, has been taken as to what is illegal at common partly good, law, and what is made illegal by particular statutes. law, and what is made illegal by particular statutes; may be supand it has been said that the latter would vitiate the ported. whole instrument, the former only that part which is Difference illegal $(a)$. But whether the whole is vitiated or not between illemust depend, in great measure, on the enactments of galityatcomthe particular statute.

A contract of hiring and service for a year, made on mon law and by statute.

Contract of a Sunday, between a farmer and a labourer, is valid, hiring made *notwithstanding the statute 29 Car. 2, c. 7, s. 5, [*48] on a Sunday which enacts that no tradesman, artificer, workman, valid. labourer, or any person whatsoever, shall do or exercise any worldly labour, business or work of their ordinary calling on the Lord's-day (b).

An agreement between a municipal corporation and $A$ greement the clerk of the peace for the borough on his appoint- by public ment, whereby he agreed to accept a fixed salary in lieu of fees, and that any surplus should be paid to the borough fund is illegal as against public policy, the fees being given to enable him to uphold the dignity and perform the duties of his office $(c)$.

Where the agreement is one which, by the Statute of other reFrauds, is required to be in writing, it must also "be quisites of signed by the party to be charged therewith, or some the Statute other person by him thereunto lawfully authorized." of Frands. It is not, however, necessary to prove an agreement signature, signed by both parties. It is sufficient if signed by the of party to be party to be charged $(d)$, even if conditional, if accepted charged sufficient.

(y) Jones v. Waite, 1 Bing. N. C. 656; 5 Bing. N. C. $341 ; 9 \mathrm{Cl}$. \& Finn. 101; Shackell v. Rosier, 2 Bing. N. C. 634; and see Hopkins v. Preseott, 4 C. B. 578; Nicholls v. Stretton, 10 Q. 1. 346.

(z) Co. Litt. 206 b, note; Wood v. Beusou, 2 Cr. \& J. 95; and see Price v. Green, 16 M. \& W. 346; Nicholls v. Stretton. 10 Q. B. 346; Sterry v. Ciffon, 9 C. B. 110.

(a) Per Bayley, J., in Wood v. Brnson, 2 Cr. \& J. 95; Chotor v. Beckett, 7 T. R. 201; Thomas v. Williams, 10 B. \& C. 664; and see 1 Wms. Saund. 66, note to Butler v. Wigye.

(b) R. v. Whitnash, 7 B. \& C. 596.

(c) Corporation of Liverpool v. Wriyht, Johns. 359; and see ace. Mayor, Re. of Dublin v. ITayes, $10 \mathrm{It}$. Rep., C. L. 226 (1876).

(d) Laythoarp v. Bryant, 2 Bing. N. C. 735; Hughes v. Burld, 8 Dowl. 478; and see 3 M. \& G. 462, note. 
- by word of mouth by the other party $(e)$, but notice of such acceptance must be given $(f)$. And this is enough, although it conclude "As witness our hands" $(g)$. Signature by means of a stamp is sufficient $(h)$. Mere initials, however, are not sufficient $(i)$. Signature at the commencement may be good, if inserted in such a manner as to govern, or have the effect of authenticating, the whole instrument $(j)$, as " $I, A$. B., agree" [*49] (k). But if, in such a case, the *agreement con clude "As witness our hands," it should be signed by the party to be charged at the end $(l)$. And if not signed at the end, it is a question for the jury, if the party meant to be bound by it $(m)$. In any case, the writing must, of course, be signed before action brought $(n)$.

Or his agent. If the agreement be signed by an agent, it will be sufficient if he were laufully authorized; it is not necessary that he should be authorized in writing (o). A subsequent adoption of the act of the agent is equivalent to a previous authority, and is sufficient to satisfy the requirement of the statute $(p)$. And in one case $(q)$, it was held that a subsequent gdoption of another person's act was sufficient, although he did not at the time he acted, assume to act as agent.

(e) Smith v. Neale, 26 L. J., C. P. 143; Povers v. Fouler, 4 E. \& B. 517; Reuss r. Piclisley, 35 L. J., Exe. $218 ; 4$ H. \& C. 588.

(f) 4 E. \& B. 519, note.

(g) Norton v. Powell, 4 M. \& G. 42.

(h) Bennett v. Brumfitl, 37 L. J., C. P. 25.

(i) Siceet v. Lee, 3 M. \&. G. 452.

(j) Caton v. Caton, 36 L. J., Ch. 886.

(k) Knight v. Croekford, 1 Esp. 190; and see Lobb v. Stanley, 5 Q. B. 574, note commencing with the defendant's name. See also Durrell v. Evans, 31 L. J., Exc. 337; 1 H. \& C. 174; Murphy v. Boese, 44 L. J., Exc. 41.

(l) Hubest v. Treherne, 3 M. \& G. 743.

(m) Johnson $v$. Dodgson, 2 M. \& W. 653; Durrell v. Evans, nbi snpra. As to the absence of any date, see Symmons v. Wunt, 2 Stark. 371.

(n) Bill v. Bament, 9 M. \& W. 36 ; but see 11 C. B. 970.

(o) 1 Smith's L. C. 575, note to Whitcomb v. Whiling. Sect. 3 of the Statute of Frauds requires that an agent under that section should be authorized in writing, and in that point differs from sect. 4. See Blogg v. Kent, 6 Bing. 614. The signature of an agent acting for both parties is sufficient; Durrell v. Evaus, uli supra ; Aldridge v. Great JVestern Railway Company, 33 L. J., C. P. $161,168$.

(p) Maelean v. Dunn, 4 Bing. 722.

(p) Kinnitz v. Surrey, Pales on Ag. 171, note, quoted in Maelean v. Dumn; S. C., nom. Klinitz v. Surrey, 5 Esp. 267. See, however, Wilson v. Tumman, 6 M. \& G. 236. See also 31 L. J., Exc. 340 . 
Where, in an action on an agreement, it is intended statute of to take advantage of the Statute of Frauds it is neces- Frauds must sary to raise such defence by pleading $(r)$. be pleaded.

\section{The Stamp.}

The Schedule to the "Stamp Act, 1870" (s), which Stamp. imposes a duty upon agreements, \&c., contains exemptions in favour of any-

"Agreement or memorandum for the hire of any labourer, artificer, manufacturer or menial servant ;

"Agreement, letter or memorandum made for or relating to the sale of any goods, wares or merchandise ;

"Agreement or memorandum made between the master *and mariners of any ship or ves- [*50] sel for wages on any voyage coastwise from port to port in the United Kingdom." ( $s$,

The same Schedule also contains the following exemptions from the duty payable on instruments of apprenticeship-

(1) "Instrument relating to any poor child apprenticed by, or at the sole charge of, any parish or township, or by or at the sole charge of any public charity, or pursuant to any Act for the regulation of parish apprentices."

(2) "Instrument of apprenticeship in Ireland where the value of the premiun or consideration does not exceed 10l."

In order that an agreement may come within the Agreement Stamp Act and require a stamp, it must be such an to be within agreement as would be evidence against both the con- Stamp Acts tracting parties; and, therefore, where $(t)$ the defendants, being the provisional committee of an unincorporated association, made and signed a resolution "that $\mathbf{E}$. T. be managing director of this association Brine. must be evidence against both parties. Vaughton v.

(r) Reg. Gen. 1883, Ord. XIX. rr. 15, 20.

(s) 33 \& 34 Vict. c. 97. See sects. 24 and 36 as to cancelling adhesive stamps.

(s) By the Nerchant Shipping Act, 1854 (17 \& 18 Vict. c. 104, sect. 2,149 ), agreements between masters of ships and seamen, if made in the form sanctioned by the Board of Trade, are exempt from stamp duty. As to who are seamen, see sect. 2 ; and by sect. 143, all indentures of apprenticeship to the sea service are also exempt.

( $t$ ) Vaughton v. Brine, 1 M. \& G. 359 ; and see Beeching v. Westbrook, 8 M. \& W. 411 ; Knight v. Barber, 16 M. \& W. 66 ; Vollans v. Hetcher, 1 Exc. 20 ; Marshall v. Poncell, 9 Q. B. 779. 
for three years, and John Vaughton (the plaintiff) secretary for the same period; that the remuneration to the former be settled at some future meeting; the latter to receive five pounds per week, and to act under the direction of the provisional committee ;" but it did not appear that the plaintiff was present when it was made, or that he was consulted with respect to it, the Court of Common Pleas held that it did not require a stamp, not being either an agreement or a memorandum of agreement. It might have been a proposal or an authority to enter into a contract.

Lucas v. But where the minute of a resolution at a public meetBeach. ing about a turnpike road, that the plaintiff, who was a [*51] * surveyor, should be allowed an additional sum for extra trouble he wonld have, was read over to the plaintiff and assented to by him, it was held to require an agreement stamp $(u)$.

Fraser $\mathrm{r}$ A mere admission in a letter to a third person that Bunn. the plaintiff was in the defendant's service does not require a stamp, not being an agreement between the parties $(x)$.

Exemptions The exemptions in the Stamp Act have been held $(y)$ in Stamp Act only to apply to the case of hiring, and not to the case do not apply of apprenticeship or to an agreement for the hire of a to apprentices, but do to firemen and stokers on board a steamboat. Wilson v. Zulueta. clerk $(z)$.. " Firemen and stokers" on board of a steamer were held $(a)$ to come within a similar exemption in the old Stamp Act as labourers and artificers, and not to be mariners under $7 \& 8$ Vict. c. $112(b)$, Colebridge, J., saying: "It appears from the contract that they undertake to do the work and discharge the duty of firemen and stokers, and to obey the orders of the engineer. Now it is quite certain if this were the case of a loco. motive engine belonging to a railway company, and these persons had agreed to do the same in connexion with it, they might well be called labourers if not artificers. So in this case I do not think they made themselves ordinary seamen, but that they engaged for the particular duty of doing the work of firemen or stokers,

(u) Lucas v. Beach, 1 M. \& G. 417.

(x) Fraser v. Bunn, 8 C. \& P. 704.

(y) R. v. St. Paul, Bedford, 6 T. R. 452.

(z) 2 Cr. \& Dix. Cir. Rep. (Irish), 225.

(a) Wilson v. Zulueta, 14 Q. B. 405 ; 19 L. J., Q. B. 49. And see $R$. v. Wortley, 2 Den. C. C. $333 ; 21$ L. J., M. C. 44, post, p. 68 , where $\mathrm{W}$. was held to be a labourer within the meaning of the exemption in the Stamp Act. See also Cornforth v. Danube and Black Sea Railway Company, 2 F. \& F. 197.

(b) See now $17 \& 18$ Vict. c. 120. 
subject to the order of the engineer, and therefore are fairly within the exemption in the Stamp Act."

And an overseer in a printing-office was also held by overseer in Pollock, C. B., at Nisi Prius, to be an "artificer" with- printingin the old Stamp Act (c). office.

*In cases of mixed contracts, that is, contracts [*52] Mixed confor the hire of labourers, \&c., and something else, the tracts. question whether or not the contract is exempt from stamp duty as coming within the above exceptions, must be determined by considering the whole scope and object of the contract. If its primary and main object be the hire of labourers, \&c. it would be free from stamp duty, and not the less within the above exception, because it also contained some secondary or collateral stipulations to which the above exception would not apply. But if, on the other hand, the primary and main object of the contract be something clearly not within the above exception, then the mere addition of a secondary or collateral contract of hiring would not bring the case within the exemptions $(d)$.

In Hughes v. Budd (e), the following agreement was held to require a stamp, and for want of one the plain- Bughes $\mathrm{v}$. tiff was nonsuited in an action for work and labour: "A memorandum of agreement between Isaac Hughes, quarryman, and the $\mathbf{Y}$. Iron Company, that is, the said Isaac Hughes, quarryman, do engage to quarry a sufficient quantity at Craig Grew, to complete a dry wall which is to be erected from the canal bridge to the Swansea road, which wall is to continue both sides of the new road as above mentioned. The stones are to be of a good and proper quality for the said walling, at the rate of two shillings per perch, thirty-six cubic feet to the perch. It was contended that it was not neces. sary that it should be stamped, either because it was an agreement with an artificer for his hire or a memorandum relating to the sale of goods. But Williams, J., was of opinion that it fell between the two, and was something composed of both. "It is not," said he, "to work generally, but to do a particular kind of work. Neither is it for goods sold and delivered, but it is to work on a particular mass of stone."

*In deciding whether any particular case comes [*53] Decisions on within the abcre exemptions in the Stamp Act, consider- Truck Act. able assistance may be derived from the decisions upon

(c) Bishop v. Letts, 1 F. \& F. 401.

(d) Smith v. Cator, 2 B. \& Ald. 778; Sadler v. Johnson, $16 \mathrm{M}$. \&. W. 775; Chatfield v. Cox, 18 Q. B. 321.

(e) 8 Dowl. 478; sce Poutton v. Wilson, 1 F. \& F. 403. 
the Truck Act, under which it has been held $(f)$ that the term "artificer" does not apply to contractors or persons who speculate upon the state of the labour-market, but only to those who are actually and personally engaged or employed to do work. Where the procuring work to be done by the hands of others comprehends the whole of what a man contracts for, the circumstances of his doing some portion of the work himself does not bring him within that statute: There must be a contract by which he binds himself to do it. On the other hand, the Truck Act applies to cases in which by the contract the personal labour of the artificer is to be given, although he may be at liberty also to procure the labour of others $(\mathrm{g})$.

Criminal proceedings.

Mounsey $\mathrm{v}$. Stephenson.

Messman to a regiment.

In prosecutions for embezzlement and other criminal proceedings, no objection can be taken on account of an agreement or other document being unstamped $(h)$.

An agreement whereby one party agreed to pay the other a fixed salary, and the other agreed not to set up a chemist's shop within a certain distance, and the parties were mutually bound in a penalty of $600 \mathrm{l}$. to perform the agreement, has been held to be sufficiently stamped with a common deed-stamp of 1 l. 15s. (i).

Whether or not an agreement by the officers of a regiment with their messman, requires a stamp, must depend in great measure on the wording of it, but it would be prudent in all cases to have such an agreement stamped with an ordinary agreement-stamp of $6 d$., as most pro[*54] *bably it would not come within the exemption. In many cases he is more of a contractor than a ser. $\operatorname{vant}(j)$.

( $f$ ) Riley v. Warden, 2 Exch. 59 ; Sharman v. Saunders, $13 \mathrm{C}$. B. 166; Ingram v. Barnes, 7 E. \& B. 115; 26 L. J., Q. B. 82, 319; Sleeman v. Barrett, 33 L. J., Exc. 153.

(g) Weaver v. Floyd, 21 L. J., Q. B. 151 ; Bowers v. Lovekin, 6 E. \& B. 584 ; 25 L. J., Q. B. 371 ; Lawrence v. Todd, 32 L. J., M. C. 238 ; Whiteley v. Armitage, 13 Weekly Rep. 144 ; Pillar v. Llynvi Coal and Iron Company, 38 L. J., C. P. 294.

(h) 33 \& 34 Vict. c. 97 , s. 17.

(i) Mounsey v. Stephenson, 7 B. \& C. 403.

(j) See Churchward v. Chambers, 2 F. \& F 229, where it was held that a messman was rightfully dismissed for not serving up dinner. 


\section{INTERPRETATION OF THE CONTRACT.}

\section{Admissibility of Parol Evidence.}

Parol evidence is admissible to show that an agreement was not intended to operate unless a particular event should happen $(k)$.

When parol

Parol evidence is also admissible to show the circumerience admissible. Parol evidence is also admissible to show the circum- To apply stances under which an agreement was made, and to written conapnly the words used to those circumstances, as in the tract. following case $(l)$ :-The plaintiffs, lace merchants in Mumford $\mathrm{v}$. London, employed six travellers for different districts, Gething. and the defendant was in their employ as assistant to one of those travellers. A vacency having occurred in the MI. district, the defendant in March, 1858, was engaged verbally by the plaintiffs to travel as head traveller for that district at a salary of $50 l$. per annum, and $8 l$. 1 ós. per week for expenses, it being at the time arranged between them that the terms of the agreement should be reduced to writing. After the defendant had started on the journey and been absent three or four weeks, a list of towns and customers was sent to him, and the following agreement which he signed and returned: "April 30, 1858 . To H. \& W. Mumford. In consideration of my entering upon your employ at a salary to commence with at $50 l$. a year, I herewith agree to do so, with the understanding that in the event of my wishing to travel, and doing so, for *any other [*כ๊]] house in the same trade on any part of the same ground to pay the sum of $50 l$. (Signed) W. Gething.

The defendant continued in the plaintiff's' employ till the early part of 1859 , when be left them and trav. elled over the same district for a rival house in the same trade, upon which the plaintiffs brought an action against him for the $50 l$. At the trial, amongst other things, it was objected that parol evidence was inadmissible to show that the agreement was to travel the M. district; but it was admitted that the plaintiffs had a verdict for the $50 l$. Upon a subsequent application to the Court to enter a nonsuit, the rule was discharged, and Erle, C. J., said:-

"I am clearly of the opinion that the parol evidence

(k) Pym v. Campbell, 25, I. J., Q. B. 277; 6 E. \& B. 370; Davis v. Joncs, 25 L. J., C. P. 91 ; 17 C. I3. 625 ; Wallis v. Littell, 31 I. J., C. P. 100 ; Lindley v. Lacey, 34 L. J., C. P. 7 ; Lister v. Smith, 33 I. J., Prob. M. \& Ad. 29.

(l) Mumford v. Gathing, 29 L. J., C. P. 105.

4 MaS. \& Swl. 
which was objected to was admissible for the purpose of ascertaining the subject-matter to which to apply the contract. It was not tendered or admitted for the purpose of varying the contract itself, or of varying the sense of the words used, but for the purpose of showing what the circumstances were under which such wide words were used, and of applying those wide words to the circumstances. The agreement says, 'in consideration of my entering upon your employ.' Those words are very wide, and might include any possible employment, menial or otherwise, which one man could undertake for another; but it is not likely that the parties meant that. Then parol evidence was admissible to show in what sense these words were used, and being admitted it showed that the parties meant that the defendant was to enter into the employ of the plaintiffs as traveller in their trade on the M. journey. The written contract was drawn up with reference to a previous conversation and proposal, and the parol evideuce applies the written words in accordance with that previous proposal. This view entirely agrees with that taken by the Court of Queen's Bench in the case of $I^{\prime}$ Donald v. Longbottom $(m)$, which was, if I may so speak of a decision to which I was myself a party, a perfectly sound decision. The written con. tract there described the article purchased as 'your wool,' and parol evidence was admitted of a previous conversation between the parties to the effect that the wool about which they were contracting consisted partly of the plaintiff's own clip and partly of wool purchased from other persons. The parol evidence was admitted to identify the subject-matter of the contract, the words 'your wool' being wide and indetinite, as are the words 'your employ' in the contract which we are now considering."

Parol evidence not admissible to vary written contract.
But where the agreement is such that it is required by the Statute of Frauds to be in writing, parol evi[*56] dence is *not admissible to show verbal altera. tions of it, for that would be a direct violation of the statute $(n)$. And the law is the same where the agreement $i s$ reduced to writing, whether it be such an agreement as calls for a memorandum or not $(o)$. Noreover,

(m) 28 L. J., Q. B. 293.

(n) Goss v. Lord Nugent, 5 B. \& Ad. 58; Stowcll v. Robinson, 3 Bing. N. C. 928 ; Stead v. Dawber, 10 A. \& E. 57.

(o) Countess of Rutland's case, 5 Rep. 25; and sce Lockett v. Nicklin, 2 Exc. 93, 97. But this would not apply to a memorandum made by a third party of the terms of the hiring, so as to 
"it seems to be necessary to inquire what are the essen- Every part of tail parts of the contract and what not, and that every a written part of the contract, in regard to which the parties are stipulating, must be taken to be material" $(p)$. Thus, where $(q)$ a written agreement of hiring and service contained stipulations for yearly payments, evidence that a verbal agreement for quarterly payments had been made, was rejected, and the fact of quarterly payments having been made, was held not to vary the rights of the parties.

But although, where parties agree that a particular Parol eviinstrument shall contain the terms of the contract, denee adparol evidence cannot be given to add to or diminish missible to those terms, yet it may be given to annex incidents, as annex inciit is termed $(r)$.

Therefore, in all contracts of hiring and service, e.g. Custom. which do not, either expressly or by necessary implication from the terms used, exclude the custom of the particular trade, business or occupation, with reference to which the contract is made, parol evidence is admissible to show that by the custom of the trade, \&c., the contract is liablo to be put to an end by notice $(s)$. The custom with reference to *notice of course [*57] Custon with varies in different trades and occupations. But where regard to a person hires a domestic servant, and nothing is said notice. about notice, that, according to the custom of England, is a hiring for a year, with liberty to either party to put an end to the contract, by giving a month's notice. The above rule is illustrated by the following cases:- Johnson $\mathrm{r}$. "Thus, where $(t)$ the plaintiff entered into the defend- Blenkensopp. ant's service, under a written agreement that he was to have $6 s$. a week, three bolls of wheat, to set potatoes for his family's use, to have' a cow kept, house and

exclude parol evidence of those terms; $R$. v. Wrangle, 2 A. \& E. 514.

(p) Per Parke, B., in Marshall v. Lynn, 6 M. \& WV. 117.

(q) Giraul v. Kiehmond, 2 C. B. 835.

(r) Intton v. Warren, 1 M. \& W. 475 ; see the cases collected in 1 Smitl's L. C. 305 et seq.; and s'partalia v. Benceke, 10 C. 13. :1:; Loekett v. Nicklin, 2 Exc. 93; Syers v. Jonas, 2 Exc. 111; Netzner v. Bollon, 9 Exc. 518; Bronene v. Byrue, 3 L. \& B. 703; Mall v. Janson, 4 F. \& B. 500; Cuthbert v. Cumming, 10 Exc. 809; 11 Exe. 405; IIumfrey v. Dale, 7 L. \& B. $266 ;$ E. B. \& E. 1001; 27 I. J., Q. I. 390; Lueas v. Bristow, 27 L. J., Q. B. 361; Ficld v. Lelean, 30 I. J., Exe. 168; Hutchinson v. Ththam, 42 L. J., C. P'. 260; Johuson v. Raylton, 50 I. J., C. L. 753.

(s) Johnison v. Applely, 4:3 L. J., C. P. 1.46. See Eians v. Roe, L. R., 7 C. P. 138, where conversation at the time of hiring was held to be excluded, as there was a contract in writing.

(t) Johnson v. Blenkensopp, Tr. T. 1811, 5 Jur. 870. 
R. v. Stokeupon-Trent.

Holcroft $\mathbf{v}$. Barber.

Parker v. Ibbetson. tiring and to keep himself a pig, no poultry to be kept, his wife to keep the museum clean, he was to keep the gardens and pleasure-grounds in clean and good order, to assist in the stables, and, when required, at hay and corn harvest, and to make himself generally useful; to enter 12th May, 1838;" evidence was admitted to show that the plaintiff was by custom only entitled to a month's warning.

And in a settlement case $(u)$, where a pauper signed the following agreement:- "Plate and dish workers. This day agreed with $B$. to serve Messrs. B. from the 11 th day of November next to the 11th November, 1817 , at prices ginod out of oven as per opposite side. We agreed to lose no time on our own account, to do our work well, and behave ourselves in every respect as good servants. Witness our hands, 10th day of January, 1815 ;" evidence was held admissible to show than an universal custom prevailed amongst china manufacturers to allow holidays at certain fixed times of the year to the platers and dishers, and that at those times the latter could, notwithstanding the above agreement, absent themselves from their work without their master's permission.

[*58] *Again, in $(v)$ an action for wrongfully dismissing the editor of a newspaper, who had been engaged by letter, evidence was admitted to prove a custom that editors, sub-editors and reporters of newspapers were always engaged for a year, unless it were otherwise expressed at the time of making an engagement.

And where the parties signed a "memorandum of agreement between $I$. and Co., of Leeds, of the first part, and P. of London, of the second part. The aforesaid $P$. engages to serve the said $I$. and Co., as agent or representative, at the salary of $150 l$. per annum in consideration thereof. Also, provided, at the end of the year, the said $I$. and Co. find the said $P$. has done suffi.

(u) $R$. v. Stoke-upon-Trent, 5 Q. B. 333. Observe, however, that in that case the dispute was between two parishes who were no parties to the agreement, and the question was whether the pauper lad gained a settlement by hiring and service. In sueh cases parol evidenee is always admissible to ascertain independent facts eollateral to the written agreement. See $R$. v. Laindon, 8 T. R. $379 ; R$. v. Northwingfield, 1 B. \& Ad. $912 ; R$. v. Billinghay, 5 A. \& E. 676 ; and cas. cit. ibid.; see also 2 Phill. Ev. 355.

(v) Holeroft v. Barbe, 1 C. \& K. 4 ; and see Baxter v. Nurse, 1 C. \& K. 13, where Tindal, C. J., in summing ap to the jury said, "There is no donbt that where there is a general understanding and is course of dealing, and agreements are made without any specific stipulations to vary them from such general course of dealing, they are included in it." 
cient business to justify them in recompensing, by making up his salary to $180 l$., to do so being a donation of $30 l$. to his present stipulated amount of $150 l .: "$ it was held that the terms of the agreement did not exclude a general custom in the trade (defendants were woollen merchants), that either party might determine the service upon giving to the other a month's notice. And, also, that the question, whether or not the custom was excluded, was one for the Court and not for the jury, though it was for the jury to find the existence or nonexistence of the custom alleged. It was also held, that the $30 l$. to be given at the end of the year was a mere gratuity, for -which no action could lie, and did not operate in any way to exclude the custom $(x)$.

Upon similar principals, parol evidence is also held Parol evito be admissible to explain the meaning of terms used, dence adwhere an ambiguity is raised by evidence as to the

meaning of those terms $(y)$.
*Thus, where $(z)$ by a written contract, the [*59] tiguous
iterms; plaintiff agreed to perform at the defendant's theatre, Grant v. and the defendant engaged her for three years, and Maddox; engaged to pay her a salary of $5 l$., $6 l$., and $7 l$. per week in those years, parol evidence was admitted to show that, according to the understanding and custom of the theatrical profession, under an engagement to perform for one or more years, actors were only paid during the theatrical season.

But where a horse-trainer by articles of apprentice- not to conship, which were in a common form, agreed to find an tradict them; apprentice sufficient meat, drink, wages, "lodging and all other necessaries" during the apprenticeship, it was held that evidence of a custom in the trade that a master should charge the apprentice and deduct from his wages the cost of "clothes and washing" was inadmissible as being inconsistent with the terms of the contract, those things being included in the term necessaries which the master was to "find" gratis. And the

(x) Parker v. Ibletson, 27 L. J., C. P. $236 ; 4$ Jur., N. S. 536. As to the 307 , see Lake v. Camplell, 5. I. T., N. S. 589, post, where a pronised "gift" of $20 l$. was held not to be a gratnity.

(y) Sotilichos v. Kemp, 3 Exe. 105 ; Smith v. Thompson, 8 C. 13. 44,59 .

(z) Grant v. Maldox, 15 M. \& W. 737. See Myers v. Sarl, 30 I. J., Q. 13. 9. See also Smith v. Thompson, 8 C. 13. 44, where it was held to have been properly left to a jury to say whether the plaintiff, a elerk, had been guilty of a misappropriation of money intrusted to him by the defendlant, his master, "for busincss purposes," in having applied part of it to the payment of his own salary. 
master was not allowed to deduct their cost from the wages due to the apprentice $(a)$.

not to vary implied incidents.

How far arrangements for remunerating servant by portion of, or percentage on, profits, \&e., make him a partuer.

And it would seem that parol evidence is not admis. sible to contradict or vary implied, any more than express, incidents $(b)$.

\section{The Retationship created by the Contract.-Partner or Servant $(c)$.}

Arrangements are frequently made between masters in trade and brokers, clerks, travellers and other agents and servants employed by them, under which such per[*60] sons, in lieu * of receiving a fixed salary, are remunerated by a portion of the sums received by them on account of their master, or by a per-centage on their earnings, or by a sum calculated with reference to the gross or net profits $(d)$ of their master or principal, or some part of such profits, or some similar method $(e)$. These various modes of payment, which are generally adopted with a view to secure or increase exertion, often give rise to a question of considerable importance, viz., how far the persons whose services are to be so remunerated are to be regarded as partners, and not mere servants or agents in the business.

$28 \& 29$ Vict. It is indeed provided by the Act passed in 1865 , to c. 86, s. 2. amend the Law of Partnership $(f)$, that "no contract for the remuneration of a servant or agent of any per-

(a) Abbott v. Bates, 43 L. J., C. P. 150 ; 45 L. J., C. L. 117. 28.

(b) Per Blackburn, J., in Burgess v. Wriekham, 33 L. J., Q. B.

(e) When a former servant claims to be a partner, his case must. be made out by strong evidenee, Pause'y v. frmstrong, 50 L. J., Ch. 683. See Beddall v. Maitland, 50 L. J., Ch. 401, an aetion which arose out of the eviction by a partner of a manager who claimed to be a partner.

(d) As to the meaning of the term "nett proceeds," see Cain v. Horsefall, 2 Carr. \& K. 349.

(e) When a plaintiff, by his particulars demand, claimed the sum of $450 l$., for his services as clerk or manager to the defendant, from August, 1837, to October, 1839 , inclusive, after the rate of $200 t$. per annum, but proved an agreement by the defendant that the plaintiff, who was manager of a bank, should have a certain per-centage, by way of commission, on all business he should introdnce: it was held that the particulars were not snfficient to let in such a demand, and the defendant was strictly entitled to a nonsuit, but plaintiff had leave to amend on payment of costs. See Harris v. Montgomery, 11 C. B. 393; 2 L., 1 . \& P. 425. An agreement by a third person to give a servant commission is a corrupt bargain, Harrington v. Victoria Grating Dock Company, 47 L. J., C. L. 594; I. R., 3 Q. B. Div. 549.

(f) $28 \& 29$ Vict. c. 86 , s. 2 . 
son $(g)$ engaged in any trade or undertaking by a share Servants or of the profits of such trade or undertaking shall of agents not itself render such servant or agent responsible as part- partners. ner therein, nor give him the rights of a partner." But it is, nevertheless, still necessary to refer to the cases before that Act in which the question of partner or servant arose.

The first cases in which the question arose were Cases precases in which objection was made to the admissibility vious to that of factors and brokers, whose remuneration was to be statute. calculated in that way, as witnesses, on the ground of interest $(h)$. Such persons, however, were held not to be disqualified on *that ground, as they would [*61] have been had they been considered partners.

The exact point decided in these cases is not, indeed, likely to arise again, all objection to the admissibility of a witness, on the score of interest, having been remored by the legislature (i). But the question, whether an agreement of the dscription before referred to renders the person, whose services are to be remunerated in the manner above pointed out, a partner or a servant, still often arises. Those cases are, therefore, important, and are frequently referred to at the present day as authorities upon that subject.

Where, indeed, the question arises between the parties As between themselves, tho mere fact, that the servant was to be re- the parties munerated by a portion of the profits, will not alone themselves. constitute him a partner $(k)$, if it appear from the Servant not whole scope of the agreement entered into, that the in- partner. tention of the parties was to create the relationship of master and servant, and not that of partners.

Thus $(l)$ where A., having neither money nor credit, Hesketh $\mathrm{r}$. offered the plaintiff that, if he would order with him Blanchard. certain goods to be shipped as an adventure, if any profit should arise from them the plaintiff should have one-half for his trouble: the plaintiff ordered the goods on their joint account, and paid for them, and $A$. hav-

(g) By seet. 6, "person" includes a partnership firm, a jointstock company, and a corporation.

(h) Dickson v. Cooper, 3 Wils. 40; Benjamin v. Porteous, $2 \mathrm{H}$. Bl. 590.

(i) See stat. $3 \& 4$ Will. 4 , c. 42, s. $26 ; 6 \&$ \& Vict. c. $8 . ; 14 \& 15$ Viet. c. $99 ; 16 \& 17$ Vict. c. $83 ; 32 \& 33$ Vict. c. 68.

(k) In Peacock: v. Pcacock, 2 Camph. 45, Lord Ellenborongh observed, " $A$ man who renders himself liable to third persons as a partner may, in truth, be the mere agent or servant of his supposed co-partner, and entitled only to fixed wages," "Sce also Walker v. Hirseh, 54 L. J., Ch. 318; L. R., 27 Ch. Div. 461."

(l) Hesketh v. Blanchard, 4 East, 14. 
Wilkinson $\mathrm{v}$.

ing died without coming to a settlement, the plaintiff was held entitled to recorer the amount from A.'s executors, and Lord Ellenborough said, "The distinction taken in Waugh v. Carver ( $m$ ) applies to this case. [*62] Quoad third persons it *was a partnership; for the plaintiff was to share half the profits. But as between themselves it was only an agreement for so much, as a compensation for the plaintiff's trouble, and for lending A. his credit."

And an agreement to divide the produce of a whalFrasier. ing voyage between the captain, officers and seamen, in certain proportions, has been held not to constitute them partners, so as to preclude one of the seaman from recovering his wages in an action against the captain $(n)$.

Geddes $\mathrm{s}$ And so (o) the manager of a glass.work company Wallace. enjoying an annual stipend, and also, by way of further remuneration, a share of the profits, calculated accord. ing to a proportion of capital and stock not advanced by him, but assigned by way of nominal interest, was held not to be a partner as between himself and the members of the company. Harrington s. So, where C. having contracted for the conveyance
Churchward. of mails by sea, agreed with $H$. to employ him during Churchward. of mails by sea, agreed with H. to employ him during payable quarterly, and, in addition, a sum equivalent to ten per cent. on the profits, it was held that this was

(m) 2 H. Bl. 335; 1 Smith's L. C. 83 . In that case A. and B., ship-agents at different ports, entered into an agreement to share in certain proportions the profits of their respective commissions, and the discount on tradesmen's bills, employed by them in repairing the ships consigned to them, \&e. And it was held that they were liable as partners, to all persons with whom either contracted as such agents, though the agrcement provided that neither should be answerable for acts or losses of the other, but each for his own, Eyre, C. J., observing, that it was plain, upon the construction of the agreement between the parties themselves, that they were not, nor ever meant to be, partners; ret that they had made themselves such with regard to their transactions with the rest of the world. See, as to Whugh v. Carrer, Cox v. Hickman, 8 H. L. C. 268; 30 L. J., C. P. 125; Bullen v. sharp. 34 L. J., C. P. $174 ; 18$ C. B., N. S. $614 ; 35$ L. J., C. P. 105; 1 Harr. \& R. $117 ; 1$ L. R., C. P. 86.

(n) Wilkinson r. Frasier, 4 Esp. 182; and see Mair v. Glennic, 4 M. \& S. $240 ;$ post, p. 71 ; Stoeker v. Brockelbank, 20 L. J., Ch. 401; post, p. 66.

(o) Geddes v. Wallace, 2 Bligh. 270; see also Lyon v. Fnoules, 32 L. J., Q. B. 71 , where it was held that the proprietor of a theatre who divided gross receipts with lessec. who provided the artors and selected the pieces. was not a partner so as to be liable to penalties under 3 \& 4 Will. 4 , c. 15 , s. 2 , for representing dramatic pieces without the author's consent. 
a contract of hiring and service, and not a partner$\operatorname{ship}(p)$.

But where $(q)$ A., a merchant and insurance broker, Partners. agreed to pay B. a certain salary for superintending his Knowles v. *mercantile concerns, and also agreed "to allow [*63] Haughton. Mr. B. one half of the profit arising from my account of insurances, from the commencement of the said account until the present period, or those that may hereafter be done," the parties having acted on this agreement, were held to be partners in the insurance business.

And where $(r)$ the plaintiff agreed with the defend- Green $\mathrm{v}$. ant to convey by horse and cart the mail between North-Becsley. ampton and Brackley at $9 l$. a mile per annum, and to pay his proportion of the expense of the cart, \&c.; money received for the carriage of parcels to be divided between them, and the damage occasioned by loss of parcels, \&c. to be borne in equal proportions, it was beld that this agreement constituted a partnership, and not a mere measure of wages, and consequently that the plaintiff could not sue the defendant for the $9 l$. a mile.

And in the following case also the parties were held to be partners $(s)$ :-

"Memorandum of an agreement entered into between Grecnham v. Messrs. R. Gray and L. Greenham, for carrying on the Gray. trade of cotton spinning and manufacturing at Mr. Gray's mills at Greenhill, Drogheda : Mr. Greenham to have the full control and management of the mill, and working of it to the extent he may think it advisable as it now stands, for the term of five years from 13th March, 1854, and to give his whole time and attention thereto, and not to enter into any other trade without the consent of Mr. Gray. Mr. Greenham is to direct and superintend all departments, from the purchases to the sales of all matters used and produced, or that it may be advisable to dispose of in or out of the mill or mill concern; and also the employment and dismissal of all parties required for, or connected with, the establishment of the D. Mill Co.; a regular set of accounts to be kept by a competent book-keeper, by double entry, who must furnish weekly and half-yearly accounts, *and make out a proper balance-sheet the first [*64]

(p) Harrington v. Churchward, 29 L. J., Ch. 521; post, p. 75.

(q) Knowles v. Waughton, Lib. Reg. 1304, A. 1808; eited in Collyer on Partn. 17.

(r) Green v. Becsley, 2 Bing. N. C. 108 ; and see Bond v. Pittard, 3 M. \& W. $35 \%$.

(s) Groenham v. Gray, 4 Ir. C. I. Rep. 501. 
Greenham v. Monday in April, and first Monday in October, each Gray. $\quad$ successive half-year. Mr. Gray to charge for the mill and concerns as it now stands, that is, all within the walls, together with the two dwelling-houses, a rent of $300 l$. per annum, over and above all head rents, insurance against fire at 7,000l., stock in process included, together with all taxes on the premises, and with which rent of $300 l$. the concern is to be debited in account half-yearly when balancing the books. The machinery to be kept in equal repair at all time to that it now is in, the expense of which is to be duly charged in the mill accounts, as the amount may be paid. Should it be considered advisable to extend the business by buildings at $\mathrm{G}$., and putting in additional machinery or otzerwise, Mr. Gray is to charge interest for the capital he may sink in such buildings and machinery at $6 l$. per cent. per annum. And for the wear and tear of the machinery so put in, a sum to be deducted yearly by way of sinking fund, at a rate to be decided on ; but for all the working capital that may be required for working the mill, as far as its present extent is capable, or to the greatest extent further buildings and machinery may be capable of and require; Mr. Gray is to supply such capital, and charge for the use of the same interest at the rate of $5 l$. per cent. per annum. Mr. Greenham is to be paid for his management, over and above his travelling expenses and other charges or costs he may incur for the benefit of the concern, $150 l$. per annum, to be paid monthly should he require it, and is to receive one-fifth part of the net profits halfyearly, and is to have for his private use one of the two mill dwelling houses that he may make choice of, free of any charge whatever, to use in such manner as may best suit his convonience." Then followed a provision appointing an arbitrator, in the event of differences.

Greenham, claiming to be partner, brought an action for the hindrance offered by Gray to the plaintiff's fulfilling his contract, and for Gray's repudiation of the agreement. Gray contended that Greenham was [*65] not a *partner, nor anything more than his man. ager or servant, and that he had misconducted himself as such, by asserting to different persons that he was a partner and not servant of Gray, and that for so doing Gray discharged him.

It was held by the Court of Exchequer in Ireland, though not without considerable doubt, that they were partners. Richards, B., said, "he had never met an in. strument devised with greater ingenuity to hide what 
the parties really meant ;" and added, "the distinction Greenham v. which has been taken between persons who are part- Gráy. ners inter se, and those who are partners quoad third parties only, does not seem to me to be very applicable to what we have here to consider. True it is that persons may act so as to constitute themselves partners, and become liable to third persons while they are not partners, nor liable inter se, but that has reference to cases where the partnership is worked out and attempted to be established by matter in pais, and is totally in. applicable here where the question is the construction of a document, and there cannot be one construction on this instrument in the case of persons who are partners quoad third persons only, and another in the case of persons who are partners inter se. The instrument is very obscure."

However, in the following case $(t$, ) the parties were Not partners. held not to be partners. C. sold to R., and conveyed Raxlinson v. to him by deed his interest in the profession and prac- Clarke. tice of a surgeon, \&c., carried on by him in P. Street, for $900 \mathrm{l}$. $500 \mathrm{l}$. to be paid on the execution of the deed, and $400 l$. at the end of a year.' C. covenanted not to practise within three miles of $\mathrm{P}$. Street, and also that, during one year from the date of the deed, he would reside in $\mathrm{P}$. Street, and carry on the profession as before, and introdnce $R$. to the patients, and promote the interest of the concern. In consideration thereof $R$. covenanted to allow $C$. during the year a moiety of the clear profits of the concern, to be paid at the expiration of the year. In an action of covenant *brought by $\mathrm{C}$. upon the deed, R. claimed to set [*66] off certain sums received by $C$. during the year from patients as money had and received to his use. Pollock, C. B., before whom the action was tried, refused to admit evidence of the receipt by C. of those sums, on the ground that the parties were partners during the first year. Upon which a bill of exceptions was tendered, and the Exchequer Chamber awarded a venire de novo, considering the parties were not partners, and that the evidence ought to have been admitted.

So, whero $(u)$ S. being entitled to certain letters-patent for making lucifer match boxes, for a money con- Brockelbank. sideration granted an exclusive licence to B. and Co. for the whole term, and by deed covenanted to serve 1 . and

(t) Rawlinson v. Clarke, 15 M. \& W. 292.

(u) Stocker v. Brockelbank, 20 I. J., 401 ; see also Osborne v. Julion, 26 I. J., Ch. 6., "Walker v. Ifirsch, L. I., 27 Ch. Div. 461 ; 54 L. J., Ch. 315." 
Co. as manager of the business for the same period, with power to B. and Co., in case of the bankruptcy or insolvency of $\mathrm{S}$., or breach of the covenants on his part, to determine the engagement by notice in writing. B. and Co. covenanted with S. that they would diligently employ themselves in the business, and that $\mathbf{S}$. should have the management thereof under their directions; that if S. should have duly observed the covenants, B. and Co. would pay him a gross sum of money at the expiration of the licence; and further, by way of salary, such a sum of money every quarter-day as should be equal to $40 l$. per cent. of the net proceeds of the business, and in case of S.'s death before, would pay his executors, during the remainder of the term, $30 l$. per cent. upon the net profits ; and it was provided, that in case B. and Co. discontinued the business, S. should have the option of purchasing their interest in the licence, and the stock, \&c., but that nothing therein contained should constitute S. a partner. After the business had been carried on for a time under this arrangement, $B$. and Co. discharged $S$. from being manager, on the ground of neglect, who thereupon filed [*67] a bill in the Court of Chancery *for an injunction to restrain 3. and Co. from excluding him from the management, and for an account. Lord Cranworth, V.-C., granted the injunction, but upon appeal, the Lord Chancellor, Lord Truro, discharged the order, with costs, to be paid by S., upon the ground that there was no partnership, that it was simply a contract of hiring and service, the remuneration to be measured with reference to the amount of the profits of the business.

Andrews v. Again, where both parties were tailors, and the dePugh. fendant, who was employed as travelling agent for the Tailor's trav- plaintiff, to receive a commission of $15 l$. per cent. on eller. the gross amount of profits, endeavored to make out that he was a partner, Kindersley, V.-C., held, that they were not partners inter se, whatever might have been the effect of their dealings as regarded third persons, and granted an injunction to restrain the defendant from receiving from any of the customers introduced by him to the plaintiff -any sums of money on account of goods delivered or business done for them by the plaintiff, and from doing any act to hinder the plaintiff from so doing $(x)$.

Similar principles have been acted on in criminal

(x) Andrews v. Pugh, 24 L. J., Ch. 58. 
cases. Thus, it has been held, that a person employed so in crimiby the owner of a colliery, as captain of one of his ves- nal cases. sels, to take out coal and sell the same, and bring back Hartley's the money to his employer, and who was remunerated ease.

for his labour, by allowing him two-thirds of the price for which be sold the coals above the price charged at the colliery, was a servant within the meaning of the statute 39 Geo. 3, c. 85, and having embezzled the price of some coal, he was convicted of larceny. All the judges holding that the mode of paying him for his labour did not vary the nature of his employment, nor make him less a servant, than if he had been paid a certain price per chaldron or per day $(y)$.

So, where a clerk to a banking firm was to receive Holmes' ease. one-third of one of the partner's profits, being the fifteenth *share of the whole profits of the house, [*68] to which the other partners assented, but they considered the clerk not liable to them for losses: it was held, that the clerk was not a partner. He was to receive only a sort of per-centage, and the agreement was assented to by the partners, merely as a private agreement between the one partner and the clerk. He was to receive a share of the particular profits of the one partner, and not of the general profits of the firm, and therefore he might be guilty of enubezzling money received on behalf of the firm $(z)$. So, where a prisoner Anonymous. was employed by the master of a coal vessel, who sent him with a cargo of coals, and the custom of the trade was for the person who superintended the business to receive two-thirds of the freight, and the owner onethird; the prisoner took the whole; whereupon he was indicted and convicted. It was objected that he and the master were joint proprietors of the freight, but a large majority of the judges held the conviction right $(\alpha)$.

And where (b) W. engaged "to take charge of the $R$. v. Wortley. glebe lands of C., his wife undertaking the dairy and poultry, at 15s. a-week till Michaelmas, 1850, and afterwards at a salary of $25 \mathrm{l}$. a year, and a third of the clear. annual profit, after all expenses of rent and rates, labour and interest on capital, \&c., are paid, on a fair

(y) R. v Harlley, Russ \& Ry. 139.

(z) Holmes' ease, 2 Lewin, 256; Chambre, J., cited in 2 Russ. on Crimes, 170 (3rd edit.).

(a) Anonymous, ibid., cited by Chambre, J.; see 2 Russ. on Crimes, 171 .

(b) R. v. Worlley, 21 I. J., M. C. 44; 2 Den. C. C. 333; see $R$. v. Walker, 27 L. J., M. C. 207 . 
R. v. Macdonald.

Tench $\mathrm{r}$. Roberts.

In re Jackson. And in another case (e), where an attorney engaged an unqualified person to conduct his business, and agreed to allow him a moiety of the profits of the business instead of a fixed salary, and the names of both of them were painted on the door of the office, and bills were made out in their joint names; Lord Tenderten ordered the attorney to be struck off the rolls, and the clerk to be sent to prison for a month.

As regards Where the question arises, not between the parties thirdpersons. themselves but between one of them and a third person, Distinction a distinction of some nicety, and difficult of application between servant receiving share of net profits,

valuation made from Michaelmas to Michaelmas; three months' notice on either side to be given, at the expiration of which time the cottage to be vacated by W., who occupies it as bailiff, in addition to his salary:" it was held that W. was servant to C., and not a partner.

So, a cashier and collector who was allowed $12 \frac{1}{2}$ per cent. of the profits in addition to his salary, with a stipulation that if the concern should be a losing one in any year he should not contribute anything towards [*69] the loss, but in *that event should be content with his salary, was held to be rightly convicted of embezzlement as a servant; Pollock, C. B. observing, "even if the language used may be sufficient to show that he was a partner with the prosecutors as to third persons, he clearly was not a partner inter se, so as to enable him who was the servant to help himself to his master's money $(c)$. defendant, who was a solicitor, under an agreement "to become an assistant to $R$., and to take one-third part of the profits of the business by way and in lieu of a salary, not to be considered as a partnership, and $R$. agreed to allow $\mathrm{T}$. the above for his share as an assistant," Sir John Leach, Vice-Chancellor, allowed a demurrer to a bill filed by $T$. for an account of salary, on the ground that this agreement substantially constituted a partnership, and was contrary to the policy of the statute 22 Geo. 2, c. 46 , s. 11, which prohibited attornies allowing unqualified persons to practise in their names. to the circumstances of particular cases, has been established between cases in which the agreement was that the servant, \&c., should be remunerated by a portion of

(e) R. v. Macdonald, 31 L. J., M. C. 67; 1 Leigh \& C. 85.

(d) Tench v. Roberts, 6 Madd. 145, note; see Candler v. Candler, ibid. 141.

(e) In re Jackson, 1 B \& C. 270. 
the net profits; and cases in which the agreement was and gross for a *remuneration by a portion of the gross [*70] earnings or earnings, or produce, or by a sum of money calculated sum calcuin proportion to the profits, or a given share of them. lated with In the former of those cases he will be considered as a profits. partner, so far as to be liable to third parties as such: it being a well established principle, that whoever participates in the profits of a trade, or has a specific interest in the profits themselves as profits, becomes chargeable as a partner to third persons in respect of transactions arising out of the trade or particular adventure in the profits of which he is to participate $(f)$. Whilst, in the latter cases, he will not be considered as a partner even with regard to third persons. This distinction will probably be regarded by the reader as one of considerable subtlety and refinement. It is, however, well established, and, though it has often elicited from judges and text-writers expressions of animadversion and regret, it has, nevertheless, been frequently acted upon in practice in America $(g)$ as well as in England, and is thought, by some writers, at least, to rest on a very just and, satisfactory foundation $(h)$.

The distinction itself is well illustrated by the case of $D r y$ v. BosDry v. Boswell ( $i)$. That was an action against B. for well. the repairs of a lighter. The witnesses first stated that the lighter was the sole property of A., who let her out to $B$., and he worked her, and that the two shared her profits equally between them. Upon which Lord Ellenborongh, C. J., said, "In that case B. was to be considered a *partner, and was jointly liable for [*71] the repairs done to the lighter. There was here a participation of profit and loss, which constituted a partnership." But the agreement with A. subsequently

(f) Gow on Partn. 13, 14.

(g) See Denny v. Cabot, 6 Metc. 90; Champion v. Bostuick, 18 Wend. 175; V'anderburgh v. Inull, 20 Wend. 70; Berthotal v. Goldsmith, 24 How. 536.

(h) 3 Kent Comm. Leet. 43, pl. 25, 33, 34 (4th elit.). See Story on Partn. ss. 36, 52; Cary on Partn. 11, note (i). Mr. Justice Story states that the Roman law fully recognized the same distinction; which is also well known and fully recognized in the French law. See Story on l'artn. ss. 50, 51; and he ardls, "This coincidence of doetrine, founded upon general reisoning between foreign jurists and the munieipal jurisprudence of the common law as to the propricty of the distinction, certainly aftords no slight confirmation of its acenracy and entire conformity to the true principles which ought to regrulate the subject."

(i) 1 Camp. 3:?; and see Wish v. Small, 1 Camp. 331; Gibbon v. Wilcox; 2 Stark. 43. 
Mair v. Ġlennie.

Smith v. Watson.

appeared to be that B., in consideration of working the lighter, should receive half her gross earnings, and that A., as owner, should receive the other half. Then Lord Ellenborough observed, that "this was only a mode of paying B. wages for his labour, and was different from a participation of profit and loss; so that, under these circumstances, no partnership could be considered as existing between him and the owner of the lighter."

This distinction was frequently recognized and acted upon by Lord Eldon, although he disapproved of it $(k)$, and has also been recognized by other judges.

Thus where $(l)$ an agreement was entered into between Mair, the owner of a ship, and Young, the master, that Young was to have in lien of all wages, primage, \&c., one-fifth share of the profit or loss of the intended voyage on ship and cargo, and was to follow Mair's instructions, do all the business himself that he could do, and for the rest make the best bargains he could; Lord Ellenborough said, there was "no pretence for saying that the captain was a partner, because his wages were to be regulated and paid by reference to a calculation on the profits of the adventure." However, it was suffcient for the decision of the case to hold that Young was not a partner in the ship.

But where $(m) A$. and B. agreed that $A$. should buy [*72] * whalebone through B., as his broker, and that B., as a remuneration for his trouble, should receive one-fourth of the profits arising from the sale, and bear one-eighth of the losses, the Court of King's Bench inclined to the opinion that B. was a partner in the profits, so as to be liable to third persons; though it was not necessary to decide that point, the question in the case before the Court depending upon whether or not B. was interested

(k) Ex parte Hamper, 17 Ves. 404, 412; Ex parte Langdale, 18 Ves. 300 ; Ex parte Watson, 19 Ves. 461 ; Ex parte Roulandson, 1 Rose, 91 ; and see Pott v. Eyton, 3 C. B. 32 ; Ex parte Chuck, 8 Bing. 469; Harrington v. Churchward, 29 L. J., Ch. 521; post, p. 75.

(l) Mair v. Glennie, 4 M. \& S. 240 ; and see Stocker v. Brockelbank, 20 L. J., Ch. 401, where Lord Truro treats the case of Mair v. Glennie as if it decided that Young was not a partner in the adventure. That was the opinion of the conrt, bnt it would scem to have been unnecessary for the decision of that case to express that opinion. The question there was, as stated in the text, as to the ownership of the ship. A similar observation applies to Meyer v. Sharp, 5 Taunt. 74.

- (m) Smith v. Watson, 2 B. \& C. 401 ; and see Reid v. Hollinshead, 4 B. \& C. 867 ; Cheap v. Cramond, 4. B. \& Ald. 670. 
as a partner in the whalebone, which he was held not to be.

The distinction above pointed out is well illustrated Pott v. Eyton. by the case of Pott v. Eyton and Jones $(n)$. That was an action by the assignees of certain bankrupts to recover money paid by them on account of the defendants. The facts were shortly these:-In 1828, Eyton was concerned in a colliery at M., and an agreement was entered into between him and Jones for opening a tally-shop at M. (near the colliery), principally with a view of supplying goods to the workmen at the colliery. Eyton built the shop, and his name appeared over the door and in the excise licences, and the invoices of goods supplied to the shop were made out in his name, and he paid for them. Jones managed the shop. The workmen at Eyton's colliery were supplied with goods from it, for which they settled at the colliery when their wages were paid until $1831(o)$. From that time they paid at the shop once a fortnight. Jones paid over to Eyton the principal part of the money taken at the shop, as he paid for the goods, but reserved enough for small payments at the shop. Eyton received for his own use $7 l$. per cent on the amount of all sales to his workmen, and Jones had all the rest of the profits. In 1834, the arrangements were changed. Jones was thenceforth to buy in his own name all goods supplied to the shop and receive payment for all goods sold; and Eyton was to receive $5 l$. instead of $7 l$. per cent. on the amount of sales to his workmen. Eyton's name remained *over the door till October, 1840, when a fire [*73] stopped the business. In 1834, when Jones began to buy goods, be opened an account with the bankrupts, who were bankers. The bank failed in 1839 , when a balance exceeding 2,000l. was due to it on that account. Besides the shop at M., Jones, after 1834, opened three more at other places, which he carried on in his own name, on his own account, and supplied with goods from the shop at $M$. The action was brought against both Eyton and Jones to recover the amount due to the bankers. No evidence was given to show that credit was, in fact, given to Eyton by the bankers, or that they knew that his name appeared over the shop, or in the licences, or supposed him to be a partner, and the jury, at the trial, found that he had not shared profit and

(n) 3 C. B. 32 ; and see Barry v. Nesham, 3 C. 13. 641 ; Heyhoe v. Burge, 9 C. B. 431.

(o) When the truck system was abolished. 
Pott v. Eyton. loss since 1834, when the account was opened, and had not been held out as a partner and his credit pledged to the bank, and gave their verdict for the defendants. And in the following term a rule for a new trial, on the ground that the verdict was against evidence, was discharged, Tindal, C. J., saying $(p)$ : —- "It was contended that an actual partnership was proved; for that Eyton, by taking $5 l$. per cent. on the sales to his workmen, received a share of the profits, and was therefore, in point of law, a partner as to third persons. But we are of opinion that the taking of that money was not sufficient to make him a partner. Traders become partners between themselves by a mutual participation of profit and loss; but, as to third persons, they are partners if they share the profits of a concern: for he who receives a share of the profits receives a part of that fund upon which the creditors of the concern have a right to rely for payment, and is therefore to be made liable to losses, although he may have expressly stipulated for exemption from them" $(q)$. Grace v. Smith $(r)$; Waugh [*74] *v. Carver (s). But in the former of those cases, Lord Chief Justice De Grey, after laying down the rule of law in the terms which $I$ have mentioned, proceeds:- "If anyone advances or lends money to a trader, it is lent on his general personal security. It is no specific lien upon the profits of the trade, and yet the lender is generally interested in those profits; he relies on-them for repayment." Afterwards he says, "I think the true criterion is to inquire whether Smith agreed to share the profits of the trade with Robinson, or whether he only relied on those profits as a fund of payment,-a distinction not more nice than usually occurs in questions of trade and usury. The jury have said that this is not payable out of the profits." So, in the present case, the jury have said there was no agreement to share the profits. This distinction has been recognized in many cases, of which it may suffice to mention Dry v. Boswell $(t)$ and Benjamin v. Porteous $(u)$. And although, in Ex parte Hamper $(x)$, Lord Eldon said the distinction was so thin that he could not

(p) 3 C. B. 39.

(q) In French v. Styringe, 2 C. B., N. S. 362, Cresswell, J., said, "That has been said ever since Waugh v. Carver, and some judges have pronounced it to be a very bad rule."

(r) 2 W. Bl. 998.

(s) 2 H. Bl. 235.

(t) 1 Camp. 329, ante, p. 70.

u) 2 H. Bl. 590 .

(x) 17 Ves. 404. 
state it as established upon due consideration, yet he Pott v. Eyton. acted upon it in that case; and again, in Ex parte Watson $(y)$, where he said, "One who receives a salary not charged upon profits-according to a known though nice distinction-is not by that a partner." Nor does it appear to make any difference whether the money is received by way of interest on money lent, or wages, or salary as agent, or commission on sales. And it appears to us that, in the present case, the payment to Eyton was in the nature of commission on certain sales supposed to be effected through his influence over his workmen, and was not sufficient to render him, as a matter of legal inference, liable as a partner: and in so far as it was a question of fact, it was disposed of by the jury."

* In the following case (z) the same question [*75] French v. might have arisen, but was avoided by the construction Styring. put upon the acts of the parties. 'I'he plaintiff was a trainer of horses at Newmarket; defendant was a wine merchant at Hudderstield. In March, 1854, a racehorse called Census was jointly purchased by plaintiff and $C$. C. afterwards sold his sharo to $M$., and it was agreed between plaintiff and M. that plaintiff should keep the horse for the purpose of training him, and should have the entire control and management of him; that $35 \%$. per week should be allowed as the expenses of his keep; that plaintiff should pay the expenses of entering the horse and conveying him to different races; that each of them should pay one-half of the horse's keep and other expenses, and that the winnings should be equally divided between them. M. having sold his share of the horse to defendant, the latter agreed with the plaintiff that he should continue to keep, train and manage him upon the same terms as had been agreed upon with M. The horse was entered and ran at several races, but never won anything, and having broke down, was sold for $20 l$. It was held that, even assuming this agreement to constitute a partnership between plaintiff and defendant, the former might recover from the latter a moiety of the disbursements made by him on account of the horse, as being in the nature of an advance of capital for the defendant.

Where, under a contract of hiring and service, a salary is to be paid in proportion to the profits, a court

(y) 19 Ves. 450.

(z) French v. Styring, 2 C. 13., N. S. 357. See also Cox v. Dickman and Bullen v. Sharp, ante, p. 62, note $(m)$. 
Bill for an ac- of equity will entertain a bill for an account of the procount of pro- fits if such account is too complicated to be taken by a fits lies in equity if accounts are complicated.

Harrington $\mathbf{v}$. Churchward. jury at common law, especially if the parties themselves have agreed that accounts shall be rendered $(a)$. As in the following case : On 1st April, 1854, a contract for the conveyance of mails was entered into with the Admiralty by J. and C. for the joint benefit of C., J., M. [*76] and the plaintiff, under these *circumstances. For some time previously C., J. and the plaintiff were in the employ of $\mathbf{R}$., the proprietor of a newspaper and owner of a despatch boat in connexion therewith. C. was a reporter, and afterwards sub-editor of the paper, and $J$. was captain, and the plaintiff engineer, of the dispatch boat. About the end of 1853, C., J., the plaintiff, and B. united together to tender for the contract, the tender was sent in and accepted, and the contract of 1st April, 1854, was the result. By agreement dated 30th November, 1854, between the plaintiff of the first part, C. of the second part, and M. of the third part, after referring to the contract of 1st April, and to the occasion for the services of the plaintiff, it was agreed that subject as thereinafter expressed the plaintiff should, during the existence of the contract of 1st April, act and be employed under the direction or subject to the control of $\mathbf{M}$., or of $\mathbf{C}$. if $M$. should so direct, as the superintendent of the engineering department of all steam ships or vessels engaged in the service or for the purposes thereinbefore mentioned, or which should otherwise in connection with the mail express be indicated to the plaintiff by M. or C., under the direction of Mr.; and it was further agreed that the plaintiff should derote his whole time to superintending the engineering department of all such steam ships or vessels as aforesaid under the direction of M., or C. if M. should so direct, and should obey the directions of M. or C., as the case might be, in connexion with the said vessels ; and it was further agreed that in return and by way of remuneration for his services $M$. should pay the plaintiff the yearly sum of $450 \mathrm{l}$. by equal quarterly payments, and in addition thereto $a$ sum equivalent to $10 l$. per cent. on the net profits and earnings, if any, to be derived from the vessels engaged in the said mail and packet service under the said contract, such percentage to commence from 1st April then last, and to be payable annually; and it was further agreed that proper books and accounts should be kept

(a) Harrington v. Churchward, 29, L. J., Ch. 521. 
of all pecuniary transactions connected with the said Harringtoi $v$. vessels and service under *the said contract, and [*77] Churchward. that such accounts should be made up annually on 1st April, and a proper balance-sheet thereof should then be made out by M. or C., and a copy thereof furnished as soon as might be to the plaintiff, and which, on being verified by a statutory declaration of $\mathbf{M}$. or $\mathbf{C}$., should be binding and conclusive upon the plaintiff. It was further agreed that in case of complaint by $\mathbf{M}$. or $\mathbf{C}$. that the plaintiff had neglected his duties or otherwise misconducted himself, the matter should, in case M. or C. should think fit, be referred to an arbitrator therein named, and in case he should decide that the conduct of the plaintiff merited dismissal, the plaintiff should immediately thereupon cease to act as superintending engineer and lose all right to salary and percentage. In 1855 a fresh but similar contract with the Admiralty was made by C., to continue in force till June, 1863, and to be then determinable in manner provided by the first contract, which was to be considered as annulled. During the second contract $C$. entered into a contract with the French government for the conveyance of French mails, and used therein some of the vessels used for the English mails. Passengers and parcels were also carried, and profits realized. Plaintiff was superintending engineer of all the vessels until 1858, when, in consequence of differences between the parties, C., who, by arrangement with M. had taken upon himself the entire performance of the contracts, gave him notice of his intention to determine the plaintiff's himng and engagement on 1st April then next, or at the expiration of the current year of his said hiring, which should tirst happen not less than three months after that notice. The plaintiff thereon filed his bill against C., J. and M., claiming either to be a partner in the undertaking, or to be entitled, in addition to his salary of $450 l$. a year, to $10 \%$. per cent. upon the whole profits of the concern. It was held by Wood, V.-C., to be so clearly a contract of hiring and service that he did not hear the defendant's counsel on *that part of [*78] the case : and it was also held, that the plaintiff had a right to file a bill for an acconnt of the profits, not in the shape of discovery, but under the clause contuined in the agreement providing that proper accounts should be made out annually, which had never been done.

But if the contract on the part of the master is only Butnotwhere to pay a certain commission, a bill in equity for an ac-contract 
merely for count will not lie : the remedy of the servant is by accommission. tion at law.

Smith r.

Leveanx.

In a case $(b)$ therefore where a mercantile firm employed the plaintiff as their traveller under an agreement that he should receive a commission of $7 l$. 10s. per cent. and an allowance of $3 l$. 10s. per cent. on all orders received from his friends ; and, disputes having arisen, the plaintiff filed his bill for an account of this commission and allowance: it was held by the Lords Justices (reversing a decision of Wood, V.-C.), that as the case was merely one of contract to pay a certain commission the proper remedy was by action at law, and the bill was dismissed with costs.

\section{Apprentice or Servant.}

Whether the contract is one of apprenticeship, or of hiring and service,

Another question, which was formerly of more importance than it is at the present day $(c)$, though even now it may often arise, is whether the agreement into which the parties have entered was intended to create the relationship of. master and apprentice, or master and servant $(d)$. In deciding this põint more attention [*79] is *now paid to the main object of the parties than to the language used by them (e). Formerly it was held that unless the word "apprentice" was used, the contract might be considered one of hiring and service $(f)$. But the cases in which that ductrine was laid down and upheld have long been overruled $(g)$, and each case is now held to depend upon its own par-

(b) Smith v. Leveanx, 33 L. J., Ch. 197 ; 9 Law T., N. S. 167. And see Turney v. Bayley, 33 L. J., Ch. 499, as to the right of a foreman claiming one-sixth of profits to the production of his master's books.

(c) Now that settlcment by hiring and service is abolished, ante, p. 2 , note $(b)$. One great difference between an apprentice and a servant is that the latter may be dismissed for misconduct, whilst the former may not in general. See Winstone v. Lynn, 1 B. \& C. 460 ; Wise v. Wilson, 1 Carr. \& K. 662; Phillips v, Clift, 4 H. \& N. 168. But where the contract of apprenticeship contained the following proviso, "Provided always that he obeys all commands and gives his service entirely to the business during office hours," it was held that an apprentie might be dismissed for habitual neglect of his duties, Westwick v. Theodor, $44 \mathrm{~L}$. J., Q. B. 110 .

(d) See further on this point, Burn's Justice, tit. "Poor". (30th ed.), pp. 204, 450, \&c.

(e) R. v. Nether Knutsford, 1 B \& Ad. 730.

(f) R. v. Little Bolton, 2 Bott, $316 ; R$. v. Eccleston, 2 East, 298.

(g) R. v. Rainham, 1 East, 531; R. v. Laindon, 8 T. R. 379; $R$. v. Crediton, 2 B.\& Ad. $493 ; R$. v. Grcat Wishford, 4 A. \& E. 223. 
ticular circumstances $(h)$. If the parties appear to depends on have contemplated the relation of master and appren- the intention tice, then the contract must be considered as one of of the parties. apprenticeship (i), and if it be an imperfect apprenticeship it cannot be treated as a contract of hiring and service. If, on the other hand, it appear that the parties contemplated the relation of master and servant, then it must be deemed a contract of hiring and service $(k)$. Where teaching and learning appear to be the primary object of the parties, then, although work is to be done for the master, the contract is to be considered as one of apprenticeship. But if working for the master appear to be the primary object, and teaching and learning the master's trade a mere secondary consideration, the existence of a stipulation by the master to teach, and a corresponding stipulation by the servant to learn, the master's trade, will not alone prevent the contract from being considered one of hiring and service $(l)$. And if a man is in fact a mere workman, and not bound by apprenticeship indenture, his being called an apprentice by the usage of trade and receiving less wages for seven years than ordinary workmen, will not make him an apprentice, so as *to exempt him from the operation of statutes [*80] merely applicable to workmen $(m)$.

\section{Tenant or Servant.}

Where a servant occupies premises belonging to his Tenant or master, as where a coachman occupies rooms over a servant. stable, or a gardener an outhouse, or a gatekeeper a lodge in the park, or a porter a lodge at the park gate, Servant ocand has on that account less wages, his occupation is cupying in law the occupation of his master $(n)$. And such premises belonging to

(h) R. v. King's Lymn, 6 B. \& C. 99; R. v. Edingale, 10 B. \& C. $739 ; R$. v. Northouram, 9 Q. B. 24.

(i) R. v. Bitborough, 1 B. \& Ald, 115; R. v. Crediton, 2 B. \& Ad. $493 ; R$. v. Newton, 1 A. \& E. $238 ; R$. v. Great W"ishfort, 4 A. \& E. $216 ; R$. v. Ightham, 4 A. \& E. 937; R. v. Northourum, 9 Q. B. 2.4.

(k) Per Bayley, J., in R. v. King's Lynn, 6 B. \& C. 99; see $R$. v. Great Wishford, 4 A. \& E. 2:2, and $R$. v.Northouram, 9 Q. B. 24 .

(l) R. v. Crediton, 2 B. \& Ad. 497; R. v. Billinghay, 5 A. \& E. $6 \% 6 ;$ R. v. Northoweram, 9 Q. B. 24.

(m) Hamilton v. Outram, 17 Fras. M. \& MeP. 798.

(n) Bertic v. Beaumont, 16 East, $34 ; R$. v. Stoek, 2 Taunt. 329; R. v. Bees, 7 C. \& P. 568 ; R. v. Ashley, 1 C. \& K. 192; St. Anue v. Linniean Society, 3 E. \& B. 793; and see Cases of Burglury 1, Russ. on Cr. 810 . See also Wright v. Stewart, 29 1. J., Q. B. 161. 
his master does not occupy as tenant, nor is he liable to poor sal rates,

nor qualified to be overseer.

Mayhew $\nabla$. Suttle. servants, when dismissed from the service, have no right to continue in the occupation of their houses as tenants, nor are they entitled to notice to quit $(o)$. Nor are they entitled de jure to a reasonable time allowed them for the removal of their furniture, \&c. But if they go on simply for that purpose, and do not remain an unreasonable time, or exclude their master, they could perhaps not be treated as trespassers $(p)$. So, under the law of settlement, the occupation of a tenement connected with and ancillary to the service, would not confer a settlement, though it would if wholly unconnected therewith $(q)$. And a Wesleyan minister, who occupies a house rented by the circuit stewards, does not thereby gain a settlement by renting a tenement, he being in the position of servant to the [*81] circuit stewards $(r)$. So a * servant at an annual salary, who resided in two rooms within the walls of a lighthouse to take care of the light, was held not liablo to be rated as occupier, his occupation being that of his master $(s)$. But a servant was held liable to poor rate who took a house not belonging to his master, although his master paid the rent $(t)$.

Upon similar principles, it has been held that a servant who occupies a tenement of his master in part payment of his services, and as subservient to, and necessary for, the performance thereof, and not merely as a matter of convenience, is not a "substantial householder" within 43 Eliz. c. 2, s. 1, so as to be appointed overseer $(u)$.

Where S., a brewer, by an agreement, reciting that he was in possession of a messuage and premises,

(o) Mayhew v. Suttle, 4 E. \& B. 347, and White v. Bailey, $30 \mathrm{~L}$. J., C. P. 253; post, p. 83.

(p) Doe v. M'Kaeg, 10 B. \& C. 721. See as to turning a servant's goods out of a house occupied by him as servant, Lake v. Campbell, 5 Law T., N. S. 582. As to recovering possession of small tenements, see $1 \& 2$ Vict. c. 74 ; of school houses, \&c., 23 \& 24 Vict. c. 136 , ss. 13,14 .

(q) R. v. Seacroft, 2 M. \& S. 472; R. v. Minster, 3 M. \& S. 276; $R$. v. Cheshunt, 1 B. \& Ald. $473 ; R$. v. Iken, 2 A. \& E. 147; R. v. Terrott, 3 East, 506 ; R. v. Ponsonby, 3 Q. B. 14 ; and cas. cit. Archbold's Poor Law, 574.

(r) R. v. Tiverton, 30 L. J., M. C. 79. That the interest of such an oceupant is determinable by a demand of possession. Sec Doe v. Jones, 10 B. \& C. 718; Perry v. Shipway, 28 L. J., Ch. 660.

(s) R. v. Tynemouth, 12 East, 46. See also R. v. Field, 5 T. IR. $587 ; 5$ A. \& E. 8.

(t) R. v. Lynn, 8 A. \& E. $379 ;$ R. v. Bishopton, 9 A. \& E. 894.

(u) $R$ v. Spurrell, 35 L. J., M. C. 74 ; L. R., 1 Q. B. 72. See the converse case, $R$ v. Hall, 1 B. \& C. 123.

(134) 
whereon the sale of beer and porter had been for some Brewer:s time last past and then was carried on and conducted servant in by U. for and on S.'s account, agreed that M. might beershop not from the date of the agreement enter into and upon the said premises, and carry on and conduct thereon such trade or business for $S$. in the place and stead, in the same manner, and with and upon the same privileges and terms as $\mathrm{U}$. had theretofore done, until the agreement should be determined and put an end to by one month's notice on either side; and the agreement also contained stipulations that M. should take all his beer from S., and not part with the trade or premises without S.'s consent, and on receiving notice to put an end to the agreement should quietly give up posiession of the premises, trade fixtares, \&c., without requiring any payment from S.: it was held both by the Queen's Bench and the Exchequer Chamber to be abundantly clear that there was no relation between the parties but that of master and servant, and that MI. could not maintain trespass against S. for entering without a month's notice, as he had no *such possession as [*82] would enable him to maintain such action $(x)$.

'The plaintiff was manager and agent of the Sweden- White $\mathrm{r}$. borg Society, and the defendants were six of the com- Bailey. mitte of the society, which was established for the pur- Manager of a pose of printing and publishing the works of Emanuel society alSwedenborg. The society having resolved to purchase a house and establish a library and reading-room for the eupy shop use of nembers, and a shop at which their publications might be stored, published and sold, advertised for a librarian and storekeeper; and a committee, who were the governing body of the society, on 6th July, 1854, resolved, "That the person to be appointed should have premises, rent and tax free, in a good situation. That 35 per cent. should be allowed to the storekeeper on all books sold out of shop, but not on ciona. tions or half subscriptions; he making such arrangements with booksellers, ayents of the society, as the committeo should from time to time determine. To carry on a retail business in other new church works and general literature for his own benefit. The committee to guarantee 150l. for the first year:" The plaintiff offered himself for the situation; and, at a meeting of the committee held on 13th July, 1854, it was resolved, "That Mr. White, of Glasgow, bo elected the storekeeper and agent, on the general terms men-

(x) Nayhew v. Suttle, 4 l. \& B. 34 . 
White r. tioned in the resolution passed at the preceding meetBailey. $\quad$ ing of the 6 th, with such modifications as may be mutually agreed upon, and that he be requested to meet the committee as early as possible to arrange the final terms, and to assist in looking for a proper house." The plaintiff was accordingly appointed, and re-appointed from year to year witb slight variations. The minute of his reappointment in 1857 was in these terms:- "That Mr. White be manager for the ensuing year, at a salary of $75 l$. a year, and six months' notice of separation on either side." In 1855 the society purchased a house which was assigned to trustees for them. [*53] On taking possession, the ground *floor was used as a shop or warehouse, the first floor as a library and reading-room, and the upper rooms were occupied by the plaintiff, by permission of the society. Abore the door of the shop there was painted in large letters, the plaintiff forcibly re-entered. Proceedings were then "Swedenborg Society," and on the posts, "William White, bookseller and publisher." The plaintiff occupied the premises and carried on his business there. Disputes arose among the members of the society, in which the plaintiff was involved. Resolutions were passed and rescinded ; and finally, at a meeting of the committee, at which the plaintiff was present, it was resolved, "That Mr. White be now dismissed, and that he be required forthwith to quit the society's house in B. Street, and to remove his own stock and property." Thereupon formal notice in writing was given to the plaintift of such dismissal and to quit the premises, and posession was taken and kept till 26th November, when taken against him in Chancery, and an injunction obtained, under which he was obliged to give up possession ; and he then brought an action of trespass for the taking and retaining possession previous to 26 th November. But he was nonsuited, as he was a servant only, and his occupation was the possession of the society, and the nonsuit was afterwards upheld by the Court ; Erle, C. J., observing, "The distinction is extremely important between granting an estate to a person and the case where the owner of the premises places him in the premises for the purpose of enabling him to perform the duty which he is employed to do. In the latter case he has no estate" $(y)$.

A servant who has been put into possession of a house or other premises by his master cannot of course

(y) Uhite v. Bailey, 30 L. J., C. I. 253. 
dispute his master's title, nor that of his master's Servant candevisee $(z)$. If he wish to do so he must first give up not dispute possession $(a)$.

master's

*Officers and servants of government who are [*S4] permitted to occupy houses belonging to government title. as part remuneration for their services may be considered as occupying as tenants within the Reform Act, enly houses 2 Will. 4 , c. 45 , s. $2 \bar{T}$, but not if they are requived to in part of occupy them with a view to the more efficient perform salary enance of their duties $(b)$.

titled to vote;

But a hall-keeper to the guildhall of a borough who but not if $r$ occupied a house (communicating with a yard at the Hall-keeper back of the guildhall) which was originally built as a to guildhall residence for and was always occupied by the hall- of a borough residence for and was always occupied by the hall- not entitled keeper for the time being, who was elected annually, to rote; and had exclusive control of the house, and paid rates and taxes, but no rent, his occupation being considered as part payment for his services, and being necessary for the due discharge of his duties, was held to occupy as servant and not as tenant, and therefore not entitled to a vote $(c)$.

And it has been held that one of the six preachers of nor preacher Canterbury Cathedral, who had a stipend of $32 t$. a vear, of Canterbury in lieu of $20 l$. a year and a house, and held his office Cathedral. during good behaviour, is not entitled to a county vote, be being merely in the position of a servant $(d)$.

\section{General Hiring, Yearly Hiring, Etc.}

Where no time is limited either expressly or by implication for the duration of a contract of hiring and A general service, the hiring is considered as a general hiring, hiring for a and in point of law a hiring for a year $(e)$. This rule year. was applicable to all contracts of hiring and service, whether written $(f)$ or unwritten, whether express or

(z) Doe v. Birchmore, 9 A. \& E. 6f:2. This rule (loes not merely apply to ejectment; Deluncy v. For, 2 C. B., S. S. 768.

(a) Doe v. Baytup, 3 A. \& Е. 188; Hoe v. Birchmore, uli supra.

(b) Hughes v. (hathrm, 5 II. \& G. 5. J)obson v. Joucs, ibid. 112 ; Bridyewater v. J)nint, :31 1.. J., C. P. 46.

(c) Clurke v. Bury st. Edmunds, 1 C. H., N. S. 23; 26 L. J., C. 1'. 12. See now The Representations of the People Act, 1884, $48 \& 49$, Vict. c. 3, s. 3.

(d) Hull v. Leris, 31 I. J. II. C. 45.

(e) Co. Litt. 42 b; Furecti v. C'axh,5 B. \& Ad. 904; Lilly v. Elaciu, 11 Q. 13. Ff?. There is scarcely a ease moon the subject of settlement by hiring and service in which this rule is not admitted; and it is never denied in any one of them.

$(f)$ See Elulerton v. Eumens, 4 C. H. $179 ; 6$ C. B. 175, 176; 13 C. B. 495 . 
implied, and whatever be the nature of the service; and [*85] is not confined to servants *in husbandry, but extends also to domestic $(g)$ and other servants, such as clerks and others $(h)$. But it is not an inflexible rule, and does not apply where the contract contains stipulations incousistent with the application of it, or where from some well-known custom upon the subject the parties may be considered to have contracted with reference to such custom, and thus to have excluded its application (i). And as we shall presently see, a yearly hiring may in general be terminated by giving the customary notice.

But the rule only applies where there has been a contract of hiring, eithe express or inplied.

Bayley v. Rimmell.

When contract cannot be implied.

Nor does the rule apply to cases in which there has been a service, but no contract of hiring, and no circumstances from which a contract can be implied $(k)$. And therefore where $(l)$ an assistant-surgeon brought an action against his employer for the amount of salary due to him, and no specific contract of hiring was proved, but evidence was given of the service, and it appeared that after the plaintiff had been some time in the defendant's service he was taken ill and went to the hospital, and never returned nor was asked to return to his employment, and that he had been paid different sums of money, but not at any fixed or definite periods : although it was contended on the part of the defendant that the evidence showed a yearly hiring, and therefore that the plaintiff, having left his situation before the end of the year, could not recover any part of his salary, yet it was held that there was no evidence to show a hiring for a year, and the plaintiff recovered for the time he had actually served.

And a contract of hiring cannot be presumed where the circumstances tend rather to rebut such a presumption, as where paupers have been taken to live with their [*86] relatives *or others out of charity $(m)$, or where the agreement was for cohabitation and not merely for service $(n)$.

But where there has been a service for more than a

(g) See R. v. Worfield, 5 T. R. 506.

(h) Hutman r. Bulnois, 2 C. \& P. 511.

(i) Baxter v. Nurse, 6 M. \& G. 935; and see post, p. 86.

(k) As there were in Beeston v. Collyer, 4 Bing. 313.

(t) Bayley v. Rimmell, 1 M. \& W. 506 ; and see Broxham v. Wagstaffe, 5 Jurist, 845.

(m) $R$ r. Pitminster, 2 Bott, 269 ; R. v. Weyhill, 2 Bott, 271; Burr. S. C. $491 ; 1$ W. Bl. 206. R. v. Stokesley, 6 T. K. $757 ; R$. v. Rickinghall, 7 East, $373 ; R$. v. Sow, 1 B. \& Ald. 178.

(n) R. v. Northwingfield, 1 B. \&. Ald 912; Bradshaw v. Hayzoard, Carr. \& M. 591. 
year, and wages paid without any express contract of where serhiring, it may be presumed that such service was under vice pera contract for a yecirly hiring (o).

And so where there has clearly been a contract, but not for any definite time, a yearly hiring may be inferred $(p)$, and slight circumstances, such as an agree- tract for inment to find clothes $(q)$, will strengthen that inference. definite time And, if the bargain be originally made for an entire yearly hiring year, but there is also a provision that in a given event, presumed. it shall be competent to the parties, or either of them Conditional to put an end to or suspend the service for a part of the year, the mere existence of this condition will not render it the less a hiring for a year ; a conditional hiring being the same, for most purposes, as an absolute hiring until the condition is acted upon $(r)$.

And this presumption, that a genoral hiring is a hir- Presumption ing for a year, may be greatly strengthened, where of yearly there appears to be some general custom applicable to hiring may the particular trade, business or occupation in which be strengththe servant is engaged to hire such servants by the tom; year, and evidence of such custom is always admis- Baxter $\mathbf{v}$. sible $(s)$. Thus, where $(t)$ the plaintiff was engaged by Nurse. the defendant, at a *weekly salary, to edit a new [*87] perodical publication, evidence was admitted, on the part of the plaintiff, to show that it was the custom, in the case of editors and other persons regularly employed on newspapers, to engage them for the whole year. But as it did not appear that the custom applied to new publications, the jury found a verdict for the defendant, on the ground that the plaintiff was not hired for a year, and an application for a new trial was refused $(u)$.

The presumption that a general hiring is a yearly hiring cannot, however, be made where it is excluded

(o) R. v. Lyth, 5 T. R. 327; R. v. Long Whatton, 5 T. R. 447; R. v. Pendleton, 15 Last, 449 ; sec R. v. St. Martin, Leicester, 8 B. \& $\mathrm{C} .67 \%$.

(p) R. v. Macelesfield, 3 T. R. 76; R. v. Ardington, 1 A. \& E. $260 ; R$. v. Newton, 10 B. \& C. 838.

(q) R. v. Worfiell, 5 T. R. 506.

(r) R. v. Byker, 2 B. \& C. 114 ; R. v. Otsett eum Ganthorpe, 4 B. \& Ad. $216 ;$ R. v. St. Helen's, Auckland, 4 B. \& Ad. 718 ; R. v. Walbottle, 9 Q. B. 248 ; R. v. Sandhurst, 7 B. \& C. 557 ; and see R. v. Herstmonecaux, 7'B. \& C. 5.51 .

(s) It must be proved by instances, and cannot be supported by evidence of opinion merely, Cunningham $v$. Fonblanque, $6 \mathrm{C}$. \& P. 44.

( $t$ ) Baxter v. Nurse, 1 Carr. \& K. 10; and see Holeroft v. Barber, 1 C. \& K. 4.

(u) 6 M. \& G. 638 ; and see Williams v. Birue, 7 A. \&. E. 177. 
When excluded by terms of contract.

Job-work.

Piece-work. But if the hiring be for a year, a mere stipulation for payment by piece-work will not render it less a yearly hiring $(d)$.

Cases of exceptive hiring. stance, is at liberty to determine the service at any time, the hiring cannot be considered yearly hiring $(x)$. Or if the hiring be expressly for less than a year $(y)$, although done purposely' to avoid the consequences of a yearly hiring $(z)$. Or if the master have not the entire control of the servant during the year, although be iiberty, when not engaged for his master, to work for other people $(a)$.

Or if the agreement be to do work by the job, as to make 70,000 bricks at a certain price, this cannot be considered a yearly hiring, for although the job may last beyond the year, it does not necessarily last so short, is excepted during which the servant is not un- by the terms of the contract. If either party, for inpay the servant yearly wages, as if the servant is at [*88] *And so if any portion of the year, however der his master's control, whether that exception be expressed or by necessary implication from the terms used $(e)$, the hiring cannot be considered a hiring for a year, so as to confer a settlement, although the contract lo for a year's service, subject to such exceptions. Thus, where a man was hired for a year, with liberty to let himself for the harvest month to any other person $(f)$, it was held that he could not: gain a settlement by service under such a hiring. So, where the servant agreed for liberty to be absent eleven days during sheep-shearing season $(g)$; or dur-

(x) R. v. Great Bowden, 7 B. \& C. 249, et cas. eit. ib.

(y) Dunsford v. Ridgwiek, 2 Salk. 535; R. v. Standon Massey, 10 East, 576. But a hiring from Whitsuntide to Whisuntide, although less than $36 \bar{b}$ days, was held sufficient hiring for a year to confer a settlement; $R$. v. Ulverstone, 7 T. R. 564 .

(z) R. v. Mursley, 1 T. R. 694; R. v. Coggeshall, 6 M. \& S. 264.

(a) $R$. v. Polesworth, 2 B. \& C. $715 ; R$. v. $L y d d, 2$ B. \& C. $754 ; R$. v. Killingholme, 10 B. \& C. 802 . But if the master have the entire eontrol during the year, it is no objection that it is given him by several contracts; $R$. v. Ravenstonedale, 12 A. \& E. 73.

(b) R. v. Woodhurst, 1 B. \& Ald. 325.

c) Trinity v. St. Peter's in Dorchester, 1 W. Bl. 443.

(d) King's Norton v. Cambden, 2 Str. $1139 ; R$. v. Birmingham, Cald. 77; Doug. 333.

(e) R. v. Gateshead, 2 B. \& C. $117 n$, as explained in $R$. v. St. Helen's, Auckland, 4 B. \& Ad. 726; and see R. v. Wolbottle, 9 Q. B. 259 .

(f) $R$. v. Bishop's Hatfield, 2Bott, 211; R. v. Althorne, 2 B. \& C. 112 .

(g) R. v. Empingham, 2 Bott, 217; Burr. S. C. 791. 
ing the sheep-shearing season $(h)$; or to work shearman's hours and be at liberty at all other times $(i)$; or as a colt shearman, to work twelve hours each day $(k)$; or where the hiring was for a year from Michaelmas, to go away a month at harvest, and make up the time after Michaelmas $(l)$; or where a bricklayer hired himself for three years, but he was to work only during certain hours each day $(m)$, and in case of frost was to have no wages, but to be at liberty to serve another master $(n)$; or where pay Saturdays and Sundays were excluded from the days on which the servant was to work (o); or Sundays only, for a hired servant is always under the government, discipline and control of the master, even on Sundays $(p)$; or where it was agreed that the servant should have a holiday to go to his feast $(q)$; or a pensioner two days in each half year to go *for his pension $(r)$; or where there was a [*89] stipulation that each man should on each working day do a full day's work, and that he should not leave the pit till that work was completed, or should forfeit $2 s$. $6 d$.; as it was, therefore, stipulated by implication that the men were not to be under the control of the master on days which were not working days, nor on any day as suon as the day's work was completed $(s)$.

Upon the same principle it was also held, that if the Hours of hours of working, were limited, the hiring, althongh work limitotherwise for a year, could not be considered a yearly ed. hiring for the purpose of conferring a settlement $(t)$. But those principles were held not to apply where the limitation of hours was merely for the purpose of regulating the amount of wages $(u)$, or where the agree-
(h) R. v. Arlington, 1 M. \& S. 622.
(i) R. v. Buckland Denham, Burr. S. C. 694 .
(k) R. v. North Nibley, 5 T. R. 21.
(l) R. v. Turvey, 2 B. \& Ald. 520.
(m) R. v. Edymond, 3 B. \& AId. 107; see R. v. Northowram, 3 R. B. 21.

(n) See R. v. Marthum, 1 East, 239; that the mere stipulation to stop wiges in bad weather would not make a hiring exceptive.

(o) R. v. Coupen, 5 A. \& E. 333. R. 21 .

(p) R. v. Kingswinford, 4 T. R. 219; R. v. North Niblcy, $5 \mathrm{~T}$.

(q) R. v. Thrckingham, 7 A. \& E. 866.

(r) R. v. Over, 1 East, 599.

(s) R. v. Gateshcad, 2 B. \& C. $117 n$, as explained in $R$. v. St. Helen's, Auckland, 4 B. \& Ad. 726; R. v. Walbottle, 9 Q. B. 529; see $R$. v. Byker, 2 B. \& C. 114.

(t) R. v. Birmingham, 9 B. \& C. 925; R. v. Frome Sclwood, 1 B. \& Ad. 207; R. v. Norton Bavant, 3 A. \& E. 161 ; R. v. Holbeck, 4 Q. B. $590 ; R$. v. Preston, 4 Q. B. 597.

(u) R. v. Ossct cum Gawthorpe, 4 B. \& Ad. 216. 
Exceptions implied by custom.

Reservation of weekly wages.

Weekly hiring. ment was to obey the rules of the factory with regard to hours, \&c., as that was merely equivalent to an agreement to obey the master's orders, which is implied in every contract $(x)$. And exceptions, merely implied by custom or usage of trade, were held not to prevent a settlement $(y)$.

Where the only circumstance from which the intended duration of a contract of hiring and service can be inferred is the reservation of wages weekly, it must be taken to be weekly hiring $(z)$. As where a man hired himself to a plumber and glazier, who was to [*90] find him board, lodging *and washing at $6 s$. per week, summer and winter $(a)$; or where. the hiring was merely at so much a week $(b)$; or where the servant was to live with his master, who was to find him board and lodging, and pay him $2 s$. $6 d$. a week (c); or where a servant in husbandry was to serve for the weekly wages of 43 ., board, washing and lodging, except in the harvest month, when his wages were to be increased to $10 \mathrm{~s}$. $6 \mathrm{~d}$. per week, and then again reduced to $4 s$. $(d)$; or where the hiring was at $8 s$. a week, and two guineas for the harvest, to do anything the gardener should set him about $(e)$; or where a gardener having asked $20 l$. a year, his master refused that, but agreed to give him so much a week $(f)$; or where a man agreed "to accept the situation as foreman of the works of R. \& Co., and to do all that lays in my power to serve them faithfully and promote the welfare of the said firm on my receiving a salary of $2 l$. per week and house to live in" $(g)$.

But where wages are calculated by piece-work and

(x) R. v. St. John, Derizes, 9 B. \& C. 896. But see R. v. Preston, 4 Q. B. 597 , where the hours were limited by a printed notice, with reference to which the agreement was made.

(y) Per Lord Mansfield in R. v. Buekland Denham, Burr. S. C. 694; per Bayley, J., in $R$. v. Edgmond, 3 B. \& Ald. 110; and sce R. v. Stoke-upon-Trent, 5 Q. B. 303.

(z) As to the notice, if any, necessary to terminate a weekly hiring, see and consider Huffell v. Armitstcad, 7 C. \& P. 56; Towne v. Campbell, 3 C. B. 921; Jones v. Mills, 31 L. J., C. P. 66; 10 C. B., N. S. $788-$ cases of weekly tenancies.

(a) R. v. Dedham, Burr. S. C. 653; 2 Bott, 292.

(b) R. v. Newton Towey, 2 T. R. 453; R. v. Odiham, 2 T. R. $625 ; R$. v. Hanbury, 2 East, $423 ; R$. v. Mitcham, 12 East, 351 ; see also Baxter v. Nurse, 6 M. \& G. 638; ante, p. 86.

(c) R. v. Pucklechurch, 5 East, 382.

(d) R. v. Dodderhill, 3 M. \& S. 243.

(e) R. v. Lambreth, 4 M. \& S. 315.

(f) R. v. Warminster, 6 B. \& C. 77.

(g) Evans v. Roe, L. R., 7 C. P. 138. 
paid weekly, such weekly payment will not constitute a Atiter, where weekly hiring $(h)$.

And if there is anything in the contract of hiring to piece-work, show that it was intended to be for a year, the reserva. or where tion of weekly wages will not control it. As where the fortnight hiring was at $3 s$. per week the year round, with liberty to go on a fortnight's notice, this was held to be a yearly hiring $(i)$. So where the hiring was at weekly or month's wages, with a stipulation for a month's notice to deter- notice remine the contract, on the ground that it was a hiring quired. of which no certain portion of time could be predicted for its duration, it was *consequently a general [*91] hiring, which the law says is a hiring for a year $(k)$. And the mere fact of receiving wages monthly is not inconsistent with a yearly hiring; a contract for a year with monthly payments is still a yearly contract $(l)$.

Where the hiring is a yearly hiring, it cannot, in gen- Yearly hiring eral, be put an end to by either party before the end cannot be of the year $(m)$. If, therefore, on the one hand, a terminated master wrongfully dismiss his servant during the year, before the the servant may maintain an action against him for year; such wrongful dismissal, and a jury would, in some cases be justified in assessing his damages at the amount of wages he would have earned had he been allowed to serve to the end of the year $(n)$. Whilst, on the other hand, a servant wrongfully quitting his master's service, or rightfully dismissed for misconduct during the year, cannot recover any wages for the portion of the year during which he has served (o).

Where the defendant having established smelting Down $\mathrm{v}$. works at Carthagena, in Spain, offered to employ the Pinto. plaintiff as foreman, by letter, containg the following passages :- "I should require you to enter into an engagement to remain with me for, at least, three years, at my option; salary, 250l. per annum." It was held,

(h) Warburton v. Heyworth, 50 L. J., C. L. 1:7; 6 Q. B. D. 1; 43 L. T. 461.

(i) R. v. Birdbrooke, 4 T. R. 245.

(k) R. v. Hampreston, 5 T. R. 205; $R$. v. Great Yarmouth, 5 M. \& S. $114 ; R$. v. Pershore, 8 B.\& C. 679 .

(l) Davis v. Marshall, 4 Law T. N. S. 216 (Exch.).

(m) Even where a steward at $80 \%$. per annum was hired "three months' notice required on each sille." it was held that the three months must end with the year; Forgan v. Burke, $12 \mathrm{Ir}$. C. I. R. 495. But see Kcon v. Hart, 2 Ir. R. (C. 1.) $138(1868)$.

(n) See Becston $v$. Collyer, 4 Bing. 309. The action for wrongful dismissal is treated of, post.

(o) Spain v. Arnot!, 2Stark. 256; Turner v. Robinaon, 6 C. \& P. $15 ; 5$ B. \& Ad. 789; Ridgeway v. Huugerford Market Company, 3 A. \& A. 171; Lilley v. Eluin, 11 Q. B. 742. 
that this did not enable the defendant to put an end to the service at his will, but that it was a yearly hiring, with an option for the defendant to require the plaintiff's service for three years, or to put an end to it at the expiration of the first, second or third year $(p)$.

in the $a b-$ sence of any stipulation or custom as to notice.

Domestic servants,

month's warning or month's wages,

wrongfully quitting forfeitall wages, not merely month.
[*92] *The above mentioned rule is, however, subject to an exception in cases in which the agreement of hiring is subject to some stipulation, either express or implied by custom (evidence of which we have already seen $(q)$, is in all cases admissible if not inconsistent with the contract), enabling either party to determine the contract by notice. In such cases, if the contract is determined by a notice, in accordance with the custom, the servant is entitled to recover wages for the fractional portion of the year during which be has served.

Thus, in the case of domestic and menial servants, with regard to whom there is a well-known ruie, founded solely on custom, that their contract of service may be determined at any time, by giving a month's warning or paying a month's wages $(r)$, if their contract of hiring is so determined, they are entitled to a proportionate amount of wages for the time they have served. But it is conceived to be perfectly clear, notwithstanding a notion to the contrary, which is believed to be not uncommon, that a domestic or other yearly servant wrongfully quitting his master's service forfeits all claim to .wages for that part of the current year during which he has served, and cannot, after having wilfully violated the contract according to which he was

(p) Down v. Pinton, 9 Exc. 327. In Cook v. Paxton, 33 L. T. 109 , nnder an agreement by the Army Works Corps, to be subject to the Mutiny Act and the Articles of War, and which also contained a stipulation as to notice to quit, the men were considered only to be entitled to notice according to the agreement, and not to a formal discharge such as is contemplated by the Mutiny Act. An agreement for twelve months certain, "after which time either party shall be at liberty to terminate this agreement by giv ing the other a three months' notice in writing," was held to terminate at the end of the year without notice, Langton v. Carleton, 43 L. J., Exc. 54 . See Brown v. Simmons, post, p. 56.

(q) Ante, p. 56.

r) Fawcett v. Cash, 5 B. \& Ad. 908; Beeston v. Collyer, 4 Bing. 313 ; and see Williams v. Brine, 7 A. \& E. 183 ; Mentzer v. Bolton. 9 Exc. 519, 520. Semble, it should be a calendar month's wages See Gordon v. Potter, 1 F. \& F. 644, in which Hill, J., directerl the jury that they must give a cook as damages for wrongful dismissal the accruing wages up to the time when she was discbarged. and a calendar month's wages in addition, withont board wages. as a master had a right to discharge a servant simply by a pay. ment of a month's wages in addition to the accruing wages up to the time of the dischargc. 
hired, claim the sum to which his wages *would [*93] have amounted had he kept his contract, merely deducting therefrom one month's wages.

This, at first sight, may appear rather harsh to some; but it is believed to be not only the law, but far more consistent with common sense and common honesty than to allow a man, at one and the same moment, to break a contract and claim a benefit under it, especially when, upon merely giving notice to his master, and paying (or agreeing to allow his master to deduct from the amount due to him) a month's wages, he could leave at any time ; and the practical effect of adhering to the strict letter of the law is merely to compel the servant to give his master notice when he wants to leave, which can be but little trouble to him, and will, in most cases, save the master a great deal of unnecessary inconvenience and trouble, and sometimes loss.

No general rule can be laid down as to who do and who are who do not come within the category of domestic or within rule menial $(s)$ servants. Each case must depend upon its as to meniel own circumstances. It has, however, been held $(t)$ that a head gardener, at $100 l$. a year, who resided in a deservants. tached house belonging to his master within his master's domain, and had the privilege of taking in apprentices, and had taken two apprentices for a year at 15l. premium, and had five under.gardeners employed for his assistance in the garden, was a menial servant, and only entitled to a month's warning. Again, it has Huntsman is. been held $(u)$ that the *hiring of a huntsman by [*94] the master of the old Berkshire foxhounds on the following terms might be terminated at a month's notice. Nicoll $\mathrm{v}$. The terms were, " $100 l$. a year ; draft hounds ; house ; coals and bones; leave to keep a pig; two coats ; two waistcoats; two pair of breeches ; two pair of boots;

(s) Blackstone, vol. i. p. 425 , says that menial servants are so called from heing intra menia, or domestics. See on this point and consider the following statutes, 16 R. 2, c. $4 ; 20$ R. 2, c. 2 ; 1 H. 4 , c. $7 ; 2$ H. 4, c. $21 ; 8$ Edw. 4, c. 2 . Lexicographers derive the expression from an old Saxon word, signifying many. See also Shakspeare, King Lear, Act 2, Se. 4-Earl of kent: "They summoned up their meiny, straight took horse," \&e. The author ventures with great difficlence to suggest that "menial" may possibly be derivel from the Greek word $\mu \eta \nu$, a month, and merely signify "monthly." There is a similar well-known word in medieal jurisprudence, which is obviously thus derived, "catamenial" meaning "aceording to the nonth, once a month, monthly."

(t) Nowlan v. Ablett, 2 Cr., E. \& R. 54 ; see Johnson v. Blenkensopp, 5 .Jnr. 870, ante, p. 57.

(u) Nicoll v. Graves, 33 L. J., C. P. 259. 
Nicoll $\mathbf{v}$. one cap ; one wbip ; one pair of spurs." In giving Graves. $\quad$ judgment in that case, Erle, C. J., said :-

"The point is whether the plaintiff is in the class of servants spoken of in the cases and in treatises as domestic or menial servants, because it is established law that a hiring for a year of any person in that class is subject to the condition that either party may determine it by giving a month's notice or a month's wages. Now is the plaintiff in that class of servants? In the excellent treatise on Master and Servant by Mr. Manley Smith, it is stated that 'no general rule can be laid down as to who do and who do not come within the category of menial servants.' It seems to me that the reason of the general rule in these cases is, that there are some contracts of service which bring the parties into close proxinity with one another, and which, though such association may be valuable, renders it the interest of both that the contract should be capable of being determined before the end of the year.

"Where the duties of the servant are such that he is required to be frequently near his master, if any ill. feeling should arise between them the presence of the servant would be a constant source of irritation to the master ; and, on the other hand, it may happen that a well-intentioned servant may have a dissatisfied master constantly finding fault with him, and the sooner he is free from such service the greater will be his happiness. The law is mutual, and it is to the advantage of both parties that such a contract when it turns out that the connection is incompatible with comfort on either side should be determinable by a month's notice. Does a huntsman then come within that description of servant? It seems to me that he would have to come frequently into communication with the person who keeps the hounds, and if the huntsman were so minded he might make the keeping of the hounds a source of irritation instead of enjoyment to the person who keeps them. I take into my mind also the fact that there might be masters of hounds who, if anything wrong were done, might be very violent, and give great annoyance to those who were dependent on them. I think in such case it wonld be to the advantage of the servant, if he had a proper spirit, to be able to say, "This is treatment I cannot submit to and I will leave your service at the end of $a$ month.' Now I think, therefore, a huntsman comes within that class or description of servant to which I have been referring. In the Tax Acts he is considered 
within the class of servants of luxury in respect of whom the master is assessed, as contra-distinguished from servants engaged in husbandry, for whom he is not assessed."

*His Lordship then referred to Nowlan v. Ablett [*9こ] and Johnson v. Blenkensopp, and added:-

"I think these cases explain the ground of my decision that, although the plaintiff contracted for a yearly hiring at $100 l$. a year and was to receive bones and other perquisites, which contemplated the continuance of the service for a year; yet, as he comes within the class of menial servants, it was with the understood condition that the hiring might be determined at any time if a month's notice was given."

But a jury of the county of Surrey have held $(x)$ that Farm bailin' a gentleman was not justified in giving only a month's not. notice to a farm bailiff, and gave a verdict for a year's wages. And the Court of Exchequer has held $(y)$, so Governess far as the question is to be treated as a matter of law, not. that a governess, at $60 l$. a year and board and lodring, does not fall within the rule by which a menial or domestic servant may be discharged with a month's notice or a month's wages. The position which she holds, the station she occupies in a family, and the manner in which such a person is usually treated in society, certainly place her in a very different situation from that which mere menial and domestic servants hold. The Tutor. same may be said of a tutor. In Ireland it has been Housekeeper held that the housekeeper to a large hotel was not a to hotel. menial servant $(z)$. But in these and similar cases an arrangement should be made at the time of hiring as to the notice expected or required, or intended to be given.

In cases to which the custom applicable to domestic Cnstom apservants does not apply, and in which no specific agree- plieable inment has been made as to the notice to be given for the other eases. purpose of determining the contract, that question must be determined by the custom applicable to the particular trade or calling with reference to which the service is to be rendered. Thus evidence has been admitted of a commercial usage of trade enabling a master to dismiss a commer- traveller cial traveller, *at $150 l$. a year, upon giving three [*96] three months' notice; and the plaintiff having declared upon

(x) Louth v. Drummond, Kingston Spring Assizes, 1849, (see Times, March 28), eoram Parke, B., who left it to the jury.

(y) Todd v. Kerrich, 8 Exe. 151; 21 L. J., Exc. 1.

(z) Lawler v. Linden, $10 \mathrm{Ir}$. Rep. I. C. 188. 
the contract as an absolute contract for a year's hiring, was defeated upon its appearing, upon his own cross-exAgent in amination, that the contract was defeasible by custom $(a)$. woollen trade Evidence has also been admitted of a custom in the one month. woollen trade to dismiss an agent at a month's no. Newspaper printer, \&c. tice (b). And in Mortimer v. Prowett (c), evidence was given to show that, where no condition was expressed in the agreement of hiring, it was usual to give a printer (newspaper) one month's, or at least a fortnight's notice, a publisher three months, and a subeditor to the end of the current year, and the jury gave the plaintiff, who filled ull these places, one month's wages.

Editor In Hollings v. Robinson (d) the plaintiff, who was engaged by the defendant as editor of the Farm and Home at $2 l$. $10 \mathrm{~s}$. a week, was held entitled to damages for wrongful dismissal, based upon the view that six months' notice should have been given to him.

Clerks. With regard to clerks, juries in London generally find that they are entitled to three months' notice, though, of course, that custom may be excluded by the terms of a particular hiring $(e)$.

Master A master mariner at $180 l$. a year was held entitled to mariner. "reasonable notice" $(f)$. And a clerk to a telegraph company to a month $(g)$.

Analogy to By analogy to the rule which prevents a yearly tentenancy from ancy from being determined before the end of the year, year to year. it is sometimes contended that particular yearly hirings can only be determined in a similar manner. This point will, in most cases, depend upon the custom of [*97] the trade or *business in question. But where a schoolmaster was appointed, by trustees of a school, on the following (among other) terms:- "The trustees shall pay you at. the rate of $55 l$. per annum, and no more, so long as, by mutual consent, you shall retain the office of master," \&c., "the appointment to be sub-

(a) Metzner v. Bolton, 9 Exe. 518. Grundon v. Master, Q. B. January 14, 1885, a jury found that a commercial traveller at 130l. a year and a percentage on orders was entitled to three months' notice. The agreement was silent as to notice.

(b) Parker v. Ibbetson, 27 L. J., C. P. 236; ante, p. 58.

(c) Q. B., Nisi Prius, June 18, 1856.

(d) Q. B., Nisi Prius, February 23, 1884.

(e) Fairman v. Oakford, 29 L. J., Exc. 459 . As to notice, where the servant is entitled to a percentage on profits, sce Harrington v. Churchward, 29 L. J., Ch. $521 ; 5$ H. \& N. 635; ante, p. 76.

(f) Green v. Wright, L. R., 1 C. P. 591.

(g) Vibert v. Eastern Telegraph Company, 1 Cab. \& E. 17. 
ject to termination by three months' notice from either party,"-it was held that the three months need not terminate with the year $(h)$. And Coleridge, J., in held not apholding the analogy of tenants from year to year not to plicable. be applicable to the case, said-"Nothing is said in the Reason. resolution or letter that the notice is to be given to terminate at the end of a year. No doubt there is a rule, with respect to tenants of land from year to year, that a notice to quit must be to quit at the end of a complete year. But no authority has been adduced to show that such a rule is applicable to notices to quit in all cases. In the case of land, there would be great inconvenience, arising from the nature of the property and the course of husbandry, to allow the relation of landlord and tenant to be terminated at any time; but with regard to a school, it must be of great importance that a master, who has done some act not sufficient to justify immediate expulsion, should not be allowed to continue in his office until the expiration of the current year. It seems, therefore, to me, that the trustees are justified in giving a three months' notice to terminate the schoolmaster's holding at any time during the year."

It has been held that an agreement of hiring (where- Yearly hiring by wine merchants hired a commercial traveller) "to be may be terbinding between the said parties for twelve months cer. minated at tain from the date thereof, and continue from time to end of first time until three months' notice in writing be given by year.

either party to determine the same," may be terminated at the end of the first twelve months by three months' notice $(i)$.

\section{* How far the Master is bound to find Work [*98] For the Servant.}

Where the contract of hiring merely contains an un-Contract to dertaking on the part of the master to pay curtain stipu-find work lated wages, in proportion to the work done by the servant, there is no implied obligation on the part of the cannot be implied from master to find ontract to wages $(k$.)

(h) Ryan v. Jenkinson, 25 L. J., Q. B. 11. See Forgan v. Burke, and Kcon v. Hart, ante, p. 91, note $(m)$. See also Bridges v. Potts, 33 L. J., C. P. $338,348$.

(i) Broun v. Symonx, 29 L. J., C. P. 251.

(k) As a general rule, in order to raise an implied eovenant it must be manifest to the judicial mind that the parties necessarily intended it, and the conelusion must be drawn from something actually found in the instrument. See per Imsh, J., in Churchyard v. Reg., L. R., 1 Q. B. 195, 211; per Kindersley, V.-C., in Dfidland R. Co. v. L. \& N. W. R. Co., 3. L. J., Ch. 831, 834. 
Agreemeat Thus, where $(l)$ the defendant, who was the owner of with colliers. a colliery, entered into an agreement with the colliers Williamson $\mathrm{v}$ and workmen, and amongst others the plaintiff, whereby Taylor. the said owner retained and hired the said other parties thereto " to hew, work, fill, drive, and put coals and do such other work as may be necessary for carrying on the said colliery as they shall be required or directed to do by the said owners, or their viewers or agents, at tho respective rates and prices, and on tho terms, "\&c. following: "First. The said owners agree to pay the said hereby hired parties once a fortnight, upon the usual and accustomed day, the wages by them to be earned, at the following rates, viz." - (specifying the rates, with regulations as to the manner of working). "Fifth. The said parties hereby hired shall, during all the times the pit shall be laid off work, continue the servants of the said owners, subject to their orders and directions, and liable to be employed by them at such work, as they shall see fit. Sixth. The said hewers hereby hired shall, when required, except when prevented by sicknoss or other sufficient unavoidable cause, do and perform a full day's work on each and every working day, or such quantity of work as shall be fairly deemed [*y9] equal to a day's work, not exceeding *eight hours, and shall not leave their work until such day's work, or quantity of work, is fully performed or finished to the extent of each man's ability; and in default thereof, each of the said parties hereby hired and so making default shall, for every such default, forfeit and pay to the said owners $2 s .6 d$. The pit to commence coal work at such times in the morning as shall be required to suit the trade." Then followed other clauses not material here. It was held that the agreement contained no promise on the part of the defendant to employ the plaintiff at reasonable times for a reasonable number of working days during the term, and that no action would lie against the defendant for not doing so, although the plaintiff was thereby unable to earn wages.

But wages must nevertheless be paid if agreed on.
But where the contract of hiring provides for the payment of certain wages (not in proportion to the work done), although it is optional on the part of the master to find work, and he may, if he pleases, discontinue his business, yet he must nevertheless pay the wages agreed on, whether he find work for the servant

(l) Williamson v. Taylor, 5 Q. B. 175; and see Lees r. Whileomb, 5 Bing. 34 ; Sykes v. Ilixon 9 A. \& E. 693 ; and other converse cases, ante, p. 44. 
or not, or he will render himself liable to an action for such damages as a jury may think proper to give. $(\mathrm{m}$.)

Thus, where the plaintiff agreed to manufacture for the defendant, with the materials and machinery to be Axpdin provided by him, cement of a certain quality, and on condition of his doing so, the defendant agreed to pay the plaintiff weekly $4 l$. for two years, and $5 l$. weekly for the following year, and then to receive him as a partner; the plaintiff also further agreed to teach the defendant how to manufacture certain kinds of cement. Each party bound himself in a penal sum to fulfil the agreement, and the defendant afterwards covenanted by deed for the performance of the agreement on his part. It was held that the stipulations in the agreement did not raise an implied covenant *that the defendant [*100] should employ the plaintiff in the business during two or three years, although the defendant was bound by express words to pay the plaintiff the stipulated wages during those periods respectively, if the plaintiff performed, or was ready to perform, the condition precedent on his part $(n)$.

And where $(o)$ a declaration stated, that by deed be- Dunn $\mathrm{v}$. tween the defendant D. and the plaintiff, the plaintiff suyles. covenanted that $D$. should, for five years from the date, serve the defendant in the art of a surgeon dentist, and attend for nine hours each day, and the defendant, in consideration of the services to be done by $D$., covenanted with the plaintiff that he, the defendant, would, during the tive years (in case $D$. shou:d faithfully perform his part of the agreement, particularly as to the nine hours, but not otherwise), pay D. 35s. per week for the first year, $2 l$. per week for the second and third, and $2 l .2 s$. per week for the fourth and fifth; that D. was in the service for some time after the making of

(m) We shall see hereafter that a servant in such case cannot, if discharged by his master, recover the wages agreed on by offering to serve and remaining idle, but only damages for the wrongful discharge.

(n) Aspdin v. Ausion, 5 Q. B. 6i1 ; see Rust v. Nollidge, 1 F. \& B. 99 ; Burton v. Great Norlhern Ruilewy Company, 9 Exe. 507; Sharp v. Waterhouse, 27 L. J., Q. B. 70.

(o) Dunn v. Sayles, 5 Q. B. 6si. In . W Iutyre v. Beleher, $32 \mathrm{I}$. J., C. P. 255; 14 C. B., N. S. 654, Erle, C. J., remarkerl. "Many persons have considered the eases of Dunn v. Sayles and Aspolin v. Austin as monstrosities. They wers a good deal olsserved upon in the case of Emmens $\nabla$. Elderlon, botl in the Exchequer Chimber and in the Honse of Lords." And see what is said by Crompton, J, to the same effect in Worthington v. Sudlow, $31 \mathrm{l}$. J., Q. B. 134. See also Rhodes v. Formoor, 47 L. J., C. L. 396 ; L. R., 1 Alp. 256. 
the deed till dismissed, and during all that time faith fully performed service, \&c., and was willing and ten. dered to perform, \&c. to the end of the tive years, but the defendant, during the term, refused to permit $D$. to remain in his service, and dismissed him. It was held, on motion in arrest of judgment that the declaration did not show any covenant corresponding to the breach. Elderton v. And where $(p)$ the plaintiff was apposnted permaEmmcns. nent solicitor to a joint stock company, at a salary of Solicitor to a $100 l$. per annum, in lieu of rendering an annual bill of company at a costs for business transacted by him for the company, salary:

Agrcement to find work implied.

Pilkington v. Scott.

Hartley $\mathrm{v}$. C'ummings.

[*101] for which * salary he was to advise and act for the company on all occasions in all matters connnected with the company, with certain exceptions, it was held by the House of Lords, affirming the judgment of the Exchequer Chamber $(q)$, that the agreement created the relation of attorney and client, and that the company was bound to continue that relation at least for a year, or pay the plaintiff his $100 l$; but the company was not bound to supply the plaintiff with business as an attorney and solicitor at all events, or to require his services as attorney or solicitor whenever they had occasion for the advice or services of an attorney or solicitor.

However, where the contract of hiring is capable of such a construction, the courts seem disposed to imply on agreement on the part of the master to find wcrk, if that is necessary to enable the servant to earn wages. Thus, in Pilkington v. Scott (r), it was held that stipnlations in an agreement whereby a workman was to be paid by the piece, that his master should pay him a moiety of his wages during any depression of trade, and might dismiss him on giving him a month's wages cr a month's notice, distinguished the case from that of Aspdin v. Austin, and that, looking at the whole of the agreement, the master was bound to employ the servant in the sense of finding him actual employment, so as to enable him to earn wages, subject to the condition of notice. And a similar decision was made in Hartley v. Cummings (s), where there was an engagement on the part of the master to find the servant other work, in the event of the master not requiring the piece-work 495.

(p) Elderton v. Emmens, 6 C. B. 160; In Dom. Proc. 13 C. B.

(q) Reversing the Judgment of the Court of Common Pleas, 4 C. B. 479 .

(r) $15 \mathrm{M} \&$ W. 657; see the agreement, ant, p. 45.

(s) 5 C. B. 247: see this case, ante, p. 45. 
stipulated for, so as to enable the servant to earn a cer. tain amount of wages per week.

And again, in $R$. v. Welch $(t)$, where the workman, R. v. Wclch. in consideration of a small sum lent in advance of wages, *"and of the wages thereinafter agreed ]*102] to be paid to him" by the masters, agreed to work for and to serve the said masters, as a tinplate worker, and not to work for or serve any one else without their leave in writing, for the full term of twelve months then next, and also until the expiration of three calendar months' notice by the workman given to the masters to determine the service, and to perform his work in a workmanlike manner, and not to absent himself during customary hours of work. And the masters, in consideration of the good and faithful services of the workman, agreed to pay him "on the Saturday night in every week during the aforesaid term (usual holidays excepted) all such wages as the articles made by him as aforesaid shall amount to, at their usual workmen's prices for similar articles." And the agreement also contained a proviso enabling either party to determine the agreement after twelve months by giving three calendar months' notice. It was held, in accordance with Pilkington v. Scott, that the agreement was not void for want of mutuality, and that the masters were bound to provide work; and Lord Campbell said, "The necessity of giving notice clearly shows that there is some obligation on the employer. What was that? To find reasonable employment according to the state of the trade. That is not an unilateral agreement, but a mutual agreement, with something to be done on each side."

And a similar decision was made in Whittle v. Frank- Whittle v. land $(u)$, upon an agreement between a collier and a Franklend. coal company. In that case, Cockburn, C. J., said:-

"The agreement by the appellant is to serve the company faithfully and exclusively as their servant from the date of the agreement until the expiration of twenty-eight days' notice, and obey their lawful commands; and on the part of the employers the agree-

(t) 2 E. \& B. 357; and see Re Bailey and Re Collier, 3 E. \& 13. 607,615 .

(u) 31 I. J., M. C. 81; 2 Best \& S. 49; 5 Law T., N. S. 639; and see M'Intyre v. Belcher, 32 L. J., C. P. 2.4; Stirling v. Mnill1ul, 34 L. J., Q. B. 1, where a covenant to keep on a husiness was impliel from an arreement $t$, pay the plaintiff a certain sum in case $\Lambda$. was "displaced" from his employment as agent to defendants. See also R.hodes v. Foruood, 47 L. J., C. I. 396. 
[*103] ment is, that they ${ }^{*}$ will pay him wages fortnightly, and not discharge him without twenty-eight days' notice. There is no express agreement that they will find him work, but that arises by necessary implication from the above two stipulations. The agreement would be perfectly illusory on the part of the employers if they could say that though they were obliged to keep him in their employ, they were yet not bound to supply work. The objection therefore as to want of mutuality fails."

Agreements in restraint of Trade contained in Contracts of hiring aNd Service.

Agreements in restraint of trade.

Agreements in general restraint of trade illegal and void.
It frequently happens that professional men, mannfacturers and tradesmen, on taking clerks, apprentices, servants and workmen into their employ, require them to enter into an agreement that they will not on leaving their service carry on a profession, manufacture or trade similar to their own within certain limits; and this is done with a view to secure themselves from competition with those who having been in their service have thereby had opportunities of becoming acquainted with their mode of carrying on business and secrets of trade, and of insinuating themselves into the good graces of their masters' customers.

All agreements of this sort in general restraint of trade $(x)$ are illegal and void, and cannot be enforced either at law or in equity $(y)$. And it makes no difference whether they are under seal or not, or whether they are made with or without consideration; it being contrary to public policy that any one should bind himself generally not to carry on his lawful trade (z).

(x) As to how far agreements made by workmen to work for a particular master for a long period, at certain wages, and no one else, are illegal, as being in restraint of trade, where there is no corresponding obligation on the part of the master to find work, see Pilkington v. Scott, 15 M. \& W. 657; Harlley v. Cummings, 5 C. B. $247 ; R$. v. Welch, 2 E. \& B. 357; see these cases ante, p. 101. In Collins v. Locke, 48 L. J., P. C. 69 , it was held that a contract, whereby certain persons carrying on the business of stevedores at Melbourne agreed to distribute their business at that port in certain proportions among themselves, and covenanted with each other that none of them would nndertake, or be in any way concerned in the stevedoring of any ship atherwise than according to such agreement, was a general restraint of trade, and void.

(y) But a servant who has performed such an agreement, whether reasonable or not, may sue for the price; Bishop v. Kitchin, 38 L. J., Q. B. 20.

(z) Com. Dig. Trade, D. 3; Clerk v. Tailors of Exeter, 3 Lev. 241 ; Ipswich Tailors' case, 11 Rep. 53 a; Mitchell v. Reynolds, 10 
*It was upon this principle, ana not as being [*10,] Ii...on r. in violation of any statute, that the bond in Hilton v. Eliersley. Eckersly $(\alpha)$ was held both by the Queen's Bench (dissentiente Erle, J.) and Exchequer Chamber to be void as Combination being in general restraint of trade. The bond was en- bonds illegal. tered into by eighteen cotton spinners, each of whom were severally bound to the plaintiff in $500 l$. The condition recited that the obligors were respectively owners of spinning-mills, and employed in them many workpeople; that there were societies and combinations among divers persons, whereby persons otherwise willing to be employed were deterred by fear of social persecution and other injuries from hiring themselves to work, and whereby the legal control of the obligors of their property was injuriously interfered with; that these combinations were sustained by funds arbitrarily levied and extorted by way of tax or rate on the persons employed by and receiving wages from the obligors, and in the opinion of the obligors it had become necessary to take *measures for vindicating their ]egal [*10j] rights to the control of their property, which would also best sustain the rights of the labourer to the free disposal of his skill and industry, and therefore the obli-

Mod. 130; 1 P. Wms. 181; 1 Smith's I. C. 356; where all the cases are collected and commented upon: and see also 3 Byth. Conv. (3rd edit.), 458, where the cases are also collected; Hinde v. Gray, 1 M. \& G. 195; Leuther Cloth Co. v. Lorsont, 39 L. J., Ch. $86 ;$ I. R., $9 \mathrm{Eq} .345$. Contracts of this nature could not be enforced by the Roman law; see Puff. lib. v. cap. 1, seet. 3; and see Puff. lib. v. cap. 5 , sect. 7 , as to monopolies. It may be well here to mention that the case in the Year Books, 3 Her. 5 , fo. 5 , pl. 26, which is sometimes, though inaccurately, eited as an authority that an agreement in general restraint of trade is void (see Com. Dig. Trade, D. 3; 1 Smith's L. C. 369: 3 Byth. Conv. 458 ), is not an authority for that position (though the position is incontestable, for in the case in the Year Book the restraint was limited in point of space, viz., "deins le ville ou le pl' etc." The real reason why the bond in that case was bad, (if, indeed, it reas held had, for in Broad $v$. Jollyfe, Cro. Jac. 596, it is said that the bond in the case in the Year Book was "allowed good,") was that no circumstances appeared to show it to be reasonable; see Pruguell v. Gosse, Aleyn, 67; Cro. Eliz. 872; Cluygute v. Bachelor, Owen, 143; and see also Hutton v. Parker, 7 Dowl. 739. The ease in the Year Book is only an authority that a restraint of trade in a particular plece is bad unless cireunstanees we recited or averred showing it to be reasonuble; and for this purpose it is eited by Lord Wensleydale in lis judgment in Mallan v. May, 11 .I. \& W. 665 , post, p. 111.

(a) 6 E. \& B. 47. The ease is so important that the judgment of the Exehequer Chamber is given at length. In the Queen's Bench, Lord Campbell, C. J., expressed great regret at the courso of decisions which had thrown upon the Judges the burden of deciding what was or was not contrary to public policy. 
Hillon $\nabla . \quad$ gors had agreed to carry on their works in regard to the Eekersley. amount of wages to be paid to persons employed therein, and the times or periods of the engagement of work-people and the hours of work, and the suspending of work, and the general discpline and management of their said works and establishments, in conformity with the resolution of a majority of the obligors present at any meeting to be convened as thereinafter mentioned. And the condition of the bond was, that if the obligors and their partners should for twelve months carry on and conduct, or wholly or partially suspend the carrying on of their works in regard to the several matters aforesaid, in conformity with the resolutions of a majority of the obligors present at a meeting to be held as thereinafter mentioned, then the bond as to each person so performing should be void. And the days, \&c. of the proposed meeting were set out; the obligee to hold the money in trust for all the obligors : with power for a majority of the obligors at a meeting to release the obligors from performance of the condition. But the bond was held void as being against public policy.

In delivering the judgment of the Exchequer Chamber, Alderson, B., said :-

"The question is, whether this is a bond in restraint

Judgment of Exchequer Chamber.
Judgment of Exchequer Chamber.

of trade, and we think it is so. Prima facie it is the privilege of a trader in a free country in all matters not contrary to law to regulate his own mode of carry: ing it on according to his own discretion and choice. If the law has in any matter regulated or restrained his mode of doing this the law must be obeyed. But no power short of the general law ought to restrain his free discretion. Now here the obligors to this bond have clearly put themselves into a situation of restraint.

"First : Each of them is prevented from paying any amount of wages except such as the majority may fix, [*106] * whatever may be the circumstances of the work to be done and his own opinion thereon. Secondly: They can only employ persons for such times and periods as the majority may fix on, however much the minority may deem it for their own interest to do otherwise. The hours of work, the suspending of work partially or altogether, the discipline of their establishments, is to be regulated by others forming a majority, and taken from every individual nember. And all this for a fixed period of twelve months. All these are surely regulations restraining each man's power of carrying on his trade according to his discre- 
tion for his own best advantage, and therefore are re- Hilton $\mathrm{v}$. straints or trade not capable of being legally enforced. Eckersley.

"We do not mean to say that they are illegal in the Judgment of sense of being criminal and punishable. The case does Exchequer not require ns, and we think we ought not to express Chamber. any opinion on that point.

"But then it is said that these reguiations, otherwise illegal, are prevented from being so considered by the circumstances against which they were intended to operate. It appears that a counter combination existed on the part of certain workmen, and that the alleged object of this bond was to counteract this, and to set the willing and industrious workman free from its powers. But supposing this to be the object, and that we may even consider it as laudable, we cannot agree 'that it is laudable or right to use such means of counteraction. The maxim 'Injuria non excusat injuriam,' is a sound one both in commun sense and at common law. This is only to put one wrong as counterbalancing another wrong, to place the industrious workman in the fearful situation of being oppressed by a majority of masters, in order to prevent him from being oppressed by a majority of his fellow-workmen. And, besides, here it is to be observed that the master's combination is not limited to the duration of the suggested combination of the workmen. It is to last for twelve months absolutely; so that if the combinations assigned as the excuse for it broke up, as they almost always do, in *a short period, this restraint upon the [*107] obligors would still continue in force after the object against which it seems to have been directed had long ceased to exist.

"The bond, therefore, if not altogether illegal and punishable, is framed to onforce at all ovents a contract by which the obligors agree to carry on their trade, not freely, as they ought to do, but in conformity to the will of otbers; and this, not being for a good consideration, is contrary to the public policy.

"W'e see no way of avoiding the conclusion, that if a bond of this sort between masters is capable of being enforced at law, an agreement to the same effect amongst workmen must be equally legal and enforceable; and so we shall be giving a legal effect to combinations of wromen for the purpose of raising wages, and make their strikes capable of being enforced at law. We think that the legislature buve been contented to make such strikes not punishable, and certainly they never contemplated them as being the subject of enforcement 
Hilton $\mathrm{r}$. by a suit at law on the part of the body of delegates Eckersley. against any workmen who might have been seduced by Judgment of some designing person to sign an engagement, with Exciequer penalty to continue in the strike as long as a majority
Chamber. were for bolding out."

Upon this last point Lord Campbell, in the Queen's Bench, said: "There must be entire reciprocity between liberty to the masters and liberty to the men; and it seems to me that a decision in favour of this bond would establish a principle upon which the fantastic and mischievous notion of a ' labour parliament' might be realized, for regulating the wages and the hours of labour in every branch of trade all over the empire. The most disastrous consequences would follow to masters and to men and to the whole community."

Hornby v.

C'lose.

Trades nnions rules illegal.

And upon similar principles, in Hornby v. Close (b), [*108]*(where it was held that a trades union was not a friendly society within the meaning of $18 \& 19$ Vict. c. 63 , s. 9 , nor established for any purpose which was not illegal within the meaning of sect. 44), some of the rules were held to be illegal (c) as being in restraint of trade; Cockburn, C. J., observing,-

"A trades union is generally understood to mean a combination of men who bind themselves not to work except upon certain conditions and to support one another if they happen to be out of employment, in conformity with the wishes and interests of the body at large. I am very far from saying that a trades union constituted for such a purpose would bring those who compose it within the reach of the criminal law; but as trades unions, so far at least as they have come under my notice, have rules and regulations that operate in restraint of trade, I think that, just as in Hilton v. Eckersley $(d)$, the combination of masters to employ only such workmen as have complied with certain con-

(b) 36 L. J., M. C. 43 ; L. R., 2 Q. B. 153 ; 10 Cox, Cr. C. 393 See Farrer v. Close, 38 L. J., M. C. 133 ; S. C. nom. Farrar v. Justices of Bradford, Law T. (1868) 238, where the rule was held not illegal. See also the report of the Trades Union Commissioners, 9th March, 1869 ; and the memorandum by Sir W. Erle on the law relating to Trades Unions annexed to that Report, and also published separately. See also "The Trade Union Acts, 1871 and $1876, " 34 \& 35$ Vict. c. 31 ; $39 \& 40$ Vict. c. 22 , (post, Appendix), which repealed "The Trades Unions Funds Protection Act," 32 \& 33 Vict. c. 61 . As to the effect of rules framed by committees of workmen or masters, see Levey v. Hill, $3 \mathrm{H}$. \& N. 702.

(c) But not criminal : R. v. Stainer, L. R., 1 C. C. R. 230 ; 39 L. J., M. C. 54.

(d) Supra, p. 104. 
ditions was held by the Exchequer Chamber (confirming the decision of this Court) to be not criminally illegal but illegal in this sense, that the breach of an agreement relating to such .a combination could not be enforced in a Court of law; so here, where we have a society which appears to be constituted for the purpose of carrying out the objects of a trades union, I think that it is illegal within the meaning of the decision in that case. Some of these rules are so much in restraint of trade that, were an action to be brought upon the contract or obligation to be implied from an assent to them, they would without any doubt be held to be in restraint of trade, so that the action could not be maintained."

But where a man who for many years had"carried on Wallis $\mathrm{r}$. the business of a carrier $(e)$ sold and assigned the good- Day. will of his business to the defendants, and covenanted Contract on with them that he would not at any time from thence- sale of busiforth during the term of his natural life, either by or ness to serve for himself, or for or with any other person whomso- for life not ever in trust for him, or *to or for his benefit, [*109] illegal. set up, exercise, or in any sort or manner howsoever use or follow the trade or business of a carrier except as thereinafter was excepted, and that he would from thenceforth cluring his life well and faithfully serve the defendants as an assistant in the said trade or business of a carrier, \&c., and the defendants covenanted to pay him certain weekly sums: it was held that the agreement was not void as being in general restraint of trade.

" $\Lambda$ nd it may often happen that individual interest $\Lambda$ greements and general convenience render engagements not to in partial recarry on a trade or to act in a profession in a particular straint of place proper. Manufactures or dealings cannot be carried on to any great extent without the assistance of agents and servants. These must soon acquire a knowledgo of the manufactures or dealings of their employers. A merchant or manufacturer would soon find a rival in every one of his servants if he could not prevent them from using to his prejudice the knowledge acquired in his employ. Engagements of this sort between masters and servants are not injurious restraints of trade, but securities necessary for those who are engaged in it. The effect of such contracts is to

(c) Wallis v. Day, 2 M. \& W. 273. As to the dictum in that ense, that a contrinet to serve another for life must be by deed, see 1 Smith's L. C. 378, noto to Mitchell $v$. Reynolds.

7 Mas. \& Ser. 
encourage rather than cramp the employment of capital in trade and the promotion of industry " $(f)$.

if made for a

Accordingly, reasonable agreements in partial reconsiderastraints of trade have always been held to be valid $(g)$. tion. For partial restraints, however, there must be some consideration, otherwise they are impolitic and oppressive $(h)$. Without a consideration such an agreement, if under seal, would be unreasonable $(i)$; and if not [*110] under seal, would be *nudum pactum $(k)$. If, however, there appear to be $a$ consideration, Courts of law will not inquire into the adeqnacy of it $(l)$.

Mallan v.

The law upon the subject of agreements in restraint May. of trade is admirably stated by Lord. Wensleydale in Mallan v. May $(\mathrm{m})$. In that case, by an agreement under seal it was agreed that the defendant should become assistant to the plaintiffs in their business of surgeon dentists for four years; that the plaintiffs should instruct him in the business, and that after the expiration of the term the defendant should not carry on the business in London or in any of the towns or places in England or Scotland where the plaintiffs might have been practising before the expiration of the said service. The agreement, so far as related to not carrying on the busiuess in London, was held valid, but the remainder of the restriction was held unreasonable and void. And in giving judgment, Lord Wensleydale said:--"The rule as laid down by Lord Macclesfield (n) and Lord Chief Justice Wiles (o) is, that total restraints of trade, which the law so much favours, are absolutely bad, and that all restraints, though only partial, if nothing more appear, are presumed to be bad, but if the circumstances are set forth, that presumption may be excluded, and the Court are to judge of those circumstances and determine whether the contract be valid

(f) Per Best, C. J., Homer v. Ashford, 3 Bing. 326.

(g) And this rule is applicable to contracts made abroad and between aliens ; Rousillion v. Rousillion, 49 L. J., Ch. 338 ; and see $i b i d$. that a contract in restraint of trade, though unlinited as to space, is not void if such universality is reasonably requisite for the protection of the contractee.

(h) Prugnell v. Gosse, Alleyn, 67 ; Claygate v. Bachelor, Owen, 143; Cro. Eliz. 872, nom. Colgate v. Bachelor. See further on this point, post, $\mathrm{p} 119$.

(i) See Hutton v. Parker, 7 Dowl. 739; Mallan v. May, 11 M. \& W. 665 .

(k) Hitchcock v. Coker, 6 A. \& E. 438.

(l) Ibid.

(m) 11 M. \& W. 653.

(n) Mitchell v. Reynolds, 1 P. Wms. 180.

(o) Wiles, 388, Gunmakers' Company v. Fell.

(160) 
or not: Mitchell v. Reynolds $(p)$. Contracts in re- Mullan v. straint of trade are in themselves, if nothing show them $M_{i} y$. to be reasonable, bad in the eye of the law: per Tindal, C. J., in Horner v. Graves $(q)$. Therefore, if there be simply a stipulation, though in an instrument under seal, that a trade or profession shall not be carried on in a particular place, without any recital in the deed, and without any averments showing circumstances *which rendered such a contract reasonable, the. [*111] instrument is void. Such are the cases cited in Prugnell v. Gosse $(r)$ and the case of the Ten Tailors of Exeter v. Clarke, $(s)$ and Claygate v. Bachelor, $(t)$; Year Book, '2 Hen. 5, fo. $5(u)$. But if there are circumstances recited in the instrument (or probably if they appear by averment), it is for the Court to determine whether the contract be a fair and reasonable one or not, and the test appears to be whether it be prejudicial or not to the public interest, for it is on grounds of public policy alone that these contracts are supported or avoided. Contracts for the partial restraint of trade are upheld not because they are advantageous to the individual with whom the contract is made, and a sacrifice pro tanto of the rights of the community, but because it is for the benefit of the public at Jarge that they should be enforced. Many of these partial restraints on trade are perfectly consistent with public convenience and the general interest, and have been supported. Such is the case of the disposing of a shop in a particular place with a contract on the part of the vendor not to carry on a trade in the same place. It is in effect the sale of a goodwill, and offers an encouragement to trade by allowing a party to dispose of the fruits of his industry : Prugnell v. Gosse $(x)$; Broad v. Joliffe $(y)$; Jelliott v. Broad $(z)$. And such is the class of cases of much more frequent occurrence, and to which this present case belongs, of a tradesman, manufacturer or professional man taking a servant or clerk into his service with a contract that he will not carry on the same trade or profession within certain limits:

(p) 1 P. Wms. 196.

(q) 7 Bing. 744.

(r) Aleyn, 67.

8) 2 Show 350.

(t) Owen, 1.13 ; see S. C. Cro. Eliz. 872, nom. Colgate v. Bachclor.

(n) See note $(z)$, ante, p. 104, as to this case in the Year Book.

(x) Aleyn, 67.

(y) Cro. Jae. 596.

(z) Noy, 98. 
Mallan v. Chesman v. Nainby $(a)$. In such a case the public May.

Homer $\mathrm{v}$.

Chesman v. derives an advantage in the unrestricted choice which such a stipulation gives to the employer of able assist[*112] ants, and the security it affords that *the master will not withhold from the servant instruction in the secrets of his trade, and the communication of his own skill and experience, from the fear of his afterwards having a rival in the same business."

\section{Ashford.}

Nainby.

Colmer r. Clark.

It is justly observed by Lord Wynford, in giving the judgment of the Court in Homer v. Ashford (b), that "it may often happen that individual interest and general convenience render engagements not to carry on trade or act in a profession in a particular place proper; that engagements of this sort between masters and servants are not injurious restraints of trade, but securities necessary for those who are engaged in it, and that the effect of such contracts is to encourage rather than cramp the employment of capital in trade and the promotion of industry."

Upon these principles, agreements in partial restraint of trade have in a variety of instances been upheld and enforced. Thus in Chesman v. Nainby (c), where the defendant, who was a linendraper, on taking the plaintiff's wife before marriage, into her service, made her enter into a bond not to carry on the business of a linen draper within half a mile of the defendant's house, the bond was held good.

And so where $(d)$ the defendant in consideration that the plaintiff, who was a tallyman, would take him into his family, and instruct him in the trade, with a provision of meat, \&c., and an allowance of $20 l$. wages a year, promised to serve the plaintiff for five years, and not to exercise the trade himself for seven years after that time, within the city and liberty of Westminster, and bills of mortality, the agreement was held good.

Davis v. And again, where (e) the defendant, in consideration Mason. of the plaintiff's taking him into his service, as assistant in the business of a surgeon, etc., agreed with the plaintiff not to exercise that business on his own ac[*113] count within the $*$ distance of ten miles from

(a) 2 Lord Raym. 1456; 2 Str. 739.

(b) 3 Bing. 326.

(c) 2 Lord Raym. 1456 ; 2 Str. 739.

(d) Colmer v. Clark, 7 Mod. 230 ; Cas. temp. Hardwicks, 53.

(e) Davis v. Mason, 5 T. ·R. 118; and see Hayvard v. Young 2 Ch. Rep. 407, where a bond by an apothecary not to set np business within twenty miles was upheld. See also Gravely v. Barnard, 43 L. J., Ch. 659. 
Thetford, where the plaintiff resided, for fourteen years, the agreement was held good.

And in another case (c), an agreement by the defend- Sainter $\mathrm{v}$. ant, in consideration that the plaintiff would engage Ferguson. him as assistant to the plaintiff as a surgeon and apothecary, that the defendant would not at any time practise in his own name, or in the name or names of any other person or persons, as a surgeon or apothecary at M., or within seven miles thereof, was also held good.

And upon similar principles the contract in Mumford Mumford $\mathrm{v}$. v. Gething $(f)$ was upheld, Erle, C. J., saying upon this Gething. point,- "The main argument urged in support of the rule was, that this contract was void as being in restraint of trade. As to that $I \mathrm{am}$ of opinion, that if no parol evidence had been given in the case at all to limit the employment, still the contract would have been good and valid: being, in my judgment, an engagement limited in point of space by the words 'on any part of the same ground,' that is to say, limited to the towns to which the defendant might be sent, it being at the option of the plaintiffs to send him to any part of England, which they had divided into districts, in which they carried on their business. I entirely disagree with the notion that these agreements are to be discouraged or held void as being in restraint of trade, in order to protect the interests of those who, like the defendants, agree to such partial restrictions. It is for the benefit of the public at large that contracts for the partial restraint of trade should be enforced, for if they were not an employer would be uncommonly scrupulous as to whom he employed, if he had no means of keeping those whom he employed in check, and of knowing how they would conduct his business, and that they would not injure him by leaving his employment and transferring the knowledge they had acquired from him to his injury to some rival in the trade. It appears to me highly *desirable that those who [*114] enter into such service as this should be at liberty to make contracts which give security that they will not use the knowledge they acquire to the injury of their employers. I entirely agree with the doctrine of Parke, B., in Mallan v. May, where he says that the public derive an advantage in the unrestricted choice. \&c., \&c. $(g)$. The defendant here was perfectly com.

(c) Sainter v. Ferguson, 7 C. B. 716.

(f) Ante, p. 54.

(g) Aute, p. 110. 
Mumforl $r$. petent to judge whether it was for his interest to enter Gething. into any agreement, and very soon after he has entered into it he goes over the same ground which he had travelled for the plaintiffs, and takes orders for a rival house. If the agreement stood alone, there is to my mind abundant reason for holding that it is limited in point of space, and that the limit is such as affords a sufficient protection to the interest of the defendant within the doctrine laid down in Mallan v. May."

How distance When an agreement not to carry on a trade within a to be meas- certain distance of a particular place has been establishured.

Leigh $\mathrm{r}$. Hind. ed, the distance should be meastured by the nearest mode of access, and "that is to be consiaered the nearest way of access which a person making the best of his way from house to house would be likely to take: that is, using the footway where there was one, and where it was most convenient to use it, and the carriage-way, either where it could be most conveniently used, or where there was no footpath" (h). And "the nearest mcde must be taken according to the existing state of the streets. If subsequently to the convenant, the convenantor took a public-house, the distance of which, by the then shortest way of access, would be greater than that agreed upon from the one he sold, and a new street were afterwards opened, whereby the distance, by the shortest way of access, became less than that mentioned in the covenant, the covenantor would thereupon incur a breach of covenant" (i).

As the crow $\quad[* 115] *$ In constructing covenants of this sort, howflies. ever, much must depend on the precise language used. When the legislature has used the expression "within twenty miles," the courts have laid down an arbitrary rule that the distance is to be measured in a straight line on a horizontal plane, or in popular language "as the crow files" $(h)$. This rule bas been applied by Wood, V. C., in granting an injunction to restrain the breach of a covenant in restraint of trade $(l)$, and, added the Vice-Chancellor, "if the parties mean the distance to be measured by roads and streets, they should say so."

On the map. In a subsequent case $(m)$ in which the defendant

(h) Per Parke, J., in Leigh v. Hind, 9 B. \& C. శ\%5; see Atkyns v. Kimier, 4 Exe. 776; 19 L. J., Exc. 13?.

(i) Per Littledale, J., in Leigh v. Hind, ubi supra.

(k) R. r. Saffron Walden, 9 Q. B. 76; Stokes v. Grissell, 14 C. B. 678; Lake v. Butler, 5 E. \& B. 92; Jevel v. Sterd, 6 E. \& B. 350.

(l) Duignan v. Walker, 1 Johns. 446; 33 L. T. 256; 28 L. J., Ch. 867 .

(m) Houfflet r. Cole, 41 L. J., Exc. 29; L. R., 7 Exc. 70; 42 L. J., Exc, 8 ; L. R., 8 Exc. 32. 
assigned to the plaintiff the lease and goodwill of a Mouffet $\mathrm{v}$. public-house, and covenanted that if he should keep a Cole.

public-house "within the distance of one half of a mile of the said premises" he would pay 500l. as liquidated damages, it was held by the Exchequer Chamber that the distance should be measured on a map, saying, "It is a very simple matter to take the ordnance map and with a pair of compasses measure the distance between any two points, and then by the scale ascertain what that distance is."

But although agreements in partial restraint of Restraint trade are in many cases upheld, yet, in order to be must be be valid, they must be reasonable, even though under reasonable. seal $(n)$. The question, whether or not any particular Whether agreement of this sort is reasonable, is one for the de- reasonable or termination of the Court $(o)$. No certain precise not is a quesboundary can be laid down *within which the [*116] tion for the restraint would be reasonable, and beyond which, ex- There is no cessive. But " a better test cannot be applied to the precise rule question whether reasonable or not, than by consider- on the subing whether the restraint is such only as to afford a ject. fair protection to the interests of the party in favour of $A$ test. whom it is given, and not so large as to interfere with the interests of the public. Whatever restraint is larger than the necessary protection of the party can be of no benefit to either, it can only be oppressive, and if oppressive, it is in the eye of the law unreasonable" $(p)$.

Applying this test to an agreement $(q)$, whereby the

(n) See Ifutton v. Parker, 7 Dowl. 739, and eas. eit. infra.

o) Homer v. Asifford, 3 Bing. 32:; Mallan v. May, 11 M. \& W. 653; Tallis v. Taltis, 1 E. \& 13. 391. In the latter case, p. 404, Erle, J., said, "It always scemed to me a difficulty, that if the Court is to decide what restraint is reasonable they must judicially determine a question, the solution of which may require knowledge loth of the statistics of the trade and of the geographical situation of places;" and Lord Campbell, C. J., added, "If it were res integre, I do not see the oljjection to casting on the defendant the burthen of pleuling and proving, as a fact, that the restraint was more than was reasomable."

(p) Per Tindel, C. J., in Hormer v. Graves, 7 Bing. 743; and seo Kitchkoek v. Coker, 6 A. \& E. 454; Mallan v. May, upi supra; Ward v. Byrne, 5 MI. \& W. 548, 561; Procter v. Sargent, 2 MI. \& G. 3:; Dendy v. IIenderson, 11 Exe. 198; Allsopp v. Wheteroft, 42 I. J., Ch. 12 ; L. R., $15 \mathrm{Eq} .59$. As to how far an agreement to serve a particnlar master and no one else for seven years is void as being an unreasonable restraint of trade, whore the master is not bound to employ the servant, see IIarlley $v$. Cummings, 5 C. B. 247; ante, p. 45 .

(q) Horner v. Graves, 7 Bing, 743; and sce Iomng v. Timmins, 1 Cr. \& J. 331. 
Horner :

Graves.

Where restraint held unreasonable

Drallan $\mathrm{r}$. Day

Price v. Green.

Cases in which restraint held to be reasonable. defendant corenanted with the plaintiff, that he the defendant would faithfully serve the-plaintiff as an assistant in the business and profession of a surgeon dentist for five years; and the plaintiff, in consider. ation of such service, and of the covenants of the defendant, did covenant with the defendant to pay him the yearly salaries therein mentioned, and to instruct him in the business or profession of a surgeon dentist; and the defendant covenanted that he would, during the said term of five years, faithfully and diligently serve the plaintiff as bis assistant, and would not depart from his service without giving him three calendar months' notice in writing of such his intention; "and that the defendant should not, nor would at the expiration or other sooner determination of the said term (provided the said plaintiff were then living and practising in the said business or profession), exercise and practise the said business or profession at or within the distance of 100 miles of the city of York, without the previous consent in writing of the said plaintiff, [*1i7] under the penalty of "*1,000l.:" the restriction was held" unreasonable, and judgment arrested.

Upon the same principle, part of the agreement in Mallan v. May $(r)$, (that part, namely, which restrained the defendant from practising as a surgeon dentist in any of the towns or places in England or Scotland, where the plaintiffs, or the defendant on their account, might have been practising before the expiration of the defendant's service,) was held to be unreasonable and void. And in Price v. Green (s), a covenant not to carry on the trade of a perfumer, toyman, and hair merchant, within the cities of London and Westminster, and the distance of 600 miles from the same respectively, was held to be void as to the 600 miles, though good as to London and Westminster.

But agreements not to carry on the business of an attorney in London, or the distance of 150 miles ronnd $(t)$, or within the city of Loudon or the counties of Middlesex or Essex (u), or in Great Britain, for the space of twenty years $(x)$, have been beld not unreason-

(r) 11 М. \& W. 653; ante, p. 110.

(s) 16 M. \& W. 346; and see Nicholls v. Stretton, 10 Q. B. 346; Collins r. Loeke, 48 L. J., P. C. 73.

(t) Bumn v. Guy, 4 East, 190; and see Galswrorthy v. Strutt, 1 Exe. 67 .

(u) May v. O'Neile, 44 L. J. Ch. 660.

(x) Whitaker v. Houe, 3 Beav. 383 ; but see as to this ease, post, p. 121. 
able. And "five miles from Northampton Square, in the county of Midtlesex," in the case of a milkman $(y)$, "London," in the case of a surgeon dentist (z), "200 miles from Birmingham," in the case of a horsehair manufacturer $(a)$, and "any part of Europe" on sale of a patent $(b)$, were considered not unreasonable distances.

And upon a dissolution of partnership between per- Tallis $\mathrm{v}$. sons in the canvassing trade, a covenant by the defend- Tallis. ant not to be concerned in that trade in "London, or within $150 *$ miles of the General Post Office, [*118] nor in Dublin or Edinburgh, or within fifty miles of either, nor in any town in Great Britain or Ireland, in which the plaintiff, or his successors, might at the time bave an establishment, or might have had one within the six months preceding," was held not unreasonable $(c)$.

And in the following case also the agreement was Dendy $\mathrm{r}$. upheld as reasonable $(d)$ :- $\quad$ Henderson.

By agreement reciting that the plaintiff, being solicitor for, and general manager of, certain estates at Agreement Torquay, in the parishes of Tormoham and St. M., and licitor and having occasion for the services of a managing clerk, to resident reside at Torquay, finding it expedient to establish an clerk. office there for the transaction of law and other business, had proposed to appoint the defendant as resident clerk there, upon his entering into the agreement thereinafter coutained: it was agreed that defendant should continually reside, except as otherwise directed by plaintiff, at Torquay, and to have the use of threo rooms in the house where such office should be kept; that defendant should have the salary therein mentiuned, and should exclusively devote his time and attention to the interest of the plaintiff, and should not make use of his own name in any business matter or as agent, except as agent for plaintiff, his executors, \&c., and should not take any other situation, or transact any other business on his own account, or for his own profit, or on account or for the profit of any other per-

(y) Proeter v. Sargent, 2 M. \& G. 20; see Benuell v. Inns, 26 L. J., Ch. (663; 24 Beav. 307.

(z) Mallau v. May, 11 M. \& W. 653; ante, p. 110. In that case

"London" was held to mean the City of London.

(a) IIurms v. Parsons, 32 L. J., Ch. 247; 32 Beav. 323; 9 Jur., N. S. 145.

(b) Leuther Cloth Company v. Lorsont, 39 I. J., Ch. 86; L. R., 9

Eq. 345. See Allsopp v. Wheatcroft, 42 I. J., Ch. 12.

c) Thllis v. Tallis, 1 E. \& B. 391.

(d) Dendy v. Henderson, 11 Exc. 194. 
Dendy v. Henderson.

Agreements not under seal in restraint of trade must show consideration.

Courts will not inquire into adequacy of consideration.

Duration of restraint (in other respects valid (unimportant. son than plaintiff, his executors, \&c., without his consent; that either party should be at liberty to determine the agreement by notice, as therein mentioned; but in case of any such determination by either party, the defendant should not, unless with and during the consent of the plaintiff (such consent to be revocable at any time), for the space of twenty-one years from the expiration of such notice, and notwithstanding the decease [*119] of the plaintiff previous to or *during the period aforesaid, reside in the parish of Tormoham or of St. M., or within twenty-one miles thereof, or transact or carry on therein or within the distance aforesaid, either for himself or any other person, or in partnership or connection with any other person, during the period of twenty-one years, any business of the nature or description of the business that might be carried on under the agreement, or might be intended so to be, under a penalty of $2,000 l$, to be recovered as liquidated damages. That the agreement should not determine on the decease of the plaintiff, unless notice should have been previously given by either party. And a plea by the defendant that although he had resided in Tormoham, he had not done so for the purpose of carrying on business of the nature referred to in the agreement, was held bad on demurrer.

In the case of an agreement in partial restraint of trade, not under seal, it is necessary, not only that it should be reasonable, but also that there should appear to be $a$ consideration to support it, otherwise it would be merely nudum pactum and void (e). An opinion at one time prevailed $(f)$, or, more accurately speaking, was supposed to prevail, that the Courts would inquire into the inadequacy of the consideration. But that opinion is now entirely exploded $(g$.

If an agreement in partial restraint of trade be in other respects valid, it is no objection that the restraint be imposed for the whole life of the party subject to it. Thus, where $(h)$ it appeared that the plaintiff, who was a druggist, had taken the defendant into his service as an assistant, at $\dot{a}$ certain annual salary, and in

(e) See ante, p. 109. 660.

(f) See per Alderson, B., in Pilkington v. Scott, 15 M. \& W.

(g) Hitcheock v. Coker, 6 A. \& E. 456 ; and see also Archer v. Marsh, 6 A. \& E. 959 ; Leighton v. Wales, 3 M. \& W. 551 ; Pilkington v. Scott, ubi supra; Sainter v. Ferguson, 7 C. B. 716 ; and see por Lord Wensleydale, in Moss v. Hall, 5 Exc. 49, 50; Tallis v. Tallis, 1 E. \& B. 391.

(h) Hitchcock v. Coker, 6 A. \& E. 433. 
consideration thereof the defendant agreed that, if he Hitcheock $\mathrm{v}$. "should at any time thereafter, directly or indirectly, Coker. in his own name, or *in the name of any other [*120] person, use, exercise, carry on or follow the trades or businesses of a chemist and druggist, or either of them, within the town of Taunton, in the county of Somerset, or within three miles therof," then he would pay to the plaintiff $500 l$. for liquidated damages, it was held that the agreement was not void merely on the ground of the restriction being indefinite as to duration, the same being in other respects a reasonable restriction.

And so, where (i) the defendant, on becoming assis- Hastings v. tant to the plaintiff, who was a surgeon, entered into a Whitley. bond not to practise as a surgeon at, or within ten miles of, S., at any time without the consent, in writing, of the obligee, it was held that the restraint was not confined to the life-time of the obligee, but was co-extensive with that of the obligor, and that there was nothing illegal in the restriction being indefinite as to duration, the same being in other respects a reasonable restriction.

So a covenant not to carry on the trade of a butcher Elres r. within fivè miles was beld good, although indefinite in Croft. point of duration $(k)$.

And as, on the one hand, the indefinite duration of a But definite restriction will not invalidate the contract whereby that limitation in restriction is imposed, if in other respects reasonable, woillt of time so, on the other hand, the definite limitation of a restriction in point of time will not render valid a restraint in other respects unreasonable.

Thus, where $(l)$ the defendant, upon entering the service of the plaintiff, who was a coal merchant, as town traveller and collecting clerk, gave him a bond conditioned (inter alia) that he should not, within two years after leaving the plaintiff's service, solicit or sell to any customers of the plaintiff, that he should not follow or be employed in the business of a coal merchant for nine months after he should *have left the [*121] plaintiff's employ, and that he should not leave his employment without giving a month's notice, it was held that the bond was void as being in general restraint of trade, and that the restriction being limited in point of time did not render it valid.

(i) Hastings v. Whitley, 2 Exc. 611 ; and see a similar agreement upheld in Sainter v. Ferguson, 7 C. J. 716.

(k) Elves v. Croft, 19 L. J., C. 1'. 385; ; 10 C. l3. 241.

(l) Ward v. Byrne, 5 M. \& W. 548 ; and see IFinde v. Gray, 1 M. \& G. 195 ; Proctor v. Sargent, 2 M. \& G. 20. 
But see

Whitaker v.

Howc.

Nicholls v.

Strctton.

A case $(m)$, however, has been decided in Equity somewhat at variance with Ward v. Byrne, in which Lord Langdale, M. R., enforced, by injunction, an agreement entered into by an attorney not to practice in Great Britain for the space of twenty years without the consent of the person to whom he had sold his business. Of this case, Patterson, J., is reported to have said $(n)$, "I cannot help thinking that the Master of the Rolls there must have proceeded on the ground that the limitation was for twenty years only." And on Ward v. Byrne being cited, the same learned Judge observed, "I do not see how that case can be reconciled with Whitaker v. Howe." It must be observed, however, that in Whitaker v. Howe the restriction was limited as to space, viz., to Great Britain ; but in Ward v. Byrne the restriction was not limited at all as to space, though it was as to time. The decision in Whitaker v. Howe, therefore, may only amount to this, that the whole of Great Britain is not an unreasonable re- ' striction on the sale of the goodwill of an attorney's bûsiness $(o)$. If it be considered as a decision that a general restraint on trade, unlimited except in point of duration, is good, it is conceived that it cannot be supported, being at variance with all the earlier authorities.

Contract not to solicit certain customers valid.

Together with the cases in which contracts in partial restraint of trade have been upheld may be.classed those in which a servant or clerk enters into a contract not to interfere with, or solicit, the business of those persons who are his employer's customers. Such agree[*122] ments are in general *valid, whether the customers are named in a schedule or not $(p)$.

Nicholls v.

Thus, where $(q)$ an articled clerk to an attorney in, Stretton. consideration of the attorney taking him as an articled clerk without any premium, covenanted that he would not during the articles, or at any time after their expiration, interfere with, or act as attorney or agent for, any person who had already been, or who should from time to time thereafter become or be the client or cor-

$(m)$ Whitaker v. Hove, 3 Beav. 383 ; see Bryson v. Whitehead, 1 Sim. \& St. 74, where an agreement not to carry on the business of a dyer for twenty years was considered too large. '

(n) In Nicholls v. Stretton, 10 Q. B. 353 ; and see S. C., 7 Beav. 42.

(o) See Harms v. Parsons, 32 L. J., Ch. 247.

(p) Hunlocke v. Blacklove, 1 Wms. Saund. 156 ; Rannic v. Irvine, 7 M. \& G. 969 ; Nicholls v. Stretton, 10 Q. B. 346.

(q) Nicholls v. Stretton, ubi supra. "See also Pearson v. Pcarson, L. R., 27 Ch. Div. $145 ; 54$ L. J., Ch. 32, as to the right of the vendor of the goodwill of a business to solicit old customers." 
respondent in business, of the attorney, or any partner of his, or any person to whom he might sell his business, it was held that the attorney might recover in respect of breaches of covenant with regard to persons who had been his clients before and at the time of making the deed, and of persons who had been his clients whilst the clerk continued under articles.

Upon similar principles a person may, by agreement, Contract not restrain himself generally from the use of a particular to use particsecret in lis trade $(r)$.

If an agreement in restraint of trade is partly good and partly bad, and the good part can be separated from the bad without injury to the sense, the good part will bo upheld, and the bad rejected (s.)

But an agreement with $\mathrm{A}$. that he will not carry on a particular trade is not binding on his executors, so as to prevent their carrying on the prohibited trade $(t)$ : Not binding though of course the agreement might be made to extend t.j executors by apt words.

It is not very easy to define what acts would amount what is to "carrying on" a particular trade. Where a tailor, "carrying having sold the goodwill of his business agreed with on" a trade. the purchaser *not to "carry on or be con. [*123] cerned or interested in " the business of a tailor within Newling v. a tixed distance of his former shop; and afterwards engaged himself as a journeyman tailor to his nephew, who carried on the same trade under the same name within the prescribed limits, Malins, V.-C., held this to be a breach of his agreement and granted an injunction to restrain him $(u)$.

But soliciting orders as servant for another does not amount to a breach of an agreement not to carry on a trade $(x)$.

And where a traveller on entering the service of an Josselyn v: ale, porter and spirit merchant bound himself not to Parson. travel for any porter, ale or spirit merchant as agent, collector or otherwise in C., or within twenty-five miles thereof, it was held that traveling as agent and collector

(r) Bryson v. Whitehead, 1 Sim. \& St. 74.

s) Chesman v. Nainby, 2 Str. 739 ; 2 Lord Raym. 1456; Mallan v. May, 11 M. \& W. 653 ; Price v. Green, 16 M. \& W. 346; Nicholls v. Stretton, 10 Q. B. 346 ; Tallis v. Tallis, 1 E. \& B. 391, 412; and see Bryson v. Whitehead, 1 Sim. \& St. 74.

( $t$ ) Cooke v. Colcraft, 2 W. I3l. 856 ; 3 Wils. 380 . Semble, however, that the restraint in that case was void, being in general restraint of trade.

(u) Newling v. Dobell, 38 J. J., Ch. 111.

(x) Clark v. Watkins, 9 Jur., N. S. 124; 11 W. R. 319 ; Aluen v. Taylor, 39 L. J., Ch. 627. 
for a firm of brewers in C. was not a breach of the con. dition of the bond $(y)$.

Mode of securing performance of contract in restraint of trade.

By penalty.

Reindel v. Schell.
The performance of a contract in restraint of trade is usually secured by a bond or covenant not to do that which it is intended to prohibit, and, in the event of a breach of that stipulation, to pay a certain sum as liquidated damages $(z)$.

In contracts of this sort, where the damages are capable of accurate measurement, the terms "liquidated damages" are to be construed as a penalty. But if there be a contract, the breach of which cannot be measured, then the courts have held that the parties mean what they say, for this reason, that the subjectmatter of the covenant is incapable of raluation $(a)$. [*124] Upon this principle, as it is *almost impossible to calculate the precise amount of dalmage which one person has sustained by the competition of another, who has been carrying on his trade in the neighbourhood after having contracted not to do so, the courts have almost, if not quite, invariably held in such cases, that the parties meant what they said, and the plaintiffs have recovered the whole amount of the stipulated penalty.

But where (b), by an agreement between plaintiff and defendant, the defendant agreed to become assistant to the plaintiff, in his profession of photographic painter, for the term of five years, and to give up his whole time to retouching portraits, \&c., and not to take employment from others, and to follow the plaintiff's directions, and not divulge his secrets of the art, and be faithful to the plaintiff in his dealings, and the plaintiff agreed to pay the defendant a weekly remuneration for every portrait retouched after certain rates, and to guarantee that the defendant should be continually supplied with portraits to retouch; and, lastly, it was agreed that they should respectively forfeit $500 l$.

(y) Josselyn v. Parson, 41 L. J., Exe. 60 ; L. R., 7 Exe. 127.

(z) Shaekle v. Baker, 14 Ves. 468.

(a) Per Lord Wensleydale in Atkyns v. Kinnier, 19 I. J., Exc. 132; 4 Exc. 776; and see Kemble v. Farren, 6 Bing. 141; Hormer v. Flintoff, 9 М. \& W. 678; Price v. Green, 13 II. \& W. 701; Galsworthy v. strutt, 1 Exc. 659 ; Reymolds v. Bridge, 26 L. J., Q. B. 12 ; 6 E. \& B. 528 ; Mereer v. Irviug, 27 L. J., Q. B. 291 ; E. B. \& E. 563 ; Bettsv. Burch, 28 L. J., Exe. 267 ; Sparrow v. Paris, 31 L. J., Exc. 137; Magee v. Lavell, 43 L. J., C. P. 131; Lea v, Whitaker, L. R., \& C. P. 70 ; Re Newman, 46 L. J., Bank. $57 ; 4$ Ch. Div. 224 ; Wallis v Smith, 52 L. J., Ch. 145; Central Dio count Co. v. Glegg, 52 L. J., Ch. 297.

(b) Reindell v. Schell, 27 L. J., C. P. 146. 
as liquidated damages, in case of any breach, by either of them, in the true performance of the terms of the agreement; it was held that there was no doubt, nor, indeed, was it disputed, that the intention of the parties was not that the sum of $500 l$. should be paid absolutely by way of liquidated drmages, on non-performance of any of the stipulations containęd in the agreement. It was merely a penalty.

And where a person has entered into a valid binding By injunccontract, not to carry on his business in a particular tion. place or manner, to the injury of another, courts of equity will restrain him from doing so by injunction $(c)$.

*Where, therefore, a solicitor's clerk executed [*125] Howard $\mathrm{r}$. a bond to his employer not to practise within fifty Woodward. miles of W. under a penalty of $1,000 l$., it was held that the employer was entitled to an injunction to restrain him from so doing $(d)$; Wood, V.-C., saying, "Was this bond an agreement that the defendant should not practise within the specified distance? or was it an agreement that he might practise there on payment of $1,000 l$. as liquidated damages? Solicitors were obliged to repose very great confidence in their managing clerks, and no doubt the clerks had in many instances the power of causing very serious injury to the solicitor's business, and it was unreasonable to expect that such a managing clerk should be permitted upon payment of a given sum, to carry off his master's business, by starting as a solicitor himself, in the immediate neighbourhood. The words of the bond were quite sufficient to show that in the present case such was not the intention of the parties."

And where the plaintiff, a milkseller, agreed to employ cornurnll v. the defendant as a servant, and the defendant agreed Hitukins. to servo the plaintiff" "for one week certain, and until the expiration of a week's notice to be given by either

(c) Whitaker v. Howe, 3 Beav. 383 ; Nicholls v. Stretton, 7 beav. 42 ; see French v. Macale, 2 J)r. \& W. 275, where Lorl st. Leonards states the general rule of equity to be, that "if a man covenant to abstain from doing a certitin act and agree that if he do it he will pay a sum of money, it would seen that he will be compelled to abstain from doing that act, and he cannot elect to break lis engagement by paying for his violation of the contract." Sce also Gerard v. O'Reilly, 3 Ir. \& W. 414.

(d) Howarl v. Wondward, 34 L. J., Ch. 47. Upon the sale of the good will of a business, where there is no covenant on the part of the vendor not to solicit the customers of the firm, an injunetion may nevertheless be granted to restrain the vendor from soliciting by his travellers, \&c., sneh customers, if it is nureasonable for him to do so. Labouchere v. Dawson, 41 L. J., Ch. 427. 
party, the wages to be 18 s. a week;" in consideration whereof the defendant agreed "not during the continuance of such service, nor within two years from quitting or being discharged from such service, to carry on or to be concerned in any way whatsoever, either as master or servant, in the trade or business of a milkman, milkseller or milk carrier within two miles from B;" an injunction was granted to restrain him from so doing, although he was an infant when he entered the service $(e)$. And Wickens, V.-C., observed:-

Cornvall v. $\quad\left[{ }^{*} 126\right] *$ * The case of Kimberley v. Jennings $(f)$ was Haxkins.

Want of mutuality objection. the greatest difficulty in the case. There the Court refused to enforce an agreenent for service by which a young man placed himself almost entirely in the power of certain traders by whom he was employed. But this contract did not seem so hard as to make him refuse his interference; it was a kind of contract well known and not unusual, for the trade of a milkman was one where the servant was in constant communication with the customers, while they never saw the master, and the covenant in question was therefore not an improper one."

The remedy by injunction is often a more complete and effectual remedy than an action for the penalty agreed upon. And it seems that the jurisdiction of courts of equity, to restrain by injunction an act which a defendant is by contract or duty bound to abstain from, is not confined to cases in which those courts have jurisdiction over the acts of a plaintiff; the want of mutuality in the contract affords no objection to the exercise of the jurisdiction $(g)$.

And it is no objection to the exercise of this equitable

No objection that Court cnnot enforce affirmative part of contract.

Lumley $\mathrm{r}$. Wagner. jurisdiction, that the court cannot enforce the affirmative part of the contract. If there is a negative part which they can prohibit a breach of, they will do so.

Thus, where a singer agreed that she would sing for a certain number of nights at the plaintiff's theatre, and not elseuhere without his written authority, the Lord Chancellor granted an injunction to restrain her from singing elsewhere, although he could not enforce the specitic performance of the entire contract $(h)$.

(c) Cornwall v. Hawkins, 41 L. J., Ch. 435 ; and see Middleton v. Brown, 47 L. J., Ch. 411.

(f) 6 Sim. 340.

(g) Dictrichsen v. Cabburn, 2 Phill. 52; Morris v. Coleman, 18 Ves. 437 ; Stocker v. Wedderburn, 3 Kay \& J. 393; but sce Hills v. Croll, 2 Phill. 62; 1 De G., M. \& G. 326 ; 14 L. J., Ch. 444; Blacket v. Bates, 35 L. J., Ch. 324 ; Donnel v. Bennet, 52 L. J., Ch. 414 ; L. R., 22 Ch. Div̀. 835.

(h) Lunley v. Wagner, 21 L. J., Ch. 898 ; 1 De G., MI. \& G. 604, (174) 
*Where a milkman, on being taken into the [*127] Grantel in service of a cowkeeper, \&c., agreed faithfully to serve, fivour of \&c., the master and his assignees or successors in busi- purchaser of ness, and that he would not during such service, nor master's within the space of twenty-four calendar months after Bencell v. qutting or being discharged from the same, commence, Inns. carry on, or be concerned in any way whatsoever, either as servant or master, in the trade or business of a cowkeeper, milkman, milkseller, or milk carrier, within the distance of three miles from C. Street, it was held, that the plaintiff, having purchased the business from the master, was entitled to an injunction to prevent the servant setting up an opposition business $(i)$.

And where the assignees in bankruptcy of A., being Clarkson v. about to sell his stock-in-trade, B., at the request of $\Lambda$. Edge. and $\mathrm{A} . \mathrm{s}$ son, C., agreed to purchase the same, and to enter into partnership with C., upon the understanding that $A$. should be engaged as manager, and give a bond not to carry on the same kind of business within a limited distance; and the bond was given, and an undertaking to employ $A$. as manager, but not for any definite time, was signed by $\mathrm{B}$. and $\mathrm{C}$., and handed to A., and he was employed accordingly: an injunction was granted to restrain him from carrying on business contrary to the terms of his bond $(k)$.

But the courts of equity will not grant an injunction Refused in where it is doubtful whether or not the act complained doubtful of amounts to a breach of contract, but will leave the cases; or parties to their action at law $(l$.$) . Neither will they after penalty.$ interfere * where a party, who is entitled to the [*128] benefit of an agreement not to carry on a trade under a

5 De G. \& Sm. 48i, overruling K('mble v. Kean, 6 Sim. 33i, where Shadwell, V. C., had refused an injunction under similar cireumstances. See also De Mattos v. Gibson, 28 L. J., Ch. $498 ; 4$ De G. \& J. 276; Ogden v. Fossick, 32 I. J., Ch. 73 ; Peto v. Brighton, Vekfeld and Tunbridge Wells Railuay Co., $32 \mathrm{~L}$. J., Ch. 67\%. In Monlague v. Flockton, 42 L. J., Ch. 677; L. R., 16 Eq. 189, on a contract to perform at a particular theatre the Court inferred a stipulation not to perform elsewhere.

(i) Bemvell v. Inns, 26 L. J., Ch. 663.

(k) Clarkson v. I:dgc, 33 L. J., Ch. 443. In this case difficnlt mixed questions of law and fact arising, the M. R., having regard to Rolt's Act ( $25 \& 26$ Vict. (c. 42 ), dismissed part of the bill without prejudice to an action at law nuon the bund. But sce Young v. Fernie, 33 I. J., Ch. 19?; Jihnson v. Wyatl, 3:3 L. J., Ch. 394 ; Stwaine v. Great Norlhern Railway Co., 33 I. J, Ch. 399; Durell v. Pritchurd, 35 I. J., Cl. 2:23, on this point; Lady Stanlcy v. Earl of Shrowesbury, 44 L. J., Ch. 389.

(l) Turner v. Evans, 2 De G., M. \& G. 740 ; 2 E. \& B. 512; Clark v. Watkins, ante, p. 123.

$$
8 \text { I.As. \& SER. }
$$


stipulated penalty as liquidated damages, has, in an action at law for breach of the agreement, recovered judgment for the full amount of stipulated penalty. As in that case the court will consider that he has purchased the right to do the act, and to restrain his doing it would be telling him that he should not have the full benefit of his purchase $(\mathrm{m})$.

Maythorn v. Again, an injunction was refused to a master coachPalmer.

\section{Refused at} common law, where penalty sucd for.
Refused in absence of contract.

(iranted to restrain discharged servant from slandering his former employer. builder to restrain a servant (who, on entering his service, had given a bond not to exercise his trade within certain limits on leaving it) from entering the service of another coachbuilder to whom the first master, on being applied to for a character, had merely written " $P$. will be of no use as foreman," and had not given notice of the bond $(n)$.

And a man is not entitled to an injunction at common law who sues for penalties at the same time as he claims an injunction.

Where, therefore, a surgeon hired an assistant, who agreed not to practise within five miles under a penalty of $100 l$, it was held that he was not entitled to an in. junction and the penalty of $100 l$., which he claimed as liquidated damages $(o)$.

And it would seem that in the absence of any.contract, express or implied, the court would not restrain a man by injunction from making use of knowledge acquired whilst the relation of master and servant subsisted, after that relation has terminated $(p)$.

It may be convenient to mention in this place a rather [*129] * curious case $(q)$ in which the Court of Appeal upheld an injunction granted by Pearson, J., against a discharged employe of the plaintiffs to restrain him from uttering to plaintiffs' customers slanderous statements as to the plaintiffs' financial position, and ordering the defendant to withdraw a notice he had given to the post-office to forward to him letters addressed to him at the plaintiffs' place of business.

(m) Sainter v. Ferguson, 1 M. \& G. 286; but see Hardy v. Martin, 1 Cox, 26; Tall v. Ryland, 1 Ch. Cas. 183 ; Barret v. Buagrave, 5 Ves. 555 ; Freneh v. Macale, 2 Dr. \& W. 269 ; supra, p. 1:24, note (c).

(n) Maythorn v. Palmer, 13 Weekly Rep. 37 (1564).

(o) Carnes v. Nisbitt, 30 L. J., Exc. 3 ir; 31 L. J., Exc. 273. See also Bilke v. London, Chatham and Dover Railway Co., $33 \mathrm{~L}$. J., Exc. 208.

(p) Reuter Telegram Co. v. Byron, 43 L. J., Ch. 661. This was a case of principal and agent, but the principlc is the same. See also Esteourt v. Estcourt Hop Co., 44 L. J., Ch. 223.

(q) Hermann Loog (Limited) v. Bean, Court of Appeal, Mar. 12, 1884; Times, Mar. 13th. The case of Hermann Loog v. Bean is reported 53 L. J., Ch. 1128 ; L. R., 26 Ch. Div. 306. 
THE DUTIES OF THE SERVANT TO THE MASTER, AND THE RIGHTS AND REMEDIES OF THE MASTER TO ENFORCE THE PERFORMANCE OF THEM.

1. As between the Mas-
ter a No ServaNt . 130

2. AS BETIWEEY THE MASTER AND THIRD PERsoNs . . . . 155

Dutics of Servant to Master, and Action by Master against Servant for Breach thereof . . . 131

Chastisement of Servant 138

Discharge of Servant what Cause will justify his Discharge . . 139
Of the Action for enticing away a Scrvant . . . 156

of the Action for Harbouring a Servant after Notice . . . . . 160

Of the Action by a Master for the Earnings of a Servant .... . 161 Of the Action for Personal Injuries to a Servant. 170 Of the Action for Seduction 174

\section{As Between Master and Servant.}

It is not proposed in the present work to enter upon a discussion of the moral duties of a servant towards his master; nor to discuss the propriety of employing the criminal law to the enforcement of rights arising out of a civil contract of hiring and service. Neither is it proposed, in this chapter, to consider the cases in which the criminal law prescribes punishment for misconduct on the part of a servant. This part of the subject will be treated of hereafter $(a)$. This chapter will be confined to a consideration of the duties which are civilly binding upon a servant, and the civil remedies open to a master who has sustained injury by the breach of such duties.

\section{*Dutres of Servant to Master, and Action by [*131] Master against Servant for Breacil thereof.}

In the first place, it is clearly the duty of a person Aetion by who has engaged to enter into the service of another, master in any capacity, to fulfil his engagement by entering against serinto such service: and if he fail to do so, without any vant; for not entering his

(a) Post, Chaps. VIII. and IX. service; 
Richards v. good reason, he will be liable to an action for such Hayward. breach of contract $(b)$. As where a man agreed to go out to Australia in the plaintiff's ship, as surgeon,-but afterwards refused to go; the plaintiff recovered damages in an action against him $(c)$. Since, however, a master would rarely deem it worth his while to bring an action against a servant who had engaged to enter into his service for refusing to do so, except, perhaps, in the case of actors and singers $(d)$, and superior servants or skilled workmen, it will be sufficient, upon that subject, to observe that, to enable a master to sustain such an action, it wonld, of course, be necessary for him to prove a legally binding contract of hiring and service $(e)$.

For leaving it too soon.

So, also, it is equally clearly the duty of every person who has entered into the service of another to continue in such service during the whole time that he has contracted for, and if he depart without any good reason Birl $\mathrm{v}$. he will be liable to an action for so doing. Where, kandall. therefore, $\mathbf{B}$. covenanted to serve $\mathbf{A}$. as a journeyman for five years, and to work at the usual hours daily under a penalty of $100 l$., but before the expiration of the five years departed out of the sorvice, A. recovered against him in an action of debt the full sum of $100 \mathrm{l}$. and costs $(f)$. In this case, also, it would be equally necessary to prove a legally binding contract of hiring and service.

Permanent illness an answer.

Temporary illness of a musician or specially skilled servant.
[*132] *But in either of the above cases, if the servant were prevented by the act of God, e. g., permanent illness, from performing his contract, that would be a good defence to an action by the master $(g)$.

Upon similar principles it has been held $(h)$ that a contract by a musician to play at a concert at a fixed time, being a contract dependent on the personal skill of the artist, is subject to an implied condition.that if the musician be without his own default disabled by temporary illness he shall be excused.

(b) Cotes v. Sadler, 2 Keb. 16.

(c) Richards v. Hayward, 2 M. \& G. 574.

(d) Astley v. Weldon, 2 B. \& P. 346 ; Kemble v. Farren, 6 Bing. 141 ; Lumley r. Wagner, 1 De G., M. \& G. 604. tract.

( $f$ ) Bird v. Randall, 3 Burr. $134 \overline{5}$; and see Huttman ₹. Boulnois, 2 C. \& P. 513; Lecs v. Whitcomb, 5 Bing. 34 ; Messiter v. Rose, 13 C. B. $162 ; 22$ L. .., C. P. 78 .

(g) Boast v. Firth, 38 L. J., C. P. 1; I. R., 4 C. P. 1 ; and see post, 154.

(h) Robinson v. Davison, 40 L. J., Exc. 172; L. R., 6 Exc. 269. See this case as to giving notice cf illness. 
And in the case of domestic servants, they have a Demestic right by custom to leave their situations at any time on servants. payment of a calendar month's wages in advance, just as a master may discharge them in a similar manner.

It is conceived, however, that a court of equity would Not enforceneither grant a decree for specific performance of a con- alble in tract of hiring and service, nor attempt to enforce the equity. performance of such a contract by granting an injunction for that purpose (i).

The duties of a servant to his master, during his ser-Duties of vice, must, generally speaking, depend, in a great mea- servant sure, upon the nature of his employment, his master's during business, and the contret he has entered into with his service master $(j)$. There are, however, many duties which are implied by law from the relationship of master and servant, and are binding *upon all servants. [*133] Thus, every servant is bound to obey all the lawful orders of his master $(k)$, and to be honest $(l)$, and diligent $(m)$, in his master's business. "Further, as in this contract, the condition of the master is more advantageous than that of the servant, the servant ought to respect his master according to his station in the world" $(n)$.

Every servant, moreover, is bound to take due and Servant is proper care of his master's property intrusted to him ; liable for and if guilty of gross negligence, whereby his master's gross negliproperty is injured, he will be liable to an action $(o)$; but he is not obliged to preserve his master's property

(i) See Slocker v. Brocklebank, 20 L. J., Ch. 408 ; Lumley v. Wagner, 1 De G., M. \& G. 604; 5 De G. \& S. 485; Johnson v. Shrevisbury and Birmingham Railway Co., 3 De G., M. \& G., $914 ; 22$ L. J., Ch. 221 ; 17 Jurist, 1015; Webster v. Dillon, V. C. Wood, Apr. 18,1857 ; 3 Jur., N. S. 432 ; Gye v. Graziani, V. C. Wood, E. T. 18.99 ; Chinnock v. Suinsbury, 30 L. J., Ch. 409 ; Wolverhampton and Walsall Railway Co. v. L. \& $N$. W. Railway Co., 43 L. J., Ch. 131 ; L. R., 16 Eq. 433. See Donnell v. Bennett, I. R., 2:? Ch. Div. 835 ; 52 L. J., Ch. 414.

(j) See Charteren Bank of India v. Rich, 3:2 I. J., Q. B. 300, whicli was an action against a bank manager for breaches of duty. In that ease the plaintiffs dismissed the defendant from his post as manager of a branch bank in India, and their manager in England wrote letters to an agent in.Indlia, directing him to make incuiries as to the alleged breaches of duty on the part of the defendant and received answers; it was held that the defendant was not entitled to inspect any of the letters or answers. See also as to this point, Wolley v. Pole, 322 L. J., C. P. 263.

(k) Post, p. 140.

(l) Post, p. 143, and post, Ch. VIII.

(m) Post, p. 144.

(n) Puff. de Off. Hom. ae Civ. lib. 2 , cap. 4, s. 2 ; and see per

Lord Kenyon in Limland v. Stephens, 3 Esp. 269.

(o) Countcss of Salop v. Crompton, Cro. Eliz. 777, 784. 
Sacage v. Walthew;

or robbery.

Servant also liable for fraud and misfeasance.

Hussy v. Pacy.

Levoson v. Kirk.

Servant inducing apprentice to leave his master. at all adventures $(p)$. In an old case $(q)$, therefore, where a carrier brought an action against his servant for losing goods, it was held that the action would not lie; Holt, C. J., saying, that "There ought to be a negligence shown in the servant to make him liable to this action, for this amounts only to a bailment of goods, where, if thieves break in and steal them, he shall not answer it." And a servant intrusted with money would not be liable to his master if robbed of it $(r)$.

But if guilty of fraud or misfeasance, he would be liable to an action at the suit of his master. Thus, where $(s)$ the plaintiff covenauted with J. S. not to import certain goods, and the defendant, being the plaintiff's servant, and knowing thereof, imported the said goods, whereby the plaintiff broke his covenant, and was sued by J. S., who recovered damages against him; it was beld that the servant was bound to indemnify his master, although it was not alleged that tho servant [*134] imported the goods with intent to demnify *his master. And where $(t)$ a merchant, on going abroad, trusted his servant to receive in his absence all goods that should arrive for him, and to pay the duties upon them, but the servant landed some without paying the duties, whereby they became forfeited to, and were seized on behalf of, the Queen : it was held that the merchant might maintain an action on the case against the servant for this malfeasance. And so it is said, that if a servant that drives his master's cart, by his negligence suffers the cattle to perish, an action upon the case lies against him (ut). And if a man deliver a horse to his servant to go to market, or a bag of money to carry to London, which he neglects to do, the master may have an action of account or detainer against him $(x)$. And a servant who induces an apprentice to leave his master's service is liable to an action for so doing $(y)$.

A master, however, cannot maintain an action against a servant for soliciting business from his (master's) customers for himself, when his service is at an end,

(p) Bac. Abr. "Master and Servant," (M. 1) ; and see 1 Smith's L. C, 98, 99 ; Nickson v. Brohan, 10 Mod. 109.

(q) Sacage v. Walthew, 11 Mod. 13.5.

(r) Walker v. Guarantec Association, 18 Q. B. 277.

(s) Hussy v. Pacy, 1 Lev. 188.

(t) Lewion v. Kirk, Cro. Jac. 265.

(1) 7 Hen. 4, 14 ; Bac. Abr. "Master and Servant," (M.)

x) 21 Hen. 4, 14; Bac. Abr. "Master and Servant," (M.)

(y) Turner v. Robinson, 5 B. \& Ad. 789 ; and see Grot. lib. 3, cap. $\tau$, sect. vi. 5 . 
and he sets up on his own account $(z)$. But it would Soliciting seem that if a servant should endeavor to induce his his master's master's customers to leave him, and transfer their busi- customers. ness to the servant, whilst the relationship of master and servant subsisted, such conduct would render the servant liable to an action at the suit of the master $(a)$.

A servant is also liable to an action at the suit of his Liability of master, where a third person has brought an action, servant to and recovered damages against the master, for injuries indemify sustained in consequence of the servant's negligence or master from misconduct; and in such action ugainst the servant, the consequences verdict against *the master, in the action brought $[* 13 \check{\text { of }}]$ gence. against him, his evidence as to the quantum of damages, though not as to the fact of the injury $(b)$. Upon this ground, formerly $(c)$, the servant through whose negligence or misconduct an injury was caused was inadmissible as a witness for his master, in an action brought against him for such injury, without a release $(d)$.

Upon this principle the Act for regulating Hackney 6 \& 8 vict. and Stage Carriages in and near London (e), which em- c. 86, s. 28. powers justices to award compensation not exceeding $10 l$. to a person aggrieved by furious driving, \&c., and to order the proprietor of the carriage, the driver or conductor of which has caused the injury to pay the compensation, enables the proprietor to recover the same in a summary way before the justice from the driver or conductor through whose default such sum shall have been paid.

But in one case a very strong opinion was expressed Colburn r. (though it became unnecessary to decide the question), Patmore. that the proprietor of a newspaper, who has been convicted upon a criminal information and fined, for the publication of a libel in the paper inserted, without his knowledge or consent, by the editor, cannot recover, in

(z) Niehols v. Martin, 2 Esp. 732. In Lec v. Ifaley, 39 L. J., Ch. 281, an injunction was granted to restrain the defendant, who lad formerly been the plaintiff's manager, from soliciting custom from the plaintift's customers in a name similar to the plaintift's. See also Mookham v. I'ottage', L. R., 8 Ch. App. 91.

(a) Nichols v. Martin, supra.

(b) Green v. The Now River Company, 4 T. R. 589 ; Pritehard v. Hitelseock, 6 M. \& G. 165.

(c) See now $3 \& 4$ Will. 4 , c. 42 , and Ycomans v. Legh, 2 M. \& W. 419 .

(d) Green v. The New River Company, uli supra; Whitamore v. Watcrhouse, 4 C. \& P. 38:3; and cases collected, 1 Phill. on Evid. 101 ; : Suith's I. C. 52, 2nd edit., note to Bent r. Baker.

(e) $6 \& 7$ Vict. c. 86, s. 28 , repealed as to Watermen by $37 \&$ 38 Vict. c. 96 . 
an action against the editor, the damages he has suztained by such conviction. $(f)$.

To account to his master.

Servant cannot set up jus tertii.

Tassell v. Cooper.

Where a servant or other agent has received money or goods from or on account of his master or principal, he is, generally speaking, accountable to him and him [*136] only for *them $(g)$, as he is considered to be estopped from setting up the title of any other person, or asserting the jus tertii, as it is sometimes expressed, in opposition to the title of his master and principal $(h)$.

Upon this principle where a farm bailiff, having (wrongfully after he was discharged) received payment for some corn of his master's, paid the money into his own private account at his bankers, it was held that it was not competent to the bankers to set up the master's rignt to the money, as they were accountable to their customer (i).

And so in equity, an agent to receive for the use of his principal cannot, by mere notice, be converted into a trustee for a third person $(j)$; and an agent employed by a trustee is acconntable to bim only, and not to the the cèstui que trust $(k)$. Upon similar principals a subagent is accountable to the superior agent, by whom he was employed, and not to the principal $(l)$.

(f) Colburn v. Paimore, 1 Cr. M. \& R. 73 ; see the note at the end of the case. And see also Campbrll v. Campber, $7 \mathrm{Cl}$. \& Fin. 181 ; 1 Smith's L. C. note to Lampleigh v. Brathucit; Shackell $\mathrm{v}$. Rozier, 2 Bing. N. C., 634. The question, however, could hardly arise since the statute $6 \&$ 7 Vict. c. $96, \mathrm{~s} .7$; ville post, Chap. V.

(g) As to the accountability of officers of companies, see "The Companies Clauses Consolidation Act, 1845" ( 8 \& 9 Vict. c. 16), s. 109 et seq.

(h) Dixon v. Hamond, 2 B. \& Ald. 310 ; Roberts v. Ogilby, 9 Price, 269; Gosling v. Birnie, 7 Bing. 339; White v. Bartlett, 9 Bing. 378; Holl v. Griffin, 10 Bing. 246; Sims v. Britain, 4 B \& Ad. 375 ; Kieran v. Sandars, 6 A. \& E. 515 ; Ireland v. Thompson, 4 C. B. 171; see Story on Ag. 217; Smith's Merc. Law, 107. A common carrier, who is bound to receive goods maly set np jus tertii against the person from whom he received them ; Sheridan v. New Quay Company, 28 L. J., C. P. 58. As to how far a servant is bound to account to his master for commission or profit received or made by the servant on execntion of his master's orders, see 29 Beav. 117; Morrison v. Thompson, 43 L. J., Q. B. 215 ; L. R. 9 Q. B. 480 ; Great Western Insuranee Co. (of New York) v. Cunliffe, 43 L. J., Ch. 741 ; Parker v. McKenra, 44 L. J., Ch. 425,$440 ;$ and as to discovery in such cases, G.W. R. Co. v. Tueker, 43 L. J., Ch. 518.

(i) Trassell v. Cooper, 9 C. B. 509.

(j) Nicholson v. Knovles, 5 Madd. 47 ; see Cranshay v. Thornton, 2 Myl. \& Cr. 1; Stuart v. Welch, 4 Myl. \& Cr. 323; Fyler v. Fyler, 3 Beav. 558.

(k) Myler v. Fitzpatrick, 6 Madd. 360. See Sellar v. Grifin, 9 Jur., N. S. 612. See also and consider Hunt v. Maniere, $31 \mathrm{~L}$. J., Ch. 142.

(l) Carturight v. Hately, 1 Ves. 292 ; Pinto v. Santos, 3 Taunt. 
The above-mentioned estoppel, however, does not Except in operate where the title of the master or principal certain cases. accrued fraudulently or tortisusly $(m)$, or under a de. feasible contract, ${ }^{*}$ which has actually been [*]37] defeated $(n)$. And in such cases the servant or agent has been allowed to set up the jus tertii in opposition to the claim of his master or principal $(o)$.

The question as to how far a servant may rely upon his accountability to his master, and the maxim Respondeat superior, in opposition to the claims of third parties, will be treated of in a subsequent chapter $(p)$. The cases, however, in which that question arose, must be carefully distinguished from those in which the action is brought by the master; as a third person, who has a good title to goods, may, in general, recover them from the servant, notwithstanding the bailment $(q)$.

Where a servant is in the habit of receiving money Presumption for the use of his master, and, by the established course of payment of dealing, pays it over to his master from time to time, by servant without any written vouchers passing between them, then the presumption of law is, that all sums so received by the servant are regularly paid over to the master. Therefore, where there has been such a course of dealing, in an action by the master against the servant for money had and received, it is not enough for the master to prove that sums have been received by the servant to his use; but the onus lies upon him to prove by positive evidence that the servant has not duly accounted with him $(r)$.

And a servant or agent receiving money from his Servant not master or principal to pay a third person, and paying liable to reit accordingly, is not liable to repay his master or fund money

447; Sims v. Britain, 4 B. \& Ad. 375; Baron v. Husband, 4 B. \& ing to orders. Ad. 611 ; Ireland v. Thomson, 4 C. 1. 171 ; Cobb v. Becke, 6 Q. B. 930; Robbins v. Fennell, 11 Q. B. 248.

(m) Hardman v. Willcock, 9 Bing. 38:, note; Checseman v. Exall. 6 Exc. 341.

(n) Murray v. Mann, 2 Exe. 538.

(o) Where he can set up the jus terlii, he must, of eourse, show a complete title in such third person ; Croxskey v. Mills, $1 \mathrm{Cr}$. M. $\&$ R. 298. If it has not been asserted, or hits been abandoned, by such third person, the servant or agent cannot rely upon it; Betleley v. Reed, 4 Q. B. 511. In trover the jus tertii may be given in evidenee under a plea "not possessed;" Laake v. Lovcday, 4 M. \& G. 972; Newnham v. Stevenson, 10 C. B. 713; Sheridan v. Newo Quay Company, 28 L. J., C. P. 58.

(p) Post, Chap. VI.

(q) Ogle v. Atkinson, 5 Taunt, 759; see Chesceman v. Exall, 6 Exc. 341; Thorne v. Tilbury, 27 1. J., Exe. $407 ; 3$ H. \& N. 53.

(r) Ecrins v. Birch, 3 Campb. 10 ; see Allee v. Baekhouse, $3 \mathrm{M}$. \& W. 633 . 
principal, although the circumstances be such that the [*138] third person clearly * cannot retain the money. The action should be brought against such third person directly, in the name of the master; or under certain circumstances, in the name of the servant or agent $(s)$.

\section{Chastisement of Servant.}

Master has no power to chastise servant of full are for breacli of duty.
It is conceived, notwithstanding passages which may be found in the books apparently to the contrary $(t)$, that no master $(u)$ would be justified by the law of England even in moderately chastising $(v)$ a hired servant of full age for dereliction of duty; and that where the books speak of a master being justified in moderately chastising his servant or apprentice, they must be taken to apply only to the case of a servant or apprentice under age $(x)$; and the only civil $(y)$ remedies a master has for idleness, disobedience or other dereliction of duty, or breach of contract on the part of a servant are, to bring an action against him (z), or as Puffendorf expressed it $(a)$, "to expel the lazy drone

(*) Risbourg v. Bruckner, 27 L. J., C. P. 90.

(t) 1 Hawkins' P. C. lib. i. cap. 29, sect. 5, cap. 60, sect. 23 ; 3 Salk. 47; Burn's Justice, "Servant," sect. 9; Bac. Abr. "Master and Servant," (X.); Hale's Hist. P. C. 454. The cases of Villenage, 9 Rep. $76 a$; Anon. 2 Mod. 167, would not apply to a hired servant. See Hob. 99 ; F. N. B. 162 , P.; and Puft. de Off' Hom. ac Civ. lib. 2 , cap. 4, sec. 2 ; and II. Barbeyrac's Note to Puff. Law of Nature and Nations, b. 6, c. 3, s. 4, note 1 ; and Grot. lib. 2 , cap. 26 , s. 3 .

(u) The master of a ship, however, has, by law, authority, in case of disobedience or disorderly conduet, to correct the mariners in a reasonable manner. See Abbott on Shipping, Part II., Chap. IV. s. 4; Watson v. Christie, 2 B. \& P. 214; Introny v. Montrie, 6 C. \& P. 471 ; R. v. Leggett, 8 C. \& P. 191 ; Edluard v. Trevellick, 4 E. \& B. 59: as to Passengers, Noden v. Johnsm, 16 Q. B. 218; Steward suspected of felony, Broughton v. Jacksom, 18 Q. B. 378; 21 L. J., Q. B 26.5. The case of mariners on board ship seems to be exceptional, but it is not confined to cases where the vessel is at sea. Lamb v. Burnett, 1 Cr. \& J. 291.

(c) See Latter v. Brathlell, 50 L. J., C. L. 166, 442, in which a housemaid, who was alleged to be pregnant, brought an action of assanlt against her master and mistress for eausing her to be examined by a doctor, but failed from not proving non-consent. Her action against the doctor also failed.

(x) 1 Bl. Comm. 428; 2 Kent's Comm. 211 ; F. N. B. 16, L. 2, where it is said that battery of a servant is a good cause of departure. In pleading a justification of moderate correction of an apprentice, it is not usual to state that he was under age; $3 \mathrm{Cl}$, P1. 3:1.

(y) See post, Chaps. VIII. and IX., as to criminal proceedings

(z) F. N. B. 167 ; Dalt. Just. e. 52.

(a) I'uff. on the Law of Nature and Nations, b. 6, c. 3, s. 4. 
*from his family, and leave him to his own beg- [*139] garly condition" $(b)$. The circumstances which justify the discharge of a servant will also sometimes justify the non-payment of his wages.

\section{Discharge of Servant.}

It is difficult to lay down any general rule as to what causes will justify the discharge of a servant $(c)$, which what causes shall comprise and be applicable to all cases; since the diseharge whether or not a servant in any particular case was of a servant. rightfully discharged, must of course often depend upon the nature of the services which he was engaged to perform, and the terms of his engagement $(d)$. It would seem, however, that the cause of discharge must be somehow connected with the duties of the service, e. $g$, a clerk could not be discharged because he could not drive; - he might fairly say non hoe in foedera veni. In fact the question in what case and upon what grounds an employer has the right to discharge a person employed by him has only been considered in modern times, and is not fuily settled $(e)$. It is conceived, however, that, according to the decisions upon the subject, the discharge of a servant may be justified for the following causes :

I. Wilful disobedience of any lawful order of his master.

*II. Gross moral misconduct, whether pecu- [*140] niary or otherwise.

III. Habitual negligence in business, or conduct calculated seriously to injure his master's business.

(b) In the present day no one would attempt to justify beating a servant for dereliction of duty, but Maeanlay, Hist. Eng. vol. i. p. 424, says that in the 17th century masters well born and bred were in the habit of beating their servants.

(c) Apprentices, with whom a premium is given and who are bound by indenture, cannot (in the absence of an express agreement to that effect; Weswick v. Theodor, L. R., 10 (2. B. 224) be discharged for misconduet; the only remedy of the master (where correction fails) being by action on the covenants in the indenture. Winstone v. Linn, 1 B. \& C. 460 ; Wise v. Wilson, 1 Carr. \& K. 662; Phillips v. C'lift, 4 H. \& N. 168; 28 L. J., Exch. 15:3. See Rayment v. Minton, 4 H. \& C. 371 . Jut it would seem to be otherwise where the apprentice is entitled to a salary ; see Mercer v. Whall, 5 Q. 13. 447. Courts of Equity will not interfere; Webb v. England, 30 L. J., Ch. 222.

(d) See Horton v. M'Murtry, 29 L. J., Exch. 200.

(e) Per Lord Wensleydale in Lomat v. Arding, 10 Exe. 736. As to the right of a master to open letters addressed to a discharged manager, see Stapleton v. Foreign Vincyard Association, 12 Weekly Rep. 976. 
IV. Incompetence, or permanent disability from illness.

Servant refusing to quit may be turned out by force.
Disobedience

Spain v. Arnott.

Farm servant refusing to work at dinner time.

Renno v. Bennelt.

Refusal to work ship except to certain port.

Turner $\mathrm{v}$. Mason.

Housemaid persisting in leaving the house without permission.
It is proposed to treat of each of these separately. But it may be first mentioned that if a servant who is rightfully discharged refuse to quit his master's premises, his master would be perfectly justified in turning him out by force $(f)$. But in all such cases it would, for obvious reasons, be more prudent to call in a constable or police officer for that purpose, or at least to procure the attendance of some respectable independent witness.

I. Wilful disobedience of any lawful order of his master $(g)$.

Where $(h)$ a yearly servant to a farmer, who usually breakfasted at five a. m., and dined at two, one day refused to go with the horses to the marsh, which was a mile off, before dinner, dinner being then ready, saying that he had done his due, and would not go until he had had his dinner, whereupon his master told him to go about his business, and he went accordingly without offering to obey his master's orders; Lord Ellenborough held that the master was justified in dismissing him.

So where $(i)$ the plaintiff, who had agreed with the defendant (under $5 \& 6$ Will. 4 , c. 19 , ss. 2,3 ) to serve as carpenter's mate of a vessel during a South Sea voyage, during the voyage mutinously refused to work the ship, except to an English port, whereupon he was put [*141] on shore *at Java, and discharged, the defendant was held to be justified in discharging him.

Again, it has been held $(k)$, that a master was justified in dismissing a housemaid, who persisted in leaving his house contrary to his orders, although she went to visit a sick and dying mother; Lord Wensleydale saying, "It was laid down by Lord Ellenborough, in Spain v. Arnott (l), and by me in Callo v. Brouncker

(f) See Donaldson v. Williams, 1 Cr. \& M. 345; Mackay v. Forl, 29 L. J., Ex. 404.

(g) As to the proper mode of pleading a discharge for disobedience of lawful orders, see, in addition to the cases mentioned in the text, Powell v. Bradbury, 7 C. B. 201; Lush v. Russell, 5 Exe. 203 ; 1 L. M. \& P. 369 ; Horton v. M'Murtry, 29 L. J., Exc. 200.

(h) Spain v. Arnolt, 2 Stark, 256 ; Callo v. Brouncker, 4 C. \& P. 518 (see Fischer v. Aide, 3 M. \& W. 486); Amor v. Fcaron, 9 A. \& E. 543.

(i) Renno v. Bennett, 3 Q. B. 768.

(k) Turner v. Mason, 14 M. \& W. 112; 2 D. \& L. 898.

(l) 2 Stark. 256. See this case, supra, p. 140. 
$(m)$, and confirmed by the Court of Qceen's Bench, in Amor v. Fearon $(n)$, that the wilful disobedience of any lawful order of the master is a good cause of discharge. Here the plea discloses a perfectly lawful order, namely, that the defendant should not absent herself from the service during a night, and the plaintiff's disobedience thereto. Then the question is, whether the replication discloses sufficient ground of excuse for such disobedience. Prima facie the master is to regulate the times when his servant is to go out from, and return, to his house. Even if the replication showed that he had notice of the cause of her request to absent herself, I do not think it would be sufficient to justify her in disobedience to bis order; there is not any imperative obligation on a daughter, to visit her mother under such circumstances, although it may be unkind and uncharitable not to permit her. But the replication states nothing to show that the defendant had any notice or knowledge of the mother's illness."

And similar principles were laid down in a case (o) Lilley $\mathrm{v}$. in which the plaintiff was engaged as a waggoner to Eluin. the defendant, but during the harvest worked in the Farm servant field generally. The practice was, during harvest, to refusing to work till eight o'clock in the evening. The plaintiff work during refused to work till that hour, not as being an unrea- out beer. sonable hour, or as not being within the terms of his contract, but because *strong beer of good [*142] quality was not allowed to him, according to a custom which he alleged to exist, but could not prove, the beer supplied being, as he contended, very bad small beer, not so good as water; whereupon the defendant refused any longer to employ the plaintiff, and took him before a magistrate, who discharged him, and he brought bis action against the defendant. But it was held that the defendant had a right to discharge him, and must be taken to have exercised that right by ordering him not to return, taking him before a magistrate, and acquiescing in the magistrates order of discharge.

So, again, in the case of a messnuan to a regiment. Churchward The plaintiff was appointed messman by an agreement $v$. Chambers. between himself and the mess committee, of which the Messman of defendant was the president, and as such the defendant a regiment signed the agreement. The committee was changed, refising to One day, in consequence of an altercation between dinner.

(m) 4 C. \& P. 518.

n) 9 A. \& E. 548. See this case, post, p. 146.

(o) Lilley v. Elwin, 11 Q. B. 742, 756. 
himself and another servant, the plaintiff declared that he would have nothing more to do with the mess and refused to send up dinner. After some minutes' delay the colonel of the regiment went down stairs, and asked the plaintiff if he meant to send up dinner; the plaintiff said he would not, and used language not respectful, upon which the colonel threatened to send for a file of solders and put him under arrest. The plaintiff then served dinner, after half an hour's delay. Next day the mess committee held a meeting and dismissed the plaintiff. He tendered an apology, which they refused to accept. He then brought his action for wrongful dismissal. Both Cockburn, C. J., and the jury thought there was just ground of dismissal $(p)$.

Disobedience However, where the plea to an action for wrongful causing loss. dismissal sets up as in excuse disobedience of orders causing loss, it is not sufficient to show disobedience which did not occasion a loss $(q)$.

Obstinate refusal.

And a mere obstinate refusal to work will not, of [*143] itself, *justify the dismissa] of a servant, as it might be an obstinate refusal to do an unlawful act (e.g., to work at trade on Sunday) $(r)$.

Moral misconduct.

Robbery.

Embezzlement.

Baillie v.

Kell.

Accountant falsifying accounts.
II. Gross moral misconduct, whether pecuniary or otherwise $(s)$.

Thus, if a servant robs his master, he may, although a month's notice is required, dismiss him without any notice, and need not pay him any wages $(t)$.

And if a servant habitually embezzle his master's property, the amount embezzled is wholly immaterial ; and although the arrears of wages sought to be recovered may exceed the amount embezzled, the servant is not entitled to anything $(u)$.

And where $(x)$ the accountant to a company received money for which he did not account, and falsified the accounts furnished by him, his employers were held justified in dismissing him, although they did not assign that as the cause of his dismissal.

(p) Churchward v. Chambers, 2 Fost. \& F. 229.

(q) Cussons v. Skinner, 11 M. \& W. 161.

(r) Juequot v. Bourra, 7 Dowl. 348.

(s) Callo v. Brouncker, 4 C. \& P. 518. See Burgess v. Beaumont, 7 M. \& G. 962, where a plea, imputing general immorality and dishonesty to a governess, was held too vague and uncertain, and a demurrer on that ground was allowed.

(t) Per Park, J., in Cunningham v. Fonblanque, 6 C. \& P. 49.

(u) Brown v. Croft, 6 C. \& P. 16, note; and see Spotswood v. Barrow, 5 Exe. 110.

(x) Baille v. Kell, 4 Bing. N C. 638.

(188) 
Upon similar principals it has been beld, that a clerk Athin v. and traveller, at $80 l$. a year, who lived and boarded in .tcton. his master's house, was rightfully dismissed for assault- Clerk ating his employer's maid-servant, with intent to ravish tempting to her $(y)$. And it is said that a maid servant being with servish maid child $(z)$, or a man-servaut being the father of a bastard child $(a)$, is a good cause of discharge.

*And it would probably be held, that a street. [*141] Street-keeper keeper or other officer reciving gratuities for conniving receiving at the breach of regulations which it was his duty to gratuities for enforce, might properly be dismissed for so doing $(b)$. breacli of

Drankenness would also be a justifiable cause of dis- rules. charge, if pleaded (c).

It would seem, however, to be no ground for discharg. ing a servant that, after the contract of hiring was Subsequent entered into, the master discovered that the servant had discovery of acted dishonestly or fraudulently to a former master, previous unless indeed the servant had by fraud, mis-statement place. or concealment of the facts, induced the second master to hire him $(d)$. In such a case the second master's remedy would be to dismiss him without notice.

III. Habitual neglience in business, or conduct calculated seriously to injure his master's business.

Upon this ground, in an action for a month's wages Negligence. by a servant who was dismissed without warning, on the ground that he was negligent in his conduct, frequently absent when his master wanted him, and often slept out at nights, Lord Kenyon beld that the plaintiff was not entitled to recover on account of his mis. conduct. And, in another case (e), Lord Wensleydale said, "That for habitual neglect the defendant was at liberty to part with the plaintiff." And in another $(f)$, Park, J., observed, "If a servant is negligent in his business, and injures his master, I am not prepared to

(y) Atkin r. Acton, 4 C. \& P. 208.

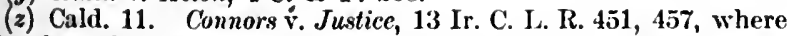
Monahan, C. J., said,- "Can any one doubt that chastity is an essential requisite in a female domestic servant? Can any one doubt that the master or mistress of a family would be justified in dismissing without the usual month's notice a female domestic servant for unchaste conduct?"

(a) R. v. Welford, Cald. 57.

(b) See Bogg v. Pearse, 10 C. B. 534 ; 2 L. M. \& P 21.

c) Speck v. Phillips, 5 M. \& W. 279 ; Wise v. Wilson, 1 C. \& K. 662, post, p. 146.

(d) See Andrewos v. Garstin, 31 L. J., C. P. 15.

(c) R.binson v. Hindman, 3 Esp. 235.

(f) Callo v. Biouncker, 4 C. \& P. 518. 
say that the master may not dismiss him, as if he were kept it might be very injurious, as he might do the business very carlessly when he knew that he was not to be kept longer."

Turner v. Upon these principles, the foremen to silk manufacRobinson. turers was held to be rightly discharged (and moreAdvising ap- [*145] over, liable to *an action), for advising and asprentice to quit.

Rielgway $\mathrm{s}$. The Hungerford Market Company. sisting an apprentice to quit the service and go to America $(g)$ : and the clerk to a company was held to be rightly dismissed for entering in a minute book a protest, in his own hand writing, agrainst a resolution of the directors, calling a meeting to appoint his successor, as such an act was inconsistent with his service $(h)$.

Lacy $\mathrm{v}$. Oxbaldisem.

Acting manager of theatre guilty of conduct likely to injure it.

So in an action by the acting manager of Coventgarden theatre, for wrongful dismissal from his situation, \&c. $(i)$; to which, amongst other pleas, the defendant pleaded that the plaintiff's conduct was calculated to prejudice the interests of the theatre: Vaughan, J., said, "It is a question of fact, whether the plaintiff, was so conducting hirnself as that it would have been injurious to the interests of the theatre to have kept him $(k)$. If he was, I should have no difficulty in saying that it would be good ground of dismissal."

Reed v.

Dunsmore.

Masterbuilder dismissing carpenter for poaching on employer's premises.

Again, where ( $l$ ) the defendant, a master-builder, dismissed the plaintiff, a journeyman carpenter, for poaching on the premises of $\mathrm{Mr}$. T., a gentleman for whom the defendant was working, and at whose premises the plaintiff was engaged working; Coleridge, J., in leaving the question to the jury whether or no this was just ground of dismissal, said, "In dealing with this question, I think that you ought to consider what Mr. T. had a right to expect from the defendant and his men. If a gentleman engages a tradesman who has several workmen under him, he has a right to expect that the workmen will conduct themselves well. If is said that they did no damage; but I do not think that it entirely depends on that, because it might have been, that Mr. T. might have said, 'I will not allow the workmen to go into my garden,' and if they had done so, they [*146] would have done no actual damage; but, *still,

(g) Turner v. Robinson, 5 B. \& Ad. 789.

(h) Ridgway v. The Hungerford Market Co., 3 A. \& E. 1 i1.

(i) Lacy v. Osbaldiston, 8 C. \& P. 80.

(k) And see The East Anglian Railuay Co. ․ Lythgoe, 2 L. MI. \& P. 2:21.

(l) Read v. Dunsmore, 9 C. \& P. 538. 
if the defendant employed persons who acted in that way, he would soon find that he was injured in his business, and would lose his custom, because gentlemen would not engage him."

So a wine merchant $(m)$ was held justified in dis- Amor v. missing a clerk, at a yearly salary, who also, at certain Fearon. periods, received a portion of the profits (but this, as Clerk claimthe master alleged, was a mere gratuity), for claiming ing to be to be a partner, as he thereby disclaimed being a servant.

And it was said by Lord Abinger $(n)$, that the Cussons v. accepting of an undrawn bill of exchange, in blank, by Skinner. the manager of a cotton company was wrong, and Manager of would have been a very justifiable cause of discharging company him the next day after it was discovered $(o)$.

But it has been held $(p)$, that a schoolmaster was not justified in discharging the plaintiff, a teacher of bill in blank. French and drawing, for not returning to the school French for two days after the vacation: as it did not appear master not that the plaintiff had been guilty of any immorality, returning for nor that the defendant was obliged to hire another ner that the der vacar person, or that the plaintiff's department was not, in tion.

fact, adequately filled, nor that the instructions in French or drawing were impeded, or that the business of the school was suspended for a single hour.

And where $(q)$ a surgeon by a written agreement, wisc $\mathrm{v}$. not under seal, agreed with the plaintiff, in considera- Wilson. tion of a *premium of 50l. to take her son, a [*147] Surgeon's young man seventeen years old, as pupil and assistant assistant for three years, to assist him "in his studies, to allow getting him to attend lectures, and to provide him with board and lodging, but dismissed him in consequence of his drunk and making shopboy mix

(m) Amor v. Fearon, 9 A. \& E. 548. See also Grecnham v. Gray, anle, p. 63; and Mereer v. Whall, 5 Q. B. 447, where, to an aetion of covenant by an articled clerk against a solicitor for dismissing him, the defendant plealed that the plaintiff conspired to induce the defendant's clients to leave him, and diselosed his professional seerets. See also in Hobson v. Covley, 27 L. J., Exe. '205, a plea that plaintiff, whilst in defendant's service, entered into negotiations for carrying on the same business as defendant without his consent.

(ii) In Cussons v. Skinner, 11 M. \& W. 170. The decision in that ease, however, did not turn on this point.

(o) And see The East Anglian Railway Co. v. Lythgne, 2 I. M. \& P. 221, where a cleth to a ratilway company was dismissed for disclosing aceounts of the railway to another company ; bnt, under the eireumstances of the case, the County Court judge thought him entitled to his salary up to his discharge.

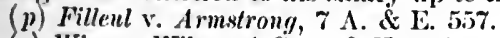

(q) Wise v. Wilson, 1 Carr. \& K. 662; see Phillips v. Clift, 4 II. $\&$ N. 168; 28 L. J., Exe. 153 .

9 Mas. \& Ser. 
coming home drunk about five times, and on some occasions, when he came home late, desiring the shopboy to make up the medicines, Lord Denman, in summing up to the jury, "said, "There is a great distinction between a contract of apprenticeship and a contract with a servant. A person has a right to dismiss a servant for misconduct, but has no right to turn away an apprentice because he misbehaves. This is a mixed case, something between that of apprenticeship and service. The plaintiff's son goes to the defendant to render assistance to him in his business, although he is also to pursue his studies; and as a justification of his dismissal, the defendant has pleaded not that the plaintiff's son did not perform all things on his part to be performed, but that he did things injurious to the defendant's practice, and so misconducted himself as to be dangerous to the defendant's practice as a sur. geon. It is proved beyond all doubt that, on some occasions, the plaintiff's son came to the defendant's house intoxicated, but I think that alone would not justify the defendant in dismissing bim. It is also proved that, on several occasions, in consequence of the plaintiff's son coming home late, he could not compound the medicines, and employed the shop boy to do it. Now, I think, this affords matter for serious consideration, and if you think that from this conduct of the plaintiff's son real danger was occasioned to his master's business, you ought to find your verdict for the defendant, as the defendant was then, in my opinion, justified in dismissing him." But the plaintiff had a verdict.

Smith v. And where $(r)$ the plaintiff was engaged as clerk to Thompson. the defendant, under a contract of hiring for two years, Clerk to shipping agent applying money given for business purposes to his own salary. [*148] to *conduct the business of a shipping agent at Southampton, and in the course of his employ it was his dnty to pay freight, dock dues, \&c., to meet which the defendant remitted money. On one occasion the plaintiff wrote to the defendant for $140 l$, inclosing an account of the purposes for which it was required, one of them being the payment of $30 \mathrm{l}$. salary due to him. self. Ten days afterwards the defendant sent the plaintiff 100l. in a letter, directing him to apply the money for "business purposes," and he applied $30 t$. in payment of his own salary, whereupon the defendant discharged him, and the plaintiff brought his action for wrongful discharge. At the trial the judge left it to

(r) Smith v. Thompson, 8 C. B. 44. 
the jury to say whether the plaintiff had been guilty of any wrongful and improper appropriation of the money, or of disobedience of orders. And it was held by. the Court of Common Pleas to have been properly so left, and that the judge was not bound to tell the jury that it was not necessary, to justify the dismissal of the plaintiff, that he should have been guilty of any moral turpitude.

And where (s) the plaintiff agreed with the defend-Lomax $\mathrm{v}$. ant to serve him for three years as manager of certain Arding. iron-works, at a salary of $4 l$. per week, upon the terms. Manager of that the plaintiff would during that time use his best ironworks endeavours to promote the interest of the defendant, not trying and attend to and carry out all reasonable requests to promote made to him by the defendant, a plea that the plaintiff interests. did not, while he was in the defendant's employ under the agreement, use his best endeavours to promote the interest of the defendant according to the agreement, wherefore the defendant dismissed the plaintiff, and rofused to pay him any salary after such dismissal, was beld a good plea to an action for wrongful dismissal. In that case, Pollock, C. B., said, "Suppose the plaintiff had conducted himself on all occasions in a negligent and lazy spirit, there may be insuperable difficulty in a legal definition of the plaintiff's conduct, and yet the defendant would be justified in *discharg. [*149] ing him from his service. It would be a question of evidence."

Where, by an agreement in writing, A. was appointed Bray v. surveyor or agent of $\mathrm{B}$. for two years and a half, at a Chandler. salary of $200 l$. a year, and a commission on every house Agent forlet by him for B., and the agreement expressly provided. bidden to that under no pretence whatsoever should A. be con- receive sidered B.'s agent to receive any money on his account; ceiving it. it was held that $\mathbf{A}$. having received deposit money from persons to whom he had let houses for B., was a good defence to an action for dismissing $A$. before the end of the term $(t)$.

The plaintiff, who was employed by the defendant to Iforton v. serve him in the business of a certain manufacture, and II'Burtry. engaged to "bring all his knowledge to bear upon it," without the knowledge of his master entered into a contract with a mercliant (not dealt with by his master) for the supply of certain articles used in tho mannfacture, the result of which was a claim to a consider-

(4) Lomax v. Arding, 10 Exc. 734.

(t) Bray v. Chandler, 18 C. B. 718. 
able amount by the merchant against the master, who thereupon dismissed the plaintiff ; it was held that the dismissal was justifiable $(u)$.

Cross action when neces-

Gould v.

Webb.

Newspaper correspondent omitting to send news letter, and overdrawing for salary, 10 ground of discharge.

If $\operatorname{good}$ ground of discharge exist, it is sufficient to justify the discharge; although not known to exist and dif ferent ground alleged.
If, however, the servant's misconduct be not such :s to go to the whole consideration of the contract on the part of the master, he will not be justified in dismissing the servant, but must, if necessary, resort to a cross action against the servant; or set up a counter-claim in answer to an action for wrongful dismissal.

Where, therefore $(x)$, to an action for wrongfully discharging the plaintiff from the defendant's employ as European correspondent of a newspaper, at a salary, the defendant pleaded, firstly, that the engagement was made upon the terms and condition that the plaintiff should, by every steamer from Liverpool to New York, forward a letter containing European news, but plain. tiff wrongfully neglected to forward any letter contain[*150] ing such news by *several steamers that sailed from Liverpool to New York, wherefore defendant discharged him; and also, secondly, that defendant employed plaintiff upon tue terms and condition that plaintiff might draw bills upon defendant for the amount of his salary as it should become due, but not for any sum not due; but plaintiff wrongfully drew on defendant and negotiated bills for sums not due, which were presented to defendant and dishonoured to the damage of defendant's credit, wherefore defendant dis charged plaintiff : both pleas were held bad on demurrer, as not showing a default by plaintiff going to the whole consideration of defendant's contract. The breach of the stipulations on the part of the plaintiff did not amount to such misconduct as to authorize the defendant to discharge him. It might have been that there was no news to send; and the second plea wonld be satisfied by prouf that the plaintiff had drawn a bill for half-a-crown too much.

Where an act of wilful disobedience of a lawful order, or other misconduct on the part of a servant which would justify his master in discharging him, exists at the time of discharge, although the master does not insist on that as the precise ground of discharge, or even if he does not know it, or allege some other ground of discharge; yet the master may afterwards, by showing that the fact existed, justify such discharge

(u) Horton v. M'Murtry, 29 L. J., Exc. 260.

(x) Gould v. Webb, 4 E. \& B. 933. 
on that ground $(y)$. It would seem from one case (z) that if the master, at the time he discharged the servant, did not know of any act of misconduct on the part of the servant which would justify his discharge, although such fact existed, the mere existence of the fact would not justify the discharge. But in a subsequent case, in which a traveller and salesman brought Barrow. an action for wrongful dismissal, and the defendant pleaded in justification that the plaintiff had received money from the defendant's customers and embezzled it, *wherefore he discharged him ; to which the [*151] plaintiff replied de injuria, and it appeared in evidence that the defendant did not know of the embezzlement when he discharged the plaintiff, it was held that on these pleadings the judge who tried the case was wrong in leaving it to the jury to say whether the defendant discharged the plaintiff for that cause, as the defendant's motive was not in issue $(a)$.

And in another case (b), Alderson, B., thus directed a Willetts v. jury: "If an employer discharge his servant, and at Green. the time of the discharge a good cause of discharge in fact exists, the employer is justified in discharging the servant; although at the time of the discharge the employer did not know of the existence of that cause. This point has been much discussed in the House of Lords and elsewhere, but what I have stated is the result." The truth is a man's rights depend on the facts, not on what he thinks or says are the facts. (c).

IV. Incompetence, or permanent disability from illness.

Where a servant of any sort is engaged on account Incompeof his skill or peculiar ability to perform certain duties, tence good and turns out to be perfectly unskilful and incompe- ground of tent to discharge the duties for which he was hired, the discharge. master will be justified in rescinding the contract and discharging the servant. Thus, where in answer to an Harmer v. advertisement in a newspaper for scene-painters, the Cornelius. plaintiff applied to the defendant, a correspondence ensued, and the defendant ultimately hired the plaintiff

(y) Baillie v. Kell, 4 Bing. N. C. 638, ante, p. 143 ; Rillgway v. Hungerford Market Co., 3 A. \& E. 171; Cussons v. Skinner, 11 M. \& W. 161 ; Mereer v. Whall, 5 Q. B. 447.

(z) Cussons v. Shinner, ubi supra.

(a) Spotiwwood v. Barrow, 5 Exc. 110. See also Cowan v. Mitbourn, 36 L. J., Exc. 124, especially the judgment of Bramwell, $B$.

(b) Willets v. Green, 3 Carr. \& K. 59.

(e) See Trent v. Hunt, 9 Exc. 14 ; Litt. s. 695. 
Harmer v. in that capacity, but he turned out to be quite incomCornelius. petent, and was discharged ; it was held that such. incompetence was a valid reason for discharging him, and in an action brought as for a wrongful discharge, the defendant succeeded $(d)$. In giving judgment for the [*152] defendant in that case, Willes, J., said : *'Where a skilled labourer, artisan or artist is employed, there is on bis part an implied warranty that he is of skill reasonably competent to the task he undertakes'spondes peritiam artis.' Thus, if an apothecary, a watchmaker, an attorney, be employed for reward, they each impliedly undertake to possess and exercise reasonable skill in their several arts. The public profession of an art is a representation and un. dertaking to all the world that the professor possesses the requisite ability and skill $(e)$. An express promise or an express representation in the particular case is not necessary. It may be, that if there is no general and no particular representation of ability and skill the workman undertakes no responsibility. If a gentleman, for example, should employ a man that is known never to have done anything but sweep a crossing to clean or mend his watch, the employer probably would be held to have incurred all risk himself. But in the case under consideration the correspondence shows, in addition to the implied representation, an express and particular representation by the plaintiff that he did possess the requisite skill. The next question is this: supposing that when the skill and competency of the party employed are tested by the employment, he is found to be utterly incompetent, is the employer bound, nevertheless, to go on employing him to the end of the term for which he is engaged, notwithstanding his incompeteney? This is a question upon which we have been furnished by the bar with no authority, probably because such labor being seldom retained for a long term certain, the question has not often arisen. But it seems very unreasonable that an employer should be compelled to go on employing a man who, having represented himself competent, turns out to be incompetent. An engineer is retained by a railway company to drive an express train for a year, and is found to be utterly unskilful or incompetent to drive or regulate the locomotive, are the railway com. [*153] pany still bound, under pain *of an action, to

(d) Harmer v. Cornelius, 28 L. J., C. P. 85 ; 5 C. B., N. S. 236.

(e) See Jenkins v. Betham, 15 C. B. 188. 
entrust the lives of thousands to his dangerous and Harmer $\mathrm{v}$. demonstrated incapacity? A clerk is retained for a Cornelius. year to keep a merchant's books, and it turns out that he is ignorant not only of bookkeeping, but of arithmetic, is the merchant bound to continue him in his employment? Misconduct in a servant is, according to every day's experience, a justification of a discharge. The failure to afford the requisite skill which had been expressly or impliedly promised, is a breach of legal duty, and therefore misconduct. The rule of the civil law-'Imperitia culpce adnumeratur' applies. We may add that a precedent of a plea grounded on the implied condition of competency, is to be found in the late Mr. Joseph Chitty's book on Pleadings, edited by the late Mr. Pearson, p. 363. So in Spain v. Arnott $(f)$, Lord Ellenborough, speaking of a servant who had refused to perform his duty, says, "The master is not bound to keep him on as a burthensome and useless servant to the end of the year ;' and it appears to us that there is no material difference between a servant who will not, and a servant who cannot, perform the duty for which he was hired."

But where $(g)$ the plaintiff, having entered into an Cuckson $\mathbf{v}$. agreement that he should serve the defendant and W. Stones. ten years in the capacity $f$ a brewer, and teach them Temporary $t$ brew; that the defendants and $W$. were tc pay the illness no plaintiff $20 l$. on the execution of the agreement, to find wagension of him a house, and to supply him with coals for the ten a permanent years, and to pay him the weekly sum of $2 l$. 10s. during contract not that term. He served the defendent and W. till W.'s rescinded. death, and afterwards worked for defendant up to Christmas, 1857, when he was taken ill. He was confinod to his bed till March, and was unable to attend to his work till 19th July, 1858, when he was again employed about the brewery, and paid as before. During his illness he was from time to time consulted by the defendant as to the mode of brewing, but was unable *to do any actual work for defendent; and it was [*154] admitted that the contract had not been rescinded. It was held that the plaintiff was entitled to recover under it the wages for the time during which he was disabled by sickness from working; although a plea to the claim for wages that the plaintiff was not during the time in question ready and willing or able to render, and did not in fact render, any service, was held on demurrer

(f) 2 Stark, 256 .

(g) Cuckson v. Stones, 28 L. J., Q. B. 25; 1 Ell. \& Ell. 248. 
to be a good plea in point of law, in the sense that the plaintiff voluntarily and wilfully refused or omitted to

Contract might be rescinded if servant permanently disabled by illness.
Remedies of master by action against third persons for depriving him of services of servant. serve. And in giving judgment, Lord Campbell said, "We concur in the observations of Willes, J., in Harmer v. Cornelius, and if the plaintiff from unskilfulness had been wholly incompetent to brew, or by the visitation of God had become, from paralysis or any other bodily illness, permanently incompetent to act (h) in the capacity of brewer for the defendants, we think that the defendants might have determined the contract. He could not be considered incompetent by illness of a temporary nature. But if he had been struck with disease so that he conld never be expected to return to his work, we think the defendants might have dismissed him and employed another brewer in his stead. Instead of being dismissed he returned to the service of the defendants when his health was restored, and the defendants employed him, and paid him as before. At the trial the defendants' counsel admitted that the contract was not rescinded. The contract being in force, we think that here there was no suspension of the weekly payments by reason of the plaintiff's illness and inability to work. It is allowed that under this contract there could be no deduction from the weekly sum in respect of his having been disabled by illness from working for one day of the week ; and while the contract remained in force we see no difference between his being so disabled for a day, or a week, or a month."

\section{[*155]*2. AS BETWEEN THE MASTER AND THIRD PERSONS.}

A master may maintain an action against any person who deprives him of the services of his servant, either by enticing him away from his master $(i)$, or by harbouring and detaining him after having been apprised of the former contract $(k)$; or by beating, confining or disabling him; or by seducing a female servant (l).

(h) As to this, see Boast v. Frith, 38 L. J., C. P. 1 ; L. R., 4 C. P. 1 ; Poussard v. Spiers, 45 L. J., C. L. 621. See also Bettini v. Gye, 45 L. J., C. L. 209 ; K. v. Raschen, 38 L. T., N. S. 38.

(i) F. N. B. 91, I., 167 B.; Evans v. Walton, post, p. 158 . In what cases a master is entitled to maintain litigation by his servant, without exposing himself to a charge of maintenance, see Elborough v. Ayres, I. R., 10 Eq. 367.

(k) F. N. B. 168, Winch, 51.

(l) Com. Dig. Trespass, B. 5; Pleader, 3 M. 11. 
The master may also, where wages have been earned by a servant enticed away or harboured by another person, waive his right of action for such tortious act, and sue for the earnings of his servant. In all these cases the master's right of action arises out of the property which he has acquired, by the contract of hiring, in the labour of his servant; and in all of them, except the action for Loss of serhis servant's earnings, the gist of the action is the loss vice gist of of service, without an allegation of which no action can such action; be sustained by a master, however great the injury to his servant $(m)$. Whilst, therefore, on the one hand, a mere attempt to deprive a master of the services of his servant without any damage following upon it would not give the master a right of action $(n)$, so, on the other, it has been held that a master, who has recovered in an action against the servant a stipulated penalty for leaving his service, cannot maintain an action against the person who induced him to leave $(o)$. Moreover, and must be the loss of service must be the natural and necessary the necessary consequence of the defendant's act, otherwise the master consequence cannot maintain any *action. Where, therefore, [*156] of defendthe director of certain oratorios had, at considerable expense, engaged one Mara, who, in consequence of a libel published by the defendant, refused to sing, being afraid of being hissed; Lord Kenyon held that the plaintiff could not maintain an action against the defendant, as the injury complained of was too remote, and impossible to be connected with the cause assigned for it $(p)$.

\section{Of the Action for Enticing away a Servant.}

An indictment will not lie for enticing an apprentice Indictment or Eervant away from his master, it being only a private will not lie; injury, which may be redressed by a civil action $(q)$.

(m) Robert Mary's ease, 9 Rep. 113a; Poley v. Osborn, cited 10 Rep. 1301, Honbury v. Ireland, Cro. Jac. 618 ; Chamberline v. Har"y, 5 Mod. 182; 1 Lord Raym. 146; Hall v. Hollander, 4 B. \& C. 660 ; Grinnell v. Wells, 7 M. \& G. 1033; 2 D. \& L. 610 ; Eager v. Grimurood, 1 Exc. 61; Dacis v. Williams, 10 Q. B. 72.). That the allegation of service under a per quoul scritium amisil is sufficient on general demurrer, see 4 D. \& L. 258.

(i) Per Lord Mansfield in Bird v. Randall, 3 Burr. 1352.

o) Bird v. Randall, ubi supra. Sed quxre, see post, p. 159.

(p) Ashley v. Harrison, 1 Fsp. 48 ; Peake, 194, that was an action for libel. And see Taylor v. Neri, 3 Esp. 386 . In Evans v. Wallon, 36 L. J., C. P. 308, Willes, J., ohserved, "I doubt whether Taylor v. Neri is maintainable after Lumley $\mathrm{v}$. Gye, $2 \mathrm{E}$. \& B. 216."

(q) R. v. Daniel, 6 Mod. 99, 182 ; 1 Salk. 380 ; Lord Raym. 1116 ; 
The Court, however, will not, on motion, quash such an indictment $(r)$; but the defendant must plead, demur,

but will for conspiracy.

Action will lie.

Mere attempt will not support action.

What sort of servants this action applies to. or move in arrest of judgment $(s)$. But an agreement to induce and persuade workmen under contract of servitude for a time certain to absent themselves from such service, is an indictable offence, althongh no threats or intimidation be proved, or any ulterior object averred $(t)$. And so is a conspiracy to obstruct a man in carrying on his business, by persuading his workmen to leave him, in order to induce him to make a change in the mode of carrying on his business $(u)$. And if one take away my apprentice or servant by force, an action of trespass will lie $(x)$; but if he [*157] merely entice *him to leave, and he do leave, an action on the case is the proper remedy $(y)$ A mere attempt to entice a servant away without any damage following, would not, however, entitle the master to maintain an action $(z)$. But it is no objection to such an action that the servant was only a journeyman, who worked by the piece, if he were the plaintiff's servant $(a)$. A man, however, who lived in his own house, and took in work for different people, could scarcely be called the journeyman of any particular master $(b)$.

A question has been raised as to what sort of servants this action may be brought for the seduction of. And it has been beld by three judges of the Court of Queen's Bench (c), that an action lies for maliciously

Con. Dig. Indictment, G. 3 ; see 5 Geo. 4, c. 9 , which repealed various statutes for preventing the seducing and enticing artificers and workmen to leave their employ and go to foreign parts.

(r) Trin. 13 Will. 3, B. R.; see $R$. v. Bilton, 1 Salk. 372.

(s) As in $R$. v. Daniel, ubi supra.

(t) R. v. Rovlands, 5 Cox, C. C. 466.

(u) R. v. Duffield, 5 Cox, C. C. 404 ; and see R. v. Sclsby, $i b .495$, note; $R$. v. Druitt, and $R$. v. Partridge, $10 \mathrm{Cox}$ C. C. 592.

(x) $R$. v. Daniel ubi supra; Reavely v. Maimataring, 3 Burr. 1306; Gilbert v. Schuenck, 14 M. \& W. 488 ; where it was held that one testamentary guardian was not justified in taking an infant ward out of the lanful service of another testamentary guardian.

(y) R. v. Daniel, ubi supra; see Hambicton v. Veere, 2 Wms. Saund. 170.

(z) Bird v. Randall, 3 Burr. 1352.

(a) Hart v. Aldridge, Cowp. 54 ; Blake v. Lanyon, 6 T. R. 221.

(b) Hart v. Aldridge, Cowp. 54.

(c) Lumley v. Gye, 2 E. \& B. 216: where it was held that an action lay for seducing a dramatic performer away from plaintiff's theatre. Coleridge, J., in support of his judgment, refers to the 2nd section of the Statute of Laborers and the form of writ given by Fitzherbert, N. B. 16\%, B, as always reciting the statute. But the first writ given by Fitzherbert is founded upon 
procuring a breach of contract to give exclusive per- Lumley $\mathrm{v}$. sonal services for a time certain, equally whether the Gyc. employment has *commenced, or is only in fieri, [*158] provided the procurement be during the subsistence of the contract, and produces damage, and that to sustain such an action it is not necessary that the employer and employed should stand in the strict relation of master and servant. Coleridge, J., however, dissented, and in a long judgment, which deserves an attentive perusal, gave elaborate reasons for holding twat the action was founded on the Statute of Laborers, and is strictly confined to cases where the employer and employed stand in such relation of master and servant as was within that statute; and that in all other cases the remedy for a breach of contract is only on the contract, and against those privy to it.

To support this action, it is necessary to prove that Scienter. the defendant knew the person to be the plaintiff's servant $(d)$; but to particularize the means of enticement $(e)$. There must also be binding contract of ser- Binding vice between the servant and his first master, or the contract.

the 3rd section of the statute, and is to recover the penalty there given to the party grieved. The other writs are against the servant, and it would hardly be contended at the present day that such actions must be confined to the elass of servants referred to by the Statute of Laborers. It would seem also from the rule given in Lutw. 1548, that the mere recital of the statute would not show that the action lay not at common law. It is there said that where an action lay both at common law and by statute, if you proeed under the statute, you must recite the statute, for "without rehearsal, non patcl, whether he uses the action by the common law, sicut potest, or the action on the statute." It is also added, "If there were no action at common law, the statute should be rehearsed." So the recital of the statute in a writ does not prove that the action did not lie at common law, bnt only that the plaintiff is not using the action at eommon law, in this instance. Thus leaving the matter where it was. Again, it may be asked, if this form of action is founded entirely npon the Statute of Laborers, why did it not cease when that statute was repealed, 5 Eliz., 26 \& 27 Vict. e. 125? Moreover, if the judgment of Coleridge, $J_{\text {., }}$ is right, what becomes of the common action for seduction of a daughter and servant? Is that to be only brought in eases within the Statute of Laborers? It is notoriously otherwise. In the Year Book, Michaelmas, 39 Ed. 3, fo. 37 B, it is said: "Although this action be given by statute, the writ lay at common law, and is not defeated by the statute." In Bowen v. Iall, 50 L. J., C. L. 305, 6 Q. B. Div. 333, the opinion of the three judges in Lumley v. Gye was upheld by Lord Selborne and Brett, L. $J$. (Lord Coleridge, C. J., diss.).

(d) Fores v. Wilson, Peake, 55.

(e) Winsmore v. Grcenbank, Willes, 582. 
Service de facto.

Erans v.

Walton.

When this aetion will not lie.

Bird v. Randall. Not after payment by servant of penalty for leaving. plaintiff will fail $(f)$; unless, perhaps, in the case of interruption of an actual subsisting service $(g)$.

In an action for enticing away a servant where it appeared that the plaintiff kept a public-house, that his daughter, who was about nineteen years old, helped in the house and business; that a fictitious letter was written by the defendant as if from a relation of the girl, saying such relation was ill and asking leave for the girl to come to her; that leave was given to the girl and she went away, but instead of going to such relation went to a house ill fame and stopped there with the defendant, and then returned to her father's house; it was held that it was a question of fact for the jury [*159] whether when the defendant caused her to *leave she was the plaintiff's servant de facto, and whether his acts did cause her to deny her services, that the Court as a jury held the affirmative, and the plaintiff was entitled to succeed $(h)$.

But the mere circumstance that the servant is an infant, and the contract therefore voidable, will not defeat the action $(i)$. This action will not lie for inducing a servant to leave his master's service at the expiration of the time for which he was hired, although the servant had otherwise no intention of leaving his master $(k)$.

It was also held by Lord Mansfield, in Bird v. Randall $(l)$ : that this action would not lie after the master has recovered from the servant a stipulated penalty for leaving the service, upon the ground, that if the seducer, or second master who employs the servant after the servant has paid the penalty, were to be liable to damages in an action brought by the first master for so doing, this would finally fali upon the servant, and in effect be an addition to the penalty; for the second master would pay the servant for his service no more than he estimates it to be worth to him; and if he

(f) Sykes v. Dixon, 9 A. \& E. 693; and see Gye v. Felton, 4 Taunt. 876 ; Pilkington v. Scott, 15 M. \& W. 657; Hartley v. Cummings, 5 C. B. 247.

(g) See per Lord Denman, in Sykes v. Dixon, ubi supra; and per Maule, J., in Hartley v. Cummings, ubi supra; and see Y. B. 22, Hen. 6, 30; Barber v. Dennis, 6 Mod. 69 ; Keane v. Boycott, $2 \mathrm{H}$. B1. 511 .

(h) Evans v. Walton, 36 L. J., C. P. 307 ; S. C. nom. Evans v. Walter, 17 Law T., N. S. 92.

(i) Keane v. Boycott, Evans v. Wallon, ubi supra, and see 7 T. R. $310,314$.

(k) Nichol v. Martin, 2 Esp. 734.

(l) 3 Burr. 1345; 1 W. Bl. 373,387 ; see Cooper v. Shepherd, 3 C. B. $266 ; 4$ D. \& L. 218 ; Buckland v. Johnson, 15 C. B. 145.

(202) 
must pay a sum of money to the first master for damages for entertaining his servant, he will make his bargain with the servant in such manner as to pay him so much the less. And Lord Ellenborough said $(m)$ he remembered Wilson, J., ruling the same point at Nisi Prius upon the dry authority of the former decision, though, as it seemed to him, with considerable doubts upon his mind as to the propriety of it. But Lord Ellenborough said he never could entirely comprehend the ground on which Bird v. Randall proceeded. "It was assumed," he said, "that the sum taken as the penalty from the servant, was the extreme limit of the injury sustained *by the master ; but there is [*160] the doubt: for the penalty might have been so limited, because of the inability of the servant to undertake to pay more, and yet it might have been very far from an adequate compensation to the master for the injury done to him by another who seduced his servant from him." And upon Lawrence, J., observing, "I suppose the Court proceeded upon the ground that the penalty was by the express stipulation of the parties made an equivalent for the loss of the service;" Lord Ellenborough added, "That is so as between the parties themselves; but it may admit of doubt whether that were the fair way of considering it as against a stranger, a wrongdoer:"

It is conceived that, in the event of the death of the On death of wrongdoer, this action, and also that for harbouring a wrongdoer. servant, might be brought against his executors or administrators, under $3 \& 4$ Will. 4 , c. 42 , s. 2, within six calendar months after they have taken upon themselves the administration of his estate, if the injury were committed within six calendar months bofore his death.

\section{Of the Action for hareourivg a Servant.}

Where a person, after notice, continues to employ another man's sorvant, that other may maintain an action against him, although at the time he hired him the second master did not know that he was hiring another man's servant; and, therefore, no action wonld lie for enticing him away $(n)$.

Thus where (o) one Hobbs, who was retained by the Blake v. plaintiff, a currier, to work by the piece, left the plain- Lanyon.

(m) In Godlsall v. Boldero, 9 East, 78.

(n) Faneet v. Beavres, 2 Lev, 63; Fosset v. Brcer, 3 Keb. 59 ; probably $S$. $C$.

(o) Blake v. Lanyon, 6 T. R. 221. 
tiff's service on a dispute between them, and at the time of departure had some work in hand; he then applied for work to the defendant, who was also a currier, and who employed him, not knowing of his en[*161] gagement with the *plaintiff. A few days afterwards, the defendant having been apprised by the plaintiff that Hobbs was his servant, and had left his work unfinished, and being threatened with an action, in case he continued to employ Hobbs, requested the servant to return to his former master and fin:sh his work. This Hobbs refused to do, and the defendant continued him in his service, whereupon the plaintiff brought his action for enticing Hobbs away, and harbouring him after notice. No evidence was given in support of the charge of enticing away, and it was contended, on the part of the defendant, that no action could be maintained for continuing to employ Hobbs after notice, as at the time the defendant engaged him he did not know he was the plaintiff's servant, but the objection was overruled. $\Lambda$ nd per Curiam, an action will lie for receiving or continuing to employ the servant of another after notice, without enticing him away.

This cause of action, however, is generally joined with that for enticing away a servant, and the observations on that form of action apply to this also.

The action for harbouring the plaintiff's servants will not lie against the captain of an English ship, to which the plaintiff's slaves had escaped, for refusing to give them up to the plaintiff $(p)$.

\section{Of the Action ix a Master for the Earnings of his Servant.}

Master entitled to servant $s$ carnings.

A master deprived of the services of an apprentice $\mathrm{cr}$ servant, who has been enticed away and harboured by another master, is not confined to an action for damages for the injury he has sustained by the loss of his servant. He may in some cases waive the tort, and bring an action to recover the wages due to his apprentice or [*162] servant from *such second master ; the maxim in such cases being quicquid acquiritur servo acquiritur domino $(q)$.

(p) Forbcs v. Cochranc, 2 B. \& C. 448. See Smith v. Gould, 2 Salk. 667, as explained by Hargrave in his argument in Sommersett's case, 20 How. St. Tr. 65, note.

$(q)$ See Barrington on Stat. 276 ; Co. Litt. $117 a$, note 1 ; Peake's Add. Cas. 121, note; Story on Ag. 421 ; Paley on Ag. 339 ; Grot. lib. 3, cap. 7, sect. 4, 2 . The French maxim was "Qui a le vilain, il a sa proye;" vide $20 \mathrm{How}$. St. Tr. 36 , note. 
This rule of law had formerly a much more extensive signitication than it now has; for, during the existence of villenage, whatever was acquired by the villein, whether realty or personalty, became the property of his lord under certain qualifications $(r)$. But even now the rule holds in some degree with respect to apprentices and servants, though with a great difference in point of extent and application, for the relation of an apprentice and servant to the master is more mild and limited than that of a villein to his lord, and only imports that the master shall be entitled to their personal labour during the time stipulated either in a particular way, or generally according to the nature of the apprenticeship or service. Consequently the master cannot claim any other acquisitions than such as are the result of that labour $(s)$.

What the apprentice or servant earns by his labour When workwhilst he remains with the master, or is actually work- ing for his ing for him, falls so ciearly within this principle, that master; there can be no room for doubt $(t)$. Nor can there be any where the apprentice or servant is employed by or with his another person with the knowledge and consent of the and consent. master, without any circumstances indicating a waiver of his earnings. MIost of the cases upon this subject relate to apprentices in a seafaring way, whose wages and prize-money $(u)$ as seamen, though earned whilst in another service, have been recovered by those to whom they were bound. But the principle which governs them seems to apply to apprentices *and [*163] servants in general, and has indeed been extended so far as to give the master a right to the wages or earnings, whether the service is performed by the apprentice with or without tho master's licence; and even though the earnings accrue in a trade or service different from that to which the apprentice is bound $(x)$.

Thus, where $(y)$ the defendant seduced an apprentice

(r) Litt. ss. 177, 194; Co. Litt. $123 \mathrm{~b}$; and see the form of enfranchisement of a villein given in Barr. on Stat. 279 .

(s) See Shanley v. Hervey, eited in Sommersett's case, 20 IIow. St. Tr. 55.

(t) See R. v. Wantage, 1 East, 601 ; R. v. Bradford, 1 M. \& S. 151.

(u) See Carsan v. Watts, 3 Doug. 350, where the master was held not entitled to prize money, tho usage being for the apprentice to have it. Hill v. Allen, 1 Ves. sen. 83.

(x) Co. Litt. 11 i a, note 1 ; Barber v. Demis, 6 Morl. 69 ; 1 Salk. 68. The ease of Eades $v$. Vandeput, 5 East, 39 , does not appear to be of much authority, for the reasous given in Foster v. Stewart, 3 M. \& S. 191.

(y) Lightly v. Clouston, 1 Taunt. 112 ; and sce Foster v. Stezart, 3 M. \& S. 191 ; Neate v. Harding, 6 Exc. 319. 
Lightly $\mathrm{r}$. from on board the plaintiff's ship in Jamaica, and em. Clouston. ployed him as a mariner to assist in navigating his own ship home, the plaintiff brought an action for the wages earned by his apprentice, and recovered.

Payment to And payment to the master has been held to be an master, good; answer to an action by the apprentice for wages $(z)$. and servant And where $(a)$ the captain of a ship let the ship to cannot recover them from him.

This action lies aiter death of tortfeazor; but admits set-off.

Earnings paid to servant may be recovered from hịm by master.

Bloxam v: Elsce.

Inventions by servant belong to him. government at forty shillings per ton per month, to be paid to the owner, and an additional shilling per ton per month, to be paid to himself, for his services, but the whole earnings (including the shiiling per ton) were paid to the owner, it was held that the captain could not maintain an action against the owner to recover the shilling per ton agreed to be paid to the captain.

One advantage attending this form of action formerly was, that it might be brought after the death of the tortfeazor, which was not the case with an action framed on the tort $(b)$; but, on the other hand, there was, and still is, this objection to it, that it admits of a set-off and deductions, which would not be allowed in the other form of action $(c)$. That, accordingly, is the more usual remedy; and, as we have seen it, it may now be brought against the executors of the tortfeazor within [*164] six months after his *death $(d)$. The jury may, in this form of action, if the circumstances justify their so doing, give the plaintiff greater damages than the mere wages of the servant would amount to.

If the wages or earnings have been paid to the servant the master may recover them from him in un action for money had and received $(e)$.

It appears to be an exception to the rule, that a master is entitled to the profits resulting from his servant's labour,- - that if a servant make an invention whilst in the employ of a master, the invention belongs to the servant, and the master cannot take out a patent for it. Though it is said to be otherwise where the servant is employed for the express purpose of invent-

(z) Bright v. Lucas, Peake's Add. Cases, 121. See the note at the end of this case.

(a) Thompson v. Havelock, 1 Camp. 527 ; see Diplock v. Blackburn, 3 Camp. 43.

(b) Per Bayley, J., in Foster v. Stewart, 3 M. \& S. 191.

(c) Per Heath, J., in Lightly v. Clortston, 1 Taunt. 112.

(d) $3 \& 4$ Will. 4, c. 42, s. 2, ante, p. 160 . See Povell v. Rex, 7 A. \& E. 426. 480 .

(e) Morison v. Thompson, 43 L. J., Q. B. 215 ; L. R., 9 Q. B. 
ing $(f)$. That was the case as to Whitehouse's Aliter, if empatent $(g)$. There an individual was employed for ployed on the express purpose of suggesting improvements, and purpose to trying experiments of all kinds. The master so admitted before the Privy Council, when he applied for an extension of the patent, and the Privy Council, before they granted the extension, compelled the master to give his servant a large remuneration $(h)$. And if a person has discovered an improved principle, and em- of servants ploys engineers, or agents, or other persons to assist may be emhim in carrying *out that principle, and they, [*165] bodied in in the course of the experiments arising from that $\mathrm{om}$ ployment, make valuable discoveries accessory to the main principle, and tending to carry that out in. a better manner, such improvements are the property of the inventor of the original improved principle, and may be embodied in his patent, and, if so embodied, the patent is not avoided by evidenco that the agent or gervant made the suggestions of that subordinate improvement of the primary and improved principle $(i)$. It would be difficult to define how far the suggestions of a workman employed in the construction of a machine are to be considered as distinct inventions by liim, so as to avoid a patent, incorporating them, taken out by his employer. Each case must depend upon its own merits. But when we see that the principlo and object of the invention are complete without it, $I$ think it is too much that a suggestion of a workman employed in the course of the experiments of something calculated

(f) Bloxam v. Elsee, 1 C. \& P. 5ī8. In that case Bayley, J., founded his olsservations on a previous case of one Arkwright, referred to in Hill v. Thompson, 8 Taunt. 395; though in Arkwright's case the invention appears to have been made by the servant before the service commenced; in which ease it would undoubtedly belong to the servant. But see the leport in Davies' Patent Cases, 61 ; and see Makepcace v. Jackson, 4 Taunt. 770, where it was held that a calico-printer, having discharged his head colourman, was entitled to the book in which that servant had entered the processes for mixing colours during his service, althongh many of the processes were the invention of the servant. That, however, was only an action of trover for the book which the master had originally provieled. As to which see Elhoood v. Literpool Victoria Legal Friendly Soeiety, 42 L. T. 694. See als3 the case in 4 Burr. 2:316, where the copyright of Rolle's Abridgment was said to be in the king, as he employed the judges who pronounced the law; and at p. 23:29 the king was also said to be entitled to the copyright of the Year Books, als ho was at the expense of taking the notes.

(g) 1 Webster's 1'. C. 473 .

(h) Per Cressivell, J., in Allen v. Rauson, 1 C. B. 570.

(i) $\mathrm{Per}$ Erle, J., 1 C. B. 567.

10 Mas. \& Sir. 
more easily to carry into effect the conceptions of the inventor should reuder the whole patent void. $(j)$.

Patent In a case in which a manufacturer of tubes, at Birmgranted in ingham, and his foreman (who had a salary of $300 l$. a master and year), had together invented certain improvements, for servant. which the master sought letters patent, the granting of which was opposed by the foreman, it was held by Lord Cranworth, L. C., that the letters patent ought only to be granted on the terms of their being vested in trustees for the benefit of both master and foreman $(k)$. In that case, it appeared almost impossible to say which was entitled to the credit of the improvement in question.

"Stock However, it has been held that a "Stock Author," author" sent sent to Paris by the proprietor of an English theatre, to Paris to for the express purpose of adapting a piece there in adapt farce, rogue for representation on the English stage, is the $\left.\begin{array}{l}\text { is "author" } \\ \text { within }\end{array} * 166\right]$ "author" of *the piece, when so adapted, within within Copyright Act. the meaning of the Dramatic Copyright Act, $3 \& 4$ Will. 4, c. 15, which vests in the author of any dramatic piece the sole liberty of representing it at any place of dramatic entertainment.

Shepherd $\mathrm{r}$. Conquest.

This was decided in the following case $(l)$ : The plaintiff's who were the proprietors of the Surrey Theatre, agreed by word of mouth with C., who was what is called a "Stock Author," that he should go to Paris, for the purpose of adapting a piece there in vogue for representation on the English stage; that the plaintiffs should pay his expenses, and should have the sole right of representing the piece in London, C. retaining the right of representation in the provinces. C. went to Paris, produced a farce, and was paid by the plaintiffs as agreed. The farce was brought out at the Surrey Theatre by the plaintiffs, and afterwards at the Grecian Saloon by the defendant, who had obtained an assignment from $C$. The plaintiffs brought an action against the defendant for penalties, under the Dramatic Copyright Act $(m)$. But it was held that the arrangement between them and $C$. did not make them the authors of the farce within the meaning of that act, although it was contended on their behalf that, under

(j) Per Tindal, C. J., 1 C. B. 574.

(k) Re Russell's patent, 2 De G. \& Jones, 130.

(l) Shepherd v. Conquest, 17 C. B. $427 ; 25$ L. J., C. P. 127 ; and see Levy v. Rutley, 40 L. J., C. P. 244 ; L. R., 6 C. P. 523, where it was held that the master and servant cannot be joint authors, without co-operation, in a common design.

(m) $3 \& 4$ Will. 4 , c. 15. 
the circumstances, C. ought to be considered as mereily Shrpcrl v. their servant, the produce of whose labour became Conquest. the property of his masters at the moment of production, so that no assignment was necessary to vest the property in the latter; and tho case was likened to those relating to patent inventions, in which suggestions of servants employed in perfecting a discovery, tending to facilitate its practical application, may be adopted by his employer, and incorporated into his design, without detracting from the originality necessary to sustain a patent for the entire. And it was also contended that the productions of an author are*to [*167] be dealt with in the same manner as the inventions of a workman, and that the former, like the latter, may become the property of an employer who hires the author's labour, and, as it was said, "buys hus brains." To that it was answered that literary productions stand upon different and higher ground from that occupied by mechanical inventions; and that whilst both literary property and patents for inventions are both the creatures of statutes, the enactments respecting them differ widely in their origin and details, and Jervis, C. J., said, "We do not think it necessary in the present case to express any opinion whether, under any circumstances, the copyright in a literary work, or the right of representation, can become vested $a b$ initio in an employer other than the person who has actually composed or adapted a literary work. It is enough to say, in the present case, that no such effect can be produced where the employer merely suggests the subject, and has no share in the design or execution of the work, the whole of which, so far as any character of originality belongs to it, flows from the mind of the person employed. It appears to use an abuse of terms, to say that, in such a case, the employer is the author of a work to which his mind has not contributed one idea; and it is upon the author in the first instance that the right is conferred by the statute which creates it. We cannot bring our minds to any other conclusion than that C., tho person who actually made the adaptation, though at the suggestions of the plaintiffs, acquired for himself, as the author of the adaptation, and so far as that adaptation gives any new character to the work, the statutory right of representing it ; and that, inasmuch as the plaintiffs have no assignment, in writing, of that right, they cannot sue for an infringement of it."

$\Lambda$ nd it has been held that a firm of photographers, 
Firm of pho- one of whose employés, at the instance of their manatosraphers nat "authors" of photograph taken by ger, took a negative, making use of their machinery and materials for the purpose, were not the "authors" of the photograph within the meaning of the $25 \& 26$ their servant. [*168] Vict. c. 68 (Copyright * Works of Art Act), and could not register themselves as such $(n)$.

5 \& 6 Vict. By 5 \& 6 Vict. c. 45 , s. 18 , it is enacted, that when c. 45 . any publisher, or other person, shall "project, conduct, Copyright in and carry on, or be the proprietor of any encyclopadia, periodicals, review, magazine, periodical work, or work published reviews, \&c., in a series of books, or parts, or any book whatsoever, parts by various persons,

and shall have employed, or shall employ, any persons to compose the same, or any volumes, parts, essays, articles, or portions thereof, for publication in or as part of the same, and such work, volumes, parts, essays, articles, or portions shall have been, or shall hereafter be, composed under such employment, on the terms that the copyright therein shall belong to such in proprietor proprietor, projector, publisher, or conductor, and (not author). paid for by such proprietor, projector, publisher, or conductor, the copyright in every such encyclopædia, review, magazine, periodical work, and work published in a series of books or parts, and in every volume, part, essay, article, and portion so composed and paid for, shall be the property of such proprietor, projector, publisher, or other conductor, who shall enjoy the same rights as if he were the actual author thereof, and shall have such term of copyright therein as is given to the authors of books by this act, except only that in case of essays, articles, or portions forming part of, and first published in, reviews, magazines, or other periodical works of a like nature, after the term of twenty-eigl't years from the first publication thereof respectively, the right of publishing the same in a separate form shall revert to the author for the remainder of the tern given by this act: Provided always, that during the term of twenty-eight years the said proprietor, projector, publisher, or conductor shall not publish any such essay, article, or portion separately, or singly, without the consent previously obtained of the author

Proviso for anthors who have preserved the right of publishing thereof, or his assigns: Provided also, that nothing herein contained shall alter or affect the right of any [*169] person who shall have *been or who shall be so employed, as aforesaid, to publish any such his composition in a separate form, who by any contract ex-

(n) Nottage v. Jackson, 52 L. J., C. L. 760; L. R., 11 Q. B. Div. 627. 
pressed or implied may have reserved, or may here- their articles after reserve to himself such right, but every author in a separate reserving, retaining, or having such right, shall be en- form. titled to the copyright in such composition when published in a separate form, according to this act, without prejudice to the right of such proprietor, projector, publisher, or conductor as aforesaid."

Accordingly it has been held (o) that the proprietor swcet $\mathrm{v}$. of a periodical who employs a gentleman to write a Benning. given article or a series of articles, or reports, expressly for the purpose of publication therein, acquires the copyright in such article, and may maintain an action for piracy thereof.

In the following case $(p)$ it was held that a com- Composer of poser of music conld not sue the person who employed music emhim to compose it as part of a dramatic piece, for per- ployed by forming it without his consent in writing, contrary to manager of a the Dramatic Copyright Act, $3 \& 4$ Will. 4, c. 15, and the General Copyright Act, 5 \& 6 Vict. c. 45 .

The plaintiff, a composer of music, was employed by the defendant, who was a manager of a theatre, to com- Kean. pose, and did compose, a certain musical composition for the purpose of being performed at, during and as part of a representation of Shakspeare's play "Much Ado about Nothing," and alleged, in his declaration, that he had the sole liberty and right of performing the said composition; and that defendant, without his consent in writing, caused it to be performed and represented at the defendant's theatre contrary to the Dramatic Copyright Act and the General Copyright Act. The defendant pleaded that the musical composition was part of a dramatic piece adapted to the stage by the defendant. with the aid of scenery, dresses, the alleged composition, and other music and accom. paniments; the general design of which representa*tion was formed by the defendant, who em- [*170] ployed the plaintiff, for reward paid to him, to compose the said musical composition, as part of the said representation and dramatic piece, on the terms that the said musical composition should become part of such dramatio piece, and that the defendant should have the sole liberty of representing and performing the said musical composition with the said dramatic piece, and as part thereof; and that the said musical composition

(o) Sweet v. Benning, 16 C. B. 459 ; see also Stevins v. Benning, 24 L. J., Ch. 153; Grace v. Newman, 44 L. J., Ch. 298; L. R., 19 Eq. Rep. 623.

(p) Hatton v. Kean, 29 L. J., C. P. 20; Law Times, 1 N. S. 10. 
Hatton v. was composed by the plaintiff under the said employKcan. ment, and on the terms, \&c. aforesaid. It was held on demurrer that the plea was a good answer to the action; and Erle, C. J., said, "I found my opinion entirely on the facts stated in the plea, and because no decision has yet been given on such circumstances as those subsisting between these parties. Lcoking at all the facts as disclosed in the pleadings, it seems to me that the defendant was substantially the author and designer of this dramatic piece. The capital and skill he employed in producing it and bringing it out were considerable, while the plaintiff's duty was small and contined to one subordinate department. The music be furnished was, as it seems to ne, cumposed under the employment, and by direction of, the defendant; was paid for by him, and became his property, and therefore be violated no contract by using it. The very terms of the engagement led me to this judgment; were it otherwise, a single successful production might induce the plaintiff to withdraw his music, to the great detriment of the defendant;" and Byles, J., added, "This falls within the class of cases in which the Court, in Shepherd v. Conquest $(p)$, abstained from expressing any opinion."

Of the Action by a Master for personal Injuries to His Servant.

Numerous instances are to be found in the books of actions by masters for personal injuries to their ser. [*171] vants; *whether caused by an assault $(q)$ or by battery $(r)$, or by negligent driving $(s)$, or by a ferocious $\operatorname{dog}(t)$; and in one case a man recovered damages in an action against a person for negligently entrusting a loaded gun to a mulatto girl, who discharged it against

Loss of service. the plaintiff's son and servant $(u)$. This action also depends on the losis of service $(v)$, but a service de facto is sufficient to support the action $(x)$.

(p) Ante, p. 166.

(q) Gilbert v. Schwenck, 14 M. \& W. 488.

(r) Duel v. Harding, Str. 595.

(s) Hall v. Hollander, 4 B. \& C. 660; Martinez v. Gerber, 3 M. \& G. 88; Gough v. Bryan, 2 M. W. 770.

(t) Hudson v. Stallebrass, 11 A. \& E. 301; Levis v. Fog, Str. 944.

(u) Dixon v. Bell, 1 Stark. 287; 5 M. \& S. 198.

(v) Robert Mary's case, 9 Rep. 113 b; and cas. cit. ante, p. 155, note $(m)$; Rosiere v. Savkins, Holt, 460. In Allan v. Barclay, vol. 2, 3rd ser., Scotch Cases, it was held in Scotland that no action lay without averment of continued contract of service.

(x) 11 Hen. 4, 2 F. N. B. 91, G., note; see Martinez v. Gerber, 3 M. \& G. 88; Evans v. Walton, ante, p. 158. 
It is in this form of action that a parent usually proceeds to recover damages for injuries sustained by his children through the wrongful acts of the defendant, for in such cases a parent cannot recover any damages for his wounded feelings, but only for the loss of service he has sustained $(y)$. Where, therefore $(z)$, the defendant drove his carriage against the plaintiff's son, who was an infant only two years and a half old, and the plaintiff brought an action for trespass, per quod serve.

Hall $v$.

Hollander. servitium amisit, against the defendant; upon its being objected that the child was not competent to perform any act of service by reason of its tender age, the plaintiff was nonsuited, and the nonsuit was afterwards held right by the Court; Bayley, J., observing, "The authorities upon this point are all one way." If, however, Capacity to there is a capacity to serve, very slight evidence is serve. sufficient to support the allegation of *service [*172] (a); and, indeed, in modern cases, where there has been a capacity to serve, the tendency of the Courts has been to infer service from residence with the parents, without proof of actual service (b). Where Action by the child injured is of such tender age as to render it servant. doubtful whether service could be presumed, the best way to avoid the difficulty is to sue in the name of the child; a course against which the objection which formerly prevailed (c)-viz., that the adoption of it excluded the child's testimony, would not now apply $(d)$.

It has, however, been held that a master cannot Master canmaintain an action for negligence per quod servitium not sue amisit against a carrier with whom his servant had carrier for entered into a contract of carriage $(e)$, as no one can negligence

(y) Flemington v. Sinithers, 2 C. \& P. 292. Mark the difference in this respect between this action and that for seduction, post, p. 174. Formerly, whilst it was petit treason for a servant to kill his master (25) Edw. 3, st. 5, c. 2 ; see now 9 Geo. 4, c. 31, s. $2 ; 24 \& 25$ Viet. c. 100, s. 8 ), parricide was held not to be petit treason unless the child served the father or mother for wages, or meat, drink or apparel; 3 Inst. 20.

(z) Hall v. Hollander, 4 B. \& C. 660.

(a) In Dixon v. Bell, 1 Stark. 287; 5 M. \& S. 19R, the plaintiff recovered for an injury to his son, eight or nine years old, without proof of actual service.

(b) See Joncs v. Brown, Peake, 233; 1 Esp. 217; Maunder v. Vinn, M. \& M. 323; Torrence v. Gibbins, 5 Q. B. 300.

(c) Duel v. Harding, Str. 595; Lewis v. Fog, ib. 9.14; Cock v. Woriham, ib. 1054; Selw. N. P. 1114.

(d) 14 \& 15 Vict. c. 99 , s. 2.

(c) Alton v. Milland Rail. Co., 34 L. J., C. P. 292 ; 19 C. B., N. S. 213. See also Becher v. The Great Eastern Rail. Co., I. R., 5 C. P. 211; Berringer v. Same Co., 48 L. J., C. J. 400; 4 C. P. Div. 163. 
Alton v. Midland Railway Co.

Form of action.

Recovery by servani no answer to action by master.

Death of servant.

Servant killed on the at the suit of the master $(l)$.

spot.

Damages. with whom the contract was made. terial.

sue for a tort arising out of a contract, but the person

Formerly where the action lay, the form of action might be either trespass or case, according as the plaintiff wished to recover damages for the direct or consequential injury $(f)$. In trespass, counts might be added for breaking and entering the plaintiff's dwellinghouse and assaulting himself, which might increase the damages $(g)$ : whereas in an action for the assault on the child merely, however atrocious it might be, the plaintiff could recover nothing unless loss of service were shown $(h)$. It was no objection to an action on the case by the master, that, under the circumstances, had the servant himself sued, he could only have sued in case for the consequential damage done to [*173] *him $(i)$. Nor was it any answer to such an action that the servant himself had already recovered damages for the injury he had sustained; for the injury to the servant and that to the master are collateral, not consequent upon each other $(j)$. Since the Judicature Acts of 1873 and 1875 , the form of action is imma-

If the servant die, the master must proceed first by indictment, as public policy will not allow him to recover damages for a private injury, until public justice is satisfied by the trial of the offender. After trial, the master may still bring his action, whether the offender be convicted or acquitted, as the private right is only suspended until public justice is vindicated $(k)$.

But if the servant is killed on the spot, no action lies

In this action, the master may recover damages for the loss of service, not only before action brought, but afterwards, down to the time when it appears by the evidence the disability to serve may be expected to

(f) Chamberlain v. Hazlewood, 5 M. \& W. 515.

(g) Ditcham v. Bond, 2 M. \& S. 436.

(h) Newton v. Holford, 6 Q. B. 927.

(i) Martinez v. Gerber, 3 M. \& G. 88.

(j) Savil v. Kirby, 10 Mod. 386; Edmondson v. Machell, 2 T. R. 4 .

(k) Croshy v. Leng, 12 East, 409 ; see Stone v. Marsh, 6 B. \& C. 551 ; White v. Spettigne, 13 M. \& W. 608; Wells v. Abraham, 41 L. J., Q. B. 306 ; Osborn v. Gillett, infra; see also Re Shepherd, 48 L. J., Bankr. 57.

(l) Osborn v. Gilletl, 42 L. J., Exc. 53 ; L. R., 8 Exe. 88. A father cannot sue as administrator under Lord Campbell's Act for loss by death of his son and servant merely for loss of profit on his work. Sykes v. North Easlern Railway Co., 44 L. J., C. P. 191. 
cease $(m)$; and he may also recover the amount of the surgeon's bill, although it has not been paid, but not physician's fees, if not paid $(n)$.

The defendant may plead that the party injured was Defence. not the plaintiff's servant $(o)$. It seems, however, unnecessary, though perhaps safer, to do so $(p)$. $\mathrm{He}$ may also pay money into Court, provided the assault complained of be not of the plaintiff himself. If there be a count in the *declaration for an assault on [*174] the plaintiff himself, the payment into Court should be confined to the other counts $(q)$.

\section{Of the Action for Seddction.}

This action also depesds upon the existcnce of the relationship of master and servant between the party bringing the action and the party seduced $(r)$, although it is the only method in which a parent, however high in rank he may be, can recover damages against the seducer of his daughter.

In one respect this action is similar to that lastly Loss of treated of, viz., that as it is the invasion of the legal service. right of a master to the services of his servant, that gives him a right of action for assaults, \&c. committed upon his servant, so it is the invasion of the same legal. right, and no other, which gives a father a right of action against the seducer of his daughter $(s)$.

But there is this important practical difference be- Damages for tween the two actions, that in the action for assaulting, injury to \&c. a servant or child, the plaintiff cannot recover any feelings. compensation for the injury his feelings may have sustained; whilst in the action for seduction he may do so $(t)$. And this, in practice, is the chief object of the action for seduction, in which liberal damages are

(m) Hodsoll v. Stallebrass, 9 C. \& P. 63 ; 11 A. \& E. 301.

(n) Ihirom v. Bell, 1 Stark. 287.

o) Torrence v. Gibbins, 5 Q. B. 297.

(p) Holloway v. Abell, 7 C. \& P. 530; Eager v. Grimuood, 1

Exc. 61 ; but see Davies v. Williams. 10 Q. 13. 725.

(q) Ncwton v. Holford, 6 Q. B. 921; 2 D. \& L. 554.

(r) Grinnell v. Wells, 7 M. \& G. 1033; 2 1. \& L. 610; Eager v. Grimicool, 1 Exe. 61; see Fores v. Wilson, Peake, 55.

(s) Per Tindal, C. J., in Grinnell v. Wells, ubi supra. See further post, p. 176. It is the same in America. Bartley v. Richtmyer, 4 Comst. 33 ; Dain v. Wycoff, 3 Seld. Rep. 191 ; Ingcr$80 n$ v. Miller (1866), 47 Barb. 47.

(t) In Dodd v. Norris, 3 Camp. 520, Lord Ellenborough expressed an opinion that it was necessary to wateh that this anomaly should not be carried further, and that the original scope of the action should not be entirely lost sight of. 
usually given, and the courts are disinclined to grant new trials merely on the ground of excess in that respect $(u)$. The custom of allowing the jury, in ascer[*175] taining the amount of damages *in this action, to have regard not merely to the injury sustained by the loss of service, but also to the wounded feelings of the plaintiff, has arisen from a laudable desire to suppress the vice of seduction, against which the criminal law has not provided any punishment; though it may be fairly doubted how far it has succeeded in accomplishing the desired object $(x)$. The custom, however, has been now so long established, that it can only be altered by the legislature.

Scienter.

There is also this distinction tu be observed between this actiou for seduction and that for enticing away and habouring apprentices or servants (the gist of which also, as we have seen, is the loss of service), that in the former it is not necessary to prove that the defendant knew the person seduced to be the plaintiff's servant, whilst in the latter it is necessary to do so $(y)$.

By whom this action may be brought.

'The gist of this action being loss of service, it follows that it may be brought by any one who has snstained that loss, whether he be merely the master and not a relative $(z)$, or the parent, brother $(a)$, or aunt - (b) of the person seduced. And, in one instance, a person seduced. And, in one instance, a person who had adopted a friend's daughter was allowed to bring an action for her seduction (c). But the right of action for an injury of this sort does not pass to the assignees

(u) Tullidge v. Wade, 3 Wils. 18; Edmondson $\mathrm{r}$. Machell, 2 T. R. 4 ; Bennett v. Aleoft, 2 T. R. 166 ; and see Duberly v. Gunning, 4 T. R. 651 ; Elliolt v. Nicklin, 5 Price, 641. See also Smith v. Woodfine, 1 C. B., N. S. 660 ; Berry v. Da Costa, 35 L. J., C. P. 191.

(x) Selw. N. P. 1115 ; Southernwood r. Ramsden, H. T. 1805 ; Chambers v. Irwin, ib. cit.; Irvin v. Dearman, 11 East 23; and see per Tindal, C. J., in Grinnell v. Wells, 7 M. \& G. 1043.

(y) Per Lord Kenyon, in Fores v. Wilson, Peake, 55; and see Winsmore v. Greenbank, Willes, 577.

(z) Fores v. Wilson, ubi supra.

(a) Howard v. Crowther, 8 M. \& W. 601.

(b) Edmondson v. Maehell, 2 T. R. 4.

(c) Iruin r. Dearman, 11 East, 23. The American courts go further than he English in making out the constructive relation of master and servant, and hold that it may exist for the purposes of this action, although the daughter was in the service of a third person at the time of the seduction, provided the case be snch that the father then had a legal right to her services, and might have commanded them at pleasure. See Bartley v. Richt myer, 4 Comst. 38 (1850); Mulvehall v. Millward, 1 Kernan's Rep. 343 (1854). 
of a master who has become bankrupt, as they have no right to make a profit of a man's wounded feeling $(d)$.

*It is no objection to this action by the master, [*176] No objection that the party seduced was of age at the time of the se- that servant duction $(e)$, nor that she was a married woman, if living of full age. with her father, and acting as his servant; for it is not competent to a wrongdoer to set up the rights of the husband as an answer to the action if he do not interfere $(f)$.

The action might formerly be brought either in trespass or case $(g)$. If the former was brought, as it more action. usually was when actual violence had been used, the plaintiff might also recover damages for any trespass committed in breaking and entering his house, and assaulting himself $(h)$. If the latter form of action was adopted, the trespass was waived, and the plaintiff could only recover for the consequential damage. But whatever the form of action, the allegation per quod servitium amisit was and still is indispensable $(i)$; to sustain which it is necessary that the party seduced should be in the actual service of the plaintiff at the time of the seduction $(k)$. Where, therefore, the plain- Father cantiff's daughter was apprenticed to the defendant's wife, not sue for for the purpose of learning the business of a milliner, seduction of and the defendant seduced her, it was held that the his daughter plaintiff could not maintain an action against him for who is apthe seduction $(l)$. So a father cannot maintain an or servant action for the seduction of a daughter who is, at the of another time of the seduction, in the actual domestic service of person. another, although she intend to return to her father's house at the end of her term of service $(m)$, nor although during leisure *hours she worked for [*177] her father $(n)$, nor if she have an establishme̊nt of her

(d) Howard v. Crowthcr, 8 M. \& W. 601 ; and see Bcckham v. Drake, 2 Ho. Lords Cas. 579. See also Hodgson v. Sidncy, $35 \mathrm{~L}$. J., Exc. 182, as to splitting cause of action in the case of injury to a bankrupt's estate, with special damage to himself.

(c) Bennet v. Alcott, 2 T. R. 166; Tullidge v. Wade, 3 Wils. 18.

(f) Harper v. Luffkin, 7 13. \& C. 387.

g) Chamberlain v. Hazlewood, 5 M. \& W. 515; 7 Dowl. 816.

(h) Ditchem v. Bond, 2 MI. \& S. 436.

(i) See Giinnell v. Wells, 7 M. \& G. 1033; 2 D. \&. L. 610, where judgment was arrested for want of it.

(k) liat a binding contract of service is not necessary. IIarper v. Luffkin, 7 B. \& C. 387.

(l) Harris v. Butler, 2 M. \& W. 539. But see Speight v. Otireira, 2 Stark. 493, infra, note $(l)$, and the American cases of Bartley v. Richtmyer, 4 Comst. 38; Duin v. Wycoff, 3 Seld. 191.

(m) Dean v. Peel, 5 Sast, 46; Blaymire v. Haley, 6 N. \& W. 55.

(n) Thompson v. Ross, 29 L. J., Exe. 1 ; 5 I. \& N. 16; 1 Law T., N. S. 43. See also Hedges v. Tagg, 41 L. J., Exc. 169. 
own, and is not a subordinate member of her father's Temporary family (o). A mere temporary absence, however, from absence from her father's house, as if on a visit to a friend, if not in home.

the actual service of another, would not defeat the action $(p)$. Therefore, where the plaintiff's daughter lived with her brother, but went every day to her father's house to do all the household business as when she resided with him, and he kept no other servant; it was held that he might maintain an action for his Serving daughter's seduction $(q)$. And where a girl was bound father part of to serve the defendant eleven hours a day as servant in the day. husbandry, but slept at her father's house, and after her day's work performed service for her father; it was held that there was sufficient loss of service to enable Seluction on the father to maintain the action $(r)$. Again, where a way home from situation. Colourable hiring.

Nor can father sue where his daughter confined at his house, if seduced whilst in service.

Child not defendant's. girl having left her situation was seduced on her way home to her father's house, it was held that he might sue (s). And where the defendant hired the plaintiff's daughter as his servant, with a view to obtain possession of her person in order to seduce her, it was held that such a hiring would not defeat an action brought by her father, as it was merely a colourable hiring $(t)$.

Again, if a girl be seduced whilst out in service, and return to her father's house in a state of pregnancy, and he support her during and after her confinement, he cannot maintain any action for the seduction, as he did [*178] not thereby ${ }^{*}$ lose her services, she being in the service of another $(u)$. And so, if the jury find that the child of which the plaintiff's daughter was delivered was not the defendant's, although he was proved to have had connexion with her, the plaintiff can sustain no action against the defendant, as he has sustained no loss of service by the defendant's act $(x)$. And it has been

(o) Manley v. Field, 29 L. J., C. P. 79.

(p) Per Parke, B., in Blaymire v. Haley, ubi supra.

(q) Mann v. Barrett, 6 Esp. 32.

(r) Rist v. Faux, 32 L. J., Q. B. 386.

(s) Terry v. Hutchinson, 37 L. J., Q. B. 257 ; 3 L. R., Q. B. 599 ; 9 Best \& S. 487.

(t) Speight v. Oliveira, 2 Stark. 493 ; Griffiths v. Tcetgen, 15 C. B. 344 ; 24 L. J., C. P. 35 . See $R$. v. Delaval, 3 Burr. 1434, where a criminal information was granted for fraudulently assigning a female apprentice for the purpose of prostitution. And see the American cases, supra, note (l). See also Evans v. Walton, ante, p. 158.

(u) Daries v. Williams, 10 Q. B. 725. In Joseph v. Cavander, Winton Summ. Ass. 1834 (cited in Rosc. on Ev. 467), the action was held to lie, though the daughter had not actually been confined before action brought, and the plaintiff had voluntarily turned her out of his house upon discovering her pregnancy.

(x) Eager v. Grimuood, 1 Exc. 61. 
questioned whether a parent can maintain this action Abandonwhere the loss of service arose from distress of mind ment after consequent upon abandonment after seduction, it be- seduction. ing conceived that the damage was too remote $(y)$.

Where this action is brought by a parent for the se- Loss of duction of a daughter who resides with him, evidence service of of very slight acts of service $(z)$, such as milking daughter cows $(a)$, making tea $(b)$, and the like, has been held residing with sufficient to prove the allegation of loss of service. Nay, the Courts are disposed to infer service from residence with the parent, where there is a capacity to serve $(c)$. Whether or not the same inference could be drawn in the case of one standing in loco parentis is not settled.

It would seem, however, that mere seduction, unat- Seluction tended with pregnancy or other ill effects whereby the without loss daughter is disqualified at least in some trifling degree of service. from performing such service as a parent might require, would not give a right of action - there would be no loss of service $(d)$.

The action for seduction cannot, except by consent $(e)$, *be brought in the court $(f)$. It would seem, [*179] however, that a defendant might formerly have been held to bail if about to quit England $(g)$.

The daughter or servant may be a witness $(h)$, but Evidence. the plaintiff is not bound to call her $(i)$. The omission to do so, however, would afford ground for such strong observations on the part of the defendant, that in practice, it is usual to call her. She can, however, only be asked as to circumstances occurring beforo and immediately after her connexion with the defendant, to show that it was against her consent $(k)$. And she is

(y) Boyle v. Brandon, 13 M. \& W. 738.

(z) Mansell v. T'hmmpson, 2 C. \& P. 303; Halloway v. Abell, 7 C. \& P. 528.

(a) Bennett v. Alcott, 2 T. R. 168.

(b) Curr v. Clarke, 2 Ch. Rep. 260.

(c) Maunter v. Venn, M. \& M. 323; Torrence v. Giblins, 5 Q.

B. 300; see Jones v. Brown, Peake, 233; 1 Esp. 217; and per Lord Wenslcydale, in Harris v. Buller, 2 M. \& W. 539.

(d) See the American case of Inycrson v. Miller, 47 Barb. 47 (1866).

(c) $19 \& 20$ Vict. c. 108 , s. 23.

f) $9 \& 10$ Vict. c. 95, s. 58.

g) See Bullock v. Jenkins, 1 L. M. \& P. 645. That, however, was an acton for crim. con.

(h) Cock v. Wortham, 2 Str. 1054; Selw. N. P. 1114; and see Tullidge v. Wade, 3 Wils. 18.

(i) Farmer v. Joseph, Holt, 451.

(k) Colyer v. Mayne, 2 Carr. \& K. 1011. 
Cross-exami- not bound to answer, on cross-examination, whether nation. before her acquaintance with the defendant she had not been criminal with other men $(l)$. And where she has been cross-examined at length as to circumstances of extreme indelicacy, and great levity of conduct in submitting to the defendant's embraces, those circumstances must be explained, if capable of explanation, on re-examination, for the plaintiff cannot, in answer, call witnesses to her general character $(m)$. Though, in one case, where the cross-examination went to show that the plaintiff's daughter had conducted herself immodestly towards the defendant before her seduction, and that she kept improper company, witnesses were allowed to be called, on the part of the plaintiff, to prove the general good character and modest deportment of the daughter, and the general respectability [*]80] of the family $(n)$. The *plaintiff cannot give Evidence of evidence of the general good character of the person general good seduced, except in answer to evidence of general bad character. character. And therefore, where evidence is given of a specific breach of chastity, the plaintiff is restricted to Promise of disproving that specific act $(o)$. Nor can evidence be marriage. admitted on the part of the plaintiff to show that the defendant accomplished the seduction by means of a promise of marriage $(p)$; at least not directly for the purpose of increasing damages, though such evidence may be given indirectly, and is frequently received for the purpose of vindicating the girl's character $(q)$. Declarations of the defendant's wife, tending to show that she aided and colluded with the defendant in seducing the plaintiff's daughter, have been admitted in evidence in aggravation of damages $(r)$.

Defence. The defendant may plead that tho person seduced was not the plaintiff's servant $(s)$, though it appears

(l) Dodd v. Norris, 3 Camp. 519.

(m) Dodd v. Norris, ubi supra; and see Bamfield v. Massey, 1 Campb. 460.

(n) Bate v. Hill, 1 C. \& P. 100. See the note at the end of the case, where it is said that the course adopted in that case is more conducive to the ends of justice than that adopted in Dodu v. Norris. And see $1 \mathrm{Ph}$. on Ev. 468.

(o) Bamfield r. Massey, 1 Campb. 460.

(p) Dodd v. Norris, 3 Campb. 519.

(q) Per Garrow, B. (in Elliot v. Nichlin, 5 Price, 647), who was counsel in Dodd v. Norris. And see Tullidge v. Wade, 3 Wils. 18; Capron v. Balmond, Exeter Spr. Ass. 1831; Rosc. on Ev. 468.

(r) Knowles v. Compigne, Winton Summ. Ass. 1834; Rosc. on Ev. 44.

(s) Torrence v. Gibbons, 5 Q. B. 297; Davies v. Williams, 10 Q. B. 725 . 
unnecessary to do so $(t)$. It is, however, safer to add such a plea if it is intended to rely on that fact as a defence to the action; or the defendant may pày money into Court $(u)$.

On the part of the defendant evidence may be given, Evidence. in mitigation of damages, not only of the general bad character of the person alleged to have been seduced, but also of particular acts of unchastity on her part $(x)$. But he cannot call witnesses to prove that she has talked of another person than the defendant as her seducer and the father of her child, unless she be first asked in cross-examination *whether she ever [*181] used those expressions $(y)$. Such evidence, however, might be admissible to show general misconduct and frequent use of loose language $(z)$.

The plaintiff may recover damages for the injury Damages. which his feelings have sustained in addition to the actual expense incurred by loss of service and payment of doctor's bills $(a)$. And, in one case, Lord Eldon told the jury that, in estimating the damage sustained by the plaintiff, they might look upon her as a parent losing the comfort as well as the service of her daughter; in whose virtue she could feel no consolation; and as the parent of other children whose morals might be corrupted by her example (b). But it would seem to be the better opinion that the plaintiff cannot aggravate the damages by proof of the wealth of the defendant $(c)$.

( ) Holloway v. Abell, 7 C. \& P. 530; Eager v. Grimwood, 1 Exc. 61 .

(u) Rules of the Supreme Court, 1883, Ord. XXII. Formerly he conld not do so; see $3 \& 4$ Will. 4, e. 42, s. 21 (repealed by 37 $\& 38$ Vict. c. 35 ); $15 \& 16$ Vict. e. 76 , s. 70 (repealed by $46 \& 47$ Vict. c. 49).

(x) Verry v. Watkins, 7 C. \& P. 308; and see R. v. Martin, 6 C. \& P. 562; R. v. Robins, 2 M. \& Rob. 541. But see prr Erle, J., 16 Q. B. 178, who said he knew no instance of evidence of general bad character being admitted in actions for seduction.

(y) Carpenter v. Wall, 11 A. \& E. 803. In Andrews v. Askey, 8 C. P. 7, Tindel, C. J., allowed her to be recalled and re-examined on this point.

(z) Carpenter v. Wall, ubi supra.

(a) Ante, p. 174 ; Andrews v. Askey, 8 C. P. 7 ; Chambers v. Irwin, Southernwoed v. Ramsden, Selw. N. P. 1127 (12tl ed). As to doctor's bills see Itixon v. Bell, 1 Stark. 287.

(b) Bedford v. M' Koul, 3 Esp. 119.

(e) Jones v. Beddington, 6 C. \& P. 589; see also Dain v. Wycoff; 3 Seld. Rep. 191. And see Berry v. I a Costa, 35 L. J., C. P. 191, where heavy damages were given in an action for breach of promise of marriage, aceompanied by seduction. 
THE DUTIES OF THE MASTER TO THE SERVANT, AND THE RIGHTS AND REMEDIES OF THE SERVANT TO ENFORCE THE PERFORMANCE OF THEM.

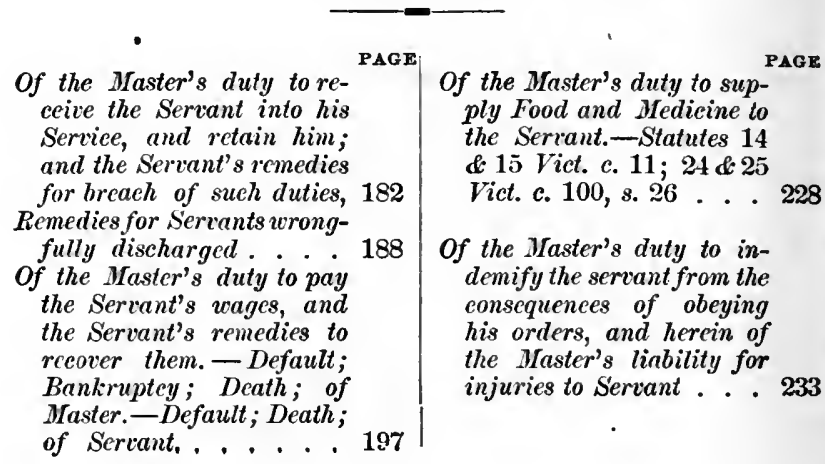

Of the Master's Duty to receive the Servant into his Service, ałd retain him; aNd the Servart's Remedies for Breach of such Duties.

Duty of master to receive servant into his service.

Action for refusal.

Clark v. Allatt.
IT is obviously the duty of every man who has engaged another person as a servant, to receive such person into his service, and if he refuses to do so without any good reason for his refusal, such person may maintain an action against him for that breach of contract $(a)$. Thus, where the defendant agreed to take the plaintiff, who was a shepherd, into his servant at certain wages for the next lambing season, for five weeks next ensu[*183] ing after the 28th *February then next, but afterwards refused to allow him to enter into his service, the plaintiff recovered.damages in an action brought for such breach of contract on the part of the defend. ant (b). To sustain this action, however, it would (c)

(a) Bracegirdle v. Heald, 1 B. \& Ald. 722, ante, p. 38 ; Blogg v. Kent, 6 Bing. 614. Where there is only one copy of the contract of hiring, the Court will compel the party in whose possession it is to produce it to the other party, $i b$.

(b) Clarke v. Allatt, 4 C. B. 335.

(c) Bracegirdle v. Heald, 1 B. \& Ald. 722. As to the requisites of the contract, see ante, Chap. II. 
of course be necessary to prove a legally-binding contract of hiring and service. It is obvious that what would be a good reason for discharging a servant would be an equally good reason for refusing to receive him into one's service, after having engaged to do so. But Conspiracy it is no answer to an action for not performing an to depart agreement to employ the plaintiff, that he has enterod into a conspiracy to depart from the agreement, unless the conspiracy has been acted upon $(d)$.

And where a person has entered into a binding agreement to take another into his service on a future day Action may mut to brought but before that day arrives, announces his intention not before the to do so, he is entitled to bo believed, and tho servant day for commay thereupon immediately bring an action againsthim, mencement and is not bound to wait till the day arrives to see if the master will change his mind. In a case (e), there-Hochster $\mathrm{v}$. fore, in which a gentleman in April engaged a courier De la Tour. to accompany him on a tour for three months on the continent of Europe, to commence on the 1st of June, but in May wrote to say he had ehanged his mind, and declined the courier's services, and the courier thereupon in May commenced an action against him, and afterwards, before the 1st of June obtained another engagement, on equally good terms, but not commencing till 4th of July; it was held that the courier was entitled to recover, although it was objected, and very powerfully contended, that the plaintiff was *bound to remain ready and willing to perform [*184] the contract till the day when the actual employment was to begin, and that there could be no breach of the contract before the 1st of June. And Lord Campbell, C. J., said : "The man who wrongfully renounces a contract into which he has deliberately entered, cannot justly complain if he is immediately sued for a compensation in damages by the man whom he has injured; and it seems reasonable to allow an option to the injured party either to sue immediately or to wait till the time when the act was to be done, still holding it as prospectively binding for the exercise of this option, which may be advantageous to the innocent party, and

(d) Hemingway v. IIamilton, 4 MI. \& W. 115. See the pleadings Mercer $\mathrm{v}$. Whall, 5 Q. B. 447.

(c) Hochster Y. De la Tour, 2 E. \& B. 678; see also Avery v. Bowden, 5 E. \& B. 728 ; 6 E. \& B. 953 ; 26 I. J., Q. B. 3 ; Danube and Black Sea Railuay, \&c. Co. v. Xenos, 31 L. J., C. P' 44, 284 ; Frost v. Kuight, 41 L. J., Exc. 78; I. R., 7 Fxc. 111. And see as to damages, Roper v. Johnson, 42 L. J., C. P. 65 ; L. R., 8 C. P. 167.

11 Mas. \& Strm 
Damages. cannot be prejudicial to the wrongdoer. An argument against the action before the 1st of June is urged from the difficulty of calculating the damages ; but this argument is equally strong against an action before the 1st of September, when the three months would expire. In either case the jury, in assessing the damages, would be justified in looking to all that had happened, or was likely to happen, to increase or mitigate the loss of the plaintiff down to the day of trial."

If not It is conceived, however, that in such case if the serbrought and vant do not act upon the master's announced renunciaservant incapacitated, master may rescind. tion of the contract, and before the day arrives for the commencement of the service, becomes either by the act of God, vis major, or his own misconduct or misfortune, incompetent or unable to perform his part of it, the master would be at liberty to avail himself of those circumstances to rescind the contract, and could not afterwards be sued for a breach of it $(f)$.

Dutr of It is also a duty of a master to retain the servant master to retain servant. during the whole time that he has contracted to do so ; and if he dismiss the servant before the expiration of [*185] that *period without lawful cause $(g)$, the servant may maintain an action against him for such wrongful dismissal.

Conrt of

Chancery will not grant injuncto compel master to retain servant $(h)$.

Where a servant is dismissed by his master during the period of service agreed upon, for alleged misconduct or other cause, the Court of Chancery will not interfere by injunction $(i)$ to restrain the master from so doing, but will leave the servant to his action at law. In a case $(k)$, therefore, in which Lord Cranworth, V.-

(f) See Avery v. Bowden, 5 E. \& B. $714 ; 6$ E. \& B. $953 ;$ Rcid v. Hoskins, 5 E. \& B. 729 ; 6 E. \& B. 953 ; see also Bartick r. $B u b a, 26$ L. J., C. P. 280 ; Crookencit v. Fletcher, 26 L. J., Exc. 153 ; Roberts v. Brett, 28 L. J., C. P. 323 ; Frost v. Kniglit, 41 L. J., Exc. 78 .

(g) See the preceding Chapter as to what causes will justify the dismissal of a servant.

(h) Or to dischage an apprentice; Webb v. England. 29 Beav. 44.

(i) See ante, p. 132. The Court of Chancery will not grant specific performance of a contract of agency, Chinnock v. Sininsbury, 30 L. J., Ch. 409; nor of a contract of partnership, Scett $\mathrm{v}$. Rayment, 38 L. J., Ch. 48 . Where the master is a trustee, however, as in the case of trustees of a school, the Court of Chancery will sometimes, on a fit case being made out, interfere. See Willis $v$. Child, 13 Beav. 117; 20 L. J., Ch. 113, where Lord Langdale, M. R., granted an injunction to restrain the trustees of a charity school from discharging the master; and see Doe v. Willis, 5 Exc. 894; Daugars v. Rivaz, 29 L. J., Ch. 685; Hayman v. The Governing Body of Rugby School, 43 L. J., Ch. 834; L. R., $18 \mathrm{Eq}$. Rep. 28.

(k) Stocker v. Brockelbank, 20 L. J., Ch. 408. 
C., granted an injunction to restrain a lucifer match Stoker $\mathrm{v}$. manufacturer from discharging his manager, who was Brockeltank. appointed under a written agreement, Lord Truro, L. C.,on appeal, dismissed the order, saying, "He did not recollect any instance of any attempt on the part of a court of equity to compel the employer to retain the servant, agent, or manager, and not to forbear to leave him to his remedy at law. Consider," added his lordship, "what the effect would be; how is it possible for an employer or an agent to go on in the intimate connexion which such a contract is calculated to create? They are to be on the same premises, acting in the management of the same business, in this case, and if there is mutual dissatisfaction, well or ill-founded, it is perfectly clear that a management conducted under such eircumstances, must tend very much to the prejudice of the concern-in this case, I think, particularly."

Similar reasons were given by Liord Justice Knight Bruce, in refusing an iujunction to restrain a railway company from discharging a contractor $(l)$.

*The nature of the service to be rendered in [*186] that case may (without entering into particulars) be Shrexsbury, described in the words of the first half of the fifth sec- \&e. Railway tion of the contract, viz., "that the said contractors Company. will from time to time at all times during the term of this contract run and work all the trains of the railway company, and provide, for the purposes of this contract, a sufficient number of efficient foremen, mechanics, engine-drivers, firemen, cleaners, store-keepers and other persons, and the requisite coke and firewood, oil, tallow, \&c. and other materials of the best quality." And Knight Bruce, L. J., said, "We are asked to com. pel one person to employ against his will, another as his confidential servant, for duties with respect to the due performance of which the utmost confidence is required. Let him be one of the best and most competent persons that ever lived, still, if the two do not agree, and good people do not always agree, enormous mischief may be done. A man may have one of the best domestic servants, he may have a valet whose arrangement of clothes is faultless, a coachman whose driving

(l) Johnson v. The Shrcusbury and Birmingham Railway Co., 3 De G., M. \& G. 914; 22 L. J., Ch. 921; 17 Jur. 1015, ante, p. 132; see also Chaplin v. North Western Railuay Co., 5 L. T., N. S. 601. As to how far the Court of Chaneery will interfere with the decision of shareholders in a joint-stoek eompany as to incompetency of offieers, see Inderwick v. Sncll, 2 Hall \& Twells, 419; 19 L. J., Ch. 542; 2 M'N. \& G. 216. 
is excellent, a cook whose performances are perfect, and yet he may not have confidence in him; and while on the one hand all that the servant requires or wishes (and that reasonably enough) is money, you are on the other hand to destroy the comfort of a man's existence, for a period of years, by compelling him to have constantly about him, in a confidential situation, one to whom he objects. If that be so in private life, how important do these considerations become when connected with the performance of such duties-duties to society -as are incumbent upon the directors of a company like this."

Ogden v.

And, upon similar principles, where the defendant Fossick.

Where contract determinable by notice or payment of wages and servant discharged, wages become a debt from master

and subject of set-off. agreed to grant a lease to the plaintiff of a wharf and [*187] *premises, and the plaintiff agreed to employ the defendant as manager at the wharf at a salary and commission, the agreement providing that the employ. ment should be co-extensive with the tenancy, a specific performance of the contract was refused by the Lords Justices (reversing the decision of the V..C.), on the ground that the contract was one entire contract and could not be divided, and as they could not enforce performance of the contract for personal services, they could not enforce the rest of the contract which depended upon it $(m)$.

Before proceeding to consider the remedies for a servant urongfully discharged, it may here be observed, that where the contract of hiring is determinable by notice or payment of salary (e.g., by a month's notice or payment of a month's salary), and the master discharges the servant at a moment's notice, the servant in such case being discharged rightfully, in accordance with the contract, the amount of salary agreed to be paid in lieu of notice (e.g., a month's salary) becomes a debt due from the master to the servant, and may be sued for as such, or set off by the servant in any action brought by the master against him to which a set-off can be pleaded. Where, therefore, a clerk to a railway company $(n)$, under an agreement for a salary of $140 l$. a year, determinable by three months' notice, or payment of three months' salary, was summarily discharged by the company, who sued him for money had and received to their use, it was held that he was entitled to set off against their claim the amount of three months'

(m) Ogden v. Fossick, 32 L. J., Ch. 73; see also Peto v. Brighton, \&c. Railway Co. 32 L. J., Ch. 677; 1 Hemm. \& M. 468.

(n) East Anglian Railway Co. v. Lythgoe, 2 L., M. \& P. 221 ; 10 C. B. 726 ; 15 Jur. 400 . 
salary which became due eo instanti that he was discharged ; Maule, J., saying, "It is clear that where there is an agreement to pay a certain sum in a certain event, an action of debt will lie for the recovery of that sum, which becomes a debt as soon as the event happens; and it is the proper subject of set-off."

*And an action to recover a smaller sum than [*188] Might 20l. upon such a claim, might formerly have been tried formerly before the ${ }^{\circ}$ sheriff, under $3 \& 4$ Will. 4 , c. 42, s. $17(o)$; be tried bewhilst, as we shall presently see, an action for wrongful discharge, being a claim for unliquidated damages, could not be tried before the sheriff under that statute.

\section{Remedies for Servant wrongfully Discharged.}

A servant wrongfully discharged has the two following remedies open to him at law, either of which he may • pursue immediately on his discharge $(p)$ :-

1. He may treat the contract of hiring and service as Twofold. continuing, and bring a special action against his master for breaking it by discharging him; and this remedy he may pursue whether his wages are paid up to the period of his discharge or not; or,

2. If his wages are not paid up to the time of his discharge, he may treat the contract of hiring and service as rescinded, and sue his master on a quan-

(o) Hation v. Macready, 2 D. \& L. 5. Sect. 17 was repealed by $30 \& 31$ Vict. c. 142, s. 6.

(p) P'agani v. Gandolfi, 2 C. \& P. 370 ; see 2 Smith's L. C. 40 , note to Cutter v. Powell. It is there stated as the result of the authorities, that a servant wrongfully discharged has his election of threc remedies, viz., the two spoken of in the text, and also "he may wait till the termination of the period for which he was liired, and may then, perhops, sue for his whole wages in indebitutus assumpsit, relying on the doctrine of constructive service:" in support of which Gandell v. Pontigny, 1 Stark. 198; 4 Campb. 375, and Collins v. Price, 5 Bing. 132, are cited. But it is also alded, "vide tamen, the observations of the judges in Smith v. Irayeard, 7 A. \& E. 544." It is conceived, however, that this third course camnot be adopted, and that the cases which appear to support it must be ensillered to be overruled. See Fovings v. Tisdal, 1 Exc. 295 ; Eldertom v. Emmens, 6 C. B. $160 ; 13$ C. B. 508; Goodman Y. Poeock, 15 Q. B. 576 ; Brckham v. Drake, 2 Ho. Lords Cases, 606, where Erle, J., said, "When a promise for continuing employment is broken loy the master, it is the duty of the servant to use diligence to find another employment." Sce per Crompton, J., iu Elderton v. Emmens, 13 C. B. 508; and see (ith edit. Snith's L. C., vol. 2, p. 41. See also Barnslcy v. Taylor, 37 L. J., Q. B. 39. 
Action for wrongful discharge preferable.

First, of the action for wrongful discharge.

tum meruit for the services he has actually rendered $(q)$.

[*189] *The former of these, however, is the remedy more usually adopted, and it is the preferable one, as, in the latter case, the action is founded on an implied contract arising out of actual services, and no such contract arises by implication of law upon a simple dissolution of a special contract of hiring and service $(r)$; and though a jury are at liberty to imply such a contract from circumstances $(s)$, and probably would in most cases do so, yet they are not bound to do so, and could only imply a contract to pay wages for the services actually rendered. And, therefore, in the latter form of action, a servant could only recover wages up to the time of his discharge. Whilst in the former case the action being founded on a contract, which the law would imply on the part of the master, to indemnify the servant against all such damages as he had sustained by reason of the master's breach of contract in discharging the servant, and not allowing him to perform his part of the contract; the servant, if he recovered at all, would recover something beyond the amount of wages due at the period of his discharge $(t)$.

First. Of the action for wrongful dismissal $(u)$. The right of a servant, wrongfully discharged, to maintain this action does not depend on the question whether or not his wages are paid up to the period of his discharge. It is utterly irrespective of that. In this action the servant seeks compensation, not for services [*190] he has rendered *previous to his discharge, but for the injury he has sustained by such discharge in

(q) Lilley v. Elıcin, 11 Q. B. 755; Planche v. Colburn, 8 Bing. 14 ; Archard v. Horner, 3 C. \& P. 349.

(r) Lamburn v. Cruden, 2 M. \& G. 253.

s) Ib.; and see Thomas v. Williams, 1 A. \& E. 685 ; and Planche v. Colburn, 5 C. \& P. 61.

$(t)$ See further as to damages, post, p. 194.

(u) As to the form of the declaration, see Lush v. Russell, 4 Exc. $637 ; 7$ D. \& L. 228. In Stirling v. Maitland, 34 L. J., Q. B. 1, the defendant, who had covenanted that if he "displaced" the plaintiff he would pay him a sum of money, having afterwards transferred the whole of his business to another, was held liable to pay the plaintiff the sum specified. In Crocker v. Molyneux, 3 C. \& P. 470 , it was held, that a serrant who was hired at thirty gnineas a year and a suit of clothes, and was provided with a livery, but was dismissed without sufficient cause before the end of the year, could not maintain trover for the livery against his mistress, the property in it being in his mistress, who provided it, and that his remedy was an action for not being allowed to serve to the end of the year and so to become entitled to the livery. 
not being allowed to serve and earn the wages agreed upon $(x)$.

In this form of action, indeed, the plaintiff cannot How wages recover wages due $(y)$ for the period during which he for actual has actually served. These wages must be recovered service before on the count for wages, which may be added to the discharge to count for wrongful dismissal.

Therefore, where $(z)$ in an action for wrongful dis- Harlley $\mathrm{v}$. missal, it appeared that the defendant was chairman of Harman. a company by which the plaintiff was retained in the capacity of superintendent of works, "the salary to be at the rate of 150 guineas per annum, either party to have the option of terminating the engagement by giving one month's written notice," and that at the end of eighteen months the plaintiff was dismissed without notice, no wages having been paid him, and a month after dismissal the plaintiff brought his action upon the agreement, stating, as the breach of it, that the defendant would not continue the plaintiff in his employ till the expiration of such month's notice, but dis charged him in the middle of a year, without notice, but the declaration did not contain the common count for wages; it was held that the plaintiff could not, without that count " which he might have added), recover anything more than a month's wages, the loss of them being the damage he had-sustained by not having received the month's notice agreed upon.

The defendant having entered into a contract with Taylor $\mathbf{v}$. the Lords of the Admiralty, to provide a steamer for Laird. exploring the Niger, wrote to the plaintiff, "I am willing to give you the command of the steamer destined for an exploring and trading voyage up the river Niger and its tributaries. Your pay to be at the rate of $50 l$. per month, commencing from 1st December, 1853, and a commission of 20 per cent. *on the net pro- [*191] ceeds of the produce you may bring down." Plaintiff replied, "In answer to your letter, offering me the command of the vessel to go out on a trading and exploring voyage to the river Niger and its tributaries, at $a$ fixed pay of $50 l$. per month, and 20 per cent. on the net proceeds of the goods obtained, I beg leave to say I accept the service and the terms you mention." The vessel went $u p$ the Niger as far as $D$., when plaintiff

(x) See Elderton v. Emmens, 6 C. B. 187; and Bcckham v. Drake, 2 Ho. Lords Cas. 606.

(y) Bee Goodman v. Pocock, post, that he may recover damages for service during a broken period.

(z) Hartly v. Harman, 11 A. \&. E. 798. 
refused to proceed further, and abandoned the command: it was held that this was not an entire contract for the whole voyage, but one which gave a cause of action for each month's salary as each month accrued, which once vested was not divested by plaintiff's desertion or abandonment of his contract. And Pollock, C. B., said, "If this meaning is not given, the result would be, that had the plaintiff died, or the voyage failed at the last moment, nothing would be payable by the defendant, because, according to his contention, the performance of the entire work contracted for was a condition precedent to the right to receive anything. This cannot have been intended" $(a)$.

Where wages But a servant, whose wages are payable at stated payable at stated periods, and action brought for wrongful discharge, wages for broken period of service must be included in the damages. periods, as quarterly, and who is wrongfully discharged between those periods, as in the middle of a quarter, may, in this form of action, recover wages for the period of service which has elapsed since the last period. ical payment of his wages, in the shape of damages for his master's breach of the contract between them. And if he elect to bring this action for his wrongful discharge, and wages for the broken period of service are not included in the damages recovered in it, he cannot afterwards recover them in an action for wages, as the action for wrongfnl discharge treats the contract of hiring and service as still in existence, while the action for wages earned in a broken quarter treats it [*192] as rescinded. And the servant cannot* do both; that would be allowing him to blow both hot and cold $(b)$.

In order to enable a servant to maintain this action,

To snstain this action he must be ready and willing to continue in his masservant must ter's service at the time he is discharged $(c)$. Ready be ready and does not imply willing $(d)$, but ready and willing
willing to serve; implies disposition, capacity and ability $(e), i$.e., not physical ability $(f)$, but freedom from any other

(a) Taylor ₹. Laird, 1 H. \& N. 266.

(b) Goodman v. Pocock, 15 Q. B. 576; 19 L. J., Q. B. 410. Therefore, if the declaration contain a connt for wages as well as one for wrongful discharge, the plaintifi must be carctul to take a verdict on one only of those counts, not on both; see per Coieridge, J., $i b$.

(c) See 2 Wms. Saund. 351 et seq., notes to Peters v. Opie.

(d) Granger v. Dacre, 1 D. \& L. 573; 12 II. \& W. 431.

(e) De Hedina v. Norman, 2 Dowl.. N. S. $239 ; 9$ M. \& W. 827; Wallis r. Warren, 4 Exe. 364; Griffith v. Selby, 9 Exc. 394.

$(f)$ A servant, who is ill, may nevertheless be ready and willing to serve, and a traverse of readiness and willingness, though a good plea on demurrer, would not be proved by evidence of servant's illness. Cuckson r. Stones, 28 L. J., Q. B. 25, ante, p. 153. (230) 
inconsistent engagement. For if the servant enter the service of another before his discharge, and is thereby disabled from serving his first master in the manner contracted for, he could not be said to be ready to serve him $(g)$, and upon a traverse of that averment, his but need not action would be defeated. But although it is necessary offer; that he should be ready and willing and able to serve his master in order to enable him to sue his master for a wrongful discharge, it is not necessary that he should offer to do so $(h)$, if he can prove bis readiness, \&c., in any other way. It is obvious, however, that an offer to discharge his duty is the best proof of his readiness to do it. And as readiness and willingness is a matter that is within his own mind only tho mastor ought at give least to have notice of it $(i)$.

Where the contract of hiring is defeasible, and either by *express agreement or by the custom of the [*193] trade, business or occupation to which it relates may be deternined by notice, care must be taken not to sue upon it as upon an absolute contract, or the action may be defeated on a plea of the general issue $(k)$.

Where a declaration in an action for wrongful dis- Hart $v$. missal stated an absolute hiring for a year, the defend- Demy. ant was not allowed to plead, together with pleas in bar of the action, a plea varying the contract by stating it to be determinable on three months' notice and determined; and payment into court $(l)$.

Where an action for wrongful discharge (the declara- where action tion in which also contained counts for wages and work referred, and labour, \&c.,) was referred to an arbitrator, who award of awarded to the plaintiff a sum of money equivalent in arbitrator a amount to the plantif a sur recivo from the dof was common bitrator for any compensation in damages for the dismissal, except so far as the special count in the declaration, and the evidence of the employment and dismissal,

(g) Spotswood v. Barrow, 1 Exe. 804; 5 D. \& I. 373, where a plea that the plaintiff' entered the service of another was held bad on speeial demurrer, as being an argmmentative traverse of his realiness to serve the defendant.

(h) Wellis v. Warren, 4 Exc. 361; 7 D. \& L. 58; and see Levy ๖. Lord Herbert, 7 Taunt. 314. But see Wilkinson v. Gaston, $9 \mathrm{Q}$. B. 137.

(i) See Doogoon v. Rose, 9 C. B. 137; see also Armitage v. Insoles, 14 Q. B. 728.

(k) Metzuer v. Bolton, 9 Exc. 518; Parkev v. Ibbetson, 27 L. J., C. P. 236 ; ante, p. 58 .

(l) Hurt v. Denny, 4 H. \& N. 609. 
might amount to such a claim; it was held that the plaintiff could not afterwards sustain another action for compensation in damages, in consequence of the dismissal from the defendant's employ, before the end of the year, but that the award of the arbitrator was a bar to such action $(m)$.

Defence, that If, in an action for wrongful discharge, the defence discharge was insisted on is, that the defendant was justified in disjustifiable, charging the plaintiff, such defence must be specially must be pleaded. [*194] pleaded $(n)$, *and cannot be given in evidence under the general issue (o). And so in an action for wages upon an implied contract, a defendant who has only pleaded the general issue, cannot go into evidence of misconduct, except such as goes to show that there was no implied contract to pay wages $(p)$,

Damages. The amount of damages which a servant would recover in an action for wrongful discharge, must, of course, depend on the nature of the contract, and the wages agreed to be paid. In the case of a domestic or menial servant $(q)$, or where there was an express agreement for a month's notice $(r)$, it would be a month's wages; but, generally speaking, the amount of damages is a question for the jury to determine. And in a case $(s)$, in which a clerk, who had been hired for two years, was wrongfully dismissed after about one quarter's service, and then brought his action for such wrongful dismissal, and the jury awarded him a sum equal to twelve months' salary, the Court of Common Pleas refused to interfere, not considering the damages excessive. Where no specific wages have been agreed upon, the measure of damages is obtained by considering what is the usual rate of wages for the employ-

(m) Dunn v. Murray, 9 B. \& C. 780.

(n) Where, to an action for wrongful dismissal, the defendant pleaded that the plaintiff misconducted himself, without this that the defendant dismissed him without reasonable cause, upou which plea the plaintiff joined issue; it was held that the plaintiff's misconduct, as well as the fact of his dismissal, was in issue. See Lush v. Russell, 5 Exc. 203; 1 L. M. \& P. 369. But see Powell v. Bradbury, 7 C. B. 201 ; Horton v. II'Murtry, 29 L. J., Exc. 260.

(o) Speck v. Phillips, 5 M. \& W. 279. See the preceding Chapter as to what causes will justify the discharge of a servant. In Hoggarth v. Taylor, 36 L. J., Exc. 61, it was held, that a composition deed under the Bankruptcy Act, 1861, was a bad plea to an action for wrongful dismissal, inability to pay unliquidated damages not being a debt within the act.

(p) Cooper v. JWhitehouse, 6 C. \& P. 545.

(q) Fewings v. Tisdal, 1 Exc. 295.

(r) Hartley v. Harman, 11 A. \& E. 798.

(s) Smith v. Thompson, 8 C. B. 44. 
ment contracted for, and what time would be lost before a similar employment conld be obtained $(t)$.

In a case where $(u)$ the defendants, directors of a servant mining * company in South America, agreed to [*195] employed employ the plaintiff as superintendent of mines for abroad, three years, at a salary increasing yearly, and the di- expenses of rectors were at liberty to dissolve the agreement at any time on giving the plaintiff twelve months' notice, or return home. French $\mathbf{v}$. paying him twelve months' salary in lieu of such notice, and a reasonable sum towards defraying his expenses to England; and if the plaintiff served the three years, he should be entitled to the expenses attending the return of himself and his family, and the directors dismissed him before the expiration of the second year, without giving him notice or paying him the year's salary: it was beld, that he was only entitled to one year's salary from the date of his dismissal, and to his own expenses for his return to England; and the jury having found for these sums only, the court refased to increase the verdict by adding expenses incurred by the plaintiff for the return of his family, or for the salary which would have accrued from the time of his dismissal to the end of the third year, when his service would have terminated.

When an action for wrongful discharge has been brought, and damages recovered and paid, no fresh action can be brought upon the same agreement $(x)$.

It may be convenient to mention here, although seamen's wages are not in general treated of in this book, that the High Court of Admiralty has jurisdiction to entertain a claim by seamen for wrongful dismissal and consequential damages $(y)$.

An action for wrongful dismissal, being a claim for unliquidated damages, was not triable before the sheriff could not be nnder $3 \& 4$ Will. 4 , c. 42 , s. 17 , which, as we have seen sheriff. $(z)$, is now repealed. The probable limit of the dam-

(I) See per Erle, J., in Beekham v. Drake, 2 Ho. Lords. Cas. 606. In Sowdon v. Mills, 30 L. J., Q. B. 176, Blackburn, J., said-"If an action is bronght by a servant for a wrongful dismissal soon after the dismissal, the judge tells the jury they must speeulate on the chance of his getting a new place and base their damages on that. If the action is delayed till the man has got a place, what was matter of speeulation before becomes eertiin then, and the jury calculate accordingly." See also as to damages, M'Kean v. Concley, 7 Law 'T., N. S. 828.

(u) French v. Brooke, 4 M. \& I. 11 ; 6 ling. 354.

(x) Barnesley v. Taylor, 37 L. J., Q. B. 39.

(y) The Great Eastern, 36 L. J., Adm. 15.

(z) Ante, p. 188, note (o). 
ages did not render it the less a claim for unliquidated Costs. [*196] damages (a). *And the costs could not be taxed on the lower scale given by the directions to the taxing officers, Trin. Term, 7 Vict., though the plaintiff recovered less than $20 l$. $(b)$.

Of the Common Action. for Whages brought by a Servant W rongFully Discharged.

Of the action for wages by servant wrongfully discharged.

Amonnt recoverable in this action.

When this form of action cannot be brought.

This form of action treats the contract of hiring and service as rescinded. The ground on which a servant wrongfully discharged may support it is one equally applicable to all contracts, viz., that when one party to a contract has absolutely refused to perform something essential on his side of the contract the other party is at liberty to rescind it, and sue for what he has already done under it upon a quantum meruit (c).

Where the servant elects to pursue this remedy immediately on his discharge, he can only recover wages for the period during which he has actually served (d). And it is conceived that even if he wait till the expira. tion of the period for which he agreed to serve, and then bring an action in this form, he cannot recover any more $(e)$.

And when a servant has refused to treat the contract of hiring and service as rescinded by his wrongful discharge, and has brought a special action against his master for such wrongful discharge, he cannot afterwards treat the contract as rescinded, and sue in this form of action for his wages during a broken quarter; they must be recovered in the special action, or not at all $(f)$.

(a) Jacquot v. Boura, 5 M. \& W. 155; Lismore v. Beadle, 1 Dowl., N. S. 566.

(b) Walther v. Mess, 7 Q. B. 189.

(c) See 2 Smith's L. C. 34, note to Cutter v. Poucll, where the cases are collected ; Planche v. Colburn, 8 Bing. 14; Archard v. Hormer, 3 C. \& P. 349 ; Smith v. Hayearl, 7 A. \& E. 544 ; Forings $\mathrm{v}$. Tisdal, 1 Exc. 295. See also Robins $\mathrm{v}$. Pover, 27 L. J., C. P. 257 ; Preskitt v. Badger, 1 C. B., N. S. 296 ; Berwick v. Horsfall, 31 L. T. 117.

(d) Smith v. Hayward, 7 A. \& E. 544 ; Fexings v. Tisdal, 1 Exe. 295. See as to the form of particulars of plaintiff's demand, IFarris v. Montgomery, 2 L. M. \& P. 425; Hurcum v. Stericker, 10 M. \& IV. 553.

(e) Ante, p. $18 \%$, note $(p)$.

(f) Goodman r. Pocock, 15 Q. B. 576. 
* Of the Duty of the Master to Pay the Ser- [*197] vant his Wages, and the Servant's Remedies to RECOVER THEM.

\section{Default; Bankruptcy; Death; of Master. Default; Death; of Servant.}

Unless the circumstances under which services of The master any sort have been rendered by one person to another are is not bound such as to afford evidence of a contract, either express to pay wages or implied, on the part of the person served to pay for unless he has them, there is no duty binding him to do so; and it is contracted clear that the servant cannot maintain any action for wages for such services $(g)$.

Upon this principle Lord Mansfield always non- Slares nonsuited slaves who had been brought over to England suited. and commenced actions for wages $(h)$. And where a person, who had been a slave in the West Indies on an estate belonging to a lady, came over with her to EngAlfred v. land, and continued in her husband's service in England, Lord Kenyon held, that he could not maintain any action for wages against the husband, without some evidence of a promise by him to pay them, as there was no original contract of service for wages $(i)$.

And so where a man and wife lived with his brother, Brothers and assisted him in carrying on his business, it was living held to be clear that he and his wife were not entitled together. to be paid for their services, unless the jury were satis- Davies v. fied that there was a contract express or implied on the part of the defendant to pay for such services $(k)$.

*So it has been held in America, that where [*198] an unmarried daughter above twenty-one remained with her father, and nothing was said about wages, no contract to pay wages could be implied (l).

And a sailor, sent by his captain to assist a vessel eground, could not sue the owner for his services $(\mathrm{m}$.)

In a case where the plaintiff had given certain gra-

(g) See Foord v. Morley, Fost. \& F. 496. The mere existence of a valid contract of hiring and service does not necessarily imply a contract to pay wages; as it often hapens with boys and others that their board, lodging and clothes, together with the opportunity of learning their master's business, or the latter consideration alone, is a sufficient compensation for their services. See $R$. v. Shinficld, 14 East, 541.

(h) $R$. v. Thames Ditton, 4 Doug. 300.
(i) Alfred v. Fitzjames, 3 Esp. 3.
(k) Davies v. Davies, 9 C. \& P. 87.
(l) Green v. Roberts, 47 Barb. 521 .
(m) Lipson v. Harrison, 22 Law T. Rep. 83. 
Contract to pay for expected services where no contract to render them.

Gorgier v. Morris.

So master not bound to pay increased wages, for increased labor, unless he has contracted to do so.

Bell v.

Drummond. Clutterbuck $\nabla .(q)$. Though it would be otherwise if C. originally inCoffin.

Contracts with sailors to pay increased wages void; future expected services, the defendant promised to give plaintiff some shares in a company, but the plaintiff did not contract, and was not under any obligation, to render any services; it was held, that the mere expectation of future services was not a valid consideration, and therefore there was no contract binding on the defendant $(n)$.

Upon similar principles it is equally clear, that where a stipulated remuneration has been agreed upon, the servant has no claim to additional remuneration on the mere ground of his performance of additional ser. vices; unless he can prove some contract, either express or implied on the part of his master, to pay him an increased salary for his additional services, he can recover no rewuneration for them (o). Thus, where a clerk to the commissioners of land-tax employed the plaintiff as his deputy at a salary of $100 l$. a year, and on new duties being imposed, which gave the clerk additional work, the plaintiff also performed that, it was held, that he was not legally entitled to any additional salary on that account: Lord Kenyon observing, that if he was, every porter in a shop, or clerk in an office, would, upon an increase of his master's business, be equally entitled to demand an increase of wages $(p)$.

[*199] *And where A: is B.'s servant, a promise by C. to pay $A$. additional wages would be void, as being without consideration, all his services being sold to $\mathbf{B}$. duced A. to enter B.'s service by a promise of wages, in additon to those paid by B. $(r)$.

And so where a sailor was under articles for a voyage out to M. and home, and on arrival at M. the captain, in consequence of the desertion of some of the crew, promised him double wages to induce him to remain, it tuitous services, and afterwards, in anticipation of was held that he could not sue the shipowners for such double wages, as he was not free from his original con-

(n) Gorgier v. Morris, 29 L. J., C. P. 208.

(o) If duties of a different nature and a different class from those he contracted to perform are required from a servant he should be paid accordingly.

(p) Bell v. Drummond, Peake, 45; and see Harris v. Watson, Peake, 72; Stilk v. Myrick, 2 Camp. 317; Frazer v. Hatton, 26 L. J., C. P. 226. The real ground upon which these cases are decided is, that there is no consideration for the promise to pay additional wages. See also Latham v. Edinburgh and Glasgow Railway Co., 4, 3rd Ser. 1084.

(q) Carter v. Hall, 2 Stark. 361, ante, p. 3.

(r) Clutterbuck v. Coffin, 3 M. \& G. 842. 
tract $(s)$. But if anything had occurred to set him free unless free from his articles, as if the prosecution of the voyage from original would be dangerous to life, in which case he would not articles. be bound to proceed at the risk of his life $(t)$, in such case a sailor might sue for a promised increase of wages $(u)$.

Where a vessel is bonâ fide abandoned at sea by order of the master for the purpose of saving life, and the of abandoned contract entered into with the mariners is thereby put ressel enan end to, they may become entitled to be rewarded as titled to salvors, though the crew in general, being bound to exert salvage. themselves to the utmost without extra remuneration, are not entitled to salvage $(x)$.

It has been held, that upon a simple dissolution of a There is no special contract of hiring and service, no new contract implied conarises, by implication of law, in respect of services per- tract to pay formed under such special contract, previously to its being so dissolved $(y)$.

Where, therefore, the plaintiff was engaged as super* inter contract. *intendent of packets in the service of a steam- [*200] Lamburn $\mathbf{v}$. boat company at a yearly salary, payable quarterly, Cruden. and a month after the termination of one of the years of the service, tendered his resignation, which after another month was accepted, but nothing was said about remuneration for the time elapsed since the termination of the last year's service, it was held that the law would not imply an engagement to pay for the services performed during that time, but that it ought to have been left to the jury to say whether the parties had come to an agreement that those services should be paid for. In fact it may be said to be a question for a jury in all cases where services have been rendered without any express contract to pay for them, whether or not there was an implied contract to do so.

In such cases the defendant may give such evidence as goes to show that the circumstances, from which the as goes to show that the circumstances, from which the Evidence to
plaintiff would induce a jury to imply a contract to pay rebut inferwages, do not warrant any such inference; as that the ence of implaintiff cohabited with him, since that goes to show plied conthat the contract was not one of hiring and service, but

Whether or not there is an implied contract to pay wages is a question for a jury. tract.
(3) Harris v. Carter, 3 E. \& B. 559.
(t) The Araminta, $18 \mathrm{Jur} .793$
(u) IIartley v. Ponsonby, 26 L. J., Q. B. 322. And see Manson จ. Royden, 37 L. J., C. P. 69.
$(x)$ The Florence, 16 Jer. 572; The Vrede, 30 L. J., Pr. Mat. \& Adm. 209. See this case, and also Neaman $v$. Walters, 3 Bos. \& I. G16, as to a passenger suing for salvage.
(y) Lainlium v. Cruden, 2 M. \& G. 253. 
of a different nature $(z)$. Or the defendsnt may show that the plaintiff misconducted himself in such a manner as to rebut any inference of an implied contract to pay for his services $(a)$. But unless such evidence shows that there was no implied contract at all, the plaintiff's misconduct should be specially pleaded. Both the plaintiff and defendant may also give evidence of the value of the services rendered $(b)$.

Where left to It sometimes happens that by the terms of the agreeemployer ment entered into, it is left to the employer to deterto decide mine whether or not any remuneration should be paid whether any [*201] for *services rendered, and, if any, what amount and what wages should be paid, should be paid $(\dot{c})$. In such cases, if it appear clearly to have beeen the intention of the parties that the employer should decide whether or not he would make any no action can remuneration for the services rendered, no action can be mantained unless he has promto pay.

Taylor v. Brewer. be maintained against him by the person employed, unless the employer has, after the performance of the work, expressly promised to pay something.

Thus, where a person performed work for a com. mittee under a resolution that any service to be rendered by him should at a certain time be " taken into consideration, and such remuneration be made as should be deemed right," it was held that no action would lie to recover remuneration for such work, as the person em. ployed threw himself upon the mercy of the committee, who were to judge whether he should have anything, and if anything, then how much $(d)$.

Roberts $\mathrm{v}$. So where $(e)$ the plaintiff wrote to the defendant and Smith. agreed to accept the appointment of secretary to a

(z) Bradshavo v. Hayward, Car. \&;M. 591.

(a) Cooper v. Whitehouse, 6 C. \& P. 345; Speek v. Phillips, 5 M. \& W. 281. See Monkman v. Shepherdson, 11 A. \& E. 411, where to an action for wages the defendant pleaded an agreement that the plaintiff should have none if he got drunk, \&c.

(b) Baillie v. Kell, 4 Bing. N. C. 638; Bird v. M'Gaheg, 2 Carr. \& K. 707 , post, p. 203 .

(c) The London Tramway Co. v. Bailey, 3 Q. B. Div. 217, where defendant became conductor of a tramway company and deposited $5 l$. as security for the discharge of his duties, \&c., and it was provided that the "manager of the company should be sole judge between the company and the conductor whether the company was to be entitled to retain the whole, or any part, of the $5 l$. and wages for the current week as liquidated damages, and that the certificate should be binding and conclusive evidence in all conrts of justice;" and it was held that the manager's certificate was final and conclusive; and that a magistrate could not make any further inquiry.

(d) Taylor v. Brewer, 1 M. \& S. 290 ; see Moffatt v. Dickson, 13 C. B. 575 ; Moffatt v. Laurie, 15 C. B. 583 .

(e) Roberts v. Smith, 28 L. J., Exc. $164 ; 4$ H. \& N. 321. 
joint-stock company at a yearly salary of $300 l$., "if the company be completely registered and put into operation; if not, I shall be satisfied with any remuneration for my time and labour you may think me deserving of, and your means can afford." The defendant, in replying, said: "It is distinctly agreed and understood that if the company is not formed and carried out, that part of your letter which alludes to your salary be null and void, and that at the expiration of three months it is entirely left to me to give *unto you such sum [*202] of money as I may deem right, as compensation for labour done, in the event of the company not being carried out." The company was never registerd or carried out. And it was held that the plaintiff could not sue the defendant for compensation for services rendered towards registering the company.

Upon the same principles no action would lie for a Gratuity at gratuity promised at the end of the year $(f)$, unless it end of year. were promised as part of the wages $(g)$.

And upon similar principles the Court of Queen's Bench have refused $(h)$ to grant a mandamus to a local Ex Marte Board of Health to pay a reasonable remuneration to a person who presided at the first election of the board, upon a suggestion that they had allowed only an inadequate sum; the board having, under the Public Health Act (i), a discretion as to what sum they think reasonable to allow, and the exercise of their discretion in this respect not being subject to review.

But if it appears from the agreement to have been If remunerathe intention of the parties that the servant should be tion intendremunerated $(j)$, but the amount of his remuneration

(f) See Parke; v. Ibbctson, 27 L. J., C. P. 236, ante, p. 58 ; see Allerson v. Mallizon, 49 L. J., C. L. 801 ; L. R., 5 Exe. Div. wages may $293 ; 50$ L. J., C. L. 460 ; L. R. 7 Q. B. I. $174 ; 52$ L. J., C. L. 737 ; L. R. $8 \Lambda_{\text {pp. }}$. Cas. 467 , which arose out of a promise to make a will in favour of a servant; see also post, 203, note $(n)$.

(g) Lake v. Campbell, 5 Law. T., N. S. 58:, where in an action for wrongful discharge, plaintiff, who was wrongfully discliarged before Lady-day, was held entitled to damages for loss of "a gift of 20l." promised if he remained till Lady-day: as the sum of 20\%. was not merely a gift, but a remuneration for work to be done, and calling it a "gift" lid not make it the less a remuneration. Pr. Erle, C. J., Williams and Willes, J. J.

(h) Ex parte Mictcalf, 6 E. \& B. 287.

(i) 11 \& 12 Viet. e. 63, s. 30.

(j) As is generally the ease where professional men are employed. In such eases, however, the onus lies npon the plaintiff to make out his (ase, if the employer raises a doubt whether the services were not to be gratuitous. Ifingcston v. Kelly, $18 \mathrm{I}$. J., Exe. 360. See Moffatt v. Laurie, 15 C. B. 583 . If services lave been rendered, it ought to be elearly and satisfactorily made 12 MAS. \& SER. ed, but amount not settled, fair be recovered.
wages may 
[*203] was not *settled, he will be entitled to recover upon the quantum meruit the fair value of his services, and the defendant may of course show that they were not so valuable as the plaintiff would make out $(k)$. Peacock v. Thus, where $(l)$ a law stationer said to his son on Peacock.

Bryant v. Flight. coming of age, "You shall have fifteen shillings a week till October; the books will then be made up and yon shall have a share; we need not talk of the share till October comes; we shall settle it then," Lord Ellen. borough held that the son was evidently enititled to a beneficial interest in the business, leaving the amount to be settled when the books should be balanced, and that the jury must consider what was a fair and just proportion for the father to give and the son to expect after what had passed between them.

So where $(m)$ A. agreed to enter into the service of $\mathbf{B}$., and wrote to him a letter as follows:- "I hereby agree to enter your service as weekly manager, commencing next Monday : and the amount of payment I am to receive I leave entirely to you;" and A. served B. in that capacity for six weeks; it was held (Lord Wensleydale, dissentiente) that the contract implied that $\mathrm{A}$. was to be paid something at all events for the services performed, and that the jury in an action on a quantum meruit might ascertain what B., acting bonâ fide, would or ought to have awarded.

And where $(n)$ a verbal agreement had been made on

ont that those services were not to be remunerated. Per Bramwell, B., in Brouning v. Great Centrat Mining Company, 291 .. J., Exe. 399. If the defendant put it out of the plaintiff's power to earn money agreed on, he would be liable to an action. Inchbald v. Western Neilgherry Coffee, \&e. Company, 34 L. J., C. P. 15.

(k) Baillie v. Kell, 4 B̈ing. N. C. 638.

(l) Peacock v. Peacock, 2 Campb. 45.

(m) Bryant v. Fright, 5 M. \& W. 114; but see Roberts v. Smith, 28. L. J., Exe. 164, ante, p. 201.

(n) Bird r. Ir'Gaheg, 2 Carr. \& K. 707. In this case evidence was admitted of the scientific skill of the plaintiff. See Baxter v. Gray, 3 M. \& G. 771 , where a surgeon, who had attended a patient in expectation of a legacy, was allowed to maintain an action for his services against the patient's executors, having been disappointed of his legaey. See also Hulse v. Hutse, 17 C. B. 711, which was an aetion on a promissory note given by a moribund uncle to a nephew who had been his clerk for many years at a guinea and 30s. a week; and had also rendered other services, which continued up to the death of the uncle. The question was whether there was any consideration for the note, and Jervis, C. J., said, "In order to make future services a good consideration for the giving of the note, we think it was inenmbent on the plaintiff to show that there was some contract for future services which might have been enforeed by the giver of the note if the reeipient omitted to perform it." Where a niece rendered services to her 
*behalf of a board of guardians with the sur- [*204] Bird v. geon, to attend a number of pauper children who had $M^{\prime}$ Galieg. been attacked by Asiatic cholera, for which he was to receive whatever remuneration the board of guardians should allow as right and proper, and he attended them for several weeks, after which the board tendered him $50 l$. as a remuneration : it was held by Maule, J., that he might maintain an action for what was right and proper, and left it to the jury to ascertain what the board, acting bona fide, ought to have awarded.

Where the plaintiff had by letter agreed that his sal- Raviins v. ary was to be paid only in the event of the success of Chaneller. the undertaking, it was held that there was evidence to go to the jury that the plaintiff had a right to receive something for his services $(o)$.

If either of the above questions depend upon the cer- If wages tificate of a third person, the obtaining such certificate depend on is in general a condition precedent to the right of the certificate of servant to maintain any action, and if it is withheld by the obtaining such third person even by fraud, no action for wages it is a condican be maintained by the servant. His remedy is an tion preceaction against the third person for withholding the cer- dent to right tificate $(p)$, as until he has spoken (even though his certificate is withheld unreasonably and capriciously $(q)$, no right can arise, which *an be enforced either [*205] at law or in equity $(r)$. In a case $(s)$ therefore, where the

uncle upon the fith of a codieil in her favor, which wasshown to her, but which was afterwards revoked, Stuart, V.-C., made a decree that the trusts of the codieil shonld be carried out. Loftusv. Maw, 32 J. J., Ch. 49. Bnt this ease was disapproved of in the House of lords in Mutdison v. Alderson, L. R., 8 App. Cas. 467 : see ante, 202, note $(f)$.

(o) Rawlings v. Chandler, 9 Exc. 687.

(p) See Morgan v. Bimie, 9 Bing. 673; Milner v. Finld, 5 Exe. 829 , which were eases of building contracts where the architect's certificate had not been obtained. See also Grufton v. Eastern Connties Railway, 8 Lxe. 699; Glenn v. Leith, 1 C. I. R. 569 ; Scott v. Avery, 5 Ho. Lords Cas. 811 ; Scott v. C'orporation of Liverpoot, 28 L. J., Ch. 230 ; Munro v. Butt, 8 E. \& I3. 738; Clarke v. Watson, 34 L. J., C. P. 148.

(4) Stallhart v. Lee, 32 L. J., Q. B. 75. If the endinet of the third person is inequitable and inmproper, or fraudulent in withholding the certificate, he would properly be male a party to a bill in equity for relief. Srott $v$. Corportion of Lircrpoot, $25 \mathrm{~L}$. J., Ch. 227 ; 27 I. J.. Ch. 041 ; 28 I.. J., Ch. 230 . See an action agtinst the employer eharging eollusion with the architect in withholling ecrtifieate: Butterlury v. Vyse, 32 L. J., Exe. 177; 8 I. T., N. S. 283. See also per Erle, C. J., in Clarke v. Watson, 34 I. J., C. P. 148, 150. And an aetion against the arehitect for withholling his eertificate, Ludbrook v. Barrett, 46 1. J., C. P. 798.

(r) The eertifirate need not be in writing, unless a written certificate is expressly required; Roberts v. Walker, 32 I. J., C. I'. 
Oxen :. plaintiff agreed to serve the defendant as apothecary's Bocen. $\quad$ assistant for one year gratuitously, and after that to receive such salary as C. should think reasonable, and it appeared that no application had been made to $\mathrm{C}$. to fix any salary, it was held that the plaintiff could not recover any salary.

Parment of By tbe Truck Act $(t)$, which does not apply to dowayes must mestic servants or servants in husbandry $(u)$, the paybe in current ment in certain trades of wages in goods, or otherwise and without and by "The Hosiery Manufacture (Wages) Act, 1874" stoppages. $(x)$, all wages the earnings of labour in the hosiery manufacture shall be made payable in net in the current coin of the realm, without any stoppages except for bad and disputed workmanship.

And not in public houses.

By "The Coal Mines Regulation Act, 1872" (y) and "The Metalliferous Mines Regulation Act, 1872" (z) the payment in public-houses, beer-shops, or other places in those acts mentioned, of wages to persons employed in or about any mines to which those acts apply, is prohibited. And by "The Payment of Wages in Public-houses Prohibition Act, 1883" (a), such prohibition is extended to the payment in public-houses, beer-shops, and other places in that act mentioned in England and Scotland of wages to all workmen as defined by that act.

Against $[* 206]$ *The action for wages should of course be whom action brought against the person by or for whom the plain. should be brought. tiff was hired. But it by no means necessarily follows that the person appointing to an office or situation is liable to pay the salary, e. $g$., in the case of collector of poor rates, the guardians appoint, but are not liable to

291. When given it is final: Goodycar v. Mayor of Weymouth, 1 Harr. \& Ruth. 67. See ante, p. 201, note (e). The damages in an action for withholding the certificate would be the vahe of the work done. See 31 L. J.. Q. B. 136.

(s) Owen v. Bowen, 4 C. \& P. 93.

(t) $1 \& 2$ Will. 4 , c. $3 \pi$. On the construction of this act, see Chawner v. Cummings, 8 Q. B. 311 (upheld in Areher v. James, 31 L. J., Q. B. 153 ; 1 Law Times, X. S. 26 ; Riley v. Warden, 2 Exc. 59 ; Sharman r. Saunders, 13 C. B. 166 ; Ingram v. Barnes, 26 L. J., Q. B. 82 ; 7 E. \& B. 115 ; Sleeman v. Barrett, 33 L. J., Exe. 153 ; Cutts v. Warl, 36 L. J.; Q. B. 161 ; Smith v. Walton, 47 L. J., M. C. 45 ).

(ii) Sect. 20. The trades to which it does apply are specificd in sect. 19, post. Appendix.

(x) 37 \& 38 Vict. c. 48 , post, Appendix.

(y) 35 \& 36 Vict. c. 76 , s. 16 , post, Appendix.

(z) 35 \& 36 Viet. c. 77 , s. 9, post, Appendix.

(a) $46 \& 47$ Vict. c. 31 , post, Appendix. 
be sued for the collector's salary, which is charged on Collector of the poor rate by $4 \& 5$ Will. 4 , c. 76 , s. $46(b)$.

poor rates.

Where a dissenting minister was appointed to a Minister chapel by part of the trustees, but received a notice appointed by discharging him and demanding possession of the trustees. chapel signed by all the trustees, upon which he sued Cooper v. them all for his salary, he was non-suited $(c)$. But in Whitehouse. the case of a servant engaged by one of several part. Servant to ners, all the partners would be liable if the contract partners. was mado in respect of the partnership $(d)$, although Beckhem $\mathrm{v}$. the contract was in writing (not being by deed), and Knight. signed by one only. However, where one proprietor of a newspaper contracted with a person to write articles Writer of for it, other proprietors, who were no parties to the newspaper. contract, cannot be made liable to pay the salary of such person by means of the statute $6 \& 7 \mathrm{~W}$ ill. 4 , c. $76(e)$.

And where $(f)$ the plaintiff himself was a promoter Projector and of a projected joint-stock company, it was held that he sccretary of could not sue a member of the provisional and manag- company. ing committee for salary alleged to be due to him for services as the secretary to the projected company. Mitson v. TisAnd Lord Wensleydale said :- "If it were a transaction among ordinary persons the evidence might be sufficient to make out a prima facie case against the persons who signed or sanctioned the employment of the party, that he was to be a paid secretary. But when we have the additional fact that he is *him. [*207] self one of the original promoters and projectors of the company, more evidence is necessary than in the case of a mere stranger ; and the question is, whether be is not so implicated in the scheme that all the acts of the provisional committee are to be considered as his acts, and consequently that he is one of his own employers. The provisional committee are a delegated body, acting for others ; and, prima facie, any contract they make is made on behalf of those who appointed them, and orders given by them are prima facie the orders of all the projectors, including the plaintiff. The plaintiff, therefore, was bound to give further evidence to show

(b) Smart v. Guardians of West IIam Imion, 10 Exe. 867.

(e) Cooper v. Whithouse, (; C. \& 1'. 5.t5.

(d) Beekham v. Knight, 1 M. \& G. 738 ; Droke v. Bcekham, 9 M. \& W. $79 ; 11$ M. \& W. 315 ; 2 Ho. Lords Cas. $579,623$.

(e) IIoleroft v. IIiggins, 2 C. B. 488.

(f) Hitson v. Viscount Curzon, 15 M. \& W. 532 ; see Holmes v. Miggins, 1 B. \& B. 7.4 Hilburn v. Cotd, 7 B. \& C. 419. A claim by one partner against his co-partner is the proper subject of an action in the Chancery Division. 
that the defendant meant to contract as a principal, independently of his acts as a provisional committeeman of the company. On the facts in evidence in this case no such intention appears."

Lucas $\mathbf{v}$. Beach.

However, where an express agreement with the plaintiff was entered into by a committee for obtaining a 'Turnpike Road Act to do certain work, and the plaintiff afterwards became a subscriber, it was held that he was not thereby precluded from recovering for work done under such express contract before he became a subscriber $(g)$.

Dobbin v. Where three partners engaged the plaintiff by an Foster.

When to sue in County Court;

or proceed before justices,

Particulars of demand. agreement in writing to serve them as foremàn for a certain period, but before that period had elapsed, one of the three retired, and the plaintiff continued to serve the other two for some years, and they afterwards became bankrupt, whereupon the plaintiff was dismissed by their assignees; it was nevertheless held that he might still sue all the three partners upon the original agreement, which was not rescinded $(h)$.

Where the amount songht to be recovered for wages is under $50 l$, the plaintiff may sue for them in the County Court (i), or if the cause of action arise in [*208] London, in the *'Sheriffs' Court (k), or Lord Mayor's Court ( $(l)$. Where the amount is under 20l., he must sue in the inferior courts, or he will lose his costs $(m)$. And, in certain cases wages of small amount due to workmen and labourers may be recovered by summary proceeding before a magistrate. (n). But where a discharged servant has brought an action in the County Court for wrongful discharge and failed, he cannot afterwards take proceedings for recovery of wages before a magistrate $(o)$.

Where by his particulars of demand the plaintiff claimed wages, it was held that he could not recover a

(g) Lucas v. Beach, 1 M. \& G. 417.

(h) Dobbin v. Foster, 1 C. \& K. 323 ; see Hobson v. Coxlcy, 27. L. J., Exc 205, ante, p 18.

(i) 13 \& 14 Vict. c. 61.

(k) 15 \& 16 Vict. c. Ixxvii.

(l) $20 \& 21$ Vict. c. clvii.

(m) Although suing in forma pauperis: Chinn v. Bullen, 8 C. B. 447 ; 7 D. \& L. $297 ; 9 \& 10$ Vict. c. $95 ; 13$ \& 14 Vict. c. 61 ; and sec Lyons v. Hyman, 1 L. M. \& P. 601 ; East Anglian Railuay Company v. Lythgoe, 2 L. M. \& P. $221 ; 30$ \& 31 Vict. c. 142 , s 5.

(n) See Chap. IX. post, and see $6 \& 7$ Vict. c. 86, s. 22 , as to wages of drivers and conductors of hackney carriages and metropolitan stage carriages, and disputes between them and their employers.

(o) Routledge v. Hislop, 29 L. J., M. C. 90. 
claim for a percentage by way of commission on business introduced by him to the defendant $(p)$.

A master cannot set off, against a claim for wages, Set-off. money paid by him to his own medical attendant, for attendance on a servant, unless there was a special agreement between the master and servant that be should do so $(q)$. Nor can he set off against a claim for wages due to a female servant under age, money advanced by him to her, to purchase a silk dress and other articles not necessary for a person in her station in life $(r)$, nor coach fare paid for the mother of such servant $(s)$. Nor can he set off, even by way of equitable defence $(t)$, damages sustained by him through the servant's negligence $(u)$; but if it can be proved to have been part of the original contract that the servant should pay out of his wages the value of his master's goods lost through his negligence, that would be *tantamount to an agreement that the wages [*209] should be paid only after deducting the value of the things so lost, which would be a good defence under the geveral issue $(x)$.

It sometimes happens that wages which have actually Payment, been paid are again demanded in consequence of no presumption receipt having been taken. In such cases, the courts of, will sometimes presume, from the lapse of time or other circumstances, that they have been paid, and the servant will not be allowed to recover in an action for them.

Thus, in a case tried many years ago at Guildhall, from course which was an action by a workman at a sugar refiners, of business, a witness proved that the plaintiff had worked there for more than two years. But Abbott, C. J., said that he should direct the jury to presume that men employed in that way were regularly paid every Saturday night, unless some evidence was given on the part of the plaintiff to satisfy the jury that the plaintiff had, in point of fact, never been paid; and as no such evidence was produced, the plaintiff was nonsuited $(y)$.

(p) Law v. Thompson, 15 M. \& W. 541 ; 4 D. \& L. 54.

(q) Sellen v. Norman, 4 C. \& P. 80.

(r) Hetlgeley v. Holt, 4 C. \& P. 104.

(s) 1 b.

(t) Stimson v. Hall, 1 H. \& N. 831.

(u) Le Loir v. Bristor, 4 Camp. 134.

(x) Per Lord Ellenborough, ibid.; and see per Iord Abinger in Clmcorth v. Piekford, 7 M. \& W. 320.

(y) Note to 4 C. \& P. 81 ; see also Lucas v. Norosilieski, 1 Esp. 296. As for the payment of wages by a stranger not himself liable as eo-rontractor, or otherwise, see Simpson v. Egginton, 10 Exe. 845,817 . 
lapse of time. And in an action for wages, as a menial servant, Gaselee, J., ruled that in the regular course, if a servant has left a considerable time, the presumption is, that all the wages have been paid $(z)$; and in another case $(a)$, Lord Wensleydale said, "Where a person serves in the capacity of a domestic servant and no demand for payment of wages is made by the servant for a considerable period after such service has terminated, the inference is either that the wages have been paid or that the service was performed on the footing that no payment was to be made."

\section{[*210] *Bankruptcy of Master (b).}

The payment of wages due to clerks, servants, labourers, and workmen, in the event of their master's bankruptcy, is provided for by "The Bankruptey Act, $1883 "(c)$, by which it is provided,

Sect. 40.-(1) In the distribution of the property of a bankrupt there shall be paid in priority to all other debts-

(a) All parochial or other local rates due from the bankrupt at the date of the receiving order, and having become due and payable within twelve months next before such time, and all assessed taxes, land tax, property or income tax assessed on him up to the fifth day of April next before the date of the receiving order, and not exceeding in the whole one year's assessment;

(b) All wages or salary of any clerk or servant in the employment of the bankrupt during four months $(d)$ before the date of the receiving order not exceeding fifty pounds; and

(z) Sellen v. Norman, 4 C. \& P. 80 . In a note to this case the reporter says with truth, "It would often save persons great inconvenience and expense if, when they paid a servant's wages, they took a regular receipt."

(a) Gough v. Findon, 7 Exc. 50.

(b) As to the effect of the bankruptey of a clerk or servant, and the appropriation of his salary to creditors, see sect. 53 of the Bankruptcy Act, 1883 . It would seem that a voluntary allowance to which the bankrupt has no legal or equitable claim is not within that section. Ex parte Wicks, Re Wicks, 50 L. J., Ch. 620.

(c) $46 \& 47$ Vict. c. 52 , which came into operation from and immerliatcly after 31st December, 1883.

(d) This means calendar month; $13 \& 14$ Vict. c. 21 , s. 4 . But the corresponding enaetment in the old Bankrupt Act, 6 Geo. 4, c. 16 , s. 48 , whereby the commissioners had power to order payment of six months' wages to servants and elerks, was held to 
(c) All wages of any labourer or workman not exceeding fifty pounds $(e)$, whether payable for time or piece work in respect of services rendered to the bankrupt during four months before the date of the receiving order.

(2) The foregoing debts shall rank equally between themselves, and shall be paid in full unless the property of the bankrupt is insufficient to meet them, in which case they shall abate in equal portions between themselves.

*(4) Subject to the provisions of this Act, all [*211] debts proved in the bankruptey shall be paid pari passu.

There are similar provisions in "The Companies Act, $1883 "(f)$, with reference to the distribution of the assets of any company being wound up under the Companies Acts, 1862 and 1867.

This very humane and beneficial enactment appears to have been originally borrowed from the Scotch in law $(g)$. The first positive enactment on the subject Geo. 4, e. 16, contained in the English bankrupt law, was the 6 Geo. ${ }^{\text {s. }} 48$.

4 , c. 16, s. 48 . Before the passing of that act, a practice prevailed of paying clerks and servants full six months' wages out of the bankrupt's estate; and the operation of the Act, which empowered the commis. sioners to order payment of so much as should be due, not exceeding six months' wages, was to legalize that practice $(h)$. The 6 Geo. 4 , c. 16 , however (as well as the $5 \& 6$ Vict. c. 122 , and $12 \& 13$ Vict. c. 106 , which reduced the amount to three months' wages, and $32 \&$ 33 Vict. c. 71 ), is now repealed, and the enactment above set forth is the one at present in force. But as the decisions upon the previous Acts are in many re- vious Acts. spects applicable to the present law, which, as it will have been observed, differs from the previous acts in the amount which may be ordered to be paid, it will be

mean six lunar months. Ex parte Humphreys, 1 Mont. \& Bligh, 413; 3 Deac. \& Chit. 114.

(e) By $12 \& 13$ Viet. c. 106 , s. 169 , they were not entitled to more than 40 s. arrears of wages.

(f) 46 \& 47 Vict. c. 28 , ss. $4,5$.

(g) See a learued note of the reporters, Mont. \& M. 101, eiting 2 Bell. Comm. 164; and see Ex parte Cranfoot, Mont. \& M. 275. There is a similar provision in the Code Napoleon, Code Civil, 1. 3 , t. 18, art. 2101. The Seotch Aet is $38 \& 39$ Vict. c. 26.

(h) see per Lord Denman in Thomas v. Williams, $1 \mathrm{~A}$. \& 1 . 690. The assignees of a bankrupt, or insolvent, caumot let out for hire his personal services, neeessary for his maintenance. Williams v. Chambers, 10 Q. B. 337. 
convenient to set before the reader sume of the more important and useful of those decisions.

Bankrupt liable to pay wages of servant working after commission.

Thomes r. Williams.
Under that Act it was held that the bankruptey of the master $(i)$ did not operate to dissolve a contract of hiring, and that the master might, notwithstanding his bankruptcy and certificate, be liable to pay the servant [*212] his wages. *Thus, in an action for wages (to which the defendant pleaded his bankruptcy and certificate), where it appeared that the plaintiff, in October, 1826, entered as clerk into the service of the de. fendant, an auctioneer, at a salary of $60 l$. per annum. The defendant became bankrupt, and a commission issued on the 10th of July, 1828. He had been imprisoned about a month before that time under an Exchequer process, at the suit of the Crown, and remained in prison a year after the commission had issued. From the commencement of the imprisonment till the issuing of the commission, and for ten days after, the defendant's business was conducted by his brother. The plaintiff attended from October, 1826, as long as the brother conducted the business, but ceased to do so when the brother ceased to conduct the business, and when he ceased $10 l$. wages were due pro rata; it was left to the jury to say whether the contract had been dissolved after the issuing of the commission by mutual consent; and they found that it had. In the following term a motion was made for a rule to enter a nonsuit, on the ground that the bankruptcy operated to dissolve the contract. But the rule was refused, and Lord Denman said, "That the 48 sect. of 6 Geo. 4 , c. 16 , made no alteration in the legal effect of the contract of hiring, and, consequently, that as the wages had not become due at the time of the commission, either by efflux of time or by a dissolution of the contract, the bankrupt certiticate forms no defence to this action;" and added, "that no inconvenience was likely to occur from his decision, as persons in the plaintiff' 3 situation must be expected to avail themselves of the section above referred to."

It will be observed, however, that in Thomas v. Williams, the plaintiff continued to act as the defendant's clerk after the commission issued; and, therefore, it was unnecessary to decide, and that case cannot beconsidered as an authority, that where a servant, whose wages are due periodically, ceases to act immediately

(i) Thomas v. Williams, 1 A. \& E. 685 ; 3 Nev. \& M. 545. See also Thomas v. Hopkins, 29 L. J., C. P. 187. 
on his master becoming bankrupt, the master will be liable, after he has obtained *his certificate, to [*213] an action for wages for such period as may have elapsed between the last time when wages became due and the bankruptcy. In such case it is conceived that the certificate would be a bar; since the bankruptey, and the fact that the servant therenpon ceased to serve, would be evidence from which might be inferred a dissolution of the contract of hiring by mutual consent, and an agreement that the servant should be paid pro rata for the broken period of service $(k)$. It can only be on the ground that the contract of hiring is rescinded, that a servant, whose wages are due periodically, is entitled, on his master's bankruptcy, to be paid in full wares for a broken pericd of service, - for the Act of Parliament only authorizes the payment of wages in full where the master shall have been indebted at the time of issuing the fiat,- and unless the contract was re. scinded, he was not indebted. And it must be borne in mind, that this provision, which gives a preference to one class of creditors over another, must on that ac. count be construed strictly $(l)$.

And in order to entitle a servant to the benetit of the Service must above provision of the bankrupt law, Lord Eldon held, be under a that his service must have been rendered under $a$ con- contract of tract of hiring, And, therefore, where a son had lived with his father seven years as a clerk, receiving only $F x$ parte board and lodging, and there was no actual contract for wages,- - though the father swore it was always his intention to pay him something for his services, and the assignees did not object, - yet Lord Eldon, though he lamented the hardness of the case, said, "that as there was in reality no contract for wages, he could make no order for the son to prove" $(m)$.

But it seems to have been considered, that there was what conno general rule as to what hiring was sufficient to tracts within entitle a servant or clerk to the benefit of the Act 6 the statute. Geo. 4 , c. 16 , s. $48(n)$. However, weekly labourers No general and workmen, *employed as excavators, were $[* 214]$ rule. considered not to come within the meaning of that Weekly section $(o)$. But it was not thought necessary that the hiring not

(k) See Lamburn v. Cruden, 2 M. \& C. 253.

(1) See Lic parte Hampson, 2 Mont., D. \& D. 462.

(m) Ex parte Glover, 1 Mont. Dig. 165 ; see Deac. \& De G. on Bankr. vol. i. 261, 262.

(n) Per Sir G. Rose, Ex parte Collyer, 2 Mont. \& A. 29; 4 D. \& C. 520 .

(o) Ex parte Crawfoot, Mont. 270; Ex parte Skinner, Mont. \& 
Yearly

hiring not necessary.

Mate of vessel.

French master.

Who are clerks.

Ex parte Harris.

service should be under a yearly hiring, though there must have been an engagement of a more permanent nature than a weekly hiring $(p)$. And, therefore, where an overlooker or manager of a cotton mill was engaged at 33s. per week, but subsequently a contract was entered into that he should be paid $104 l$. per annum, to be paid in weekly sums, he was held to come within the Act $(q)$. And a person engaged as traveller, at an annual salary was also held to come within the Act $(r)$. And where a person entered into an agreement with his father, to serve him as clerk and foreman in consideration of two suits per annum and two guineas a week, he was held within the Act $(s)$.

And it was also held, that the mate of a vessel, hired by the bankrupt, who was master and part owner, under under a verbal agreement, was entitled to six month's wages $(t)$.

And a French teacher in a school at Brighton was held to be within $12 \& 13$ Vict. c. 106 , s. 168 and entitled to a quarter's salary $(u)$.

The provision as to clerks is not limited to trade clerks, nor is it necessary that the trading should have continued during the whole of the period for which wages are claimed $(x)$

A trader borrowed $550 t$. nnder an agreement, by which the lender was to become his clerk at a salary of 222l. 10s. per annum, the trader to produce his accounts and balance sheet to the lender, who was to collect debts and alone draw cheqnes. If the balance was in the [*215] trader's favour at any *time, he might draw to the amount of it. On payment of the loan, or on proceedings been taken to recover it, the agreement was to be at an end; the lender to have the option of becoming a partner. The trader became bankrupt, and it was held that the lender was a clerk, and entitled to three months' salary in full, under 12 \& 13 Vict. c. 106 , s. 168 ; and, also, that his having been absent from business, owing to ill health, for the three months imme-

Bli. 417 ; 8 D. \& C. 332, where a coach-guard and weekly servant at $2 l$. per week was held not to be entitled to the benefit of the Act. See now sect. 40, supra, p. 210.

(q) Ex parte Collyer, ubi supra.

(q) Ibid.

(r) Ex parte Neal, MIont. \& M. 194.

(s) Ex parte Humphreys, Mont. Bli. 413; 3 D. \& C. 114.

(t) Ex parte Homborg, 2 Mont. D. \& D. 642.

(u) Ex purte Collinet, 1 Bank. \& Ins. Rep. 82.

(x) Ex parte Gough, Mont. \& B. 417. 
diately preceding the bankruptcy, with the bankrupt's leave, did not take away this right $(y)$.

A. entered the service of B., as book-keeper and cashier, in 1844, and remained till December, 1848, without any agreement being made as to the amount of his salary, but he drew small sums from time to time. A. stated that in December, 1848, it was agreed between him and $B$. that his salary should be at the rate of $250 l$. per annum from 1844, and that the reason why no agreement was made before was, that $B$. was making experiments in a manufacture, from which he hoped to derive a large fortune, out of which A. expected to be paid. B. became bankrupt in February, 1849 , and $A$. was allowed to prove for his salary $(z)$.

In a case $(a)$, in which it was decided that a clerk Clerk leaving who left the bankrupt's service six months before the service six fiat issued, on account of his having assigned all his months property in trust for his creditors, thereby putting it before fiat, in out of his power to pay the clerk, was entitled to six consequence months' wages, under 6 Geo. 4 , c. 16 , the Court pro- bankruptcy, nounced no opinion whether servants voluntarily quit- within the ting the service of their masters did or did not come Act. within sect. 48. The ground, however, on which that query, as to case was decided was, that although there was an in-voluntarily terval of six months between the quitting of the ser- quitting. vice and the fiat, yet the servant quitted in consequence of his master having assigned all his estate and effects, and thereupon *ceased to carry on his trade, [*216] which was an act of bankruptcy, whereby the servant lost his employment as well as his wages $(b)$.

But in another case $(c)$, where it appeared that about Such a twelve months before the bankruptcy, the bankrupt servant not compounded with his creditors, and it was then agreed within the between the bankrupt and his clerk that he should Act after he quit the service of the bankrupt, and that a year's wages, a dividend to amonnting to $250 l$. should remain as a debt instead of be declared. being included in the composition; and the clerk quitted the service and obtained another similar situation, the bankrupt's son succeeding him as clerk to the bankrupt, and the trade being carried on as usual for another year, when the bankruptcy took place; the clerk was not allowed six months' wages in full after

(y) Exp parte Herris, 1 Do G. 165.

(z) Ex parte Hickin, 19 L. J., Bank. 8.

a) Sx parte Saunders, 2 Mont. \& A. 684.

(b) Ex parte Gee, Mont. \& Ch. 108.

(c) Ibid. 
he had allowed a first and final dividend to be declared.

Workmen by And it was held that the workmen of a coachmaker, the piece not who worked by the piece, and received a specified sum within Act. for each particular job under separate and distinct contracts, and where there was no hiring for a specific time, were not servants within 6 Geo. 4 , c. 16 , s. $48(d)$.

Nor musicmaster ;

Again, it has been held that a music-master attending a school twice, and paid $2 s$. $6 d$. an hour for the nor drillsergeant.

It is no objection that there are no funds to pay costs.

Company in liquidation.

Semble, that misconduct of servant would deprive him of benefit of Act. Out of what monies wages to be paid.

Colliers' drawers.

Where a company wound up. time during which he was occupied; and a drill-sergeant attending twice a week, and paid $4 s$. a lesson, were not clerks or servants, labourers or workmen, with sect. 32 of the Bankruptcy Act, 1869 , so as to be entitled to payment of their salary or wages in full $(e)$.

It is no objection to ordering the payment of wages in full that if paid there will be no money left to pay the expenses of investigating the bankrupt's affairs $(f)$.

And the rule giving clerks, \&c., priority would apply to a company in liquidation $(g)$.

[*217] *It would seem, however, that if the misconduct of the clerk has been such as would have justified his dismissal without wages, he might be deprived of his right to be paid his wages in full $(h)$.

And it is to be observed, that formerly the payment of wages was not to be out of the first monies got in, but as soon as there was a sufficient fund for the purpose after providing for the expense of working the fiat $(i)$.

Where coal proprietors employed colliers to whom work was let off at so much per score baskets, and each collier had a drawer attached to him, it was held that as the drawers could not have maintained an action against the proprietors for their wages they were not entitled to wages under 12 \& 13 Vict. c. 106 , s. $169(k)$.

Where a company engaged MI. to act as their agent for five years at a fixed salary, and also for a commission of ten per cent. on the net profits in each year, and the company was wound up before the end of the five years, it was held that $\mathbf{M}$. was not entitled to any compensation for loss of commission during the unexpired

(d) Ex parte Grellier, Mont. \& MI. 95. See now sect. 40 (c), ante, p. 210.

(e) Ex parte Walker, Re Heath, 42 L. J., Bankr. 49.

f) Ex parte Powis, Re Bowen, 43 L. J., Bankr. 24.

(g) Re The Association of Land Financiers, 50 L. J., Ch. 201.

(h) Ex parte Hampson, 2 Mont., D. \& D. 462..

(i) Ibid.

(k) Ex parte Ball, 3 De G., M. \& G. 155. 
part of the five years $(l)$. But in another case $(m)$, where a company engaged D. and G. to act as their commercial travellers for three years in a certain district, but was wound up before the end of the three years, Bacon, V.-C., held that D. and G. were entitled to compensation in respect of commission for the unexpired part. of the three years, distinguishing the case from Maclure's case.

\section{Death of Master.}

By the death of the master, or one of a firm of mas- Diseharges ters $(n)$, the contract is at an end, and the servant is servant. *discharged (o), unless the contrary is stipulated [*218] by the terms of the contract $(p)$; and the sureties to a where conbond for the faithful service of the servant are released tract for an $(q)$. And it seems that where there is no custom upon entire year's the subject which ean be imported in to the contract, and ser the service is under an entire contract for a year's service and a year's pay, if the master dies in the middle titled to any of the year the servant is not legally entitled to any wages. wages for a broken period of service.

Thus, where $(v)$ debt was brought upon a writing, by

(l) Re English and Scottish Marine Inswrance Co., Maclure's Claim, 39 L. J., Ch. 685.

(m) Te Patent Floor Cloth Co., Dean and Gilbert's Claim, $41 \mathrm{I}$. J., Ch. 476.

(n) Hoey v. IP Euan, 5, 3rd Ser. 814 ; see Tasker v. Shepherd, ante, p. 19.

(o) Wentw. Off. Ex. 141, 14th edit.; Wms. Exors. 757. But see $R$. v. Ladock, Burr. S. C. 179 ; 2 Bott. 277; 1 Nol. P. L. 461, where it was held that a pauper gained a settlement by serving ont the year with the executors of the master, who died in the middle of the year; on the ground that the serviee to the exeentors was a eontinuance of the same service and not a new contract. And see also Jackson v. Bridge, 12 Mod. 650. . A contract of apprentieeship, in so far as it was a personal contract, is put an end to by the death of the master. $K$. v. Peck, 1 Salk. $66 ;$ Baxter v. Burfiell, 2 Str. 1266 ; Bae. Abr. "Master and Servant," G. As to the liability of the apprentiee to serve the exeentors, see Cooper v. Simmons, 5 L. T., N. S. 712. As to the effert of the death of one of two partners who had hired the plaintiff, see Theker $v$. Shepherd, ande, p. 19. It may he convenient to mention hero that if A. hire B. to serve C. and C. dies, A. is only entitled to wages up to the time of C.'s death. See Taylor v. Calduell, 32 L. J., Q. I. 164 ; post, p. 224.

(p) Furrow v. Wilson, 39 I. T., C. P. 326 ; L. R., 4 C. P. 744.

(q) Barker v. Parker, 1 T. R. 287.

(r) Conntess of Plymouth v. Throgmorton, 1 Salk. 65; see Elderlon v. Enmens, (i C. B. 160 . In Whinewp v. Wughes (40 I. J., C. P. 104), where by an apprenticeship deed $A$. was to serve 13 . and 13. to teach $A$. for a term of years, but there was no provision as to service to B.'s executor's or return of premium, and B. died dur- 
Countess of Plymouth r. Throgmorton. which the defendant's testator had appointed the plaintiff's testator to receive his rents, and promised to pay him 100l. per annum for his service, the plaintiff show ed that the defendant's testator died three quarters of a year after, during which time be served him, and he demanded $75 l$. for three quarters; after judgment for the plaintiff in the Common Pleas, the defendant brought a writ of error, and it was argued that without a full year's service nothing could be due, for that it was in nature of a condition precedent, that it being [*219] one consideration and one debt, it *could not be divided : and the Court of Queen's Bench were of that opinion, and reversed the judgment.

Where, however, there is a custom applicable to persons in the situation in which the servant was, as there is with regard to domestic servants, who are generally considered entitled to wages for the time they serve, though they do not continue in the service during the whole year, the servant would probably be held entitled to recover wages for the period of actual service $(s)$. And it is conceived that in all cases where the contract

So where contract not for an entire year.

Apportionment Act.

Master's executors pay wages.

Query, whether wages entitled to preference over other debts. is not an entire contract for a whole year's service on one side, and a whole year's pay on the other, a servant, whose master dies in the middle of a year might recover, in the common action for wages, his wages for the broken period of service, upon principles similar to those which allow a servant, wrongfully discharged, to treat the contract. as rescinded, and sue for his wages for the period of actual service $(t)$.

The Apportionment Act, 4 \& 5 Will. 4, c. 22, would not in general apply to cases of hiring and service $(u)$.

The executors or administrators of their master are the persons to whom servants mnst look for payment of their wages after his decease.

It is stated by some authorities $(x)$, that the wages of domestic servants and of labourers are entitled to preference over other debts of the deceased. But it is difficult to point out any legal ground on which such

ing the term, it was held that no action for damages or for money had and received lay against B.'s executors for a return of any portion of the preminm: dissenting from Hirst v. Tolson, $19 \mathrm{~L}$. J., Ch. 441; 2 Mac. \& G. 134, in which Lord Cottenham had held differently in the case of an articled clerk to an attorney.

(s) See Cutter v. Powell, post, p. 227.

(t) Ante, p. 188.

(u) Lowndes v. Earl of Stamford, 18 Q. B. 425.

(x) 2 Bl. Comm. 511, citing 1 Roll. Abr. 927; and see Toller on Exors. 286. 
preference can be claimed in England (y), though they are entitled to priority in France $(z)$.

*The subject of legacies to servants, and how [*220] Legacies to far such legacies operate to extinguish the servant's servants. claim to wages, will be treated of hereafter in a separate Chapter $(a)$.

Where a farm servant left his wages from time to Wares left time in his master's hands, and it was agreed between in master's them that the debt thus due should carry interest, and hands: the master died, having by his will given all his real interest. and personal property to his wife, out of which he desired that she would discharge all his legal debts; it was held, in a suit for the administration of his estate in Chancery, that the Statute of Limitations did not operate as a bar to arrears of interest upon the sum left by the servant in his master's hands (b).

\section{Default of Servant.}

When a servant, whose wages are due periodically, Servant refuses to perform his part of the contract, and serve making dehis master in the manner contracted for, or so conducts fault, or himself that the master is justified in dis cightfully himself that the master is justified in discharging him discharged, without notice, he is not entitled to be paid any wages entitled to for that portion of time during which he has served no wages. since the last periodical payment of wages $(c)$. That

(y) 2 Wms. Exors. 822, note (s), 3rd edit. It may be here mentioned as a caution to servants, that upon the death of their master the only persons entitled to deal with his personal property are his legal personal representatives, that is, his executors if he has left any; or, if not, his administrators; and that in a case where a housekeeper, on her master's death, without leaving any executors, applied certain casl in the house, and the produce of the sale of some of her master's property, to the payment of the expenses of his funeral and other expenses, without any anthority to do so, she was afterwards held liable to an action at the suit of the widow and administratrix for the money so received and applied. Welchman v. Sturgis, 13 Q. B. 552.

(z) Code Civ. liv. iii. tit. xviii. ch. ii. s. 1. 2101.

(a) See the last Chapter in the Book.

b) Blower v. Blower, 28 L. J., Ch. 181.

(c) See Dalt. Just. ch. 58, p. 199, where it is said, "If a servant of his own accord slall depart from his master pefore his time expired, he shall Jose all his wages." Walsh v. Walley, 43 L. J., Q. B. 102; I. R., 9 Q. B. 367. Saunders v. Whittle, 33 L. T., N. S. 816 ; 24 W. R. 400. Gregsen v. Watson, 34 L. T., N. S. 143. Where by the rules of a cotton mill any person absenting himself was to give notice to the overlooker, and in defuult all wages then earned were to be forfeited, and a weaver having obtained leave for holf a day, promising to return next morning, did not return till the afternoon, she was held not to furfeit her wages. Trylor v. Cair, 30 L. J. M. C. 201.

13 MAs, \& SER. 
is to say, if a servant whose wages are only dueyearly abscond from his master, or is rightfully discharged before the expiration of the year, he could recover nothing for services rendered previous to such departure or discharge. And the same principle would apply to the case of a quarterly, monthly or weekly hiring. In any [*221] of such cases, if the servant fail to perform *his part of the contract, or be rightfully discharged $(d)$ at any intervening period between the days when his wages are due, he can recover nothing for the broken period of service. This is upon the principle that the contract was an entire contract, and the performance of the service for the whole time agreed upon was in the nature of a condition precedent to the right to recover any wages. And it is a general rule (e), applicable to all contracts, that, while a special contract remains unperformed, the party whose part is unperformed cannot sue in indebitatus assumpsit for compensation for what he has done under the contract until the whole is completed $(f)$.

Hulle r. Thus, in an action $(g)$ for wages for work performed Heightman. by the plaintiff, who was a seaman on board the defendant's ship during a voyage from Altona to London, where it appeared that the service was under an agree. ment, by which the plaintiff agreed to serve from Altona to Lonđon and back again, and there was an express stipulation, by which the plaintiff was bound to demand no wages till the conclusion of the voyage, the plaintiff was nonsuited on the ground that the contract remained unperformed and unrescinded, and the plaintiff should have sued the defendant upon the contract, and the nonsuit was held by the Court of King's Bench.

Upon similar principles, in a variety of cases, servants who have been rightfully discharged, and have afterwards sued their late masters for wages, have failed to recover anything.

Thus, in an action $(h)$ brought by a yearly servant to

(d) See the preceding Chapter as to what cause will justify the discharge of a servant.

(e) See cases cited in 2 Smith's L. C. 10, note to Cutter r. Ponell.

$(f)$ And he cannot sue the other party specially for non-performance of the contract, unless he has himself performed, or been ready to perform, his part of it; as has been already shown whilst treating of the action for wrongful dismissal.

(g) Hulle v. Heightman, 2 East, 145 ; and see 2 Smith's L. C. 16. See also Beale v. Thompson, 4 East, 546 ; Appleby v. Dods, 8 East, 300 ; Jesse v. Roy, 1 C. M. \& R. 368.

(h) Spain v. Arnott, 2 Stark. 236 ; and see Robinson v. Hindman. 3 Esp. 235. 
a *farmer, to recover wages for his service from [*222] Spain v. Michaelmas to July, when he was discharged under cir-Arnott. cumstances which were held to justify his discharge, it was held that he conld not recover anything. And Lord Ellenborough said, "If the contract be for a year's service, the year must be completed before the servant is entitled to be paid." Lord Tenterden afterwards, on two occasions $(i)$, expressed a similar opinion. And, upon the authority of these cases ( $k$ ), Lord Den-Turner v. man nonsuited a servant, who, having been properly Robinson. discharged (as was admitted), afterwards brought an action for wages during a broken period of service, and the nonsuit was held right by the Court of King's Bench $(l)$. The principle on wbich these cases were decided, was afterwards $(\mathrm{m})$ applied to the case of a Ridgxay $\mathrm{v}$. clerk to a public company, whose salary had been paid IIungerford quarterly, and who, having been discharged for impro-Market Co. per conduct some little time after the quarter-day, was held not to be entitled to recover anything for the period which had elapsed since the last periodical payment of his salary. In his judgment, in that case, Lord Denman said, "Turner v. Robinson, and many other cases, hare shown that if a party hired for a certain time, so conduct himself that he cannot give the consideration for his salary, he shall forfeit the current salary even for the time during which he has served."

And in a subsequent case $(n)$, in which an action was Lilley $\mathbf{v}$. brought by a waggoner and servant in husbandry (who Elwin. left his work and was afterwards summoned before a magistrate under the statute 4 Geo. 4 ; c. 34 , s. 3 , and by him discharged from the service) against his master, it was held that he could not recover wages for the time of his actual service, as he was bound to give a whole year's service before earning any wages, and broke his contract by leaving the service before the year's end.

*But default of the servant after the day on [*223] Except in which a periodical payment of wages accrued due would respect of not deprive him of his right to recover such periodical periodical payment-would not divest a vested right. In a case payments (o), therefore, in which it was part of the engagement of the plaintiff that he should remain in charge of a ves-

P. 208 .

(i) Inttman v. Boulnois, 2 C. \& P. 510; Atkin v. Acton, 4 C. \&

(k) In Turner v. Robinson, 6 C. \& I'. 15.

(l) 5 B. \& Ad. 789.

(m) Rilgway v. Iungerford Market Co., 3 A. \& F. 171.

(u) Lilley v. Elwin, 11 Q. B. 742.

(o) Taylor v. Laird, 1 HI. \& N. 267 ; 25 I. J., Fxe. 329. 
Taylor $\mathrm{v}$. sel which was to sail on a trading and exploring expeLaird. dition to the Niger during the whole voyage; but the pay was to be "a tixed pay of $50 l$. per month," and the plaintiff in the middle of the voyagerefused to proceed; the Court held that he was entitled to recover the monthly wages which accrued before his refusal; Pollock, C. B., saying, "There 'per month' means 'each month,' or 'monthly,' and gives a cause of action as each month accrues, which once vested is not subsequently lost or divested by the plaintiff's desertion or abandonment of his contract. The words are plain, and no mercantile man could doubt what was meant. But further, if this meaning is not given, the result would be that had the plaintiff died or the voyage failed, at the last moment nothing would be payable by the defendant, because, according to his contention, the performance of the entire work contracted for was a condition precedent to the right to receive anything."

Button v. Thompson.

Servants enlisting as soldiers.

And a similar decision was given in another similar case $(p)$, where the ship's articles provided for " amount of wages per calendar month;" and the plaintiff recovered, although he was left behind, through his own negligence, at one of the places at which the ship stopped before the completion of the voyage.

By the Army Act, $1881(q)$, it is enacted, "(1) A soldier of Her Majesty's regular forces shall not be liable to be taken out of Her Majesty's service by any process, execution, or order of any court of law or otherwise; or [*224] to be compelled to *appear in person before any court of law, except in respect of the following matters, or one of them (that is to say)-

"(a) On account of a charge of or conviction for crime; or

"(b) On account of any debt, damages, or sum of money when the amount exceeds $30 l$. over and above all costs of suit.

"(2) For the purposes of this section a crime shall mean a felony, misdemeanor or other crime or offence punishable according to the law in force in that part of Her Majesty's dominions in which such soldier is, with fine or imprisonment or some greater punishment, and shall not include the offence of a person absenting himself from his service or neglerting to fulfil his contract,

(p) Button v. Thompson, 38 L. J., C. P. 225. See also Stubbs v. Holywell Railway Co., post, p. 228 .

(q) $44 \& 45$ Vict. c. 58 , s. 144 , and see sect. 96 as to apprentices and indentured labourers in a colony. 
or otherwise misconducting himself respecting his condurt."

But there seems to be no provision in the Army Act, as there was formerly in the Mutiny Act $(r)$, authorizing the justice before whom a recruit is attested to adjudge him a reasonable proportion of his wages for the time he has actually served.

\section{Death of Servant:}

The executors of a servant are not liable upon a con- Executors tract for personal services, there being an implied con- not liable on dition in such contracts, that if the servant shall die contracts for this contract shall be considered as discharged. "There personal seris a class of contracts," said Blackburn, J., in Taylor v. Caldwell (s), "in which a person binds himself to do Taylor v. something which requires to be performed by him in person; and such promises, e.g. promises to marry or promises to serve for a certain time, are never in practice qualified by an express exception of the death of the party; and therefore, in such cases, the contract is in terms broken if the promisor dies before fulfilment. Yet it was very early determined, that if the performance is personal the executors are not liable." *Hyde v. Dean of Windsor $(t)$. See 2 Williams [*225] on Executors, 1560, where a very apt illustration is given. "Thus," says the learned author, "if an anthor undertakes to compose a work, and dies before completing it, his executors are discharged from this contract; for the undertaking is merely personal in its nature, and by the intervention of the contractor's death has become impossible to be performed." For this, he cites a dictum of Lord Lyndhurst in Marshall v. Broadhurst (u), and a case mentioned by Patteson, J., in Wentworth v. Cook $(x)$. In Hale v. Wright $(y)$, Crompton, J., in his judgment, puts another case. "Where a contract depends upon personal skill, and the act of God renders it impossible; as, for instance, in the case of a painter employed to paint a picture, who is struck blind, it may be that the performance might be excused." It seems that in those cases the only ground on which the parties

(r) See 22 Vict. c. 4, s. 63.

(8) 32 I. J., Q. 13. 167; 3 B. \& S. 826 . See also Stubbs v. Ifolyvell Ruihury Co., prost, p. 228.

(t) Cro. Eliz. 552.

(u) 1 Tyrw. 349.

(x) 10 A. \& E. 45 ; 8 L. J., Q. B. 230.

(y) E., B. \& E. 7.16; :7 1.. J., Q. B. 34. 
Taylor v. Caldwell.

or their executors can be excused from the consequences of the breach of contract is, that from the nature of the contract there is an implied condition of the continued existence of the life of the contractor; and perhaps, in the case of the painter, of his eyesight. In the instance just given the person, the continued existence of whose life is necessary to the fulfilment of the contract, is himself the contractor; but that does not seem in itself to be necessary to the application of the principle, as is illustrated by the following example: In the ordinary form of an apprentice deed, the apprentice binds himself in unqualified terms to serve until the full end and term of seven years be fully complete and ended, during which term it is covenanted that the apprentice bis mas. ter faithfully shall serve; and the father of the apprentice, in equally unqualified terms, binds himself for the performance by the apprentice of all and every [*226] * covenant on his part (see the form 2 Chitty on Pleading, 342). It is undeniable that if the apprentice dies within the seven years, the covenant of the father that he shall perform his covenant to serve for seven years is not fulfilled, yet surely it cannot be that an action would lie against the father. Yet the only reason why it would not is that he is excused because of the apprentice's death $(z)$. These are instances where the implied condition is of the life of a human being, but there are others, "in which the same implication is made as to continued existence of a thing." His lord. ship gave several examples; and added, "The principle seems to us to be, that, in contracts in which the performance depends on the continued existence of a given person or thing, a condition is implied that the impossibility arising from the perishing of the person or thing shall excuse the performance. In none of the cases is the promise in words other than positive, nor is there any express stipulation that the destruction of the person or thing shall excuse the performance, but that excuse is by law implied ; becanse, from the nature of the contract, it is apparent that the parties contracted on the basis of the continued existence of the particular person or chattel."

Wages. Where the death of the servant prevents his perform. ing his part of the contract, and completing the period of service agreed upon, his representatives can recover

(z) See Boast r. Firth, 38 L. J., C. P. 1 ; L. R., 4 C. P. 1 ; ante, p. 132 ; where, upon the principle of Taylor v. Calducll, permanent illness of an apprentice was held to be a good answer to an action of covenant on the apprenticeship deed.

(260) 
nothing for the broken period of service, unless there exist a custom, in the particular occupation in which the servant was engaged, to support the claim to wages for such service, as is the case with regard to domestic servants, or the master of a ship who is not a seaman within the rule of the common law, that freight is the mother of wages $(a)$

*Thus where P., being at Jamaica, subscribed [*227] Cutter v. and delivered to $\mathrm{C}$. the following note:- "Ten days Powell $(b)$. after the ship Governor Parry, myself master, arrives at Liverpool, I promise to pay to Mr. T. Cutter the sum of thirty guineas, provided he proceeds, continues and does bis duty as second mate in the said ship from hence to the port of Liverpool." C. went on board and did his duty from 31st July to 20th September, when he died before the ship reached Liverpool. His representative brought an action for his wages for the period during which he had served, but it was held that, C. not having completed the voyage, his representative could not recover any wages. And Ashhurst, J., said,- "Here the intestate was by the terms of his contract to perform a given duty before he could call upon the defendant to pay him anything: it was a condition precedent, without performing which the defendant is not liable. And that seems to me to conclude the question; the intestate did not perform the contract on his part; he was not indeed to blame for not doing it; but still, as this was a condition precedent, and he did not perform it, his representative is not entitled to recover." And Lawrence, J., added,-“"With regard to the common case of a hired servant, to which this bas been compared, such a servant, though hired in a general way, is considered to be hired with reference to the general understanding upon the subject that the servant shall be entitled to his wages for the time he serves, though he do not continue in the service during the whole year. So, if the plaintiff in this case could

(a) Inackins v. Twizell, 8 E. \& 13. 883. That rule is altered now, and seamen's wages are not dependent on the earning of freight, 17 \& 18 Vict. c. 104, s. 183.

(b) Cnfter v. Povell, 6 T. IR. 320 ; 2 Smith's I. C. 1 ; see also the case of Hollingsworth $v$. Pthmer, 4 Exe. 267 , where a similar question arose, but it became umecessary to décide it. The seaman, or his representative, under similar circumstances now would recover wages, $17 \& 18$ Vict. c. 104 , ss. 184,185 , \&e. See also Appleby v. Jeyers, $36 \mathrm{~L}$. J., C. P. 331, reversing s. C. $35 \mathrm{I}$. J., C. P. $_{295}$, where the plaintiff who contracted to ereet certain - machinery was held not entitled to recover for part which was burnt down before the whole was completed. 
have proved any usage that persons in the situation of this mate are entitled to wages in proportion to the time they served, the plaintiff might have recovered according to that usage. But if this is to depend [*228]*altogether upon the terms of the contract itself, she cannot recover anything" $(c)$.

Stubbs v. ITolycell Railway Co.

In a case $(d)$, however, in which an engineer was appointed to construct certain works which it was calculated would occupy fifteen months, and was to be paid for his services during that period $500 l$., by equal quarterly payments, and shortly after the end of the third quarter be died, two quarterly payments then remaining unpaid; it was beld that, although his death put an end to the contract for the future (e), it did not divest the right of action for the two quarterly payments, and his administrator was entitled to recover them, and not merely upon a quantum meruit for the amount of work actually done.

\section{Of the Master's Dutx to Supply Food and Medicine} to the Servant.-Stat. $14 \& 15$ Vict. c. $11 ; 24$ \& 25 Vict. c. 100, s. 26.

Food.

Formerly omission to supply food was merely breach of contract.

Except in ase of servant of tender years.

The duty of a master or mistress to supply food and other necessaries to their servants, arises solely from a contract, either express or implied, on their part to do so. And the omission to perform this duty was formerly merely a breach of contract, for which they were civilly, but not criminally, liable, except in the case of a servant of tender years $(f)$. But at a meeting of all the judges (except Lord Kenyon and Rooke, J.), held 25th February, 1802, the general opinion was, that it was an indictable offence as a misdemeanor to refuse or neglect to provide sufficient food, bedding, \&c., to any infant of tender years unable to provide for and take care of itself (whether such infant were child, apprentice or [*229] servant), whom a man was *obliged by duty or contract to provide for, so as thereby to injure its health $(g)$.

(c) In Bray v. Finch, 26 L. J., Exc. 91. which was an action by the administrator of a person who had been many years servant to the keeper of a private lunatic asylum. and left his wages in his master's hands, the court refused an order for the production of defendant's books, under sect. 50 of the Common Law Procedure Act, 1854.

(d) Stubbs v. Holyuell Raihnay Co., 36 L. J., Exc. 166. See Taylor $\times$ Laird; Button 5. Thompson, ante, p. 223.

(e) See Taylor v. Caldwell, antc, p. 224.

(f) R. x. Ridlley, 2 Camp. 650.

(g) See Friend's ease, Russ. \& Ry. C. C. 22. If, however, a mistress culpably neglects to supply proper food and lodging to her 
A married woman, however, cannot be convicted of $R$. v. Sakna misdemeanor in neglecting to supply even an infant ders. servant with proper food, unless it bo shown that her husband supplied her with food to give the child, and she wilfully neglected to give it. The omission to provide food is the omission of the husband, the wife being in the nature of a servant to the husband $(h)$.

In the case of the Sloanes, who were indicted in Feb- S'loanes' case. ruary, 1851, upon a charge of starving and otherwise ill-treating their servant-girl, who was sixteen years old; the learned judges $(i)$ who tried the case considering that she was not of tender years, that part of the charge was abandoned $(k)$.'

In consequence of the great scandal caused by the 14 \& 15 Vict. Sloanes' case, the statute $14 \& 10$ Vict. c. 11 was ${ }^{\text {c. } 11 .}$ passed (l). That Act was partly repealed in 1861, Persons rewhen the statutes relating to criminal law were con- fusing or solidated $(m)$. But its provisions were, at the com- neglecting to time, substantially re-enacted by $24 \& 25$ Vict. c. 100 , sary fool to 8. $26(n)$, whereby it is made a misdemeanor for any apprentices person legally liable to provide apprentices or servants or servants, with necessary food, clothing or lodging, wilfully or bodily harm without lawful excuse to omit to do so; or unlawfully to them, and maliciously to do or cause to be done any bodily guilty of a . harm to any such apprentice or servant, *so [*230] mistethat the life of such apprentice or servant shall be endangered or the health permanently injured.

And by s. $73(o)$ guardians and overseers may be re. Costs of presquired, and the clerk of the guardians bound over to ecution. prosecute: and provision is also made for the costs of the prosecution $(p)$.

servant at a time when the servant is reduced to such an enfeebled state of body or mind as to be helpless, and unable to take eare of herself, or is so under the dominion and restraint of her mistress as to be unable to withdraw herself from her control, and the deatl of the servant is caused or accelerated by such neglect, the mistress is liable to be convicted of manslaughter. $I$. v. Smith, 34 L. J,. M. C. $153 ; 10$ Cox, Cr. C. 82.

(h) R. v. Sicunilers, 7 C. \& P. 277.

(i) Coleridge and Cresswell, JJ.

(k) The defendants pleaded guilty to the charge of assaulting, \&w. the servant, and were punished for thet.

(l) Post, Appendix.

(im) $24 \& 25$ Vict. e. 95.

(n) Sce sects. 26,73 , at length in the Appendix, post.

(o) See sects. 29, 73, at length in the Appendix, post.

(p) The act also provides in the subsequent sections for the keeping of a register and periodieal visitation, by the guardians or oversecers, of all young persons hired or apprenticed from any workhouse or union. See the act printed at length in the $A$ ppendix. 
Medicine.

A master is legally bound to provide medical attend-

Master is not ance for an apprentice $(q)$, but not for a servant, in bound to pro- case of illness or accident $(r)$. Lord Kenyon, indeed, vide medical was of opinion $(s)$ (and it was said by Lord Alvanattendance for servants. ley $(t)$, that he had reason to believe that that was not a hasty opinion, but formed upon reflection) that a master was obliged to provide for his servant in sickness and in health; and that he, therefore, was liable for medicines furnished to his servant while in his service. Not that his servant was at liberty to go abroad and contract debts for medicines, but that whilst he was under his master's roof the master was under a legal as well as a moral obligation to provide the neces. sary medicines, and to pay for such as were administered to his servant under such circumstances. And Lord Eldon $(u)$ seemed disposed to follow Lord Kenyon's opinion. But subsequent decisions have laid down a different doctrine, and it may now be considdered as established law that a master is not bound to provide medical advice for his servants, and that it makes no difference wh-ther or not the servant be living under his master's roof. The first formal decision Wennall $v$ [*231] upon this point was made in the case *of WenAdney. nall v. Adney $(x)$, which was an action by a surgeon to recover the amount of his bill for medical attendance upon a servant of the defendant, who had his arm broken while driving defendant's team, and who had been hired by the defendant at the yearly wages of $3 l$. 10s. and victuals. The defendant had made no express promise to pay the plaintiff, and it was held that there was no implied promise on his part to do so; and therefore the plaintiff was nonsuited, and the nonsuit was afterwards held right by the Court of Common Pleas. In giving judgment, Lord Alvanley, C. J., after stating his concurrence with the learned Judge who tried the case, in thinking the defendant not liable, said that,

(q) R. v. Smith, 8 C. \& P. 153.

(r) The case of seamen on board a ship is peculiar, and is provided for by statute 17 \& 18 Vict. c. 104 , s. 234 . See Couch v. Steel, 3 E. \& B. 402 . And as to that case see Atkinson v. Nexcastle, \&e. Water co., 46 L. J., C. L. 775; L. R., 2 Exc. Div. 441.

(s) Scarman v. Castcll, 1 Esp. 270.

(t) In Wennall v. Adney, 3 B. \& P. 252.

(u) Simmons v. Wilmott, 3 Esp. 93.

(x) 3 B. \& P. 247. Lord Mansfield had indeed at Nisi Prins held that a master was not legally bound to repay the parish for the cure of his servant, Newby v. Wiltshire, 2 Esp. 739; 4 Dong. 284. But the case in the text is the first decision in banc. upon the subject. 
"previous to the case of Scarman v. Castell, there is no authority in the law of England to be found which warrants the position contended for on the part of the plaintiff. I have no doubt whatever that parish officers Parish liable. are bound to.assist where such accidents as these take place: and that the law will so far raise an implied contract against them as to enable any person who affords that immediate assistance which the necessity of the case uspally requires to recover against them the amount of money expended." And Heath, J., observed, "I believe that the humanity of Lord Kenyon misled him when he adopted the doctrine upon which he decided the case of Scarman v. Castell. Probably, at the moment, it occurred to him that if the master was not bound to provide medical assistance fcr his servant, the latter would be left wholly destitute: but I am perfectly sure it is more for the advantage of servants that the legal claim for such assistance should be against the parish officer rather than against their masters, for the situation of many masters who are obliged to keep servants is not such as to enable them to afford sufficient assistance in cases of serious illness." And Rooke, J., added, "It must be left to the humanity of every master *to decide whether ho will assist [*232] his servant according to his capacity or not."

Since the case of Wennall v. Adney, it has never, it Master may is believed, been serionsly contended that any legal render himliability exists on the part of the master to supply medical assistance for his eervants, but in the few cases self liable by his conduct. which have happened at Nisi Prius it has usually been contended, on the part of the plaintiff, that the master has by his conduct rendered himself liable, either by calling in his own usual medical attendant, or by recognising the employment of the medical man called in by the servant. Therefore $(y)$, in an action for tho Cooper $v$. amonnt of a surgeon's bill, which contained a charge of Phillips. 7s. $6 d$. for attending a servant of the defendant named Read, who had hurt her ankle in getting over a gute; and also a charge of $12 l$. for attending one Parry, who had acted as wet-nurse to two of the defendant's children; the defendant was held not liable to pay tho former charge, as the plaintiff was not the regular medical attendant of the family, and had been employed by Read without the knowledge of her master or mistress. But the latter charge the defondant was

(y) Cooper v. Phillips, 4 C. \& P. 581: and seo Sellen v. Norman, 4 C. \& P. 80. 
held liable to pay: as it appeared that Parry's illness arose from suckling the defendant's youngest child, and his wife knew of the plaintiff's attendance but did not express any disapprobation of it; although it also appeared that the defendant did not know the plaintiff, and had sent the surgeon who regularly attended his family to see Parry, and had also sent her 10 s. to pay for medicines. Mr. Justice Taunton considering that his doing so showed that he considered himself liable to take care of her in that illness, and that it must be taken that the wife had the general superintendence of the house.

Qucry, It is beliered, however, that no case has yet occurred whether in which the question has arisen in an action by a sermaster who has contracted to supply necessary food, is liable to supply medieine in case of illness.

vant against his master, who had agreed to supply the servant with necessary food, whether the master in such [*233] case is *bound by his contract to furnish plysic to the servant in case of illness. But when the question shall arise, the decision of it must depend upon the exact nature of the contract entered into. Sometimes a master engages to supply his servant with necessary victuals, and it may be argued that necessary victnals mean such victuals as may suit the state of bealth or infirmity in which the servant happens to be; as if a servant be in need of wine or victuals of that description which are given by way of medicine $(z)$.

Parish lable. In the event of illness or accident, however, happening to a pauper, the parisu in which it takes place is bound to provide the necessary medical advice and assistance $(a)$. And an overseer neglecting to provide medical assistance when required to a pauper labouring under dangerous illness is indictable, although such pauper is not in the parish workhouse, nor had previously to his illness received or stood in need of parish relief $(b)$.

(z) See per Lord Alvanley in Wennall v. Adney, 3 B. \& P. 247.

(a) Wennall r. Adney, ante, p. 231 ; Simmons v. Wilmot. 3 Esp. 91 ; and see Watling $\mathrm{v}$. Walters, 1 C. \& P. 132, as to deputy overseer's liability. And the parish cannot recover the expenses from the master, Newby v. Wiltshire, 2 Esp. 739 ; 4 Dongl. 284 ; nor from the parisl where the pauper was settled, Atkins v. Banwell, ¿ East, 505; Gent v. Tompkins, 5 B. \& C., 746, note ; nor may a pauper, who has met with an aceident, be removed to the place of his settlement during lis illness, $R$. v. Bury St. Edmunds, 10 East, 25 ; R. v. Ludlow, 4 B. \& Ald. 660 ; Tomlinson v. Bentatl, 5 B. \& C. 739 ; Paljuter v. Williams, 1 C. \& M. 810. But where a servant, having met with an accident, was carried to the nearest house, which was in the next parish, that parish was held liable, Lamb v. Bunce, $4 \mathrm{M}$. \& S. 275, until an order of removal made, $R$. v. Otdland, 4 A. \& E. 929.

(b) R. v. Warren, Russ. \& R. C. C. 48, n. 
Of the Master's Duty to Indemify the Servant from the Consequences of obeying his Ordeks, and herein of the Master's Liability for Injuries to Servant.

It is also the duty of a master to indemnify his ser- When master vant from the consequences of doing, in obedience to is liable to his master's orders, any act pursuant to orders which indemnify he was bound to *obey; or any act which was [*234] consequences either lawful in itself, or which, not being in itself un- of obeying lawful, might have been either lawful or unlawful, but his comwhich the servant was induced by the conduct of his mands. master to believe to be lawful, as the rule that one wrongdoer cannot sue another for contribution (c) would not apply in such cases $(d)$.

Thus, if a servant, in obedience to the command of his master, commit a trespass upon the property of another, not knowing that he is doing any injury, he is nevertheless answerable for the tort as well as his master to the party injured; yet he is entitled to an action against his master for the damages he may suffer, although the master also was ignorant that the act committed was unlawful, because he is deemed the principal offender.

In respect to offences in which is involved any moral delinquency or turpitude, all parties are deemed equally guilty, and courts will not inquire into their relative guilt. But where the offence is merely malum prohibitum, and is in no respect immoral; it is not against the policy of the law to inquire into the relative delinquency of the parties and. to administer justice between them, although both parties are wrongdoers $(e)$.

Where the defendant employed the plaintiff, who Dixon $\mathbf{v}$. was a brickmaker, to make bricks with R.'s trademark, Fawcus. and $R$. filed a bill in chancery against the plaintiff

(c) Merryweather v. Niron, 8 T. R. 186.

(d) Southern v. IIou, Bridgman's Rep. 126 ; Cro. Jac. 468 ; Adamson v. Jarvis, 4 Bing. 66; Betts v. Gibbous, 2 A. \& E. 57 ; Toplis v. Grane, 5 Bing. N. C. 650 ; Collins v. Evans, 5 Q. \& B. 8.30 ; Rawlings v. Bell, 1 C. B. 951; Smith's Mere. Law, 115 ; Story on Agency, sect. 339 ; see Chillers v. Wooler, 29 L. J., Q. B. 129 ; Dugdale v. Lovering, 44 L. J., C. P. 197. And see also the following cases, in which the question has been whether an action for money paid would lie by a person employed against his employer: Britain v. Lloyd, 14 A. \& W. 762; Bayliffe v. Butterworth, 1 Exe. 425 ; Bayley v. Wilkins, 7 C. B. 886 ; Westrop v. Solomons, 8 C. B. 345 ; Lewis v. Campbell, ib. 541. As to costs see Gerrard v. Cottrell, 10 Q. B. 679.

(e) See Loroell v. Boston and Lowell Railroad Corporation, 23 Pick. 33. 
which he compromised, it was held that he might recover from the defendant the costs of the chancery suit $(f)$.

When not. $\left[{ }^{* 235}\right] *$ But it is conceived that a master is not bound to indemnify his servant from the consequences of an act which is malum in se, or which the servant knew to be unlawful, although done by him in obedience to his master's orders, as the servant was not bound to obey his master's orders in such case; and the master is

Not if servant act contrary to orders.

Bunker v. Midland Railway Co.

Implied dnty cannot be sued on as implied contract.

Riley v. Baxendale. only bound to indemnify an innocent agent. And a master is not bound to indemnify his servant from damage arising in consequence of his acting contrary to his master's order : as if a servant entrusted to sell, and expressly ordered not to warrant, does warrant, and suffers damage in consequence $(g)$.

Accordingly a boy of fifteen who by the rules of a railway company was not allowed to drive, but on one occasion, by the orders of a foreman, drove a vanload of fish to market and got thrown from his seat and seriously injured, was held to have been rightly nonsuited in an action against the company, as by the rules he was forbidden to drive, and he knew that $(h)$.

And it by no means follows that where there is a duty cast on the master by the law that that duty can be transformed into a matter of contract; a man may expressly contract to do his duty, but the law will not imply a contract to do it.

Where, therefore, an administratrix sued under $9 \&$ 10 Vict. c. 93 , alleging in her declaration that the deceased entered the defendant's service as porter, on the the terms that the defendants would take due and ordinary care not to expose him to extraordinary danger and risk in the conrse of such employment, and that be was from want of such care exposed to extraordinary danger and risk, and killed, but did not give any evidence of an express contract on such terms, she was nonsuited, and the nonsuit was upheld by the Court of Exchequer, Martin, B., observing, that he had on several occasions nonsuited plaintiff's in such cases $(i)$.

[*236] *And inasmuch as a servant, when he engages to serve a master, impliedly undertakes as between himself and his master to run all the ordinary risk $(k)$ of

(f) Dixon v. Fawcus, 30 L. J., Q. B. 137.

(g) See per Houghton, J., in Southern v. How, Cro. Jac. 471 ; see Grylls v. Davies, 2 B. \& Ad. 516.

(h) Bunker v. The Midland Railuay Co., 47 L. T., N. S. 476.

(i) Riley v. Baxendale, 30 L. J., Exc. 87.

(k) In Mansficld v. Baddeley, 34 L. T., N. S. 696, where tl.s (268) 
the service (including the risk of negligence on the Nor for part of a fellow-servant when he is acting in the dis-injuries in charge of his duty as servant of him who is the com- ordinary dismon master of both), the master is not in general bound chirge of to indemanify him against the consequences of injuries duty. sustained in the ordinary discharge of the duties for which he was hired; that is, at least, if the master provide competent fellow-servants, and tackle and machinery reasonably proper and adapted to the work in hand. This principle has, during the last fortyfive years, and especially since the first edition of this work was published, then discussed and applied in a great number of cases in England, Scotland, Ireland and America ; and as it is one of considerable importance and extensive application, it will be desirable to state some of these cases at greater length than would otherwise have been thought necessary. For although the general principle is settled, and may now be considered to be substantialiy the same in all the countries just mentioned $(l)$, the application of it to the circumstances of particular cases will probably yet give rise to considerable litigation and dispute. And as we shall shortly see, the question who are fellow-workmen, or collaborateurs, as it is sometimes expressed, is still unsettled $(m)$.

The first case in which the question arose was Priest- Priestley $\mathrm{r}$. ley ${ }^{*}$ v. Fouler $(n)$. The plaintiff in that case [*237] Fowler.

plaintiff, a dressmaker in the employ of defendant, was asked to go into the kitchen, and was there bitten by a savage $\log$ which was usually tied $u p$, but on this occasion was loose, it was held that the master was liable, as the risk was not an ordinary risk incidental to the service. But in America it has been held that an injury to a pointsman from use of worn-out rail was an ordinary risk. Michigan, \&e. Railway Co. v. Austin, 40 Mieh. Rep. 247.

(1) There was supposed to be a difference in the law upon this sulject in Scotland, prior to Bartonshill Company v. Reid, in Dom. Proc. post, p. 251.

(m) The Employers' Liability Act, 1880, 38 \& 39 Vict. c. 90, is consiclered hereatter.

(n) 3 M. \& W. 1: sec IFinterbottom v. Wright, 10 M. \& W. 109; Bronen v. Mallett, 5 C. B. 599,616 ; Seymour v. Maddox, 20 L. J., Q. B. 327; 16 Q. B. 326. Upon similar prineiples it has been held that a guest who was injured in going through a glass door, could not maintain an action against his host, Southcote v. Stunley, 25 L. J., Exc. 339 ; 1 H. \& N. 247. See also Corby v. Irill, 27 L. J., C. P. $318 ; 4$ C. B., N. S. 556 ; Hounsell v. Smyth, 29 L. J., C. P. $203 ; 7$ C. B., N. S. 73 ; Bolch v. Smith, 31 L. J., Exe. $201 ; 7$ H. \& N. 736; Wilkinson v. Fairrie, 32 I. J., Exc. $73 ; 1$ H. \& C. 633 ; Indermaur v. Dames, 35 I. J., C. P. $184 ; 36$ I. J.. C. P. 181 ; 1 IIfarr. \& Ruth. 243; Gautret v. Eqprton, 36 L. J., C. P. 191 ; Sullixan v. Waters, 14 Ir. C. I. R. 460-467; Smilh v. London and St. Katherine's Dock Co., 37 I. J., C. P. 217; L. R., 3 C. 
Pricstley $\mathrm{v}$. was a servant of the defendant in his trade of a butcher, Fonoler. and the defendant desired him to go with certain goods of the defendant, in a van belonging to the defendant, and conducted by another servant. The plaintiff accordingly went, but the van, being overloaded, broke down, and the plaintiff, who was riding on it, was thrown off and his thigh broken. It did not appear whether the defendant knew of the defects in, or overloading of, the van ; the court, therefore, was not called upon in that case (o) to decide how far such knowledge on his part of a defect, unknown to the servant, would make him liable. But, under the circumstances, he was held not liable, Lord Alinger, C. B., saying, "If the master be liable to the servant in this action, the principle of that liability will be found to carry us to an alarming extent. $\mathrm{He}$ who is responsible by his general duty, or by the terms of his contract, for all the con. sequences of negligence in a matter in which he is the principal, is responsible for the negligence of all his inferior agents. If the owner of the carriage is therefore responsible for the sufficiency of his carriage to his servant, he is responsible for the negligence of his coachmaker, or his harness-maker, or his coachman. The footman, therefore, who rides behind the carriage, may have an action against his master for a defect in [*238] the carriage, owing to the negligence *of the coachmaker, or for a defect in the harness, arising from the negligence of the harness-maker, or for drunkenness, neglect or want of skill in the coachman $(p)$; nor is there any reason why the principle should not, if applicable in this class of cases, extend to many others. The master, for example, would be liable to the servant for the negligence of the chambermaid, for putting him into a damp bed; for that of the upholsterer for sending in a crazy bedstead; whereby he was made to fall down while asleep and injure himself; for the negligence of the cook in not properly cleaning the copper vessels used in the kitchen ; of the butcher in supplying the family with meat of a quality injurious to the

P. 330 ; Smith v. Steele, 44 I. J., Q. B. 62 ; Woodley v. Metropolitan Railway Co., 46 L. J., C. L. 521; 2 Exc. Div. 384 ; Wathins v. Great Western Railway Co., 46 L. J., 817; White v. France, 46 L. J., C. L. 823 ; L. R., 2 C. B. Div. 308 ; Burehell v. Hickisson, 50 L. J., C. L. 101 ; Heaven r. Pender, 52 L. J., C. L. 702; L. R., 11 Q. B. Div. $503 . \quad$ Reversing S. C., 51 L. J., C. L. 465 ; L. R., 9 Q. B. Div. 302.

(o) See cases infra on this point.

(p) See what Pollock, C. B., said as to this in Holmes v. Clark, 30 L. J., Exc. 138. 
health ; of the builder for a defect in the foundation of Priestley v. the house, whereby it fell and injured both the master Fowler. and the servant by the ruins. The inconvenience, not to say the absurdity, of these consequences, afford a sufficient argument against the application of this principle to the present case. But, in truth, the mere relation of the master and the servant never can imply an obligation on the part of the master to take more care of the servant than he may reasonably be expected to do of himself. $\mathrm{He}_{\mathrm{\theta}}$ is no doubt bound to provide for the safety of his servant, in the course of his employment, to the best of his judgment, information and belief. The servant is not bound to risk his safety in the service of his master, and may, if he thinks fit, decline any service in which he reasonably apprehends injury to himself; and in most of the cases in which danger may be incurred, if not in all, he is just as likely to be acquainted with the probability and extent of it as the master. In that sort of employment especially, which is described in the declaration in this case, the plaintiff must have known, as well as his master, and probably better, whether the van was sufficient, whether it was overloaded, and whether it was likely to carry him safely. In fact, to allow this sort *of [*239] action to prevail, would be an encouragement to the servant to omit that diligence and caution which he is in duty bonnd to exercise on the behalf of his master, to protect him against the misconduct or negligence of others who serve hin, and which diligence and caution, while they protect the master, are a much better security against any injury the servant may sustain by the negligence of others engaged under the same master, than any recourse against the master for damages could possibly afford. We are, therefore, of opinion that the judgment ought to be arrested."

The next case occurred in America (q). Two persons

(q) Farwell v. The Boston and Worecster Railroad Cmporation, 4 Mete. Rep. 49 ; see Story on Ag. 453 e, note 1 . The juldrment is also printed in : $\mathrm{L}^{\prime}(\mathrm{C}$. 316. This case has been freculuently acted upon in America. See Broun v. Maxwell, 6 Hill's Rep. 5.92 (1844); Coon v. Syracuse and Utica Railroal Co., G Barbour's Rep. 231 (1819); Haycs v. Western Railroal Corporation, 3 Cuslı. Rep. 270; Aluro v. Agawam Canal Co., 6 Cush. Rep. 75 (1850); King v. Boston and Worcester Railroad Corporation, 9 Cush. Rep.' 112 (1851); Gilshamon v. Stony Brook Railraal Corporation, 10 Cush. Rep. 228 (1852); Wright v. New York Contrat latuluay Co., 11 Smith's Rep. 562 (1862); Faullner v. Eric Railuay Co., 49 Barb. 324 (1867). But the principle wonld not apply so as to prevent the wife of a fellow-servant from reeovering, Gomon v. Housatonic Railroad Co., 17 Amer. Rep. 82. Sce also the 14 MAS. \& SEL. 
Farvell $\mathrm{r}$. were employed by the defendants in their business, the The Boston one as an engineer to manage the engines and cars on and Worcester the road, the other to manage the switches on the railCorporation. way. The latter, although be was properly selected by the company as a person of due skill and reasonable diligence, negligently put or left a switch across the railway, wherehy the engine and cars were thrown off the line, and the engineer was severely injured. $\mathrm{He}$ brought an action for the injury sustained against the company, but it was held, upon full argument, that the action was not maintainable, but should have been [*240] brought against the wrongdoer *himself $(r)$. Shaw, C. J., in delivering judgment, went into an elaborate examination of the whole subject, which he discussed with great ability $(s)$, and, among other authorities, cited, with approval, the case of Priestly v. Fowler.

Hutchinson v. The next case in England was Hutchinson v. The The York, York, Newcastle and Beruick Railway Company $(t)$. Nercastle and The nature of the case sufficiently appears from the Railway Co. judgment of Alderson, B., who said, "The question is whether the defendants are liable for the injury oceasioned to one of their own servants by a collision while he was travelling in one of their carriages in discharge of his duty as their servant; in respect of which injury they would undoubtedly have been liable if the party injured had been a stranger travelling as a passenger for hire. We think that they are not. 'This case appears to us to be undistinguishable in principls from that of Priestly v. Fowler." His lordship then

Scotch case of M'Naughton v. The Calcdonian Railway Co., 19 Sec. Ser. 271; 3 M'Q. 311 ; also reported 28 Law. 'T. 376; 21 Sec. Ser. 160. See also Waller v. South Eastern Raihray Co., 32 L. J., Exc. 205 ; 2 H. \& C. 102 ; 9 Jur. N. S. 501 ; 8 L. T., N. S. $325 ;$ where it was held that the guard of a passenger train and the "ganger" of platelayers, through whose negigence the train ran off the line and the guard was injured, were fellowservants.

( $r$ ) It has since been held in America that the fellow-servant is responsible to the sufferer under such circumstances, Osborne v. Morgan, 130 Mass. Rep. 102; 39 Amer. Rep. 437, post, p. 268, overruling Albro v. Jaquith, 4 Gray, 99.

(s) See per Martin, B., in Waller v. South Eastern Railway Co., 32 L. J., Exc. 209.

$(t) 5$ Exc. 343 ; 19 L. J., Exc. 296 . This case, it will be observed, is similar to the American case last cited in the text, which happened previously; but, as none of the American cases were cited in it, the judgment is of more value, as showing the concurrent opinion of judges of both countries, unbiassed by each other. See also $M$ 'Eniry v. Waterford and Kilkenny Railuay Co., 8 Ir. C. L. R. 312. 
proceeded to state that case; to explain the principle Iutchinson $\mathrm{r}$. upon which a master is in general liable for accidents The I'ork, resulting from the negligence or unskilfulness of bis Nexcastle and servant, and to show that a servant could not recover Berwick against his master'for injury sustained in consequence of his own unskilfulness or negligence. He then continued - "The difficulty is as to the principle applicable to the case of several servants employed by the same master, and an injury resulting to one of them from the negligence of another. In such a case, however, we are of opinion that the master is not in general responsible. Put the case of a master employing A. and B., two of his servants, *to drive his cattle to [*241] market; it is admitted if, by the unskilfulness of A., a stranger is injured, the master is responsible; not so if A., by his unskilfulness, burts himself; he cannot treat that as the want of skill of his master $(u)$ Suppose, then, that by the unskilfulness of A., B. the other serrant is injured while they are jointly engaged in the same service; there, we think, $B$. has no claim against the master; they have both engaged in a common service, the duties of which impose a certain risk upon each of them, and, in case of negligence on the part of the other, the party injured knows that the negligence is that of his fellow-servant, and not of his master. $\mathrm{He}$ knew when he was engaged in the service that he was exposed to the risk of injury, not only from his own want of skill or care, but on the part of his fellowservant also, and he must be supposed to have contracted on the terms that as between himself and master he would run that risk. Now, applying these principles to the present case, it follows that the plain. tiff has no title to recover. $H$., the deceased $(x)$, in the discharge of his duty as one of the servants of the defendants, had put himself into one of their railway carriages under the guidance of others of their servants, and by the neglect of those other servants, while they were engaged together with him in one common service, the accident occurred. This was a risk which H. must be taken to have agreed to run when he entered into the defendants' service, and for the conse-

(u) Semble, the non-liability of the master in that ease would procecl from the principle of avoiding cireuity of action; as the servant himself would be liable over again to his master. An objection which would not apply to holding a master responsible to one servant for the tortious acts of another.

$(x)$ The action was brought by his administratrix, under the statute $9 \& 10$ Vict. c. 93 . 
Hutchinson v. quences of which therefore they are not responsible. The York, The declaration indeed states the accident to have Nerocastle and arisen from the combined neglect of the servants who Bervick Railwoay Co. were managing the carriages in which the deceased [*242] was travelling, and other of their servants *who were managing the train with which the plaintiff's carriage came into collision; and it was argued that this allegation is divisible, and in order to sustain the declaration it would not be necessary to prove any negligence on the part of the train in which $H$. was travelling; but it would be sufficient to prove negligence on the part of the other train, and so it was contended that even admitting the defendants would not be liable for any neglect on the part of those who were manag. ing the train in one of the carriages of which $H$. was travelling, yet there could be no principle exempting them from liability for the acts of those who, though equally with $\mathrm{H}$. servants of the defendants, were not at the time of the accident engaged in any common act of service with him. But we do not think there is any real distinction between the two cases. The principle is, that a servant when he engages to serve a master undertakes, as between himself and his master, to run all the ordinary risks of the service, and this includes the risk of negligence upon the part of a fellow-servant when he is acting in the discharge of his duty as servant of him who is the common master of both. The death of $\mathrm{H}$. appears on these pleadings to have happened while he was acting in the discharge of his duty to the defendants as his masters, and to have been the result of carelessness on the part of one or more other servant or servants of the same masters while engaged in their service. And whether the death resulted from mismanagement of the one train or of the other, or of both, does not affect the principle; in any case it arose from carelessness or want of skill, the risk of which the deceased had, as between himself and the defendants, agreed to run. It may, however, be proper, with reference to this point to add, that we do not think a master is exempt from responsibility to his servant for an injury occasioned to him by the act of another servant, where the servant injured was not at the time of the injury acting in the service of his master. In such a case the servant injured is substantially a stranger, and entitled to all the privileges he would have had if he had [*243] not been a servant. It was contended that *the 
plea in this case $(y)$ is bad on special demurrer, as being but an argumentative denial of the cause of action stated in the declaration; but this objection is unfounded. Though we have said that a master is not responsible generally to one servant for any injury caused to him by the negligence of a fellow-servant while acting in one common service, yet this must be taken with the qualification that the master shall have taken care not to expose his servants to unreasonable risk. The servant when he engages to run the risk of his service, including those arising from the negligence of fellow-servants, has a right to understand that the master has taken reasonable care to protect him from risk by associating him only with persons of ordinary skill and care; and the real object of the plea in this case is, to show that the defendants had discharged a duty, the omission to discharge which might have made them responsible to the deceased. The plea, therefore, appears not to be open to the objection insisted on. For these reasons we are of opinion that the plaintiff has shown no ground of action, and so our judgment must be for the defendants."

Upon similar principles it was afterwards held, in Wigmore v. Wigmore v. Jay $(z)$, that a master builder was not lia- Jay. ble to an action at the suit of the administratrix $(a)$ of a bricklayer who was killed by reason of the falling of the scaffold on which he was working. The scaffold was erected under the superintendence of the defendant's foreman, the defendant not being present, and was constructed by the men in the employ if the defend. ant, the deceased not being one of them ; and the falling of the scaffold was caused by the *unsound- [*244] ness of one of the ledgers or horizontal poles employed in its construction.

The following case shortly afterwards occurred in

(y) The plea, in substance, was that the collision took place solely by the negligence, \&c., of the defendant's servants, who were severally fit and competent persons.

(z) 5 Exe. 354 ; 19 L. J., Exc. 300 ; see also Innocent $v$. Peto, 4 F. \& F. 8 ; and see Seymour v. Maldox, 16 Q. B. 326; 20 I. J., Q. B. 327 ; where it was held that the manager of a theatre was not liable to an aetion at the suit of a singer for injuries sustainel by lim in falling through a hole in the stage. See also cas. cit. ante, p. 237. note (n). Seymour v. Madllox, has, however, been questioned in Ameriea; Ryan v. Fouler, 10 Smith's Rep., App., New York, 410 , where a factory girl, who had been injured by the fall of a privy, recovered against her master. c. 93 ,

(a) This action was also brought under the statute 9 \& 10 Vict. 
Albro v. America (b), and is not unlikely to be useful in EngAgavam land. The defendants were large manufacturers of Canal Co. cotton goods, and the plaintiff was a spinner in their employ. J. was their superintendent, having a general supervision and charge of their establishment, and of the manufacture there carried on. The treasurer of the corporation was their general financial agent. Subordinate to the superintendent were the overseers of rooms in the factory, who were hired and discharged by the superintendent, usually with the advice of the treasurer. The overseers of the rooms hired and discharged the operatives employed in their respective rooms, and all these officers and operatives were paid for their services by the defendants' paymaster at the counting-room. The plaintiff was injured tbrough the negligence of J., in directing the person employed in the manufacture of the gas, with which the mill was lighted, to throw off all the weights from the gasometer, whereby the gas was forced into the mill where the plaintiff worked, in great quantities, extinguished the lights, and so tilling the room where plaintiff was, as to throw her into spasmodic fits, and occasion her serious and lasting injury. But it was held, upon the authority of Priestly v. Fowler, Farwell v. The Boston and Worcester Railroad Corporation, Hutchinson v. The York, \&c., Railway Company, and Wigmore v. Jay (c), that the plaintiff could not recover, as the accident occurred through the negligence of J., who was a fellow-servant of the plaintiff $(d)$. And Fletcher, J., said, "It cannot affect the principle, that the duties of the superintendent may be different, and, perhaps, may be considered as of a somewhat higher character than [*245] those of *the plaintiff, inasmuch as they are both the servants of the same master, have the same employer, are engaged in the accomplishment of the same general object, are acting in one common service, and derive their compensation from the same source. The plaintiff and the superintendent must be considered as fellow-servants within the principle and meaning of the cases above referred to." The court, however, expressed an opinion that it would have been otherwise had J. been an unfit person, of which there was no suggestion.

(b) Albro v. Agawam Canal Co., 6 Cush. 75 (1850).

(c) See these cases, supra.

(d) It was afterwards held upon the same principles that $\boldsymbol{J}$. was not liable, Albro v. Jaquith, 4 Gray's Rep. 99. But that caso? has been subsequently overruled, Osborne v. Morgan, 130 Mass. Rep. 102 ; 39 Amer. Rep. 437, post, p. 268. 
Upon somewhat similar principles, it was held, in a shipowner case in England $(e)$, in which the declaration disclosed not liable to nothing more than that the plaintiff had embarked as a seaman on the defendant's vessel, and that the vessel was not seaworthy but leaky, in consequence of which tho plaintiff became wet and ill; that this disclosed no contract or legal duty of which there had been a breach the subject of an action. And Lord Campbell said, "For aught that appears on this count, the defendant may have been perfectly ignorant of the defects in the vessel, whilst the plaintiff may have examined the vessel before ho engaged himself, and have known her state well. Or it may be that both parties were aware of it, and that it was their intention that the seaman should work and fare the harder and have that considered in his wages. There being no allegation of a scienter, if we held the defendant liable on this count, we must hold a shipowner always liable to an action from every seaman, if from any accident, a butt having started, or the like, the ship was not seaworthy. No such action has ever been brought; this is a case of the first impression, in support of which neither a decision nor even a dictum has been brought to our notice, nor has any legal principle been urged in its support." And afterwards added, "that Priestley v. Fouler $(f)$ seemed to be in principle the same * case as this, and to [*246] establish that there is no implied contract with the seamen that the vessel is seaworthy." And Coleridge, J., said, "This is in truth a contract between master and servant, and is to be decided on the principles applicable to that relation."

Similar principles aro applicable to workmen of IIend eonseveral sub-contractors. If, for instance, a builder who tractor not agrees to erect a house makes separate contracts with other persons to complete certain portions of the work, as, for instance, with a bricklayer, a carpenter and plumber, the persons employed by the latter are the Fig.t. servants of the builder, working together for one common object. Where, therefore $(g)$, a workmen, employed under a sub-contractor at the Crystal Palace to do work thero, was killed by the negligence or careless-

(c) Couch r. Stcel, 3 E. \& B. 402; 23 I. J., Q. B. 1\%1. Jiut see Athinson v. The Newastle and Gateshend Water ('o., 4ti I. J., C. L. 775 ; I. R., f Exe. 404; Gorris r. Seott, 43 L. J., Exe. 9:.

(f) 3 M. \& W. 1, ante, p. 287.

(g) Wiggett v. Fox, 11 Exe. 832; Murray v. Curric, 40 I. J., C. P. 26; I. R., G C. P. 24; Bourke v. White Moss Colliery ('o., ti I. J., C. L. $283 ; 1$ C. P. Div. $556 ; 2$ C. P. Dir. 205 . 
ness of another workmen engaged in doing business for the defendants, who were the general contractors for the whole, under whom the sub-contractor, whose servant the deceased was, had been engaged to perform a definite portion of the whole contract; it was held that the defendants were not liable to an action at the suit of his administratrix, under Lord Campbeli's Act, $9 \& 10$ Vict. c. 93 . And Alderson, B., said,-- "The true principle is, in our opinion, to be found in Hutchinson r. The New Castle, \&c. Railway $(h)$. We think that the sub-contractor and all his servants must be considered as being for this purpose the servants of the defendants whilst engaged in doing work, each devoting his attention to the work necessary for the completion of the whole, and working together for that purpose. We should not give full or reasonable effect to the principle which governs such cases (and which, as stated in Priestley v. Fowler, mainly arose from the enormous inconveniences which would enste from holding the common employer to be liable in such circumstances), if it were not to extend it as far as tho present question."

Volunteer assisting servants.

\section{Degg v.} Midland Raitoay Co.
[*247]*And the principle has been extended to prevent a volunteer recovering under similar circumstances $(i)$.

This also was an action by an administratrix, under Lord Campbell's Act $(k)$. The deceased was a clerk in the employ of Messrs. Pickford, the carriers. On the day on which he met with his death he was occupied in the goods shed adjoining the C. station of the defendants' railway in loading goods for his employers. Three porters of the defendants were trying to turn a truck on a turntable in a siding, and the deceased, seeing that their strength was not sufficient for the purpose, called out that he would assist them, left his work and went on to the siding. While in the act of moving the turntable an engine of the defendants,

(h) 5 Exc. 343, ante, p 240.

(i) Degg v. The Midland Railway Co., $20 \mathrm{~L}: \mathrm{J}$. , Exc. 171; $1 \mathrm{H}$. \& N. 773; see also Abraham v. Reynolds, 5 H. \& N. 143; Cleveland v. Spiers, 16 C. B., N. S. 399. In Wright v. London and North Western Railway Co., 44 L. J., Q. B., 119; L. R., 1 Q. B. $252 ; 45$ L. J., Q. B. $570 ;$ L. R., 10 Q. B. 298 , it was held that a person who had sent a heifer by rail to $P$. Station, and, with the assent of the station-master, assisted in shunting into a siding the horse-box in which the heifer was, was not a rolunteer, and he recovered against the defendants. See also Swainson v, North Eastern Raihoay Co., 47 L. J., C. L. 372; L. R., 3 Exc. Div. 341.

(k) $9 \& 10$ Vict. c. 93 . 
which was omployed in moving trucks, was set in Degg v. motion and backed down the siding, and the trucks Midland attached to it came in contact with the truck on the Railway Co. turntable, and the deceased being forced against a wall, received injuries of which he died. 'The defendants' servants were persons competent to do the work, and the defendants did not authorize the negligence, and it was therefore held that the action was not maintainable. In giving judgment for the defendants, Bramwell, B., said,- "The cases show that if the deceased had been a servant of the defendants, and injured under such circumstances as occurred here, no action would be maintainable, and it might be enough for us to say that those cases govern this; for it seems impossible to suppose that the deceased, by volunteering his services, could have any greater rights or impose any greater duties on the defendants than would have existed if he had been a hired servant. But we were pressed by an expression found in the cases, that a servant *un. [*248] dertakes as between him and his master to run all ordinary risks of the service, including the negligence of a fellow-servant, Wiggett v. Fox (l) being cited for this purpose; and it was said there was no such undertaking here. But in truth there is as much in the one case as in the other. The consideration may not be so obvious, but it is as competent to a man to agree, and as roasonable to hold that he does agree, that if allowed to assist in the work, though not paid for it, he will take care of himself from the negligonce of his fellow-workmen as it would be if he were paid for his services. But we were also told that there was and could be no agreement, that Degg was a wrorgdoer, and thorefore the action was maintainable $(m)$. It certainly would be strange that the case should be better if he wero a wrongdoer than if he had not been. 'We are of opinion that this argument cannot be supported."

This case was upheld by the Exchequer Chamber in anothor $(n)$, in which the plaintiff had been injured by Potter v. the fall of a bale of cotton. It appeared that one of the defendant's sorvants, who was employed in his ware. house, lot the bale fall from it negligently, that another of his servants was below to receive the bale; and that P., the plaintiff, intervened to assist the servant below, and that the plaintiff, so far as the master was con-

(l) 11 Exc. 832, supra, p. 246.

(in) Upon the principle of Bird r. Holbrook, 4 Bing. 628, and such cases.

(n) Potter v. Faulkner, 21 L. J., Q. B. $30 ; 1$ B. \& S. 800. 
Potter v. Faulkner.

cerned, was entirely a volunteer upon the occasion, and was injured by that which was found to be negligence in the servant above. The question was whether $P$., under the circumstances, could sue the master for the negligence of one of his servants. "It is the case," said Erle, C. J., in delivering judgment, "of one who volunteers to associate himself with the defendant's servant in the performance of the defendant's work; and this, without the consent or even the knowledge of the defendant. Such an one cannot stand in a better [*249] position than those with whom he *associates himself in respect of their master's liability. He can impose no new or greater obligations on the employer than those to which he was subject in respect of their master's liability. Now it is clear law that the master would not have been liable if the servant below had been injured by the negligence of the servants above. As between master and servants the duty of the master is to take care that the servants whom he hires shall be of competent skill and ordinary carefulness. When he has done that he has done his duty as between them. We are of opinion that no such duty is cast upon him as the plaintiff has contended for. We have considered the case of Degg v. The Midland Railuay Company, and we are of the opinion that that case has been well decided, and we affirm the principle of that judgment. We therefore affirm the judgment of the court below."

Servant of But where a workman in the employ of one railway one company company w:s engaged in repairing their carriages upon injured by a siding belonging to another company, but in the joint servant of occupation of both companies, and he was placed siding in joint occupation, may recover.

Vose $\mathrm{v}$. Lancashire, de. Railway Co. between the carriages, so that he could not see what might be coming, and was necessarily making a noise at his work, so that he could not hear, and an engine belonging to the other company came up into the siding and drove the carriages together, so that he was crushed between them and killed, and the jury found that the company to whom the engine belonged were guilty of negligence by reason that their rails were defective and that neither the deceased nor his fellow-servants were so; it was held that his representative might maintain an action against that company for compensation under Lord Campbell's Act, they not having been his em. ployers (o). In giving judgment in that case, Pollock, C. B., said,-_I must say now (I am speaking merely

(o) Tose v. The Lancashire and Yorkshire Railway Co., 27 L. J, Exc. $249 ; 2$ H. \& N. 723. 
my own personal private opinion) $(p), \mathrm{I} *$ think [*250] Iose r. Lanwe ought to be extremely cautious how we relax the cashire, \&c. rule that was laid down in this court originally, but Railway Co. which now is undoubtedly the law of the land, with respect to servants in a common employ suffering by the negligence of each other. I believe there never was a more useful decision, or one of greater practical and social importance in the whole history of the law. I believe it was the law-I thoroughly understood it to be so before attention was called to it; for if it had not been so we could hardly have lived into the present century without having actions brought over and over again. No such action ever had been brought before the time when it was proposed to make a master liable in respect of one servant for the negligence of another. I think we ought to be exceedingly cautious how we allow what I must say I consider to be the important benefits of that decision to be frittered away by nice distinctions, or to bo broken in upon by the ingenuity of advocates or by the verdicts even of juries."

So, again, where a railway station, which was used Hrarburton $\mathrm{v}$. both by the Great Western Railway Company and the Grat Western London and North Western Railway Company, but was Railway Co. under the charge of a servant of the latter company, and a train belonging to the Great Western Railway Company, and driven by one of their engine-drivers, having been improperly and negligently shunted into a siding, injured the plaintiff, who was a servant of the London and North Western Railway Company, engaged in cleaning carriages on the siding. It was beld that the plaintiff might maintain an action against the Great Western Railway Company for dam. ages, the injury having been caused by the negligence of the engine-driver in the discharge of his ordinary duty to them, and not in the course of any common employment with the plaintiff $(q)$.

And it has been held in the Privy Council $(r)$, that Principles of the * principles laid down in Priestley v. Fouler, [*251] do not apply to the case of a contract of towage.

(p) Watson, B,, shortly afterwards expressed the concurrence of the Court in this opinion, in Griffiths v. Gillow, :7 1. J., Exe. 467, post, p. 251 .

(q) Warburlon v. Great Western Lailuay Co., 36 I. J., Exc. 9.

(r) Bland v. Ross, 14 Moore, P. C. C. 210 , where the ship tugged ran into the tug. See Spaight v. Trdeastle, I. R., 6 App. Cas. 217, where Bland v. Ross was approved by the IIouse of Lords. 
Miner injured by negligence of fellow-workmen cannot recover.

Griffiths $\mathrm{r}$. Gidllou.

Bartomshill Coal Co. v. Reid.
Huwever, where $(s)$ the plaintiff was, with other workmen in the employ of the defendant, engaged in sinking a mine, and was at the bottom of the pit, and assisted in filling a tub with water which was drawn up to the top to be emptied, and through something occurring at the top, where his fellow-workmen were employed to empty it, it fell down upon the plaintiff and injured him; it was held that he could not sue the defendant for the injury. In that case there was some evidence that the plaintiff was himself contributory to the accident, as he knew that the hook by which the barrel was attached to the tackle to be drawn up was unsafe, and made no complaint; and moreover, the defendant had supplied a proper apparatus which the plaintiff's fellow-workmen neglected to use. There was no evidence that the defendant had given any directions to that effect. It was thought by the Court of Exchequer that to hold the defendant liable would be utterly to fritter away the rule that a master is not responsible for injury caused to one servant by the negligence of another.

And a similar decision was arrived at by the House of Lords, in the following case $(t)$ :- The appellants were the owners of a coalpit, Reid and $\mathrm{H}^{\prime}$ 'Guire were miners in their service. According to the usual course of working the coals in this pit, the miners were let down into and drawn up from the pit in a cage, which was worked by a rope running over a pulley, fixed by machinery, at a considerable height above the mouth of the pit, aud worked by a stationary steam-engine, fixed at a few yards distance from the pit. $S$. was the engineman employed by the appellants to attend to [*252] this engine, and it was his duty to attend to *the drawing up and letting down of the cage, so that the workmen might be moved up and down safely; but he disregarding his duty when the cage was coming up, when two workmen, Reid and II'Guire, were in it, neg. ligently omitted to take the proper means for stopping it at a few feet above the mouth of the pit, where there was a platform on which the men ought to bave got

(s) Griffiths v. Gidlow, 2 ๘ L. J., Exc. 405; 3 H. \& N. 648; 31 L. T. 300 .

(t) Bartonshill Coal Co. v. Reid, 3 M'Q. 226; Same Company v. MF Guire, 3 II'Q. 300. The judgment of Lord Cranworth, L. C., in Reid's ease, deserves an attentive pertusal; he was two sears deliberating over it; not that he had any doubt about the nonliability of the master, but from other causes; see also IVeims v. Muthieson, 4 M'Q. 215. 
out, and allowed it to be carried with great force to the Bartonshill top of the machinery, in consequence of which it was Coal Co. v. upset, and the men thrown out and killed. It was Reid. held by the House of Lords, after a long and elaborato discussion and consideration of all the English and Scotch cases, that the representatives of neither of them could maintain any action against the owners of the coalpit. And that there was no difference, in this respect, between the law of England and Scotland. There appeared to be no doubt but that $S$. and the miners were engaged in a common work.

Considerable difficulty, however, has arisen, and must who are hereafter arise, in deciding in particular cases what fellow-workconstitutes servants of the same master, fellow-work- men engaged men or collaborateurs, as they are sometimes called, in common within the meaning of tho rule laid down in Priestly v. Fowler, and the cases which have followed it. The cases already cited as instances of the application of the rule afford great assistance in determining this question, and further aid may be derived from the following dicta of judges on the subject:-

"It is not necessary for this purpose," said Lord Cranworth, in Bartonshill Coal Company v. Reid (u), "that the workman causing and the workman sustaining the injury should both be engaged in performing the same or similar acts. The driver and tho guard of a stage coach, the steersman and the rowers of a boat, the workman who draws the red-hot iron from the forge and those who hammer it into shape, the engineman who conducts a train and the man who regulates the switches or the signals, are *all engaged in [*253] common work. And so in this case, the man who lets the miners down into the mine, in order that they may work the coal, and afterward brings them up, together with the coal which they have dug, is certainly engaged in a common work with the miners themselves. They are all contributing directly to the common object of their common employer in bringing the coal to the surface."

And Lord Chelmsford, in M'Guire's case (x), said, Bartonshill "It is necessary in each particular case to ascertain Co. v. .M"whether the servants are fellow-labourers in the same Guire. work; because, although a servant may bo taken to have engaged to encounter all risks which aro inci-

(u) 3 M'Q. 295, supra. 307.

(x) Per Lord Chelmsford in Bartonshill Co. v. NG Guire, 3 M'Q. 
dent to the service which he undertakes, yet he cannot be expected to anticipate those which may happen to him on occasions foreign to his employment. Where servants, therefore, are engaged in different departments of duty, an injury committed by one servant upon the other, by carelessness or negligence, in the course of his peculiar work, is not within the exception, and the master's liability attaches in that case in the same manner as if the injured servant stood in no such relation to him. There may be some nicety and difficulty in particular cases, in deciding whether a common employment exists, but in general, by keeping in view what the servant must have known or expected to have been involved in the service which he undertakes, a satisfactory conclusion may be arrived at."

Servants of saine master engaged in different occupations.

IN Naughton v. Caledonian R. Co.

Searle $\mathrm{v}$. Lindsay.
This diclum of Lord Chelmsford agrees with what was said by the Lord Ordinary in M'Naughton v. The Caledonian Railway Company (y). " "It may be," said he, "that the two persons, viz. the wrongdoer and the injured, though both at the time servants of ono master, are engaged in different operations and in distinct departments of work. A dairymaid is bringing home milk from the farm, and is carelessly driven over by the [*254] coachman. *A painter or slater is engaged at his work on the top of a high ladder placed against the side of a country-house, and is injured by the careless. ness of the gardener, who wheels his barrow against the ladder and upsets it. A clerk in a shipping company's office is sent on board a ship belonging to the company with a message to the captain, and ho meets with injury by falling through a hatchway which the mate has carelessly left unfastened, though apparently closed. A ploughman is at work on a piece of ground held by a railway company, and adjacent to a railway, and is while in the employment of the company killed by an engine, which, through the rashness or carelessness of the en: gine-driver, leaps from the line of rails into the field. In such and similar cases it could hardly be contended that the rule laid down in Priestley v. Fowler, would apply."

The plaintiff $(z)$ shipped as third engineer on board the defendant's screw steamer. In order to raise or lower the screw a winch was used, which was worked by handles put on each end of the spindle of the winch

(y) 19 Sec. Ser. $273 ;$ S. C. nomine $M \Gamma$ Norton v. Caledonian Railway Co., 28 Law Times, 376 ; 21 Sec. Ser. 160.

(z) Scarle v. Lindsay, 31 L. J., C. P. 106 ; 11 C. B., N. S. 429. (284) 
when it became necessary to work it. In the course of Chicf engithe voyage the captain having given orders to get up neer and steam the chief engineer directed several men on board, third engiincluding plaintiff, to work the winch in order to bring neer on boaed down the screw. Three men were placed at one handle, and the plaintiff and two others at the other handle. Whilst they were working the winch, one of the handles, which ought to have been, but was not fastened by a pin or screw to make it secure, went off, which caused tho other at which plaintiff was working to go round with great rapidity. The plaintiff was knocked down and injured. The chief engineer had been spoken to on the subject of fastening the handles several times and had promised to put on fastenings. After the accident the handle was secured. The plaintiff sued the shipowner for damages but was nonsuited by Erle, C. J., and the nonsuit was afterwards upheld by the *court, [*255] on the ground that the damages were caused by the negligence of a fellow-servant within the rule laid down in Priestley v. Fouler.

Numerous other cases of a similar nature have occurred which it seems sufficient to refer to shortly. Thus, as we have seen $(\alpha)$,--the guard of a railway train and a ganger of platelayers : a labourer employed in loading trucks and a deputy foreman of platelayers $(b)$ : one of a gang of scaffolders and the foreman of the gang $(c)$ : a carpenter and joiner employed in painting an engine shed near a turntable, and the company's servants engaged in managing traffic, who negligently turned a carriage on the turntable and upset a ladder whereby the painter was thrown down and injured $(d)$ : a miner and an underlooker whose duty it was to superintend the mining operations $(c)$ : a workman employed by an engine-maker, and the foreman who ordered him to get on a travelling crane moving on a tramway, which fell and injured the workman $(f)$ : a manager of barges and a man employed in lowering sacks $(g): a$

(a) Ante, p, 239, note (q).

(b) Lovegrove r. London, Brighton and South Coast Railuay Co., 33 I. J., C. P. $330 ; 16$ C. I3., N. S. 669.

(c) Gallagher v. Piper, ibid.

(d) Morgan v. Vale of Neath Railuay Co., 3:3 I.. J., Q. B. 260; 5 liest \& S. 5\%0, 796; '3; I. J., Q. I3. 23 ; I. R., 1 Q. I3. 146 ; sec Murphy r. Smith, 19 C. I3., N. S. 361; T'unney v. Midland Railway Co., I. R., 1 C. P. 291.

(c) Mall v. Johnson, 34 L. J., Exc. 222; 3 II. \& C. 589.

f) Feltham v. England, :36 L. J., Q. B. 14.

g) Lavclt v. Howcll, 45 L. J., C. L. 387. 
general traffic manager and a milesman ( $h$ ), have been held to be fellow-servants within the rule laid down in Priestley v. Fowler. But a compulsory pilot is not a fellow servant of the crew $(i)$ : nor are an enginedriver and a signalman on joint staff of two railways with one station $(k)$.

American cases.

[*256] *It has been held in America ( $l$ ) that the brakesman of one train who was injured in consequence of part of a train immediately preceding him becoming detached and rolling back upon his train, through the negligence of the brakesman of the preceding train, could not sue the company whose servants they both were. And also, as we have seen, that the superintendent of a cotton mill, in giving orders as to the mode of lighting the gas, was the fellow-servant of a spinner in the employ of the mill-owner $(m)$.

And in the following case $(n)$, which also occurred in America, the master was held not liable upon the same ground.

Labourer

The plaintiff was a common labourer, employed by employed by the defendants in mending the road-bed of their rail railway company allowed to ride to and fro on trucks. way at a distance from his residence, and was allowed morning and evening to ride with other labourers on the gravel train of the defendants. This was done by consent of the defendants, no compensation being paid cirectly or indirectly by labourers for the passage, and the company being under no contract to convey them to ard fro. One day a collision took place with a handcar on the track, through the negligence of those in charge of the gravel train, and the plaintiff was injured: it was held that the plaintiff could not sue the defendants, although it was contended that he and those through whose negligence the accident occurred were not engaged in any common enterprise. The court, however, thought otherwise, and that it made no differ-

(h) Conway v. Belfast and Northern Counties Railway Co., Ir. Rep., 9 C. L. 498; Ir. Rep., 11 C. L., 345; see also Slierrit v. Scallan, Ir. Rep., 11 C. L. 398; MeCarthy v. British Shipowners Co., L. R. Ir., 10 C. L. 384.

(i) Smith v. Sieele, 44 L. J., Q. B. 60; L. R. 10 Q. B. 125.

(k) Swainson v. North Eastern Railway Co., 47, L. J., C. L. 372; L. R., 3 Exc. 341 ; 37 L. T., N. S. 102. See Charles v. Taylor, L. R., 3 C. P. 492 .

(7) Haycs v. The Western Railroad Corporation, 3 Cush. 270.

(in) See Albro v. Agawam Canal Co., ante, p. 244.

(n) Gillshannon v. Stony Brook Railroad Corporation, $10 \mathrm{Cush}$. 228 (1852). See also Wright v. New I'ork Central Railroad Co., 11 Smith's Rep. App., New York, 562, et cas. ib. cit. 
ence whether the transport to and fro was part of the contract of service or merely a permissive privilege.

Sometimes a person called a fellow-labourer ought Deputy rather to be considered to stand in the position of a master. deputy-master, vico-principal, or alter ego; and if an act of negligence causing injury to a workman is brought *home to one who is in that position, [*257] it may be a question whether the real master is not responsible for his negligence. In Hall v. Johnson, where it was considered to be past all doubt that the underlooker and the workman were fellow-labourers, the Court of Exchequer Chamber expressly reserved their opinion on the point.

It has been repeatedly held in England that a fore- Foreman is man cannot be looked upon as a deputy master $(o)$. not. And the same would now be held in Scotland $(p)$.

But in Scotland, where by the general pit regulations Underthe underground manager is invested with exclusive ground manpowers and duties to which a peculiar importance is at-ager in Seottached, he was at one time not considered a fellow-ser- land was. vant with the miners (q.)

And where a master employs boys and girls, or inex- Naster liable perienced workmen or apprentices $(r)$, and directs them where he has to act under the superintendence and to obey the orders direeted of a deputy, whom he puts in his place, it may be they soung are not, within the meaning of the rule, employed in a obey orders common work. They are acting in obedience to the ex- of superior press commands of their employers, and if he, by the servant. carelessness of his deputy, exposes them to improper risks, it may be that he is liable for the consequences.

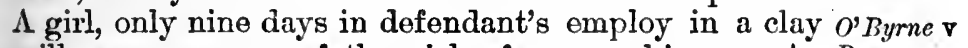
mill, was unaware of the risks from machinery. A., Burn. acting under the defendant as manager of the works, put her to remove some waste clay, whilo the rollers were in motion. A. ought to have done this himself; and it onght not to have been done at all till the move-

(o) Gallagher v. Piper, ante, p. 255; Hall v. Johnson, ante, p. 255 ; Wellham v. England, 36 L. J., Q. B. 14 ; 7 lest \& S. 676 . See Grizzle v. Frost, 3 F. \& F. 622; Wigmore v. Jay, ante, p. 243; IIowells $v$. The Landore Siemens Steel Co., 44 L. J., Q. B. 25; I,. R., 10 Q. B. 62 ; Allen v. The New Gas Co., 45 L. J., C. L. 668; I. R., 1 Exe. Div. 251.

(p) Wilson v. Merry, L. R., 1 Sc. App. 326 (1868). Seo also the Americun cases of 'Crispin v. Bablitt, 81 New York IRep. 520; Slater v. Jevitt, 85 N. Y. R. 61.

(q) Somerrille v. Gray, 1 Third Ser. 768 (1863). See also $M I^{\prime} A n-$ las v. Brownlie, 22 Sce. Ser. 975; Wilson v. Mrrry, 5 Thirl Ser. $807(1867)$; but sce this case in the House of Lords, L. I., 1 Sc. App. 326.

(r) Mr Millan v. M'Millan, 23 Sec. Ser. 1082.

15 Mas. \& SER. 
[*258] ment of the rollers was suspended. The *little girl, in attempting to remove the waste clay in obedience to A's order, sustained a severe injury. from the rollers; for which she brought an action against the master, and he was held liable $(s)$.

Master working with servant not within rule exempting master from liability for negligence of tellow-servant.

Ashworth v. stanvix. Hellors $\mathrm{v}$. Shaw.

The rule, however, which exempts a master from liability to an action for damages for injuries sustained by one workman through the negligence of his fellow-servants does not apply where the fellow-servant was also the master, that is, where the master was working with his servant at the time the accident occurred.

It was upon this principle that in the case of $A s h$ uorth v. Stanwix, which has been already noticed $(t)$, the defendant was held liable. Similar principles were acted on in Mellors $\mathrm{v}$. Shaw $(u)$. In that case the plaintiff at the time of the accident was in the service of the defendants who were owners of the pit in which the plaintiff was injured. The defendant Shaw was manager and superintendent of the pit and was in the habit of attending daily, and used occasionally to go down the shaft. The shaft had been used as an airshaft for several years and had been converted into a drawing shaft about a year before tho accident. It had been usual to have bonnets or coverings of iron to protect the cages in which the men ascended and descended, but none were in use at the time of the accident. On the day in question the plaintiff when ascending the shaft was injured by some of the "bind" cr strata of earth through which the shaft was sunk falling upon him. After the accident Shaw ordered bonnets to be put on. It was held that the defendant Shaw, and therefore tho other defendant also, was liable for per. sonal negligence, and that he was not within the rule laid down in Priestly v. Fowler (v).

Master not liable if he employ competent servants.
[*259] *Again, a master cannot De held impliedly to warrant to one servant the competency of his fellowservants. If he does his best to get competent ser-

(s) O'Byrne v. Burn, 16 See. Ser. (Seotch Rep.) 1025. Sce the commentary on this case in The Bartonshill Coal Co. v. Reid, 3 M'Q. 234. See also Hardie v. Addie', 20 Sec. Ser. 553. This case, however, was settled, and not, as sometimes inaceurately stated, reversed in the House of Lords. See 21 Sec. Ser. 1382, note. See also what is said by the Lord President in Somerville v. Gray, 1 Third Ser. 7\%:.

(t) Ante, p. 17

u) 30 L. J., Q. B. 333; ; 1 Best \& S. 437.

(v) Ante, p. $23 \%$. 
vants that is all he is bound to do. This was decided in the following case $(x)$ :-

The defendant was employed to decorate the Carl- Tarrant $\mathrm{v}$ ton club-house. In order to paint the entrance hall a $W e b b$. scaffolding was erected, upon which plaintiff and others were at work. One of the upper poles broke, and the plaintiff fell and was injured. The scaffolding was erected by M., who was employed for that purpose by the defendant, who did not interfere, except that when MI. told him the painters said it wanted an additional upright to make it secure, the defendant said that if M. hearkened to the painters he would have nothing else to do. The acsident was mainly attributable to the want of that upright, though some ascribed it to an accumulation of boards put on the scaffolding by the workmen themselves. It was held that the defendant would not be liable if the jury should be of opinion that he used every possible care to employ a competent person to erect tho scaftolding, and Jervis, C. J., said,- "The master may be responsible where he is personally guilty of negligence, but certainly not where he does his best to get competent persons. $\mathrm{He}$ is not bound to warrant their competency."

Where an injury happens to a servant while in the Nor for actual use of an instrument, engine or machine, of the injuries to nature of which he is as much aware as his master, and the use of which is the proximate cause of the injury, use of instraho cannot recover against his master for such injury the nature of unless the injury arose through the personal negligence which he is of the master. And it is no evidence of such personal acquainted. negligence of the master that he has in use in his works an engine or machine less safe than some other which is in general nse. Where *therefore, a sugar- [*260] Dymen $\mathrm{v}$. refiner's labourer was killed through the fall of sugar- Lecich. moulds which he was raising by machinery, to which he attached it by means of a clip which slipped off, it was held that his administratrix could not maintain an action, under Lord Campbell's Act, against his master, althongh it appeared that another and safer mode of raising the moulds was usual and had been left off by defendant $(y)$.

Nor can a workman recover damages from his em-

(x) Tarrant v. Wcbb, 18 C. 13. 797 ; 25 I. J., C. P. 261. See also DL'Kinncy v. Irish North Western Ratha!y C'o., 2 Ir. Rep., C. L. 600. According to Shipp v. The Satern Counties Railuay Co., 9 Exc. 223, post, p. 265, the master is the proper judge of the number of servants requisite for any partieular work.

(y) Dynen v. Lcach, :26 L. J., Exc. 221. 
Not for

injuries sustained throngh original bad construction of building.

\section{Brown v.} Accrington Cotton Co.

Nor where injury caused by default of servant.

Nor where act of third person proximate cause of injury. Alsopv. Yates.

ployers for injuries sustained by him whilst at work in their mill and resulting from the buildings having originally been badly constructed, unless personal negligence be proved against the employers themselves or some person acting by their orders for whom they are responsible $(z)$.

And of course a master would not be liable where the injury was cansed to the servant by his own negligence. As where a miner, engaged in an operation called "stooping" (or cutting away portions of pillars or stoops of coal left in original working to support roof), neglected to use the usual props to secure the roof as he worked, and the roof fell on him $(a)$, or a workman in a coalpit was injured by his own haste or carelessness in descending a ladder, which was not proved to be defective $(b)$. In such cases, as the servant's own negligence materially contributed to his injury, he could have no claim on the master $(c)$.

Nor is the master liable where the act of a third person is the proximate cause of the injury. The plaintiff was a labourer employed by the defendant to do work at the building of a house in a street at Liverpool, and there had been a hoarding put up to protect [*261] the building from persons *and carriages passing. The plaintiff had complained that the hoarding was too narrow, and he had not room to pass with a hod of mortar between it and a crab and cradle that had been erected: While he was working a vehicle was coming up the street where there was plenty of room and struck the hoarding, in consequence of which be got injured. He then brought an action against his employer, but was nonsuited, as after he had complained he had continued working there voluntarily with full knowledge, and the part which the master had in the injury was too remoto $(d)$.

Master liable But if the master personally interfere he may be if he person- liable.

allyinterfere.

(z) Broion v. Accrington Cotton Spinning and Manufacturing Co., 34 L. J., Exc. 203. See also Potts v. Port Carlisle Dock and Railway Co., 8 W. R. 524, ib. cit. ; Ovington v. M'Keane, 2 Third Ser. 1066. See this case as to how far a master can recover, from the vendor to him of a chain, damages he has been obliged to pay to the representatives of a servant who was killed by its breaking.

(a) Cook v. Bell, 20 Sec. Ser. (Scotch Rep.) 137.

(b) O'Neill v. Wilson, 20 Sec. Ser. 427.

(c) See Senior v. Ward, 28 L. J., Q. B. 139, post, p. 266 ; and see also Butterfield v. Forrester, Bridge v. Grand Junction Raileay Co., and cases of that sort, post.

(d) Alsop v. Yates, 27 L. J., Exc. 156; S. C. nom. Assop v. Yates, 2 H. \& N. 768. 
The plaintiff was a bricklayer in the service of the Roberts $\mathrm{v}$. defendants, who were builders, and one day, in conse- Sinith. quence of the breaking of a putlog, the plaintiff fell from a scaffolding and broke his leg. The defendants had employed a labourer to erect a scaffold, who had complained that some of the poles were rotton, and had broken them and laid them aside. Smith (the defendant) came up and asked who broke them, and told the labourer they would do very well, as there were no bricks or mortar to be put apon them. The labourer used such as he thought sound, and three where one would have done, but one broke; hence the injury. It was held by the Exchequer Chamber $(e)$ that there was evidence to go to the jury of the personal interference and negligence of the master, in which case he was liable, and a new trial was granted.

And where a master employs his servants in a work Master of danger, he is bound to exercise due care in order to bound to have his tackle and machinery in a safe and proper have machincondition, so as to protect them against unnecessary ery in order. risks $(f)$.

*Upon this principle a workman employed in a [*262] Workmen in stone quarry who was injured in blasting, because, owing stone quarry to a defective system, he could not get out of the way injured quickly enough to avoid injuries took place, was held entitled to recover explosion fective sysagainst his master $(g)$.

So, where an accident occurred in consequence of a Defeetive rope giving way which had been used to fasten one of crab, the spokes or arms of a crab $(h)$.

So, where a stevedore was injured through the break- or chain. ing, from wear and tear and bad welding, of a chain attached to a donkey engine used in loading defendant's ship, as defendant had not taken proper steps to have the chain examined and tested $(i)$

So, where a workman (employed by a railway con-

(c) Roberts v. Smith, 2 H. \& N. 213; 26 L. J., Exc. 319; and see per Pollock, C. B., in Vose v. The Lancashire and Yorkshire Railway Co., 27 L. J., Exc. 251. See also Grifiilhs v. Gidlow, 27 L. J., Exe. 405; Cook v. Duncan, 20 See. Ser. (Scotch Rep.) 180; Ormond v. Holland, 1 E. B. \& E. 102.

(f) Per Lord Cranworth, in Bartonshill Coal Co. v. Reid, 3 M'Q. 288.

(g) Stvord v. Camerou, 1 Sec. Ser. (Scotch Rep.) 493. See this and the two following eases stated and eommented on by Lord Cranworth, in Bartonshill Chal ('o. v. Reirl, 3. M'Q. 289. See the American case of Slone v. Cheshire Railroad Corporation, 19 New Ilampsh. Rep. $42 \%$.

(h) Dixon v. Rankin, 14 See. Ser. 420.

(i) Murphy v. Phillips, 35 J. T., N. S. 477. 
Defect in tractor), whose duty it was to uncouple the waggons, construction ou stepping on to the break for that purpose it slipped of railway down with him, in consequence of there being no block break. on it, which it was the duty of the contractor to have seen attached, and the workman was injured, the master was held liable as the machinery was insufficient $(k)$.

Miner killed by fall of

So, also, the master was held liable where a workman stone. was killed by the fall of a large stone while he was at work underground, if in the opinion of a jury his death was occasioned by the unsafe state of the roof of the mine, and the negligence or unskilfulness of the owners in having so left it when the workmen were sent to work there. But he would not have been liable if the condition of the mine was known to the workman, so that his death, which arose from working under it, was the consequence of his own rashness, and not of any neg. lect of the owner ( $l$ ).

Miner killed [*263] *So, where miners employed at piecework in coming up working coal while in the pit, into which they had been out of mine. let down in the usual manner, remonstrated with the Bryden $\mathbf{v}$. Stewart. underground agent as to the state of the mine, complaining, among other things, that air was not adequately admitted, and also that their wages were not sufficient, and on his refusing redress they declined to work any longer, and desired to be drawn up again. The agent acceded to this, and one of the men in the course of the ascent was thrown over and killed. The jury found that the death arose from the pit not being in a safe and sufficient state. It was held by the House of Lords that the men had a right to leave their work if they thought fit, and that their employers were bound to take all reasonable measures for the purpose of having the shaft in a proper condition, so that the men might be brought up safely, and not having done so were liable for the consequences $(m)$.

Upon similar principles the defendant would have been held liable in Senior v. Ward $(n)$ had not the

(k) Gray v. Brassey, 15 Sec. Ser. 135. See also Matthencs r. M'Donald, 3 Third Ser. 506.

(l) Paterson v. Wallace, $1 \mathrm{M}^{\prime} \mathrm{Q} .748$.

(m) Brydon v. Stevart, 2 M'Q. 30. See the Bartonshill Coal Co. จ. Reid, 3 I'Q. 296, ante, p. 251, where the accident arose from negligence of fellow-workmen, and the master was held not liable; and Griffiths v. Gidlow, 27 L. J., Exc. 405; 3 H. \& N. 648, ante, p. 251, where the master did provide proper apparatus, and was held not liable.

(n) 28 L. J., Q. B. 139, post, p. 266; see also Caswell r. Worth, 5 E. \& B. 849. 
deceased's own negligence disentitled the plaintiff, his representative, to recover.

And if a master order a servant to use machinery, Master liable tackle or implements, which he (the master) knows, for knowingly and the servant does not know, to be unsound or un. ordering safe, in that case the master would of course be liable servant to to indemnify the servant, from the consequence of tackle. using such insecure apparatus. Thus, where a declaration alleged that the defendant was possessed of a ladder unsafe and unfit for use by any person carrying Willians v. corn up the same, and the plaintiff was the defendant's servant, yet the defendant well knowing the premises, wrongfully and deceitfully ordered the plaintiff to carry corn up the ladder, and the plaintiff in obedience to *the order, and believing the ladder to be pro- [*264] per, and not knowing the contrary, did carry corn up for the defendant, but, by reason of its being unsafe and unfit, fell from it and was injured; it was held, on demurrer, to be sufficient, without an averment that the plaintiff had no notice that the ladder was unsafe (o).

So, where the declaration alleged that the defend- Davies $\mathbf{v}$. ants, well knowing that certain carcases were diseased England. and infectious, employed the plaintiff, who was ignorant of that fact, to cut them up, whereby the plaintiff was injured, it was held to disclose a good cause of action $(p)$.

Where the cause of injury or mischief is equally But not known, and palpable to the person employed as to the where danger master, the servant could not then complain of an acci- equally dent; for it might be said that he went to the work known to with his eyes open, and he could not be said to have and servant. been put to work on a matter of which he was ignorant that there was risk involved. Thus, where the defend- Potts r. ant was building a house, and employed no architect. Plunket, The plaintiff was the house carpenter, and the defendant chose some flags which were to be set by another person as a landing place, under the plaintiff's direction as to the slope of landing. The plaintiff and the other person went on the landing when partially set; it broke, and the plaintiff was injured, but the defendant was held not liable $(q)$.

(o) Williams v. Clough, 27 I. J., Exc. 325; 3 II. \& N. 258; and see Potts v. Plunkett, 33 Law' 'T. 111, per Lefroy, C. J.

(p) Davies v. England, 33 L. J., Q. B. 321. See also Smyly v. Glasgow and Londonderry Sleam Packel Co., 2 Ir. C. L. R. 24; 16 Weekly Rep. 483 (1868).

(q) Polls v. Plunliell, in Ireland, 33 L. T. 111; 9 Ir. C. I. I. 290. In Wolling v. Oaster, 40 L. J., Exe. 43; L. R., 6 Exe. 74, 
Servant bound to complain or refuse to work if machinery or staff' insufficient.

Skipp v. Eastern

Connties Railway Company.

S), whore ( $r$ ) it was the duty of the plaintiff, a ser[*265] vant to *a railway company, to attach the carriages of the luggage trains to the engine. One day he was thrown under the carriages and severely injured. There was evidence that the company's staff was not sufficient for the performance of this work, but the plaintiff had been employed in this particular service for several months prior to the accident, and had not made any complaint on the subject to the company: it was held, that the company were not liable, volenti non fit injuria. It was also said by Lord Wensleydale, that it was not a question for the jury whether the number of servants employed by the company was sufficient for the performance of the work. The company are themselves the proper judges of the number they require for carrying on the business of the line. The plaintiff, it was said, brought the accident upon himself, for if he found that he could not do the work which was set him he ought to have declined in the first instance, whereas he carried it on for several months and never complained.

Master liable

Where the legislature has by statute imposed upon for injuries to the master a duty for the protection of the servant, servant through breach of statutory rules. the servant may maintain an action against his master for any breacin of statutory regulations, whereby he has sustained particular injury. And neither the imposition of penalties by the statute for the benefit of the injured person, nor the provision that such penalities are only to be sued for with the sanction of the Secretary of State, take away the right of the party injured to sue for damages in person. Of this nature are actions against millowners under the Factory Acts for not properly fencing machinery, whereby workpeople get injured $(s)$. But even in such cases the master is

it was held not to be necessary to aver the servant's ignorance in a declaration which averred master's knowledge, as such ignorance could be implied. See Griffiths v. London and St. Katharine's Dock Co., 53 L. J., C. L. 504; L. R., 12 Q. B. Div. 493, which shows that the master's knowledge and servant's ignorance must concur to give cause of action.

(r) Skipp v. The Eastern Counties Railway Co., 9 Exc. 223. In America it has been held that the servant was bound to give notice of defects, Keegan v. The Western Reilroad Co., 4 Seld, 175 (1853); M'Millan v. Saratoga and Washington Railroad Co., 20 Barbour's Rep. 450 (1855). Snch notice must be given to the master; see Smith v. Hovard, 22 L. T., N. S. 131, where complaint to a foreman was held insufficient.

(s) Such as Coe v. Platt, 6 Exc. 75i; 7 Exc. 460, 923; Caswell r. Worth, 5 E. \& B. 849 ; Dole v. Sheppard, 5 E. \& B. 856 ; Sehoficld v. Schunck, 5 E. \& B. 858 , note; Holmes v. Clarke, 30 L. J., Exc. 
not liable if the servant by his own negligence or wii But not then ful miscunduct, (e.g., by setting the machinery in if servant * motion) cause the accident, or could have [*266] cause avoided the injury by the exercise of ordinary care $(t)$.

Upon this ground the defendant was held not liable Breach of in the case of Senior v. Ward $(u)$, in which the facts collieryrules were these :-

After the passing of the Act for the Inspection of Senior $\mathrm{r}$. Coal mines $(x)$, special rules were framed and duly ap- Ward. proved of for the regulation of the defendant's colliery, and by one of these rules it was provided, that every morning, before the miners were let down the shaft into the mine, the cage, by which they were to doscend, should be let down and pulled up again, heavily loaded, to test the sufficiency of the rope and of the tackling. But the defendant who superintended the working of his colliery, instead of enforcing this rule allowed it to be entirely neglected, and to his knowledge it had been entirely neglected by his workmen for many weeks before the accident happened, which caused the death of the deceased. The night before the accident the rope, by which the cage was suspended, being then in good condition, was injured by an accidental fire in the colliery. Next morning the deceased and other miners were let down the shaft without any testing of the rope and the tackling. If that testing had taken place, the insufficiency of the rope would have been discovered, and the men would all have been saved. But the rope broke, and the deceased, with several others, was killed on the spot. There was most culpable negligence on the part of the defendant in neglecting the vule and in keeping in his employment a banksman whom he knew habitually disregarded it. Looking to these facts only, although the banksman was a fellowservant of the deceased, and both the deceased and he were employed by the defendant *in the colliery [*267] as fellow-labourers, Lord Campbell said, " $\mathrm{He}$ should have held the defendant liable, his negligence having rnaterially contributed to the death of the deceased. But according to the report of the learned judge who

135; 31 L. .J., Exe. $350 ; 7$ H. \& N. 937 ; 3 L. T., N. S. 675; Britton v. Grcat Western Cotton, Co. 41 L. J., Exc. 99 ; L. R., 7 Exc. 130.

(t) Casuerl v. Worth, ubi supra.

(u) $2 \prec$ L. J., Q. B., 139; 1 EIl. \& Ell. 38.5.

(x) 18 \& 19 Vict. c. 108. This Aet was repealed by $23 \& 24$

Vict. e. 151 ; and that $A$ et was also repealed. See now $36 \&$ \& 37 Vict. ce. 76 \& 77 , post Appendix. But the alteration of these Acts does not effect the principle of scrior $\mathrm{v}$ Ward. 
Senior $\mathrm{r}$. tried the case, it was further in evidence, that gross Ward.

Breach of sanitary rules.

Gorris v. Seott.

Master not liable if servant not bound to obey.

One servant liable to another for negligence in course of common employment. negligence was to be imputed to the deceased himself, and that this negligence materially contributed to his death. With the exercise of ordinary prudence be would have escaped the danger, and his life would have been saved. $\mathrm{He}_{e} \mathrm{knew}$ the rule for testing the rope and tackling every morning; and he knew that this rule was habitually violated; further, on the morning of the accident he and other miners were told by the banksman, that they had better examine the ropes before they went down. Nevertheless they disregarded this warning, immediately getting into the cage, the rope broke as it descended, and they were billed.

And where the statutory duty was imposed for the benefit of the public, e. g., to prevent the introduction and spreading of contagious diseases, and not for the benefit or protection of individuals, it was held that the plaintiff, who had sustained special damage by the breach of such duty by the defendant, had no cause of action against him $(y)$.

A master, moreover, is not liable to a servant for injuries sustained in the performance of orders which he was not bound to obey ; e. g., a servant is not bound to risk his life or limb in obedience to his master's orders; and if he do so, he (the servant) must take the consequences, his master is not liable for them $(z)$.

Similar principles would, it is conceived, apply to any case in which a servant sustained injury in the discharge of duties for which he was not hired, or in acting in obedience to orders which he was not bound to [*268] obey. If, *for instance, a female servant (say a lady's-maid) were ordered to stand outside an upper window and clean it, or to hold a horse, and sustained injury, it is conceived that neither she nor her representative, in case of her death, could maintain any action against her master for such injury.

Whether or not one servant is liable to another for damages arising from an accident, in the course of their common employment, is a question which it is believed has never been raised in England. But there seems no good reason why one servant should not be liable to his fellow-servant for such damages if caused by negli. gence. A dictum to the contrary has indeed been attributed to Pollock, C. B., in one report of Southcote v.

(y) Gorris v. Scott, 43 L. J., Exe. 92 ; L. R., 9 Exe. 125.

(z) Ante, p. 235. 
Stanley $(z)$, but is not to be found in another report of the same case $(a)$. And in 1855 it was decided in America, in Albro v. Jaquith (b), that one servant was not liable to a fellow-servant under such circumstances, but that decision has been subsequently (in 1881) overruled in Osborne v. Morgan (c). In that case it ap- Osbmrne v. peared that the plaintiff was at work as a carpenter in Morgan. the establishment of a manufacturing corporation, putting up, by direction of the corporation, certain partitions in a room in which the corporation was conducting the business of making wire. The defendants, one, the superintendent, and the others, agents and servants of the corporation, being employed in that business, negligently and without regard to the safety of persons, rightfully in the room, placed a tackle, block and chains upon an iron rail suspended from the ceiling of the room, and suffered them to remain there in such a manner, and so unprotected from falling, that by reason thereof they fell upon and injured the plaintiff. Upon these facts *it was held that the plaintiff was a [*269] fellow-servant of the defendants, and, overruling Albro v. Jaquith, that the action was maintainable against them.

In Scotland, also, the fellow-servant has been held liable $(d)$.

Soon after the publication of the last edition of this book, the attention of Parliament was drawn to the hardship inflicted upon working-men by the operation of the rule we have been cousidering, which exempts a master from responsibility to one servant for injuries sustained through the negligence of a fellow-servant, over whom in many cases he had no sort of control, and whom in many cases he was bound to obey. The matter was accordingly, in 1876 , referred to a select committee, who made a report, which in 1877 was again referred to a select committee, who finally reported in 1877 in.favour of a change of the law.

This led to the passing of the Employers' Liability Employers Act, 1830 (43 \& 44 Vict. c. 42), which came into opera- Liability tion on the 1st January, 1881, and will continue in force Aet, 1880.

(z) 1 H. \& N. 250.

(a) 25 L. J., Exc. 339. And observe what Alderson, B., is reported to have said on this point in this case.

(b) 4 Gray's Rep. (Massach. 1885) 99. A previons action against the company had failed, Albro v. Agawom Canal Co., ante, p. 244.

(c) 130 Mass. Rep. 102 ; 39 Amer. Rep. 437.

(d) Wright v. Roxburgh, 2 Third Ser. 748. 
till the 31st December, 1887, and to the end of the then next session of Parliament, and no longer, unless Parliament shall otherwise determine. But inasmuch as this Act of Parliament only applies to a limited class of persons, viz., to a "workman," which means a "railway servant and any person to whom the Employers and Workmen Act, 1875 (e), applies," i. e., "does not include a domestic or menial servant, but, save as aforesaid, means any person who, being a labourer, servant in busbandry, journeyman, artificer, handicraftsman, miner, or otherwise engaged in manual labour, whether under the age of twenty-one years or above that age, has entered into or works under a contract with an employer, whether the contract be made before or after the passing of this Act, be express or implied, oral or in $[* 270]$ writing, and be a contract of service or *a contract personally to execute any work or labour," and it has been decided that they may contract themselves out of the Act $(f)$, and the Act does not get rid of the doctrine of common employment; it is still necessary to preserve the foregoing statement of the decisions upon the subject previous to the passing of the Act.

The Actitself, and the decisions upon it, will be found in the Appendix, post.

(e) $39 \& 39$ Vict. c. $90 ;$ s. 10. 357.

f) Griffiths v. Eurl Dudley, 51 L. J., C. L. 543 ; 9 Q. B. D. 
[*271] * *CHAPTER V.

THE LIABILITY OF A MASTER TO THIRD PERSONS FOR THE ACTS OF IIIS SERVANT.

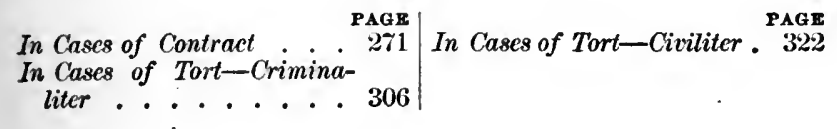

\section{In Cases of Contract.}

THE power which a servant possesses of binding his Serrant can master by contracts entered into in his name is founded only bind his upon or rather is the basis of the general law of prin- master as his cipal and agent. It is only upon the ground that a servant is the agent of his master, that a master can in any case be made liable upon contracts entered into by his servant, and the principle on which the liability of the master upon such contracts depend is, that the act of the servant is, in fact, the act of the master; the maxim being, Qui facit per alium, facit per se (a).

And since many persons, such as infants and married Incapacity of women, who are incapacitated in general to do acts on Incapacity their own behalf, which will be absolutely binding upon contract on them, may nevertheless as agents for others do acts his own which will be binding upon the persons for whom they behalf, no act $(b)$; it would be no cbjection to the liability of a objection to master upon *the contract of his servant that [*272] liability. the servant was an infant or a married woman $(c)$ at the time the contract was entered into,- - provided the contract was in other respects binding upon the master.

(a) Sce Bac. Abr. Master and Servant, K. Where a clerk left a bag and papers belonging to his master at an inn, and left without paying his bill; it was held that the innkeeper had a lien on them as against the master, Sncad v. Watkins, 1 C. B., N. S. 267.

(b) Co. Litt. 52 (a); Bac. Abr. Authority, B.; Story on Ageney, ss. 7 and 8 , where sce the rule of the civil law. See also Emerson v. Blonden, -1 Fsp. 142 ; Palethorp v. Furmish, 2 Esp. 511, note; Prestwick v. Marshall, 7 Bing. 565 ; Lindus v. Bradrell, 5 C. B. 583.

(c) As to the effect of a contract made by a married woman as agent, after the termination of her authority to act as agent, see Smout v. Ibery, 10 M. \& W. 1. 
If contract But in order that a contract made by a servant may within scope be binding upon his master, it must be within the of servant's scope of the authority entrusted to the servant; since authority.

no agent can bind his principal beyond the scope of his authority $(d)$.

What is scope of servant's anthority.

It therefore becomes necessary to inquire what is the scope of authority entrusted to a servant with regard to binding his master upon contracts. The answer to this question involves the consideration of several others, for the authority of a servant to contract in his master's name may be given either expressly by deed, writing, or word of mouth; or by implication from the conduct of the master (e). And in either of those cases it may be general ( $i$. e., not unqualified, but to act in all cases of a particular nature), or it may be special ( $i$. e., to act in one particular instance) $(f)$. Again, in any of the before-mentioned cases the authority given may be either limited by precise instructions, or unlimited $(g)$.

Fxpress - Where authority to contract in his master's name is authority by given to a servant by deed or writing, but little diffdeed or writing. [*273] culty *is likely to arise in ascertaining the extent of his authority, except, perhaps, from some ambiguity in the expressions used in the instrument conferring it $(h)$. In such cases it is the duty of the court to explain them, and they will be construed strictly $(i)$.

(d) And of course an agent cannot bind his principal where a statute requires the personal signature of the person to be charged-as, for instance, Lord Tenterden's Act, 9 Geo. 4, c. 14 , s. 1 ; Hyde v. Johnson, 2 Bing. N. C. 776, where it was held that an acknowledgment signed by a clerk would not bar the Statute of Limitations; see also Bayley v. Ashton, 12 A. \& E. 493. So, under sect. 6 of the same statute, it was held in the Exchequer Chamber (reversing on this point the decision of the Court of Qucen's Bench in Swift v. Winterbotham, 42 L. J., Q. B. 111 ; L. R., 8 Q. B. 244), that a banking company was not bound by the misrepresentation of their manager as to the credit of a customer, Swifi v. Jewsbury, 43 L. J., Q. B. 56; L. R., 9 Q. B. 301, though the manager himself was held clearly liable in both Courts. But where a statute did not require the personal signature of an appellant to a notice of appeal, it was held that a notice signed by his solicitor's elerk in the appellant's name, he being duly authorized to sign, was sufficient, $R$. v. Justiees of Kent, 43 L. J., M. C. 112 ; L. R., 8 Q. B. 305.

(e) F. N. B. 120, G.

f) Whitehead v. Tueket, 15 East, 408 ; Paley on Ag. 199.

(g) Paley on Ag. 2.

(h) Smith's Merc. Law, 4th ed. 116; and see Attwond v. Munnings, 7 B. \& C. 278; Withington v. Herring, 5 Bing. 442; Heraud v. Leafe, 5 C. B. 157.

(i) Howard v. Baillie, 2 H. Bl. 618; Murray v. East India Co., 5 B. \& Ald. 211 ; Attuood v. Munnings, ubi supra; Paley on Ag. 
Letters containing private instructions as to the mode Letters of in which the authority given is to be exercised (as dis- instruction. tinguished from the instrument conferring the authority), being documents of a less formal kind, will receive in general a more liberal construction. But where a servant intending to act in conformity with his instructions has acted in a manner contrary to his master's intention, the court will, as between him and his master, construe them in a manner favourable to the servant and against the master, if they are capable of such a construction, upon the principle that verba fortius accipiuntur contra proferentem $(k)$.

The effect of express verbal instructions to the ser- Express vant will be considered hereafter, as it depends upon verbal whether the servant has a general anthority to act for authority. his master, or is merely specially employed on one particular occasion.

Where a master has recognized and adopted a contract Ratification. entered into in his name by his servant, he will be equally liable upon it, as if he had previously expressly authorized the servant to enter into it, the maxim. in such cases being omnis ratihabitio retrotrahitur et mandato priori cequiparatur $(l)$. This doctrine, said Lord Cranworth in Bird v. Broun $(m)$, "is intelligible in principle and easy in its *application when applied to [*274] cases of contract. If A. B , unauthorized by me, makes a Birl $\mathrm{r}$. contract on my behalf with J. S., which I afterwards re- Brown. cognize and adopt, there is no difficulty in dealing with it as having been originally made by my authority. J. S. entered into the contract on the understanding that ho was dealing with me, and when I afterwards agreed to admit that such was the case, J. S. is precisely in the condition in which he meant to be; or, if he did not believe A. B. to be acting for mo, his condition is not altered by my adoption of the agency, for he may sue A. B. as principal at his option, and has the same equities against me if I sue which he would have had against A. B." $(n)$.

192 ; and see Flemyng v. Hector, 2 M. \& W. 172 ; Cockerell v. Aueomple, 26 I. J., C. P. 194 ; 2 C. B., N. S. 441, where a member of a coal club was held liable for coal ordered by the secretary.

(k) Story on Ag. 74, 75 .

(l) Co. Litt. 207 a; Story on Ag. s. 239 et seq., where see the rule of the Roman law, which was similar. And see Saunderson v. Griffiths, 5 B. \& C. 909 ; Vere v. Ashby, 10 B. \& C. 298; Maclean v. Dunn, 4 Bing. 722; Fitzgerald v. Dressler, 33 Law Times, 43 ; 29 I.. J., C. P. 113.

(m) 4 Exc. 798.

(n) There is more difficulty in the application of this doctrine in casces of tort; as to which see post. 
A master, however, cannot in this manner render himself liable upon a contract made by a servant, unless the servant, at the time he entered into it, assumed to act as his agent $(o)$.

Nor can he thus avail himself by adoption of an act done in his name, which, in order to be vaiid at all, ought to have been valid at the time it uas done $(p)$.

Notice to quit.

Nust be of entire contract. Such, for instance, as a notice to quit, since such a notice, to be good, must be one that the party to whom it is given may act upon it immediately $(q)$. It is conceived, however, that even if such a notice were given, in his master's name, by a servant not authorized to give it, to a tenant from year to year, and the master ratified it and gave notice to the tenant of such ratification bcfore the commencement of the last half of the [*275] tenancy, such ratification would render the *notice va'id $(r)$; though that might, perhaps, more properly by called a fresh notice to quit given by the master himself.

Where a master adopts and ratifies a contract made by his servant, he adopts it in toto, and cannot adopt part, and repudiate part which he had not previously authorized the servant to agree to : $e . g$., if a man, not a horsedealer, authorize a servant to sell a horse, and expressly orders him not to warrant or sell the horse upon any condition, yet, if the servant sell the horse upon condition to be returned if not approved of by the purchaser, and the master receive the price, he thereby ratifies the contract and the condition; and, if the horse be returned, is bound to return the money $(s)$.

Where a master has admitted his liability upon a con.

(o) Wilson v. Tumman, 6 M. \& G. $236 ; 4$ Inst. 317 ; Walker v. Hunter, 2 C. B. 334; see Smith v. Hull Glass Company, 11 C. B. 897. It was a maxim of the Canon law, "Ratum quis habere non potest, quod ipsins nomine non est gestum." See note $a$ to 6 M. \& G. 239. See also Ancona v. Harks, 31 L. J., Exe. 163; Woollen v. Wright, 31 L. J., Exc. 513.

(p) As to how far the shareholders of a limited liability company can ratify an act of the directors which was ultra vires, though not expressly or impliedly prohibited, see Riche v. The Ashbury Railway, \&e. Company, 34 L. J., Exc. $17 \%$.

(q) Doe v. Walters, 10 B. \& Co. 626; Doe v. Goldwin, 2 Q. B. 146 ; and see per Lord Wensleydale, in Buron v. Denman, 2 Exc. 183 ; Story on Ag. s. 246.

(r) See Bird v. Brown, 4 Exc. 799; Jardine v. Lcathley, 32 I. J., Q. B. 132 .

(s) Sce and consider Ferguson v. Carrington, 9 B. \& C. 59; Foster v. Smith, 18 C. B. 156 ; Pauling v. London and North Western Railway Company, 8 Exc. 867; Ramazotti v. Bowring, 29 L. J., C. P. 30 ; but see Bosanquet v. Foster, 9 C. \& P. 659; Same v. Corser, ib. 665. 
tract made by his servant, the weight due to that ad- Admission of mission depends on the circumstances under which it liability by was made $(t)$. If no other person has been induced master. by it to alter his condition, the master is not concluded or estopped by it, but may prove it to have been mistaken or untrue $(u)$.

Where the authority of a servant to bind his master Extent of upon contracts arises merely by implication, the gen- servant's eral rule is, that the authority of a servant is co.exten. implied sive with his usual employment, and the scop of his authority. authority is to be measured by the extent of his employment $(v)$. For a master who accredits a servant by employing him must abide by the effects of that credit, and will be bound by contracts made with innocent third persons in the seeming course of that employment, and on the faith of that credit, *whether [*276] he intended to authorize them or not, or even if he exprossly though privately forbade them; it being a gen. eral rule of law, founded on natural justice, that where one of two innocent persons must suffer by the fraud of a third, he who enabled that third person to commit the fraud should be the sufferer $(w)$. Upon this principle, where a servant usually buys for his master upon when servant credit, and the master is in the habit of paying for usually buys goods so purchased, the master is liable to pay for any goods of a similar nature which the servant may obtain upon credit, even though, in a particular instance, the master furnished the servant with money to pay for the goods and the servant embezzled the money; or even if the servant after he has been discharged pledge his master's sredit, unless the party giving credit knew that the servant was discharged $(x)$; the master in fact being estopped from denying the authority of the servant to bind him $(y)$. Thus, where $(z)$ the defendant,

(t) Newton v. Beleher, 12 Q. B. 924.

(i) Nevton v. Liddiard 12 (2. B. 925; see Heane v. Rogers, 9 B. \& C. 577; Pickard v. Sears, 6 A. \& 1. 474; Freeman v. Cooke, 2 Exc. 654.

(v) Smitl's Mere. Law, 116; Paley on Ag. 162; and see Poth. on Obl. ly Evans. No. 456 .

(w) Hern v. Nicholls, 1 Silk. 289; Barring v. Corric, 2 B. \& Ald. 143. In Fitzherbert v, Mather, 1 T. R. 16, Buller, J., said, "It is the common question every day at Guildhall, when one of two imocent persons must suffer by the fraud or negligence of a third, which of the two gave credit?"

(x) Nieksm v. Broham, 10 Mod. 109; Anon. 1 Show. 95; Aishcombe v. Hundred of Snelholme, Holt 460;- v. IIarvison, 12 Morl. 346; Sir Robert Wayland's ease, 3 Salk 234; Anon. 12 Mod. 564; Boulton V. Arlsden, 3 Sillk. 234; 1 Lord Raym. 225.

(y) See per Erle, C. J., in re Swan, 30 I. J., C. P. 118.

(z) Hinzard v. Treadiocll, 1 Str. 506.

16 MAS. \& SEr. 
Hazarl $\mathrm{v}$. who was a considerable dealer in iron, and known to Treadwell. the plaintiff as such, though they had never dealt together before, sent a waterman to the plaintiff for iron on trust, and paid for it afterwards. He sent the same waterman a second time with ready money, who received the goods but did not pay for them; the defendant was held liable "for the sending him upon trust the first time, and paying for the goods was giving him credit so as to charge the defendant upon the second contract" $(a)$.

Wayland $[$ [*277] *So where (b) a master used to give his servant case. money every Saturday to defray the charges of the foregoing week. 'The servant kept the money, yet per Holt. C. J., "The master is chargeable ; for the master, at his peril, ought to take care what servant he employs, and it is more reasonable that he should suffer for the cheats of his servant than strangers or tradesmen."

Rusby v. Scarlett.

Summers $\mathbf{\nabla}$.

Again, where (c) a gentleman kept a book with his coachman in which were entered the articles procured by, and the sums advanced to, him ; but there did not appear to be any connection between the sums advanced and the demands he was to pay: the gentleman was held liable to pay for hay and straw dalivered for the use of his horses, although he had given the coachman money to pay the bills, which he had embezzled.

Solomon.

So where the defendant, a jeweller, kept a shop in the country, living himself in London, and visiting the country shop once a month to take stock, \&c. The country shop was managed by a shopman, A., from whom the plaintiff had for some years been in the habit of receiving orders in the country in the defendant's name, for goods which were sent to the conntry shop, and afterwards were paid for by the defendant. A. absconded, went to London and ordered jewellery there of the plaintiff in the defendant's name, which . he carried away with him; it was held that the previous course of dealing justified the plaintiff in assuming that A. had general authority to order goods for the shop on the defendant's credit, and that the defendant was,

(a) See, however, Todd v. Robinson, Ry. \& M. 217; Gilman v. Robinson, Ry. \& M. 226; 1 C. \& P. 642. A general agency to order goods could hardly be implied from a single recognized dealing. In most cases it would be a question for a jury whether the defendant held out the servant as his agent for the purpose of ordering the goods in question.

(b) Sir R. Wayland's case, 3 Salk. 234 ; and see Miller v. Hamitton, 5 C. \& P. 433.

(c) Rusby v. Scarlett, 5 Esp. 76. 
therefore, liable for the goods obtained by $\mathrm{A}$. in Lon don $(d)$.

Giving ser-

And if the master was originally liable for a debt in- vant money curred by his servant, he could not discharge himself by to pay debt. merely giving the servant money to pay it $(e)$. But if the creditor should so deal with the master as to lead him to *believe that the debt was discharged, [*278] the creditor might, under such circumstances, be precluded from afterwards suing the master $(f)$.

Upon similar principles the owner of a saw mill Tradesman beld $(g)$ bound by a contract entere a baund by bect (g) furnd a contered into by his fore- contract of Scotch fir staves; as a foreman employed to conduct a. business like that in which the defendant was engaged, must be taken to have a general authurity to bind his Winkficld $\mathrm{v}$. master by such contracts. And if a person goes to the Packington. office of a carrier and asks what a thing will be done for, and he is told by a clerk, or servant, who is transacting the business there that it will be done for a certain sum, the master can charge no more, although he has previously ordered his clerks to charge more $(h)$. The fact that the servant has snade a bad bargain gives the master no equity to be relieved from it $(i)$.

So again where the granary clerk to a cornfactor said Coventry. "all right" when a delivery order for flour was presented, his master was held to be estopnea from saying that no property had passed for want of appropriation of the flour $(j)$.

A company established for the manufacture of glass, completely registered under $7 \& 8$ Vict. c. 110 ( $k)$, had power under their deed of settlement to appoint a manager of their works, \&c., to "superintend and transact, under the control of the board of directors, the manufacturing business of the company," and to whom the board of directors were, by anotber part of the deed, authorized to delegate "such and so many of the pow-

(d) Summers v. Solomon, 26 L. J., Q. B. $301 ; 7$ E. \& 13. 879. Bramwell, B., did not assent to the law laid down in this case, 3 H. \& N. 794.

(e) Heald v. Kenworthy, 10 Exc. 739.

(f) Macfarlane v. Giannacopulo, 3 H. \& N. 860.

g) Richardson v. Cartwright, 1 Carr. \& K. 32子; see Thompson v. Bell, 10 Exc. 10, where a joint-stock bank was held bound by an act of the manager. See also Pauling v. London ant North W'stern Railuray Company, 8 Exe. 867.

(h) Winkfield v. Packington, 2 C. \& P. 599.

(i) Girifiths v. Jones, 42 L. J., Ch. 468.

(j) Woolley v. Corentry, 32 I. J., Exe. 185.

(k) This aet was repealed by "The Companies Act, 1862," 25 $\& 26$ Vict. c. 89, s. $20 \overline{5}$. 
ers thereby given to them as would enable him to carry [*279] on the said works *and manufacturing business in an efficient manner." It was held that the company were liabie for goods supplied to them for the purposes of their manufactures upon orders given by such manager, although there was no express delegation of au.

or mänaging director. Tolterdell v. Farcham Blue Brick and Tile Co.

Shareholiter in mine bound by contract of purser.

Directors bound by contract of secretary.

Firm bound by indorsement of manager.

Presumptive agency extended to stranger in countinghouse.

Payment to such a person in course of

\section{thority $(l)$.}

So where seven person signed a memorandum of association of a company for making bricks, and two of them, one professing to act as managing direstor, and the other as chairman of the company, engaged the plaintiff as foreman of certain brickworks, it was held, that in the absence of proof to the contrary the company must be taken to have given authority to such two persons to engage the plaintiff, and was liable to pay his wages $(m)$.

So where goods were ordered by the purser of a mine on the cost-book principle, a shareholder was held liable $(n)$.

So provisional directors have been held liable to pay for advertisements which they passed a resolution to insert, and which resolution was acted on by the secretary $(o)$.

So where the plaintiffs trading as S. \& Co. sold goods to the defendant, who paid for them by cheque payable to S. \& Co., and K. their manager indorsed the cheque "S. \& Co., per K., agent," though he had no authority to do so, and the cheque was paid by the bankers, the defendants were held to be discharged $(p)$.

The principal of presumptive agency on which these cases were decided has been extended to cases in which the person who assumed to act as servant was not really servant, but was considered to have been held out as servant, by the act of the master.

Thus a merchant has been held bound by a payment [*280] in *the usual course of business to a person found in his counting-house and appearing to be entrusted with

(l) Smith v. Hull Glass Co., 11 C. B. 897 ; see also Ex parte Greenwood, 3 De G., M. \& G. 459; 18 Jurist, 387; Ernest v. Nicholls, 6 Ho. Lords Cas. 401 ; Forbes v. Marshall, 11 Exc. 166, 179; Re Athenzum Life Assurance Co., 27 L. J., Ch. 829 ; Agar v. Same Company, 3 C. B., N. S. 725; 27 L. J., C. P. 95 ; Prince of Wales Assurance Society v. Athenæum Assurance Society, 27 L. J., Q. B. 297.

$(m)$ Totterdell $\nabla$. Fareham Blue Brick and Tile Co., 35 L. J., C. P. 278 .

(n) Gcakes v. Jackson, 36 L. J., C. P. 108.

(o) Maddick v. Marshall, 16 C. B., N. S. 387 ; 17 C. B., N. S. 829, and see Riley v. Packington, 36 L. J., C. P. 204.

(p) Charles v. Blackwcll, 45 L. J., C. L. 542; I. R., 2 C. P. Div. 151. 
the conduct of the business there, though it tarued ont business held that the person was never employed by him, and the good.

money never came to his hands; for, said Lord Tenterden, "The debtor has a right to suppose that the tradesman has the control of his own premises, and that he will not allow persons to come there and intermeddle in his business without his authority" $(q)$. Tender to And so a tender to a persun, probably a chief clerk, in person in an the office of an attorney, who refused to accept the attorney's amount tendered as insufficient, has been held good: office, being equivalent to a tender to the attorney himself $(r)$. probably a And an attorney bas been held liable to refund money good. and pay the costs of the application where some one in his office extorted an excessive sum for costs, although the matter did not come to his personal cognizance $(s)$. And payment to a sheriff's bailiff's assistant has been held good as against the sheriff $(t)$.

Again, although "it may be admitted that an author- Implied ity to draw, does not import in itself an authority to anthority of endorse, bills, still the evidence of such authority to elerk to draw is not to be withheld from the jury, who are to endorse bills. determine on the whole of the evidence whether such authority to endorse exists or not" $(u)$. And, there- Prescott $\mathbf{v}$. fore, where the defendants' confidential clerk had been Flinn. accustomed to draw cheques for them, and in one instance, at least, they had authorized him to endorse, and in two other instances had received money obtained by his endorsing in their names, a jury were held warranted in inferring therefrom that the clerk had a general authority to endorse $(x)$.

*And in a case (y) in which the defendant was [*281] Smith v. held liable upon a charter-party signed by his brother $w^{\prime}$ 'Guire. ("per proc. of" the defendant), whom he had left at Limerick to conduct his business, which consisted in buying up corn for shipment, Pollock, C. B., observed:"It would be most inconvenient if a person could not

(q) Burrett v. Deere, Mood. \& M. 200; and see per Manle, J., in Smith v. Itull Glass Co., 11 C. 13. 928; and in Milcheson v. Oliver, 5 E. \& B. 439.

(r) Wilmot v. Smilh, Mood. \& Malk. 238. In Moffat v. Parsons, 5 Taunt. 307, tender of payment to a servant who, in pursuance of his master's orders, refused to accept it, was held a good tender to the master.

(s) Palmer v. Evans, 1 C. B., N. S. 151.

(t) Gregory v. Cotterell, 5 1.. \& B. 571.

(u) Per Tindal, C. J., Prescolt v. Flinn, 9 Bing. 22.

(x) Preseott v. Flinn, ubi supra; and see Burber v. Gingell, 3 Esp. 60; Lleweliyn v. Winckworth, 13 M. \& W. 598; Summers v. Solomon, supra, p. 277.

(y) S'mith v. 'U'Guire, 3 H. \& N. 561; 27 I. J., Exe. 465. 
go into a shop and purchase an article without first asking the shopmen whether he has authority to sell it. It may be that he was merely employed to sweep the shop; but it would be absurd to apply to the general business of life the doctrine as to the necessity of ascertaining whether an agent is acting within the scope of his authority -indeed the business of London could not go on." And he afterwards said: "When the holder of a bill has ascertained that the person who has accepted the bill as agent or by procuration is a clerk in the house, and in the course of his employment has from day to day accepted bills of that sort, that is enough, and he need not ask for his power of attorney or authority, nor whether that particular bill is on account of the firm. When you find him in the house acting and recognized as the agent of the firm, you need not make any further inquiry, and yet it may turn out that he has never accepted a bill without a schedule being laid before him in the morning of all bills that were to be accepted by him on that day. Persons are supposed to carry on their business according to the ordinary arrangement of mankind generally. If a person conducts his business as the defendant did, by an agent who acts in his absence, in my judgment it is a question for the jury whether, according to the ordinary mode in which business is carried on, the reasonable conclusion to be drawn from these circumstances is not that he had authority as a general agent, and if so, the principal is bound, though it should turn ont that he had limited the extent of the agency by certain rules and regulations."

Wilson v. [*282] *And it has been beld to be no answer to a West Hurlle- bill filed against a railway company for specific perpool Railicay formance of an agreement entered into by an agent to allege that he was not anthorized by deed under seal, where the company had acted on the agreement by entering into possession and making a railroad $(z)$.

Guarantee. And a man has been held liable upon a guarantee given in his name by his son, who had signed for his father in three or four instances, and had accepted bills for $\operatorname{him}(a)$.

Where a servant is employed to transact business, and has no particular orders with reference to the

(z) Wilson v. West Harllepool Raihcay Co., 34 L. J., Ch. 241 11 L. T., N. S. 327 . So, è concrso, where the bill was filed by the company. London and Birmingham Railway Co. v. Winter, Cr. \& Ph. 5\%.

(a) Walkins $\mathrm{r}$. Vince, 2 Stark. 368. 
manner in which the business is to be transacted, he is Servant considered as invested with all the authority necessary without prefor transacting the business entrusted to him, and ciseauthority which is usually entrusted to agents $(b)$ employed in has all powmatters of a similar nature. In this respect there is and usual in no distinction whether the authority be general or similar cases. special, express or implied. In each case it embraces the appropriate means to accomplish the desired end (c). Thus a servant sent without money to buy goods has implied authority to pledge his master's credit $(d)$.

Upon this principle it was held in a very old Warranty by case $(e)$ that if a goldsmith make plate wherein he mingles dross, so that it is not according to the standard, and send his servant to a fair to sell it, who sells it for good plate, according to the standard, an action upon the case lies against the master. And so a horse-dealer has been held liable upon the warranty of his servant entrusted to sell, *where the [*283] warranty was part of the transaction of sale $(f)$, and evidence that be expressly told the servant not to warrant is inadmissible $(g)$.

As so also where a person, who was not a horsedealer, Ifclyear v. sent his servant with his horse to Tattersall's for sale, Ilauke. with instructions to warrant him sound, and he warranted him free from vice; the master was held liable upon the warranty, although it was contended on his behalf that the servant was but a special agent, and he having exceeded his authority, the master ought not to be bound. But, said Lord Ellenborough, C. J., "the master having entrusted the servant to sell, he is entrusted to do all that he can to effectuate the sale, and if he does exceed his authority in so doing, he binds

(b) Story on Ag. 60; and see per Lord Wensleydale, in Cox v. Milland Counties Raihwy Co.. 3 Exc. 278.

(c) Story on Ag. 85, 97; Honard v. Baillie, 2 H. Bl. 618.

(d) Tobin v. Crawforel, 9 MI. \&. W. 718.

(e) Southern v. How, Cro. Jac. 471; and see Hern v. Nieholls, 1 Salk. 289. As to how far the master is affected by frum in his servant, see Cornfoot v. Fowke, 6 M. \& W. 358 ; Fuller v. II"ilsom, 3 Q. B. 58 ; Jones v. Downman, 4 Q. B. 235 , note; Doncuman v. Williams, 7 Q. B. 103 ; Story on Ag. 264.

(f) Fenn $\checkmark$. ILarrison, 3 T. R. 760; Pickering v. Busk, 15 East, 47 ; Helyear v. Havke, 5 Esp. 72; Woodiu v. Burforl, 2 Cr. \& M. 391 ; see Coleman v. Riches, 16 C. B. 113. See also Dingle v. Iture, 29 L. J., C. P. 143 ; Utell v. Atherton, 30 L. J., Exc. 337; 7 H. \& N. 172; Barvick v. Euglish Joint Stock Bank, 36 L. J., Exe. 147; I. R. 2 Exe. 259.

(g) Loward $\mathrm{v}$ Shcwoard, 36 L. J., C. P, 4: L. R. 2 C. 1. 150. 
Alexander v. his master" $(h)$. And in another case $(i)$, where the Gibson. defendant's servant, who was entrusted to sell and receive the price, sold a horse at a fair to the plaintiff, and warranted him sound, the defendant was held liable for a breach of the warranty; and Lord Ellenborough said, "If the servant was authorized to sell the horse, and to receive the stipulated price, I think he was incidentally authorized to give a warranty of soundness. It is now most usual on the sale of horses to require a warranty, and the agent who is employed to sell, when he warrants the horse, may fairly be presumed to be acting within the scope of his authority. This is the common and usual manner in which the business is done, and the agent must be taken to be vested with power to transact the business with which he is entrusted in the common and usual manner. I [*284] am of opinion, therefore, that if the *defendant's servant warranted this horse to be sound, the defendant is bound by the warranty" $(k)$

Brady v. Tod. But where a tradesman, who was not a horsedealer, had a farm which was managed by a bailiff named G., and $G$. by his authority sold a horse to the plaintiff, and also gave a warranty which he was not authorized to give, it was held that the defendant was not liable upon the warranty $(l)$. And upon Helyear v. Hawke, Alexander v. Gibson, and Fenn v. Harrison being cited, Erle, C. J., said, "We understand the judges in those cases to refer to a general agent employed for a principal to carry on his business, that is, the business of horse-dealing, in which case there would be by law the authority here contended for. But the facts of the present case do not bring the defendant within this rule, as he was not shown to carry on any trade of dealing in horses; the main reliance was placed on the argument that an authority to sell is by implication an authority to do all that in the usual course of selling is

(h) Helyear v. Hawke, 5 Esp. 72. In Smith v. M'Guire, $3 \mathrm{H}$. \& N. 563, Pollock, C. B., said, "If a man sends his servant to market to sell goods, or a horse for a certain price, and the servant sells them for less, the master is bound by it."

(i) Alexander v. Gibson, 2 Camp. 555; see 16 C. B. 113.

(k) And if an agent, entrusted to sell and warrant, do sell and warrant, and receive the money, but afterwards, in consequence of the goods sold not answering the warranty, return the money to the purchaser, the principal cannot treat the price as money had and received to his use, by the agent. Murray v. Mann, 2 Exc. 538.

(l) Brady v. Tod, 30 L. J., C. P. $223 ; 9$ C. B., N. S. $502 ; 4$ L. T., N. S. 212 . See Brook v. Hassall, 49 L. T., N. S. 569. 
required to complete a sale, and that the question of Brady v. Tod. warranty is in the usual course of a sale required to be answered; and that therefore the defendant by implication gave to $G$. an authority to answer that question, and to biud him by his answer. It was a part of this argument, that an agent authorized to sell and deliver a horse is held out to the buyer as having authority to warrant. But on this point also the plaintiff has, in our judgment, failed. We are aware that the question of warranty frequently arises upon the sale of horses; but we are also aware that sales may be made without any warranty or even an inquiry about warranty. If we laid down for the first time that the servant of a private owner entrusted to sell and deliver a horse on one particular occasion, is, therefore, *by [*285] law authorized to bind his master by a warranty, we should establish a precedent of dangerous consequence. For the liability created by a warranty, extending to unknown as well as known defects, is greater than is expected by persons inexperienced in law: and as everything said by the seller in the bargaining may be evidence of warranty to the effect of what he said, an unguarded conversation with an illiterate man sent to deliver a horse may be found to have created a liability which would be a surprise equally to the servant and the master. We therefore hold that the buyer taking a warranty from such an agent as was employed in this case takes it at the risk of being able to prove that he had the principal's authority, and if there was no authority in fact, the law from the circumstances does not in our opinion create it."

"When the facts raise the question it will be time enough to decide the liability created by such a servant as a foreman alleged to be a general agent, or such a special agent as a person entrusted with the sale of a horse in a fair or other public mart where stranger meets stranger; and the usual course of business is for the person in possession of the horse, and appearing to be the owner, to have all the powers of an owner in respect of the sale ; the authority may, under such circumstances as are last referred to, be implied, though the circumstances of the present case do not create the same inference."

It may be convenient to mention in this place the stexast $\mathrm{v}$. case of Stewart v. Beaumont $(\mathrm{m})$, thongh that was an Beaumont. action for malicious prosecution. The defendant, who 
Stewart r. Was a colonel in the army, had been at Aldershot, and Beaumont. a soldier named $K$. had acted as his servant there. On leaving camp defendant left a horse behind, and told $K$. that if he could find a person willing to buy the horse for $17 l$. he should let defendant know, as he was ready to dispose of him for that sum. $K$. sold the horse to plaintiff, a respectable farmer, for 10l, and [*286] absconded with the money. *Defendant finding plantiff had the horse claimed it, but he refused to give it up, declaring he had bought it honestly. Defendant obtained a search warrant, having sworn to a deposition that the horse was "stolen," and that it was "concealed" on plaintiff"s premises. The plaintiff was not privy to K.'s fraud, and bought honestly. The de. fendant denied any authority to $K$. to sell, and declared that his doing so was dishonest. But Erle, C. J., pointed out that $K$. having possession of the horse, and being held out by the defendant as having authority to sell it, K.'s dishonesty as between him and his master was quite immaterial to the question in the present case, which was reasonable and probable cause for charging the plaintiff with stealing it. If either there was an authority to sell, or if defendant allowed $K$. to appear as having anthority, then plaintiff was owner of the horse and entitled to recover ; there was no reasonable or probable cause. The plaintiff recovered a verdict.

Warranty But although a warranty by a servant entrusted to must be part sell, given at the time of sale, and as part of the transof transaction action of selling, may bind the master, yet an acknowlof sale to edgment to that effect, made at another time, would bind master. not bind him $(n)$. And where there had been a pre. Burford. vious bargain between the plaintiff and the defendant, who was a horse dealer, for the sale of a horse, and the defendant's servant, being sent to deliver the horse and receive the price, gave a warranty, the defendant was beld not liable (o).

Alteration in And so a master has been held not bound by an warranty. alteration in a warranty made by a servant sent to receive the price $(p)$.

These two last-mentioned cases, however, depend upon the general rule, that an implied authority cannot be extended to collateral transactions.

(n) Helyear v. Hatcke, 5 Esp. 72, ante, p. 283 ; Peto v. Hagne, 5 Esp. 135 ; Allen v. Dutnstone, 8 C. \& P. 760 ; see Dyer, 76 a, citing $5 \mathrm{H}$. $7,41 \mathrm{~b}$.

(o) Iroodin v. Burford, 2 Cr. \& M. 391.

(p) Strbde v. Dyson, 1 Smith, 400. 
*Thus, though a clerk, apprentice or shopman, [*287] Implied may have an implied authority to receive money paid authority in the usual course of business, you could not from that infer an authority to receive payments out of the cannot be extended to usual course of business, as deposit on a wager, pay-transactions. ment of a mortgage, legacy or the like $(q)$. So, a clerk who has authority to receive cash across the counter, has not authority to receive payments by cheque by post $(r)$, or by setting off amount due to his master against amount due from him, the clerk, to his master's debtor $(s)$. So a general manager of a railway company has no authority to enter into a contract respecting land $(t)$. So, a clerk employed to obtain orders, is not by reason thereof authorized to receive payment for goods suppled $(u)$ : and a debtor paying him makes him his agent to hand the money to the creditor, and if he fails to do so, must pay over again. So, a traveller who receives orders for goods from his employer's customers, if authorized to receive payment for them in money, cannot take other goods in payment $(x)$.

But although an authority to accept or indorse bills would not of itself authorize a clerk to pay or receive money due on such bills; yet if in the course of his employment a clerk has, with the knowledge of his master, been allowed to do so, that would constitute a sufficient authority for that purpose, and discharge the holders of the bills $(y)$.

And where a master gave his servant a blank cheque clerk filling and directed him to fill it up with the amount of a bill up a checque and *expenses, which the clerk was to ascertain, [*288] for too large and take up the bill; but the clerk filled up the cheque for a much larger amount, including $250 l$. which he alleged to be due to him for his salary : he was convicted of forgery $(z)$.

(q) Sanderson v. Bell, 2 Cr. \& M. 304; and see Syles v. Giles, $5 \mathrm{MI}$. \& W. 545, where it was held that an auctioneer, expressly authorized by the conditions of sale to receive a deposit, had no implied anthority to receive the residue of the purehase-money. See also Boulton v. Reynolds, 29 L. J., Q. B., 11, where it was held that a man in possession of goods distrained for rent has no anthority in law to receive the rent. 277 .

(r) Kaye v. Brett, 5 Exc. 269 ; see Summers v. Solomon, ante, p.

(8) Suceling v. Pearce, 30 I. J., C. P. 109.

(t) Wilson v. West Hartlepool Harbour and Railway Co., $34 \mathrm{I}$. J., Ch. 241.

(u) Putlock v. Warr, 31 Law T. 86.

(x) IInvarl v. Chetpman, 4 C. \& P. 508.

(y) Pole v. Leask, 29 L. J., Cl. 893.

(z) R. v. Wilson, 2 C. \& K. 527. 
Wine mer- And a clerk to a wine merchant who is authorized by chant's clerk his master to sign delivery orders per procuration, and pledging by so doing obtains possession of dock warrants relat. dock warrants. ing to wine belonging to his master, cannot afterwards bind his master by obtaining an advance of money upon such dock warrants, nor is he an agent entrusted with the possession of the documents of title to goods within the meaning of the factors Act, 5 \& 6 Vict. c. 39 , and if he pledge the dock warrants his master may recover them from the holder $(a)$.

$\Lambda d m i s s i o n$ by So, in an action against pawnbrokers (b) to recover. servant out plate deposited with them upon a mortgage, out of the of course of business will not bind the master.

usual course of business, an admission by a shopman of the defendant's that they had the plate was held not admissible as evidence against them, for the transaction was not a transaction in the business of a pawnbroker, but a loan, as by any other lender of money at five per cent., and there was no evidence to show the agency of the shopman in private transactions, unconnected with the business of the shop. And Tindal, C. J., said, "If the transaction out of which this suit arises had been one in the ordinary trade of business of the defendants, as pawnbrokers, in which trade the shopman was agent or servant to the defendant, a declaration of such agent that his master had received the goods, might probably have been evidence against the master, as it might be held within the scope of such agent's authority to give an answer to such an inquiry made by any person inter[*289] ested in the goods deposited with the * pawnbroker. In that case the rule laid down by the Master of the Rolls in the case of Fairlie v. Hastings (c), which may be regarded as the leading case on this head of evidence, directly applies."

Great Western So, in an action against carriers by railway for not Railway Co. delivering cattle within a reasonable time, an admission v. Willis.

(a) Lamb r. Attenborough, 31 L. J., Q. B. 41. See further, Hayman v. Plewker, 32 L. J., C. P. 132; 13 C. B., N. S. 527; Baincs v. Swainson, 32 L. J., Q. B. 281; 4 Best \& S. 270; Fuentes v. Montis, 37 L. J., C. P. 137 ; L. R., 3 C. P. 268 ; 38 L. J., C. P. 95 ; L. R., 4 C. P. 93 ; Vaughan v. Moffat, 38 L. J., Ch. 144 ; Cole v. North Western Bank, 44 L. J., C. P. 233.

(b) Garth v. Howard, 8 Bing. 451 ; 5 C. \& P. 346 ; see Gardner v. Moult, 10 A. \& E. 464 , where the defendants were held bound by an admission by their servant of an act of bankruptcy on the part of a bankrupt.

(c) 10 Ves. 128; and see on this point, Story on Agency, s. 136; 1 Ph. on Ev. 382 ; Price v. Marsh, 1 C. \& P. 60 ; Jones v. Hart, Lord Raym. 738 ; Salk. 441. 
made a week after the transaction by a night inspector who had charge of the night cattle trains at a station through which the trucks containing the plaintiff's cattle would pass, that he had forgotten the plaintiff's cattle, was held not to be evidence against the defend. ants, as he was not to be presumed to have been authorized by the company to make admissions on their behalf of things gone by $(d)$.

And it would be no answer to an action by a master against carriers for loss of, or injury to, his goods, that they had received them from a servant, and had settled with him, unless the servant was authorized by his master to settle (e). And an estate or farm agent employed to receive rents, and conduct such farming operations as repairing, draining, cutting timber, and the like, could not, without express authority, make admissions in writing, or otherwise, as to bis employer's title, or bind him by proposals to purchase, or take on lease, the lands of another $(f)$. Even an attorney, employed in a matter of business, is not an agent to make admission for his client, except after action commenced, and in matters relating to that action $(g)$,

*Upon similar principles it is that, although [*290] Entry by an entry made at the time when the facts recorded took deceased place by a deceased clerk or other servant in the usual course of business, is evidence, after his decease, of the clerk only evidence of facts usually facts stated in such entry; yet if other facts, not usually stated. stated in entries of a similar nature, happen to be mentioned in making a particular entry, it is not evidence of those facts $(h)$.

Moreover, the implied power of a servant to bind his Implied master upon contracts relating to matters within the anthority is usual scope of his employment, is not increased by the not inereased

(d) Great Western Railway Co. v. Willis, 34 L. J., C. J. 195; 18 C. J3.. N. S. 748. And see Olding v. Sinith, 16 Jur. 497 , where on a question under the Truck Act colliery owners were held not bound by any act or declaration as to disposal of wages made by either the overman or the coal clerk. See also Lanev. Pratt, 1 haw T. 62:3; Kirkstall Brenevy Co. v. Furness Railway Co., 43 L. J., Q. B. 142 ; I. R., 9 Q. B. 468 .

(e) Coimbs v. Bristol and Exter Railway Co., 3 H. \& N. 1.

(f) Ley v. Peter, 26 I. J., Exe. 239.

(g) Wagstaff v. Wilson, 4 B. \& A(1. 339; Blackstone v. Wilson, 26 I. J., Exe. 229.

(h) Chambers v. Bernasconi, 1 C. M. \& R. 347; see Priee v. Enil of 'Torrington, Salk. 285; 1 Smith's I. C. 290,1 Plı. on Ev. ch. $7, \mathrm{s.} 8$, where all the prior cases are stated aud commented on. See also $R$. v. Dukinficld. 11 Q. 13. 678; 7 Exe. 3; S'mith v. Blakey, 36 L. J., Q. B. 156. 
gency of particular occasion.

IIavlayne v. Bourne.

Cox v. Midland Counties Railuay Co.

Contract made in servant's name. emergency of any particular occasion $(i)$. And, therefore, where $(k)$ a mining company fell into difficulties in consequence of the calls not being paid up, and the agent from want of funds was unable to pay the labourers, who applied to the magistrates and obtained warrants of distress upon the materials belonging to the mine: whereupon the agent borrowed money upon the credit of the company and paid the wages, it was held that he had no implied authority to do so; athough there were circumstances in the case from which a jury might have inferred an express authority to borrow money for the purposes of the mine.

So it was held in one case $(l)$ that a station master had no implier authority in case of accident to bind the company by calling in a surgeon to attend on passengers, for the power to enter into such a contract was not incident to his employment. But that case has been doubted, and it has been since held that a general manager $(m)$ and a chief inspector of police, who was for the time the superior of the station master $(n)$, have [*291] such authority; or, *at all events, that there was evidence to go to the jury that they had such authority.

It makes no difference in the master's liability that the contract is made in the servant's name, if in reality he were acting as agent for his master in making the contract. For parol evidence is always necessary to show that the party sued is the person making the contract and bound by it. Whether he does so in his own name, or in that of another, or in a feigned name, and whether the contract be signed by his own hand, or by that of an agent, are inquiries not different in their nature from the question who is the person who has just ordered goods in a shop. If he is sued for the price the contract is not varied by appearing to have been made by him in a name not his own $(o)$.

(i) Story on Ag. 87. See further on this point the eases of tort, pest.

(k) Haxtayne v. Bourne, 7 M. \& W. 595; and sec Ricketts v. Bennett, 4 C. B. 686; In re The German Mining Company, 22 Law J., Ch. 926.

(t) Cox v. Midland Counties Railway Company, 3 Exc. 268.

(m) Walker v. Great Western Railatay Company, 36 L. J., Exc. 123; L. R., 2 Exc. 228.

(n) Langan v. Great Western Railway Company, 30 L. T., N. S. $173(1873)$.

(o) $\mathrm{Per}$ Lord Denman, C. J., in Trueman v. Loder, 11 A. \& E. 594,595 ; and see Thompson v. Davenport, 2 Smith's L. C. 351, 352 ; Lindus v. Bradwell, 5C. B. 583 . The general rule with regard to contracts made by agents is, that the agent may sue or bc sued in respect of his privity, and the principal in respect of his (316) 
And so if a landed proprietor send his steward habit- Servant's ually to the neighbouring fairs and markets to make intention sales and purchases for him in matters connected with merely to the management of his estate, and the steward makes all these contracts in his own name, but is universally known to have no land of his own, and to be acting solely for his employer, by his direction, and on his credit; the steward's intention to make himself the owner of articles bought on one particular occasion in the course of the same dealing could not deprive the vender of his recourse against the master $(o)$.

And, since the nature of the usual employment of a Effect of priservant is the measure of his implied authority, it fol- vate orders lows that that authority can neither be limited by the to servant. private instructions of the master, nor controlled by any secret agreement between him and his servant. If this could be done, in what a perilous predicament would the world stand in respect of their dealings with persons who *may have secret communication [*292] with their principals ! There would be an end of all dealing but with the master $(p)$. Should the servant deviate from his master's orders, or be guilty of a breach of any secret agreement between himself and his master, he will be accountable to his master for any loss he may Innocent sustain thereby, but third persons cannot be affected by any limitation of the servant's authority not communicated to them $(q)$. In such cases, however, it is material to bear in mind the distinction before adverted to, between a special aud a general authority ("the latter getweral and of which does not import an unqualified authority, but special that which is derived from a multitude of instances, agent. whereas the former is confined to an individual instance") ( $r$ ), as the legal effect of secret instructions And differis very different in the two cases. The difference can- ences in efnot be more clearly stated than in the words of Mr. fect of private Smith, in his Compendium of Mercantile Law. He orters in says $(s)$ : "The authority of a general agent to per-

interest. See Sims v. Bond, 5 B. \& Ad. 389. Where, however, a servant or other agent has signed a written coutract in his own name, he eannot give parol evidence to discharge himself from liability upon the contract, Higgins v. Senior, 8 M. \& W. 834.

(o) See per Lord Denman, in Trueman v. Loder, 11 A. \& E. 593.

(p) 10 Morl. 110.

(q) Paley on Ag. 199 ; 1 Pothier on Oblig. hy Evans, n. 79; see also ib. n. 447, 448; Cahill v. Dawson, 2(6 L. J., C. P. 253 ; 3 C. B., N. S. 106.

(r) Per Lord Ellenborough in Whitehead v. Tucket, 15 East, 408 ; and see Paley on $\mathrm{Ag} .199$.

(*) Smith's Mere. Law, 119; see Story on Ag. s. 126, and note 2 to s. 127; Hawken v. Boune, 8 M. \& W. 710. 
form all things usual in the line of business in which he is employed cannot be limited by any private order or direction not known to the party dealing with him. But the rule is directly the reverse concerning a particular agent, $i$. e., an agent employed specially in one single transaction, for it is the duty of the party dealing with such a one to ascertain the extent of his anthority, and if he do not he must abide the consequences" $(t)$.

How far ser-

A servant may be regarded as the general agent of vant general agent of his master, and how far special. his master for all purposes within the scope of his em. ployment. If employed for any unusual purpose, he may be looked upon as the special agent of his master [*293] (u). Thus, *for instance, if a man were in the habit of paying for hay and straw purchased by his groom, the groom might be regarded as his general agent for tho purchase of a reasonable quantity of hay and straw, and the master would be liable to pay for such hay and straw purchased by the groom, even if in a particular instance the groom acted contrary to his master's orders. But such a groom could not be looked upon as the general agent of his master, so as to render him liable to pay for anything else the groom might choose to buy in his master's name, the obtaining other things not being within the scope of his employment. If ho were sent by his master with money to purchase beer or wine, he would be a special agent for that occasion; and if the person of whom he bought it chose to let him take it away without payment and without ascertaining that he had authority to pledge his master's credit, he must abide the consequences; the master would not be liable.

Implied gen- Bearing, therefore, this distinction in mind, it may eral authority be stated as a general rule, that wherever a master has cannot be by words, conduct or demeanour held out his servant limited by as his general agent, whether in all kinds of business
private orders. or in transacting business of a particular kind, the master will be bound by the act of his sêrvant, if within

( $t$ ) Mr. Justice Story, after quoting the words in the text, adds, "This is true if the agent is not held ont as possessing a more enlarged authority." Story on Agency, s. 126, note 2.

(u) The nature and extent of a servant's implied authority must, however, as is obvious, frequently involve questions fit for the consideration of a jury. See Smith's Merc. Law, 117; Dyer v. Pearson, 3 B. \& C. 38 ; Todd v. Robinson, Ry. \& M. 217; Gillman v. Robinson, Ry. \& M. 226 ; Barnett v. Lambert, 15 M. \& W. 493 ; Reynell v. Lewis, 15 M. \& W. 517; Williams v. Pigott, 2 Exc. 201 . 
the scope of his usual employment, notwithstanding the servant has acted contrary to his master's orders.

Thus, where $(x)$ a master sent his servant, who was Nickson v. used to transact affairs of that nature for him, on Sat- Brolan. urday, with a note drawn on Sir S. E., with orders to get from Sir S. E. either bank bills or money and turn them into Exchequer notes, but the servant, to save himself time and trouble, went to $B$., and prevailed with him to give him a bank *bill for the note [*294] upon Sir S. E., and then, in pursuance of his master's orders, invested it in Exchequer notes, which ho brought to his master, not letting him know but that he had gone to Sir S. E. Sir S. E. failed upon the Monday following. The question was upon whom the loss should fall, B. or the master. And the whole court were of the opinion that the master was chargeable and he only, for a servant, by transacting affairs for his master, does thereby derive a general authority and credit from him; and, if this general authority should be liable to be determined for a time by any particular instructions or orders to which none but the master and servant are privy, there would be an end of all dealing but with tho master.

Upon similar grounds rests the distinction that if a Horsehorse-dealer or a person keeping livery stables, having dealer liable a horse to sell, expressly direct his servant not to war- on warranty rant him, and the servant do nevertheless warrant him, of servant, still the master would be liable upon the warranty, be- to warrant. cause the servant was acting within the general scope of his authority, and the public cannot be supposed to be cognizant of any private conversation between the master and servant $(y)$; but if the owner of a horse But not on were to send a stranger to a fair with express directions warranty of not to warrant the horse, and the latter acted contrary stranger, to the orders, the purchaser could only have recourse to ordered to the person who actually sold the horse, and the owner warrant.

(x) Niekson v. Broham, 10 Mod. 109; Ward v. Evans, 2 Salk. 442; 6 Mod. 36; 2 Lord Raym. 928; Thorold $v$ Smilh, 11 Mod. 71, 87; see 1)uke of Beaufort v. Nerle, 1: Cl. \& F. 248; Smith v. MI'Guire, 3 11. \& N. 554; 27 L. J., Exe. 465 .

(y) Ante, 283; Fenn v. Harrison, 3 T. R. 760; Pickering v. Busk, 15 East, 45; Howard v. Sheward, 36 L. J., C. P. 42. To the distinetion pointed ont in the text must be referred the judgments of Martin, B., and Bramwell, B., in Itdall v. Atherton, 30 L. J., Exe. 337; 7 H. \& N. 172. See prr Willes, J., in Barcick v. English Joint Stoek Bank, 36 I. J., Fxc. 148. See Story on Agrency, 8. 132. In note 4, that learned author says, "In Ameriea livery stable keepers are not understood to give their servants any general authority to sell their horses."

17 Mas. \& SER. 
would not be liable on the warranty, because the servant was not acting within the scope of his authority $(z)$.

Precious v. [ [295] *Upon the same principle a gentleman, who by Abel. an agreement with his groom allowed him five guineas a year for which he was to keep the horses shod, was held nevertheless to be liable to pay a farrier's bill for shoeing his horses, as it did not appear that the farrier knew of the agreement ; and Lord Kenyon said, "That unless the farrier knew of the agreement and expressly trusted the groom it was no defence, for a tradesman has nothing to do with any private agreement between Rimell $\mathrm{v}$. the master and servant" $(a)$. And where $(b)$ a gentleSampayo. man contracted with his coachman, at $220 l$. a year, to provide horses and his own livery and everything con. nected with the carriage, but the coachman went in his master's livery to the plaintiff's stables and represented that he wanted a pair of job-horses for his master's carriage, and an agreement was made with him, at ten guineas a month, whereupon he took the horses away, and his master used them, and the plaintiff then sued the master for four months' hire; it was held not necessary for the plaintiff to prove that the coachman acted by his master's authority, as he had used the horses: and Littledale, J., said, "If the coachman made the contract in bis own name, and represented to the plaintiff the agreement between himself and his master, of course, under such circumstances, the plaintiff cannot recover ; but if he made no such representation of any agreement between himself and his master, I think that by the master sending him forth into the world, wearing his livery, to hire horses which he (the master) afterwards uses, knowing of whom they were hired, and yet not sending to ascertain if his credit had been pledged for them, an implied anthority is given, and the master is bound to pay the hire. A master may be prevented by business or want of time from making a bargain himself, and may send his servant, and provided the business be within the regular department of the servant, the master is clearly liable." The jury, how-

(z) Ibid. But if the master is unwilling to adopt a warranty given by his servant under such circumstances, he is bound to take back the horse and return the money, if paid. To hold otherwise would be to allow him to take adrantage of his serrant's frand. See per Lord Abinger in Cornfoot $\mathbf{v}$. Foncke, $6 \mathrm{M}$. \& W. 381; and per Erle, C. J., in Brady v. Tod, ante, p. 284.

(a) Precious v. Abel, 1 Esp. 350.

(b) Rimell v. Sampayo, 1 C. \& P. 255. 
ever, having *found that there was no evidence [*296] of any direct application to the master on the part of the plaintiff, found a verdict for the defendant $(c)$.

If a third party, dealing with his servant on behalf If third of his master, know of the private agreement or in-party know structions given by the master to his servant, he cannot of private of course charge the master $(d)$ upon any contract con- orders, trary to that agreement. Accordingly, where (e) the not bound. defendant sent his son to obtain from the plaintiff a Jordan $v$. horse which he had agreed to sell to the defendant, and Norton. the plaintiff knew that the son was instructed only to take the horse if warranted, but the son took it without a warranty, it was held that the defendant was not liable to pay for the horse, which did not answer the warranty agreed to be given.

But where a servant is employed by his master to where act for him in a single transaction, he must be regarded servant is a as the special agent of his master; and, in such case, it special agent is incumbent upon every one dealing with him, who parties dealwishes to charge his master upon his contracts, to in- must inquire quire into the extent of his authority, as, should he ex-into his ceed it, his master will not be bound. authority.

And, therefore, where $(f)$ the plaintiff sent his ser-Wrard v. vant to receive $60 l$. from B., and B. desired E., who Evans. owed him money, to strike off $60 l$. from his debt and pay the plaintiff's servant; E. accordingly credited himself with $60 l$. in account with B., but instead of giving the plaintiff's servant morey gave him a goldsmith's note, which the servant accepted as payment; it was held that the plaintiff was not bound by the act of the servant in receiving the note instead of money.

Again, where $(g)$ the defendant drew a cheque in favour * of a creditor, and gave it to his own [*297] Waters $\nabla$. farm bailiff (who bought and sold cattle for him) with instructions to deliver it to the creditor in whose favour it was drawn, but the bailiff, at the request of the creditor, got it discounted by the plaintiff (a banker at some distance), and gave the money to the creditors; some days afterwards the bankers on whom the cheque

(c) See Hiscox v. Greenuood, 4 Lsp. 174, where a servant having aeted beyond the scope of his employment, Lord Ellenborongh thought the tradesman, not having inquired of the master, could not charge him.

(d) Howard v. Braithwaite, 1 Ves. \& B. 299.

(e) Jordan v. Norton, 4 M. \& W. 155. In this case, however, it will be observed that the son was a spccial agent, into whose authority the party dealing with him is bound to inquire.

(f) Ward v. Evans, 2 Lord Raym. 928; Salk. 442. -

(g) Waters v. Brogden, 1 Y. \& J. 457. 
was drawn failed, and the plaintiff having omitted to present the cheque to them, brought an action against the defendant for the amount; but Alexander, C. B., was of opinion that the defendant was not bound by the act of his farm bailiff, who had no authority to act as he had done.

Henkel v. And where the defendant directed a telegraph clerk Pape. to telegraph for "three" rifles, and by mistake he tel egraphed for "the" rifles, and plaintiff sent fifty, the defendant was only held liable to pay for three, as the telegraph clerk was only the defendant's agent to transmit the message actually given for transmission $(h)$.

Femn r. So, as we have seen, if the owner of a horse send a Harrison. stranger to a fair, with express directions not to warrant the horse, and the latter act contrary to the orders, the purchaser could only have recourse to the person who actually sold the horse, and tbe owner would not be liable on the warranty, because the servant was a special agent, and was not acting within the scope of his anthority $(i)$.

And so where And where a person dealing with an agent has notice, person deal- either from the mode in which the authority is exercising with him ed, or it would seem in any other manner, that the agent has notice is acting under a special authority; as, for instance, that he is a special agent. where a bill of exchange is accepted or indorsed by a clerk or cashier "per procuration" of A. B. (the master), C. D, (the agent or servant), he is, à fortiori, bound to inquire whether or not the authority has been properly followed; and if he do not make such inquiries, and [*298]. it turn out that * the party exceeded his authority, he must suffer for his temerity $(k)$.

Alexander $\mathrm{v}$.

Therefore, where $(l)$ the manager of a banking comMakenzie. pany, who had authority to draw, accept and indorse bills, on account and for the benefit of the company, indorsed a bill for the accommodation of one G., "per proc." of the company, and signed his name, it was held, that the company were not bound by such indorsement. And Coltman, J., said, "Any house may allow a clerk to indorse bills of exchange in the name and on account of the firm, and so give currency to them, notwithstanding any secret limitation of his authority. If

(h) Henkel v. Pape, 40 L. J., Exc. 15.

(i) Fenn v. Harrison, 3 T. R. 760; see Paley on Ag. 202. But see per Erle, C. J., in Brady v. Tod, ante, p. 284. 149 .

(k) Jordan v. Norton, 4 M. \& W. 155 ; Neale v. Turton, 4 Bing.

(l) Alexander v. Mackenzie, 6 C. B. 766 ; see Smith v. Johnson, 3 H. \& N. 222; Smith v. I'Guire, 3 H. \& N. 554, ante, p. 281. 
this banking company had been in the halit of allowing their cashier or manager to indorse bills on their behalf, that would have imported a general authority, and the public would not have been bound to inquire into the circumstances or the precise extent of such authority. But in every instance the indorsement by the form of it bears an intimation to the public, that the manager acts under a special authority; and therefore the persons into whose hands the bills might come, were bound to see that the authority was properly pursued" $(m)$.

If, upon inquiry into the authority of such an agent, Written it should turn out that he is acting under a written au- authority of thority, parties dealing with him should call for the servant must production of the authority; for, should the agent exceed his authority, his principal will not be bound $(n)$. This rule indeed applies equally to the case of a general agent.

If, however, the act assumed to be done is within Private the authority given (in ascertaining which the authority instructions must be strictly construed) (o), the principal will be need not. bound, *although the act done may be in viola- [*2y9] tion of private instructions as to the mode of executing the authority. With such instructions third parties have nothing to do $(p)$. It is therefore important to bear in mind the distinction between the two, although it is not in all cases easy to distinguish the one from the other.

The employment of workmen or servants to do an Employment act is not necessarily a violation of the rule delegatus of servants non potest delegare. Thus, for instance, where a merchant receives goods from abroad for sale, and he deputes his foreman to go to the proper place for selling potet delegare. such goods, and the foreman sells them accordingly, in that care it would be impossible for the consignor to say that the sale was void because the merchant did not personally sell them himself, but employed another person for that purpose, by whom the sale was effected. The merchant would no doubt be answerable for all the acts of his foreman, but provided such acts were proper and within the scope of his authority they would be

(m) See acc., Stagg v. Elliott, 31 L.. J., C. P. 260.

(n) Attwood v. Munnings, 7 B. \& C. 278 ; Story on Agency, s. 72 ; and see the American case of North River Bank v. Aymer, 3 Hill R. 262, there quoted. See also Bulfour v. Ernest, 28 L. J., C. P. 170, et cas. ib. cit. 618 .

(o) Attwool v. Munnings, ubisupra; Howard v. Baillie, 2 H. $\mathrm{Bl}$. 545.

(p) Story on Ag. 73; and see Sincthurst v. Taylor, 12 M. \& W. 
the acts of the merchant himself. And therefore where a proposal for a life policy was accepted on behalf of a life assurance company by their agent in Australia, who acted in the transaction through the medium of sub-agents, and the premium was paid, it was held binding on the company though the agent had no authority to appoint sub-agents and there were sume informalities but of form only $(q)$.

Where But where a master has not either expressly, or by master is not implication, from a course of dealing authorized his bound by servant to pledge his credit, his servant cannot, by so servant. Stubbing v. Heintz. doing, render him liable to pay for goods so obtained.

Thus $(r)$, where the defendant contracted with the plaintiff to serve him with meat at a certain price for ready money, and the cook was accustomed to order the meat, and when the bill amounted to a few shillings [*300] or a guinea, used *to pay it, generally on Mon: day morning, and the defendant always gave her money to pay ; which course of dealing. continued for a long time, till, at last the defendant got a cook who embezzled the money; it was held that the defendant was not liable, and Lord Kenyon, C. J., said, "Nothing could be clearer than that where a man gives his servant money to pay for commodities as he buys them, if the servant pockets that money, the master will not be liable to pay it over again. But if the master employs his servant to buy things on credit, he will be liable to whatever extent the servant shall pledge his credit."

Pierce v. And so where (s) the defendant dealt with the plainRogers. tiff for the porter used in his family, and was in the habit of paying ready money to the plaintiff for a certain quantity which was allowed for the family, but the maid-servant obtained some clandestinely for her own use, and that of the defendant's wife's mother, but it did not appear that the plaintiff knew of this circumstance, it was held that the defendsnt was not liable; Lord Eldon saying, that "to allow such a demand would be to put it in the power of servants and tradesmen to ruin the master."

Maunder v. Again, where $(t)$ a butler ordered brandy in his masConyers. ter's name, and the brandy was consumed by the butler and cook, without the master being privy to the order,

(q) Rossiter v. Trafalgar Life Assurance Association, 27 Bear. 377.

(r) Stubbing v. Heintz, Peake, 47 ; and see per Lord Abinger, C. B., in Flemyng v. Hector, 2 M. \& W. 181.

(8) Pearce v. Rogers, 3 Esr. 214.

(t) MFaunder v. Conyers, 2 Stark. 281. 
delivery or consumption, the master was held not liable to pay for it.

And where $(u)$ a lady ordered of a tailor two suits of livery a year for her coachman, and the tailor supplied Countess of one; but, at the desire of the coachman, supplied Berkeley. plain clothes instead of the other, it was held that the lady was only liable to pay for the livery actually supplied, and was entitled to set off against a subsequent account for clothes the price of a suit of livery which had been supplied and paid for, but taken back by the tailor from the coachman.

Upon similar principles where $(x)$ a servant, having Hiscox $\mathrm{v}$. *injured his master's chaise by careless driving, [*301] Greenwood. left it with a coachmaker to be repaired without. acquainting his master, and without any orders from him, and it appeared that he had never employed the coachmaker, who refused to deliver up the chaise without payment of his bill for the repairs. 'The master having brought an action for the chaise, recovered; as it was held that the coachmaker, not having inquired of the master whether the order for repairs was given by his authority, had no claim against him for the amount of his bill.

And of course if the person ordering the goods was Trustees not the defendant's servant, the defendant would not under inbe liable, as where a debtor carrying on trade under spectorship an inspectorship deed, ordered goods for the purpose, leed not it was held that the trustees under the deed were not goodsordered liable to pay for them as he was not their servant $(y)$. by trader.

So, if a servant be left in charge of children with a Servant left sufficient allowance for their support, he has no power in charge of to pledge his master's credit for necessaries or goods childrea. supplied for the support of the children $(z)$.

The bailiff of a large farming establishment, through Implied auwhose hands all payments and receipts take place, has thority of no implied authority to pledge the credit of his em- farm bailiff. ployer by drawing and endorsing bills in his name $(a)$. Nor has the resident agent $(b)$ of a mining company, or a co-adventurer (c), an implied authority to borrow money upon the credit of the shareholders. Nor has

(u) Hunter v. Countess Dowager of Berkeley, 7 C. \& P. 413.

(x) Hiscox v. Greenwood, 4 Lsp. 174.

(y) Easterbrook v. Barker, 40 L. J., C. P. 17, following Redpath

v. Wigg, 35 L. J., C. P. 105.

(z) Atlyns v. Pearee, 26 I. J., C. P. 252.

(a) Davidson v. Stanley, 2 M. \& G. 271 ; see Waters v. Brogden,

1 Y. \& J. $45 \%$.

(b) Hautayne v. Bourne, 7 M. \& W. 595.

(c) Ricketts v. Bennett, 4 C. B. 686. 
Mining agent the manager of a discount company authority to pur. chase shares $(d)$.

And the secretary of a company who has authority only to accept bill's drawn by A. on the company, cannot bind the directors by accepting bills drawn by B. (e).

Agent to in- [*302] *Nor has the country agent of an insurance surance com- coinpany authority to receive payment of premiums pany. after the usual fifteen days' grace $(e)$. Nor has the agent of an insurance company power to bind the company by issuing policies contrary to the deed of settlement $(f)$.

Secretary of intended

Nor has the secretary of an intended railway company implied authority, as such, to bind individual railway com-members of the provisional or managing committee pany.

upon contracts, even for articles necessary for carrying on the business of the company. In order to fix them with liability to pay for goods, work or labour, \&c., ordered by the secretary, it is necessary to connect the party sought to be charged with the order, either by showing his previous consent or subsequent recognition of it $(g)$. The same principle applies to letters written by such secretary. They are only binding upon the board of directors, or such members of it as authorized Rennie r. the secretary to write them $(h)$. Therefore, where $(i)$ Wynn. an engineer brought,an action against a provisional committeeman of a railway company for work and labour in surveying the intended line of railway, and the only evidence to charge the defendant was a letter written by the secretary, but there was no evidence to connect the defendant with the letter, the plaintiff was nonsuited.

Cashier of Upon similar principles it has been held in America bank. in a case $(k)$ in which case the cashier of a bank

(d) Carimell's case, 43 L. J., Ch. 598.

(e) Neale v. Turton, 4 Bing. 149. Where a traveller took a bill in his own name and absconded, it was held not to be payment to his employer, Hogarth v. Wherley, 44 L. J., C. P. 330 ; L. R., 10. C. P. 630.

(e) Aeey v. Fernie, 7 M. \& W. 151. N. 789 .

(f) Hamburgh v. Hull and London. Fire Insurance Co., $3 \mathrm{H}$. \&

(g) Barnett v. Lambert, 15 M. \& W. 489 ; Reynell v. Lexvis, 15 M. \& W. 517 ; Cooke v. Tonkin, 9 Q. B. 936 ; Barker v. Stead, 3 C. B. 946 ; Williams v. Pigott, 2 Exc. 201 ; Bailey v. Jacaulay; and other cases, 19 L. J., Q. B. 73; 13 Q. B. 815 ; Burbidge v. Morris. 34 L. J., Exc. 131.

(h) Burnside v. Dayrell, 3 Exc. 224 ; and see Todd v. Emly, 7 M. \& W. 429 .

(i) Rennic v. Wynn, 4 Exe. 691.

(k) United States Bank v. City Bank of Columbus, 21 How. 3.56. 
wrote to the * secretary of the treasury say- [*303] ing that the bearer was authorized to contract for the transfer of money from New York to New Orleans, and such a transaction was not within the scope of the powers of the cashier, nor authorized by the directors, that the bank was not bound to reimburse the money which the secretary of the treasury advanced. And in another case $(l)$, it was held that a release given by the president and cashier of a bank to the indorser of a promissory note of his liability upon it, did not bind the bank: neither one or both having authority to make contracts of that kind.

Nor can a master be rendered liable upon a contract Credit given made by his servant, if at the time the contract is en- to servant tered into, the party with whom it is made know not only that the servant is only an agent, but also who his master or principal is $(m)$; and notwithstanding that knowledge choose to make the servant his debtor, deal-agent, and ing with him and him alone. In that case the party who his cannot, on the failure of the servant to perform the contract, turn round and charge his - master, having once made his election $(n)$ at the time when he had the power of choosing between the one and the other $(o)$.

The fact that articles purchased by a servant have Use by. been used by the master will not alone make the master master of liable to pay for them where the previous conduct of things obthe master was not such as to give the servant an implied tained on authority to pledge his credit. That fact, however,

But the eashier of bank has authority to judge the gennineness of orders for payment of money, and to pay them; $R$. v: Prince, 38 L. J., II. C. 8 ; L. R. 1 C. C. R. 150 . Therefore obtaining cash from him by a forged order is obtaining money by false pretences, and not larceny, ibii. See $R: v$. Middleton, 42 I. .J., M. C. 73, where a elerk in the post-office, by mistake, handel to the prisoner $8 l .16 s .10 \%$. (on his presenting an order for 10s.), and he took the money animo furanci, and was held rightly convieted of lareeny.

(l) Bank of Uniled States v. Dumn, 6 Peters, 51.

(m) If the party know the servant to be merely an agent, but do not know who his prineipal is, and debit the servant; he may, in that ease, charge the prineipal when diseovered, Thomson $v$. Divenport, 9 B. \& C. 78; and see Thomas v. Eilwarls, 2 M. \& W, 215.

(n) $\Lambda$ s to what amounts to an election, and whether anything short of suing to judgment amounts to an election, see Curtis: Willinmsnn, 44 I. J., Q. B. 27; Prieslly v. Frnic, 31 I. J., Exc. $172 ; 3$ Hurlst. \& C. 977 ; and other eases, $i b$. cit.

(o) Sce per Lord Tenterden in Thomson $v$. Daicnporl, 9 B. \& C. 86, following the case of Addison v. Gundassequi, 4 Taunt. 574; and Paterson v. Gundessequi, 15 East. 62; see 2 Smith's L. C. 313 et seq. And see the e.nverse ease of liamazotti v. Bouring, $29 \mathrm{I}$. J., C. r. 20. 
would be sufficient prima facie evidence to charge the [*304] master, unless he *could discharge himself by showing either that the credit was given to the servant, or that the servant was supplied by him with ready morey to pay for the articles purchased, and therefore had no authority to plodge his master's credit $(p)$.

Termination of implied authority by notice.

Injunction to stay action brought after notice.

Notice to tradesman's servant not sufficient.

And a master who has been in the habit of paying for goods ordered by his servant, and has thus impliedly given him authority to pledge his credit, may, by giving notice to the tradesman who has supplied the goods on those terms, revoke or terminate the servant's authority to pledge his master's 'credit, provided such notice is given before the authority is acted on $(q)$.

Where it is clear that the tradesman has received notice of the revocation or termination of the servant's authority to pledge his master's credit, a court of equity would grant an injunction to restrain an action brought by such tradesman against the master to recover the price of goods supplied to the servant as on the master's credit after notice: as in the case of a wine merchant suing the master for the price of wine supplied to a discharged butler after notice of such discharge $(r)$.

Where $(s)$, however, the defendant had been in the habit of dealing with the plaintiff for beer on credit, but once, when he paid the bill, told the man who brouglit the beer that he would run up no more bills with the plaintiff; but would pay for the beer as it came ir, and afterwards gave his servant money to pay for the beer, but the servant embezzled it, the defendant was held liable, as he did not show that the plaintiff [*305] himself had notice of this change *in the mode of dealing; and Lord Eldon said, that unless he had, it must be taken that the plaintiff understood that the dealings between him and the defendant continued in the usual way.

And it is clear that mere notice to the servant him.

(p) Paley on Ag. 165; Pearce v. Rogers, 3 Esp. 214. See, however, Rimell v. Sampayo, 1 C. \& P. 255, ante, p. 295, where Littledale, J., thought that if the master use the articles, he ought to ascertain that his credit is not pledged; but the jury thought that the tradesman ought to ascertain that the servant had authority to pledge his master's credit. And see Hisco $x$ v. Greenvood, 4 Esp. 174, ante, 301; Pauling v. London and North Western Railway Company, 8 Exc. 867; Smith v. Hull Glass Company, 11 C. B. 897 .
(q) Chappell v. Bray, 30 I. J., Exe. 24.
(r) Duke of Devonshire v. Laforest, M. R., Feb. 23, 1854.
(s) Gratland v. Frceman, 3 Esp. 85.

(328) 
self, who had general authority to make contracts in Mere revoeahis master's name, would not exonerate the master tion of serfrom liability upon contracts made by the servant after vant's his discharge $(t)$.

Thus, in a case $(u)$ where a servant had power to authority insuflicient.

draw bills of exchange in his master's name, and after- Harrisou. wards was turned out of the service, Holt, C. J., said, "If he draw a bill in so little time after that the world cannot take notice of his being out of service, or if he were a long time out of his service, but that kept so secret that the world cannot take notice of it, the bill in those cases shall bind the master."

The case of Monk v. Clayton $(x)$, "where the act of a Monk v. Clayservant, though out of place, bound his master by rea- ton. son of the former credit given him by his master's service, the other not knowing that he was discharged," is one of a similar kind.

The master's death operates as a revocation of the Death of servant's authority to pledge his credit; after that master. event, therefore, the master's representatives would not be bound by the servant's contracts $(y)$.

Lapse of time, also, would, it is conceived, in many Lapse of cases raise a presumption that the servant's authority time. to pledge his master's credit was terminated $(z)$.

\section{*IN Cases of Tort-Criminaliter. [*306]}

A master is not, generally speaking, criminally re- Master is not sponsible for the acts of his servants, unless he ex- in general repressly command or personally co-operate in them. In sponsible, prim criminaliter, criminal cases they must each answer for their own for the acts acts, and stand or fall by their own behaviour $(a)$. of his ser-

(t) Trueman v. Lorler, 11 A. \& E. 589; Aste v. Monfague, 1 Fost. \& F. 264. See Tassell v. C'nom 9 C. 13. 509, where the question arose whether a farm bailiff;, who had orders to deal no more with his master's property, was justified in receiving noney for wheat sold previously.

(u) —. Harrison, 12 İod. 346; and see Nersome v. Coles, 2 Camp. 617, where, after a dissolution of partnership, and notice of it published in the London Gazctte, and sent round to all the customers of the firm, the retiring partners were lekl not liable to pay bills drawn or aecepted by the remaining partuer in the name of the old firm.

(x) Cited by the Court in Nirkson v. Brohan, 10 Mod. 110.

(y) See Blades v. Free, 9 B. \& C. 16\%.

z) v. Harrison, 12 Mol. 346.

(a) R. v. Huggins, 2 Str. 882; 2 Lord Raym. 1574; Paley on Ag. 303; Story on $\Lambda$ g. s. 452; Snith's Merc. Law, 139 . So a sheriff is not liahle criminaliter, tlough he is civililer, for the act of his bailiff, Laycork's ease, Latel, 187; Srunderson v. Baker, 3 Wils. 310, 316; Woolgate v. Knatehbull, 2 T. R. 148; Stankay q. 
And where one employs another to do a thing, and there are several ways of doing it, one criminal and another innocent, and he does it in a criminal manner, the employer is not responsible (b).

except where But where one man expressly orders another to do he expressly an illegal act, it is clear that the employer at least is orders an illegal act. accountable for that act $(c)$. Whether or not the person employed is also criminally responsible must depend upon circumstances $(d)$.

Wilson $\mathrm{v}$. Stewart.

It has been held (e), that if the keeper of a place of public resort leaves his premises in the management of a servant, and prostitutes are suffered to meet together and remain in the house contrary to $2 \& 3$ Vict. c. 47 , s. 44 , the mere relation of master and servant [*307] neither makes nor * prevents the latter from being an aider and abettor in the offence: and if the servant in knowingly suffering the prostitutes to meet together and remain is carrying out his master's orders, the master is guilty as principal and the servant as aiding and abetting, and the latter may be convicted under $11 \& 12$ Vict. c. 43 , s. 5 .

If a man employs an innocent agent $(f)$ for the pur-

t. v. Perry, 2 B. \& P. 15\%; Peehell v. Layton, 2 T. R. 512, 712; Browen v. Compton, 8 T. R. 424; Sturmy q. t. v. Sheriff of Middlesex, 11 East, 25; or his bailiff's follower, Gregory $\mathrm{r}$. Cotterell, 25 L. J., Q. B. 33; 5 E. \& B. 571; see Boulton v. Reynolds, 29 L. J., Q. B. 11. So the highbailiff of a county court is liable for the wrongful act of a person employed by one of his subbailiffs to whom a warrant is delivered for execution; Burton v. Le Gras, 34 L. J., Q. B. 91.

(b) See Pcaehy v. Rovland, 13 C. B. $182 ; 20$ L. T. 208. See also per Lord Wensleydale in Cooper v. Slade, post; p. 311.

(e) Fost. 125. Upon this principle it was held that the conviction of a servant for using water, unappealed against, was evidence against his master that he had no right to use it so, Eaton v Sicansea Waterworks, 17 Q. B. 267.

(d) See a curious case of $R$. v. Woodburn and Coke, 17 How. St. Tr. 54, where W., a hired labourer, and C., his master, were tried, condemned, and executed under the Corentry Act ( $22 \&$ 23 Car. 2, c. 1) for slitting a man's nose.

(e) Wilson v. Stewart, 32 L. J., M. C. 198; 3 Best \& S. 913. See also Howells v. Wynne, 32 L. J., M. C. 241; where it was held that a charter-master might be convicted of aiding and abetting a banksman to violate rules made under the act for inspection of coal-mines, $23 \& 24$ Vict. c. 151 , s. 11 . See now $35 \& 36$ Vict. c. 76, s. 52, post, Appendix.

$(f)$ An agent, or servant, concurring in a crime for the purpose of aiding in the detection of his employer, is looked upon as an innocent agent, $R$. v. Bannen, 1 C. \& K. 295 ; 2 Mood. C. C. 309. The distinction between an innocent and a guilty agent is now practically unimportant in punishing the principal, since an accessory before the fact may now be indicted, tried, convicted 
pose of committing any crime, the employer is the Employer of principal offender, and liable to be indicted and pun- an innocent ished as such, although be be absent when the crime is agent is prinactually committed. This principle is constantly acted cipal though upon in the administration of criminal law. But it may be convenient to mention a few cases illustrative of it.

The prisoner, who was a wet nurse in a family, and Murder. had put her own child out to nurse, gave'S. the person $R . \mathrm{v}$ Michael. in charge of it, a bottle of laudanum, with directions to give it to the child, saying it was medicine and would do the child good; but S. said the child was well and did not want medicine, and put the bottle on the mantelpiece without opening it. A few days afterwards, whilst $\mathbf{S}$. was out, one of her children got hold of the bottle and gave some to. the child, who died in consequence: it was held by the juoiges that the admin. istering the poison by S.'s child was, under the circum. stances, as much in point of law an administering by the prisoner as if she had actually administered it with her own hand. They, therefore, held that she was rightly convicted of murder $(g)$.

So, where the prisoner $(h)$ gave a forged note to a boy Forgery. *(who did not know that it was forged), and di- [*308] R. v. Giles. rected him to pay it away at N.'s shop for goods. The boy did so, paid the note to $\mathrm{N}$. and brought back the goods and change to the prisoner. This was held by the twelve judges to be an utteritg of the forged note by the prisoner to $\mathrm{N}$.

Again, where two dock porters stole a quantity of mo- Receiving lasses, and by direction of $\mathrm{H}$, a dealer in that article, stolen goods. took it to his warehouse and left it with MI., who was $R$. v. Parr. H.'s servant, and who knew it to be stolen: it was held that both the dealer and his servant might beconvicted of receiving stolen goods, although the dealer was ab. sent at the time the molasses was left at his warehouse, but it was clear that shortly after he came home be was aware of the molasses having been left, and there

and punished in all respects as if he were a principal, $24 \& 25$ Vict. c. 94, s. 1, and see sect. 6 .

(g) $R$. v. Michael, 9 C. \& P. 356; 2 Mood. C. C. 120 . And see $R$. v. Wilson, 26 L. J., M. C. 18 ; 1 Dears. \& B. C. C. 127 , causing poison to be taken with intent to procure abortion.

(h) R. v. Giles, 1 Mood. C. C. 166; and see R. v. Palmer, 1 New Rep. 96; 2 Leach, 978; R. v. Brisac, 4 East, 164; R. v. Mazeau, 9 C. \& P. $696 ; R$. v. Clifford, 2 C. \& K. 202 . And see $24 \& 25$ Vict. c. 98 , s. 45 (forgery), as to criminal possession of any matter which is in actual custody of another; also 24 \& 25 Vict. c. 99, s. 1 (coinuge offences). 
Obtaining money by false pretences.

R. v. Butcher.

was strong ground for supposing that he then knew that it had been stolen $(i)$.

So, in a case $(k)$ where $\mathrm{B}$. was one of the many persons employed by a company, whose wages were paid weekly at a pay-table by the treasurer of the company. On one occasion when B.'s wages were due, the prisoner promised a boy a penny if he would go and get B.'s money. The boy innocently went to the pay-table, and said to the treasurer, "I am come for B.'s money," and B.'s wages were given him. $\mathrm{He}$ took the money to the prisoner, who was waiting outside, and gave him the penny: it was held that the prisoner might have been convicted on a count charging him with obtaining B.'s money from the treasurer by falsely pretending to the treasurer (as he aid by means of the boy) that the boy had authority from $B$. to receive his wages.

Upon similar principles, a person who employed an-

Accessory after the fact, by an agent, R. v. Jarvis.

Stealing coal by hands of servants.

R. v. Bleasdale. other to harbour poachers, who were indicted for mali. ciously shooting at a keeper, was convicted as an [*309] accessory *after the fact, though he himself did no act of relieving them $(l)$.

Again, where $(m)$ the lessee of a coal-mine had, from the shaft opened to work it, carried on extensive workings of coal, and by means of these workings had gotten coal belonging to about forty different proprietors, without their sanction or knowledge, and had thus unlawfully possessed himself of $10,000 \mathrm{l}$. worth of the coal of other persons (the evidence extended to the getting of coal continuously during a period of upwards of four years, and to operations conducted by different underlookers and by many different workmen); but it did not appear that the lessee had himself personally touched or removed any of the coal ; he was nevertheless convicted of stealing it $(n)$ : Erle, J., observing, "The prisoner did not by his own hand pick or remove the coal; but if a man does, by means of an innocent agent, an act which amounts to a felony, the employer

(i) R. v. Parr, 2 Mood. \& Rob. 346.

(k) R. v. Butcher, 28 L. J., M. C. 14; 1 Bell Cr. C. 6.

(l) R. v. Jarvis, 2 Mood. \& Rob. 40.

(m) R. v. Bleasdale, 2 C. \& K. 765 ; see Mitchell v. Brown, 28 L. J., M. C. 53 ; 1 E. \& E. 267 , where it was held that the owner of a vessel might be convicted of throwing rubbish, \&c., into a navigable river contrary to a statute, though not on board when it was done; see also Searle v. Reynolds. 7 Best \& S. 704 ; Barnes v. Akroyd, 41 L. J., M. C. 110 ; L. R., 7 Q. B. 704.

(n) Under $7 \& 8$ Geo. 4 , c. 29 , s 37 . A mine owner who has reason to suspect this may obtain an order for an inspection from the Court of Chancery ; Bennett v. Whitehouse, 29 L. J., Ch. 326. 
and not the innocent agent is the person accountable for that act."

But where a master was engaged in making fireworks Master not illegally (i. e. contrary to statute $9 \& 10$ Will. 3 , c. 7 , s. respensible $1)$, some of which, in his absence, by an intervening where annegligent act of his servant, exploded, and a rocket other's flew across the street, set fire to a house, and burnt one added to his of the inmates to death; it was held that the master caused death. could not be convicted of manslaughter, as it was the superadded negligence of some one else that caused the death $(o)$.

If the servant be not an innocent agent, he would, Servant, unin law, be regarded as the principal offender, and his lessinnocent, master, *if absent when the crime was commit- [*310] is principal, ted, would be considered an accessory before the fact $(p)$. and master Though this distinction now is practically unimportant before the in punishing the master $(q)$. fact.

There, are, moreorer, many cases in which the act of Exceptions the servant, having been within the usual scope of his in eases of employment, has been considered to have been done by implicl the implied command of the master, and he has been orders of held criminally responsible for it, although he may, in the particular instance, have been perfectly ignorant of the doing it. Thus, in case of libel $(r)$, previously Cases of libel, to the statute $6 \& 7$ Vict. c. 96 , the publishers and proprietors of newspapers and other publications were frequently held liable to criminal informations for libels published by their servants in the usual course of their employment, although such publishers and proprietors personally had nothing to do with the publication of the libels $(s)$.

To remedy this state of the law, the statute $6 \& 76 \& 7$ Vict. Vict. c. 96 providede. 96, s. 7 .

Sect. 7. "That whensoever upon the trial of any indictment or information for the publication of a libel

(o) R. v. Bennett, 28 L. J., M. C. 27 ; 1 Bell Cr. C. 1 .

(p) R. v. Williams, 1 C. \& K. 589 . A person abroad may, by the employment as well of a conscious as of an unconscious agent, render himself amenable to the law of England when he comes within the jurisdiction of our Courts; per Lord Campbell in $R$. v. Garret, 23 L. J., M. C. $23 ; 1$ Dears. C. C. 241.

(q) Supra, p. 307, note $(f)$.

(r) As to the liability of a man to indictment for a libel which he caused to be published, see $R$. v. Cooper, 8 Q. B. 533; see also Parkes v. Prescott, 38 L. J., Exc. 105.

(s) $R$. v. Almon, 5 Burr. $2686 ; R$. v. Walter, 3 Esp. $21 ; R$. v. Gutch, M. \& M. 433, 438 ; see May's Const. Hist. vol. 2,107 . As to the liability of the editor to indemnify the proprietor when fined for the publication of a libel, see Colburn v. Patmore, $1 \mathrm{Cr}$. M. \& R. 73 . 
R. v. Holbrook.

Action for penalties.

Cooper v. vilade. under the plea of not guilty evidence shall have been given which shall establish a presumptive case of publication against the defendant by the act of any other person by his authority, it shall be competent to such defendant to prove that such publication was made without his authority, consent, or knowledge, and that the said publication did not arise from want of due care or cantion on his part."

Since the passing of this statute, it has been held that the general anthority given to an editor of a news. [*311] paper * to use his discretion in the insertion of articles, is not of itself sufficient to make proprietors criminally responsible for libellous articles inserted by the editor without their knowledge, and without any specific authority or consent from them $(t)$.

Again, in the following case, a man was held liable to an action for penalties, through the act of one who was considered his agent $(u)$.

An election was about to take place at C.; S. was one of the candidates, and in his committee-room the question was discussed whether paying the expenses of bringing up out-voters was legal. S., after referring to a law-book, said it was, but limited it to the payment of expenses out of pocket. A circular had been previously prepared and printed, requesting out-voters to come up and vote for S. Upon S. making this declaration of his opinion, a clerk to an agent of S. (without any express direction from $S$. or from the agent) wrote at the bottom of each circular, "your railway expenses will be paid." A voter who resided at $H$., received one of the circulars with this added note; he came to C. and voted for S., and afterwards received $8 s$., the expenses to which he had bona fide been put by his journey. It was held by the House of Lords, that the words added to the circular must be treated as written by authority of S., and that he was, therefore, liable to the penalties attached to bribery under the Corrupt Practices Prevention Act, $1854(v)$. In giving judg. ment, Lord Wensleydale said,

"I take the law to be clear, that a man cannot be guilty by his agent of an illegal act and be held responsible for that act, unless he has given the agent authority, express or implied, to do that illegal act. I

(t) R. v. Holbrook, 47 L. J., C. L. 35; 3 Q. B. Div. 60 ; and $S$. C. after second trial, 48 L. J., C. L. $113 ; 4$ Q. B. D. 42.

(u) Coop v. Slade, 6 Ho. Lords Cas. 793.

(v) $17 \& 18$ Vict. c. 102 . See now. $46 \& 47$ Vict. c. 51, s. 7; and sects. 17, 21, and 22 , as to illegal employment at elections. 
know that the law of agency in such cases has been much extended by committees of the House of Com mons, but I take it to be a clear proposition of law, that if a man employs an agent for a perfectly legal purpose, and *that agent does an illegal act, [*312] that act does not affect the principal unless a great deal more is shown; unless it is shown that the principal directed the agent so to act, or really meant he should so act or afterwards ratified the illegal act, or that he appointed one to be his agent to do both legal and illegal acts, to do everything in short which he might think proper to support the interests of the candidate. If the candidate gives his agent such a general author. ity, and the agent is guilty of bribery, the candidate is no doubt responsible for it. I know that there is a very great difference in parliamentary practice upon this subject, but I conceive that the rule of law is as I have laid it down, that no man who is an agent for a legal purpose can make the principal responsible for an illegal act, unless the principal has in some way, directly or indirectly, authorized it, as I have explained."

So, also, masters have been frequently held liable to Informations informations for penalties incurred by the breach of for penalties. some statutory regulations by persons in their employ, although the masters themselves may have been perfectly ignorant that in the particular instance any breach of the law has been committed. These informations, it is true, do, in strictness, partake more of the nature of civil proceedings to recover that which is a debt to the crown, than of a criminal proceeding $(x)$, but still they are penal proceedings, and it is conceived,

(x) See per Bayley, B., in Attorney-General v. Siddon, 1 Cr. \& J. 226 ; and see Atcheson v. Everitt, Cowp. 391, that penal aetions are civil suits; and Atlorney-General v. Bowman, 2 B. \& P. 352, that witnesses to character are not almissible. Previous to $17 \&$ 18 Viet. e. 122, s. 15 , which is now repealed, it was doubted whether the defendant, in informations for penalties, was admissible as a witness under 14 \& 15 Vict. c. 99, Attorney-General v. Radloff, 10 Exc. 84; sec Taylor on Evidence, s. 1225. He was not admissible in informations under the Game Act, cattell $v$. Ireson, 27 L. J., M. C. 107; nor under the Beer Act, I'urker v. Green, 31 I. J., M. C. 133 ; 2 Best \& S. 299 ; sce Lrgg v. P'ardoe, 9 C. B., N. S. 259 ; see also Attorney-General v. le Merchant, 2 T. R. 201 ; Unwin v. Leaper, 1 M. \& G. 752, where Bosanquet, J., suys; "It has heen deeided to be an offence to eompromise a penal action which had not actually been brought. See now 28 \& 29 Vict. e. 104 , ss. 33 and 34 , which enacts that proecedings on the revenue side of the Court shall not be dcemed criminal proceedings within the meaning of the Evidence Acts, $14 \& 15$ Vict. $c$. 99 , and the Evidence Amendment Act, 1853, 16 \& 17 Vict. c. 83. Sce Attorney-General v. Bradlaugh, 4 L. J., C. L. 205." 
therefore, that they may be properly mentioned in this place. Perhaps the most familiar instances of the master's liability to this kind of proceeding are to be found in cases of informations for breach of the revenue laws, in which cases, if a master were not held responsible for the acts of his servants, the revenue laws [*313] *might, as was once (y) observed by Pollock, C. B., "be evaded with the utmost facility and impunity, and they would be reduced to a mere dead letter" $(z)$.

Anon., Dyer. In an old case in Dyer $(a)$, it appeared that the deputy of a customer in a creek of a port (in which case a deputy was to be made by the statute of the first year of Q. Eliz. c. 12 [c. 11, s. 8]), falsely concealed the custom of a merchant, and the customer himself, ignorant of this, certified by his oath the customs of the port into the exchequer, according to the false

(y) Attorney-General v. Allen, Exc. Mich. Term, 1850. This criminal liability of a master for the acts of his servant in violating the revenue laws, received a forcible illustration in the in. formation (understood to amount to 120 or upwards) filed against the London Dock Company and the St. Katherine's Dock Company; the alleged severity of which proceeding produced a large meeting of influential merchants, \&c., in the City of London, in December, 1851, at which a series of articles (as they were termed) were agreed upon, as the foundation of a proposed alteration in the law of customs. One of these articles, 7, was follows: "Merehants, shipowners, and others, should not be made responsible for the crimes or offences of their servants or crews, except where guilty knowledge, or the most culpable negligence, is clearly traced home to them." In December, 1852, a deputation from the Coinmittee of London Merchants for Reform of Board of Customs waited on Lord Derby (then Prime Minister), with a memorial containing a series of resolutions, one of which (No. 10) was the same as article 7, above mentioned. And in the following year, by the Customs Consolidation Act, 18.53, 16 \& 17 Vict. c. $10 \%$, s. 213 , power was given to the Commissioners of Customs to waive the forfeiture of ships or boats having prohibited goods on board, if satisfied that they were on board without the knowledge or privity of the owner or master of such ship or boat, and without any wilful neglect, or want of reasonable care, on their parts. Similar power was given by The Supplemental Customs Consolidation Act, 1855,18 \& 19 Vict. c. 96, s. 26. But those Acts were repealed by $39 \& 40$ Vict. c. 36 , s. 28. See sect. 209.

(x) By 28 \& 29 Vict. c. 66, s. 12 , a maltster was expressly subjected a penalty of $100 \%$. for any omission, neglect or refusal to do anything by that act required to be done, or for doing any act prohibited to be done by any maltster or his workman or servant. That act was repealed by $43 \& 44$. Vict. c. 20 , which imposed a duty on beer. But by sect. 31, "If any person by himself or any person in his employ obstructs, hinders, or molests an officer of Inland Revenue in the execution of his duty, or any person acting in the aid of such officer, he shall incur a fine of 100l."

(a) Anon., Dyer, 238 b. 
information of his deputy, 'and judgment was given for the Queen against the customer, who was held liable for the forfeiture of the treble value of the merchandize so customed, and to be fined and ransomed according to the statute 3 Hen. 6 , c. 3 . And in Lane v. Cotton (b), Holt, C. J., after citing the above case *in [*314] Cotton. Dyer, said, "And what is the reason thereof, but because the principal shail answer for his deputy."

Again, where (c) an excise officer discovered on the defendant's premises a quantity of tobacco, for which cralv. Siddonhe requested to see the permit, and the defendant's servant said he had one, when in fact there was none, and ultimately produced a permit for the removal of different tobacco, and dated after the discovery by the offcer, the defendant was held liable to an information for penalties for harbouring and concealing tobacco withont paying duty, although at the time of the discovery he was from home, and had been absent for some time previously. In giving judgment, Bayley, B., said,-

"This is a case in which, to my mind, the act of the servant is to be considered as being an act done in the the master's business, and within the scope of the authority probably given by the master to the servant.

"This is not the ordinary case of a servant selling in his master's shop the articles in which the master deals, in which it is quite clear that he is acting within the ordinary scope of the authority which he has received from his master, and therefore that the act of the servant in making the sale is the master's act; upou which principle all the cases of libel have gone $(d)$.

"Neither is this the case of an act done by a servant in the manufacture of articles which the master is himself to manufacture. There the servant is nerely acting in the business of the master, and within the scope of the anthority which ho actually receives from his master. The authority which he receives from his master is an authority to make and manufacture, and. the master is responsible for his condnct, prima facie, as to the means he adopts in making and manufactur. ing.

"But this is a case certainly of a different descrip. tion, and I agree with the distinction that was taken

(b) 12 Mod. 489.

(c) Attorney-General v Siddon, 1 Cr. \& J. 220; 1 Tyr. 41 ; and see Attorney-General v. Riddle, 2 Cr. \& J. 493.

(g) R. v. Almon, 5 Burr. $2686 ; R$. v. Gutch, M. \& M. 433 ante, p. 310 . 
Attorney-Gen-when it was argned, that this does not fall within the eral v. Siddon. ordinary range of the case of a servant's act being the master's act. But in order to form a judgment whether this is the master's act or not, and within the scope of the authority which ought to be considered as given by the master to the servant, you must look at the nature of the act, and see with what view that act was done, and the participation which the master had in anything to which that act referred.

"This is the case of a servant of a fraudulent master endeavoring by his own act to conceal his master's fraud, and to prevent the consequences which would otherwise fall upon the master in respect of that [*315] fraud. *From the nature of the service in which the party is employed, and from the conduct of the master in his fraud, you may infer whether or no the servant had prima facie an authority from the master ; not perhaps specifically for the doing of this specific act, but for the purpose of doing that which, in the exercise of his discretion upon a moment of embarrassment, which the possession of an improper article might naturally create, the servant should think and deem to be best."

The learned baron then went through the facts of the case, which, in his opinion, formed prima facie evidence to show that the act of the servant was the act of the master, though, said he, "The master was certainly at liberty to have produced evidence for the purpose of rebutting that prima facie case, but, in the absence of any evidence to rebut that case, it was rightly left to the jury, and the jury were bound to consider it as being the master's act."

R. v. Dixon. So, where $(e)$ a statute $(f)$ for regulating the making of bread, enacted, that if any of the loaves authorized by that act to be made, should have in them any alum, \&c., "every person offending therein" should be liable to certain penalties: it was held, that a master baker was liable to an indictment for supplying loaves contain-

(e) R. v. Dixon, 4 Camp. 12 ; 3 M. \& S. 11; and see $R$. v. Bradley, 10 Mod. 156.

(f) 36 Geo. 3 , c. 22 ,now repealed, $24 \& 25$ Vict. c. 101 . See $6 \& 7$ Will. 4 , c. 37, s. 8 , and Core v. James, 41 L. J., M. C. 19; L. R., 7 Q. P. 135 ; see also sect. 7, and Robinson v. Clift, $45 \mathrm{~L}$ ? J., M. C. 109, as to sending out bread without scales, \&c. And see Ridgoay v. Ward, Q. B., M. T. 1884 . Under sect. 13, the servant may be compelled to recompense the master who has incurred penalties through the default of the servant. Ridgwau $\nabla$. Ward is reported 54 L. J., M. C. $20 ; 14$ Q. B. D. 110. 
ing lumps of crude alum, though his foreman proved that he was the person who made the bread.

And where a statute $(g)$ imposed a penalty on every ${ }_{l}$. v. Dean. person who should be concerned in the unshipping of any goods, the duties for which had not been paid, it was held $(h)$ that each partner $(i)$ of a firm, whose clerk had been guilty of a fraud by altering the blue book at the Custom-house (in which the amount of goods was entered * for duty), was liable to the penalty in- [*316] curred through the act of their clerk, as they derived a benefit from his fraud, and produced no evidence to rebut the prima facie evidence of knowledge on their part which arose from that circumstance.

So, also, a guardian of the poor has been held liable Dacies $\mathrm{v}$. to the penalties provided by $4 \& 5$ Will. 4 , c. 76 , s. 77 Harrey. (which prohibits any person appointed to any office concerned in the administration of the poor-laws from supplying for his own profit any goode, \&c., ordered to be given in parochial relief to any person), where his son and partner sold an iron bedstead delivered by the order of the relieving officer at the house of a pauper to whom it was lent by the guardians, without any guilty knowledge on the part of the guardian, the bedstead having been supplied by his partner with knowledge of the circumstances in the ordinary course of the partnership business $(k)$.

And masters have frequently been convicted and held Breaches of liable to penalties for breaches of the Licensing Act Licensing 1872 (35 \& 36 Vict. c. 94), committed by their servants. Act, 1872. Thus, where a constable in uniform and on duty went Mullens $\mathrm{v}$. to the house of a licensed person, and was there supplied with brandy by a servant, the licensed person was held liable to be convicted, although he was not present at the time, nor did he know that the brandy had been supplied, nor had he given any express authority to the servant to supply it $(l)$.

So, a licensed person has been held liable to convic- Relgate $\mathrm{v}$. tion for "suffering gaming" where, after she had gone Haynes. to bed and left a porter in charge, gaming was carried on, and he might have known it, as it was unnecessary

(g) $3 \& 4$ Will. 4 , c. 53, s. 44 .

(h) $R$. v. Dean, 12 M. \& W. 39.

(i) It would have been otherwise had the penalty been attached to each offence, and not to cach party concerned, ibid.; and see $R$. v. Clerk, Cowp. 610.

(k) Daries v. Harvey, 43 I. J., M. C. 121.

(l) Srullins v. Collins, 43 L. J., II. C. 67 ; I. R., 9 Q. B. 292. 
Parnbrokers' servants.

Master not liable to penalties for acts of serrant beyond scope of his authority.

Harrison v. Leaper.

Indictments for nuisances. to prove an actual knowledge on her part of what was going on $(m)$.

[*317] *And an employer has been held liable to penalties for breach of the Truck Act by his bookkeeper paying wages otherwise than in current coin of the realm $(n)$.

By the Pawnbrokers Act, 1872 (o) (which imposes penalties on pawnbrokers in certain cases), it is enacted-

Sect. 8. "For the purposes of this Act, anything done or omitted by the servant, apprentice, or agent of a pawnbroker in the course of, or in relation to the business of the pawnbroker, shall be deemed to bedone or omitted (as the case may be) by the pawnbroker; and anything by this Act authorized to be done by a pawnbroker may be done by his servant, apprentice, or agent."

A master, however, could not be thus rendered liable to penalties for any act of his servant, beyond the scope of his authority $(p)$.

And where a servant in charge of a steam threshingmachine let on hire to his master, erected it within twenty-five yards from a carriage-way, but there was no evidence that the master ordered it to be so erected, it was held by the Court of Queen's Bench, that the master could not be convicted under the Highway Act, 5 \& 6 Will. 4 , c. 50 , s. 70 , which imposes a penalty upon any person who shall erect or cause to be erected any steam-engine, \&c. within the distance of twentyfive yards from any carriage-way $(q)$.

Again, masters are liable to indictments for public nuisances $(r)$, such as carrying on offensive trades,

(m) Redgate v. Haynes, 45 L. J., M. C. $65 ; 1$ Q. B. Div. 89. See Besley v. Davies, 45 L. J., M. C. 27 ; 1 Q. B. D. 84 , where it was held that actual knowledge is not necessary, something amounting to constructire knowledge must be shown. But in Somerset v. Hart, 53 L. J., M. C. 77 , it was held that knowledge of a potman who was not "in charge" of the premises was not sufficient. See also Templeman r. Trafford, 51 L. J., M. C. 4, a conviction for breach of the Pharmacy Act, 1863 (31 \& 32 Viet. c. 17).

(n) Smith v. Walton, 47 L. J., M. C. 45; 3 C. P. D. 109; 37 L. T., N. S. 437 .

(o) $35 \& 36$ vict. c. 93

(p) See Olding v. Smith, 16 Jur. 497; $R$. v. Gilroy, 4 Third Ser. 656 (retailing beer without a licence).

(q) Harrison v. Leaper, 26 Just. Peace, 69, 373; 5 L. T. 640. See Hearne v. Garton, 2 E. \& E. 66.

(r) In Turberville v. Stampe, 1 Lord Raym. 264, Holt, C. J., said, "If my servant throws dirt in the highway, I am indictable." See 1 Bl. Comm. 431; 2 Noy's Maxims, c. 44; Hall's case, (340) 
committed by their servants, although their masters have nothing to *do personally with the nuisance [*318] complained of. In such cases, also, if a master could shield himself from criminal responsibility on the ground that he personally had nothing to do with the carrying on the trade, the real offender might escape with impunity, and the public grievance remain unredressed. It has indeed scarcely ever been contended that the master, in such cases, was not guilty on the ground that the nuisance was perpetrated through the agency of others $(s)$; and where that objection has been taken, it has been speedily overruled.

Thus, in Rex v. 'Medley ( $t$ ), the chairman, deputy chairman and other directors of a gas company, and several persons employed by them in carrying on the works, were jointly indicted for a nuisance occasioned by conveying the refuse of gas, \&c., into the river Thames, whereby fish were destrcyed, and the water rendered unfit to drink. On the part of the defendants it was contended that the directors of the company were not liable, as no criminal participation on their part, in the acts done by their workmen, was shown, and they did not even know what was done. But they were found guilty and fined, Lord Denman, C. J., saying it made no difference, that the directors were ignorant of what had been done, provided they gave authority to the manager to conduct the works. "It seems to me both common sense and law, that if persons for their own advantage employ servants to conduct works, they must bo answerable for what is done by those servants."

And again, where a railway company $(u)$ was in- $R$. v. Great dicted * for cutting through and obstructing a [*319] North of highway by works performed in a course not conform-

England Railway Co.

1 Mod. 76; R. v. Cross, 3 Camp. 224; Bush v. Steinman, 1 B. \& P. 407; Redie v. London and North Westem Railway Co., 4 Exe. 244.

(8) See R. v. Pedly, 1 A. \& E. 822, where a landlord was held liable to he indieted for a nuisince committed by his tenants, such nuisance being the inevitable result of the occupation, and the landlord receiving rent for that oecupation. See, however, Rich v. Basterfield, 4 C. B. 783.

(t) 6 C. \& P. 292. Sce also R. v. Slcphrus, 7 Best \& S. $710 ; 10$ Cox, Cr. C. 340; 35 L. J., Q. B. 251, where a master was held liable to indictment for obstrueting the river, although he specially ordered his servants not to do it.

(u) R. v. Great North of England Railway Co., 9 Q. B. 315. In R. v. Pease, 4 B. \& Ad. 30 , some of the members of a railway company were indicted together with their servants for a nuisance oceasioned by the railway; and see $R$. v. Scott, 3 Q. B. $5.13 ; R$. v. Train, 3 F. \& F. 
able to the powers conferred by the Act of Parliament; and one of the grounds on which it was argued that the company was not liable to an indictment for a misfeasance committed by their servants was that the individuals doing the act might be indicted and punished. Lord Denman said,-

"We are told that this remedy is not required because the individuals who concur in voting the order, or in executing the work, may be made answerable for it by criminal proceeding. Of this there is no doubt. But the public knows nothing of the former, and the latter, if they can be identified, are commonly persons of the lowest rank, wholly incompetent to make any reparation for the injury. There can be no effectual means for deterring from an oppressive exercise of power for the purpose of gain, except the remedy by indictment against those who truly commit it-that is, the corporation acting in the majority; and there is no principle which places them beyond the reach of the law for such proceedings."

Innkeeper's servant refusing to receive gucsts.

Upon similar principles it is conceived that an innkeeper might be rendered liable to an indictment for a refusal by his servant to receive a guest into the inn, if it were within the scope of the servant's employ. ment to receive guests $(x)$; or a tenant (whose landlord has reserved the game) might be proceeded against under the Game Act $(y)$ if he employed another person to kill game $(z)$.

As to servant's liability, post.

The master's liability to answer in a criminal suit for the act of his servant does not, however, by any means involve the exemption of the servant himself to answer criminally for his own acts. The question, however, as to how far the command of the master will justify the act of the servant will be more properly brought under consideration in a separate chapter.

[*320] *Since, however, this liability of masters to answer criminally for the illegal acts of their servants,

$(x)$ See $R$. v. Ivens, 7 C. \& P. 213 , where the master refused to receive the guest. And as to that case, see Fell v. Knight, $8 \mathrm{M}$. \& W. 269. The stat. 26 \& 27 Vict. c. 41 , which limits the liability of innkeepers in respect of the goods of their guests, contains an exception where such goods have been stolen, lost or injured through the wilful act, default or neglect of such innkeeper or any servant in his employ.

(y) $1 \& 2$ ivill. 4 , c. 32.

(z) See Spicer v. Barmard, 28 L. J., M. C. 176, which was the converse case; the tenant was held not liable for his servant killing rabbits, as lie had a right to do so himself. and "qui facit per alium, facit per se." 
might occasionally operate hardly upon masters by put- When master ting it in the power of wicked servants to subject their cxcmpt, on masters to penalties by their own wilful violation of the conviction of law, it is sometimes enacted, for the protection of servant. masters, that servants wilfully transgressing the law, shall themselves be subject to a penalty, and their master, upon conviction of his servant, shall be exempt from further criminal liability $(a)$.

And where a master has been convicted in penalties Bakers Act. for breach of the Baker's Act (b) through the wilful act, neglect or default of any journeyman or other servant, and has paid the fines, it is provided (c) that such servant may be ordered to recompense his master for the money so paid.

There is a similar provision in the Act for regulating Hackney of Hackney Carriages in London $(d)$, and in the Alkali, Carriages \&c. Works Regulation Act, 1881 (e); but under the last Act. mentioned Act the servant may be convicted and fined. Alkali Act,

But where an Act of Parliament ( $f$ ), which imposed various penalties on maltsters who should violate the provisions of the Act, contained also a clause $(g)$ for punishing, by summary proceedings before a magistrate, any workman, servant or labourer employed by or in the service of any maltster, who should, maliciously and with intent to injure such maltster, violate the provisions of the Act; with a proviso that the maltster himself should still continue liable to the penalties imposed for violation of * the Act [*321] unless he should forthwith prosecute such workman, \&c. to conviction, and produce to the Commissioners of Excise a certificate of such conviction; and a maltster fraudulently procured the conviction of his servant for an offence under the Act, with a view to protect himself from proceedings for the same offence, the Court

(a) See for instance, $7 \& 8$ Geo. 4, e. $52 \mathrm{s.} \mathrm{46,} \mathrm{which,} \mathrm{however,}$ was repealed by $438 \& 44$ Vict. c. 20, s. 49 ; see ante, p. 313 , note (z); and sec the provision in the Libel Act, 6 \& 7 Vict. c. 96, s. 7, ante, p. 310.

(b) $6 \& 7$ Will. 4. c. 37 .

(c) Sect. 13.

(d) 6 \& 7 Vict. c. 86, s. 28

c) $44 \& 45$ Vict. e. 37, s. 25 . Sce also the Metropolitan Firo Brigade Act, $1865,28 \& 29$ Viet. e $90, \mathrm{~s} .23$, which subjects the occupier of a house, any chimmey of which is on fire, to a penalty of 20 s.; but enables him to reeover it from any person by whose neglect or wilful default it was caused.

(f) $7 \& 8$ Geo. 4, c. 52. See note (a) supra.

(g) Sect. 46 
of Queen's Bench granted a certiorari to remove and quashed the conviction $(h)$.

Master only liable where servant commits breach of a public duty binding on his master. $R$. v. Watts.

Expense of special constables to keep order among workmen thrown on companies carrying on works.

Master generally liable for torts of servant.
And as the liability of a master to answer criminally for the acts of his servants presupposes, and is in fact founded upon, the violation of some public duty legally binding upon the master, it can, of course, only exist where such duty exists, and must cease when such duty ceases to be binding. And, therefore, where a vessel was sunk by accident in a navigableriver, and without any default on the part of the owner or his servants, as the law does not ordinarily cast upon the owner of a vessel sunk under such circumstances the duty of using any precaution, by placing a buoy or otherwise, to prevent other vessels from striking against it, it was held that the owner was not liable to an indictment, or to an action at the suit of a party sustaining injury in consequence of a collision with the sunken vessel, for omitting to remove it or take precautions to prevent accidents $(i)$.

It may be convenient to mention in this place that whenever the appointment of special constables has been rendered necessary by the behaviour of labourers and others employed on railroads, canals and other public works, the expenses thereof may be thrown on the companies carrying on the works $(k)$.

\section{[*322] *IN Cases of TorT-Civiliter.}

A master is ordinarily liable to answer in a civil suit for the tortious or wrongful acts of his servant, if those acts are done in the course of his employment in his master's service $(l)$. The maxims applicable to such cases being respondeat superior $(m)$, and that before al-

(h) R. v. Gillyard, 12 Q. B. 527.

(i) R. v. Watts, 2 Esp. 675 ; see Parnaby v. Lancaster Canal Co., 11 A. \& E. 223 ; Brown v. Mallett, 5 C. B. 599 ; Hancock v. The York, Neweastle and Berwick Railway Co., 10 C. B. 348; White v. Crisp, 10 Exc. 312 ; Metcalfe v. Hetherington, 11 Exc. 257 ; Gibbs v. Liverpool Dock Trustees, 26 L. J., Exe. 109; 1 H. \& N. 439; $S$. $C$. in error, 27 L. J., Exe. 321 ; 3 H. \& N. 164. And see $R$. v. Barrett, 2 C. \& K. 343, where it was held that an engineer could not be convicted of manslaughter, on an indictment which did not allege a duty in him which he had neglected to perform.

(k) 1 \& 2 Vict. c. 80.

(l) "By the civil law the liability was confined to the person standing in the relation of paterfamilias to the wrongdoer, "Dig. lib. 9, tit. 3. But by the English law the liability is more extensive.

$(m)$ "The maxim of respondcat superior is bottomed on this principle; that he who expects to derive advantage from an act which is done by another for hin nust answer for any injury which a third person may sustain from it. This maxim was first 
luded to, Qui facit per alium, facit per se. This rule, with some few exceptions, which will be hereafter pointed out, is of universal application, whether the act of the servant be one of omission or commission, whether negligent, fraudulent or deceitful, or even it be an act of positive malfeasance or misconduct; if it be done in the course of his employment, his master is responsible for it civiliter to third persons $(n)$. And it makes no difference that the master did not actually authorize or even know of the servant's act or neglect, for even if he disapproved of or forbade it he is equally liable if the act be done in the course of the servant's employment (o).

*And it is but reasonable that it should be so, [*323] for surely it is more just that he who selects a person as his servant, from a knowledge of or belief in his skill and care, and who can remove him for misconduct $(p)$, and whose orders that servant is bound to receive and obey, should suffer for the misconduct of that servant,

applied to public officers by the Stat. Westm. 2, e. 11, from the worls of which statute it is taken, 'Si custos gaolze non habeat per quod justicictur vel unde solvat, respondeat superior suus quicustoliam hujusmodi gaole sibi commisit.' 'The terms of the statute of Westm. 2 , embrace only those who delegate the keeping of gatols to deputies, and were intended only, as Lord Coke tells us ( 2 Inst. 3-2), to apply to those who, having the custody of gaols of freehold or inheritance, commit the same to anotlier that is not sufficient. The principle of the siatute has, however, sinee been extencled to sheriffs, who are responsible for their undersheriffs and bailiffs, but has not been applied to any other publie officer. Although. the office of sheriff be now a burthensome one, yet they are entitled to poundage and other fees for aets done by their oflicers which in old time might be a just equivalent for their responsibility." Per Lord Wynford, in Mall v. Smith, 2 Bing. 160.

(n) Story on Ag. 45\%; Paley on $\mathrm{Ag}$. 294, 298, and eases there cited. Pothier on Oblig. by Evans, No. 456 ; see also the cases cited, post, and Philadelphia and Reading Railroad Corporation v. Derby, 1.1 Howard's (Amer.) Rep. 468.

(o) So a landlork is liable for the acts of his broker, Frcemanv. Rosher, 13 Q. B. 780 ; Gauntlett v. King, 3 C. B., N. S. $59 . \quad$ So a elient is liable for the tortious act of his attorney in the conduet of a suit, and cannot shield himself from responsibility by ignorance of a partieular Aet, nor under the prineiple, hereafter noticed, that a person who employs a contractor is not liable for the acts of the contractor's servants, Collell v. Foster, 2S L. J., Exc. 612. In that case, Bramwell, B., expressed a great desire to limit tho doetrine of respondeat superior, and to make the aetual wrongdoer alone responsible. Seo also Smith v. K' $\mathrm{cal}, \mathrm{I}$. I., 9 Q. 13. Div. 340 .

(p) The mere power of removal, apart from the power of original selection, will not render the person who has it liable for the acts of persons who he has power to remove, if they are not his servants, Reclie v. London and North Western Railway Co., 4 Exe. 244; and see Chilcot v. Bromley, 12 Ves. 114; Kclly v. Mayor, ce. of New Yorli, 1 Kernan's (Amer.) liep. 432. 
than that an innocent third person, who had not the opportunity of selection, or the power of removal and enforcing obedience to his orders, should be prejudiced by such misconduct.

Accordingly, numerous instances occur in which this principle, of holding the master responsible civiliter for the tortious acts of his servants, has been acted upon and enforced $(q)$.

Michael $\nabla$.

Thus, where $(r)$ the servants of A. brought a coach Alestrec. with two ungovernable horses into Lincoln's Inn Fields, to train them, and they being not to be managed ran upon the plaintiff, the master was held liable for the damage occasioned.

Jones r. Hart. [*324] *So, where (s) a pawnbroker's servant took a pawn, and when the pawner came and tendered the money to the servant, he said he had lost the goods, the

Negligent driving by servant. master was held liable in trover. So, where the servants of A., with his cart, ran against another cart, wherein was a pipe of sack, and overturned the cart and spoiled the sack, it was held that an action lay against A. And so, where $(t)$ a carter's servant ran his cart over a boy, it was held the boy should have his action against the master for the damage he sustained by this negligence. In fact actions against masters for damages sustained by the negligent driving of their servants are so common, that it is unnecessary to multiply instances of the master's liability in such cases $(u)$.

(q) Whether the act complained of amount to a misfeasance, negligence, or omission of dnty is obviously a question of fact, and must in each case depend upon the particular circumstances of the case. See Crofts v. Waterhouse, 3 Bing. 319. The Judge at Chambers has a discretion as to granting an order for particulars of the plaintiff's claim, but as a general rule, not to be departed from without grave reasons, will not grant one in an action for "running down" by defendant's servants, Wceks v. Macnamara, 3 H. \& N. 568.

(r) Michacl v. Alestree, 2 Lev. 172. In this case the action was bronght against both master and serrant; but it is better generally to sue only the master, Whitrmore v. Waterhouse, $4 \mathrm{C}$. \& P. 383 ; see also Parsons v. Winchell, 5 Cush. (Amer.) Rep. 592. Except, perliaps, in a case like Stevens v. Midland Railucay Co., 10 Exc. 352, where the action failed against the master, but sncceeded against the servant. But a plaintiff cannot recover damages first against the master and afterwards against the servant for the same injury. Per Cockbnrn, C. J., 46 L. J., C. L. 431, in Wright v. London General Omnthus Co.

(s) Jones v. Hart, 2 Salk. 441; Cary v. Webster, 1 Str. 480; Mead v. Hamond, Armory v. Delamirie, 1 Str. 505.

(t) Jones v. Hart, ubi supra.

(u) As to how far knowledge of the servant is knowledge of the master in an action for keeping a ferocious animal, see Stiles v. Cardiff Steam Natigation Co., 33 L. J., Q. B. 310; Smith v. 
So, an innkeeper has been held liable for damage to the horse and gig of a guest through the negligence of the ostler $(x)$.

Again, where $(y)$ the defendant's servants so negli- Serrant gently *kept a fire lighted in his field, that it [*325] negligently extended to and consumed the heath of the plaintiff, lighting fire. the defendant was held liable to an action for the injury, Turberville $\mathrm{v}$. and Lord Holt observed, "If the defendant's servant Stamp. kindled the fire in the way of husbandry and proper for his employment, though he had no express command of his master, yet his master shall be liable to an action for damage done to another by the fire, for it shall be intended that the servant had authority from his master, it being for his master's benefit" $(z)$.

And a coal merchant has been held liable to a passenger for the negligence of his carter in leaving coal shoot open $(a)$.

Great Eastern Railway Co., 36 I. J., C. P. 22; Gladman v. Johnson, 36 L. J., C. P. 153. In Balduin v. Casella, 41 L. J., Exe. 167; L. R., 7 Exc. 325, the knowlerlge of the defendant's eoachman that a dog under his charge was mischievons, was held sufficient to make the defendant liable. See also A pplebcev. Pcrey, 43 L. J., C. P. 365; L. R., 9 C. P. 647. As to the liability of the master for a libel published by his authority, see Parkes v. Prescolt, 38 L. J. Exc. 105.

(x) Bather v. Day, 32 L. J., Exe. 171.

(y) Turberville v. Slamp, Lord Raym. 264; 1 Salk. 13; 1 Comyn's Rep. 32. And see Beatien v. Finglam, 2 H. 4, fo. 18, pl. 6, cited 1 C. B. 586, note; Sercnulat v. Saisse, 35 I. J., Pr. C. C. 17. But see also Mackenzie v. M'Lcorl, 10 Bing. 385, post. A person on whose property a fire accidentally begins is not now liable to an action at the suit of any person who may be iujured thereby; see 6 Ann. e. 31 , s. $6 ; 12$ Geo. 3 , c. $73 ; 14$ Geo. 3 , c. 78 , s. $86 ; 7$ \& 8 Viet. c. 84 , s. 1, and Schednle $A$., which Acts are general law, Richards v. Easto, 15 M. \& W. 251; 3 D. \& L. 522. But where a fire is caused, or having been knowingly lighted is permitted to extend, by negligence, the master is still liable, Filliter v. Phippard, 11 Q. B. 347. And see instances of actions against railway companies for negligent management of their engines by their servants, whereby sparks flew out and caused fire. Allvidge v. The Great Western Lailway Co., 3 M. \& G. 515; Piggolt v. Eastern Counties Railway Co., 3 C. B. 2:?!); Vanghan v. Triff Vale Railway Co., 28 I. J., Exe. 41; 3 H. \& N. 7.43; reversed 29 1. J., Exe. 247; 5 H. \& N. 679; Frecmantle v. London and North Western Railway Co., 31 I. J., C. P. 12; 10 C. I3., N. S. 89; Jones v. Festiniog Railway Co., 37 I. J., Q. B. 214; I. R., 3 Q. B. 733; Stokes v. Eastern Countics Railway Co., 3 F. \& F. 691.

(z) Note the diflerence between this case and Williams v. Jones, 33 I. J., Exc. 297; 3 H. \&. C. 602; 11 I. 'T., N. S. 109, where a master was held not liable for a fire caused by the negligent use of a pipe by his servant. 276.

(a) Whitcley v. Pepper, 46 L. J., C. L. 436; L. li., 2 Q. B. Div. 
Actions against

carriers.

Actions against carriers of goods;
Actions against carriers, whether by land $(b)$ or water $(c)$, for loss or injury to goods entrusted to their [*326] care, also *frequently involve a similar principle, since carriers are generally liable for the honesty of their servants $(d)$.

A carrier, bowever, is not answerable for loss of luggage intrusted to his servant to carry for his own private gain $(e)$, or in defiance of a known course of business $(f)$. Nor is a railway company liable for injuries arising from negligence of their servants, if by a special contract entered into by the consignor all risk of damage, from whatever cause, is agreed to be borne by the consignor $(g)$. Nor a carrier by water, where by special

(b) By the Carriers Act, 11 Geo. 4 \& 1 Will. 4, c. 68, and the Railway and Canal Traffic Act, 1854,17 \& 18 Vict. c. 31 , s. 7, the liability of carriers by land is limited in certain cases. But by sect. 8 of the first-mentioned Act, it is provided, "That nothing in that Aet shall be deemed to protect any mail contractor, stage-coach proprietor, or other common carrier for hire, from liability to answer for loss or injury to any goods or articles whatsoever arising from the fclonious acts of any coachman, guard, bookkeeper, porter, or other servant in his or their employ, nor to protect any such coachman, guard, bookkeeper, or other servant from liability for any loss or injury occasioned by his or their own personal neglect or misconduct." Felony by the carrier's servant is, therefore, a good answer to a defence under the Carrier's Act. But mere suspicion is not cnough, there must be evidence of felony sufficient to convict a servant of the carrier. See Hinton v. Dibbin, 2 Q. B. 646; Butt v. Great Western Railway Co., 11 C. B. 140; Grcat Western Railway Co. v. Rimmell, 18 C. B. 575; 27 L. J., C. P. 201; Metealfe v. London and Brighton, \&e. Co., 27 L. J., C. P. 205, 333; Keys v. Belfast Railvay Co., 8 Ir. C. L. R. 167; Vaughton v. London and North Western Railway Co., 43 L. J., Exe. 75; L. R., 9 Exc. 93; Gogarty v. Great Southern and Western Railway Co., 7 Ir. C. L. Rep. 344; M'Queen v. Great Western Railway Co., 44 L. J., Q. B. 130; Way v. Grcat Eostern Railwag Co., 45 L. J., C. L. 874.

(c) See the Railway and Canal Traffic Act, 1854, 17 \& 18 Vict. c. 31. By the Merchant Shipping Act, 1854,17 \& 18 Vict. c. 104, s. 502 ct scq., and the Merehant Shipping Act Amendment Act, $1862,25 \& 26$ Vict. c. 63 , s. 54 et scq., the liability of shipowners is limited in certain cases. See Brown v. Wilkinson, 15 M. \& W. 391; Leyecster v. Logan, 26 L. J., Ch. 306; Cope v. Doherty, 27 L. J., Ch. 600. See Abbott on Ship., Part IV.,Chap. 7 , 9th edit. 324 , as to the law previously.

(d) Sub-contractors' servants are "servants in the employ" of the earrier within sect. 8 of the Carriers Act, supra, note (b); Maehu v. South Western Railway Co., 2 Exc. 415; and see Crouch v. Great Wcstern Railway Co., 26 L. J., Exc. 418, 422.

(e) Butler v. Basing, 2 C. \& P. 613. See and consider Boucher v. Lawson, Rep. temp. Hardwicke, 85.

(f) Slim v. Great Northern Railway Co., 14 C. B. 647.

(g) Austen v. Manehester, \&c. Railway Co., 10 C. B. 454; Carr v. Lancashire, \&.8. Railway Co., 7 Exc. 707; Phillips v. Edwards, 28 L. J., Exc. 52. But see M'Manus v. Laneashire and Yorkshire 
contract he stipulated not to be liable for passenger's luggage unless a bill of lading was signed, and none was signed $(h)$. But they may be liable even for such damage apparently excepted by the special contract, if such damage is caused by the gross negligence of their servants in stowing the goods $(i)$; or since 17 \& 18 Vict. c. 31, the Railway and Canal Traffic Act, if the Court or judge trying the cause shall be of opinion that under the circumstances the conditions of the special contract exempting them from liability are unjust and unreasonable $(k)$. Again, carriers have been held liable for goods delivered to their servant, notwithstanding a bye-law that they would not be liable unless booked, in *the absence of evidence that [*327] they had provided means of booking $(l)$.

Carriers of passengers also are responsible for injuries happening to them through the misconduct $(m)$ of and passentheir drivers and servants $(n)$, but not of course if such injury happen by accident $(o)$. Whether or not the

Railway Co., 28 L. J., Exe. 353; 4 H. \& N. 327; Gregory v. West Midlund Ruilway Co., 33 L. J., Exc. 155, where such a provision was held umreasonable. As to a railway company limiting their liability to their own line, see Fowles v. Great Western Railway Co., 7 Exe. 699.

(h) Wilton v. Royal Atlantie Mail Steam Navigation Co., $30 \mathrm{~L}$. J., C. P. 369.

(i) Phillips v. Clark, 26 L. J., C. P. 168; 2 C. B., N. S. 156; Grill v. General Serew Co., 35 L. J., C. I'. 321; 27 L. J., C. P. 205 .

(k) MPanus v. The Lancashire and Yorkshive Railway Co., 28 L. J., Exc. 353.

(l) Creat Western Raihway Co.v. Goodman, 12 C. B. 313; Witliams v. Great Western Railway Co., 10 Exe. 15.

(m) White v. Boullon, P'ake, 81. See generally on this sub. ject, Selw. N. P. tit. "Carriers"; and see Ross v. Hill, 2 C. B. 877 ; 3 I. \& L. 788, where a cab proprietor was held liable for the loss of a passenger's luggage through the negligence of the driver; ace. I'oules v. IIider, 6 E. \& B. 207; 2.) L. J., Q. B. 331. lut see Fowler v. Lock, 41 L. J., C. P. 99; L. R., 7 C. P. 272; L. R., 10 C. P. 90 ; Venables v. Smith, 46 L. J., C. L. $470 ; 2$ Q. B. Div. 279 ; Steel v. Lester, 3 C. P. Div, 121; 47 L. J., C. I. 43 ; King v. Spurr, 51 1. J., C. L. 105; 8 Q. B. Div. 104. See also Williams v. Cranston, 2 Stark. 82, where a plaintiff, suing the servant, was nonsuited, on the ground that he ought to have sued the master; Cacenagh v. Such, 1 I'rice, 328, acc.

(n) A railway company, issuingathrough ticket over its own and other lines, is liable to a passenger taking snch ticket for negligence on another line, not a portion of theirs, see Birkett $\mathrm{v}$. The Whitehaven Junction Rrihtay Co., 28 I. J., Exc. 348; Mytton v. The Midland Railuay Co., $23 \mathrm{~J}$. J., Exe. 395 . This is on the ground that the contract to carry was made with them.

(o) Crofts v. Waterhomse, 3 Bing. 321 ; Bradley v. Waterhouse, M. \& M. 154. Where the balance is even as to the cause of the accident, the onus is on the plaintin to turn the scalc. Cotton v. 
injury complained of in any particular case arose from the negligence of servants, or was the effect of accident, would be a question proper for the consideration of a jury $(p)$.

Áctions against railway (q), banking $(r)$, and steam[*328] *packet $(s)$ companies, also necessarily involve similar principles, as such companies can only act through the instrumentality of servants $(t)$.

Wood, 29 L. J., C. P. 333 ; 8 C. B., N. S. 33 ; Hammaek т. White, 31 L. J., C. P. 129 ; 11 C. B., N. S. 588 ; Smith v. Great Eastern Railway Co., 36 L. J., C. P. 22 ; Manzoni v. Douglas, 50 L. J., C. L. 289. See also Wilds v. Hudson River Railroad Co., 10 Smith's Rep. App. New York, 431.

(p) Sec Briddon v. Great Northern Railway Co., 28 L. J., Exc. 51 , where a train was detained by snow.

(q) Such as Muschamp v. Lancaster and Preston Junction Railway Co., 8 M. \& W. 421 ; Crouch v. North-Western Raihcay Co., 2 Carr. \& K. 789 ; Simith v. Brighton Railway Co., 7 C. B. 782 ; Riehards v. The Same Co., 7 C. B. 839 ; Chilton v. Croydon Railway Co., 16 M. \& W. 212 ; Eastern Counties Railway Co. v. Broom, 6 Exc. 314; Great Northern Railway Co. v. Shepherd, 8 Exc. 30; Buteher v. South-Western Railway Co., 16 C. B. 13 ; Stevens v. Midland Railway Co., 10 Exc. 352; W hitfield v. South-Eastern Railway Co., 27 L. J., Q. B. 229 ; 1 E., B. \& E. 115 ; Edwards v. Midland Railway Co., L. R., 6 Q. B. Div. 287. As to liability of railway company for negligence of their servants where damage arose through defective fences, see Midland Railway Co. v. Daykin, 17 C. B. 126 ; see also Giles v. Taff Vale Railway Co., 2 E. \& B. 822; Smith v. Great Eastern Railway Co., ubi supra; Self v. London, Brighton and South Coast Railuay Co., 42 L. T., N. S. 173; Clarke v. Midland Railway Co., 43 L. T., N. S. 381.

(r). Such as Barwick v. The English Joint-Stock Bank, post, p. 329 ; Mackay v. The Commercial Bank of New Brunswick, 43 L. J., P. C. C. 31 ; L. R., 5 Pr. C. 394 ; Bank of New South Wales v. Oveston, L. R., 4 A pp. Cas. 290.

(s) Fenton r. City of Dublin Steam-Packet Co., 8 A. \& E. 835; Bennett v. Peninsular and Oriental Steam Navigation Co., 6 C. B. $7 \% 5$.

(t) Ante, p. 22. And see Maund $\mathrm{v}$. The Monmouthshire Canal Co., 4 M. \& G. 452, where the defendants were held liable in tresspass for the act of their servant. In Chilton $\mathrm{r}$. Croydon Railtcay Co., 16 M. C W. 212 ; Eastern Counties Railway Co. v. Broom, 6 Exc. 314; 20 L. J., Exc. 196; 6 Railw. Cas. 743 ; Goff r. Great Northern Railway Co., 30 L. J., Q. B. 148; Seymour v. Greenwood, 30 L. J., Exc. 189, 327; Wilson v. Lancashire and Yorkshire Railvay Co.; Farran v. Same Co., 30 L. J., Exc. 192; 27 L. T. 20; Moore v. Metropolitan Railway Co., L. R., 8 Q. B. 36 ; Bayley v. Manchester, Sheffield and Lincolnshire Railway Co., 41 L. J., C. P. 278 ; L. R., 7 C. P. 415 ; 42 L. J., C. P. 78 ; L. R., 8 C. P. 148 ; it was held that railway companies might be liable to an action of trespass for an assault committed by their servant. In America a railway company have been held liable to an action of trespass because their conductor assaulted and kissed a female passenger; Croaker v. The Chicago and North-Western Railvay Co., 17 Amer. Rep. 504 ; and for an assanlt by a brakesman on a passenger who accused him of having stolen his watch; Chicago and Eastern Railroad Co. v. Flaxman, 42 Amer. Rep. 33 (1382). See also 
Where $(u)$ the owner of a boat, which was accus- Invasion by tomed to ply for hire and carry passengers across a ha- servant of ven, employed a servant for that purpose, and the ser- right to ferry. vant on one occasion received a passenger on board, Huzzey v. and carried him across the haven near tho line of an ancient ferry, and paid the fare over to his master, it was held that the servant was acting at the time in the course of his master's service, and for his master's benefit, and the master was answerable for his act, and would have been liable in an action on the case for such act, if it had been distinctly proved to have amounted to an invasion of the ferry.

And a master is liable for the fraud of his servant, Frand of committed in the course of his master's business, and servant. within *but, as we shall hereafter see, not be- [*329] yond, the scope of his anthority. Thus, if a goldsmith make plate, wherein he mingles dross, so that it is not according to the standard, and send his servant to a fair to sell it, who sells it for good plate according to the standard, an action upon the case lies against the master $(x)$.

Upon this principle a sheriff has been held liable for

Whitfield v. South-Eastern Railway Co., 27 I. J., Q. B. 229 ; 1 E., 13. \& E. 115; Green v. London General Omnibus Co., 29) I. J., C. P. 13 ; and the American cases of Moore v. Fitehbourg Railroad Corporation, 4 Gray, 465; The Pliladelphia, \&e. Railroad v. Quigley, 21 Howard's Rep. 202; IIewett v. Swift, 3 Allen's Rep. $4: 0$.

(u) Inzzy v. Field, 2 C., M. \& R. 432. Where the lessee by parol of a ferry, finding it did not answer, agreed to become servant to the lessor and account to him for the profits of the ferry, his interest as tenant was held to have been surrendered hy operation of law, Peter v. Kendal, 6 B. \& C. 703. In Llackwell v. Wiswal, 21 Barbour's (Amer.) Rep. 35i, the lessor of a ferry was held not liable for the acts of lessee's servants.

$(x)$ Southern v. How, Cro. Jac. 471; and see Grammar v. Nixon, 1 Str. 653; IIern v. Nicholls, 1 Salk. 289; Cornfoot v. Fowke, 6 M. \&W. 358; Faller v. Wilson, 3 Q. B. 58 ; Jones v. Dormman, 4 Q. B. 235 , note; Downman v. Williams, 7 Q. B. 103 ; Watson v. Earl Charlemont, 12 Q. B. 856 ; Coleman v. Riches, 16 C. B. 104 ; The National Erehange Co. of Glasgow v. Drew, $2 \mathrm{M}$ 'Q. 103; Ranger v. Great Western Railway Co., 5 Ho. Lords Cases, 72; Re British Bank, 28 L. J., Ch. 257 ; Conybeare v. New Brunswick and Canada Kailivay aud Land Co., 29 L. J., Ch. 435; ; 1 Giff. 319; 1 De G., F. \& J. 578 ; 31 I. J., Ch. 297 ; 9 Ho. Iords Cases, 711 ; Barry v. Croskey, 2 Johns. \& II. 1 ; Sivift v. Winterbotham, 42 I. J., Q. 13. 111 ; L. R., 8 Q. B. 244 ; Same v. Jewesbury, 43 L. J., Q. B. 513 Mackay v. Commercial Bank of New Brunswick, L. R., 5 Pr. C. $394 ; 43$ I. J., Pr. C. C. 31 ; Weir v. Bell, 47 L. J., C. I. 704 ; 3 Exc. Div. 238; Chapleo v. Brunswick Benefit Building Society, 49) L. J., C. I. 796 ; Thring on Joint Stock Co. 40 ; Story on Ag. s. 264. As to the masters liability to an action on the varranty, see ante, p. 282.

19 Mas. \& SEr. 
the fraud of his officer $(y)$, and an attorney has been compelled by the Court to pay costs occasioned by his clerk fraudulently simulating the seal of the Court upon a writ (z), Jervis, C. J., remarking, "There are many acts of a servant for which, though criminal, the master is civilly responsible by action."

Udell $\mathrm{v}$. Atherton.

And it would seem that it was not from any doubt of this principle, but as to the application of it to the facts of the particular case, that the Court were equally divided in the case of Udell $\mathrm{v}$. Atherton ( $a$ ), where the question was as to the liability of a timber merchant to an action for deceit, in consequence of his traveller having by fraud induced the plaintiff to purchase a log of mahogany. For in a subsequent case $(b)$ in the Ex-

Barvick v.

The English Joint-Stock

Bank. [*330] chequer Chamber, in which *the question was as to the liability of a banking company for the fraud of their manager, Willes, J., in delivering judgment, said,-

"If it was a fraud on the part of the manager, then arises the question whether the bank, the employers, are answerable for it? It is enough to say as to that, that we conceive we are in no respect overruling the opinion of two of the learned Barons, Martin and Bramwell, in the case of Udell v. Atherton, which was most relied on to establish the proposition that a principal is not answerable for the fraud of his agent. Upon looking to that case it seems very clear that the division of opinion - which took place in the Court of Exchequer arose, not so much on the question whether the principal is answerable for the act of his agent in the course of his business (for that question was settled as early as Lord Holt's time), as on the application of that principle to the peculiar facts of the case. The person whose act was relied on there as constituting a liability on the sellers was the defendant's agent, adopted by them under peculiar circumstances, and not being their general agent in their business as the manager of the bank

(y) Raphael v. Goodman, 8 A. \& E. 565. In Wright v. Child, 4 H. \& C. 529, it was held that the sheriff's officer was not the agent of the execution creditor.

(z) Dunkley v. Ferris, 11 C. B. 457.

(a) 30 L. J., Exc. 337; 7 H. \& N. 172.

(b) Barwick v. The English Joint-Stock Bank, 36 L. J., Exc. 147 ; L. R., 2 Exc. 259. See also Foster v. Green, 31 I. J., Exc. 158; The Thetis, 38 L. J., Adm. 42 ; Mackay v. Commercial Bank of New Brunswick, Weir v. Bell, and Chapleo v. Brunswick Benefit Building Society, suprn, note $(x)$; Swire v. Francis (1877), L. R., 3 App. Cas. $106 ; 47$ L. J., Pr. C. C. 18; Shaw v. Port Philip Colonial Gold Mining Co., 53 L. J., C. L. $369 ; 50$ L. T., N. S. 685. 
is here. But with respect to the question whether a principal is answerable for the acts of his agent done in the course of his master's business, and for the master's benefit, no sensible distinction can be dıawn between the case of frand and that of any other wrong, as to which the general rule is that the master is answerablo for such wrong if committed in the course of his service, and for his benefit. That is the principle which is acted on every day in running-down cases, and which has been applied also to direct trespasses to goods, as where owners of ships have been held liable for the acts of the masters abroad in improperly selling cargoes. It has been held applicable to actions of false imprisonment in cases where officers of a railway company intrusted with the execution of the bye-laws have wrongfully, but intending to act in the course of their duty, imprisoned persons supposed to have come within the bye-laws. It bas been acted on in the case of a person employed by the owner of boats to navigate boats and take fares for their use where a ferry has been infringed or such like wrong committed. In all these cases it may be said, as it was said here, that the master had not authorized the particular act. It is true he has not authorized the particular act, but he has put his agent in his place as to a class of acts, and he must be answerable for the manner in which the agent conducts himself in doing his business."

It has, however, been held in the House of Lords $(c)$, Servant that negligence of trustees of a corporation, in leaving enabled to the * corporate seal in the hands of the secre. [*331] tary, whereby he was enabled fraudulently to affix it to five powers of attorney for the transfer of stock belonging to the corporation, did not prevent them from saying land of Irethat the powers of attorney were forged, and suing the tces of Ecuns's bank for not transferring the stock on their subsequent commit fraud by master's negligence. application. In giving the opinion of the judges to the House of Lords in that case, Lord Wensleydale said,-

"If a man should lose his cheque-book, or neglect to lock the desk in which it is kept, and a servant or stranger should take it up, it is impossible, in our opin. ion, to contend that a banker paying his forged cheque would bo entitled to charge his customer with that payment. Would it be contended that, if he kept his

(c) Bank of Ireland v. Truste's of Ewans's Charities, 5 Ho. Lords Cas. 359. The secretary had been convicted of the forgery. See Re Swan, 30 L. J., C. P. 113 ; Swan v. Australasian Co. 31 L. J., Exe. 435; Guardians of Halifax Union v. Wheclwright, $44 \mathrm{~L}$. J., Exc. 121. 
goods so negligently that a servant took them and sold them, he must be considered as having concurred in the sale, and so be disentitled to sue for their conversion on a demand and refusal."

Telegraph It may be convenient to mention in this place that it elerk sending bas been held that a telegraph company are not liable wrong message.

Master's

liability extends to persons not immediately employed by himself, if they are his servants. to an action at the suit of the receiver of a wrong mes. sage for the mistake of their clerk in transmitting it, although the mistake caused serious loss to the plaintiff $(d)$.

The rule that a master is responsible for the acts of his servants applies, not only to domestic servants who may have the care of carriages, horses and other things in the employ of the family, but extends to other servants whom the master or owner selects and appoints to do any work or superintend any business, although such servants be not in the immediate employ or under the superintendence of the master. As, for instance, if a man is the owner of a ship, he himself appoints the master, and he desires the master to appoint and select the crew ; the crew thus become appointed by the owner, and are his servants for the management and gorernment of the ship, and if any damage happens through their default it is the same as if it happened through [*332] the immediate default of the owner *himself. The same principle prevails if the owner of a farm has it in his own hands, and does not personally interfere in the management, but appoints a bailiff or hind who hires other persons under him, all of them being paid out of the funds of the owner and selected by himself, or by a person specially deputed by him ; if any damage happen through their default the owner is answer. able, because their neglect or default is his, as they are appointed by and through him (e). So in the case of a mine, the owner employs a steward or manager to superintend the working of the mine, and to hire under-workmen, and he pays them on behalf of the owner. These under-workmen then become the immediate ser-

(d) Dixon v. Reuters' Telegraph Co., 46 L. J., C. L. 197, following Playfair v. United Kingdom Electric Co., 38 L. J., Q. B. 249 ; L. R., 4 Q. B. 706.

(e) See $R$. v. Hoseason, 14 East, 605. And see Foreman v. Mayor, \&c. of Canterbury, 40 L. J., Q. B. 138, where Blackburn, J., said, "It is probable that the negligence was not that of the surveyor, but of some subordinate appointed by the surveyor, but who still was a servant of the local board of health as much as the guard or porter on a railway is the servant of the company, although he is appointed by the manager or the secretary" See also Taylor v. Greenhalgh, 43 L. J., Q. B. 168. 
vants of the owner, and the owner is answerable for their default in doing any acts on account of their enuployer $(f)$.

Upon this principle it was that the defendant was Wayland $\mathbf{v}$. held liable in Wayland v. Elkins $(g)$ for damage done Elkins. to the plaintiff's house by a waggon being driven against it. The defendant and $D$. were carriers from London to Gosport, and by an arrangement between them D. horsed the waggon from London to Farnbam, and the defendant then conducted it from Farnham to Gosport. At the time the mischief happened the waggon was drawn by D.'s horses, and was driven by a servant of $D$., who had been hired by and received his wages from D., and with whose employment the defendant had no concern whatever, but *the wag- [*333] gon was the property of the defendant; and Gibbs, C. J., held that the action might be maintained " upon this principle; the waggon belongs to Elkins, and he receives the profits derived from the use of it. On what terms he engages with $D$. we do not know, but being jointly entitled with $D$., and since it is no objection that $\mathrm{D}$. had not been joined, the case is the same as if Elkins had received all the profits. Then since the waggon was to be drawn for the benefit of Elkins, the servant to all legal purposes was the servant of Elkins, although for inferior purposes, and as between the parties he may be considered as the servant of D."

T'o the same principle may also be referred the case of Randleson v. Murray ( $h$, though that case is some- Murray. times placed with a different class of cases, those, narnely, in which an owner of fixed property has been beld responsible for the acts of persons not strictly speaking his servants $(i)$. In that case the defendant who was a warehouseman at Liverpool, had employed a master porter to remove some barrels of flour from

(f) Per Littledale, J., in Laugher v. Pointer, 5 B. \& C. 5.54; and see per Mullett, J., in Btake v. Ferris, 1 Seld. (American) Rep. 58. In Stone v. Cartworight, 6 T. R. 411 , it was held that the agent of a colliery, belonging to an infant, who was appointed manager by the Court of Claneery, was not liable for damago caused by colliers lired by a bajlifl employed under him to superintend the works. The action shomld have been against the infant; and see $R$. v. Bleasilale, 2 Carr. \& K. 765, ante, p. 309.

(a) 1 Stark, 272; Holt, 227. See the reporter's note at the enil of the latter report.

(h) 11 A. \& F. 109 . It may well be doubted how fir this ease would bo supported now. See Murphy v. Caralli, 34, L. J., Exc. $14 ; 3$ H. \& C. 462.

(i) As to those cases, see Reedie v. London and North-Wcstern Railway Co., 4 Exe. 224, post, p. 354. 
his warehouse. The master porter used his own tackle, and brought and paid his own men, but employed a master carter to carry the barrels away, and the master carter brought his own carts and men, one of whom was the plaintiff. The master pcrter's tackle failed whilst being used by his men, a barrel fell and injured the plaintiff, and the defendant was held liable for the damage, on the ground that the men were on point of law his servants $(k)$.

Willett $\mathrm{v}$ It was upon this principle also that, where a firm of Boote. potters engaged workmen to work in their manufactory [*334] for *a year at daily wages, and on the same day engaged $R$. to work for them by piecework for the same period, and the work which the workmen had to do was in fact included in the piecework of R., and R. paid the workmen's wages out of the amount paid to him by the firm for piecework, it was held that the workmen were the servants of the tirm, so as to be liable to conviction for leaving their employment, under 4. Geo. 4 , c. $34{ }^{\prime}(l)$.

Wanstall $\mathbf{v}$.

And so where a corn-factor was absent from his shop, Pooley. and, during his absence, his sister managed his business ; she wanted to send out some corn to a customer, and for this purpose employed a person who occasionally worked for her brother, and who at the time of such employment was in a state of inebriety. This man, contrary to the practice of the corn-factor's shop, took out the corn on a small warehouse truck, which he negligently left on the road, whereby a person driving along in a chaise was injured : the corn-factor was held liable in an action at the suit of this person $(m)$.

Upoh this principle, in America, a railway company has been heid liable for the acts of a contractor for 3 portion of their line, where in blasting rocks, pursuant to the contract, a stone was thrown upon and injured the plaintiff $(n)$.

And so, where a tollgate keeper let the beam of the

(k) A. and S. sold to P. a box in the loft of their store, and $P$. promised to send his porter for it. He did so, and, by permission of $A$. and $S$., the porter went up into the loft, and proceeded to lower the box by means of tackle belonging to $A$. and $\mathrm{S}$. The box fell and injured the plaintiff: it was held in America that A. and S. were not liable. Stevens v. Armstrong, 2 Seld. 435 (1852).

(l) Willett v. Boote, 30 L. J., M. C. 6.

(m) Wanstall v. Pooley, Q. B. M. T. 1841,6 Cl. \& F. 910, n.

(n) Stone v. Oheshire Railroad Corporation, 19 New Hampsh. Rep. 427; Lowell v. Boston and Lowell Railroad Corporation, 23 Pick. 24. 
gate down upon and injured the plaintiff, who was passing, the company were held liable, as it was dono in the course of his employment $(o)$.

And if a servant is acting in the execution of his master's orders, and by his negligence causes injury to a third party, the master will be responsible, although the act of servant servant's act was not necessary for the proper performance of his duty to his master, or was even contrary to his master's orders. Upon this subject nice questions often arise as * to how far the servant was [*335] ter's orders. acting in his master's service at the time the injury was done: though the law is clear, it is sometimes difficult of application to particular cases. It is well illustrated by the following cases, in which the master was held liable.

In an action $(p)$ for the negligent driving of the defendant's coachman, whe eby the plaintiff's carriage striking was upset : it appeared that the accident arose from another perthe defendant's coachman striking the plaintiff's horses son's horses with his whip, in consequence of which they moved whilst forward, and the chariot was overturned. At the time master. when the horses were struck the two carriages were en- Croft $\mathrm{v}$. tangled. The defendant was held liable for the dam- Alison. age caused by his servant's act, although wanton, as it was done in pursuance of his employment. And, per Curiam: "The distinction is this: if a servant driv. ing a carriage, in order to effect some purpose of his own, wantonly strike the horses of another person, and produce the accident, the master will not be liable. But if, in order to perform his master's orders, he strikes, but injudiciously, and in order to extricate himself from a difficulty, that will be negligent and careless conduct, for which the master will be liable, being an act done in pursuance of the servant's employment."

So, if a coachman were driving his master, and were ordered not to drive so fast, but he nevertheless con- driving too tinued to do so, and an accident occurred in conse- tisst. quence, the master would be responsible for the injury ; for in that case the coachman would still be driving for his master, though driving badly $(q)$.

(o) Noblesville and Engletomn Gravel Roat Co., v. Gause, 40 Amer. Rep. 224; and see note by the reporter, p. 2:26.

(p) Croft v. Alison, 4 B. \& Ald. 590. In Welsh v. Lawrence, 2 Chit. 262, evidence that the chainstay of a cart broke, in consequence of which the horse ran away and plaintifl"s loorse was injured, was held to support an aetion for negligent driving by defendant's servant, as the master is bound to have good tackle.

(I) 7 I. \& G. 566 ; see Sleth v. Witwon, 9 C. \& I. 612. 
Servant making detour with master's cart.

Joel v. Morison.

Sleath $\nabla$. Wilson.
So a master was held $(r)$ liable for damage caused by [*336] *the negligent driving of his cart in the city by his servant, although it was proved that the cart ought not, in carrying out his orders, to have been in the city at all ; and Lord Wensleydale said,-

"If the servant, being on his master's business, took a detour to call upon a friend, the master will be responsible. If you think the servant lent the cart to a person who was driving without the defendant's knowledge, he will not be responsible. Or if you think that the young man who was driving took the cart surreptitiously, and was not at the time employed on his master's business, the defendant will not be liable. The master is only liable where the servant is acting in the course of his employment. If he was going out of his way against his master's implied commands, when driving on his master's business, he will make his master liable; but if he was going on a frolic of his own, without being at all on his master's business, the master will not be liable."

Again, a master was held $(s)$ liable for damages caused by the negligent driving of his servant, who, after having set his master down, drove round to deliver a parcel of his own, and did not drive directly where he was ordered to go, Erskine, J., saying,-

"Evidence has been given that the master directed the servant to drive to the Red Lion, in Castle Street, but that the servant improperly drove to the Old Street Road to deliver a parcel of his own ; and the point has been put to the Court that, inasmuch as it is clear that the servant was not at that time engaged in his master's business, this action cannut be maintained. But I am of opinion that this action may be maintained. I think the law has been most properly laid down by Mr. Baron Parke in the case which has been cited $(t)$. It is quite clear that if a servant without his master's knowledge

(r) Joel v. Morison, 6 C. \& P. 501. And see Booth v. Mister, 7 C. \& P. 66 , where a master was held liable for damage caused by his cart, which was intrusted to his servant, but which another person, a friend of the sevent, was driving when the accident happened; Lord Abinger saying he thought that as the defendant's servant was in the cart, the reins being held by another man made no difference. See also Wheatley v. Patrick, 2 M. \& W. 650. The amount of deviation is a question of degree, which is one for the jury. Whitman v. Pcarson, 37 L. J., C. P. 156; 3 L. R., C. P. 422 .

(s) Sleath v. Wilson, 9 C. \& P. 607 ; S. C. nomine Heith v. Wilson, 2 M. \& Rob. 181,

(t) Joel v. Morison, ubi supra. 
takes his master's carriage out of the coach house, and with it commits an injury, the master is not answerable, and on this ground, that the master has not intrusted his servant with the carriage. But whenever the mas. ter has intrusted the servant with the control of the carriage it is no answer that the servant acted improperly in the manugement of it" $(u)$.

*This liability of the master for the act of his [*337] Limpus $\mathrm{v}$. servant when driving for him is forcibly illustrated by General a case $(x)$ in which an ounnibus company were held Omuibus (o. liable for the acts of their driver in "nursing" a rival omnibus, whereby the omnibus of the defendants ran against the horses and omnibus of the plaintiff and overturned it, although it was a direct contravention of the printed regulations of the company to race with or obstruct other omnibuses or hinder or annoy the driver or conductor thereof in his business, whether that omnibus be one belonging to the company or otherwise. And the Exchequer Chamber upheld the direction of Martin, B., to the jury, that if the defendants' driver being irritated acted carelessly, recklessly, wan. tonly or improperly, but in the course of his employ. ment, and in doing that which he believed to be for the interests of the defendants, then the defendants were responsible for the acts of their servant : that the instructions given by the defendants to the driver not to obstruct other omnibuses, if he did not pursue them, were immaterial as to the question of the master's liability, but if the true character of the driver's act was that it was an act of his own, and in order to effect a purpose of his own, then the defendants were not responsible.

The defendants sent a barge under the management

(u) But Cockburn, C. J., did not adopt this. See Story v. Ashton, post, p. 241. So a landlord is liable for any irregularity conimittel by a broker whom he has authorized to distrain, if the liroker has distrained the right goods, although the irregnlarity becommitted without the knowledge or sanction of the landlord, Haseler v. Lemoyne, $2 \Varangle$ L. J., C. P. 103. But not if he distrain the wrong goods, Lewis v. Reed, $13 \mathrm{MI}$. \& W. 834 ; or things not distrainable, Freeman v. Rosher, 13 Q. B. 780.

(x) Limpus v. General Omnibus Co., 32 L. J., Exe. 34 ; 1 H. \& C. 526. See also Whitman v. Peirson, ante, p. 336, note $(r)$, where in contractor was held liable for the negligence of a servant to twom he had intrusted a horse and cart, but who went home to dinner and left them ontside, when the horse ran away and did damage. And see Bayley v. Manchester, shefficld and Lineolnshire Railuay Co., 41 I. J., C. P. 278 ; 42 L. J., C. I. 78; I. R., 8 C. P. 148, 472; Ward v. General Omnibus Co., 42 L. J., C. P'. 265. 
Page v. of a lighterman to a wharf to beloaded; he was unable Defrics. $\quad$ to get up to the wharf in consequence of the plaintiff's barge lying in the way without any one in charge of it. The foreman of the wharf told him to shove the plain[*338] tiff's *barge away as it had no business there, and to bring his own alongside. He moved the plain. tiff's barge and made it fast to a pile in the river. When the tide went down the plaintiff's barge settled upon a projection in the bed of the river and was in. jurod $(y)$. It was held, overruling Lamb v. Palk $(z)$, that the defendants were liable, as the lighterman was acting within the scope of his employment as their servant.

Patten v. Where the general manager of the defendant, a Rea. horse dealer, had a horse and gig of his own, which he used for the defendant's business as well as his own, and was allowed to keep them on defendant's premises at his expense; and on one occasion the manager, on putting the horse into the gig, told defendant he was going to $\mathrm{S}$. to collect a debt for him and afterwards to see his own doctor, and before be got to $\mathrm{S}$. he ran the gig against and killed the plaintiff's horse ; it was held that there was abundant evidence to make the defend. ant responsible, although he had not expressly requested the manager to use the horse and gig on that occasion. And it was also beld that the proper question to leave to the jury is, whether at the time of the act com * plained of, the servant was driving on his master's business and with his authority $(a)$.

Effect of

And it has been held that the exception in a bill of exception in lading of "accidents or damage of the seas, rivers and bill of lading. steam navigation, of whatever nature or kind soever," does not protect the shipowner from liability for dam. age arising from a collision caused by the negligence of the crew $(b)$.

Master liable And a master has been held liable for damage done though injury immediately caused by stranger. Illidge $\mathrm{v}$. Goodwin. to a third person which would not have happened but for the negligence of the defendant's servant, although the immediate cause of the damage was a stranger.

[*339] *Thus, a master scavenger was held liable for injury caused by the negligence of his servant in leaving his cart and horse unattended in the street, although

(y) Page v. Defries, 7 Best \& S. 137.

(z) 9 C. \& P. 629, post, 340.

(a) Patten v. Rea, 2 C. B., N. S. $606 ; 26$ L. J., C. P. 235.

(b) Lloyd v. General Iron Sereno Collier Co., 33 L. J., Exc. 269 ; Czech v. General Steam Navigation Co., 37 L. J., C. P. 3 ; et cas. ib. cit. 
the immediate cause of the injury was a passer-by who struck the horse, which backed the cart into the plaintiff's shop-window (c). In 'that case it was a misfeasance to leave the horse unattended $(d)$.

Moreover a master is, generally speaking, liable for Extent of all the consequences arising from the misconduct of his master's servant, where an injury arises to a third person from liability. such misconduct: though Pollock, C. B., in one case said he entertained considerable doubt whether a man is responsible for all the possible consequences that may, under any circumstances, arise in respect of mischief which by no possibility could he have foreseen, and which no reasonable person, under any circum. stances, could be calle 1 upon to have anticipated $(e)$.

A master, however, is not responsible for the wrong- Master not ful act of his servant unless that act be done in the responsible execution of the authority given by his master $(f)$. for servant's Beyond the scope of his employment he is as much a act beyond stranger to his master as any third person, and there authority. fore, his act cannot be regarded as the act of his master $(g)$.

Upon this principle it was held $(h)$, that a master was not liable for the act of his housemaid in light- M'Kenzie $\mathbf{v}$. . ing furze and straw with a view to clean a chimney which smoked, whereby the house was burnt down, as sho was merely employed to light the fire, and others were employed to clean the chimney, and, moreover, she had been expressly *cautioned not to at- [*340] tempt to clean the chimney in that way; the court considering that in acting as she did she was acting beyond the scope of her employment, which was merely to light the fire.

Again $(i)$, a master was held not liable for an unlawful act committed by his servant, who was authorized Myons v. to distrain cattle damage feasant on his land, in driving the plaintiff's horses, which were on the highway, on to

(c) Illidge v. Goodwin, 5 C. \& P. 190. And see Clark v. Chambers, 47 L. J., C. J. 427 ; 3 Q. B. Div. 327.

(d) See :3 E. \& 13. 153. See also and consider Harrison v. Great Northern Railway Co., 33 L. J., Exc. 266.

(c) Grcentund v. Chaplin, 19 L. J., Exe. 293; see Rigby v. Hexitt, ib. 291.

(f) Milllleton v. Fowler, 1 Salk. $2 \times 2$; Croft v. Allison, 4 B. \& Ald. $590 ;$ Lamb v. Palk, 9 C. \& P. 629; M'Manus v. Cricketl, 1 Eust, 106; see Garth v. Honard, 8 Bing. 451, ante, p. 288.

(g) See ante. pp. 275, 288, 299, 329; Wilson v. Rankin, $34 \mathrm{I}$. J., Q. B. 62; M'Gowan v. Dyer. L. R., \& Q. B. 141.

(h) N'Kenzie v. M'Leod, 10 Bing. 385.

(i) Lyons v. Martin, 8 A. \& E. 512. See Limpus v. General Omnibus Co., ante, p. 337. 
his master's land and then dictraining them, as the doing so was not within the scope of his authority; and Patteson, J., said, "A master is liable where his servant causes injury by doing a lawful act negligently, but not where he wilfully does an illegal one."

Goodman r. So if a man sends his servant on an errand without Kennell. providing him with a horse and he meets a friend who has one, who permits him to ride, and an injury happens in consequence, the master is not responsible for that act. If it were so, every master might be ruined by acts done by his servant without his knowledge or authority $(k)$.

Lamb v. Palk. And where ( $l$ ) the plaintiff's van, which had brought mineral water to the back entrance of the plaintiff's premises, was unloading, and the plaintiff's gig standing behind it, when the defendant's coachman, with a carriage and pair of horses, came up from the mews into the street, and the carriage, being unable to pass the van for want of room, was obstructed for tive minutes, when the defendant's coachman got off his box and took hold of the head of the horse which was in the van, in order to remove the van, this caused the van to move, and a case of mineral water that a person was taking from the van fell down on the shafts of the plaintiff's gig, and broke them: it was held by Gurney, B., after consulting other judges, that the defendant was not responsible for the damage done, as the coachman was not acting in the employ of his mistress at the time the matter occurred.

Mitchell v. [*341] *So where the defendant's carman, having finCrassweller. ished the business of the day, returned to their shop in Welbeck Street with their horse and cart, and got the key of the stable, which was close by, but instead of going there at once and putting up the horse as it was his duty to do, he, without his master's knowledge or consent, drove a fellow.workman to Euston Square, and in his way back ran over and injured the plaintiff; it was held, that inasmuch as the carman was not at the time of the accident engaged in his master's business, they were not respousible for the consequences of his unauthorized act $(m)$. And Maule, J., said, "The mas-

(k) Goodman v. Kennell, 3 C. \& P. 167.

(t) Lamb v. Lady Elizabeth Palk, 9 C. \& P. 629. But see as to this case Page v. Defries, 7 Best \& S. 137, ante, p. 337.

( $m$ ) Mitchell v. Crassweller, 13 C. B. 237 . It was held in this case, that under " not guilty" the defendants might show that the driver was not at the time of the accident acting as their servant. 
ter is liable, even though the servant in the performance of his duty, is guilty of a deviation or a failure to perform it, in the strictest and most convenient manner. But where the servant, instead of doing that which he is employed to do, does something which be is not employed to do at all, the master cannot be said to do it by his servant, and therefore is not responsible for the negligence of the servant in doing it."

So where a wine-merchant, carrying on business in V. Storey v. Street, Minories, sent his clerk in a cart to deliver wine Ashton. at Blackheath, and it was the carman's duty to bring back empty bottles to V. Street and then to put up the horse and cart; but on the way back the clerk asked the carman to drive him to his house in the City Road, and asked him to go elsewhere, and when they had proceeded about two miles out of the way, the plaintiff was knocked down by the cart and seriously injured, the defendant was held not liable $(n)$. And Cockburn, C. J., said,-

"I think the law"as laid down in Mitchell v. Crassweller presents us with a true view of the case. I cannot adopt the proposition of Erskine, J., in * Sleath $\mathrm{v}$. [*342] Wilson (o), that whenever the master has intrusted his servant with the control of the carriage it is no answer that the servant acted improperly in the management of it. I think that a servant can only be said to be acting in the employment of his master, so long as he is doing some act with his master's assent. I think that if a driver while acting in his master's business were to make a slight deviation in order to carry some business of his own into effect, in such a case the master might be liable, and that the question would be one of degree as regards the extent of the deviation. But this is not the present case. Here the man starts upon an entirely independent journey which has nothing to do with that which he undertook on behalf of his employer. While returning home by way of King William Street he starts on a journey to the City Road, and is two miles out of tho. way when the accident happens. In Mitchell v. Crasueller, the driver after returning to his master's

(n) Storey v. Ashton, 38 L. J., Q. B. 223; L. R., 4 Q. B. 476. See Rayner v. Mitchell, 2 C. P. Div. 35\%; and see Burns v. Poulson, 42 I. J., C. P. 302 ; L. R., 8 C. P. 563 , where it was held to be a question for the jury whether or not in the particular case the servant was acting within the scope of his employment. See also Venables v. Smith, 46 L. J., C. L. 470 ; 2 Q. B. Div. 279; Cormick v. Digby, 9 Ir. C. L. R. 5̃5\%.

(o) Ante, p. 336 . 
house started upon an entirely independent journey. Here the case is not quite so strong, but in deviating as he did the arriver did in fact start upon an independent journey. I think that it would be a strange thing to hold that in such a case the master is responsible."Mellor, J., and Lush, J., concurred.

Stevens v.

Woodward.

So it has been held that a solicitor was not liable for the negligence of a clerk who after his master had gone for the day went into his master's private room and used his lavatory, leaving the tap flowing, whereby the stockin-trade of the plaintiff who occupied the room below was injured $(p)$.

Poulton v.

London and

And it was upon the principle that the servant was

South Western Railway Co. acting beyond the scope of his authority that the railway company were held not liable to an action for false imprisonment in consequence of their officer having given the plaintiff into custody for travelling without a ticket for certain horses, as the company could only au. thorize giving a passenger into custody for travelling withont a ticket for himself $(q)$.

Bolingbrokev. And upon the same principle it was held that the proLocal Board of Health of Swindon. prietors of a sewage farm, of which B. was manager, [*343] were *not liable for a trespass upon the land of an adjoining owner committed by $B$. which he had no express authority from the defendants to commit, although it was done to improve the drainage from the farm and benefit the neighborhood $(r)$

The principle upon which these cases were decided is further illustrated by the following American cases :

Wright $\mathrm{v}$. The defendant's servant was driving his waggon and Wilcox. team, and the plaintiff's son (a boy on his way to school), asked for a ride. The servant said he might when they got up the hill he was then ascending. When the bill was ascended, the lad took hold of the side of the waggon, between the front and hind wheels. The driver did not stop. He was cautioned by a bystander, that if he did not stop he would kill the boy. He looked behind him. The horses were walking, and the driver

( p) Stevens v. Woodxard, 50 L. J., C. L. 231 ; 6 Q. B. Div. 318. But see Milner v. Great Northern Railway Co., 50 L. T., N. S. 367.

(q) Poulton v. London and South Western Railway Co., 8 Best \& S. 616 ; 36 L. J., Q. B. 294 . See also Edwards v. London and N.rth Western Railway Co., 39 L. J., C. P. 241 ; L. R., 5 C. P. 445; Walker v. South Eastern Railway Co., 39 L. J., C. P. 346 ; Allen v. London and South Western Railway Co., 40 L. J., Q. B. 55 ; L. R., 6 Q. B. 65 ; Bank of New South Wales v. Ouston, L. R., 4 App. Cas. 270, 286.

$(r)$ Bolingbroke v. Local Board of Health of Swindon, 43 L. J., C. P. 287 ; L. R., 9 C. P. 575. 
seeing the plaintiff's son and other boys attempting to get on the waggon, cracked his whip, and put the horses into a trot. The plaintiff's son fell, and the hind wheel went over and injured him; it was held, that as the driver whipped the horses, intending to throw the boy off, this was a wrong on the part of the servant, for which the master was not liable, any more than he would have been for an assault committed by the servant $(s)$.

Upon similar principles, where a man deposited with Foster $v$. a bank for safe custody a cask containing a quantity of Essex Bank. gold doubloons, some of which were fraudulently abstracted by the cashier and chief clerk, it was held that the bank was not responsible for the fraud or felony of the cashier and clerk; as, when they abstracted the gold from the cask, they were not acting within the scope of their employment, and it was said that the bank was no more answerable for their act than it would have been if they had stolen the *pocket-book [*344] of any person who might have laid it upon the desk while he was transacting some business at the bank $(t)$.

So, if a master of a ship sign a bill of lading for Grant $\mathrm{v}$. goods which have never been shipped $(u)$; or a wharf- Norway. inger's servant fraudulently sign a receipt, purporting to be an acknowledgment that certain goods have been delivered at his master's wharf to be shipped, no such goods having in fact been delivered $(x)$; neither the Coleman $\mathrm{v}$. wharfinger in one case, nor the shipowner in the other, Riches. will be bound by such act of their servant. In neither case was there any actual authority to do the act complained of, nor did the facts warrant the inference of an implied authority.

And if one employ another to do an act which may when master be done in a lawful manner, but the latter in doing it not liable for commit a public nuisance, the employer is not responsi- illegal act of ble $(y)$. Under ordinary circumstances the authority servant

(8) Wright v. Wilcox, 19 Tendell's Rep. 343, following M'Manus v. Crickett. See Hoffman v. New York Centrat, d'c. Railtroad Co., 41 Amer. Rep. 337, and reporter's note, p. 340. In that ease the conductor kieked off the car a boy who was stcaling a ride, and the company were held liable.

(t) Foster v. Essex Bank, 17 Mass. Rep. 479. See Giblin v. M'Mullen, 38 L. J., Pr. C. C. 25 L. R., 2 Pr. C. C. 317 ; post, p. 359. 330.

(u) Grant v. Norway, 10 C. B. 665 ; Hubbersty v. Ward, 8 Exc.

(x) Coleman v. Riches, 16 C. B. 104.

(y) Pcachy v. Rowland, 13 C. B. 182 ; 22 L. J., C. P. 81 , post, p. 356 . 
Malicious prosecution.

Nor if person injured omit to use ordinary care.
Bridge v.

Grand Junction Railway Co. of the agent is limited to that which is lawful. If, in seeking to carry out the purpose of his employment, he oversteps the law, he outruns his authority and his principal will not be bound by what he does $(z)$.

If a servant maliciously, and without reasonable and probable cause, indict another for stealing his master's goods, the master would not be liable to an action for malicious prosecution $(a)$.

Nor is a master responsible for injury caused by his servant's negligence to a person who might, by the exercise of ordinary care, have avoided the consequences of the servant's negligence (b). It is not, however, suffi[*345] cient, in *order to exempt a master from responsibility, to show that the party injured did, by bis own act, contribute to the injury ; but it must be shown that he did not use ordinary care to avoid the consequences of the servant's negligence (c). Whether or not the party injured did use ordinary care would be a question proper for a jury to decide, taking into consideration all the circumstances of the case $(d)$. But if he did not, he wonld have no right to recover compensation from the defendant for what, properly speaking, was the effect of his oun want of caution.

Therefore, in an action (e) by a passenger in the train of one railway company against another company, with a train belonging to which a collision had taken place, whereby the plaintiff . was injured, a plea by the defendants, that the injury was caused in part by the

(z) Per Cockburn, C. J., in Wilson v. Rankin, 34 L. J., Q. B. 67 ; affirmed 35 L. J., Q. B. 87 . See also Earle v. Rowcroft, 8 East, 133, 139.

(a) Stevens $\vee$. Midland Railway Co., 10 Exc. 352 ; 23 L. J., Exc. 328. See, as to this case, Edwards v. Midland Railway Co., L. R., 6 Q. B. Div. 287 ; see also cas. cit. ante, p. 342 , note $(q)$.

(b) So, e converso, a master cannot recover against a third person for damage which has arisen through his own servant's negligence, Pardington v. South Wales Railway Co., 26 L. J. Exc. 165; Ellis v. South Western Railway Ca.. 2 H. \& N. 424; 26 L. J., Exc. 349. In Gough v. Bryan, 2 M. \& W. 770 , a plea that the damage complained of was caused by the negligence of the plaintiff's servant, was held bad as amounting to the general issue. See 11 M. \& W. 313 . But see also Caswell v. Worth, 5 E. \& B. 849 , where a plea, that the plaintiff wilfully set in motion the machinery for an injury caused by which the action was brought, was held good; but the objection that it amounted to the general issue does not appear to have been taken.

(c) Butterfield v. Forrester, 11 East, 60 ; and see Clayards v. Dethick, 12 Q. B. 439.

(d) Ellis v. South Western Raihvay Co., ubi supra.

(e) Bridge v. The Grand Junction Railway Co., 3 M. \& W. 244; acc. in America, Center v. Finney, 17 Barbour's Rep. 95. 
negligence of the persons who had the care of the train in which the plaintiff was riding, was held bad, as it was consistent with all the facts stated in it that the plaintiff, or those who had the chargo of the train in which ho was riding, could not by tue exercise of crdinary caro have avoided the consequences of the defendant's negligence. And Lord. Wensleydale said,-

"The rule of law is laid down with perfect correctness in the case of Butterfield v. Forrester $(f)$; and that rule is, that although there may have been negligence on the part of the plaintiff, yet, unless ho might by the exercise of 'ordinary care bave avoided the consequences of the defendant's negligence, ho is entitled to recover; if by ordinary care he might have avoided them, he is the author of his own wrong." .

*Tho samo principle was again acted upon in [*346] case $(g)$ in which a master was held liable for the Davics v. negligence of his waggoner, who had driven over and killed the plaintiff's ass, which was wrongfully left fettered in the public road; for although the plaintiff was negligent in leaving his donkoy there, yet the donkey's being there was not the immediate causo of the injury.

And in the case of Tuff v. Warman $(h)_{\star}$ in the Ex- Tutf $\mathbf{v}$. chequer Chamber, Wightman, J., in delivoring judg-Warman. mont, said,-

"The proper question for the jury in cases of this kind is, whether the damage was oceasioned entirely by the negligence or improper conduct of the defendant, or whether the plaintiff himself so far contributed to the misfortune by his own negligence or want of ordinary and common care and caution, that but for such negligenco or want of ordinary care and caution on his part the misfortune would not have happened. In the first case the plaintiff would be entitlod to recover; in the latter, not, as but for his own misconduct the misfortuno would not have happened. Mero negligence,

(f) Ubi supra.

g) Darics v. Mann, 10 M. \& W. 546 ; see also Morrison v. The General Steum Nacigation Co., 8 Exe. 730 ; Dowell v. Same Co., 5 E. \& B. 195 ; 26 L. J., Q. B. 69.

(h) 27 L. J., C. P. 322 ; S. C. in the Court below, 26 I. J., C. P. 253; 2 C. B., N. S. 740 ; and see Senior v. Ward, 2S L. J., Q. B. 139 ; Scott v. Dublin and Wicklow Railway Co., $11 \mathrm{Ir}$. C. I. I. 377 ; Vaughan v. Cork and Youghal Railway Co., 12 Ir. C. L. R. 297; Walton v. London, Brighton and South Coast Tailuray Co., 1 Harr. \& Ruth. 424; Radley v. London and North Western Railivay Co., 43 L. J., Exc. 73 ; L. IR., 9 Exe. 71 ; 44 L. J., Exc. 73; I. R., 10 Exc. 100 ; 46 L. J., Exc. 573 ; L. R., 1 App. C. 754 ; Dublin, Wicklow, \&e. Railway Co. v. Slattcry, L. R., 3 App. C. 1155.

20 MAS. \& SER. 
or want of ordinary care or caution, would not, however, have disentitled him to recover unless it was such that but for the negligence and want of ordinary care and caution the misfortune would not have happened, or if the defendant might by the exercise of caution on his part have avoided the consequences of the neglect or carelessness of the plaintiff. This a ppears to be the result deducible from the opinion of the judges in the cases of Butterfield v. Forrester, Bridge v. The Grand Junction Railway Co., Davies v. Mann, and Dowell v. T'he General Steam Navigation Co."

Passenger in public conveyance identified with driver.

Thorogood v. Bryan.

And this principle, of holding a master not responsible for damage done by his servant to a person who might by the exercise of ordinary care have avoided the damage, has been extended so far as to hold that a passenger in a public conveyance could not recover damages for an injury sustained in consequence of the neg[*347] ligence of the driver of *another cunveyance against the owner of that conveyance, if the persons having the conduct of the conveyance in which he is a passenger could by the exercise of ordinary and reasonable care have avoided those consequences; but that his remedy in such case is against the person conveying him, or that person's servants: thus identifying to a certain extent the passenger and the driver of a public conveyance. It may, indeed, be doubted $(i)$ how far the case in which this decision was arrived at will be supported; but even if it is supported, the consequences will not be very important in a practical point of view, as it only goes to the question who is the proper party to be responsible in each case; that the party injured has his remedy against some one still remains perfoctly clear.

The case above alluded to is Thorrogood ₹. Bryan (k), which was an action against an omnibus proprietor to recover damages for the negligence of her servant, who

(i) See 1 Smith's L. C. 266 ; Rigby v. Hewitt, 5 Exc. $240 ; 19$ L. J, Exc. 291 ; Greenland v. Chaplin, 5 Exc. 243 ; 19. L. J. Exc. 293. It is observable that, in the case alluded to in the text (Thorogood v. Bryan), none of the cases were cited in which a master has becn held not responsible for the act of one whom he did not select to discharge the duty he was discharging at the time an accident happened, such as Quarman v. Burnett, Rapson v. Cubitt, \&c. ; see these cases, post.

(k) 8 C. B. 115. See acc. Broun v. New York Central Railway Co., 31 Barb. 385. But see Lannen v. Albany Gas Light Co., 46 Barb., 270. As to how far a shipowner is identified with pilot. see Thompson v. North Eastern Railway Co., 30 L. J., Q. B. 67 ; 2 Best \& S. 106. The owner of cargo is not in eâdem comditiont as a passenger, The Milan, 31 L. J., Pr. Mat. \& Adm. 105. 
had caused the death of the plaintiff's husband $(l)$ by knocking him down and driving over him just as he had alighted from another omnibus. The deceased was a passenger in an omnibus belonging to B., and the defendant was owner of another rival omnibus running on the same line of road. Both vehicles had started together, and frequently passed each other, as either stopped to take up or set down a passenger. Deceased, wishing to alight, did not wait for the omnibus to draw up at the kerb, but got out whilst it was in motion, and far enough from the path to allow another carriage to pass on the near side. The defendant's *omnibus [*348] coming up at the moment, deceased was unable to get out of the way, was knocked down and run over, and shortly after died of the injuries so sustained. But it was held by the Court of Common Pleas that the defendant was not liable to make compensation for the consequencies of her servant's negligence, as there appeared to have been negligence on the part of the driver of the omnibus in which the deceased was a passenger ; and, for the purposes of that action, the passenger must be considered as identified with the person having the management of the omnibus he was con veyed by. Upon this case, however, it may be observed that the passenger, at the time the accident happened, had left his omnibus ; and, moreover, that he had left it under circumstances which showed a want of ordinary care on his own part $(m)$. This would seem to be sufficient ground for supporting the decision in that case, even should the juagment, identifying the driver with the passenger, be considered erroneous $(n)$.

The case of Thorogood v. Bryan has, however, been Armstrong v. supported and followed in a case in which a travelling Laneashire inspector of the London and North Western Railway and Yorkshire Company, who was travelling in a carriage of a train of that company upon the defendants' line with a free pass, was injured through a collision causod by the contributory negligence of the driver of the London and North Western Railway train (o).

Where the plaintiff, a child of five years old, was

(l) The action was brought under the statute 9 \& 10 Vict. e. 93.

(m) See the case put by Coleridge, J., in Woolf v. Beard, $8 \mathrm{C}$. \& P. 374,375 .

(n) See remarks on this case, and subsequent cases, in which it was diseussed in Smith's Ieading Calses, th edit., p. 400.

(o) Armstrong v. Laneashire and Yorkshire Railway Co., 44 I. J., Exc. 89 ; L. R., 10 Exc. 47 ; 33 L. T. :2:8. See also Spright v. Tedcaslle, L. R., 6 App. Cas 223 ; The Energy, L. R., 3 Adm. \& Ecc. Rep. 48. 
Child identi- under the care of his grandmother, who purchased fied with tickets for both from A. to B., on the defendants' railpersontaking way, and while crossing the line at $A$. to be ready for charge of it. their train, they were both knocked down and injured Waite $\mathbf{v}$.

North-Eastern [*349] by another train; *the accident wás partly owing Railway Co. to the defendants' negligence, but there was also such negligence on tho part of tho grandmother as would have prevented her from recovering against the defendants; it was held by the Court of Queen's Bench, and affirmed by the Exchequer Chamber, that there was a complete identification of the plaiutiff with the grandmother, and that by reason of her negligence the action in his name could not be maintained $(p)$.

Where person injured is incapable of taking care.

Lynch v. Nurdin.

Who is the master of the servant doing the damage?
But where the party injured was a child incapablo of taking care of itself, and was not under the care of any one who was capable o: taking care of it, a master has been held liable for injury cansed to the child by the negligence of his servant, aithough the child itself, by its own act brought about the accident. Thus, where $(q)$ a carman, who had charge of a cart, went into a house and left tho horse and cart standing at the door, without any one to take care of them, for about halfan-hour, and during his absence, a child, under seven years of age, got upon it, and another boy led the horse on, whereby the child was thrown down, run over, and his leg broken; it was held that the carman's master was liable for the damages sustained by tho child, although the child was a trespasser and contributed to the mischief by his own act; the jury having found that he merely indulged the natural instinct of a child in amusing himself with the empty cart and deserted horse.

The difficulty, however, which arises in cases of this sort is not so much in assertaining the law as in applying it to the circumstances of each particular case, and ascertaining who is to be regarded as the master in each [*350] case, for it is *obvious that the liability arising from the relationship of master and servant cannot oxist unless the relationship itself exist $(r)$. In all cases,

(p) Waite v. North Eastern Railway Co., 27 L. J., Q. B. 417; 28 L. J., Q. B. 258.

(q) Lynch v. Nurdin, 1 Q. B. 29. But see Lygo v. Newbold, 9 Exc. 302. It was held in Abbott v. M'Fie, Hughes v. Same, $33 \mathrm{~L}$. J., Exc. 177 ; 2 H. \& C. 744, that a child may be guilty of contributory negligence so as to exempt the defendant from liability. See also Mangan v. Atherton, 35 L. J., Eve. $161 ; 4$ H. \& C. 385 ; Lay v. Midland Raihicay Co., 34 L. T., N. S. 30.

$(r)$ In Stables v. Eley, 1 C. \& P. 614, a person who had formerly been in partnership with another man was held liablc to an 
therefore, of injury by the act of a servant, it is most important to ascertain in the tirst place whose servant the person was who caused the injury. And this is an inquiry of greater difficulty than would at first be imagined, and frequently involves questions oì considerable nicety. For instance, in the ordinary case of a person hiring a Coachman, carriage, horses and driver $(s)$, on a job, although it is with carriage now settled that, if in such a case any accident or or horses on injury happen to a third person through the careless- job, not ness or misconduct of the driver, the hirer is not, in servant of general $(t)$, liable to make compensation for such injury, yet thero was formerly considerable doubt upon the subject, and some of the judges expressed opinions that the hirer was responsible, as being the dominus pro tempore $(u)$; and he certainly is in some respects, the master, for he may order the carriage to be driven where ho pleases. The question was argued at great length in Laugher v. Pointer $(v)$, where the owner of a carriage hired for the *day of a livery-stable [*351] keeper, a pair of horses and a driver, through whose negligence an injury was done to the plaintiff's horse; and the question was, whether the owner of the carriage, or the livery-stable keoper who supplied tho horses and driver, was liable to make compensation for

action on the case tor injury caused by the negligent driving of the carter of that other, after the dissolution of the partnership, as his name was on the cart that did the damage. And in $M^{\prime}$ Kone v. Wood, 5 C. \& P. 1, a man was held liable to an action for keeping a mischievous, dog when the $\operatorname{dog}$ belongel to a person who had formerly been his servant, and had been seen about his premises. In Hibbs r. Ross, 35 L. J., Q. B. 193 ; 7 Best \& S. 665, it was held that the registered owner of a ship was liable for the negligence of a shipkeeper in charge of a ship lying in dock.

(s) If the horses are driven by the servant of the hirer he wonld lie liable, Sammell r. Wright, 5 Esp. 263. As to how far a cabdriver is the servant of the proprietor, see Venables v. Smith, 46 L. J., C. I. $470 ; 2$ Q. I3. D. 279, and other cases cit. ante, 327, note $(m)$.

( $t$ ) The hirer may make himself liable by ordering, sanctioning, or adopting the act of the driver, M Langhlin v. Prior, $4 \mathrm{MI}$. \& G. 48, post, p. 375; Burgess v. Gray, 1 C. B. 578, post, p. 358.

(u) See per Heath, J., in Bush v. Steinman, 1 B. \& 1.409. The owner may maintain trespass for injury to them, Dean v. Branthwaite, 5 lisp. 35 . Where $\Lambda$. hired IB.'s servant to thatch for him, with B.'s assent, B. was held liable for negligence of the servant. But semble, he was not for incompctence, Holmes 5 . Onim, 2 C. B., N. S. $790 ; 26$ L. J., C. P. 261 .

(v) 5 B. \& C. 547. And see Chileot v. Bromley, 12 Ves. 114, where Sir W. Grant held that a joh coaelman snpplied with earriage and horses was not a servant of the person to whom they were supplied, although he paid the coachman board wages, as the contract was with the joly-master, and the coachman was a sulject of the contract, not a party to it. 
the injury. The judges before whom the case was argued, differing in opinion, they all gave separate and very elaborate judgments, which, as observed by Mr. Justice Story, in his valuable work on Agency $(x)$, "have exhausted the whole prior learning on the subject, and on that account should be attentively studied." The Lord Chief Justice, afterwards Lord 'Tenterden, and Mr. Justice Littledale, holding that the owner of the carriage was not liable ; and Bayley and Holroyd, JJ., holding that he was. The point was thus left unsettled, for not only the Court of Queen's Bench but the Quarman v. twelve judges differed upon it $(y)$. It again arose, and Burnett. $\quad$ was definitely settled in Quarman v. Burnett, $(z)$, in the Court of Exchequer, after fully considering the judgments given in Laugher v. Pointer, thought the weight of authority and legal principle was in favour of the view taken by Lord Tenterden and Mr. Justice Littledale, and decided accordingly, that the hirer was not liable. And it was also held, that the facts that the hirer always had the same driver, who was the only one his master kept, and always gave him a fixed gratuity and provided him with a livery, which he kept [*352] in *the hirer's hall, and while he was hanging up which the accident happened, made no difference in the hirer's liability $(a)$.

(x) Sect. $4,33 \mathrm{~b}$.

(y) See per Lord Wensleydale, in Quarman r. Burnett, 6 M. \& W. 50i. In Brady v. Giles 1 H. \& Rob. 494, where a similar question arose in an action on the case, Lord Abinger, C. B., left it to the jury to say whether the postillions were acting as the servants of the owner of the chaise, or of the hirer, and said it always appeared to him that the Queen's Bench pursued an erroneous course in Laugher $v$. Pointer, when they allowed the question to be discussed as a question of law. And see $W^{\prime}$ Laughlin r. Prior, 4 M. \& G. 48 , post, p. 375.

(z) 6 ir. \& W. 499 . And see Fenton v. The City of Dublin Steam Paeket Co., 8 A. \& E. 835, where the owner of a ship who let it by charter-party, whereby he agreed to find seamen, was held liable for their negligence, and Dean v. Hogg, 10 Bing. 345; Dalyell v. Tyrer, 28 L. J., Q. B. 52. See also Rex v. Haydon, 7 C. \& P. 445, where it was held that the clriver of a glass-coach, having stolen a purse from the hirer, conld not be convicted of larceny as a servant, so as to be liable to the punishment for the aggravated offence under $7 \& 8$ Geo. 4 , c. 29 , s. 46 , but was guilty of simple larceny only.

(a) In Commissioners of Works v. Angus, 50 L. J., 350, Lord Blackburn said, "Ever since Quarman v. Burnett it has heen considered settled law that one employing another is not liable for his collateral negligence unless the relation of master and servant existed between them. So that a person employing a contractor to do work is not liable for the negligence of that contractor or his servants. On the other hand, a person causing something to 
The principle upon which Quarman v. Burnett (b) was Persons decided has been frequently applied to other cases, employing in which a man has employed a person, carrying on a contractor distinct trade or calling, to perform certain works for him, and an injury bas been cansed through the unskil acts of lis fulness, negligence or default of the workmen employed by that person $(c)$. In such a case, the workmen are selected and employed by the contractor, and it would be obviously unjust to hold his employer, who had nothing to do with the selection of the workmen, liable for the consequences of their unskilfulness or negligence. To make the primary principal or employer responsible in such cases would, as observed by Mullett, J., in Blake v. Ferris (d), be to push the doctrine of *re- [*303] spondeat superior beyond the reason on which it is founded. The test generally is, whether or not the employer retained the power of controlling the work $(e)$.

be done the doing of which casts on him a duty, eannot eseape from the responsibility attaching on him of seeing that dnty performed by delegating it to a eontractor. He may bargain with the contractor that he shall perform the duty, and stipulate for an indemnity from him if it is not performed, but he eannot thereby relieve himself from liability to those injured by the failure to perform it. Iole v. The sittingbourne Kailway Co., 5 H. \& N. 483 ; lickard v. Smith, 10 C. B., N. S. 470 ; Tarry v. Ashton, 45 L. J., Q. B. 260 ; L. R., 1 Q. B. D. 314.

(b) Upon analogous prineiples (somewhat governed by the law maritime), it has been held that the master of a general ship is not liable to the owner of goods for damage done to then by the careless stowage of a stevedore appointed by the eharterer, but paid by and to act under the captain's orders, the stevedore not being the servant of the master. Blaikie v. Stembridge, $28 \mathrm{~L}$. J., C. 1 . 329 ; 6 C. B., N. S. 894 ; 29 L. J., C. P. 212 . Of course, however, the master might make himself liable for the stevedore's acts by interfering, ibid. In Sack v. Ford, 3:2 L. J., C. P. $12 ; 13$ C. B., N. S. 90, the shipowner was held liable under the charter-party. Sec kobcrts v. Shaw, 32 L. J., Q. B. 308 . In Murray v. Curric, 40 L. J., C. P. 26; I. R., ( C. B. 24, a stevedore was held liable for the negligence of one of the erew whom he employed to help unload. See also Goslin v. The Agrienturul Hall Co., 45 L. J., C. L. 348; 1 C. P. Div. 489.

(c) An attorney is not such a contractor, therefore the elient is liable to an action of trespass if ca. sa. set aside, Collett v. Foster, 2 H. \& N. 356; and see Freeman v. Rosher, 13 Q. 13. 780.

(d) 1 Selden's (Americ.) Rep. 58. See Pendlebury v. Circenhalgh, 4i L. J., Q. 13. 3, reversing Taylor v. Greenhalgh, 43 L. J., Q. B. $168 ; 1 \mathrm{Q}$. B. Div. 36 .

(c) Saller v. Henlock, 4 E. \& B. 570, where a labourer, partienlarly skilful in making drains, was employed to eleanse a drain for the defendant, who paid him 5s. for the job, the defendant was held liable for injuries eaused througl such labourer's neyligence. As to how far a lindlord is liable for the acts of men sent in to repair a well, see Mills v. IIolton, $2 \mathrm{HI}$. \& N. 1.4 . 
If he has parted with whole control.

Butcher employing Smithficld drover.

Milligan $\mathrm{v}$. Wedge.

Rapson v. cubitt.

Recdie v.

London and North Wcstern Railway Co.
If he has parted with the whole control, he is not in general liable $(f)$.

Thus, where a butcher bought a bullock in Smithfield Market, and employed a licensed drover to drive it home, and the drover employed a boy, through whose negligence the bullock injured the plaintiff's property; it was held, that the butcher was not liable, as the drover exercised a distinct calling, and the boy who caused the mischief was his servant, not the servant of the butcher $(g)$. And so where a builder was employed to make certain alterations at a club-house, including the preparation and fixing of certain gas.fittings, to do which be made a sub-contract with a gas-fitter, through the negligence of whom, or his servants, the gas exploded and injured the plaintiff $(h)$, the builder was held not liable, as the relation of master and servant did not exist between him and the party causing the injury $(i)$. So where a viaduct was being built by contractors for a railway company, under a deed, by [*354] which, *amongst other things, it was provided that the contractors were to do the work, but the company had a general right of watching the progress, and if the contractors employed incompetent workmen, the company had the power of dismissing them: the company were held not liable for injuries sustained by a workman, who was killed by a heavy stone which fell from a travelling truck, through the negligence of some of the contractor's workmen, whilst building the viaduct, as the workmen, who caused the injury, were not the servants of the company; and the power reserved to them of dismissing incempetent workmen did not make

(f) See Serendat v. Saisse, 35 L. J., Pr. C. C. 17. A test may be whether or not the contractor paid the workmen. Turner v. Great Eastern Railuay Co., 34 L. T., N. S. 431.

(g) Milligan v. Wedge, $12 \mathrm{~A}$. \& E. 737. In this case Littledale, J., stated that he retained the opinion he had expressed in Laugher v. Pointer. See Martin v. Temperley, 4 Q. B. 298, post, p. 365. And see also $R$. v. Hey, 2 Carr. \& K. 983 , where it was held that a drover was a bailee, and not a mere servant of the person who employed him, and therefore, that having sold some pigs intrusted to him and absconded with the money, he could not be convicted of larceny. He had no original intention of stealing the pigs.

(h) That in such a case the gas-fitter is liable to the person injured, see Parry v. Smith, 48 L. J., C. L. 731; L. R., 4 C. B. Div. $3: 5$.

(i) Rapson v. Cubitt, 9 M. \& W., 710. See Gayford v. Nicholls, 9 Exe. 702; Chthberison v. Parsons, 12 C. B. 304 . In M'Keon v. Bolton, 1 Ir. C. L. Rep. 279 , a person employed to remove dust was held to be a servant, and not a contractor, and the employer was held liable for an accilent caused by a heap, left in the street.

(374) 
them responsible for tho consequences of the contractors employing such. And it was also held, that the defendants being the owners of the land on which the accident happened made no difference $(k)$.

So again, commissioners of navigation, who had en-Allen $\mathrm{v}$. tered into a contract with a person to do certain works, Hayward. were held not liable for an injury arising from the imperfect performance of part of those works, as the contractor was not their servant $(l)$.

So in another case $(m)$, where a railway company en- Inight $\mathbf{v}$. tered into a contract with A. to construct a portion of Fox. their line. A. contracted with B., who resided in the country, to erect a bridge on the line. B. had in his employment C., who acted as his general servant and as a surveyor, and had the management of B.'s business in London, for which ho received an annual salary. $B$. entered into a contract with C., by which C. agreed for 40l. to erect a scaffold, which had become necessary in building the bridge; but *it was agreed that $B$. [*355] was to provide the requisite materials, and lamps, and other lights. The scaffold was erected upon the footway by C.'s workmen, and a portion of it improperly projected, and owing to that and the want of sufficient light, D. fell over it at night and was injured; but it was held that $D$. could not maintain an action against $B$. for the injury thus occasioned; even though, after the accident, B. had caused other lights to bo placed near the spot to prevent a recurronce of similar accidents.

Again, whero certain commissionors $(n)$ had con-Orerton v. tracted with A. for all the paving required in a certain Freman. district, and A contracted with B. to lay down a certain portion of it, and B.'s workmen left some paving-stones at night in such a position as to constitute a public nuisance, and the plaintiff tumbled over them whilst on foot; it was held that $A$. was not liable to an action at the suit of the plaintiff, as the injury was not caused by $h i s$ workmen.

(k) Reedie v. London and North-IVestern Railway Co., 4 Exe. 244; and see Gloct y. The Same Co., 5 Exe. 66, where the defendants were held not liable in trover for the aets of a contractor's workman. See also Steel v. South-Eastern Ratilway Co., 1(; C. B. 5i)0.

(l) Allea v. Hayward, 7 Q. 13. 960; see Cloyards v. Dethiek, 12 Q. B. 433). See also the American cases of Lowell $v$. Boston and Loacell liailroad Corporation, 23 Piek. 24; Stone v. Cheshire Raitroad Corporation, 19 New Hamps. Rep. 427; Blake v. Ferris, 1 Seld. 49, (62 (1851); Milliard v. lichardson, 3 Gray, 349 (185i), in the last of which are two elaborate judgments. Kelly v. Mayor of New York, 1 Kernan, 432 (18.54).

(m) Knight s. Fox, 5. Exc. 721.

(n) Oterlon v. Frecman, 21 L. J., C. P. $52 ; 11$ C. В. 867. 
Brig towed by steamer.

Sproul v.

Hemmingway.

And similar principles were acted upon in a case which occurred in America (o). A brig, which was towed at the stern of a steamboat employed in the business of towing vessels in the river Mississippi below New Orleans, was, through the negligence of the master and crew of the steamboat, over whom those in charge of the brig had no control, brought into collision with a schooner lying at anchor in the river. A suit was brought by the owners of the schooner against the owner of the brig for the damages sustained by the collision; and [*356] the question was *whether the owner of the brig was liable therefor. It was held, upon full argument, that he was not, upon the ground that the master and crew of the steamboat were not the servants of the owner of the brig; were not appointed by him; did not receive their wages or salaries from him; had no power to order or control them in their movements, and had no contract with the master and crew of the steamboat, but only through the master with the owners of the steamboat for a participation in the power of the steamer, derived from the public use and employment thereof by the owners.

Liability of British master for acts of servant abroad.
It would seem that, according to the law of Spain, where a servant commits a wrongful act, the wrong is not imputed to the master, and therefore where a British ship damaged a pier in Spain, it was held that the owners could not be rendered liable by the applica. tion of the principles of English law; James, L. J., observing, "If I take my servant abroad with mo to drive my carriage $I$ do not take the maxim respondeat superior with me" $(p)$.

But, if the act contracted to be done be in.itself un. lawful the original employers are responsible. As

(o) Sproul v. Hemingway, 14 Pick. R. 71 ; see Story on Ag. 453 c, in a note to which is a long extract from the judgment of Chiet Justice Shaw. See Oakley v. Portsmouth and Ryde Steam Packit Co., 11 Exc. 618; Wilson v. Newport Dock Co., 4 H. \& C. 232. In general, in England, the owner of a ship tugged is liable for damages caused by the tug, which merely supplies motive power. Stevens v. Gourley, 14 Moore's Pr. C. C. 92. But see the case of "The Ameriean," tug, and "Syria," tow, 43 L. J., Adm. 25, 30, where the tug was held liable and the tow exonerated; but there the tug violated the Admiralty rules. This case, however, shows that tug and tow are not for all purposes to be regarded as ope vessel. Where there was a pilot on board the tow, and the tng came into collision with another vessel, the tug was held liable: The Mary 47 L. J., P. M. \& Adm. 66; L. R., 5 Prob. Div. 14; and the tow also in The Sinquasi, 50 L, J., P. D. \& Adm. 5; L. R., 5 Prob. Div. 241.

(p) The Moxham, 46 L. J., P. D. \& Adm. 17. 
where the defendants, without having any power or Employer of authority to break up streets, employed contractors to person doing do it for the purpose of laying down gas pipes, and unławful act the plaintiff fell over a heap of stones left by the con- liable; tractors and hurt himself, the defendants were held liable $(q)$. If, however, the act contracted to be done unless act may be done in a lawful manner, the employer, as we might be have seen, is not responsible if it is done in an unlauful done in manner, or so as to be a public nuisance $(r)$.

Therefore where a man employed a builder to pull manner. down a party wall, and he did it so negligently as to IIunler. injure the plaintiff's house, the employer was hold not liable $(s)$.

*And when there is a legal obligation upon a [*357] Employer person to do a thing he cannut by contracting with some legally bound one else to do it release himself from responsibility. He to do a thing may indeed bargain with tho contractor that ho shall is responsible perform the duty and stipulate for an indemnity from for acts of him if it is not performed, but he cannot thereby reliev contractor's himself from liability to those injured by tho failuro to violation of perform it $(t)$. As where a statute imposed on the de- employer's fendants the duty of making a bridge that would open, duty. and they employed a contractor who made a bridge that IIole v. and they employed a contractor who mado a bridge that Sittingourne would not open as the statuto required, tho defendants and shermess were held liable $(u)$. So an omployer allowing a coal- Railuay Co. merchant to make an opening in the road for coals is Piekard v. responsible for the negligence of the coal-merchant's Smith. men in omitting to close the opening $(v)$. So whero a Graly $v$ statute requiring a drain to be made by the owner of a Pulien. house authorized him to make a cutting in the road, but also required him to fill up the cutting properly afterwards, and he employed a contractor to mako the

(q) Ellis v. Sheffield Gas Co., 2 E. \& B. 767; see Suller v. Honlock, 4 E. \& 13. 57̈0; Blake v. Thirst, 32 L. J., Exc. 188.

(r) Peachey v. Rowland, ante, p. 344.

(8) kutler v. Hunter, 31 L. J., Exc. 214; 7 H. \& N. 8:6. But sec P'erciral v. Hughes, 51 L. J., C. L. $388 ; 9$ Q. B. IDiv. 441; 52 L. J., C. L. 719.

(t) See per Lord Blackburn, in Commisioners of Worlis, de. v. Angins, 50 L. J., C. L. 750. See also Bower v. Peate, 45 L. J., C. J. 446 ; 1 Q. B. Div. 321 ; Angus v. Dallon, 47 L. J., C. I. 16;3; 48 I. J., C. I. 225 ; 50 L. J., C. L. 689 ; I. R., 6 App. Cas. 740; P'reival v. IInghes, supra, note (s). See also Le Maitre v. Dacis, 51 I. J., Ch. 173 ; L. R., 10 Ch. Div. 281.

(i) Hole v. Sittingboume and Sheerness Railway Co., 30 L. J., Exe. $81 ; 6$ H. \& N. 488.

(c) Pickard v. Smith, 10 C. B., N. S. 470. See Perciral v. Hughes, supra, note $(s)$; and see Whitcley v. Pepper, 46 I. J., C. L. 436 ; 1. R., 2 Q. B. Div. 276 ; where the eoal merehant was held liable; and Clayp v. Kemp, 12:2 Mass. (Amer.) Rep. 
drain whose men neglected to fill up the cutting proporly, the owner of the house was held liable $(x)$.

Person employing contractor liable for personal interference. Burgess v. Gray.

And unless he has parted with the whole control.
And where a contractor is employed, his employer may, by personal interference with the workmen, adopt their acts, and so render himself liable, where, ordinarily, he would not be so. As in the case of Burgess $\mathrm{v}$. [*358] Gray $(y)$, in which *it appeared that the defendant was the proprietor of some newly-built houses which he had employed P. to build for him, and P. in forming a drain from premises belonging to the defendant at the back of the new houses to the common sewer, had, by his servants, caused a quantity of gravel to be deposited by the roadside. The drain being finished, P. employed a person to carry away the gravel, and paid him so much a load, which he charged to the defendant, but the person so employed left some on the road, and the plaintiff, whilst driving in the eren ing along the road, ran upon the gravel left in the road, was upset, and injured. The defendant's attention had been called to the gravel left in the road by a policeman, and he had promised to remove it as soon as he con!d, and, after the accident, had said it was caused by the plaintiff's carelessness. On the part of the defendant, it was, amongst other things, contended on the principle of Quarman v. Burnett (z), that he was not liable, as he had employed a contractor; but it was nevertheless held that, under the circumstances of the case, he was liable.

And unless a person who employs a contractor to do work for him has parted with the whole control of that work, he will still remain liable for the acts of that person and his workmen. In such case it must be assumed that he adopts all that is done in carrying on the work $(a)$.

(x) Gray v. Pullen, 34 L. J., Q. B. 265, reversing S. C., 32 L. J., Q. B. 169 ; 5 Best \& S. 970. See Hyams v. Webster, 36 L. J., Q. B. 166, affirmed in Exc. Ch. 98 L. J., Q. B. 21. See also West Riding and Grimsby Railway Co. v. Wakefield Local Board of Health, 33 L. J., M. C. 174 , where the company were held liable to repair a road used by their contractor's workmen. In Bartlet v. Baker, $3 \mathrm{H}$. \& C. 153 , a contractor was held not liable after he had sold some piles in the river.

(y) 1 C. B. 578. The defendant in this case was held liable partly on the ground that it did not appear that he had parted with the whole control of the work, and partly on the ground that he had sanctioned and adopted the act of the person who placed the gravel in the road. It is on the latter account that it is cited in the text. See, however, Kright v. Fox, 5 Exc. 721 , ante, p. 354 ; and see also the cases of trespass, post.

(z) Ante, p. 351.

(a) Per Cresswell, J., in Burgess v. Gray, 1 C. B. 592. 
'This liability of the master for the act of his servant, Naster not however, presupposes and is founded upon some obliga- liable for tion binding upon the master, either by contract or servant's otherwise, to do or abstain from doing the act the nut act when he oth or the not be doing or doing of which is complained of. $\Lambda$ master liable if lie cannot be liable for his servant omitting to do an act did it himunless he himself was bound to do it. Nor again, can self. a master be liable for his servant doing an act which he himself was at liberty to *perform, except, of [*3509] course, in the case of a trust or licence personal to the master.

Where the plaintiff, who was an officer in the army, Finueane v. being about to leave London, sent his trunk to the Small. house of the defendant (who was an upholsterer) for safe custody, and agreed to pay one shilling per week for house-room, and when the plaintiff returned he received the trunk, but the whole of the contents had been taken out and stolen, and the plaintiff brought an action against the defendant, charging bim as bailee; Lord Kenyon held that the action could not be supported when it appeared that he had taken as much care of the plaintiff's goods as he had of his own, and said, "To support an action of this nature positive negligence must be proved. It has appeared in evidence in this case that the goods were lodged in a place of security, and where things of much greater value were kept. This is all that it is incumbent on the defendant to do; and if such goods are stolen by the defendant's own servants that is not a species of negligence of a de. scription sufficient to support this action, inasmuch as he bas taken as much care of them as of his own $(b)$.

Where a customer deposited with his bankers for Giblin v. safe keeping certain securities which were stolen by a M'Mullen. clerk of tho bankers, it was held by the Privy Council that the bankers wero not liable unless the loss was occasioned by their gross negligence (c), and that under the circumstances there was no evidence of neg. ligence $(d)$.

So a lodging-house keeper, in the absence of any misfeasance by him, is not responsible for a loss Houldar v. through the dishonesty of his servants $(e)$; since a

(b) Fimucane v. Smal, 1 Fsp. 315.

(c) As to this, see Re United Service Co. v. Johnston, 40 L. J., Ch. 286 .

(d) Giblin v. M'Mullen, 38 L. J., Pr. C. C. 25 ; L. R., 2 Pr. C.

C. 317. See Foster v. Essex Bank, ante, p. 343.

(e) Ho?der v. Soulby, 29 L. J., C. P. 246; 8 C. B., N. S. 254.

See Calye's case, 8 Rep. 32 ; 1 Sinith's L. C. 105. 
lodger must take care of his own goods in lodgings, as he must with respect to valuables about his person when he walks the street.

Clark v. [*360] *But where A. entrusted B. (a chronometer Earnshaw. maker) with a chronometer to be repaired, and B. suffered his servant to sleep in the shop in which the chronometer was deposited, and B.'s servant stole it, and it appeared that $B$. at the time when the theft was committed had deposited his own watches in a more secure place, B. was held liable to $\mathrm{A}$. for its value $(f)$.

Liability of boardinghouse heeper for negligence of servants. Dansey v. Richardson.
In the following case $(g)$ the judges were equally divided in opinion as to whether or not the master was liable:-The defendant was a lodging-house. keeper, and the plaintiff was received, with her luggage, as a guest for reward, paying, in fact, between $2 l$. and $3 l$. a week. She had the use of sitting, drawing and dining rooms in common with others, her own bedroom, her board, and the attendance of the servants, among whom were a butler and page; and these, when required, went on errands for the guests, and carried their luggage to and from their rooms when they arrived and departed. On the 10th of December, in the evening, the plaintiff was to leave the house and to dine before she went. About half-past five, being in her bedroom, she was told dinner was ready by one of the men-servants, to whom she gave part of her luggage to take downstairs, and the other servant afterwards carried down the remainder: all were placed in the hall near the fore-door. Shortly before her departure, she sent the butler out, to a shop near, for biscuits; and it was not seriously contested by the defendant's witnesses that this servant going out left the fore-door ajar, and a thief, profiting by the opportunity, entered and carried off a box of the plaintiff's containing valuable property. There was no evidence whether the defendant had received a character for carefulness with the. butler when he entered her service. There was conflicting evidence whether he had on former occasions left the door ajar, and, if so, whether that was within the knowledge of the defendant; and also, whether [*361] *any former robberies, attributable to the same cause, had occurred. At the trial, Erle, J., told the jury that a boarding-house keeper was bound to take due and reasonable care about the safe keeping of the guests' goods, which he explained to be such care as

(f) Clarke v. Earnshaw, 1 Gow, 30.

(g) Dansey v. Richardson, 3 E. \& B. 144. 
a prudent house-keeper would take of the house for Inensey $\mathrm{r}$. the purpose of protecting her own goods; that leaving Richarlson. the door ajar might bo a want of such care, but that the defendant was not answerable for such negligence in the servant unless she had herself been guilty of some negligence, as in keeping such a servant with notice of his habits. The jury found for the defendant. On a rule for a new trial, it was held by the whole Court that a boarding house keeper is not bound to keep a guest's luggage safely to the same extent as an innkeeper, but that she undertakes by implication of law, although nothing is expressed, to take due and proper care of a guest's baggage, and that neglecting to take due care of the outer door might be a breach of such duty, and that, so far, the direction was right. And Erle, J., and Wightman, J., held, that unless the defendant herself was guilty of negligence, the act of the servant in leaving the door ajar was not one for which the defendant was responsible, it not being a neglect of any public duty which was owing to plaintiff, nor a breach of contract between plaintiff and defendant, but merely negligence of the servant towards his mistress, and that, therefore, the direction was right. Whilst Lord Campbell, C. J., and Coleridge, J., held that the act of the servant was, under the circumstances, the act of the defendant: and that thero was no distinction between the personal negligence of the defendant and that of her servant in her employment, the defendant being equally answerable for both, and therefore they held tho direction wrong $(h)$.

But where a master is obliged, by Act of Parliament, Master to employ a particular person, and all power of selection obliged by is taken from him, it would be unjust to render him law to em*responsiblo for the wrongful acts of that per- [*362] ploy a son. Accordingly, tho statutes ( $i$, which compel ship- person, not owners, \&c., wanting a pilot to employ the first duly liable for his licensed pilot who shall offer himself $(k)$, provido $(l)$ acts.

(h) The Court being equally divided, no new trial was granted.

(i) G Geo. 4 , c. 125 , s. 19 ; see $16 \& 17$ Vict. e. $129 ; 17 \& 18$ Vict. c. 104, s. 353 ; c, 120.

(k) As to when it is eompulsory to employ a pilot, see The Killarney, 30 L. J., Pr. Mat. \& Adm. 41; 1 Lush. 427; The Eart of Auckland, 30 I. J., Pr. Mat. \& Adm., 121; 1 Lush. 164; The Aunaplis, 30 L. J., Pr. Mat. \& Adm. 201 ; 1 Lush. 355; Tyne Improvement Commissioners v. General Steam Nurigation Co., 36 I.. J., Q. B. 22; General Steam Navigation Co. v. British Colonial Steam Nuvigution Co., 37 I. J., Exc. 194; I. R., 3 Exc. 330 ; 33 L. J., Exe. 97 ; The Lion, 88 L. J., Adm. 51.

(l) 6 Geo. 4 , c. 125 , s. $55 ; 17 \& 18$ Vict. c. 104, s. 338 . And 
Pilot Acts. that no owner of any ship shall be answerable for any damage which shall happen to any person by reason of the neglect or incapacity of any licensed pilot, acting in the charge of such ship. The books contain numerous instances in which shipowners have been held not to be responsible for injuries caused by their vessel whilst under the command of a licensed pilot $(\mathrm{m})$. Lucy v. And it has even been held (n), upon the construction of Ingram. the Act of Pariiament, that a shipowner was not liable for injury caused by the negligent navigation of his ship whilst under the care of a pilot, although it was not compulsory upon him, under the circumstances, to employ a pilct; as it was compulsory upon the pilot to [*363] servo if *called upon, and he having been called upon had taken the control of the ship.

Aet of negligence must be exclusively act of pilot.

The decisions exempting the owner from responsibility when a vessel is under compulsory pilotage have, however, to a certain extent, been modified by a case before the Privy Council $(o)$, in which it was laid down that the presence of a pilot on board a vessel by compulsion does not prima facie exonerate the owners from responsibility for an act of negligence in the management of the vessel : but they are bound to show that the act of negligence was exclusively that of the pilot. And before that question can arise, it must be establish. ed that, under the circumstances of the case, the vessel

see the Harbours, Docks, and Piers Clauses Act, 1847, 10 \& 11 Vict. e. 27 , s. 74 , which makes the owners of ressels answerable for damage to works by any ressel or by any person employed about the same, \&c., contains a proviso, "That nothing herein eontained shall extend to impose any liability for any such damage upon the owner of any ressel where such ressel shall, at the time when such damage is eaused, be in charge of a duly licensed pilot, whom such owner or master is bound by law to employ and put his vessel in eharge of.". See on the construction of this section, River Wear Commissioners v. Adamson, 46 L. J., C. L. $83 ; 1$ Q. B. D. 546 ; in Dom. Proe. L. R., 2 App. Cas. 743 , orerruling Dennis v. Tovell, 42 L. J., M. C. 33; L. R., 8Q. B. 10.

(m) Bennct v. Moita, 7 Taunt. 258; and see eases eiterl in Lucey v. Ingiam, 6 M. \& W. 302 ; and the eases of The Maria, 1 W. Rob. Adm. R. 95, on tho Neweastle Pilot Aet, 41 Geo. 3, c. Ixxxvi.; The Peerless, 29 L. J., P. M. \& Ad. 49: Tho Halley, 37 L. J., Adm. 1 ; S. C. in Privy Couneil, nom. The Liverpool. Brazil and River Plate Stcam Navigation Co. v. Benham, B7 L. J., Adm. 33 ; Tie Princeton, 47 L. J., P. D. \& Adm. 33 ; The Vesta, 51 L. J., P. D. \& Adm. 25. A defendant snceeding on this point is entitled to costs, The Juno, 45 L. J., P. D. \& Adm. 105.

(n) Lueey v. Ingram, 6 M. \& W. 302. But sce General Steam Navigation Co. v. British Colonial Steam Navigation Co., ubi supra; The Lion, 38 L. J.. Adm. 51 ; and note the difference between tho 6 Geo. 4 , and $17 \& 18$ Vict. c. 104.

(o) Hammond v. Rogers, 7 Moore, P. C. C. 160. 
was obliged by Act of Parliament to have a pilot on board at the time of the accident $(p)$.

"It has," said Sir J. Colville in delivering the judg- The velasment of the Privy Council in the case of The Velasquez quez.

$(q)$, "been established, by a long course of decisions both in the High Court of Admiralty and the Privy Council, that to entitle the owners of a ship which is under the charge of a licensed pilot to the benefit of the provision in the act which exempts them from liability, where the collision has been occasioned by the fault of the pilot, it lies upon them to prove that it was caused solely by his fault. To show to what extent this general burden lies upon the owners, is sufficient to cite the case of The Schwalbe $(r)$. There the cause of collision was The Scralbe. an improper starboarding of the helm; an act of navigation presumably attributable to an order from the pilot. Lord Chelmsford in delivering judgment said, 'The owners, therefore, fail in the evidence necessary to transfer the responsibility from themselves, and, without considering whether there was any negligent act or omission $n \mathrm{n}$ the part of the crew of The Schwalbe, their lordships think it sufficient to say that the owners have not succeeded in establishing that the collision is to be attributed solely (if at all) to the fault of the pilot.' Again, the cases *have clearly established [*364] that if for any act or omission which contributed to the accident, the master or crew is to blame, then, although the pilot is also to blame, the owners are not exempted from liability. One of the strongest cases of this kind is that of The Christiana, $(s)$, for there every act of The Chrisomission (and there were several of them) which con-tiana.

tributed to the accident, was an act for which the pilot was to blame, yet, inasmuch as for one of them, viz., the omission to strike and haul down certain yards and masts, the master was held to be also in fault, the ownors were not exonerated from liability. And on the

(b) Rodrigues v. Melhuish, 10 Exc. 110. See The City of Cambridge, $43 \mathrm{~J}$. J., Adm. 6; S. C. in Privy Conncil, sub nom. Wood v. Smith, 43 L.- J., Adm. 11 ; L. R., 5 P. C. 451 . In an action ugainst the pilot, he is not entitled to notice of action as for a thing done in pursuance of the Pilot Act, Lawson v. Dumlin, $9 \mathrm{C}$. 13. 5. An action against the pilot for negligence is not an Admiralty cause within" $31 \& 32$ Vict. e. 71 , and $3: \& 33$ Vict. c. 51 (giving Admiralty jurisdiction to County Courts), Flourer v. Bradley, 44 L. J., Exc. 1.

(q) 36 L. J., Adm. 19.

(r) 14 Moore, P. C. C. 241. See also The Mobile, Swabey's Adm. Rep. 127, and Maude and Poll. on Sh. 223, 224; The Queen, 38 L. J., Adm. 39.

(8) 7 Moole, P. C. C. 160.

21 Mas. \& Ser.

If master or crew to blame. owner not exempt. 
If pilot in fault, and master or crew not in fault, owner exempt.

The George.

If master or crew negligent, and pilot in fault, must prove that pilot's fault caused accident.

The Iona.

If not compulsory to take pilot, he is servant of owners.

On Suez Canal.

Owner not liable for damage caused by fault of pilot in the 'Thames. other hand, such cases as The George $(t)$, and The Atlas $(u)$ seem to show that if it be proved on the part of the owners that the pilot was in fault, and there is no sufficient proof that the master or crew were also in fault in any particular which contributed or may have contributed to the accident, the owners will have relieved theinselves of the burden of proof which the law casts upon them. If, however, the evidence shows that there were acts of negligence on the part of the master and crew which may have contributed to the accident, as well as fault on the part of the pilot, the duty of showing that the former did not contribute in part to the accident seems to be involved in the obligation of the owners to prove that the causa causans of the collision was exclusively the fault of the pilot. The Iona $(x)$, one of the most recent cases decided by this committee, seems to go to the full length of this proposition."

If, however, it is not compulsory to take a licensed pilot, the pilot is the servant of the owners, and they are responsible for his acts $(y)$. The decisions establishing this proposition are of greater importance now that it is proposed to abolish compulsory pilotage.

By Article 4 of the Regulations for the Navigation of the Suez Canal, every ship above 100 tons is bound to take one of the Company's pilots; but by the same article the responsibility for the management of the ship rests solely with the captain. It has been held by the Court of Appeal that the owners are not exempt from liability on the ground of compnlsory pilotage $(z$.

[*365] *It may be convenient to mention in this place that a compulsory pilot is not within that section of the Thames Conservancy $\Lambda$ ct, 1857 ( $a$ ), which makes the owner of every vessel navigating the Thames answerable for all damagres "done by such vessel or by any of the boatmen or other person belonging to, or employed in or about the same by any means whatsoever to any of

(t) 4 Totes of Cases, 161.

(ii) 5 ibid. 50 .

(x) 4 Moore, P. C. C., N. S. 336.

(y) The Earl of Auckland, 30 L. J., Pr. Mat. \& Adm. 124; The Stettin, 31 L. J., Pr. M. \& Adm. 208; The Hanna, 36 L. J., Adn. 1; The Woburn Abbey, 38 L. J., Adm. 38; The Lion, ibid. 51. As to how far the liability of the shipowner is linited by the provisions of the Merchant Shipping Act Amendment Act, 1862, 25 \& 26 Vict. e. 63 , s. 54 , see The Warkworth, 53 L. J., P. D. \& Adn. 4 ; L. R., 9 Prob. Div. 20, $14 \overline{3}$.

(z) The Guy Mannering, 51 L. J., P. M. \& Adm. 57 ; L. R., 7 Prob. Div. 52, 132.

(a) 20 \& 21 Vict. c. cclvii., s. 96.

(384) 
the property or effects of the conservators," and consequently the owner of the vessel is not liable for damage done by the fault of the pilot (b).

- And where a master has a power of selection, it makes where no difference in his liability for the acts of the person master has selected, that he is bound to select from a particular power of class of persons, however numerous or limited that class may be. selection, he is liable, though

Thus, although by the statute for regulating water- limited to men and lightermen on the Thames $(c)$, and the byelaws obtained in pursuance thereof, no one besides freemen or apprentices to freemen, or to widows of free-men, ne class. Martin $\mathbf{v}$ of the Watermen and Lightermen's Company (with certain exceptions), may navigate craft on the river for hire, within the limits of the Act, under a penalty : but any person may keep and use craft for carrying their own goods, by their servants being such freemen or apprentices; and on board of every barge, \&c. there must be at least one able and skilful man authorized by law to navigate; yet the owner of a barge, who hired two qualified persons to navigate it within the limits, was held liable for injury caused to another vessel by their negligence. And it was held to make no difference whether the navigators were hired for the job or by time $(d)$. On that occasion Patteson, J., said,-

"On the part of the defendant it is argued that this - is the case, not of master and servant, but of an independent contract to perform the work, as in Milligan v. Wedge (e), and Quarman v. Burnett $(f)$. But that is *clearly erroneous. Independently of the act, [*366] the men navigating the barges would clearly be the defendant's servants. If the defendant, being at liberty to employ whom he pleased, engaged persons to manage his barges on the Thames, I cannot see how it is possible to contend that they were not his servants, as much as a man. whom he might employ to drive his carriage. Where, indeed, a man hires another man's servant from him, though such servant be employed to drive where the person hiring pleases, it has been held in Quarman v. Burnett, that the servant so hired is not the servant of the person so hiring. The case certainly carried the exception a great way, but there the servant 163.

(b) The Conservators of the River Thames v. Hall, 37 L. J., C. P.

(c) $7 \& 8$ Geo. 4 c. lxxv. See now $22 \& 23$ Vict. c. cxxxiii.

(d) Martin v. Temperley, 4 Q. B. 298.

(e) 12 A. \& E. 737 , ante, p. 35:3.

(f) $6 \mathrm{M} \&$ W. 499 , ante, p. 351 . 
Martin v. hired was ordinarily in the employment of the person Temperley. from whom he was hired, and who let horsas along with the driver. That case is not like the present. The second question then is as to the effect of stat. $7 \&$ 8 Geo. 4, c. lxxv. That indeed confined the defendant to employing as his servants only individuals of a particular class. It narrowed the number of persons from whom he could select. But that is very different from the state of things ereated by the Pilot Act, where a party must take the first pilot who offers himself. Here the defendant had the power of selection, though from a limited number : and no case has gone so far as to decide that the person hired ceases to be the servant of the person hiring, if he is necessarily selected from a number, though limited. I was much struck by the argument deduced from the old statute of apprentice. ship. According to the doctrine contended for on the part of the defendant, it would hardly have been pos. sible while that act was in force to employ a man as a servant. I do not put the case on the largeness of the number from which the selection may here be made; the principle seems to me the same whether the number be five hundred or five thousand. If there be a power of selection, and not as in the Pilot Act, a provision preventing any choice, the person hired is the servant of the person hiring."

Liability of master for. acts of servant whom he is obliged by circunstances to employ without power of selection, and whose conduct is beyond his control.

Owner of fixed property liable for acts of persons not strictly his servants,
There is another class of cases which must be shortly adverted to in this place, though it is believed that there is no actual decision upon the question raised by them-the eases, namely, in which a man is obliged by force of circumstances, and without any power of selection or choice, to employ a particular servant or agent whose conduct is beyond the control or direction of his principal. Such cases, however, cannot often arise, except in cases of salvage, into the law of which moral considerations and considerations of policy enter largely, and which therefore scarcely come within the scope of this work $(g)$.

There is also a large class of cases which must not be entirely omitted here, but which it will be sufficient [*367] to refer *to generally, as they do not properly relate to the law of master and servant, in which the ouners of fixed real property, as land and houses, have been held responsible for the acts of persons not, strictly speaking their servants. The doctrine, however, on which these cases rest was placed within its proper

(g) See the case of The Atlas, 31 L. J. Pr. Mat. \& Adm. 210. (386) 
limits, in a very elaborate judgment pronounced by Lord Cranworth $(h)$, in a case in which he stated that, after full consideration, he had come to the conclusion that no distinction in point of law existed, in cases like that under consideration, between fixed property and ordinary moveable chattels, unless, perhaps, in cases where the Act complained of is such as to amount to a but only in 'asses of nuisance.

We have hitherto been considering chiefly the lia- Liability of bility of a master to answer for his servant's acts in an master in action on the case. But a master may also, in many trespass for cases, be liable to an action of trespass for an injury servant's act, caused by the direct act of his servant. The liability, however, of a master to be sued in this form of action, for injuries cansed by his servant, does not depend upon the relationship of master and servant, though the existence of that relationship may possibly afford an $i$ fortiori reason for holding the master responsible. His liability depends upon the fact, that the act of trespass if done by complained of was done by his command, that, in truth, mand. it was his own act, although done through the instrumentality of his servant, according to the maxim Qui facit per alium, per seipsum facere videtur. For, although a man may be a trespasser by his oun involuntary act $(i)$, no man can be made a tresspasser against his will *by the act of his servant. Unless, [*368] therefore, there be evidence of the concurrence of the master's will in the act of the servant, a master can, in no case, be treated as a trespasser for the act of his servant $(k)$.

If a master expressly order his servant to commit a If the comtrespass, there can be no doubt about the concurrence mand be of his will in his servant's act, and no difficulty in treating him as a co-trespasser with his servant : and it can express, master liable whether present or

(h) Reedie v. London and Sorth Western Railuay Co, 4 Exc. 244, not. which was an action for damages sustained by a person passing under a viaduct in course of construction on the defendants' railway, and they were held not liable. In that case all the previous authorities will be found. See also Orerton v. Frecman, 21 L. J., C. P. 52; 11 C. B. 867; Knight v. Fox, 5 Exe. 724, aute, p. 354; Higgs v. Maynard, 1 IIarr. \& Ruth. 581; White v. Jameson, L. R., $18 \mathrm{Eq}$. 303. The case of Reedie v. Londom and North Western Railway Co. has been followed in Amerian, Simons v. Monier, 29 Barb. 420.

(i) Scott v. Sheppard, 3 Wils. $403 ; 2$ W. BI. 899 ; Leame v. Bray, 3 East, 593 ; 5 Esp. 18 ; and see per 'Tindal, C. J., in IY' Laughlin v. Prior, 4 M. \& G. 56 .

(k) Morley v. Gaisford, 2 H. Bl. 442: M'Manus v. Criekett, 1 East, 106 ; per 'Tindal, C. J., in I'Laughlin s. Prior, 4 M. \& G. 58 ; Lyous v. Martin, 8 A. \& E. 51:. 
make no difference whether he himself were present or absent when the trespass was committed: if it were done by his orders, he would equally be a trespasser in either case.

So, if trespass Again, if an act of trespass, on the part of a servant, be the neces- be the natural or necessary consequence of an act which sary conse- his master ordered to be done, his master will be liable quence of obeying master's command.

Gregory :. Piper. to an action of trespass. And in this case, also, the presence or absence of the master at the time the tres.. pass is comnitted can make no difference in his lia. bility.

Thus, where $(l)$ the defendant, who disputed the plaintiff's right of way throngh a yard, employed a labourer to lay down rubbish in order to obstruct the way, but gave him orders not to let any of the rubbish touch the plaintiff's wall; the labourer executed those orders as nearly as he could, but some of the rubbish, it being of a loose kind, naturally shingled down towards and ran against the plaintiff's wall : the defendant was held liable in an action of trespass. And Littledale, J., said,- -

"Where a servant does work by order of his master, and the latter imposes a restriction in the course of executing his order, which it is difficult for the servant to comply with, and the servant, in the execution of the order, breaks through the restriction, the master is liable in trespass. Suppose the case of two persons possessed of contiguous unenclosed land, and that the one of them desired his servant to drive his cattle, but not to let them go upron the land of his neighbour, and that the cattle went upon the land of the neighbour, the master would be answerable in trespass, because he has only a right to expect from his servant ordinary, not extraordinary, care. If the servant, therefore, in [*369] carrying *into execution the orders of his master uses ordinary care, and an injury is cone to another, the master is liable in trespass. If the injury arise from the want of ordinary care in the servant, the master will only be liable in case. Here the servant used ordinary care in the course of executing his master's order and notwithstanding that the rubbish ran against the wall."

So, if trespass And if an act of trespass be committed by a servant be committed in the usual course of his employment, although there by servant in be no express command on the part of his master to do pursuance of the specific act complained of, yet his master may be

(l) Gregory v. Piper, 9 B. \& C. 591. 
liable to an action of trespass, as in such case the com-general, withmand will be implied from the nature of the servant's out specific, employment. If, for instance, in the case of Lyons $\mathrm{v}$. orders, Martin, $(m)$, the servant of the defendant had merely distrained the plaintiff's cattle damage feasant, thero can be no doubt the defendant would have been held liable in trespass for the consequences of his servant's act.

And if an act of trespass be committed by a servant or for the on behalf and for the benefit of his master, it is per-benefit of, fectly clear that the master, although he gave no pre- and ratified vious command to his servant to commit the trespass, by, master. may nevertheless render himself liable to an action of trespass by a subsequent ratification of the servant's act $(n)$.

But where an act of trespass has been committed by If trespass a servant without the orders of his master, the presence committedby or absence of the master at the time the act is done servant withforms a very material ingredient in considering whether out orders, or not the master is liable to an action of trespass for the act of his servant. For, if an act of trespass be master not committed by a servant in his master's absence, without liable if his orders, there is *no ground whatever for [*370] alssent; treating the master as a trespasser. He may be liable in another form of action, but he is not liable to an action of trespass, as his will did not concur in the act of his servant $(o)$.

But if an act. of trespass has been committed by a but may be servant in the presence of his master, if the master liable if knew that his servant was about to commit a trespass present. and did not restrain him, there may be ground for presuming the concurrence of his will in his servant's act, and he may be liable to an action of trespass, although be did not expressly order the trespass to be committed. For as every master must be presumed to have power

(m) 8 A. \& 1. 512; see this case, ante, p. 340.

(a) See Eus/mm Counties Railuny Co. v. Broom, 6 Exe. 314. In that case an officer of the company took Broom into enstody for breach of the company's bye-laws, and took him hefore a magistrate; when the attorney of the company attended to prefier a eharge against Broom. This was held not to amount to a ratification of the act of the officer. And see lioe v. Birkenheal, de. Railuay Co., 21 I. J., Exe. 9; 7 Exc. 86; Bny;ly v. Manchester, Shegiehl and Lincolushire Railway ('o., 41 L. J., C. I'. 278; I. R.. 7 C. P. 415; 42 I. J., C. I. 78; L. R., 8 C. P. 14 \%. Mere knowledge is no evidence of ratification, Moon v. Touers, 8 C. B., N. S. 611.

(o) M'Manus v. Crickett, 1 East, 106; see Timothy v. Simpsom, 6 C. \& P. 499; and Wright v. Wilcox, 19 Wendell's (Amer.) Rep. 343 , ante, p. 343 . 
Chandler v. Broughton.

If damage not too remote.

Gilbertson $\mathrm{v}$. Richardson.

Master may be liable to two actions by same plaintiff, arising out of one accident, to control his servant, it may fairly also be presumed from his knowing that his servant was about to commit a trespass, and not interfering to restrain him, that he concurred in his servant's act. Qui non prohibet, cum prohibere possit-jubet.

Thus, a gentleman, who was sitting by the side of his servant in a gig which was çriven by the servant, was held liable to an action of trespass for injury caused by the horse running away and dashing the gig against the church in Langham-place, as he had the immediate control over the servant; and Bayley, B., said,-

"The rule is this: if master and servant are sitting together, and the servant is driving the master, the act of the servant is the act of the master, and the trespass of the servant is the trespass of the master. Here the act is immediately injurious to the plaintiff and the master was present" $(p)$.

If the act of the defendant or his servant be such as to amount to a trespass on his part, it is no objection to suing him in that form of action, that the damage sustained by the plaintiff was not caused immediately by the defendant's act, so as the damage be not too remote.

Thus, where $(q)$ it appeared that the plaintiff was driving with a friond along Oxford-street, in a chaise [*371] *drawn by a high-spirited horse, and one of the traces getting accidentally over the shaft, he alighted for the purpose of adjusting it. While so doing, the defendant drove his carriage against the wheel of the plaintiff's chaise, and the plaintiff's friend was thrown by the shock off the seat on to the dashing-board, which, falling on the horse, caused him to kick, whereby the chaise was damaged: it was held that the defendant might be sned in trespass for the damages sustained.

When the circumstances of the case are such that the master is liable for damages caused by the negligence of his servant, it has been held by the Court of Appeal, reversing the judgment of the Divisional Court, that a plaintiff who had recovered damages in the County Court for injuries to his cab through the negligent driving of the defendant's servant, might afterwards bring another action in the superior Court for his personal injuries, although it was strenuously contended that he must sue once for all $(r)$.

(p) Chandler v. Broughton, 1 C. \& M. 29.

(q) Gilbertson v. Richardson 5 C. B. 502.

(r) Bruusden v. Humphrcy, 53 L. J., C. L. 476, reversing $S . C$, 52 L. J., C. L. $756 ; 11$ Q. B. Div. 712. 
Where the person injured has been awarded, by a but not to magistrate having jurisdiction under $6 \& 7$ Vict. c. 86 , action after s. 28 , and has accepted, a sum of money as compensa- driver contion 28 , tion from the servant, he cannot afterwards sue the magistrate. master $(s)$.

But if the circumstances of the case do not show any Master not exercise of volition, either express or implied, on the liable in part of the master, he is not liable to be sued in tres- tresspass for pass for the wilful act of his servant.

Thus, in Morley v. Gaisford ( $t$ ), which was an action on the case for injury sustained in consequence of orders. the negligent driving of the defendant's servant, it Morley $\mathrm{v}$. was held that case and not trespass was the proper Gaisforl. remedy, the Court saying, that "it was difficult to put a case where the *master would be considered [*372] as a trespasser for an act of his servant which was not dono at his command."

The point, however, was more formally decided in $M \cdot M a n u s \mathrm{v}$. M'Manus v. Crickett ( $u$ ), which was an action of tres-Crickett. pass for forcibly driving the defendant's chariot against the plaintiff's chaise. It appeared that the defendant's servant wilfully drove the chariot against the plaintiff's chaise, but that the defendant was not himself present $(x)$, nor did he in any manner direct or assent to the act of the servant, and it was held that for this wilful and designed act of the servant an action of trespass would not lie against his master. Lord Kenyon, C. J., after showing from various old cases that a master was not liable in trespass for the wilful act of his servant done without his command, said,-

"This doctrine does not at all militate with the case in which a master has been holden liable for the mischief arising from the negligence or unskilfulness of his servant, who had no purpose but the execution of his master's orders; but the form of those actions proves that this action of trespass cannot be maintained; for if it can be supported, it must be upon the ground that in trespass all are principles; but the form of those actions shows, that where a servant is in point of law a trespasser, the master is not chargeable as such, though liable to make a compensation for the damage consequential from his employing of an unskil-

(s) Wright v. London General Omnibus Co., 46 L. J., C. I., 4:99; L. R., 2 Q. 13. $2 \% 1$.

(t) 2 H. HL. 442.

(u) 1 Fast, 106 ; and see Wright v. Wilcox, ante, p. 343.

$(x)$ No one was in the carriage: the act was done by the servant either in going for, or after he had set down, his inaster. 
ful or negligent servant. The act of the master is the employment of the servant; but from that ne immediate prejudice arises to those who may suffer from some subsequent act of the servant."

Gorden v. So, again, in Gordon v, Rolt $(y)$, which was an action Rolt. of trespass for breaking the plaintiff's crane. The plaintiff had set up the crane in a dockyard, with a view to its being tested, and, if approved of, ultimately purchased by the Government. The crane itself was not fixed to the soil, but was placed in a socket which was so fixed. The defendant was the contractor for certain works then in progress in the dockyard, and employed $\mathrm{H}$. as a sub-contractor. The workmen of [*373] H. broke the crane by using *it to snap off the head of a pile which had been half sawn through. Cutting off the piles was part of the defendant's work under the contract, but he had never given any authority to $\mathrm{H}$. or his men to use the crane, nor did he know that they had used it. H. knew that his men occasionally used the crane, but he never authorized them to use it for any particular purpose. And it was held, that the defendant was not liable to an action of trespass for the act of H.'s workmen in breaking the crane. In the course of the argument, Lord Wensleydale said,-

"The result of the authorities is, that if a servant in the course of his master's employ drives over any person, and does a wilful injury, the servant, and not the master, is liable in trespass: if the servant by his negligent driving causes an injury, the master is liable in case: if the master himself is driving, he is either liable in case for his negligence, or in trespass, because the act was wilful."

Sharrod $\mathrm{v}$. And again, in Sharrod v. The London and Nortin The London Western Railuay Company (z), which was also an ac. and Norlh Western Railway Co. tion of trespass for driving a railway engine over and killing the plaintiff's sheep. The sheep had got on the railway in consequence of a defect of fences, and were run over by an express train drawn by a locomotive engine driven by a servant of the company, who had directions to drive at a certain rate per hour. But it was held the company were not liable to an action of trespass, although the injury was caused by the direct act of their servant, as they did not order him to drive over the sheep, nor was his doing so the necessary or

(y) 4 Exc. 365 ; D. \& L. 87.

(z) 4 Exc $5=0 ; 7$ D. \& L. 213. 
probable consequence of executing the orders of the Sharrod $\mathrm{v}$. company. And Lord Wensleydale said,-

The London

"The immediate act which caused the damage to the and North plaintiff's cattle was the impact of a machine which was under the control of a rational agent, the servant Weslern Railof the defendants; not so much so, indeed, as a horse or carriage drawn by horses or propelled by mechanical power along an ordinary highway would be, in which cases both the direction and the speed of the machine are under government, but still in such a degree as to make the cases similar for the purpose of deciding the present question. We may treat the case, then, as if the damage had been done by an ordinary carriage drawn by horses; and it being now settled that an *action of trespass will lie against a corpora. [*374] tion $(a)$, we may consider for the present purpose the defendants as one natural person and the carriage under the eare of his servants. Now the law is well established on the one hand, that whenever the injury done to the plaintiff results from the immediate force of the defendant himself, whether intentionally or not, the plaintiff may bring an action of trespass; on the other, that if the act be that of the servant, and be negligent, not wilful, case is the only remedy against the master. The maxim 'Qui facit per alium, facit per se' renders the master liable for all the negligent acts of the servant in the course of his employment; but that liability does not make the direct act of the servant the direct act of the master. Trespass will not lie against him; case will, in effect, for employing a careless servant; but not trespass, unless, as was said by the Court in Morley v. Gaisford (b), the act was done 'by his. command;' that is, unless either the particular act which constitutes the trespass is ordered to be done by the principal, or some act which comprises it; or some act which leads by a physical necessity to the act complained of. The former is the case, when one, as servant, is ordered to enter a close to try a right, or otherwise; the latter, where such a case occurs Gregory v. Piper $(c)$, where the rubbish ordered to be removed from a natural necessity fell on the plaintiff's soil; but when the act is that of the servant in performing his duty to his master, the rule of law we consider to be that case is the only remody against the master, and

(a) See Maund v. The Monmouth Canal Co., 4 M. \& G. 452.

(b) 2 II. Bl. 44\%, ante, p. 371.

(c) 9 B. \&. C. 591 , ante, p. 368. 
Sharrod $\mathrm{v}$. then only is maintainable when that act is negligent or The London improper; and this rule applies to all cases where the and North

Western Railway Co. carriage or cattle of a master is placed in the care and under the management of a servant, a rational agent. The agent's direct act is not the direct act of the mas. ter. Each blow of the whip, whether skilful and careful or not, is not the blow of the master; it is the vol. untary ast of the servant; nor can it, we think, be reasonably said that all the acts done in the skilful and careful conduct of the carriage are those of the master, for which he is responsible in an action of trespass, to the same extent as if he had given them himself, because he has impliedly ordered them; but those that were careless and unskilful were not, for he has given no order, except to use skill and care.

"Our opinion is, that in all cases where a master gives the direction and control over a carriage, or animal, or chattel, to another rational agent, the master is only responsible in an action on the case for want of skill or care of the.agent-no more; consequently this action cannot be supported.

"We should observe, that though the master in this case is taken to have ordered the driver of the engine to proceed at a great speed, it did not follow as a necessary consequence that it would impinge on the plain. tiff's cattle. It might not have happened if the driver had seen the cattle sooner or the cattle had heard the [*375] engine and got out of the way. *The act, therefore, cannot be treated as a trespass on the ground that it was by necessary implication ordered to be done by the defendants - the principle on which the case of Gregory v. Piper was decided. This is the simple case of an act done by the servant in the course of his em. ployment, not specifically ordered by the master; and though the injury by such an act be direct so far as relates to the servant, we have recently held that a master would not be responsible in trespass" $(d)$.

So it has been held (e) that a railway company was

(d) Gordon v. Rolt, 4 Exc. 365; 7 D. \& L. 87, ante, p. 372.

(e) Roe v. The Birkenhead, Lancashire and Cheshire Railway Co., 21 L. J., Exc. 9 ; 7 Exc. 36. In this case a letter written by the solicitor to the company, with a view to a compromise, was held not to be evidence of ratification by the company of the act done. See also Poulton v. London and South Western Railuay Co.. 8 Best \& S. 616 ; 36 L. .J., Q. B. 294, ante, p. 342, where the eompany were held not liable to an action in consequence of their officer having given the plaintiff in charge for travelling without a ticket for ecrtain horses. But see the case of Roe $\mathrm{v}$. The Birkenhead, \&e. Railway Co., explained by Blackburn, J., in 
not liable to an action of trespass for an arrest of the Roe v. Birplaintiff by one of the officers of the company (for non- kenhead, \&e. payment of an excess of fare claimed, but not due), as Railuay Co. there was no proof of any authority, either express or implied, given by the defendants, or of any ratification by them of the act done.

The same principles which render a man liable to be So, a man sued in an action of trespass for the wrongful act of his may be servant will also render him liable to be sued in that liable in form of action for the wrongful act of one who is not, trespass for strictly speaking, his servant.

Thus, where $(f)$ the defendant, who, together with servant a party of friends, had hired a carriage and four horses, M' Langhlin driven by two postillions in the service of the owner of v. Prior. the horses, to go to Epsom, rode on the box of the carriage, and in going through a toll-bar, at which there was a crowd, called out to the postillion on the leader "go in there," pointing to a position in front of a gig in which the plaintiff was riding, which belonged to and was driven by M., and the postillion pushed his horses forward, and in doing so, upset the gig and the plaintiff, and M. fell *out. Some one in the L*376] carriage cried out "go on, go on," but M. got up, stopped the horses and would not allow the carriage to proceed, although the defendant offered to settle then, until the defendant gave his card, saying, that he would be answerable for all that had occurred if M. would allow him to proceed. The defendant was held liable in trespass for the injury sustained by the plaintiff; although, according to the decision before adverted to in the case of Quarman v. Burnett $(g)$, the postillions conld not be considered as his servants : Erskine, J., saying-

"The cases in which it has been decided that case will not lie against the hirer of a carriage and horses for the misconduct of the driver, not being his servant, do not apply here; for this is an action treating the defendant as a co-trespasser, and is not brought against him as a master for the misconduct of his servant."

An exception, however, to the general rule, which ren- Superior ders a man responsible in a civil action for the tortious publieofficers: acts of those employed by or under him, is to be found

Goff v. Great Northern Railway Co., 30 I. J., Q. B. 148. There is no douht now that a railway company may be liable to an action for filse imprisonment for the act of theirafticer. See ante, p. 328 , note $(t)$.

(f) M'Laughlin v. Prior, 4 M. \& G. 48.

(g) Ante, p. 351 . 
M'Laughlin in the case of public officers, such as the postmasterv. Prior. general, the lords commissioners of the treasury, the commissioners of customs and excise, the auditors of the exchequer, \&c., who are not liable for any negligence or miscondect of the inferior officers in their Lane v. several departments $(h)$. The principle upon which Cotton. their non-liability depends was settled in the year 1699, in an action brought against the postmaster general, for the loss of a letter containing exchequer bills, by the negligence of his servants and deputies; and three judges, against Lord Holt, held, that the plaintiff was not entitled to recover $(i)$.

The ground of the op:nion of the three judges appears to have been, that the post-office establishment is a branch of the public police created by statute for purposes of revenue as well as for public convenience, and that the Government have the management [*377] *and eontrol of the whole concern. It is, in short, a Government instrument, established for its own great purposes. The postmasters enter into no contract with individuals, and receive no hire, like common carriers, in proportion to the risk and value of the letters under their charge, but only a general compensation

Whitfield v. from Government. The same question was again still Lord Le more elaborately discussed in a case in the time of Lord Despencer. Mansfield (k), brought against the postmaster-general, to recover the amount of a bank-note stolen out of a letter by one of the sorters of letters, when the court adhered to the doctrine of the three judges, in Lane $v$. Cotton, against the opinion of Lord Holt $(l)$. And Lord Mansfield said,-

"The ground of Lord Chief Justice Holt's opinion in that case is founded upon comparing the situation of the postmaster to that of a common carrier, or the master of a ship taking goods on board for freight. Now, with all deference to so great an opinion, the comparison between a postmaster and a carrier and the master of a ship seems to me to hold in no particular whatever. The postmaster has no hire, enters into no contract, carries on no merchandise or commerce. But the post-office is a branch of revenue and a branch of

(h) Cowp. 766; see Story on Agency, 319. The subordinates themselves, however, may be responsible, Rowning v. Goodchild. 3 Wills. 543; 2 W. Bl. 906 ; Stock v. Harris, 5 Burr. 2709, post.

(i) Lane v. Cotton, 2 Lord Raym. 646; 12 Mod. 482; seo Winterbottom v. Wright, 10 M. \& W. 109.

(k) Whitfield v. Lord Le Dispenser, Cowp. 754.

(l) Page 764. 
police, created by Act of Parliament. As a branch of revenue there are great receipts; but there is likewise a great surplus of benefit and advantage to the public, arising from the fund. As a branch of police, it puts the whole correspondence of the kingdom (for the exceptions are very trifling) under Government, and intrusts the management and direction of it to the Crown and officers appointed by the Crown. There is no analogy, therefore, between the case of the postmaster and a common carrier" $(m)$.

Upon similar principles, the captain of a man-of-war Nicholson $\mathrm{v}$. has been held not responsible for damage done to an- Mouncey. other vessel by his ship during the watch of the first lieutenant, who was on deck and had the direction of the ship-the captain not being on deck, nor called upon by his duty to be so, as he did not appoint the officers or crew, and had no choice whether he would serve with them or not, and had no power of dismissal over them. They were, in fact, *all servants of the [*378] same master $(n)$. These three last-mentioned cases were, in fact, decided upon the ground that the Government was the principal and the defendant merely the servant $(o)$.

But this exception would not apply so as to exempt Aliter, for a person, who was a public officer, from responsibility for the act of one who was his own servant. And, therefore, in Lord North's case $(p)$, where it appeared that King Edw. 6 sold a quantity of lead, and appointed Lord North, who was Chancellor of his Court of Augmentations, to take bond for payment of the money, and Lord North erdered his clerk to take the bond, which was done, and the bond delivered to Lord North, who gave it back again to his clerk in order to send it baek again to the clerk of the Court of Aurmentations, but Lord North's clerk suppressed the bond: it was the opinion of all the judges of England, that Lord North was chargeable to the king.

Another exception to the general rule above stated was formerly supposed to be found in that class of cases in which commissioners appointed under Acts of Par-

(m) See Story on Bailm. s 462; Story on $A$ gency, s. 319 , note 2.

(n) Nicholson v. Mouncey, 15 East. 384.

(o) See per Blackburn, J., in Mersey Docks and Harboner Board v. Gibbs, 35 L. J. Exc. 231. See also Buron v. Denman, 2 Exe. 167.

(p) Dyer, 161; see Boson v. Sandford, 3 Mod. 323; and see Wildes v. Norris, 22 L. J., MI. C. 4, as to how far deputy clerk of the peace is liable for the negligence of his assistant, pursuant to 5J Geo. 3, c. 2$\}$. 
Public commissioners, turnpike trustees, \&c. liable in certain cases. liament, for local purposes, and acting gratuitonsly, such as comraissioners of sewers $(q)$, paving commissioners $(r)$, navigation commissioners $(s)$, \&c., and trustees of turnpike roads $(t)$, were held not responsible for damage done by persons acting nnder their orders, in [*379] carrying into effect $*$ the purposes for which they were appointed $(u)$. In such cases the commissioners, \&c. are of course not responsible for the consequences of acts which they are authorized to do $(x)$, if done

(q) Jones v. Bird, 5 B. \& Ald. 844; and see Clayards v. Dethick, 12 Q. B. 439.

(r) Leader v. Yoxton, 2 W. Bl. 924; 3 Wils. 461; Governor, de. of Cast Plate Manufactuvers v. Meredith, 4 T. R. 794; Hall v. Smith, 2 Bing. 156.

(s) Allen v. Hayncard, 7 Q. B. 968, note.

(t) Sutton v. Clarke, 6 Tannt. 29; Harris v. Baker, 4 M. \& S. 26; Duncan v. Findlater, $6 \mathrm{Cl}$. \& Fin. 903. In $R$. v. Pocock, 17 Q. B. 34, it was held that trustees for repairing a road were not chargeable with manslanghter of a person who was accidentally killed in consequence of the road being ont of repair, as their neglect of duty was not immediately connected with the death.

(u) As to the proper mode of recovering from such commissioners salary due to officers appointed by them, such as street-keeper loy paving commissioners, see Bogg v. Pcarse, 10 C. B. 534; 2 L. II. \& P. 21; clerk, Kendall v. King, 25 L. J., C. P. 132; 17 C. B. 483; Bush v. Martin, 33 L. J., Exe. 17: Richardson v. Corcoran, 7 Ir. C. L. Rep. 121 ; Hall v. Taylor, 27 L. J., Q. B. 311 ; 1 E. B. \& E. 197; organist, Edwards r. Loundes, 1 E. \& B. 81. It would seem that the remedy by mandamus is inapplicable, Bush $\mathrm{v}$. Beavan, 32 L. J., Exc. 54. See Bush v. Martin, ubi supra. See also 1 Bail. C. C. 141. Debt will not lie for salary due out of borough fund, Addison v. Mayor of Preston, 12 C. B. 108.

(x) Protection is sometimes given by Acts of Parliament to persons acting in pursuance of them. A person is entitled to that protection who acts bona fide and in the reasonable belief that he is pursuing the Act of Parliament, althongh he is really not doing so; for as observed by Pollock, C. B., in Hughes v. Buckland, one who acts in perfect execution of the Act of Parlianent does not stand in need of protection. The protection is required by him who acts illegally, but under the belief that he is right. See Parton v. Williams, 3 B. \& Ald. 330; Hughes v. Bucklend, 15 M. \& W. 346; 3 D. \& L. 702; Huggins v. Waydey, 15 M. \& W. 357; Daris v. Curling, 8 Q. B. 286; Sinith v. Hopper, 9 Q. B. 1005; Kine v. Evershed, 10 Q. B. 143; Horn พ. Thornborough, 3 Exe. 846 ; 6 D. \& L. 651; Gosden v. Elphick, 4 Exc. 445; 7 D. \& L. 194; Bhunday v. Stubbs, 1 L. M. \& P. 675; see also Kent v. Great Western Railway Co., 4 D. \& I. 481; 3 C. B. 714, et cas. ib. cit.; Booth v. Clive, 2 L. M. \& P. 283; Read v. Coker, 13 C. B. 850; Arnold v. Hamel, 9 Exc. 408; Burling v. Harley, 27 L. J., Exc. 258; Hermann v. Seneschal, 32 L. J., C. P. 43; Whatman v. Pearson, L. R., 3 C. P. 422. In Neuton v. Ellis, 5 E. \& B. 115, it was held that a contracter, under a local board of health, was entitled to notice of action under sect. 139 of the Public Health Act, 11 \& 12 Vict. c. 63; and see Mason v. Birkenhead Improvement Commissioners, 29 L. J., Exc. 407; Poulson v. Thirsk, 36 L. J., C. P. 225. Where powers are given by local Acts, to trustees or commissioners, bond 
within the limits of their powers and with due care and attention; and, on the other hand, if they exceed their powers, they are also of course liable $(y)$; and so they are if they act wantonly and oppressively $(z)$, or maliciously $(a)$, or even carelessly and negligently $(b)$, in *the exercise of their powers. And it was also [*380] at one time supposed that such persons because they acted gratuitously, were not liable for the negligent execution of orders properly given by them.

The cases in which these principles were applied are numerous (c), but were most broadly stated by Lord Wynford, in the case of Hall v. Smith $(d)$.

That was an action on the case for negligently leav- Hall $\mathrm{v}$. Smith. ing a ditch or tunnel open, into which the plaintiff fell and was injured. The defendants were the clerks to the commissioners for paving, \&c., Birmingham (who, by Act of Parliament might be sued in the name of their clerks), the surveyor, the contractor, and a workman, who was in the ditch when the accident happened. The jury found a verdict for the workman, and against all the other defendants, but the verdict against the clerks to the commissioners was afterwards set aside, and a verdict ordered to be entered for them.

fides is immaterial, although it seems to be sufficient, to entitle them to the protection of the statute, if they are trustees, \&e. de facto. Harrison v. Varty, Q. B., Trin. T. 1815, eited by Parke, B., in Hughes v. Bucktand, 15 M. \& W. 356; Brahtem v. Watkins, 4 D. \& L. $42 ; 16$ M. \& W. 77 . But where protection is given to a person filling a particular charaeter, he must, to entitle himself to the protection, fill that character at least de fucto. It is not sufficient for him to think he fills it, Hopkins v. Crowe, 4 A. \& E. 774 .

(y) Jones v. Bird, 5 B. \& Ald. 84.1; Clayards v. Dethiek, 12 Q. B. 439 .

(z) See per Gibbs, C. J., in Sutton v. Clarke, 6 Taunt. 43; per Bayley, J., in Boutton v. Crouther, 2 B. \& C. 709.

(a) See Acland v. Buller, 1 Exc. 837; Walker v. Goe, 3 II. \& N. 395,404 .

(b) Jones v. Bird, 5 B. \& Ald. 844; see 2 B. \& C. 711. The plaintiff must at least show negligence, Whitehouse v. Birmingham Canal Co., 26 I. J. Exe. 25; Whitchouse v. Fellowes, 30 I. J., C. P. 305; 10 C. B., N. S. 779.

(c) See, in addition to the eases cited in Hall $\mathrm{v}$. Smith, Bonlton v. Cronother, 2 B. \& C. 703; Mntnean v. Finllater, 6 Cl. \& Fin. 90:; Allen v. Huyward, 7 Q. B. 968, note; Pilgrim v. 'Southampton, \&e. Railway Co., 7 C. B. $205,228$.

(d) ¿ Bing. 156; see Parnaby v. The Lancaster Canal Co., 11 A. \& E. 223. In Scott v. Mayor of Wanchester, 1 H. \& N. 60, Mllerson, B., said, "Ifall v. Smith goes too far ; the person who selects the workmen is the party liable. Commissioners may get rid of liability by making contracts; but if they employ their own servants to do the work, they will be liable for the acts of such servunts."

22 MAS. \& SER. 
Overrulcd.

But that case must now be considered as overruled, in so far as it can be taken to lay down any such doctrine as the non-liability of such persons for acts done by their orders in supposed execution of their powers. And inasmuch as corporations formed for trading and other profitable purposes, although they may act without reward to individual members of the corporation, are in their nature mere substitutions for individuals, the true rule of construction must now be taken to be, [*381] that, in the absence of anything in *the statutes which create such corporations showing a contrary intention, the legislature intended that the liability of corporations thus substituted for individuals should, to the extent of their corporate funds, be co-extensive with that imposed by the general law on individuals who are owners of similar works. If, indeed, the legislature, either by express enactment or necessary intendment, enacts that they should not be subject to such a liability, then of course there can be no question as to their nonliability. But in the absence of any express or implied exemption from liability, the liability of corporations must now be considered as co-extensive with that of individuals.

Mersey Doeks

This was decided in the House of Lords in the cases and Harbour

Board v.

Gibbs.

Same v.

Penhalloro. referred to in the note $(e)$, in which it was held that trustees appointed by statute for public purposes with power to levy toll, but not deriving any personal benefit, are liable in their corporate capacity for damage sustained by reason of the default of their servants or agents to the same extent as absolute owners levying

(e) The Mrrsey Docks and Harbour Board v. Gilbs; Same v. Penhallow, 35 L. J., Exc. 225. See also Coe v. Wise, 37 L. J., Exc. 262. In these cases all the previous anthorities are referred to and most elaborately and carefully discussed. See also Foreman v. Mayor of Canterbury, 40 L. J., Q. B. 138; Hammond v. Vestry of St. Paneras, 43 L. J., C. P. 157 ; Winch v. Conservators of River Thames, 43 L. J., C. P. 167 ; Hill v. Hawker, 43 I. J., Exc. 129; 44 I. J., Exc. 49 ; Forbes v. Lee Conservancy Board, 48 L. J., C. L. 402 ; I. R., 4 Exc. 116 ; White v. Hindley Loeal Board, 44 L. J., Q. B. 114 ; L. R., 10 Q. B. 219 ; Blackmore v. Vestry of Mile End, 51 L. J., C. L. 496 ; Jolliffe v. Wallasey Local Board, 43 L. J., C. P. 41 ; L. R., 9 C. P. 62 ; Kent v. -Worthing Loeal Board, 52 L. J., Q. B. $77 ; 10$ Q. B. D. 118 . In Frankleton v. Sherloek, 8 Ir. C. L. Rep. 90 , it was held that commissioners acting nnder the Irish Town. Improvement Act, $1854,17 \& 18$ Vict. c. 103 , were not liable for the act of a watchman appointed by them, who arrested the plaintiff on her way to church, and charged her with being an improper character, on the ground that he was not appointed to discharge any duty which belonged to them to discharge. 
tolls for their own profit, although there is no improper conduct on the part of such trustees.

Another exception to the general responsibility of a Master not master for the tortious acts of his servant is established liable to one by the cases already considered in the preceding chapter $(f)$, in which it has been held that a master is not anothes responsible * to his own servant for any injury [*382] happening to him through the negligence or wrongful act of a fellow-servant. In order, however, to bring a case within this exception it must, as we have seen, appear that both the servant injured and the wrongdoer were at the time the injury was done, acting in the service of the common master, and also, that the wrongdoer was a person of ordinary skill and care. But where these circumstances concur, the party injured has no remedy against his master $(g)$, except in cases within the Employers' Liability Act, 1880, which will be found in the Appendix.

(f) Ante, p. 236 et scq.

(g) See Story on Ag. $453 d$. 
(340)

[*383]

*CHAPTER VI.

THE LIABILITY OF A SERVANT TO THIRD PERSONS FOR ACTS DONE ON BEHALF OF HIS MASTER.

In Cases of Contract . . . \begin{tabular}{r|rr} 
PAGE & 383 & In Cascs of Tort-Civiliter 415
\end{tabular} In Cases of Tort-Criminaliter 403

\section{In Cases of Contract.}

Servant not generally liable upon contracts entered into in his master's name;

but may be liable.
Generaliy speaking, a servant who, having authority to do so, enters into a coutract in his master's name, is not himself personally liable upon such contract $(a)$, though he may, undoubtedly, like any other agent, contract in such a manner as to make himself personally liable (b).

In order to make a servant liable personally on a contract made in his master's name, there must be some wrong or omission of right on the part of the servant (c). Thus, if he do not possess authority from his master to contract in his name, or, which is in effect the same thing, if he exceed the authority given him, and fraudulently misrepresent his authority, there can be no doubt that he will be personally liable to the person with whom he deals in his master's name. If, however, the person dealing with him knows of his want of authority and yet chooses to charge the master, it would seem that the servant could not afterwards be made liable in the event of the master failing to pay [*384] $(d)$. Questions of this sort frequently *resolre themselves into mere questions of credit. To whom was the credit given? The answer to which must depend upon the circumstances of the case. If the credit was given to the master, the servant could not be made liable, provided he had authority to contract. But if

(a) Paley on Ag. 368 ; Story on Ag. 261 ; Ex parte Hartopp, 12 Ves. 352 ; Owen v. Gooch, 2 Esp. 567.

(b) Per Ashurst, J., in Macbcath v. Haldimand, 1 T. R. 181; per Bayley, J., in Thomson v. Davenport, 9 B. \& C. 89 ; and in Burrell v. Jones, 3 B \& Ald. 50.

(c) Smout v. Ilberry, 10 M. \& W. 1.

(d) Paterson v. Gandasequi, 15 East, 62 ; 2 Smith's L. C. '313. 
the credit was given to the servant, even for goods supplied for his master's use, he could not discharge himself from liability on the ground that he was a mere agent. A servant would also be liable if, at the time he entered into a contract, he did not disclose his master's name, and it was not known to the party contracting with him, although he was known to be a mere agent $(e)$.

The following rather curious case shows the difficulty servants may get into by using their own names when in reality acting for their masters $(f)$.

The plaintiff, a farmer, put up the produce of his Willianson $\mathbf{v}$. farm to auction. The defendant had been, for some Barton. time previous to and at the time of the sale was, foreman to S., a contractor, which was well known to the plaintiff who was present at the sale, but was not known to the auctioneer. The defendant at the auction bid for several lots of hay, and when the auctioneer asked for his name, in the usual way, he answered "Barton" only, and the auctioneer wrote it down as the name of the buyer. A fow days after the sale the auctioneer sent in an account to the defendant. The hay was without any direction or interference of the defendant, taken away in S's. carts, and consumed by his horses before his death, which occurred ten days after the auction. An action was brought against the defendant for the price of the hay, to which the defense set up was that plaintiff bought the hay for his master $S$. At the trial the jury found for the defendant. But upon a rule for a new trial the judges were equally divided in *opinion as to his liability, and leave [*385] to appeal was granted, but the appeal does not appear to have been argued.

But where a servant has once had authority to contract in his master's name, and the authority is revoked without his knowledge, he would not be liable upon contracts entered into in his master's name, in ignorance of the revocation of his authority. If for instance, a man leaves a housekeeper in possession of his house, and goes abroad and dies, the housekeeper would not be liable to pay for goods obtained on her master's credit after his death, and before she knew of his

(e) So in the case of auctioneers, Janson v. Roberdean, Peake, 163 ; Franklyn v. Lamond, 4 C. B. 637. See Fisher v. Marsh, 34 L. J., Q. B. 177 .

(f) Williamson v. Barton, 31 I. J., Exc. 171. In Ex parte Bird, $33 \mathrm{I}$. J., Bankr. 49, an agent taking shares in his own names was held liable as a contributory.

Servant not liable if his authority revoked without his knowledge. 
Death of master.

How servant can avoid personal liability upon contracts entered into on behalf of his master.

Clerks held liable on bills drawn for their master. death, provided they were of a description which she was authorized by her master to pledge his credit for during his life $(g)$; although in such case her master's representatives would not be liable, as her authority to pledge his credit was in fact revoked by his death $(h)$. When clerks or other servants enter into written con. tracts on behalf of their employers, they should be care. ful to do so in such a manner as to exclude the possi. bility of their being personally liable themselves upon such contract, in the event of their employer failing to perform the engagements thus entered into. For if such a contract purport on the face of it to bind the clerk, or party signing it, himself personally, it is not competent for him to discharge himself from liability by evidence that he was acting merely in a ministerial capacity as agent for his employer $(i)$. To exempt himself from personal responsibility, a clerk should either sign his employer's name, or, if he signs his own, should expressly state his ministerial character, as by using the words "per procuration," or other words of a similar import $(k)$.

[*386] *The necessity of the above caution is exem. plified by the following cases, in which clerks have been held personally liable upon bills of exchange ac. cepted or drawn for the benefit of their employers:-

Thus, where $(l)$ the defendant accepted generally a

(g) Smout v. Ilberry, 10 M. \& W. 1. 47.

(h) Blades v. Free, 9 B. \& C. 167 . See $44 \& 45$ Vict. c. 41, s.

(i) Higgins v. Senior, 8 M. \& W. 834 ; see 2 Smith's L. C. 351. And see $i b$. that the master himself may be liable if he were the real principal. See also Calder v. Dobell, 40 L. J., C. P. 89, 225. But if the written contract describe the person who is really only an agent as principal, the real principal can neither sue nor be sued upon the contract, Iumble v. Hunler, 12 Q. B. 310 .

(k) As to indorsement forged "by procuration," see Charles v. Blaekvell, 46 L. J., C. L. 368.

( $l$ Thomas v. Bishop, 2 Str. 955 ; see Healey v. Story, 3 Exc. 3. Mr. Justice Story, in his work on Agency, s. 159, note 3, and 269 , note 1 , seems to doubt the authority of Thomas v. Bishop, and, in the latter note, quotes an American case to show that such notes as that in Thomas v. Bishop are, in America, regarded as drawn upon the drawee in his official capaeity. But in the case he quotes, the acceptance was "as agent." And it would seem that the mode in which the bill in Thomas v. Bishop was addressed to the defendant, left it ambiguous whether the words "cashier," \&c., were mere words of description or not, and the defendant, by accepting the bill generally, showed that he considered the bill to be addressed to him personally, and not in hi. official character. See the observations of Patteson, J., in Dati. v. Clarke, 6 Q. B. 16 . See Jenkins v. Morris, 16 M. \& W. 877, which is a case the converse of Thomas v. Bishop.

(404) 
bill of exchange directed to him by the name of " $\mathrm{H}$. Thomas v. B., cashier of the York Buildings Company," he was Bishop.

held personally liable for the amount of the bill to an indorsee, although he proved that the letter of advice was addressed to the company, and that the bill being brought to their house, he was ordered to accept it, which he did in the same manner that he had accepted other bills. For the bill, on the face of it, imported to be drawn on the defendant, and it was accepted by him generally, and not as servant to the company, to whose account he had no right to charge it till actual payment by himself.

So where $(m)$ a broker, who was employed to sell Lefevre v. goods, drew a bill for the price on the purchaser, he Lloyd. (the broker) was held liable upon the bill, although it was contended that he merely drew as the servant of the seller; for, having put his name on the bill, all the legal consequences of the act attached to him as much as to any other person whose name was thereon.

Again, where $(n)$ a bill of exchange was directed to Nicholls $\mathrm{r}$. "Mr. James Diamond, purser, West Downs Mining Diamond. Company," and accepted thus: "James Diamond, accepted *per proc. West Downs Mining Com- [*387] pany," Diamond was held personally liable upon it, as the legal effect of the acceptance was that he accepted in his own right as principal, and as agent for all the other members of the firm, but as the bill was only directed to him he only was liable.

So where (o) a bill of exchange was directed to "Mr. Nare v. W. C.," and "accepted for the company, W. C. purser," Charles. W. C. was held personally liable: and Lord Campbell said,- -

"Thomas v. Bishop, it appears, has been doubted on the other side of the Atlantic, but for a century it has been uniformly considered good law in this country, and it is clearly in point. In Nicholls v. Diamond, the decision itself, and far the greater part of the reasoning in the judgments are precisely what we now adopt."

So where the trustees and secretary of a benefit build- Price $\mathrm{v}$. ing society signed promissory. notes in the following Faylor.

(m) Leferre v. Lloyd, 5 Taunt. 749; and see Sowerby v. Buteher, 2 C. \& M. 371.

(n) Nicholls v. Diamond, 9 Exe. 156.

(o) Mare v. Charles, 5 E. \& 13.978. Sce also Penrose v. Martym, 28 L. J., Q. B. 29, where the secretary to a joint-stock company (litnited) was held personally liable upon a bill which he accepted as secretary, but omitting the word "limited," under $19 \& \$ 0$ Vict. c. 47, s. 31 . 
Bottomley v. form: "Midland Counties Building Society. No. 3, Fisher. Birmingham, March 12, 1858. Two months after demand we promise to pay P. 100l., with interest after the rate of six pounds per cent. per annum. W. $R$. Heath, John Taylor, Trustees; W. D. Fisher, secretary :" both trustees $(p)$ and secretary $(q)$ were held to be personally liable.

Althongh And in such cases it makes no difference that a party party taking taking the bill, do so with full knowledge that a person the bill know whose name is on the bill is a mere servant. Thus, the clerk to be acting for his agent to a country bank, to whom the plaintiff sent a sum master.

Leadbitter $\mathrm{v}$. of money in order to procure a bill upon London, and who, thereupon, drew a bill in his own name for the amount upon the firm in London, the two firms being the Farrow.

[*388] same, *was held personally liable as drawer of the bill, although the plaintiff knew that he was agent, and supposed that the bill was drawn by him as such, and on account of the country bank, to which the agent paid over the money $(r)$. And Lord Ellenborough said,-

"Is it not a universal rule that a man who puts his name to a bill of exchange thereby makes himself parsonally liable, unless he states upon the face of the bill that he subscribes it for another, or by procuration of another, which are words of exclusion? Unless he says plainly, 'I am the mere scribe,' he becomes liable. Now, in the present case, although the plaintiff knew the defendant to be agent to the Durham bank, he might not know but that he meant to offer his own re. sponsibility. Every person, it is to be presumed, who takes a bill of the drawer, expects that his responsibility is to be pledged to its being accepted. Giving. full effect to the circumstance that the plaintiff knew the defendant to be agent, still the defendant is liable like any other drawer who puts his name to a bill without denoting that he does it in the character of procurator. The defendant has not done so, and therefore has made himself liable."

Reason. The rule illustrated by these cases is an inflexible

(p) Price v. Taylor, 29 L. J., Exc. 331; 5 H. \& N. 540.

(q) Bottomlcy v. Fisher, 31 L. J., Exc. 41\%. If a servant is called upon to pay a sum dne from his master which his master is liable to pay, but he is not, and after discussion and threat of litigation the servant gives a promissory note in his own name for the amount, he is bound to pay it when due, and cannot set up as a defence that there was no consideration for the note, Cook v. Wright, 30 L. J., Q. B. 321.

(r) Leadbitter v. Farrow, 5 M. \& S. 345; and see per Gibbs, C. J., in Goupy v. Harden, 7 Taunt. 162. 
one, and, is by no means confined to bills of exchange, but applies to other written contracts $(s)$, and is founded upon the principle before adverted to, that parol evidence is not admissible to contradict or vary any contract which has been reduced to writing $(t)$.

Where written contracts are entered into by cierks or Cases where other agents a difficulty frequently arises, from the mode it is doubtful in which they are worded, as to the meaning of the parties; whether serwhether they intended to contract for themselves per- vant bound sonally or not. In such cases the general rule applies, that the construction of written documents is for the court. And it may be said, that, generally speaking, the onus of proving that a person who has signed a written document merely acted as agent for some one else in so doing, *lies upon the agent who would [*389] exempt himself from responsibility $(u)$.

When the defendant convenanted "for himself, his Held liable heirs, executors, \&c., on the part and on behalf of " in Appleton A. B., that A. B. would pay a sum of money, the de- v. Binks. fendant was held personally liable $(x)$.

So where the solicitors of the assignees of a bank-Burrell $\mathbf{v}$. rupt, upon whose lands a distress had been put by the Jones. landlord, gave a written undertaking thus: "We, as solicitors to the assignees, undertake to pay," \&c.; they were held personally liable $(y)$.

Again, where "C., on the part of N.," agreed to let Tanner $\mathrm{v}$. certain premises to $\mathrm{P}$. for a term of years, and C. Christian. signed the agreement but $\mathrm{N}$. did not, $\mathrm{C}$. was held personally liable to an action for not completing the lease $(z)$.

So where "R. and F., of London, merchants," signed Lemnard v. a charter.party "by authority of and as agents for Mr. Robinson. A. H. S., of Memel," R. and F. were held personally liable for a breach of it. $(a)$.

(8) Jones v. Litlledale, 6 A. \& E. 486 ; Magee v. Atkinson, 2 M. $\&$ W. 440. See per Lord Wensleydale, in Higgins v. Senior, $8 \mathrm{M}$. \& W. 845; Kelner v. Baxter, 36 L. J., C. P. 94.

(t) Aute, p. 54 .

(u) Smith's Mere. Law,152.

(x) Appleton v. Binks, 5 Last, 148 . See Dounman v. Williams, 7 Q. B. 111 ; Norton v. Herron, 1 C. P. 648 ; Ry. \& M. 2:29.

(y) Burrell v. Jones, 3 B. \& Ald. 47; and see Jerson v. Connington, 1 B. \& C. 160; Hall v. Ashurst, 1 C. \& M. 714; Watson v. Mhrrell, 1 C. \& P. 307. In Clarke v. Lord Rivers, 37 L. J., Ch. 70, a demurrer was allowed to a bill filed against the client and the solieitor in the alternative.

(z) Tanner v. Christian, 4 E. \& B. 591 ; and see Reil v. Dreaper, 90 L. J., Exe. 268.

(a) Lenuard v. Robinson, 5 E. \& B. 125 ; sce also Cooke v. Willson, 26 L. J., C. P. $15 ; 1$ C. B., N. S. 153 ; Parker v. Winlow, 
And where the defendants signed a contract on behalf of a proposed company, they were held personally liable $(b)$.

Agent held [*390] *But where A. an auctioneer, entered into not liable in and signed an agreement as agent of B., and B. shortly Spittle $\mathbf{v}$. Lavender. afterwards signed it with these words, "I hereby sanction this agreement, and approve of A.'s having signed it on my behalf," it was held that $\mathrm{A}$. was not personally responsible $(c)$.

Downman v. And so where A. (an agent) made a promise in the Williams.

following terms: "I undertake (on behalf of Messrs. E. \& Co.) to pay," \&c., it was held to be (upon the face of it) an undertaking as agent, and not to be binding upon A. personally, as there appeared no want of authority on his part to make such an undertaking, and no excess of authority in making it $(d)$.

Lewis $\mathrm{v}$.

Nicholson.

So, again, where solicitors to certain assignees, "on behalf of the assignees," consented to do certain things, the solicitors were held not to be personally liable $(e)$.

Exparte

Buckley.

Mahony $\mathbf{v}$. Kekule.

And where a banker signed a promissory note, "I promise to pay," \&c., "for C. M. P. and S., R. M.," it was held that this did not give a separate right of action against the party signing $(f)$.

Again, where a contract was made in London, as follows: "Contract between Messrs. V. and T., Morlaix, France, and M. (plaintiff), London. M. engages himself hereby with Messrs. V. \& T., Morlaix, from, \&c., till, \&c., for the proper and merchantable cutting, messing and preparing of French provisions, at Morlaix (as pork, beef and bacon), on receiving a free passage

27 L. J., Q. B. 49 ; 7 E. \& B. 942 ; Paice v. Walker, 39 L. J., Exc. 109 ; Hongh v. Manzanos, 48 L. J., Exe. 398; L. R., 4 Exc. 104. But see Gadd v. Honghton, 46 L. J., C. L. 71 ; L. R., 1 Exc. 357. Where H. signed a charter-party "for D. \& Co., H. agent," it was held to be a good defence, by way of equitable plea, that it was originally agreed between plaintiff and defendant that defendant was only to sign as agent, and not to be personally liable. Wake v. Harrop, 30 L. J., Exc. 273.

(b) Kelner v. Baxter, 36, L. J., C. P. 94; Scott v. Lord Ebury, 36 L. J., C. P. 161 ; Richardson v. Williamson, 40 L. J., Q. B. 145 ; Dutton v. Mrrsh, 40 L. J., Q. B. 175; L. R., 6 Q. B. 361. As to the admissibility of evidence to show custon to make the agent personally liable, see Hutchinson v. Tatham, 42 I. J., C. P. 260 ; Southwell v. Bowditeh, 45 L. J., C. L. 630 , reversing S. C. ilid, p. 374 .

(c) Spittle v. Lavender, 2 Brod. \& B. 452 ; see Bowen v. Morris, 2 Tannt. 374.

(d) Downman v. Wiltiams, 7 Q. B. 103 ; see the American cases cited in Story on Ag. 154.

(e) Lewis v. Nicholson, 18 Q. B. 503.

(f) Ex parte Buckcly, 14 M. \& W. 469. 
ont to Morlaix from London and back again, and wages of 30 s. sterling per week, Messrs. V. \& T. finding the requisite tools. Should any differences arise on account of M.'s inability or improper conduct, this contract is to be considered null and void, and MI. has no claim for further wages nor free passage back to London." And signed, "For V. \& T. * Charles Kekule" [*391] (defendant). The defendant was held not to be personally liable $(g)$.

Again, where three directors signed a promissory note in this form: "Three months after date we jointly Lindus v. promise to pay F. S. or order $600 l$, for value received in stock on account of the L. \& B. Iron and Hardware Co., Limited;" they were held not to be personally liable $(h)$.

And where the secretary to a railroad company signed note in this form: "On demand I promise to pay R Alexander v: 1,500l. with legal interest until paid, value received. For the M. T. \& W. Railway Company. J. Sizer, Secretary ;" he was held not to be personally liable; Kelly, C. B., referring to the well-known form of a Bank of England note, for which no one ever thought of making the officer who signs personally liable $(i)$.

Where the plaintiff and several others, being per- Luens v. formers in the orchestra at the opera, Covent Garden, Beale. had a claim against the defendant for thirteen nights' salary, and negotiations took place in the green-room of the theatre, the plaintiff acting on behalf of himself and the other performers, and the plaintiff signed the following document: "The gentlemen of the orchestra, \&c. are willing and hereby pledge themselves to continue their services and attend their duties provided $B$. will guarantee the payment of the thirteen nights due on the 5th ult. Signed on behalf of the gentlemen of the orchestra. C. Lucas;" it was held to be a joint contract, and that the plaintiff could not sue alone for a breach of it $(k)$.

(g) Mahony v. Kekule, 14 C. B. 390 ; 23 L. J., C. P. 54 ; and see Grcen v. Kope, 18 C. B. 549, that in all cases it is a question of intention to be gatherel from the terms of the contract; whether the principal be a foreigner or not. See also Deslandes v. Gregory, 20 L. J., Q. B. 93; 30 L. J., Q. B. 36; where the defendauts, having signed a charter-party "as agents," were held not liable.

(h) Lindus v. Melrose, 27 I. J., Exe. $326 ; 3$ II. \& N. 177; see Aggs v. Nicholson, 25 L. J., Exc. 342; 111 . \& N. 165.

(i) Alexander v. Sizer, 35 J. J., Exe. 59. Where judgment has been obtained against the master, the servant camnot be sued. See Pricslley v. Fernie, 34 L. J., lixe. 172.

(k) Lueas v. Beale, 20 L. J., C. P. 13.4 ; 10 C. 13. 739. See also Jung v. Phosphate of Lime Co., 37 L. J., C. P. 73. 
Remedy against servant.

Servant not generally liable to third persons for money paid to him on account of his master.

[*392] *The remedy in England against a clerk or other agent, who professes to make a contract binding upon his master, but has no authority to do so, is either by an action for the deceit, alleging and proving the scienter, or probably on an implied contract that he had authority, but not by treating him as principal (l). In America, however, it would seem that he may, in some cases at least, be sued as a principal upon the instrument $(m)$.

A question, however, more frequently arises as to the personal responsibility of a clerk, or other servant, or agent, to persons other than his master, or principal, for money which has been paid to him on account of his master. And the question is one of much importance, and some difficulty. The general rule applicable to cases of this sort, undoubtedly, is respondeat supevior $(n)$. Payment to a clerk, or servant, authorized to receive the money $(o)$, is payment to the master, who receives by the hand of his clerk $(p)$. Generally speaking, therefore, when money is rightfully obtained by, or paid to, a clerk, or other servant, authorized to [*393] receive it on account of his *master, any action to recover it back should be brought against the mas-

(l) See Polhill v. Walter, 3 B. \& Ad. 114 ; Jenkins v. Hutchinson, 13 Q. B. 744 ; 18 L. J., Q. B. 274 ; Lewis v. Nicholson, 18 Q. B. 503, 515 ; Collen v. Wright, 26 L. J., Q. B. 147; 7 E. \& B. $301 ; 27$ L. J., Q. B. 215 ; 8 E. \& B. 647 ; Simons v. Patchett, 26 L. J., Q. B. 195 ; 7 E. \& B. 568 ; Randell v. I rimen, 25 L. J., C. P. 307; 18 C. B. 786 ; Eastuood v. Bain, 3 H. \& N. 758 ; Richardson v. Dunn, 30 L. J., C. P. 44 ; Pow v. Daris, 30 L. J., Q. B. 257 ; 1 Best. \& S. 220 ; Hughes v. Græme, 33 L. J., Q. B. 335 ; Spedding v. Nevell, 38 L. J., C. P. 133 ; Cherry v. Bank of Australasia, 38 L. J., Pr. C. C. 49 . See also Engell v. Fitch, 37 L. J., Q. B. $145 ; 35$ L. J., Q. B. 304 ; Godxin v. Francis, 39 L. J., C. P. 121 ; Beatlie v. Lord Ebury, 41 L. J., Ch. 804 ; 44 L. J., Ch. 20 ; Weeks v. Propert, 42 L. J., C. P. 129 ; Chapleo v. Brunswick Benefit Building Society, 50 L. J., C. L. 372. In Richardson v. Williamson, 40 L. J., Q. B. 145 , Cockburn, C. J., said he would allow the pleadings to be amended, so as to fix the defendants. See also West London Commercial Bank v. Kitson, 53 L. J., C. I. 218, 345.

(m) Story on Ag. 264, note; see also 2 Smith's L. C. 340.

(n) See ante, p. 322 , note $(m)$.

(o) Otherwise he is a mere stranger. See Bridges v. Garrett, 38 L. J., C. P. 242 ; 39 L. J., C. P. 251.

(p) See Ex parte Byrne, 35 L. J., Bankr. 43, that possession by a clerk of his master's books is possession by the master. In $R$. v. Lambton, 5 Price, 428, where a man made up a parcel of bills and notes and gave them to his servant to give to the postman, it was held to be clear that until the servant had done so they were in the possession of the master, and liable to be seized under an extent against him, and that, although the bills were specially indorsed. 
ter $(q)$. And this rule is but just: for since, in general, an agent cannot dispute the title of his principaland it is only in very special cases $(r)$ that he can set up jus tertii against his principal-a servant who had recei ved money on account of his master could not dispute his master's right to it, and to hold him responsible to third persons would be to subject him to two actions for the samo cause.

Upon this principle depends the case of Sadler v. Sadler $\mathbf{v}$. Evans (s). In that case it appeared that the defend-Evans. ant, as receiver to Lady W., received quit-rent due to her from the plaintiff, and gave a receipt for it as such. The plaintiff, contending that Lady $W$. was not entitled to the quit-rent, brought an action for money had and received against the receiver, but was nonsuited on the ground that the payment to the receiver was payment to Lady W., and the action ought to have been brought against her. And the court, in discharging a rule which had been obtained to set aside the nousuit, observed, that in case of payment to a known agent, the action ought to be brought against the principal, unless in special cases (as under notice, or mala fide).

The principle upon which Sadler v. Evans was de- Naster licided may be not inaptly illustrated by a case the exact able. converse of it. The defendant's agent, R., had con- The Duke tracted to sell an estate belonging to the defendant to of Narfolk $\mathbf{v}$. the plaintiff, and had received a deposit from him ; but Wortiy. the conditions of sale not being complied with, the plaintiff brought an action against the defendant to recover his deposit. On the part of the *de- [*394] fendant it was objected that no proof was given that the deposit had been paid over to him, and, in fact, it had not been paid to him. But Lord Ellenborough said it made no difference whether it was actually paid over or not; $R$. acted completely as the agent of the defendant ; therefore, when the deposit was lodged with

(q) Selw. N. P. 102, 11th ed.; Smith's Mere. Law. 153; Paley on Ag. 389 ; see Henming v. Hale, 29 I. J., C. P. 137; Collins v. Brool, 29 L. J., Exe. 255.

$(r)$ Such, for instance, as where the master has been guilty of frand, see IIardman v. Wilcox, 9 Bing. 34\%, note; Chersman $\mathrm{v}$. Exall, 6 Exc. 341 ; Sheridan v. New Quay Co., 28 I. J., C. P. 58 ; or what is equivalent to eviction by title paramount, Biddle v. Bond, 34 L. J., Q. B. 197 ; 6 Best \& S. 225.

(8) 4 Burr. 1985 ; see Grecuway v. IItrd, 4 T. R. 5.55; Sterenson v. Mortimer, Cowp. 806 ; ace. in Ameriea, Colvin v. Holbrook, 2 Comst. Rep. 126. 
the agent, this was, in law, eo instanti a payment to the principal $(t)$.

Clerk not liable.

Edden v. Read.

Stephens v. Badcock.

And the following cases, where the action was against the clerk, servant, or agent, were decided upon similar principles:-The defendant, a banker's clerk, signed a receipt for money paid into the bank by the plaintiff, thus: "For Spooner and Attwood, Wm. Read." He was held not liable to an action for money had and re. ceived at the suit of the plaintiff; but the action should have been brought against Spooner and Attwood; the receipt being evidence that they, and not the defendant, had received the money $(u)$.

And so an attorney's clerk, who, in his master's absence, received some money which was paid to him at his master's office, by a debtor to a client of his mas. ter, and signed a receipt thus, "For Mr. S. John, John Badcock," was held not responsible to the client for the money, although he had not paid it over to his master, as he was accountable to his master for it, and the client must look to him for redress. And Lord Tenterden said, "It is perfectly clear that the defendant received the money as the agent or servant of John, and must have paid it over to him if he had returned. The receipt given was the receipt of John, and (if he had not been bankrupt) would have been evidence against him in action brought by the present plaintiff $(x)$. Bamford $\mathrm{v}$. Upon similar principles it has been held $(y)$ that at-
Shuttleworth. torneys, who, upon an agreement for the sale of an Shuttleworth. torneys, who, upon an agreement for the sale of an
[*395] estate *belonging to one Stott, had, as his agents, received from the plaintiff a deposit, were not liable to an action at the suit of the plaintiff for a return of the deposit, on the sale going off for want of title in Stott, as they received the money as his agents, and to account to him. And Coleridge, J., said that payment over of the deposit was immaterial. The moment the money was in the defendant's hands it was in Stott's hands.

Cases against And so it has been held $(z)$, that an action for money revenue officers. had and received would not lie against a revenue officer

( $t$ ) The Duke of Norfolk v. Worthy, 1 Camp. 337 ; see Edgell $\mathrm{v}$. Day, 1 Harr. \& Ruth. 8; L. R., 1 C. P. 80.

(u) Edden v. Read, 3 Camp. 338.

(x) Stephens v. Badcock, 3 B. \& Ad. 354.

(y) Bamford v. Slenttleworth, 11 A. \& E. 926 ; and see Hurley v. Baker, 16 M. \& W. 26. I

(z) Whitbread v. Brooksbank, Cowp. 69; and see Greenway r. Hurd, 4 T. R. 555, where it appeared that the money had been paid over before action brought. 
for an over-payment; though, in a subsequent case (a), Whitbread $\mathrm{v}$. where the duty paid remained in the hands of the col- Brooksbank. lector not paid orer, with the consent of the attorney-Campbell $\mathrm{v}$. general, for the express purpose of trying the validity Hall. of imposing the duty, the court did not raise any objection to an action for money had and received against the collector. But in a more recent case (b) it was Atlec v. held, that the action would not lie against the receiver- Backhouse. general of excise, to recover duties said to have been overpaid to him, inasmuch as the money was paid to him for the purpose of being paid over pursuant to Act of Parliament, and it was not shown that it remained in his hands till he had notice to retain it. And the court said that, unless the contrary were proved, they would presume the money had been applied by a public officer, as it was his duty to apply it.

The rule exempting a clerk or other servant from re- Servant not sponsibility to third persons for money rightfully re- liable if he ceived on account of his master, applies $\dot{a}$ fortior $i$ where has paid the the money has been paid over by such clerk to his mas. ter $(c)$. In that case, even though the money was origimoney to his master. nally paid by mistake, the clerk. paying it over to his master does no *wrong. It was paid to him for [*396] the purpose of being paid over, and he has effected that purpose, and cannot again be called upon to account for the money, even though his master has no right to retain it. In an old case $(d)$, therefore, where the de-Cary $\mathrm{r}$. fendant, who was a clerk of the South Sea Company, Webster. received from the plaintiff $600 l$. on account of the third subscription, and by mistake never entered it in the book, but paid it over to the company, Pratt, C. J., ruled that no action would lie against him at the suit of the plaintiff. And in a subsequent case (e), Lord Mansfield said,-

"In general the principle of law is clear, that if money be mispaid to an agent expressly for the use of his principal, and the agent has paid it over, he is not liable in an action by the person who mispaid it, becanse it is just that one man should not be a loser by the mistake of another, and the person who made the mistake is not

(a) Camplell v. Hall, Cowp. 205.

(b) Atlee v. Backhouse, 3 M. \& W. 633.

c) Paley on Ag. 390 ; Smith's Merc. Law; 153. It was upon this ground that a mandamus was refused in $R$. v. Shaw, 5 T. R. 549, see per Patteson, J., in $R$. v. Jeyes, 3 A. \& E. 424.

(d) Carry v, Wobster, Str. 480.

(e) Buller v, Harrison, Cowp. 565. 
without redress, but has his remedy over against the principal."

Horsfall $\mathrm{v}$. Upon this principle it was held $(f)$, that an action Handley. for money bad and recejved would not lie against a church-warden to recover back dues which had been paid to him, but which he had paid over to the treasurer of the trustees of the chapel. And similar principles have been acted on in several subsequent cases, some of which are referred to in the note $(g)$.

Passing money in

The mere passing money in account by an agent withaccount not count of, his principal, is not, however, equivalent to eqnivalent to payment over $(h)$, that is, if the account may be conpayment, unless account settled. sidered as still open. But if the agent, having a claim against his principals, transmit to them an account in which, giving credit for the amount received, he debits [*397] them with the amount *of his claim and strikes a balance in their favor, and afterwards in a subsequent account gives them credit for this balance, which ac. counts are all adopted and agreed to by the principals; the account then becomes settled, and the transaction is equivalent to payment over of the money $(i)$.

Servant obtaining money wrongfully cannot discharge himself by payment to his master.

And the doctrine that the receipt of a servant or agent is the receipt of his master or principal, does not apply to the cases of a servant who is a wrongdoer, so as to discharge him $(k)$. If, therefore, a servant acting illegally or wrongfully, gets money into his hands, he cannot defend himself from an action at the suit of the party legally or rightfully entitled to it, on the ground

(f) Horsfall v. Handley, 8 Taunt. 136.

(g) See Greenway v. Hurd, 4 T. R. 553; Coles v. Wright, 4 Taunt. 193 ; Tope v. Hockin, 7 B. \& C. 110 ; Vern. 136, 208 ; and see Atlce v. Backhouse, 3 M. \& W. 633; White r. Bartlett, 9 Bing. 378; Ireland v. Thompson, 4 C. B. 171.

(h) Buller v. Harrison, Cowp. 565 ; and see M'Carthy v. Colvin, 9 A. \& E. 607.

(i) Holland v. Russell, 30 L. J., Q. B. 308 ; 22 L. J., Q. B. 297.

(k) Nor can payment by the servant be considered payment by the master, so as to expose him to the application of the maxim afterwards mentioned in the text, " in pari delicto potior est conditio defendentis." And therefore, where the plaintiff's clerk received money from his customers, and paid it to the defendants. upon the chances of the coming up of tickets in the State Lottery of 17\%2, contrary to the Lottery Act of that year, it was held by Lord Mansfield that the plaintiff might recover the money from the defendants; Clark v. Shee, Cowp. 197 ; and sei Corking v. Jarrard, 1 Camp. 37, as quoted by Park, J., in Abboth. v. Barry, 2 Brod. \& B. 371. Where the receipt of money by both master and servant is illegal, the latter is not liable to an action for money had and received at the suit of the former; $M$ Gregor v. Love, Ry. \& M. 57 ; Nicholson v. Gooch, 25 L. J., Q. B. 137. 
that he acted merely as the agent of his master, and has paid over the money to him $(l)$. No one but the person legally entitled to the money can give a discharge for it, and until it is paid to him, the servant or agent is liable to be sued by him for it; provided he is not prevented from suing by the rule "in pari delicto potior est conditio defendentis" $(m)$.

This was decided in Miller $\mathrm{v}$. Aris $(n)$ which was an Miller $\mathrm{v}$. *action bronght by the plaintiff, who had been [*398] Aris.

a prisoner in the Coldbath-fields Prison, against the governor of the prison, to recover a sum of money paid by the plaintiff for lodging, while he was confined as a prisoner in that prison, and which sum exceeded the amount allowed by the prison regulations. On behalf of the defendant it was contended that he was not lia. ble, as he had accounted at the sessions to the county for all the sums received on account of the gaol, but he was nevertheless held liable, Lord Kenyon saying that Sadler v. Evans (o), and such cases, did not apply, where there is corruption in the foundation of the contract, or it is bottomed in oppression or immorality.

And so a sheriff's officer was held liable to refund to Snoxdon v. the plaintiff a sum of money which he had illegally Davis. extorted from him, under colour of a warrant from the sheriff; and it was held to be no defence that the defendant had paid the money over to the sheriff, as the defendant acted illegally in receiving the money, which could not, therefore, have been paid to him for the pur. pose of being paid over to the sheriff $(p)$.

So, where a parish clerk extorted illegal fees, colore

(l) This is strongly illustrated by Sharland v. Mildon, Same v. I.oosemore, 5 Hare, 469 , where it was leld by Wigram, V.-C., that the agent of an executor de son tort, eollecting the assets, knowing them to belong to the testator's estate, and that his principal was not the legal personal representative, made himself personally liable as exeeutor de son tort, notwithstanding he load duly accounted for his receipts to his principal. See also Sykes v. Syke8, 39 L. J., C. P. 179. But see Pond v. Underwood, 2 Id. Raym. 1210 ; 1 Wms. Exors. 461.

( $m)$ As the plaintiff was in Goodall v. Lowondes, 6 Q. B. 464 ; and see Smith v. Bromley, 2 Doug. 695; Williams v. Hedley, 8 Last, 378; Higgins v. Pitt, 4 Exe. 324; Atkinson v. Denby, 30 L. J., Exe. 361.

(n) 3 Fsp. 232 ; Selw. N. P. 103.

(o) 4 Burr. 1955, anle, p. 393.

(p) Snowdon v. Davis, 1 Taunt. 359 ; see Smith v. Sleap, $12 \mathrm{M}$. \& W. 585 ; Valpy v. MIanley, 1 C. B. 594; Wakefield v. Newbon, 6 Q. B. 276 ; Davies v. Vernon, 6 Q. B. 443 ; Oates v. Huds'm, 6 Exc. 346 ; sec also Parker v. Bristol and Exeter Railuay Co., 6 Exe. 705,706 ; Townson v. V'ilson, 1 Camp. 396 ; Chappcll v. Potes, 2 M. \& W. 867.

23 MAS. \& SER. 
Stecle r.

Willians.

officii, it was held that the plaintiff might recover them back from him, and need nut sue the rector, for whom they were said to have been received $(q)$.

Nor where he Neither does the doctrine above mentioned apply to obtains the cases in which a servant or agent gets money into his money by means of a trespass or other tort. hands by means of a trespass or other tort, committed by the orders of or in company with his master or principal. For all persons concerned in a tort are principals, and as the party injured might bring his action against the servant for damages sustained in conse. - [*399] quence of his wrongful *act, he is allowed to waive his right to proceed in that form of action, and sue for the money received by the wrongdoer. Upon Thgman v. this ground, where (v) the defendant by direction of his Hopkins. father, who claimed to be executor of the plaintiff's wife deceased, went to her lodgings and took a large sum of money from a bureau, which he said belonged to his father as executor, and which he paid over to him accordingly : the defendant was held liable to an action for the money at the suit of the plaintiff, although it was contended that he merely acted as agent to his father, against whom the action should have been brought. And Tindal, C. J., said,-

"The defendant was a wrongdoer in taking the money, and would have been liable to the plaintiff in trespass. The plaintiff, however, waives the tort and sues the defendant for money had and received; and the defendant cannot relieve himself from liability by paying over the money to another party, as he might have done if the original taking had been lawful. The circumstance distinguishes the present case from Stephens $v$. Badcock (s); for there the defendant received the money as agent for a party who was entitled to receive it, whereas here the receipt was altogether wrongful, and it must be taken with all its consequences."

As to servant's lia-

But a clerk or other servant or agent who has received money on account of his master, and has not bility to third paid it over to him before receiving notice not to do so, person's in- from or on behalf of the person who paid it, may be fore payment liable to refund the money, and cannot shelter himself to his master. from such liability under the maxim respondeat superior, if the circumstances of the case are such that, had the

(q) Steele v. Williams, 8 Exc. 625.

(r) Tugman v. Hopkins, 4 M. \& G. 389; and see Sharland v. Mildon, 5 Hare, 469; Edwards v. Hodding, 5 Taunt. 815 ; Neate v. Harding, 6 Exc. 349 .

(s) 3 B. \& Ad. 354 ; see this case, ante, p. 394. 
money been paid over to the master, he would have had no defence to an action to recover it: as in such case the servant, if obliged to pay the money over to the person entitled to it, would have a good defence to any action brought against him by his master, and would not be estopped from disputing his title to the money.

*Thus, in Carey v. Webster $(t)$, it was said by [*400] Cary s. Pratt, C. J., that if the defendant had not paid the Webster. money over, the plaintiff would have had his option either to charge him or the company; as in the com. mon case of payment to a goldsmith's servant, who does not carry it to the account of his master, the party has an election to go against either: he may charge the servant, because, till the money is paid over, the ser. vant receives it to his own use, or he may pass by the servant and make his demand upon the master, because the payment to the servant is made in confidence of the credit given him by the master.

So, in an action $(u)$ brought by the plaintiff, an Buller $\mathrm{v}$. underwriter, to recover back from the defendant, who IIarrison. was agent for the insured, Messrs. I. \& S., resident at New York, a sum paid by the plaintiff upon a loss, sup. posed to be fair, but which turned out to be foul; the defendant had passed the whole sum in his account with Messrs. L. \& S., and given credit to them for it against a sum in which they stood indebted to him, but had accepted no fresh bills nor given any fresh credit to his principals, and had not paid the money over to them: it was held that the mere placing the money to the credit of the principals was not equivalent to paying it over; and that the defendant was liable to refund the money to the plaintiffs. In delivering judgment, Lord Mansfield said,-

"In general, the principle of law is clear, that if money be mispaid to an agent expressly for the use of his principal, and the agent has paid it over, he is not liable in an action by the person who mispaid it, because it is just that one man should not be a loser by the mistake of another, and the person who made the mistake is not without redress, but has his remedy over against the principal. On the other hand, it is just that as the agent ought not to lose he should not be a gainer hy the mistake. And, therefore, if after the payment so made to him, and before he has paid the money over to his principal, the person corrects the

(t) Str. 480 , ante, p. 396.

(u) Buller v. IIarrison, Cowp. 565. 
mistake, the agent cannot afterwards pay it over to his principal without making himself liable to the real owner for the amount. But the present case turns upon this, that the agent was precisely in the same situation at the time the mistake was discovered as before."

Cox v.

Prentice.

[*401] *So where $(x)$ it appeared that the defendant had received a bar of silver from his correspondert at Gibraltar, and sold it to the plaintiff at a price calculated with reference to the number of ounces, which,

- on assay, it was supposed to contain, and it turned out afterwards that it contained fewer ounces than had been supposed; the plaintiff was held entitled to recovery from the defendant the money overpaid to him, as he had not paid it over to his principal, although he had forwarded an acconnt to him, in which he had credited him with the full sum, but which was still unsettled. And Lord Ellenborough, C. J., said-

"I take it to be clear that an agent who receives money for his principal is liable as a principal, so long as he stands in his original situation, and until there has been a change of circumstances by his having paid over the money to his principal, or done something equivalent to it. Here it has been admitted that no money has been paid over by the defendant to his principal, nor has there been any other thing done by him to create a change of circumstances. The only. question then is, whether the action lies against the defendant, considering it as if it were an action against the principal."

Murray v: Mann.

So in the following case $(y)$ a principal was held not entitled to set off against a debt due from him to his agent a sum of money received by the agent on acconnt of his principal, but returned by him to the person who paid it before action bronght, under circumstances which were held to justify the agent in returning the money. It was an action by a livery-stable keeper for the keep of a horse belonging to the defendant, to which the defendant pleaded a set-off for money received by the plaintiff for the use of the defendant. The horse had stood sometime in the plaintiff's stables, when at length, the plaintiff sold it with a warranty for $125 l$.

(x) Cox v. Prentice, 3 M. \& S. 344. It may be observed of both Buller v. Harrison, and Cox v. Prenticc that the principal was foreigner. As to which see Story on Ag. s 263; Paley on Ag. 248 ; Thompson v. Devenport, 9 B. \& C. 78. See, however, Pale on Ag. 283, 389 ; Story on Ag. s. 300 ; and Smith's Merc. Law. 153.

(y) Murray v. Mann, 2 Exc. 538. 
which sum the defendant claimed to set off against the Murray : plaintiff's demand. But it appeared that the horse, Hann. not answering the warranty, had * *een returned [*402] by the purchaser, to whom the plaintifi had returned his money before the action was brought; and it was held that the plaintiff was justitied in returning the money, which could not, therefore, be set off against his claim for the keep of the horse. On behalf of the defendant it was contended that the plaintiff, an agent, could not set up his own fraud in giving a false warranty, by which he was obliged to return the money, against his principal, the defendant; but, said Lord Wensleydale,-

"The ans 1 is, that the principal never had a right to the $125 l$, except by the act of his agent in making a contract which was defeasible by reason of fraud. It is true that fraud does not make a contract actually void, but only voidable at the election of the party; but the moment the purchaser chose to declare it void, the price uas recoverable back from the plaintiff, and it ceased to be money in his hands received for the use of the defendant. I am, therefore, clearly of opinion that the set.off was defeated by the proof of fraud. The plaintiff does not, in truth, set up his own fraud against the defendant, but says, 'I only recoived that money subject to a defeasance, which has taken effect." ",

A servant may also, in some cases, be liable to an action at the suit of a third person for non-payment of money which he has to money which he has received from his master with third persons orders to pay it to such third person. But in order to for money rerender him liable to such an action it is not sufficient ceived from that he should have received the money from his master be paid to with orders to pay it to a particular person, he must them. bave done some act amounting to a specific appropriation of the money to the use of that person; he must have assented to hold it to his use, otherwise there is no privity between them, and the servant is only responsible to his master $(z)$, and such assent must of course be before action brought.

This position is well illustrated by the case of Houell

(z) Paley on Ag. 394; Williams v. Eierctt, 14 Wast, 522 ; Lilly v. Hays, 5 A. \& E. 548; and other eases eited, 1 Wms. Saund. $210 b$, note. And see Gidley v. Lord Palmerston, 3 Brod. \& 13. 275, where the secretary at war was held not liable to an action at the suit of a retired elerk at the war-office for his retired allowance, althongh the sceretary at war had received the money applicable to such allowance. Sce also Moore v. Bushell, 2\%. L. J., Exc. 3; Hill v. Royds, 38 L. J., Ch. 538. 
IIowell v. v. Batt $(a)$. That was an action for money had and Batt. [*403] received. *The plaintiff was a joint proprietor of a coach running from Exeter to London, and the defendant was office.keeper and servant to C., the proprietor at Exeter. The defendant used, in his capacity of office-keeper, at stated intervals, to make up the share-bills of the coach, and take sums of money from a balance of C.'s, which he had in hand, and send them to the proprietors as their shares of the profits. On one occasion 23l. were due to the plaintiff, and the defendant made up a packet purporting to contain that sum, and sent it to the plaintiff. The packet only con. tained $20 l$. and the action was brought for the difference. No sum of money was expressly given to the defendant by C., for the plaintiff, but after the action was brought the defendant admitted that he had bad the money of C., but said he had sent it to the plaintiff. The plaintiff was nonsuited on the ground that there was no privity between him and the defendant; and a rule to set aside the nonsuit was afterwards refused, Parke, J., observing, "If it had been proved that the defendant had, as it were, attorned to the plaintiff and agreed to hold the money for his use, and not subject to the direction of $\mathrm{C}$., the case would have been different."

\section{IN Cases of Tort-Criminaliter.}

Master's liability does not involve servant's exemption.

Servant generally responsible, criminaliter, for his own acts.

We have seen in the preceding chapter that a master is in many cases liable to answer criminally for the acts of his servants. Such liability on the part of the master does not, however, by any means, always involve the exemption of the servant from a similar liability to answer criminaliter for his own acts, although performed by him in the discharge, or supposed discharge, of his duty to his master, or in obedience to his master's commands. In criminal matters it is a general rule that every person must answer for his own acts, and the command of no person can excuse an illegal act. A servant, therefore, is not, generally speaking, excused from liability to answer criminally for any violation of $[* 404]$ the law which he may commit, on the *ground that he was only acting in obedience to his master's commands (b). This is so obviously the case in re-

(a) 5 B. \& Ad. 504 ; see Barron v. Husband, 4 B. \& Ad. 611.

(b) 1 Hawk. P. C. 3; 1 Hale, P. C. 44, 516; 4 Blackst. Com. 28. In $R$. v. Parr, 2 M. \& Rob. 346 , both naster and servant were jointly indicted for receiving stolen goods. 
gard to offences which are mala in se, that no more mala in se. need be said upon the subject. But where the illegai act charged is merely malum prohibitum, the fact that the servant was acting in obedience to his master' commands, would be strong evidence to rebut that hibitu. prima facie inference of the existence of a vicious mind, which generally arises from the mere doing an illegal act; and in such cases it may sometimes happen that in this way the command of the master may, in effect, exempt the servant from criminal responsibility for the consequences of illegal acts done in obedience to his master's orders.

Thus, where $(c)$ on the trial of an indictment under $R$. v. Jamcs. $7 \& 8$ Geo. 4 , c. 30 , s. 6 , for maliciously obstructing an airway belonging to a mine, with intent to hinder and delay the working of the mine, it appeared that the defendants had acted under the orders of $P_{\text {. }}$, the lessee of an adjacent mine, and it was contended by the counsel for the prosecution, that although the defendants were acting under P.'s orders, still that an order to do wrong afforded no justification; Lord Abinger, C. B., inquired, "If a servant did this by his master's order, and supposing bona fide that the master had a right to order it to be done, would it not be too much to say that the servant is answerable as a felon for doing the thing maliciously when the malice, if there is any, is his master's, and not his own?" Upon which, the counsel for the prosecution said, "Suppose a master orderer his servant to shoot a man, that would be no excuse for the servant if he did it." "But," said Lord Abinger, "that is an act which is malum in se. But if a master, having a doubt or no doubt of his own rights, sets *his servants to build a wall in a mine, [*405] they would, if he proved to have no right, be all liable in action of trespass, but it would not be felony in the servants. The rules respecting acts mala in se do not apply. If a master told his servant to shoot a man, he would know that that was an order he ought to disobey. But if the servant bona fide did these acts, I think they do not amount to an offence within this statute. If a man claims a right which he knows not to exist, and he tells his servants to exercise it, and they do so, acting bona fide, I am of opinion that that

(c) R. v. Janes, 8 C. \& P. 131. And see R. v. Bleastale, 2 Carr. \& K. 768 ; ante, p. 309, where Erle, J., satil, "It' a man does by means of an innocent agent an act which amounts to a felony, the employer, and not the innocent agent, is the person accountable for that act." 
R. v. Jamcs. is not felony in them even if, in so doing, they obstruct the airway of a mine. What I feel is thiz, that if these men acted bona fide in obedience to the orders of a superior, conceiving that he had the right which he claimed, they are not within this Act of Parliament. But if either of these men knew that it was a malicious act on the part of his master, I think then that he would be guilty of the offence charged." The prisoners were acquitted.

Unqualified Where a servant who was not qualified went out servant conrsing with a master who was qualified, it was held sporting with that the servant could not be convicted for using dogs qualified to kill and destroy game $(d)$. And so an unqualified

Cases under Hawkers person who set traps to destroy same by order of his master. who was qualified, was held not liable to the penalties imposed by 5 Ann. c. $1+(e)$. But where an unqualified servant went out shooting with a master who was qualified, and fired a gun and shot game for him, he was held liable to the penalty imposed by 5 Ann. c. 14, for keeping and using a gun to kill game without a qualification $(f)$, Bayley, J., saying,-

"The principle upon which the two former cases proceeded was, that the using the greyhounds was the act [*406] of the owner and master, and not * of those who accompanied him. So, also, the trap being set by the master's orders and in his presence, must be taken to have been set by him. But we cannot say that of using the gun, neither his hand nor his skill was applied to it. If we were to bold that the firing of the gun was the act of the master, he might in the same manner use twenty guns at the same time. I think we must con. sider the gun to have been used by the person who actually fired it, and, if so, the cases cited are inapplicable, and there can be no doubt that $\mathrm{S}$. was properly convicted."

Act.

Although an agent who takes round goods of several employers, and offers them for sale, is bound to take out a licence under the Hawkers Act $(g)$, yet it has been held that a servant or traveller, who is sent round by

(d) R. v. Taylor, 15 East, 460 ; see also Lewis v. Taylor, 16 East, 49 ; Hudson v. Footte, 9 Ir. C. L. R. 203 ; 10 Ir. C. L. R. 509.

(e) Walker v. Mills, 2 Br. \& B. 1 ; see also Spicer v. Barnarl, $2 \mathrm{~N}$ L. J., M. C. 176 ; Padwick v. King, 29 L. J., M. C. 42 , where the right of a tenant to kill rabbits was held to justify his servants in so doing by his direction.

(f) Ex parte Sylvester, 9 B. \& C. 61.

(g) R. v. Turner, 4 B. \& Ald. 510 ; R. v. $M$ ' Gill, 2 B. \& C. 142. 
his employer to collect orders, in pursuance of which goods are afterwards sent, is not within that Act $(h)$.

And now it is expressly provided by statute $(i)$ that $24 \& 25$ vict. commercial travellers selling or seeking orders for goods, c. $: 21$, s. 9. \&c. to or from persons who are dealers therein, and who buy to sell again, and servants of the real workers or makers of any goods or wares seeking orders for any such goods or wares, are exempt from liability to take ont a hawker's licence.

It has also been held, that a servant is liable to the Thames penalties imposed by the Thames Watermen's Act, mpon Watermen's any porson not being a freeman of the Watermen's Act.

Company, who shall act as a waterman, \&c., on the Thames, although he was working for and paid by the owner of the barge, at a fixed weekly salary $(k)$.

C. was the book-keeper and accountant, and I. the Acting as secretary of a company incorporated and registered broker withunder the Joint Stock Companies Act, 1862, for buying out licence. and selling on behalf of other persons shares and stocks, scott r. \&c. There was no evidence that any of the directors, (ousin.s. manager or other person connected with the company Same v.Inglis. was a duly licensed broker. C. on one occasion bonght, and I. on *another sold, stock for a customer, [*407] and signed the bought and sold notes "p. pro. manager," I. adding "secretary" after his signature. It was held that $\mathrm{b}$ oth $\mathrm{C}$. and $\mathrm{I}$. were liable to penalties under 57 Geo. 3, lx. s. 2, for acting as brokers without a licence $(l)$.

Again, a sheriff's officer has been held liable to an Attachment attachment for extortion $(m)$.

And a servant who manages a place of public resort may bo convicted for aiding and abetting his master in harbonring prostitutes under $11 \& 12$ Vict. c. 43 , s. $5(n)$. against sherifl"s: officer for extortion. Servant aiding and

Where a shopman to a jeweller was indicted for ob-ahetting taining money by false pretences, he having sold a chain, master. \&c., which was hung in the window, marked "fine gold," Shopman when it was not gold, Alderson, B., said the indictment "fine grold", would not lie without showing guilty knowledge on whit was not. the part of the defendant, who was merely acting as shopman, and the jury having found that there was no guilty knowledge, the prisoner was acquitted.

(h) R. v. J'Knight, 10 B. \& C. 73-4.

(i) $24 \& 25$ Vict. c. 21 , s. 9.

(k) R. v. Tihle, 4 E. \& B. 888.

(1) Scott v. Comsins, Same v. Inglis, 38 I. J., C. 1'. 156.

m) Mltsters v. Lonlher, 11 C. B. 948.

(n) Wilson v. Stewart, 32 1. J., M. C. $198 ; 8$ L. T., N. S. 277. 
"If," said the learned Baron, "the master had been indicted, the evidence might apply; because the jury would infer that he was aware of the quality of the articles that he was selling, but it was different in the case of a shopman. Although, undoubtedly, a gross fraud, it did not constitute an indictable offence" $(o)$.

Servant

liable to indictment for breach of duty to his master which involved public duty.

r. Haines. There are also many cases which may properly be mentioued in this place, but to which it is unnecessary to advert at any iength, as they scarcely come within the scope of the present work, in which servants may be liable to indictment for culpable neglect of the duty undertaken by them towards their employer, where that duty also involved a duty to the public. Such, for instance, as the driver of a carriage or the captain of a vessel, who by negligent driving or navigation, causes the death of any person. In such cases, though the master may be liable in a civil action for the consequences [*408] of his servant's *negligence, yet the servant must answer criminally for his own personal negli. gence $(p)$.

In a case, therefore, in which the ground bailiff of a mine, whose duty it was to cause proper air-headings to be put up to prevent the accumulation of noxious gases, neglected to do so, and an explosion of fire-damp took place, which killed a person, for whose manslaughter he was indicted; Maule, J., in summing up, told the jury that if they were satisfied that it was the ordinary and plain duty of the prisoner to have caused an air-heading to be made, and that a man using reason. able diligence would have had it done, and that by the omission the death of the deceased occurred, they ought

R. v. Barrett. to find the prisoner guilty of manslaughter $(q)$. But it has been held that an engineer, under similar circumstances, could not be convicted of manslaughter upon an indictment which did not allege a duty in him which he had neglected to perform $(r)$. It would seem, how-

(o) R. v. Lamade, Centr. Cr. Court, Feb. 4th, 1853.

(p) R. v. Allen, 7 C. \& P. 153, R. v. Green, ib. 156, where the captains of steamers were indicted for the manslaughter of persons killed by being run down by the steamers; but were aequitted, as there was no proof of any personal act; and see $R$. v. Taylor, 9 C. \& P. 672; see also R. v. Ledger, 2 Fost. \& F. $85 \pi$ (station master); $R$. v. Trainer, 4 F \& F. 105 (engine-driver and fireman); $R$. v. Birchall, 4 F. \& F. 1087; R. v. Gray, 4 F. \& F. 1098.

(q) R. v. Haines, 2 Carr. \& K. 368 , the prisoner was acquitted. See also $R$. v. Poeoek,17 Q. B. 38. The neglect of duty. must be immediately conneeted with the death.

(r) R. v. Barrett, 2 C. \& K. 343. See the form of the indict ment in the note to $R$. v. Haines, ubi supra. 
ever, to be sufficient to allege facts from which the law would infer such duty $(s)$.

Where a banksman, whose duty it was to place a $R$. v. Irughes. stage on the mouth of a shaft to receive a loaded truck run down to it on a tramway, neglected to place the stage, in consequence of which the truck fell down the shaft and killed a workman, the banksman was held guilty of manslaughter $(t)$. In that case Lord Campbell said,-

"It was the duty of the prisoner to place the stage on the mouth of the shaft. The death of the deceased was the direct consequence of the omission of the prisoner to perform this duty. If the prisoner, of 'malice *aforethought, and with the premeditated de. [*409] sign of causing the death of the deceased, had omitted to place the stage on the mouth of the shaft, and the death of the deceased had thereby been caused, the prisoner would have been guilty of murder. According to the common law form of an indictment for murder by reason of the omission of a duty, it was necessary that the indictment should allege that it was the duty of the prisoner to do the act, or to state facts from which the law would infer this duty $(u)$. But it has vever been doubted that if death is the direct consequence of the malicious omission of the performance of a duty (as of a mother to nourish her infant child), this is a case of murder. If the omission was not malicious and arose frum negligence only, it is a case of manslaughter. It has been held that to make the captain of a vessel guilty of manslaughter in causing a person to be drowned in running down a boat, proof of a mere omission on his part to do the whole of his daty is not sufficient $(x)$. But there is no authority for the position that without an act of commission there can be no manslanghter; and, on the contrary, the general doctrine seems well established that what constitutes murder being by design and of malice prepense constitutes manslaughter when arising from culpable negligence."

Moreover, many instances are to be found in the books Indictments of cases in which servants and workmen have been fornuisances. joined with their masters and employers in indictments

(s) R. v. ITughes, infra.

(t) R. v. Inughes, 26 L. J., N. C. $202 ; 1$ Bell, C. C. 248 .

(u) R. v. Eduards, 8 C. \& P. 611; R. v. Goodwin, 1 Russ. on Cr. 563, note, 4th edit.

(x) R. v. Allen, 7 C. \& P. 153. 
for nuisances; some of which, by way of example, are referred to in the note $(y)$.

Punishment

of persons

The performance of their duties to their masters by employed on Parliament. Thus in the Act for Regulating Railways railways gmilty of misconduct.

$3 \& 4$ Vict. c. 97 , s. 13. $(z)$, there is, for the protection of the public, inserted a provision for the punishment of servants of railway companies who are guilty of misconduct. By that Act it is enacted,- -

"That it shall be lawful for any officer or agent of any railway. company, or for any special constable dnly appointed, and all such persons as they may call to their assistance, to seize and detain any engine-driver, guard, porter or other servant in the employ of such com[*410] pany who shall be found *drunk while employed upon the railway, or commit any offence, against any of the bye laws $(a)$, rules or regulations of such com. pany, or shall wilfully, maliciously or negligently do or omit to do any act whereby the life or limb of any person passing along or being upon the railway belonging to such company or the works thereof respectively shall be or might be injured or endangered, or whereby the passage of any of the engines, carriages or trains shall be or might be obstructed or impeded, and to convey such engine-driver, guard, porter or other servant so offending, or any person counselling, aiding or assist ing in such offence with all convenient despatch before some justice of the peace for the place within which such offence shall be committed without any other warrant or authority than this Act; and every such person so offending and every person counselling, aiding or assisting therein as aforesaid, shall, when convicted before such justice as aforesaid (who is hereby author. ized and required, upon complaint to him made upon oath, without information in writing, to take cognizance thereof and to act summarily in the premises) in the discretion of such justice be imprisoned,

(y) R. v. Pease, 4 B. \& Ad. 30; R. v. Seott, 5 Q. B. 543 ; R. v. Charlesworth, 16 Q. B. $1012 ; R$. v. Betts, 16 Q. B. 1022; sce $R$. v. Sharpe, 3 Railw. Cas. 33 . See also Wilson v. Peto, 6 B. Moore, where a clerk who directed the workmen and superintended the erection of a buildiug which occasioned a nnisance was held liable as a co-defendant with the contractor. Thompson v. Gibson, 7 M. \& W. 456.

(z) 3 \& 4 Vict. c. 97, s. 13.

(a) As to the making of bye-laws, see the Companies Clauses Consolidation Act, $1845,8 \& 9$ Vict. c. 16, s. 127 et seq., and the Railways Clauses Consolidation Act, 1845,8 \& 9 Vict. c. 20 , s. 108 et seq. 
with or without hard labour, for any term not exceeding two calendar months, or in the like discretion of such justice shall for every such offence forfeit to her Majesty any sum not exceeding ten pounds, and in de. fault of payment thereof shall be imprisoned with or without hard labour as aforesaid" [for such period not exceeding two calendar months, as such justice shall appoint; such commitment to be determined on payment of the amount of the penalty, and every such penalty shall be returned to the next ensuing court of quarter sessions in the usual manner $(a)$.]

"Provided always (b), that (if upon the hearing of Scet. 14. any such complaint he shall think fit) it shall be lawful Justice of the for such justice, instead of deciding on the matter of peace cmcomplaint summarily, to commit the person or persons powered to charged with such offence for trial for the same send any case at the quarter sessions for the county or place wherein sessions. such offence shall have been committed, and to order that any such person so committed shall be imprisoned and detained in any of her Majesty's gaols or houses of correction in the said county or place in the.meantime, or to take bail for his appearance, with or without sureties, in his discretion; and every such person so offending and convicted before such court of quarter sossions as aforesaid (which said court is hereby required to take cognizance of and hear and determine such complaint), shall be liable, in the discretion of such court, to be imprisoned, with or without hard labour, for any term not exceeding two years."

By the Act for the better Regulation of Railways (c), Extended by * passed a few years afterwards, after reciting [*411] 5 \& 6 Vict. the foregoing provision, and that it was expedient to c. 55, s. 17. extend the same, it is enacted,-

"That it shall be lawful for any officer or agent of Punishment. any railway company, or for any special constable duly of persons appointed, and all such persons as they may call to employed on their assistance, to seize and detain any engine-driver, railways waggon-driver, guard, porter, servant or other person misconduct. employed by the said or by any other railway company,

(a) The words in brackets were repealed by $47 \& 48$ Vict. c. 43. See the Summary Jurissiction Act, $1879,42 \& 43$ Vict. c. 49.

(b) Sect. 14. See sect. 16 as to obstructing officers of the company.

(c) 5 \& 6 Viet. c. 55 , s. 17. See also the Railways Clanses Consolidation Act, 1845,8 \& 9 Vict. c. 20 , ss. 124,125 , which makes the owners of engines, \&e., brought on the railway liable to the eompany for damage done by the servants of snch owners, but enables the owners to recover from their servants in the same way as the company recover from the owners. 
or by any other company or person in conductirg traffic upon the railway belonging to the said company, or in repairing or maintaining the works of the said railway, who shall be found drunk while so employed upon the said railway ; who shall commit any offence against any of the bye laws $(d)$, rules or regulations of the said company ; or who shall wilfully, maliciously or negligeatly do, or omit to do, any act whereby the life or limb of any person passing along or being upon such railway, or the works thereof respectively, shall be or might be injured or endangered; or whereby the passage of any engines, carriages or trains shall or might be obstructed or impeded, and to convey such engine-driver, guard, porter, servant or other person so offending, or any person counselling, aiding or assisting in such offence, with all convenient dispatch, before some justice of the peace for the place within which such offence shall be committed, without any other warrant or authority than this Act; and every person so offending, and every person counseling, aiding or assisting therein as aforesaid shall, when convicted upon the oath of one or more credible witness, or witnesses, before such justice as aforesaid (who is hereby authorized and required upon complaint to him made upon oath, without information in writing, to take cognizance thereof, and to act summarily in the premises), in the discretion of such justice be imprisoned, with or without hard labour, for any term not exceeding two calendar months; or, in the like discretion of such justice, shall, for every such offence, forfeit to her Majesty any sum not exceeding ten pounds, and in default of payment thereof shall be imprisoned, with or without hard labour, as aforesaid," [for such period not exceeding two calendar months. as such justice shall appoint, such commitment to be determined on payment of the amount of the penalty, and every such penalty shall be returned to the next ensuing conrt of quarter sessions in the usual manner $(e)$.]

Clanses are also to be found in various Acts of Parliament subjecting clerks and servants to punishment for offences committed against those Acts.

Factors' clerks assisting them in [*412] *Thus the Larceny Act $(e)$ which makes it a misdemeanor for factors or agents to obtain advances on

(d) Supra, p. 410 , note (a).

(e) The words in brackets in this Act were (probably by an oversight) not repealed by $47 \& 48$ Vict. c. 43 . See ante, p. 410 , note $(a)$.

(e) 24 \& 25 Vict. c. 96, s. 78. 
tho property of their principals for the use of any per-obtaining for son other than such principals, also enacts, that,-

their use

advances on

"Every clerk or other person who shall knowingly property of" and wilfully act and assist in making any such consign- principal. ment, deposit, transfer or delivery, or in accepting or procuring such advance as aforesaid, shall be guilty of a misdemeanor,"

and subject to the same punishment as their masters.

By sect. 81, "Whosoever being a director, member Public offior public officer of any body corporate or public com-cers of any pany, shall fraudulently take or apply for his own use company or benefit, or for any use or purposes other than the frandulently use or purposes of such body corporate or public com. appropriatjany, any of the property of such body corporate or public company, shall be guilty of a misdemeanor" $(f)$.

Sec. 82. "Whosoever being a director, public officer or keeping or manager of any body corporate, shall as such recejve fiaudulent or possess himself of any of the property of such body accounts, corporate or public company otherwise than in payment of a just debt or demand, and shall with intent to defraud omit to make, or to canse or direct to be made a full entry thereof in the books and accounts of such body corporate or public company $(g)$; or shall with or wilfully intent to defraud, destroy, alter, mutilate or falsify any destroying book, paper, writing or valuable security, belonging to books, \&c., the body corporate or public company, or make or con. cur in the making of any false entry, or omit or concur in omitting any material particular in any book of account or other document $(h)$; or shall make, circu- or publishing late or publish, or concur in making, circulating or pub-fraudulent lishing any written statement or account which he shall statements. know to be false in any material particular, with intent to deceive or defrand any member, shareholder or creditor of such body corporate or public company, or with intent to induce any person to become a shareholder or partner therein, or to intrust or advance any property to such body corporate or public company, or to enter into any security for the benefit thereof $(i)$, shall be guilty of a misdemeanor."

Again, the Act for Consolidating the Law relating to Making or Forgery $(k)$ enacts, that-

(f) Ibid. s. 81 .

g) Ibid. s. 82.

(h) Ibid. s. 83.

(i) Ibid. s. 84 .

(k) 24 \& 25 Vict. c. 98, s. 28 . This was formerly not forgery ;

R. v. White, 2 C. \& K. 404 ; Den. C. C. 208. 
\&e. by procuration without lawfelony.

Drivers of carriages injuring persons by furious driving. ful authority,
Servants or mariners wilfully injuring Westminster
"Whosoever with intent to defraud shall draw, make, sign, accept or indorse any bill of exchange or promissory [*413] note or any undertaking, * warrant, oriler, authority or request for the payment of money or for the delivery or transfer of goods or chattels, or of any bill, note or other security for money, by procuration or otherwise, for, in the name or on the account of any other person without lawful authority or excuse, or shall offer, utter, dispose of or put of any such bill, note, undertaking, warrant, order, anthority or request so drawn, made, signed, accepted or indorsed by procuration or oth. erwise without lawful authority or excuse as aforesaid, knowing the same to have been so drawn, made, signed, accepted or indursed as aforesaid, shall be guilty of felony, and being convicted thereof shall be liable at the discretion of the court to be kept in penal servitude for any term not exceeding fourteen years, and not less than [five years, $27 \& 28$ Vict. c. 47 ] or to be imprisoned for any term not exceeäing two years, with or without hard labour, and with or without solitary confinement." And the Act for Consolidating the Law relating to Offences against the Person $(l)$, enacts, that-

"Whosoever having the charge of any carriage or vehicle shall by wanton or furious driving or racing, or other wilful misconduct, or by wilful neglect, do or cause to be done any bodily harm to any person whomsoever shall bo guilty of a misdemeanor,"

and liable to two years' imprisonment and hard labour.

Clauses also are to be found in various other Acts of Parliament subjecting workmen and servants to penalties for offences against the Act committed whilst in the supposed discharge of their duty to their employers. Thus, in the Act for Rebuilding Westminster Bridge $(\mathrm{m})$, there is a clause which provides that in case of damage or mischief done to the bridge by any ship, lighter, \&c., through the wilful negligence of any perBridge liable son having the command of any such ship, lighter, \&c., to indemnify or any of the mariners or persons employed therein, master.

the owner of such ship, lighter, \&c., shall be answerable for the amount; and then follows a clause enacting,-

"That in case the owner of any such ship, lighter, barge, boat, float, raft or vessel shall be compelled to pay any penalty, or to make satisfaction for any dam.

(l) $24 \& 25$ Vict. c. 100 , s. 35

(m) $16 \& 17$ Vict. c. 46 , ss. 15,16 . There are similar clauses in the Thames Embankment Act, 25 \& 26 Vict. c. 93, ss. 48,49 , 
ages by reason of any neglect or defanlt done or committed by his servants or mariners, or any of them, such servants or mariners, and *each and every [*414] of them, shall be liable to pay such penalty or damages (with the costs thereof) to such owner; and in case of non-payment upon demand thereof, and oath made by such owner of the payment made by him of such penalty, satisfaction, or damages, and that the same, and the costs thereof, have not been repaid to him by such servants or mariners, or any of them, although demanded (such oath to be made before any one or more justice or justices of the peace of the county or place where such penalty or satisfaction shall have been recovered), the amount thereof, provided the same shall not exceed the sum of twenty pounds, shall be recov. ered in the same manner as any penalty is thereby directed to be recovered,"

i. e., under the provision of the Companies Clauses Consolidation Act, $184 \check{5}(n)$.

And in the Metropolitan Building Act, 1855 (o), Workmen there is a provision that if any workman, labourer, ser- violating vant, or other person employed in or about any build- Metropolitan ing, wilfully, and without the privity or consent of the Building person causing such work to be done, does anything in or about such building contrary to the rules of that Act, he shall, for each such offence, incur a penalty not exceeding $50 \mathrm{~s}$.

Numerons other instances are to be found in the Statute Book of penalties imposed upon servants for neglect of duty to their employers, some of which are referred to in the note $(p)$.

A distinction of considerable importance must here It is no be adverted to, which obtains between civil and crimi- answer in nal proceedings for the consequences of negligence. criminal

(n) 8 \& 9 Vict. c. 16 .

o) 18 \& 19 Vict. c. 122, s. 48.

(p) See the Coal Act (London), $1 \& 2$ Vict. c. ci.. s. $3 ; 14 \&$ proceedings

15 Viet. c. clxvi., s. 22; the Harbours, Docks, and Piers Clanses Act, 1847,10 \& 11 Viet. c. 27, s. 74 (see The River Weer Commissioners v. Adausm, 46 L. J., C. L. 83 ; L. R., 2 App. Cas. 7.43, overruling Denmis v. Tovell, 42 L. J., II. C. 33 ; L. R., 8 Q. I. 10); the Ciunpowder Act, 23 \& 24 Vict. c. 139 , ss. 15,16 ; the Lunacy Act, $186^{\circ}, 25$ \& 26 Vict. c. 111 , s. 39 ; the Telegraph Act, $1863,26 \& 27$ Vict. e.' 112 , ss. 41,$45 ;$ the Alkali Act, 186:3, $26 \& 27$ Vict. c. 124, s. 5 ; the Coal Mines Regulation Act, 187:, 35 \& 36 Vict. c. 76 , s. 51, sub-s. 31, post, A ppendix ; the Metalliferous Mines Regulation Act, 18\%2, 3\% \& 36 Vict. c. 77, s. 23 , post, Appendix; the Act as to Threshing Machines, 41 \& 42 Vict. c. $12, \mathrm{s.} 1$; the Factory and Workshop Act, 1878 , 12 Vict. c. 16, ss. 5,87 .

24 MAS. \& SER. 
that person injured or others contributed to his injury.

All wrongdoers are principals.

Sands v. Child.

Servant liable for misfeasance, though in obedience to his master's order's ;
In civil proceedings, as we have seen, no person can re. cover damages against a master for the negligence of his servant if he has by his own negligence contributed [*415] to or caused *the injury complained of. But in criminal proceedings the converse of that proposition is true : and it is no answer to a criminal charge, as of manslaughter, that the deceased by his own negligence or improper conduct, or by being deaf or drunk, con. tributed to his own death $(q)$. So highly does the law value human life, that every person who has contributed to destroy it is responsible; and it does not diminish that responsibilitv that others also have been guilty of negligence $(r)$.

\section{Iv Cases of Tort-Civiliter.}

It is a general rule in cases of tort, that all persons concerned in the wrong are liable to be charged as principals. It was said in Sands v. Child (s) "that the warrant of no man, not even of the king himself, can excuse the doing of an illegal act; for although the commanders are trespassers, so are also the persons who did the fact." A servant, therefore, can in no case excuse himself from liability to an action founded upon a misfeasance or positive wrong done to another person, upon the ground that he acted merety in obedience to his master's orders or for his master's benefit $(t)$.

(q) R. v. Sivindall, 2 C. \& K. 230.

(r) Ibid.; and see $R$. v. Haines, 2 C. \& K. 368. But see what Willes, J., said in R. v. Birchalt, 4 F. \& F. 1087.

(s) 3 Lev. 352. See Bennett v. Bayes, 29 L. J., Exe. 224. But see Buron v. Denman 2 Exc. 16\%, where the captain of a man-ofwar, having committed an act of trespass, which was afterwards adopted and ratified by the Crown, was held not liable to be sued by the party injured, who had his remedy against the Crown only (such is it was). See Tobin v. Reg., 33 L. J., C. P. 199 ; 16 C. B., N. S. 310 ; Feather v. Reg., 35 L. J., Q. B. 200.

(t) In Pearson v. Graham, 6 A. \& E. 902, Lord Denman, C. J., said, "It might be very doubtful whether a servant delivering goods by his master's order could be said to have converted those goods as against the assignees of his master. Coles v. Wright, 4 Taunt. 198, rather seems to show that he eould not." The care of Coles v. Wright, however, seems to belong to a different class of cases, ante, p. 395. It was an action for money had and reecived, and the defendant was held not liable, as he had paid the money over to his master. And in Pearson v. Graham, the defendant, who had received no express orders as to the goods in question, but took mpon himself, under a general anthority, to sell and deliver them at a time when, as it afterwards turncd out, his master had committed an act of bankruptey, was heid liable to an aetion of trover, at the suit of the master's assignees. Any distinction between the effect of a special and a general au- 
But for mere nonfeasance or omission *of duty, [*416] but not for a servant is not liable to answer in a civil action at the mere nonsuit of third persons, but only to his own master $(u)$, feasance. who, in accordance with the maxim already alluded to, "Respondeat superior," is liable to answer for his servant's neglect $(x)$. This distinction between misfeasance and nonfeasance was thus stated by Lord Holt, in his celebrated judgment in Lane v. Cotton $(y)$ :

"It was objected at the bar that they have this rem. Cane v. edy agaiust Breese (the servant). I agree if they could prove that he fook out the bills they might sus him for it: so they might anybody else on whom they could fix that fact; but for a neglect in him they can have no remedy against him, for they must consider him only as a servant, and then his neglect is only chargeable on his master or principal: for a servant or deputy quatenus such cannot be charged for neglect, but the principal only shall be charged for it; but for a misfeasance an action will lie against a servant or deputy, but not quatenus a deputy or servant, but as a. wrongdoer."

Upon the principle that a servant is liable for a mis-Perkins v. feasance, the defendant was held liable in Perkins v. Simith.

thority from the master to the servant, upon the liability of the servant, would scemto be opposed to the cases of P'ring v. Sinith and Stephens v. Elwall, afterwards cited in the text, and which cases were not eited in Pearson $\mathrm{v}$. Graham.

(u) Gidley v. Lord Palmerston, 3 Brod. \& 13. 275, 285.

$(x)$ So the servant of a carrier is not generally responsible for the loss of a parcel to the owner, who slould look to the master, Williams v. C'runstoun, 2 Stark. 82; Calunyh v. Such, 1 Price, 328 , as the luty (the breach of which gives the right of action) is towards the master. See Matshall v. The York, Newcastle, and Berwick Railway Co., 21 L. J., C. 1'. 31; 11 C. 13. (3.5.5; where it was held that a servant might maintain an action against carriers for loss of his lugrage, althongh his master paicl the fare. Seo also Collett v. Norlh Western Railway Co., 16 Q. B. 984; Longmeid v. Holloway, 6 Exc. 767 ; Dalycll v. Tyrer, 28 L. J., Q. B. 5:. In Alton v. Midland Railuay Co., 31 L. J., C. 1. 292; 19 C. B., N. S. 213, it was held that a master conld not sue the company for loss of services of his servant injured by the company where the servant entered into the contract of carriage with the compauy. Though it wonld seem that he might maintain such an uction against another company who had injured lis servant, Berringer v. Great Eastern Reailuay Co., 48 I. .J., C. L. 400; and it has been held that a carrier's servant miglit sue a person who sent a dangerous article, nitric acid, to be carried, not properly labelled, which burst and injured the plaintiti. farment $v$ Burnes, 31 I. J., C. P. 13\%. In such a case, if the servant dies, aclio personalis moritur cum personâ. Pulling v. Great Eastern Railvay Co., 51 I. J., C. L. 453.

(y) 12 Mod. 488. 
Perkins v. Smith.

Stephens v. Eluall.

[*417] Smith $(z),{ }^{*}$ which may be regarded as a leading case upon this subject. In that ease the facts were shortly these:- The plaintiff was assignee of a bankrupt, and the defendant servant and riding clerk to a creditor of the bankrupt; the defendant went to the bankrupt's shop to try and get his master's money and found it shut up, but the bankrupt delivered to the defendant certain goods, for which the defendant gave a receipt in his master's name, and then sold the goods for his, master's use; upon which the bankrupt's assignee brought an action of trover against the servant. It was objected that the action was improperly brought against the servant, who acted wholly in this matter for his master, and that the conversion, which is the gist of the action of trover, was found to be to the nse of the master. But after two arguments at the bar, the Court gave judgment to the plaintiff, Lee, C. J., saying,-

"The point is whether the defendant is not a tortfeasor, for, if he is so, no authority that he can derive from his master can excuse him from being liable in this action. The act of selling the goods is the conversion, and whether to the use of himself or another, it makes no difference. I am very well satisfied that this servant has done wrong, and that no authority that could be derived from his master, before or after the fact, can excuse him."

The rule thus laid down was again acted on in Stephens $\mathrm{v}$. Elwall (a), which was also an action of trover by the assignees of a bankrupt for goods which the bankrapt had sold after his bankruptey to $\mathrm{D}$., to be

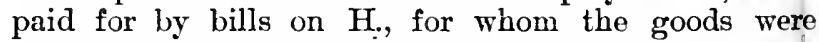
bought. $\dot{H}$. was in America, and the defendant was his clerk; the goods were delivered to the defendant, . who sent them to H. in America. At the trial it was contended, on the authority of Perkins v. Smith, that the defendant was liable, although he merely acted as clerk

(z) 1 Wils. 323 ; see Simonds v. Atkinson, 1 H. \& N. 146 ; and see Hichal $v$. Alestrce, 2 Lev. 12:, ante, p. :3:23, where the action (for negligent driving) was brought against both master and servant.

(a) 4 M. \& S. 259; see Grcenway v. Fisher, 1 C. \& P. 190. In Dixon v. Birch, 42 L. J., Exc. 135, it was held that the salaried manager of an hotel belonging to a company was not an inikeeper liable for loss of goods, although the licence (under $9 \mathrm{Ge}$. 4, c. 61) was granted to him personally. In Mill v. Hawker, 43 L. J., Exe. $129 ; 44$ L. J., Exc. 49 , it was held that a district surveyor was liable to an action for committing a trespass by order of the Highway Board. 
to $\mathrm{H}$; the judge, however, thought *otherwise, [*418] Stephens v. and so directed the jury, who found a verdict for the Elwall. defendant. But in the following term a new trial was granted, Lord Ellenborough, C. J., saying:-

"The only question is, whether this is a conversion in the clerk, which undoubtedly was so in the master. The clerk acted under an unavoidable ignorance and for his master's benefit when he sent the goods to his master; but nevertheless his acts may amount to a conversion, for a person is guilty of a conversion who intermeddles with any property and disposes of it, and it is no auswer that he acted under authority from another who had himself no authority to dispose of it. And the court is governed by the principle of law and not by the hardship of any particular case. For what can be more hard than the common case in trespass where a servant has done some act in assertion of his master's right, that he shall be liable, not only jointly with his master, but, if his master cannot satisfy it, for every penny of the whole damage; and his person also shall be liable for it; and what is still more, that he shall not recover contribution" (b).

Similar principles were again enforced in Cranch v. White (c). That was an action of trover for a bill of White. exchange which had been entrusted by the plaintiff to one Roberts to get discounted. Roberts owed the defendant's mother, who was a coal merchant, and whose clerk the defendant was, a large sum for coals, and instead of getting the bill discounted, Roberts endorsed it and placed it in the hands of the defendant, who carried it to the credit of Roberts's account with his, the defendant's, mother. The defendant, when apprised of Roberts's fraud, refused to deliver up the bill; but it was held that by so doing he rendered himself liable to the action of trover which was brought against him, although it was contended on his behalf that the action should have been brought against his mother; Tindal, C. J., saying that any justification of the defendant's conduct, as the agent of his mother, fell to the ground on the authority of Perkins v. Smith and Stephens v. Elivall.

(b) See, as to this point, Merryweather v. Nixan, 8 T. R. 186;2 Smitl's L. C. 481, where the subsequent cases will be found colleeted. See also Farcbrother v. Ansley, 1 Camp. 343; Atumson v. Jervis, 4 Bing. 66. $\Lambda \mathrm{s}$ to ,whether the Court wonld interfere to protect the servant, see Gregory v. Slowman, 1 E. \& B. 360.

(c) 1 Bing. N. C. 414 ; and see Davies v. Vernon, 6 Q. B. 443. 
Powell v. Hoyland.

Servant not liable without proof of actual conversion by him.

Mires $\mathrm{v}$. Solebay.

Alexander v. Southey.
[*419] *And again, in Powell v. Hoyland $(d)$; where the defendant, acting on behalf of $\mathrm{Y} . \& \mathrm{Co}$., obtained from the plaintiff certain bills of exchange under circumstances which did not entitle Y. \& Co. to them. These circumstances were unknown to the defendant at the time he obtained the bills from the plaintiff, but he, was afterwards, and before he had delivered the bills to Y. \& Co., informed of the facts, and told that his employers had no right to the bills. In spite of this information he refused to give the bills to the plaintiff. and delivered them to his employers; and it was held that by so doing he became liable to an action of trover; Lord Wensleydale observing, "there is no doubt that, though the defendant did not receive the bills for himself but as the agent of Y. \& Co., he may be liable in an action of trover, if the facts show a conversion by him;" which they were held to do.

Where, however, a servant merely refuses to deliver goods received from his master to any other person. without his master's orders, such refusal has been held not to amount to a conversion by the servant, and ho has accordingly been held not liable to an action of trover $(e)$.

Upon this distinction depends the old case of Mires v. Solebay $(f)$. There the defendant, by command of his master, drove some sheep, which the plaintiff claimed to have purchased, on to his master's land, and then refused to deliver them to the plaintiff: $h_{\theta}$ was held not liable in trover for so doing; "for it being in obedience to his master's command, though he had no title, yet he shall be excused."

So where $(g)$ the defendant, who was servant to an [*420]*insurance company, had in his custody in a warehouse, of which he kept the key, certain goods belonging to the plaintiff, saved from a fire at the plain. tiff's house, and which had been carried to the ware. house by the servants of the company, and, upon the plaintiff demanding the goods, said he could not de-

(d) 6 Exc. 67.

(e) If he refuses to give up goods to the rightful owner, and rely on his master's title he may be liable in trover; aliter, if lie merely give a qualified refusal and refer to his master, Lee . Robinson, 25 L. J., C. P. 249 ; Lee v. Bayes, 18 C. B. 599, 607.

(f) 2 Mod. 242.

(g) Alexander v. Southey. 5 B. \& Ald. 247; and see Grylls $\%$. Davies, 2 B. \& Ald. 514. In Day צ. Bream, 2 II. \& Roh. 54, a porter who, in the course of his bnsiness, delivered parcels co:1taining libellous publications, was held not liable to an action for libel, as he was ignorant of the contents of the parcel. 
liver them without an order from the company, he was held not liable to an action of trover, as the refusal to deliver the goods without an order from his master did not amount to a conversion of the goods.

"If," said Holroyd, J., "we were to hold this refusal to be a conversion, it would go this length, that if a person were to call at a gentleman's house and to ask his servant to deliver goods to him, and the servant were to refuse to do so unless a previous application was made to his master, it would amount to a conversion on the part of the servant. In this case the goods came into the defendant's possession lawfully, and the refusal is only till an order is obtained from the defendant's employers. In Perkins v. Smith the defendant received the goods wrongfully at first, and the conversion was by an actual sale of them. Now it is clear that the authority of the master would not amount to a defence of that which was altogether a tortious act of the servant. The case of Mires v. Solebay is an authority in point."

But a warehouseman $(h)$ who refused to deliver Wilson $\mathrm{v}$. goods out of his warehouse to the rightful owner, Anderton. without the direction of the person from whom he (the warehouseman) received them, was held liable to an action of trover at the suit of the rightful owner, as such refusal was considered to be sufficient evidence of conversion. In that case, however, the defendant was a warehouseman, and it was considered that the defendant had by his conduct identified himself with the person from whom he received the goods; whereas, in Alexander v. Southey, the defendant was merely a servant, and referred the parties to his master $(i)$.

Where a servant of the law refused to give up goods Verrall $\mathbf{v}$. which had been attached by legal process, saying that Robinson. they were in the custody of the law, his doing so was held not to amount to a conversion so as to render him liable to an *action at the suit of the owner of [*421] the goods $(k)$. There, however, the defendant ro. mained passive; had he taken upon himself to decide, he might perhaps have rendered himself liable ( $l$ ).

We have already seen that if a servant is guilty of a fraud in transacting his master's business, the master may be liable to an action at the suit of the party de-

(h) Wilson v. Anderton, 1 B. \& Ad. 450.

(i) See Catterall v. Kenyon, 3 Q. B. 310.

(k) Verrall v. Robinson, 2 C., M. \& R. 495.

(l) Catlerall v. Kenyon, 3 Q. B. 310. 
As to servant's liability for fraud in transacting his master's business.

Cullen v. Thompson.

Public officers in subordinate capacity personally liable for misfeasance. frauded ( $m$ ). And it would seem to be the better opinion that the servant also is liable, if he knowingly commit a fraud in his master's business, to answer for it to the party injured, and cannot shelter himself under his master's responsibility, although authorized by his master to commit the fraud; for, as observed by Mr. Justice Story $(n)$, it is an illegal act and contrary to sound morals. It is, indeed, laid down in Rolle's Abridgment (o), that if the servant of a taverner sell bad wine knowingly, no action lies against him, for he only did it as servant. But that position has been frequently doubted by text writers $(p)$, and would seem to be contrary to the principle of the cases before referred to, in which the command of the master has been held no justification of a misfeasance on the part of the servant.

Upon this principle the manager and secretary of a joint stock company, who had furnished detailed statements and were cognizant of a fraudulent report issued and signed by directors only, were held liable to third persons who on the faith of such report had become shareholders in the company $(q)$.

[*422] *We have also, whilst treating of the liability of a master for the tortious acts of his servants, seen that an exception to his general liability in such cases is established in the case of public officers in a superior capacity who are not in general responsible for the tortious acts of their subordinate officers. It by no means follows, however, that such subordinate officers are not themselves responsible for their own misdeeds. On the contrary, the exemption of their superior officers from liability to answer for their misfeasances, would seem to offer an à fortiori reason for holding them responsible for their own acts, otherwise wrongs committed by them might go altogether unredressed, since, upon public

(m) Ante, p. 328. See also Bedford v. Bagshax, 29 L. J., Exc. 59, et cas. ib. sit. Suift v. Winterbotham, Suift v. Jewsbury, ante, p. 272 .

(n) Story on Ag. 310.

(o) 1 Roll. Abr. 95; see Com. Dig. Action upon the ease for a Deceit, $\mathrm{B}$.

( $p$ ) See Mr. Justice Coleridge's edit. of Blackst. Comm. vol. i. 431, note 11 ; Story on Ag. 310, note 1; Smith's Merc. Law, 155, note $(k)$; Paley on Ag. 399, note.

(q) Cullen v. Thompson, 9 Jur., N. S. $85 ; 6$ L. T., N. S. 870. As to the criminal liability of such manager, see ante, p. 412. Where a servant took an agreement for a lease as agent for his master, but afterwards denied his ageney, and claimed it for himself, Wood, V.-C., held him to be a trustee for his master, and decreed costs against him on the higher scale. Earl Stamford v. Dauson, 15 Weekly Rep. 896. 
grounds, Government are not generally responsible for the misfeasances of their officers $(r)$.

Accordingly, in the cases before referred to, of actions Ineputy postagainst the postmaster-general for the loss of letters, we master.

find it admitted on all hands that the servant, throngh whose negligence the letters were lost, would have been liable to actions at the suit of the parties injured, and the only question made was, as to the liability of the master.

"As to an action on the case lying against the party really offending," said Lord Mansfield $(s)$, "there can be no doubt of it; for whoever does an act by which another person receives an injury, is liable in an action for the injury sustained. If the man who receives a penny to carry the letters to the post-office loses any of them, he is answerable, so is the sorter in tho business of his department, so is the postmaster for any fault of his own."

*Upon this principle, in several cases, the [*423] deputy postmaster has been held liable to an action for the non-alelivery of letters which it was his duty to have delivered, as well as the penalty for detaining letters imposed by statute $(t)$.

There is also a large class of cases, which may be con- Ministerial veniently noticed in this place, in which public officers in publiconlicers a merely ministerial capacity $(u)$ have been held liable to liable for answer in an action at the suit of the party injured for negligence, negligence in the performance of the duties cast upon them. Thus, for instance, a sheriff, whose duty in many sheriff; cases, such as the receipt, execution and return of writs, is that of a merely ministerial officer is liable to be sued by the party aggrieved for any act of irregularity, misfeasance or nonfeasance in executing writs $(x)$.

(r) It has, however, been held that the captain of a man-ofwar, who had eommitted an act of trespass in the pnblic service, which was subsequently ratified by the ministers of state, was not liable to an action at the suit of the party injured, who had his remedy, snel as it was, against the Crown only, Buron v. Jenman, 2 Exc. 167, ante, p. 415, note (s). In Bredlanyh v. Gossett, 53 L. J., C. L. 209 ; 12 Q. B. Div. 271 , it was held that no action will lie against an oflicer of the Honse of Commons for acts done under an order of the House with the excention of which he is charged by a resolution of the House, although such resolution may forbid a member of the House to do that which lyy the law of the land he has a right to do.

(s) In Whitfield v. Lord Le Despenser, Cowp. i(i).

(t) Stock v. Marris, 5 Burr. 2709; Bames v. Folcy, ib. 2711; Rouning v. Goodchild, ib. 2715; 3 Wills. $443 ; 2$ W. BI. 906 ; sce Couth v. Stecl, 23 I. J., Q. B. 126.

(a) But no action lies against persons acting in al judicial eapaeity, Groentelt v. Bururll, 1 Jord Raym. 454; see Jiller v. Sreare, 2 iv. Bl. 114, ; Doswell v. Impey, 1 is. \& C. 16;3.

(x) Bace. Abr. Slserifl, II.; Watson's Sherifl, 117. 
but not undersheriff.

Returning officer.

Overseer.

Lottery commissioners.

Collector of customs.

But an action by the party grieved does not generally lie $(y)$ against an under-sheriff for a breach of duty in the office of sheriff; the action must be brought against the high-sheriff as for an act done by him $(z)$, and if it proceeds from the default of the under-sheriff or bailiff, that is a matter to be settled between them and the high-sheriff $(a)$.

A returning officer at an election of members of parliament, was held by the House of Lords, in the great case of Ashby v. White, to be liable to an action for maliciously refusing to receive the vote of a person entitled to vote $(b)$.

[*424] *And the case of Perring v. Harris (c), which was an action against an overseer of the poor, for maliciously omitting to insert the plaintiff's name in the poor-rate, whereby she was prevented from obtaining a licence to sell beer, was one of a similar nature.

So lottery commissioners have been held liable to an action for not adjudging a prize to the holder of a ticket entitled to receivo it. $(d)$.

And so a collector of customs, appointed by the com. missioners under the statute $3 \& 4$ Will. 4 , c. 51 , was held liable $(e)$ to an action at the suit of the party grieved, for nonfeasance in the exercise of his office, viz., for refusing to sign a bill of entry of certain goods without payment of an excessive duty. In giving judgment in that case Lord Denman, C. J., said,-

"The defendant is a public ministerial officęr, and being so is responsible for neglect of his duty to any

(y) In certain cases it docs by Act of Parliament, see Comp. 405. And in Ireland all aetions may, by 57 Geo. 3, c. 68 , s. 3, be brought against the under-sheriff, unless for the immediate act of the sheriff.

(z) For the under-sheriff ought to act in the name of the highsheriff, see Wats. Sheriff, 37; and Stroud v. Watts, \& C. B. 92y; 3 D. \& L. $799 ;$ R. v. Sehlessingcr, 10 Q. B. 670.

(a) Cameron v. Reynolds, Cowp. 403.

(b) 2 Lord Raym. 938; 1 Salk. 19; 6 Mod. 45; 1 Smith's L. C. 227; and see Cullen v. Morris, 2 Stark. 577; Pryce v. Belcher, $3 \mathrm{C}$. B. $58 ; 4$ D. \& L. 238 , which were similar actions, and from which it wonld seem that malice is a necessary ingredient in such action, as the returning officer is partly a judicial and partly a ministerial officer, thongh it was formerly thought otherwise, see per Holroyd, J., in Doswcll v. Impey, 1 B. \& C. 165. But see Pickering v. James, 42 L. J., C. P. 217.

(c) 2 MI. \& Rob. 5.

(d) Schinotti v. Bumsted, 3 T. R. 646.

(e) Barry v. Arnaud, 10 A. \& E. 646. And see Barrow v. Arnaud, 8 Q. B. 595 , where it was not even suggested that the de fendant was not liable to be sued, if the duty claimed in that case was excessive. 
individual who sustains damage by such neglect. Schinotti v. Bumsted $(f)$ is a strong authority to this effect; the facts in that case respecting the commissioners of the lottery tending much more to raise a doubt whether the defendants had not a judicial discretion entrusted to them; and in Lacon v. Hooper $(g)$, which was an action against the Commissioners of Cus. Commistoms for not making a certain order for the payment sioners of of money to which the plaintiffs claimed to be entitled Cnstoms. under an act for the encouragement of the South Sea whale tishery, it was not questioned but that even they would be liable to the action if the neglect of duty were made out."

Where an act of parliament provided that no matter or thing done, or contract entered into by the Commissioners of Sewers, or by any clerk, surveyor or other officer or person acting under their direction, should, if the matter *or thing were done or the contract [*425] were entered into bona fide for the purpose of executing the act, subject them personally to any action or liability whatever, and any expense incurred by them was to be borne and paid out of the funds under the con. trol of the commissioners; it was held that the effect of this was to absolve from personal liability to an action persons who bona fide did some act under the direction of the commissioners which but for that clause would subject them to an action $(h)$.

Where a vessel of the royal navy, towing two trans. Hodgkinson ports, anchored by order of the admiral, and the cap. v. Fernie. tain ordered tho vessels in tow to hold on by their warps, and afterwards a breeze sprung up and one of transports swinging to it came into collision with another transport in another column, and the captain stated in evidence that after the order to hold on by the warps it would have been proper for the master of the transport to let go his anchor if anything occurred which would have made it dangerous to his own or other ships if he did not do so: it was held in an action against the owner of the transport for damage done by the collision, that the judge was right in leaving it to the jury to say whether the master was not guilty of negligent seamanship in not dropping his anchor when the wind changed $(i)$.

(f) 6 T. R. 646.

g) 6 'T. R. 224.

(h) Ward v. Lee, 26 I. J., Q. B. 142.

(i) Ilodgkinson v. Fernie, 26 I. J., C. P. 217. 
THE SERVANT'S CHARACTER.

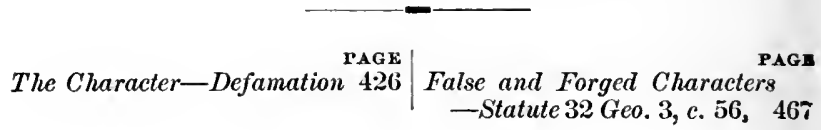

\section{The Character-Defanation.}

"The giving a character of a servant," says the learned author of the Treatise on Slander (a), "is one of the most ordinary communications which a member of society is called on to make, but it is a duty of great importance to the interest of the public: and in respect of that duty a party offends grievously against the interests of the community in giving a good character where it is not deserved, or against justice and humanity in either injuriously refusing to give a character, or in designedly misrepresenting one to. the detriment of the individual."

Master not bound to give any eharacter.

Carrol v. Bird.
It is clear, however, that in the absence of any specific agreement to that effect, there is no legal obligation binding a person who has retained another as a servant to give that person any character at all on dismissal, and that no action will lie against him for refusing to do so. Where, therefore $(b)$, an action was brought by a servant against her master for whiolly refusing to give her any character whatever, on dismissal, by reason of which refusal one S. refused to hire her, Lord Kenyon said, the action could not be supported; that in the case of domestic and menial servants there was no law to compel the master to give the servant a character; it might be a duty which his feelings [*427]*might prompt him to perform, but there was no law to enforce the doing of it.

And where a master does give a discharged servant a character $(c)$, what he says or writes upon the subject to

(a) Starkie on Slander, vol. i. 293.

(b) Carrol v. Bird, 3 Esp. 201.

(c) Where A., who had been servant to G., applied to D. for a situation, and $D$. agreed to take her, if, in answer to a letter written to G., a satisfactory reply was received. D. wrote to $G$. 
a person bona fide inquiring is, in general, looked upon when given, as a privileged communication $(d)$, and no action what- the commuever can be maintained by the servant (e) against him on account of it, if done bona fide, and without any nication is malicious feeling on his part, against his late servant. It is a mistake to suppose that the law allows this privilege only for the benefit of the giver of the character. It is of importance to the public that characters should be readily given. The servant who applies for the character, and the person who is to take him, are equally benefited. Indeed, there is no class to whom it is of so much importance that characters should be freely given as honest servants. It is for that object that the communications are protected $(f)$.

In order to support any action in respect of a char. acter given by a master to a servant, it must be proved that the character was false, and also that it was mali. ciously given. It is not sufficient merely to prove that the character was false, if given bona fide, for, as observed by Lord Denman in Fountain v. Boodle $(g)$, sufficient. even though the statement should *be untrue in [*428] fact, the master will be held justified by the occasion in making that statement, unless it can be shown to have proceeded from a malicious mind $(h)$. If, however, the party giving the character knows what he says to be untrue, that may deprive him of the protection which

for A.'s character, and G. answered the letter by post, directing the reply to $\mathrm{D}$.; but $\mathrm{A}$., wishing to intercept the letter, went to the post-office, stated that she was $D$.'s servant, obtained the letter and then burnt it. It was held by the fifteen judges that this was larceny, $R$ v. Jones, 2 Carr. \& K. $236 ; 1$ Den. C. C. 188.

(d) The principle seems to be that defamatory worls are primi facie malicious: some occasions rebut the presumption of malice: those are called cases of privileged communication. If the worls be more defamatory than the occasion recuire, that agrain raises the presumption of malice. Per Erle, C. J., in C'ooke v. Hildes, 5 E. \& B. $: 3: 35$.

(c) As to actions by the receivers of false eharacters against the givers, see post.

(f) Per Wightman, J., in Garlner v. Slule, 13 Q. B. 801. But they are not privileged from production under an order for discovery, Wcbb v. Enst, 49 L. J., C. L. 250; 5 lixe. Div. 108. And see Hill v. Camplell, 44 I. J., C. P. 97, as to all orler to inspect a letter written by defendant's wife, containing the libel complained of.

(g) 3 Q. B. 12 , post, p. 433 ; and see Harris v. Thompson, $13 \mathrm{C}$. B. 3333.

(h) In Harris v. Thompson, ubi supra, Willians, J., said, "Few rules of law are of greater practical importance than that which requires proof of express malice, where the words are spoken under circumstances which make the communication privileged." 
the law throws around such communications when made bona fide $(i)$.

Implied In ordinary cases of slander the law implies such malice not malice as is necessary to maintain the action, and, sifficient. therefore, in such cases it is sufficient to charge that the defendant spoke the words complained of falsely; it is not necessary to state that they were spoken maliMalice in ciously $(j)$. But in actions for such slander as is prima fact must be facie excusable on account of the cause of speaking or proved. writing it, as in the case of servants' characters, confidential advice or communications to persons who ask, or have a right to expect it, malice in fact must be proved by the plaintiff $(k)$.

Edmonson v. [*429] *Therefore, where an action $(l)$ was brought Stevenson. by a servant against her former mistress for saying to a lady who came to inquire her character, that "she was saucy and impertinent, and often lay out of her owu bed, but was a clean girl, and could do her work well;" though the servant proved that she was by this means prevented from getting a place, yet, per Lord Manstield, this is not to be considered as an action in

(i) Per Lord Ellenborough, C. J., in Hodgson v. Scarlett, 1 B. \& Ald. 240. The servant, if charged with dishonesty and mioconduct in the defendant's service, is at liberty to prove his good character and conduct in former services, since general character is in some respects in issue, King r. Waring, 5 Esp. 13. So the plaintiff may prove by the evidence of other servants in the same family, that whilst he remained in the defendant's service he conducted himself well, and that no complaints of the nature ascribed to him by the defendant then existed, 3 B. \& P. 589. The tendency and bearing of this evidence is to show that the defendant knew that the character which he gave was false: the plain reason for this is, that the knowledge of misconduct frequently rests with the defendant himself, and being unable to prove it by the testimony of others, if the general presumption (of bona fildes on the part of his master) were to operate against him he would be left without defence. To prevent such inconvenience the law requires malice to be proved from other sources. In case, however, the plaintiff should be able expressly to prove that the defendant was aware of the falsity, no further proof of malice wonld be requisite; nor indeed could stronger proof of it be adduced than that the defendant had given a eliaracter of the plaintiff injurious to his reputation, with a full knowledge that it was untrue. 2 Stark. on Sland. 58.

(i) Styles, 392; Mercer v. Sparkes, Owen, 51 ; Noy, 35 ; and see per Le Blane, J, in $R$. v. Creevey, 1 M. \& S. 282; Rowe v. Roach, 1 M. \& S. 304.

(k) See per Bayley, J., in Bromage v. Prosser, 4 B. \& C. 254, 256 ; 1 Stark. on Slander, 292 ; Clark v. Molyneux, 47 L. J., C. L. 230 , where a defamatory communication made by a elergyman to his curate for the purpose of obtaining his advice, was held to be privileged.

(l) Edmonson v. Stevenson, Bull, N. P. 8. 
the common way for defamation by words, but that the gist of it must be malice, which is not implied from the occasion of speaking, but should be directly proved; that it was a confidential declaration and ought not to have been disclosed. But if without ground, and purely to defame, a false character should be given, it would be a proper ground for an action. The same learned judge, on several other occasions, laid down similar law. And since in all subsequent cases such has been universally consid-followed. ered to be the rule $(\mathrm{m})$; the struggle on the part of the plaintiff in actions,for defamation by a servant against a master being, generally, to show that the words complained of were uttered under such circumstances as showed express malice on the part of the defendant.

"The rule," said Lord Campbell, C. J., in Taylor v. Hawkins $(n)$, "is, that if the occasion is such as will Hawkins. repel the presumption of malice, then it is a privileged communication, and $i i$ lies on the party complaining to show that malice existed, and if he does not show that by evidence, then it is the office of the judge to say that there is no evidence to go to the jury, and to nonsuit, or direct a verdict for the defendant. If that were not so, the question must be left in every case to the jury, and they might be justified in finding a verdict for the plaintiff. So that, if a man gives a character to a servant fairly and honestly, sill it must be left to the jury to say whether or not there was malice; and it would be competent *to them to find a [*130] verdict with damages in a case where nothing had been done beyond fairly giving a character to a servant."

It is not, however, sufficient to entitle the plaintiff to It is not have the question of malice left to the jury, that the sufficient facts proved should be merely consistent with the presence of malice, as well as with its absence; for the existence of malice is condsistent with the evidence in all cases, except those in which something inconsistent with malice is shown in evidence; so that to say that in all cases where the evidence was consistent with malice it ought to be left to the jury, would be, in

(m) See Hargrawe v. Le Breton, 4 Burr. 242;; Weatherston v. Mawkins, 1 T. R. 111; Lowry v. Aikenhead, Mich. T. \& Geo. 3, cited in Kogers v. Clifton, 3 B. \& P. 594; see per Tindal, C. J., in Ilooper v. Truscott, 2 Bing., N. C. 45\%; and Smith v. Thomas, 2 Bing., N. C. 381. In Child v. Afleck, 9 13. \& C. 406, Parke, J., said, "The rule laid down by Lord Mansfield in Edmmson v. Stcienson, has been followed ever sinee." And see the cases cited, 1 Wms. (Saund.) 130.

(n) 16 Q. 13. 303; 20 L. J., Q. B. 313; and see per Lord Denman, C. J., in Kelly v. Partington, 4 B. \& Ad. 702. 
Cases showing express malice.

Rogers v. Clifton.

Officiously calling ou former master ; effect, to say that the jury might find malice in any case in which it was not disproved, which would be in. consistent with the admitted rule that in cases of privileged communications malice must be proved, and, therefore, its absence presumed till such proof is given. It is certainly not necessary, in order to enable a plaintiff to have the question of malice submitted to the jury, that the evidence should be such as necessarily leads to the conclusion that malice existed, or that it should be inconsistent with the non-existence of malice; but it is necessary that the evidence should raise a probability of malice, and be more consistent with its existence than with its non-existence $(o)$.

Since, then, the liability of a master to an action for defamation, in consequence of the character given by him to a discharged servant, so completely depends upon the existence of express malice on his part, it will be desirable to set before the reader some of the cases in which the circumstances have been such as to show express malice on the part of the master, who has accordingly in such cases been held liable $(p)$.

[*431]. *In Rogers v. Clifton $(q)$ it appeared that the plaintiff, having been hired as a servant by the defendant, lived six months in his service, when the latter turned him away without giving him a month's warning, in consequence whereof the plaintiff, conceiving himself entitled to a month's wages, refused to quit the service without being paid that sum. On this re. fusal the defendant procured a police officer to put the plaintiff out of the house, and employed his attorney to settle his wages with him. Immediately after this the defendant called on M., with whom the plaintiff had previously lived, to inform him that the plaintiff had behaved in an impertinent and scandalous manner, that the defendant had discharged him, but he refused to go without a month's wages, and the defendant

(o) Per Maule, J., in Somerville v. Haxkins, 10 C. B. 583; 20 L. J., C. P. 133; and see Taylor v. Hawkins, ubi supra; Harris v. Thompson, 13 C. B. 333; Spill v. Maule, 38 L. J., Exc. 138; L. R., 4 Exc. 23:; Laughton v. Bishop of Sodor and Man, 42 L. J., Pr. C. C. 11 .

(p) The circumstances under which the master and servant parted, any expressions of ill-will uttered by the former, his officiously acquainting others with the servant's misconduct, without any previous application to him for a character, are all facts which are proper for the consideration of a jury, to enable them to form their opinion upon the question of intention. See 2 Stark. on Slander, 58.

(q) 3 B. \& P. 587. 
therefore desired M. not to give him another character. The plaintiff afterwards offered himself to $\mathrm{H}$., who and bad charwrote to the defendant for his character, and the de- acter given fendant in reply said he was "a bad tempered, lazy, to person impertinent fellow," and had given him a great deal of alout to hire; trouble, whereupon $H$. refused to hire the plaintiff. The plaintiff brought an action against the defendant for defamation, and proved, by servants of the family, that, while in the defendant's service, he had conducted himself well, and that no complaints of the nature where no ascribed to him in the defendant's letter had all that previons time existed. The jury found a verdict for the plain- eomplaints tiff, and a rule nisi, which had been obtained by the made. defendant to enter a nonsuit, was afterwards discharged, on the ground that the character given by the defendant was proved to be untrue, and his condnct shown to be malicious by his officious interference in going to the plaintiff's former master.

In Pattison v. Jones $(r)$ the defendant having dis-Pattison $v$ charged his servant, the plaintiff, and hearing that he Jones. was about to be engaged by $B$., wrote to $B$. and informed him that he had discharged the plaintiff for misconduct. B. having *desired further infor. [*432] mation, the defendant wrote a second letter to him, stating the grounds on which he had discharged the plaintiff. It was held, in an action by the servant Information against the defendant for the libel contained in the volunteered second letter, that assuming the letter to be privileged, to person it was a question for the jury whether the second letter alout to was written bona fide, or maliciously with intent to in. hire; jure the plaintiff, and the jury having found a verdict and second for the plaintiff, the Court refused to disturb it, Bayley, J., stating it as his opinion that a master "may (when he thinks that another is about to take into his service one whom he knows ought not to be taken) set himself in motion and do some act to induce that other to seek information from and put questions to him. The answers to such questions, given bona fide with the intention of communicating such facts as the party ought to know, will, although they contain slanderous matter, come within the scope of a privileged communication. But in such a case it will be a question for a jury whether the defendant has acted bona fide intending honestly to discharge a duty; or whether he has

(r) 8 B. \& C. 578. The action was brought on the second letter.

25 MAS. \& SER. 
acted maliciously, intending to do an injury to the servant."

Kelly v. In Kelly v. Partington (s) the plaintiff had been in Partington. the defendant's service as shopwoman, but was disDishonesty charged. S., who was going to hire the plaintiff, incharged to person about to hire; quired her character of the defendant, who charged her with having secreted money taken from his till, and also stated that when she came into his service she borrowed half a sovereign of her mother, and that before she had been there two months and before she re. ceived any wages, she paid her mother the money and and repeated made her a present of a sovereign. The plaintiff's relation of brother-in-law, A., afterwards called upon the defend. servant. ant for an explanation of the words, when he repeated the same charges, wherenpon A., with reference to the other statement, observed that the defendant no doubt made entries in some book of the times at which he [*433] *paid his servants' wages, and that on reference to it he would probably find that he was mistaken in what he had asserted. The defendant then went to his desk, took out a memorandum book and looked at it; after which he turned to $\mathrm{A}$. and asked "Do you know when she received ber wages?" A. answered "No;" but he would go by the defendant's account, as that was likely to be correct. The defendant then said, "If you do not know I am not going to tell you," and put the book into the desk again. A. upon this made some allusion to intended proceedings at law, and said he considered the case of theft as trumped up, to with contemptuous grin. which the defendant made no answer, but "grinned" in a contemptuons manner at $\mathbf{A}$.; and upon his remon. strating, and observing that if the plaintiff had not had friends she might have gone upon the town, the defendant said (speaking of himself and his wife), "What is that to us?" Evidence was then given in contradiction of defendant's statement as to the time when the plaintiff repaid the half-sovereign. Upon this case the defendant's counsel urged that the plaintiff should be nonsuited, on the ground that there was

Slight evidence of malice. no proof of express malice. But Patteson, J., before whom the case was tried, refused to nonsuit the plaintiff, and in the following term an application on the part of the defendant for leave to enter a nonsuit was refused by the Court of Queen's Rench, as there were circumstances, though slight, from which malice might be inferred.

(8) 4 B. \& Ad, 700.

(448) 
In Fountain v. Boodle $(t)$, the plaintiff, a young Fountain v. person who had been educated for a guverness, was Boode. engaged by the defendant, Mrs.' B., in November, False state1839 , as daily governess to instruct young children, ment made to which employment she retained about fourteen month, person about During that period D., sister-in-law of the defendant, being in want of an instructress for her children, Mrs. B. recommended the plaintiff to her for that purpose; and in September, 1840, S. wanting a person to instruct his wife, a very young lady, *in the seve- [*434] ral branches of plain English education, Mrs. B. recommended the plaintiff to him for that purpose. From the $19 \mathrm{th}$ to the $23 \mathrm{rd}$ of November, 1840 , the plaintiff was prevented by illness from attending at Mrs. B.'s; and on her return to her employment there, a letter was given to her from Mrs. B., dated 19 th November, informing her that her services would not be required beyond the 19th December, but without assigning any reason. At the latter date she ceased accordingly to instruct the defendant's children. In September, 1841, plaintiff was about to be engaged by $\mathrm{N}$., as instructress for her children; and N. applied by letter to Mrs, B. respecting the plaintiff's character, in the following terms: "I shall be obliged by your informing me whether you consider her competent to undertake tho instruction of little girls from nine to thirteen years of age (with assistance in music only), and iî you were perfectly satisfied with her tuition; also for what reason you declined her attendance; and whether you consider her a person of good principles and ladylike deportment, of a mild but firm disposition. I will thank you to reply to this question at your earliest convenience: and for any other observations you may think proper to make, I shall feel obliged." 'To this appli cation Mrs. B. replied in the following letter, the alleged libel: "In answer to your inquiries respecting Miss F., I beg to say she had to instruct five of my children from three to nine years old; it is about a twelvemonth since I employed her, and she taught them as a daily governess for fourteen months, and engaged herself to teach everything but music, which she know nothing of: and I parted with her on account of her incompetency and not being ladylike nor good. tempered. When I engaged her she recommended a young friend of hers to teach the music, whom I was much pleased with, and I discontinued her services 
Fountain $\mathbf{v}$. when I took another governess." To this was added Boodle. " a postscript, "May I trouble you to tell her that this is the third time I have been referred to. I beg to decline any more applications." $\mathrm{N}$., in consequence, [*435] broke off her engagement with *plaintiff, which was the special damage complained of. The two appli. cations alluded to in the postscript were those of $D$. and S. General evidence was given of the plaintiff's competency, good temper and manners by her personal friends. There was no direct evidence of the ground

Left to jury to say if made knowinigly. of dismissal. The defendant's counsel contended that the communication was privileged; but Lord Denman, C. J., refused to nonsuit the plaintiff, and left it to the jury to say whether, looking at the whole case, there was sufficient proof that Mrs. B., in writing the letter, had been influenced by some improper feeling towards the plaintiff to make a false statement knowingly. And they found a verdict for the plaintiff. In the fol. lowing term a rule for a new trial, on the ground of misdirection, and of the verdict being against the weight of evidence, was applied for but refused. And Lord Denham, C. J., said,-

"A character bona fide given to a servant of any de. scription is a privileged communication, and in giving it bona fides is to be presumed. Even though the state. ment should be untrue in fact, the master will be held justified by the occasion in making that statement, un . less it can be shown to have proceeded from a malicious mind. Malice may be established by various proofs ; one nuay be, that the statement is false to the knowledge of the party making it. Up to this point the summing up was not complained of : but another part of it was brought before the court as objectionable. The misstatement here imputed was, that the defendant had discharged the plaintiff by reason of her faults enumer. ated in the letter. This could be known to nobody besides the defendant, but she might have shown the probability of that being the real motive from remonstrances made by her during the plaintiff's attendance, or complaints at its being terminated. I told the jury to the effect that if the plaintiff brought any evidence of wilful untruth, some evidence of the contrary might be reasonably expected when the nature of the case allowed it. This is a general proposition applicable to every form of action and to evidence of all kinds." "The court wished for time to consider whether there was in the present case any evidence of wilful falsehood in the character given." 
His lordship then went through the evidence and added,-

"Here was undoubtedly some evidence of the injurious character being dictated by some indirect motive. Of course, then, it must be laid before the jury. But the learned counsel contends that it is so extremely slight, that, though uncontradieted in any particular, the jury ought to have * found a verdict against [*436] its sufficiency. $\mathrm{He}$ observes that the privilege is but illusory, if circumstances so minute can be raised into proof of malice. Much more illusory would it be to hold that there was evidence on which the jury must decide, but that they must decide one way or the verdict cannot stand. We cannot place ourselves in their stead and impose our own judgment upon them. They have advantages for attaining the truth which we do not possess, and are the proper tribunal for that purpose. They are bound to decide upon the weight of the evidence laid before them, and we cannot say that they have done wrong in the present instance."

In a case where $(u)$ it appeared that the plaintiff Rumsey v. was servant to W. C., whose wife called on Mrs. Webb, Webb. and asked her how her (Mrs. C.'s) sister had behaved Information to the plaintiff during Mrs. C.'s absence in the country; of servant's whereupon Mrs. Webb said, "Mrs. C. you are not given to aware what kind of a servant you have; if you were master by a you would not keep her, for I can assure you she is neighbour. often out with our married man; she was out with him last Sunday morning, and when you were in the country she was out gossiping till eleven or twelve o'clock at night;" upon which the mistress discharged her servant; and it appeared that Mrs. C. had, on a previous occasion, asked Mrs. Webb to look after her servant. Coltman, J., left it to the jury to say whether the words were spoken with the honest intent of giving a neighbour important information of what was going on in his family, or whether it was done in an idle, gossiping and malicious spirit. They found a verdict for the plaintiff, and the court afterwards rofused to disturb their finding.

The defendant's conduct in putting a justification Justification upon the record which he does not attempt to prove, plealed, but and will not abandon, rnay be taken into consideration mot proved or as proving malice, aad aggravating the injury. And if the dofendant's conduct in that respect may at all effect the verdict, every other part of his conduct may

(u) Rumsey v. Webb, Carr. \& M. 104. 
equally be laid before the jury ; refusing to make reparation for unjustifiable slander may have that effect; and the malice proved to exist at the time of the trial, [*437] but connected with the *subject matter of it, may well be believed to have existed at the time of speaking the words $(z)$.

Gilpin v. The plaintiff was master of a national-school in a Fonoler.

Pastoral

letter distributed by a rector, about his schoolmaster, not privileged, evidence of malice.

Cooke v. Wildes. parish of which the defendant was rector, and also one of the managers of the school. The defendant re quested the plaintiff to teach a Sunday-school in connexion with the national school, which he declined on account of the increased labour, and was, in consequence, dismissed. The plaintiff being about to set up a school on his own account in the same parish, the defendant wrote and distributed in that and the adjoining parish a pastoral letter, in which he denounced the plaintiff's conduct as unchristian-like, and warned his parishioners against affording any countenance to the projected school, either by subscriptions, or by sending their children to it. It was held by the Exchequer Chomber that the communication was not privileged, and also that there was evidence for the jury of express malice. They also held that, in determining the question of malice, the jury might look at the libel itself $(y)$.

The defendant $(z)$ was deputy clerk of the peace, and, as such, submitted to the quarter sessions $(a)$ his acDeputy clerk count of the expenses of printing the register of connty of the peace voters; and previously to this he addressed a letter to reporting conduct of tradesmen to finance committee. the finance committee of magistrates, explaining why he had taken away the contract for printing from the plaintiffs (who were printers formerly employed), stat. ing therein that he thought it his daty to report the circumstances, "particularly as the character and con. duct of the persons who are chiefly employed by the county as printers and stationers are involved." The letter then stated circumstances to show that, as appeared from a comparison with terms offered by other printers, the plaintiffs had demanded too high terms upon grounds not supported by facts, and it concluded, [*438] *" under the circumstances I have stated, it will be seen that I had no alternative but to adopt the course

(x) Simpson v. Robinson, 12 Q. B. 511. See further on this point, Wilson v. Robinson, 7 Q. B. 68; Warwick v. Foulkes, $12 \mathrm{M}$. \& W. 507.

(y) Gilpen v. Fowler, 9 Exc. 615.

(z) Cooke v. Wildes, 5 E. \& B. 328 ; 24 L. J., Q. B. 367.

(a) Under stat. $2 \& 3$ Will. 4 , c. 45 ss. 55,56 , and $6 \& 7$ Vict. c. 18, s6. 49,54 . 
I have taken, rather than submit to what appears to have been an attempt to extort a considerable sum from the county by misrepresentation." It was held that. although the occasion was privileged, there was evidence from the language of the letter, that there was express malice.

In the last two cases it was also decided, as indeed had been previously laid down (b), that, in considering may be the question of express malice, the libel complained of looked at. may itself be looked at, although it be a privileged communication.

In Ireland $(c)$, and America $(d)$ also, it has been Exceeding laid down that, although expressions used beyond what oecasion, the occasion warranted would not divest a privileged evidence of communication of its privilege, yet that such expressions would be evidence of malice in fact.

In Fryer v. Kinnersly $(e)$ the facts were these: The Fryer v. defendant was a country gentleman and a member of Kinnersly. an Horticultural Society of which E. was superintendent, and E. was in the habit of recommending gardeners to members. Defendant being in want of a gardener applied to E., and E. recommended the plaintiff, whom he had known for five or six years, and the defendant engaged him from 1st February, 1862. In 1863, defendant being dissatisfied with plaintiff, gave him a quarter's notice to leave, which expired on 30th April, 1863. Just before that date an altercation took place between plaintiff and defendant, and defendant on 20 th April wrote the following letter to E. :-

"On Saturday I had another scene with Fryer in my garden. He was extremely violent, came towards me several times with an open clasp-knife in his hand, and his eyes starting from the sockets with rage, a perfect *raving madman. I was fortunately accompanied [*439] by my upper servant. He accused me of having opened a letter of his and said he had written to the General Post Office about it, and would take proceedings, as it was an indictable off ence. I have found in my post-bag since my notice to him to leave, a letter and a dirty newspaper. The letter was delivered to him unopened, and certainly no letter for him was ever opened by me. I went to-day to inquire at the B. post-office if he had

(b) In Wright v. Woodgate, 2 Cr. M. \& R. 573.

(c) Ruckley v. Kierwan, 7 Ir. C. L. Rep. (1857,) 75.

(d) Gasselt v. Gilbert, 6 Gray, 94.

e) 33 I. J., C. P. $96 ; 15$ C. B., N. S. 422. Upon this caso being cited in Cowles v. Potts, 34 L. J., Q. B. 248, Blackburn, J.. said, "I do not quite understand the ratio decidculi." 
Fryer v.

Kinnersly.

Facts not showing malice.

Child v. A.fheck.

Reports heard since dismissal ;

Child v. Affleck. made any complaint there about me, but found that no complaint had been made there. Mr. B. told me that some time ago Fryer obtained a post-office order for some one in London, and not having givon the correct name and address the money was not paid. He came to the post office and abused Mr. B. in very rude language. I think it right that you should be informed of Fryer's violent conduct, as you might unwittingly recommend him without being aware of his temper and faults. I have engaged the gardener of whom I spoke to you; he has been here, and likes the place."

The plaintiff brought an action for libel, and the Court of Common Pleas held that whatever might have been their decision, had the letter been confined to a simple statement of the servant's conduct, yet that the letter clearly went, in their judgment, beyond what was justified by such a communication : and the plantiff recovered a verdict and damages $(f)$.

But in the following cases $(g)$ it was held that the facts proved were not evidence of malice. The plaintiff had been in the service of the defendants, Mrs. A. having, before she hired her, made inquiries of two persons, who gave her a good character. The plaintiff remained in the defendant's service a few months, and was afterwards hired by another person, who wrote to Mrs. A. for her character, and received the following answer, the alleged libel :-

Mrs. A.'s compliments to Mrs. S., and is sorry that in reply to her inquiries respecting E. Child, nothing can be in justice said in her favor. She lived with Mrs. A. but for a few weeks, in which short time she frequently conducted herself disgracefully; and Mrs. A. is concerned to add she has, since her dismissal, been credibly informed she has been, and now is, a prostitute, in Bury."

[*440] *In consequence of this letter the plaintiff was dismissed from her situation. It further appeared that after that letter was written Mrs. A. went to the persons who had recommended the plaintiff to her, and made a similar statement to them. But there was no evidence of the good conduct of the plaintiff at the period to which the letter referred. It was held that

(f) And see Williamson v. Frere, 43 L. J., C. P. 161, where it 'was held that unnecessarily sending a message by telegraph, which would necessarily be seen by the clerks, instead of by letter, was 'evidence of malice.

(g) Child v. Affleck, 9 B. \&. C. 403; and see Dixon v. Parsons, 1 Fost. \& F. 24. 
the letter was privileged, and the other communications repeated to having been made to persops who had recommended person who the plaintiff, were not evidence of malice. The plaintiff recommenclwas nonsuited, and two of the learned judges $(h)$ expressed opinions that Mrs. A would have stopped short of her duty in withholding the information contained in the latter part of the letter.

The plaintiff had been cook in the defendant's family, Garduer v. and left $(i)$. M. applied for her character at a time slade. when Mrs. Slade was ill. Mr. S. answered the applica- Answers to tion, and gave the plaintiff a good character, whereupon inquiries M. hired her. Mrs. S. recovered, and having occasion induced by M. hired her. Mrs. S. recovered, and having occasion defendant ins to write to M. about another cook, asked about her deal- to ficts disings with respect to meat, \&c., in the kitchen, and covered since ended, "I mention this particularly, having discovered character that I have been imposed upon in this way a short time given. ago." M. called on Mrs. S., and she in conversation spoke the words complained of, which were to the effect that she suspected that the conduct of the plaintiff, wher in her service, was not honest. After action brought she wrote to M. saying, *"You will re- [*441] member that I imputed no dishonesty; for of that I have no knowledge." The jury found that the defendant by her letter intended to induce inquiries on B.'s part as to the plaintiff, and found a verdict for the plaintiff. But the court afterwards ordered a nonsuit to be entered, on the gronnd that the communication was privileged, and there was no evidence of malice. And Lord Denman said,--

"I think the privilege which protects a master in giving a character lasts as long as anything is discovered before unknown to the master: as, for instance, if

(h) Bayley and Littledale, JJ.

(i) Gardner v. Slade et ux., 13 Q. B. 796. See also Owens v. Roberts, 6 1r. C. L. Rep. (1856), 386, where Mronahan, C. J., said, "We are of opinion that if a person, having an interest in obtaining information as to the aflairs of another porson, makes a bon $\hat{a}$ fide applieation to a third person for that purpose, and the latter in reply to such inquiry gives the information required, such a communication is privileged : for the fact of such an inquiry having been made, not officiously but bona firle and by a person interested, imposed upon the person of whom the inquiry is mite an obligation either not to speak at all 1 pon the suljecet, or if he does so, to spoak the truth. And we are of opinion upon all the uuthorities, that in the case of a person making an inquiry of another who is the acpuaintance of the third person as to whom the inquiry is made, and from his position likely to be acyuainted with the aflairs of the latter, and whore the party making the inquiry is or is about to become a crevitor of such third person, that such a communication is privileged." 
I give a good character to a servant, and next day discover that the servant is dishonest; surely, in such a case it becomes my duty to communicate my discovery to the person to whom I have given the character."

And Coleridge, J., added, "Nobody can doubt that." Harris v. The plaintiff $(k)$ was secretary of the Brewers' InsurThompson. ance Company, and being charged with misconduct was Facts learnt called upon to attend a board of directors to explain, at one board but declined to so; whereupon the directors, after hearof directors communicat- ing the nature of the charges, passed a resolution deed to another claring him to have been guilty of gross misconduct by member and dismissing him. The defendant, who was a direcof both tor of that company and also of another company called boards. the London Necropolis Company, communicated the facts of the plaintiff's dismissal from the service of the former company "for gross misconduct," at a board meeting of the latter company, and proposed a resolution to dismiss him from his employment as their auditor, and in answer to an inquiry from the chairman, - said the misconduct consisted in "obtaining money from the solicitors of the company under false pretences and paying a debt of his own with it;" and upon the plain. tiff's appearing on a subsequent day with his attorney before the board to meet the charges against him, the defendant refused to go into them. It was held that such refusal was no evidence of malice; as being consistent with bona fides, bona fides must be presumed until the contrary was proved.

Manby v. [*442] *The defendant $(l)$, on returning home late one Witt.

Master telling one servant he was discharged because he and another had robbed him. night, heard that the footman had been giving away provisions, which he had obtained froin the cook; and thereupon dismissed them both. Next morning they came together to the defendant and asked his reason for dismissing them; he at that time declined to give any reason; but on another occasion, in answer to similar. inquiries, told M. that he discharged him "because he and the cook had been robbing him, and told $\mathbf{E}$. that he discharged her "because she and the footman had been robbing him." Each brought an action against the defendant, but both were nonsuited, as it was held that there was no evidence of malice; and Jervis, C. J., said,"The malice that will deprive a communication of this sort of the excuse arising out of the occasion of the speaking of the words must be such as to induce the Court, or any reasonable person, to conclude that the

(k) Harris v. Thompson, 13 C. B. 333.

(l) Manby v. Witt, Eastmead v. Witt, 18 C. B. 544. 
occasion has been taken advantage of to give utterance to an unfounded charge."

From these cases the reader will have deduced the Court to rule which prevails in cases of this sort, that it is the decide on duty of the court to decide whether or no the communi- privilege. cation containing the defamatory matter complained of comes within the class of privileged communications $(m)$; and for the jury to decide as to the existence or Jury on . non-existence of any malicious motives in the mind of maliee. the defendant in making it $(n)$

Where part of the communication is privileged and Part privipart is not, the former, of course, will not protect the leged ; latter $(o)$.

In most of the cases hitherto mentioned, the alleged defamation has taken place in some communication communicabetween *a former master and a person about to [*443] tions by and hire a discharged servant. But it frequently happens to other perthat defamatory opinions are uttered and expressions that dith masters are nsed with reference to the character of servants by their privileged. masters in communication with other persons, and by other persons in communication with their masters. It is important therefore, to inquire how far such communications are within the protection which, as we have seen, the law throws around communications made by the master to a person inquiring the character of a discharged servant; in other words, how far such communications are privileged.

It must be observed, however, that, as the reason why communications of the nature last referred to are held to be privileged does not arise from the existence of the relationship of master and servant between the parties defarned and defaming, but from principles of public policy and convenience, it would seem to be more consistent with those principles that the rulo should be co-extensive with them, than that it should be confined to one particular class of cases, to whicin, in common with others, they are applicable. Accordingly, it will be found that a variety of communications come within the class which are held to be privileged, and that the cases already mentioned are to be ro-

(m) In Wenman v. Ash, 13 C. I3. 845, Maule, J., said, "Tlhough more a question of fact in each particular ase than a question of law, the Courts have assmmed the jurisdiction of decilling it." See Cooke v. Wildes, 5 E. \& 13. 328, unte, 1. 437; and Ginssill v. Gillorl, 6 Gray, 94.

(n) But see Taylor v. Hawkins, ante, p. 429 ; Gilpin v. Fowler, 9 Exc. 623 .

(o) Warren v. Warren, 1 C. M. \& IR. 250; Tuson v. Evaus, 12 A. \& E. 733 ; Clarke v. lioe, 4 Ir. C. I. Rep. 1. 
garded rather as exampler of the application of a general rule to a particular class of cases, than as forming of themselves a class from which a rule may bo deduced. The general rule is, indeed, far more extensive in its application, and cannot, perhaps, be better expressed than is done by Lord Wensleydale, in Toogood v. Spyring $(p)$.

Toogood v. Spyring.

"In general, an action lies for the malicious publication of statements which are false in fact, and inju. rious to the character of another (within the well. known limits as to verbal slander), and the law considers such publication as malicious unless it is fairly made by a person in the discharge of some public or private duty, whether legal or moral, or in the conduct of his own affairs in matters where his interest is con. cerned. In such cases the occasion prevents the inference of malice which the law draws from unauthorized communications, and affords a qualified defence [*444] depending *upon the absence of actual malice. If fairly warranted by any reasonable occasion or exigency, and honestly made, such communications are protected for the common convenience and welfare of society, and the law has not restricted the right to make them within any narrow limits."

It is not, however, necessary here to follow out the application of the rule thus. laid down to all the cases to which it has been applied $(q)$. It will be sufficient to lay before the reader those cases which bear mcre immediately upon the subject now under consideration, to which it has been held applicable. And in doing so, it will be convenient consider,

I. Communications made in the discharge of a public duty;

II. Communications made in the discharge of private duty; and

III. Communications made by a person in the conduct of his own affairs in matters where his interest is concerned.

I. Communications made in the discharge of a public duty.

In course of judicial proceedings.

To this class may be referred the cases in which communications made in the course of judicial pro-

(p) 1 C., M. \& R. $193 . \quad$ See this case, post, p. 459.

(q) As to how far communications from master to clerk are privileged; and whether a Court of equity would grant an injunction to restrain a former clerk from disclosing his master's dealings, see Gartside v. Outram, 26 L. J., Ch. 113. 
ceedings $(r)$ have been held to be privileged on the ground of public *policy which requires that [*445] whatever is given as evidence in a court of justice should be free from being made the subject of an action. False evidence may be punished by indictment for perjury.

In Trotman v. Dunn (s) the facts were shortly Trotman v. these:-The plaintiff on his return from transporta- Dunn. tion, served the defendant as journeyman baker, but was suddenly dismissed by him. He then claimed a week's wages, and to enforce this demand summoned the defendant before a Court of Conscience. While they was attending there, the defendant said of the plaintiff, " $\mathrm{He}$ has been transported before, and ought to be transported again. He has been robbing me of nine quartern loaves a week." And the plaintiff brought this action. It did not appear distinctly in what stage of the proceedings the words complained of were spoken, or to whom they were addressed. For the defendant, it was contended that the words having been used in a court of justice were privileged. And Lord Ellenborough, C. J., said,--

"If it had been proved that the defendant spoke these words in opening his defence to the Commissioners of the Court of Conscience, I should immediately have directed a nonsuit. This would have been a privileged communication, and the words could not be considered as spoken maliciously in the manner and form stated in the declaration. If the plaintiff had been robbing the defendant, the latter was justified in dismissing him immediately, and no claim to a week's further wages could exist. The Court of Conscience

(r) See 1 Starkie on Slander, 239, 2ist; Rerix v. Simith, 18 C. B. 126; Henderson צ. Brommend, 2X 1. J., Exe. :360; 4 H. \& X. 569. such commnnieations may, howerer, where the circumstances admit of it, he made the subject of an action for malicions moseculion. See Cufler v. Dixon, 4 Rep. 14 h. Want of juriscliction in the Court before whieh the proceedings take place, alpears to make no differenee in the privilege. See the eases cited in the unte to Buekley r. Wood, a Rep). 14 h. (Thomis, and Fraser's elit.); Lake vo King, 1 Wus. Samnd. 131 b, and note $(k) ; 1$ Sturk. on S1. 253. As to low far a megistirate or judge is privileged in his ohservations, see Kendillon $\therefore$. Mattly, Carr. \& M. 40\%; Coroner, Thomas v. Chirton, 31 I. J., Q. B. 139. In Dawkins v. Lord Rokby, 42 I. J., Q. B. 63, Kelly, C. 13, said, "The anthorities are clear, uniform, and ennelusive that no artion of liled or slander lies whether againt judges or witnesses or partics for words written or spoken in the orlinary eourse of any proceeling before any Conrt or tribunal recognized by law." See cals. ib. cit. See also Dawking v. Paulet, 39 I. J., Q. B. 53.

(s) 4 Camp. 211. 
had to decide upon the propriety of the ground of dismissal. Therefore, if the defendant used the words in a judicial mode, for the purpose of his defence, he is justified. On the contrary, if he spoke them ad invidiam, and in a culminatory manner, they are actionable, though uttered in the room where the Court of Conscience was sitting."

The defendant had a verdict.

Slanderons Slanderous words spoken to a constable on giving a words spoken servant into custody on a charge of stealing, have also to policeman, been held to come within the same category. Thus, in on giving servant in charge.

Jolenson v. Evans.

Murphy $\mathrm{v}$. Kellett. Johnson v. Evans (t), which was an action.for slander, [*446] the *words were, "She is a thief, and tried to rob me of part of her wages." The plaintiff had been servant to the defendant. Upon a dispute taking place he discharged her, and some difference arising respecting the payment of her wages, he charged her with having attempted to cheat him respecting her wages, and used the words as laid, but the plaintiff failed in proving them to have been spoken at that time. Having, however, sent for a constable in order to take her into custody, he used the same words to the constable when he came, to whom he meant to havd given her in charge, but which in fact he did not do. It appeared from the evidence of the constable, that the words were addressed to him in his character of constable, and in the course of the charge and complaint which the defendant made to him against the plaintiff. Lord Eldon, C. J., nonsuited the plaintiff, saying, that-

"Words used in the course of legal or judicial proceedings, however hard they might bear on the party of whom they were used, were not such as would support an action for slander. In this case they were spoken by the defendant under the belief of a fact. and when he was about to proceed legally to punish it, It would be amatter of public inconvenience, and operate to deter persons from preferring their complaints against offenders, if words spoken in the course of their giving charge of them, or preferring their complaint, should be deemed actionable."

To this class may also be referred the cases of Murphy ซ. Kellett $(u)$, in which an opinion expressed by the medical officer of a union to the guardians, as to the wine of the plaintiff, who had made a tender to supply the patients, was beld to be privileged:

(t) 3 Esp. 32 ; but see Smith v. Hodgekins, Cro. Car. 276.'

(u) 13 Ir. C. L. R. 488. 
M'Elveney v. Connellan $(x)$, in which a report made by $M$ 'Elreney $\mathrm{v}$. the Inspector-General of Prisons in Ireland to the Comucllan. Lord Lieutenant of Ireland, under 7 Geo. 4 c. 74, s. 59, was held to be a state document and privileged; and Cox v. Feeney $(y)$, in which the publication in a Cox $\mathrm{v}$. newspaper of a report of an inspection of charities Feeney. *ander the charitable Trusts Act, containing a [*447] letter written some years before by the dean to the bishop, who was visitor of a college, reflecting on the conduct of the plaintiff, who was one of the professors of the college; were also beld to be privileged:

To this class may also, perbaps, be referred the cases already mentioned, in which communications made by a master respecting the character of a discharged servant have been held to be privileged, though some may think that they more properly belong to the class next to be considered, viz. :-

II. Communications made in the discharge of a private duty.

In this class may be included; in addition to the cases already mentioned, in which a character given to a discharged servant has been held to be a privileged communication, the cases in which masters, after having given a discharged servant a bad character, have repeated it to the friends or relations of the servant upon being called uppon by them for an explanation of the bad character given, which has lost the servant a place. Such communications have been held to be privileged when made bona fide; though, as wo have already seen in one such case $(z)$, the repetition of a bad character, when accompanied by a "contemptuous grin," was held to be slight evidence of malice.

In Whetherston v. Hawkins (a), the plaintiff brought Weatherston an action against his former master for publishing the v. IIaxkins. following letter to C., the plaintiff's brother-in-law, re- Letter specting the plaintiff's character as a servant. "Two written to days I gave him money to go into the city and buy books. friend of When he servant, reWhen he came home $I$ desired him to reckon up his peating bad account; he did so. But being one day more curious character than I sometimes was, I looked over his account, article given to perby article; and in ${ }^{*}$ one, a book I well knew the [*448] son about to price of, I found that he had charged me one shilling more than it cost, and that shilling he kept in his pocket. The next day tho very same affair. And both
(x) 17 Ir. C. L. R. 55.
y) 4 F. \& F. 13.
z) Kelly v. Partington, 4 B. \& Ad. 700, supra, p. 433.
(a) 1 T. R. 110. 
Weatherston these days my neighbour Metcalf was in my shop, and v. Hawkins. knows it well, and said he would not keep such a man a day, or something to that purpose. Two magazines he charged $2 s$. for binding, the people received no more than 1s. 8d., and say he paid no more. This I can prove." It appoared that the plaintiff had been in the service of the defendant, and was by him turned away. Rogers, to whom the plaintiff was recommended as a servant, applied to the defendant for a character, which not being good, Rogers declined to take him. Upon this C. called repeatedly upon the defendant, upon which the above letter was written, ine order to prevent an action for the words spoken to Rogers by the defendant. But the present action was brought. It was, however, held by Lord Mansfield, C. J., and other judges, that it would not lie, as, instead of the plaintiff's showing the libel complained of to be false and malicious, it appeared to be incident to the application by Rogers to the master of the servant. And the letter was written to the brother-in-law of the plaintiff for the express purpose of preventing an action being brought $(b)$.

Taylor $\mathrm{v}$. Hawkins.

Charge of dishonesty made to person abont to hire;

And so in Taylor v. Hawkins (c), it appeared that the plaintiff was a shopman of the defendant, and that the defendant, having a suspicion that he had embezzled money in the course of his employment, sent for the plaintiff, and, in the presence of a friend, Mr. T., uttered the words complained of in the first count, which were, "You pocketed the 5s., and altered the cheque; and you intended to alter the book, but being $\left[{ }^{*} 449\right]$ busy at the time, it *escaped your memory," and immediately afterwards discharged him. After his discharge, the plaintiff being about to enter the service of $B$., the defendant was referred to for a character, but, in consequence of what the defendant then stated to him, B. declined to take the plaintiff into his employand repeated ment. Upon this the plaintiff's brother called upon the to friend of defendant to inquire why he' had given the plaintiff servant. such a character as kept him from obtaining a situation; upon which the defendant said, "What would

(b) In King v. Warring, 5 Esp. 15, Lord Alvanly refused to allow a letter to be giren in eridence, which had been procured by the plaintiff from the defendant by means of another letter, not written with a fair view of inquiring a character, but to procure an answer upon which to ground an action for a libel; and see 3 B. \& P. 592 .

(c) 20 L. J., Q. B. 313 ; 16 Q. B. 308 ; and see Harrisv. Thompson, 13 C. B. 333 , ante, p. 441. 
you do yourself if any of your shopmen or servants robbed you ?" to which the plaintiff's brother replied, "I hope my brother has not been robbing you." "The defeudant then said, "He has robbed me; I believe that he has robbed me for years past; I can prove it from the circumstances under which bo has been discharged by me." This last answer was what was complained of by the second count of the declaration. It was held that the occasion on which these communications were made was such as to render them privileged, and that the presence of a third party when they were made did not alone render them not so.

In this class may also bo included communieations Communicabona fide made by a master to his other servants respect- tions by ing the character of a discharged servant.

Thus, where $(d)$ the plaintiff who had been in the service of the defendant, and had been dismissed on a Thursday on a charge of theft, came on the following Saturday upon tho defendant's premises for the purpose of receiving wages which were due to him, and then had some communication with the defendant's servants, when the defendant said to them, "I have dismissed that man for robbing me. Do not speak to him any more in public or in private or I shall think you as bad as him;" this was held to be a privileged communication, and the plaintiff, having brought an action for slander against his master, was nonsuited, Lord Truro ruling, that, in the absence of any *other [*450] evidence of express malice on the part of the defendant, there was no case to go to tho jury; and this ruling was afterwards upheld by the Court of Common Pleas.

Communications mado by a tenant to his landlord ro- Letter specting the character of a servant about to bo hired by written by the latter have also been held to bo privileged $(e)$. tenant to his Thus, where $(f)$ the father of the plaintiff had been for respecting some years gamekeeper to the Marquis of Anglesey, person who and the plaintiff wished to become his lordship's game- wished to be keeper and overlooker of fences for a farm of which the defendant, an old man, was tenant; and the defendant master to his other servants.

\section{Hawkins.} landlord's gamekeeper.

(d) Somerville v. IIawkins, 20 L. J., C. P. 131 ; 10 C. B. 483; see also Manby v. Witt, ante, p. 442.

(c) As to how far a communication by a landlord to his tenant refleeting on the character of the tenant's servants is privileged, see Knight v. Gibbs, 1 A. \& E. 43.

(f) Cockayne v. Itodgkinson, 5 C. \& P. 543. The question of privilege appears not to have been raised in Baylis v. Latorence, 11 A. \& E. 920, in which ease the libel complained of wus contrined in a letter written hy defendant to plaintill's landlord, complaining of his conduct about game. 
Cockayne v. sent a letter to the Marquis, informing him, amongst Hodgkinson. other things, that the plaintiff encouraged poachers, and sold game. Mr. Justice Parke left it to the jury to say whether it was the duty of the defendant to make communications to the Marquis in respect of any neglect of duty in his gamekeepers; and said that-

"If he was desired to do so by the noble Marquis, or his agents, any communication he made would be privileged, if he wrote it bona fide, and considering that he was doing his duty to the Marquis as his land: lord. If it was the duty of the defendant to make the communication, the case falls within the principle of many other cases. To write of another that he is a thief is a libel; but if one gentleman asks another gentleman respecting a servant's character, and he writes that the servant was a thief, he is protected if he acts bona fide."

His lordship also left the case to the jury on the question of malice, and they found for the defendant.

Cleaver v. Sarraude.

It may also be proper to mention in this place a case of Cleaver v. Sarraude $(g)$, where, in an action for a libel contained in a letter written confidently by the defendant to the Bishop of Durham, who employed the [*451] plaintiff as *steward to his estates, to inform him of certain supposed malpractices on the part of the plaintiff, the judge who presided declared himself of opinion that the action was not maintainable, as the defendant had been acting bona fide. In that case, however, it is to be observed, that it does not appear in what position the defendant stood with reference to the Bishop of Durham. If he was a perfect stranger to him it would seem, from the subsequent case of Coxhead v. Richards, to which it is now proposed to call the reader's attention, to be extremely doubtful whether the opinion of the learned judge would now be followed, since no duty or interest on the part of the defendant to communicate to the bishop what he did not know to be true appeared.

Coxhead v. Richards.

In Coxhead v. Richards (h), the facts were shortly these:-The plaintiff was a mariner, and had the command of a ship belonging to W., of which ship Cass, an intimate friend of the defendant, was mate. Cass wrote to the defendant reflecting in strong terms upon the plaintiff's conduct in a particular voyage, but requesting

(g) Cited by Lord Ellenborongh in M'Dougal v. Claridge, 1 Camp. 268.

(h) 2 C. B. 569 ; see also Blackham v. Pugh, 2 C. B. 611 ; Begnet v. Dcacon, 2 C. B. 628 ; Davies v. Snead, 39 L. J., Q. B. 202; Waller v. Loeh, 51 L. J., C. L. 274. 
the defendant not to show the letter to W. On receipt Cochrorl v. of the letter, however, the defendant showed it to a Richurds. naval friend, one of the elder brethren of the Trinity House, and also to Soames, an extensive shipowner, and in accordance with their advice, communicated it to W., who immediately superseded the plaintiff in his command, and ceased to employ him. The plaintiff upon this brought an action for libel against the defendant; and the defendant pleaded a justification, but failed to sustain it. And it did not appear that W. had instituted any inquiry into the charges contained in Cass's letter. On the part of the defendant it was contended that the action would not lie, on the ground that the communication of the letter to W. was privileged. And Tindal, C. J., told the jury that the *occasion and cir- [*452] cumstances nnder which that communication took place, furnished a legal excuse for making it; that the plain. tiff, to entitle himself to a verdict, must show malice in fact, and the jury must find for the defendant if they thought the communication strictly honest on his part, and made solely in the execution of what he believed to be a duty; but for the plaintiff, if they thought the communication was made from any indirect motive whatever, or from malice against the plaintiff. The jury found for the defendant. And in the following term a rule nisi was obtained by the plaintiff for a now trial on the ground of misdirection. The rule was twice argued in consequence of a difference of opinion amongst the judges; and, ultimately, the four judges before whom the case was argued differed; Tindal, C. J., and Erle, J. (i), holding that the communication was privileged, as the defendant bona fide believed, and had reason to believe, the statement to be true, and that it was his duty to communicate it to the plaintiff's mas. ter; and Coltman and Cresswell, JJ., holding that it was not privileged, as there was no duty which obliged the defendant to make the communication without ascertaining its truth.

Where the directors of a society (k), in their annual report, published a "caution to the public" against Gilbet.

(i) And it is said that the opinion of Erskine, J., who retired from the bench, between the first and seeond argument of the casc, was understood to be in favour of the defendant. See the note of the reporters, 2 C. B. 583; and see ace. Maris v. Reeres, 5 Ir. C. L. Rep. 79 . In Amann v. Danm, 29 I. J., C. P. 314, Willes, J., expressed his concurrence in the opinion of Tindal, C. J., and Erle, J.

(k) Gassett v. Gilbert, 6 Gray (Amer.) Rep. 94. 
Direetors' report.

Philadelphia, \&c. Railroad Corporation v. Quigley.

Lavless v. Anglo-

Egyptian Cotton and Oil Co.

Auditors' report printed and sent to shareholders with directors' report, privilezred. trusting a person who had formerly been employed to obtain and collect subscriptions for them, but had since been dismissed, such publication was held to be justifiable only so far as it was made in good faith, and re. quired to protect the society and the public against the false representations of that person. The question. whether they acted in good faith and did not exceed their privilege, is for the jury.

[*453] *In a case $(l)$ in America, in which a railroad corporation was held liable, in its corporate capacity, for a libel published by its agents in the course of its busi. ness and of their employment, it was held to be within the course of its business and the employment of the president and directors for them to investigate the conduct of their officers and agents, and report the result to the stockholders. It was also held, that in the ab. sence of malice or bad faith, a report to the shareholders was privileged, but that such privilege did not extend to the preservation of the report and evidence in a book for distribution amongst the persons belonging to the corporation. And the corporation was held liable in damages for publishing it in that form.

Upon the two above-cited American authorities being cited from a previous edition of this work in a subsequent case $(m)$, in England, Mellor, J. and Hannen, J. expressed their approval of them. The facts were as follows:- The defendants were a company established for the purpose of growing cotton in Egypt. The plaintiff was their manager there, and it was his duty to furnish defendants with an account of his transactions to enable them to give the shareholders any account of the profits of the undertaking. The auditors were of opinion, and reported, that a depreciation in the stock of the company was owing to the mismanagement of the plaintiff. They came to this opinion, after explanations had been offered to them by one B., but these explanations were offered to them only, and not to the directors. At the ordinary general meeting of shareholders, the directors laid before them a statement of the accounts, and in this statement repeated what had been reported to - them by the auditors. There was nothing whatever. to show that they had any reason to doubt the truth of this report, nor was there in what happened at

(l) The Philadelphia, Wilmington and Baltimore Railroad Corporation v. Quigley, 21 How. (Amer.) Rep. 202.

(m) Lawless v, Anglo-Egyptian Cotton and Oil Co., 38 L. J., Q. B. 129 ; L. R., 4 Q. B. 262 . 
*the meeting any extrinsic evidence of malice [*454] Laviess $\mathrm{v}$. on their part. By a resolution passed at the meeting Anglothe report of the directors with the accounts, and the Egyptian report of the auditors, were ordered to be printed, and cotton and sent to the shareholders at large; and they were accordingly sent to a printer, printed, and circulated among tbe shareholders, and used by them at an adjourned meeting. An action for libel was brought against the company and tried before Kelly, C. B., who ruled that it was not a privileged communication, and the plaintiff having proved special damage, recovered a verdict for $500 l$. But the Court of Queen's Bench afterwards set aside the verdict, and ordered a nonsuit to be entered on the ground that it was a privileged communication, and that the sending it to the printer merely to be printed did not destroy the privilege, as that was a reasonably necessary mode of making a communication which the directors were bound to make to their shareholders, absent as well as present; they were not bound to employ confidential clerks, to write a letter to each shareholder.

In the following case $(n)$ also, the slander complained Concles $\mathbf{v}$. of was held to be a privileged communication. The Potts. plaintiff was trustee of a charity, and also farm bailiff Discussion as to Mr. Cooper. Attempts had been made to remove to conduct of the plaintiff from the trust, and being unwilling to trustee of a resign he requested Cooper to obtain signatures to a protest against his being turned out. Cooper ap. plied to the defendant to sign the protest: he refused, and upon Cooper asking his reasons for refusing, said he would not keep a big rogue like the plaintiff in the trust. Cooper further pressed the defendant for his reason for his opinion, and he then said that the plaintiff had left the parish under discreditable circumstances, and withont settling with his creditors, *including the defendant. Cooper [*455] further stated that in consequence of what the defendant told him he dismissed the plaintiff. The plaintiff brought an action, and the jury found a verdict for him, but they also found that the defendant had not acted with malice. The Court of Queen's Bench afterwards ordered the verdict to be entered for the defend. ant, on the ground that the communication was privi.

(n) Covles v. Potts, 34 L. J., Q. 13. 247. Sec Purcell v. Sourler, 46 L. J., C. L. 308 , where it was held that the publicution in is newspaper of a report of a discussion at a board of guarilians of the conduct of the medical officer was not privileged, as the board was not necessarily a public meeting. 
Cowles v. leged having been bona fide spoken with reference to Potts. the discussion whether it was proper to retain the plaintiff as a trustee of the charity, and Blackburn, J., having stated that the law laid down in Toogood v. Spyring (o), had always been approved of, added, "In the more recent decisions, such as Whitely v. Adams $(p)$, the tendency has been to extend the limits of the moral dutyor reasonable exigency which authorizes the publication of defamatory matter. But we think that the present case falls strictly within the limits as laid down in Toogood v. Spyring.

Rule in In Harrison v. Bush $(q)$, a legal canon was pro. Harrison v. pounded by counsel, and adopted by the Court, that Bush.

Where mutual interest concerned.

M'Dougal r. Claridge.

Wilson $\mathrm{v}$. Robinson. "a communication made bona fide upon any subjectmatter in which the party communicating has an in. terest, or in reference to which he has a duty, is privileged, if made to a person having a corresponding interest or duty, although it contain criminatory matter which, without this privilege, would be slanderous and actionable."

III. Communications made by a person in the con. duct of his own affairs where his interest is concerned. Communications of this sort have also frequently been held to be privileged, when made bona fide with a view to the interest of both the writer and the persons addressed, for if a communication of this sort, which was not meant to go beyond those immediately interested in it, were the subject of an action for dam[*456] ages, it would be impossible * for the affairs of mankind to be conducted. Upon this ground a letter written by the defendant to Messrs. W., bankers, charging the plaintiff, who was a solicitor, with improper conduct in the management of their affairs, in which the defendant was himself interested, was held to be privileged $(r)$.

So a letter written by one part owner of a brig to another part owner, who had recommended the plain-

(o) Ante, p. 443.

(p) 33 L. J., C. P. 89 ; 15 C. B., N. S. 392.

(q) 5 E. \& B. 348; see also Dickson v. Earl Wilton, 1 Fost. \& F. 419; Whileley v. Adams, ubi supra; Dickson v. Hilliard, 43 L. J., Exe. 37.

(r) M'Dougal v. Claridge, 1 Camp. 267; see Wright v. Woolgate, 2 Cr. M. \& R. 573; Shipley v. Todhunter, 7 C. \& P. 680 . In the latter case Tindal, C. J., in summing up to the jury said, "There can be no doubt that a man has a right to conmunicare to any other information he is possessed of in a matter in which they have a mutual interest."

(468) 
tiff as master, reflecting upon the master's conduct, was held to be privileged $(s)$.

But words spoken by one subscriber to a charity, in irartin $\mathrm{v}$. answer to inquiries by another subscriber respecting Strong. the conduct of a medical officer of the charity, have been held not to be privileged; and in action for slander the plaintiff recovered a verdict and damages $(t)$. In that case, however, there did not appear to be a sufficient reason for the conversation between the parties to constitute a privileged communication. And in a subsequent case Lord Wensleydale said that if those observations had been made in a matter of contest, and the contest was whether the person slandered should be elected, it appeared to him that it would have been a privileged communication. The case alluded to is Kine v. Sewell $(u)$, in which the defendant, having kine v. been requested by $A$. to recommend a person to value Sewell. some work done for him by the plaintiff's master under contract, told $\mathrm{A}$. that the plaintiff had stolen some of the materials, and afterwards repeated the charge to the plaintiff's master; but it was held that the defendant was not liable to an action. without proof of express malice on his part; for although the charge appeared to be untrue, yet the communication having been made bona fide to $a^{*}$ person interested, in discovering [*457] a wrong-doer, and who made inquiries, and believed to be true by the defendant, was privileged.

Where a person having ground or supposed ground Complaints of complaint against a servant or public officer, makes a made to representation of his conduct to his master or superior master with officer with a view to obtaining redress, the communica- a view to tion has been held to be privileged on the ground of interest in the party making it, if bon a fide and honestly made, although the person addressed has not in reality the supposed power.

In Lake v. King $(x)$ a petition presented to a com- Lake v. King. mittee of the House of Commons, containing criminatory matter, was held privileged, the committeo having power to inquire, although no power to give redress to the petitioner. So where a person $(y)$, having a just

(s) Wilson v. Robinson, 7 Q. B. 68.

(t) Martin v. Strong, 5 A. \& E. 535; see Corles r. Potts, ante, p. 454.

(u) 3 M. \& W. 303; see Kershaw v. Beiley, 1 Exc. 743.

(x) 1 Wms. Saund. $131 \mathrm{~b}$; and see Dunne v. Anderson, 3 Bing. 88; Ry. \& M. 287.

(y) Fuirman v. Ites, 5 B. \& AId. 642; and see Wenman r. Ash, 13 C. 13. 837. 
Fairman v. claim against an officer in the army, and who therefore Ives.

R. v. Bayley. of an action. And Best, J., cited The King v. Bayley $(z)$, in which a letter addressed to General Willes and the four principal' officers of the Guards, to be by them presented to the king, stating that the prosecutor had obtained from the defendant a warrant for the payment of money due to him from government, under a promise of paying the defendant such money, and that the prosecutor had received the money, and had not paid it over to the defendant, was held to be no libel, but a representation of an injury drawn up in a proper way for redress, and added,-

"That case is like the present. Neither the officers nor the king could give the defendant direct assistance in [*458] receiving the money wrongfully * withheld. But the king had authority to dismiss an officer from his service, and most probably would dismiss any one who hesitated to do what honour and justice required. In the present case there was at least probable cause for thinking that the Secretary at War would advise his Majesty that the plaintiff was not worthy to remain in the army unless he did the defendant immediate justice."

Blake $\mathbf{v}$

So in an action $(a)$ for libel upon the plaintiff, in his Pinfold. situation of guard of the Exeter mail, by reason of which he was dismissed from his situation. The libel complained of was a letter written to Sir Francis Freeling, chief secretary to her Majesty's postmaster-general, by the defendant, who was unconnected with the postoffice, complaining of some misconduct of the plaintiff towards the defendant's wife in a journey by the mail. It was held by Taunton, J., that the letter was clearly not privileged, on the ground of its being an official communication (b). But that learned judge also expressed an opinion, that the occasion on which the letter was published, rendered its publication excusable, in the

(z) Bac. Abr. Libel, A. 2

(a) Blake v. Pinfold, 1 Mood. \& Rob. 198.

(b) Within the cases of Home v. Bentinck, 2 B. \& B. 130; Wyatt v. Gore, Holt, 299. See Dawkins v. Paulet, and Daukins v. Lord Rokeby, ante, p. 444, note $(r)$. 
absence of express malice. And in another similar case (c), Alderson, B., laid down similar law.

Upon similar principles, a letter written by a dis- Letter by charged butcher to his customer, reflecting on the tradesman to honesty of the customer's housekeeper, was held a customer reprivileged communication $(d)$.

And a memorial, transmitted to tho the Home Secretary, customer's cumplaining of the conduct of the plaintiff who was a servant. county magistrate, during an election of an M. P. for a Ifarrisons $\mathrm{r}$. borough in the county, has been held to be privileged, Bush. although in practice the advice of the Keeper of the Nemorial to Great Seal is generally acted upon as to the removal of Home Secrejustices; as the memorial might be considered as ad- plaining of a dressed to the Queen through the Home Secretary, who magistrate. might himself have caused an inquiry to be made, have communicated *with the Keeper 'of the Great [*459] Seal, and have in effect recommended the removal of the plaintiff $(e)$.

Upon similar principles a letter from a servant to his Letter from master, reflecting upon the character of a third person, servant to his who had either complained, or threatened to complain, master abont to the master about the servant, would be privileged $(f)$.

Where a communication is privileged, the mere fact Presence of that a third person was present at the time it was made, third person will not render it less so, though, if an opportunity of will not tako publishing the libel in the presence of a third person is away privisought out, that may be evidence of malice. Thus, lege, thongh where $(g)$ it appeared that the plaintifi was a journey- witness may man carpenter, and had been in the employ of B., a be evidence master carpenter, in the constant employ of the Earl of Devon at Powderham. The defendant was tenant to the Earl, and required some repairs at his farm, and plainitiff, pursuant to B.'s orders, went with another workman to the defendant's house for the purpose of doing them. The work was done in a negligent manner, and not to the satisfaction of $B$. Diring the pro gress of the work the plaintiff got drunk, and circumstances occurred which induced the defendant to believe that the plaintiff had broken open the cellar and

(e) Woodicard v. Luender, 6 C. \& P. 548.

(d) Coward v. Wellinglon, 7 C. \& P. 531. See also Amann v. Damm, 29 L. J., C. P. 313.

(e) Ilarrison v. Bush, 5 E. \& B. 344, overruling, to a certain extent, Blagg v. Sturt, 10 Q. B. 899, in which case, however, there was express malice. See Junt v. Goodlake, 43 L. J., C. P. 55 .'.

(f) See Wright v. Woodgate, 2 Cr. M. \& R. 5i:s.

(g) Toogood Y. Spyring, 1 Cr. M. \& R. 181 : and see Palmore v. Lavorence, 11 A. \& E. 380 ; Taylor v. Muckins, 20 L. J., Q. B. 313 , ante, p. 448 . 
Toogood $\mathbf{v}$. obtained access to his cyder. B. had requested the deSpyring. fendant to inspect the work, and afterwards, whilst the plaintiff and one T. were at work at Powderham, the defendant came up, and in his presence, charged the plaintiff with breaking open the cellar, getting drunk, and spoiling his job. The plaintiff denied the charge, but defendant said he would swear $\cdot$ it, and so would his men. In a subsequent conversation, in the plaintiff's absence the defendant, in answer to a question by T., whether he really thought the plaintiff had broken open [*460] his cellar, said he *was sure of it, and his peoplo would swear to it. Defendant then went away in search of B., whom he saw, and to whom he repeated that the plaintiff had broken open the door, got drunk, and spoiled his job. B. thereupon went to the plaintiff, and told him that until his character was cleared he could not remain in the employ of the Earl. The next day $B$. investigated the charge, and told the plaintiff he considered it not made out, and his character was cleared, and he might go to work again; but the plaintiff refused to work, saying his character was not cleared, and brought his action against the defendant. It was held, that the communication to $\mathrm{B}$. was privileged, and that the statement made to T. upon the second meeting in the plaintiff's absence was not, but that the statement made to the plaintiff, though in the presence of T., was privileged. And in delivering the judgment of the Court of Exchequer, Lord Wensleydale, after laying down the principles which have been already cited $(h)$, said,- -

"Among the many cases which have been reporled on this subject, one precisely in point has not, I believe, occurred; but one of the most ordinary and common instances in which the principle has been applied in practice is that of a former master giving the character of a discharged servant; and I am not aware that it was ever deemed essential to the protection of such a communication, that it should be made to some person interested in the inquiry, alone, and not in the presence of a third person. If made with honesty of purpose to a party who has any interest in the inquiry (and that has been very liberally construed) (i), the simple fact that there has been some. casual bystander cannot alter the nature of the transaction. The business of life could not be well carried on if such restraints

(h) Ante, p. 443.

(i) Child v. Afleck, 9 B. \& C. 403. See this case, ante, p. 439. 
were imposed upon this and similar communications, Toogood $\mathrm{v}$. and, if, on every occasion in which they were made, spyring. they were not protected unless strictly private. In this class of communication is no doubt comprehended the right of a master bona fide to charge his servant for any supposed misconduct in his service, and to give him admonition and blame; and we think that the simple circumstance of the master exercising that right in the presence of another, does by no means of necessity take away from it the protection which the law would otherwise afford. Where, indeed, an opportunity is sought for making such a charge before third per sons, which might have been made in private, it would afford strong evidence of a *malicions intention, [*451] and thus deprive it of that immunity which the law allows to such a statement, when made with honesty of purpose; but the mere fact of a third person being present does not render the communication absolutely unanthorized, though it may be a circumstance to be left with others, including the style and character of the langnage used, to the consideration of the jury, who are to determine whether the defendant has acted bona fide in making the charge, or been influenced by malicious motives. In the present case the defendant stood in such a relation with respect to the plaintiff, though not strictly that of master, as to authorize him to impute blame to him, provided it was done fairly and honestly, for any supposed misconduct in the course of his employment, and wo think that tho fact, that the im. putation was made in T.'s presence, does not of itself render the communication unwarranted and officious, but at most is a circumstance to be left to the consideration of the jury. We agree with the learned judge, that the statement to T. in the plaintiff's absence was uuauthorized and officious, and therefore not protected, although made in the belief of its truth, if it were, in point of fact, false."

Where communications made with reference to the Rules, where character of servants do not come within the class of communicaprivileged communications, they are, of course, subject tion not to the ordinary rules which govern actions for defama- privileged. tion. It is not, however, necessary here to enter into a full examination of those rules which have been already treated of in the work before referred to $(k)$; it is suffi-

(k) Starkie on Slander. Neither is it necessary to enter into a. diseussion of what expressions are, and what are not, actionable. It may, however, be remarked, that where the expressions nsed are capable of a harmless and also of an injurious meaning, the 
cient to state, that in actions for slander, the general rule is, that where the natural consequence of the words is a damage ; as if they import a charge of having been guilty of a crime, or of having a contagious distemper, [*462] or if they are prejudicial *to a person in an office, or to a person of a profession or trade, they are in themselves actionable; in other cases the party who brings an action for words, must show the damage which he has received from them $(i)$.

Imputation affecting servant in his character of servant.

Seaman v. Bigg.

From hence it appears that an acticn for slander may be maintained by a servant without proof of special damage, where the imputation affects him in his situation of servant, that is where it is made with reference to his character or conduct as such, and imputes to him the want of some qualification for or misconduct in his sitnation.

Thus, in Seaman v. Bigg $(m)$, in the time of Charles I, it was held that the words, "Thou art a cozening knave, and hast cozened thy master of a bushel of bar. ley," spoken of a bailiff and servant in husbandry, were actionable: for, said the Court, though "true it is generally an action will not lie for calling one "cozening knave,' yet where the words are spoken of one who is a servant and accomptant, and whose credit and maintenance depends mpon his faithful dealing, and he by such disgraceful words is deprived of his livelihood and means of maintenance, there is good reason it should bear an action, that he might have recompense for loss of his credit and means."

plaintiff is at liberty to point them by immendo to the latter, if in their ordinary sense they are capible of such a eonstruction. Thus, in Clcgg v. Laffer, io Bing. 250, where the defendant, in writing to one of his friends, said of the plaintiff, "He is so inflated with $200 l$. or $300 l$. which he has made in my service-God only knows whether honestly or otherwise-that," \&c., and the plaintiff in lis declaration explained the words by inmuendo thus-"Meaning to insinuate that the plaintiff had conducted himself in a dishonest manner in the defendant's service," the Court of Common Pleas held that the imnuendo did not exceed the limits which, according to the definitions in the authorities, it is allowed to make. See further on this point, $1 \mathrm{Wms}$. Saund. 243 a, note (i); Griffiths v. Levis, 8 Q. B. 841. But the innuendo must not be too large, Dry v. Robinson, 1 A \& E. 554; Wheeler v. Huynes, 9 A. \& E. $2: 6$; see Williams v. Gardiner, 1 M. \& W. 245.

(l) Bac. Abr. Slander, A.; 1 Stark. on Slander, 10.

(m) Cro. Car. 480; and see Reignald's ease, Cro. Car. 563, where similar words were held actionable when spoken of a deputy clerk to a register. See also Wright v. Moorhouse, Cro. Eliz. 358. In Fox v. Broderick, 14 Ir. C. L. R. 4.53, it was held that a letter addressed by a bont fide mistake to the master instead of to a servant at the master's house was libelious. 
Upon this ground it has been held that to impute drunkenness to a master mariner in command of a vessel at sea $(n)$; or to say of a gamekeeper in a hunting country that he killed foxes $(o)$; were actionable without special damage.

But unless the imputation be connected with the ser- Mnst be convant's occupation, or show the want of some general nected with requisite, no action can be maintained in respect of it. character. "Every authority which I have been able to find," said *Bayley, B., in Lumby v. Allday $(p)$, "either [*463] Lumby v. shows the want of some general requisite, as honesty, Allday. capacity, fidelity, \&c., or connects the imputation with the plaintiff's office, trade or business." In that case, therefore, where the defendant said of the plaintiff, who was clerk to the Birmingham and Staftordshire Gas Light Company, "You are a fellow, a disgrace to the town, unfit to hold your situation for your conduct with whores. I will have you in the Argus. You have bought up all the copies of the Argus, knowing you have been exposed. You may drown yourself, for you are not fit to live, and are a disgrace to the situation you hold," Bayley, B., intimated a strong opinion that the charge proved was not actionable; because the imputation it contained did not imply the want of any of those qualities which a clerk ought to possess, and because the imputation had no reference to his conduct as clerk.

And where the plaintiff complains of the imputation Manner of of scandulous conduct in his occupation, it is necessary comrection for him to set forth in the declaration in what manner must appear it was connected with his occupation by the defendant in the deciar(q). And, therefore in an action for slander of a salaried superintendent of police, at Leeds, where the de- James $\mathbf{v}$. claration did not show how the slander was connected by the defendant with the plaintiff's office, judgment was arrested $(r)$.

Where the words complained of by the plaintiff are special not actionable per se, it becomes necessary for the plain. damage; tiff to allege and prove what is called special damage,

(n) Irwin v. Brandwood 33 L. J., Exc. 257 ; 2 H. \& C. 960.

(o) Foulger v. Neweomb, 36 L. J., Exc. 169.

- 1 ) 1 Cr. \& J. 305 . See also Connors v. Justice, 13 Ir. C. L. R. 451.

(q) See Ayre v. Craven, 2 A. \& E. 8; Doyley v. Roberts, 3 ling. N. C. 835 ; Sonthee v. Denny, 1 Exc. 196 ; Hoprood v. Thorn, 8, C. B. 293 ; Miller v. David, 43 I. J., C. P. 84 , where it was held not to be actionable to say of a stonemason that he was ringleader of the nine-hour system, \&c.

(r) James v. Brook, 9 Q. B. 7. 
i. e., some actual specific injury resulting from the use of the words. And it is also necessary for the plaintiff to prove special damage where it is alleged in a declaration for words which are actionable per se. But in must be legal [*464] either of those cases, $*$ it is said not to be suffi. consequence cient for the plaintiff to prove a mere wrongful act of of the words spoken. a third person induced by the slander, but that the special damage complained of must be the legal and natural consequence of the words spoken. Therefore $(h)$, in an action for slander, where special damage aileged was, that in consequence of words used by the Vicars $\mathrm{v}$. defendant, J. O. had discharged the plaintiff, and R. P. Wilcocks. had refused to hire him ; and it appeared that the plaintiff had been retained by J. $O$. as a journeyman for a year at certain wages, and that before the expiration of the year his master had discharged him in consequence of certain words spoken by the defendant, who accused the plaintiff of cutting his cordage ; and it also appeared that the plaintiff afterwards applied to R. P. for employment, but he refused to employ him in consequence of the words and because his former mas. ter had discharged him for the offence imputed to him: it was held that the action could not be maintained, as the special damage alleged was not the legal and natural consequence of the words spoken. And Lord Ellenborough added,-

"Here i $\hat{i}$ was an illegal consequence; a mere wrongful act of the master, for which the defendant was no more answerable than if, in consequence of the words, other persons had afterwards assembled and seized the plaintiff and thrown him into a horse-pond; by way of punishment for his supposed transgression. Upon the second ground, non liquet that the refusal by R. P. to employ the plaintiff was in consequence of the words spoken as it is alleged to be ; there was at least a concurrent cause, the act of his former master in refusing to continue him in his employ which was more likely to weigh with R. P. than the mere words themselves of the defendant."

Kelly v. Upon similar principles in an action for slander by a Partington. shopwoman and servant for saying of her, "She secreted 1s. $6 d$. under the till, stating, these are not times to be robbed" $(i)$; in consequence of which it was alleg. ed one S. refused to engage her in his service, judgment

(h) Vicare v. Wilcocks, 8 East, $1 ; 2$ Smith's L. C. 487. But see Lynch v. Knight, 9 Ho. L. C. $57 \%$.

(i) Kelley v. Partington, 5 B. \& Ad. 645; and see Ashley v Harrison, 1 Esp. 48 ; Taylor v. Neri, 1 Esp. 386, ante, p. 150. 
was *arrested on the ground that the special [*465] damage alleged was not the natural result of the words used; and Patteson, J., observed,-

"It is said that the words are actionable because a person after hearing them chose in his caprice to reject the plaintiff as a servant. But if the matter was not in its nature defamatory, the rejection of the plaintiff cannot be considered the natural result of the speaking of the words. To make the speaking of the words wrongful, they must in their nature be defamatory."

But these cases have not been altogether approved of Not approved $(k)$; and in a subsequent case it was held that the dis- of. charge of the plaintiff by her employer, in consequence of words used by the defendant, was not too remote an injury to entitle the plaintiff to recover damages in respect of it; the Court distinguishing that case from Vicars $\mathrm{v}$. Wilcocks. In the case alluded to $(l)$, it ap- Knight $\mathbf{v}$. peared that the plaintiff and another young woman Gibbs. lodged in the house of E., whose wife was a straw-bonnet maker, and employed them in the way of her business: The defendant, who was landlord of the house, and lived next door but one, came to Nrs. E., and spoke of the plaintiff and her fellow-lodger thus: "I am ashamed of their conduct; they were singing and mak. ing a noise, and tabouring the windows (i. e., tapping them with their fingers); it is no use their denying it; their conduct is shameful and disgraceful, more like a bawdy-house than anything else, and no moral person would like to have such peoplo in his house." After this Mrs. E. dismissed them, which was the special damage complained of. She gave the following evidence as to her motives:- "I dismissed them because I thought it would offend the defendant to keep her longer; it was in consequence of what he had said. It was not because I *believed the words, but because I [*466] was afraid that it would offend the defendant to keep her; he was my landlord, and came to complain of the conduct of my lodgers." The plaintiff recovered a verdict, with which the Court refused to interfere, Parke, J., observing,- -

(k) See 1 Starkie on Slander, 206, note $x$. That learned author considers Vicars v. Wilcocks ineonsistent with the eases in which the special clamage has consisted of loss of marriage, where the party, who by reason of the slander broke off the marriage, was under a promise to marry. And see Morvis v. Langulete, $2 \mathrm{~B}$. \& P. 234; Green v. Button, 2 Cr. M. \& R. 707; Lymch v. Kinight, 9 Ho. I. C. 577; and the note to Vicars v. Wilcocks, 2 Smith's L. C. 487 .

(l) knight v. Gibbs, 1 A. \& E. 43. 
"It is said that the witness would have turned the plaintiff away on the defendant's wish to that effect being intimated, although no slanderous words had been used. But it is clear that if the words in question had not been used, the plaintiff would not have been dismissed; and it is sufficient for this action to show that she was turned out in consequence of such words of the defendant. The effect of the evidence may be that the witness would have turned the plaintiff away if different words had been used, but different words were not used, and she was sent away in consequence of these. In Vicars v. Wilcocks, supposing the point there to have been rightly decided, there were two distinct causes of the special damage - the words used and an act done by a third person; and the damage might have resulted from either." And Patteson, J., added, "The case is not like Ticar's v. Wilcocks, because here the whole cause of the special damage proceeds from the defendant himself; nothing is done by any other person."

Hoey $\mathrm{v}$ Where, however, in an action for false imprisonment Felton.

Action for endorsing cab-driver's licence. the plaintiff laid as special damage the loss of a situation which he would otherwise have got, and the fact was that the defendant imprisoned the plaintiff from half-past one till past two, and the plaintiff tendered eridence that if he had appeared at a certain place at two he might have obtained a situation; but when he got out of prison he did not go to seek the situation, but went bome instead, and did not make any application for it till the following day, when it was too late: it was held that the damage was not the natural result of the unlawful act of the defendant, but too remote: and Erle, C. J., eited Vicars v. Wilcocks with approbation $(m)$.

Before quitting this part of our subject it may be noticed that it has been held $(n)$ that an action lies by [*467] a cab-driver *against his master for wrongfully and unjustly defacing his licence as a driver under the statute $6 \& 7$ Vict. c. $86(o)$ (which by sect. 21 of that stat-

(m) Hoey v. Felton, 31 I. J., C. P. $105 ; 11$ C. B., N. S. 142. But see Lynch v. Knight, 9 Ho. L. C. 5\%, where Vicars v. Wileocks was not approved of.

(n) Hurrell v. Ellis, 2 C. B. 295 ; ace. Rogers v. Macnamara, 14 C. B. 27 , where it was held to be no justification that the matter endorsed on the licence was true. In Carter v. Cooper, Guildhall, December 11th, 1869, a cab-(lriver recovered 10\%. damages against a cab proprietor for endorsing his licence, "on account of short money," as the reason of his discharge.

(o) For regulating hackney and stage carriages in and near London. 
ute the proprietor of every hackney carriage is required Hurrcll $\mathrm{v}$. to retain in his possession whilst the driver remains in Eltix. his service), and which licence the defendant had defaced by writing upon it a bad character of the plaintiff as a driver. And it was beld, after verdict, to be not necessary to aver that it was malicionsly done. But in a previous case $(p)$ Lord Abinger had stated his Action will opinion that if a servant enter into a service and bring not lie for a written character with him, his master could not be endorsing considered to do wrong if he wrote upon it that the per. servant's son to whose character it related had afterwards been character. in his service and was dismissed for ill-behaviour.

It has been held that the Court of Chancery has no Rowan. jurisdiction to restrain the publication of a libel even when its publication will be injurious to property or reputation $(q)$.

False and Forged Characters-Stat. 32 Geo. 3, c. 56.

If a master knowingly give a false character of a servant to a person about to hire him, and the servant afterwards rob or injure his new master, he may, in an action for the deceit, recover from the former master the damages he has sustained in consequence of such false character having been given $(r)$.

* Moreover in such cases a criminal responsi- [*468] bility is sometimes incurred by a person giving a false character $(s)$.

(p) Taylor v. Rowan, T C. \& P. 70; 1 MLod. \& Rob. 490.

(q) Prudential Assurance Co. vi Knott, 44 L. J., Ch. 192.

(r) Wilkii v. Real 15 C. B. 192. See Pusley v. Freman, 3 T. R. 51; 2 Smith's L. C. 71, in a note to which will be found a discussion of the interesting question, how far legal, withont moral, fraud furnishes a ground of aetion. 1t is coneeived that Lord 'Tenterden's Aet, 9 Geo. 4, c. 14, s. 6, which provides "that no action shall be bronght whereby to charge any person upon or by reason of any representation or assurance male or given, concerning or relating to the character, conduct, credit, ability, trado or dealings of any other person to the intent or purpose that snch other person may obtain ercdit, monies or goods upon, unless such representation or assurance be male in writing signed by the party to be charged therewith"-would not apply to charucters given to servants to enable them to obtain situations, as that Act was passed to remedy an evil which had grown up of ermuling the Statute of Frands (which required guarantees to be in writing,) by suing parties for false representation as to characters of third persons, whereby goods had been obtained, and thus iulirectly fixing them with the debts of such third persons, see $L, y d c$ v. Barnard, 1 M. \& W. 101 ; Tatton v. Wade, 1s C. B. 371.

(8) Knowingly uttering a forged testimonial to character with intent to deceive, and thereby obtain a situation of enolument. is a forgery at common law; R. v. Sharman, 23 L. J., M. C. 51 ; 
32 Geo. 3. c. 56 .

Sect. 1.

Any person personating master or giving false character ;
Sect. 2.

or asserting that a servant has been hired for a period of time, or in a station;

Sect. 3. or was discharged at any other time, or had not been hired in any previous service, contrary to fact;

Sect. 4.

By the statute 32 Geo. 3, c. 56 , after reciting that-

"Whereas many false and counterfeit characters of servants have either been given personally or in writing by evil-disposed persons being or pretending to be the master, mistress, retainer or superintendent of such servants, or by persons who have actually retained such servants in their respective service, contrary to truth and justice and to the peace and security of his Majesty's subjects ; and whereas, the evil herein complained of is not only difficult to be guarded against, but is also of great magnitude and continually increasing, and no sufficient remedy has hitherto been applied."

It is enacted that, after 1st July, 1792 :-

"If any person or persons shall falsely personate any master or mistress, or the executor, administrator, wife, relation, housekeeper, steward, agent or servant of any such master or mistress, and shall either per. sonally or in writing give any false, forged or counterfeited character to any person offering him or herself to be hired as a servant into the service of any person or persons, then and in such case every such person or persons so offending shall forfeit and undergo the penalty or punishment hereinafter mentioned."

"If any person or persons shall knowingly and wilfully pretend or falsely assert in writing that any sert vant has been hired or retained for any period of time whatsoever, or in any station or capacity whatsoever other than that for which or in which he, she or they shall have been hired or retained such servant in his, her or their service or employment, or for the service of any other person or persons, that then, and in either of the said cases, such person or persons so offending as aforesaid shall forfeit and undergo the penalty or punishment hereinafter mentioned."

"If any person or persons shall knowingly and wil. fully pretend or falsely assert in writing, that any ser. vant was discharged, or left his, her or their service at any other time than that at which he or she was dis: charged, or actually left such service; or that any such servant had not been hired or employed in any previous $\left[{ }^{*} 469\right]$ service, contrary to truth *that then, and in either of the said cases, such person or persons shali forfeit and undergo the penalty or punishment hereinafter mentioned."

"If any person shall offer himself or herself as a

R. v. Moah, 27 L. J., M. C. 204 ; 1 Dears. \& Bell. C. C. 550 ; 4 Jur., N. S. 464. 
servant, asserting or pretending that he or she hath or any person served in any service in which such servant shall not offering himactually have served; or with a false, forged or counter- self as a feit certificate of his or her character; or shall in any- servant wise add to or alter, efface or erase any word, date, have served matter or thing contained in or referred to in any where he has certificate given to him or her by his or her last or for- not served, or mer master or mistress, or by any other person or per. with a false sons duly authorized by such master or mistress to give alteriutiug, or the same, that then, and in either of the said cases, certificate; such person or persons shall forfeit and undergo the penalty or punishment hereinafter mentioned."

"If any person or persons having before been in ser- Sect. 5 . vice shall, when offering to hire himself, herself or or who havthemselves as a servant or servants in any service what- ing been soever, falsely and willfuly pretend not to have been before in hired or retained in any previous service as a servant, service shall that then, and in such case, such person or persous shall to have been forfeit and undergo the penalty or punishment herein- in such after mentioned." service;

"If any person or persons shall be convicted of any or Seet. 6 . either of the offence or offences aforesaid, by his, her or shall on contheir confession, or by the oath of one or more credible viction, forwitness or witnesses before two or more justices of the feit $20 l$. peace for the county, riding, division, city, liberty, town or place where the offence or offences shall have been committed (which oath such justices are hereby empowered and required to administer), every such offender or offenders shall forfeit the sum of twenty pounds, one moiety whereof shall be paid to the person Application or persons on whose information the party or parties of torfeiture. offending shall have been convicted, and the other moiety thereof shall go and be applied for the use of the poor of the parish wherein the offence shall have been committed; and if the party who shall have been Persons not so convicted shall not immediately pay the said sum of paying the twenty pounds so forfeited, together with $(t)$ the costs penalty with and charges attending such conviction, or shall not giving notico give notice of appeal, and enter into recognizance in of appeal, the manner hereinafter mentioned and in that behalf \&e., may be provided, such justice shall and may commit every such offender to the house of correction, or some other prison of the county, riding, division, city, liberty, town or place in which he or she shall have been convicted, thereto remain and be kept to hard labour" $(t)$.

( $t$ ) See $47 \& 48$ Vict. c. 43. 
Sect. 8.

Offenders discovering accomplices before information indemnified.
Sect. 10.

Parties aggrieved may appeal to the quarter sessions, where the matter may be finally determined in a summary way, \&c.

Proceedings not to be quashed for want of form, or removed by certiorari.
[Sect. 7 was repealed by the Statute Law Revision Act, 1871, 34 \& 35 Vict. c. 116.]

By sect. 8 it is provided, -

"That if any servant or servants who shall have been guilty of any of the offences aforesaid shall, before any information has been given or lodged against him, her or them for such offence, discover and inform against any person or persons concerned with him, her or?them $[* 470]$ in any ${ }^{*}$ offence against this act, so as such offender or offenders be convicted of such offence in manner aforesaid, every such servant or servants so discovering and informing shall thereupon be discharged and indemnified of, from and against all penalties and punishments to which at the time of such information given, he, she or they might be liable by this act, for or by reason of such, bis, her or their own offence or offences."

[Sect. 9 was repealed by $47 \& 48$ Vict. c. 43 .

And by sect. 10 it is provided,-

"That if any person shall think himself or herself aggrieved by anything done in pursuance of this act, such person may appeal to the justices of the peace at the next general or quarter sessions of the peace $(u)$; and no conviction or order made concerning any matters aforesaid, or any other proceedings to be had touching the conviction or convictions of any offender or offenders against this act, shall be quashed for want of form, or be removed by certiorari, or any other writ or process whatsoever, into any of his Majesty's courts of record at Westminster."

(u) See $47 \& 48$ Vict. c. 43. 
PAGE.

Murder of Master by Servant 471 Assault on Master by Servant 472 Burglary by Sevvant in Master's house . . . . . 472

Servant negligently fiving Master's house. . . . . 474

Stealing in a shop, warchouse or counting-house . . . 475

Stealing in dwelling-house to value of $5 l$.

Stealing goods in process of manufacture . . . . . 478

Destroying goods in process of manufacture . . . . 478

Larceny and embezzlement by Clerks and Servants . . 479
II the is a Clert or Serume PAGE.

What is a receipt on account of his Master . . . . . 511

What is an embezzlement . 519

Indictment . . . . . . . 526

Fatsification of Aceounls. . 531

Offences committcd by Public

Servants or Police . . . 532

Embezzlement by Officers of the Bank of England or Ireland . . . . . . . 534

Embezzlement by Servals in the Post Office . . . . . 535

Clerks of Courts utlering false copies or certificates of Records . . . . . . 541

\section{Murder of Master by Servant.}

Formerly both by the common law and also by the stat. $25 \mathrm{Edw}$. 3, st. 5, c. 2, it was petit treason for a servant to kill his master or mistress $(a)$. So much of the stat. $25 \mathrm{Edw}$. 3, however, as relates to petit treason was repealed by 9 Geo. 4 , c. $31(b)$; and now by $24 \& 2524 \& 25$ vict. Vict. c. 100 , s. 8 , it is enacted that every offence which e. 100 , s. 8 . before the first of July, 1828, would have amounted to petit treason shall be deemed to be murder only, and no greater offence ; and all *persons guilty in [*472] respect thereof, whether as principals or as accessories, shall be dealt with, indicted, tried and punished as principals and accessories in murder $(c)$.

(a) See 3 Inst. 20 ; Dalt. Just. ch. 142. Lord Coke, 3 Inst. 48, mentions the cuse of one Margaret Dary, a young woman who was attainted of high treason for poisoning her mistress (under statute 22 Hen. 8, c. 9), and with some others were looled to death in hot water in Smithfield. But, he adds, this statute wus too severe to live long, and therefore was repealed, $1 \mathrm{Edw}$. 6, e. 12 , and 1 Mary, c. 1 .

(b) The Irish Aet was 10 Geo. 4, e. 34 , s. 3. Both these Acts were repealed by $24 \& 95$ Vict. c. 95.

(c) See further on this subject, Russ. on Crimes. 
R. v. Harley. Where a servant put poison into a coffee pot, and when her mistress came down to breakfast, said she had put the coffee-pot there for her, such servant was held indictable under 9 Geo. 4, c. 31 , s. 11 , for "causing poison to be taken" $(d)$.

\section{Assaults committed by Servants on their Masters.}

The 21st sect. of 5 Eliz. c. 4, which provided a special punishment for assaults committed by servants on mas. ters, was repealed by 9 Geo. 4, c. 31 , s. 1 , and the offence is now punishable in the same way as assaults committed by other persons $(e)$.

The statute $24 \& 25$ Vict. c. 100 , s. 41 , which provided for assanlts arising from combinations, was repeal. ed in $1871(f)$, and that act was also repealed in 1875 by $38 \& 39$ Vict. c. 86 , which will be found in the Ap. pendix.

\section{Burglary by a Servant in his Master's House.}

A servant who lives in his master's house may be guilty of burglary in that house, as well as a stranger, for the opportunity which his situation affords him of committing that crime aggravates rather than extenu-

Opening

door, \&c., with design to commit felony, R. v. Gray.

to let in robber, Cornwall's Case. ates bis guilt $(g)$. Where, therefore, one of the servants in the house opened his lady's chamber door (which was fastened with a brass bolt) with design to [*473] commit a rape, C. J. King ruled it to *be burglary, and the defendant was convicted and transported $(h)$.

And where (i) a servant, in the night-time, opened the street door and let in a robber, and showed him the side-board from whence he took the plate, and then again opened the door and let him out, it was held, at a meeting of all the judges, to be burglary in the ser-

(d) R. v. Harley, 4 C. \& P. 369.

(e) See 9 Geo. 4 , c. 31 , ss. $27,28,29$; the Irish Act was 10 Geo. 4, c. 34, s. 28. Both those Acts are now repealed. See ante, note $(b)$. Justices, however, had no jurisdiction nnder !? Geo. 4 , c. 31 , s. 27 , to convict of an assault, except upon the complaint of the party aggrieved, $R$. v. Deny, 2 L. M. \&. P. 230 . That a servant may justify an assault to obtain possession of his master's property, see Blades v. Higgs, 10 C. B., N. S. 713.

(f) By 34 \& 35' Vict. c. 32.

(g) See 4 Bl. Com. 227 ; Bac. Abr. tit. Burglary. As to burglary in general, see 1 Russ. on Crimes, B. 4, ch. 1.

(h) $R$. v. Gray, 1 Str. 481.

(i) Cornicall's case, 2 Str. 881 ; and see 19 St. Tr. 782, note; 1 Hale, P. C. 553 ; 2 East, P. C. 486. 
vant as well as in the other, and he was afterwards executed. But where a servant opened the door and let R. v. Johnson. in a robber for the purpose of catching him, having previously communicated with the police, it has been held that the robber even could not be convicted of burglary $(k)$.

And in R. v. Mears (l), a case is cited, where a jour- to obtain neyman who had embezzled money received for his money premaster, and left it in his chamber in his master's house, viously emand being discharged, entered the house in the night and took the money from the chamber, it was held to be no burglary, because the taking the money did not amount to felony, - that is, to larceny,--the money not having been taken out of the possession of the master.

In the case of a servant opening a door of his mas- Distinction ter's house for a felonious purpose, without any plan between or conspiracy with other persons to commit a robbery, eases where it seems to have been considered that the question, opening door whether such act will amount to a breaking must de is within whether such act will amount to a breaking, Inust de-servant's pend upon the point whether the door might have been trust, and opened by the servant in the course of his trust and where not. employment. Thus, it is said, that if a servant unlatch a door or turn a key in a door of his master's house, and steal property out of the room, such opening of the door, being within his trust, is not a breaking: but that if a servant break open a door, whether outward or inward (as a closet, study or counting-house), and steal goods, such opening, not being within *his [*47t] trust, will amount to a breaking of the bouse, either within the statutes relating to the breaking of dwellinghouses in the daytime or within the law of burglary $(m)$.

Servants vẹgligevtly setting Fire to their Master's House, \&c.

By stat. 14 Geo. 3 , c. 78 , s. 84 , after reciting that 14 Geo. 3 , fires often happen by the negligence $(n)$ and careless- c. 78, s, 84 . ness of servants, it was enacted,-

(k) R. v. Johnson, Carr. \& MI. 218; see R. v. Eygington, 2 B. \& P. 508.

(l) 1 Show. $53 ; 3$ B. \& P. 108.

(m) 2 Russ. on Crimes, 11, citing 2 Hate, 35. 355; but the learned editor of the 4th edit. (Greaves) adds, "sed quire, and see Edmond's Chse, Hutt. 20 ; Kel. 67; 1 llale. 55.t, where n servant who unlatehed the stair-foot door and went with a hatehet to kill his master, was hell guilty of bureryary." Sce also $R$. $v$. Wenmouth, 8 Cox, Cr. C. 348, where a servant burst open the door of a shop in the night, to steal money from the till.

(n) Unlawtully and maliciously setting fire to a dwelling- 
Servants by carelessness firing a house to forfeit $100 \%$., or be imprisoned eighteen months.

Repealed.
"That if any menial or other servant or servants, through negligence or carelessness, shall fire or cause to be fired any dwelling-house or out-house or houses or other buildings, whether within the limits of that act or elsewhere within the kingdom of Great Britain, such servant or servants being thereof lawfully convicted by the oath of one or more credible witness or witnesses, made before two or more of his Majesty's justices of the peace, shall forfeit and pay the sum of 100l. unto the churchwardens or overseers of such parish where such fire shall happen, to be distributed amongst the sufferers by such fire, in such proportions as to the said churchwardens shall seem just; and in case of default or refusal to pay the same immediately after such conviction, the same being lawfully de. manded by the said churchwardens, that then and in such case such servant or servants" should be impris. oned for eighteen months, with hard labour.

This clause, however, "raising the same sum whatever the extent of suffering, and the number of the sufferers, and inflicting the same penalty to whatever degree the negligence might have been culpable, without any power to lower the fine or shorten the imprisonment, can scarcely," observed Lord Denman (o), "be supposed to have undergone much consideration on the [*475] part of the legislature." *It has accordingly been repealed on and after 1st January, $1866(p$.

Stealing in a Shop, Warehouse or Counting-house.

$24 \& 25$ Vict. c. $96, \mathrm{~s} .56$.

By stat. $24 \& 2 \check{\delta}$ Vict. c. 96 , it is enacted, sect. 56 $(q)-$

"That whosoever shall break and enter any dwelling house, school-house, shop, warehouse or counting house, and commit any felony therein, or being in any dwell. ing-house [\&c., as before] shall commit any felony therein and break out of the same, shali be guilty of felony, and being convicted thereof shall be liable at the discretion of the court to be kept in penal ser-

house, any person being therein, is a felony, 24 \& 25 vict. $c$ 97 , s. 2.

(o) In Filliter v. Phippard. 11 Q. B. 354. It was held to be general law, although contained in a local and personal act, Richards v. Easto, 15 M. \& W. 251 ; Filliter v. Phippard, ubi supra ; Ex parte Gorley, 34 L. J., Bankr. 1.

(p) $28 \& 29$ Vict. c. 90 , s. 34.

(q) By sect. 57, honsebreaking with intent to commit felony, which was formerly only a misdemeanor at common law, is marle a felony. 
vitude for any term nct exceeding fourteen years, and punishment. not less than [five jears, $27 \& 28$ Vict. c. 47 ], or to be imprisoned for any term not exceeding two years, with or without hard labour, and with or without solitary confinement" $(r)$.

Upon a similar enactment in $7 \& 8$ Geo. 4 , c. 29 , s. What is a 15 , it was held by Alderson, B. $(s)$, that to come within shop.

it "the place must be more than a mere workshop, it must be a shop for the sale of articles. A workshop such as a carpenter's shop or a blacksmith's shop would not come within the act." Lord Denman, C. J., how- What is at ever, in a subsequent case $(t)$, refused to be guided by conntingthe opinion of Alderson, B., and held that a black. honse. smith's shop was within the act. And in another R. v. I'otter. case $(u)$, a machine-house where a weighing-machine was kept, at which all goods sent out were weighed and a book kept in which were entered all goods weighed and sent in, and in which house the account of the time of the men was taken and their wages paid (although the books were brought there for the purpose, being usually kept elsewhero), was held to ba a countinghouse.

*Servant or other Person Stealing in a [*476] Dwelling-house to the Value of $£$ ó or Moke.

It is enacted by $24 \& 25$ Vict. c. 96 , s. $60(v)$, that 24 \& 2 ; virt. "Whosoever shall steal in any dwelling.house any c. \%;, $\therefore$. (i). chattel, money or valuable security $(w)$ to the value in the whole of tive pounds or more, shall be guilty of felony, and being convicted thereof shall be liable at the discretion of the Court to the same punishment Punishnent. as under sect. 56," supra.

It is not thought necessary to encumber this work with all the decisions on this or the previous statute $7 \& 8$ Geo. $4(x)$, which do not apply exclusively to servants; though they obviously apply to them as well as other persons. The following decisions, however, having taken place on indictments under 7 \& 8 Geo. 4, against servants, could not well be onitted here consistently with the object of this work.

(r) See further, 2 Russ. on Crimes, 94, 4th edit.

(*) In $R$. v. Sauuders, 9 C. \& P. 79.

(1) R. v. Carter, 4 C. \& K. 173.

u) R. v. Potter, 2 Den. C. C. 235.

(v) As to stealing in a dwelling-house with menaces, see sect. 61 .

(x) As to the meaning of "valuable security," see the inter-

pretation clanse, sect. 1 , and $R$. v. Lowrie, 36 L. J. M. C. 24 .

$(x)$ See them collected in 2 Russ. on Crimes, 82 , th edit. 
R. v. Jones.

In a case $(y)$ which happened soon after the passing of the act, a shopman was charged with stealing in a dwelling house sixty.eight yards of lace, the property of his master. The prisoner had sent the lace (which was in several distinct pieces) from Abingdon to London in a parcel by the coach, and no one piece of lace was worth $5 l$; whereupon his counsel suggested that in favorem vitce it might be taken that the pieces of lace might have been stolen at different times; but Bolland, B., said,-

"I cannot assume that to have been so. We find that the lace is all sent in one parcel, and all brought out of the prosecutor's house at once, and unless you can give some evidence to show that it was stolen at different times you do not raise your point; but even if you did I should think it would be of no avail, for on the last Winter Circuit it appeared that a person at Brighton stole goods in the same way that you wish me to suppose that this person did; for it was shown that he stole the articles one or two at a time, and under [*477] value, but that he carried them out of *his master's house altogether, the articles amounting in all to more than $5 l$. value; and Mr. Baron Garrow, after much consideration, held that as the articles were all brought out of the prosecutor's house together, it was a capital offence."

The prisoner was found guilty.

Where $(z)$ an under-butler was indicted for stealing

(y) R. v. Jones, 4 C. \& P. 217.

(z) R. v. Phetheon, 9 C. \& P. 552. And see $R$. v. Wright, 9 C. \& P. 55t, note, where a serrant, who was indicted for stealing his master's plate, setting up as a defence his intention to replace it, Hullock, B. (Holroyd, J., being present), left it to the jury to say whether the prisoner took the plate with intent to steal it, or whether he merely took it to raise money on it for a time and then return it, for that in the latter case it was no larceny. To which the learned reporters add the following note: "This decision has given rise to much discussion in rarious cases; and much difficulty has been found in applying the doctrine it lays down to the facts of particular transactions. In some instances, where it has appeared clearly that the party only intended to raise money on the property for a temporary purpose, and at the time of pledging the article, had a reasonable and fair expectation of being able shortly by the receipt of money to take it out of pawn, juries, under the advice of the judge, have acted upon the doctrine and acquitted. But, in other instances, where they could not discover any reasonable prospect which the party had at the time of pledging of being able soon to redeem the article, they have considered the doctrine as in applicable and have convicted. See also $R$. v. Ifolloway, 2 C. \& K. 944, post, p. 479 n. (c); R. v. Trebilcock, 1 Dears. \& Bell, C. C. 453. 
his master's plate to the value of 181 . $5 s$., in his dwell- $R$. r. Theing-house, and found guilty, but the jury recommended theou. him to mercy on the ground that they believed that he intended to replace the property, which it appeared he had pledged, a finding which the prisoner's counsel contended amounted to a verdict of not guilty; Gurney, B., without expressing any opinion on the point, directed that the prisoner should be tried on another indictment which had been found against him for stealing a silver saucepan belonging to his master. This also the prisoner had pledged; and his counsel contended that he meant to replace this also. But in summing up, Gurney, B., said,-

"If this doctrine of an intention to redeem property is to prevail, courts of justice will be of very little use. A more glorious doctrine for thieves it would be diffi. cult to discover, but a more injurious doctrine for hon. est men cannot well be imagined."

The jury found the prisoner guilty, and he was transported for fourteen years.

*By 24 \& 25 Vict. c. 96, s. 61, "whosoever [*478] 24 \& 25 vict. shall steal any chattel, money or valuable security in c. 96, s. 61 . any dwelling-house, and shall by any menace or threat Stealing in a put any one being therein in bodily fear, shall be guilty dwellingof felony, and being convicted thereof shall be liable at house with the discretion of the court to" [same punishment as under s. 56, ante, p. 485].

- Servant or other Person Stealing Goods in Process of Manufacture.

By 24 \& 25 Vict. c. 96, s. 62 , "whosoever shall steal Scet. $6 \%$ to the value of ten shillings any woollen, linen, hempen or cotton yarn or any goods or article of silk, woollen, linen, cotton, alpaca or mohair, or of any one or more of those materials mixed with each other or mixed with any other material whilst laid, placed or exposed during any stage, process or progress of manufacture in any building, field or other place, shall be guilty of felony, and being convicted thereof shall be liable at the discretion of the court to [same punishment as under s. 56, ante, p. 485]. 
Servant or other Person Destroying Goods in Process of Manufacture.

$24 \& 25$ Vict. By 24 \& 25 Vict. c. 97 , s. 14, "whosoever shall unc. 97, s. 14. lawfully and maliciously $(a)$ cut, break or destroy, or damage with intent to destroy or to render useless any goods or article of silk, woollen, linen, cotton, hair, mohair or alpaca, or of any one or more of those materials, or any framework-knitted piece, stocking, bose or lace being in the loom or frame or on any machine or engine or on the rack or tenters or in any stage, process or progress of manufacture, or shall unlawfully or maliciously cut, break or destroy or damage with intent to destroy or to render useless $(b)$ any warp or shute of silk, woollen, linen, cotton, hair, mohair or alpaca, or of any one or more of those materials mixed with each other or mixed with any other material, or shall unlawfully and maliciously cut, break or destroy or damage with intent to destroy and render useless any loom, frame, machine, engine, rack, tackle, tool or implement, whether fixed or moveable, prepared for or employed in carding, spinning, throwing, weaving, fulling, shearing or otherwise manufacturing or preparing any such goods or articles, or shall by force enter any house, shop, building or place with intent to commit any of the offences in this section mentioned, shall be guilty of felony, and being convicted thereof shall be liable at the discretion of the court to be kept in penal servitude for life or for any term not less than [tive years, $27 \& 28$ Vict. c. 47 ], or to be imprisoned for any term [*479] not *exceeding two years, with or without hard labour, and with or without solitary confinement, and if a male under the age of sixteen years, with or without whipping."

\section{Larceny and Embezzlement by Clerks and Servants.}

Distinction between larceny and embezzlement.
The legal distinction between these two offences is that the former consists in the felonious taking of property, \&c., out of the possession of the master $(c)$,

(a) An indictment under this section should say "feloniously," or it would be ball. $R$. v. Gray, 33 L. J., M. C. 78.

(b) See $R$. v. Fisher, 1 L. R., C. C. 7.

(c) In $R$. v. Holloway, 1 Den. C. C. 370; 2 Carr. \& K. 946, Lord Wensleydale said, "The definitions of larceny are none of them complete. East's is the most so, but that wants some explanation. His definition is 'the wrongful or fraudulent taking and carrying away by any person of the mere personal goods of another from any place with a felonious intent to convert them 
whether that possession be actual or constructive, whilst the latter consist in the receiving property, \&c., for or on account of the master, and fraudulently appropriating it, before it reaches his possession, either actual or constructive. Morally and substantially, however, the offence is the same in both cases, and accordingly the punishment for both offences is now the same. But although, since Lord Campbell's Act for the Improvement of the Administration of Criminal Justice $(d)$, a person indicted for one of those offences may be found guilty of the other, yet there is still a great practical difference between the two; for even now, should a person be indicted for and convicted of either of those offences, upon evidence which proves the other, the conviction may be quashed and the pris. oner escape (e).

Most of the technicalities, therefore, which formerly surrounded these offences, and which it was hoped would be done away with by Lord Campbell's Act, still survive. It therefore becomes absolutely necessary to advert to the numerous cases which have been and still continue to be decided upon the distinction above pointed out.

*At common law a servant might be guilty of [*480] Larceny by felony in feloniously taking away the goods of his mas- servant at ter, though they were goods under his charge, as a common law. shepherd, butler, \&c., and may at this day, for any such offence, be indicted as for a felony at common law; but at common law, if a man had delivered goods to his servant to keep or carry for him, and he carried them away animo furandi, it was doubtful whether such servant was guilty of felony, or merely a breach of trust. These doubts gave rise to, and are recited in the stat. 21 Hen. 8, c. 7, whereby such an offence was made felony $(f)$. Subsequent decisions, however, 'es-

to his (the taker's) own use and make them his own property, without the consent of the owner.' This is defective for not stating what the fraudulent taking is, and what the felonions intent is; this may be explained, that the 'taking' is without any colour of right, and the 'intent' an intent to deprive the owner permanently of the property. Cases also show that a taking of goods with an intent to return them is not larceny." See also supra, p. 477 , note $(z)$.

(d) $14 \& 15$ Vict. c. 100 , s. 13 . That section was repealed by $24 \& 25$ Vict. c. 95 , but $24 \& 25$ Vict. c. 96 , s. 72, post, is a similar enactment.

(e) R. v. Gorbutt, 26 L. J., M. C. 47; 1 Dears. \& Bell, C. C. 166.

(f) It is said by Gould, J., in $R$. v. Wilkins, 1 Ieach, C. C. 520, that this statute did not mean to weaken, but assist, the common law. But it is remarkable that the stat. 5 Eliz. c. 10 
Where servant had bare custody.

tablished that where a party had only the bare charge or custody of the goods or money of another, the legal possession remained in the owner, and the party might be guilty of trespass and larceny in fraudulently converting them to his own use $(g)$. This rule holds universally in the case of servants whose possession of their master's goods by delivery of their master is held to be the possession of the master himself, where the master only intended to part with the custody of the goods, and if the servant converts such goods to his own use it is larceny, whether he had a felonious intent. at the time he received them, or conceived such an in[*481] tention afterwards $(h)$. Thus, *in the case of a butler, or other servant, to whose care a master entrusts his plate or other goods, it has uniformly been held that such servants are guilty of felony by embezzling such plate or goods, or taking them fraudulently away; and this doctrine is not confined to menial servants only, for it appears, both by Hale and Hawkins, that if a shepherd who has the care of sheep, and who, from the nature of his enuployment, must be constantly in the pastures, takes away any part of the flock with intent to steal it, he is guilty of felony, although, in both cases, the plate is actuaily delivered to the butler (i),

(which revived and made perpetnal the stat. 21 Hen. 8), recites that it had been repealed by the general words of stat. 1 Mary, sess. 1, c. 1. The statute of Mary, however, only enacted that all offences made felony during the reign of Hen. 8, which vere not felony before, shonld be repealed. Hence it would seem that, at the time 5 Eliz. c. 10 was passed, it was considered that servants embezzling goods entrusted to them were not guilty of felony at common law, but only by the statute of Hen. 8 . The point, however, is more curious than important at the present day. The stat. 5 Eliz. was repealed, $7 \& 8$ Geo. 4 , c. 27.

- (g) Bac. Abr. Master and Servant, M. 2; Hale's Hist. P. C. $505 ; 2$ East, P. C. c. 16, s. 14 , p. $564 ; 2$ Russ. on Crimes, 191, 4th edition, where several cases will be found in support of the rule stated in the text.

(h) To incite a servant to steal his master's goods is a misdemeanor, indictable at the sessions, although it be not charged in the indictment that the servant stole the goods, nor that any other act was done, except the soliciting and inciting, $R$. v. Higgins, 2 East, 5; R. v. Gregory, 36 L. J., M. C. 60 . If the felony has been committed by the serrant the "counselling, procuring or commanding" it to be committed is a felony by 24 \& 2 " Vict. c. 94, s. 2. See ibid. Semble the means nsed need not be set out in the indictment, see $R$. v. Hague, 33 L. J., M. C. 81.

(v) $R$. v. Ashley, 1 Carr. \& K. 198 , it was held that plate belonging to a club could not be described as the property of th. house steward in an indictment against a member of the clnb for stealing it. But see $R$. v. Burgess, 32 L. J., M. C. 185 ; where ir was held that a member of a co-operative society might be convicted of larceny from B., a servant of the society, for stealing 
and the sheep to the shepherd; for the possession still remains in the master $(k)$. Lord Coke says $(l)$ "these things be in onere et non in posssessione, promi, coci, pastoris, \&c." And this law prevails in all cases where servants have not the absolute dominion over the property, but are only entrusted with the care or custody of it for a particular purpose $(m)$.

Thus, a foreman and book-keeper to a mercer, not residing in his master's house, but going there every Cascice's day to transact business, who received from his master certain bills to send to a correspondent by post, in the ustal course of business, but, instead of sending them all, kept back one for which he obtained cash, and absconded with the money, was held rightly convicted of larceny; as the possession of *the bill still re- [*482] mained in his master $(n)$. So a carter going away with Robinson's his master's cart was holden to have been guilty of Casc. felony (o). So where a tradesman's servant and porter Bass's Casr. was sent with a package of goods from his master's house with directions to deliver them to a customer, but by the way opened the package, sold the goods, and pocketed part of the price, all the judges held this to be felony $(p)$.

And so where a corn-factor, having purchased a spear's Case. cargo of oats, sent his servant with a barge to receive part of the oats in loose bulk, and the servant ordered some of the oats to be put into sacks which he afterwards embezzled, the judges held it to be larceny $(q)$.

from 13.'s till in the shop of the soeiety, money received for goods of the society sold by $B$. as their servant, for which he was perionally accountable.

(k) Sce per Gould, J., in Leach, C. C. 523.

(l) 3 Inst. 108.

(m) Upon this principle it was held in $R$. v. Wilkins, 1 Leaeh, C. C. 520, that to obtain goods by false pretences from the servant of the owner to whom they were delivered for the purpose of being carried to a etstomer who had purchased them, was a taking from the possession of the master: and a person so taking them with a preconceived design to steal them was guilty of felony. Sce $R$. v. Johnson, 21 L. J., M. C. 32.

(n) Paralice's case, 2 East, l'. C. 565, cited by Gould, J., in 1 Leach, 523 ; see 2 Russ. on Crimes, 383 , 4 th ed.; and see $l . v$. Metealfe, Moo. C. C. 433.

(o) Robinson's case, 2 East, P. C. 565. A servant going of with his master's box and his master's wife was held guilty of lareeny of the box, $R$. v. Mutters, 34 L. J., M. C. 5.1. Fvidence of a eonfession of guilt to his master was held admissible in $R$. v. Jarvis, 37 L. J., M. C. 1.

(p) Bass's case, 2 East, P. C. $566 ; 1$ Leach, 251, 524.

(q) Spear's case, 2 Fast, P. C. 568 . In $R$. v. Walsh, 4 Taunt. 276, Heath, J., said, "That case went upon the ground that the corn was ia the prosecutor's barges, which was the same thing as 
Larender's Case.

Chipehase's Case.

So a servant going off with money given to him by his master to carry to another, or get changed $(r)$, and applying it to his own use, was holden guilty of larceny $(s)$.

And so it was held to be larceny, for the confidential clerk of a merchant to take a bill of exchange unindorsed from its proper repository, discount it, and convert the proceeds to his own use; although the had the general management of his master's cash concerns, and authority to get bills discounted $(t)$.

R. v. Wright. $[* 483] *$ *And so, in the following case the prisoner Banker's clerk taking money from iron safe. was held guilty of larceny $(u)$ : The prisoner W. was employed by a banking company to conduct a branch bank, and the whole of the duties thereof were discharged by him alone. He was paid $150 l$. a year, for which he was bound to provide a place for carrying on the business, and the place so provided was in his own house, where he carried on business as a wine merchant. The office was titted up at the expense of the bank, and in it there was an iron safe provided by the bank, into which it was W.'s duty to put any money received during the day, which had not been required for the purposes of the bank. There were duplicate keys of this safe, one in W.'s custody and one under the control of the manager of the bank. W. furnished weekly accounts of moneys received and paid by him, showing the balance in his hands, and of what notes, \&c., the balance consisted. In September, 1855, W.'s accounts were audited, and the cash found correct, but although for two years afterwards he furnished the usual weekly accounts, no examination was made during that time of the balances in his hands. In September, 1857, the manager having appointed a time for examining the cash in W.'s hands, he said

if it had been in his granary." See also $R$. v. Reed, Dears. C. C. 263 ; and see Abrahat's case, 2 East. P. C. 569 ; Aldridge v. John$80 n, 7$ E. \& B. $885 ; R$. v. Bunkall, 33 L. J., M. C. $75 ; 9$ Cox, Cr. C. 419 ; S. C., nom. R. v. Bucknell, 9 L. T. 395 , 4 th edit.

(r) $R$. v. Goode, Carr. \& M. 582; R. v. Smith, 1 C. \& K. 423 ; $R$. v. Cooke, L. R., 1 C. C. R. $295 ; 40$ L. J., M. C. 68 . Where one workman, who was sent to the pay-table to get money for four, stole it, it was held to be the money of the four workmen, and not of the master. R. v. Barnes, 35 L. J., M. C. 204 ; L. R. 1 C. C. R. 45.

(s) Lavender's case, Huntingdon Lent Ass. 1793, twice considered by the judges, East. T, 1793, and Trin. T. 1793; see 2 Russ. on Crimes, 160.

$(t)$ Chipchase's case, 2 Leach, 699 ; 2 East, P. C. c. 16, s. 15, p. 567 ; 2 Russ. on Crimes, 396,4 th edit.

(u) R. v. Wright, 1 Dears. \& Bell, C. C. 431. 
he was about 3,000l. short in his cash, and handed $R$. v. Wright. over to the manager $755 \mathrm{l}$. $10 \mathrm{~s}$., which he said was all the cash he had left, and which he took from a drawer in the counter, not from the safe. Afterwards, when before the magistrates on a charge of embezzling the $3,000 l$., he said, "I admit that I have taken the amount of money which appears in my weekly return, dated September 12, 1857, and entered as a deficiency of 3,021l. 9s. 9d." The jury found W. guilty of larceny as a clerk in having stolen some money received from customers, which, before such stealing, had been placed in the safe and made the subject of a weekly account. And it was held by the Court for the Consideration of Crown Cases Reserved, that there was evidence that W., as his *duty required, placed in the safe [*484] money which had been previously received from customers, that ho thereby determined his own exclusive possession of the money, and that by afterwards taking some of such money out of the safe, animo furandi, he was guilty of larceny. It was also held, that the find. ing, that W. stule "some money," was sufficiently certain, as it was not necessary that they should find that any specific amount was stolen on any particular day.

And where some barilla, which the prosecutors had bought, was weighed out in the presence of their clerk, ing. and delivered to their carter's servant to cart, and he allowed other persons to take away the cart and dispose of the barilla for his benefit jointly with that of the other persons, it was held that $h e$, as well as the other persons, was guilty of larceny at common law $(x)$.

Again, where $(y)$ a man sent his servant with his $R$. v. Reed. (the master's) cart to the railway station for some coals, which were put into the cart, and on the way home the servant, without authority from his master, disposed of some of the coals to a third person, he was

(x) R. v. Harding, Russ, \& Ry. 125. Where a master finding some brass eastings in the poeket of a thief sent for a policeman, and they were taken out, but afterwards given baek to the thief, who by the master's direclion took them to the house of the person to whom he had intended to sell them, and sold them to him and gave his master the price, it was held that that person eould not be convicted of receiving stolen gools. $R$. v. Dolan, 24 I. .J., M. C. 59 ; 1 Dears. C. C. 436 , overrnling $R$. v. Lyons, Carr. \& MI. 217. See R. v. Sehmidl, 35 I. J., M. C. 94.

(y) k. v. Reed, 1 Dears. C. C. 168, 257. This ease was twice argued, and long considered, but ultimately deciderl npon the authority of Spear's case, supra, p. 48: ; but Lorl Wensieydale said that if it were res now he should have pronounced un opinion that the prisoner's offence was not larceny. See, also, R. v. Norval, 1 Cox, Cr. C. 95.

28 MAS. \& SElı. 
held to be guilty of larceny, as the coals, having been placed in the master's cart, were not in the exclusive possession of the servant, but constructively in the pos. session of his master.

Person employed to drive cattle who sold and pocketed the money.

R. v. Stock.

Other cases of larceny.

Servant receiving gools from master on his account.

False pretenses.
And so a person employed to drive cattle to a par. ticular place, who had no authority to sell the cattle, but did so, and converted the money to his own use, having had a felonicus intent at the time he receired charge of the cattle, was held guilty of larceny of the cattle.

[*485] *Thus, where $(z)$ the prosecutor saw the prisoner at Bristol fair, and hired him to drive fifty sheep for him from Bristol to Bradford fair. This was on a Thursday, and the prisoner, with the sheep, was to meet the prosecutor on the following Sunday evening at the turnpike-gate, nearest to Bradford. The prisoner had no authority to sell the sheep, but was only to drive them to Bradford, for which he was to receive two shil. lings and sixpence per day. The prisoner never was a servant of the prosecutor, but had been cecasionally employed to drive sheep, and he never had anthority to sell. The prisoner never went to Bradford, but sold the sheep, telling the purchaser he had authority to do so. The jury found that the prisoner at the time he received the sheep intended to convert them to his own use, and not to go to Bradford. And he was convicted of felony, which conviction was afterwards held right by the judges.

So a servant who receires goods from his master, on the master's account, and wrongfully appropriates them, is not guilty of embezzlement, but of larceny $(a)$.

And a contractor's servant who used false weights with intent to steal the difference between the true and false weights, was convicted of attempting to steal $(b)$.

In the following case (c), however, it was held; that

(z) R. v. Siock, 1 Moo. C. C. 8\%. But see as to drovers generally, R. v. Hey, post, p. 493.

(a) R. v. Hackims, 1 Den. C. C. $584 ; 4$ Cox, C. C. 274. It is said by the Court in R. v. Whittingham, 2 Leach, C. C. 913 , that "if a servant receired money, either from the master, or from a thirl person on his master's account," he was guilty of embezzl ment: hut in R. v. Hackins, Lord Truro said, "The dictnm in R. v. Whittingham must be associated with some facts which do unt appear in the report of the case." See also $R$. v. Metealf, 1 Mo\%. C. C. 433 , where the prisoner was held properly convicted of larceny for appropriating a cheque which he received from his master to pay a creditor. $R$. v. Johnson, 21 L. J., M. C. $32 ; R$. T Poyser, 5 Cox, C. C. 241.

(b) R. v. Chescmrm, 31 ฯ. J., M. C. 89; Leigh \& C. 140.

(c) R. v. Essex, 27 L. J., M. C. 20; 1 Dears. \& B. 371. 
vnder the circumstances, a clerk ought to have been indicted for false pretences.

At a savings bank the course of business was this :-The depositor gave a notice to the clerk of the amount *required, and if present on next night of business [*486] received a cheque from the manager; if absent, he allowed the clerk to receive and cash such cheque, and kept the cash till called for, and both depositor and clerk signed the book. The clerk, by falsely pretending to the manager that G. had given notice for $50 l$. and was not in attendance, obtained from the manager a cheque for $50 l$, and afterwards the cash, which he pocketed; it it was held, that he ought to have been indicted for false pretences, and not for larceny, as he acted as agent for the depositor.

If a servant who has authority to sell, and enter salo in a book, do sell, and omit to make an entry of the sale selling gnoods in the book, and pocket the price, he cannot be convicted with authorof larceny of the goods, but of embezzlement of the money $(d)$. But if a servant who has no authority to sell, part with his master's goods, under colonr of a pretended sale, to a purchaser, both servant and purchaser may be indicted for larceny $(e)$.

R. v. Evex.

And if a servant take his master's property, and hand anthority. it over to another as a gift, it is as much a felony as if $R$. r. $H 00^{\circ} \mathrm{m}, y$. he sell it, or take it to a pawnbroker and pledge it. In Giving away a case, therefore, where $(f)$ a cook, out of compassion, as she alleged, gave away a bundle containing bread, candles, soap and butter, done up in one of her master's towels (altogether not worth eighteenpence), she was convicted of larceny, and she, as well as the receiver were sentenced to three months' imprisonment (haring, under the circumstances, been recommended to mercy by the jury who tried them).

Where a nursery-maid, who was indicted for stealing Appropriatbank-notes, the property of her master, in his dwelling ing things *house, set up as her defence, that she found [* $\left.{ }^{*}+87\right]$ master"s them in the passage, and, not knowing to whom they house. belonged, kept them to seo if they were advertised: it $R$. $v$. hirr. was held that she ought to have inquired of her master

(d) R. v. Betts, 28 L. J., M. C. 69; 1 Bell, C. C. 90; R. ง. Brackett, 4 Cox, C. C. 274.

(e) $R$. v. Hornby, 1 C. \& K. 30.).

(f) R. v. White, 9 C. \& P. 344. Where certain friends of the servants were entertained by then at night without their master's leave, it was held that the justices might have convicted the friends under the Vagrant Aet, 5 Geo. 4, e. 83, s. 4, as heing in the house for an unlawful purpose. Kirkin v. Jenkins, 32 L. J., i.. C. 140. 
whether they were his or not; and that not having done so, but having taken them away from the house, she was guilty of stealing them $(g)$.

Clandes-

And it was formerly held $(h)$ that a servant who tinely taking clandestinely took his master's corn was guilty of master's felony, although he took it to give to his master's corn, though horses, and without any intention of applying it to his
for his horses.
own private benefit. But this offence is not now a felony, but is punishable on summary conviction before two justices (i).

Pudaler paid by weight mixing master's metal with pig-iron. R. v.
Richards.

The prisoner was employed as a puddler by an iron company. The puddlers employed were in the habit of receiving a certain quantity of pig-iron which they put into the furnaces, and they were paid for their work according to the quantity drawn out of the fur. nace and formed into puddle-bars. The prisoner put an [*48S] iron axle *(not pig-iron) belonging to his masters into the furnace, by the melting of which, in addition to the pig-iron, his profit would be increased about 1d. Tindul, C. J., at first doubted whether the act of the prisoner, though unquestionably fraudulent and wrong, came within the definition of larceny, as the iron

(g) R. v. Kerr, 8 C. \& P. 176. And see R. v. Thurborn, 2 C. \& K. 831 ; 1 Den. C. C. 337 , where it was held that if a person finds goods that have been lost, or are reasonably supposed by him to have been lost, and appropriates them with intent to take the entire dominion over them, but reasonably believing that the owner can be found, it is larceny. But if he have no intention of apppropriating it at the time of finding, the subsequent conception of such an intention would not convert the honest taking into a dishonest one, and so make him a felon by relation. $R$. v. Preston, 21 L. J., M. C. $41 ; 2$ Den. C. C. $353 ; R$. v. Dix $\theta n, 1$ Dears. C. C. $5 \$ 0 ; R$. v. Christopher, 1 Bell, C. C. $27 ; 28$ L. J., M. C. $35 ; R$. v. Moore, 30 L. J., M. C. 77 ; Leigh \& C. 1; R. v. Glyde. 37 L. J., M. C. 107.

(h) R. v. Morfit, R. \& R. C. C. $307 ;$ R. v. Handley, Carr. \& Marshm. 574; R. v. Privett, 2 Carr. \& K. 114; 1 Den. C. C. 193. In the last report of the last case, it is said that although all the judges agreed that they were bound by previous decisions to hold it to be larceny, several of them expressed a doubt, if they shoulal have so decided, if the matter were res integra. The following passage in Hanna's "Life of Dr. Chalmers," vol. i. p. 412, may assist the deliberations of those who still doubt on this matter. "Examining once at a farmhouse, one of the ploughmen was called up. The question in order was "What is the Eighth Commandment?' But what is stealing? 'Taking what belongs to another and using it as if it were your own.' Would it be stealing, then, in you, to take your master's oats or hay contrary to his orders, and give it to his horses? This was one of the many ways in which he (Dr. C.) sought to instil into the minds of his people a high sense of justice and truth, even in the minutert transactions of life."

(i) 26 \& 27 Vict. c. 103, post, Appendix. 
was to come back to the owners in the same substance, though in another form; but, upon the counsel for the prosecution citing $R$. v. Morfit, and such cases, left it to the jury to say whether the prisoner put the axle into the furnace with a felonious intent to convert it to a purpose for his own profit, for if he did so this was larceny. The jury found the prisoner guilty $(k)$.

And where a carter, who was allowed by his master a Taking wore small quantity of hay for the use of the horses on their hay than journey to and from London, took from his master's stables two trusses of hay above the quantity allowed, and put them on the tail of his master's waggon, and afterwards the ostler at a public-house on the road-side received them from the carter; it was held that tho carter was guilty of larceny, that the larceny was complete the moment the hay got into the cart animo fu. randi, and, therefore, that the ostler was properly indicted for receiving the hay, knowing it to have been stolen; but that if it had been hay allowed for the horses which was stolen it would have been otherwise $(l)$.

In $R$. v. Hall $(m)$, where a serrant took his master's Offering goods to his master and endeavoured to induce him to master his purchase them, pretending that the goods were sent by own goods a person with whom the master dealt, it was held to be larceny. But in $R$. v. Webb $(n)$, it was held (o) not to be *larceny for miners employed to bring ore to [*489] Miner fraudthe surface, and paid by the owners according to the ulently addquantity produced, to remove from the heaps of other ing to heap miners, ore produced by them and add it to their own, in order to increase their wages; the ore still remaining in the possession of the owners. And upon the allowed. R. v. Gruncell. for sale. R. v. IIall. of ore. li. v. Webb. Tanner, skins.

(k) R. v. Riehards, 1 C. \& K. 532.

(l) R. v. Gruncell, 9 C. \& P. 365.

(m) R. v. Hall, 2 Carr.\& K. 947 ; 1 Den. C. C. 381 ; 3 New Sess. Cas. $407 ; R$. v. Manning, 22 I. J., M. C. 21 . See R. v. Becham, 5 Cox, Cr. C. 156, where a man was convicted of lareeny of a railI way ticket although given up.

(n) Moo. C. C. 431. This offence would be lareeny now. By $24 \& 25$ Vict. e. 96 , ร. 39, "Whosoever being employed in or about any mine shall take, remove or conceal any ore of any metal, or any lapis calaminaris, manganese, mundick, or other mineral found or being in such mine, with intent to defrand any proprietor of, or any adventurer in such mine, or any workman or miner employed therein, shall be guilty of felony: and, being convicted thereof, shall be liable at the diseretion of the Court to be imprisoned for any term not exeeeding two years with or without hard labour, and with or without solitary continement. Sce $R$. v. Trevenner; 2 M. \& Roh. 476. This section applies to all England and Ireland; not Scotland, see sect. 12:2.

(o) Patteson, J., dissentiente. 
R. v. Hollo- authority of that case it was held in $R$. v. Holloway $(p)$ way. not to be larceny for a workman in the employ of a tanner to take skins from his master's warehouse to the foreman at another part of the premises, pretending that he had done work on them for which he was to be paid, and intending to return the skins to his master after he had been paid for his pretended work, but an attempt to commit the misdemeanor of obtaining money by false pretences. And the authority of $\mathrm{R}$. v. $\mathrm{Hol}$. Glove loway was acted upon in the following case $(q)$ :-The finisher, prisoners were indicted for stealing. The master was gloves. R. v. Pool.

Foreman, workmen's a glove-maker, and the prisoners were in his employ as glove-finishers. When they had done any work the practice was to take the finished gloves to an upper room and lay them on a table, in order that the workmen might be paid according to the number finished. The prisoners broke open a store-room on their master's premises, took out a quantity of finished gloves and laid them on the table in the upper room, with intent fraudulently to obtain payment for them as for so many gloves finished by them. The gloves were never off the master's premises. It was held that they could not be convicted of larceny as they claimed no property or lien on the gloves, and had not sold, or attempted to sell them, as in $R$. v. Hall $(r)$.

wages-false [*490] *Where a foreman made out and rendered to his master, A., an account of $14 l$. as due from A. to his pretences. $R$.v. Leonard. workmen, and $\mathrm{A}$. gave him a cheque for the amount, all of which was due except $7 s$., which the foreman kept when he got the check cashed, and paid the workmen the rest; it was held that the foreman might be convicted upon an indictment which charged that by this false pretence he obtained the cheque from $A$. with intent to defraud him of the same (s).

Clerk, false account of customs dues.

R. v. Thomson.
And where a clerk made out a false account of customs dues and obtained the amount from his master's cashier, pocketing the difference between the true and the false amount, he was held guilty of obtaining money under false pretences $(t)$. And it has also been held that he might be indicted for stealing the difference, as

(p) 2 Carr. \& K. 944; 1 Den. C. C. $370 ; 3$ New Sess. Cas. 410.

(q) R. v. Pool, 27 L. J., M. C. 53; 1 Dears. \& B. 345.

(r) Ante, p. 488.

(s) R. v. Leonard, 2 C. \& K. $514 ; 1$ Den. C. C. 304.

(t) R. v. Thomson, 32 L. J., M. C. 57 ; Leigh \& C. 233.

R. v. Barnes, 2 Den. C. C. 59. 
whilst it remained in his custody it was in the possession of his master $(u)$.

But in the following case $(v)$, of a somewhat similar Altering nature, the indictment was held bad, and the prisoner sums total so escaped punishment:- A. worked for the prosecutors as as to increasi a journeyman, and the quantities of work done by him anount due for them during each week were entered in a book kept to journeyfor that purpose. The prices for the work so entered false prewere placed in a column opposite to each quantity of tences. work, and added up on behalf of the prosecutors at the $R$. v. Oatcs. end of each week. The weekly totals of these prices were entered by them in this book, and the amount of the totals paid by them to $O$. as the ascertained sum due to him for work done, on the production by him of this book. After these weekly totals had been entered as above, $O$. altered them into larger amounts, and then procured payment of the larger amounts on producing the books, and afterwards erased the larger amounts and restored the figures of the original totals. He was indicted for obtaining money by false *pretences. [*491] The indictment in some counts averred that he falsely pretended that, he having executed certain work, there was a certain sum of money due and owing to him for and on account of the work, being parcel of a larger sum claimed by him, whereas there was not then due and owing to him such money, being parcel of a larger sum. And in other counts it was averred that he falsely pretended that there was due and owing to him the wholo amount of such sum of money, but only a smaller sum. It was held that the indictment was bad, as a false pretence of an existing fact was not sufficiently alleged, and the averments would be proved by evidence of a mere wrongful overcharge.

And again, where $(x)$ a workman stated that he had Overeharge done. more work than he really had, and requested pay. for work ment for the work he stated he had done, and his mas. ter knowing that it was a false overcharge, and wishing to entrap him, paid him the amount demanded, it was held that the workman could not be indicted for obtaining money under false pretences, as it was not the falsehood which induced his master to part with the money.

If a weaver or silk-throwster deliver yarn or silk to silk-thrombe wronght by his journeymen in his house, and they ster's C'use. carry it away and convert it to their own use, this is

(u) R. v. Cooke, L. R., 1 C. C. 295 ; 10 I. J., II. C. 68.

(v) $R$. v. Outes, 1 Dears. C. C. 459.

(x) R. v. Mills, 26 L. J., M. C. 79 ; 1 De:irs. \& B. 205. 
larceny at common law, but if to be wrought out of the house it is not, for the journeymen in that case are considered bailees and not servants $(y)$. They may, however, now be convicted of larceny under $24 \& 25$ Vict. c. 96, s. $3(z)$.

Clerk fur- $[* 492] *$ In a case $(a)$ in which the prisoner, who was nished with clerk to a dealer in skins, received at different times cash, obtaining goods on credit.

R. v. Goodenough.

several sums of money from his master for the purpose of purchasing skins, and credited his master with the amounts in his day cash-book, but obtained the skins on credit, and debited his master in his day.cash-book with several sums of money as having been paid for those skins, applying the cash to his own use; it was held that he could not be convicted of larceny of the money.

Falsifying And a similar decision was made in the following accounts and case $(b)$ :-

receiving balance.

The prisoner was bailiff to the prosecutor, and it was R. v. Green. part of his duty to receive and make payments on behalf of his master, and maketentries of such receipts and payments in a book which was examined by the prosecutor from time to time. On one occasion the prisoner showed a balance in his favour of $2 l$., by taking credit for payments falsely entered in his book as having been made by him, when in fact they had not been made by him, and received from his master the sum of $2 l$. as a balance due to him: it was held that the offence of which the prisoner was guilty was not larceny, whatever else it might have been.

Where a master parts not only with the custody, but also with the possession, of goods to a servant, and the

(y) East P. C. 632.683 ; R. v. Saward, 5 Cox, C. C. 295.

(z) By that section it is enacted, that " whosoever being a bailee of any chattel, money or valuable security, shall fraudulently take or convert the same to his own use or the use of any person other than the owner thereof, altbough he shall not break bulk or otherwise determine the bailment, shall be guilty of larceny, and may be convicted thereof upon an indictment for larceny; but this section shall not extend to any offence punishable on summary conviction." This proviso was introduced to prevent the clause applying to the cases of persons employed in the silk, woollen and other manufactures, who dispose of goods entrustcd to them, and are liable to be summarily convicted under sundry statutes. See Greaves, Crim. Law Consol. Acts. Under this section the person must be bound to return the identical goods or coin deposited. R. v. Hassall, 30 L. J., M. C. 175; Ieigh \& C. 58.

(a) R. v. Goodenough, Dears. C. C. 210. The prisoner was indicted for embezzlement and found guilty of larceny, but the conviction was quashed.

(b) R. v. Green, Dears. C. C. 323. 
servant converts them to his own use, it is not larceny Where masunless he had a felonious intent at the time he received ter parts with them. And therefore in the case of drovers $(c)$ and ymssession, other servants entrusted with goods with authority to as well as sell and receive the purchase-money, if such servants felonious.s sell and *embezzle the money, the offence will $\left[{ }^{*} 493\right]$ intent at the not be larceny unless the servant had a felonious intent time of when he took possession of the goods $(d)$.

Therefore, where $(e)$ a person sent some pigs by the sary to conprisoner to a lady to be looked at, but he sold the pigs, ceny. and did not take them to her, Alderson, B., left it to $k$. v. Haricy. the jury to say whether the prisoner had a felonious intent from the commencement of the transaction; and whether he received the pigs as bailee to deal with them, or only as a servant having the custody of them, and whose duty it was to bring them back. "If," said his lordship, "the prosecutor meant that the prisoner should leave the pigs with the lady, and either bring back the money, or make a bargain for the sale of them, then he will be in the situation of a bailee. The question is, whether they were delivered to the prisoner simply that he should show them to the lady, and bring them back bodily ; if they were, then, if the felonious intent came upon him at that time, it would come upon him at the timo when he had only the custody, and not the possession, and in that case he would be guilty of stealing them."

But it has been held $(f)$, that a drover by trade, who Drovers by was employed to drive pigs to a particular place, was paid by the day, and by the custom of the trade had a right to drive other persons' cattle also, but who sold trade are not servants. I. v. IIfy. the pigs and absconded with the money, could not be convicted of larceny as a servant, as he was a mere bailee and not a servant, and had no original intention of stealing the pigs. In that case the prisoner was convicted, but tho question having been reserved for the consideration of the judges, the conviction was held improper. In giving judgment in that case, Lord Wensleydale said,--

"The question is whether, on the facts stated in this case, the prisoner *received the custody of the [*494]

(c) R. v. Goodbody, 8 C. \& P. 665. K. 395 .

(d) R. v. Exans, Carr. \& M. 63:2; and see R. v. Glass, 2 ('arr. \&

(e) R. v. Ifartey, 9 C. \& P. 353; and see R. v. Emms, Curr. \& M. 632 ; but see $R$. Jones, Carr. \& MI. 611.

(f) R. v. Hey, 2 Carr. \& K. 983 ; 1 Den. C. C. 602 ; li. v. Gibbs, 1 Dears. C. C. 445. 
R. v. Hey. pigs as a servant of the prosecutor, or as a bailee; in the latter case he could not be guilty of larceny, unless he had intended to appropriate them to his own use at the time of the receipt, which was not the case; in the former he would be guilty of larceny, according to the finding of the jury; as to which they were properly directed by the learned assistant barrister. There are several reported cases bearing upon the question, whether a person is a mere servant or a bailee. There are none precisely like the present, though the case of Rex v. Bernard M'Namee (g) nearly approaches it. In this case on the one hand, the circumstance that the prisoner was paid the expenses of the cattle, and also that the customary mode of his remuneration was by the day, tend to show that he was a mere servant; on the other, the fact of his being a drover by trade, and also of his having the liberty to drive the cattle of any other person by the general usage with respect to drovers, raises an inference that he was not a servant. The learned assistant barrister felt himself bound by the decision of the judges in the case of Reg. v. Hughes (b), but that case was under the statute $7 \& 8$ Geo. 4, c. 29 , s. 47 , which makes embezzlement by a servant, or person employed in the capacity of a servant, to receive money, felony; and the learned Recorder of London referred the question to the judges, whether the prisoner fell under either description, though if the indictment had been referred to, it was necessary to prove that he was a servant. The judges decided that the prisoner was properly convicted, and consequently that he was a servant or person employed in that capacity, and authorized as such to receive money, so that his receipt would be a discharge to the debtor. This is almost exactly the same question; it is whether the prisoner had the custody of the cattle as a servant to the prosecutor at the time of the receipt of them, and we think he could not be so considered, unless in driving the cattle to market he was his servant, and the prose. cutor responsible for any negligent act of his in so driv-

(g) 1 Moo. C. C. 368 . In that case a general drover, who hal been employed by the prosecutor off and on for nearly five years, but not as a regular servant, and was employed to take some sheep to G. fair, being paid 3s. a day, sold the sheep entrusteil to him withont having authority to do so, and pocketed the money, was held properly convicted of felony, as he had merely the custody of the sheep and his possession was his master's; and he had no intention of stealing the sheep at the time he received them. And see $R$. v. Jackson, 2 Moo. C. C. 32.

(h) 1 Moo. C. C. 370. 
ing them. This subject has undergone much discussion of late, and has been placed on its proper footing by the case of Quarman v. Burnett ( $i)$, and other cases; one of which is that of a general drover, who was held in the case of Milligan v. Wedge $(k)$ not to be a servant, so as to make the owner of the cattle responsible for his negligence. After the full consideration which this subject has undergone, we doubt whether the case of Rex v. Bernard $M$ 'Namee, above referred to, would now be decided in *the same way. Upon the [*495] whole we think it was not proved in this case that the prisoner was a mere servant, and the conviction was improper.

Where a prisoner is indicted for larceny as a servant, Prisoner he may be convicted of simple larceny, as proof of the indicted for allegation in the indictment that he was a servant, is larceny as a only necessary for the purpose of convicting him of the servant may compound offence. If, therefore, a prisoner is indicted be convicted as servant of A., and he turn out to be the servant of lisceny. B., he should be convicted of simple larceny $(l)$.

Whether or not, if when a prisoner is indicted as a oure, when servant and he turn out to be a bailee, he may be con- he is bailee. victed of simple larceny, does not appear to have been decided $(m)$. It would seem that he might.

By the stat. 24 \& 25 Vict. c. 96 , it is enacted,-

Sect. 5. "It shall be lawful to insert several count 24 \& 25 Y Vict. in the same indictment against the same person, for Tlure larany number of distinct acts of stealing not exceeding eenies in six three, which may have been committed by him against months from the same person within the space of six calendar sime person. months from the first to the last of such acts, and to proceed thereon for all or any of them" $(n)$.

Sect. 6. "If, upon the trial of ary indictment for where a larceny, it shall appear that the property alleged in single taking such indictment to have been stolen at one time, was is charged, taken at different times, the prosecutor shall not by the prosereason thereof be required to elect upon which taking eutor need reason thereof be required to elect upon which taking not clect. he will proceed, unless it shall appear that there were unless in more than three takings, or that more than the space cert:tin cases. of six calendar months elapsed between the first and the last of such takings, and in either of such last. mentioned cases the prosecutor shall be required to elect to proceed for such number of takings, not exceed.

(i) 6 M. \& W. 499 . See this case, ante, p. 3is.

(k) 12 A. \& E. 737. See this case, ante, p. 3.33 .

(l) R. v. Jennings, 1 Dears. \& B. 417; Jurist (185s), 146.

(ii) See unte, 491, note (z). R. v. Bucknall, 33 L. J., M. C. 75.

(n) See R. v. Ileyuood, 33 L. J., M. C. 1333. 
ing three, as appear to have taken place within the period of six calendar months from the first to the last of such takings" $(o)$.

$14 \& 15$ Vict.

And by $14 \& 15$ Vict. c. 100, s. $5,-$

c. 100, s. 5 .

Form of

indictment.

Conviction for attempt to steal.

"In any indictment for stealing, embezzling, destroy. ing or concealing, or for obtaining by false pretences any instrunent, it shall be sufficient to describe such instrument by any name or designation by which the same may be usually known, or by the purport thereof, without setting out any copy or fac-simile thereof, or otherwise describing the same or the value thereof."

[*496] *Under sect. 9, should the evidence fail to prove the complete offence, the prisoner may be convicted of an attempt to commit it $(p)$.

$14 \& 15$ Vict. c. 100, s. 18 .

Coin and bank-notes may be deseribed simply as money.

Sect. 18. "In every indictment in which it shall be necessary to make any averment as to any money or any note of the Bank of England or any other bank, it shall be sufficient to describe such money or bank-note simply as money, without specifying any particular coin or bank-note, and such allegation, so far as regards the description of the property, shall be sustained by proof of any amount of coin or of any banknote, although the particular species of coin of which such amount was composed, or the particular nature of the bank-note shall not be proved; and in cases of embezzlement and obtaining money or bank-notes under false pretences, by proof that the offender embezzled or obtained any piece of coin or bank-note, or any por. tion of the value thereof, although such piece of coin or bank-note may have been delivered to him in order that some part of the value thereof should be returned to the party delivering the same, or to any other person, and such part shall have been returned accordingly."

Punishment

Various statutes have at different times been passed of larceny by with a view to the prevention of the crime of larceny servants. by servants, by the subjection of such persons to a heavier punishment than awaits ordinary offenders. 'These statutes, however, were all repealed by $24 \& 25$ Vict. c. 95, and at the same time the law upon the sub. ject was consolidated in the $24 \& 25$ Vict. c. 96.

$24 \& 25$ vict. By sect. 67 of that statute it is enacted, that-

c. 96, s. 67. "Whosoever being a clerk or servant, or being em. ployed for that purpose or in the capacity of a clerk or servant, shall steal any chattel, money or valuable security $(q)$ belonging to or in the possession or power

(o) See R. v. Firth, 38 L. J., M. C. 54.

(p) See $R$. v. Cheeseman, 31 L. J., M. C. 89 ; Leigh \& C. 140.

(q) Ante, p. 47, note $(u)$. 
of his master or employer, shall be guilty of felony, and being convicted thereof shall be liable at the discretion of the Court to be kept in penal servitude for any term not exceeding fourteen years, and not less than [five years, $27 \& 28$ Vict. c. 47 ], or to be inprisoned for any term not exceeding two years, with or without hard labour, and with or without solitary confinement, and if a male under the age of sixteen years, with or without whipping" $(r)$.

*Larceny or embezzlement by a clerk or ser- [*497] Summary vant may be dealt with summarily under the Summary convietion. Jurisdiction Act, 1879 (s), if the prisoner plead guilty. 42 \& 43 Vict.

In order to convict a person of the aggravated of- $c .49$. fence of larceny as a servant $(t)$, and subject him to the increased punishment provided for that offence, it is of course necessary that he should be a servant. We shall hereafter, whilst treating of embezzlement by servants, place before the reader the various decisions upon this point. But it may be here mentioned, that it has been Driver of held that the driver of a glass coach hired for the day, glass coach is not the servant of the party hiring it within the not servant meaning of this Act $(u)$. A doubt was expressed by of hirer. Coleridge, J., in one case, whether a similar section ( 7 Public \& 8 Geo. 4, c. 27 , s. 46 ) extended to public servants servants. under the Crown $(x)$. But the case of such persons is now provided for by the stat. $24 \& 25$ Vict. c. 96 , ss. 69, $70(y)$.

Where, however, the money or other property had never been in the possession of the master, it was held that the servant was not guilty of larceny in misappropriating it. There could be no tortious taking in the first instance, and consequently no trespass, without which there could be no larceny $(z)$. Thus, where $(a)$ Bull's Case.

(r) It would secm that the power of the Conrt, to award the common law punishment of fine and imprisonment is not taken away but added to, by this act. See $R$. v. Johnson, 3 M. \& S. 540 .

(s) $42 \& 43$ Vict. e. 49 . See the First Schedule to the Aet.

(t) Upon an indictment for larceny, as a servant, the prisoner may, as we have seen, be convicted of simple lareeny, supra, p. 495. The allegation in the indietment that $A$. B., "leing the servant," \&c., stole, \&c., is sufficient, $R$. v. Somerton, 7 B. \& C. 463.

(u) R. v. Haydon, 7 C. \& P. 445.

(x) R. v. Lovell, 2 Moo. \& Rob. 236.

y) Post, p. 532.

(z) See Russ. on Cr. 401 ; 4th edit.

(a) Bull's Case, cited 2 Leach, C. C. 841. Upon the anthority of this case, it was held in $R$. v. Ifeadge, Russ. \& Ry. 160, that : servant, under similar circumstances, was properly indicted for embezzlement under the stat. 39 Geo. 3 , e. 85 . And see Waile's 
a shopman sold goods in the shop and pocketed the price, instead of putting it into the till, it was held that he could not be convicted of larceny of the money, as Bazeley's [*498] it had never been in his master's *possession. Case.

Which gave rise to Statutes against embezzlement.

Since which it is still larceny to take property out of master's possession.

The same law was laid down in a case where (b) a banker's clerk pocketed a $100 l$. note, instead of putting it into his master's drawer. These decisions gave rise to the first statute against embezzlement, 39 Geo. 3, c. 85. That statute, as well as $7 \& 8 \mathrm{Geo} .4$, c. 29 , is now repealed; and the punishment of such offences is provided for by $24 \& 25$ Vict. c. 96 , s. 68 , the provisions of which will be stated presently. However, since the passing of $7 \& 8$ Geo. 4 , it has been held that, if the master has had possession of property, either by his own hands or by the hands of his clerk or servant, a servant cannot be guilty of embezzling it, but if he purloin it, it will be larceny. Thus, where $(c)$ a clerk in the employ of $A$. received from another clerk $3 l$. of A's money to pay for an advertisement, for which he only paid $10 \mathrm{~s}$, but charged A. $20 s$., pocketing the difference, all the judges held that he was not properly convicted of embezzlement under $7 \& 8$ Geo. 4 , c. 29 , s. 47 .

But mis- But if such property is merely in the course of passapyropria- ing to the master, and have not arrived into his possestion of goods sion, although in the hands of a clerk, if that clerk mis. passing towards master's possession embezzlement. R. v. Masters appropriate it; he will be guilty of embezzlement. Thus, where $(d)$ it was the duty of A's clerks to receive money on account of A., and pay it over to A.'s superintendent, whose duty it was to pay it over to the prisoner, whose duty it was to pay it over to A.'s cashier, these persons being all servants of $A$., the prisuner.

Case, 1 Leach, C. C. 28, the case of a elerk in the Bank of England purloining a bond, which gave rise to the stat. 15 Geo. 2, c. 13 .

(b) Bazcley's Case, 2 Leach, C. C. 835 . In $R$. v. Rudick, 8 C. \& P. 237, a servant, sent out to eollect money for his master, was robbed of it on his way frome. In an indictment for the robbery the money was laid as the property of the master, and upon an objection to this being taken by counsel for the prisoners, Alderson, B., directed a fresh bill to be sent up to the grand jury, laying the money as the property of the servant; adding, "It is difficult to see how such an offence as embezzlement conld have been a part of our criminal law, if the possession of the servant of property which had never come to the hands of the master were construed to be in the possession of the master."

(c) R. v. Murray, 1.Moo. C. C. $276 ; 5$ C. \& P. 145, note.

(d) R. v. Masters, 2 Carr. \& K. $930 ; 1$ Den. C. C. $332 ; 3$ New Sess. Cas. 326. Bnt see 2 Russ. on Cr. 450 , note $(d)$, where Mr. Greaves gives his reasons at length for thinking this case wrongly decided. 
having received money in this way and embezzled it, was held to be *properly convicted of embezzle- [*499] ment under $7 \& 8$ Geo. 4 , c. 29 , s. 47.

And if the property has once completely arrived into To steal the master's possession (although merely constructively goods once by the hands of the thief) and be there misappro. completely priated, the offence will be larceny. Thus in $R$, arrived in Watts $(e)$, the prisoner was a clerk in the Globe Insur- possession, ance Office, and it was his duty to receive from the though messenger the banker's pass-book, together with the vouchers, to compare the entries in the pass.book with the entries in the books of the company, and to $R$. v. Watts. preserve the vouchers for the use of the company. One day the prisoner fraudulently destroyed a cheque for $1,400 l$., which was delivered to him with the pass-book in the usual way, and altered the pass.book, having, in fact, paid the amount into his own private bankers, and he was held to have been properly convicted of stealing the cheque from his masters, as his possession of it was the possession of his masters.

"The paper in question," said Lord Truro, "as soon as it had passed from the hands of the messenger, and arrived at its ultimate destination, the custody of the prisoner for the directors, was really in their possession, and when he afterwards abstracted it for a fraudulent prorpose he was guilty of stealing it from them, as a butler, who has the keeping of his master's plate, would be guilty of larceny if he should receive plate from the silversmith for his master at his master's house, and afterwards fraudulently convert it to his own use, before it had in any other way than by his act of receiving come to the actual possession of the master."

"This case is distinguishable from those in which the goods have only been in the course of passing towards the master, as in Reg. v. Masters $(f)$, where the prisoner's duty was only to receive the money from one fellow-servant and pass it on to another, who was the ultimate accountant to the master. Here the paper had reached its ultimate destination when it came to the prisoner's keeping, and that keeping being for his masters, made his possession theirs."

A similar decision was arrived at in the following $R$. v. Wright. case $(g)$ :- The prisoner was employed by a banking

(c) 2 Den. C. C. 14.

(f) Vbi supra.

(g) R. v. Wright, 27 L. J., M. C. $65 ; 1$ Dears. \& B., C. C. 431. 
R. v. Wright. [*500]* company to manage a branch for them at $B$. He provided an office for the bank in his own house. The office was furnished by the company, and an iron safe provided there by them, of which there were duplicate keys, the company keeping one, and the prisoner the other. It was the duty of the prisoner to receive money from customers to place it at night in the safe, to pay away from time to time as much as was required for the business of the bank, to pay cheques, to pay over weekly any balance not required for the business at B., and to send in weekly accounts to the company. He carried on the business, receiving and paying money, and sending in weekly accounts. In auditing his accounts a deficiency of $3,000 l$. was discovered, and he admitted that he had taken that amount of money. It was held that he was properly convicted of larceny, as a clerk, in having stolen some money received from customers, which before he stole it had been placed in the safe, and made the subject of a weekly account; the court considering the case similar to the ordinary one of a shopman robbing a till.

What

amounts to delivery to master.

R. v. Hayward.

Punishment of embezzlement.
The question therefore, as to what amounts to a delivery to the master, is one of importance. Some cases on this point have already been considered $(h)$.

Where a man sent his servant to fetch home some straw which he had bought, and the servant brought it home, took it into his master's court-yard, and put it down at the stable-door, which was locked; and afterwards, on the door being opened, put part of the straw into the hay-loft, but took the rest away again, and sold it, Tindal, C. J., held the putting it down at the stable-door was a delivery of it to the master, and that the servant could not be convicted of embezzlement. He was found guilty of larceny (i).

By $24 \& 25$ Vict. c. 96 , s. 68 , it is enacted, that-

"Whosoever being a clerk or servant, or being em[ $\% 01]$ ployed for the purpose *or in the capacity of a clerk or servant $(k)$, shall fraudulently embezzle any

In this case it was assumed that the money was placed in the safe, as it was the prisoner's duty to place it there.

(h) Such as Spear's Case, ante, p. 482; $R$. v. Reed, ante, p. 484.

(i) R. v. Hayzard, 1 Carr. \& K. 518. See also R. v. Roberts, 3 Cox, C. C. 74 .

(k) By the Merchant Shipping Act Amendment Act, 1862, 25 $\& 26$ Vict. c. 63 , s. 16 , any person appointed to any office or service by or under any local marine board shall be deemed to be a clerk or servant, within the meaning of this section; and if any such person frandulently applies or disposes of any chattel, money or valuable security received by him whilst employed in 
chattel, money, or valuable security which shall be de 24 \& 25 vict. livered to or received or taken into possession by him c. $96, \mathrm{~s}$. 68. for or in the name or on the account of his master or employer, or any part thereof, shall be deemed to have feloniously stolen the same from his master or employer (l), although such chattel, money or valuable security was not received into the possession of such master or employer otherwise than by the actual possession of his clerk, servant or other person so em. ployed; and being convicted thereof, shall be liable to" [same punishment as for larceny by servants, ante, p. 496.]

Embezzlements by clerks or servants, \&c., under Summary forty shillings, may also be dealt with summarily under conviction. the Summary Jurisdiction Act, $1879(\mathrm{~m})$, if the prisoner consents or pleads guilty.

In order to constitute an offence within the above What consection (68) three things must concur (o). stitutes en-

1. The prisoner must be $(p)$ a clerk or servant, or bezzlement. employed for the purpose or in the capacity of a clerk or servant.

2 He must receive or take into his possession some chattel, money or valuable security, for or in the name or on account of his master or employer.

*3. He must fraudulently embezzle the same [*502] or some part thereof $(q)$.

But as the words "by virtue of his employment"

such office or service for or on account of any such local marine hoard or for or on account of any other public board or department to his own use, or to any use or purpose other than that for which the same was paid, entrusted to or received by him, or frandulently withholds, retains or keeps back the same or any part thereof contrary to any lawful directions or instructions which he is required to obey in relation to such oflice or service, he shall be deemed guilty of embezzlement within the meaning of the said section "-and pmishiable as a clerk or servant. In the indictment the property may be laid in the board, and s. 71, post, p. 526, applies.

(l) It would seem that if the words "and may he indicted and tried accordingly" had been added here, many of the difficulties attendant upon the preservation of the nice teclunical distinctions between larceny and embezzlement might have been avoided.

(m) 42 \& 43 Vict. c. 49 , First Schedule.

(o) And see per Lord Ellenborough in $R$. $\vee$. Johnson, 3 M. \& 8. 548,549 , on the old stat. 39 Geo. 3 , c. 85 .

(p) Or have been at the time of the offence committed, $L, v$. Lovell, 2 M. \& Rob. 236.

(q) It is no objection to an indictment for embezzlement that the society whose funds are embezzled is a society some of whose rules are illegal as heing in restraint of trade, $R$. $v$. Stainer, 39

L. J., M. C. 54 ; L. R., 1 Cr. C. R. 230. See ante, p. 87.

29 MAS. \& SER. 
were designedly omitted from $24 \& 25$ Vict. c. 96 , s. 68 , it is no longer necessary to prove that the prisoner was authorized to receive the money $(r)$, and conse. quently the decisions on the old statute which con. tained these words are no longer binding $(s)$.

It will be convenient to consider these three heads separately. Many of the decisions which will be mentioned took place under the old stat. 39 Geo. 3, c. 85 , and $7 \& 8$ Geo. 4 , c. 29 , but they may with propriety be inserted here.

1. The prisoner must be a clerk or servant, or em ployed for the purpose or in the capacity of a clerk or servant.

Apprentice. It was the opiuion of all the judges that an appren tice $(t)$, and also a female servant $(u)$, were within the

Female servant.

Servant to corporation; though not appointed under common seal.

Acountant to overseers.

Treasurer to guardians. stat. 39 Geo. 3 , c. 85 . And it is clear that a fomale servant is within the statute of Geo. $4(x)$, which "there can be no doubt would also be held to embrace persons employed in the capacity of clerks or servants to corporations" $(y)$, though not appointed under the common seal $(z)$.

[*503] *A person employed by the overseers of a township as their accountant and treasurer, and who received and paid all monies receivable or payable on their account, was held to be a clerk and servant within $39 \mathrm{Geo} .3$; c. $85(a)$. And the treasurer to the gnardians of the pour of Birmingham appointed under the stat. 1 \& 2 Will. 4, c. lxvii (local and personal), is a servant of the guardians within the meaning of the stat. $7 \& 8$ Geo. 4 , c. 29 , and as such indictable for embezzlement $(b)$.

(r) See 2 Russ. on Cr. 412, 4th edit.

(s) Such as $R$. v. Snowley, 4 C. \& P. 390, post, p. 512. See $R$. v. Cullum, L. R., 2 C. C. 28 ; 42 L. J., M. C. 64.

(t) R. v. Mrellish, Russ. \& Ry. 80.

(u) R. v, Smith, Russ. \& Ry. 267.

(x) See $7 \& 8$ Geo. 4 , c. 28 , s. 14.

(y) Per Vaughan, J., in Williams v. Stolt, 1 Cr. \& M. 689 . See the remark made upon this dictum of Vaughan, J., in Greaves' edition of Russ. on Crimes, vol. ii, p. 417 , note $(r)$, 4th edit. The learned editor, however, appears when he wrote that note to have forgotten the difference between the wording of the statntes of Geo. 3, and that of Geo. 4. The interpretation put upon the word "person" by $7 \& 8$ Geo. 4. c. 28 , s. 14, would seem hardly applicable to $7 \& 8$ Geo. 4 , c. $29, \mathrm{~s}$. 47 , unless the "person" were a servant.

(z) R. v. Beacall. 1 C. \& P. 467.

(a) R. v. Squire, R. \& Ry. 349; 2 Stark. 349.

(b) $R$. v. Weleh, 2 Carr. \& K. 296; 1 Den. C. C. $199 . \quad$ And see now $12 \& 13$ Vict. c. 103 , s. 15 , post, p. 506. 
In $R$. v. Hughes (c) it was held that a person em-Servant employed by a farmer on one occasion as a drover in ployed to Smithfield to drive some cattle home to the purchaser drive cattle and receive the price, was a servant within the meaning for farmer; of the act of Geo. 4. Drovers in general, who exercise not drovers a distinct calling, would not, however, now be consid-in general. ered as servants under that act $(d)$.

Where the prisoner was indicted as the servant of $A$. Servant of and others, and it appeared that $\mathrm{A}$. \& Co. were a joint unincorpostock company, but there was no evidence of their in- rated jointcorporation, it was held that the prisoner was properly pany. convicted (e).

It has been held that the clerk of a savings bank was Clerk to properly described in an indictment for embezzlement trustees of under the statute of Geo. 4, as clerk to the trustees, savings although he was elected every year by ballot at a meet- bink. ing of the managers $(f)$. And that a clerk appointed clerk to by a station committee of four several railway com-joint station panies to receive the charge for the carriage of parcels of several by all of them, *might be described as the ser- [*504] railways. vant of the four companies or of the committee $(g)$.

A clerk to a joint-stock banking company, established Clerk to joint under 7 Geo. 4 , c. 46 , may be convicted of embezzling stock bank, the money of the company, although he is a shareholder thongh or partner in such company $(h)$.

And it has been held that a son who, during the Clerk to illness of his father, who was clerk to a local board, local board. assisted him in his office and in the business of the board, was "employed as a clerk" to the board, although not appointed or paid by them, and was rightly convicted of embezzlement $(i)$.

But where W., who was a member of a friendly soci-Clerk to oty, and was also clerk or secretary to the society, friendly offered to put out their money to more advantage in society. London, and drew it out with the consent of the society,

(c) R. v. IIughes, 1 Moo. C. C. 3\%0; and sce eats. cit. infru, note $(n)$.

(d) See R. v. Goodbody, \& C. \& P. 665; and see R. v. Hey, 2 Carr. \& K. 983; 1 Den. C. C. 602 , ante, p. 493.

(e) R. v. Frankland, 32 L. J., M. C. 69.

(f) $R$. v. Jenson, 1 Moo. C. C. 4.3 ; and see $R$. v. IIall, 1 Moo. C. C. $474 ; R$. v. Callaghan, \& C. \& P. 15t. As to what is suffieient evidence of acting as a trustee to support inference of legal nppointment, see $R$. v. Essex, 1 Dears. \& 13. 36\%.

(g) R. v. Bayley, 26 I. J., M. C. 4; 1 Dears. \& B. 121.

(h) R. v. Atkinson, Car. \& M. 525; and see $l$. $\checkmark$. Whatts, 2 Den. C. C. 14 , ante, p. 499 , where a clerk, who was also a shareholder in an insurance office, was convicted of embezalement, and see infra, note (i).

(i) R. v. Foulkes, L. R., 2 C. C. 150; 4 i L. J., M. C. 65. 
Member of committee to manage excursion. R. v. Bren.

Treasurer of friendly society. R. v. Tyree. R. v. Murphy.

Occasional servant. but appropriated it to his own use, it was held that he could not be convicted of either larceny or embezzlement, as he was part-ouner $(j)$. And where a committee formed of the members of two friendly societies for the purpose of conducting a railway excursion, appointed certain persons to sell the excursion tickets to the members of the societies, and the money received from the sale of the tickets was to be paid over to a specified person, and to belong to the two societies in celtain proportions, and the prisoner, who was a member of the [*505] committee, was one of those *nominated to sell tickets, but received no remuneration for so doing, and a certain number of tickets were given him by the committee to sell; he sold some and fraudulently appropriated the proceeds to his own use : it was held that he was not

- liable on an indictment for embezzlement charging hira as servant to the other members of the committee $(k)$.

Again it has been held $(l)$ that a treasurer of a friendly society (duly enrolled and certified) without salary, whose duty it was to receive monies paid into the society and hold them to the order of the secretary, countersigned by the chairman or a trustee, and to account whenever called upon, was not a clerk or servant within $24 \& 25$ Vict. c. 96 , s. 68.

In a case in Ireland, where it appeared that all the property of the society was vested in trustees, it was held by the Court of Criminal Appeal there, that he might be described as servant to the trustees $(m)$. But that case, as explained by Bovill, C. J., in R. v. Tyree, did not decide that the treasurer was a servant.

And it was held, that a person occasionally employed $(n)$; a person employed upon commission to travel for

(j) R. r. Waite, 2 Cox, C. C. 245; R. v. Taffs, 4 Cox, C. C. 169 But that defence would not avail now, since 31 \& 32 Vict. c. 116 , enacts, that "If' any person being a member of any copartnership, or being one of two or more beneficial owners of any money, goods or effects, bills, notes, securities or other property, shall steal or embezzle any such money, \&c., or other property of or belonging to any such copartnership, or to such joint beneficial owners. every such person shall be liable to be dealt with, tried, convictei and punished for the same as if such person had not been or was not a member of such copartnership or one of such beneficial owners."

(k) R. v. Bren, 33 L. J., M. C. 59.

(l) R. v. Tyree, 38 L. J., M. C. 58.

(m) $R$. v: Murphy, 4 Cox, C. C. 101 . See also $R$. v. Proud, 31 L. J., M. C. 71 ; Leigh \& C. 97 (this case was not argued b. counsel).

(n) R. v. Spencer, Russ. \& Ry. $299 ; R$. v. Winnall, 5 Cox, C. C. 326 ; and see $R$. v. Hughes, 1 Moo. C. C. $370 ; R$. v. Metcalf, 1 
orders and to collect debts, although employed by many Clerk and different houses on each journey, and although he paid traveller his own expenses out of his commission, and did not live employed by with any of his employers, nor act in any of their count- rany houses. ing-houses $(o)$; were servants within the stat. of Geo. 3.

*So, as we have seen, a person employed to [*506] Person emcarry out coals and sell them, and who was allowed a ployed to portion of the profits for his remuneration, was held, carry ont and majority of the judges, to be a servant within thell coals, a servant within the thongh enmeaning of the stat. of Geo. 3, although it was con titled to part tended that he was a partner $(p)$ of protit.

And the cashier and collector of a firm, who had in collector addition to a fixed yearly salary a percentage on the paid by perprofits, but was not liable for losses of the firm, was centage on held to be not the less on that account the servant of profits in to the firm, and liable to indictment for embezzlement $(q)$. salary.

And a servant, who manufactured an article from materials the property of his master for a customer, and who, having received the price, embezzled the whole ployed to Servant emploved to of it, was held to be within the act, although, by the from master's agreement between him and his master, he was to have at materials, the week's end a proportion of the price for his work $(r)$. thongh en-

And it has been held (s), that a person employed by titled to part And it has been held ( $s$ ), that a peron en the overseers to collect the poor-rate was properly de-collector of scribed as the servant of the overseers, without men- poor-rate tioning the churchwardens; and he having embezzled a employed hy rate collected from B., was held properly convicted overseers. under the stat. of Geo. 4.

And now, to aroid technical difficulties which had $12 \& 13$ rict. previously arisen $(t)$, it is provided by Act of Par-e. 103, s. 15. liament $(u)$,-

Moo. C. C. $433 ; R$. v. Tongue, 30 L. J., M. C. 49 ; Bell, C. C. 289 ; post, p. 514 ; but see $R$. v. Freeman, 5 C. \& P. 534, contri.

(o) R. v. Carr, Russ. \& Ry. 198 ; and see $R$. v. Leach, 3 Stark. 70. In $R$. v. White, 8 C. \& P. 742, the driver of a coach, who was employed by one of the proprietors, was held to be his servant ; and see R. v. Batly, 2 Moo. C. C. 257 ; and R. v. Tite, 30 L. J.. M. C. 142 ; Leigh \& C. 29 , where the donbt suggested by Loril Wensleydale, in $R$. v. Goolbody, 8 C. \& P'. 667, is cleared up.

(p) $\mathcal{K}$. v. Hartley, Russ. \& Ry. 139 ; and cases eited, ante, p. 51.

(q) R. v. Macilonald, 31 L. J., M. C. 67; 1 Leigh \& C. 85.

(r) R. v. Huggins, Russ. \& Ry. $1+5$.

8) R. v. Adey, 1 Den. C. C. $571 ; 4$ Cox, C. C. 209 . And see R. v. Ward, Gow, N. P. R. 16\&, the case of an extra collector of poor-rates, paid by a percentage on his collection, who was held to be a servant within 39 Geo. 3 , c. 8.5 .

(t) R. v. T.ensend, 2 C. \& K. $168 ; 1$ Den. C. C. 1 \%. In li. v. Trueman, 2 Cox, C. C. 306, a eollector of poor-listes was held not to be a servant, but an independent officer.

(u) 12 \& 13 Vict. c. 103 , s. 15 . See now 24 \& 25 Vict. e. $96, \mathrm{~s}$. 70, post, p. 532. 
Collectors of poor-rates and assistant overseers appointed under order of Poor Law Board servants of inhabitants of parish.

Property. Superintendent of police.

R. v. Baxter.

But not person employed to collect sacrament money; nor schoolmaster employed on one occasion by treasurer;

nor bailiff of county court;
"That in respect of any indictment or other criminal proceeding, every collector or assistant overseer appointed under the authority of any order of the Poor Law Commissioners or the Poor Law Board $(x)$, shall [*507] be *deemed and taken to be the servant of the inhabitants of the parish, whose money or other property he shall be charged to have embezzled or stolen, and shall be so described; and it shall be sufficient to state any such money or property to belong to the in. habitants of such parish, without the names of any such inhabitants being specified."

And a superintendent of county police has been held to be properly described as the clerk and servant of the chief constable, appointed under $2 \& 3$ Vict. c. $93(y)$. In that case it was the superintendent's duty to receive from the constables money received by them, and re. turn to the chief constable a statement of such moneys; and to pay the constables' wages weekly. In practice be kept accounts with the men, and set off sums re: ceived by them against their wages, the balance struck going over to next account, and so on weekly, no money passing. A constable thus accounted for $2 l$. $3 s .6 d$, but the superintendent fraudulently omitted that sum in his account with the chief constable, and subsequently denied its receipt. He was, nevertheless, held to have received it constructively, by the mode in which the accounts were kept, and convicted of embezzlement.

But it has been held that the clerk of a chapelry, who was employed to collect the sacrament money from the communicants, was not the servant of the minister, church-wardens, or poor of the township, in which the chapel was situate $(z)$. And that a schoolmaster of a charity school, no part of whose duty it was to receive subscriptions, but who, on one occasion, was requested by the treasurer to receive a sum of $15 \mathrm{l}$. On account of the schools, did not stand in such a relation to the treasurer or the committee, as to bring him within the Act (a).

And a bailiff of a county court who has fraudulently appropriated the proceeds of levies made under the [*508] process * of the county court cannot be called the servant of the high bailiff $(b)$.

(x) In $R$. v. Carpenter, 35 L. J., M. C. 169, an assistant overseer appointed by the inhabitants in vestry nnder 59 Geo. $3, c$. 12 , s. 7 , was held to be "sufficiently within the statute."

(y) R. v. Baxter, 5 Cox, C. C. 302.

(z) $R$. v. Burton, 1 Moo. C. C. 237 . It does not appear, from the report, who had the appointment of the clerk.

(a) $R$. v. Nettleton, 1 Moo. C. C. 259.

(b) R. v. Glover, 33 L. J., M. C. 169. 
And a person, chosen and sworn in at a court-leet nor person held by a corporation, as chamberlain of certain com. sworn in as monable lands, who received no remuneration, but whose chumberlain duties were to collect money from the commoners and to collect others using the commonable lands, to employ the coney for money so received in keeping the lands in order, to lands; account at the end of the year to two aldermen of the corporation, and to pay over any balance in his hands to his successor, was held not to be a servant within the meaning of the Act of Geo. 4 (c).

And a similar decision was made in the case of a nor a eomcommission agent, who was also paid a nominal salary mission agent of 1l. a year $(d)$. The prisoner kept a refreshment receiving a house, and was employed by the prosecutors to get saliry. orders for their goods, collect the money, and pay it $R$. v. Walker. over. He was paid by commission. $\mathrm{He}$ was to go abont among the farmers to get orders, but no definite time was to be spent in so doing, and he was styled their agent for the district. The prosecutors had a store at B. under the control of the prisoner, who supplied customers from the stores pursuant to the orders he obtained. In order to obtain the security of a guarantee society for the prisoner's conduct, and in compliance with their regulations, it was arranged that the prosecutors should pay the prisoner $1 l$. a year. The prisoner having got into arrear was treated by the prosecutors as a debtor for the amount. The prisoner fraudulently appropriated money received from customers, and gave a false account. It was beld that he could not be convicted of embezzlement, as he was not the servant of the prosecutors, but rather their agent.

Again, in a case $(e)$ in which the prisoner was em- Nor an agent ployed *to obtain orders for the sale of iron [*509] merely enmanufuctured hy the prosecutors in a different county titled to and was to receive a commission on orders obtained by commission. him, bnt was to account to the prosecutors for any $K: \mathrm{v}$. May. money he might receive, he received money for them which he fraudulently appropriated: it was held, that he could not be considered to have been the clerk or servant of the prosecutors or employed by them in that capacity, but was rather an agent. However, in a Bnt conmer. case $(f)$, which occurred very soon afterwards, in cial truveller which the prisoner was engaged by the prosecutor, a euployed by

(c) Williams v. Stott, 1 Cr. \& M. G7;; 3 Tyrwh. 688.

(d) R. v. Watker, 27 L. J., M. C. 207 ; 1 Dears. \& B., C. C. 600 ; 4 Jurist, N. S. 465.

(e) R. v. Maty, 30 I. J., M. C. 81 ; Leigh \& C. 13.

ff) R. v. Tile, 30 I. J., M. C. 142 ; Leigh \& C. 29. 
sons held to shirt manufacturer, as a commercial traveller, paid by be a servant. commission and at liberty $t$ ) receive orders for others $R$. v. Tite. than the prosecutor, he was held to be a servant, and not the less so that he was at liberty to obtain orders for several masters.

Distinction The distinction seems to be that a traveller is under between traveller and commission agent. orders to go here and there; but a commission agent may go where he likes. Whether or not the control necessary to constitute the relationship of master and servant existed, would be a question for the jury unless the agreement was in writing, in which case it must be construed by the court $(g)$.

R. v. Bowers. That the distinction above pointed out is the true one, is shown by the case of $R$. v. Bowers $(h)$. The prisoner there was permitted by his employers to carry on a retail coal trade on his own account, and was em. ployed by them, under an agreement in writing, as their agent for the sale of coals on commission. He was also to collect moneys in connection with his ordors, but not to be held responsible for bad debts, and the [*510] commission not to be due till the * money had been received by his employers, he gas not to keep such mo. neys more than a week, and a month's notice on either side to be given to terminate the agreement. He was held not to be a servant within $24 \& 25$ Vict. c. 96 , s. 68, and Erle, C. J., said,-

"The cases have established that a clerk or servant must be under the orders of his master or employed to receive the monies of his employer to be within the statute: but if a man be entrusted to get orders and to receive money, getting the orders when and where he chooses and getting the money when and where he chooses, he is not a clerk or servant within the statute."

R. v. Mar-

Again, where the prisoner was employed on the fol. shall. lowing "Terms of employment-Re John Marshall1s. per ton procuration fee payable ont of the first pay. ment, 4 per cent. for collecting, and $3 d$. on the last payment. Collections to be paid in Friday evening before five, p. m., or Saturday before two, p. m., cash orders 18 .

(g) If the servant be engaged, or his duties defined by a written instrument, that of course must be produced, and parol evidence is not admissible to show the terms of hiring or dnties unless notice to produce has been given, $R$. v. Clapton, 3 Cox, C. C. 126, where Patteson, J., said he remembered two or three unreported cases tried at Warwick, one before Coleridge, J., in which it was held that under such circumstances the agreement must be produced.

(h) 35 L. J., M. C. 206 ; L. R., 1 C. C. 41 . And see $R$. Negus, L. R., 2 C. C. $34 ; 42$ L. J., M. C. 62 . 
6d. per ton;" it was held that he was not a servant and that the ease was within $R$. v. Bowers $(i)$.

A carrier, exclusively employed between glove-sewers Not al (arrier and the manufacturers, has been held $(k)$ not to be the who was a servant of either, but a bailee. A. and B. were two among other sewers of gloves residing at C., the manu- R. v. (iibbs. facturers residing at $D$. The prisoner was a carrier residing at $C$., and was exclusively employed between the glove-sewers at $\mathrm{C}$. and the manufacturers at $\mathrm{D}$. The sewers were not known to the manufacturers, but when a sewer wanted work, the prisoner gave her name and a number to the manufacturers, and received from them unsewn gloves for ter to sew. Each sewer, having her number, sent back by the prisoner the gloves when sewn, with her name *pinned to the parcel. [*511] These parcels tho prisoner delivered to the manufac. turers, and if the parcels were found correct, he received the total amount due to the sewers in one sum, and fresh parcels of unsewn gloves. His duty then was to deliver to each sewer her fresh work, and also the money due to her, deducting his charge. If any, work was missing the manufacturer looked to the sewer if found, but if not, to the prisoner for it. The prisoner, according to the course above stated, took out numbers for $\mathrm{A}$. and $\mathrm{B}$., and having received money for both of them from the manufacturers, denied the receipt of it, and applied it to his own use. It was held that he was not the servant of either A. or B., but merely a bailee, and wis only guilty of a breach of trust, not of embezzlement.

2. He must receive or take into his poseession some chattel, money or valuable security, for or in the name or on account of his master or employer.

Althongh we have seen in $(l)$, the words "by virtue of his employment" having been designedly omitted from tho present act, many of the following cases are 797.

(i) R. v. Marshall, Cr. Cas. Res., II. T. 1870; 21 L. 'T., N. S.

(k) $R$. v. Gibbs, Dears. C. C. 445 . He wonld now be indicted under $24 \& 25$ Vict. e. 96 , s. 3, as a frambulent bailee. In $k$. $v$. Hoare, 1 Fost. \& F. 647, it was held hy Wightmin, J., after consulting Pollock, C. B., that a person hid formerly been n servant, and was employed to colleet debts withont remuneration, and who, under the circumstances, was not a serraut, eould not be indieted under 20 \& 21 Viet. c. 54, s. 4, as a bailce; as a person who received money on behalf of another did not thereby hecome it bailee of the money, not being bound to haud over the particular sum which he had received.

(l) Ante, p. 502. 
R. v. Gibbs. no longer binding as authorities, yet it is thought more convenient to retain them in the present edition, as they may yet be referred to on other points.

Servant receiving money withont anthority to do so, not within the old Acts.

If a servant, who had no authority $(m)$ to do so, received money on account of his master, and appropriated it, he was formerly held not to have received it by virtue of his employment, and could not be convicted of embezzlement. Therefore, where $(\hat{n})$ a butcher's apprentice, whose duty it was to go round for orders for meat, but who was never employed to collect debts, on one occasion got a customer, on whom he called, to pay $R$. v. Mellish. him a bill, and pocketed the money ; it was held by all the judges, that he could not be convicted of embezzle. [*512] ment, as it did not *appear by the evidence, that he was ever employed to receive money for his master, or received the money in question by virtue of his em$R$. v. Thorley. ployment. This decision was followed in $R$. v. Thorley $(o)$. In that case the prisoner was servant of $B$. and Sons, carriers, who had a warehouse at Birmingham, his employment was to look up goods to be carried by his master's waggons, but ho had no authority to receive money, all monies being collected by a collecting clerk. On one occasion, a debtor of $B$. and Sons went into their counting house, part of the warehouse at Birm. ingham, to pay a debt, and seeing the prisoner standing at the desk, with some books near him, supposing him to be a clerk anthorized to receive money, paid him the money, for which he gave a receipt in the name of $B$. and Sons. The prisoner pocketed the money. But it was held, that as he had no authority to receive it, the case was not within the stat. of Geo. 4. And a similar decision was made in $R$. v. Hautin, $(p)$, where it was also held, that a servant, who, although not authorized to receive money for his master, $\mathrm{did}$ so, and pocketed it, could not be convicted of larceny of his master's money, as it had never been in his posession; and not of larceny of the money of the person paying the bill, as he had entirely parted with the property of it.

R. v. Snoxley. Upon similar principles it was held $(q)$ that a person

(m) Authority to the customer to pay to the servant would bo snfficient, R. v. Aston, 2 C. \& K. 413.

(n) $R$. v. Mellish, Russ. \& Ry. 80.

(o) 1 Moo. C. C. 343 . Semble, this is the case cited by Alderson, B., as $R$. v. Craxley in $R$. v. Hartin. 7 C. \& P. 281. See Barrett v. Deere, Mood. \& M. 200, and other cases, ante, p. 230.

(p) 7 C. \& P. 281, Alderson, B.

(q) R. v. Snouley, 4 C. \& P. 390 . Of the anthority of this cast, however, Patteson, J., after consulting Lord Wensleydale, expressed great doubts in $R$. v. Aston, 2 C. \& K. 413 . In that cass 
hired to lead a stallion round the country, for which *he was to charge for each mare $30 s$, and not [*513] take less than 20 s., coudd not be convicted of embezzlement, although it was proved that he had not accounted for a sum of $6 s$., which was the whole charge he had made on one oceasion for covering a mare, as it was his duty to take not less than $20 \mathrm{~s}$., and this sum of $6 s$. was not received by him by virtue of his employment, but contrary to his duty.

So where $(r)$ A. was employed only as town traveller and collecter to go round and take orders from customers, and enter them in the books, and receive the money for the goods supplied in consequence; but he had no authority whatever to take or direct the delivery of goods from the shop. A customer having ordered two articles of $A$. he entered only one in the order book, but B., the proseeutor's carman, delivered both to the customer. An invoice was made out by the prosecutor for the first article, amounting to $6 s$. $6 d$., and B. entered the second aricle as $4 s .6 d$. A. afterwards received from the customer the whole $11 s$, but only accounted $t_{\text {) }}$ the prosecutor for $6 s$. $6 d$. It was held that this was not embezzlement, but larceny, as A. did not receive the $4 s$. $6 d$. for and on account of his master, but contrary to and in breach of his duty towards that master; and A. was acquitted.

- Upon similar principles it had been held (s), that a $R$. v. Harris. servant authorized to grind corn, brought with a ticket, could not be convicted of embezzlement for pocketing money received for grinding corn brought without a ticket.

But if a person be employed only on one occasion to Servant emreceive money, if, acting at that time in the capacity of ployed to a servant, he receive money and misappropriate it, it receive will be embezzlement.

though onls

Thus where $(t)$ a person employed by a carrier was on one

a brewer's drayman, who was anthorized to sell porter at 9s. 6id. a dozen, sold some at $6 x$, saying he would call agnin for the money. His master having heard of it, told the purchaser he might pay the drayman when he called. He did so, and the drayman having pocketed the money was convicterl of emberzlement. In that case, however, the master athmizcd the customer to pay the smaller smm to the servant. And in R. v. Marris, $2: 3$ 1. J., M. C. 112 ; Dears, C. C. 351, Lord Wensleydale said thut "as at present advised, he thought he was right in $h$. v. Snowley."

But see now ante, p. 502, and $R$. v. Cullum, ib. cit.

(r) R. v. Wilson, 9 C. \& I'. 27.

(8) R. v. Httrris, 23 L. J., M. C. 112 ; Dears. C. C. 314.

(t) Speneer's cease, Russ. \& Ry. 299, ante, p. 505; and sece R. v. Hughes, 1 Moo. C. C. 370 , ante, p. 503 ; and R. v. Smith, post, p. 
Spencer's

Case.

R. v. Tongue.

on one occasion directed by his employer to receive a [*514] sum of * $2 l$, which he did receive, but misappropriated, he was held rightly convicted of embezzlement.

The prisoner was secretary to a money club. By the rules he was to make out the promissory notes to be signed by members and their sureties to whom money was advanced. He was a member of the committee, whose duty it was to inquire into the sufficiency of pro. posed sureties. He was also to summon special meetings, and to countersign all cheques on the treasurer. Members paid their instalments on club nights to the stewards who handed same over to the treasurer. In consequence of loubts of the solvency of the makers of a particular promissory note, it was, by direction of the club handed over by the prisoner by the payee, the trustee of the club, with directions to sue upon it, or to get better security for the money advanced. The prisoner employed an attorney, sued on the note in his own name, received payment from one of the makers, appropriated the money to his own use, denied the receipt of it and returned the note to the trustee as unpaid. It was held that the duties of the prisoner as secretary were sufficiently cognate to that of the receipt of money for the club to make his employment to receive money in this instance au employment of hin as clerk or servant, and that, notwithstanding he sued in his own name to get the money, he still received it for and on account of his employers, and he was convicted of embezzlement under $7 \& 8$ Geo. 4 , c. $29(u)$.

And servant anthorized to from a particular class of customers, but received and receive money from a particular class of customers, who received money from another class, within the act.

And where a servant was authorized to receive money appropriated money from others, it was held that he might be convicted of embezzlement $(x)$.

And so $(y)$ a clerk, who was employed as evening col[*515] *lector to a carcase butcher, in which capacity it was his duty to receive every evening from the porters employed in the business such monies as they re. ceived from customers in the course of the day, and pay the amount over to M. (another clerk), but who

515 ; R. v. Stanbury, 2 Cox, C. C. 272 ; R. v. Winnall, 5 Cox, U. C. 326 .

(u) R. v. Tongue, 30 L. J., M. C. 49 ; Bell, C. C. 289.

(x) R. v. Williams, 6 C. \& P. 626. From that report it does not appear that the prisoner was authorized to receive money at all. But in $R$. v. Hawtin, 7 C. \& P. 281, Alderman, B., puts the derision on the ground stated in the text.

(y) R. v. Beechey, Russ. \& Ry. 319 ; but see $R$. v. Thorley, 1 Moo. C. C. 343. 
was not expected in the course of his employment to Bucluey's receive money from customers themselves, having call- Case.

ed on some debtors of his master, and received from them a cheque which he embezzled, was held to have received it "by virtue of bis employment," within the meaning of the act of Geo. 3. And a similar decison was made in the case of a toll-collector $(z)$, who on one occasion was ordered to receive a debt due to his employers, which he received and embezzled, "because though this was out of the ordinary course of the prisoner's employment, yet as he was servant to $H$. and J., and in his character of servant to them had submitted to be employed by them to receive the note and monies, and had received them by virtue of his being so employed, the case was within the statute."

The secretary of a benefit building society, according $R \mathrm{r}$. Iastic. to the certified rules had nothing to do with the receipt of money when paid off by mortgagees, but the rules were not strictly followed and the secretary was in the habit of receiving such monies, and on one occasion em. bezzled a sum so paid to him. It was held that the course of business was evidence that in addition to his dnties as secretary under the rules he was employed by the trustees as their servant to receive the mortgage money, and received it by virtue of his employment, and might be convicted of embezzlement under $7 \& 8$ Geo. 4 , c. 29 , s. $47(a)$.

*In the following case $(b)$ it was held that a $[* 516]$ Contractor's contractor's carman receiving money for the contractee, carman emcould not be convicted upon an indictment which charged bezzling him with embezzling money belonging to the contractor. The prosecutor W. had contracted with the Great Northern Railway Company to tind and provide them contrictor's money.

R. v. Biaumont.

with necessary horses and carmen for the purpose of conveying and delivering to the customers of the com. pany the coals of the company in their own waggons, and that he or his carmen should, day by day, duly ac.

(z) R. v. Smith, Russ. \& Ry. 516. But in Frove's ense', 1 Lew. 88 (2 Russ. on Cr. 444), which was precisely similar, lord Wensleydale directed an aequittal, observing that he had never approved of the decision in $R$. v. Simith.

(a) R. v. Hastie, 32 L. J., M. C. 62 ; Leigh \& C. 269 . Of this case it is to be observed that, although it o'curred long after:4 $\& 25$ Vict. c. 96 came into operation, the indirtment appears to have been framed on $7 \& 8$ Geo. 4, c. 29 , probably from the thoughtless use of an obsolete printed form.

(b) R. v. Benumont, Dears. C. C. 270 ; 23 L. J., M. C. $5.4(1854)$. This case was twice argued on account of a ditterence of opinion among the judges. 
count for and deliver to the company's coal-manager all monies received from customers in payment for coals so delivered. By the contract the carmen were to obey the orders of the company's coal-manager in all things connected with the carrying and delivery of coal and re. ceipt and payment of money. The delivery notes, as well as receipted invoices of the coals, were handed to W.'s carmen, and the former were taken to his office to be entered in his books; but the invoices receipted by the company were left with the customer on payment of the amount. The prisoner B. was servant of W., and was employed by him as carman in the delivery of coals pursuant to the said contract, and it was B.'s duty to pay over direct to the clerks of the company any money he might receive for such coals. B. delivered coals to one of the company's cnstomers, and brought the delivery order to the office to be entered. He received for the coals $5 l .10 s$., leaving the receipted invoice with the customer, but converted the money to his own use. He was indicted for embezzlement as servant of W.; but it was held by a majority of the judges that he could not be convicted, as the evidence showed such a privity as to make him the agent of the company in receiving the money, and that the money was not received on account of W., but on account of the company.

R. v. Thorpe. [*517] *However, in a subsequent and very similar case $(c)$ a different decision was arrived at; but $R$. v. Beaumont was not cited. H. was agent of the Great Northern Railway. Company at Huddersfield, for the purpose of carrying out goods to be there delivered by the company, and employed his own servants, and used his own drays and horses, and was answerable to the company for monies collected by his servants for the carriage of goods. The prisoner T. was H.'s servant, and, as such, it was his duty to go ont with a dray, to take with him goods, and a delivery-book handed to him by J. E., a clerk in the service of the company, and to deliver the goods according to the directions contained in the delivery-book, and to receive the amount of carriage therein specified as due to the company, and then to account for the sums so received with $J$. $E$. On several occasions T. took out goods for the cumpany, and received from the consignees payments for the carriage as in the delivery-book, amounting to $6 l$, which

(c) R. v. Thorpe, Dears. \& B. 562 ; 27 L. J., M. C. 264 (185 ). This case was not argued by counsel. See $R$. v. Gale, 46 L. J., M. C. 124 . 
sums were paid to, and received by him as due to the company; and the receipts were given by ' $T$. in the name of the company. T. absconded, and never paid these sums either to J. E. or to his master $\mathrm{H}$., but $\mathrm{H}$. paid up the amount to the company in pursuance of his arrangement. T. was indicted for embezzlement $a s$ the servant of $H$., and convicted, and the conviction was upheld, as, although $\mathrm{T}$. received the money "in the name" of the company, he received it "on account" of $\mathrm{H}$.

If the money misappropriated has been received from Serrant the master $(d)$, or if it bas been in his possession $(e)$, stealing the servant cannot, as we have seen, be convicted of money embezzling it, but should be convicted of larceny, received from which, as we shall hereafter see, may now be done, which has although the prisoner be *indicted for embezzle- [*518] been in his ment. In a case $(f)$, however, where it appeared from possession, the evidence that the prosecutors were spinners, and that the prisoner, who was in their employ, had been from time to time entrusted by them with money for the purpose of paying wages to workpeople; and the duty of the prisoner was to keep an account in a book of the monies which he so received and disbursed, and the book when produced contained three entries made by the prisoner, in each of which he charged his employers with more money than he had paid on their account, and the book had been balanced by the prisoner; but there was no evidence that he had actually accounted with his employers, Wightman, J., stopped an indictment for larceny, observing that, perhaps the prisoner never intended to deliver this account, or, if be did, to deliver it with explanations ; but this was no accounting, and the prisoner was acquitted.

But if a tradesman, suspecting his servant's honesty, But if regive marked money to a friend to purchase something ceived from at his shop, and the servant, instead of putting the muney into the till pocket it, this offence will be em-

R. v. Butler. third person, thongli master's agent, held

(d) R. v. Hawkins, 1 Den. C. C. 584 ; R. v. Beaman, Carr. \& M. 595, where a servant, sent with 6 s. to buy coals, poeketed one, and was convicted of larceny. $R$. v. Goode, Carr. \& M. 582 ; and see R. v. Johnson, 21 L. J., M. C. 32 ; $R$. v. Cooke, ante, p. 490.

(e) $R$. v. Murray, 1 Noo. C. C. 276 , ante, p. 498 ; and see $R$. v. Masters, and $R$. v. Watts, ante, p. 499.

(f) R. v. Butler, 2 Carr. \& K. 340. Where a servant, who was employed by her mistress to pay bills, received from her money to pay a bill of a cheesemonger, named Sadler, and bronght back the bill with the words "paid Sadler" on it, which she herself had written, having pocketed the money, she was convicted of forgery, R. v. Huseman, 8 C. \& P. 180. 
to be em- bezzlement $(g)$. If the money has been put into the till bezzlement. and is abstracted thence, it is larceny. Where a servant is sent by his master to get change
sent if servant for a note, gets it and embezzles the change, he is not change em- liable at common law for stealing that, but should be bezzle the indicted for embezzlement, as the master never had change. possession of the change $(h)$.

[*519] *3. He must fraudulently embezzle the same, or some part thereof $(i)$.

Embezzlement may be defined as the fraudulent retention of personal property of any kind belonging to ancther, whilst in the course of passing to the possession of the owner. It is not sufficient, however, in support of a charge of embezzlement, to prove a mere receipt, and non-payment over of money that is a mere Refusal to matter of account. A positive refusal to account must account mnst be shown $(k)$. Thus, where $(l)$ a man gave money to be shown. his servant to pay taxes, and the only evidence of emR. v. Smith. bezzlement was that the collector had never received the money, it was held that the servant could not be convicted of embezzlement. So, where $(m)$ the clerk

(g) R. v. Headge, Russ. \& Ry. 160 ; S. C. nom. R. v. Hedges, 2 Leach, 1033. In that case it is said, "It seems to be the opinion of the judges that the stat. 39 Geo. 3, e. 85 , did not apply to cases which are larceny at common law." In Russ. on Crimes, vol. ii. p. 416,4 th ed., it is said that the enactment of the new stat. like the repealed stat. has the effect, it should seem, of constituting the offence described in it a larceny. $R$. v. Hedges, was followed in $R$. r. Gill, 1 Dears. C. C. $289 ; 23$ L. J., M. C. 50.

(h) R. v. Sullens, 1 Moo. C. C. 129 ; R. v. Thomas, 9 C. \& P. $741 ; R$. v. Reynolds, 2 Cox, C. C. 170 . If he steal the note it is larceny, as he only had the custody, not the possession of that, Bass's case, ante, p. 482 ; R. r. Atkinson, 1 Leach, C. C. 302; and see $R$. v. Walsh, Russ. \& Ry. 215; 4 Taunt. 258; 2 Leach. C. C. $1054 ; R$. v. Goode, Carr. \& M. 582 ; R. v. Smith, 1 Carr. \& K. 423; $R$. v. Johnson, 21 L. J., M. C. 32 ; 2 Den. C. C. 310.

(i) The embezzlement need not take place vhilst servant, if the receipt were whilst servant, $R$. v. Lovell, 2 M. \& Rob. 236.

(k) In addition to the cases cited in the text in support of this position, the case of $R$. v. Taylor, 3 B. \& P. 596, may be referred to. In that case it was held that the offence was completed in the county in which the clerk refused to account; and, accordingly, that he might be indicted and tried in thatconnty, though he received the money in another county. Now he may be indicted in either, 7 Geo. 4, c. 64, s. 12 ; and see $R$. v. Hobson, Russ. \& R. $56 ; R$. v. Murdock, 21 L. J., M. C. $22 ; 2$ Den. C. C. 298.

(l) R. v. Smith, Russ. \& Ry. 267.

(m) R. v. Hodgson, 3 C. \& P. 422 ; bnt see $R$. ن. Jackson, 1 C. $\&$ K. 384 , post. And see $R$. v. Hebb, 2 Rnss. 1242, where Garrow, B., held that a clerk could not be convicted of embezzlement from whose books it appeared that he had receired more than he had paid away. See also $R$. v. Butler, 2 C. \& K. 340, (526) 
to the proprietors of a coach, whose duty it was to re-R.v. Iodgson. ceive money for passengers, \&c., enter the sums in a book, and remit the money weekly to his employers, duly charged himself in his book with all sums received, but did not remit the money to his employers, as he ought to have done, it was beld that he could not be convicted of embezzlement.

And in $R$. v. Jones $(n)$ it was held that a clerk who Mere omishad *merely omitted to enter in his book a sum [*520] sion to of money which he had received could not beconvicted account no of embezzlement, as it did not appear that he had de- embent. nied the receipt of it, or gave any false account respecting it.

But if he had rendered an account, in which the Aliter, of sums received were omitted, that would be evidence of account conembezzlement (o). And it was held by Coleridge, J. taining $(p)$, that a baker's servant, whose duty it was, on the evening of every day, to render an account of all the monies received during the day for his master, and immediately pay over the amount, having wilfully omitted bezzlement. to account, might be convicted of embezzlement, as such an omission was equivalent to a denial of the receipt of the money. And where $(q)$ a female servant Leaving was sent to receive rent due to her master, received the situation and rent and went off to Ireland, it was held, by the same alsconding. learned judge, that the circumstance of her quitting her $R$. v. Wilplace and going off to Ireland was evidence from which liamsa jury might infer that she intended to appropriate the money, and she was found guilty.

So in a case $(r)$ in which it appeared to be the duty of $\mathrm{L}$, the prisoner, to receive remittances from cus-

ante, p. 518 ; see, however, $R$. v. Grove, post, p. 521. In $R$. v. Lister, 26 L. J., M. C., 26, Pollock, C. B., said, "I entirely dissent from the dictum of Vaughan, B. in $R$. v. Modgson.."

(n) 7 C. \& P. 833 ; and see another case against the same person, 7 C. \& P. 834. Making a fillse entry would be eviclence of cmbezzlement, Re Windsor, 31 I. J., M. C. 163.

(o) R. v. Creed, 1 Cars. \& K. 63. See R. v. Butler, 2 C. \& K. 340 , ante, p. 518, a easo where a servant had male $u p$ his account, hut hal never delivered it ; and it wats held no arcounting.

(p) R. v. Jaekson, 1 Carr. \& K. 384. In R. v. Worlley, "21 L. J., M. C. 44, Lord Camphell said, "There are many authorities which show that the denial of the receipt of the money by the prisoner constitutel an emhezrlement."

(q) R. v. Williams, 7 C. \& P. 338.

(r) R. v. Lister, 26 I. J., M. C. $26 ; 1$ Dears. \& Hell, C. C, 118. In R. r. Betts, 1 Bell, C. C. 90 , it was held that a miller's foreman, who hal autlority to sell flour and enter the sale in a book, conld not be convieted of lareeny of some flour which he sold without entering the sale in a book, but should have been indicted for embezzlement of the money received for it.

30 MAs. \& SER. 
Entry in one tomers for his master, to enter the amounts received in book not an a cash-book, to furnish an extract from the cash-book accounting where duty to enter in several.

R. v. Lister. to the cashier, also to enter the amount to his master's credit in a banker's book, and to pay the amount with others, from time to time into the bank, and also to enter each amount in his master's ledger to the credit of the customer who paid it. Having received a sum of [*521] money from a customer, $\mathbf{L}$. did *not enter it in the cash-book, or in the extract furnished to the cashier, or in the banker's book, or pay the amount into the bank for his master, bat he did enter it in the ledger to the credit of the customer. $\mathrm{He}$ was nevertheless held to have been rightly convicted of embezzlement, and it was also held that the making the entry in the ledger did not exempt him from punishment.

And where an assistant overseer who collected poorrates entered money received in a book, charging him. self with it, but omitted to pay it into the bank to the overseer's account, he was held to be rightly convicted of embezzlement $(s)$.

Promise to But where a servant, having received money admitted account, but the receipt, and promised to accoust, but did not do so, omission to it was held by Erskine, J. $(t)$, that he could not be condo so, no em- victed of embezzlement. In that case, the collector of $R$. v. Creed. a water company, as was his practice, gave the turn cock three receipts for water-rate, desiring him to receive the amounts. He received the money, and, when asked, admitted that he had done so, and said he would pay it over on Monday, but absconded.

Claim of

And where (u) the master of a coal ship retained right no em- part of the freight received for carriage of coals, claimbezzlement. ing a right to do so according to a recognized custom $R$.v. Norman. between owners and captains in the course of business, Cresswell, J., held that he could not be convicted of embezzlement.

Embezzle-

In suppoit of an indictmont for embezzlement, it is, ment of some in general, necessary to prove that some specific sum specific sum has been embezzled. But, in one case, that rule ap-
must be proved.

R. v. Grove. pears to have been relaxed $(x)$. In that case the prisoner was cashier in a bank. His duty was to take charge of the cash, and when any payment was mado into the bank, in money and paper, the course was for him to hand over the paper to a clerk, and to enter the cash received in a book, kept by himself, called "tho

(s) R. v. Guelder, 30 L. J., M. C. 34 ; Bell, C. C. 281.

(t) R. v. Creed, 1 Carr. \& K. 63.

(u) R. v. Norman, Carr. \& M. 501.

(x) R. v. Grove, 7 C. \& P. 635 ; 1 Moo, C. C. 447. 
money-book." It was also his duty, *at the [*522] R. r. cirotc. closo of each day, to see that the cash in hand agreed with "the money-book," and to strike a balance denoting the sum in cash which he had in his charge, and which ought to have been kept either in a drawer in the counter, of which he had the key, or in a box in the banking-house, of which also he had the key. One day the cash in the money-book, at the close of business, was $1,762 l$, which was duly carried forward, and formed the first item in the next day's account. On the latter day, at the close of business, the prisoner made the balance in the money-book $1,309 l$., which amount he ought to have in one or the other of the above-named places of deposit. Upon examination, however, it was found that, instead of $1,309 l$, the prisoner had only $345 l$, leaving a deficiency of $964 l$. The prisoner, who admitted that he was short about $900 l$., was indicted for embezzling "money to a large amount, to wit, 500l." The.only witness against the prisoner was the partner in the bank, whe discovered the delinqueney, and who could not say when tho money had been purloined, from what persons it had been received, what sort of money had been abstracted, or whether from the till, or upon the receipt from eustomers. The jury found the prisoner guilty of embezzlement to the amount charged, and, after argument and considerable doubt, eight judges, against seven, held that there was sufficient evidence to go to the jury of the prisoner having received certain monies on a particular day, and for them to find that ho embezzled the sum men. tioned in the indictment. However, in a subsquent case $(y)$, where a shopman was indicted for einbezzloR. v. Jones. ment, and the counsel for the prosecution offered to prove that there was a deficiency in the prisoners accounts, but said that there was no proof of the embezzlement of any particular sum, and cited $R$. v. Grove, Alderson, B., directed an acquittal, saying, that-

"Whatover difference of opinion thero might bo in the case of $R$. v. *Grove, proceeded more upon [*5:3] the peculiar facts of that case than upon the law. It is not sufficient to prove, at the trial, a general deficiency in account. Somo specific sum must bo proved to be embezzled, in like manuer as in larceny some particular article must be proved to have been stolen."

(y) R. v. Jones, 8 C. \& P. 288. Of this ease it may be remarked that Alderson, B., was one of the seven dissentient judges in $R$. v. Grove, and in Grove's ease, there was an admission, which in this case there was not. 
R. v. Chapman.

R. v. Lambert.
And again, in a case $(z)$ where it was the duty of a clerk and traveller to receive money for his employer, pay wages out of it, and make entries of all monies received and paid in a book, and to enter the weekly totals of receipts and payments in another book, upon which last book he, from time to time, paid over balances to his employer. The clerk, having entries in the first book amounting to $25 l$, entered them in the second as $35 l$., and two months afterwards, in accounting with his master, made his balance $10 l$. too little by these means, and paid it over accordingly. On this evidence he was indicted for embezzling the 10l., but Williams, J., asked the counsel for the prosecution, "Can you show any precise sum received by the prisoner, on account of his master, and the whole or part of that very sum appropriated by him to his own use?" And in the absence of such evidence, directed an acquittal.

However, in the following case $(a)$, Erle, C. J., allowed a prisoner to be convicted without such specific proof. L. was indicted for embezzling the sum of $270 l$., part of a sum of $2,783 \mathrm{l}$. 7s. $9 \mathrm{~d}$., which he had received on account of the Receiver-General of her Majesty's Customs. L. was assistant teller to the Customs. It was his duty to receive money from merchants and others who had to pay money to the Receiver-General and enter such receipts in a cash-book. He had also, in the course of his employment, to make certain payments and enter them on the other side of the same bool, and balance the amounts each day, paying over so much of the surplus as was in notes to a superior officer and retaining the cash, which was carried to the next day's [*524] account. When he paid over the notes *it was his duty to give to the same officer a memorandum of the receipts and disbursements of the day. One day he was ordered, about eleven o'clock, to make up his accounts, but continued to receive money until two, when he left the office and did not return. His desk and books were then examined, and in the latter were found, entered as received, several sums, amounting to $2,783 \mathrm{l}$. $7 s .9 d$; and on the other side payments, amounting to 130l. 13s. 3d. The balance found, which ought to have been $2,652 l$. $14 s$. $6 d$., was $270 l$. short. The whole of the money was received between ten and two o'clock on that day. On the part of the prisoner it was contended, that

(z) R. v. Chapman, 1 Carr. \& K. 119 ; and see R. v. Welch, 2 Carr. \& K. 296.

(a) R. v. Lambert, 2 Cox, C. C. 309 ; Centr. C. C. Aug. 1847; and see $R$. v. Moah, Dears. C. C. 626, post, p. 533. 
he could not be convicted of embezzlement as there was $R$. v. Laulno evidence showing the appropriation of any particu-bert. lar sum received from any one person. But Erle, C. J., said,-

"I think the offense is sufficiently made out within the meaning of the statute $(b)$, if the jury are satisfied that the prisoner received in the aggregate the amount with which he appears to have charged himself, and that he absconded, or refused, when called upon, to account, leaving a portion of the gross sum deficient. There would be a constant failure of justice if I were to decide otherwise, since it is impossible, in cases like the present, where a number of different amounts of money have been received, to 'specify which sum or sums, or the parts of which sum or sums, have been embezzled."

Where a clerk received six bank-notes, on his master's $R$. v. Hall. account, in payment of a particular debt, and made an entry in his master's book of a smaller sum as received, but afterwards paid over to his master the identical notes which he had received, applying them, in his account, to another debt received by him for his master, he was held to have been rightly convicted of embez. zlement in respect of these six notes (c).

It is, however, no objection to an indictment for em- No objection bezzlement that the master had no right to the money; that mister if it be received by the clerk or servant by virtne of his *employment and on account of his master, it [*525] will be sufficient $(d)$.

And it has been held to be embezzlement in the sec- Embezzleretary to a society fraudulently to withhold money re. ment by ceived from a member to be paid over to the irustees; and that he might be stated to be the clerk and servant of the trustees, and the money might be stated to be their property, though the socieiy was not enrolled, and though the money ought in the ordinary course, to havo been received by a steward (e). However, in an- Clerk of ilother case, whore a society, in consequence of adminis- legal society tering to its members an unlawful oath, was an un- (ammot be lawful combination and confederacy under the stats. $3 y$ Geo. 3, c. 79 and 57 Geo. 3, c. 19 , s. 25 , it was held had no right to the money, if receivet in his accolntht. secretary of society not enrolled. R. v. Hall. convicted of ('mberzlement.

(b) It does not appear from the report whether $I$. wits indicted under $7 \& 8$ Geo. 4 , or 2 Will. 4 , c. 4 ; but most probably the latter.

(c) R. v. Hall, 3 Stark. 67; Russ. \& Ry. 463. Snch a case as this is not very likely to oceur again since $24 \& 2 ;$ Vict. c. $96, s$. 71 , post, p. 526 .

(d) R. v. Beacall, 1 C. \& P. 312, 454.

(e) R. v. Hall, 1 Moo. C. C. 474 . 
R. v. Hunt. that a person charged with embezzlement as clerk and servant to such society could not be convicted $(f)$.

Unstamped receipt.

Indictment against receivers.

The receipt of the money by the prisoner may now be proved by an unstamped receipt, although the amount is above $40 s$. $(g)$.

A person who receives goods, \&c., knowing them to have been embezzled, may be convicted on a common indictment charging him as a receiver of stolen goods. $R$. v. Framp- Therefore, where W. and T. were charged on an indictton. ment, first,. with embezzling certain oats, secondly, with being servants of A. B. and stealing his oats, and there was a fourth count charging $F$. with receiving certain oats feloniously stolen, knowing them to have been feloniously stolen; and the jury found W. guilty on the first count of embezzlement, acquitted T. and found F. guilty on the fourth count of receiving, the con! viction was held to be good; and Pollock, C. B., said, "It seems very likely that the statute provided that embezzlement should be deemed stealing for the express purpose of providing for the case of receivers, there [*526] being no statute in terms applicable *to receiving goods knowing them to have been embezzled" $(h)$.

Place of trial. Where a country traveller, whose duty it was to col-

$R$. v. Rogers. lect outstanding accounts and remit the money "at once" to his employers in Middlesex, collected an account at York which he never remitted, but subsequently sent from Doncaster to his employers, and they receired in Middlesex, a letter which the jury found amounted to a denial of the receipt of the money at York. It was held that he might be tried at the Middlesex sessions $(i)$.

$R$. v. Tread- But where it was the duty of a commercial traveller golds to remit daily to his employers the monies which he collected, and on the 1st and 2nd of March he collected at Newark two sums which he did not account for: there was no evidence that he returned to Grantham where he resided on either of those days; in the first week of April his employer went to $G$. and saw him and taxed him with receiving monies and not acconnting for them; whereupon he handed to his employer a list of monies received and not accounted for, including

(f) R. v. Hunt, 8 C. \& P. 642.

(g) $17 \& 18$ Vict. c. 83 , s. 27 . Formerly it could not: $R$. y. Hall, 3 Stark. 67; see $R$. v. Wortley, 21 L. J., M. C. 44; 2 Den. C. C. 333 .

(h) $R$. v. Frampton, 27 L. J., M. C. 229; Dears. \& B. 585. And see $24 \& 25$ Vict. c. 96, s. 91 .

(i) R. v. Rogers, 47 L. J., M. C. 10.

(532) 
the above two sums. It was held that there was no evidence of embezzlement within the borough of G., and that he could not be tried at G. quarter sessions $(k)$.

\section{Indictment $(l)$.}

By 24 \& 25 Vict. c. 96 , s. 71 , for preventing difficulties in the prosecution of offenders in any case of embezzlement, fraudulent application or disposition hereinbefore mentioned, it is enacted, that-

"It shall be lawful to charge in the indictment and Three disproceed against the offender for any number of distinct tinet acts of acts of embezzlement, or of fraudulent application or embezzledisposition, not exceeding three $(m)$, which may have ment may le been *committed by him against her Majesty [*527] charged in or against the same master or employer within the indictment. space of six months from the first to the last of such acts $(n)$; and in every such indictment, except where the offence shall relate to any money or any valuable security, it shall be sufficient to allege the embezzlement or fraudulent application or disposition to be of money, without specifying any particular coin or valuAs to allegation and proof of tho able security; and such allegation, so far as regards the description of the property, shall be sustained if the offender shall be proved to have embezzled or fraudulently applied or disposed of any amount (o), although the particular species of coin or valuable security of which such amount was composed shall not be proved; or if he shall be proved to have embezzled or frandulently applied or disposed of any piece of coin or any valuable security, or any portion of the value thereof, although such piece of coin or valuable security may have been delivered to him in order that some part of the value thereof should be returned to the party delivering the same or to some other person, and such part shall have been returned accordingly."

(k) R. v. Treadgold, 48 I. J., M. C. 102.

(l) The indietment must show a lareeny, R. v. M'Grigor, $3 \mathrm{H}$. \& P. 106; R. v. Johnson, 3 M. \& S. 540; sce R. v. Morh, Dears. C. C. 626 .

(m) See $R$. v. Balls, 40 L. J., M. C. 148, where prisoner was to account weekly for small sums received during the week, and he was held rightly convicted of embezaling various small sums received in three eonsecutive weeks.

(n) And see $24 \& 25$ Vict. e. 96, s. 5, ante, p. 495.

(o) But if the prisoner has reeeived a cheque and there is no evidence that it has been converted into money, he camnot he convicted of embezzling money. R. v. Kicna, 37 L. J., M. C. 43. 
Object of that act.

Particulars.

Prosecutor confined to one sum where gross sum charged and sereral sums proved.

Three counts advisable.

R. v. Purehase.

R. v. Noake.

This provision was intended to remove considerable difficulties which formerly beset a prosecutor, and often prevented a prosecution under the repealed statute $(p)$. It was found, however, on the other hand, that it frequently caused great hardships to prisoners, who, from the general mode in which indictments are framed under it, could not obtain any satisfactory information as to the specific charges made against them $(q)$. To remedy this evil, it has become the practice for judges, on motion supported by affidavit $(r)$, to grant an order for particulars, which ongit at least to contain the names of the persons from whom the sums of money are alleged to have been received $(s)$.

[*528] *And it was held $(t)$, that if a servant was indicted under the act of Geo. 4, for embezzlement, and the indictment contained only one count, charging the receipt of a gross sum on a particular day, if it turned out that the money was received in different sums on different days, the prosecutor must make his election and confine himself to one sum and one day.

In an indictment under this section it is the safest course to have three separate counts, each of the two last of which should aver that the money was not only received, but embezzled within six months from the day mentioned in the first count. Where an indictment coutained only one count, which charged that within six calendar months the prisoner received three sums. laying a day to the receipt of each, and that "on the several days aforesaid" the prisoner embezzled these sums, it was held bad, because it did not show that the sums were embezzled within six months of each other (u). And where an indictment contained three counts, the first of which was in the usual form, but the second stated "that within six calendar months from the day mentioned in the first count of this indictment," to wit, \&c. at \&c., the said $\mathrm{N}$. being then and there employed, \&c. did by virtue of his employment, \&c. receive, \&c.

(p) 2 Russ. on Crimes, 416 ; see $R$. v. Moah, Dears. C. C. 631.

(q) It is conceired that this observation applies with twofold force since $24 \& 25$ Vict. c. 96, s. 72 , post, p. 5:8.

( $r)$ The affidarit should state that the prisoner does not know the charges intended to be brought against him, that it is necessary for his defence to be furnished with the particular charges. and that he has applied to the prosecutor for a particular and been refused, see 2 Russ. on Crimes, 469 , note.

(s) R. v. Hodgson, 3 C. \& P. 422 ; R. v. Bootyman, 5 C. \& P. 300 .

(t) R. v. Williams, 6 C. \& P. 626.

(u) R. v. Purehase, Carr. \& M. 617. 
and the said last-mentioned money, to wit, on the day and year last aforesaid, at \&c. feloniously did embezzle, \&c., and the third was in the same form, Cresswell, J., held the second and third counts bad, and confined the prosecutor to evidence on the first count only $(x)$.

By the $24 \& 25$ Vict. c. 96 , it is enacted, sect. $72,24 \& 25$ Virt. that-

"If, upon the trial of any person indicted for embez- Persons inzlement or fraudulent application or disposition as afore- dieted fir emsaid, it shall be proved that he took the property in bezalement question in any such manner as to amount in law to as a clerk. larceny, he shall not by reason thereof be entitled to be be., not to acquitted, but the jury shall be at liberty to return as if the offence their verdict that such person is not guilty of embezzlement or fraudulent application or disposition, but is guilty of simple larceny, or of larceny as a clerk, servant, or person *employed for the purpose, or in the [*ว29] capacity of a clerk or servant, or as a person employed in the public service or in the police, as the case may be; and thereupon such person shall be liable to be punished in the same manner as if he had been convicted upon an indictment for such larceny; and if, upon the trial of any person indicted for larceny, it shall be proved that he took the property in question in any such manner as to amount in law to embezzlement or fraudulent application or disposition, he shall not by reason thereof be entitled to be acquitted, but the jury shall be at liberty to return as their verdict that such person is not guilty of larceny, but is guilty of embezzlement or fraudulent application or disposition, as the case may be; and thereupon such person shall be liable to be punished in the same manner as if he had been convicted upon an indictment for such embezzlement, or fraudulent application or disposition, and no person so tried for embezzlement, fraudulent application or disposition, or larceny as aforesaid, shall be liable to be afterwards prosecuted for larceny, fraudnlent application or disposition, or embezzlement upon the same facts $(y)$."

Other Acts of Parliament have also at various times special Acts been passed for the protection of masters in trade from for protection frauds and embezzlements of property by their servants. In this place, however, it is unnecessary to do turn out to be lareny, and rice versî. 
more than refer to those acts, most of which will be found in the Appendix.

After trial for When a servant who has robbed his master has been crime, master prosecuted and tried for the offence, the master may, if may sue servant; he thinks proper, sue him for the damages he has sustained thereby. But he cannot proceed by action until after the trial of the servant $(z)$, as public policy requires that offenders against the law should be brought to justice, and for that reason a man is not permitted to abstain from prosecuting an offender by receiving back stolen property or any equivalent or composition for a felony without suit, and of course, therefore, he [*530] cannot be allowed to maintain *a suit for that purpose. It would not prejudice the civil remedy that the offender was acquitted of the crime, if he was or after his tried $(a)$. And it would seem that if the servant die death his executors ; before conviction the master might maintain a suit in equity against the servant's executors $(b)$. or make him After conviction for embezzlement, the servant is still
bankrupt. liable to be made bankrupt, notwithstanding the Felons Act, $1870(c)$.

If servant gol abroad with -proceeds of felony, master may perhaps sue before trial for crimes.

If the servant abscond with the stolen property or. money to a foreign country, it would seem to be no. answer to an action in that country to recover the property or money, that by the law of England a prosecution for felony must precede an action to recover the proceeds of it $(d)$. But the decision of the question would depend on the lex fori or law of the country in Scott v. Lord which the action is brought.

Seymour.

Money stolen a good consideration for security therefor. Chowne v. Baylis.

Where a servant robbed his master of money and before conviction deposited deeds, \&c. as security for the amount stolen, and the master afterwards prosecuted to conviction, it was held by the Court of Chancery that the money taken was a good consideration for the security $(e)$.

(z) If he procecd by action before the trial, the judge may direct a nonsuit; or perhaps even a verdict for the defendant, though the difficulty about a verdict for defendant is that the plaintiff would thereby be prevented from suing even after the prosecution. Wellock v. Constantine, 32 L. J., Exc. 285. But in Osborn v. Gillctt, 42 L.. J., Exc. 54, Bramwell, B., said, "Wellock v. Constantine must be looked upon as overruled by Wells v. Abrahams, 41 L. J., Q. B. 306 "; L. R. 7 Q. B. 554.

(a) Crosby v. Leng, 12 East, 409 ; Stone v. Marsh, 6 B. \& C. 551 ; Marsh v. Keating, 1 B. N. C. 198 ; White v. Spettigue, 13 M. \&W. 608.

(b) Wickham v. Gattrell, 23 L. J., Ch. 783.

c) 33 \& 34 Vict. c. 23 . See Re Harris, 51 L. J., Ch. 1.

(d) Scott v. Lord Seymour, 31 L. J., Exc. 457.

(e) Chowne v. Baytis, 31 L.. J., Ch. 757. And see Dudley and West Bromwich Bank v. Spittle, 1 John. \& H. 14. 
Where a barrister filed a bill to recover out of the statute of assets of a deceased clerk an amount of fees which the Limitations clerk had received and embezzled in his lifetime, it no bar. was held in equity $(f)$, that the Statute of Limitations Tced v. Becere. could not be set up as a defence; for, said Stuart, V.C.,-

"The clerk was clearly a receiver and agent by whom money was received in confidence, and therefore under the same implied contract as that supposed to arise out of the duty of trustees, assignees and executors, of faithfully, diligently and accurately accounting, when called upon, to his principal $(g)$. That being so the money must be considered as money *of the [*531] employer in the hands of his confidential agent. There had therefore been all along possession by the agent, but no adverse possession, and therefore the bar of the statute, which was founded on adverse possession, did not apply."

If a warrant of attorney is given to his master by a Security servant charged with embezzlement upon a distinct given on agreement by the master not to prosecute the charge, agreement the agreement is illegal, and the court would upon a secute set summary application set aside the warrant of attor-aside. ney $(h)$. But when a warrant of attorney was obtained Mere threat from a servant upon a threat by his master that, if he not sutticient. did not go to his attorney and give satisfactory security Ward v. for an amount which he ought to have accounted for, Lloyd. he would prosecute him for unlawfully making use of his money, the Court of Common Pleas refused to set it aside as there did not appear to have been any agreement not to prosecute. "Such an agreement," said Coltman, J., "is not to be inferred from hasty expressions used by a man when seeking to obtain security for a just debt" $(i)$.

\section{Falsification of Accounts.}

By the Falsification of Accounts Act, 1875 (38 \& 39 Vict. c. 24), after reciting that it is expedient to amend the law so as to punish the falsification by clerks, offi-

(f) Thed v. Becre, 28 I. J., Ch. 78\%. Lut in Re Ilackins, 28 W. R. 240 , it was held that the Statute of limitations might be barred by the eourse of dealing between master and servant.

(g) The Earl of IIardwicke v. Vernon, 14 Ves. 50.4; Dinnildie v. Bailcy, 6 Ves. 136. See Burdick v. Garrick, 39) I. .J., Ch. 369.

(h) Ex parte Critchley, 3 D. \& I. 527; and see Collins v. Blantern, 1 Sinith's L. C. 325; Keir v, Lceman, 6 Q. B. 308; 9 Q. B. 371.

(i) Ward v. Lloyd, 6 M. \& G. 785. 
cers, servants, and others of their employers' accounts, books, writings, or documents, it is enacted-

Punishment for falsification of accounts, \&c.

Intention to defraud, sufficient indictment.

Act to be read with $24 \& 25$ Vict. c. 96 .

50 Geo. 3 , c. 59 , s. 2 . Officers giving in false statements of money intrusted to their care, mislemeanor, \&c.

$24 \& 25$ Vict. c. 96, s. 69 .

1. That if any clerk, officer, or servant, or any person employed or acting in the capacity of a clerk, officer, or servant, shall wilfully and with intent to defraud, destroy, alter, mutilate, or falsify any book, paper, writ. ing, valuable security, or account which belongs to or is in the possession of his employer, or has been received by him for or on behalf of his employer, or shall wilfully and with intent to defraud make or concur in making any false entry in, or omit or alter, or concur in omitting or altering, any material particular from or in any such book, or any document or account, then in every such [*532] case the person so *offending shall be guilty of a misdemeanor, and be liable to be kept in penal servitude for a term not exceeding seven years, or to be imprisoned with or without hard labour for any term not exceeding two years.

2. It shall be sufficient in any indictment under this Act to allege a general intent to defraud, without naming any particular person intended to be defrauded.

3. This act shall be read as one with $24 \& 25$ Vict. c. 96 .

Offences commited ux Persons employed in the Public Service or by the Police.

By stat. 50 Geo. 3 , c. 59 , s. 2 , it is enacted, that-

"If any officer, collector or receiver, intrusted with the receipt, custody or manggement of any part of the public revenues, shall knowingly furnish false statements or returns of the sums of money collected by him, or intrusted to his care, or of the balances of money in his hands, or under his control, such officer, collector or receiver so offending, and being thereof convicted shall be adjudged guilty of a misdemeanor, and shall be adjudged to suffer the punishment of fine and imprisonment, at the discretion of the court, and and be rendered for ever incapable of holding or enjoying any office under the Crown."

And by stat. $24 \& 25$ Vict. c. 96, s. 69 , it is enacted, that-

"Whosoever being employed $(k)$ in the public service of ber Majesty, or being a constable or other person employed in the police of any county, city, borough, dis-

(k) Acting in the employment is sufficient without proof of formal appointment, $R$. v. Borrett, 6 C. \& P. $124 ; R$. v. Townsend, Carr. \& M. 178. 
trict or place whatsoever, shall steal any chattel, money Larceny by or valuable security $(l)$, belonging to or in the posses- persons in sion or power of her Majesty or intrusted to or received or taken into possession by him by virtue of his employment, sliall be guilty of felony, and being convicted thereof shall be liable to" [same punishment as larceny by servants, except whipping, ante, p. 496].

Sect. 70. "Whosoever being employed in the public seet. 70. service of her Majesty, or being a constable or other Embezzleperson employed in the police of any county, city, ment by borough, district or place whatsoever and intrusted by persons in virtue of such employment $(\mathrm{m})$ with the receipt, custody, the Qneen's management or *control of any chattel, money [*533] service, or by or valuable security, shall embezzle any chattel, money or valuable security which shall be intrusted to or re. ceived or taken into possession by him by virtue of his employment, or any part thereof, or in any manner fraudulently apply or dispose of the same or any part thereof to his own use or benefit or for any purpose whatsoever except for the public service, shall be deemed to have feloniously stolen the same from her Majesty, and being convicted thereof shall be liable to [same punishment as sect. 69, supra]; and every offender against this or the last preceding section may be dealt with, indicted, tried and punished either in the county or place in which he shall be apprehended or be in custody, or in which he shall have committed the offence; and in every caso of larceny, embezzlement or fraudu- Form of lent application or disposition of any chattel, money or warrant of valuablo security in this and the last preceding section commitment mentioned, it shall be lawful in the warrant of commit- and indictment by the justice of the peace before whom the offender shall be charged, and in the indictment to be preferred against such offender, to lay the property of

(l) Sec ante, p. 476, note (w).

(m) In R. v. Tounsend, Carr. \& M. 178, it was held that a postoffice letter-carrier, who was in the daily habit of ealling at the lowge of $\mathrm{G}$. Infirmary, and there receiving letters with a peuny on each to prepay the postage, and taking them to the (isneril Post Office, having embezzled some of the pence thus received, might be convieted under 2 Will. 4, e. 4 , of which this is a reenactment; as there was evidence to io to the jury that the pence were received by him by virtue of his employment as a letterearrier. In $R$. v. Lotell, 2 Moo. \& Rob. "236, it was held to be sufficient in an inclietment uncler this act, to state that a clork embezzled money recival by him whits such elerk, without any more specific allegation, that he embezzled whilst clerk. It is remarkable that the words "by virtue of his employment," which were designedly omitted in sect. 68 (ante, $1.50: 2)$, are inserted in sects. 69 and 70 . 
any such chattel, money or valuable security in her Majesty."

Public stores.

\section{R. v. Moah.}

By the Public Stores Act, $1875(n)$, if stores are found in the possession or keeping of a person being in her Majesty's service or in the service of a public department, then if such person does not satisfy the court that he came lawfully by the stores so found, he is liable on summary conviction to a penalty not exceeding $5 l$.

The following important case (o) may be mentioned here. M., an officer of inland revenue, received certain taxes in respect of which he was allowed to retain in his hands a balance of about $300 l$. to meet contingent expenses. It was his duty to render accounts to certain inspectors, and these accounts, when rendered, showed a much larger balance in his hands than he was allowed to retain. At last the General Surveyor of Inland Revenue examined M.'s accounts, and produced to him a statement extracted from them, showing a balance in his hands of upwards of 5,000l., which he admitted. The surveyor then asked him if he was prepared to pay [*534] over that balance, or any part *of it, and he said no. The surveyor then reminded him that there was a balance of excise duties alone of about $300 \%$. standing against him from the previous Monday. M. then took out 255l. in bank-notes, and a cheque for $25 \%$. $8 s .4 d$, and a money order for $14 s$, and said that was all the money he had in the world. The surveyor then asked him what he had done with the rest, and he said he had spent it in an unfortunate speculation. Hewas indicted for embezzlement under 2 Will. 4 , c. 4 , s. 1 , and convicted, as it was held by all the judges before whom the case was argued, that there was evidence of the receipt of a particular sum of $300 l$., and a misapplication of part of it. And Cresswell, J., after stating his opinion to that effect, added,-

"I by no means say that the conviction is not sustainable as to the 5,000l. It is a question of law of great importance, and the authorities are somewhat conflicting. In $R$. v. Grove $(p)$, under circumstances somewhat similar, the conviction was sustained by, a majority of eight judges to seven; but in a subsequent, case that decision was not followed, and was said to have proceeded upon some special facts. In $R$. v. Lam-

(n) 38 \& 39 Vict. c. 25 , s. 9.

(o) R. v. Moah, Dears. C. C. 626 ; 25 L. J., M. C. 66.

(p) Supra, p. 521. 
bert $(q)$, however, which cannot be distinguished from $R$. . Moah. this case, my brother Erle held that evidence of a general deficiency was sufficient to sustain the indictment. As at present advised, I should say that the prisoner being shown by his own accounts to have a balance in hand of 5,000l. due to the Crown, and he making no attempt to explain it on the ground of error or loss of the money, merely says that he has expended it for his own purposes, he may upon that evidence be convicted of embezzling the money, and that having been once indicted for embezzling the whole amount, and either convicted or acquitted, he never could beindicted again for embezzling any part of it. I merely throw this ont as showing my grounds for saying that $I$ am by no means satisfied that this indictment, is not sustainable as to the whole amount of the prisoner's deficiency."

\section{Embezzlemext by Officers of the Bank of Exgland or Ireland.}

By stat. $24 \& 25$ Vict. c. 96 , s. 73 , it is enacted, $24 \& 25$ Vict. thatc. 96, s. 73 .

"Whosoever being an officer or servant of the gov- Embezzleernor and company of the Bank of England or of the ment by Bank of Ireland, and being intrusted *with $(r)$ [*535] ofticers of the any bond, deed, note, bill, dividend warrant or warrant England or for payment of any annuity or interest or money, or Ireland. with any security, money or other effects $(s)$ of or belonging to the said governor and company, or having any bond, deed, note, bill, dividend warrant, or warrant for payment of any annuity or interest or money, or any security, money or other effects of any other person, body politic or corporate, lodged or deposited with the said governor and company, or with him as an officer or servant of the said governor and company, shall se crete, embezzle or run away with any such bond, deed, note, bill, dividend or other warrant, security, money or other effects as aforesaid or any part thereof, shall be guilty of felony; and being convicted thereof, shall be liable at the discretion of the court to be kept in

(q) Supra, p 523.

(r) A person eannot be convicted under this Act who merely has access to notes, \&c., but is not intrusted with them, Bakevell's Cuse, liuss. \& Ry. 35; and see Phillips v. Huth, 6 M. \& W. 57:; Hatfeld v. Phillips, 14 M. \& W. 665 .

(s) In R. v. Aslett, 1 Bos. \& P., N. R. 1, it was held, that Exeherer bills, signed by a person not anthorized to sign them, were effects within the meaning of this Aet. And it was also held that 39 Geo. 3 , c. 85 , did not repeal 15 Geo. 2 , c. 13 . 
penal servitude for life, or for any term not less than [five years, $27 \& 28$ Vict. c. 47 ], or to be imprisoned for any term not exceeding two years, with or without hard labour, and with or without solitary confinement."

$24 \& 25$ Vict. And by stat. $24 \& 25$ Vict. c. 98 , s. 6 , it is enacted c. 98, s. 6 .

Clerks of the "Whosoever being a clerk, officer or servant of or Bank making other person employed or intrusted by the gorernor out false dividend warrapts. and company of the Bank of England, or the governor and company of the Bank of Ireland, shall knowingly make out or deliver any dividend warrant or warrant for parment of any annuity, interest or money payable at the Bank of England or Ireland, for a greater or less amount than the person on whose behalf such warrant shall be made ont is entitled to, with intent to defraud, shall be guilty of felony; and, being convicted thereof, shall be liable, at the discretion of the court, to be kept in penal servitnde for any term not exceeding seven years, and not less than [five years, $27 \& 28$ Vict. c. 47], or to be imprisoned for any term not exceeding two, years, with or withont hard labour, and with or without solitary confinement."

\section{Offences by Officers and Servants employed by or tader. the Post-Office.}

7 Will. $4 \& \quad$ By the stat. 7 Will. 4 \& 1 Vict. c. 36 , which consoli1 Vict. c. 36 , dated the law relating to the post-office, it is enacted, s. 25 . sect. $25 .--$

Opening or

"That every person employed by or under the postdelaying post office $(t)$ who shall, contrary to his duty, open or proletters a mis- [ $\left.{ }^{*} 536\right]$ cure or suffer to be opened a post letter, *or demeanor. shall wilfully detain or delay or procure or suffer to be detained or delayed a post letter, shall in England and Ireland be guilty of a misdemeanor, and in Scotland of a crime and offence, and, being covicted thereof, shall suffer such punishment by fine or imprisonment or by

Proviso. both as to the court shall seem meet. Provided always, that nothing herein contained shall extend to the opening or detaining or delaying of a post letter returned for want of true direction: or of a post letter returned by reason that the person to whom the same shall be directed is dead or cannot be found, or shall have re fused the same, or shall have refused or neglected to pay the postage thereof, nor to the opening or detaining or delaying of a post letter in obedience to an ex

( $t$ ) See post, p. 53\%. 
press warrant in writing under the hand (in Great $r$ Will. 4 \& Britain) of one of the principal secretaries of the state; 1 Vict. c. : and in Ireland ander the band and seal of the Lord s. 25. Lieutenant of Ireland."

Sect. "26. "That every person employed nnder the Scet. 26 . post-office who shall steal or shall for any purpose Embezzlewhatever embezzle, secrete $(u)$, or destroy a post letter ment, \&c., shall in England and Ireland be guilty of felony, and of any letter in Scotland of a high crime and offence, and shall, at or packet, the discretion of the court, either be transported beyond the seas for the term of seven years $(x)$, or be imprisoned for any term not exceeding three years; and if any such post letter so stolen or embezzled, secrete 1 or destroyed, shall contain therein any chattel or money whatsoever, or any valuable security, every such offender shall be transported beyond the seas for life."

By sect. 32. For the protection of printed votes and Sect. 3\%. proceedings in Parliament, and printed newspapers sent by the post, it is enacted, that-

"Every person employed in the post-office who shall steal, or shall, or for any purpose, embezzle, secrete $(y)$ Stealing, \&c., or destroy, or shall wilfully detain or delay, in course rotes or proof conveyance or delivery thereof by the post, any ceedings in printed votes or proceedings in parliament, or any parliament, printed newspaper, or any other printed paper what- or other ever sent by the post without covers, or in covers open printed at the sides, shall, in England and Ireland, be guilty paper, misof a misdemeanor, and in Scotland of a crime and of. demeanor. fence, and, being convicted thereof, shall suffer such punishment by tine or imprisonment, or by both, as to the court shall seem meet."

*Since the passing of this Act of Parliament, [*537] Embezaling which contains no provision for the punishment of em- jostage of bezzlement of monies received for postage, it is usual letters. $(z)$ to indict and proceed against persons in the employ

(u) In an indictment for secreting a letter, it is not necessary to state the purpose for which the letter was seereted, R. v. H'ynn, 2 C. \& K. 859. In that case a person employed in the post-oflice committed a mistake in the sorting of two letters containing money, and to a void a supposed penalty attuehed to such a mistake ho threw the letters unopened and the money down a water-closet. He!d by all the judges, that there was a larceny of the letters and money; and also a "secreting" of the letters within this statute. And see $R$. v. Poynton, 32 J. J., M. C. 29; Leigh \& C. 247 , where the prisoner put a letter in his pocket, instend of delivering it, at once produced it unopened, he was nevertleless convicted.

$(x)$ See now $20 \& 21$ Vict. c. 3 , which subst itutes penal servitude.

(y) See R. v. Wynn, 2 C. \& K. 859, supra, note (u).

(z) R. v. Townsend, Carr. \& M. 178, ante, p. 532, noto (m). 31 IIS. \& SEr. 
of the post-office who commit that offence under the provisions of the Acts relating to embezzlement by public servants. See now $24 \& 25$ Vict. c. 96, s. 70 , ante, p. 532 .

Evidence of acting as servant sufficient.

But prisoner must have been a servant of the post-oficice.

Servant employed in receivinghouse not such a servant.

Alitr, person hired by post-mistress to carry letters.

Meaning of "person employed by or under the post-office." "Officer of" the postoffice.

$R$ v. Reason.

To convict a person under the 7 Will. $4 \& 1$ Vict. c. 36 , evidence of acting in the employ of the post-office would be sufficient evidence of such employment, with out proof of any formal appointment $(a)$, though, in an Irish case, it was held that some proof of acting with the sanction of the post-office authorities was necessary (b). Moreover, the prisoner must have been a servant in the employ of the post-office when he committed the offence imputed to him (c). And therefore it was held, under the old Post-Office Act, 52 Geo. 3, c. 143, that a servant employed at a receiving-house to clean boots, \&c., and who used to assist in tying up and sealing the post-office bag, was not a servant of the postoffice $(d)$.

But a man employed by the post-mistress to carry letters from one place to another at a weekly salary paid to him by the post-mistress, but which was repaid to her by the post-office, was held to be a person employed by the post-office within that Act $(e)$. And now, by the interpretation clause of 7 Will. $4 \& 1$ Vict. c. 36 , the expression "persous employed by or under the postoffice" shall include every person employed in any business of the post-office, according to the interpretation given to the expression "officer of the post-office," and that expression shall include the postmaster-general and [*538] every deputy postmaster, agent, *officer, clerk, letter-carrier, guard, post-boy, rider or any other person employed in any business of the post-office, whether employed by the postmaster-general, or by any person under him, or on behalf of the post-office.

The prisoner was employed under the post-office as letter-carrier from $\mathbf{C}$. to $\mathbf{F}$. The letters were delivered to him in a sealed bag, which it was his duty to deliver, as he received it, to the postmaster at F., and, on such delivery, his duty was completed. One day he brought from $C$. the sealed bag containing letters, and delivered it safely at F. post-office, to the F. postmaster, whose

(a) R. v. Rees, 6 C. \& P. 606 ; R. v. Borrett, 6 C. \& P. $124 ; R$. v. Tounsend, Carr. \& M. 178.

(b) R. v. Trenwyth, Ir. Circ. Rep. 172, sed quare.

(c) But he need not have embezzled it whilst in the employ, $R$. v. Lovell, 2 Moo. \& Rob 236.

(d) R. v. Pearson, 4 C. \& P. 572.

(e) R. v. Salisbury, 5 C. \& P. 155. 
duty it was to sort the letters in time to make up the bags for the mail passing through $F$. The prisoner, at the request of $\mathrm{F}$. postmaster, assisted in sorting, and while so doing, stole a letter containing $1 l$. It was held that he was a person employed under the post-office within the meaning of 7 Will. $4 \& 1$ Vict. c. 36 , s. $26(f)$.

By 7 Will. $4 \& 1$ Vict. c. 36 , s. 47 , the term post let- What is a ter shall mean any letter or packet transmitted by the "post post under the authority of the postmaster-general, and letter." a'letter shall be deemed a post letter from the time of its being delivered to a post-office to the time of its being delivered to the person to whom it is addressed; and the delivery to a letter-carrier or other person authorized to receive letters for the post shall be a deiivery to the post-office, and a delivery at the house or office of the person to whom the letter is addressed, or to him, or to his servant, or agent, or other person considered to be authorized to receive the letter, according to the usual manner of delivering that person's letters, shall be a delivery to the person addressed.

Under this Act it has been held that a post letter means a letter put in the ordinary way into the postoffice. And, therefore, where $(g)$ a letter-carrier was Trap letter. suspected, and, for *the purpose of trying his [*539] honesty, an assistant inspector of letter-carriers enclosed $R . r$. Ratha marked sovereign in a letter addressed to Mr. M., then sealed the letter, and marked it, as if it had been put into the post in the regular way as a paid letter, but it never was posted: on the following day, whilst the prisoner was not attending, the letter was put amongst a heap which he had to deliver, and the prisoner was seen to take the letter into his possession, but never delivered it, and the marked sovereign was found in his pocket: it was held by all the judges, that he could not be convicted of stealing a "post letter." And a smilar deci- Fietitions sion was made, under similar circumstances, where such address.

(f) R. v. Reason, 23L. J., M. C. 11 ; Jurist (1853), 1014 ; Dears. C. C. 226 .

(g) $R$. v. Rathbone, Carr. \& M. 220 ; 2 Moo. C. C. 242 ; ace. $R$. v. Shepherd, Dears. C. C. 606 ; 25 L. J., M. C. 52. In this case the prisoner was a suspected sul)-sorter at the General l'ost Ofice. A letter was made up, cash enclosed, and the usual stamp put on the letter. The usual course of posting a letter at the outer hall of the General Post Office is to place it in the receiving box. In this case, however, an inspector delivered the letter at the window in the outer hall to another inspeetor, who handed it to a third, who, after loeking it up for the night, landed it to a sorter, who placed it anong the letters which it was prisoner's duty to sort. The prisoner was convicted of simple larceny. 
R.v. Gardner. a letter had an entirely fictitions address $(h)$. In both the above cases, however, the prisoners were convicted

R. v. Young. of larceny. And, in a subsequent case, where such a letter was posted, although with a fictitious address, the prisoner was convicted (i).

R. v. Mence. A servant was sent to the post with a letter and a penny to prepay the postage, but finding the shop-door of the receiving house shut, she put the penny inside the letter, fastened it in with a pin, and dropped it into the letter box, intending that the penny should be applied to the payment of the postage. A messenger, in the General Post Office, stole this letter, with the money in it, and Lord Denman held, that it came within the description of the Act of Parliament, viz., a letter containing money, although the money was not put in for the purpose of being conveyed in the letter $(k)$.

R. v. Bick- S., postmistress at G., received a letter from D., with erstaff.

1l. for a post-office order, to be obtained at L., 3d. for the poundage, $1 d$. for the postage, and $1 d$. for the messenger, who was to get the order. The letter when received by S. was unsealed, but addressed; she in due course delivered it to the prisoner, who was the post. [*540] office messenger, with *the money, and in. structed him to obtain the order at L., enclose it in the letter and pest the letter at $\mathrm{L}$. $\mathrm{He}$ pocketed the money and never delivered the letter at $L$.; and it was held by Cresswell, J., that under these circumstances the letter must be considered as a post letter, and the prisoner in the employ of the post-office; and he was convicted under the statute $(l)$.

Bat in another case $(\mathrm{m})$, where a person delivered R. v. Glass. two $5 l$. notes to the wife of the postmaster at C. (where money orders were not granted), and asked her to send them by the letter-carrier from C. to W., in order that he might get two $5 l$. money orders at the W. postoffice: she gave instructions accordingly to the lettercarrier, and by his desire put the notes into his bag; but he afterwards took them out, and pretended he had lost them (having had no intention of stealing them at the time he received them): it was held by the fifteen judges that this was not larceny, the notes not being in

(h) R. v. Gardner, 1 C. \& K. 623; but see R. v. Neney, ib. 630, note; R. v. Young, 2 C. \& K. 466.

(i) R. v. Young, 2 C. \& K. 466.

(k) R. v. Mence, Carr. \& M. 234.

(l) R. v. Bickerstaff, 2 C. \& K. 761.

(m) R. v. Glass, 2 C. \& K. 395. 
the possession of the prisoner in the course of his duty as a post-office servant.

A post-office being at an inn, a person was sent to put a letter containing promissory notes into the post. R. v. Harky. He took it to the inn with money to prepay the postage: he did not put into the letter-box, but laid the letter with the money upon it upon a table in the passage of the inn, in which passage the letter-box was, and pointed out the letter to the prisoner, who was a female servant in the inn, who said "she would give it to them." The prisoner, who was not authorized by the innkeeper, her master, to receive letters for him, stole the letter and its contents: and Patteson, J., held that this was not a post letter within the meaning of the Act; so the prisoner was convicted of larceny $(n)$.

By the 11 \& 12 Vict. c. 88 , s. 4 , it is enacted that $11 \& 12$ Vict. every officer of the post-office who shall grant or issue c. 88. any money-order with a fraudulent intent shall, in Penalty on England and Ireland, be guilty of felony, and in officers of Scotland, * of a high crim $\Theta$ and offence, and [*541] post-office shall, at the discretion of the court, either be trans- money orders ported $(o)$ beyond the seas for the term of seren years, frauduor be imprisoned for any term not exceeding three lently. years.

By sect. 5, the property in anything stolen from the post-office may be laid, in indictments, \&c., as in "her Majesty's Postmaster-General,"- without any further or other description whatsoever.

\section{Clerks of Courts utterina False Copies or Certifi- CATES OF RECORDS.}

By $24 \& 25$ Vict. c, 98, which consolidated the law $24 \& 25$ Vict. relating to forgery, it is enacted, sect. 28 , that- $\quad$ c. 98, s. 28 .

"Whosoever being the clerk of any court or other Forging officer having the custody of the records of any court, copies or or being the deputy of any such clerk or officer, shall certiticutes of ntter any folse copy or certificate of any record, knowing records, ntter any false copy or certificate of any record, knowing process of the same to be false, and whosoever other than such courts not of clerk, officer or deputy shall sign or certify any copy or records, and certificate of any record as such clerk, officer, or deputy, ${ }^{11 s i n g}$ forged and whosoever shall forge or fraudulently alter or offer, utter, dispose of or put off, knowing the same to be forged or fraudulently altered, any copy or certificate of any record, or shall offer, utter, dispose of or put off

(n) R. v. Harley, 1 C. \& k. 89.

(o) Sce now $20 \& 21$ Vict. c. 3 , substituting penal servitude. 
any copy or certificate of any record, having thereon any false or forged name, handwriting or signature, knowing the same to be false or forged, and whosoever shall forge the seal of any court of record or shall forge or fraudulently alter any process of any court other than such courts as in the last preceding section mentioned, or shall serve or enforce any forged process of any court whatsoever, knowing the same to be forged, or shall deliver or cause to be delivered to any person any paper falsely purporting to be any such process or a copy thereof, or to be any judgment, decree or order of any court of law or equity, or a copy thereof, knowing the same to be false, or shall act or profess to act under any such false process, knowing the same to be false, shall be guilty of felony, and being convicted thereof shall be liable, at the discretion of the court, to be kept in penal servitude for any term not exceeding seven years, and not less than [five years, 27 \& 28 Vict. c. 47 ], or to be imprisoned for any term not exceeding two years, with or without hard labour, and with or without solitary confinement." 
1872 . . . . . . . . . . . . .

PAGR

\section{JURISDICTION OF JUSTICES GeNeraLLY.}

The jurisdiction of justices in disputes between masters and servants formerly depended on the Master and Servant Act, 1867, and the statutes 20 Geo. 2, c. 19,6 Geo. 3, c. 25 , and 4 Geo. 4, c. 34 . Those statutes, however, which were treated of at length in the previous edition of this work, were all repealed in 1875 , and the law upon the subject placed upon a more satisfactory footing by the Conspiracy and Protection of Property Act, $1875(a)$, and the Employers and Workmen Act, 1875 (b). As those Acts and the rules under the latter are printed at length in the Appendix it is thought sufficient in this place to refer generally to them.

A person convicted under these Acts who has reason Habcas to think he is wrongly convicted, may apply for a habeas corpus; corpus ad subjiciendum; or, to save the expense of his or rule to being brought up on habeas corpus, a rule may be ob- show (ause tained on his behalf from either of the courts at West- why one minster, f calling on the justices, the prosecutor, and issue. the keeper of the gaol in which he is confined, to shoy cause why a habeas corpus should not be issued, or why he should not be discharged out of custody with. out being brought up. Notice of this *rule [*543] must be given to all the parties. But if no cause bo shown, a habeas corpus must still be issued before the prisoner can bo discharged $(c)$.

(a) $33 \& 39$ Viet. c. 86 .

(b) 38 \& 39 Vict. c. 90.

(c) In E.x parte Cross, 2 H. \& N. 3is, Pollock, C. B., in granting a rule of this sort in the Court of Exchequer, referred to $F x$ partc Martins, 9 Dowl. 194, in which Patteson, J., " was informed by one of the Masters of the Crown Ofice, that it was never the 
Return to

habeas eorpu showing both warrants sufficient.

R. v.

Richards.

sccond good warrant. return.
Affidavits on

Where a return by a gaoler to a habeas corpus set forth a bad conviction and warrant of a justice under 4 Geo. 4, c. 34, and also proceeded to set forth a good conviction and warrant under that statute (which was delivered a week after, though dated the same day as the first), it was held that the prisoner was not entitled to be discharged $(d)$.

And where a writ of habeas corpus, was obtained upon an affidavit setting out a bad warrant, a second good warrant was allowed to be substituted for it on the return to the writ $(e)$.

Upon a return to a habeas corpus, it is open to the prisoner to show by affidavit that there was no evidence from which the justice might reasonably draw an infer. ence that the relation of master and servant existed between the prisoner and his employer, as that would show that the justice had no jurisdiction. But if the affidavits show evidence both ways, the prisoner will be remanded $(f)$. And affidavits will not be permitted to show that the offence was committed beyond the jurisdiction of the justice. That is a question of fact which must be tried by him at his peril $(g)$. Where a warrant is good on the face of it, it is doubtful whether affidavits are admissible raising objections not [*544] *appearing on the warrant, as, for instance, disclosing a former conviction for the same offence $(h)$.

\section{Aubitration of Disputes between Masters and WORKMEN.}

The stat. 5 Geo. 4, c. 96, which consolidated, and 6Geo. 4, c. 96. with the Arbitration (Masters and Workmen) Act, 1872

practice in the Queen's Bench to waive the necessity of a party appearing before the court on a habeas eoryus, where the validity of the commitment is to be discussed, and, thongh he regretted that the defendant should be pnt to the expense of a habers corpus, said he conld not alter the practice in that particular." "However," said Pollock, C. B., "we have adopted a difterent practice." The case of Ex paite Jaeklin, 2 D. \& L. 103, in which Coleridge, J., granted such a rule, and the note of the reporter to that case, "that the same course had been adopted in several late cases," were not called to the attention of the Chief Baron. The practice now seems to be similar in all the courts. In $E r$ parte Geswood, 2 E. \& B. 952, the validity of the commitment was discussed, and the prisoner ordered to be discharged withou being brought personally into court.

(d) R. v. Richarls, 5 Q. B. 926.

(e) Ex parte Smith, 27 L. J., M. C. 186.

(f) Re Bailey, 3 E. \& B. 60 \%.

(g) Ex parte Smith, 27 L. J., Mi. C. 186.

(h) Ex parte Baker, 27 L. J., H. C. 155 ; 2 H. \& N. 219.

$(550)$ 
(i), now regulates the law relative to the arbitration of disputes between masters and workmen, also gives to justices $(k)$ cortain powers in such cases; and it is, therefore, conceived, that the prorisions of that statute may most appropriately be brought before the reader in this place $(l)$. But it must be observed, in the first place, that the Councils of Conciliation Act, $1867(\mathrm{~m})$, does not repeal the 5 Geo. 4 , c. 96 .

The first section was repealed by $36 \& 37$ Vict. c. 91 . The act then proceeds (sect. 2) to enumerate the causes of dispute which may be referred to arbitration in the following terms :-

2. That the following subjects of dispute arising be- Causes of tween master and workmmen, or between workmen and dispute that those employed by them, in auy trade or manufacture, may be in any part of the United Kingdom of Great Britain and Ireland, moy $(n)$ be settled and adjusted in manner hereafter mentioned; that is to say, disagreements respecting the price to be paid for work done, or in course of being done, whether such disputes shall happen or arise between them respecting the payment of wages as agreed upon, or the hours of work as agreed upon, or any injury or damage done or alleged to have been done to the work, or respecting any delay or supposed delay in finishing the work, or the not finishing the work in a good and workmanlike manner, or according to any contract, or to bad materials ; * cases [*545] where the workmen are to be employed to work any new pattern which shall require them to purchase any new implements of manufacture, or to make any alteration upon the old implements, for the working thereof, and the masters and workmen cannot agree upon the com. pensation to be made to such workmen for or in respect thereof; disputes respecting the length, breadth or

(i) Post, p. 5i;3.

(k) By 7 Will. 4 \& 1 Vict. c. 67, s. 3 , it is enacted, that wherever the expression "justice of the peace" ocenrs in 5 Geo. 4 , c. 96, it shall be construed to mean "magistrate."

(l) By $19 \& 20$ Vict. c. 46, it is enacted, that notling contained in 5 \& 6 Will. 4, c. 70 (an Aet for abolishing in Scotland injprisonment for civil debts of small amount) shall apply to imprisonment under 5 Geo. 4 , c. 96.

(m) 30 \& 31 Vict. c. 105 . Sec this Act, post, p. 556.

(n) Upon the question as to how far this is rompulsory and ousts the jurisdiction of the superior court when an arbitration is demanded under sect. 3, the following ases may be consulted with advantage, though they did not arise under this act : Crisp v. Bunbury. 8 Bing. 394 ; Ex parte Payme, 5 1). \& I. 679; Morrion v. Glover, 4 Exe. 430 ; Doe v. Glover, 15 Q. 13. 103 ; and IP Dougal v. Paterson, 6 Exc. 33\%, note; 2 I. M. \& 1. 681. 
5 Geo. 4, e. 96. quality of pieces of goods, or in the case of cotton manufacture, the yarn thereof, or the quantity and quality of the wool thereof; disputes respecting the wages or compensation to be paid for pieces of goods that are made of any great or extraordinary length; disputes in the cotton manufacture respecting the manufacture of cravats, shawls, policat, romal and other handkerchiefs, and the number to be contained in one piece of such handkerchiefs ; disputes arising out of, for or tonching the particular trade or manufacture or contracts relative thereto, which cannot be otherwise mutually adjusted and settled; disputes between mas. ters and persons engaged in sizing or ornamenting Justices not goods ; but nothing in this act contained shall authoto establish a rize any justice or justices acting as hereinafter menrate of wages tioned, to establish a rate of wages, or price of labour, withont $\quad$ or workmanship at which the workmen shall in future

Limitation of be paid, unless with the mutual consent of both master time within and workmen; provided always, that all complaints by which work- any workmen as to bad materials shall be made within men to lodge three weeks of his recoiving the same, and all com. ther com- plaints arising from any other cause shall be made
plaints. within six (o) days after such cause of complaint shall arise. 3. That whenever such subjects of dispute shall
of reintment arise as aforesaid, it shall be lawful for the master and of referees. workman, or either of them; to demand and have an arbitration or reference thereof, in manner following, that is to say, where the party complaining and the party complained of shall come before or agree by any writing under their hands to abide by the determination of any justice of the peace or magistrate of any county, riding, division, stewartry, barony, city, burgb, town or place within which the parties reside $(p)$, it shall and may be lawful for such justice of the peace or magistrate to hear and finally determine in a summary manner the matter in dispute between such parties; but if such parties shall not come before or so agree to abide by the determination of such justice of the peace or magistrate, then it shall be lawful for any such justice or magistrate, and such justice of the peace or magistrate is hereby required, on complaint made before him and proof by the examination of the party making such complaint, that application has been made

(o) Extended to fourteen days by 7 Will. 4 \& 1 Vict. e. 67.

(p) By 7 Will. $4 \& 1$ Viet. e. 67 , s. 2 this power may be exercised by the justices or magistrates of the district where the party complained against resides. 
to the person or persons against whom such canse of 5 (ieo.4, (. 96 . complaint has arisen, or his, her or their agent or agents, if such dispute has arisen with such agent or agents, to settle such dispute, and that the same has not been settled upon such complaint being made, or, where the dispute relates to a bad warp, that such cause of complaint has not been done away with *within [*546] forty-eight hours after such application, to summon before him such person or persons, or agent or agents, on some day not exceeding three days, exclusive of Sunday, after the making such complaint, giving notice to the person making such complaint of the time and place appointed in such summons for the attendance of such person or persons, agent or agents as aforesaid; and if at such time and place the person or persons so sum. moned shall not appear by himself, herself or themselves, or send some person on his, her or their behalf to settle such dispute, or appearing shall not do away such cause of complaint, then and in such case it sháll be lawfull for such justice, and he is hereby required, at the request of either of such parties, to nominate arbitrators or referees for settling the matters in dispute, and such justice shall then and there at such meeting propose not less than four nor more than six persons, one-half of whom shall be master manufacturers or agents or foremen of some master manufacturer, and the other half of whom shall be workmen in such manufacture, such respective persons residing in or near to the place where such disputes shall have arisen; out of which master manufacturers, agents or foremen the master engaged in such dispute or his agent shall choose one, and out of which workmen so proposed the workman or his agent shall choose another, who shall have full power to hear and finally determine such dispute.

4. That in case any or either of the persons so pro- Regulations posed by any such justice shall refuse or delay to ac- for appuintcept such arbitration, or accepting shall not act therein ment of other within two days after such nomination, the justice shall proceed to name another or other persons of the descriptions aforesaid in the room of the person so refusing as aforesaid to be arbitrator or arbitrators in the place of any such arbitrator or arbitrators so refusing or delaying to accept or who shall not act; and in every accrepting do case of a second nomination the arbitrators shall meet not ant within twenty-four hours after the application for the therein. same, and at the same place at which the meeting of the referees first named was appointed, or at some other con- 
5 Geo.4, c. 96. venient place as the justice may appoint; and the expense of every such application for the appointment of a second referee shall be borne and defrayed by the party through whose default or the default of whose referee such ap. plication is rendered necessary, and the justice making such second appointment shall certify the same in the form for that purpose set forth in the act $(q)$ or in some other form to the like effect; and in every case where a second arbitrator shall be appointed as aforesaid, and such second arbitrator shall not attend at the same time and place appointed for settling the matters in dispute, it shali be lawful for the other arbitrator at such time and place to proceed by himself to the hearing and deter. mining of the same matters in dispute; and in such case the award of such sole arbitrator shall be final and conclusive as to all matters in dispute submitted to such arbitrator, withont being subject to review, appeal, or suspension.

Neeting of referees.

Notice of which to be given.

Place for the meeting of the referees.

Attendance parties.
5 . That the arbitrators or referees being so nominated as aforesaid, the said justice shall thereupon appoint $\left[{ }^{*} \tilde{5} 4 \overline{7}\right]$ a place of meeting according to the *directions of this act, and also a day for the meeting; notice of which nomination and of the day of meeting shall thereupon be given by such justice to the persons so nominated arbitrators or referees, and to any party to any such dispute who may not have attended the meeting before such justice as aforesaid; which appointment shall be by such justice certified in the form there given $(r)$, or in some other form to the like effect; and the person so appointed as aforesaid shall hear and examine the parties and their witnesses and determine such dispute within two days after such nomination, exclusive of Sundays; and the determination of such arbitrators shall be final and conclusive.

6. That in all cases where complaints are made respecting bad warps or utensils by workmen, the place of meeting of the referees shall be at or as near as may be to the place where the work shall be carrying on; and in all other cases at or as near as may be to the place or places where the work has been given out.

7. Provided, that if any person so complaining as aforesaid shall not attend or send some person on his or her behalf at the time and place appointed by such justice of the peace for the purpose of naming such persons as aforesaid, such person shall not in such case

(q) See the form in the appendix.

(r) See this form in the Appendix. 
be entitled to the benetit of this act; and if any person 5 (ieo.t, $\because 9$;. against whom any such complaint shall have been made as aforesaid shall not attend or send some person on his or her bebalf, the justice of the peace shall thereupon nominate a person for him out of such persors so proposed as aforesaid.

8. That the said arbitrators and referees shall met Node of at the time and place fixed by the justice of the peace investifation by whom such referees were appointed, and shall by of complaint inspection of the work in regard to which the dispute by arbitrator. may have arisen, by hearing and examining the parties, or any other persons on their behalf, or that attend to give evidence respecting the matters in dispute, upon oath (which the said arbitrators and referees are hereby empowered to administer) or otherwise, or by otherwise ascertaining the true state of the cuse in such manner as to such arbitrators and referees shall appear necessary, proceed to determine the matter or matters in dispute referred to them; and the award to be mado by such arbitrators and referees shall be final and conclusive between the parties without being subject to review or challenge by any court or authority whatsoever.

9. That it shall be lawful for any arbitrator or arbitrators, referee or referees, and he or they are hereby Arrest and anthorized and required at the request in writing of of refractory any of the parties, to issue his or their summons to any witnesses. witness or witnesses to appear and give evidence before snch arbitrator or arbitrators, referee or referees, at the time and place appointed for hearing and determining any such dispute, and which time and place shall be specified in such summons; and if any person so summoned to appear as a witness as aforesaid, shall not appear before such arbitrator or arbitrators, referee or referees, at the time and place specitied in such summons, or offer some reasonable excuse for the default, or appearing *according to such summons sball [*548] not submit to be examined as a witness and givo his evidence before such arbitrator or arbitrators, referee or referees, touching the matter of such dispute, then and in every such case it shall be lawful for any one or more of his majesty's justices of the peace acting in and for the county, stewartry, riding, division, barony, city, burgh, town or place where such dispute shall have arisen, and they are hereby authorized (proof on oath in the case of any person not appearing according to such summons having been first made before such justioe or justices of the due service of such summons on every such person by delivering the same to him, or 
5 Geo.4, c. 96. by leaving the same twenty-four hours before the time appointed for such person to appear before such arbitrator or arbitrators, referee or referees, at the usual place of abode of such person) by warrant under the hands of any such justice or justices to commit any such person so making default in appearing, or appear. ing and refusing to give evidence, to some prison with. in the jurisdiction of any such justice or justices, there to remain without bail or mainprize for any time not exceeding two calendar months, nor less than seven days, or until such person shall submit himself to be examined, and give his evidence before such arbitrator or arbitrators, referee or referees as aforesaid: provided Proviso. always, that in case such dispute shall be heard and determined before such offender shall submit to be ex. amined and give evidence as aforesaid, then and in every such case he, she or they shall be imprisoned the full term of such commitment.

Adjourn- 10. That in case such arbitrators and referees so apment of com- pointed cannot agree upon and decide such matter or plaint from matters in dispute so referred as aforesaid, or shall not referees to a justice; make and sign their award within three days after the date of the order of such justice certifying their appointment, then the said arbitrators and referees shall without delay go before the justice by whom they were appointed, and in case of his absence or indisposition, before any other of his majesty's justices of the peace acting in and for the county, stewartry, riding, division, barony, city, burgh, town, liberty or place, and residing nearest to the place where the meeting to settle such dispute shall have taken place, and shall state to such justice or justices who may be present the points in difference between them the said arbitrators and referees, which points in difference the said justice or justices shall and is and are hereby authorized and required to hear and determine upon the statement of the arbitrators and referees; and the said justice or justices is and are hereby directed and required to settle and determine the matter in dispute with all possible dispatch, and, in all cases, within the space of two days after the expiration of the time hereby allowed to the arbitrators

whose determination final. and referees, to make and sign their award; and the determination of such justice or justices shall be final and conclusive between the parties so differing as aforesaid, without being subject to review or challenge by any court whatsoever.

11. That if either arbitrator or referee shall neglect or refuse to go before such justice of the peace in the 
manner herein directed, it shall any may be lawful for $5 \mathrm{Geo.4,c.} 96$. such justice, after summoning the arbitrators to attend Proceeding him, to determine the matter or matters in dispute upon where one the *statement and representation of either of the [*549] referee rearbitrators who shall come before him.

12. Provided always, that no justice of the reace, be- jetore ing also a master-manufacturer or agent, shall ac $t$ as Master not to such justice under this act.

13. Provided always, that as well in all such cases of dispute as aforesaid as if all other cases, if the parties Disputesmay mutnally arre that the matter in disputo shall be ar by adjusted bitrated and determined in a different mode to the one mode of hereby prescribed, such agreement shall be valid, and apbitration which the award and determination thereon final and conclu- the parties sive between the parties; and the same proceedings of may agree. distress, sale and imprisonment as hereafter mentioned shall be had towards enforcing such award (by application to any justice of the peace of the county, stewartry, riding, division, barony, city, town, burgh or place within which the parties shall reside) as are by this act prescribed for enforcing awards made under and by virtue of its provisions.

14. Provided always, that where any work shall have Partners, been delivered to any workman by the agent or servant agents and of any master or masters to be, when finished, deliv. servants to be ered to such agent or servant; and also where two or considered more persons shall carry on the business of such man. ufacture as partners; in every such case respectively the like proceedings shall and may be had and made against such agent, servant or partner, and shall be as effectual as if the same had been had and made against the principal or all the partners; and all the said persons respectively shall obey the award made thereupon, and all such order or orders as shall be made by the said justice or justices in or respecting the matters in 'dispute, and shall be subject to the same proceedings and consequences for refusing or delaying to abide by or perform the same as if the proceedings had been had against the principal or against all the partners.

By sect. 15 it is enacted, that it shall be lawful in all Master not cases for any master or workman by writing under his resident may band to authorize any person to act for him in submit. depute ting to arbitration, and atrending arbitrators or justices, another touching the matter of any arbitration.

16. Provided also, that in all cases where any proceedings may be had against a master or masters under this act, or where such proceedings shall have been commenced, and the master or masters shall become or be 
5 Geo.4, c. 96. bankrupt, or any assignment of his or their estate or Provision for effects shall have been made under the said bankruptcy, the case of or otherwise by deed or in law, the factor or trustee the master becoming bankrupt after proceedings sommenced. upon, or the assignee or assignees of, such estate or effects shall be liable to the proceedings authorized by. this act against the master or masters, as fully as the master or masters was or were before the bankruptcy or assignment; and such proceedings may be commenced or carried on against such factor, trustee, assignee or assignees, who shall fulfil andabide by the award made thereupon, and all such order or orders as shall be made by the said justice or justices in or respecting the matters in dispute, and shall be subject to the same proceedings and consequences for wilfully refusing or delaying to abide by or perform the same, as if the proceedings had been had against the master or masters before his or their bankruptcy or the assignment of his [*550] *or their estate or effects: provided that all sums of money to be paid in pursuance of such award or orders shall be recoverable only out of the estate or effects of such master or masters, and not out of the proper money of such factor, trustee, assignee or assignees.

In whose name proceedings shall be, where the complainant is a married woman, or an infant.

Tickets of particulars to be given out with work.
17. That where any married woman or infant under the age of twenty-one years shall have cause of complaint in any of the cases provided for by this act against any master or masters, his or their agent or servant, or factor or trustee, or assignee or assignees, as aforesaid, such complaint may be lodged, and all further proceedings thereupon had, by and in the name of the husband of such married woman, and of the father, or if dead, of the mother, or, if on the death of both parents, of any of the kindred of any such infant, or of the surety or sureties in any indenture of apprenticeship of any such infant, being an apprentice, or of any person nominated by such infant, if he or she shall not have parent, kindred or surety; and all such proceedings shall be as effectual, valid and binding, as if such married woman was sole, and such infants were of full age, and pursued by themselves the remedies provided by this act.

18. That with every piece of work given out by the manufacturer to a workman to be done, there shall (if both parties are agreed) be delivered a note or ticket in such form as the said parties shall mutually agree upon, and which said note or ticket, in the event of dispnte between the manufacturer and workman, shall be evi 
dence of all matters and things mentioned therein, or is Geo.4, c. 96 . respecting the same $(s)$.

19. That a duplicate of every such note or ticket shall be made and kept by the master or agent deliver- Duplicates of ing the same, which duplicate shall be evidence of all the matter and things therein contained, in case the workman shall not produce to the arbitratore or the said justice, as the case may be, the said note or ticket so delivered to him with the said work.

20. That it shall not be allowable to any manufac- Manufacturer who shall have received into his possession any turers receivarticle, without objection made within twenty-four ing articles hours, by bimself, or his clerk or foreman, afterwards not to comto make any complaint on account of work so received. plain after-

21. Provided always, that if the parties, by and between whom the said reference shall take place as afore- Extention of seid, shall think it expedient or be desirous to extend time limited the time hereby limited for the making the award or award. umpirage, it shall and may be lawful for them to extend the same accordingly, by indorsement, according to the form in the schedule annexed to the act, on the back of the order of the justice of the peace certifying the appointment of the referees, to be signed by both of them, in the presence of one or more credible witness or wituesses.

22. That the award or umpirage to be made upon Form of any reference demanded under this act shall and may awarl. be drawn up and written at the * foot or upon [*5̃1] the back of the said order certifying the appointment of the referees, according to the form in the schedule to this act annexed $(t)$.

23. That upon fulfilment of the award or umpirage, on awned the same shall be acknowledged by the party in whose being finlbehalf the same was made, by an acknowledgement at filled, fultilthe foot of the said award in the form of the schedule ment to lne the foot of the said awa in the form of the sell to this act annexed, which, with the award, shall there- ceged. upon be delivered to the party fulfilling the same.

24. That if any party shall refuse or delay to fulfil Performince an award under this act for the space or term of two of award may days after the samo shall have been reduced into writ. le enfirced ing it shall be lawf for any such justice as a foresaid, ly distresy, on the application of the party aggrieved, and he is that, the bereby required by warrant under his hand, according party refusto the form in the schedule to the act annexed, or in ing shall he

(a) As to tiekets of work to be delivered to persons employed in the manufacture of hosicry, see $8 \& 9$ Vict. c. 77 ; and to silk werrers, 8 \& 9 Viet. c. 128 , in the Appendix.

( $t$ ) See these forms in the Appendix. 32 MAS. \& SER. 
5 Geo.4, c. 96 . some other form to the Jike effect, to cause the sum and imprisoned $(u)$.

In ecrtain cases the warrant of distress shall be withlield and the defaulter committer to prison.

On payment of the sinm awarded with costs, party discharged. sums of money directed to be paid by any such award, to be levied by distress and sale of any goods and chattels of the person or persons liable to pay the same, together with all costs and charges attending such distress and sale, such sale to take place within such time not exceeding five dass, as the said justice shall think proper, and the overplus, if any, to arise by such sale, to be rendered to the owners of the goods and chattles distrained; and in case it shall appear by any return to such warrant that no sufficient distress can be readily bad, which return may be in the form contained in the schedule to the act annexed, or in some other form to the like effect, it shall be lawful for any such justice is aforesaid, and he is hereby required, by warrant under his hand, according to the form in the schedule to the act annexed $(x)$, or in some other form to the like effect, to commit the person or persons so liable as aforesaid to the common gaol, or some house of correction within his or their jurisdiction, there to remain without bail for any time not exceeding three montbs.

By sect. 25, after reciting that cases may occur where the recovery of such sum or sums of money by distress and sale of the goods and chattels of the defaulter may appear to the justice or justices of the peace by whom the warrant is to be issued, to be attended with consequences ruinous, or in an especial manner injurious to the defaulter and his family; to prevent such consequences it is enacted, that the said justice or justices, in all such cases, shall withhold such warrant, and comnuit the defaulter to the common gaol, or some house of correction within his or their jurisdiction, there to remain without bail for any time not exceeding three months, such commitment to be in the form or to the effect of the form in the schedule to this act annexed $(x)$.

By sect. 26 it is enacted, that where any person shall be committed to prison for refusing or delaying to fultil [*552] an award as aforesaid, and such *person shall, at any time during the period of his or her imprisonment, pay to the governor or keeper of the prison the full amount of the sum awarded with all reasonable espenses incurred through such refusal or delay, it shall be lawful for such governor or keeper of such prison,

(u) These proceedings by distress, sale and imprisonment may be had towards enforcing awards under the Councils of Conciliation Act, $1867,30 \& 31$ Vict. c. 105 , s. 4 , post, p. $55 \%$.

(.x) See the form in the Appendix. 
and he is hereby required, forthwith to discharge such .j (iew. 4, c. HH). person from his custody.

27. That the justice or justices by whom any person Form of or persons shall be commited to prison for not appear- warrant of ing as a witness, or not submitting to be examined, shall cause the warrant or order for such commitment to be drawn up in the form or to the effect set forth in the schedule to this act.

28. That no appeal or certiorari shall lie against any xo appeal or proceedings under this act. (ertiorari.

29. That no proceedings under this act shall be in. Want of valid for want of form. form.

Section 30 provides a table of fees to be taken for Table of fees. proceedings under the act $(y)$, and enacts that a table of fees signed by the clerk to the justices shall be hung up in every place where any general or quarter sessions, or petty or other sessions of the peace, shall be held.

Section 31 enacts, that all costs, time and expenses Costs and attending the application to justices to be made under expenses how this act, and of the arbitration pursuant thereon, shall to be settled. be settled by the arbitrators or arbitrator by whom such dispute shall be settled, and where the same shall be determined by any justice of the peace, pursuant to this act, then the costs, tim 3 and expenses aforesaid shall be settled by such justice; and where the arbitrators appointed as aforesaid cannot agree as to the costs, time and expenses to be allowed, the same shall be settled by the justice or justices of the peace by whom the said arbitrators were named, and in case of his absence or indisposition, by any justice of the peace for the same county, stewartry, riding, division, barony, city, burgh, liberty, town or place nearest to the place at which the arbitrators met to settle the dispute; provided always, that no master manufacturer, his foreman or agent, sball in any case be allowed for costs, time or expenses by the said justice or justices, unless it shall appear to him or them that the proceedings of the workmen were vexations and oppressive.

32. Provided that every agreement, submission, award, ticket, matter or tining under and by virtue of this act,

(y) The following is the table of fees:-To the clerk of the justice or justices-for each summons, two pence; for every wath or allirmation, three pence; for drawing and entering the order, four pence; for every warrant, six pence. To the consteble or other preter officor-for serviee of summons or order, four pence; tor executing warrant of distress and sale of goods, one sluilling; for custody of goods distrained, per diem, three pence; for every mile he shall travel, three pence; for every caption, six pence. 
5 Geo.4, c. 96. or relating to any other mode of arbitration as aforesaid, Proceedings shall and may be drawn up and written upon unstamped exempt from paper.

stamp duty. [*553] *33. Provided also, that no action shall be Limitation of brought against any arbitrator, justice of the peace, conexecuting act. stable, headborough or other officer, or against any other: person or persons whomsoever, for any matter or thing whatsoever done or committed under or by virtue or in the execution of this act, unless such action shall be brought within six calendar months next after the doing or committing of such matter or thing.

In actions for 34. Provided also, that if any action or suit shall executing hereafter be commenced or prosecuted against any act.

General issue. person or persons for anything done under, by virtue or in execution of this act $(z)$, such person or persons may plead the general issue, and give this act and the special matter in evidence, and if the plaintiff shall become nonsuited, or suffer discontinuance or forbear further prosecution, or if judgment shall be given for the defendant or defendants, such defendant or defend.

Costs ants shall recover his, her or their full costs, and for which he, she or they shall have like remedy as in cases where costs by law are given to defendants.

Proviso for acts not hereby repealed.

35. Provided always, that nothing in this act contained shall extend or be construed to extend to repeal, abridge, annul or make void any of the clauses, pro. visions, remedies or powers contained in any law or statute now in force and not repealed by this act.

35 \& 36 Vict. By the Arbitration (Masters and Workmen) Act, e. 46 . $1872(a)$, after reciting 5 Geo. 4, c. 96, and that it is expedient to make further provision for arbitration between masters and workmen, it is enacted-

As to agreements under this act.

Sect. 1. The following provisions shall have effect with reference to agreements under this act:

(1.) An agreement under this act shall either designate some board, council, persons or person as arbitrators or arbitrator, or define the time and manner of appointment of arbitrators or of an arbitrator; and shall designate, by name or by description of office or otherwise, some person to be, or some person or persons (other than the arbitrators or arbitrator) to appoint an umpire in case of disagreement between arbitrators:

(2.) A master and a workman shall become mutually bound by an agreement under this act (here-

(z) Vide ante, p. 379 , note $(x)$.

(a) 35 \& 36 Vict. c. 46. 
inafter referred to as the "agreement") upon 3i \& 36 Vict. the master or his agent giving to the workman c. 46. and the workman accepting a printed copy of the agreement:

Provided that a workman may, within fortyeight hours after the delivery to him of the agree. ment, give notice to the master or his agent that he will not be bound by the agreement, and thereupon the agreement shall be of no effect as between such workman and the master:

*(3.) When a master and workmen are bound [*554] by the agreement they shall continue so bound during the continuance of any contract of em. ployment and service which is in force between them at the time of making the agreement, or in contemplation of which the agreement is made, and thereafter so long as they mutually consent from time to time to continue to employ and serve without having rescinded the agreement. Moreover, the agreement may provide that any number of days' notice, not exceeding six, of an intention on the part of the master or workman to cease to employ or be employed shall be required, and in that case the parties to the agreement shall continue bound by it respectively until the expiration of the required number of days after such notice bas been given by either of the parties:

(4.) The ageement may provide that the parties to it shall, during its continuance, be bound by any rules contained in the agreement, or to be made by the arbitrators, arbitrator, or umpire as to the rate of wages to be paid, or the hours or quantities of work to be performed, or the conditions or regulations under which work is to be done, and may specify penalties to be enforced by the arbitrators, arbitrator, or umpire for the breach of any such rule:

(5.) The agreement may also provide that in case any of the following matters arise they shall be determined by the arbitrators or arbitrator, viz:

a. Any such disagreement or dispute as is mentioned in the second section of the principal act; or

b. Any question, case or matter to which the provisions of the Master and Servant Act, $1867(b)$, apply;

(b) The Master and Servant Act, 1867 , was repealed by is \& 39 Vict. c. 86, s. 17, post, Appendix. 
$35 \& 36$ Vict. c. 46 . and thereupon in case any such matter arises between the parties while they are bound by the agreement the arbitrators, arbitrator, or umpire shall have jurisdiction for the hearing and determination thereof, and upon their or his hearing and determining the same no other proceeding shall be taken before any other court or person for the same matter; but if the disagreement or dis. pute is not so heard and determined within twen. ty-one days from the time when it arose, the ju. risdiction of the arbitrators, arbitrator, or umpire shall cease, unless the parties have, since the aris. ing of the disagreement or dispute, consented in writing that it shall be exclusively determined by the arbitrators, arbitrator, or umpire:

A disagreement or dispute shall be deemed to arise at the time of the act or omission to which it relates:

(6.) The arbitrators, arbitrator, or umpire may hear and determine any matter referred to them in such manner as they think fit, or as may be prescribed by the agreement:

(7.) The agreement, and also any rules made by the [*55] arbitrators, *arbitrator, or umpire in pursuance of its provisions, shall in all its proceedings as well before them as in any court, be evidence of the terms of the contract of employment and service between the parties bound by the agreement:

(8.) The agreement shall be deemed to be an agreement within the meaning of the thirteenth section of the principal act $(c)$ for all the purposes of that act:

(9.) If the agreement provides for the production or examination of any books, documents, or accounts, subject or not to any conditions as to the mode of their production or examination, the arbitrators, arbitrator, or umpire may require the production or examination (subject to any such conditions) of any such books, documents, or accounts in the possession or control of any person summoned as a witness, and who is bound by the agreement, and the provisions of the principal act, for compelling the attendance and submission of witnesses, shall apply for enforcing such production or examination.

Short title. 2. This act may be citer as "The Arbitration (Mas. ters and Workmen) Act, 1872. 


\section{*CHAP'TER X. \\ COUNCILS OF CONCILIATION.}

[*556]

Br 30 \& 31 Vict. c. 105 , which was passed in 1867 , and is intituled "An Act to establish Equitable Councils of Conciliation to adjust differences between Masters and Workmen," after reciting the 5 Geo. 4, c. 96 (a), and the several acts passed to amend the same, and reciting, that-

In order the better to facilitate the settlement of disputes between masters and workmen, it is expedient, without repealing the said several acts, that masters and workmen should be enabled, when licensed by her Majesty, to form equitable councils of conciliation or arbitration, and that the powers in the said acts con. tained for enforcing awards made under or by virtue of the provisions thereof should be extended to the enforcing of awards to be made by and under the authority of such equitable councils of conciliation,

proceeds to enact as follows:-

1. If any number of masters and workmen, in any particular trade or trades, occupation or employment, Power to her being inhabitant householders or part occupiers of any secretiry of house, warehouse, connting-house, or other property state to within any city, borough, town, stewartry, riding, di- license vision, barony, liberty, or other place, and who, being a conciliation. master in such trade, shall have resided and carried on tho same within any such place for six calendar months previous to the signing of such petition, and being a workman shall have resided for a like period within any such place, and shall have worked at his trade or calling for seven years previous to the signing of such petition, shall at a meeting specially convened for that purpose agree to form a council of conciliation and arbitration, and sball jointly petition her Majesty to grant them a licence to furm such council, to hold, bave and exercise all the powers granted to arbitrators and referees under the before-recited acts, and in such petition for the same shall set forth the number of the council, and also the names, occupation and residence of the petitioners, and the manner in which the ex.

(a) Ante, p. 544 . 
$30 \& 31$ Vict. penses of the said council and of the registry hereinc. 105. after directed are to be provided for, it shall then be lawful for her Majesty, or her Majesty's principal Secretary of State for the Home Department, to grant such licence, provided notice of such petition has been published one month before the application for such licence in the London Gazette, and in one or more of [*5j\%] the local newspapers of the place *whence each petition emanates: provided always, that it shali be lawful for any masters and workmen in any particular trade or trades, occupation, or employment as aforesaid, within the limits of the application of the Metropolitan Local Management Act, or within any two or more boroughs or districts of the metropolis, to associate themselves for the purposes of this act, and with such licence as aforesaid to form councils as aforesaid, as if they resided within any one borough or district.

Conncils to consist of not less than two nor more than ten masters and worknien, and a chairman.

Petitioners for conncil to elect first council.

Powers, \&c. of councils.

2. The said council shall consist of not less than two masters and two workmen, nor more than ten masters and ten workmen and a chairman; the number to constitute the said council to be inserted in the licence; but no member of the council shall adjudicate in any case in which he or any relation of his is plaintiff or defendant.

3. For the purposes of this act, the persons whose names, occupations and abodes are attached to the petition praying for a licence shall and they are hereby authorized to proceed to the appointment of a council of conciliation and arbitration from among themselves within thirty days after such grant of licence; and the said council shall remain in office until the appointment of a new council in its stead.

4. The council shall have power to appoint their own chairman, clerk or such other officer or officers as they may deem requisite, and shall have power to hear and determine all questions of dispute and difference between masters and workmen, as set forth in the before recited act of the fifth year of King George the Fourth, chapter ninety-six, which may be submitted to ther by both parties, and shall have, hold and exercise all the powers and authority granted to arbitrators and referees by and under the various enactments and provisions of the acts before recited; and any award the said equitable councils of conciliation and arbitration may make in any case of dispute or difference submitted to them under the before-recited act or acts, or under this act, shall be final and conclusive between the parties to such arbitration, without being subject to review or chal(566) 
lenge by any court or authority whatsoever; and the 30 \& 31 rict. said council are hereby further authorized to adjudicate c. 10.5.

upon and determine any other case of dispute or difference submitted to them by the mutual consent of master and workman or masters and workmen, and the same proceedings of distress, sale and imprisonment as are provided by the said recited acts or any of them shall be had towards enforcing every such award (by application to any justice of the peace of the county, stewartry, riding, division, barony, city, town, burgh or place within which the parties shall reside), as are by the said recited acts or any of them prescribed for enforeing awards made under or by virtue of the provisions of them or any of them, and any award in writ.ing under the hand of the chairman of the council shall be deemed sufficient evidence of the validity of such award to authorize such proceedings of distress, sale and imprisonment; but nothing in this act contained shall anthorize the said council to establish a rate of wages or price of labour or workmanship at which the workmen shall in future be paid.

5. A quorum of not less than three (one being a Quorum to master and another a workman, and the third the chair- form council. man), may constitute a council for the *hearing [*558] and adjudiciation of cases of dispute, and may accordingly make their award ; but a committee of council, Committec to be denominated the committee of conciliation, shall of enciliatbe appointed by the council, consisting of one master tion to be and one workman, who shall sit at such times is shall be appointed by appointed, and be renewed from time to time as occasion sball require; and all eases or questions of dispute which shall be submitted to the council by both parties shall in the first instance be referred to the said coinmittee of conciliation, who shall endeavor to reconcile the parties in difference; when such reconciliation shall not be effected, the matter in dispute shall be remitted to the council, to be disposed of as a contested matter in the regular course.

6. The chairman of the council, who shall bo some Chairman to person unconnected with trade, shall preside at their presidte at meetings, and shall be appointed at their first meeting meetings of meetings, and shall be appointed at their first meeting council, nul after obtaining such licence as aforesaid. When the to have votes of the council shall be equal, the chairman for "isting vote. the time being is to have the casting vote.

7. No counsel, solicitors or attornies to be allowed to No comnscl, attend on any hearing before the council or committee of of conciliation unless consented to by both parties. without

8. On the first Monday in November in the year consent. 
30 \& 31 Vict. next after the first appointment of the council, and on c. 105. the first Monday in November in each succeeding year, Council to be a council and chairman shall be appointed, who shall elected for remain in office until the appointment of a new council; one year. - and in case of vacancies arising betwixt the fixed days Case of vacancy, \&c. of election in each year, caused by the death or removal of any member of the council or of the chairman, an election shall take place within fourteen days, and another member be elected to fill up the said vacancy from the class to which he may belong, or a chairman be appointed, as the case may be, and the member or chairman so elected shall serve the remainder of the year.

House- $\quad 9$. For the purposes of this act, each person being holders and twenty-one years of age, belonging to the trade, having part occupiers may demand to be registered, and have a. vote for the council, and may be elected thereto.

Register of voters to be kept. a licence for a council, and being an inhabitant householder or part occupier of any house, warehouse, count. ing house, or other property, who, being a master in such trade, has resided and carried on the same within the limits of any city, borough, town, stewarty, riding, division, barony, liberty, or other place, wherever an equitable council of conciliation and arbitration is formed, for the space of six calendar months previous to the ninth day of November in any one year, and being a workman has resided for a like period within the same limits, and has worked at his trade or ealling seven years previous to the ninth day of November in any one year, shall be entitled to be registered as a voter for the election of the council, and shall be qualified to be, elected a member of such council ; but the masters shall appoint their own portion of the council, and the workmen elect their portion of the conncil.

10. The clerk of each division of the council shall keep a register of every person claiming to have his name inscribed on the register as a roter for the council, whether master or workman (but distinct from each other), the said register to contain the name, occapation and abode of each person engaged in the par. ticular trade or occupation as set forth in the licence granting the formation of the council ; and the said [*559] clerk shall, upon * payment of a registration fee being made to him, register the same immediately, or be liable to be fined for neglect, the said fine to be applied to the funds of the said council, and the council is hereby empowered to fix and determine the amount of such fee and fine respectively : provided that in case it shall appear to the council that any person ought not 
to be so registered, the council shall strike the name of 30 \& 31 Vict. such person off such register. c. 105 .

11. The clerk of the council shall, for the purposes of this act, be the returning officer; he shall convene masters :mil meetings of masters and peetings of workmen, by ad- workmen to vertisement, fourteen clear days previous to the first elect the day of November; and each class shall at such meetings proceed to nominate and elect members to the council for the year next ensuing; the votes to be taken by show of hands or division of numbers, and in such place as the council may authorize; and the clerk shall declare to the said meeting the names of the candidates who are elected, and the same shall be final and conclusive, unless a poll is demanded at the time the declaration is made; but either party may de. mand a poll of those only whose names are registered in the books of the council.

12. A poll being demanded by six registered voters, In (ase a poll the council shall appoint time and place for that pur. is demanded pose, where each voter shall be entitled to record his council to vote.

13. The clerk shall, within seven days after the day alpurint time andl place. of nomination, in case of a poll being demanded, declared declare the number of votes given to each candidate, witlin seven and those having received the largest number of votes days of shall be declared duly elected.

14. The council shall also appoint a clerk, who shall Appointment continue in office until a new appointment shall be of clerk. made in his stead, and who shall keep a record of all their proceedings, and do and perform such other duties as this act may authorize or the said conncil may require.

15. The council may hold their sittings in any publie l'lace of room used for conducting public business, with the meeting. permission of the authority having the power to grant such permission.

16. Every council elected nnder this act shall from 'To make list. time to time make out a list of fees which shall be of lees, lyecharged for any proceeding and other expenses under laws, di: this act, and shall appoint such officers as may bo nec. essary, and make such byelaws, rules and regulations for their guidance, and for the taking and scrutiny of the votes given for the election of the members of the council, and also for the despatch of business, as they may deem necessary; such byelaws, rnles, regulations and fees not to be legal and binding in law unless and until they shall be sanctioned by tho Secretary of State for the Home department. 
$30 \& 31$ vict. 17. The acts before recited shall remain in full force c. 105. and effect as though this act had not been passed: 5 Geo.4, c. 96, This act shall not be construed to extend to domestic \&c. to remain servants or servants in husbandry. in full force. Citation of act.

18. In citing this act for any purpose whatever it shall be sufficient to use the expression "The Councils of Conciliation Act, 1867."

19. This act shall commence on the 2nd day of July, Commence-
ment of act. 1867.

[The schedule to this act was repealed by $41 \& 42$ Vict. c. 79.] 
COMBINATION AMONGST MASTERS AND WORKMEN.

\section{The Conspiracy and Protection of Property Act, $18^{7} \overline{5}$.}

A OREAT variety of statutes formerly existed relative to the combination of workmen $(a)$. Those statutes were all repealed in 1824 by the 5 Geo. 4 , c. 95 , which substituted other provisions in lieu thereof, "for the pur.
pose of protecting the free employment of capital and 5 Geo. 4 , e. 95 , labour, and for punishing combinations interfering with such freedom by means of violence, threats or intimidation." "The evils resulting in one year from and 6 (ieo. 4, this statute," said Sir W. Erle (b), "were sufficient to e. 129, subproduce its.repeal, and the substitution of 6 Geo. 4 , c. stituted ; 129." That Act, however, was repealed in $1871(c)$, and repealed. (when the Trade Union Act, $1871(d)$, was passed). Trade Union In 1872, a great strike of London gas stokers having Act, 1871; taken place, which might have involved London in darkness, and been attended with serious consequences, they were indicted and convicted for conspiracy $(e)$. That *decision, which is said to [*561] have caused great dissatisfaction amongst those principally affected, led, amongst other causes, to the repeal of the act of $34 \& 35$ Viet. c. 32 , and the passing of Repealed. "The Conspiracy and Protection of Property Act, Conspiracy $1875, " 38$ \& 39 Vict. c. 86 , to which it is now proposed and Protecto call the reader's attention. But as it is necessary to tion of l'roprint the whole of the act in the Appendix, it is thonght perty Aet, sufficient in this place to refer to the sections relating to conspiracy and protection of property, and the section (7) relating to intimidation or annoyance by violence or otherwise.

By sect. 3 it is enacted that-

(a) The history of the law upon this subjeet will be found in Stephen's Hist. of the Criminal Law, Vol. 3, Ch. XXX. p. 202.

(b) In his valuable Memorandum on the Jaw relating to Trades Unions presented to the Trades Union Commission, Cli. 2 , and printed at the end of the 11 th leport, which is dated gth March, 1869 . This memorandnm is also published separately.

(c) By 34 \& 35 Vict. c. 3\%.

(d) 34 \& 35 Vict. c. 31 , post, Appendix.

(e) R. v. Bunn, 12 Cox, C. C. 316. 
Amendment of law as to conspiracy in trade disputes.

Breach of contract by persons employed in supply of gas or water.
An agreement or combination by two or more persons to do or procure to be done any act in contemplation or furtherance of a trade dispute between employers and workmen shall not be indictable as a conspiracy if such act committed by one person would not be punishable as a crime.

Nothing in this section shall exempt from punish ment any persons guilty of a conspiracy for which a punishment is awarded by any Act of Parliament.

Nothing in this section shall affect the law relating to riot, unlawful assembly, breach of the peace, or sedition, or any offence against the State or the Soverign.

A crime for the purposes of this section means an offence punishable on indictment or an offence which is punishable on summary conviction, and for the commis. sion of which the offender is liable under the statute making the offence punishable to be imprisoned either absolutely or at the discretion of the court as an alternative for some other punishment.

Where a person is convicted of any. such agreement or combination as aforesaid to do or procure to be done an act which is punishable only on summary conviction, and is sentenced to imprisonment, the imprisonment shall not exceed three months, or such longer time, if any, as may have been prescribed by the-statute for the punishment of the said act when committed by one person.

4. Where a person employed by a municipal authority $(f)$, or by any company or contractor upon whom is imposed by Act of Parliament the duty or who have otherwise assumed the duty of supplying any city, borough, town, or place, or any part thereof with gas or water wilfully and maliciously $(g)$ breaks a contract of service with that authority or company or contractor, knowing or having reasonable canse to believe [*562] *that the probable consequences of his so doing either alone or in combination with others will be to deprive the inhabitants of that city, borough, town, place or part, wholly or to a great extent of their supply of gas or water, he shall on conviction thereof by a court of summary jurisdiction, or on indictment as hereinafter mentioned, be liable either to pay a penalty not exceeding twenty pounds, or to be imprisoned for a

(f) See seet. 14; in Scotland, sect. 18; in Ireland, sect. 21; post, Appendix.

(g) See sect. 15, post, Appendix. 
term not exceeding three months, with or without hard labour.

Every such municipal authority, company or contrac. tor as is mentioned in this section shall cause to be posted up at the gasworks or waterworks, as the case may be, belonging to such authority or company or contractor a printed copy of this section in some conspicuous place where the same may be conveniently read by the persons employed, and as often as such copy becomes defaced, obliterated or destroyed shall eause it to be renewed with all reasonable despatch.

If any municipal anthority or company or contractor make default in complying with the provisions of this section, in relation to such notice as aforesaid, they or he shall incur on summary conviction a penalty not exceeding five pounds for every day during which such default continues, and every person who unlawfully in. jures, defaces or covers up any notice so posted up as aforesaid in pursuance of this act shall be liable on summary conviction to a penalty not exceeding forty shillings.

5. Where any person wilfully and maliciously breaks Breach of a contract of service or of hiring, knowing or having a contract inreasonable cause to believe that the probable conse-volviug quences of his so doing, either alone or in combination injury to with others, will be to endanger human life or cause perwons or serious bodily injury or to exposo valuable property, whether real or personal, to destruction or serious injury, he shall on conviction thereof by a court of summary jurisdiction, or on indictment as hereinafter mentioned $(h)$, be liable either to pay a penalty not exceeding twenty pounds or to be imprisoned for a term not exceeding three months, with or without hard labour.

7. Every person who with a view to compel any other penalty for person to abstain from doing or to do any act which intimilition such other person has a legal right to do or abstain or ummoyince from doing, wrongfully and without legal authority - wivelener

(1.) Uses violence to or intimidates such other person or his wife or children, or injures his property ; or

(2.) Persistently follows such other person about from place to place; or

(3.) Hides any tools, clothes, or other property owned or used by such other person, or deprives him of or hinders him in the nse thereof; or

(4.) Watches or besets the house or other place where

(h) See seet. 9, post, Appendix. 
such other person resides or works or carries on business or happens to be, or the approach to such house or place; or

(5.) Follows such other person with two or more other persons in a disorderly manner in or through any street or road,

shall on conviction thereof by a court of summary jurisdiction, or on indictment as hereinafter mentioned (i), [*563] be liable either to pay a penalty *not exceeding twenty pounds or to be imprisoned for a term not exceeding three months, with or without hard labour.

Attending at or near the house or place where a person resides or works, or carries on business, or happens to be, or the approach to such house or place, in order merely to obtain or communicate information, shall not be deemed a watching or besetting within the meaning of this section.

Since the passing of this Act of Parliament it is clear that no agreement or combination in contemplation or furtherance of a trade dispute between employers and workmen can be treated as an indictable conspiracy unless the act agreed upon would be criminal if com. mitted by, one person. It is, therefore, thought unnecessary to encumber this edition with the cases decided upon the repealed statute of 6 Geo. 4, c. 129 , which will be found in the previous edition.

Injunction to It may be convenient here to mention that, although restrain in general the Court of Chancery has no jurisdiction to printing, \&c. prevent the commission of criminal acts, yet, inasmuch notices and as its function is to protect property, it will entertain a placards warning - bill to restrain acts which, although eriminal, are of workmen not such a nature as to injuriously affect rights of property. to work for And, therefore, in a case $(k)$ in which certain members plaintiffs.

Springhead Spinning Co. v. Riley. of a Trades Union Association employed at the plaintiff's mill left the service in consequence of a reduction of wages; and the association then posted in the district and advertised in the local papers placards or notices warning all workmen not to seek or renew work at the mill until the dispute was settled; Malins, V. C., overruled a demurrer for want of equity to a bill filed against the president, secretary and printer to the association to restrain them from printing and publishing the placards or notices, which bill charged that the plaintiff's business was materially injured and the value

(i) Sect. 9, post, Appendix.

(k) Springhead Spinning Co. v. Riley, 37 L. J., Ch. 889 ; L. R., 6 Eq. 551. 
of their good will depreciated thereby; although the acts of intimidation complained of were punishable under 6 Geo. 4, c. 129 (now repealed).

*Where a party of coal-whippers having a [*564] Discontented feeling of ill-will to a coal-lumper who paid less than workmen the usual wages, created a mob, and riotously went to "riotously. the house where he kept his pay-table, and cried out "beginning that they would murder him, and began to throw stones, master's brickbats, \&c., and broke windows, and partitions, and house. part of a wall, and continued after his escape throwing $R$. v. Bath. stone's at the house till they were compelled to desist by the threats of the police, it was held by Gurney, B., that they might be convicted of beginning to demolish under the stat. $7 \& 8$ Geo. 4 , c. 30 , s. $8(l)$, though their principal object was to injure the lumper, provided it was also their object to demolish the house, either on account of its being used by him or his men, and though they had not any ill-will against the owner of the house personally $(m)$.

Administering an oath not to work under certain Unlawful prices, and to keep the secrets of a lodge, is adminis- oaths. tering an unlawful oath within the stats. $37 \mathrm{Geo}$. 3, c. 123 ; 39 Geo. 3, c. 79 ; 52 Gen. 3, c. 101 , and 57 Geo. 3 , c. 19; not as has been ignorantly supposed because it has reference to any matter respecting wages, but on the ground that every association of that kind bound together by an oath not to disclose the proceedings of that society is for that reason, and not for the other, an nnlawful combination within the meaning of the statntes $(n)$.

(l) See now $24 \& 25$ Vict. c. 97, s. 11.

(m) $R$. v. Batt, 6 C. \& P. 329.

(n) R. v. Ball, 6 C. \& P. 563 ; R. v. Lovelass, 6 C. \&. P. 596 ; 1

M. \& Rob. $349 ;$;. v. Dixon, 6 C. \& P. 601. 


\section{LEGACIES TO SERVANTS.}

Who entitled IT is thought convenient to collect into a separate to legacies as chapter the various decisions upon this subject, as the "servants" question, Whether particular individuals are entitled to legacies left to a class of persons as "servants," fredepends on quently arises $(a)$; and the answer to it rather depends intention of upon the words of the will and the attention of the the testator. testator in each case, than upon the strict legal construction of the contract into which he has entered with the persons claiming the legacy. For it by no means follows that every person with whom a testator had entered into a contract of hiring and service, was an object of his testamentary bounty; although, in many cases, a clue to his intention may be fonnd by ascertaining the exact nature of such contracts. For similar reasons no rule can be laid down which will be applicable to all cases. Each case must depend upon its own particular circumstances. It is, however, of course, necessary that a person claiming to be entitled to a legacy left to each one of a class of persons, should be one of that class to whom the legacy is left-that a person claiming a legacy as a servant should be a servant-otherwise he cannot be entitled to it. It has,

But servant must serve testator $e x$ clusively;

Townshend $\mathbf{v}$. Windham. therefore, been held $(b)$ that a person who was not [*566] obliged to give up his whole time to *his master, although in some sense he might be called a servant, was yet not entitled to a legacy left to servants.

Thus where (c) the Dake of Bolton by his will devised "unto such of my servants as shall be living with me at the time of my death one year's wages;" The Lord Keeper said, "stewards of courts, and such who

(a) In Pickuell v. Spencer, 40 L. J., Exc. 132, a devise to A., with a direction to pay B. $5 l$. a year wages as long as he shall continue to labour on the farm, was held to give $A$. the fee. In Jenner v. Turner, 50 L. J., Ch. $161 ; 16 \mathrm{Ch}$. D. 188 , a condition in a will in restraint of marriage with a domestic servant was held good. As to the effect of a promise to make a will in favour of a servant, see Alderson v. Maddison, 50 L. J., C. L. 466; 52 L. J., C. L. 737; L. R., 8 App. Cas. 474.

(b) This is in accordance with the decisions on the law of settlement, ante, p. 87.

(c) Townshend v. Windham, 2 Vern. 546.

(576) 
are not obliged to spend their whole time with their bnt need not master, but may also serve any other master, are not live in his servants within the intention of the will, but I will not house or be narrow it to such servants ouly that lived in the testa. fed by him. tor's house or had diet from him."

Upon similar principles it has been held that a ser- So, he must vant to be entitled to a legacy left to "servants," must not he subject not be subject to the orders of any other person than the to orders of testator. That is, that a person serving the testator any one but under a contract made by the testator with that person's master, does not come within the class of persons contemplated by the will, although the testator might in some sense be considered his dominus pro tempore.

Thus where $(d)$ a testator, after bequeathing legacies Coachman to two of his servants by name, if in his service at the supplied to time of his decease, gave and bequeathed unto all his testator hy "other servants" who should be living with him at the job-master, time of his decease $50 \mathrm{l}$. each, and $10 \mathrm{l}$. each for mourn- and horses, ing; and by a codicil revoked the legacies of $50 l$. and is not the $10 l$. for mourning to his other servants not particularly testator's named, and made the following bequest: "To all my other servants in lieu thereof the sum of $500 l$. each, Chromley. and $20 l$. each for mourning:" Sir W. Grant, M. R., held that a coachman supplied, in the course of busi ness, with a carriage and horses hired by the year from a job-master, was not entitled to the legacy as a servant within the intent and meaning of the will. 'The coach. man, in that case, did not board or lodge in the testator's house, but received from *him $12 s$. a week as [*567] board wages, and a livery with the other male servants, the job-master also paying him $9 s$. a week; but the coachman served no other person than the testator, and was returned by him as his coachman under the act imposing a duty on male servants. However, Sir W. Grant observed, truly, that the coachman was merely the subject of the contract, which was with the jobmaster, not a party to it.

And in Howard v. Wilson (e), in a suit of subtraction of legacy, a coachman, a married man oviginally nuter hired hired $b y$, and who had lived five years with a testatrix, by testator, residing over her stables in town, occasionally accompa although jutnying her into the country, where he lived in the house, mis wages and though, like all her servants, on board wages, waiting found livery. sometimes at table, and remaining with her though she

(d) Chilcot v. Bromley, 12 Ves. 114; and see Qunrman v. Burnett, 6 M. \& W. 499, ante, p. 351.

(e) 4 Hagg. 107. 
Howard v. changed her job-master was held entitled under a beWilson. quest "to each of my servants living with me at the time of my death 10l. ;" although the testatrix paid a job-master 200l. a year, out of which he paid the coachman wages and board wages (except 3 s. a week extra in the country), and found him in liveries; Sir J. Nicholl distinguishing the case from Chilcot v. Bromley $(f)$.

Bulling v. The late Earl of Leicester by his will $(g)$ gave

Hillice.

"One year's wages in advance to each of my servants

Farm baliff

held to be a servant. in my service at my death, who shall have lived with me five years or upwards, and one-half of a year's wages to each of my other servantsin my service at my death; the said several legacies to my said servants to be in addition to whatever sum may be due to them respect. ively for wages up to my death; also an additional sum of $10 l$. to each of my upper servants and of $5 l$. to each of my under servants respectively for mourning. And I direct that each of the said legacies expressly given for mourning, and each of the said legacies to my said servants shall be paid within one calendar month next after my death."

Knight Bruce, V.-C., held it to be perfectly plain that a farm bailiff, who had lived with tho Earl twentyeight years, at 3500 . a year, living on the home within [*568] the park, *rent free, the Earl paying all rates and taxes, and who was allowed keep for a cow and a horse, and to take pupils to instruct in agriculture, was a servant within the meaning of the will, and clearly entitled to his year's wages of $350 l$. $(h)$, and interest at four per cent. from one month from the testator's decease, the time when the legacy was directed by the will to be paid.

Ogle v. Where (i) the Earl of $A$. by his will, after bequeathMorgan. ing legacies to several servants by name, bequeathed "Servants on "to each person as a servant in my domestic establish domestie establishment" only applies to indoor servants. ment at the time of my decease a year's wages beyond what shall be due to him or her for wages:" Knight Bruce, V.-C., held that a head gardener at weekly wages, who had formerly resided in a garden-house in the middle of the garden (which had been furnished by the Earl, and all the expenses of which were defrayed by him, and the domestic work of which was performed

(f) Ubi supra.

(g) 9 Jurist, 936.

(h) The 10l. for mourning had been paid.

(i) Ogle v. Morgan, 19 L. J., Ch. Cas. 531; reversed by Lord Truro, L. C., 1 De G. M'N. \& G. 359 ; Vaughan v. Booth, 16 Jur. 808. 
by his domestic servants and a charwoman paid by him), but, on the Earl wishing to pull down the gardenhouse, had removed to another cottage belonging to the Eari in an adjoining village, and who was allowed milk and firewood, was entitled to the legacy. But Lord Truro, on appeal, reversed that decision, considering that the testator had in view the distinction between indoor and outdoor servants when he used the term "servants in my domestic establishment."

Moreover, to entitle a servant to a legacy of a year's Servant must wages it has been beld that he must have been a yearly be a yeurly servant, and a servant who has been paid weekly wages servant. is not entitled. Thus, where a will contained the fol- Booth v. lowing words, "I give to each of my servants one year's Dean. wages over and above what may be due to them at the Servant at time of my decease," a question was made whether a not entitled person who had worked in the testator's garden, un- not entitled der his gardener, for several years, at weekly wages, year's watges. and a boy who had served *the testator for some [*56y] time as a cowboy at weekly wages, and neither of whom resided with or formed part of the testator's family, were to be considered as entitled under the will to a year's wages; but Sir J. Leach, M. R., was of opinion that these persons were not servants in the sense in which the testator had used the expression. In speaking of a year's wages the testator plainly used that expression with reference to family servants usually hired by the year $(j)$.

And so where (k) a testator by his will gave "to Blackucll v. each of his servants living with him at his decease, and rennant. who had lived with him three years," a legacy of one Nor gardener year's wages, Sir G. Turner, V..-C., held, that a head at reekly gardener who at the time of the death of the testator lived in a cottage of the testator in the grounds, free of rent, and was employed at $17 \mathrm{~s}$. a week, was not entitled to the legacy; as although clearly a servant, and not to be excluded on the ground that he was not living in the same house with the testator, yet the bequest only applied to servants hired by the year. He could not impute to the testator that he meant by a year's wages the aggregato amount of fifty-two weeks' wages. And as the evidence on the part of the plaintiff failed to make out that he was a yearly servant, his cliaim was dismissed with costs.

(j) Booth v. Dean, 1 Myl. \& K. 560. But see Thrupp v. Collett, post, p. 5 io.

(k) Blackwell v. Peunant, 9 Hare, 551. 
Breslin v. Waldron.

Thrupp v. Collett.
Upon the authority of these cases a similar decision was made in Ireland, in a case $(l)$ in which a testator bequeathed " unto each and every of the servants, male and female, who shall respectively have been living in my service for the space of six calendar months im. mediately previous to my decease, the amount of one year's standing wages over and above any yearly salary or wages I may owe them respectively at my decease." A person who stated that he was " a servant in the employment of the testator as a gardener for a period of [*570] nearly eleven years prior to his *decease, and was hired by the testator as such servant on the 17th of March, 1841 , at wages or remuneration equiyalent to the sum of $52 l$. a year, payable by a weekly allowance of $12 \mathrm{~s} .6 \mathrm{~d}$. in money, and by means of a house rent free, and a certain allowance of milk and coals yearly; all of which money and other wages and allowance were equivalent in value to the said yearly salary of $52 l$. a year," was held by Brady, L. C., not entitled to any legacy under the above bequest, as the terms of the bequest made it essential that the servant should have been engaged on a yearly hiring and wages, and it could not be inferred from the petitioner's statement that there was a yearly hiring, or a hiring at yearly wages. But he (the L. C.) thought it certainly not of any importance that the petitioner did not live in the house, nor that his wages were paid weekly or at irregular intervals, if they were in truth yearly wages.

However, where $(m)$ a testator, among other pecuniary legacies, gave to his executors the sum of $1,000 l$. to be equally divided between all the servants in his ser. vice at the time of his decease (except as in his will mentioned), it was held by Sir J. Romilly, M.,R., that a head gardener and under gardener at weekly wages, who lived at their own houses, adjacent to that of the testator, and were occupied in their employment of gardeners the whole of the working days, and occasion. ally on Sundays, to feed the cattle and attend to the garden, and had no employment from any other person during their engagement with the testator, were servants within the meaning of the will.

"The case of Townshend $\mathbf{v}$. Windham" (n), said the M. R., "lays down that the mere fact of responsibility is not a ground upon which the court ought to proceed,

(l) Breslin v. Waldron, 4 Ir. Ch. C. 333 (1885).

(m) Thrupp v. Collett, 5 Jurist, N. S. 111 ; 26 Beav. 147.

(n) 2 Vern. 546, supra, p. 566.

(580) 
and it would appear to $\mathrm{me}$ a very strange decision to hold that a person is not a servant because he does not live in the house but in a cottage belonging to his mas. ter. It is a common thing to pay gardeners by the week. The gardener was in the employment of the *testator for upwards of a year, and during the [*5i1] whole of that time was engaged in the management of the garden. I can see no definition of 'servants' which would exclude the gardener. The same observation applies to the under gardener, and he also is entitled as one of the servants of the testator."

The servant also must, generally speaking, continue Service must in the service of the testator to the time of his death. continue to

Sir Robert Henley, by will (o), gave $100 l$. apiece to death of all his servants. The Court declared that none but such testator. as were his servants before the making of the will $(p)$, Jones $\mathrm{v}$. and did so continue to be servants to him until the time Henley. of his death, could have any pretence to the legacy: and such only as were his menial servants, and lived all along in the house with him from the date of the will until his death, and no others.

But where $(q)$ a testator bequeathed a legacy to Jane Herbert $\mathrm{v}$. H., "if in his service at the time of his decease," and it $K$ crid. appeared that Jane $\mathbf{H}$. had quitted his house a few days Quitting before his death, Lord Eldon held, that parol evidence house but was admissible to show that though she had quitted his not service. house, she contined and was considered by him as still in his service: and upon that evidence the legacy was established.

And in a subsequent case $(r)$, where a testator had Purker v. several servants, and by a codicil to his will bequeathed Marehant. to some of them by name legacies of $1,000 l$. each, and Servant who then gave "to the other servants $500 l$. each;" it was lived with held by Lord Lyndhurst, L. U. (affirming the decision testator at of Knight Bruce, V..C.), that A. R., a female servant but had lesh who was in the testator's service at the date of the co- long hefore dicil; though for ten weeks only, and quitted it three his death, years and a half before *his death, was entitled [*572]

(o) Jones v. Henley, 2 Chanc. Rep. 361. held entitled under bequest to "other

(p) The question does not appear to have been raised in my subsequent cases, whether it was necessary that the servant should have been in the service of the testator at the date of his rill, :us well as at the time of his death. See Parker v. Marchant, infira.

(q) Herberl v. Reid, 16 Ves. 481.

(r) Parker v. Marchanl, 6 Jurist, $292 ; 1$ Y. \& C., N. S. 290; s. C., on appeal, 7 Jur. 457 (the point in the text is not noticed in the report, 2 Cr. \& Ph.) 
Parker v. to a legacy of $500 \mathrm{l}$. considering that the case of Jones Marchant. v. Henley (s) did not apply. And his lordship sain,-

"The testator had several servants, some of whom had lived in his service for many years, as he states in his codicil. The others lived with him for a shorter period of time. He distinguishes between them. He gives to three of them by name, who had lived in his service for many years, $1,000 l$. each, and he then expresses himself thus, 'to the other servants $500 l$. each.' What is meant by the other servants? The rest. After taking out of the whole class the three individuals who are named, Mrs. D. and the two others, to whom he gives $1,000 l$. each, he then gives 500l. to the remainder. It appears to me as if he had named them, and as he annexes no condition to the gift, I am of the opinion that A. R. is entitled, on the construction of this codicil, to the legacy of $500 l . "$

Servant wrongfully discharged not entitled;

Darlow v. Edwards

Even a servant wrongfully discharged is not entitled to a legacy left by a will, which requires that the lega: tee shall be "in the service" to be entitled to it. And therefore, where a man left his landed estate to his son and charged it with the payment to his faithful servant S., of an annuity of $12 l$. "provided she shall be in $\mathrm{my}$ service at the time of my decease;" and two days before his death discharged her without sufficient ground, paying her wages; it was held by the Exchequer Chamber, that although she might perhaps recover damages in an action for wrongful discharge, yet she was not in the service of the testator at the tirne of his decease, and therefore not entitled to the annuity $(t)$.

nor one who has voluntarily left.

Venes $\mathrm{v}$.

Marriott.

Promissory notes left by master payable to his servant, but not delivered in master's lifetime void.
And a similar decision was made where a servant voluntarily left the house of a lunatic master during his lifetime, receiving wages up to the end of his year, 16th October, though the testator died on the 8th October $(u)$.

Where a man on his death left among his papers two letters sealed and directed "for Sarah Gough, my late [*573] *servant," one of which contained a promissory note for $400 l$., and the letter stated that it was "in con. sideration of her long and faithful services" (she hav ing been his housekeeper, but having left on having a

(s) Ubi supra.

(t) Darlow v. Edvarrls, 32 L. J., Exe. 51 ; 1 H. \& C. 547 ; 6 L. T., N. S. 905 .

(u) Re Serres' Estate, Venes v. Marriott, 31 I. J., Ch. 519 . In Re Hartley's Trusts, 47 L. J., Ch. 610, it was held that an order in lunacy operated as a dismissal of a servant of a testatrix who was lunatic, and the servant was held not to be entitled to a legacy left to those in the service. 
child by him), and that his executors would pay her the rough $\mathrm{v}$. amount of the note; and the other letter was similarly findom. addressed, and inclosed a note for $200 l$, and in the letter there was the following passage:- "In addition to any sum I owe you, I enclose you $200 l$. as a mark of my respect," and there was also a recommendation that the money should be invested for the benefit of the child; it was held that the notes were void as notes for want of delivery in the maker's lifetime, and therefore the executors were not liable upon them; and they were also void as testamentary dispositions, for non-compliance with the Wills Act $(x)$.

And a similar decision was made by Kindersley, V.-C., Trimuer v. in a case $(y)$ in which a housekeeper who had been forty Dentyy. years in the testator's service, and to whom an annuity was bequeathed by his will, claimed some Austrian bonds which were in a box belonging to the testator, of which, and the key, she had the custody. The bonds were rolled up in packets, and one containing ten had this endorsement, signed by the testator, "The first five numbers of the Austrian Bonds belong to and are Hannah Danby's property. Signed, J. MI. W. Turner." It was held that, as there had been no actual transfer or delivery of the five bonds, they still formed part of the testator's assets, for although $\mathrm{H}$. D. had the custody she had not the possession of the bonds.

By his will dated November, 1876, B., a testator who Servant who died in July, 1883, bequeathed "to each of my servants haul left who shall at my death have been in my service twelve service not calendar months or longer, one year's wages in addition entitled to *to anything owing by me, and to my gardener, [*574] addition" to P. G., 300l. in addition." In August, 1880, P. G., who wayes. had been in testator's service thirty-three years, left the Binyon v. service, and on leaving the testator made him a present Ciriere. of $100 l$. It was held by Kay, J., that, as P. G. was not in the service at the death of the testator, he had not fulfilled the condition, and was not entitled to the $300 l$. $(z)$.

When a legacy is left by a master to his servant, it will, sometimes, be considered as a satisfaction, either in the whole or in part, of any wages due at the time of

(x) Gough v. Findon, 21 I. J., Exe. 5Q; i Exe. 4t; see Ilulse จ. Ifulse, 17 C. B. 711 , 721. But there may be at gool domatio mortis causa of promissory notes without indopsement. I'ral $\mathrm{x}$. Veal, 29 I. J., Ch. 321. In lie Ninn's Vill, 41 I. J., Ch. 25i, F. R. was held entitled to a legacy "to my housekeeper M. R."

(y) Trimmer v. Danby, 25 I. J., Ch. 424.

(z) Benyou v. Gricre (Times, June '28th, 1884). 
How far

legacy is a satisfaction of debt. for wagres.

Matthews v. Matthers.

Re Fuller the master's death, unless a contrary intention appear from the master's will $(a)$. Courts of equity, however, are inclined to infer a contrary intention from slight circumstances. Thus, in Mattheurs v. Mattheus (b), Sir Thomas Clarke, M. R., said he remembered a case, before Lord Hardwicke, where an old lady, indebted to a servant for wages, by will gave ten times as much as she owed or was likely to owe; yet because the legacy was made payable $a$ month after her own death, the Court laid hold of that circumstance to take it out of the general rule $(c)$.

A testator $(d)$ bequeathed by will as follows :- "Likewise, should my executors think proper, to my manservant whom I call Sam (the plaintiff) I give 20l. conditional on his continuing to conduct himself faithfully in all respects," and appointed executors. The will was made and the testator died in the district of the County [*575] Court of Kent. *The executors renounced probate, and MI. who resided in London, took ont adminis. tration with the will annexed in the Prerogative Court of Canterbury. Sam sued M. in the County Court of Kent for the 20l. But the Court of Queen's Bencl granted a prohibition on the ground that the grant of letters of administration was part of the cause of action, and the judge of the County Court of Kent had no jurisdiction in respect of it over M. And it was doubted whether the bequest was a legacy which might be recovered in the proper county court, or a bequest in trust only to be enforced in equity. Lord Campbell thought it was a legacy which might be recovered in the county court.

Germane to the subject we have been treating of, and therefore proper to be introduced in this place, are the cases in which the question has arisen whether a direc-

(a) See Le Sage v. Coussmaker, 1 Esp. 188.

(b) 2 Ves. sen. 636; see also ('hancey's case, 1 P. Wms. 408. However, in Richarlson v. Greese. 3 Atk. 69, Lord Hardwicke said that legacies to servants had never been held to be in satisfaction of debts. See Smith v. Smith, 31 L. J., Ch. 91. In France legacies to servants are not considered as satisfaction for wages, Code Civ. liv. 3, tit. 2, sec. 6, 1023 .

(c) In Roch v. Callen, 6 Hare, 534, an annnity of $20 l$. left to a servant by a codicil was held to be cumulative upon and not in substitution of a similar annuity left by the will. Where a testatrix directed her executors to purchase an annuity of $50 l$. a year in government securities for her servant MI., it was held that the annuity was perpetual and not for life only; Ross v. Borer, $31 \mathrm{~L}$. J., Ch. 709. And a legacy to "servant and friend A.," and a year's wages to all servants, was held cumulative. Wilson v. O'Leary, 40 L. J., Ch. 709.

(d) Re Fuller, 2 E. \& B. 573. 
tion or injunction in a will to employ a particular I)irestion ly steward or agent imposes on the devisee an obligation testutor to in the nature of a trust in favour of the person so emplloy $^{-}$ named (e). This question arose in the case of Lauless particular v. Shaw $(f)$. There the testator, after devising his agent. estates, charged with certain annuities, to his friend Laclexs v. Shaw (then aged twenty years) for life, with remainders shur. over in strict settlement, and directing the residue of his personal estate to be invested in the purchase of other real estates, to be settled in like manner, and after bequeathing to his friend and agent, Lawless, 100l. as a token of esteem, and after directing his executors to pay to his agent $150 l$., to be distributer among the poor on his estates, declared it to be his "particular desire that his executors, whilst acting in the manage. ment of all or any of his affairs under his will, as also his friend Shaw, when he should enter into the receipt of the rents of his estates, should continue Lawless in the receipt and *management thereof, [*576] and likewise should employ and retain him in the receipt, agency and management of lands to be purchased and settled in pursuance of the will at the usual fee allowed to agents, he having acted for the testator since he became possessed of the estates fully to his satisfaction." The testator also bequeathed to his friend and agent, Lawless, $150 l$. to purchase a monumental tablet. Soon after the testator's decease, Shaw dismissed Lawless from his office as land agent, but without impeach. ing his character or capacity. Lawless filed a bill in Chancery against Shaw, claiming to be reinstated, which was dismissed by Lord Plunket, and his decree (though upon a rehearing reversed by his successor, Iord St. Leonards) was afterwards affirned in the House of Lords. In delivering judgment in the Honse of Lords, Lord Cottenham, C., after stating that all cases upon a subject like this must depend npon the testator's intention, and that Lawless was only agent to the testator in his lifetime during his pleasure, and that by the terms of the will the testator desired he should continue in the agency, and that the natural presumption was that the testator wished him to continue upon the same terms, and showing to what absurd conse-

(e) See generally on this subject, Knight $v$. Kuight. 3 lenv. 148; Green v. Marsden, 1 Drew. 646. In Thermeroft v. Letshmur, 31 L. J., P. Mat. \& $\Lambda \mathrm{dm}$. 150, an appointment by letter of an agent and collector was hold not testamentary.

$(f)$ Jloyd \& Goold, 154; S. ('. in Dom. Proc. 5 Cl. \& F. 129. 
Lawless v. Shaw. quences the upholding Lawless's claim would lead, said,--

"There is, it is true, a great variety of cases in which the expression of a wish has been held to create a trust; but the rule of construetion in these cases is that there should be certainty in the object and in the subject of a trust so created ; that the expressions ' in the will should not leave the matter in a doubtful ambiguity. Cary v. Cary $(g)$ has been referred to. There Lord Redesdale expressed the rule in these words, "When a testator, having in his power to dispose of property, expresses a desire as to the disposition of the property, and the objects to which he refers are certain, the desire so expressed amounts to a command, and if he shows his desire, he in fact expresses his intention, provided the objects to which be refers are so defined that a court can act upon the desire so expressed." In Foley v. Parry $(h)$ the court beld that a desire that a devisee in remainder should be educated and maintained from [*577] the *income of the devised property created a trust in his favour. There everything concurred to show that such was the intention of the testator. In Hibbert v. Hibbert $(i)$ a trust was held to be created as to a West Indian estate, and $\mathrm{H}$., the person in whose favour the desire was made, was appointed consignee. But there the words were clear and express in his favour, though the estate to which they applied appeared doubtful. In Tibbits v. Tibbits $(j)$ there was no doubt as to the subject matter, but still that case carried the doctrine of creation of trusts further than any which had preceded it, though, as it seems to me, not so far as the decree (of Lord St. Leonards) in the present case has carried it. It is true that all the court requires is that the subject and object shall be defined and certain. Then what is the subject in the present case? It is the right to be employed in the receipt of the rents, and the agency and management, of the land of another person upon the usual fees. What is the necessary effect of this alleged right? It goes to exclude Shaw from the management of his own estate, or from the receipt of the rents themselves. Then this question arises: Suppose that he parts with the estate, would it, in the hands of a purchaser, be subject to the same liability to this claim of agency on the part of

(g) 2 Sch. \& Lef. 173.

h) 5 Sim. 138, affirmed on appeal, 2 M. \& K. 138.

(i) 3 Mer. 681 .

(j) 19 Ves. 656 ; Jac. 317. 
Lawless? Was it the desire or the wish of the testator Lavelesy $\vee$ that it should be so ? or did he merely wish that his shuw. devisee should employ a man whose conduct had given satisfaction to himself? Some cases of difficulties of another kind were put in the course of the argument. It was asked, among other things, whether, if a testator should say that he desired his son to be educated at a particular school that would create a trust in favour of the schoolmaster? That would certainly be a matter for the advantage of the schoolmaster, but it could not be contended that he would have a right to enforce the performance of this desire of the testator. It would be an expression of desire made for the benefit, not of the schoolmaster, but of the scholar. Having examined all the cases, and quite satisfied myself that there is not a case which comes at all near the present, I mean indeed that all are against the construction contended for by the respondent, I am of opinion that the judgment pronounced by Lord Plunket was correct, and that the decree of Lord Chancellor Sugden must so far be reversed."

In a previous case $(k)$ in which a testator devised his Auditor. estates to trustees upon trust to let the same, and apply Williums $\mathbf{v}$. the rents in paying off certain incumbrances, and ap- Corbet. pointed A. to be auditor of the accounts during the exexcution of the trusts, and directed the trustees to pay him the usual annual remuneration ; Sir L. Shadwell, V.C., held that *the trustees were not justified [*578] in removing $A$. from the office, there being no imputation on his conduct, for that he had as much right to be auditor as any one of the devisees had to the estates.

Where a testator $(l)$, after leaving some legacies, pro. Knight v. ceeded thus, "I trust to the liberality of my successors Kinight. to reward any others" of my old servants and tenants according to their deserts," Lord Langdale, M. R., thought be could not be understood to have intended to create an imperative trust.

(k) Williams v. Corbet, 8 Sim. 349.

(l) Knight v. Knight, 3 Beav. 148. 



\section{APPENDIX.}

*22 GEO. 2, c. 27.

An Act for the more effectual preventing of Frauds and Abuses committed by Persons employed in the Manufacture of Hats, and in the Woollen, Linnen, Fustian, Cotton, Iron, Leather, Furr, Hemp, Flax, Mohair and Silk (a) Manufactures; and for preventing unlawful Combinations of Journeymen Dyers and Journeymen Hotpressers, and of all Persons employed in the said several Manufactures; and for the better Payment of their Wages.

Whereas by an act made 13 Geo. 2, intituled "An Act to explain and amend an Act made in the first year of the reign of her late Majesty Queen Anne, intituled 'An Act for the more effectual preventing the Abuses and Frauds of Persons employed in the working up the Woollen, Linnen, Fustian, Cotton and Iron Manufictures of this Kingdom, and for extending the said Act to the Manufactures of Leather," 'it is amongst other things enacted, that if any pelson or persons hired or employed in the working up of any woollen, linnen, fustian, cotton or iron manufactures shall purloin, imbezil, secrete, sell, pawn, exchange or otherwise illegally dispose of any the miterials with which he, she or they shall be respectively entrusted to work up such woollen, linnen, fustian, cotton or iron manufactures, whether the same be or be not first made up or manufactured, or shall reel false or short yarn, the person or persons so offending, and being thereof convieted in manner preseribed by the said act of 1 Ann., shall forfeit double the value of the damages which the owner or owners of such materials shall respectively sustain thereby, together with full costs of prosecution for every such offence; and in ease inmediate parment of the respective forfeitures, together with sueh costs of prosecution as atoressid, shall bo neglected or refused to be made, that then it shall and may be luwful to und for the same justice of the peace, before whom such eonvietion shall be made, to cause the offender or offenders to be committed to the house of correetion, to be there whipped and kept to hard labour for any time not exceeding fourteen days; and in case of a further conviction for a second or other subsequent offence, for imbezilling or purloining any of the materials in the said Act of 1 Ann. mentioned, that the person or persons so offending shall, for every second or other subsequent offence forfeit four times the value of the damages which the owner or owners of sueh materials (whether the same be or be not mude up or manufactured) shall sustain thereby, together with sueh costs of prosecution as shall be adjudged reasonable by the justice before whom such oftender or offenders *shall be respectively convicted: and in case immediate pay- [*5,41]

(a) Repealed as to woollen, linen, eottoa, flax, mohair, and silk manufactures, 6 \& 7 Vict. c. 40 , post. 
ment of the respcctive forfeitures, together with such costs of prosecution an aforesaid, shall be neglected or refused to be made, that then such justice, or any other justice of the peace for the county, riding, division, city, town or place where such offences shall be committed, shall cause the said offenders to be committed to the house of correction, to be there kept to hard labour tor any time not exceeding three months, nor less than one month, as to such justice shall seem reasonable; and also during the time of such commitment shal anse the said offender or offenders to be publickly whipped in the market town where such offender or offenders shall be respectively committed at the market place or cross of such town, once or oftener, as to such justice shall seem reasonable; and it is by the said act of 13 Geo. 2 also further enacted, that every persoln or persons who shall buy or receive, accept or take, by way of gift, pawn. pledge or sale, of or from any of the persons in the said act of 1 Ann. mentioned. any woollen, linnen, fnstian, cotton, or iron manufactures, either before or after the same shall be mannfactured or converted into merchantable wares, knowing the same to be so purloined or imbezilled, and being thereof lawfully convicted, shall severally suffer the like forteitures and penalties as are by the said acts respectively inflicted on persons purloining or imbezilling such of the materials or manufactures enumerated in the said acts respectively ; all which forfeitures, when recovered, are by the said act of 13 Geo. 2 directed to be applied in manner following; that is to say, one moiety thereof to the use of the partyor parties injured, and the other moiety to the use of the poor of the parish onlywhere the offence shall be committed, with the like liberty and benetit of appealing to all parties as is given in and by the said act of 1 Ann. : and it is by the said act of 13 Geo. 2 also further enacted, that if any person or persons lired or employed in eutting, paring. Washing, dressing, sewing, making up, or otherwise manufacturing of gloves, breeches, leather, skins, boots, shoes, slippers, wares, or other goods or merchandizes, to be made use of in any of the trades or employments, or in manner last mentioned, or in any branch or particular thereof, shall fraudulently purloin, inbezil, secrete, sell, priwn, or exchange all or any part of the gloves, breeches, leather, skins, parings, or shreads of gloves, or leather, or other materials with which he, slie or they shall be entrusted to work up or manufacture, or shall purloin, imbezil, secrete, sell, pawn or exehange any gloves, brecehes, boots, shoes, slippers or wares when made, wronght up, or manufactured, or do or wilfully permit any otler act to lessen the value of such, or any part of such gloves, breeches, leather, skins, paring.s or shreads of gloves, or leather, boots, shoes, slippers or other wares last particularized, either before or after the same shall be respectively so made into wares, and be thereof lawfnlly convicted, in manner preseribed by the said last mentioned act, before one or more justice or justices of the peace for the county, riding, dirision, city, town or place, where steh oflence shall be committed, or where the party or parties so charged shall reside or inhahit. such justice or justices shall and may award the person or persons so offending to make a reasonable and suitable recompence and satisfaction for every oftence to the parties respectively injured, for the damage by them sustained, so as the same do not exceed donble the value of the gloves, breeches, leather, boots, shoes, slipper, wares, goods or materials by such offender or offenders so purloined or imbezilled, secreted, sold, pawned or exchanged ; one-half thereof to go to the party or parties grieved, and the other half to the nse of the poor of the parish or place where such offence shall be committed, together with the full charges attending such convietion, to be levied by warrant under the hand and seal or hands and seals of such justice or justices, by distress and sale of the offender's goods; but if such offender or offenders shall not have goods sufficient to answer the forfeitures and the expenses attending the premisses, and shall also neglect or refuse immediately to pay the same, that then the said offender [*581] or *offenders shall by like warrant of such justice or justices last described, be for every distinct offence committed to the house of correction, or other publick prison of such county, riding, city, town or place, and there kejt to lard labour for the space of fourteen days, and shall be there likewise whipped in such manner as the said justice or justices shall order and direct; and 
in ease also of a subsequent con viction for a second or any other snch like offenee, that the person or persons so offending, for every second or other subsecjuent offence, shall forfeit four times the valne of the damages which the owrer or owners of such materials, either before or after the same shall be respectively made up into wares, shall sustain thereby, together with such costs of prosecution as shall be adjudged reasonable by the justice before whom such offender or offenders shall be respectively convieted; and in ease immerliate payment of the respective forfeitnres, together with such costs of prosecution as nitoresaid, shall be neglected or refused to be made, that then it shall and may le lawiul to and for such justice to commit the offender or offenders last desirilerl to the house of correction or other publick prison, to be there kept to hard labour for any time not exceeding three months; nor less than one month, as to such justice shall seem reasonable; and also during the time of such commitment shall cause the said offender or offenders to be publiekly whipperl in the market town where such offender or oflenders shall be respeetively conmitted, at the market-place or cross of such town, once or oftener, as to sueh justice shall secm reasonable; and it is by the said aet of 13 Geo. : also further (11icterl, that every person and persons who shall knowingly or willingly buy or receive, accept or take, by way of pawn, pledge, sale, or in any other minncr, of or from any of the persons offending in either of the particulars last mentioned, or of or from any other person or persons whatsoever (except of or from the person or persons in whom the property of sueh gloves, breeclies, leather, boits, shoes, slippers, wares, goods, or other materials shall be at the time of such sale, pawn, or exchange), or offer so to do, such person or persons ofiending therein respectively shall for every offence, being convicted thereof in manner before prescribed by the said last mentioned act, make sueh suitable and reasonalle recompence and satisfaction, within two days next after the matter or tact shall be determined by any one or more justiee or justices as aforesuid, upon hearing the same, or else be subjeet to such distress, and, for want of sutticient distress, to be liable to the like punishment as is by the said aet dirceted to be inflieted on such person or persons as shall purloin, imbezil, secretc, sell, pawn or exchange any gloves, breeches, leather, boots, sloes, slippers, wares, goods or other materials or effects of that sort as aforesaid, and so in like manner for any second and every other subsequent ofience: aml whereas the penalties and forfeitures to which offenders against the said aets are subjected liave not been sufficient to deter persons from committing the offenees throreby intendel to be prevented : and wherces many persons employed in the making of folts or lats, and in preparing or working up the manufactures of furr, hemp, thax, moliar, and silk, and also the manutactures male up of wool, furr, homp, tlax, mohnir, cotton, or silk, or some of them mixed one with another, hare of late been guilty of divers frauds and abuses, by purloining, imbezilling, secreting, selling, pawning, exchanging, or otherwise unlawtully disposing of the materials with which they have been intrusted; and it is theretiore become necessary to make provision for preventing such offences tor the future: therefore, for amending and rendering more effectual the said act male 13 Geo. 2 , and for extending the provisions and regulations therein and herein made to the several manufactures hereinbefore mentioned, be it enacted by (\&.. \&e.), thut if any person or persons whatsoever who shall be hired or employed to make uny felt or hat, or to prepare or work up any wollen, linnen, fustian, cotton, iron, leather, furr, hemp, flax, mohair. or silk mamufictures, or any manufactures male up or wool, furr, hemp, flax, cotton, molair, *or silk, or of any of [*2*t] the said materials mixed one with another, shall, from and after the 2 th day of June, 1749, purloin, imbezil, scerete, sell, pawn, exchange, or otherwise unlawfully dispose of any of the materials with which he, she or they shull be respectively intrusted, whether the same or any part thereof be or he not flrst wrought, made up, nanufactured or converted into merchantuble wares (b), or shall reel false $(c)$ or short yarn, and shall be thereof lawfilly convicted

(b) See 17 Geo. 3, e. 56, post, and sect. 16, as to tools, \&e.

(c) This punishment for recling false or short yarn laving been found too 34 Mas. \& SEr. 
(d) by the oath or (if the owner thereof be of the people called Quakers) solemn affirmation of the owner of such goods or materials, or by the oath or affirmation of any other credible witness or witnesses, or by the esnfession of the person or persons charged with such offence, before any one $(c)$ or more justice or justices of the peace of the county, riding, division, city, liberty, town or place where such offence shall be committed, or where the person or persons so charged shall reside or inhabit (which oath or affirmation the said justice or justices is and are hereby impowered and required to administer), it shall and may be lawfil to and for the said justice or justices, by warrant under his or their hand and seal or hands and seaIs, to commit the person or persons so convicted to the house of correction, or other public prison of such county, riding, division, city, liberty, town or place $(f)$, [there to be kept to hard labour for the space of fourtan days, and also to order the person or persons so convicted to be once publickly whi,jped at the market place, or some other publick place of the city, toun or place where such offender or offenders shall be respectively commitled; and in case of a furthr conviction in manner before prescribed by this act, for or upm a second or other su'ssequent offence of the sxime kind, it shall and may be lawful to and for the justice or justices bcfore whom sueh comriction shall be had, to commit the person or persons so again offending to the house of carrection, or other publick prison as aforesaid, there to be kept to hard labour for any time not exceeding thrce months, nor less than one month; and also to order the person or persons so again offending to be publickly whipped at the market place, or some other publick place of the city, town or place where such offender or ofendere shall be respectively committed, tutice or oftener, as to such justicc or justices shall appear reasonable $(g)$; anything in the said act of 1 Ann., or in the said in part recited act of 13 Geo. 2, to the eontrary in anywise notwithstanding.]

2. And be it further enacted by the authority aforesaid, that if any person or persons shall buy, receive, accept or take, by way of gift, pawn, pledge, sale or exchange, or in any other inanner whatsoever, of or from any person or persons hired or employed to niake any felt or hat, or to prepare or work up the woollen, linnen, fustain, eotton, iron, leather, furr, hemp, flax, mohair or silk manufactures, or any manufactures made up of wooll, furr, hemp, flax, cotton, mohair or silk, or of any of the said materials mixed one with another, any thrums or ends of yarn, or any other materials of wooll, furr, hemp, flax, cotton or iron, or any [*533] leather, "mohair or silk, whether the same or any part thereof be or be not first wrought, made up or manufactured, knowing the person or persons of whom he, she or they so buy, receive, accept or take the said materials to be so lired or imployed as aforesaid, and not having first obtained the consent of the person or persons so hiring or imploying him, her or them, who shall offer to sell, pawn, pledge, exchange or otherwise dispose of the said materials, or shall buy, receive, accept or take in any manner whatsoever, of er from any other person or persons whomsoever, any of the said materials, whether the same be or be not first wrought, made up or manufactured, knowing the sane to be so purloined or imbezzilled, then and in every such case the person or persons so buying, receiving, accepting or taking any such materials, being thereof lawfully convieted in manner before preseribed by this act for the conviction of persons purloining or imbezzilling the said materials, sha!l for the first offence

severc was repealed, 14 Geo. 3 , c. 44 , and a punishment by penalty for the first offence not exceeding $20 \mathrm{~s}$. nor less than 58 .; for the second offence, not exceeding $5 l$. nor less than $40 \mathrm{~s}$; and for the third and subsequent offences, imprisonment with hard labour for one calendar month, and to be once publicly whipped at the nearest market town on a market day, substituted.

(d) As to form of eonviction, see $58 \mathrm{Geo} .3$, c. $51, \mathrm{~s} .5$; but see also 11 \& 12 Vict. c. 43.

(?) Two, 17 Geo. 3, c. 56, s. 2, post.

(f) The remainder of this section was repealed by $47 \& 48$ Vict. c. 43.

(g) See 17 Geo. 3, e. 56, post, which alters the punishment, and sect. 16, as to tools, \&c. 
forfeit the sum of twenty pounds $(h)$; and in case the said forfeiture shall not be immediately paid, the justice or justices before whem such conviction shall he had, shall commit the party or parties so convicted to the house ut corretion, or other publick prison as aforesaid, there to be kept to hard labour for the s]nee of tourteen days, unless the said lorfeiture shall be sonner puid; and if, within two days before the expiration of the stid fourteen days, the vid finlfeiture shall not be paid, the said justice or justiees is and are horeby impowered and required to order the person or persins so convicted to be jubliwkly whipped at the market place, or some otlier publick place of the city, town ur place where sueh offender or offenders shall be respectively committed, onc' or oftener, as to such justice or justices shall appear reasonable; and, in "ase of a further conviction for or upon a second or any wher subseduent oflence if the same kind, the person or persons so again offending, heing thereof convirted in manner before prescribed by this act, shall for cvery seconil or other subseyuent offenee, forfeit the sum of forty pounds ( $i)$; [and in case the sail forfeituri whrll not be immediatcly paid, the justice or justices before whom such convictim shetl be lad shall eommit the party or parties sy contivel to the honst of correction, or other public prison as aforesaid, there to be kgt to hard labour for any time not crecriting thre months, nor less than one menth, unless the sridl focfiture shall bc sooner prid; and if, within scven days before the copiration of the time for which surh utfenter or ofenilers shall be so comnitted, the said forfeiture shatl not be paid, the snid justice or justices is and are hereby impoteced and required to order such offender ar offinders to be publickly whipped at the market place or some oher mblick ptace of the eity, torn or place where he, she or they shatl be respectively committel, twice or oftener, a.s to such

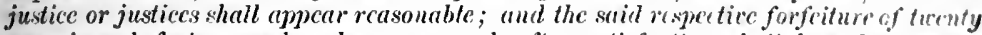
pounds and forty pounds, when recorered, afier sutisfaction shall have bien male thercout to the party or parties injured, together wih such costs of prosention us shall

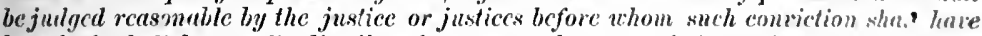
been hat, shalt be cqually distributed amongst the poor of the parish or place where the person or persms so eonvicted shatl veside or iuhabit; anything in the said teo first-mentioned acts, or cither of them, to the contrary in anyeise notwithstanding.]

[Sect. 3 was repealed by 30 \& 31 lict. c. 59.]

4. And be it further enacted hy the authority aforesaid, that if any peran or persons shall be charged with anil afterwards convicted $(k)$ of purloining or em-

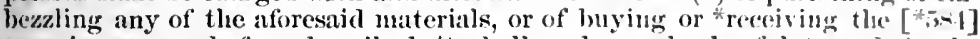
sane in manner before described, it shall and may be lawful to and for the justice or justices of the peace before whom such eouviction shall be h:ul to issue a warrant under his or their hand and seal, or hatuls amd setls, directed ts any person or persons, impowering him or them, in the presence of a constable or headborough, and in the diy-time, to enter into mal soneh the houses, out-louses, slops, cellars, vaults and other plices belmering to (k) the person or persons so convieted as aloresaid; and if upou any such searel or searehes there shall be found any thrums or eads of yath, or any a ther materials of wooll, furr, hemp, flux, cotton, iron, leather, mohair or silk, it shall and may be lawful to and for the person of persins impiwereal to nuke such search or searches as aforesaid to bring such materials before the suid justice or justices, to be by him or then detained and krpt in safie astumly: and if within the spaee of twenty-four alays next after such thrums of ouds of yar:l, or other materials, shall be sa taken and detaincel, it shull be nande dppear to the satisfaction of the said justice or justices that the person or persin from whose houses, out-houses, shops, collars, vatults or other places as atioresuid, the said inaterials shall be so taken and detained, is or are the lawful owner r owners thereof, and came to the possession of the sane iu an lomest and law ful manner, then all suel thrums or ends of yaru, or of her materials, s.) tuken and

(h) See 17 Geo. 3, c. 56, post; and sect. 16, as to tools, Sc.

(i) See 17 Ge.. c. 56, ss. 3 and 4, post. where the penalties are inerrast. This section from (i) repealed by 17 \& 45 Vict.

( $k$ ) See 17 Geo. 3, c. 56, post, p. 593, as to search before conviction, and in premises not belonging to person convicted. 
kept as aforesaid, shall be restored to the person or persons out of whose custody or possession the same shall have been so taken; but in ease it shall not be made appear within the time before limited, to the satisfaction of the said justice or justices, that the person or persons convieted as aforesaid is or are the lawful owner or owners of the said materials so taken and detained as aforesaid, then and in every such case the said materials shall be decued and adjudged to be purloined or embezzilled; and it shall and may be lawful to and for the said justice or justices to direct all such thrums or ends of yarn, or other materials, to be publickly sold, and the money arising by such sale (the charges of sueh sale being first deducted) to be equally distributed amongst the poor of the parish or place where the person or persons so convicted shall reside or inhabit.

5. Proviled always, and it is hereby enaeted, that the said justice or justices shall, within three days after such materials shall be brought to him or them as aforesaid, give notice thereof in writing under his or their hand and seal, or hancls and seals, to the person or persons convicted as afresaid, appointing in such notice a time and place for his, her or their attending in order to make out and prove his, her or their property in sueh materials so taken and detained as aforesaid; which time so to be appointed shall be within twentyone days and not less than eighteen days after such notice given; and if the person or persons so convieted shall be detained in any louse of correction or other prison as aforesaid, the said justice or justices shall also cause a copy of the said notice, attested under his or their hand and seal or hands and seals, to be delivered to the master or keeper of such louse of correction or other prison, which master or keeper is hereby required to bring or eause to be brought before such justice or justiees the person or persons named in such notice, at the time and place therein speeified, if the person or persons named in such notice. be then in the custody of sueh master or keeper; and if any such master or keeper shall neglect or refuse to do so, such master or keeper shall, for every such neglect or refusal, forfeit to the person or persons respcetirely named in such notice the full value of all the materials so taken, detaincd and sold, to be reevered by distress and sale of the goods and chattels of such master or keeper, by warrant under the hand and seal or hands and seals of the justice. or justices signing such notice, in ease the said forfeiture shall not be immediately paid.

$[\% 5-5] * 6$. Provided also, and it is hereby further enacted, that if any person shall think himself or herself aggrieved by the judgment or order of the said justice or justices relating to the sale or disposal of the said materials so found and detained as aforesaid, such person shall have liberty to appeal against the judgment or order of the said justice or justices to the justices of the peace in the general or quarter sessions of the peace which shall be held for the same county, riding, division, city, hberty or town corporate, next after such judgment or order shall be given or made; and that in the meantime the sale and disposal of such materials shall be postponed $(l)$; [notice in writing under the hand of the person intending to appeal, siguifying such his or her intention, being given to the justire or justices by whom such order shall have been male before the? time appointed for the sale and disposal of such materials; and the justices of the peace in the sail general or quarter sessions of the peace are hereby authorized and imporered to summon and cxamine witucsses upon oath (or being of the people callct Quaker:s, upon their solemn affirmation), and to hear and finally determine the matter of the said appeal; ant in case the said appellant shall not prosecute such his or her appeal, or for any other cause the judgment of the said justice or justices by whom such order shall have been matle shall be affirmed, it shall and may be laxful to anl for the justices in the said general or quarter scsions of the peace to avarl such costs as they in their discretion shall think reasonable, to be paid by the appellant for defraying the expenses sustained by the defendant or defendants in such appeal.]

7. And be it further enacted by the anthority aforesaid, that if any person or persons entrusted with any of the materials hereinbefore mentioned, in order to

(l) The remainder of this section was repealed by $47 \& 48$ Vict. c. 43 . 
prepare, work up or manufacture the same, shall not use all such materials in the preparing, working up or manufacturing of the same, and shall neglert or delay for the space of twenty-one days $(m)$ after such matcrials shall he prepared, worked up or manufactured, to return (it required by the owner or owners of such materials so to do) so much of the said materials as shall not be usedl ats aforesaid to the person or persons entrusting him, her or them therewith, such neglect or delay shall be deemed and adjudged to he an imbezzling or purloining of sneh materials; and the person or persons so neglecting or delaying, lxing thereof convicted in manner before preseriben for the convirtion of offenders against this act, shall suffer the like punishment $(n)$ as persoms convieted of imbezzling or purloining any of the miterials hereinbefore mentioned are by this act rendered subject and liable to.

[Seet. 8 was repealed by 47 \& 43 I Iict. e. 43 ; sect. 9 wels repealed by 17 lico. :3, e. 5f, s. 8, post, p. 593; sects. 10 \& 11 were repealed by 34 \& 35 int. c. 116.]

12. And whereas by an act made in the 12 th Geo. 1 , intituled, "An Act to prevent unlawful Combinations of Workmen employed in the Woollen Ninufactures, and for better Payment of their Wages," all contracts, covenants or agreements, and all by-laws, ordinances, rules or orders, made or entered into or hereafter to be made or entered int, by or between any persons bronght up in or professing, using or exercising the art and mystery of a wooll comber, or weaver or journcyman wooll comber, or journeyman weaver, in any parish or place within this kingdom, for regnlating the same trude or mystery, or for regulating or settling the prices of gools, or for advancing their wages, or for lessening their usual hours of work, are decelared to bo illegal, null and void to all intents and purposes; and it is hy the said list mentioned act (amongst other things) enacted, that if any wooll comlser or weaver or journeyman wooll comber, or journeyman weaver or other person concerned in any of *the woollen manufactures of this kingdom, [*:Nit] shall at any time kecp up, eontinue, act in, make, enter into, sign, seal or be knowingly concerned in any contract, covenant or agreement, by-law, orlinance, rule or order of any club, society or combination, by the sidil act declared to be illegal, or shall presume or attempt to put any such illegall agreenent, by-law, ordinance, rule or order in execution, every person so oflending, luing thereof lawfully convieted in manner prescribed by the sibil act, whall, at the discretion of the justices of the peace before whom such convietion shall be had, be committed either to the honse of correction, there to le kept to laard labour for any time not exceeding three months, or to the common gool of the county, eity, town or plaee where such offence shall be committerl, there to remain without bail or mainprize for any time not exieceling three monthis: I ud it is by the said last mentioned act also further enarted, that if any person retained or employed as a wooll comber or weaver, or servant in the art or mystery of a wooll comber or weaver, shall depart from his service before the end of the time for which he is hired or retained, or shall guit or return lis work before the same shall be finished according to agrecment, unless it be for some reasonable cause, to be allowed by two or more justices of the pratce within their respeetive juristlietions, every person so oflending, being thereof convicted in manner preseribed by the said art, sliall he committed to the house of errrection, there to be kept to hard labour for any" time not exverding three months; and if any wooll comber, weaver, servant or person hired, retaincel or employed in the said art or mystery, shall wilfully damnify, spoil or destruy (without the consent of the owner) any of the goods, wares or work committed to his care or charge, or wherewith he shall be entrusted, such oflonder heing thereof convieted slall forfeit and pay to the owner or owners of smoll promls or wares so damnified, spoiled or destroyel, donble the value thereof, to be levind by distress and sale of the offender's goods and chattels, ly warrunt or warrants, under the hands and seals of any two or more justices of the peace w ithia

(m) Seo 17 Geo. 3, c. 56, s. 7, post, p. .592.

(n) Ibid. 
their respective jurisdictions; and for want of sufficient distress such justices shall commit the party or parties offending to the house of eorrection, there to be kept to hard labour for any time not exceeding three months, or until satisfaction be made to the party or parties agrgrieved for the same: And it is by the said last mentioned act also further enacted, that every clothier, serge maker or woollen or worsted stuff maker, or persons concerned in making any woollen cloths, serges or stuffs, or concerned in employing wooll combers, wearers or other labourers in the woollen manufactory, shall pay to all persons by them employed in the woollen manufacture the full wages, or other price agreed on, in good and lawful money of this kingdom, and shall not pay the said wages, or other price agreed on, or any part thereof, in goods or by way of truek, or in any other manner than in money, or make any deduetion from such wages or price for or on account of any goods sold or delivered previous to such agreement, by any person or persons whatsoever; and for the more easy recovery of the said wages, or price agreed on, any two or more justices of the peace, within their respective jurisdictions, are authorized and required, upon complaint made for that purpose, to summon before them the party or parties offending, and for non-payment of such wages, or price agreed on, in money as aforesaid, or sufficient satisfaction given for the same, to the good liking of the party or parties aggrieved, to issue their warrant or warrants under their hands and seals for levying such wages or price due as aforesaid by distress and sale of the oftender's goods and chattels, rendering the overplus to the owner; and, for want of sufficient distress, to commit the party or parties offending to the common gaol of the county, eity, town or place where such offence shall be committed there to remain without bail or mainprize for the space of six months, or until he, she or they shall pay such wages or price agreed on, in money as $[* 587]$ aforesaid, or gixe full satisfaction for *the payment of the same, to the good liking of the party grieved: And it is by the said last mentioned act also further enaeted, that if any clothier, serge maker, woollen or worsted stuff maker or person concerned in making any woollen cloths, serges or stufts, or any way concerned in employing wooll combers, weavers or other labourers in the woolen manufactory, shall pay any person or persons employed by them their wages or other price agreed on, or any part thereof, either in goods or by way of truck, or in any otlier manner than in money, every person so offending shall also forfeit and pay the sum of ten pounds, one moiety thereof to the informer and the other moiety to the party or parties aggrieved, to be levied by distres: and sale of the oftender's goods as aforesaid, rendering the overplus (if any be) ts the owner: And it is by the said last mentioned act also provided, that it shall be lawful for any person aggrieved by any order or orders to be made by any two or more justices of the peace as aforesail, to appenl to the justices of the peace at the next general quarter sessions to be holden for the eounty, eity, division, parish or place where such order shall be made, giving reasonable notice of such appeal, the reasonableness of which notice shall be determinerl by the justices at the quarter sessions to which sueh appeal is made; and if it shall appear to them that reasonable time of notice was not given, then they shall adjourn the said appeal to the next quarter sessions, and then and there finally hear and determine the same; and the justices who in the general quarter sessions shall hear the matter shall have power to award reasonable costs to either party, as to them shall seem just: And it is by the said last mentioned act also further enacted, that if any person or persons shall assault cr abuse any master wooll comber, master weaver, or other person concerned in any of the woollen mannfactures, whereby any such master or other person shall receive any bodily hurt for not complying with, or not conforming or not submitting to any such illegal by-laws, ordinances, rules or orders aforesail; or if an person or persons shall write or cause to be written, or knowingly send or cause to be sent, any letter or other writing or message, threatening any hurt or harm to any such master wooll comber or master weaver, or other pe:son concerned in the woollen mannfacture, or threatening to burn, pull down, or destroy any of their houses or out-houses, or to cut down and destroy any of their trees, or to maim or kill any of their cattle, for not complying with any 
demands, claims or pretences of any of his or their workmen, or ot hers emplozed by them in the said manufacture, or for not eonforming or not snbmitting to any such illegal by-laws, ordinances, rules or orders as aforesild, every jerwon so knowingly and willingly offending in the prensisses, being thereof law fully convieted, upon any indictment to be found within twelve calenkar month next after any such offence committed, shall be adjudged guilty of ficlonv, and shall be transported for seven years to some or one of his llajesty's colonies or plantations in Ameriea, by such ways and means, and in such manner, and under such pains and penalties as felons in other cases are by law to be transported: And whereas, it is necessary that the said several provisions and regulations in the said last in part recited art should be extended to journeymen dyers, journeymen hot pressers, and all other porsons employed in the wowllen manufactures of this kingdon, and also to journeymen, servants, workmen and labourers employed in the making of felts or hats, and in the manufuctures of silk, mohair, furr, hemp, flax, linnen, cotton, fustian, iron, and loather, or any manufactures made up of wooll, furr, hemp, thax, cotton, mohuir or silk, or of any of the said materials mixed one with another, be it therefore enucted by the authority aforesaid, that the said several betore recited clanses in the said act made in 12th Geo. 1, and all the provisions, regulations, pains, penalties and forfeitures therein eontained, shall, from and atter the said $24 t h$ day of . Inne, 1749, extend, and be construed, deemed and *aljudged, to cxtend to [*5<8] journeymen dyers, journeymen hot pressers, and all other persons whatsoever employed in or about any of the woollen mimufuctures of this kingdom, and also to journeymen, servants, workmen and labourers, and all other persons whatsoever employed in the making of felt or hats, or in or about any of the manufactures of silk, mohair, furr, lemp, flax, linnen, cotton, fustian, iron or leather, or in or about any manufactures made uj, of wooll, firr, licmp, flax, cotton, mohair or silk, or of any of the said materials mixed one with another, in as full and ample a manner as the said provisions, regulations, pains, penalties and forfeitures, are by the said last mentioned art iledared to extend to the several and respective persons therein named; and the pains, ponalties and forfeitures which shall be incurred by reason of any oflence committed arginst. the said last mentioned act, by any person or persons employed or concermed in or about any of the said manufaetures hereinbetore enmmerited, shall be ir:flicted, levied and recoverel in the same manner as the pains, penalties and forfeitures eontained in the said last in part recited act are directed to be inflicted, levied and reeovered upon and igatinst the several and respective persons therein mentioned $(o)$.

\section{GEO. 3, c. 56.}

An Act for amending and rendering more effectual the several I.aus now in being, for the more effectual preventing of lrands and Abuses by Persons employed in the Mamufucture of Mats, and in the Woollen, Linen, Fustian, Cotton, Iron, Leather, Fur, Hemp, Flax, Mohair, and Silk, (p) Manufactures; and also for making Provisions to prevent Frauds by Journeymen Dyers.

Whereas by an act made 22 Geo. 2 (intituled "An Avt for the more eflectual

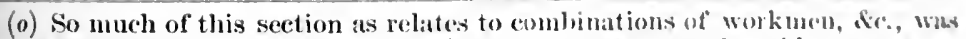
repenled, (; Geo. 4, e. 199 (ante, p. $5(60)$; so much as resated a folony was re pealed by 9 Gco. 4, e. 31 (ante, p. 47i); and somuch as relates to the payment

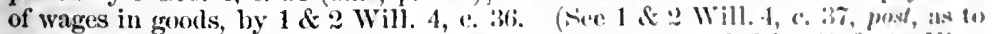
wages.) And so nueh as applies ts any cusetment repealed by d7 is ds biet. c. 43, was repealed by that act.

(p) Repealed as to woollen, linen, cotton, thax, moluair und silk manufactures, $6 \& 7$ Vict. c. 40, post; and see li. v. Button, 11 (?. B. 9)11. 
preventing of Frauds and Abuses committed by Persons employed in the Manufaeture of Hats, and in the Woollen, Linen, Fustian, Cotton, Iron, Leather, Fur, Hemp, Flax, Mohair, and Silk Manufactures ; and for preventing unlawful Combinations of Journeymen Dyers and Journeymen Hotpressers, and of all persons employed in the said several Manufaetures, and for the better payment of their Wages"), it was enacted that if any person or persons whatsoever, who slould be hired or employed to make any felt or hat, or to prepare or work up any woollen, linen, fustian, cotton, iron, leather, fur, hemp, flax, mohair or silk manufactures, or any manufactures made up of wool, fur, hemp, flax, eotton, mohair or silk, or of any of the said materials mixed one with another, should, from and after the twenty-fourth day of June one thousand seven hundred and forty-nine, purloin, embezzle, seerete, sell, pawn, exchange or otherwise unlawfully dispose of any of the materials with which he, she or [*589] they should be respectively intrusted, whether the *same or any part thereof be or be not first wrought, made up, manufactured or converted into merchantable wares, and should be thereof lawfully eonvieted in manner therein mentioned, before any one or more justice or justiees of the peace of the county, riding, division, eity, liberty, town or plaee where such offence should be committed, or where the person or persons so eharged should reside or irhabit, it should and might, be lawful to and for the said justice or justiees, by warrant under his or their hand and seal or hands and seals, to commit the person or persons so eonvieted to the house of eorrection or other publie prison of sneh county, riding, division, eity, liberty, town or place, there to be kept to hard labour for the spaee of fourteen days, and also to order the person or persons so convicted to be once publicly whipped at the market place or some other publie place of the eity, town or place where sueh offender or offenders should be respectively committed ; and in ease of a further convietion, in manner before prescribed by the said aet, for or upon a seeond or other subsequent offence of the same kind, it should and miglit be lawful to and for the justice or justices before whom such convietion should be had to eommit the person or persons so again offending to the house of eorrection or other publie prison as aforesaid, there to be kept to hard labour for any time not exceeding three months, nor less than one month, and also to order the person or persons so again offending to be publiely whipped at the market place or some other publie place of the eity, town or place where sueh offender or offenders should be respeetively committed, twice or oftener, as to such justice or justices should appear reasonable; and whereas it is thought neeessary to vary the punishment for the offences hereinbefore reeited; be it therefore enaeted, by (\&c. \&c.) that from and after the 1st day of July, 17\%7, so mueh of the said reeited act as preseribes what the punishment shail be in any of the eases before mentioned, or before whom such eonviction sliall be had, whether for a first offence or a second or any subsequent offence, shall be repealed ; and instead of inflicting the punishment so directed the justices of the peace before whom the eonvietion shall be shall commit the person convieted to the honse of correction or other publie prison, there to be kept to hard labour, in the ease of a first offenee, for any time not less than fourteen days nor more than three months, and in the case of a second or any subsequent offence, for any time not less than three months nor more than six months, and may likewise, for the first or for any subsequent offence, order the person eonvieted to be onee publiely whipped, if sueh additional punishment shall by the said justice or justiees be deemed proper.

2. Provided always, and be it further enaeted by the authority atoresaid, that no person or persons who shall be elarged with any offenee or offenees against the said reeited act of 22 Geo. 2 , shall be liable to be convieted unless before two or more justices of the peace for the eonnty. riding, division, eity, liberty, town or place where the offenee shall be eommitted; anything eontrined in the said reeited aet to the eontrary hereof notwithstanding.

3 . And whereas by the said aet of 22 Geo. 2 , it was also enaeted, that if any person or persons should bny, receive, aecept or take, by way of gift, pawn, pledge, sale or exehange, or in any other manner whatsoever, of or from any person or persons hired or employed to make any felt or hat, or to prepare or 
work up the woollen, linen, fustian, cotton, iron, leather, fur, hemp, llax, mohair or silk manufuctures, or any manufactures made up of wool, fur, himp, flax, cotton, mohair or silk, or of any of the said materials mixed one with another, any thrums or ends or yarn, or any other materials of wool, fur, hemp, flax, cotton or iron, or any leather, mohair or silk, whether the same or any part thereof be or be not first wrought, made up or manufactured, knowing the person or persons of whom he, she or they so buy, receive, accept or tike, the said materials t $\Theta$ be so hired or employed as aforesaid, and not having * first obtained the consent of the person or persons so hiring or employ- [*590] ing him, her or them, fwho should offer to sell, pawn, pledge, exchumge or otherwise dispose of the said materials or should buy, receive, aecept or take, in any manner whatsoever, of or from any person or persons whomstever, any of the said materials, whether the same be or be not first wrought, made up or manufactured, knowing the same to be s) purloined or embezzled, then and in every such case the person or persons so buying, receiving, acepting or taking any such materials, being thereof lawfully convicted in manner before prescribed by the said act for the conviction of persons purloining or embezzling the said materials, should for the first offence forfeit the sum of twenty pounds, and in case the said forfeiture should not be immediately paid, the justice or justices before whom such conviction should be had should commit the party or parties so convicted to the house of correction or other public prison as aforesaid, there to be kept to hard labour for the space of fourteen days, unless the said forfeiture should be sooner pail ; and if within two days before the expiration of the said fourteen days the said forteiture should not be paid, the said justice or justices is and are hereby empowered and required to order the pergon or persons so convicted to be publicly whipped at the market place, or some other public place of the city, town or place where such offender or otlenders should be respectively committed, once or oftener, as 10 such justice or justices should appear reasonable; and in case of a further conviction for or upon a second or any other subsequent offence of the same kind, the person or persons so again offending, being thereof convieted in manner betore prescriber by the said act, should for every seeond or other subsequent offence fiorfeit the sum of forty pounds; and in case the said forfeiture should not be immediately prid, the justice or justices before whom such conviction should be had should ('ommit the party or parties so convieted to the house of correction or other public prison as aforestid, there to be kept to harl labour for any time not exereding three months nor less than one month, unless the said forteiture should bo sooner paid; and if within seven days before the expiration of the time tor which such offender or offenders should be so emmitted the said forteiture should not be paid, the said justice or justices is and are thereby empowered and required to order such offender or offenders to be publicly wliiplest at the narket place, or some other public place of the eity, town or place where he, she or they should be respectively committed, twice or oftener, wr to such justice or justices should appear reasonable; and the said respective fortitures of twenty pounds and forty pounds, when recovered, after sitisfaction should have been male thereout to the party or parties injumed, together with such cosis of prosecution as should be judged reasonahle by the justice or justices hefore. whom such conviction should have been had, shomld be equally distributed amongst the poor of the parish or place where the persun or prisons so convieted should reside or inhalit: And whereas it is thonght neceswary wincrose the pecuniary penalties directed by the said recited act for the said oflendes last. mentioned, and to vary the applieation of the said penalties for the same, and further to ehange the consequences of non-payment: be it therefore further enacted, that from and after the said 1st day of July, 17\%7, so much of the said recited act of 22 Geo. 2 as enacts what the ponalty or punishurent shall ln for such buying, receiving, accepting, or taking ly way of gift, pawn, pledge, salo or exchange, or in any other manner as is described by the sald ant in tho terins aforesaid, and how such penalty shall be applied, and what punishmont shall be inflicted in case of non-payment. shall bo repenled ; mol insterul thereof the penalty for the first offence shall be any sum not more than forty 
ponnds nor less than twenty ponnds as the justices before whom the conviction shall be shall judge to be most proper; and every such pecuniary penalty shall be applied, under the direction of the justices before whom the conviction shall [*591] be, in manner *following: (that is to say), in the first place, the expences of the prosecution shall be thereout defrayed, and then snch satisfaction shall be made thereout to the party or parties injured as the said justices shall think proper, and afterwards so much of the said penalty shall be paid to the informer or informers as such justices shall think fit, not exceeding in any case ten pounds, and the remainder, if any, shall be paid and distributed to and amongst the poor of the parish, town or place where the convietion shall be, o: for the use of such publie charity or charities as such justices shall appoint $(q)$; and if such peeuniary penalty as aforesaid shall not be paid on conviction, the said justices shall commit the person convicted to the house of correction or other public prison, there to be kept to hard labour [the rest of this section was repealed by 47 \& 48 Viet. $c .43]$.

4. And be it further enacted by the authority aforesaid, that from and after the 1st day of July, 17\%7, if any person or persons shall be brought befure any justices of the peace, and shall be charged upon oath or (being of the people called Quakers) upon solemn affirmation of having been guilty of buying, reeeiving, accepting or taking, by way of gift, pawn, pledge, sale or exchange, or in any other manner as is deseribed by the said recited act, in the terms aforesaid, and it shall appear to such justices that the person or persons so charged hatl or have been already convicted of the like offence for which he, she or they is or are then charged, that then such justices shall not proceed to convict such person or persons, but shall eommit him, her or them to the house of correction or some other public prison, there to remain until the next general or general quarter sessions of the peace to be lield in and for the county, riding, division, city, liberty, town or place where the offence shall have been committed, or until such oftender or oflenders shall have entered into a recognizance to answer for such offence at the next general or general quarter sessions; and the justices in sueh general or general quarter sessions are hereby authorized and required to take cognizance thereof, and to lear and determine the same; and if such person shall be convicted upon the oath or (being of the people called Quakers) upon the affirmation of one or more credible witness or witnesses, the person so eonvicted shall forfeit and pay for such offence any sum not more than one hundred pounds nor less than fifty pounds, as the said justices shall judge to be most proper; and every such penalty shall be applied and disposed of, under the direction of the said justices in their general or general quarter sessions, in such manner and proportions as the penalty hereinbefore imposed for the first offence of the like nature is by this act directed to be applied and disposed of ; and if such penalty shall not be pain on eonviction the said justices shall commit the person so convieted to the house of eorrection or other public prison, there to be kept to hard labour [the rest of this section was repealed by 47 \& 43 riet. $c$. 43 ].

5 . And whereas many frauds are practiced in respect to such materials as aforesaid, by persons who sell them knowing them to have been purloined or embezzled; be it therefore further enacted, that after the said 1st dlay of July. $17 \%$, if any person shall sell, pawn, pledge, exchange or otherwise unlawfully dispose of, or offer to sell, pawn, pledge, exchange or otherwise unlawfully dispose of, any such materials as aforesaid, whether wrought or unwrought, mixed or unmixed, knowing them to have been purloined or embezzled, every sucls person lawfully convicted shall be liable to the same punishment as he or sho $[* 592]$ would be liable to by virtue of $*$ this act on being convicted of receivinis purloined or embezzled materials knowing them to have been purloined or embezzled.

(q) As to the distribution of the penalty, see now 58 Geo. 3 , c. 51 , which applies to this aet, althongh therein erroneously referred to as having beeil passed in the thirteenth year of Geo. 3. See $R$. v. Wilcock, 7 Q. B. 317; In e Boothroyd, 15 M. \& W. 1. 
6. And whereas such materials as aforesaid which have. been purloined or embezzled are frequently received by persons knowing the same tw have been so purloined or embezzled, and such materials being afterwarls worked up or otherwise disposed of renders it difficult to convinet such oflenders: ix it therefore enacted by the authority aforesaid, that from and after the siid list diy of July, 1777, when any person or persons shall be brought ol charged ujwon out h before any two or more justices of the peace, by irtue of this act, with he.ing suspected of or with having purloined or embezzled or with having received any such materials as aforesaid, whether the same be wrought or unwrought, mixed or unmixed knowing the same to have been either purloined or cuber zled or received from some person or persons not entitled to dispese therenti, and it shall be made to appear upon oath or (being of the people called Quakers) upon the allirmation of one or more credible witness or witnesses, to the satisfaction of such justices, that such person or persons hath or have purloined or embezzled or hath or have receivel any siull materials ats atiresaid, knowing the same to have been purloined or embezzled or rereived froms some person or persons not entitled to dispose thereof", it shall and may be law" ful for such justices, or for the justiees at their general or general quarter sessions of the peace and they are hereby respectively anthorizod and rmowwered (if they shall think fit) to eonvict snch person or persons of having purloined or embezzled or of having received such materials als atoresait, knowing the same to have been purloined or embezzled or received from some person or persons not entitlel to di pose thereof, although no proof shall bo given to whom such materials belong; and the person or persons so convicted shall for every such offence be subject to such and the like penalties and punishments, at the discretion of such justices respectively, as persons convicted of buying or receiving any such materials as aforesaid, knowing the same to have been purloined or embezzled, are by this act subject and liable to $(r)$.

7. And whereas by the said reeited act of $2: 2$ Geo. 2 , it was also enacted, that if any person or persons intrusted with any of the materials therein and hereinbefore mentiond, in order to prepare, work up or manuficture the same, should not use all such materials in the preparing, working up, or manuliueturing of the same, and should negleet or delay, for the space of twenty-one dings after such materials should be prepared, worked up or manufictured, to return (if required by the owner or owners of 'such materials so to do) so much of the said materials as should not be used as aforesaicl, to the person or persins intrusting him, her or them therewith, such neglect or delay should le dirmert a purloining or embezzling of such materials; and the person or perans ws neglecting or delaying, being thereof convicted in manner thereinbefore proseribed for the conviction of offenders against the said act, should sutlir the like punishment as persons convicted of purloining or cmber\%ling any uf the materials thereinbefore mentioned are by the satid act rendered sulijert and liable to: And whereas the space of twenty-one days allowel hy the said reeited act is thought too long a time to be allowed for returning the said materiais, under the cireumstances, and in manner atoresald, and it may he proper to make the punishment for not roturning such materials the sume as for purloining or embezzling, under this act: be it therefore further cuaketed, that from and after the said ist day of July, 177\%, so nuch of the said revited act as allows twenty-one days after the * preparing, working uy or m:11- [*,i:3] uficturing the saicl materials, for returning so much of the said matterials. no shall not be used in such preparing, working up or mantufucturing. and doclares that the punishment for not so returing the sald materials withiu the said time shall be the same as under the said act is directed for purloining or cmbersling. shall be repealed, and only eight days shall he allowed tor returning the said materials in manner aforesaid, and the punishment for not returning them

(r) A conviction under this acts for emberaling matrrials, although confirmed on appeal, cannot he removed ly certiorari, that writ being taken uwny by sect. 2:. See R. v. Cook, 1 Dowl. N. S. :300. 
within the said eight days shall be the same as is by this act directed to be inflicted for purloining or embezzling.

[Sect. 8 was repealed by 38 \& 39 lict. c. 86, s. 17 , post.]

9. And whereas it frequently happens that persons receive the said materials in fictitious names, in order to be manufactured; and that persons receive such materials in their own names, in order to be manufactured by themselves, and afterwards deliver the same to others to be manufactured, without the knowledge or consent of the owners thereof, and that carriers, or other persons employed to deliver materials to workmen to be prepared or manufactured, do designedly deliver such materials to other persons than those intended by the owner of such materials; be it therefore further enacted by the authority aforesaid, that from and after the said 1st day of July, 17\%;, if any person shall receive any of the aforesaid materials in a fictitious name, in order to be manufactured, or if any person shall receive in his or her own name any of the said materials, in order to be manufactured by himself or herself, and afterwards deliver the same, or any part thereof, to any other person to be mautactured (without the consent of the owner thereof), or if any carrier, or other person employed to deliver any such materials to any wokman, to be prepared or wronght up, shall designedly deliver the same to any other person than the person to whom such materials were ordered or intended to be delivered by the owner thereof, all and every person and persons offending in any of the cases aforesaid shall for every such offence be liable to prosecution, in the same manner and to the same punishment as is by this act directed in respect to persons taking in any of the said materials, in order to work np, and afterwards wilfully neglecting or refusing the performance of their work for the space of time aforesaid.

10. And whereas it frequently happens that materials used in the manufactures before mentioned are found or known to be concealed in the possession of persons who have reeeived the same knowing them to be purloined or embezzled, or of persons known not to be entitled to dispose of the same: And whereas the discovery and conviction of the purloiners and embezzlers, buyers and receivers of such materials, is full of difficult $y$, from the close and clandestine manner in which the offence is committed, and there is still greater difficulty in proving whose property such materials are; and it wonld tend to the discouragement and suppression of such offenees if the discovery and conviction of such offenders were rendered more easy: And whereas by the said recited act of 22 Geo. 2 , justices of the peace, after conviction of any offender for purloining or embezzling the said materials, or for buying or receiving the same, are anthorized to grant warrants for searching the houses and other places of the persons so convicted, but no such authority is given before convietion, nor in any other house or place except such as belongs to a person convicted; be it therefore further enacted, that it shall and may be lawful for any two $(s)$ justices of the peace of any county, riding, division, city, liberty, town or place, upon complaint made to them upon oath by any one credible person, or [*594] (being of the people called Quakers) *upon solemn affirmation, that there is cause to suspect that any such purloined or embezzled materials, whether mixed or unmixed, wrought or unwrought, are concealed in any dwellinghouse, onthonse, yard, garden or other place $(t)$ or places, by virtue of a warrant under their hands and seals ( $u$, to cause every such dwelling-louse, ont-

(s) If the complaint is made to different justices from those who determined it, the conviction should state that, as required by 3 Geo. 4 , c. 23, s. 2 : a conviction which omitted sueh statement was quashed, $R$. v. Witcock, 7 Q. B. 31\%.

$(t)$ A "warehouse" of a silk dealer and manufacturer upwards of a mile and a half from his dwelling-house, is a "place" within the meaning of this section, R. r. Edmundson, 23 L. J., M. C. 213; 2 Ell. \& Ell. 77; 33 Law Times Rep. 23\%.

(u) A search warrant under this section is necessary to justify entering a house, to search for embezzled materials, Davis v. Nest, $6 \mathrm{C}$. \& P.16\%. But in trespass for breaking and entering the house of A., and taking his woollen yarn, the 
house, yard, garden or place to be searched in the daytime, and if any snch materials suspected to be purloined or embezzled shall be firmd therein, to cause the same, and the person or persons in whose house, outhonse, yird, garden or other place the same shall be found, to be brought before any two $(x)$ justices of the peace for the same county, ridling, division, city, liberty, town or place, and if the said person or persons sluall not give an account to the sitisfaction of such justices how he, she or they came by the same, then the said person or persons so offending shall be deemed and adjudged guilty of a misdemeanor, and shall be punished in manner hereinatter mentioned, although no proof shall be given to whom such materials belong $(y)$.

11. And be it further enacted, that cvery peace oflicer, constahle, healborough or tythingman in every county, eity, town corporate or other place where there shall be officers, and every beadle within his ward, parish or district, and every watchman, during such time only as he is on his duty, shall and may apprehend or cause to be apprehended all and every person or persons who may reasonably be suspected of having or carrying or any ways conveying, at any time after sunsetting and before sumrising, any of such materials suspected to be purloined or embezzled, and the same, together with stuch person or persons, as soon as conveniently may be, convey or carry betore any two justices of the peace for the comty, riding, division, city, liberty, town or plice within which the suspected person or persons shall be apprehended; and if the person or persons so apprehended in conveving any such materials shall not produce the party or parties, duly entitled to dispose thereof, from whom he, she or they bonght or received the same, or some other credihle witness, to testify upon oath or (being of the people ealled Quakers) upon sol(nin allirmattion to the sale or delivery of the said materials (whicll oath or animation respeetively such justices are herely empoivered to administer) or shall not give an account, to the satisfietion of such justices, how he, she or they (ame by the same, then the said person or persons so apprehended shall be dicemed and adjudged guilty of a misdemeanor, and be punished in manner hereinuter .mentioned, although no proof shall be given to whom such naterials helong.

12. Provided always, and be it further enacted, that in either of the two 'ases last before mentioned, when any person or persons who slall be lrought before any two justices of the peace shall request of such justices * to ajpoint $[* ; 9 ; \%]$ a reasonable time to produce the person or persons, duly entitled to sell or dispose of the same, of or from whom he, she or they bought or received the same, or some one or more credible witness or witnesses to prove the sale or delivery thereof, then and in such ease it shall and may be lawful for the said justices, and they are hercby authorized and required to appoint such raisonable time as aforesaid, and to issue out a summons to the constable or other peacer oflicer of the parish or place where such person or persons, or sucle witnesv or witnesses, shall respectively reside, requiring him, her, or them to appear ledore two or more justices at such time and place as shall be so appointed by such justices, in order to be examined and give evidence on oath or (being of the people called Qunkers) solemn affirmation of the several matters aforesail; lut such pernon or persons, at the time of making such rejuest, shall enter into n recognizance, with or without surety or sureties, as sueh justices shall think proper, for his, her or their appearance before them at the time so to he set, or, for want of such recognizance as aforesaid, shall be committerl until the time that whall be set or appointed by the sain justices for the appourance of such party or parties, witness or witnesses; and if at such appointed time sucl person or persons shall

defendant may, under not guilty, show a eondemnation of the yurn under this statute; as that shows that $A$. could have no property in it, $i$.

(x) See note (s), supra.

(y) In a conviction under this section it is not necessury to state the ownership of the goods, In re Boothroyd, 15 M. \& W. 1 ; :ml sece ibid. us to distrihntion of penalty. As to an ind ictment for perjury eommitted hy cxhibiting thase information under this section, $R$. v. Goolfellow, Carr. \& 11.569. 
be convicted of any of the offences aforesaid $(z)$, then and in such case he, she or they shall suffer such punishment as is hereinbefore directed to be inflicted on persons guilty of such offences.

13. And be it further enacted, that where any person or persons shall be convicted of a misdemeanor in either of the two cases last before mentioned, it shall and may be lawful for the justices before whom the conviction shall be to cause the said materials so found or seized as aforesaid to be deposited in the hands of the churchwardens or overseers of the poor of the place where such materials shall be found or seized, or in any other convenient place, for any time not exceeding thirty days, and in the mean time to order the said churchwardens and overseers of the poor, or one of them, to insert an advertisement in some one or more of the public newspapers usially published or circulated in or near such place, or otherwise to cause notice to be given by some public crier, and by fixing on the church or chapel door notice describing such materials, and where the same are so deposited, to the end that persons having lost such materials or any reputable person or persons in their behalf, may come and claim the same; and in case any person or persons can prove his, her or their property iil the said materials upon oatl, or (being of the people called Quakers) upon his; lier, or their solemn affirmation, to the satisfaction of any two justices of the peace for sucl county, riding, division, city, liberty, town or place, then such justices shall order restitution of such materials to the owner or owners thereof, after paying the reasonable charges of removing, depositing and giving public notice of the same; but if before the end of the said thirty days no person or persons shall come and prove his, her or their property in sucl materials nor any reputable person or persons on his, her or their behalf: then the sairl justices shall order and direct the same to be sold ${ }^{\circ}$ for the best price that can reasonably be had, and after deducting such charges as aforesaid, together with the charges of sale, one moity of the money arising from such sale shall be given to the person or persons, or either of them, who shall apprchend or prosecute [*596] the offender or offenders guilty of *either of the misdemeanors aforesaid, as the said justices shall appoint, and the other moiety thereof, either to and amongst the poor of the parish, town or place where the conviction shall be, or to such pablic charity or charities as the justices convicting shall appoint.

14. And be it further enacted, that every person deemed and adjudged guilty of a misdemeanor, in having in his or her possession any materials suspected to be purloined or embezzled, and not producing the party or parties, being duly entitled to dispose of the same, of whom le or she bought or received the same, nor giving a satisfactory account how he or she came by the samc, or of a misdemeanor in having, carrying, or conveying of the said materials suspected to be purloincd or embezzled, and not producing the party or parties, being duly entitled to dispose of the same, of whom he or she bought or received the sami, nor any credible witness to testify upon oath, or (being of the people called Quakers) upon solemn affirmation, the sale or delivery thereof, nor giving a satisfactory account how he or she came by the same (as the case shall be), shall for every such misdemeanor forfeit, for the first offence, the sum of twenty pounds, and for the second offence the sum of thirty pounds, and for every sul)sequent offence the sum of forty pounds; [poxer of distress repealed by $47 \& 43$ Vict. c. 43], of which forfeiture one moiety shall be pail to the informer, and the other moiety thereof to and amongst the poor of the parish, town or plare where such conviction shall be, or to such public charity or charitics as the justices convicting shall appoint (a) [rest of this section repealcl by 47 \& 48 rict. $c$. 43].

(z) A conviction which stated that A. B. was convicted before the magi trates upon the oath of 'T. J., a credible witness, of laving in his possession, in his dwelling-house, certain materials used in the woollen manufacture, suspected to be embezzled and purloined, to wit, \&c. he not producing the party from whom he bought the same or giving a satisfactory account; and then goirg on to adjudicate, was held good in Davis v. Nest. 6 C. \& P. 167.

(a) As to distribution of the penalty, see ante, p. 591, note $(q)$. 
15. And whereas it sometimes happens, hy occasion of the very long detention of such materials as aforesaid, delivered ont to journeymen or other jersons employed to work up the same, it camnot he known to the mister or owners of such materials whether the same may have been pnrloined or emberzled, or whether the said materials are wholly or in part wrought or begun to be wrought, or in what state or condition such materials may be; for remaly whereof be it further enacted, that from and after the sind 1st day of d uly, 1777 , it shalf be lawful for the owner or owners of any such materials, from time to time, as occasion shall require, to demand entrance, and enter at all seasonable hours in the daytime, into the shops or outhonses of any person or persons employed by him or them to work up any of the said materials, or other place or places, where the work shall be carricd on, and there te inspert the state and condition of such materials; and in case of refusal by any such person or persons so employed to permit such entrance or inspection, he, she or they so refusing shall forfeit and pay such sum of money, not exceeding forty shillings nor less than ten shillings, as the justices before whom he, she or they shall be convicted shall think proper, to be recovered and applied in the same manner as is by this act directed for the misdemeanor of being in the posisession ot any such materials without being able ts acconnt satisfuctorily for such posicesion.

16. And whereas the said recited act of 22 Geo. 2 contains no provision for the proteetion and recovery of the tools and implements with which any persul or persons employed in preparing, working upormanufaet aring such mat trial a as at toresaid shall be intrusted for that purpose, nor any provision in respect to the drugs and ingredients used in dyeing, preparing or mannfacturing such of the sitid materials as are usually dyed, prepired or mamntactured, bo it therefore enacted, that from and after the said 1st day of July, 17\%7, every penulty or pumishment directed by or other provision contained in the sidd recited act in respect to the said materials, so far as the said recited act is not varied loy this act, and all the provisions in this act contained in respect to the said matcrials, shall extend and be applieable to any tool or tools and implement or in*plements, with which any person or persons shall be intrusted for mik- [*.5:7] ing, working upor manufacturing the said materials, and aiso to any drugor drugs, ingredient or ingredients, with which any person or persons shall be intrusted, for the purpose of dyeing, preparing or manufacturing such of the aforesid materials as are usually dyed, prepared or mannfietured, in the same manner as if the said tools and implements, l rugsand ingredients were particularly" unentioned both in the said recited act and in the preceding provisions of this act.

17. And whereas journeymen dyers (b), servants and apprentices frequently abuse the trust reposed in them, by dyeing goods for their own protit, without the consent of their masters, be it therefore enarted, that from and atter the said 1st day of July, 1777, if any person hirel, retained or employed as a journeyman dyer, or as a servant or apprentice, in the dyeing of any felt or hat, or any woollen, linen, fustian, cotton, leather, fur, llax, mohair or silk materials, whether the same shall be wrought or unwronght, or shall be mixed or mmixed with other of the said materials, shall, without the consent of the misster, person or persons by whom such jonrneyman, servant or apprentice shall be hired, retained or employed, wilfully dye any of the saicl materials, whether wromght or unwrought, or mixed or unmixed with ot her of the stid materials, or without such consent shall wilfully receive any such materials as uforesaid, for the purpose of dyeing the same, whether the same shall be dyed cr proined for

(b) This act is not repealed as to dyers by $6 \mathbb{E} ;$ Vitt. e. 40 ; se sect. 31 , which confines that act to manufecturers; see i1 Q. I3. 941. "Where n dyer permitted his servants to use his dye, fe., for their own materials mul such as he entrusted them with, but they made a protit by using them for other materials without his knowledge, and there was no proot of a conspiracy hesictes the concurrence in that act; it was held, that asimming the act itsclif to le a larreny, the servants might still be convicted of the conspiracy as a distinct oflenee, $l$ : v. Button, 11 Q. B. 929 . 
dyeing, he or she so guilty of either of the said offences shall for the first offence forfeit the sum of ten shillings, and for the second offence the sum of twenty shillings, and for every subsequent offence the sum of forty shillings; or if any person shall procure any such materials as aforesaid to be dyed by any person so hired, retained or employed as a journeyman, servant or apprentice, without the consent of his or her master or employer, or shall offer any such materials to any such journeyman, servant or apprentice, for the purpose aforesaid, he or she so offending, being thereof lawfully convicted by the oath or (being of the people called Quakers) affirmation of one or more credible witness or witnesses, before two or morc justices of the peace for the county, riding, division, city, liberty, town or place where the offence shall be committed, shall for the first offence forfeit the sum of five shillings, and tor the second offence the sum of twenty shillings, and for crery subsequent offence the sum of four pounds; and each of the said penalties shall be paid to the informer or informers, and in case of nonpayment on conviction the person so convicted shall be committed by the justices before whom the conviction shall be to the common gaol or house of correction. [The rsst of this section was repealcd by 47 \& 48 Vict. c. 43.]

[Sect. 18 was repcalcd by 24 \& 25 Vict. c. 101.]

[Sect. 19 was repealed by 38 \& 39 Vict. c. 83, s. 17 , post.]

20 . And whereas the said act of 22 Geo. 2 only gives an appeal from from an order of any justice or justices of the peace to the general or general quarter sessions of the peace where an order is made by any justicc or justices of the peace in the casc of the buyer or receiver of such purloined or embezzled materials as aforesaid, and in respect to the sale or disposal of such materials found on searching by warrant, after any conviction for purloining or embez[*598] zling, or for receiving or buying such purloinèd or* embezzled materials; and whereas it is thought more proper to give a right of appealing in the case of other orders of any justice or justices of the peace to be made by force of an act made in the 1:th Geo. 1 (intituled "An Act to prevent unlawful Combinations of Workmen employed in the Woollen Manufactures, and for better Payment of their Wages") (c), and of the said act, and also in the case of all orders to be made by any justices of the peace under this act; be it therefore further enacted, that if any person shall think himself or herself aggrieved by the order or judgment of any two justices before whom he or she shall have been convicted of any of the offences in the said acts of 12th Geo. 1 and the 22 Geo. 2 , or in this act, such person may appeal, and the said justices are hereby required to make known to such person, at the timc of such conviction his or her right to appeal $(d)$, to the next general or general quarter sessions of the peace

(d) If they niake known to a party convicted his right to appeal, and le declines appealing, they need not proceed to inform him of the necessary steps to be taken in order to appeal, $R$. v. Justices of West Riding of Yorkshire, 3 M. \& S. 494.

(c) to be holden for the county, riding, division, city, liberty, town or place where such conviction shall have been made (such person at the time of such conviction giving to such justices notice in writing of his or her intention to appeal, and also entering into a recognizance, at the time of such notice, with sufficient sureties, conditioned to try such appeal, and to abide the judgment of and pay such costs as shall be awarded by the justices at such sessions); but if the person giving such notice of appeal shall not at the time of giving such notice enter into such recognizance as aforesaid, then the justiees to whom such notice of appeal shall have been given shall and may commit such person or persons to the house of correction or other public prison of such county, riding, division, city, liberty, town or place, there to remain until the next said general or general quarter sessions of the peace to be holden in and for such place, unless such recognizance shall be sooner entered into $(f)$; and the said justices

(c) As to wages, see $1 \& 2$ Will. 4 , c. 37 , post, p. 603 .

(e) The rest of this section was repealed by $47 \& 48$ Vict. c. 43.

$(f)$ Where a party convicted under this Act gave notiee of appeal, and wa committed for not entering into recognizances, and by the practice of the ses 
before whom such conviction shall have been malc, or ans other two or more justices of the same county, riding, division, city, liberty, town or placr, are hereby empowered and required to take, and the justices at such sessions are hereby authorized and required, upon due proof made of such notiere of allenesl, either by the acknowledgment of the justices to whom the same shall have Inesn given or otherwise, to hear and determine the matter of the said appeal, and to award such costs as to them shall appear just and reasonable to be paid by either party; and if upon the hearing of such appeal the jud erment of the justices hefore whom the apellant shall have been convicted shall be aflimed, such abrpellantshall, *within forty-eight hou's next after the same shall he so [*,ig9] allimed, suffer such corporal punishment as shall have been directed to be inflicted upon him or her for the offence whereof he or she shall have han wonvicted, or shall immediately pay the sum which he or she shall have beon adjudged to torfeit, together with sneh costs as the justices in the said sessions shall award to be paid by him or her, for defraying the expenses sustained by the defendant or lefendants in such appeal, or in defiult of making such payments shall be committed to the common gasl or house of correction, in the same manner and for the same time, to becomputed from the atlirmance of such conviction, as shall be directed by the original judgment of conviction, unless the person or persons so eonvicted shall have been imprisoned muler the original conviction, in which case the time for which such person or persen ishall have been so confined shall be ineluded in the order of eonfirmation.

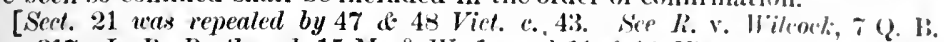
317; In Re Boothroyd, 15 M. \& W. 1; and 11 \& 12 IFe. c. 4:, on the form of conriction.]

22. Provided always and be it further enacted, that no order made touming or concerning any of the matters in this act contained, or any procecedings io the

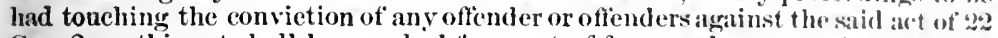
Geo. 2 , or this act shall be quashed for want of form, or be removed or removitble by certiorari into his Majesty's Court of King's Bench $(g)$ [the rest of this setion was repealed by 47 \& 48 Vict. c. 433 ].

23. Provided also, and be it further enacted, that nothing herein contained shall extend or be construed to extend to repeal any former law or laws now in being for the punishnient of any of the offences herein alowe specitied, except so fir as is particulariy expressed by this act ; and no oflender who shall have been proceeded against upon or by virfue of this act for any of the ofliences herein specified shall for the same oflence be afterwarls proceeded aguinst upon or by virtue of any such former law or laws.

[Sect. 24 was repealed by 3.4 a 35 Vict. e. 116.]

25. And be it further enactel, that if any suit or action shall be commeneed or prosecuted against any person or persons for anything done or to be done in pursuance of this act, every such suit or action shill be severally hronght, lasis and tried in the county or place where the fact was committed, and not clowwhere; and the defendant or defendants in every such action or suit shall and

sions the appeal was to be entered and the order for hearing it obtnined by the party disputing the conviction; but the party not having entered the ajpeal the sessions discharged hint; semble, that the convieting magist rates had no longer power to commit in execution of the conviction; but at nny rato mo mandanus should be granted to compel them to do so; R. $v$. Trugford, is A. N E. 430; but see $R$. v. Bolton, infra. A party convicted under sicct. \&, cuntercut into recognizance and gave notice of appeal, which he ufterwards abandoned. At the sessions, the respondents applied to inter the appeal, and for their ansts incurred by not receiving notice of ahandonment: held, on motion for mendimus, that the Recorder acted properly in refusing buth applications, ll. v. liecorder of Bolton, 2 D. \& I. 510.

(g) This section takes away the writ of certiorarionly from offences for the first time created by 22 Geo. 2 , c. 27 , and does not apply to those (reated by 1 ":

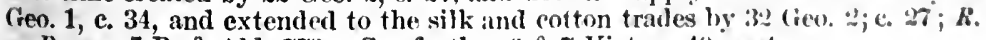
r. Rogers, 5 B. \& Ald. 773. See further (; \& 7 Vict. c. 10 , past.

35 MAS. \& SER. 
may plead the general issue, and give this act and the spccial matter in evidence, at any trial to be had therenpon, and the same was done in pursuance of and by the authority of this act ; and if it shall appear to be so done, or if any such suit or action shall be bronght in any other county or place than where the fact was committed, then the jury shall find for the defendant or defendants [the residue of this section as to treble costs was repealcd by $24 \& 25 \mathrm{Vict}$. c. 101].

Form of the Acard to be written at the Foot or upon the Back of the Order of the Justices of the Pcace certifying the Reference.

We, I. K. and L. M. [name and describe the referees], the referees appointed to settle the matters in dispute between the parties within named [or I. K., one of the referees so appointed; or, L. M., the other referee appointed, having failed to attend; or, I. N. O., the justice, as the case may $b c]$, do hereby adjudge and determine that [here set forth the determination; to which the rcferce or referees or justice, as the case may bc, shall subscribe their names.]

\section{Form of Endorsement, extendiny the Time limited for making the Award.}

We, A. B. and C. D., parties to the within reference, do hereby agree to extend the same to the our hands this day of inclusire. Witness

Witness

day of

A. B.

C. D.

Form of Acknowlcdgment of Fulfilment of the Award, to be uritten at the Foot or on the Back thereof.

I, A. B., do hereby acknowledge that the above award hath been fulfilled by C. D., who is hereby discharged of the same. Witness my hand this day of

Witness

A. B.

Form of the Oath to be administered by the Arbitrators or Justice to the parties and Witnesses under this Act.

The evidence that you shall give before us, the arbitrators appointed by $\mathrm{A}$. B. and C. D. [the parties] to determine the matters in difference between them under and by the virtue of an act passed in the fifth year of the reign of King George the Fourth, intituled "An Act to consolidate and amend the Laws relative to the Arbitration of Disputes between Masters and Workmen," shall be the truth the whole truth, and nothing but the truth.

So help you Gon.

Form of Commitment of a Person summoned as a Witncss before the Arbitrators.

Whereas proof on oath hath been made before me, one of his Majesty's justices of the peace for the county [or riding, stewarty, division, city, burgh. liberty town or place] of on this day of A. B. hath been duly summoned and hath neglected to appear and give evidenc. before C. D. and E. F., the arbitrators appointed by and between G. H. and I. $\mathbf{K}$. to determine the matters in dispute between them, at [or riding, stewarty, division, city, burgh, liberty, town or place] of 
on the day of under and by virtne of an act made in the fifth year of the reign of his present Majesty, intituled "An A.t" [her wh forth the title of this aet $(h)]$, and the said A. B. being required by me, the said justice to give evidenee before the said arbitrators, and still refuising so to to, therefore I, the *said justice, do herel,y, in pursuance of the said act, [ $\left.{ }^{*}(6) 1\right]$ commit the said A. B. to the [dlescribing the prison and the house of corrction], there to remain without bail or mainprize, for his [or her] oflence aforsiaid, until he [or she] shall submit himself [or herself] to be examined and give his [or her] evidenee before the said arbitrators touching the matters refierred to them as aforesaid, or shall otherwise be discharged by due course of law : And you, the [comstable or other peace officer or officers to whom the varrant is lirectid], are hereby authorized and required to take into your eustody the lody at the said A. B., and him [or her] safely to convey to. the siid prison [or house of correction], and him [or her] there to deliver to the gaoler [or kecper] thereof, who is hereby authorized and required to receive into his custody the hody of the said A. B., and him [or her] safely to detain and keep pursuant to this commitment. Given under my hand this day of in the year of our Lord

[This commitment to be directed to the proper peace officer and the gaoler [or keeper] of the prison [or house of correction]].

\section{Form of Warrant of Distress.}

To the constable of Whereas of under an award made by
day of pursuant to an act pawerl in the fifth year of the reign of his present Majesty, intituled "An A.t" [state the title of this act $(i)]$, is liable to pay to of the sum of ${ }^{\circ}$ and also the sum of . and the said having refused or neglected to pay the same for the spaee of two days and upwards subsequent to the making such award, these are therefore to eommand you to levy the said sum of ${ }^{\circ}$ by distress and sale of the goods and ehattels of the said and I do hereby order anit direet the goods and ehattels so to be distrained to be sold and disprosed of within days, unless the said sum of for which such distress shall be made, together with the reasonable charges of taking and keeping such distress, shall be sooner paid : and you are also herehy commamlenl to eertify to me what you shall do by virtue of this my warrant. (iiven under my hand and seal at the day of

\section{Form of the Canstable's Return to the Warrant of Distress.}

constable of

do hereby eertify to

justice of the peace of that I have made diligent search for, but do not know of, ner can find any goods and chattels of by distress and sale whereof I may livy the sum of pursuant to his warrant for that purjose. I)ated the" day of in the year of our Iord
day of $\quad$ in the year of our Lord

\section{Form of Commitment thereupon to the Honse of Corretion.}

Here name To the eonstable of and also to the keeper of the house of the county. $\}$ correction at

Whereas day of of nnder an award made by on the in the year of our Lord pursuant to an act passed in the fifth year of the reign of his present Majesty intituled "An Act" [stale the

(h) See last form, supra.

(i) See form, supra. 
title of this act $(k)]$, beeame liable to pay to

the sum of

and also

[*60\%] the sum of for costs, time and *expenses, making together the sum of and having refused or neglected to pay the same for the space of two days and upwards subsequent to the making of such award, my warrant was according to the provisions of the said act duly made and issued for the levying the said sum of by distress and sale of the goods and chattels of the said : and whereas it appears by the return of constable of dated the day of that he hath made diligent search for, but doth not know of, nor can find any goods and chattels of the said by distress and sale whereof the said sum of may, be levied. pursuant to my said warrant: These are therefore to command you the said constable of to apprehend the said and convey him to the said house of correctionat aforesaid and deliver him there to the keeper of the said house of correction; and these are also to command you the keeper of the said house of correction to receive him the said into the said house of correction, and there keep him without bail or mainprize for the space of months, unless the said sum of so ordered to be paid as aforesaid, shall be sooner satisfied, with all reasonable expenses. Given under my hand and seal at the day of

\section{Form of Commitment where the Warrant of Distress is withheld.}

Here name $\}$ To the constable of the county. $\}$ correction at

Whereas

of

and also to the keeper of the house of

day of in theyear of our Lord pursuant to an act passed in the

day of in the year of our Lord pursuant to an act passed in the

under an award made by

on the fifth year of the reign of his present Majesty, intituled "An Act" [state the title of this act $(t)]$, became liable to pay to the sum of and also the sum of for costs, time and expenses, making together the sum of which he has refused or neglected to pay for the space of two days and upwards subsequent to the making of such award; and whereas it appears ts me that the recovery of such sum and warrant of distress, and sale of the goods and chattels of the said will be attended with consequences ruinous or in an especial manner injurious to the defaulter [and his family, if any], and I have therefore determined to withhold such warrant, and to commit the said to prison pursuant to the said act: These are therefore to command you the said constable of to apprehend the said and convey him to the said house of correction at aforesaid, and deliver him there to the keeper of the said house of correction; and these are also to command you the keeper of the said house of correction to receive him the said into the said house of correction, and there keep him without bail or mainprize for the space of months, unless the said sum of so ordered to bc paid as aforesaid shall be sooner satisfied with all reasonable expenses. Given under my hand and seal at the day of

(k) See supra.

(l) See supra. 
An Act to Prohibit the payment, in certain Trades, of Wages in Goods, or otherwise, than in the current Coin of the Realm $(m)$.

[15th October, 1S:31.]

Whereas it is necessary to prolibit the payment, in certain trides, of wages in goods, or otherwise than in the current coin of the realm; be it therefire. enacted by (\&c. \&c.), that in all contracts hereafter to be made for the hiring of any artificer in the trades hereinafter enumerated, or for the pertornanee ly any artificer of any labour in any of the satid trades, the watges of suchl artifice $r$ shall be made payable in the eurrent coin of this realm only and not otherwix.; and that if any such contract the whole or any jart of such wages shall be malle payable in any manner other than in the current coin atoresaid, such contract shall be and is leereby declared illegal, null and void $(n)$.

2. And be it further enacted, that if any contract hereafter to loe made between any artifieer in any of the trades hereinater enumerated, and his cmployer, any provision shall be made direetly or indirectly resipecting the plices where, or the manner in which, or the person or persons with whom the whole or any part of the wages dne or to become due t.s any surch artiticer shall be laid ont or expended, such contract shall be and is hereby dechared illegal, null and void.

3. And be it further enacted, that the entire amount of the wages earned by or payable to any artificer in any of the trades hereinatter enumeraterl in respect of any labour by him done in any such trade, shall be actually paid to suchl artificer in the eurrent coin of this realm, and not *otherwise; and crery [*(i) - ${ }^{*}$ ] payment made to any such artificer by his employer, of or in resject it : any such wages, by the delivering to him of goods (o) or otherwise than in the cur-

(m) Previous Aets were repealed by $1 \& 2$ Will. 4 , c. 36, which was also repealed by 37 \& 38 Vict. e. 35 . See firther as to the payment of wages without stoppages in the hosiery manufacture, $37 \&: 38$ Vict. e. is, post.

(n) Plaintifl, a framework knitter, worked as a weaver of gloves for defendant in frames provided by defentant at an agreed gross prior per dozen pairs. Defendant was a subeontractor, furnishine the work by agreenent to a master manufacturer, who found machinery and materials. Defendant settled with plaintiff' weekly for the work done, deducting out of the grosi price per doz'n certain charges which were according to the known custon of the trale, namely: 1. A frame rent per week; 2. A pilyulent per week for use of de'fendant's premises to work in, standing room tor the frame, defendant's trouble and loss of time in proeuring materials and conveying them to platintift, defenlant's responsibility to the master manulacturer umler whom he cont ran':ed for 2 a work, superintendence of the work, sorting the gouds when mude. and alelivering then to the master manufacturer; 3 . bavment to a loy thr winding the yarn, and wear and tear of machinery; 4. A penny per shilling on tlue netsum earned by plaintiff above fourtcen shillings pur work ns (a) muensittion fo defendant for a per centage paid by him to the master mannficturer on the amount of goods manufactured by defendant for him with machinery rented of him by defendant. There was no witten rontrinet lo.twen platintifl and defendant: held that the agreement to pay plaintill's wages with thesc dowetoms was not a contract to pay part of such wages otherwise than in the eurrent coin of the realm, within this soction; nor was contraef in writing under sent. $2: 3$ necessary to legalize such derluetions; lndil als', that there was not in this cas" any demise of a "tenement" within seet. 2:3; and quire. whether there was $n$ demise of anything at a rent thereon resersed within that sertion, (harmer : Cummings, 8 Q. B. 311 ; ace. Areher v, James, 1 I. T. R., X. S. $2 t$; 1 linst. if F. ; 31 I. J., Q. B. 153 .

(o) Payment by a note which is ultimately, thongh not inmoliatily, to re- 
rent coin aforesaid, except as hereinafter mentioned, shall be and is herebr declared illegal, null and void.

4. And be it further enacted, that every artificer in any of the trades hereinafter enumerated shall be entitled to recover from his employer in any such trade, in the manner by law provided for the recovery of servant's wages, or by any other lawful ways and means, the whole or so much of the wages earned by such artificer in such trade as shall not have been actually paid to him by such his employer in the current coin of this realm $(p)$.

5. And be it further enacted, that in any action, suit or other proceeding to be hereafter brought or commenced by any such artificer as aforesajd, against his employer, for the recovery of any sum of money due to any such artificer, as the wages of his labour in any of the trades hereinafter enumerated, the defendant shall not be allowed to make any set-off, nor to claim any reduction of the plaintiff's demand, by reason or in respect of any goods, wares or merchandize had or received by the plaintiff as or on account of his wages or in reward for his labor, or by reason or in respect of any goods, wares or merchandize sold, delivered or supplied to such artificer at any shop or warehouse kept by or belonging to such employer, or in the profits of which such employer shall have any share or interest $(q)$.

6. And be it further enacted, that no employer of any artificer in any of the trades hereinafter enumerated shall have or be entitled to maintain any suit or action in any court of law or equity against any such artificer, for or in respect of any goods, wares or merchandise sold, delivered, or supplied to any such artificer by any such employer, whilst in his employment, as or on account of his wages or reward for his labour, or for or in respect of any goods, wares or nerchandize sold, delivered or supplied to such artificer at any shop or warehouse kept by or belonging to such employer, or in the profits of which such employer shall have any share or interest.

7. And be it further enacted, that if any such artificer as aforesaid, or his wife or widow, or if any child of any such artificer, not being of the full age of twenty-one years, shall become chargeable to any parish or place, and if within the space of three calendar months next before the time when any such charge shall be incurred such artificer shall have earned or have become entitled to receive any wages for any labour by him done in any of the said trades, which wages shall not have been paid to such artiticer in the current coin of this realm, it shall be lawful for the overseers or overseer of the poor in such parish or place to recover from the employer of such artificer in whose service such labour was done the full amount of wages so unpaid, and to proceed for the recovery thereof by all such ways and means as such artiticer himself might have proceeded for that purpose ; and the amount of the wages which may be so recovered shall be applied in reimbursing such parish or place all costs and charges incurred in respect of the person or persons to become chargeable, and the surplus shall be applied and paid over to such person or persons.

$\left[{ }^{*} 605\right] *{ }^{*}$. Provided always, and be it further enacted, that nothing herein contained shall be construed to prevent or to render invalid any contract for the payment, or any actual payment, to any such artificer as aforesaid, of the whole or any part of his wages, either in the notes of the governor and company of the Bank of England, or in the notes of any person or persons carrying on the business of a banker, and duly licensed to issue such notes in pursuance of the laws relating to his Majesty's revenue of stamps, or in drafts or orders for the payment of money to the bearer on demand, drawn upon any person or persons carrying on the business of a banker, being duly licensed as aforesaid,

sult in the delivery of goods is equally an offence within the Act and is ccmplete on the delivery of the note. Ashersmith v. Drury, 28 L. J., M. C. $5 ; 1$ EII. \& Ell. 46 ; 32 L. T. Rep. 103. See also Pillar v. Llynvi Coal and Iron Co., 38 L. J.. C. P. 294.

(p) See Weaver v. Floyd, 21 L. J., Q. B. 151.

(q) See Riley v. Warden, 2 Exc. 59 , post, p. 607 , note $(a)$; Olding v. Smith, 16 Jur. 497. 
within fifteen miles of the place where such drafts or orders shall he so pail, if such artificer shall be freely consenting to receive sueh dratts or orders ats aforesaid, bnt all payments so made with such consent as aforesidid in any such notes, drafts or orders as aforesaid, shall for the purposes of this atet be ats valid and effectual as if such payments had been made in the current coin of the realm.

9. And be it further enacted, that any employer of any artificer in ans of the trades hereinafter enumeraterl, who shall, by himself or by the ancency of any other person or persons, direetly or indirectly enter into any contract or mate any payment $(s)$ herehy declared illegal, shail for the first offence forfeit a sum not exceeding ten pounds nor less than fivc pounds $(t)$, and for the second oflence any sum not exceeding twenty pounds nor less than ten pounds, and in cave of a third offence any such employer shall be and be deemed guilty of a mislemeanor, and being thereof convicted, shall be punished by fine only, at the discretion of the court, so that the fines shall not in any case exceed the sinm of one hundred pounds $(u)$.

10. And be it further enacted, that all offences committed against this act, and not hereinbefore declared a misckemeanor, shall be entuired of and deternined, and that all fines and penalties for such oflenees shall be suod for and recovered by any person or persons who shall sue for the same, betiore any two justices of the peace having jurisliction within the county, ricling, city or pline in which the offence shall have been committed $(r)$; and that the ameoint of the fines, penalties and other punishments to be inilicted upon any such oflierilers shall, within the limits hereinbefore prescribed, be in the discretion of such justices, or, in cases of misdemeanor, of the court before which the oflene' may be tried [the words from "and in case of a second oflence" to "conrt and jury" were repealed by 47 \& 48 Vict. $c .43$ ]. P'rovilled always, that no person shall be punished as for a seeond oftence under this act unless ten days at the loist shall have intervened between the conviction of sueh person for the *irst and [*tioti] the conviction of $(x)$ such person of the second offence, but cach separate offence committed by any sueh person betore the expiration of the sidid term of ten days shall be punishable by a separate penalty, as thongh the sune were a first offence; and that no person shall be punished as for a thircl oflence under this act, unless ten days at the least shall have intervened between the conviction of such person for the second and the conviction by $(x)$ sur.h persen of the third offence : but each separate offence committed by any such person before the expiration of the saill term of ten days shall be punishable hy a soparate penalty, as though the same were a second oflence; and that the finth or any subsequent offence which may be committed by any slleh perwon ugainst this act shall be enquired of, tried and punished in the minner hercinlesore provided in respect of any third oflence; and that if the person or persons preferring any sueh information shall not be able or shall not see tit fo jereluces evidence of any such previous conviction or convictions as aforestid, any such

(8) If wages have been paid in goods. sulsequent payment in cras will not purge the oflenee which has been committed, the provisions of the liet which declare the payment void and also illegal and punishable being cummlative, Wilson v. Cookson; Fisher v. Jones, 32 L. J., M. C. 177. In S'milh v. Walton, 17 I. J., M. C. 45 ; 3 C. P. Div. 109; 37 L. T., N. S. 437 , it was held that where an employer's bookkeeper delivered to an artificer a piees of "loth which hes had damaged instead of wages, the employer was liable to a penalty wittin sect. 9.

$(t)$ Words in italics repealed by $17 \& 48$ Vict. e. 43.

(u) Affidavits in support of a rile for a cevtioneri to remove a eonviotion under this section, should be intituled "In the Quren's liench" simply, Fax garte Wallwork, 4 D. \& I. 40:3.

(v) The offence is complete where the noto is given, although the gombls are delivered ont of the jurisdiction of the convieting justices, Ashersmith v. Drury, supra, 1. 604, note (o).

$(x)$ Sie. 
offender as aforesaid shall be punished for each separate offence by him committed against the provisions of this act by an equal number of distinct and separate penalties, as though each of snch offences were a first or a second offence, as the case may be ; and that no person shall be proceeded against or pnnished as for a second or as for a third offence at the distance of more than two years from the commission of the next preceding offence.

[Scets. 11 d 12 were repealed by 47 \& 48 Iict. $c .43$.

13. And be it further enacted, that no person shall be liable to be convicted of any offense against this act committed by his or her copartner in trade, and without his or her knowledge, privity or consent; but it shall be lawful, when any penalty or any sum for wages, or any other sum, is ordered to be paid, nnder the authority of this act, and the person or persons ordered to pay the sane shall neglect or refuse to do so, to lery the same by distress and sale of any goods helonging to any copartnership concern or business in the carrying on of which such charges may have become due or such offence may have been committed: and in all proceedings under this act to recover any sum due for wages it shall be lawful in all cases of copartnership for the justices, at the learing of any complaint for the nonpayment thereof, to make an order upon any one or more copartners for the payment of the sum appearing to be due; and in such ease the service of a copy of any summons or other process, or of any order, upon one or more of such copartners, shall be deemed to be a sufficient service upon all.

14. And it is declared and euacted, that in all cases it shall be deemed and taken to be sufticient service of any summons to be issued against any offender or offenders by any justice or justices of the peace, under the authority of this act, if a duplicate or true copy of the same be left at or upon the place used or occupied by such offender or offenders for carrying on his, her or their trade or business, or at the place of residence of any such offender or offenders, being at or upon any such place as aforesaid, the same being directed to such offender or offenders by lis, her or their right or assumed name or names.

[Sects. 15 \& 16 were repealed by 47 \& 48 Iict. c. 43.$]$

17. And be it further enacted. that no conviction, order or adjudication made by any justices of the peace under the provisions of this act shall be quashed for want of form, nor be removed by certiorari or otherwise into any of his Majesty's superior courts of record. [The rest of the section was repealed by 47 \& 48 Vict. c. 43.]

18. And be it further enacted, that out of any penalty or forfeitnre incnrred by any offence committed against this act, it shall be lawful for the court or jus$\left[{ }^{*} 607^{\circ}\right]$ tices imposing the same to award any sum to the informer, *not exceeding in any case the sum of $t$ wenty pounds; aud the rest of an $y$ such pecuniary penalty or forfeiture shall go to the treasurer of the county in which the offence shall be committed, in aid of the rates of such connty : provided always, that every proceeding whatsocver for any offence against this act shall be commenced within three calendar months atter such offence shall have been committed.

19. And be it further enacted, that nothing herein contaiued shall extend to any artiticer, workmen or labourer, or other person engaged or employed in any manufacture, trade or occupation, excepting only artificers, workmen, labourers, and other persons employed in the several manufactures, trades and occupations following; (that is to say), in or about the naking, casting, converting or manufacturing of iron or steel, or any parts, branches or processes thereof $(y)$; or in or about the working or getting of any mines of coal $(z)$, ironstone, limestone, salt rock; or in or about the working or getting of stone, slate or clay $(a)$; or in the making or preparing of salt, bricks, tiles or quarries; or in

(y) In Millard v. Kelly, 32 L. T. 123, a labourer employed in loading boats with iron, was held within the Act.

(z) In Boxcers v. Lorekin, 25 L. J., Q. B. 371; 6 E. \& B. 584, butty colliers, who engaged to get coal at so much per yard, and were bound to work personally, and who did so work, were held within the Aet, although they employed other workmen under them.

(a) A contractor to execute a railway cutting at so much per cubic yard, who 
or abont the making or manufacturing of any kinds of nails, chains, rivets, anvils, viees, spades, shovels, screws, keys, locks, bolts, hinges or any ot her articles or hardware made of iron or steel, or of iron and stecl combincel, or ut any plated articles of eutlery, or of any goods or wares made of brass, tin, Jiall, pewter or other metal, or of any japanned gools or wares whatsecer; or in or about the making, spinning, throwing, twisting, doubling, winding, weaving, combing, knitting, bleaching, dyeing, printing, or otherwise preparing of any kinds of woolen, worsted, yarn, stuff, jersey, linen, fustian, cloth, serge, cottun, leather, fur, hemp, flax, mohair or silk manjfactures whatsoever, or in or alout any manufactures whatsoever made of the said last-mentioned materials, whetluer the same be or be not mixed one with another; or in or about the making or otherwise preparing, ornamenting or finishing of any glass, porrelain, china or earthen ware whatsoever, or any parts. branches, or processes thereof, or any materials used in any of such list-mentioned trades or employmcouts; or in or about the making or preparing of bone, thread, silk, or cotton lace, or of lace made of any mixed materials.

20. And be it further enacted, that nothing herein contained shall extend to any domestic servant or servant in husbandry.

21. And be it further enacter, that no justice of the peace, being a person also engaged in any of the trades or orcupations enumerated in this at, or the fatlier, son or brother of any such person, shall act as a justice of the peace under this act.

22. And be it further enacted, that in all cities, boronghs or corporate town, where the magistrates for the time being are discualitied by the forchoing (lause from administering this act, then and in every sncls *ase, and so ofien [ ${ }^{*}(i 0 \times$ ] as the same slall happen, it shall be lawful tor the magistrates of the county in which the offence may be committed (and not discualitied as afiresidd) to administer, and they are hereby authorized and empowered to hear, examin. and determine any offences eommitted against this act in any surd cities, Inroughs or corporate towns; and it shall be lawful for the complainant to remove the cases of information or complaint from the said cities, boroughs or corporite towns to any other eonrt of session or petty session not exeeceling twelve miles from the place where the offence shall have been committed, any law, charter, usage or custom to the contrary notwithstanding.

23. And be it further enacted and declared, that nothing herein contained shall extend or be construed to extend to prevent any (mployer or any artiticer. or agent of any such employer, from supplying or contracting to suplyly to any such artificer any medicine $(b)$ or medical attendance, or any fiuel, or any miterials, tools or implements to be by such artiticer employed in his tradc or usecupation, if such artificers be employed in mining, or any hay, corn or other provender to be eonsumed by any horse or other least of indell emplogend by any such artificer in his tradeand oceupation; nor from demising to uny artiticer, workman or labourer employed in any of the trades or ocellpations cenumerated in this act the whole or any part of any tenenent at any rent (r) tol be theroon reserved; hor from supplying or contracting to supply any such artiticer an! vietuals dressed or prepared under the roof of any suleli employer, and the re consumed by such artificer; nor from making or contrating to make any stopplige or reduction trom the wages of any such artificer, for or in respect of any such

employs men under him to assist, is not a worlimul or labourer within the true meaning of this Act, nlthough he does a portion of the work himself. "Where the eartl removed is clay, which is used tor making bricks; yusre, whether labourer engaged in the removal of such carth is a person "mployed in or about the working or getting of clay," within sect. 1!), listey vidirdin, "?

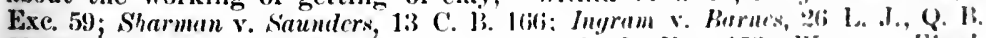

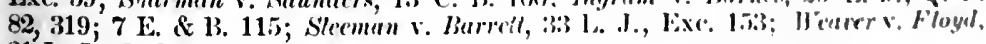
21 L. J., Q. B. 151.

(b) See Ex parle Cooper, Re Marris, conrt of Apl. Feh. 21st, IR-1.

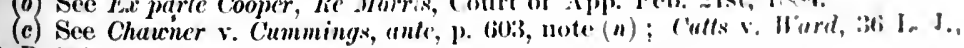
Q. B. 161 . 
rent; or for or in respect of any such medicine or medical attendance ; or for or in respect of such fuel, materials, tools, implements, hay, corn or provender, or of any such victuals dressed and prepared under the roof of any such employer; or for or in respect of any money advanced to such artificer for any such purpose as aforesaid; provided always, that such stoppage or deduction shall not exceed the real and true value of such fuel, materials, tools, implements, hay, corn and provender, and shall not be in any case made from the wages of such artificer, unless the agreement or contract for such stoppage or deduction shall be in writing, and signed by such artifieer.

24. And be it further enacted and declared, that nothing herein contained shall extend or be construed to extend to prevent any such employer from advancing to any such artificer any money to be by him contributed to any friendly society or bank tor savings duly established according to law, nor from advancing to any sueh artificer any money for his relief in sickness, or for the education of any child or children of such artificer, nor from deducting nor contraeting to deduct any sum or sums of money from the wages of snch artificers for the education of any such child or children of sucb artificer, and unless the agreement or contract for such deduction shall be in writing, and signed by such artificer $(d)$.

25. And be it further enacted and declared, that in the meaning and for the purposes of this act all workmen, labourers $(e)$ and other persons in any manner engaged in the performance of any work, employment or operation of what nature soever, in or about the several trades and occupations aforesaid, shall be and be deemed "artificers;" and that within the meauing and for the purpose [*609] aforesaid all masters, bailiff's, foremen, *managers, elerks and other persons engaged in the hiring, employment or superintendence of tle labour of auy such artificers, shall be and be deemed to be "employers;" and that within the meaning and for the purposes of this act any money or other thing had or contracted to be paid, delivered or given as a recompence, reward or remuneration for any labour done or to be done, whether within a certain time or to a certain amount, or for a time or an amount uncertain, shall be decmed and taken to be the "wages" of such labour; and that within the meaning and for the purposes aforesaid any agreement, understanding, device, contrivance, collusion or arrangement whatsoever on the snbject of wages, whether written or oral, whether direct or indirect, to which the employer and artificer are parties or are assenting, or by which they are mutually bound to each other, or whereby either of them shall have endeavoured to impose an obligation on the other of them, shall be and be deemed a "contract."

26. And be it furtlier enacted, that this act shall not commence or take effect till the expiration of three calendar months next after the day of passing the same.

27. And be it further enacted, that the provisions of this act shall extend over the whole of that part of the United Kingdom of Great Britain and Ireland called Great Britain. 43.]

[The schedule referred to in the foregoing act was repealed by $47 \& 48$ Vict. $c$.

(d) See Pillar v. Llynti Coal and Iron Co., 38 L. J., C. P. 294; 4 L. R., C. P. 752.

(e) See Riley v. Warden, ante, p. 607, note (a). 


\section{$6 \& 7$ Vicr. c. 40.}

An Act to amend the Laws for the Prevention of Frauds and Abuses by Persons employed in the Woollen, Worsted, Linen, Cotton, Flax, Mohair and Silk Hosiery Manufactures, and for the further securing the Property of the Manufacturers and the Wages of the Workmen engaged therein.

[1st August, 1843.]

Whereas an aet was passed in the session of Parliament held in 8 \& 9 Will. 3, intituled "An Act for the further Encouragement of the Mammirature of" Lustrings and Alamodes within this Realm, and fir the better preventing the Inportation of the same," whereby (amongst other matters thercin contained) certain penalties, forfeitures and punishments therein reterred to were inposed upon persons embezzling or otherwise unlawtully selling or receiving. :Ls thercin mentioned, silk deliveréd by the silk manufacturers to be worked up: and whereas an act was passed 1 Ann. intituled "An Act for the more eflectual preventing the Abuses and Frauds of Persons employed in Working up the Woollen, Linen, Fustian, Cotton and Iron Manufictures of this Kingtom:" and whereas the said act was made perpetual hy an act passed in the $9.1 \mathrm{~m}$. intituled "An Act for reviving and continuing an Act made in the First Yrar of her Majesty's Reign for the more efiectual preventing Abuses and Frawlis of Persons employed in the Working up the Wosllen, Linen, Fustian, Cotton and Iron Manufactures of this Kinglom :" and whereas an act was passed in the 12 Geo. 1, intituled "An Act to prevent unlawful Combinations of Workmen employed in the Woollen Manufuetures, and for better layment of their Wages:" and whereas an act was passed in the 13 Geo. 2 , intituled "An Act to explain and amend an Act made in the First Year of the Reign of her late Majesty Qween Anne, intituled 'An Act for the more eflectual preventing the Abuses and Frauds of Persons employed in the Working up the Woollen, linen, Fustian, *Cotton and Iron Manufactures of this Kingdom, and also for [*610] exteuding the said Act to the Manuficture of lesther:" ' and whereas un act was passed in the 22 Geo. 2, intituled "An Act for the more cllertual preventing of Frauds and Abuses eommitted by Persons employed in the Manutiuture of Hats, and in the Woollen, linen, Fustian, Cotton, Irou, Leather, Fur, llemp, Flax, Mohair, and Silk Manufaetures, and for preventing unlawful Combinations of Journeymen Dyers and Journeymen IIotpressers, and of all I'roms employed in the said several Manufactures, and for the better I'nyment of their Wages:" and whereas another act was passed in the 17 (iwo. 3, intitulenl "An Act for amending and rendering more etliectual the several haws now in being for the more effectual preventing of lirads and Abuses by Persons cmployed in the Manufaeture of Hats, and in the Woblen, Linen, lustian, cotton, Iron, Leather, Fur, Ilemp, Flax, Mohair and silk Manutuetures; mul also for making l'rovisions to prevent Frands by Journeymen Iyers: " and wherens an act was passed in the $3:$ Geo. 3 , intituled "An" Alet for extending the l'rovisions of an Act marle in the Thirtenth Fear of the lieign of lis present Majesty, intituled 'An Act to empower the Magistrates therein mentiond to settle and regulate the Wages of Persons employed in the silk Mannliutures within their respective jurislietions, to Manntactures of silk mixol with ot her Materials, and for the more effectual Punishmont of buyers and licerisen of

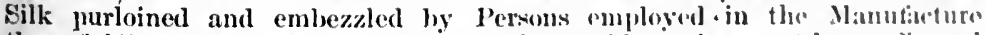
thereof :'" and whereas the provisions of the said acts have not been celleretual to prevent frauds, embezzlements and abuses hy persons employerl in the woollen, linen, cotton, flax, molair and silk hosicry manufactures. nnd it is expedient to repeal so mueh of the said recited urts as relates to the said manu. fuctures, and to make further provisions in lien thereot, as well for the hemelt and encouragement of trade and manufaetures as for the sereurity of the property of manufacturers and the wages of the workmen engaged in the stid manutic- 
tures : be it therefore enacted, by (\&c. \&c.), that from and after the commencement of this act, so much of the said recited acts or any of them as relates to the woollen, linen, cotton, flax, mohair and silk manufactures, or any of them, or any manufactures whatsoever made of wool, cotton, flax, mohair or silk materials, whether the same be or be not mixed with each other, or with any other matcrials, shall so far as respects the manufactures, trades, occupations and employments hereinafter mentioned, bc and the same are hereby repealed save and except so far as the same may have repealed any former acts or enactments.

2. And be it enacted, that if any person whosoever entrusted with any woollen, worsted, linen, cotton, flax, mohair or silk materials for the purpose of being prepared, worked up or manufactured either by himself or by any person or persons to be employed by or under him, or by himself jointly with any person or persons to be employed with, by or under him, or for any purpose or work connected with manufacture or incidental thereto, or any parts, branches or processes thereof, or any tools or apparatus for manufacturing the said materials, shall sell, pawn, purloin, embezzle, secrete, exchange or otherwise fraudulently dispose of the same materials, tools or apparatus, or any part thereof, he siall, upon being thereof lawfully convicted by the oath of the owner of such materials, tools or apparatus, or any part thereof, or of any other credible witness or witnesses before two or more justices of the peace, forfeit the full value of the same, and also forfeit such penalty not exceeding ten pounds, together with costs, as to the said justices shall seem meet; and every such forfeiture and penalty shall be applied under the direction of the convicting justices in manner following (that is to say), in the first place in making such satisfaction to the party injured as the said justices shall think proper, and the remainder, if any, shall be appled in the same manner as is hereinatter $\left[{ }^{*} 611\right]$ directed for the disposal of any other penalty * under this act $(f) ;[$ and in default of payment of such forfeiture and penalty with costs immcdiately on conviction, or within such period as the justices so convicting may direct, the said justices may issue thcir warrant to distrain and sell the goods and chattles of the person so convicted for the amount thereof and costs; and the proceeds of any distrcss, after paying the penalty, forfeiture and costs, and also the costs of such distress, shall be paid over to the person convicted;] but if no sufficient distress shall appear or shall be found whereon to levy the said penalty, forfeiture and costs, the said justices may either immediately, or at any time after such conviction, commit any person so convicted to the common gaol or house of correction, to be there imprisoned with or without hard labour, as to the said justices shall seem meet [the rest of this scetion was repealed by $47 \& 48$ rict. $c .43$ ].

3. And be it enacted, that any person whosoever entrusted with any woollen, worsted, linen, cotton, flax, mohair or silk materials for the purpose of being prepared, worked up or manufactured, either by himself or by any person or: persons to be employed by or under him, or by himself jointly with any person or persons to be employed with, by or under him, or for any purpose or work connected with manufacture or incidental thereto, or any parts, branches or processes thereof, or with any tools or apparatus for manufacturing the said materials, shall neglect or delay to return the said materials, tools or apparatus, or any part thereof, for the space of fourteen clear days after being required so to do by the party entrusting him therewith, or by some person on his behalf, by notice in writing to be served upon or left at the last or usual place of abode or business of such person (unless prevented by some reasonable and sufficient cause to be allowed by the justices before whom he shall be brought), then and in every such case all or so much or so many of the said materials, tools or apparatus as shall not be returned to the person so entrusting him therewith within the time aforesaid shall be deemed to be embezzled by the person so neglecting or delaying to return the same; and the person so neglecting or delaying to return the same shall for every such offence be liable to be pro-

( $f$ ) The paragraph relating to distress warrant on nonpayment was repealed by $47 \& 48$ Vict. c. 43. 
ceeded against for embezzlement in the same manner and subject to the same forfeitnre and penalty with costs, and to be applied in the sinu manner, it are respectively hereinbetore preseribed and imposed in respect to persins selling, pawning, purloining, embezzling, secreting, exchanging or otherwise fraudulently disposing of the said materials.

4. And be it enacted, that any person who shall purchase or take in pawn or who in any other way shall receive into his premises or possession any woollen, worsted, linen, cotton, flax, mohair or silk materials, and whether the same or any part of the said materials be or be not wholly or partially wrought, mide up or manufactured into merchantable wares, or any tosls or appriratus for manufacturing the same, knowing that such materials, tools or apparatus ares purloined or embezzled or fraudulently disposed of, or that the perwon from whom he shall purehase, take in pawn, or receive the sime is foundulently or unlawfully disposing thereof, or knowing sueb person to be employed or ent rusted by any other person or persons to work up, either by limself or by or with others, the materials so purchased, taken in pawn, or received fur any other person or persons, and not having first obtained the consent of the persin or persons so employing or entrusting him therewith, shall, on ennviction by the: oath of the owner or of any other eredihle witness or witnesses, be dremod and aljndged guilty of a misdemeanor, and be punished in manner hereinatter mentioned.

5. And be it enacted, that if any person shall sell, pawn, pleclye, exrhange or otherwise unlawfully dispose of, or otler to sell, pawn, pledge, cexcluange or otherwise disp.sse of any sueh materials, tools or *apparatus as atoresaicl, [ 6120$]$ knowing the same to have been so purloined or cmbezzled or receivel from $\mu^{2} \mathrm{r}^{-}$ sons fraudulently disposing thereof as atoresairl, he shall, on conviction by the onth of the owner of such materials, trols or appatutus, or any part thereof, or of any other credible witness or witnesses, be deemed and aljudiged gnilty of a mistemeanor, and be punished in manner hercinafter mentioned.

6. And be it enacted, that on proof on oath that there is just cante to saspect that any such materials, tools or apparatus as aforesaid have bech frandulently sold, pawned, pledged, purloined or embezzled by the prerion to whom the same were entrusted, or that any such materials, tixols or apparatus have been purehased or received, or sold, pawned, pledged, exelhinged or utherwise unlawfully disposed of or offered for sile, pawn, pledge, exchimge or other disposal by any person knowing the same to have been purloined or embersled, or received from some person traululently disposing therest; it slabll and may be lawful for any one justice of the peace, and such justice is laerehy repuired to issue his warrant for apprehending any such person and bringing him hefore him or some other justice of the peace for examination; and if, " pкin such examination, the charge of having fraululently sold, pawned. purloined, embezzled or otherwise fraudulently disjosed of any such materials, texols or apparatus, or of having purchased, or rereived, or sold, pawned, pledged, exchanged or otherwise fraudulently disposed of, or of having offered for sale, pawn, pledge, exehange or other dispowal any such materials, tevols or apparatus knowing them to have been purloined, or emberzled or receivest from some person fraudulently disposing thereof, shall the suppurted by evidence to raise a strong presumption of guilt, such justice shall commit such person to the comm.m gaol or house of correction, in order that he may lwe brought forward for trial at the next petty sessions, nnlexs he enter into surh bail with two sufficient sureties as may be rejuired for his appearance before such court on any day to be fixed by such justice.

[Sect. 7 was repealed by 38 a 39 lict. e. 86, s. 17.]

8. And be it enacted, that upon proof on oath before a justice of the prace, that there is reasonable cause to suspect that nny person has in his pusweswion or on his premises any sueh materials, tools or apparstus ns aftoresuid. which hare been purloined, embezzled or otherwise fraudulently disposed of, it whall be lawful for the said justice, and such justice is hereby required to wrant hiv warrant to search the dwelling-house und premises of such perwm, and if uny such property shall be found therein to cause such materials, tools or appas- 
ratus, and the person in whose possession or on whose premises the same shall be found, to be brought before him or some other justice of the peace to be dealt with in the same manner as any person brought before a justice under the enactment next hereinalter contained.

9. And be it enacted, that every peace officer and constable, and every watehman duly appointed by law, during such time as he shall be on duty, shall and may apprehend or cause to be apprehended any person whom he may reasonably suspect of having or carrying or in any way conveying, at any time after sunsetting and before sunrising, any such materials, tools or apparatus as aforesaid, suspected to be purloined, embezzled or otherwise fraudulently disposed of, and shall lodge such person, together with the property, in a police office or other place of security, in order that he may be brought before a justice of the peace as soon as convenient, who is hereby empowered to discharge sueh person, or to order his detention until the next court of petty sessions, unless he enter into such bail, with two sufficient sureties as nay be required tor his appearance hefore such court on any day to be fixed by the said justice, and if the person so apprehended in the act of committing any such offence as aforesaid, or of conveying any such property as last aforesaid, shall not produce before the said eourt the person duly entitied to dispose of such [*613] property from whom he bought *or received the same, or shall not give an aecount to the satisfaction of the said court that the property is honestly come by, then the person so apprehended shall be deemed and adjudged guilty of a mistemeanor, and be punished in manner hereinatter mentioned, although no proof shall be given as to whom such property belongs.

10. And be it enacted, that it shall be competent for the party accused, in all proceedings brought under the authority of this act, to move for and obtain an adjournment of the time fixed for trial for snch a reasonable time as may appear to the eourt to be necessary for the party accused to produce the person duly entitled to sell or dispose of the said property, of whom he bought or received the same, or evidence respecting the same, but the party aceused and requesting such adjournment shall be obtained in custody or committed to prison, unless he enter intes such bail, with two sufficient sureties as shall be required for his appearance before such court, at such time and place as shall be appointed.

11. And be it enacted, that any person who shall be deemed and adjudged guilty of a misclemeanor agreeably to any of the provisions of this act, shall, in addition to heing deprived, without compensation, of any sueh materials, tools and apparatus which have been purloined, embezzled or otherwise frandulently disposed of, and which shall have been found in his possession, forfeit any sum not exceeding twenty pounds for each offence, together with costs, upon being thereof lawfully convicted, by the oath of one or more credible witness or witnesses, before two or more justices of the peace: and every such forfeiture shall be applied under the direction of the justices so convicting in manner following (that is to say), in the first place, in making such satisfaction to the party injured as the said justices shall think fit, and the remainder (if any) shall be applied in the same manner as is hereinafter direeted for the disposal of any other penalty under this act, [in default of payment of s:eh forfeiture and penalty with costs, immediatcty on conviction, or within such period as the court shall direct, any justice or justiccs may issue his or their warrant to distrain and sell the goods and chattets of the person so convicted for the amounts thercof and costs, and the proceeds of any distress, after paying the forfeiture and costs and also the costs of such distress, shall be paid over to the person comrictcd] $(g)$; but if no sufficient distress shall appear or shall be found whereon to lery the said forfeiture and costs, any justice or justices may either immediately, or at any time after such conviction, commit any person so convicted to the commun gaol or house of correction, to be imprisoned there with or without hard labour, as to the said court shall seem meet [the rest of this section vas repealed by 47 d 43 Vict. $c$. 43].

12. And be it enacted, that where no proof shall be given, at the time of con-

(g) The words in italics were repcaled by $47 \& 48$ Vict. c. 43. 
riction, of the ownership of property found in the possession of a person convicted under this act, the justices or court shall "ause the property so found in be deposited in some safe place for any time not excecling thirty days. and shall, if the property be of sufficient value to pay the expenses therewif, order an advertisement to be inserted in one or more of the public newsplasers of the town or eity where'or nearest the place where the same was found and by tixing a notice on some publie place, describing such property and where the same may be inspected, or in case of the said property not being of suffieient value to pay the said expenses, then hy fixing such notices as aforesaid only; and in ease any person shall prove his own or his employer's ownership or property therein upon oath, to the satisfaction of a justice, restitution of such property shall be ordered to the owner thereof, alter paying the reasonable (ust of removing, depositing, advertising and giving notice of the samo; lut if no ownership be proved to such property, the justice shall, at the termination of thirty days, *order sueh property to be sold, and after deducting the [*61.] charges atoresaid with the charges of sale, shall order the residue to he applitied in the same manner as is hereafter directed for the disposill of any other pronalty under this act.

13. And be it enacted that it shall be lawful for the owner of any such materials as aforesaid, or any other person duly anthorized by him. or other the person who shall have so entrusted such materials from time to time as ocension shall require, to demand leave of entrance and enter, at all resiconable hours in the daytime, into the shops or outhouses of any person employed to work up or manufaeture, either by himself or by any other person under hir:, any of the said materials, or other place or places where the work shall be carried on, and there to inspeet the state and condition of such materials; and in case of refusal or neglect by any such person or persons so employed to permit such entrance or inspection, such person shall, for so refusing to permit such entrance or inspection, forfeit any sum not excecding twenty shillings as the justices before whom he shall appear or be bronght, shall think proper, to be applied in the same manner as is hercinafter directed for the disposal of any other penalty under this act: provided always, that nothing herein contained shall authorize any such owner or other person as aforesaid to insiect any frame, tools or apparatus wherewith such materials are worked up, in case such frame, tools or apparatus comprise any new invention or improvement not disclosed to the public.

14. And be it enacted, that if any manufacturer, agent or any other person in his employment or service, shall make outh before a justice of the peace that any such materials, tools or apparatus as aforesaid, have been entrusted to any persou as atoresaid, and that he has abseonded, or that the deponent has just canse to suspeet and does suspeet that such person is about to abseond, it shull be lawful for such justiee, and he is hereby required to issue his warrant to apprehend such person and bring him before him or some other justice of the peace, and if such person shall have ahsconded, or shall not forthwith give security, to be approved of by the said justice, for the return, in $n$ finished state, of all such materials so entrusted to him within such time as shull bo then agreed on, sueh justiee shall, hy warrant, order any eonstable, with his assistants, to enter the house or other premises of such person and take possesssion of all sueh materials, tools or apparatus so delivered to him as aforesuid, and to bring the same before the said justice or any other justice, when such justice shall direct the same to be delivered to the owner or his ingent or servant, or other person duly anthorized by him, and shall forthwith release the person in eustudy; but if all such materials, tools or apparatus slull not the found in the house or other premises or the possession of such person, or shall not be produced before such justice, such person shall be deemed and tuken to have purloined or embezzled such materials, tools or apparatns, or snch part thereof as shall not be found or produced, and shall be liable to any of the punishments awarded for sueh offence.

15. And be it enacted, that if any person shall receive any of the aforesnid materials in a fietitious name, in order to be manufactured, every such person 
so offending, and being convicted thereof on the oath of one or more credible witness or witnesses before two or more justices, shall, for erery sueh offence. be liable to the same punishment as is hereinbefore directed in respect to persons not fulfilling their engagements.

16. And be it enacted, that in cases where any person shall hare been com. mitted for purloining, embezzling or fraudulently disposing of all or any part of such materials, tools or apparatus as aforesaid which may have been entrusted to him, or shall have been convicted of any other offence against any of the provisions of this act, it shall be lawful for the justice who so committed such person or for any justice or court before whom he has been convicted for that or any other offence, and he or they is or are hereby required to issue his $\left[{ }^{*} 615\right]$ or their warrant authorizing a ${ }^{*}$ constable, with his assistants, to enter the house and premises of such person, and take possession of all such property so entrusted as shall be found therein, and to bring the same before the said justice or court, when the said justice or court shall direet the same to be delivered to the manufacturer, agent or person duly authorized to receive the same.

[Sect. 17 was repealed by 33 \& 39 Iict. c. 86, s. 17. III. $(f)$.

18. And be it enacted, that no frame, loom or machine, materials, tools or apparatus which shall be entrnsted for the purpose of being used or worked in any of the said manufactures, or any work connected therewith or incidental thereto, or any parts, branches or processes thereof; whether such frame, loom or machine, materials, tools or apparatus shall or shall not be rented or taken by the hire, shall at any time or times hereafter be distrained or seized or be liable to be distraincd or seized for rent or for debt or under any execution or other proceedings whatever, unless the rent be due or the money be owing by the owner of the said frame, loom or machine, or of the said materials or tools or apparatus aforesaid, or of any part thereof respectively.

19. And be it eacted, that if any landlord or other person by virtue of any distress, warrant, execution or other proceedings for rent in arrear or money due or alleged to be due by any person whomsoever, shall distrain, seize, carry off, sell or otherwise dispose of any frame, loom or machine, materials, tools or apparatus belonging to any other person which shall have been entrusted for the purpose of being used or worked in any of the said manufactures, or any work connected therewith or incidential thereto, or any parts, branches or processes thereof, and whether the same shall or shall not be rented or taken by the hire, or shall distrain, seize, carry off, sell or otherwise dispose of any materials as aforesaid, or any tools or apparatus as aforesaid, belonging to any other person, and shall refuse to restore possession of all such frames, looms, machines, tools or apparatus to the person owning, letting or entrusting the same when demanded by him or some person duly authorized by him of the said landlord or other person or the person acting as agent or bailiff of such landlord or other person, it shall and may be lawful to and for any justice of the peace, upon complaint on oath before him, to summon the said landlord or other person to appear before any two or more justices of the peace to answer the said complaint, and, on proof of the said oftence, the said justices may thereupon order the property so seized, distrained, carried off or sold, to be forthwith restored, and issue their warrant to a constable or constables empowering him or them to seize the said property wherever the same shall be fonnd, and deliver possession thereof to the person owning, letting or entrusting the same, and to lery by distress and sale of the goods of the said landlord or other person the costs of obtaining the said order and recovering and obtaining possession of the said property; and in case the said property cannot be found and seized within a time not exceerling twenty-one days, to be limited in the said warrant, or in case the said property shall have been damaged by the same having been distrained, seized, carried off or sold, then it shall be lawfnl for such two justices or any other two justices, on proof thereof (the said landlord or other person having been first summoned by a justice) to issue their warrant to levy by distress and sale of the goods and chattels of such landlord or other 
person the full value of the said property or the amount of such damage as the ease may be, together with all costs of recovering and levying the kume.

20. And be it cnacted, that if any person or persons shall obliterate, effuee or alter the owner's name or initials, or other distinguishing mark on any frame, loom or machine, or any bar or part thereof; or the moulds thereot, without the order or authority of the owner thereof, he shall, on couviction thereof lefore two justices of the peace, forteit any such sum not exceceling two pounds as such two justices shall order and direct, to be applied in the first place in paying the costs of the proceedings before *such justices, and the surplus, it [* *ili] any, to the party injured; and in default of payment of such torfeiture immediately on conviction or within sueh period as the justices so convicting shall] direct, then the said justices may either inmediately or at any tims after such conviction commit any person so convicted to the common gaol or louse of (rorrection, there to be imprisoned with or without hard labour as to the said justices shall seem meet [the rest of the section was repraled by 47 if ix rict. $c$. 43].

21. And for the discouragement of frivolons and vexations informations and prosecutions noder this aet, be it enacted, that it shall be law ful for any justices or court of petty sessions before whom any case under this act is triell to award costs to the defendant with an allowance for his loss of time in "ase of accinittal, to be paid by the prosecutor, and also if it shall appeall to surh justices or court that the cliarge was made from a malicious, vexatious or frivolous motive, or in case the party shall be charged with embezzlement of naterials by reasun of any deficiency in the weight of the materials which he shall have returned to the person by whom they were entrusted to such party as compared with the weight of the materials received, and it shall be proved upon the hearing of the ease that such materials were knowingly and frandulently delivered to the party charged whilst in a damp state, so that the apparent woight thereof was thereby increased, it shall be lawful for such justices or eourt to award to the defendant such further sum of money not exceeding twenty ponnds as to such justiees or court shall seem fit to be paid by such prosecutor als a compensation for the injury done; and, in detault of payment, such eosts and allowances and compensation may be levied by distress and sale of the proseeutor's goods.

[Seets. 22 \& 23 were repealed by 17 \& 48 riet. e. $4: 3]$.

24. Provided always, and be it enacted, that every eomplaint and prosecution under this aet shall be eommened within six calendar months after the commission of the offence, unless the offending party shall have in the mean time left the country and not otherwise [the rest of this scetion uras repeated by 47 \& 48 Vict. c. 43 . See atso 37 \& 38 Viet. e. 96 i].

25. And be it enacted, that in all complaints, warrants, proceedinges or prosecntions under this act any justice or justices of the peace and the court of petty sessions for the county, eity, borough or place where the ofline shall be committed or the complaint arise, or where the said materials, frame, lomm, machine, tools or apparatus slabll be given ont or intrusted, lent or lifed, or where the manufacturer, master or employer shall earry on his trale or business, shall have full power and anthority to act mil to hear and detcrmines sucl complaint, warrant, proceeding or posecution, and do all other matters incident thereto: provided always, that in all convictions or aljuclications under this act one at least of the convicting or adjudieating justices shall lo a person not engaged in any mannfacture, trade, oc'upation or cmployment tas which this act extends, and shall not be the fither, son or hrother of my such person.

26. And be it enacted, that all forfeitures and penalties npon convictions under this act not speeially provided for shall he paid to the sluriff or other proper officer of the county, eity, borough or place in which such conviction shall take place for her Majesty's use, and shall be returned to the court of quarter sessions under the provisions of an act passed in the : 3 (ien. 4 , intitulest "An Act for the more speedy return and levying of l'in's, l'enaltios and Furfeitures, and Recognizances estreated."

27. And be it chacted, that in every ense of summary conviation or adjudica 36 MAs. \& SEI. 
tion under this act not specially provided for, where the sum forfeited or ad. judged to be paid, or which shall be imposed as a penalty by any justice o: justices of the peace, together with costs, if awarded, which costs such justicu or justices is and are hereby authorized to award if he or they shall think fit in any proceeding, adjudication or conviction under this act, shall not be paid immediately, or within such period as the said justice or justices shall direct, or [*617] where a warrant of distress * ${ }^{*}$ hall be issued and no sufficient distress shall be found, it shall be lawful for the convicting justice or justices to commit the offender to the common gaol or house of correction, there to be imprisoned with or without hard labour, according to the discretion of the said justice or justiees [the rest of this section was repealed by $47 \& 48$ Vict. $c$. 43 ].

[Sect. 28 was repcaled by 47 \& 48 Vict. $c$. 43.

29. And be it enacted, that in all cases of summary conviction under this act where the sum adjudged to be paid shall exceed twenty shillings, or the imprisonment shall exceed one calendar month, any person who shall think himself aggrieved by such conviction may appeal to the next conrt of general or quarter sessions [the rest of this section was repealed by 47 \& 48 Vict. c. 43].

30. And be it enacted, that no order or conviction, or proceedings touching the same respectively, nor adjudication made or appeal therefrom shall be quashed for want of form or be removed by certiorari or otherwise into any of her Majesty's superior courts of record [the rest of this scction was repcaled by 47 \& 48 Vict. c. 43 .]

31. And be it enacted, that for the protection of persons acting in the execution of this act all actions and prosecntions for damage to be commenced against any person for anything done in pursuance of this act shall be laid and tried in the county where the fact was or is charged to have been committed, and shall be commenced within two calendar months after the fact committed, and not otherwise, and notice in writing of such action and of the cause thereof shall be given to the defendant one calendar month at least before the commencement of the action, and in any such action the defendant may plead the general issue, or in case of any action of replevin may arow generally that the goods and chattels in question were taken under and by virtue of this said act, and may give this act and the special matter in evidence at the trial to be hal thereupon, and no plaintiff shall recover in any such action if tender of sufficient amends shall have been made before sneh action brought, nor if a sufficient sum of money shall have been paid into court after such action brought, by or on behalf of the defendant or arowant: provided always, that in all such actions of $(g)$ damages the plaintiff shall be bound to establish not merely that damages have been suffered by him, but that the same have been wilfully and. maliciously caused by the defendant or avowant.

[Sect. 32 was repcaled by 37 \& 38 Vict. c. 96.$]$

33. And be it enacted, that nothing in this act contained shall extend to Scotland or Ireland or be construed to extend to repeal any act or statute or part thereof now in foree and not repealed by this act.

34. And be it enacted, that this act shall not extend or be constrned to any manufacture, trade, occupation or employment, except only the manufactures $(h)$, trades, occupations and employments following (that is to say), the manufacture of woollen, worsted, linen, cotton, flax, mohair or silk materials in, on or by the stocking frame, warp machine or any otler machine employed in the mannfacture of framework knitted or looped labrics, and every trade, occnpation, operation or employment whatsover connected with or incidental to the. manufacture of stockings, gloves, and other articles of hosiery.

35. And be it enacted, that in all cases under this act the singular is to inclnde the plural, and the masculine the feminine, and in an indictment or information for offences against the property of partners, joint stock companies or trustees, it shall be sufficient to lay the ownership in the name of one partner or trustee and another or others; that the words "woollens, worsted, lincn, cotton,

(g) Sic.

(h) See R. v. Button, 11 Q. B. 941. 
flax, mohair or silk materials," shall be construed, to extend to any of the said materials mixed with each other *or with any other material or materials, [* ${ }_{(i 1}-$ ] and that the words "manufaciure" and "work" shall extend to all trasles, occupations, operations and employments whatsoever connected with or incidental to the manufacture of any of the said materials or any parts, branehes or processes thereof, and likewise to sueh materials whether the same or any part thereof be or be not, in the whole or in part, first wrought, made up or manufactured, or converted into merchantable wares.

[Seet. 36 and 37 were repealed by 37 \& 38 Vict. c. 96.]

\section{$8 \& 9$ VIст. с. 77.}

An Act to make further Regulations respecting the Tickets of Work to be delivered to Persons employed in the Manufacture of Hosiery in certain cases. [4th August, 1845.]

Whereas by an act passed 5 Geo. 4, intituled "An Act to consolidate and amend the Laws relative to the Arbitration of Disputes between Masters and Workmen," it is enacted (i), amongst other things that "with every piece of work given out by the manufacturer to a workman to be done, there shall (if both parties are agreed) be delivered a note or ticket in sueh form as the salid parties shall mutually agree upon :" and whereas it is expedient that, so far st.s relates to persons employed in the woollen, worsted, linen, cotton and silk hosiery manufactures, such further provision should be made for delivery to them of a note or ticket of work as is hereinafter expressed; be it therefore enacted by \&c., \&c., that [from and after the 1st day of January in the year $1816(k)$ ], when any manufacturer of hosiery, or the agent of any such manufacturer, gives out to a workmen the materials to be wrought, such manutieturer or agent shall at the same time deliver to snch workmen a printed or written ticket, signed by such manufacturer, containing the particulars of the agreement between such manufacturer and such worknan, as in the schedule to this act annexed; and such manufacturer or agent delivering such ticket shall make or cause to be made, and shall preserve until the work contracted to be done shall have been completed or paid for, a duplieate of such note or ticket.

2. And be it enacted, that in the event of any dispute between the mannfacturer or his agent and the workmin, such ticket, and the said duplicate thereof, shall be required to be produced, and shall, together or cither of them, be evidence of all things mentioned therein or respeeting the same.

3. Provided always, and be it enseted, that where the subject of dispnte relates to the alleged improper or imperfeet execution of any work delivered to a manufacturer or his agent, such piece of work shall be jroduced in order to ajudication, "or if not produced, shall be deemed and taken to have been suttlciently and properly executed.

4. And be it enacted, that if any manufacturer or agent shall neglert or refuse to deliver such ticket to snch workman as aforesilid, with the materials so giren out, and if such workman shall complain thereof to any justice est the" peace having jurisdiction in the place where the materials shall hov ben delivered out, or where the workman shall reside, snch justice miy sunumun such manufacturer or agent to attend before two justices at a time or plince appointed for hearing the *omplaint, and set forth in the summons; ["(31:)] and if the person to whom such summons be directed appear according to the tenor thereof, or if he does not appear, and the due service of the summons is

(i) Sect. 18, antc. p. 550.

(k) Repealed 38 \& 39 Vict. c. 66. 
proved, the said jnstice may proceed to hear and determine the complaint; ant if such neglect or refusal as aforesaid be proved, either by the confession of the party complained against, or by the oath of the complainant, or of any other credible witness or witnessess, such justices may convict such offender, and may, upon conviction, adjudge him to pay such penalty not exceeding five pounds together with the costs attending the conviction, as such justices shall think fit, and the party so adjudged to pay such penalty 'and costs shall pay the same accordingly ; provided always, that in all convictions of ajudications under this act, one at least of the convicting or ajudicating justices shall be a person not engaged in any mannfacture, trade, occupation or employment to which this act extends, and shall not be the father, son or brother of any such person.

[Sects. 5, 6 and part of 7 were repealed by 47 \& 48 Viet. c. 42.]

7 . . and the said penalty shall be paid over to the sheriff or other proper officer of the county, city, borough or place in which such conviction shall take place, for her Majesty's use, and shall be returned to the court of quarter sessions, under the provisions of an act passed $3 \mathrm{Geo}$. 4, intituled " An Act for the more speedy Return and levying of Fines, Penalties, and Forfeitures, and Recognizances estreated."

8. And be it enacted, that no order or conviction, or proceeding tonching the same respectively, shall be quashed for want of form, or be removed by certiorai or otherwise into any of her Majesty's superior courts of record [the rest of this section was repealed by 47 \& 48 Vict. $c$. 43 .]

9. And be it enacted, that the word "manufacturer" in this act shall be understood to mean any person furnishing the materials or work to be wrought into hosiery goods, to be sold or disposed of on his own account, and the word "agent" to include any person conveying or delivering the same to the workman, and the word "workman" any person actually employed in the mauufacture of the same.

[Sect. 10 was repealed by 38 \& 39 Vict. c. 66.]

\section{SCHEDULE.}

If the material to be manufactured be into stockings:

Gauge.

Ribbed or plain.

What kind of material.

Size.

Jacks in width.

Mark.

Length of leg.

Length of foot.

Narrowings in leg.

Narrowings in heel.

Narrowings in gusset.

Narrowings in toe.

Dumps or clocks.

Bound heels or toes.

Wrought heels or cut.

Wrought feet or cut.

Turnings in leg.

Welted or not.

Weight per dozen.

Price per dozen pair of making legs.

Price per dozen pair of making feet.

Name of party patting ont the work.

Name of artificer.

[*620] *If the material to be manufactured be into socks: Gange. 
Ribbed or plain.

What kind of material.

Size.

Jacks in width.

Mark.

Length of leg with top.

Length of toot.

Narrowings in heel.

Narrowings in gusset.

Narrowings in toe.

Cut or wrought heels.

Cut or wronght feet.

Price per dozen pair.

Name of party putting ont the work.

Name of artificer.

If the material to be manufactured be into gloves:

Gauge.

Ribbed or plain.

What kind of material.

Size.

Jacks in width of hand.

Jacks in width of finger.

Mark.

Length of hand.

Length of finger.

What kind of welts.

Plaited or not.

What figure in back of hand.

Weight per dozen.

Price per dozen pair of making hands.

Price per dozen pair of making fingers.

Name of party putting out the work.

Name of artificer.

If the material to be manufactured be into shirts:

Gauge.

Ribbed or plain.

What kind of material.

Size.

Jacks in width of body.

Jacks in width of sleeve.

Mark.

Length of body.

Iength of sleeve.

Fashioned or not.

Welted or not.

Weight per dozen.

Price per dozen of making bodies.

Price per dozen pair of making sleeves.

Name of party putting out the work.

Name of artificer.

If the material to be mannfactured be into caps:

Gauge.

Ribbed or plain.

Material.

Jacks in width.

Fashion. 
[*621] *Striped or plain.

Weight per dozen.

Price per dozen.

Name of party putting out the work.

Name of artificer.

If the material to be manufactured be into any other description of hosiery:

Gauge.

Length.

Width.

Weight.

Price.

Fashion.

Name of party putting out the work.

Name of artificer.

8 \& 9 VIст. c. 128.

\section{An Act to make further Regulations respecting the Tickets of Work to be delivered to Silk Weavers in certain cases.}

[9th August, 1845.]

Whereas by an act passed in the fifth year of the reign of King George the Fourth, intituled "An Act to consolidate and amend the Laws relative to the Arbitration of Disputes between Masters and Workmen," it was enacted ( $l$ ), amongst other things, that "with every piece of work given out by the manufacturer to a workman to be done there shall (if both parties are agreed) be delivered a note or ticket in such form as the said parties shall mntually agree upon:" and whereas it is expedient that, so far as relates to silk weavers, such further provision should be made for delivery to them of a note or ticket of work as hereinafter is expressed : be it therefore enacted by (\&c. \&c.), that [from and after the 1st day of January in the year $1845(\mathrm{~m})$ ] when any manufacturer of silk goods or of goods made of silk mixed with other materials, or the agent of any such manufacturer, gives ont to a weaver of such goods a piece of warp to be woven, such manufacturer or agent shall at the same time deliver to such weaver (unless both parties shall by writing under their respective hands agree to dispense therewith) a printed or written ticket signed by such manufacturer or agent containing the following particulars of the agreement between such manufacturer or agent and such weaver (that is to say):

The count or richness of the warp or cane :

The number of shoots or picks required in each inch :

The number of threads of weft to be used in each shoot :

The name of the manufacturer, or the style of the firm under which he carries on business;:

The weaver's name, with the date of the engagement:

And the price in sterling money agreed on for executing each yard imperial standard measure of thirty-six inches of such work in a workmanlike manner :

And such manufacturer or agent delivering such ticket shall make or [*622] * cause to be made, and shall preserve until the work contracted to be done shall have been completed or paid for, a duplicate of such note or ticket.

(l) Sect. 18, ante, p. 550.

(m) Repealed 38 \& 39 Vict. c. 66. 
2. And be it enacted, that in the event of any dispute between the manufixtorer or his agent and the workmen, sueh ticket and the sild duplicate therest shall be required to be produced, and shall, together or either of them, be evidence of all things mentioned therein or respecting the sime.

3. Provided always, and be it enacted, that where the subject of dispute relates to the alleged improper or imperfect execution of any work delivered to any manufacturer or his agent, such piece of work shall be producerl, in order to adjudication, or if not produced, shall be deemed and taken to have beensuficiently and properly executed.

4. And be it enacted, that if any of the parties to the saill complaint shall make oath before any justice having cognizance of such complaint, that he or she believes that the attendance of any person as a witness will be material to the hearing of such complaint, such justice may summon such jerson, having been paid or tendered a reasonable sum for his expenses, to ajpear and give evidence on oath before him at a time and place set forth in the stid summons; and if any person so summoned shall not appear at the time and place set forth in the said summons, and shall not make excuse for the defiult to the satisfaction of such justice, and if the due service of the summons be proved, or if such person appearing according to the summons shall not submit to be examined as a witness, then such justice may adjudge such person so making default in appearing or refusing to give evidence to pay such penalty not exceeding five pounds as such justice shall think fit, and the party so adjulged to pay such penalty shall pay the same accordingly.

5 . And be it enacted, that every summons required by this act slanl be served by delivering the same to the person summoned, or by lasing the sime at his or her usual place of abode, twenty-four hours at least leelure the time appointed by the summons for such person to appear.

6. And be it enacted, that if any such penalty or costs so adjulgerl by any justice to be paid is not paid immediately upon aljuclication such justice may issue his warrant to distrain and sell the goods and ehattels of the person si) aljudged to pay the same for the amount thereof, with cost; and the procecels of such distress, after paying the penalty and costs, and the custs of such distress and sale, shall be paid over to the person eonvicted and the said penalty shall be paid over to the sheriff or other proper officer of the eounty, city, borough or place in which such convietion shall take place, for her llajesty's use, and shall be returned to the court of quarter sessions, under the provisions of an act passed in the $3 \mathrm{Geo} .4$, intitulet " $\mathrm{An}$ Act for the more speedy leturn and levying of Fines, Penalties and Forfeitures, and lecognizances estrentetl."

[Sect. 7 was repealed by 38 \& 39 Vict. c. 86, s. III. $(g)$, post.]

8. And be it enacted, that no order or conviction or proceceling tenching the same respectively shall be quashed for want of form or be removed by cerfiorari or otherwise into any of her Majesty's superior courts of recold ; and that when any distress shall have been made for leving any money by virtue of this act the distress itselfeshall not be deemed unlawful, nor the party making the same a trespasser, on account of any defect or want of form in the summons, warrant, convietion, warrant of distress, or other proceedings in relation thereto, nor shall the party distraining be deemed a trespasser from the beginning on account of any irregularity afterwards committel by him, lout the jervon aggrieved by such irregularity may recover full satisfiction for special damago (if any) by action on the case.

[Sect. 9 was repcaled by 38 \& 39 Vict. c. 66.] 
An Act for the better protection of Persons under the Care and Con. trol of others as Apprentices or Servants; and to enable the Guar. dians and Overseers of the Poor to institute and conduct Prose. cutions in certain cases $(l)$. [20th May, 1851.]

Whereas it is expedient to make provision for the better protection of persons who are under the care and control of others as apprentices or servants; be it therefore enacted by (\&c. \&c.).

[Sections 1, 2, 6 and 7 were repealed by $24 \& 25$ Vict. c. 95; and by $24 \& 25$ Vict. $c$. 100, the provisions set out in the note $(m)$ ucere substituted.]

3. That the guardians of every union and of every separate parish under the management of a board of guardians, and the overseers of every parish not in union or under the management of a board of guardians, shall provide and keep [*624] a book or books, and shall cause to be *registered therein the name of every young person under the age of sixteen who shall thereafter be hired or taken as a servant from the workhouse of such union or parish, together with the several other particulars specified in the schedule hereunto annexed; and

(l) See ante, p. 228.

( $m$ ) 24 \& 25 Vict. c. 100 , s. 26 . Whosoerer, being legally liable either as a master or mistress to provide for any apprentice or servant necessary food, clothing or lodging, shall wilfully and without lawful excuse refuse or neglect to provide the same, or shall unlawfully and maliciously do or cause to be done any bodily harm to such apprentice or servant, so that the life of such apprentice or servant shall be endangered, or the liealth of such apprentice or servant shall have been or shall be likely to be permanently injured, shall be guilty of a misdemeanor, and being convicted thereof shall be liable, at the discretion of the court, to be kept in penal servitude for the term of [five years, $27 \& 28$ Vict. c. 47, s. 2], or to be imprisoned for any term not exceeding two years, with or without hard labonr.

73. Where any complaint shall be made of any offence against sect. 26 of this act, or of any bodily injury inflicted upon any person under the age of sixteen years, for which the party committing it is liable to be indicted, and the circumstances of which offence amount in point of law to a felony or an attempt to commit a felony, and two justices of the peace before whom such complaint is heard shall certify nnder their hands that it is necessary for the purposes of public justice that the prosecution shall be condueted by the guardians of the union or place, or where there are no guardians, by the overseers of the poor of the place in which the offence shall be charged to have been committed, such guardians or overseers as the case may be, upon personal service of such certificate or a duplicate thereof, npon the clerk of such guardians or upon any. one of such overseers, shall conduct the prosecution, and shall pay the costs reasonably and properly incurred by them therein (so far as the same shall not be allowed to them under any order of the court) out of the common fund of the union, or ont of the funds in the hands of the guardians or overseers as the case may be, and where there is a board of guardians, the clerk or some other officer of the union or place, and where there is no board of guardians one of the overseers of the poor may, if snch justices think it necessary for the purposes of public justice, be bound over to prosecnte.

77. The court before. which any misdemeanor indictable under the provisions of this act shall be prosecuted or tried, may allow the costs of the prosecution in the same manner as in cases of felony, and every order for the payment of snch costs shall be made out, and the sum of money mentioned therein paid and repaid npon the same terms and in the same manner in all respects as in cases of felony. 
erery such entry shall be signed by the presiding ehairman of such marl of guardians at an ordinary meeting thereof, or by some one of such overseers; provided that nothing herein contained shall be taken to supereetle or atlect the obligation to keep such register of poor children apprenticed by oversers or guardians as is required by the statute of the 42 nd Geo. 3 , c. 46 , and the statute of the 8 th Vict. c. 101.

4. That where any young person undér the age of sixteen shall have been or shall be hired or taken as a servant from the workhouse of any union or parish, or shall have been or shall be bound out as an apprentice by the guardians of any union, or the guardians or overseers of any parish, it shall be lawful for such guardians or overscers respectively, and they are hereby required, solong as such young person shall be under the age of sixteen, and shall be known to them to reside as servant or apprentice in the same service into which such young person shall have so gone as a servant from such workhouse or as such apprentice within such union or parish respectively or within five miles of any part of such union or parish, to eause the relieving officer, or, where there is no relieving officer, then some other officer duly anthorized for the purpose, to visit such young person at least twice in every year, and to rcport to them in writing whether he has found reason to believe that such roung person is not supplied with necessary food, or is subjected to cruel or illegal treatment in any respect.

5. That where any young person under the age of sixteen shall hereafter he hired or taken as a servant trom the workhouse of any union or parish, or shall be bonnd out as an apprentice by the guardians of any union, or by the guardians or overseers of any parish, and the residence of the master or mistress shall be more than five miles from any part of such union or parish, then a written notice of such hiring, taking or binding, specifying the name and age of the apprentice or servant, and the name, description and residence of such master or mistress, shall be fortliwith sent from such guardians or overseers to the guardians or overseers of the union or parish in which such master or mistress shall reside; and thereupon it shall become the duty of sueh last-mentioned guardians or overseers to cause the particulars contained in such notice to be registered in some book or books, to be provided by them for the purpose, together with the name of the union or parish from which such notice shall have been received; and such last-mentioned guardians or overseers shull couse such young person to be visited as frequently and in the same manner in all respects as if such young person had been hired or taken from their own workhouse, or had been bound out as an apprentice by themselves.

[Sections 6 and 7 are repealed. See note to sect. 1.]

8. That the words "guardians," "union," "overseers," "justice of the peace," "officer," "poor," "parish" and "workhouse," used in this act shall be construed in like manner as in the act of the 5 th Will. 4 , e. $76(n)$.

9. That this act shall extend only to England and Wales.

(n) This section does not apply to $24 \& 25$ Viet. c. 100 , which has no interpretation clause. But the words therein used would probably receive the same interpretation as is given by this section. 
ForM OF REGISTER.

\begin{tabular}{|c|c|c|c|c}
\hline Name of Child. & Age. $\begin{array}{c}\text { Date of hiring } \\
\text { or taking as } \\
\text { Servant. }\end{array}$ & $\begin{array}{c}\text { Name of } \\
\text { Master or } \\
\text { Mistress. }\end{array}$ & $\begin{array}{c}\text { Trade or } \\
\text { other description } \\
\text { of Master or } \\
\text { Mistress. }\end{array}$ & $\begin{array}{c}\text { Residence } \\
\text { of Master or } \\
\text { Mistress. }\end{array}$ \\
\hline & $\cdot$ & &
\end{tabular}

26 \& 27 VICT. c. 103.

\section{An Act to amend the Law in certain Cases of Misappropriation by Servants of the Property of their Masters.}

\section{[28th July, 1863.]}

Whereas the offence of taking corn or other food by a servant from the possession of his master, contrary to his orders, for the purpose of giving the same or of having the same given to the horses or other animals of such master, is by law a felony (n); and whereas it is desirable to alter the law in this respect: be it enacted by (\&c. \&c.), as follows:

1 . If any servant shall, contrary to the orders of his master, take from his possession any corn, pulse, roots or other food, for the purpose of giving the same or of having the same given to any horse or other animal belonging to or in the possession of his master, the servant so offending shall not by reason thereof be deemed guilty of or be proceeded against for felony, but shall, on conviction of snch offence before two justices of the peace, at their discretion, either be imprisoned, with or withont hard labour, for any term not exceeling three months, or else shall forfeit and pay such penalty as shall to them to be meet; not exceeding the sum of five pounds, and if such penalty shall not be paid, either immediately after the conviction, or within such period as the said justices shall at the time of the conviction appoint, the servant so offending shall be imprisoned, with or without hard labour, for any term not exceeding three months, unless such penalty be sooner paid (o): provided alvays, that if upon the hearing of the charge the said justices shall be of opinion that the same is too trifling, or that there are circumstances in the case which render it inexpedient [*626] to inflict any punishment, they shall have power to *dismiss the charge, without proceeding to a conviction: provided also, that if upon the trial of any servant for felonionsly taking from his master any corn, pulse, roots or other food consumable by horses or other animals, such servant shall allege that he

(n) See ante, p. 487.

(o) The words in italics were repealed by $47 \& 48$ Vict. c. 43 . 
took the same under such circumstances as would eonstitute an offence punishable under this act, and thereof shall satisfy the jury charged with his trial, then it shall be lawful for such jury to return a verdict accordingly; and thereupon the court before which such trial shall take place shall proceedl to award such punishment against such servant as may be awarded by two justices of the peace on the convietion of any person under the provisions of the atet: protided also, that in case of non-payment of any penalty to be imposed by the court on such servant, he shall be imprisoned, with or withont hard labour, for any term not exceeding three months, as the court shall order, nnless such penalty be sooner paid.

2. Provided always, that if any person shall think himself aggrievel by any conviction under this act, such person may appeal to the next court of general quarter sessions of the peace [which shall be holden not less than tichler days after the day of such conviction, for the county, ridling, division, city, borough or place wherein the cause of complaint shall have arisen: provided also, that such person shall give to the informant a noticc in writing of such appeal, und of the cause and matler thereof, within three days after such eonviction, aul seven ctctur days at the least, before such scssions, and shall also remain in custody until the sait sessions, or shall enter into a recognizance, with two suffeient sureties, brfore a justice of the peace, conditioned personally to appcar at the suid sessions, and to try such appeal, and to abide the judgment of the court thereupon, and to pay such costs as shall be by the court awarded, or, if such appeal shall be against any conriction whereby only a penalty, with or without costs, is adjudged to be paid, shall diposit with the clerk of the convicting justiees such a sum of money as such justices shall decm to be sufficient to cover the penalty and costs, if any, so adjudged to be paid, and the costs of the ap$p c a l](p)$, and upon such notice being given, and such recognizance being $e n$. tered into, or such deposit being made, the justices before whom such recognizance shall be entered into or such deposit shall be made shall liberate such person, if in custody; [the rest of this section was repented by 47 at 48 lict. c. 43, down to] provieled that the right of appeal against any conviction under this uct shall not apply so as to enable any person to appeal against any verdict of a jury as aforesaid.

3. No such conviction, or adjudication made on appeal therefrom, shall be quashed for want of form, or removed by certiorari into any of her Ilajesty's superior courts of record [the rest of this section uras repealcd by 47 di is riet. c. 43].

4. Every offence under this act may he prosecuted and every convietion under this act may be enforced in the manner direeted by the act 11 \& $12 \mathrm{Vict}$. $\mathrm{c}$. 43; and all provisions contained in the said aet shall, unless repugnunt to any of the provisions of this act, be applicable to sueh prosecution and conviction, in the same manner as if they were incorporated in this act: provided that nothing in this act contained shall in any manner alter or effeet any enactments relating to procedure in the case of any offenee punishable on summury conviction within the city of London or the metropolitan police district, or the recovery or application of any penalty for any such oftence.

5. This act shall extend to England only.

6. This act shall commence and take effect from the 1st day of September, 1863.

(p) The words in italics were repealed by $47 \& 48$ Viet. c. 43. 
Form of Summons of a Witness to be issued by Chairman.

\begin{abstract}
County of
To the of the

] Conciliation and Arbitration.

Whereas it appeareth to me, A. B., Chairman of the said Equitable Council of Conciliation and Arbitration held at , that G. H. of

in the borough [or county, as the case may be,] is a material witness to be examined concerning the dispute between C. D. of and $E$. F. of under the act [here set forth the title of the act]: these therefore are to require you forthwith to summon the said G. H. to appear before the said Equitable Council of Conciliation and Arbitration, held at the the noon of the day of 18 , so that the said dispute may be adjudicated upon and settled forthwith according to law; and be you then there to certify what you have done in the premises. Herein fail not. Lord

Given under my hand, this

day of

(Signed) A. B.,

Chairman of the Equitable Council of Conciliation and Arbitration.
\end{abstract}

\title{
Form of Award.
}

We, I. K. and L. M. [name and describe the arbitrators], the arbitrators in the matters in dispute between [here state the names of plaintiff and defendant to the reference], do hereby adjudge and determine that [here set forth the determination; to which the chairman and arbitrators shall subscribe their names.]

Signed this

day of

18.

\section{Form of Endorsement, extending the Time limited for making the Avard.}

We , Members of the Equitable Council of Conciliation and Arbitration, do hereby agree to extend the time of hearing or making an award, as the case may be, in the matter in dispute between

of to the day of

Witness our hands, this

day of

of

and

\section{Form of Acknowledgment of Fulfilment of the Award.}

I

, Chairman of the

Equitable Council of Conciliation and Arbitration, do hereby acknowledge that the award in the matter of dispute between of and of hath been duly fulfilled by who is hereby discharged of the same. Witness my hand this

day of A. B., Chairman. 
*Form of Aeknowledgment of Futfilment of the Axard (q).

I

, Chairman of the

Equitable Council of Conciliation and Arbitration, do hereby acknowledge that the award in the matter of dispute between of

of and

of to the

daly day of IR

A. B., Chairman.

Form of Oath to be administered by the Arbitrators to the Parlies and Witnexsen under this Act.

The evidence that you shall give before this Equitable Conncil of conciliation and Arbitration between and under and by virtue of this act [here state the tille of this act] shall be the truth, the whole truth, and nothing but the truth.

So help you God.

\section{Form of Commitment of a Person summoned as a Witness before the Arbitrators.}

Whereas proof on oath hath been made before me, one of her Majesty"s justices of the peace for the county [or riding, stewartry, division, city, burgh, liberty, town or place] of on this day of that $A$. B., hath been duly summoned and hath negleeted to appear and give evidence hefore the Equitable Council of Coneiliation and Arbitration for the in the matters of dispute between C. D. and E. F., at in the county [or riding, stewartry, division, city, burgh, liberty, town or place] of on the day of under and by virtue of an act male in the twentyfourth year of the reign of her present Majesty, intituled "An Act" [here set forth the title of this act], and the said A. B. being required to mprear und give evidence before the said arbitrators, and still refusing so to do: therefore 1 , the said justice, do hereby, in pursuance of the said act, commit the said A. B. to the [describing the prison and the house of correction], there to remain, without bail or mainprize, for his [or her] offence aforesaid, until he [or she] shall sulsmit himself [or herself] to be examined and give his [or her] evidence before the said arbitrators tonching the matters referred to them, or shall otherwise to discharged by due course of law : And you, the [eonstuble or other prace officer or officers to whom the warrant is directel] are hereby anthorized and reunired to take into your custody the body of the said $A$. B., and him [or her] sately convey to the said prison [or honse of eorrection], and him [or her] there to deliver to the gaoler [or keeper] thereof, who is hereby authorized and reguired to receive into his eustody the body of the said $\mathrm{A}$. B., and him [or her] sulely to detain and keep, pursuant to this commitment.

Given under my hand this day of in the year of our Iorl

(This commitment to be direeted to the proper peace oflicer und gioler [or kceper] of the prison [or house of correction].)

\section{Form of IVarrant of Distress.}

To the constable of

Whereas lay of

of

- under an award male by in the year of our Iorl

on the pursuant to an act passed in the twenty-fourth year of the reign of her present Majesty, intituledt "An Act" [state the title of this act], is liable to pay to the sum of and also the snm of tof $[$ ("102) ; and the sidid having refused or neglected to pay the sume for the space of two days and upwards subsequent to the making of such award, these are therefore to

(q) Sie. But there is some mistake in the insertion of this form. 
command you to levy the said sum of

by distress and sale of the goods and chattels of the said ; and I do hereby order and direct the goods and chattels so to be distrained to be sold and disposed of within days, unless the sum of for which such distress shall be made, together with the reasonable charges of taking and keeping such distress, shall be sooner paid: and you are liereby also commanded to certify to me what you shall do by virtue of this my warrant.

Given under my hand and seal, at

the

day of

\section{Form of the Constable's Return to the Warrant of Distress.}

I constable of do hereby certify to justice of the peace that I have made diligent search for, but do not know of, nor can find any goods and ehattels of by distress and sale whereof I may lery the sum of pursuant to his warrant for that purpose. Dated the $\begin{array}{ccc}\text { day of } & \text { in the year of our Lord } \\ \text { this } & \text { in the year of our Lord } & \text {. Given under my hand }\end{array}$

\section{Form of Commitment thereupon to the House of Correction.}

Here name To the constable of and also to the keeper of the house of the county. $\}$ correction at
Whereas of under an award made by on the day of in the year of our Lord pursuant to an act passed in the twenty-fourth year of the reign of her present Majesty, intituled "An Act" [state the title of this act], became liable to pay to the sum of and also the sum of for costs, time and expenses, making together the sum of and having refused or neglected to pay the same for the space of two days and upwards subsequent to the making of such award, my warrant was, according to the provisions of the said act, duly made and issued for the levying the said sum of by distress and sale of the goods and chattels of the said : and whereas it appears by the return of constable of dated the day of that he hath made diligent search for, but doth not know of, nor can find any goods and chattels of the said by distress and sale whereof the said sum of may be levied pursuant to my said warrant: These are therefore to command you the said constable of to apprehend the said and convey him to the said house of cor-
aforesaid and deliver him there to the keeper of the said house of correction; and these are also to command you the keeper of the said house of correction to receive him the said into the said house of correction, and there keep him without bail or mainprize for the space of months, unless the said sum of so ordered to be paid as aforesaid, shall be sooner satisfied, with all reasonable expenses.

Given under my hand and seal at the day of .

\section{Form of Commitment where the Warrant of Distress is withheld.}

Here name To the constable of the county. $\}$ correction at Whereas day of in the year of our Lord and also to the keeper of the honse a $\left[{ }^{*} 630\right]$ [state the title of this act], became liable to pay to *
and also the sum of for costs, time and together the sum of which he has refused or neglected to pay for the space of two dass and upwards subsequent to the making of such award; and whereas it appears to me that the recovery of such sum and warrant of distress and sale of the goods and chattels of the said will be attended with consequences ruinous or in an especial manner injurious to the defaulter [and 
his family, if any], and I therefore have determined to withhold such warrant, and to commit the said to prison pursuant to the sidid act: These are therefore to command you the said eonstable of and convey him to the said house of correction at apprehend the sild and to deliver him there to the keeper of the said house of eorrection; and these are also to command you the keeper of the said house of correction to receive him the said him without bail or mainprize for the space of into the sidid house of correction, and there ke( $p$ months, unless the said sum of so ordered to be paid as aforesaid shall be sooner satistied with all reasonable expenses.

Given under my hand and seal at the day of .

\section{0 \& 31 VICT. c. 130.}

\section{An Act for the Regulation of Agricultural Gangs.} [20th August, 1887.]

Whereas in certain counties in England certain persons known as gangmasters hire children, young persons, and women with a view to contracting with farmers and others for the execution on their lands of various kinds of agricultural work : and whereas it is expedient to make regulations with respect to the employment of ehildren, young persons, and women by gangmasters:

Be it enacted by, \&c. \&c., as follows :

1. This act may be cited for all purposes as "The Agrieultural Gangs Aet, 1867."

2. This act shall come into operation on the 1st of January, $186 \%$.

3. The following words and expressions shall in this act have the meanings hereby assigned to them, unless there is something in the context inconsistent with such meanings; that is to say,

"Child" shall mean a child under the age of thirteen years:

"Young person" shall mean a person of the age of thirteen years and under the age of eighteen years:

"Women" shall mean a female of the age of eighteen years or npwards :

"Gangmaster" shall mean any person, whether male or female, who hires children, young persons, or women with a view to their being employed in agrieultural labour on lands not in his own occupation; and, until the contrary is proved, any children, young persons, or women employed in agricultural labonr on lands not in the occupation of the person who hired them sliall be deemed to have been hired with the aforesaid view :

"Agricultural gang" shall mean a body of ehildren, young persons, and women, or any of them, uniler the control of a gangniaster:

4. The following regulations shall be observed by every gangmaster with respect to the cmployment of children, young persons, and wome'n:

*(1.) No child under the age of eight years shall be cmployed in any agri- ["631] eultural gang $(r)$ :

(2.) No females shall be employed in the samo agricultural gang with malcs:

(3.) No female shall be employed in any gang under any male gangmaster unless a female licensed to act as gangmaster is also present with that gang:

And any gangmaster employing any child, young person, or woman in mntravention of this section, and any oceupier of land on which such employment

(r) By 36 \& 37 Vict. c. 67 , s. 16 , the words in italics were repeuled. and ten sears substituted for eight. But that act was repenled by 39 \& $40 \mathrm{Vict}, \mathrm{c}, 79$, 8. 52, which act prohibits the employment of children under ten. 
takes place, unless he proves that it took place without his knowledge, shall respectively be liable to a penalty not exceeding twenty shillings for each child, young person, or woman so employed.

5. No person shall act as a gangmaster unless he has obtained a licence to act as such under this act.

Any person acting as a gangmaster without a licence under this act shall incur a penalty not exceeding twenty shillings for every day during which he so acts.

6. No licence shall be granted to any person who is licensed to sell beer spirits, or any other excisable liquor.

7. Licences to gangmasters shall be granted by two or more justices in divisional petty sessions, on due proof to the satisfaction of such justices that the applicant for a licence is of good character, and a fit person to be intrusted with the management of an agricultural gang.

The justices shall annex to their licence a condition limiting, in such manner as they think expedient, the distances within which the children employed by such gangmaster are to be allowed to travel on foot to their work, and any gangmaster violating the condition so annexed to his licence shall for each offence be liable to a penalty not exceeding ten shillings.

Any person aggrieved by the refusal of the justices to grant him a licence to act as gangmaster may appeal to the next practicable court of general or quarter sessions; and it shall be lawful for such court, if they see cause, to grant a license to the applicant, which shall be of the same validity as if it had been granted by the justices in petty sessions.

8. Licenses under this act shall be in force for six months only, and may be renewed on similar proof to that on which an original licence is granted.

9. There shall be charged in respect of each grant or renewal of licence a fee of one shilling, and such fee shall be accounted for and applied in manner in which the fees ordinarily received by the authority granting the licence are applicable.

10. On any conviction of a gangmaster of any offence against this act the justices who convict him shall endorse on his licence the fact of such conviction; and on any conviction of such gangmaster of a second offence against this act the justices may, in addition to any other penalty, withhold his licence for a period not exceeding three months; and on any conviction of any gangmaster of a third offence against this act the justices may, in addition to any other penalty, withhold his licence for a period not exceeding two years.

And after a fourth conviction for an offence against this act the gangmaster shall be disqualified from holding or receiving a licence under this act.

11. All penalties under this act may be recovered summarily before two or [*632] more justices in manner directed by an act passed 11 \& 12 Vict. * ${ }^{*}$. 43 , intituled "An Act to facilitate the performance of the Duties of Justices of the Peace out of Sessions within England and Wales with respeet to Summary Convictions and Orders," or any act amending the same.

12. This act shall not apply to Scotland or Ireland. 


\section{TAX ON MALE SERVANTS.}

By $32 \& 33$ Vict. c. 14, whereby a duty of 158 . was granted "for cvery mall. servant" $(8)$, it is enacted:

Sect. 19. The provisions and regulations contained in this section whall the observed, viz. :

(1) It shall not be necessary for any member of the royal family to mak. any declaration or to take out any licence under this act, nor shall it be necessary for the sheriff of any county, or mayor or othur oflicer in any corporation or royal burgh serving an annual offece therein, to take out a licence for any servants, carriages, or horses, employerl or kept by him for the purpose of his office during his year of service.

(2) It shall not be necessary for any person ordinarily residing in Ireland and being a representative peer on the part of Ireland, or a member $\|^{\circ}$ the House of Commons, and not residing in Great Britain longer than during the session of partiament, and forty days before and forty days after the session, or for any person ordinarily residing in Ircland and residing in Great Britain by the order or direetion of the Iord Lientenant for the time being, or of his chief secretary for the purpowe of public business, to make any declaration, or to take out any licence under this act in respect of any servants, carriages, horses or mulew, or armorial bearings employed, kept or used hy him, save in respect of any subject matter of duty, which shall be emploverl, kept or used by such person in Great britain during his residence in Ireland.

As to Male Servants.

(3) The term " male servant" $(t)$ means and includes any male servint employed, either wholly or partially, in any of the following (aparities; that is to say, maitre d'bôtel, house-steward, master of the horste, groom of the chambers, valet de chambre, butler, nnder-butler, elerk of the kitchen, confectioner, cook, honse porter, footman, page, waiter, coachman, groom, postilion, stable boy or lielper in the stables, gardener, under-gardener, parkkeeper, gamekeeper, nncler-ganmekeeper, huntsman and whipper-in, or in any capaeity involving the dutics of *any of the above descriptions of servants, by whatever style the [*6ia3] person acting in such capacity may be calleid.

(4) Every person who shall furnish any male servant on hire shall. for the purposes of this act, be deemed to be the employer of snch servant.

(5) It shall not be necessary for licences to be taken out in the fillowing cases, viz.:

By any offieer in Her Majesty's army or navy, for any servant being a soldier in the army, or a person actually borne upon the looks of a ship and employed by such officer in accordance with the regulations of her Majesty's service :

(8) Sect. 27 provides a penalty of 201 . for every person who employs a males kervant without a proper licence under this act, or who shull employ a greater number of male servants than he shall be anthorized by his linence to employ.

(t) By 39 \& 40 Vict. c. 16, s. 5, the term "male servant," as used in 32 s 34 Vict. c. 14, shall not include a servant who, being bont fide employel in any cupacity other than the capacities specified or referred to in provision numhered three of sect. 19 of the said act, is occasionally or partially cmployed in any of the said capacities so specified or referred to, and shall not include a person who has been bond fide engaged to serve lis eniployer for a portion only of each day, and does not reside in his employer's house.

37 MAS. \& SEr. 
By any licensed retailer of exciseable liquors, or licensed keeper of a refreshment honse, for any servant emplosed by him solely for the purposes of his business, such servant being the only male servant employed by him :

By any person who shall hare made entry of his premises in accordance with sect. 28 of this act $(u)$, tor any servant employed by him at snch premises in the course of his trade, other than a servant employed to drive a carriage with any horse let to hire for any period exceeding twenty-eight days; provided that such person shall have complied with all the provisions contained in the said section :

By any person duly licensed by proper authority to keep or use any public stage or hackney carriage, for any servant neeessarily employed by him to drive such stage or hackney carriage, or in the case of such stage or hackney carriage, or of the horse or horses kept and used by him to draw the same.

\section{$33 \& 34$ VICT. с. $30(x)$.}

\section{An Act to abolish Attachment of Wages. [14th July, 1870.]}

Whereas by an order in council made on the 18th day of November, 1867, certain of the provisions of "The Common Law Procedure Act, 18.54," were extended and applied to all the conrts of record established under the provisions of "The Connty Conrts Act, 1846," and also to the City of London Courts of Record as constituted by "The Connty Courts Act, 1867:"

And whereas much inconvenience has arisen by the attachment of wages to satisfy julgments recovered in some of such first-mentioned courts, and it is expedient to prevent the attachment of wages to satisfy judgments recovered in any conrt of record or inferior court :

Be it enacter by, \&c. \&e.

1. That after the passing of this act no order for the attachment of the wages of any servant. labourer, or workman shall be made by the jndge of any court of record or inferior court $(y)$.

2. That this act may be cited as "The Wages Attachment Abolition Act, $1870 . "$

\section{An Act to amend the Law relating to Trades Unions (z).}

Be it enacted by, \&e. \&c., as follows : [29th June, 1871.]

\section{Preliminary.}

1. This act may be cited as "The Trade Union Act, 1871."

(u) That is, horse-dealers and lirery-stable keepers, or letters of horses for hire, or keepers of horses to be used for drawing any public stage or hackney carriage.

$(x)$ And see c. 63 as to Scotland. In Gordon r. Jennings, 51 L. J., C. L. 417, it was held that the secretary of a tramway company at $50 l$. a year, subject to dismissal at a quarter's notice, was not within this act.

(y) Semble. This act only applies to inferior courts of record, and not to the High Court; per Stephen, J., Booth v. Trail, 12 Q. B. D. 9.

(z) And see $39 \& 40$ Vict. c. 22 , post. 


\section{Criminal Provisions.}

2. The purposes of any trade union shall not, by reason merely that they are in restraint of trade, be deemed to be unlawfu], so as to reniler any member of such trade union liable to criminal prosecution for conspiracy or otherwise.

3. The purposes of any trade union shall not, by reason merely that they are in restraint of trade, be anlawful so as to render void or voidalile any ingrenment or trust.

4. Nothing in this act shall enable $(a)$ any court to entertain any leonl proceeding instituted with the object of directly enforcing or recovering damages for the breach of any of the following agreements, namely,

(1.) Any agreement between members of a trade union as snch, concerning the conditions on which any members for the time being of such trade union shall or shall not sell their goods, transact business, employ, or be employed :

(2.) Any agreement for the payment by any person of any subseription or penalty to a trade union:

(3.) Any agreement for the application of the funds of a trale union (b), -

(a.) To provide benetits to members; or,

(b.) To furnish contributions to any emplnyer or worknan not a member of such tralle union, in consideration of such employer or workmen acting in enformity with the rules or resolutions of such trade union; or

(c.) To discharge any fine imposed upon any person by sentence of a court of justice; or

(4.) Any agreement made between one trade union and another; or

(5.) Any bond to secure the performance of any of the ahove-montioned agreements.

But nothing in this section shall be deemed to constitute any of the abovementioned agreements unlawful.

5. The following acts, that is to say,

(1.) The Friendly Societies Acts, 18i5) and 1858, and the aets amending the same ;

(2.) The Industrial and Provident Societies Aet, 1867, and any act amending the same; and

(3.) The Companies Acts, 1862 and 1867,

shall not apply to any tracle union, and the registration of any tracle union nnder any of the said acts shall be void, and the deposit of the rules of uny

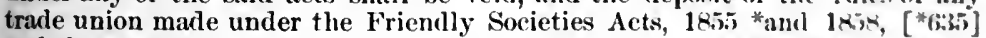
and the acts amending the same, before the passing of this act, shall cease to be of any effect $(c)$.

\section{Registered Trade Unions.}

6. Any seven or more members of a trade union may by sulsoribing their names to the rules of the union, and otherwise eomplying with the provisions of this act with respect to registry, register sueh trabe union mbler this act, provided that if any one of the purposes of such trade union be mulawfinl such registration thall be voidl.

7. It shall be lawful for any trade union registered under this aet to purchase or take upon lease in the name of the trustees for the time being of snch union any land not exceeding one aere, and to sell, exchange, mortgage, or lot the same, and no purchaser, assignee, mortgagee, or tenant shall he hound to impuire whether the trustees have authority for any sale, exchange, mortgage or letting,

(a) On these words, see per Jessel, M. R., in Rigby v. Connol, $1:$ I. J.. Ch. 332.

(b) See Rigby v. Connol, 14 Ch. D. 482 ; 49 I. J., Ch. 328 : Duker v. Litllowoy,

49 L. J., Ch. 802 ; and see Wolfe v. Mathews, 51 I. J., Ch. 833; 21 Ch. D. 19.1.

(c) And see 39 \& 40 Vict. e. 22, s. 2 . post. 
and the receipt of the trustees shall be a discharge for the money arising thercfrom; and for the purpose of this section every branch of a trade union shall be considered a distinct union.

8. All real and personal estate whatsoever belonging to any trade union registered under this act shall be rested in the trustees for the time being of the trade union appointed as provided by this act for the use and benefit of such trade union and the members thereof, and the real or personal estate of any branch of a trade union shall be rested in the trustees of such branch $(d)$, and be under the control of such trustees, their respective executors or administrators, according to their respective claims and interests, and upon the death or removal of any such trustees the same shall vest in the succeeding trustees for the same estate and interest as the former trustees had therein, and subject to the same trusts, without any conveyance or assignment whatsoever, sare and except in the case of stocks and securities in the public funds of Great Britain and Ireland, which shall be transferred into the names of such new trinstees; and in all actions, or suits, or indictments, or summary proceedings before any conrt of summary jurisdiction, touching or concerning any such property, the sime shall be stated to be the property of the person or persons for the time being holding the said office of trustee, in their proper names, as trustees of such trade union, without any further description.

9. The trustees of any tride union registered under this act, or any other officer or such trade union who may be authorised so to do by the rules thereof, are hereby empowered to bring or defend, or canse to be bronght or defended, any action, suit, prosecution, or complaint in any court of law or equity, touching or concerning the property, right or clain to property of the trade union; and shall and may, in all cases concerning the real or personal property of such trade union, sue and be sued, plead and be impleaded, in any court of law or equity, in their proper names, without other description than the title of their oftice ; and no such action, surt, prosecutiou, or complaint shall be disrontinued or shall abate by the death or removal from office of such persons or any of them, but the same shall and may be proceeded in by their successor or successors as if such death, resignation or removal had not taken place; and such successors shall pay or receive the like costs as if the action, suit, prosecution, or complaint and been eommmenced in their names for the benefit of or ws be reimbursed from the funds of such trade union, and the summons to be issued to such trustee or other officer may be server by leaving the same at the registered office of the trade union.

10. $\Lambda$ trustee of any trade union registered under this act shall not be liable [*636] to make good any deficiency which may arise or happen in the ${ }^{*}$ finds of such trade union, but shall be liable only for the moneys which shall be actually received by him on account of such trade union.

11. Every treasurer or other officer of a trade union registered under this act, at such times as by the rule of such trade union he should render such account as hereinafter mentioned, or upon being requircd so to do, shall render to the trustees of the trade union, or to the members of such trade mion, at a meeting of the trade minion, a just and true acconnt of all moneys received and paid by him sinee he last rendered the like account, and of the balance then remaining in his hands, and of all bonds or securities of such trade union, which acconnt the said trustees shall canse to be audited by some fit and proper person or persons by them to be appointed; and such treasurer, if thereunto required, upon the said account being audited, shall forthwith hand over to the said trustees the halance which on such andit appears to be dne from him, and shall also, if required, hand over to such trustees all securities and effects, books, papers, and property of the said trade union in his hands or eustody; and if he fail to do so the trustees of the said trade union may sue such treasurer in any competent court for the balance appearing to have been due from him upon the account last rendered by him, and for all the moneys since received by him on acconnt of the said trade union, and for the securities and

(d) Ib. s. 3, post. 
effects, books, papers, and property in his hands or eustoly, lenving him to wt off in such action the sums, if any, which he may have since pairl on accoust of the said trade union; and in such action the silil trustees shitll he motithel to recover their full cost of suit, to be taxed as between attorney and client.

12. If any officer, member, or other person being or representing himself tor be a member of a trade union registered under this det, or the nominee, exe(')]tor, administrator, or assignee of a member thereof. or any person wlatisuever. by false representation or imposition obtain posisesion of any moneys, securition, b rok3, papers, or other effects of such trade union, or, having the sime in his possession, wilfully withold or fraudulently misipply the same, or wilfully apply any part of the same to purposes other than those expresised or directed in the rules of sucl trade union, or any part thereof, the contt of summary jurisdiction for the place in which the registered office of the trade nnion is sitnats (e) upon a complaint made by any person on behalf of such trade union, in by the registrar, or in Seotland at the instance of the procurator tiscel of the (r) to which such complaint is competently male, or of the trade nnion, with his occurrence, may, by summary orler, order such ofticer, member, or ot heer jw.rson, to deliver up all such moneys, securities, books, palpers, or other ellocts to the trade union, or to repay the amount of money applied improperly, and to pay, if the court think fit, a further suni of money not exceeding twenty pounds, together with costs not exceeding twenty shillings; and in defunlt of such delivery of effects, or repayment of such amonnt money, or puyment of such penalty and costs aforesaid, the said court may order the said person so convictul to be imprisoned, with cr without hard labour, for any time not exceeding three months: Proviled, that nothing herein contained shall prevent the sidil trate union, or in Scotland Her Majesty's Advocate, from proceeding by indictment against the said party; provided, also that no person shall be procerederl antinst by indictment if a conviction shall have been previously obtained for the sulne oflence under the provisions of this Act.

\section{Registry of Trade Cnion.}

13. With respect to the registry, under this act, of a trade union, and of the rules thereof, the following provisions shall have effect.

(1.) An application to register the trade union and printed copies of *the [ ${ }^{*} 637$ ] rules, together with a list of the titles and names of the oflicers, shall be sent to the registrar under this Act.

(2.) The registrar, upon being satistied that the trale nuion has complim with the regulations respecting registry in force uncler this act, slasll register sueh trade union and such rules:

(3.) No trade union shall be registered under a name identical with that by which any other existing trale union has heen registerml, or sol nearly resembling such name as to be likely to dereive tle members or the public $(f)$ : .

(4.) Where a trade union applying to be registered hats been in operation for more than a year before the date or such application, there shall be delivered to the registrar before the registry therewif, a general statement of the receipts, funds, effects, and expenditure of such trade union in the same form, and showing the salme partienlars, as if it were the annual general statement required as hercinatier mentioncal to $I_{N}$. transmitted annually to the regist rir :

(5.) The registrar upon registering such trable union slutll issue a crertilisats of registry, which certiticate, nuless proved ta have been withdrawn ar cancelled, shall be conclusive evidence that the regulutions of this uet with respect to registry have been compliod with:

(e) And see $39 \& 40$ Vict. c. 22, s.5, post.

(f) See R. v. Registrar of Friendly sonieties, 41 L. I., (2. B. 366i ; 1. K., 7 Q. B. 941 . 
(6). One of Her Majesty's Principal Secretaries of State may from time to time make regulations respecting registry under this Act, and respecting the seal (if any) to be used for the purpose of such registry, and the forms to be used for such registry, and the inspection of documents kept by the registrar under this Act, and respecting the fees. if any, to be paid on registry, not exceeding the fees specified in the second schedule to this act, and generally for carrying this act into effect.

14. With respeet to the rules of a trade union registererl under this act, the following provisions shall have effect:

(1.) The rules of every such trade union shall contain provisions in respect of the several matters mentioned in the first schedule to this act:

(2.) A copy of the rules shall be delivered by the trade union to every person on demand on payment of a sum not exceeding one shilling.

15. Every trade union registered under this act shall have a registered offiec to whieh all communications and notices may be addressed ; if any trarle union uncler this act is in operation for seven days without having such an office. such trade union and every oflicer thereof, shall each ineur a penalty not exceeding five pounds for every day during which it is so in operation.

Notice of the situation of such registered offiee, and of any change therein. shall be given to the registrar and recorded by him; until sueh notice is given the trade union shall not be deemed to have complied with the provisions of this act.

16. A general statement of the receipts, funds, effects, and expenditure ot every trade union registered under this act shall he transmitted to the registrar before the first day of June in every year, and shall show fully the assets and liabilities at the date, and the receipts and expenditure during the rear precelling the date to which it is made ont, of the trade union; and shall show separately the expenditure in respect of the sereral objects of the trade union. and shall be prepared and made out up to such date, in such form, and shal! [*638] conprise such partieulars, as the *registrar may from time to time require; and every member of, and depositor in, any such trade union.shall be entitled to receive, on application to the treasurer or secretary of that trade union, a copy of such general statement, without making any payment for the same.

Together with such general statement there shall be sent to the registrar a copy of all alterations of rules and new rules and ehanges of officers mad. by the trate union during the year preceding the date up to which the general statement is made out, and a copy of the rules of the tracle nnion as they exist at that date.

Every trade union which fails to comply with or acts in eontravention o: this section, and also every otheer of the trade union so failing, shall each be liable to a penalty not exceeding five pounds for each offence.

Every person who wiltully makes or orders to be made any false entry in or any omission from any such general statement, or in or from the return of sueh copies of rules or alterations of rules, shall be liable to a penalty not exceeding fifty pounds for each offence.

17. The registrars of the friendly societies in England, Scotland, and Ireland shall be the registrars under this act.

The registrars shall lay before parliament annual reports with respect to the matters transacted by such registrars in pursuance of this act.

18. If any person with intent to mislead or defraud gives to any member of : trade union registered nnder this act, or to any person intending or applying to beeome a member of such trade union, a copy of any rules or of any alteration; or amendments of the same other than those respectively which exist for the: time being, on the pretence that the same are the existing rules of such trade union, or that there are no other rules of such trade union, or if any person, with the intent aforesaid gives a copy of any rules to any person on the pretence that such rules are the rules of a trade union registered under this act which is not 
so registered, every person so offending shall be decmed guilty of a misclemeanor.

\section{Legal Procecdings.}

19. In England and Ireland all offences and penalties under this act may be prosecuted and recovered in manner directed by the Summary Jurisdic tion Acts.

In England and Ireland summary orders under this act may be macle and enforced on complaint before a eourt of snmmary jurisdiction in manner provided by the Summary Jurisdietion Acts.

- Provided as follows :-

1. The "Court of Summary Jurisdiction," when hearing and determining an information or complaint, shall be constituted in some one of the following manners; that is to say,

(A.) In England,

(1.) In any place within the jurisdiction of a metropolitan police mayistrate or other stipendiary magistrate, of such magistrate or his substitute :

(2.) In the eity of London, of the Lord Mayor or any alderman of the said city :

(3.) In any other place, of two or more justices of the peace sitting in petty sessions.

(B.) In Ireland,

(1.) In the police distriet of Dublin metropolis, of a divisional justice :

(2.) In any other place, of a resiclent magistrate.

In Scotland all offenees and penalties under this aet shall be prosecuted and recovered by the procurator fiscal of the county in the sheritl court under the provisions of The Summary Procedure Aet, 1864.

In Scotland summary orders under this act may be mate and entorced on complaint in the sheriff court.

All the jurisdictions, powers, and authorities neeessary for giving ${ }^{*}$ effect [ $\left.{ }^{*} 63: 4\right]$ to these provisions relating to Scotland are hereby conferred on the slieritis and their substitutes.

Provided that in England, Seotland, and Ireland-

2. The deseription of any oflence under this act in the worls of such act shall be sufficient in law.

3. Any exception, exemption, proviso, exeuse, or qualification, whether it loes or not accompany the description of the offence in this act, may be proved by the defendant, but need not be specitied or negatived in the infirmation, and if so specified or negatived, no proof in relation to the matters so specifled or negatived shall be required on the part of the informant or prosecutor.

20. In England or Ireland, if any party feels aggrieved by any orler or conviction made by a court of summary jurisdiet ion on determining any (o)mplnint or information ninder this act, the part $y$ so agerieved may appenl therefrum, sulject to the conditions and regulations following:

(1.) The appeal shall be male to some court of general or quarter sessions [the rest of this scetion was repealed by 47 \& 48 lict. c. 4.3.]

21. In Scotland it sluall be eompetent to any person to appeal against any order or conviction nnder this aet to the next Cirenit Court of Justicinry, or where there are no circuit courts to the High Court of Justiciary nt Filinburgh. in the manner preseribed by and under the rules, limitations, inditiens, and restrietions contained in the aet passed in the twentieth year of the reign of His Majesty King George the Sccond, chapter forty-three, in regarl to njpenls to circuit courts in matters criminal, as the same may be altered or unenderl by any acts of parliament for the time heing in foree.

All penalties imposed under the provisions of this act in Sentlumb noy he $\mathrm{cm}$ forced in default of payment by inprisonment for a term to be smerified in the summons or complaint, but not caceeding three cnlendar months. 
All penalties imposed and reevvered under the provisions of this act in Scotland shall be paid to the sheriff elerk, and shall be accounted for and paid by him to the Queen's and Lord Treasurer's Remembrancer on behalf of the Crown.

22. A person who is a master, or fatler, son, or brother of a master, in the particular manufacture, trade, or business in or in connection with which any oflence under this act is charged to have been committed shall not act as or as a member of a court of summary jurisdiction or appeal for the purposes of this act.

\section{Definitions.}

23. In this act-

The term Summary Jurisdiction Acts means as follows :

As to Engrand, the act of the session of the eleventl and twelfth years of the reign of her present Majesty, chapter forty-three, intituled "An Act to facilitate the pertormance of the dnties of justices of the peace out of sessions within England and Wales with respect to summary convictions and orders," and any acts amending the same $(f)$.

As to Ireland, within the police district of Dublin metropolis, the acts regulating the powers and duties of justices of the peace for such district, or of the police of such district, and elsewhere in Ireland, "The Petty Sessions (Ireland) Act, 1851," and any act amending the same.

In Scotland the term " misdemeanor" means a crime and offence.

[The term "trade union" means such eombination, whether temporary or perma[*640] nent, for regulating the relations between workmen and masters, or *betwee'n workme'n and workmen, or beticcen masters and masters, or for imposing restrintive conditions on the eonduct of any trate or business, as vould, if this act had not passed, have been dcemed to have been an unlavful combination by reason of some one or more of its purposes being in restraint of trade] $(g)$ : Provided that this act shall not affect-

1. Any agreement between partners as to their own business;

2. Any agreement between an employer and those employed by him as to such employment ;

3. Any agreement in consideration of the sale of the goodwill of a business or of instruction in any profession, trade, or handieraft.

\section{Repeal.}

24. The Trades Unions Funds Protection Act, 1869, is hereby repealed.

Provided that this repeal shall not affect-

(1.) Anything duly done or suffered under the said act :

(2.) Any right or privilege aequired or any liability incurred under the said act:

(3.) Any penalty, forfeiture, or other punishment incurred in respect of any offence agiunst the said act:

(4.) The institution of any investigation or legal proceeding or any other remedy for uscertaining, enforeing, recovering, or imposing any such liability, penalty, forfeiture, or punishment as aforesaid.

\section{SCHEDULES.}

\section{Frnst Schedule.}

Of Matters to be provided for by the Rules of Trade Unions Registered under this Act.

1. The name of the trade union and place of meeting for the business of the trade union.

2. The whole of the objects for which the trade union is to be established,

(f) See the Summary Jurisdiction Act, 1879, 42 \& 43 Vict. c. 49.

(g) The words between brackets were repealed by the Act of 1876 , and the definition of "trade union" altered, $39 \& 40$ Vict. c. 22, s. 16, post. 
the purposes for which the funds thereof shall be applicable, and the conditions under which any member may become entitled to any benefit assured thereby, and the fines and forfeitures to be imposed on any member of such trade union.

3 . The manner of making, altering, amending, and rescinding rules.

4. A provision for the appointment and removal of a general committee of management, of a trustee or trustees, treasurer, and other officers.

5. A provision for the investment of the funds, and for an annual or periodical audit of accounts.

6. The inspection of the books and names of members of the trade union by every person having an interest in the funds of the trade union.

\section{Secoxd Schedule.}

Maximum Fees.

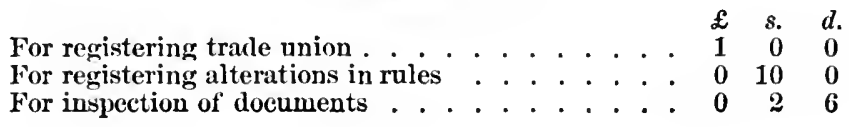

*35 \& 36 Vicr. c. 61.

[*641]

An Act to regulate the use of Steam Whistles in certain Manufac-
tories.

Be it enacted by, \&c., \&c. as follows:

1. This act shall not apply to Scotland.

2. No person shall use or employ in any manufactory, or any other place, any steam whistle or steam trumpet for the purpose of sunımoning or clismissing workmen or persons employed without the sanction of the sanitary anthority, and every person offending against this section shall be liable to a penalty not exceeling tive pouncls, and to a further penalty not exceeding forty shillings for every day during which such offence continues: Provided always, that the sanitary authority, in case they have sanctioned the use of such instrunent as aforesaid, may at any time revoke such sanction on giving one month's notice to the person using the same: Provided also, that it shall be lawful for the Iocal Government Board, on representation made to them by any person that he is prejudicially affected by such sanction, to revoke the same, and such revocation shall have the same force and effect as if it had been made by the sanitary authority.

3. "Sanitary authority" means the authority at the time being empowered to execute the Nuisance Removal Acts, as defined and extended-by the Sanitary Act, 1866.

4. All offences and penalties under this act may be prosecuted and recovered in England in manner directed by the act of the session of the eleventh and twelfth years of the reign of her present Majesty, chapter forty-three, and any acts amending the same $(a)$, and in Ireland, in the police district of Dublin metropolis, in manner direeted by the acts regulating the powers and duties of justices of the peace for such distriet, or of the police of that district, and clsewhere in manner directed by the Petty Sessions (Ireland) Aet, 1851, and any act amending the same.

(a) Sce the Summary Jurisdiction Act, 1879, 4 \& \& 43 Vist. c. 49. 


\section{$35 \& 36$ VIоT. c. 76.}

\section{An Act to consolidate and amend the Acts relating to the Regula- tion of Coal Mines and certain other Mines.}

Whereas it is expedient to consolidate and amend the law relating to the regulation and inspection of coal mines and certain other mines:

Be it enacted by, \&c., \&c. as follows:

\section{Preliminary.}

1. This act may be cited as "The Coal Mines Regulation Act, 1872."

2. This act, except as hereinafter provided, shall not come into operation in England and Scotland until the first day of January, one thousand eight hundred and screnty-three, and in Ireland until the first day of January, one thousand eight hundred and serenty-four, which dates are in this act respectively referred to as the commencement of this act.

$[* 642] * 3$. This act shall apply to mines of coal, mines of stratified ironstone, mines of shale, and mines of fire-clay.

\section{PART I.}

\section{Employment of Women, Young Persons, and Children.}

4. No boy under the age of ten years, and no woman or girl of any age, shall be employed in or allowed to be for the purpose of employment in any mine to which this act applies below ground.

5. A boy of the age of ten and under the age of twelve years shall not be employed in or allowed to be for the purpose of employment in any mine to which this act applies below ground, except in a mine in which a Secretary of State, by reason of the thinness of the seams of such mine, considers such employment necessary, and by order, published as he may think fit, for the time being allows the same, nor in such case

(a.) for more than six days in any one week; or

(b.) if he is employed for more than three days in any one week for more than six hours in any one day; or

(c.) in any other case for more than ten hours in any one day; or

(d.) otherwise than in accordance with the regulations hereinafter contained.

6. A boy of the age of twere and under the age of thirteen years, and a male young person under the age of sixteen years, shall not be employed in or allowed to be for the purpose of employment in any mine to which this act applies below ground for more than fifty-four hours in any one week, or more than ten hours in any one day, or otherwise than in accordance with the regulations hereinafter contained.

7. For the purpose of the provisions of this act with respect to the employment of boys and male young persons in a mine below ground, the following regulations shall have effect; that is to say,

(1.) There shall be allowed an interval of not less than eight hours between the period of employment on Friday and the period of employment on the following Saturday, and in other cases of not less than twelve hours between each period of employment:

(2.) The period of each employment shall be deemed to begin at the time of leaving the surface, and to end at time of returning to the surface:

(3.) A week shall be deemed to begin at midnight on Saturday night, and to end at midnight on the succeeding Saturday night.

8. The following regulations shall have effect with respect to boys of the age of ten and under the age of twelve years employed in any mine to which this act applies below ground: 
(1.) Every boy shall attend school for at least twenty hours in every two weeks during which he is so employed:

(2.) In computing for the purpose of this act the time during which a boy has attended sehool, there shall not be included any time during which such boy has attended either,

(a.) in excess of three hours at any one time, or in excess of five hours on any one day, or in excess of twelve hours in any one week; or (b.) on Sundays; or

(c.) before eight o'clock in the morning or after six o'elock in the evening:

Provided that the non-attendanee of any boy at school shall be excused-

(1.) For any time during which he is certified by the principal teaeher of the school to have been prevented from attendance by sickness or other unavoidable cause:

*(2.) For any time during which the school is elosed for the eustomary [*643] holidays, or for some other temporary cause; and

(3.) For any time during which there is no sehool which the boy can attend within two miles (measured according to the nearest road) from the residence of such boy or the mine in which he works.

The inmediate employer of a boy in every mine to which this act applies, who has employed such boy for any time amonnting in the whole to not less than fourteen days, shall on Monclay in every week during the employment of such boy obtain from the prineipal teacher of some school a certificate that the boy so employed has in manner required by this act attended school during the preceding week, if attendance at sehool was so required during that week.

The certificate may be in such form as a Secretary of State may from time to time prescribe.

The immediate employer, where he is not the owner, agent, or manager of the mine, shall deliver such certificate to the owner, agent, or manager of the mine, and the owner, agent, or manager shall obtain the delivery of such certificate, and shall keep any certificate ohtained or delivered in pursuance of this section for six months in the ofice at the mine, and shall produce the same to any inspector under this act at all reasonable times when required by him during that period, and allow him to inspect and copy the same.

Every person who forges or counterfeits any certificate required by this section, or gives or signs any such certificate falsely, or wilfully makes use of any forged, connterfeit, or false certificate, shall be liable on eonviction to imprisonment for a period not exeeeding three months, with or without hard labour.

9. The principal teacher of a school which is attenced by any boy employed in a mine to which this aet applies, may apply in writing to the person who pays the wages of such boy to pay such sum as hereinafter mentioned on account of any boy in respect of whom he may have duly granted a certitieate in pursuance of this act; and after the date of such application, such person, so long as he employs the boy, shall pay to the principal teacher of the said school for every week that the boy attends that school, tho weekly sum specitied in the application, not exceeding twopence per week, and not exceeling one twelfth part of the wages of the boy and may deduct the sum so paid by him fiom the wages pavable for the services of such boy.

Any person who after such application refuses to pay on demand any sum that ina become due as aforesaid shall be liable to a penalty not exceeding ten shillings.

10. If an inspector uncler this act is satisfied by inspection of a school or otherwise that the principal teacher of a school who grants ceertiticates of school attendance required under this act onght to be disqualitied for granting such certificates for any of the following reasons, namely,

(1.) Becanse he is unfit to instruct chilliren by reason either of his ignorance or negleet, or of his not having the neccessary books and materials:

(2.) Because of his immoral conduct: or,

(3.) Because of his continued neglect to fill up proper certificates of school attendance : 
in any such case he may serve on the teacher a written notice stating the reason for such disqualification. At the expiration of two weeks from the date of such notice the teacher shall, subject to the appeal hereinafter mentioned, be disqualified for granting certificates.

The inspector shall, so far as he can, serve on every employer of a child who obtains certificates from such teacher a notice to the like effect as the notice served on the teacher, and also specifying a school which the child employed [*644] by such employer can attend within two miles (measured *according to the nearest road) from the place of employment or the residence of the child.

Any teacher who is disqualified as aforesaid, and any employer who obtains certificates from him, may within three weeks after the service of the notice on the teacher, appeal therefrom to the Education Department, who may confirm or reverse sucli disqualification.

After a teacher is disqualified for granting certificates, no certificate given by him shall be deemed to be a certificate in compliance witl this act, unless in the case of there being no other school which the child employed in a mine can attend within tiro miles (measured according to the nearest road) from the mine or the residence of such child, or unless with the written consent of an inspector under this act.

The inspectors under this act shall in their reports to a Secretary of State report the name of every teacher disqualified under thistsection during the preceding twelve months, the name of the school at which he taught, and such last-mentioned report shall be communicated to the committee of council on education.

11. The following regulation shall apply to every boy of ten and under twelve years of age, employed below ground in any mine to which this act applies :

The parent, guardian, or person having the custody of or control over any such boy shall cause him to attend school in accordance with the regulations of this act:

Every such parent, guardian, or person who wilfully fails to act in conformity with this section, shall be liable to a penalty of not more than twenty shillings for each offence.

12. With respect to women, young persons, and children employed above gronnd, in connexion with any mine to which this act applies, the following provisions shall have effect:

(1.) No child under the age of ten rears shall be so employed:

(2.) The regulations of this act with respect to boys of ten and under twelve years of age shall apply to every child so employed :

(3.) The regulations of this act with respect to male young persons under sixteen years of age shall apply to every woman and young person so employed :

(4.) No woman, young person, or child shall be so employed between the hours of nine at night and five on the following morning, or on Sunday, or after two o'clock on Saturday afternoon :

(5.) Intervals for meals shall be allowed to every woman, young person, and child so employed, amounting in the whole to not less than half an hour during each period of employment which exceeds five hours, and to not less than one hour and a half during each period of employment which exceeds eight hours.

The provisions of this clause as to the employment of women, young persons, and children after two o'clock on Saturday afternoon, shall not apply in the ease of any mine in Ireland, so long as it is exempted in writing by a Secretary of State.

13. The owner, agent, or manager of every mine to which this act applies shall keep in the office at the mine a register, and shall cause to be entered in such register the name, age, residence, and date of first employment, of all boys under the age of twelve years, and of the age of twelve and under the age of thirteen years, and of all male young persons under the, age of sixteen years who are employed in the mine below ground, and of all women, young persons, 
and children employed above ground in connexion with the mine, and a memorandum of the certificates of the school attendance of such boys obtained in pursuance of this act, and shall produce such register to any inspector under this act at the mine at all reasonable times when required by him, and allow him to inspect and copy the same.

The immediate employer of every boy or male young person of the ages *aforesaid, other than the owner, agent, or manager of the mine, before [*645] he causes such boy or male young person to be in any mine to which this act applies beles ground, shall report to the manager of such mine, or some person appointed by such manager, that he is about to employ him in such mine.

14. Where there is a shaft or an inclined plane or level in any mine to which this act applies, whether for the purpose of an entrance to such mine; or of a communication from one part to another part of such mine, and persons are taken up or down or along such shaft, plane, or level by means of any engine, windlass, orgin, driven or worked by steam or any mechanical power, or by an animal, or by manual labour, a person shall not be allowed to have charge of such engine, windlass, or gin, or of any part of the machinery, ropes, chains, or tackle conneeted therewith, unless he is a male of at least eighteen years of age.

Where the engine, windlass, or gin is worked by an animal, the person under whose direction the driver of the animal acts shall, for the purposes of this section, be deemed to be the person in charge of the engine, windlass, or gin, but such driver shall not be under twelve years of age.

15. If any person eontravenes or fails to eomply with, or permits any person to contravene or fail to comply with, any provision of this aet with respect to the employment of women, girls, young persons, boys, or children, or to tho attendance of boys at school, or to the register of boys and male young persons, or of women, young persons, and ehildren, or to the reporting the intended employment of boys or male young persons, or to the employment of persons abeut any engine, windlass, or gin, he shall be guilty of an offence against this act; and in case of any such contravention or non-compliance by any person whomsoever, the owner, agent, and manager shall cach be guilty of an oflenee against this aet, unless he prove that he had taken all reasonable means by publishing and to the best of his power enforcing the provisions of this act to prevent such contravention or non-compliance (a).

If it appear that a child, boy, or young person, or a person employed about an engine, windlass, or gin, was employed on the representation of lis parent or guardian that he was of that age at which his employment wonld not be in contravention of this act, and under the belief in good faith that he was of that age, the owner, agent, or manager of the nine and employer shall be exempted from any penalty, and the parent or guardian shall, for such misrepresentation, be deemed guilty of an offence against this act.

\section{Wages.}

16. No wages shall be paid to any person employed in or about any mine to which this act applies at or within any publie house, beer shop, or place for the sale of any spirits, beer, wine, cyder, or other spirituous or fermented liquor, or other house of entertainment, or any office, garden, or place belonging or contiguous thereto, or oceupied therewith $(b)$.

Every person who contravenes or, fails to eomply with or permits any person to contravene or fail to comply with this section, shall be guilty of an offence against this act; and in the event of any such contravention or non-compliance by any person whomsoever, the owner, agent, and mannger shall each be guilty of an offence against this act, unless he prove that he had taken all rensomable

(a) See Hall v. Hopwood, 49 L. J., M. C. 17.

(b) And see $35 \& 36$ Vict. c. 77 , s. 9 , post, and $46 \& 47$ Vict. c. 31 , post. The repealed act, 5 \& 6 Vict. c. 99 , s. 11 , made wares so paid recoverable as if not paid. See Weaver v. Floyd, 21 L. J., Q. B. 151. 
means by publishing and to the best of his power enforcing the provisions of this section to prevent-such contrarention or non-compliance $(b)$.

$\left[{ }^{*} 646\right]{ }^{*} 17$. Where the amount of wages paid to any of the persons employed in a mine to which this act applies depends on the amount of mineral gotten by them, such persons shall, after the first day of August, one thousand eight hundred and seventy-three, unless the mine is exempted by a Secretary of State, be paid according to the weight of the mineral gotten by them, and such mineral shall be truly weighed accordingly.

Provided always, that nothing herein contained shall preclude the owner; agent, or manager of the mine from agreeing with the persons employed in such mine that deductions shall be made in respect of stones or materials other than mineral contraeted to be gotten, which shall be sent out of the mine with the mineral contracted to be gotten, or in respect of any tubs, baskets, or hutehes being improperly filled in those cases where they are filled by the getter of the mineral or his drawer, or by the person immediately employed by him, such deductions being determined by the banksman or weigher and check weigher (if there be one), or in case of difference by a third party to be mutually agreed on by the owner, agent, or manager of the mine on the one hand, and the persons employed in the mine on the other.

Where it is proved to the satisfaction of a Secretary of State that by reason of any exigencies existing in the case of any mine or class of mines to which the foregoing provision in this section applies, it is requisite or expedient that the persons employed in such mine or class of mines should not be paid by the weight of the mineral gotten by them, or that the beginning of such payment by weight should be postponed, sueh Secretary of State may, if he think fit, by order exempt such mine or class of mines from the provisions of this section, either without condition or during the time and upon the conditions specified in the order, or postpone in such mine or class of mines the beginning of such payment by weight, and may from time to time revoke or alter any such order.

If any person contravenes or fails to comply with, or permits any person to cortravene or fail to comply with, this section, he shall be guilty of an offence against this act; and in the event of any contravention of or non-compliance with this section by any person whomsoever, the owner, agent, and manager shall each be guilty of an offence against this act, unless he prove that he had taken all reasonable means by publishing and to the best of his power enforcing the provisions of this section to prevent such contravention and non-compliance.

18. The persons who are employed in a mine to which this act applies, and are paid according to the weight of the mineral gotten by them, may, at their own cost, station a person (in this act referred to as " a check weigher") at the place appointed $f r$ the weighing of such mineral, in order to take an account of the weight thereof on behalf of the persons by whom he is so stationed. The check weigher shall be one of the persons employed either in the mine at which he is so stationed or in another mine belonging to the owner of that mine. He shall have every facility afforded to him to take a correct account of the weighing for the persons by whom he is so stationed; and if in any mine proper facilities are not afforded to the check weigher as required by this section, the owner, agent, and manager of such mine shall each be guilty of an offence against this act, nnless he prove that he had taken all reasonable means by enforcing to the best of his power the provisions of this section to prevent such contravention or non-compliance.

The check weigher shall not be authorised in any way to impede or interrupt the working of the mine, or to interfere with the weighing, but shall be authorised only to take such acconnt as aforesaid and the absence of the check weigher shall not be a reason for interrupting or delaying sach weighing.

If the owner, agent, or manager of the mine desires the removal of a check [*647] weigher on the ground that such check weigher has impeded or *interrupted the working of the mine, or interfered with the weighing, or has other-

(b) Sce Hall v. Hoproood, 49 L. J., M. C. 17. 
wise misconlucted himself, he may complain to any court of summary jurisdiction, who, if of opinion that the owner, agent, or manager shows sufficient primâ facie ground for the removal of such check weigher, slall call upon the check weigher to show cause against lis removal. On the hearing of the case the court shall hear the parties, and, if they think that at the hearing sufficient ground is shown by the owner, agent, or manager to justify the removal of the check weigher, shall make a summary order for his removal, and the check weigher shall thereupon be removed, but without prejudice to the stationing of another check weigher in his place.

The court may in every case make such order as to the costs of the proceedings as they think just.

If in pursuance of any order of exemption made by a Secretary of State, the persons employed in a mine to which this act applies are paid by the measure or gauge of the material gotten by them, the provisions of this section slall apply in like manner as if the term "weighing" included measuring and ganging, and the terms relating to weighing shall be construed accordingly.

19. The Weights and Measures Act, or any act for the time being in force relating to weights and measures $(c)$, shall apply to the weights used in any mine to which this act applies for determining the wages payable to any person cmployed in such mine accorling to the weight of the mineral gotten by such person, in like manner as it applies to weights used for the sale of any article, and the inspector of weights and measures for the district appointed under the said act shall accordingly fron time to time, but withont unneeessarily impeding or interrupting the working of the mine, inspect and examine, in manner directed by the said act, the weighing machines and weights used for mines to which this act applies, or the measures or gauges used for such mines: Provided that nothing in this section shall prevent the use of the measures and gauges ordinarily ased in such mine.

The term "Weights and Measures Act" in this section means-

(a) As to Great Britain, the act of the session of the fifth and sixth years of the reign of King William the Fourth, chapter sixty-three, "to repeal an act of the fourth and fifth year of his present Majesty relating to weights and measures, and to make other provisions instead thereof ;" and,

(b) As to Treland, the Weights and and Measures (Ireland) Amendment Act, 1862 , as amended by the act of the session of the thirtieth and thirtyfirst years of the reign of her present Majesty, chapter ninety-four, "to provide for the inspection of weights and measnres, and to regulate the law relating thereto in certain parts of the police district of Dublin Metropolis."

\section{Single Shafts.}

20. After the commencement of this act the owner, agent, or manager of a mine to which this act applies shall not employ any person in such mine, or permit any person to be in such mine for the purpose of employment therein, unless there are in communication with every seam of such mine for the time being at work at least two shafts or outlets, separated by natural strata of not less than ten feet in breadth, by which shafts or outlets distinct means of ingress and egress are arailable to the persons employed in such seam, whether such two shafts or outlets belong to the same mine, or one or more of them belong to another mine, and unless there is a communication of not less than four feet wide and three high between such two shafts or outlets, and unless there is at each of ${ }^{*}$ such two shafts or outlets or upon the works belonging to the $\left[{ }^{*} 648\right]$ mine and either in actual use or available for use within a reasonable time proper apparatus for raising and lowering persons at each such shaft or outlet.

(c) 41 \& 42 Vict. c. $49.35 \& 36$ Vict. c. 76 , s. 18 . "See Hopkinson v. Caunt, Weekly Notes, 1885, p. 64." 
Provided that such separation shall not be deemed incomplete by reason only that openings through the strata between the two shafts or outlets have been made for temporary purposes of ventilation, drainage, or otherwise; or in the case of mines where inflammable gas has not been found within the preceding twelve months for the same purposes although not temporary.

Every owner, agent; and manager of a mine who acts in contravention of or fails to comply with this section shall be guilty of an offence against this act.

Any of her Majesty's superior courts of law or equity, whether any other proceedings have or have not been taken, may, upon the application of the Attorney-General, prohibit by injunction the working of any mine in which any person is employed, or is permitted to be for the purpose of employment, in contravention of this section, and may award such costs in the matter of the injunction as the court thinks just; but this provision shall be without prejudice to any other remedy permitted by law for enforcing the provisions of this act.

Written notice of the intention to apply for such injunction in respect of any mine shall be given to the owner, agent, or manager of such mine not less than ten days before the application is made.

21. No person shall be precluded by any agreement from doing such acts as may be necessary for providing a second shaft or outlet to a mine, where the same is required by this act, or be liable under any contract to any penalty or forfeiture for doing such acts as may be necessary in order to comply with the provisions of this act with respect to shafts or outlets.

22. The provisions of this act with respect to shafts or outlets shall not apply in the following cases; that is to say,

(1.) In the case either of opening a new mine for the purpose of searching for or proving minerals, or of any working for the purpose of making a communication between two or more shafts, so long as not more than twenty persons are employed below ground at any one time in the whole of the different seams in connexion with each shaft or outlet in such new mine or such working:

(2.) In the case of any proved mine so long as it is exempted in writing by a Secretary of State on the ground either-

(a.) that the quantity of mineral proved is not sufficient to repay the outlay which would be occasioned by the sinking or making of a second shaft or outlet, or

(b.) if the mine is not a coal mine, or mine with inflammable gas, that sufficient provision has been made against danger from other causes than explosions of gas by using stone, brick, or iron in the place of wood for the lining of the shaft and the construction of the mid wall; or

(c.) that the workings in any seam of a mine have reached the boundary of the property or other extremity of the mineral field of which such seam is a part, and that it is expedient to work away the pillars already formed in course of the ordinary working, notwithstanding that one of the shafts or outlets may be cut off by so working away the pillars of such seam ;

and so long as there are not employed below ground at any one time in the whole of the different seams in connexion with the shaft or outlet in any such mine, more than twenty persons, or (if the mine is not a coal mine, or mine with inflammable gas) then such larger number of persons as may for the time being be allowed by a Secretary of State:

[*649] *(3.) In the case of any mine one of the shafts or outlets of which has become, by reason of some accident, unavailable for the use of the persons employed in the mine, so long as such mine is exempted in writing by a Secretary of State, and as the conditions on which such exemption is granted are duly obserred.

23. The provisions of this act with respect to shafts or ontlets shall not, until 
the 1st day of January, 1875, apply to any mine which is not at the passing of this act required to have two shatts or ontlets.

24. If a written representation is made to a Secretary of State by the owner or agent of a mine not required at the passing of this aet to have two shafts or outlets, either-

(1.) Within six months after the commencement of this act, alleging that by reason of the mine being nearly exhausted he ought to be exempted from the obligation of providing an additional shaft or outlet in pursuance of this act; or,

(2.) Within six months immediately preceding the 1st day of January, 1875, alleging that an extension of time for providing an additional shaft or outlet ought to be granted to him:

the question as to whether such exemption or extension of time ought to be granted shall be referred to arbitration, and the date of the receipt of such representation by a Secretary of' State shall be deemed to be the date of the reference, and the award made upon sueh arbitration may exempt the owner of such mine from the obligation of providing an additional shaft or outlet, and may grant to the owner of sueh other mine as aforesaid such extension of timo as may be specified by the award, but if the result of the arbitration is against the owner or agent, or if no award is made by reason of any defanlt or neglect on the part of the owner or agent, the owner or agent shall be bound by the provisions of this act as if this section had not been enacted.

\section{Division of Mine into Parts.}

25. Where two or more parts of a mine are worked separately the owner or agent of such mine may give notice in writing to that effect to the inspector of the distriet, and thereupon each such part shail, for all the purposes of this act, be deemed to be a separate mine.

If a Secretary of State is of opinion that the division of a mine in pursuance of this section tends to lead to the evasion of the provisions of this act, or otherwise to prevent the carrying of this act into effect, he may object to such division by notice served on the owner or agent of the mine; and such owner or agent, if he decline to acquiesee in such objection, may, within twenty days after the receipt of stich notice, send a notiee to the inspector of the district stating that he declines so to acquiesce, and thereupon the matter shall be determined by arbitration in manner provided by this act; and the date of the receipt of the last-mentioned notice shall be deemed to be the date of the reference.

\section{Certificated Managers.}

26. Every mine to which this act applies shall be under the control and daily supervision of a manager $(d)$, and the owner or agent of every sueh mino shall nominate himself or some other person (not being a contractor for getting the mineral in such mine, or a person in the employ of sneh contractor) to be the manager of such mine, and shall send written notiee to the inspeetor of the district of the name and arklress of such manager.

A person shall not be qualified to be a manager of a mine to which this ${ }^{*}$ act applies unless he is for the time being registered as the holder of a [ $\left.{ }^{*} 650\right]$ certificate under this aet.

If any inine to which this aet applies is worked for more than fourteen days without there being such a manager for that mine as is required hy this section, the owner and agent of such mine shall each beliable to a penalty not exceeding fifty pounds, and to a further penalty not excecding ten pounds for every day during which such mine is so worked.

Provided that-

(a.) The owner of such mine shall not be liable to any sueh penalty if he prove that he had taken all reasonable means by the enforement of

(d) See Ilowclls v. Landore Stecl Co., L. R., 10 Q. B. 62 ; 44 L. J., Q. B. 25. 38 Mas. \& SEr. 
this section to prevent the mine being worked in contravention of this section :

(b.) If for any reasonable cause there is for the time being no manager of a mine qualitied as required by this section, the owner or agent of such mine may appoint any competent person not holding a certiticate under this act to be manager, for a period not exceeding two months, or such longer period as may elapse before such person has an opportunity of obtaining by examination a certificate under this act, and shall send to the inspector of the district a written notice of the name and address of such manager, and of the reason of his appointment ; and

(c.) A mine in which less than thirty persons are ordinarily employed below ground, or of which the average daily out-pnt does not exceed twentyfive tons, shall be exempt from the provisions of this section, unless the inspector of the district, by notice in writing served on the owner or agent of such mine, requires the same to be under the control of a manager.

27. For the purpose of granting in any part of the United Kingdom, to be from time to time defined by an order in writing made by a secretary of State, certificates of competency to managers of mines for the purposes of this act, examincrs shall be appointed by a board constituted as hereinafter mentioned.

A Secretary of State may from time to time appoint, remove and reappoint fit persons to form such board as follows; namely, three persons heing owners of mines to which this act applies in the said part of the United Kingdom, and three persons cmployed in or about a mine to which this act applies in the said part of the United Kingkom, not being owners, agents or managers of a mine, and three persons practising as mining engineers, agents or managers of mines, or coal viewers in the said part of the United Kingdom, and one inspector under this act ; the persons so appointed shall during the pleasure of the Secretary of State form the board for the purposes of the said examinations in the said part of the United Kingdom.

28. The proceedings of the board shall be in accordance with the rules contained in scherlule two to this act; the board shall from time to time appoint exaniners, not being members of the board, except with the consent of the Secretary of State, to conduct the examinations in the part of the United Kingdom for which such board acts, of applicants for certificates of competency under this act, and may from time to time make, alter, and revoke rules as to the conduct of stuch examinations and the qualifications of the applicants, so, however, that in every such examination regard shall be had to such knowledge as is necessary for the practical working of mines in the said part of the United Kingdom; every such board shall make from time to time to a Secretary of State a report and return of their proceedings, and of such other matters as a Secretary of State may from time to time require.

29. A Secretary of State may from time to time make, alter, and revoke rules as to the places and times of examinations of applicants for certificates of competency under this act, the number and remuneration of the examiners, [*651] and the fees to be paid by the applicants, so that the *fees do not exceed those specified in schedule one to this act. Every such rule shatl be duly observed by every board appointed under this act to whom it applies.

30. A Secretary of State shall deliver to every applicant who is duly reported by the examiners to have passed the examination satisfactorily, and to have given satisfactory evidence of his sobriety, experience. ability, and general good conduct, such a certificate of competency as the case requires. The certificate shall be in such form as a Secretary of State from time to time directs, and a register of the holders of such certificates shall be kept by such person and in such manner as a Secretary of State from time to time directs.

31. Certificates of service for the purposes of this act shall be granted by a Secretary of State to every person who satisfies him either that before the passing of this act he was acting, and has since that day acterl, or that he has at any time within five years before the passing of this act for a period of not less than twelve months acted, in the capacity of a manager of a mine or such 
part of a mine as can under this act be made a separate mine for the purposes of this act.

Every such certificate of service shall contain particulars of the name, place, and time of birth, and the length and nature of the previous service of the person to whom the same is delivered, and a certificate of service may be refiusel to any person who fails to give a full and satifactory account of the particulars aforesaid, or to pay such registration fee as the Secretary of State may direct, not exceeding that mentioned in schedule one to this act.

A certificate of service shall have the same effect for the purposes of this act as a certificate of competency granted under this atet.

32. If at any time representation is made to a Secretary of State by an inspector or otherwise, that any manager holding a certificate under this act is by reason of incompetency or gross negligence unfit to discharge his dutics, or has been convicted of an offence against this act, the Secretary of State may, if he think fit, cause inquiry to be made into the conduct of such manager, and with respect to such inquiry the following provisions shall have effect:

(1.) The inquiry shall be public, and shall be held at such place as the Sceretary of State may appoint by such county court judge, metropolitan police magistrate, stipendiary magistrate, or other person or persons as may be chrected by the Secretary of State, and either alone or with the assistance of any assessor or assessors named by the secretary of State :

(2.) The Secretary of State shall, before the eommencement of the incuiry, furnish to the manager a statement of the case upon which the inquiry is instituted :

(3.) Some person appointed by the Secretary of State shall undertake the management of the case :

(4.) The manager may attend the inquiry by himself, his counsel, attorney, or agent, and may, if he think fit, be sworn and examined as an ordinary witness in the case :

(5.) The pcrsons appointed to hold the inquiry, in this act referred to as the court, shall, upon the conclusion of the inquiry, send to the Secretary of State a report containing a full statement of the case, and their opinion thereon, and such report of, or extracts from the evidence, as the court think fit:

(6.) The court shall have power to cancel or suspend the certificate of the manager, if they find that he is by reason of incompetency or gross negligence, or of his having been convicted of an offence against this act, unfit to discharge his duty :

(7.) The court may, if they think fit, require a manager to deliver up his eertifieate, and if any manager fail, withont sufficient eause to the satisfaction of the court, to comply with such requisition, *he shall [*652] be liable to a penalty not exceeding one hundred pounds. The court shall hold a certificate so delivered until the conclusion of the investigation, and shall then either restore, cancel, or,suspend the same, according to their judgment on the case :

(8.) The court shall have for the purpose of the inquiry, all the powers of a court of summary jurisdiction, and all the powers of an inspeetor under this act :

(9.) The court may also, by summons under their hands, require the attendance of all such persons as they think fit to call before them and examine for the purpose of the inquiry, and every person so summoned shall be allowed such expenses as would be allowed to a witness attending on subpena before a court of record ; and in ease of dispute as to the amount to be allowed, the same shall be referred by the court to a master of one of the superior courts, who, on request under the hands of the members of the court, shall ascertain and certify the proper amount of sucli expenses.

33. The court may make such order as they think fit respeeting the eosts and expenses of the inquiry, and sucl order shall, on the application of ally party

(65\%) 
entitled to the benefit of the same, be enforced by any court of summary jurisdiction as if such costs and expenses were a penalty imposed by such court.

The Secretary of State may, if he think fit, pay to the members of the court of inquiry, including any assessors, such remuneration as he may, with the consent of the Treasury, appoint.

Any costs and expenses ordered by the court to be paid by a Secretary of State, and any remuneration paid under this section, shall be paid out of moneys provided by Parliament.

34. Where a certificate of a manager is cancelled or suspended in pursuance of this act, a Secretary of State shall cause such cancellation or suspension to be recorded in the register of holders of certificates.

A Secretary of State may at any time, if it is shown to him to be just so to do, renew or restore, on such terms as he think fit, any certificate which has been cancelled or suspended in pursuance of this act.

35. Whenever any person proves to the satisfaction of a Secretary of State that he has, without fault on his part, lost, or been deprived of any certificate previonsly granted to him under this act, such Secretary of State shall, npon payment of such fee, if any, as he may direct, but not exceeding the fee specified in schedule one to this act, cause a copy of the certificate to which the appli. cant appears by the register to be entitled, to be made out and certified by the person who keeps the register, and delivered to the applicant, and any copy which purports to be so made and certified as aforesaid shall have all the effect of the original certificate.

36. All expenses incurred by a Secretary of State with the concurrence of the Commissioners of her Majesty's Treasury in carrying into effect the provisions of this act with respect to certificates of competency or service, shall be defrayed out of moneys provided by Parliament.

All fees payable by the applicants for examination for or for a copy of a certificate under this act shall be paid into the receipt of her Majesty's Exchequer in such manner as the Treasury may from time to time direct, and be carried to the Consolidated Fund.

37. Every person who commits any of the following offences; that is to say,

(1.) Forges, or counterfeits, or knowingly makes any false statement in any certificate of competency or service under this act, or any official copy of snch certificate; or

(2.) Knowingly utters or uses any such certificate or copy which has been forged or counterfeited, or contains any talse statement; or

(3.) For the purpose of obtaining, for himself or any other person, employment [*653] as a certified manager, or the grant, renewal, or *restoration of any certificate under this act, or a copy thereof, either

(a.) makes or gives any declaration, representation, statement, or evidence which is false in any particular, or

(b.) knowingly utters, produces, or makes use of any such declaration, representation, statement, or evidence, or any document containing the same, shall be guilty of a misdemeanour, and be liable on conviction to imprisonment for a term not exceeding two years, with or without hard labour.

\section{Returns, Notices, and Abandonment.}

36. On or before the first day of February in every sear the owner, agent, or manager of every mine to which this act applies shall send to the inspector of the district on behalf of a Secretary of State a correct return, specifying, with respect to the year ending on the preceding thirty-first day of December, the quantity of coal or other mineral wrought in such mine, and the number of persons ordinarily employed in or about such mine below ground and above ground, distinguishing the persons employed below ground and above ground, and the different classes and ages of the persons so employed whose hours of labour are regulated by this act. 
The return shall be in such form as may be from time to time preseribed by a Secretary of State, and the inspeetor of the district on behalf of a Secretary of State shall trom time to time on application furnish forms for the purpose of such return.

The Secretary of State may publish the aggregate results of such returns with respect to any particular county or inspector's distriet, or any large portion of a county or inspector's distriet, but the individual return shall not be published without the consent of the person making the same, or of the owner of the mine to which they relate, and no person except an inspector or Seeretary of State shall be entitled, without such eonsent, to see the same.

Every owner, agent, or manager of a mine who fails to eomply with this section or makes any return which is to his knowledge false in any particulat shall be guilty of an offence against this act.

39. Where in or about any mine to which this act applies, whether above or below ground, either

(1.) loss of life or any personal injury (e) to any person employed in or about the mine oeeurs by reason of any explosion of gas, powder, or of any steam boiler; or

(2.) loss of life or any serious personal injury to any person employed in or about the mine occurs by reason of any aceident whatever,

the owner, agent, or manager of the mine shall, within twenty-four hours next after the explosion or aeeident, send notiee in writing of the explosion or accident and of the loss of life or personal injury occasioned thereby to the inspector of the district on behalf of a Secretary of State, and shall specify in such notice the charactor of the explosion or accident, and the number of persons killed and injured respectively.

Where any personal injury, of which notiee is required to be sent under this section, results in the death of the person injured, notice in writing of the death shall be sent to the inspector of the district on behalf of a Secretary of State within twenty-four hours after such death comes to the knowledge of the owner, agent, or manager.

Every owner, agent, or manager who fails to aet in complianee with this seetion shall be guilty of an offence against this act.

40. *In any of the following cases, namely, [*654.]
[*6.

(1.) Where any working is commenced for the purpose of opening a new shaft for any mine to which this act applies:

(2.) Where a shaft of any mine to which this act applies is abandoned or the working thereof discontinued ;

(3.) Where the working of a shaft of any mine to which this aet applies is recommeneed after any abandonment or discontinuance for at period not exeeding two months; or

(4.) Where any change occurs in the name of, or in the name of the owner, agent, or manager of, any mine to which this act applies, or in the oftieers of any incorporated company which is the owner of a mine to which this aet applies,

the owner, agent, or manager of such mine shall give notice thereof to the inspector of the distriet within two months after such eommencenent, ahandonment, diseontinuanee, recommeneement, or change, and if such notice is not given the owner, agent, or manager shall be guilty of an oflence agatinst this act.

41. Where any mine to which this act applies is alondoned or the working thereof diseontinued, at whatever time such abondonment or discontinuauce oecurred, the owner thereof, and every other person interested $(f)$ in the min-

(e) Under the repealed aet, 18 \& 19 Viet. e. 108 , s. 9, whieh did not eontain the words "or any personal injury," it was held that when an accident wis not attended with loss of life, but only with persoral injury, notice was not required. Underhill v. Longridge, 29 I.. .J., M. C. 65 ,

(f) See Evans v. Lady Mostyn, L. R., 2 C. P. 5.17 ; 47 L. J., M. C. 25. 
erals of such mine, shall canse the top of the shaft and any side entrance from the surface to be and to be kept securely fenced for the prevention of accidents:

Provided that-

(1.) Subject to any contract to the contrary, the owner of the mine shall, as between him and any other person interested in the minerals of the mine, be liable to carry into effect this section, and to pay any costs incurred by any other person interested in the minerals of the mine in carrying this section into effect:

(2.) Nothing in this section shall exempt any person from any liability under any other act, or otherwisc.

If any person fail to act in conformity with this section, he shall be guilty of an offence against this act.

Any shaft or side entrance which is not fenced as required by this section, and is within fifty yards of any highway, road, footpath or place of public resort, or is in open or uninclosed land, shall be deemed to be a nuisanee within the meaning of section eight of the Nuisances Removal Act for England, 1855, as amended and extended by the Sanitary Act, 1866.

42. Where any mine to which this act applies is abandoned, the owner of such mine at the time of such abandonment shall, within three months after such abandonment, send to a Secretary of State an accurate plan on a scale of not less than a scale of two chains to one inch, or on such other scale as the plan used in the mine at the time of such abandonment is constructed on, slowing the boundaries of the workings of such mine up to the time of the abandonment, with the view of its being preserved under the care of the Secretary of State, bat no person, execpt an inspector under this act, wshall be entitled, without the consent of the owner of the mine, to see such plan when so sent until after the lapse of ten years from the time of such abandonment.

Every person who fails to comply with this section shall be guilty of an offence against this act.

\section{Inspection.}

43. A Secretary of State may from time to time appoint any fit persons to be in[*655] spectors of mines to which this act applies, and assign them their *duties, and may award them such salaries as the Commissioners of her Majesty's Treasury may approve, and may remove such inspectors.

Notice of the appointment of every such inspector shall be published in the London Gazette.

Any such inspector is referred to in this act as an inspector, and the inspector of a district means the inspector who is for the time being assigned to the district or portion of the United Kingdom with reference to which the term is used.

Any person appointed or acting as inspector under the Metalliferous Mines Regulation Act, $1872(g)$, if directed by a Secretary of State to act as an inspector under this act, may so act, and shall be deemed to be an inspector under this act.

44. Any person who practices or acts or is a partner o fany person who practices or acts as a land agent or mining engineer, or as a manager, viewer, agent, or valuer of mines, or arbitrator in any difference arising between owners, agents or managers of mines, or is otherwise employed in or about any mine (whether such mine is one to which this act applies or not), shall not act as an inspector of mines under this act.

45. An inspector under this act shall have power to do all or any of the following things; namely,

(1.) To make such examination and inquiry as may be necessary to ascertain whether the provisions of this act relating to matters above ground or below ground are complied with in the case of any mine to which this act applies : 
(2.) To enter, inspect and examine any mine to whieh this act applies, and every part thereof, at all reasonable times by day and night, but so as not to impede or obstruct the working of the salid mine:

(3.) To examine into and make inquiry respecting the state and condition of any mine to which this act applies, or any part thereof; and the ventilation of the mine, and the suffieiency of the special rules for the time being in foree in the mine, and all matters and things conneeted with or relating to the safety of the persons employed in or about the mine or any mine eontiguous thereto :

(4.) To exereise such powers as may be neessary for earrying this act into effect.

Every person who wilfully obstruets any inspeetor in the exeeution of his duty under this act, and every owner, agent and manager of a mine who refuses or neglects to furnish to the inspector the means necessary for making any entry, inspection, examination or inquiry under this act, in relation to such mine; shall be guilty of an offenee against this aet.

46. If in any respeet (which is not provided against by any express provision of this aet, or by any special rule) any inspector find any nine to which this act applies, or any part thereof; or any matter, thing or practice in or connected with any such mine $(h)$, to be dangerons or defective, so as in his opinion to threaten or tend to the bodily injury of any person, such inspector may give notice in writing thereof to the owner, agent or manager of the mine, and shall state in such notice the particulars in which he considers such mine, or any part thereof, or any matter, thing or praetice, to be langerous or defeetive, and require the same to be remedied; and unless the same be forth with remedied the inspector shall also report the same to a secretary of State.

If the owner, agent or manager of the mine objects to remedy the matter complained of in the notice he may, within twenty days after the * $\mathrm{re}-\left[{ }^{*} 656\right]$ ceipt of such notice, send his objection in writing, stating the grounds thereof, to a Seeretary of State; and thereupon the matter shall be determined by arbitration in manner provided by this act; and the date of the receipt of such objection shall be deemed to be the date of the reference.

If the owner, agent or manager fail to comply either with the requisition of the notice, where no objection is sent within the time aforesaicl, or with the award made on arbitration, within twenty days after the expiration of the time for objeetion or the time of making the award (as the ease may be), he shall be guilty of an ofience against this act, and the notice and award shall respeetively be deemed to be written notice of such oflenee.

Provided that the coirt, if satisfied that the owner, agent or manager has taken active measures for complying with the notice or award, but has not, with reasonable diligence, been able to complete the works, may adjourn any proeecdings taken before them for punishing such offence, and, if the works are completed within a reasonable time, no penalty shall be inflieted.

No person shall be prechuled by any agreement from doing such acts as may be necessary to comply with the provisions of this section, or be liable under any contract to any penalty or forfeiture for doing such acts.

47. The owner, agent or manager of every mine to which this aet applies, shall keep in the oflice at the mine an aceurate plan of the workings of such mine, and showing the workings up to at least six months previously (i).

The owner, agent or manager of the mine shall prodnce to an inspector under this act at the nine, such plan, and shall, if requested by the inspector, mark on such plan the progress of the workings of the mine up to the time of such production, and shall allow the inspector to examine the same; but the inspeetor is not hereby authorised to make a copy of nny part of such plan.

If the owner, agent or manager of any mine to which this act applies fails to keep such plan as is prescribed by this seetion, or wilfully refuses to produce or allow to be examined such plan, or wilfully withlolds any portion

(h) See R. v. Spoon Lane Colliery Co., L. R., 3 Q. B. 673; 18 L. J., M. C. 25.

(i) Compare $35 \& 36$ Viet. c. 77 , s. 19, post. 
of any plan, or coneeals any part of the workings of his mine, or produces an imperfeet or inacenrate plan, unless he shows that he was ignorant of sueh coneealment, imperfection or inaecuracy, he shall be guilty of an offence against this act; and, further, the inspector may, by notice in writing, (whether a penalty for such offence has or has not been inflieted,) require the owner, agent or manager to cause an aceurate plan, such as is prescribed by this section, to be made within a reasonable time, at the expense of the owner of the mine, on a scale of not less than a scale of two chains to one inch, or on such other seale as the plan then used in the mine is construeted on.

If the owner, agent or manager fail within twenty days, or such further time as may be shown to be necessary, after the requisition of the inspector to make or eause to be made such plan, he shall be guilty of an offence against this act.

48. Every inspector under this act shall make an annual report of his proceedings during the preeeding year to a Secretary of State, which report shall be laid before both Houses of Parliament.

A Secretary of State may at any time direct an inspector to make a special report with respect to any aceident in a mine to which this aet applies, which accident has eaused loss of life or personal injury to any person, and in sueh case shall eanse such report to be made public at such time and in such manner as he thinks expedient.

\section{*Arbitration.}

49. With respect to arbitrations under this act, the following provisions shall have effect :

(1.) The parties to the arbitration are in this seetion deemed to be the owner, agent, or manager of the mine on the one hand, and the inspector of mines (on behalf of the Secretary of State) on the other:

(2.) Each of the parties to the arbitration may, within twenty-one days after the date of the reference, appoint an arbitrator :

(3.) No person shall act as arbitrator or umpire under this act who is employed in, or in the management of, or is interested in the mine to which the arbitration relates:

(4.) The appointment of an arbitrator under this section shall be in writing, and notice of the appointment shall be forthwitl sent to the other party to the arbitration, and shall not be revoked without the consent of such other party :

(5.) The death, removal, or other ehange in any of the parties to the arbitration shall not affeet the proceedings under this section :

(6.) If within the said twenty-one days either of the parties fail to appoint an arbitrator, the arbitrator appointed by the other party may proceed to hear and determine the matter in difference, and in such case the award of the single arbitrator shall be final :

(7.) If before an award has been made any arbitrator appointed by either party die or become incapable to act, or for fourteen days refuse or neglect to act, the party by whom snch arbitrator was appointed may appoint some other person to act in his place; and if he fail to do so within fourteen days after notice in writing from the other party for that purpose, the remaining arbitrator may proceed to hear and determine the matters in difference, and in such ease the award of such single arbitrator shall be final :

(8.) In either of the foregoing cases where an arbitrator is emporered to act singly, upon one of the parties failing to appoint, the party so failing may, before the single arbitrator has actually proceeded in the arbitration, appoint an arbitrator, who shall then aet as if no failure had been made:

(9.) If the arbitrators fail to make their award within twenty-one days after the day on which the last of them was appointed, or within such extended time (if any) as may have been appointed for that purpose by both arbitrators under their hands, the matter in difference shall be determined by the umpire appointed as hereinafter mentioned: 
(10.) The arbitrators, before they enter upon the matters roferred to them, shall appoint by writing under their hands an umpire to decide on points on which they may differ:

(11.) If the nmpire die or become incapable to act before he has made his award, or refuses to make his award within a reasonable time after the matter has been hrought within his cognizance, the persons or person who appointed such umpire shall forthwith appoint another umpire in his place :

(12.) If the arbitrators refuse or fail or for seven days after the request of either party neglect to appoint an umpire, then on the application of either party an umpire shall be appointed by the chairman of the general or quarter sessions of the peace, within the jurisdiction of which the mine is situate:

(13.) The decision of every umpire on the matters referred to him shall be final :

(14.) If a single arbitrator fail to make his award within twenty-one days after the day on which le was appointed, the party who appointed him may appoint another arbitrator to act in his place:

*(15.) The arbitrators and their umpire, or any of them, may examine [*658] the parties and their witnesses on oath; they may also consult any counsel, engineer, or scientific person whom they may think it expedient to consult:

(16.) The payment, if any, to be made to any arbitrator or umpire for his services shall be fixed by the Secretary of State, and together with the costs of the arbitration and award shall be paid by the parties or one of them according as the award may direct. Such costs may be taxed by a master of one of the superior courts, who, on the written application of either of the parties, shall ascertain and certify the proper amount of such costs. The amount, if any, payable by the Secretary of State, shall be paid as part of the expenses of inspectors under this act. The amount, if any, payable by the owner, agent, or manager, may in the event of non-payment, be recovered in tlic same manner as penalties under this act:

(17.) Every person who is appointed an arbitrator or umpire under this section shall be a practical mining engineer, or a person accustomed to the working of mines; but when an award has been made under this section, the arbitrator or umpire who made the same shall be deemed to have been duly qualified as provided by this section.

\section{Coroners.}

50. With respect to coroners inquests on the bodies of persons whose death may have been caused by explosions or accidents in mines to which this act applies, the following provisions shall have effect:

(1.) Where a coroner holds an inquest upon a body of any person whose death may have'been caused by any explosion or accident, of which notice is required by this act to be given to the inspector of the distriet, the coroner shall adjourn such inquest unless an inspector, or some person on behalf of a Secretary of State, is present to watch the proceedings :

(2.) The coroner, at least four days before holding the adjourned inquest, shall send to the inspector for the district notice in writing of the time and place of holding the adjourned inquest:

(3.) The coroner, before the adjournment, may take evidence to identify the body, and may order the interment thereof:

(4.) If an explosion or accident las not oc asioned the death of more than one person, and the coroner his sent to the inspector of the district notice of the time and place of holding the inquest not less than forty-eight hours before the time of holding the same, it shall not be imperative on him to adjourn such inquest in pursuance of this section, if the majority of the jury think it unnecessiry so to adjourn : 
(5.) An inspector shall be at liberty at any such inquest to examine any witness, subject nevertheless to the order of the coroner :

(6.) Where evidence is given at an inquest at which an inspector is not present of any neglect as having caused or contributed to the explosion or accident, or of any defect in or about the mine appearing to the coroner or jury to require a remedy, the coroner shall send to the inspector of the district notice in writing of such neglect or default :

(7.) Any person having a personal interest in, or employed in, or in the management of the mine in which the explosion or accident occurred, shall not be qualified to serve on the jury empannelled on the inquest; and it shall be the duty of the constable or other officer not to summon any person disqualified under this provision; and it shall be the duty of the coroner not to allow any such person to be sworn or to sit on the jury.

Every person who fails to comply with the provisions of this section shall be guilty of an offence against this act.

$$
\text { *PART II.-Rules }
$$

\section{General Rules.}

51. The following general rules shall be observed $(k)$, so far as is reasonably practieable, in every mine to which this act applies:

(1.) An adequate anount of ventilation ( $l$ shall be constantly produced in every mine, to dilute and render harmless noxious gases to such an extent that the working places of the shafts, levels, stables, and workings of such mine, and the travelling roads to and from such working places, shall be in a fit state for working and passing therein.

(2.) In every mine in which inflammable gas has been found within the preceding twelve months, then once in every twenty-tours if one shift of workmen is employed, and once in every twelve hours if two shifts are employed dnring any twenty-four hours, a competent person or competent persons, who shall be appointed for the purpose, shall, before the time for commencing work in any part of the mine, inspect with a safety lamp that part of the mine, and the roadways leading thereto, and shall make a true report of the condition thereof, so far as ventilation is concerned; and a workman shall not go to work in such part until the same and the roadways leading thereto are stated to be safe. Every such report shall be recorded without delay in a book which shall be kept at the mine for the purpose, and shall be signed by the person making the same.

(3.) In every mine in which inflammable gas has not been fonnd within the preceding twelve months, then once in every twenty-four hours a competent person or competent persons, who shall be appointed for the purpose, shall, so far as is reasonably practicable, immediately before time for commencing work in any part of the mine, inspect that part of the mine and the roadways leading thereto, and shall make a true report of the condition thereof so far as ventilation is concerned; and a workman shall not go to work in such part until the same and the roadways leading thereto are stated to be safe. Every report shall be recorded without delay in a book which shall be kept at the mine for the purpose, and shall be signed by the person making the same.

(4.) All entrances to any place not in actual course of working and extension, shall be properly fenced across the whole width of such entrance, so as to prevent persons inadvertently entering the same.

(5.) A station or stations shall be appointed at the entrance to the mine or to different parts of the mine, as the case may require; and a workman shall not

(k) See Dickinson v. Fleteher, 43 L. J., M. C. 25.

(l) See Knowles v. Diekinson, 29 L. J., M. C. 135; Brough v. Homfray, 37 L. J., M. C. 177; 9 Best \& S. 492; L. R., 3 Q. B. 771. 
pass beyond any such station until the mine or part of the mine beyond the same has been inspected and stated to be safe.

(6.) If at any time it is found by the person for the time being in charge of the mine or any part thereof, that by reason of noxious gases prevailing in such mine or such part thereof, or, of any cause whatever, the mine or the said part is dangerous, every workman shall be withdrawn from the mine or such part thereof as is so found dangerons $(m)$, and a competent person, who shall be appointed for the purpose, shall inspect the nine or such part thereof as is so found dangerous, and if the danger arises from inflammable gas shall inspect the same with a locked safety lamp, and in every case shall make a true report of the condition of such mine or part thereof, and a workman shall not, except in so far as is nccessary for inquiring into the eause of danger or for the removal thereof, or for exploration, be re-admitted into the mine, or such part thereof as was so *found dangerous, until the same is stated by such re- $\left.{ }^{*} 660\right]$ port not to be dangerous. Every such report shall be recorded in a book which shall be kept at the mine for the purpose, and shall be signed by the person making the same.

(7.) In every working approaching any place where there is likely to be an aceumulation of explosive gas, no lamp or light other than a locked safety lamp shall be allowed or used, and whenever safety lamps are required by this act, or by the special rules made in pursuance of this act to be used, a competent person, who shall be appointed for the purpose, shall examine every safety lamp immediately before it is taken into the workings for use, and ascertain it to be secure and securely locked, and in any part of a mine in which safety lamps are so required to be used, they shall not be used until they have been so examined and found secure and securely loeked, and shall not without dne authority be unlocked, and in the said part of a mine a person shall not, unless he is appointed for the purpose, have in his possession any key or contrivanee for opening the lock of any such safety lamp, or any lucifer match or apparatus of any kind for striking a light.

(8.) Gunpowder or other explosive or inflammable substance shall only be used in the mine underground as follows $(n)$ :

(a.) It shall not be stored in the mine:

(b.) It shall not be taken into the mine, except in a case or canister containing not more than four poinds:

(c.) A workman shall not have in use at one time in any one place more than one of 'such eases or canisters:

(d.) In charging holes for blasting, an iron or steel prieker shall not be used, and a person shall not have in his possession in the mine underground

(m) R. v. Spon Lane Colliery Co., L. R., 3 Q. B. 673; 48 I. J., M. C. 25.

(n) See also 35 \& 36 Vict. c. 77, s. 23, subs. (2), post. By the Stratified Ironstone Mines (Gunpowder) Aet, 1881 (44\& 45 Vict. e. 26 ), it is enacted that, "Seet. 2 (1). It shall be lawful for one of her Majesty's prineipal Seeretaries of State, if he shall think fit, on the application of the owner, agent or manager of any stratified ironstone mine in the lias formation, to exempt such mino from so much of the general rule 8 in the Coal Mines Regnlation Aet, 1872, as forbids gunpowder or other explosives or inflammable substance from being taken into or being in the possession of any person in any mine except in eartridges.

"(2) The application shall be transmitted by the owner, agent or manager to the inspector of the district, and the requirements of seets. 53 and 57 of the Coal Mines Regulation Act, 1872, as to the posting of any proposed special rule, shall extend to any such application; provided that the exemption shall not come into force until grantel by the Secretary of State.

"(3) The Secretary of State may at any time revoke such exemption, but such revocation shall not come into force until written or printed notice thereof has been posted up at the mine for twenty-four hours.

"(4) A list of the exemptions granted or revoked under this act shall be set forth by the inspector of the district in his annual report." 
any iron or steel pricker, and iron or steel tamping rod or stemmer shall not be used for ramming either the wadding or the first part of the tamping or stemming on the powder:

(e.) A charge of powder which has missed fire shall not be unrammed:

(f.) It shall not be taken into or be in the possession of any person in any mine, except in cartridges, and shall not be used, except in accordance with the following regulations, during three months after any inflammable gas has been found in any such mine; namely,

[*661] (1.) A competent person, who shall be appointed for the *purpose, shall, immediately before firing the shot, examine the place where it is to be used, and the places contiguous thereto, and shall not allow the shot to be fired unless he finds it safe to do so, and a shot shall not be fired except by or under the direction of a competent person, who shall be appointed for the purpose:

(2.) If the said inflammable gas issued so freely that it showed a blue cap on the flame of the safety lamp, it shall only be used-

(a.) Either in those cases of stone drifts, stone work and sinking of shafts, in which the ventilation is so managed that the return air from the place where the powder is used passes into the main return air course without passing any place in actual course of working; or

(b.) When the persons ordinarily employed in the mine are out of the mine or out of the part of the mine where it is used;

(g.) Where a mine is divided into separate panels in such manner that each panel has an independent intake and return air-way from the main air course and the main return air course, the provisions of this rule with respect to gunpowder or other explosive inflammable substance shall apply to each such panel in like manner as if it were a separate mine.

(9.) Where a place is likely to contain a dangerous accumulation of water the working approaching such place shall not exceed eight feet in width, and there shall be constantly kept at a sufticient distance, not being less than five yards, in advance, at least one bore-hole near the centre of the working, and sufficient flank bore-holes on each side.

(10.) Every underground plane on which persons travel, which is self-acting or worked by an engine, windlass or gin, shall be provided (if exceeding thirty yards in length) with some proper means of signaling between the stopping places and the ends of the plane, and shall be provided in every case, at intervals of not more than twenty yards, with sufficient man-holes for places of refuge.

(11.) Every road on which persons travel underground where the load is drawn by a horse or other animal shall be provided, at intervals of not more than fifty yards, with sufficient man-holes, or with a space for a place of refuge, which space shall be of sufficient length, and of at least three feet in width, between the waggons running on the tramroad and the side of such road.

(12.) Every man-hole and space for a place of refuge shall be constantly kept clear, and no person shall place anything in a man-hole or such space so as to prevent access thereto.

(13.) The top of every shaft which for the time being is out of use, or nsed only as an air shaft, shall be securely fenced.

(14.) The top and all entrances between the top and bottom of every working or pumping shaft shall be properly fenced, but this shall not be taken to forbid the temporary removal of the fence for the purpose of repairs or other operations, if proper precautions are used.

(15.) Where the natural strata are not safe, every working or pumping shaft shall be securely cased, lined, or otherwise made secure (o).

(16.) The roof and sides of every travelling road and working place shall be made secure, and a person shall not, unless appointed for the purpose of exploring or repairing, travel or work in any such travelling road or working place which is not so made secure.

(o) See Mellors v. Shaw, 30 L. J., Q. B. $333 ; 1$ Best \& S. 437. 
(17.) Where there is a downeast and furnace shaft, and both such shafts are provided with apparatus in use for raising and lowering ${ }^{*}$ persons, every [*662] person employed in the mine shall, upon giving reasonable notice, have the option of using the downcast shaft.

(18.) In a mine which is usually entered by means of machinery, a competent person of such age as preseribed by this act shall be appointed for the purpose of working the machinery which is employed in lowering and raising persons therein, and shall attend for the said purpose during the whole time that any person is below ground in the mine.

(19.) Every working shaft used for the purpose of drawing minerals or for the lowering or raising of persons shall, if exceeding fifty yards in depth, and not exempted in writing by the inspector of the district, be provided with guides and some proper means of communicating distinct and definite signals from the bottom of the shaft and from every entrance for the time being in work between the surface and the bottom of the sliaft to the surface, and from the surface to the bottom of the shaft and to every entrance for the time being in work between the surface and the bottom of the shatt.

(20.) A sufficient eover overhead shall be used when lowering or raising persons in every working shaft, except where it is worked by a windlass, or whero the person is employed about the pump or some work of repair in the shaft, or where a written exemption is given by the inspector of the district.

(21.) A single linked chain shall not be used for lowering or raising persons in any working shaft or plane except for the short coupling chain attached to the eage or load.

(22.) There shall be on the drum of every machine used for lowering or raising persons such flanges or horns, and also if the drum is conical, such other appliances, as may be sufficient to prevent the rope from slipping $(p)$.

(23.) There shall be attached to every machine worked by steam, water or mechanical power and nsed for lowering or raising persons, an adequate break, and also a proper indieator (in addition to any mark on the rope) which shows to the person who works the machine the position of the cage or load in the shaft.

(24.) Every fly-wheel and all exposed and dangerons parts of the machinery used in or about the mine shall be and be kept securely fenced.

(25.) Every steam boiler shall be provided with a proper steam gauge and water gange, to show respectively the pressure of steam and the height of water in the boiler, and with a proper satety valve.

(26.) After dangerous gas has been found in any mine, a barometer and thermometer shall be placed above ground in a conspienous position near tho entrance to the mine.

(27.) No person shall wilfnlly damage, or withont proper anthority remove or render useless any fence, fencing, casing, lining, guide, means of signalling, signal, cover, chain, flange, horn, break, indicator, steum gauge, water gauge, safety valve, or other appliance or thing provided in any mine in compliance with this act.

(23.) Every person shall observe such directions with respect to working as may be given to him with a view to comply with this act or the special rules.

(29.) A competent person or competent persons who shall he uppointed for the purpose shall, once at least in every twenty-four hours, cxamine the stato of the external parts of the machinery, and the state of the head gear, working places, levels, planes, ropes, chains and other works of the mine which are in actual use, and once at least in every week shall examine the state of the shafts by which persons ascend or descend, and the guides or eonductors therein, and shall make a true report of the *result of such examination, and snch [*663] report shall be reeorded in a book to be kept at the mine for the purpose and shall be signed by the person who made the same.

(30.) The persons employed in a mine may from time to time appoint two of their number to inspect the mine at their own cost, and the persons so ap-

(p) See Baker v. Carter, 3 Ex. Div. 132; 47 L. J., M. C. 87. 
pointed shall be allowed, once at least in every month, accompanied, if the owner, agent, or manager of the mine thinks fit, by himself or one or more officers of the mine, to go to every part of the mine, and to inspect the shafts, levels, planes, working places, return air-ways, ventilating apparatus, old workings, and machinery ; and shall be afforded by the owner, agent, and manager, and all persons in the mine, every facility for the purpose of such inspection, and shall make a true report of the result of such inspection, and such report shall be recorded in a book to be kept at the mine for the purpose, and shall be signed by the persons who made the same.

(31.) The books mentioned in this section, or a copy thereof, shall be kept at the office at the mine, and any inspector nnder this act, and any person employed in the mine, may at all reasonable times, inspect and take copies of and extracts from any such books.

Every person who contravenes or does not comply with any of the general rules in this section, shall be guilty of an offence against this act; and in the event of any contravention of or non-compliance with any of the said general rules in the case of any mine to which this act applies, by any person whomsoever, being proved, the owner, agent, and manager shall each be guilty of an offence against this act, unless he proves that he had taken all reasonable means, by publishing and to the best of his power enforcing the said rules as regulations for the working of the mine, to prevent such contravention or non-compliance $(q)$.

\section{Special Rules.}

52. There shall be established in every mine to which this act applies such rules (referred to in this act as special rules) $(r)$, for the conduct and guidance of the persons acting in the management of such mine, or employed in or about the same, as, under the particular state and circumstances of such mine, may appear best calculated to prevent dangerous accidents, and to provide for the safety and proper discipline of the persons employed in or about the mine; and such special rules, when established, slall be signed by the inspector who is inspector of the district at the time such rules are established, and shall be observed in and about every such mine, in the same manner as if they were enacted in this act.

If any person who is bound to observe the special rules established for any mine, acts in contravention of or fails to comply with any of such special rules, Ine shall be guilty of an offence against this act ; and also the owner, agent, and manager of such mine, unless he proves that he had taken all reasonable means, by publishing and to the best of his power enforcing the said rules as regulations for the working of the mine so as to prevent such contravention or non-compliance, shall each be guilty of an offence against this act.

53. The owner, agent, or manager of every mine to which this act applies shall [*664] frame and transmit to the inspector of the district, for *approval by a Secretary of State, special rules for such mine within thrce months after the commencement of this act, or within three months after the commencement (if subsequent to the commencement of this act), of any working for the purpose of opening a new mine, or of renewing the working of an old mine.

The proposed special rules, together with a printed notice specifying that any objection to such rules on the gronnd of anything contained therein or onitted therefrom, may be sent by any of the persons employed in the mine to the inspector of the district, at his address, stated in such notice, shall, during not less than two weeks before such rules are transmitted to the inspector. be posted up in like manner as is provided in this act respecting the publication

(q) See Hall v. Hoprood, 49 Li. J., M. C. 17 ; Baker v. Carter, 3 Ex. Div. 132; 47 L. J., M. C. 87 ; Wynne v. Forester, 48 L. J., M. C. 140 ; 5 C. P. Div. 361.

(r) See Honells v. Wynne, 32 L. J., M. C. 241, where a charter-master was convicted of aiding and abetting a banksman to commit a violation of a special rule, limiting the number of persons to be lowered in to the pit at one time. 
of special rules for the information of persons employed in the mine, and a certificate that such rules and notice have been so posted up shall be sent to the inspector with the rules, signed by the person sending the same.

If the rules are not objected to by the Secretary of State within forty days after their receipt by the inspector, they shall be established.

54. If the Secretary of State is of opinion that the proposed special rules so transmitted, or any of them, do not sufficiently provide for the prevention of dangerous accidents in the mine, or for the safety of the persons enployed in or about the mine, or are unreasonable, he may, within forty days after the rules are received by the inspector, object to the rules, and propose to the owner, agent, or manager in writing any modifications in the rules by way either of omission, alteration, substitution, or addition.

If the owner, agent, or manager does not, within twenty days after the modifications proposed by the Secretary of State are received by liim, object in writing to them, the proposed special rules, with such modifications, shall be established.

If the owner, agent, or manager sends his objection in writing within the said twenty days to the Secretary of State, the matter shall be referred to arbitration, and the date of the receipt of such objection by the Secretary of State shall be leemed to be the date of the referenee, and the rules shall be established as settled by an award on arbitration.

55. After special rules are established under this aet in any mine, the owner. agent, or manager of such mine may from time to time propose in writing to the inspector of the district, for the approval of a Secretary of State, any amendment of such rules or any new special rules, and the provisions of this act with respect to the original special rules shall apply to all snch amendments and new rules in like manner, as near as may be, as they apply to the original rules.

A Secretary of State may from time to time propose in writing to the owner, agent, or manager of the mine any new special rules, or any amendment to the special rules, and the provisions of this act with respect to a proposal of a Secretary of State for modifying the special rules transmitted by the owner, agent, or manager of a mine shall apply to all such new special rules and amendments in like manner, as near as may be, as they apply to such proposal.

56. If the owner, agent, or maniger of any mine to which this act applies makes any false statement with respect to the posting up of the rules and notices, he shall be guilty of an offence against this act, and if special rules for any mine are not transmitted within the time limited by this act to the inspector for the approval of a Secretary of State, the owner, agent, and manager of such mine shall each be guilty of an offence against this act, unless he prove that he hal taken all reasonable means, by enforeing to the best of his power the provisions of this section, to secure the transmission of such rules.

57. For the purpose of making lnown the special rules and the provisions of this act fto all persons employed in and about each mine to which this act applies, an abstract of the act supplied, on the applicition *of the [*665] owner, agent, or manager of the nine, by the inspector of the distriet on behalf of a Seeretary of State, and an entire copy of the special rules shall be published as follows:

(1.) The owner, agent, or manager of such mine shall cause snch abstract and rules, with the name and address of the inspector of the district, and the nime of the owner or agent and of the manager appended thereto, to be posted up in legible characters, in some conspicuous place at or near the mine, where they may be conveniently read by the persons employed; and so often as the same become deficed, obliterited, or destroyed, shall cause them to be renewed with all reasonable despatch:

(2.) The owner, agent, or manager shall supply a printed copy of the abstract and the special rules gratis to each person employed in or about the mine who applies for sucl copy at the oflice at which the persons immediately employed by such owner, agent, or manager are paid :

(3.) Every copy of the special rules shall be kept distinct from auy rules which depend only on the contract between the employer and employed. 
In the event of any non-compliance with the provisions of this section by any person whomsoever, the owner, agent, and manager shall each be guilty of an offence against this act ; but the owner, agent, or manager of such mine shall not be deemed guilty if he prove that he had taken all reasonable means, by enforcing to the best of his power the observance of this section, to prevent such non-compliance $(s)$.

58. Every person who pulls down, injures, or defaces any proposed special rules, notice, abstract or special rules when posted up in pursuance of the provisions of this act with respect to special rules, or any notice posted up in pursuance of the special rules, shall be guilty of an offence against this act.

59. An inspector under this act shall, when required, certify a copy which is shown to his satisfaction to be a true copy of any special rules, which for the time being are established under this act in any mine, and a copy so certified shall be evidence (but not to the exclusion of other proof) of such special rules and of the fact that they are duly established under this act and have been signed by the inspector.

\section{PART III.-SUPPLEMENTAL}

\section{Penalties.}

60. Every person employed in or about a mine, other than an owner, agent, or manager, who is guilty of any act or omission which in the case of an owner, agent or manager would be an offence against this act, shall be deemed to be guilty of an offence against this act.

Every person who is guilty of an offence against this act shall be liable to a penalty not exceeding, if he is an owner $(t)$, agent, or manager, twenty pounds, and if he is any other person, two pounds, for each offence; and if the inspector has given written notice of any such offence, to a further penalty not exceeding one pound for every day after such notice that such ofience continues to be committed.

61. Where a person who is an owner, agent, or manager of or a person employed in or about a mine is guilty of any offence against this act which, in the opinion of the court that tries the case, is one which was reasonably calculated to endanger the safety of the persons employed in or about the mine, or cause [*666] serious personal injury to any of such *persons, or to cause a dangerous accident, and was committed wilfully by the personal act, personal default, or personal negligence of the person accused, such person shall be liable, if the court is of opinion that a pecuniary penalty will not meet the circumstances of the case to imprisonment, with or without hard labour, for a period not exceeding three months.

If any person feel aggrieved by any conviction made by a court of summary jurisdiction on determining any information nnder this act, by which conviction imprisonment is adjudged in pursuance of this section, or by which conviction the sum adjudged to be paid amounts to or exceeds half the maximum penalty, the person so aggrieved may appeal therefrom, subject to the conditions and regulations following:

(1.) The appeal shall be made to the next court of general or quarter sessions [the rest of this sub-sect. and sub-sect. (2.), (3.), (4.) and (5.) were repealed by 47 \& 48 Vict. c. 43 .]

Provided that in Scotland-

(1.) This section shall not apply to any conviction made by a sheriff:

(2.) The term "entering into a recognizance before a justice of the peace" shall mean finding caution with the clerk of the justices of the peace to the satisfaction of a justice of the peace, and the term "recognizance shall mean a bond of caution:

(s) See Hall v. Hopnoood, and other cases cited ante, p. 663, note (q).

(t) As to one of several joint owners, see $R$. v. Brown, 26 L. J., M. C. 183; 7 E. \& B. 757. 
(3.) In Scotland it shall be competent to any person empowered to appeal by this seetion, to appeal against a convietion by the sheriff to the next cireuit court, or where there are no eireuit courts to the high court of justieiary at Edinburgh, in the manner prescribed by such of the provisions of the act of the twentieth year of the reign of King George the Second, ehapter forty-three, and any acts amending the same, as relate to appeals in matters criminal, and by and under the rules, limitations, conditions, and restrietions contained in the said provisions.

62. All offences under this act not declared to be misdemeanours, and all penalties under this act, and all money and costs by this aet directed to be recovered as penalties, may be proseeuted and reeovered in manner direeted by the Summary Jurisdietion Aets before a court of summary jurisdietion $(u)$.

Proeeedings for the removal of a check weigher shall be deemed to be a matter on which a court of summary jurisdietion has anthority by law to make an order in pursuance of the Summary Jurisdietion Acts, and summary orlers under this aet may be made on complaint betore a court of summary jurisdiction in manner provided by the Summary Jurisdietion Aets.

The "Court of Summary Jurisdiction," when hearing and determining an information or complaint, shall be constituted-

(a.) In England, either of two or more justices of the peace in petty sessions sitting at a place appointed for holding petty sessions, or of some magistrate or officer for the time being empowered by law to do alone any act authorized to be done by more than one justice of the peace, and sitting alone or with others at some court or other place appointed for the administration of justice; or,

(b.) In Seotland, of two or more justices of the peace sitting as julges in a justice of the peace court, or of the sheriff or some other magistrate or officer for the time being empowered by law to do alone any act authorized to be done by more than one justice of the peaee, and sitting alone or with others at some court or other place appointed for the administration of justiee; or,

*(c.) In Ireland, within the police district of Dublin metropolis, of [*66\%] one of the divisional justices of that district sitting at a poliee eourt within the district, and elsewhere of two or more justices of the peace sitting in petty sessions at a place appointed for holding petty sessions.

63. In every part of the United Kingdom the following provisions shall have effect :

1. Any complaint or information made or laid in pursuanee of this act shall be made or laid within three months from the time when the matter of such complaint or information respeetively arose $(x)$ :

[Sub-sects, 2 and 3 were repealed by $47 \& 48$ Vict. $c$. 43 .]

4. The owner, agent, or manager may, if he think fit, he sworn and examined as an ordinary witness in the ease where he is eharged in respect of any eontravention or non-eomplianee by another person :

5. The court shall, if required by either party, eause minutes of the evidence to be taken and preserved :

6. A court of summary jurisdiction shall not impose a penalty under this act exceeding fifty pounds, but any sueh court may impose that or any less penalty for any one offence, notwithstanding the offence involves a penalty of higher amount.

61. No prosecution shall be instituted against the owner, agent, or manager of a mine to which this act applies for any oftence under this aet which can be prosecuted before a court of summary jurisdiction, except by an inspector, or with the consent in writing of a Secretary of State; and in the ease of any offence of which the owner, agent, or manager of a mine is not guilty if he proves that he had taken all reasonable means to prevent the commission

(u) See post, p. 669.

(x) See R. v. Mainwaring, 27 L. J., M. C. 278.

39 Mas. \& SEr. 
thereof, an inspector shall not institute any prosecution against such owner, agent, or manager, if satisfied that he had taken such reasonable means as aforesaid.

65. In Scotland the following provisions shall have effect:

(1.) All jurisdictions, powers, and authorities necessary for the court of summary jurisdiction under this act are hereby conferred on that court:

(2.) Every person found liable under this act by a court of summary jurisdiction in any penalty, or to pay any money or costs by this act directed to be recovered as penalties, shall be liable in default of immediate payment to be imprisoned for a term not exceeding three months; and the conviction and warrant may be in the form of No. 3 of Schedule K. of the Summary Procedure Act, 1864 :

(3.) In Scotland any penalty exceeding fifty pounds shall be recovered and enforced in the same manner in which any penalty due to her Majesty under any act of parliament may be recovered and enforced.

66. Nothing in this act shall prevent any person from being indicted or liable under any other act or otherwise to any other or higher penalty or punishment than is provided for any offence by this act, so that no person be punished twice for the same offence.

If the court before whom a person is charged with an offence under this act think that proceedings ought to be taken against such person for such offence under any other act or otherwise, the court may adjourn the case to enable such proceedings to be taken.

67. $A$ person who is the owner, agent, or manager of any mine to which this act applies, or the father, son, or brother of such owner, agent, or manager, shall not act as a court or member of a court of summary jurisdiction in respect of any offence under this act.

[*668] 68. *Where a penalty is imposed under this act for neglecting to send a notice of any explosion or accident; or for any offence against this act which has occasioned loss of life or personal injury, a Secretary of State may (if he think fit) direct such penalty to be paid to or distributed among the persons injured, and the relatives of any persons whose death may have been occasioned by such explosion, accident, or offence, or among some of them.

Provided that-

(1.) Such persons did not in his opinion occasion or contribute to occasion the explosion or accident, and did not commit and were not parties to committing the offence :

(2.) The fact of such payment or distribution shall not in any way affect or be receivable as evidence in any legal proceeding relative to or consequential on such explosion, accident, or offence.

Save as aforesaid, all penalties imposed in pursuance of this act shall be paid into the receipt of her Majesty's Exchequer, and shall be carried to the Consolidated Fund.

In Ireland all penalties imposed and recovered under this act shall be applied in manner directed by the Fines Act (Ireland), 1851, and any act amending the same.

69. The owner, occupier, or manager of every mine shall on the first of January every year, and 'at any other time when required by the Secretary of State, send to the inspector of his district a return of facts relating to his mine in the form given in Schedule Four.

\section{Miscellaneous.}

70. If any question arises whether a mine is a mine to which this act or the Metalliferous Mines Regulation Act, $1872(y)$, applies, such question shall be referred to a Secretary of State, whose decision thereon shall be final.

71. All notices under this act shall be in writing or print, or partly in writing and partly in print, and all notices and documents required by this act to

(y) Post. 
be served or sent by or to an inspector may be either delivered personally, or served and sent by post by a prepaid letter ; and, if served or sent by post, shall be deemed to have been served and received respectively at the time when the letter containing the same would be delivered in the ordinary course of post; and in proving such service or sending, it shall be sufficient to prove that the letter containing the notice was properly addressed and put into the post.

72. In this act, unless the context otherwise requires,-

The term "mine" includes every shaft in the course of being sunk, and every level and inclined plane in the course of being driven for commencing or opening any minc, or for searehing for or proving minerals, and all the shafts, levels, planes, works, machinery, tramways, and sidings, both below ground and above ground, in and adjacent to a mine and any such shaft, level, and inclined plane, and belonging to the mine :

The term "shaft" includes pit:

The term "plan" includes a map and section, and a correct copy or tracing of any original plan as so defined :

The term "owner," when used in relation to any mine, means any person or body corporate who is the immediate proprietor, or lessee, or occupier of any mine, or of any part thereof, and does not include a person or body corporate who merely receives a royalty, rent, or fine from a mine, or is merely the proprietor of a mine subject to any lease, grant, or license for the working thereof, or is merely the owner of the soil, and not interested in the minerals of the mine; *but any contractor for the working of [*669] any mine or any part thercof shall be subject to this act in like manner as if he were an owner, but so as not to excmpt the owner from any liability :

The term "agent," when used in relation to any mine, means any person having, on behalf of the owner, care or direction of any mine, or of any part thereof, and superior to a manager appointed in pursuance of this act:

The term "Secretary of State" means one of her Majesty's Principal Secretaries of State:

The term "chill" means a child under the age of thirteen years.

The term "young person" means a person of the age of thirteen years and under the age of sixteen years:

The term "woman" means a female of the age of sixteen ycars and upwards:

The term "Summary Jurisdiction Acts" means, as follows :

As to England, the act of the session of the eleventh and twelfth years of the reign of her present Majesty, chapter forty-three, intitnled " $\mathrm{An}$ Act to facilitate the performance of the dutics of justices of the peace out of sessions within England and Wales with respect to summary convictions and orders," and any acts amending the sane $(z)$ :

As to Scotland, "The Summary Precedure Act, 1864 :"

As to Ireland, within the police district of Dublin metropolis, the acts regulating the powers and duties of justices of the peace for such district, or of the police of such district, and elsewhere, "The Petty Sessions (Ireland) Act, 1851," and any act amending the same:

The term "Court of Summary Jurisdiction" means-

In England and Ireland, any justice or justices of the pcace, mctropolitan police magistrate, stipendiary or other migistrate, or oflicer, by whatever name called, to whom jurisdiction is given by the Summary Jurisdiction Acts or any acts therein referred to:

In Scotland, any justice or justices of the pcace, sheriff, or other magistrate, to the proceedings before whon for the trial or prosecution of any offence, or for the recovery of any penalty under any act of parliament, the provisions of the Summary Jurisdiction Acts may be applied.

73. In the application of this act to Scotland-

(1.) The term "Attorney General" means the Lord Advocate:

2. The term "injunction" mcans interdict:

3. The term "misdemeanour" means "crime and oflence:"

(z) Sce the Summary Jurisdiction Act, 1879, $42 \& 43$ Vict. c. 49. 
(4.) The term "chairman of quarter sessions" means the sheriff of the county:

(5.) The term "sheriff" includes sheriff substitute:

(6.) The term "attending on subpœna before a court of record" means attending on citation the Court of Judiciary :

(7.) The Queen's and Iord Treasurer's Remembrancer shall perform the duties of a master of one of the superior courts under this act :

(8.) The term "stipendiary magistrate" means a sheriff or sheriff substitute:

(9.) Notices of explosions, accidents, loss of life, or personal injury shall be deemed to be sent to the inspector of the district on behalf of the Lord Advocate :

(10.) Section sixteen of "The Public Health (Scotland) Act, 1867," shall be substituted for "section eight of the Nuisances Removal Act for England, 1855, as amended and extended by the Sanitary Act, 1866."

$\left[{ }^{*} 670\right] * 74$. The persons who at the commencement of this act are acting as inspectors under the acts hereby repealed shall continue to act in the same manner as if they had been appointed under this act.

75. The special rules which at the commencement of this act are in force under any act hereby repealed in any mine to which this act applies shall continue to be the special rules in such mine until special rules are established under this act for such mine, and while they so continue shall be of the same force as if they were established under this act.

76. The acts described in schedule three to this act are hereby repealed to the extent in the third column of that schedule mentioned.

Provided that this repeal shall not affect anything done or suffered before the commencement of this act, and all offences committed and penalties incurred before the commencement of this act may be punished and recovered in the same manner as if this act had not passed.

\section{SCHEDUI, ES.}

\section{Schedule ONe.}

Table of maximum Fees to be paid in respect of Certificates of Managers of Mines.

By an applicant for examination .......... Two pounds. By applicant for certificate of service for registration . . . . Five shillings. For copy of certificate . . . . . . . . . . Five shillings.

\section{Schedule Two.}

\section{Proccedings of Board for Examinations.}

1. The board shall meet for the despatch of business, and shall from time to time make such regulations with respect to the summoning, notice, place, management, and adjournment of such meetings, and generally with respect to the transaction and management of business, including the quorum at meetings of the board, as they think fit, subject to the following conditions :-

(a.) The first meeting shall be summoned by the inspector of the district, and shall be held on such day as may be fixed by a Secretary of State;

(b.) An extraordinary meeting may be held at any time on the written requisition of three members of the board addressed to the chairman ;

(c.) The quorum to be fixed by the board shall consist of not less than three members;

(d.) Every question shall be decided by a majority of votes of the members present and voting on that question ;

(e.) The names of the members present, as well as of those voting upon each question shall be recorded;

(f.) No business shall be transacted unless notice in writing of such business has been sent to every member of the board seven days at least before the meeting. 
2. The board shall from time to time appoint some person to be chairman, and one other person to be vice-chairman.

3. If at any meeting the chairman is not present at the time appointed for holding the same, the vice-chairman shall be the chairman of the neeting, and if neither the chairman nor vice-cliairman shall be present, then the members present shall choose some one of their number to be chairman of such meeting.

${ }^{*} 4$. In case of an equality of votes at any meeting, the chairman for [*671] the time being of such meeting shall have a second or casting vote.

5. The appointment of an examiner may be made by a minute of the board signed by the chairman.

6. The board shall kecp minutes of their proceedings, which may be inspected or copied by a Secretary of State, or any person authorised by him to inspect or copy the same.

\section{Schedule Three.}

\begin{tabular}{|c|c|c|}
\hline Date of Act. & Title of Act. & Extent of Repeal. \\
\hline 5 \& 6 Vict. c. 99. & $\begin{array}{l}\text { An act to prohibit the em- } \\
\text { ployment of women and } \\
\text { girls in mines and colli- } \\
\text { eries, to regulate the em- } \\
\text { ployment of boys, and } \\
\text { to make other provisions } \\
\text { relating to person work- } \\
\text { ing therein. }\end{array}$ & $\begin{array}{l}\text { The whole act so far as it re- } \\
\text { lates to mines to which this } \\
\text { act applies. }\end{array}$ \\
\hline 23 \& 24 Vict. c. 151. & $\begin{array}{l}\text { An act for the regulation } \\
\text { and inspection of mines. }\end{array}$ & $\begin{array}{l}\text { Sections one to five, both in- } \\
\text { clusive, so far as they relate } \\
\text { to mines to which this act } \\
\text { applies, and the residue of } \\
\text { the act entirely. }\end{array}$ \\
\hline $25 \& 26$ Vict. c. 76. & $\begin{array}{c}\text { An act to amend the law } \\
\text { relating to coal mines. }\end{array}$ & The whole act. \\
\hline
\end{tabular}




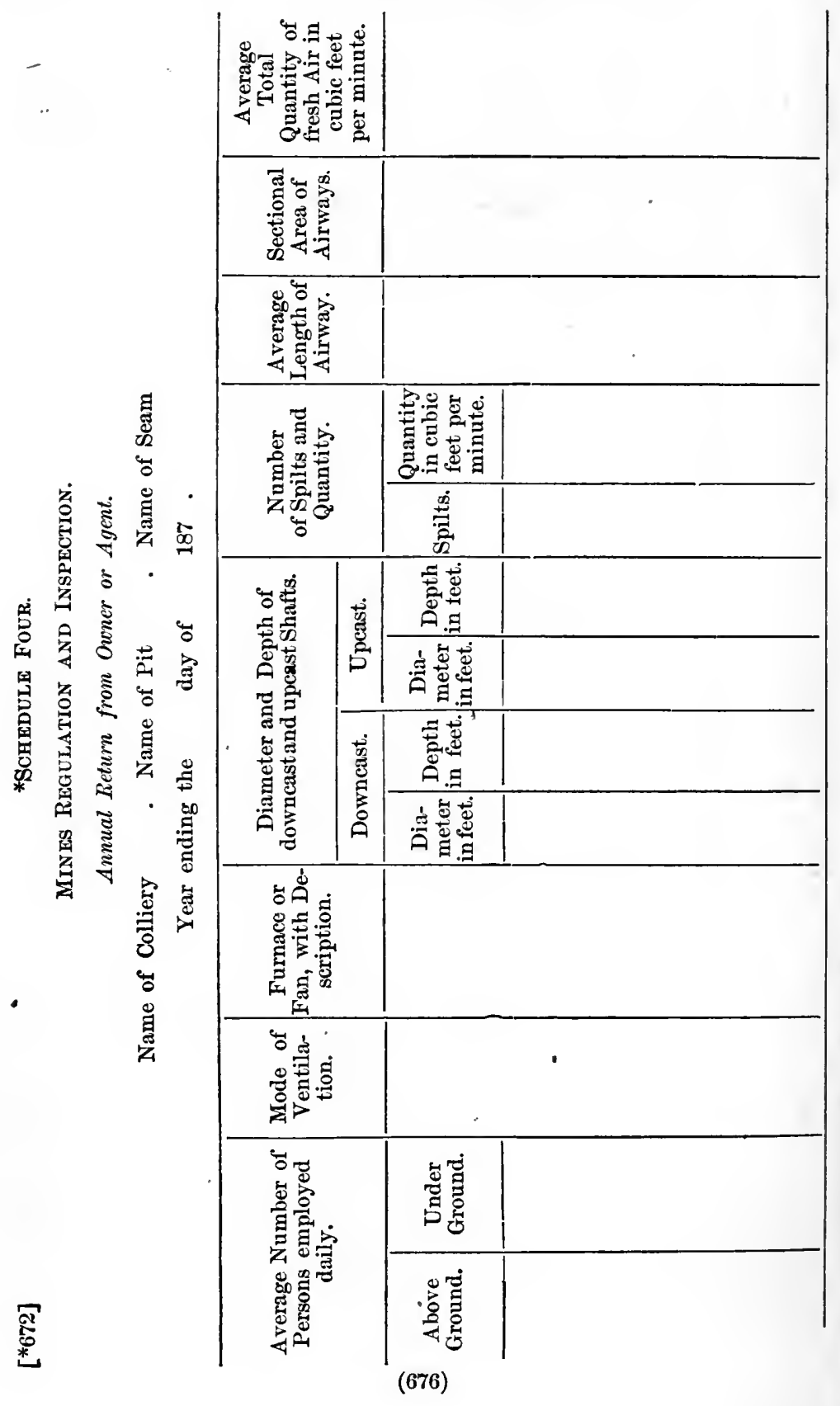




\section{An Act to consolidate and amend the Law relating to Metalliferous Mines.}

Whereas it is expedient to amend the law relating to the regulation and inspection of mines other than mines to which the Coal Mines Regulation Act, 1872, applies :

Be it therefore enacted by, \&c., \&c., as follows :

\section{Preliminary.}

1. This act may be cited as "The Metalliferous Mines Regulation Act, 1872."

2. This act shall not come into operation nntil the 1st day of January, 1873, which date is in this act referred to as the commencement of this act.

3. This act shall apply to every mine of whatever description other than a mine to which the Coal Mines Regulation Act, $1872(y)$, applies.

\section{PART I. \\ Employment of Women, Young Persons, and Children.}

4. No boy under the age of twelve years, and no girl or woman of any age, shall be employed in or allowed to be for the purpose of employment in any mine to which this act applies below ground.

5. A boy of the age of twelve years and under the age of thirteen years, and a male young person of the age of thirteen and under the age of sixteen years shall not be cmployed in or allowed to be for the purpose of employment in any mine to which this act applies below ground for more than fifty-four hours in any one week, or more than ten hours in any one day, or otherwise than in accordance with the regulations following; that is to say,

(1.) There shall be allowed an interval of not less than eight hours between the period of employment on Friday and the period of employment on the following Saturday, and in other eases of not less than twelve hours between each period of employment; provided always, that in the ease of boys and young male persons whose employment is at such distance from their ordinary place of residence that they do not return there during the intervals of labour, and who are not employed during more than forty hours in any week, an interval of not less than eight hours shall be allowed between each periof of employment :

(2.) The period of each employment shall be deemed to begin at the tinse of leaving the surface, and to end at the time of returning to the surface:

(3.) A week shall be deemed to begin at midnight on Saturday night, and to end at midnight on the succeeding Saturday night.

6. The owner or agent of every mine to which this act applies shall keep in the office at the mine, or in the principal office of the mine belonging to the same owner in the district in which the mine is situated, a register, and shall cause to be entered in such register the name, age, residence, and date of tirst employment of all boys of the age of twelve and under the age of thirteen years, and of all male young persons of the age of thirteen and under the agre of sixteen years who are employed in *the mine below ground, and of all women, [*674] young persons, and ehildren employed above ground in eonnexion with a mine, and shall produce such register to any inspector under this act at the mine at all reasonable times when required by him, and allow him to inspect and copy the same.

(y) Ante, p. 641, and see sect. 39, post, p. $68 \%$. 
The immediate employer of every boy or male young person of the ages afore- said, other than the owner or agent of the mine, before he causes such boy or male young person to be in any mine to which this act applies below ground, shall report to the owner or agent of such mine, or some person appointed by such owner or agent, that he is abont to employ him in such mine.

7. Where there is a shaft, inclined plane, or level in any mine to which this act applies, whether for the purpose of an entrance to such mine or of a communication from one part to another part of such mine, and persons are taken up, down, or along such shaft, plane, or level by means of an engine, windlass, or gin, driven or worked by steam or any mechanical power, or by an animal or by manual labour, a person shall not be allowed to have charge of such engine, windlass, or gin, or of any part of the machinery, ropes, chains, or tackle connected therewith, unless he is a male of at least eighteen years of age.

Where the engine, windlass, or gin is worked by an animal the person under whose direction the driver of the animal acts shall, for the purposes of this section, be deemed to be the person in charge of the engine, windlass, or gin, but such driver shall not be under twelve years of age.

8. If any person contravenes or fails to comply with any provision of this act with respect to the employment of women, girls, young persons, or boys, or to the register of or report respecting boys and male young persons, or to the employment of persons about any engine, windlass, or gin, he shall be guilty of an offence against this act; and in case of any such contravention or non-compliance by any person whomsoever in the case of any mine, the owner and agent of such mine shall each be guilty of an offence against this act, unless he proves that he had taken all reasonable means by publishing and to the best of his power enforcing the provisions of this act to prevent such contravention or noncompliance.

If it appear that a boy or young person or a person employed about an engine, windlass, or gin, was employed on the representation of his parent or guardian that he was of that age at which his employment would not be in contravention of this act, and under the belief in good faith that he was of that age, the owner or agent of the mine and the immediate employer shall be exempted from any penalty, and the parent or guardian shall, for such misrepresentation, be deemed guilty of an offence against this act.

\section{Hages.}

9. No wages shall be paid to any person employed in or about any mine to which this act applies at or within any public house, beer shop, or place for the sale of any spirits, wine, beer, cyder, or other spirituous or fermented liquor, or other liouse of entertainnient, or any office, garden, or place belonging or contiguous thereto, or occupied therewith $(z)$.

Every person who contravenes or fails to comply with, or permits any person to contravene or fail to comply with, this section shall be guilty of an offence against this act, and in the event of any such contravention or non-compliance $\left[{ }^{*} 675\right]$ in the case of any mine by any person whomsoever *the owner and agent of such mine shall each be guilty of an offence against this act, unless he prove that he had taken all reasonable means by publishing and to the best of his power enforcing the provisions of this section to prevent such contravention or non-compliance.

\section{Returns, Notices, and Abandonment}

10. On or before the first day of August in every year the owner or agent of every mine to which this act applies shall send to the inspector of the district on behalf of a Secretary of State a correct return $(a)$, specifying, with respect to the year ending on the preceding thirty-first day of December, the quantity

(z) And see 35 \& 36 Vict. c. 76, s. 16 , ante, p. 645 , and $46 \& 47$ Vict. c. 31 , post.

(a) Sect. 10 was repealed by 38 \& 39 Vict. c. 39 , s. 4 , post. 
of mineral sold or produced from such mine, and the number of persons ordinarily employed in or about such mine, below ground and above ground, distinguishing those who are employed below ground and above ground, and distinguishing the different classes and ages of the persons so employed whose hours of labour are regulated by this act.

The return shall be in sueh form as may be from time to time preseribed by a Seeretary of State, and the inspector of the district on behalf of a Secretary of State shall from time to time on application furnish forms for the purpose of such return.

Every owner or agent of a mine who fails to comply with this section, or makes any return which is to his knowledge false in any particular, shall be guilty of an offence against this aet.

Provided that in any mine where not more than twelve persons are employed underground, the returns speeifying the quantity of mineral sold or produced from such mine shall be made by the barmaster or other officer, if any, employed to collect the dues or royalty ; and where there is such a barmaster or other officer the owner or agent of such mine shall not be required to send any return speeifying the number of persons employed in or about such mine.

11. Where in or about any mine to which this act applies, whether above or below ground, either-

(1.) loss of life or any personal injury to any person employed in or about the mine oecurs by reason of any explosion of gas, powder, or of any steam boiler; or

(2.) loss of life or any serious personal injury to any person employed in or about the mine occurs by reason of any accident whatever,

the owner or agent of the mine shall, within twenty-four hours next after the explosion or accident, send notice in writing of the explosion or aecident and of the loss of life or personal injury oceasioned thereby to the inspector of the district on behalf of a Secretary of State, and shall specify in sueh notice the character of the explosion or accident, and the number of persons killed and injured respectively.

Where any personal injury, of which notice is required to be sent under this section, results in the death of the person injured, notice in writing of the death shall be sent to the inspector of the district on behalf of a Secretary of State within twenty-four hours after such death comes to the knowledge of the owner or agent.

Every owner or agent who fails to act in compliance with this section sliall be guilty of an oftence against this act.

12. In any of the following cases, namely,

(1.) Where any working is commeneed for the purpose of opening a new shaft for any mine to which this act applies;

(2.) Where a shaft of any mine to which this act applies is abandoned or the working thereof discontinued;

(3.) Where the working of a shaft of any mine to which this act ${ }^{*}{ }_{10}$ - [*676] plies is reconmenced after any ahandonment or discontinuance for a period exceeding two months; or,

(4.) Where any change occurs in the name of, or in the name of the owner or agent of, a nine to which this aet applies, or in the officers of any incorporated company which is the owner of a mine to which this act applies:

the owner or agent of such mine shall give notice thereof to the inspector of the district within two months after such commencement, abandonment, discontinuanee, recommencement, or ehange, and if such notice is not given, the owner or agent shall be guilty of an offence against this act.

Provided that-

(1.) This section shall apply only to any working or mine in whieh more than twelve persons are ordinarily employed below ground; and

(2.) In the case of a partnership working a mine within the stannaries of Devon and Cornwall, if notice of every change in the purser of the 
partnership is sent as required by this section, notice of a change in the nembers of such partnership need not be sent in pursuance of this section.

13. Where any mine to which this act applies is abandoned or the working thereof discontinued, at whatever time such abandonment or discontinuance occurred, the owner thereof, and every other person interested $(b)$ in the minerals of the mine, shall cause the top of the shaft and any side entrance from the surface to be and to be kept securely fenced for the prevention of accidents.

Provided that-

(1.) Subject to any contract to the contrary, the owner of the mine shall, as between him and any other person interested in the minerals of the mine, be liable to carry into effect this section, and to pay any costs incurred by any other person interested in the minerals of the mine in carrying this section into effect :

(2.) Where such abandonment or discontinuance has cccurred in the case of a mine before the passing of this act, this section shall apply only to such shaft or side entrance of the mine as is situate within fitty yards of any highway, road, footpath, or place of public resort or in open or unenclosed land, or not being situate as aforesaid, is required by an inspector in writing to be fenced, on the ground that it is specially dangerous :

(3.) Nothing in this section shall exempt any person from any liability under any other act, or otherwise.

If any person tial to act in conformity with this section he shall be guilty of an offence against this act.

Any shaft or side entrance which is not fenced as required by this section, and is within fifty yards of any highwas, road, footpath, or place of public resort, or is in open or unenclosed land, or is required by an insyector as aforesaid to be feneed, shall be deemed to be a nuisance within the meaning of section eight of the Nuisances Removal Act for England, 1855, as anended and extended by the Sanitary Act, 1866.

14. Where any mine to which this act applies in which more than twelve persons have ordinarily been employed below ground is abandoned, the owner of such mine at the time of the abandonment shall, within three months atter such abandonment, send to a Secretary of State an accurate plan, on a seale of not less than a scale of two chains to one inch, or on such other scale as the plan last used in the mine is constructed on; showing the boundaries of the [*67] workings of such mine up * to the time of the abandonment, with the view of its being preserved under the care of the Secretary of state, but no person other than an inspcetor shall be at liberty to inspect or to copy such plan within ten years of its receipt by the Secretary of State without the license of such Secretary of State.

Every person who fails to comply with this section shall be guilty of an offence against this act.

\section{Inspection.}

15. A Secretary of State may from time to time appoint any fit persons to be inspectors of mines to which this act applies, and assign them their duties, and may award them such salaries as the Commissioners of her Majesty's Treasury may approve, and may remove such inspectors.

Notice of the appointment of every such inspector shall be published in the London Gazette.

Any such inspector is referred to in this act as an inspector, and the inspector of a district means the inspector who is for the time heing assigned to the district or portion of the United Kingdom with reference to which the term is used.

Any person appointed or acting as inspector under the Coal Mines Regulation

(b) See Ecans v. Lady Mostyn, L. R., 2 C. P. 54 ; ; 4 \% L. J., M. C. 25. (680) 
Act, 1872, if directed by a Secretary of State to act as an inspector under this act, may so act and shall be deemed to be an inspector under this act.

16. Any person who practises or acts or is a pirtner of any person who practises or acts as a land agent or mining engineer, or as a manager, viewer, agent, or valuer of mines, or arbitrator in any differences arising between owners, agents, or managers of mines, or is otherwise employed in or about any mine (whether such mine is one to which this act applies or not), shall not act as an inspector of mines under this act.

17. An inspector under this act shall have power to do all or any of the following things; namely,

(1.) To make such examination and inquiry as may be necessary to ascertain whether the provisions of this act relating to matters above ground or below ground are complied with in the case of any mine to which this act applies :

(2.) To enter, inspect. and examine any mine to which this act applies, and every part thereof, at all reasonible times, by day and night, but so as not to impede or obstruct the working of the said mine :

(3.) To examine into and make inquiry respecting the state and condition of any mine to which this act applies, or any part thereof, and the ventilation of the mine, and the sufficiency of the special rules (if any) for the time being in force in the mine, and all matters and things connected with or relating to the safety of the persons employed in or about the mine or any mine contiguous thereto:

(4.) To exercise such other powers as may be necessary for carrying this act into effect.

Every person who wilfully obstructs any inspector in the execution of his duty under this act, and every owner and agent of a mine who refuses or neglects to furnish to the inspector the means necessary for making any entry, inspection, examination, or inquiry under this act in relation to such mine, shall be guilty of an offence against this act.

18. If in any respect (which is not provicled against by any express provision of this act, or by any special rule) any inspector find any mine to which this act applies, or any part thereof, or any matter, thing, or practice in or connected with any such mine, to be dangerous or defective, so as in his opinion to threaten or tend to the bodily injury of any person, such inspector may give notice in writing thereof to the owner or agent ${ }^{*}$ of the mine, and shall [ ${ }^{*} 678$ ] state in such notice the particulars in which he considers such mine, or any part thereof, or any matter, thing, or practice; to be dangerous or defective' and require the same to be remedied; and unless the same be forthwith remedied, the inspector shall also report the same to a Secretary of State.

If the owner or agent of the mine oljjects to remedy the matter complained of in the notice, he may, within twenty days after the receipt of snch notice, send his objection in writing, stating the grounds thereof, to a Secretary of State; and thereupon the matter shall be determined by arbitration in manner provided by this act; and the date of the receipt of such objection shall bo deemed to be the clate of the reference.

If the owner or agent fail to comply either with the requisition of the notice, where no objection is sent within the time aforesaid, or with the award made on arbitration, within twenty days after the expiration of the time for objection or the time of making of the awird (as the case may be), he shall be guilty of an offence against this act, and the notice and award shall respectively be deemed to be written notice of such offence.

Provided that the court, if satisfied that the owner or agent has taken active measures for complying with the notice or award, but has not, with rensonable diligence, been able to complete the works, may adjourn any proceedings taken before them for punishing such offence; and, if the works are completed within a reasonable time, no penalty shall be inflicted.

No person shall be preeluded by any agreement from doing such acts as may be necessary to comply with the provisions of this section, or be liable under any contract to any penalty or forfeiture for doing such acts. 
19. The owner or agent of every mine to which this act applies shall keep in the office at the mine, or in the principal office of the mines belonging to the same owner in the district in which the mine is situated, an accurate plan of the workings of such mine, showing the workings up to at least six months previously, other than workings which were last discontinued at a date more than twelve months before the commencement of this act $(c)$.

The owner or agent of the mine shall produce to an inspector under this act, at one of the aforesaid offices, such plan, and shall, if requested by the inspector, mark on such plan the progress of the workings of the mine up to the time of such production, and shall allow the inspector to examine the same.

If the owner or agent of any mine fails to keep such plan as is prescribed by this section, or wilfully refuses to produce or allow to be examined such plan, or wilfully withholds any portion of any plan, or conceals any part of the workings of his mine, or produces an imperfect or inaccurate plan, unless he shows that he was ignorant of such concealment, imperfection, or inaccuracy, he shall be guilty of an offence against this act; and, further, the inspector may, by notice in writing (whether a penalty for such offence has or has not been inflicted), require the owner or agent to cause an accurate plan, such as is prescribed by this section, to be made within a reasonable time at the expense of the owner of the mine, on arscale of not less than a scale of two chains to one inch, or on such other scale as the plan used in the mine is constructed on.

If the owner or agent fail within twenty days, or such further time as may be shown to be necessary, after the requisition of the inspector, to make or cause to be made such plan, he shall be guilty of an offence against this act.

Provided that this section shall apply only to a mine to which this act applies, and in which more than twelve persons are ordinarily employed below ground.

[*679]. *20. Every inspector under this act shall make an annual report of his proceedings during the preceding year to a Secretary of State, which report shall be laid before both Houses of Parliament.

A Secretary of State may at any time direct an inspector to make a special report with respect to any accident in a mine to which this act applies, which accident has caused loss of life or personal injury to any person, and in such case shall cause such report to be made public at such time and in such manner as he thinks expedient.

\section{Arbitration.}

21. With respect to arbitrations under this act, the tollowing provisions shall have effect :

. (1.) The parties to the arbitration are in this section deemed to be the owner or agent of the mine on the one hand, and an inspector of mines on behalf of the Secretary of State on the other:

(2.) Each of the parties to the arbitration may, within twenty-one days after the date of the reference, appoint an arbitrator:

(3.) No person shall act as arbitrator or umpire under this act who is employed in or in the management of or is interested in the mine to which the arbitration relates:

(4.) The appointment of an arbitrator under this section shall be in writing, and notice of the appointment shall be forth with sent to the other party. to the arbitration, and shall not be revoked without the consent of such other party :

(5.) The death, removal, or other change in any of the parties to the arbitration shall not affect the proceedings under this section :

(6.) If within the said twenty-one days either of the parties fail to appoint an arbitrator, the arbitrator, appointed by the other party may proceed to hear and determine the matter in difference, and in such case the award of the single arbitrator shall be final:

(c) Compare 35 \& 36 Vict. c. 76, s. 47, ante, p. 656. 
(7.) If before an award has been made any arbitrator appointed by either party die or become incapable to act, or for fourteen days refuse or neglect to act, the party by whom such arbitrator was appointed may appoint some other person to act in his place; and if he fail to do so within fourteen days after notice in writing from the other party for that purpose, the remaining arbitrator may proceed to hear and determine the matters in difference, and in such case the award of such single arbitrator shall be final :

(8.) In either of the foregoing cases, where an arbitrator is empowered to aet singly, upon one of the parties failing to appoint, the party so failing may, before the single arbitrator has actually proceeded in the arbitration, appoint an arbitrator, who shall then act as if no failure liad been made.

(9.) If the arbitrators fail to make their award within twenty-one days after the day on which the last of them was appointed or within such extended time (if any) as may have been appointed for that purpose by both arbitrators under their hands, the matter in difference shall be determined by the umpire appointed as hereinafter mentioned :

(10.) The arbitrators, before they enter upon the matters referred to them, shall appoint by writing ander their hands an umpire to decide on points on which they may differ :

(11.) If the umpire die or become incapable to act before he has made his award, or refuses to make his award within a reasonable time after the matter has been brought within his cognizance, the persons or person who appointed such umpire shall forthwith appoint another umpire in his place:

(12.) If the arbitrators fail or refuse, or for seven days after the request * of either party neglect to appoint an umpire, then on the ap- [*680] plication of either party an umpire shall be appointed by the chairman of the general or quarter sessions of the peace within the jurisdiction of which the mine is situate:

(13.) The decision of every umpire on the matters referred to him shall be final :

(14.) If a single arbitrator fail to make his award within twenty-one days after the day on which he was appointed, the party who appointed him may appoint another arbitrator to act in his place:

(15.) Thearbitrators and their umpire, or any of them, may examine the parties and their witnesses on oath; they may also consult any counsel, engineer, or scientifie person whom they may think it expedient to consult :

(16.) The payment, if any, to be made to any arbitrator or umpire for his services, shall be fixed by the Secretary of State, and together with the costs of the arbitration and award, shall be paid by the parties or one of them according as the award may direct. Such eosts may be taxed by a master of one of the superior courts, who, on the written application of either of the parties, shall ascertain and certify the proper amount of such costs. The amount, if any, payable by the Secretary of State, shall be paid as part of the expenses of inspectors under this act. The amount, if any, payable by the owner or agent may, in the event of nonpayment, be recovered in the same manner as penalties under this act:

(17.) Every person who is appointed an arbitrator or umpire under this seetion shall be a practical mining engineer or a person accustomed to tho working of mines; but when an award has been made under this seetion, the arbitrator or umpire who made the same shall be deemed to have been duly qualified as provided by this section.

Coroners.

22. With respect to coroners inquests on the bodies of persons whose death may have been caused by explosions or accidents in mines to which this act applies, the following provisions shall have effect : 
(1.) Where a coroner holds an inquest upon a body of any person whose death may have been caused by any explosion or accident, of which notice is required by this act to be given to the inspector of the district, the coroner shall adjourn such inquest unless an inspector, or some person on behalf of a Secretary of State, is present to watch the proceedings:

(2.) The coroner, at least four days before holding the adjourned inquest, shall send to the inspector of the district notice in writing of the time and place of holding the adjourned inquest:

(3.) The coroner, before the adjournment, may take evidence to identify the body, and may order the interment thereof.

(4.) If an explosion or accident has not occasioned the death of more than one person, and the coroner has sent to the inspector of the district notice of the time and place of holding the inquest not less than fortyeight hours before the time of holding the same, it shall not be imperative on him to adjourn such inquest in pursuance of this section, if the majority of the jury think it unnecessary so to adjourn :

(5.) An inspector shall be at liberty at any such inquest to examine any witness, subject nevertheless to the order of the coroner:

(6.) Where evidence is given at an inquest at which an inspector is not present of any neglect as having caused or contributed to the explosion or

[*681] accident, or of any defect in or about the mine *appearing to the coroner or jury to require a remedy, the coroner shall send to the inspector of the district notice in writing of such neglect or default :

(7.) Any person having a personal interest in or employed in or in the management of the mine in which the explosion or accident occurred, shall not be qualified to serve on the jury empannelled on the inquest; and it shall be the duty of the constable or other officer not to summon any person disqualified under this provision, and it shall be the duty of the coroner not to allow any such person to be sworn or to sit on the jury.

Every person who fails to comply with the provisions of this section shall be guilty of an offence against this act.

\section{PART II.-RULES.}

\section{General Rules.}

23. The following general rules shall, so far as may be reasonably practicable, be observed in every mine to which this act applies :-

(1.) An adequate amount of rentilation shall be constantly produced in every mine to such an extent that the shafts, wnzes, sumps, levels, underground stables and working places of such mine, and the travelling roads to and from such working places, shall be in a fit state for working and passing therein.

(2.) Gunpowder or other explosive or inflammable substance shall only be used underground in the mine as follows $(d)$ :

(d) And see $35 \& 36$ Vict. c. 76, s. 51, subs. 8, ante, p. 660.

(a.) It shall not be stored in the mine :

b. It shall not be taken into the mine, except in a case or canister containing not more than four pounds :

(c.) A workman shall not have in nse at one time in any one place more than one of such cases or canisters :

(d.) In charging holes for blasting, except in mines excepted from the operation of this section by the Secretary of State, an iron or steel pricker shall not be used, and a person shall not have in his possession in the mine underground any iron or steel pricker, and an iron or steel tamping rod or stemmer shall not be used for ramming either the wadding or the first part of the tamping or stemming on the powder: 
(e.) A charge of powder which has missed fire shall not be unrammed.

(3.) Every urderground plane on which persons travel, which is self-acting, or worked by an engine, windlass, or gin, shall 'be provided (if exceeding thirty yards in length) with some proper means of signalling between the stopping places and the ends of the plane, and shall be provided in every case, at intervals of not more than twenty yards, with sufficient man-holes for places of refuge.

(4.) Every road on which persons travel underground, where the produce of the mine in transit exceels ten tons in any one hour over any part thereof, and where the load is drawn by a horse or other animal, shall be provided, at intervals of not more than one hundred yards, with sufficient spaces for places of refuge, each of which spaces shall be of sufficient length, and of at least three feet in width between the waggons running on the tram-road and the side of the road; and the Secretary of State may, if he see fit, require the inspector to certify whether the produce ${ }^{*}$ of the mine in transit on the road afore- [ $\left.{ }^{*} 682\right]$ said does or does not ordinarily excecd the weight as aforesaid.

(5.) Every man-hole and space for a place of refuge shall be constantly kept clear, and no person shall place anything in a man-hole or such space so as to prevent access thereto.

(6.) The top of every shaft which was opened before the commencement of the actual working for the time being of the mine, and has not been used during such actual working shall, if so required in writing by the inspector of the district, be sccurely fenced, and the top of every other shaft which for the time being is out of use, or used only as an air shaft, shall be securely fenced.

(7.) The top and all entrances between the top and bottom of every working or pumping shaft shall be properly fenced, but this shall not be taken to forbid the temporary removal of the fence for the purpose of repairs or other operations, if proper precautions are used.

(8.) Where the natural strata are not safe, every working or pumping shaft shall be securely cased, lined, or otherwise made secure.

(9.) Where one portion of a shaft is used for the ascent and descent of persons by ladders or a man-engine, and another portion of the same shaft is used for raising the material gotten in the mine, the first-mentioned portion shall be cased or otherwise securely fenced off from the last-mentioned portion.

(10.) Every working shaft in which persons are raised shall, if exceeding fifty yards in depth, and not exempted in writing by the inspector of the district, be provided with guides and some proper means of communicating distinct and definite signals from 'the bottom of the shaft and from every entrance for the time being in work between the surface and the bottom of the shaft to the surface, and from the surface to the bottom of the shaft and to every entrance for the time being in work between the surface and the bottom of the shaft.

(11.) A sufficient cover overhead shall be used when lowering or raising persons in every working shaft, except where it is worked by a windlass, or where the person is employed about the pump or some work of repair in the shaft, or where a written exemption is given by the inspector of the district.

(12.) A single linked chain shall not be used for lowering or raising persons in any working shaft or plane except for the short coupling chain attached to the cage or load.

(13.) There shall be on the drum of every machine used for lowering or raising persons such flanges or horns, and also if the drum is conical, such other appliances, as may be sufficient to prevent the rope from slipping.

(14.) There shall be attached to erery machine worked by steam, water, or mechanical power, and used for lowering or raising persons, an ade- 
quate break, and also a proper indicator (in addition to any mark on the rope) which shows to the person who works the machine the position of the cage or load in the shaft.

(15.) A ladder permanently used for the ascent or descent of persons in the mine shall not be fixed in a vertical or orerhanging position, and shall be inclined at the most convenient angle which the space in which the ladder is fixed allows, and every snch ladder shall have substantial platforms at intervals of not more than twenty yards.

(16.) If more than twelve persons are ordinarily employed in the mine below ground, sufficient accommodation shall be provided above ground

[*683] near the prineipal entrance of the mine, and not in the *engine-house or boiler-house, for enabling the persons employed in the mine to conveniently dry and change their dress.

(17.) Every fly-wheel and all exposed and dangerous parts of the machinery used in or about the mine shall be and be kept securely fenced.

(18.) Every steam boiler shall be provided with a proper steam gauge and water gauge, to show respectively the pressure of steam and the height of water in the boiler, and with a proper safety valve.

(19.) No person shall wilfully damage, or without proper authority remore or render useless, any fencing, casing, lining, guide, means of signalling, signal, cover, chain, flange, horn, break, indicator, ladder, platform, steam gauge, water gauge, safety valre, or other appliance or thing provided in any mine in compliance with this act.

Every person who contravenes or does not comply with any of the general rules in this section shall be guilty of an offence against this act, and in the event of any contravention of or non-compliance with any of the said general rules in the case of any mine to which this act applies, by any person whomsoever, being proved, the owner and agent of such mine shall each be guilty of an offence against this act, unless he proves that he had taken all reasonable means by publishing and to the best of his power enforcing the said rules as regulations for the working of the mine to prevent such contravention or noncompliance.

\section{Special Rules.}

24. The owner or agent of any mine to which this act applies may, if he think fit, transmit to the inspector of the district, for approval by a Secretary of State, rules (referred to in this act as special rules) for the conduct and guidance of the persons acting in the management of such mine or employed in or about the same, so as to prevent dangerous accidents, and to provide for the safety and proper discipline of the persons employed in or about the mine, and such special rules, when established, shall be signed by the inspector who is inspector of the district at the time such rules are established, and shall be observed in and abont every such mine in the same manner as if they were, enacted in this act.

If any person who is bound to observe the special rules established for any mine acts in contravention of or fails to comply with any of such special rules, he shall be guilty of an offence against this act, and also the owner and agent of such mine shall each be guilty of an offence against this act, nnless he prores that he had taken all reasonable means by publishing and to the best of his power enforcing the said rules as regulations for the working of the mine to prevent such contravention or non-compliance.

25. The proposed special rules, together with a printed notice specifying that any objection to such rules on the ground of anything contained therein or omitted therefrom may be sent by any of the persons employed in the mine to the inspector of the district, at his address, stated in such notice, shall, during not less than two weeks before snch rules are transmitted to the inspector, be posted up in like manner as is provided in this act respecting the pnblication of special rules for the information of persons employed in the niine, and a certificate that such rules and notice have been so posted up shall be sent to the inspector with the rules signed by the person sending the same. 
If the rules are not objected to by the Secretary of State within forty days after their receipt by the inspector they shall be established.

If the owner or agent makes any false statement with respect to the posting up. of the rules and notices he shall be guilty of an offence against this act.

*26. If the Secretary of State is of opinion that the proposed special [*684] rules so transmitted, or any of them, do not sufficiently provide for the prevention of dangerous acciclents in the mine, or for the safety of the persons employed in or about the mine, or are unreasonable, he may, within forty days after the rules are received by the inspector, object to the rules, and propose to the owner or agent in writing any modifications in the rules by way either of omission, alteration, substitution, or addition.

If the owner or agent do not, within twenty days after the modifications proposed by the Secretary of State are received by hinı, olject in writing to them, the proposed special rules, with such modifications, shall be established.

If the owner or agent sends his objection in writing within the said twenty days to the Secretary of State, the matter shall be referred to arbitration, and the date of the receipt of such objection hy the Secretary of State shall be deemed to be the date of the reference, and the rules shall be established as settled by an award on arbitration.

27. After special rules are established under this act in any mine, the owner or agent of such mine may from time to time propose in writing to the inspector of the district for the approval of a Secretary of State any amendment of such rules or any new special rules, and the provisions of this act with respeet to the original special rules shall apply to all such amendments and new rules in like manner, as near as may be, as they apply to the original rules.

A Secretary of State may from time to time propose in writing to the owner or agent of a mine in which there are no special rules, any special rules, and to the owner or agent of a mine in which there are special rules, any new special rules, or any amendment to such special rules, and the provisions of this act with respect to a proposal of the Secretary of State for modifying the special rules transmitted by the owner or agent of a mine shall apply to all such proposed speeial rules, new special rules, and amendments in like manner, as near as may be, as they apply to such proposal.

28. For the purpose of nlaking known the special rules (if any) and the provisions of this act to all persons employed in and abont each mine to which this act applies, an abstract of the act supplied, on the application of the owner or agent of the mine, by the inspeetor of the distriet on hehalf of a Secretary of State, and an entire copy of the special rules (if any) shall be published as follows:

(1.) The owner or agent of such mine shall cause such abstract and rulos (if any), with the name and address of the inspector of the district, and the name of the owner or agent appended thereto, to be posted up in legible characters, in some conspicuous place at or near the mine, where they may be conveniently read by the persons employed; and so often as the same become defaced, obliterated, or destroyed, shall cause then to be renewed with all reasonable despateh :

(2.) The owner or agent slall supply a printed copy of the abstract and the special rules (if any) gratis to each person employed in or about the mine who applies for such copy at the office at which the persons inmediately employed by such owner or agent are paid:

(3.) Every copy of the special rules shall be kept distinct from any rules which depend only on the contract between the employer and employed.

If any owner or agent fail to act in compliance with this section he shall be guilty of an offence against this act, but the owner shall not be decmed guilty if he prove that he has taken all reasonable means, by enforcing the observance of this section, to prevent such non-compliance.

*29. Every person who pulls down, injures, or defaces any proposed [*685] 40 MAs. \& SER. 
special rules, notice, abstract, or special rules when posted up in pursuance of the provisions of this act with respect to special rnles, or any notice posted up in pursuance of the special rules, shall be guilty of an offence against this act.

30. An inspector under this act shall, when required, certify a copy which is shown to his satisfaction to be a true copy of any special rules which for the time being are established under this act in any mine, and a copy so certified shall be evidence (but not to the exclusion of other proof) of such special rules and of the fact that they are duly established under this act, and have been signed by the inspector.

\section{PART III.-SUPPI.EMENTAL.}

\section{Penalties.}

31. Every person employed in or about a mine, other than an owner or agent, who is guilty of any act or omission which in the case of an owner or agent would be an offence against this act, shall be deemed to be guilty of an offence against this act.

Every person who is guilty of an offence against this act shall be liable to a penalty not exceeding, if he is an owner or agent, twenty pounds, and if he is any other person two pounds, for each offence; and if an inspector has given written notice of any such offence, to a further penalty not exceeding one pound for every day after such notice that such offence continues to be committed.

32. Where a person who is an owner or agent or a person employed in or about a mine is guilty of any offence against this act which, in the opinion of the court that tries the case, is one which was reasonably calculated to endanger the safety of the persons employed in or about the mine, or to cause serious personal injury to any such persons, or to cause a dangerous accident, and was committed wilfully by the personal act, personal default, or personal negligence of the person accused, such person shall be liable, if the court is of opinion that a pecuniary penalty will not meet the circumstances of the case, to imprisonment, with or without hard labour, for a period not exceeding three months.

If any person feel aggrieved by any conviction made by a court of summary jurisdiction on determining any information under this act, by which conviction imprisonment is adjudged in pursuance of this section, or by which conviction the sum adjudged to be paid amounts to or exceeds half the maximum penalty, the person so aggrieved may appeal therefrom, subject to the conditions and regulations following:

(1.) The appeal shall be made to the next court of general or quarter sessions $[$ the rest of this subsection, and subsections (2), (3), (4) \& (5), were repealed by 47 \& 48 Vict. c. 43$]$.

Provided that in Scotland-

(1.) This section shall not apply to any conviction made by a sheriff:

(2.) The term "entering into recognizance before a justice of the peace" shall mean finding caution with the clerk of the justices of the peace to the satisfaction of a justice of the peace; and the term "recognizance" shall mean a bond of caution:

(3.) It shall be competent to any person empowered to appeal by this section, to appeal against a conviction by a sheriff to the next circuit court; or where there are no circuit courts to the high court of justiciary at Edinburgh, in the manner prescribed by such of the provisions of the act of the twentieth year of the reign of King George the Second, chapter forty-three, and any acts amending the same, as relate to appeals in matters criminal, and by and under the rules, limitations, conditions, and restrictions contained in the said provisions.

[*686] *33. All offences and penalties under this act, and all money and costs by this act directed to be recovered as penalties, may be prosecuted and re-

(a) Sic, read "manner." 
corered in matter $(a)$ directed by the Summary Jurisdiction Acts before a court of summary jurisdiction.

The "Court of Summary Jurisdiction," when hearing and determining an information or complaint, shall be constituted-

(a.) In England, either of two or more justices of the peace in petty sessions sitting at a place appointed for holding petty sessions, or of some magristrate or officer for the time being empowered by law to do alone any act authorised to be done by more than one justice of the peace and sitting alone or with others at some court or other place appointed for the administration of justice; or

(b.) In Scotland, of two or more justices of tle peace sitting as judges in a justice of the peace court, or of the sheriff or some other magistrate or officer for the time being einpowered by law to do alone any act authorised to be done by more than one justice of the peace, and sitting alone or with others at some court or place appointed for the administration of justice; or

(c.) In Ireland, within the police district of Dublin metropolis, of one of the divisional justices of that district sitting at a police court within the district; and clsewhere of two or more justices of the peace sitting in petty scssions at a place appointed for holding petty sessions.

34. In every part of the United Kingdom the following provisions shall have effect:

1. Any complaint or information made or laid in pursuance of this act shall be made or laid within three months from the time when the matter of such complaint or information respectively arose:

[Subseetions 2 \& 3 uere repcaled by 47 \& 48 Viet. e. 43.]

4. The owner or agent may, if he think fit, be sworn and examined as an ordinary witness in the case where he is charged in respect to any contravention or non-compliance by another person:

5. The court shall, if required by either party, cause minutes of the evidence to be taken and preserved.

35. No prosecution shall be instituted against the owner or agent of a mine to which this act applies for any offence under this act which can be prosecuted before a court of summary jurisdiction, except by an inspector, or with the consent in writing of a Secretary of State; and in the case of any offence of which the owner or agent of a mine is not guilty, if he proves that he had taken all reasonable means to prevent the commission thereof, an inspector shall not institute any'prosecution against such owner or agent, if satistied that he had taken such reasonable means as aforesaid.

36. In Scotland the following provisions shall have cffect:

(1.) All jurisdictions, powers, and authorities necessary for the court of summary jurisdiction under this act are herelyy conferred on that court:

(2.) Every person tound liable under this act in any penalty, or to pay any money or costs of this act directed to be recovered as penalties, shall be liable in default of immediate payment to be imprisoned for a term not execeding three months, and the conviction and warrant may he in the form of No. 3 of Schedule K. of the Summary Procedure Act, 1864.

37. Nothing in this act shall prevent any person from being indieted or liable under any other act, or otherwise to any other or higher penalty or ${ }^{*}$ punishment than is provided for any offence by this act, so that no [*687] person be punished twice for the same oflence.

If the court before whom a person is charged with an offence under this act think that proceedings ought to be taken against such person for such oflence under any other act or otherwise, the court may adjourn the case to enable such proceedings to be taken.

38. Where a penalty is imposed under this act for neglecting to send a notice of any explosion or accident or for any offence against this act which has oceasioned loss of life or personal injury, the Secretary of State may (if he think 
fit) direct sueh penalty to be paid to or distributed among the persons injured, and the relatives of any persons whose death may have been occasioned by such explosion, accident, or offence, or among some of them :

Provided that-

(1.) Such persons did not in his opinion occasion or contribute to occasion the explosion or accident, and did not commit and were not parties to committing the offence :

(2.) The fact of such payment or distribution shall not in any way affect or be receivable as evidence in any legal proceeding relative to or consequential on such explosion, accident, or offence:

Sare as aforesaid, all penalties imposed in pursnance of this act shall be paid into the receipt of her Majesty's Exchequer, and shall be carried to the Consolidated Fund.

In Ireland all penalties imposed and recovered under this act shall be applied in manner directed by the Fines Act (Ireland), 1851, and any act amending the same.

\section{Miscellaneous.}

39. If any question arises whether a mine is a mine to which this act, or the Coal Mines Regulation Act, 1872, applies, such question shall be referred to a Secretary of State, whose decision thereon shall be final.

40. All notices under this act shall be in writing or print, or partly in writing and partly in print, and all notices and documents required by this act to be served or sent by or to an inspector or Secretary of State may be either delivered personally, or served and sent by post, by a prepaid letter, and if served or sent by post shall be deemed to have been served and received respectively at the time when the letter containing the same would be delivered in the ordinary course of post ; and in proving such service or sending, it shall be snfficient to prove that the letter containing the notice was properly addressed and put into the post.

41. In this act, unless the context otherwise requires, -

The term "mine" includes every shaft in the course of being sunk, and every level and inclined plane in the course of being driven for commencing or opening any mine, or for searching for or proving minerals, and all the sliafts, levels, planes, works, machinery, tramways, and sidings, both below gronnd and above ground, in and aljacent to a mine, and any such shaft, level, and inclined plane, and belonging to the mine:

The term "shaft" includes pit :

The term "plan" includes a map and section, and a correct copy or tracing of any original plan as so defined :

The term "owner" when used in relation to any mine means any person or body corporate who is the immediate proprietor, or lessee, or occupier of any mine, or of any part thereof, and does not include a person or body corporate who merely receives a royalty, rent, or fine from a mine, or is merely the proprietor of a mine subject to any lease, grant, or license for the working thereof, or is merely the owner of the soil, and not_interested in the minerals of the mines:

The term "agent" when used in relation to any mine means any person having, on behalf of the owner, care or direction of any mine, or of any part thereof:

[*688] *The term "Secretary of State" means one of her Majesty's principal Secretaries of State:

The term Summary Jurisdiction Acts means as follows:-

As to England, the act of the session of the elerenth and twelfth years of the reign of her present Majesty, chapter forty-three, intitnled "An Act to facilitate the performance of the duties of jnstices of the peace out of sessions within England and Wales with respect to summary convictions and orders," and any acts amending the same $(a)$ :

(a) See the Summary Jurisdiction Act, $1879,42 \& 43$ Vict. c. 49. 
As to Scotland, "The Summary Procedure Aet, 1864 :"

As to Ireland, within the polise distriet of Dublin metropolis, the acts regulating the powers and duties of justices of the peace for such district, or of the police of such district; and elsewhere, "The Petty Scssions (Ireland) Aet, 1851," and any act amending the same :

The term "Court of Summary Jurisdiction" means-

In England and Ireland, any justice or justices of the peace, metropolitan police magistrate, stipendiary or other magistrate, or ofticer, by whatever name called, to whom jurisdiction is given by the Summary Jurisdiction Acts or any acts therein referred to:

In Scotland, any justice or justices of the peace, sheriff, or other magistrate, to the proceedings before whom for the trial or prosecution of any ofience, or for the recovery of any penalty under any act of parliament, the provisions of the Summary Jurisdiction Acts may be applied.

42. In the application of this act to Scotiand-

(1.) The term "chairman of quarter sessions" means the sheriff of the county.

(2.) The term "sheriff" includes "sheriff substitute."

(3.) The queen's and lord treasurer's remembrancer shall perform the duties of a master to one of the superior courts under this act.

(4.) Notices of explosions, accidents, and loss of life or personal injury shall be deemed to be sent to the inspector of the district on behalf of the lord advocate :

(5.) Section sixteen of. "The Public Health (Scotland) Aet, 1867," shall be substituted for "section eight of the Nuisances Removal Act for England, 1855," as amended and extended by the Sanitary Act, 1866."

43. This act shall apply to the Isle of Man, with the following modifications :

(1.) The term "chairman of quarter sessions" means the governor, lientenant governor, or deputy governor of the said isle for the time being:

(2.) The clerk of the rolls shall perform the duties of a mastsr of one of the superior courts under this act:

(3.) The law of the said isle as to the abatement or removal of nuisances affecting the health of her Majesty's subjects shall be substituterl for section eight of "The Nuisances Removal Act for England, 1855," as amended and extended by "The Sanitary Act, 1866."

44. The persons who at the commencement of this aet are acting as inspectors under any act hereby repealed' shall continue to act in the same manner as if they had been appointed under this act.

45. The acts deseribed in the schedule to this act are hereby repealed, so fir as they are not repealed by the Coal Mines Regulation Act, 18\%:.

I'rovided that this repeal sliall not affect anytling done or suffered before the commeneement of this act, and all offences committed and penalties ineurred before the commencement of this aet may be punished and recovered in the same manner as if this act had not passed.

*SCHEDULE.

\begin{tabular}{l|l}
\hline Date of Act. & Title of Act. \\
\hline $5 \& 6$ Vict. c. $99 .$. & $\begin{array}{c}\text { An act to prohibit the employment of women and girls in } \\
\text { mines and collieries, to regulate the employ ment of } \\
\text { boys. and to make other provisions relating to persons } \\
\text { working therein. } \\
\text { An act for the regulation and inspection of mines. }\end{array}$ \\
\hline
\end{tabular}


37 \& 38 VIст. с. 48.

\section{An Act to provide for the payment of Wages without Stoppages in the Hosiery Manufacture (e). \\ [30th July, 1874.]}

Whereas a custom has prevailed among the employers of artificers in the hosiery manufacture of letting out frames and machinery to the artificers employed by them, and it is desirable to prohibit such letting of frames and machinery, and the stoppage of wages for frame rents and charges in the hosiery manufacture :

Be it enacted by, \&c., \&c., as follows :

1. In all contracts for wages the full and entire amount of all wages the earnings of labour in the hosiery manufacture shall be actually and positively made payable in net, in the current coin of the realm, and not otherwise, without any deduction or stoppage of any description whatever, save and except for bad and disputed workmanship.

2. All contracts to stop wages, and all contracts for frame rents and charges, between cmployer and artificers, shall be and are hereby declared to be illegal, null, and void.

3. If any employer shall bargain to deduct, or shall dednct, directly or indirectly, from the wages of any artificer in his employ any part of such wages for frame rent and standing or other charges, or shall refuse or neglect to pay the same or any part thereof in the current coin of the realm, he shall forteit a sum of five pounds for every offence, to be recovered by the said artificer or any other person suing for the same in the county court in the district where the offence is committed, with full costs of suit.

4. If any frame or machine which shall have been entrusted to any artificer or other person by his employer for the purpose of being used in the hosiery manufacture for such employer, or in any process incident to such manufacture, shall, whilst the same shall be so entrusted, be worked, used, or employed without the consent in writing of such employer or other person so entrusting such frame or machine, in the manufacture of any goods or articles whatever for any other person than the person by whom such frame or machine shall have been so entrusted, then and in every such case the artificer or other person to whom the same shall have been so entrusted shall forfeit and pay the sum of ten shillings for every day on an part of whieh any such frame or machine shall [*690] have been so worked, used or employed, to be recoverable by and * for the benefit of the person who shall have so entrusted the same, in the county court for the district where the offence shall have been committed, with full costs of suit.

5. No action, suit, or set-off between employer and artificer shall be allowed for any deduction or stoppage of wages, nor for any contract hereby declared illegal.

6. Nothing in this act contained shall extend to prevent the recovery in the ordinary course of law, by suit brought or commenced for the purpose, of any debt due from the artificer to the employer.

7. Within the meaning and for the purposes of this act, all workmen, labourers, and other persons in any manner engaged in the performance of any employment or operation, of what nature soever, in or about the hosiery manufacture, shall be and be deemed "artificers;" and, within the meaning and for the purposes aforesaid, all masters, foremen, managers, clerks, contractors, subcontractors, middlemen, and other persons engaged in the hiring, employment, or superintendence of the labour of any such artificers shall be and be deemed to be "employers;" and, within the meaning and for the purposes of this act, any money or other thing had or contracted to be paid, delivered, or given as a recompense, reward, or remuneration for any labour done or to be done, whether

(e) And see the Truck Act, $1 \& 2$ Will. 4 , c. 37 , ante, p. 603. 
within a certain time or to a eertain amount, or for a time or for an amount uncertain, shall be deemed and taken to be the wages of such labour; and, within the meaning and for the purposes aforesaid, any agreement, understanding, device, contrivanee, collusion, or arrangement whatsoever on the subject of wages, whether written or oral, whether direet or indirect, to which the employer and artificers are parties or are assenting, or by which they are mutually bound to each other, or whereby either of them shall have endeavored to impose an obligation on the other of them, shall be and be deemed a "contract."

8. This act shall not eommenee or take effeet till the expiration of three calendar months next after the day of passing the same.

9. This act may be cited for all purposes as the Hosiery Manufacture (Wages) Aet, 1874.

\section{8 \& 39 VIот. с. 39.}

\section{An Act to amend the provisions of the Metalliferous Mines Regula- tion Act, 1872, with respect to the annual Returns from Mines.} [19th July, 1875.]

Whereas by section ten of the Metalliferous Mines Regulation Act, $1872(f)$, the owner and agent of every mine was required to send annually such return as is mentioned in that section, and it is expedient to make further provision with respect to such return :

Be it therefore enacted by, \&c., \&c., as follows:

1. From and after the commencement of this aet, the owner or agent of every mine to which the Metalliferous Mines Regulation Aet, 1872, applies, shall, on or before the first day of February in every year, send to the inspeetor of the district on behalf of a Seeretary of State a correct return, specifying, with respect to such mine, for the year ending on the preeeding thirty-first day of Deeember, the quantity in statute weight of the mineral dressed, and of the undressed mineral which has been sold, *treated, or used, during that [*691] year, and the number of persons ordinarily employed in or about sueh mine, below ground and above ground, distinguishing those who are employed below ground and above ground, and distinguishing the different classes and ages of the persons so employed whose hours of labour are regulated by the Metalliferous Mines Regulation Aet, 1872 .

The return shall be in such form as may be from time to time prescribed by a Secretary of State, and the inspector of the district on behalf of a Secretary of State shall from time to time, on application, furnis: forms for the purpose of such return.

Every owner or agent of a mine who fails to comply with this seetion, or makes any return which is to his knowledge false in any partienlar, shall be guilty of an offence against the Metalliferous Mines Regnilation Aet, 187:?

Provided that-

(1.) In any mino where not more than twelve persons are employed underground, the returns speeifying the quantity of mineral produced shall be made by the barmaster or other loeal officer, if any, employed to collect the dues or royalty; and

(2.) Where there is sneh a harmaster or other offieer the owner or agent of such mine shall not be required to send any return specifying the number of persons employed in or abont such mine.

2. This act shall come into operation on the ?nd day of August, 1875, whieh day is in this act referred to as the commencement of this act. 
3. This act shall be construed as one with the Metalliferous Mines Regulation Act, 1872, and that act and this act may be cited together as the Metalliferous Mines Regulation Acts, 1872 and 1875 , and this act may be cited separately as the Metalliferous Mines Regulation Act, 1875.

4. Section ten of the Metalliferous Mines Regulation Act, 1872, is hereby repealed as from the commencement of this act.

Provided that such repeal shall not affect anything done or suffered in pursuance of the said section, or any obligation or liability incurred under the said section, or any penalty incurred in respect of any offence committed against the said section, or any legal proceeding or remedy in respect of such liability or penalty; and any such legal proceeding or remedy may be carried on as if this act had not passed.

38 \& 39 Vicr. c. 86.

\section{An Act for amending the Law relating to Conspiracy, and to the Protection of Property, and for other purposes.}

[13th August, 1875.]

Be it enacted by, \&c., \&c., as follows :

1. This Act may be cited as the Conspiracy and Protection of Property Act, 1875 .

2. This act shall come into operation on the 1st day of September, 1875.

\section{Conspiracy, and Protcction of Property.}

3. An agreement or combination by two or more persons to do or procure to be done any act in contemplation or furtherance of a trade dispute between employers and workmen shall not be indictable as a conspiracy if such act committed by one person would not be punishable as a crime.

[*692] *Nothing in this section shall exempt from punisliment any persons guilty of a conspiracy for which a punishment is awarded by any act of parliament.

Nothing in this section shall affect the law relating to riot, unlawful assembly, breach of the peace, or sedition, or any offence against the state or the sovereign.

A crime for the purposes of this section means an offence punishable on indictment, or an offence which is punishable on summary conviction, and for the commission of which the offender is liable under the statute making the offence punishable to be imprisoned either absolutely or at the discretion of the court as an alternative for some other punishment.

Where a person is con ricted of any such agreement or combination as aforesaid to do or procure to be done an act which is punishable only on summary conviction, and is sentenced to imprisonment, the imprisonment shall not exceed three months, or such longer time, if any, as may have been prescribed by the statute for the punishment of the said act when committed by one person.

4. Where a person employed by a municipal authority or by any company or contractor upon whom is imposed by act of parliament the duty, or who have otherwise assumed the duty of supplying any city, borough, town, or place or any part thereof, with gas or water, wilfully and maliciously breaks a contract of service with that authority or company or contractor, knowing or having reasonable cause to believe that the probable consequences of his so doing, either alone or in combination with others, will be to deprive the inhabitants of that city, borongh, town, place, or part, wholly or to a great extent of their supply of gas or water, he shall on conviction thereof by a court of summary 
jurisdiction or on indictment as hereinafter mentioned, be liable either to pay a penalty not exceeding twenty pounds or to be imprisoned for a term not exceeding three months, with or without hard labour.

Every such municipal authority, company, or contractor as is mentioned in this section shall cause to be posted up, at the gasworks or waterworks, as the case may be, belonging to such authority or company or eontractor, a printed copy of this section in some conspieuous place where the same may be conveniently read by the persons employed, and as often as sueh copy becomes defaced, obliterated, or destroyed, shall eause it to be renewed with all reasonable despatch.

If any munieipal authority or company or contractor make defanlt in eomplying with the provisions of this section in relation to such notice as aforesaid, they or he shall incur on summary conviction a penalty not exceeding five pounds for every day during which such default continues, and every person who unlawfully injures, defaces, or covers up any notice so posted up as aforesaid in pursuance of this act, shall be liable on summary conviction to a penalty not exceeding forty shillings.

5. Where any person wilfully and maliciously breaks a contraet of service or of hiring, knowing or having reasonable cause to believe that the probable consequences of his so doing, either alone or in combination with others, will be to endanger human life, or cause serious bodily injury, or to expose valuable property whether real or personal to destruction or serious injury, he shall on conviction thereof by a court of summary jurisdietion, or on indictment as hereinafter mentioned, be liable either to pay a penalty not exceeding twenty pounds, or to be imprisoned for a term not excecling three months, with or without hard labour.

\section{Miscellaneous.}

6. Where a master, being legally liable to provide for his servant or apprentice necessary food, elothing, medieal aid, or lodging, wilfully and without lawful exeuse refuses or negleets to provide the same, whereby the health of the servant or apprentice is or is likely to be seriously or permanently injured, he shall on summary conviction be liable either to * pay a penalty not [*693] execeding twenty pounds, or to be imprisoned for a term not exceeding six months, with or without hard labour.

7. Every person who, with a view to compel any other person to abstain from doing or to do any act which such other person has a legal right to do or abstain from doing, wrongfully and without legal anthority,-

1. Uses violence to or intimidates such other person or his wife or ehildren, or injures his property ; or,

2. Persistently follows such other person about from place to place; or,

3. Hides any tools, clothes, or otlier property owned or used by such other person, or deprives him of or hinders him in the use thereof; or,

4. Watches or besets the house or otler place where such other person resides, or works, or carries on business, or happens to be, or the approach to such house or place $(f)$; or,

5. Follows such other person with two or nore other persons in a disorderly manner in or through any street or road,

shall, on conviction thereof by a court of summary jurisdiction, or on indictment as hereinaiter mentioned, be liable either to jay a penalty not excecding twenty pounds, or to be imprisoned for a term not exceeding three months, with or without hard labour.

( $f$ ) Picketing consists in posting members of a trades union at all the approaches to the works struck against for the purpose of observing and reporting the workmen going to or eoming from the works, and of using such influence as may he in their power to prevent the workmen from accepting work there. Report of Trades Union Comm., 9th March, 1869, par. 68. And sce R. v. Druitt, $10 \mathrm{Cox}, \mathrm{C}$. C. 592 , which arose out of the tailors' strike in 1867. 
Attending at or near the house or place where a person resides, or works, or carries on business, or lappens to be, or the approach to such house or place, in order merely to obtain or communicate information, shall not be deemed a watching or besetting within the meaning of this section.

8. Where in any aet relating to employers or workmen a pecuniary penalty is imposed in respect of any offence under such act, and no power is given tc reduce such penalty, the justices or court having jurisdiction in respect of such offence may, if they think it just so to do, inipose by way of penalty in respect of such offence any sum not less than one fourth of the penalty imposed by such act.

\section{Legal Proccedings.}

9. Where a person is accused before a court of summary jurisdiction of any offence made punishable by this act, and for which a penalty amounting to twenty pounds, or imprisonment, is imposed, the accused may, on appearing before the court of summary jurisdiction, declare that he objects to being tried for such offence by a court of summary jurisdiction, and thereupon the court of summary jurisdiction may deal with the ease in all respects as if the accused were charged with an indictable oflence and not an offence punishable on summary conviction, and the offence may be prosecuted on indictment accordingly.

10. Every oflence nnder this act which is made punishable on conviction by a court of summary jurisdiction or on summary conviction, and every penalty under this act recoverable on summary conviction, may be prosecuted and recovered in manner provided by the Summary Jurisdietion Act.

11. Provided, that upon the hearing and determining of any indictment or information under sections four, five, and six of this act, the respective parties to the contract of serviee, their husbands or wives, shall be deemed and considered as competent wituesses.

[*694] *12. In England or Ireland, if any party feels aggrieved by any conviction made by a court of summary jurisdiction on determining any information under this aet, the party so aggrieved may appeal therefrom, subject to the conditions and regulations following:

(1.) The appeal shall be made to some court of general or quarter sessions [the rest of this section was repealed by 47 \& 48 Viet. $c .43]$.

\section{Definitions.}

13. In this act-

The expression "the Summary Jurisdiction Act" means the act of the session of the eleventh and twelfth years of the reign of her present Majesty, chapter forty-three, intituled "An Act to facilitate the performance of the duties of justices of the peace out of sessions within England and Wales with respect to summary convictions and orders," inelusive of any acts amending the same $(f)$; and

The expression "court of summary jurisdiction" means-

(1.) As respects the city of London, the lord mayor or any alderman of the said city sitting at the Mansion House or Guildhall justice room : and

(2.) As respects any police court division in the metropolitan police district, any metropolitan police magistrate sitting at the police court for that division; and

(3.) As respects any city, town, liberty, borough, place, or district for which a stipendiary magistrate is for the time being acting, such stipendiary magistrate sitting at a police court or other place appointed in that behalf; and

(4.) Elsewhere, any justice or justices of the peace to whom jurisdiction is given by the Summary Jurisdiction Act: Provided that, as respects any case within the cognisance of such justice or justices as last afore-

(f) See the Summary Jurisdiction Act, 1879, $42 \& 43$ Vict. c. 49. (696) 
said, an information under this act shall be heard and determined by two or more justices of the peace in petty sessions sitting at some place appointed for holding petty sessions.

Nothing in this section contained shall restrict the jurisdiction of the lord mayor or any alderman of the eity of London, or of any metropolitan police or stipendiary magistrate, in respect of any act or jurisdiction which may now be done or exercised by him out of court.

14. The expression "municipal authority" in this act means any of the following authorities, that is to say, the Metropolitan Board of Works, the Common Council of the city of London, the Commissioners of Sewers of the city of London, the town council of any borough for the time being subject to the act of the session of the fifth and sixth years of the reign of King William the Fourth, chapter seventy-six, intituled "An Act to provide for the Regulation of municipal corporations in England and Wales," and any act amending the same, any commissioners, trustees, or other persons invested by any local act of parliament with powers of improving, cleansing, ligliting, or paving any town, and any local board.

Any municipal authority or company or contractor who has obtained authority by or in pursuance of any general or local act of parliament to supply the streets of any eity, borough, town, or place, or of any part thereof, with gas, or which is required by or in pursuance of any general or local act of parliament to supply water on demand to the inhabitants of any eity, borough, town, or place, or any part thereof, shall for the purposes of this act be deemed to be a municipal authority or company or contractor upon whom is imposed by act of parliament the duty of supplying such city, borough, town, or place, or part thereof, with gas or water.

*15. The word "maliciously" used in reference to any offence under this [*695] act shall be construed in the same manner, as it is required by the fifty-eighth section of the act relating to malicious injuries to property, that is to sity, the act of the session of the twenty-fourth and twenty-fifth years of the reign of her present IIajesty, chapter ninety-seven, to be construed in reference to any offence committed under such last-mentioned act $(g)$.

\section{Saving Clause.}

16. Nothing in this act shall apply to seamen or to apprentices to the sea service.

\section{Repeal.}

17. On and after the commencment of this aet there shall be repealed :

I. The act of the session of the thirty-fourth and thirty-tifth years of the reign of her present Majesty, chapter thirty-two, intituled, "An Act to amend the Criminal Law relating to violence, threats and molestation" $(h)$; and

II. "The Master and Servant Act, 186\%," and the enactments specified in the first schedule to that act, with the exceptions following as to tho enactments in such schedule; (that is to saly,)

(1.) Except so much of sections one and two of the aet passed in tho thirty-third year of the reign of King George the Third, chapter fifty-tive, intituled "In Act to authorise justices of the peace to impose tines njon constables, overseers, and ot her peace or parish officers for neglect of duty, and on masters of apprentices for ill-usage of such their apprentice; and also to make provision for the execution of warrants of distress

(g) Under that seetion it is unnecessary to prove malice against the owner of the property.

(h) Which repealed 6 Geo. 4 , c. 129 ; 22 Vict. c. 34 ; and 24 \& 25 Vict. c. 100, s. 41. 
granted by magistrates," as relates to constables, overseers, and other peace or parish officers; and

(2.) Except so much of sections five and six of an act passed in the fifty-ninth year of the reign of King George the Third, chapter ninety-two, intituled "An Act to enable justices of the peace in Ireland to act as such, in certain cases, out of the limits of the counties in which they actually are; to make provision for the execution of warrants of distress granted by them; and to authorise them to impose fines upon constables and other officers for neglect of duty, and on masters for illusage of their apprentices," as relates to constables and other peace or parish officers; and

(3.) Except the act of the session of the fifth and sixth years of the reign of her present Majesty, chapter seren, intituled "An Act to explain the acts for the better regulation of certain apprentices;" and

(4.) Except sub-sections one, two, three, and five of section sixteen of "The Summary Jurisdiction (Ireland) Act, 1851," relating to certain disputes between employers and the persons employed by them; and

III. Also there shall be repealed the following enactments making breaches of contract criminal, and relating to the recovery of wages by summary procedure; (that is to say,)

(a.) An act passed in the fifth year of the reign of Queen

[*696] *Elizabeth, chapter four, and intituled "An Act touching dyvers orders for artificers, labourers, servantes of husbandrye, and apprentices ;" and

(b.) So much of section two of an act passed in the twelfth year of King George the first, chapter thirty-four, and intituled "An Act to prevent unlawful combination of workmen employed in the woollen manufactures, and for better payment of their wages," as relates to departing from service and quitting or returning work before it is finished; and

(c.) Section twenty of an act passed in the fifth year of King George the Third, chapter fifty-one, the title of which begins with the words "An Act for repealing several laws relating to the manufacture of woollen eloth in the county of York," and ends with the words "for preserving the credit of the said manufacture at the foreign market;" and

(d.) An act passed in the nineteenth year of King George the Third, chapter forty-nine, and intituled "An Act to prevent abuses in the payment of wages to persons employed in the bone and thread lace manufactory ;" and

(e.) Sections eighteen and twenty-three of an act passed in the session of the third and fourth years of her present Majesty, chapter ninety-one, intituled "An Act for the more effectual prevention of frauds and abuses committed by weavers, sewers, and other persons employed in the linen, hempen, union, cotton, silk, and woollen manufactures in Ireland, and for the better payment of their wages, for one year, and from thence to the end of the next session of Parliament;" and

(f.) Section seventeen of an act passed in the session of the sixth and seventh years of her present Majesty, chapter forty, the title of which begins with the words "An Act to amend the laws," and ends with the words "workmen engaged therein;" and

(g.) Section seven of an act passed in the session of the eighth and ninth years of her present Majesty, chapter one hundred and twenty-eight, and intituled "An Act to make further regula- 
Provided that-

tions respecting the tickets of work to be delivered to silk weavers in certain cases."

(1.) Any order for wages or further sum of compensation in addition to wages made in pursuance of section sixteen of "The Summary Jurisdiction (Ireland) Act, 1851," may be enforced in like manner as if it were an order made by a court of summary jurisdiction in pursuance of the Employers and Workmen Act, 1875, and not otherwise; and

(2.) The repcal enacted by this section shall not affect-

(a.) Anything duly done or suffered. or any right or liability acquired or incurred under any enactment hereby repealed; or

(b.) Any penalty, forfeiture, or punishment incurred in respect of any offence committed against any enactment hereby repealed; or

(c.) Any investigation, legal proceeding, or remerly in respect of any such right, liability, penalty, forfeiture, or punishment as aforesaid; and any such investigation, legal procecding, and remedy may be carried on as if this act had not passed.

\section{*Application of Act to Scotland.}

18. This Act shall extend to Scotland, with the modifieations following; that is to say,

(1.) The expression "municipal authority" means the town council of any royal or parliamentary burgh, or the commissioners of police of any burgh, town, or populous place under the provisions of the General Police and Improvement (Scotland) Act, 1862, or any local authority under the provisions of the Public Health (Scotland) Act, 1867 :

(2.) The expression "The Summary Jurisdiction Act" means the Summary Procedure Act, 1864, and any acts amending the same :

(3.) The expression "the court of summary jurisdiction" means the sheriff of the county or any one of his substitutes.

19. In Scotland the following provisions shall have effect in regard to the prosecution of offences, recovery of penalties, and making of orders under this act :

(1.) Every offence under this act shall be prosecuted, every penalty recovered, and every order made at the instance of the Lord Advocate, or of the Procurator Fiscal of the sheriff court :

(2.) The proceedings may be on indictment in the Court of Justiciary in Edinburgh or on circuit or in a sheriff court, or may be taken summarily in the sheriff court under the provisions of the Summary I'rocedure Act, 1864 :

(3.) Every person found liable on conviction to pay any penalty under this act shall be liable, in default of payment within a time to be fixed in the conviction, to be imprisoned for a term, to be also fixed therein, not exceeding two months; or until snch penalty shall be sooner paid, and the conviction and warrant may be in the form of No. 3 of Schedule K. of the Summary Procedure Act, 1864 :

(4.) In Scotland all penalties imposed in pursuance of this act shall be paid to the clerk of the court imposing them, and shall by him be accounted for and paid to the Queen's and Iord 'Treasurer's Remembruncer, and be carried to the Consolidated Fund.

20. In Scotland it shall be competent to any person to appcal against any order or conviction under this act to the next cireuit Court of $J$ usticiary, or where there are no eirenit courts to the High Conrt of Justiciary at Edinburgh, in the nuanner prescribed by and under tle rules, limitations, conditions, and restrictions contained in the act passed in the twentietl year of the reign of his Majesty King George the Second, chapter forty-three, in regard to appeals to circuit conrts in matters criminal, as the same may be altered or amended by any acts of Parliament for the time being in force. 


\section{Application of Act to Ireland.}

21. This act shall extend to Ireland, with the modifications following; that is to say,

The expression "The Summary Jurisdiction Act" shall be construed to mean, as regards the police district of Dublin metropolis, the acts regulating the powers and duties of justices of the peace for such district; and elsewhere in Ireland, the Petty Sessions (Ireland) Act, 1851, and any acts amending the same :

The expression "court of summary jurisdiction" shall be construed to mean any justice or justices of the peace, or other magistrate to whom jurisdiction is giren by the Summary. Jurisdiction Act:

The conrt of summary jurisdiction, when hearing and determining complaints under this act, shall in the police district of Dublin metropolis be

[*698] constituted of one or more of the divisional justices of *the said district, and elsewhere in Ireland of two or more justices of the peace in petty sessions'sitting at a place appointed for holding petty sessions :

The expression "municipal anthority" shall be construed to mean the town council of any borough for the time being, subject to the act of the session of the third and fourth years of the reign of her present Majesty, chapter one hindred and eight, entitled "An Act for the Regulation of Municipal Corporations in Ireland," and any commissioners invested by any general or local act of Parliament, with power of improving, clcansing, lighting. or paving any town or township.

\section{8 \& 39 Vіст. с. 90.}

An Act to enlarge the powers of County Courts in respect of disputes betueen Employers and Workmen, and to give other Courts a limited civil jurisdiction in respect of such disputes.

[13th August, 1875.]

Be it enacted by, \&c., \&c., as follows:-

\section{Preliminary.}

1. This act may be cited as the Employers and Workmen Act, 1875.

2. This act, except so far as it authorises any rules to be made or other thing to be done at any time after the passing of this act, shall come into operation on the 1st day of September, 1875.

\section{PART I, \\ Jurisdiction-Jurisdiction of County Court.}

3. In any proceeding before a county court in relation to any dispnte between an employer and a workman arising out of or incidental to their relation as such (which dispute is hereinafter referred to as a dispute under this act) the court may, in addition to any jurisdiction it might have exercised if this act had not passed, exercise all or any of the following powers; that is to say,

(1.) It may adjust and set off the one against the other all such claims on the part either of the employer or of the workman, arising out of or incidental to the relation between them, as the court may find to be subsisting. whether such claims are liquidated or unliquidated, and are for wages, damages, or otherwise; and,

(2.) If, having regard to all the circumstances of the case, it thinks it just to do so, it may rescind any contract between the employer and the work- 
man upon such terms as to the apportionment of wages or other sums due thereunder, and as to the payment of wages or damages, or other sums due, as it thinks just ; and,

(3.) Where the court might otherwise award damages for any breach of contract it may, if the defendant be willing to give seeurity to the satisfaction of the court for the performance by him of so much of his contract as remains unperformed, with the consent of the plaintiff, accept such security, and order performance of the contract aceordingly, in place either of the whole of the damages which would otherwise have been awarded, or some part of such damages.

*The security shall be an undertaking by the defendant and [*699] one or more surety or sureties that the defendant will perform his contract, subject on non-performance to the payment of a sum to be specified in the undertaking.

Any sum paid by a surety on behalf of a defendant in respect of a security under this act, together with all costs incurred by such surety in respect of such security, shall be deemed to be a debt due to him from the defendant; and where such seenrity has been given in or under the direction of a court of summary jurisdiction, that court may order payment to the surety of the sum which has so become due to him from the defendant.

\section{Court of Summary Jurisdietion.}

4. $A$ dispute $(i)$ under this act between an employer and a workman may be heard and determined by a court of sunımary jurisdiction, and suèh, court, for the purposes of this act, shall be deemed to be a court of civil jurisdiction, and in a proceeding in relation to any such dispute the court may order payment of any sum which it may find to be due as wages, or damages $(k)$, or otherwise, and may exercise all or any of the powers by this aet conferred on a county court: Provided that in any proceeding in relation to any such dispute the court of summary jurisdiction-

(1.) Shall not exercise any jurisdiction where the amount elaimed exceea ten pounds; and

(2.) Shall not make an order for the payment of any sum exceeding ten pounds, exclusive of the costs ineurred in the case; and

(3.) Shall not require security to an amount exceeding ten pounds from any defendant or his surety or sureties.

5. Any dispute between an apprentice to whom this act applies and his master, arising out of or incidental to their relation as such, (which dispute is hereinafter referred to as a dispute under this act,) may be heard and determined by a court of summary jurisdiction.

6 . In a proceeding before a court of summary jurisdiction in relation to a dispute under this act between a master and an apprentice (l), the court shall have the same powers as if the dispute were between an employer and a workman, and the master were the employer and the apprentice the workman, and

(i) Absenting himself without notice by a workman, and complaint thereon to the justices by the employer, amounts to a dispute so as to give justices jurisdiction. Clemson v. Hubbard, 45 L. J., M. C. $69 ; 1$ Ex. Div. 179; 33 L. T., N. S. 814. And see Leslie v. Fitzpatrick, 47 L. J., M. C. $22 ; 3$ Q. 13. D. 229, where the workman was an infant. See also Grainger v. Aymsley, 6 Q. B. D. 182; 50 L. J., M. C. 48.

(k) In Hindley v. Haslam, 3 Q. B. D. 481, it was held that an employer might proceed against his workman before the justices for negligently damaging materials, although the workman had sued him for wages in the county court, and recovered them.

(l) If the complaint against the apprentice amounts to a charge of felony he is eutitled to the verdict of a jury. In rc Jacklin, 2 D. \& L. 103. 
the instrument of apprenticeship a contract between an employer and a workman, and shall also have the following powers:-

(1.) It may make an order directing the apprentice to perform his duties under the apprenticeship; and

(2.) If it rescinds the instrument of apprenticeship it may, if it thinks it just so to do, order the whole or any part of the premium paid on the binding of the apprentice to be repaid.

[*700] *Where an order is made directing an apprentice to perform his dnties under the apprenticeship, the court may from time to time, if satisfied after the expiration of not less than one month from the date of the order that the apprentice has failed to comply therewith, order him to be imprisoned for a period not exceeding fourteen days.

7. In a proceeding before a conrt of summary jurisdiction in relation to a dispute under this act between a master and an apprentice, if there is any person liable, under the instrument of apprenticeship, for the good condnct of the apprentice, that person may, if the court so direct, be summoned in like manner as if he were the defendant in such proceeding to attend on the hearing of the proceeding, and the court may, in addition to or in substitution for any order which the court is authorised to make against the apprentice, order the person so summoned to pay damages for any breach of the contract of apprenticeship to an amount not exceeding the limit (if any) to which he is liable under the instrument of apprenticeship.

The court may, if the person so summoned, or any other person, is willing to give security to the satisfaction of the court for the "performance by the apprentice of his contract of apprenticeship, accept such security instearl of or in mitigation of any punishment which it is authorised to inflict upon the apprentice.

\section{PART II.}

\section{Procedure.}

8. A person may give security under this act in a connty conrt or court of summary jurisdiction by an oral or written acknowledgement in or under the direction of the court of the nndertaking or condition by which and the sum for which he is bound, in such manner and form as may be prescribed by any rule for the time being in force, and in any case where security is so given, the conrt in or under the direction of which it is given may order payment of any sum which may become due in pursuance of such security.

The Iord Chancellor may at any time after the passing of this act, and from time to time make, and when made, rescind, alter, and add to, rules with respect to giving security under this act.

9. Any dispute or matter in respect of which jurisdiction is given by this act to a court of summary jurisdiction shall be deemed to be a matter on which that court has anthority by law to make an order on complaint in pursuance of the Summary Jurisdiction Act, but shall not be deemed to be a criminal proceeding; and all powers by this act conferred on a court of summary jurisdiction shall be deemed to be in addition to and not in derogation of any powers conferred on it by the Summary Jurisdiction Act, except that a warrant shall not be issued under that act for apprehending any person other than an apprentice for failing to appear to answer a complaint in any proceeding under this act, and that an order made by a conrt of summary jurisdiction under this act for the payment of any money shall not be enforced by imprisonment except in the manner and under the conditions by this act provided; and no goods or chattels shall be taken under a distress ordered by a court of summary jurisdiction which might not be taken under an execution issned by a county court.

A court of summary jurisdiction may direct any sum of money, for the payment of which it makes an order under this act, to be paid by instalments, and may from time to time rescind or vary such order.

Any sum payable by any person under the order of a court of summary juris- 
diction in pursuance of this act, shall be deemed to be a debt due from him in pursuance of a judgment of a competent court * within the meaning of [*\%01] the fifth section of the Debtors Act, $1869(\mathrm{~m})$, and may be enforced accordingly; and as regards any such debt a court of summary jurisdiction shall be deemed to be a court within the meaning of the said section.

The Lord Chancellor may at any time after the passing of this act, and from time to time make, and when made, rescind, alter, and add to, rules for carrying into effect the jurisdiction by this act given to a court of summary jurisdiction, and in particular for the purpose of regulating the costs of any proceedings in a court of summary jurisdietion, with power to provide that the same shall not exceed the costs which wonld in a similar case be incurred in a county court; and any rules so made, in so far as they relate to the exercise of jurisdiction under the said fifth section of the Debtors Act, 1869, shall be deemed to be prescribed rules within the-meaning of the said section.

\section{PART III.-Definitions and Miscellaneors.}

\section{Definitions.}

10. In this act-

The expression "workman" does not include a domestic or menial servant, but save as aforesaid, means any person who, being a labourer, servant in husbandry $(n)$, journeyman, artificer, handicraftsman, miner, or otherwise engaged in manual labour $(o)$, whether under the age of twenty-one years or above that age, has entered into or works under a contract with an employer, whether the contract be made before or after the passing of this act, be express or implied, oral or in writing, and be *a contract of service or a contract personally [ ${ }^{*} 702$ ] to execute any work or labour.

The expression "the Summary Jurisdiction Act" means the act of the ses-

(m) Sub-s. (b) of that section was repealed by "The Bankruptcy Act, 1883," $46 \& 47$ Viet. c. 52, s. 169.

(n) It was held that a person engaged by the owner of a farm to keep the general accounts of the farm, to weigh out food for eattle, to set men to work, to lend a hand to anything if wanted, and in all things to carry out the orders given to him, was not "a servant in husbandry" within 4 Geo. 4 , c. 34 , but rather in the position of a steward or bailiff. Davies v. Berwick, 30 L. J., M. C. 84. It was also held that a magistrate had no jurisdiction nnder 4 Geo. 4, e. 34, over a contract to weave certain pieces of silk goods at certain prices agreed upon. Hardy v. Royle, 9 B. \& C. 603 ; or a contract to make and complete a road of certain dimensions aceording to a specification for a certain sum, Laneaster v. Greaves, 9 B. \& C. 628 ; or a building contract, West v. Smallwood, $3 \mathrm{M}$. \& W. 418 ; or a contract to print certain pieces of woollen goods, Ex parte Jolinson, 7 Dowl. 702; Jolnson v. Reid, 6 M. \& W. 124; as they were not contracts of hiring and service, but of a different nature.

(o) A potter's printer under a contraet with his employers to do work in which he was assisted by "transferrers," whom he engaged and paid, was held t) he within the act. Grainger v. Aynsley, 6 Q. B. D. 182; 50 L. J., M. C. 48. In Wiles v. Cooper, 3 A. \& E. 524, it was considered donbtful whether under the now repealed acts of 20 Geo. 2 , c. 19 , and 4 Geo. 4, c. 34 , justices had power to order payment on an information" for wages for labour as a carpenter." And see Riley v. Warden, 2 Ex. 59 ; Sharman v. Saunders, 133 C. B. 166 ; Ingram v. Barnes, 26 L. J., Q. B. 82 ; Slceman $\checkmark$. Barrett, 32 L. J., Ex. 153; Pillar v. Llynvi Coal and Iron Co., 38 I. J., C. P. 29.4; I. R., 4 C. P. 752 ; Whiteley v. Armitage, 13 Weekly Rep. 144 , as to the meaning of the word "labourer" in the Truck Act, $1 \& 2$ Will. 4, c. 37, ante, p. 603; and $R$. v. Wort$l e y, 21$ L. J., M. C. $44 ; 2$ Den. C. C. 333, ante, p. 51, as to the meaning of that word in the Stamp Act. A farmer is not a "labourer" under the Lord's Day Act. R. v. Cleworth, 4 Best \& S. $92 \%$.

$$
41 \text { Mas. \& SFr. }
$$


sion of the eleventh and twelfth years of the reign of her present Majesty, chapter forty-three, intituled "An Act to facilitate the performance of the duties of Justices of the Peace out of sessions within England and Wales with respect to summary convictions and orders," inclusive of any acts amending the same $(0)$.

The expression "court of summary jurisdiction" means-

(1.) As respects the city of London, the Lord Mayor or any alderman of the said city sitting at the Mansion House or Guildhall justice room ; and

(2.) As respects any police court dirision in the metropolitan police distriet, any metropolitan police magistrate sitting at the police court for that division; and

(3.) As respects any city, town, liberty, borongh, place, or district for which a stipendiary magistrate is for the time being acting, such stipendiary magistrate sitting at a police court or other place appointed in that behalf; and

(4.) Elsewhere any justice or justices of the peace to whom jurisdiction is given by the Summary Jurisdiction Act : Provided that, as respects any case within the cognizance of such justice or justices as last aforesaid, a complaint under this act shall be heard and determined, and an order for imprisonment made by two or more justices of the peace in petty sessions sitting at some place appointed for holding petty sessions.

Nothing in this section contained shall restrict the jnrisdiction of the Iord Mayor or any alderman of the city of London, or of any metropolitan police or stipendiary magistrate in respect of any act or jurisdiction which may now be done or exercised by him ont of court.

11. In the case of a child, young person, or woman subject to the provisions of the Factory Acts, 1833 to $1874(p)$, any forfeiture on the ground of absence or leaving work shall not be deducted from or set off against. a claim for wages or other sum due for work done before such absence or leaving work, except to the amount of the damage (if any) which the employer may have sustained by reason of such absence i $r$ leaving work $(q)$.

\section{Application.}

12. This act, in so far as it relates to apprentices, shall apply only to an apprentice to the business of a workman as defined by this act upon whose binding either no premium is paid, or the premium (if any) paid does not exceed twenty-five pounds; and to an apprentice bound under the provisions of the acts relating to the relief of the poor.

\section{Saving Clause.}

13. Nothing in this act shall take away or abridge any local or special jurisdiction touching apprentices.

This act shall not apply to seamen or to apprentices to the sea service.

[*703]

$$
\text { *PART IV. }
$$

\section{Application of Act to Scotland.}

14. This act shall extend to Scotland, with the modifications following; that is to say,

In this act with respect to Scotland-

(o) See the Snmmary Jurisdiction Act, 1879, $42 \& 43$ Vict. c. 49.

(p) These acts were repealed by "The Factory and Workshop Act, 1878," 41 $\& 42$ Vict. c. 16, s. 107 , post.

(q) See Warburton v. Heyuorth, 50 L. J., C. L. 137 ; 6 Q. B. Div. 1, distinguishing Gregson v. Watson, 34 L. T., N. S. 143. 
The expression "county court" means the ordinary sheriff court of the county :

The expression "the court of summary jurisdiction" means the small debt court of the sheriff of the county :

The expression "sheriff" includes sheriff substitute :

The expression "instrument of apprenticeship" means indenture :

The expression "plaintiff" or "complainant" means pursuer or complainer :

The expression "defendant" includes defender or respondent :

The expression "the Summary Jurisdiction Aet" means the act of the seventh year of the reign of his Majesty King William the Fourth and the first year of the reign of her present Majesty, chapter forty-one, intituled "An Act for the more effectual recovery of small debts in the Sheriff Courts, and for regulating the establishment of circuit courts for the trial of small debt causes by the sherift's in Scotland," and the acts amending the same :

The expression "surety" means cantioner :

This act shall be read and construed, as if for the expression "the Lord Chancellor," wherever it oceurs therein, the expression "the Court of Session by act of sederunt" were substituted.

All jurisdietions, powers, and antlorities necessary for the purposes of this act are hereby eonferred on sheriftis in their ordinary or small debt courts, as the case may be, who shall have full power to make any order on any summons, petition, complaint, or other proceeding under this act, that any county court or court of summary jurisdiction is empowered to make on any complaint or other proceeding under this act.

Any decree or order pronounced or made by a sheriff under this act shall be enforced in the same manner and under the same conditions in and under which a decree or order pronounced or made by him in his ordinary or small debt court, as the case may be, is enforced.

\section{PART V.}

\section{Application of Act to Ireland.}

15. This act shall extend to Ireland, with the modifications following; that is to say,

The expression " county court" shall be construed to mean civil bill court: The expression "Lord Chancellor" sliall be construed to mean the Lord Chancellor of Ireland :

The expression "The Summary Jurisclietion Act" shall be construed to mean, as regards the police district of Dublin metropolis, the acts regnlating the powers and duties of jnstices of the peace for such district, and elsewhere in Ireland, the Petty Sessions (Ireland) Act, 1851, and any acts amending the same :

The expression "court of summary jurisliction" shall be construed to mean any justice or justices of the peace or other matgistrate to whom jurisdiction is given by the Summary Jurisdiction Act :

The court of summary jurisdiction, when hearing and determining conplaints under this act, shall in the police district of Iublin metropolis be constituted of one or more of the divisional justices *of the [*-04] said distriet, and elsewhere in Ircland of two or more justices of the peace in petty sessions sitting at a pluce appointed for holding petty sessions :

The expression "fifth section of the Dehtors Act, 1869," shall be construed to mean "sixth section of Debtors Act (Ireland), 1872." 


\section{RULES-1877.}

The rules made under the powers contained in the Employers and Workmen Act, 1875, and which are now in use in courts of summary jurisdiction in England, shall, on and from the 1st day of Norember, $187 \%$, cease to be used, and from such day there shall be used in lieu thereof, the following rules :-

1. A person desirous to enter an action in a court of summary jurisdiction in England under the Employers and Workmen Act, 1875, shall deliver to the clerk of the court particulars in writing of his cause of action, and the clerk of the court shall enter in a book to be kept for this purpose in his office a plaint in writing, stating the names, addresses, and descriptions of the parties, and the substance of the action intended to be brought; and therenpon a summons to appear to a plaint shall be issued according to the form in the schedule, and a copy thereof be served in the manner hereinafter provided, not less than four clear days before the return-day of the summons; and no misnomer or inacenrate description of any person or place in any such plaint or summons shall vitiate the same, so that the person or place be therein described so as to be commonly known.

2. The particnlars shall be annexed to and be deemed part of the summons.

3. Such summons may issue in any district in which the defendant or one of the defendants dwelt or carried on his business or was employed at the time the cause of action arose, or in which he or one of them happens to be at the time of the entry of the plaint.

4. Service of a summons to appear to a plaint may be made by serving a copy of the same personally upon the defendant, or by leaving such copy with some person, apparently sixteen years old, at the house or place of dwelling or place of business or of employment of the defendant, or of one of the defendants, or at the office of his or their employer for the time being.

\section{Witnesses.}

5. Summonses to witnesses shall be granted to either party on application and payment of the fees for the issuing and service of the same, and of the proper amount of conduct money.

\section{Hearing.}

6. A defendant shall not, except by leave of the court, on such terms as to it may seem fit, be permitted to set up against the claims of the plaintiff any set-off or counter-claim, unless he shall have served, or caused to be served, by registered post letter or otherwise, two clear days at least before the return-day, a notice directed to the plaintiff at his address as mentioned in the summons, stating his intention to rely upon such set-off or counter-claim as a defence to the action, and setting forth the particulars of such set-off or counter-claim.

7. Where service of any notice is made by post, it shall, unless the contrary be proved, be deemed to have been made on the day upon which the letter wonld have been delivered in the ordinary course of post.

$[* 705] * 8$. If upon the return-day of any summons, at any continuation or adjournment of the court, the plaintiff shall not appear, the cause may be struck out, and the court may award to the defendant, by way of costs and satisfaction for his attendance, and such sum as it in its discretion shall think fit; but the plaintiff may bring a fresh action in respect of the same cause of complaint.

9. If on the day named in the summons, or at any continuation or adjournment of the court, the defendant shall not appear, or sufficiently excnse his absence, or shall neglect to answer when called in court, the court, upon due proof of service of the summons, may either adjourn the cause from time to time or hear it ex parte, and the judgment thereupon shall be as valid as if both parties had attended; provided that the court in any such case, at the same or any subsequent court, may set aside any judgment so given in the absence 
of the defendant, and the execution thereupon, and may grant a new trial upon such terms, if any, as it may think fit.

10. Every undertaking by way of security under the said act may be given to the Court, or to such person as the court may direct, in writing or orally; and upon the production of the written undertaking, or of any note made by the clerk of the court where the undertaking was given orally, the court may summon any person liable to the court or to any surety for any sum which has become forfeited, and may make such order thereon as to the court may seem fit.

\section{Enforcing Judgment.}

11. Any sum adjudged by the court to be paid nnder the said act, and any instalment or part thereof which has become due, and any sumordered by the court to be paid in respect to the forfeiture of any sum under any security given under the said act, may be recovered by distress-warrant in the form in the schedule issued by any justice or magistrate acting in and for the district for which the court was held; provided always, that the person liable for the payment of any such sum shall have been at some time served with the order of the court in the same manner as a summons to appear to a plaint is hereby directed to be served.

12. Where an order has been made directing an apprentice to perform his $\dot{d} n-$ ties under his apprenticeship, and he shall have failed to comply therewith, no order of commitment shall be made on account of his having so failed until he shall have been personally served with a judgment-summons.

\section{Judgment-Summons.}

13. No order of commitment under the Debtors Act, 1869 , shall be made nnless a summons to appear and be examined on oath, hereinafter called a judgment-summons, shall have been personally served upon the judgment-debtor.

14. A judgment-summons may issue although no distress-warrant has been applied for, and its service where made out of the district may be proved by affidavit.

15. Every judgment-summons may be according to the form in the schedule, and shall be served not less than two clear days before the day on which the jud gment-rlebtor or apprentice is required to appear, except the judgmentdebtor or apprentice is stated to be about to remove or to be keeping out of the way to avoid service.

16. The hearing of a judgment-summons may be adjourned from time to time.

17. Any witness may be summoned to prove the means of the judgmentdebtor, in the same manner as witnesses are summoned to give evidence upon the hearing of a plaint.

*18. An order of commitment made under the Debtors Act, 1869, may [* \%06] be according to the form in the schedule, and shall, on whatever diay it may be issued, bear date on the day on which the order for commitment was made, and shall continue in force for one year from such date and no longer.

19. When an order of commitment for non-payment of money is issued, the defendant may, at any time before his body is delivered into the custody of the gaoler, pay to the officer holding such order the amount indorsed thereon as that on the payment of which he may be discharged; and on receiving such amount the ofhcer shall discharge the defendant, and shall forthwith pay over the amount to the clerk of the court.

20. The sum indorsed on the order of commitment as that upon payment of which the prisoner may be discharged may be paid to the clerk of the court from which the commitment order was issued, or to the gaoler in whose custody the prisoner is. Where it is paid to the clerk, he shall sign and seal a certificate of such payment, and upon receiving such certificate by post or otherwise, the gaoler in whose custody the prisoner shall then be shall forthwith discharge such prisoner. And where it is paid to the gaoler, he shall, upon payment to him of such amount, together with costs sufficient to pay for trans- 
mitting by post office order or otherwise such amount to the court under the order of which the prisoner was committed, sign a certificate of such payment, and discharge the prisoner, and forthwith transmit the sum so received to the clerk of the court.

21. A certificate of payment by a prisoner shall be according to the form in the schedule.

22. All costs incurred by the plaintiff in endeavouring to enforce an order shall be deemed to be due in pursuance of such order under sect. 5 of the Debtors Act, 1869, unless the court shall otherwise order.

\section{Service of Process.}

23. Service of any summons, order, or process under the act or these rules may be made by any officer duly anthorized to serve summonses within the district in which the summons, order, or process is to be served, and may be proved by affidavit, or by oath vivâ voce.

\section{Costs.}

24. The costs to be paid in the first instance by every person seeking the assistance of the court shall be those contained in the schedule annexed hereto.

25. The court may, in its discretion, allow any party, in respect of any expense he may have incurred in the employment of a solicitor, any sum not exceeding ten shillings where the sum claimed exceeds forty shillings, and not exceeding fifteen shillings where it exceeds five pounds.

\section{Forms.}

26. The forms given in the schedule shall be used, with ${ }^{\circ}$ such variation as may be necessary to meet the circumstances of each court.

29th August, 1877.

\section{*SCHEDULE.}

1.

\section{Sumuons to Apprar.}

Eimployers and Workmen Act, 1875.

In the [county of
- Petty Sessions District of
Between A. B., Plaintiff,
[Address, description, ]
and
C. D., Defendant,
[Address, description.]

].

CAIRNS, C.

\section{- CAIRNS, C.}


2.

Summons to Wits Ess.

Employers and Workmen Act, 1875.

In the [county of

- Petty Sessions District of

Between A. B., Plaintiff,

].

and

C. D., Defendant.

You are hereby required to attend at on the day of 18 , at the hour of in the noon, to give evidence in the above cause on behalf of the [plaintiff or defendant, as the case may be]. To

Given under my hand and seal this day of , 18 .

J. S. (L.S.)

3.

Judgment for Plaintiff.

Employers and Workmen Act, 1875.

In the [county of
- Petty Sessions District of
Between A. B., Plaintiff,
and

C. D., Defendant.

It is this day adjudged that the plaintiff do recover against the defendant the sum $£$ for debt [or damages], and $£$ for costs, amounting together to the sum of $£$

And it is ordered that the defendant do pay the same to the plaintiff on or before the day of [or by instalments of for every days; the first instalment to be paid on or betore the day of* , 18 ]; [*708] and if the same be not paid as ordered it is lereby further ordered that the same be levied by distress and sale of the goods and chattels of the said defendant.

Given under our hands and seals this day of .

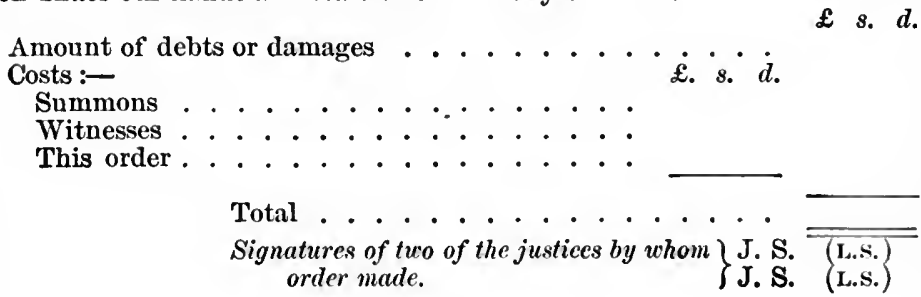

4.

JUDGMENT For Defendant.

Employers and Workmen Act, 1875,

In the [county of

$$
\begin{gathered}
\text { Petty Scssions District of } \\
\text { Between A. B., Plaintiff, } \\
\text { and } \\
\text { C. D., Defendant. }
\end{gathered}
$$

Upon hearing this eause this day, it is adjudged that judgment be entered for the defendant, and that the plaintiff do pay the sum of $\&$ for the defendant's costs on or before the diy of ; and if the same be not paid as ordered it is hereby further ordered that the same be levied by distress and sale of the goods and clattels of the said plaintiff.

Given under our hands and seals this day of , 18.

Signatures of two of the justices by whom J. S. (I..s.) oreler made. 
5.

\section{JUDGMENT SuMmoxs.}

Employers and Workmen Act, 1875, and the Debtors Act, 1869.

In the [county of . Petty Sessions District of ].

Between A. B., Plaintiff.

[Address, description,]

and

C. D., Defendant.

[Address, description.]

Whereas the plaintiff [or defendant] obtained an order against you the above-named defendant [or plaintiff] in this eourt on the 18 , for the payment of pounds shillings and pence [or that day of , you (here sct out the order made, in the casc of an apprentice, upon him to perform his duties)]:

And whereas you have made default therein :

You are therefore hereby summoned to appear personally in this court at [place where court holden] on the day of , 18, at the hour [*709] of in the noon to be examined on oath by the court *tonching the means you have or have had since the date of the order to satisfy the snm payable in pursuance of the said order; and alsot to show cause why you should not be eommitted to prison for such default.

Given under my hand and seal this day of , 18

£. s. $\quad d$.

†Amount of order, and costs

Costs of distress against the goods, if any ${ }^{*} \cdot \cdots \cdot \cdots$

$$
\text { \& s. } \quad d \text {. }
$$

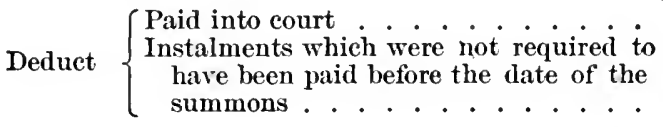

Sum payable

Cost of this summons

Amonnt upon the payment of which no further proceedings

will be had until default in payment of next instalment,

† The parts within daggers to be omitted where a summons issucs against an apprentice under section 6 of Employers and Workmen Act, 1875.

6.

\section{ORDER OF COMMTTMENT.}

Fimployers and Workmen Act, 1875, and The Debtors Act, 1869.

In the [county of Petty Sessions District of ].

Between A. B., Plaintiff, and

C. D., Defendant.

To the constable of and all other peace offieers of the county, and to the governor or keeper of the [prison of the county to which debtors are committed].

Whereas the plaintiff [or defendant] obtained an order against the defendant 
[or plaintiff] in this court on the day of , 18 , for the payment of $£ \quad[$ or, in the case of an apprentice, that he should, \&c.]:

And whereas the defendant has made default therein :

And whereas a summons was, at the instance of the plaintiff [or defendant] duly issued out of this court, by which the defendant [or plaintifi'] was required to appear personally at this court on the day of , 18 , t to be examined on oath touching the means he had then or had had since the date of the order to satisfy the sum then due and payable in pursuance of the order, and $\dagger$ to show cause why he should not be committed to prison for such default :

And whereas at the hearing of the said summons, the defendant [or plaintiff] appeared [or the summons was prosed to have been personally and duly served] and tit has now been proved to the satisfaction of the court that the defendant [or plaintiff] now has [or has had] since the *date of the [*710] order the means to pay the sum then due and payable in pursuance of the order, and has refused [or neglected] [or then refused or neglected] to pay the same, and the defendant [or plaintiff] $\dagger$ has shown no cause why he should not. be committed to prison:

Now, therefore, it is ordered that, for such default as aforesaid, the defendant [or plaintiff] shall be committed to prison for days, funless he shall sooner pay the sum stated below as that upon the payment of which he is to be discharged. $\dagger$

These are, therefore, to require you, the said constable and peace officers, to take the defendant [or plaintiff'] and to deliver him to the governor or keeper of the [prison aforesaid], and you the said governor or keeper to receive the defendant [or plaintiff] and him safely keep in the said prison for days from the arrest under this order, or until he shall be sooner discharged by due course of law.

Given under our hands and seals this [insert date of order of commitment] day of , 18

Signatures of two of the justices J. S. by whom order of committal is made. $\}$ J. S.

†Total sum payable at the time of hearing of the judgment-summons . . . . . . . . . . . . .

Hearing of summons, cost of this order, and mileage .

Total sum upon payment of which the prisoner will be discharged prior to conveyance to prison . . . . . . .

If conveyed to prison, the eonveyance thereto .....

$\dagger$ The parts within the daggers to be omilted where order made under section 6 of Employers and Workmen Act, 1875.

7.

Certificate for the Drscharge of a Prisoner from Custony.

Employers and Workmen Act, 1875, and the Debtors Act, 1869.

In the [county of

$$
\begin{gathered}
\text { Petty Sessions District of } \\
\text { Between A. B., Plaintiffs, } \\
\text { and } \\
\text { C. D., Defendant. }
\end{gathered}
$$

I hereby certify that the defendant [or plaintiff ] who was committed to your custody by virtue of an order of comnitment under the seals of two justices of this court, bearing date the day of , 18 , has paid and satisfied the sum of money for the non-payment whereof he was so committed, 
together with all costs dne and payable by him in respect thereof; and that the defendant [or plaintiff] may, in respect of such order, be forthwith discharged out of youir custody.

Dated this day of , 18

To the governor or keeper of Clerk of the Court.

[*711]

In the [county of

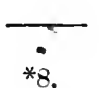

\section{DISTRESS WARRANT.}

\section{In the teounty of}
- Petty Sessions District of
Between A. B., Plaintiff, and
C. D., Defendant.

Whereas at a court holden at

$$
\text { , on the day of }
$$

].

ordered by the conrt that julgment should be entered for the plaintiff [or defendant], and that the plaintiff [or defendant] should pay to the defendant [or plaintiti'] the sum of $£$ for debt [or damages] and costs [or the defendants costs of action] on or before the day of , [or by instalments of for every days, the first instalment being ordered to be paid on or before the day of , 18 ]; and that if the same were not paid as ordered, it was further ordered that the same should be levied by distress and sale of the goods and chattels of the said defendant [or plaintiff]:

And whereas default has been made in parment according to the said order: These are therefore to command you forthwith to lery the sum of $\mathfrak{E}$

being the amount due to the plaintiff [or defendant] inder the said order, by distress of the goods and chattels of the plaintift (excepting the wearing apparel and bedding of him or his family, and the tools and implements of his trade, if any, to the value of five ponnds), together with the reasonable eharges for taking and keeping the said distress; and that you do pay what you shall have so levied to the clerk of this conrt.

Given nuder my hand and seal this

To the constable of day of, 18 .

$$
\text { J. S. (L. S.) }
$$

and all other peace officers

in the county.

NoTicE.-The goods and chattels are not to be sold nntil after the end of five clear days next following the day on which they were seized, unless they be of a perishable nature, or at the request of the said defendant [or plaintiff ].

\section{9.}

\section{Undertaking in Writixg BY Defendant to Perform Contract.}

\section{Employers and Workmen Act, $18 \%$.}

\section{In the [county of . Petty Sessions District of ]. \\ Between A. B., Plaintiff, and \\ C. D., Defendant.}

Whereas it has been found by this conrt on the day of , 18, that the defendant had broken the contract for the breach of which he was summoned:

And whereas the court would have awarded to the plaintiff the sum of 
$£$ by way of damages suffered by him in consequence of such breach, and would have ordered him to pay such sum, but that the defendant was willing to give security for the performance by him of so much of the contract as remains unperformed:

Now, therefore, I the undersigned defendant, and we the undersigned *sureties [or the undersigned surety], do undertake that the said de- [* $\left.{ }^{*} 12\right]$ fendant will perform so much of the said contract as remains unperformed, that is to say, [here set out so much ofuthe eontract as remains to be performed]:

And I, the said defendant, and we [or I] the said sureties [or surety] hereby severally acknowledge ourselves bound to forfeit to A. B., the plaintiff, the sum of pounds and shillings, in case the said defendant fails to perform what he has hereby undertaken to perform.

(Signed where not.taken orally)

Taken before me this day of $\quad, 18$.

C. D., Defendant.

E. F., G., Sureties.

\section{J. S. (L. S.)}

NoTE.-This undertaking may be given orally, and proved by the produetion of a note of the same, made at the time by the elerk of the court.

10.

Order on an Apprentice to Perform his Duties.

Employers and Workmen Act, 1875.

In the [county of

- Petty Sessions District of ].

Between A. B., Plaintiff,

and

C. D., Defendant.

It is ordered that the defendant do forthwith perform the duties he has contracted to perform under his apprenticeship to the plaintiff.

Given under our hands and seals this day of , 18 .

Signatures of two of the justices J. S. (L. S.)

by whom order made. $\}$ J. S. (L. S.)

11.

Order rescinding a Contract of Apprenticesmip.

In the [eounty of . Petly Sessions District of ].

Between A. B., Plaintiff,

and

C. D., Defendant.

It is adjudged that the [or this when ordor endorsed on deed of apprenticeship] instrument of apprenticeship made between the plaintiff and defendant be reseincled, and that the plaintiff [or defendant] do pay to $M$. N. of, the sum of pounds, being the whole [or a part] of the premium paid by the said M. N. on the binding of the defendant [or plaintiff] as apprentice to the plaintiff [or defendant].

Given under our hands and seals this day of , 18.

Signatures of two of the justiees J. S. (L. S.) by whom order made. $\}$ J. S. (L. S.) 
Order where Security given for Performance of CoNtract by ay APPRENTICE.

Employers and Workmen Act, $18 \% 5$.

In the [county of

Between A. B., Plaintiff,

\section{- Petty Sessions District of} and

C. D., Defendant.

and

E. F., bondsman under the contract of apprenticeship of the defeudant.

Whereas on the day of , 18 , it was ordered that the defendant should forthwith perform the duties he had contracted to perform under his contract of apprenticeship to the plaintiff:

And whereas it hath been made to appear to the satisfaction of the court on the oath of the plaintiff [and of G. H. of ] that the defendant has failed. to comply with the requirements of the said order :

And whereas by the said failure the defendant hath rendered himself liable to be committed :

And whereas E. F. [or R. S. of ] is willing to give security to the amount of pounds for the due pertormance by the defendant for his duties. under his said contract of apprenticeship :

Now, therefore, the court doth direct snch security to be forthwith given, and doth order that if payment of the said sum be not made on the defendant failing to perform his contract such sum may be levied by distress of the goods and chattels of the said E. F. [or R. S.], or an application be made to this court for commitment of the said E. F. [or R. S.] according to the provisions of this act.

Given under our hands and seals this. day of , 18 .

Signatures of two of the justices J. S. (L.S.)

by whom order made.

13.

Security in Writing for Performance of Contract by an Apprentice.

Employers and Workmen Act, 1875.

In the [county of $\quad$ Petty Sessions District of ].

Between A. B., Plaintiff,

and

C. D., Defendant,

and

E. F., bondsman under the contract of apprenticeship of the defendant.

Whereas on the

day of

18 , it was ordered that the defendant. should forthwith perform the duties he had contracted to perform under his contract of apprenticeship to the plaintiff :

And whereas it was made to appear to the satisfaction of the conrt that the defendant had failed to comply with the requirements of the said order:

And whereas by the said failure the defendant hath rendered himself liable to be committed :

And whereas I, E. F. [or R. S. of [*714] *give security to the amount of ] am willing to and do hereby by the defendant for his dnties under the said contract of apprenticeship, and do hereby acknowledge myself bound to forfeit to the said plaintiff the above 
sum in case the said defendant do fail to perform the duties that have been ordered to be performed by the court.

$$
\begin{array}{lll}
\text { Signed before me this day of } 18 . \text { (Signed) } & \text { E. F. or R. S. } \\
& & \text { J. S. (L.S.) }
\end{array}
$$

NoTE.-The securty may be given orally, and proced by the production of a note of the same made at the time by the clerk of the court.

\section{4.}

\section{Summons to a Bondsmax for ax APPREntice.}

\section{. Employers and Workmen Act, 1875.}

In the [county of

To E. F. of

Take notice that you are hereby summoned to attend at

$$
\begin{array}{r}
\text { Petty Sessions District of } \\
\text { Between A. B., Plaintiff, } \\
\text { and } \\
\text { C. D., Defendant. }
\end{array}
$$

\section{].}

day of , 18 , at o'clock in the noon, to show cause why the court should not, in addition to or in substitution for any order to be made against the said defendant, order you to pay the amount of any damages which it may find that the plaintiff has suffered in consequence of the breach of the contract of apprenticeship made between you and the plaintiff and the defendant.

$$
\text { Given under my hand and seal this day of , } 18 \text { J. S. (L.s.) }
$$

\section{5.}

\section{Order on a Bondsuran for an Apprentice to pay Damages.} Employers and Workmen Act, 1875.

\section{In the [county of} Between A. B., Plaintiff,

$$
\text { and }
$$

C. D., Defendant, and

E. F., bondsman mider the contract of apprenticeship of the defendant.

It is adjudged that the said boudsman do pay to the plaintiff, on or before the day of , 18 , the sum of ponnds for damages suffered by him in consequence of the breach of the contract of apprenticeship made between the plaintiff, defendant, and the said bondsman; and if the same be not paid as ordered, it is hereby further ordered that the same be levied by distress and sale of the goods and chattels of the said bondsman.
Given under our hands and seals this

$$
\text { day of }
$$ , 18 .

Signatures of two of the justices ) J. S. (I.S.) by whom order made. $\}$ J. S. (L.S.) 
*16.

Plaist Axd Misute Book.

Employers and Workmen Act, 1875.

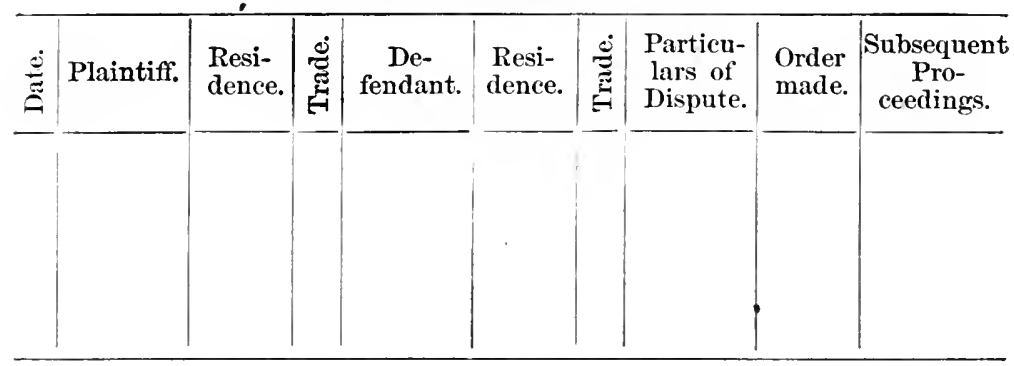

cosTs.

8. $d$.

For entry of every plaint, including summons thereon . . . . . 10

For order in writing on a plaint . . . . ........2 20

For every undertaking given by way of security . . . . . . . . 20

For judgment-summons, including hearing . . . . . . . . . 10

For warrant of distress or order of commitment . . . . . . . . 20

For summons to witness . . . . . . . . . . . . 10

N. 13. Where the sum claimed exceeds $11.0 \mathrm{~s} .0 t$. , or the sum in respect of the nonparment of which the summons for or order of commitment or warrant of distress issues exceeds 1l. 0s. 0d., an additional fee of one shilling on each fee shall be taken.

For mileage in serving or executing process, ) Such reasonable costs as may and for cost of conveying to prison ......... 29th August, $18 \% 7$.

CAIRIS, C.

\section{$39 \& 40$ Vict. о. 22.}

\section{An Act to amend the Trade Union' Act, 1871. [30th June, 1876.]}

Whereas it is expedient to amend the Trade Union Act, $1871(r)$ :

Be it therefore enacted by, \&c., \&c., as follows :

1. This act and the Trade Union Act, 1871, hereinafter termed the principal act, shall be construed as one act, and may be cited together as the "Trade Union Acts, 1871 and $1876, "$ and this act may be cited separately as the "Trade Union Act Amendment Act, 1876."

2. Notwithstanding anvthing in section five of the principal act contained, a trade union, whether registered or unregistered, which insures or pays money on the death of a child under ten years of age shall be deemed to be within the provisions of section twenty-eight of the Friendly Societies Act, 1875.

(r) $34 \& 35$ Vict. c. 31 , ante, p. 634. 
*3. Whereas by section eight of the principal act it is enacted that [*716] "the real or personal estate of any branch of a trade union shall be vested in the trustees of such branch :" The said section shall be read and construed as if immediately after the hereinbefore recited words there were inserted the words "or of the trustees of the trade union, if the rules of the trade union so provide."

4. When any person, being or having been a trustee of a trade union or of any branch of a trade union, and whether appointed before or after the legal establishment thereof, in whose name any stock belonging to such union or branch transferable at the Bank of England or Bank of Ireland is standing, either jointly with another or others, or solely, is absent from Great Britain or Ireland respectively, or becomes bankrupt, or files any petition, or executes any deed for liquidation of his affairs by assignment or arrangement, or for composition with his creditors, or becomes a lunatic, or is dead, or has been remored from his office of trustee, or if it be unknown whether such person is living or dead, the registrar, on application in writing from the secretary and three members of the union or branch, and on proof satisfactory to him, nuly direct the transfer of the stock into the names of any other persons as trustees for the union or branch; and such transfer shall be made by the surviving or continuing trustees, and if there be no such trustee, or if such trustees refuse or be unable to make such transfer, and the registrar so direct, then by the Accountant-General or Deputy or Assistant Accountant-General of the Bank of England or Bank of Ireland, as the case may be ; and the Governors and Companies of the Bank of England and Bank of Ireland respcetively are hereby indennified for anything done by them or any of their officers in pursuance of this provision against any claim or demand of any person injuriously affected thereby.

5 . The jurisdiction conferred in the case of certain offences by section twelve of the principal act upon the court of summary jurisdiction for the place in which the registered office of a trade union is situate may be exercised either by that court or by the court of summary jurisdiction for the place where the offence has been committed.

6. Trade unions carrying or intending to carry on business in more than one country shall be registered in the country in which their registered oftice is situate : but copies of the rules of such unions, and of all amendments of the same, shall, when registered, be sent to the registrar of each of the other countries, to be recordered by him, and until such rules be so recorded the union shall not be entitled to any of the privileges of this act or the principal act, in the conntry in which such rules have not been recorded, and until such amendments of rules be recorded the same shall not take effect in such country.

In this seetion " country" means England, Scotland, or Ireland.

7. Whereas by the Life Assurance Companies Act, 1870 , it is provided that the said act shall not apply. to societies registered under the acts relating to friendly societies: The said act (or the amending acts) shall not apply nor he deemed to have applied to trade unions registered or to be registered under the principal act.

8. No certificate of registration of a trade union shall be withdrawn or eancelled otherwise than by the chief registrar of friendly societies, or in the case of trade unions registered and doing business exchusively in Scotland or I reland, by the assistant registrar for Scotland or Ireland, and in the following cases:

(1.) At the request of the trade union to be evidenced in such manner as such chief or assistant registrar shall from time to time direet :

(2.) On proof to his satisfaction that a certificate of registration has been obtained by frutul or mistake, or that the registration of the trade union has become void under section six of the Trade *Union [* $\left.{ }^{*} 17\right]$ Act, 1871, (s), or that such trade union has wilfully and after notice from a registrar whom it may concern, violated any of the provisions of the trade union acts, or has ceased to exist. 
Not less than two months previous notice in writing, specifying briefiy the ground of any proposed withdrawal or cancelling of certificate (unless where the same is shown to have become void as aforesaid, in which case it shall be the duty of the chief or assistant registrar to cancel the same forthwith) shall be given by the chief or assistant registrar to a trade union before the certificate of registration of the same can be withdrawn or cancelled (except at its request).

A trade union whose certificate of registration has been withdrawn or cancelled shall, from the time of such withdrawal or cancelling, absolutely cease to enjoy as sueh the privileges of a registered trade union, but without prejudice to any liability actually incurred by such trade union, which may be entoreed against the same as if such withdrawal or cancelling had not taken place.

9. A person under the age of twenty-one, but above the age of sixteen, may be a member of a trade union, unless provision be made in the rules thereof to the contrary, and may, subject to the rules of the trade union, enjoy all the rights of a member except as herein provided, and execute all instruments and give all quittances necessary to be executed or given under the rules, but shall not be a member of the committee of management, trustee, or treasurer of the trade union.

10. A member of a trade union not being under the age of sixteen years may, by writing under his hand, delivered at, or sent to, the registered office of the trade union, nominate any person not being an officer or servant of the trade union (unless such officer or servant is the husband, wife, father, mother, child, brother, sister, nephew, or niece of the nominator), to whom any moneys payable on the death of such member not exceeding fifty pounds shall be paid at his decease, and may from time to time revoke or vary such nomination by a writing under his hand similarly delivered or sent; and on receiving satisfactory proof of the death of a nominator, the trade union shall pay to the nominee the amount due to the deceased member not exceeding the sum aforesaid.

11. A trade union may, with the approval in writing of the chief registrar of friendly societies, or in the case of trade unions registered and doing business exclusively in Scotland or Ireland, of the assistant registrar for Scotland or Ireland respectively, change its name by the consent of not less than two thirds of the total number of members.

No change of name shall affect any right or obligation of the trade union or of any member thereof, and any pending legal proceedings may be continued by or against the trustees of the trade union or any other officer who may sue or be sued on behalf of such trade union notwithstanding its new name.

12. Any two or more trade unions may, by the consent of not less than two thirds of the members of each or every such trade union, become amalgamated together as one trade union, with or without any dissolution or division of the funds of such trade unions, or either or any of them; but no amalgamation shall prejudice any right of a creditor of either or any nniou party thereto.

13. Notice in writing of every change of name or amalgamation signed, in the case of a change of name, by seven members, and countersigned by the secretary of the trade union changing its name, and accompanied by a statutory declaration by such secretary that the provisions of this act in respect of changes of name have been complied with, and in the case of an amalganation signed by seven members, and countersigned by the secretary of each or every [*718] union party thereto, and *accompanied by a statutory declaration by each or every such secretary that the provisions of this act in respect of amalgamations have been complied with, shall be sent to the central office established by the Friendly Societies Act, 1875, and registered there and until such change of name or amalgamation is so registered the same shall not take effect.

14. The rules of every trade union shall provide for the manner of dissolving the same, and notice of every dissolntion of a trade union under the hand of the secretary and seven members of the same, shall be sent within fourteen days thereafter to the central office hereinbefore mentioned, or, in the case of trade unions registered and doing business exclusively in Scotland or Ireland, 
to the assistant registrar for Scotland or Ireland respectively, and shall be registered by them: Provided, that the rules of any trade union registered before the passing of this act shall not be invalidated by the absence of a provision for dissolution.

15. A trade union which fails to give any notice or send any document which it is required by this act to give or send, and every officer or other person bound by the rules thereof to give or send the same, or if there be no such officer, then every member of the committee of management of the union, unless proved to have been ignorant of, or to have attempted to prevent the omission to give or send the same, is liable to a penalty of not less than one pound and not more than five pounds, recoverable at the suit of the chief or any assistant registrar of Friendly Societies, or of any person aggrieved, and to an additional penalty of the like amount for each week during which the omission continues.

16. So much of section twenty-three of the principal act $(s)$ as defines the term trude union, except the proviso qualifying such definition, is hereby repealed, and in lieu thereof be it enacted as follows:

The term "trade union" means any combination, whether temporary or permanent, for regulating the relations between workmen and masters, or between workmen and workmen, or between masters and masters, or for imposing restrictive conditions on the conduct of any trade or business, whether sueh combination would or would not, if the principal act had not been passed, have been deemed to have been an unlawful eombination by reason of some one or more of its purposes being in restraint of trade.

\section{$41 \& 42$ Vicr. c. 16.}

\section{An Act to consolidate and amend the Law relating to Factories and Workshops $(t)$. [27th May, 1878.]}

Be it enacted by, \&c., \&c., as follows:

\section{Preliminary.}

1. This act may be cited as the Factory and Workshop Act, 1878.

2 . This act shall come into operation on the 1st day of January, 1879 , which day is in this act referred to as the commencement of this act: Provided that at any time after the passing of this act, any appointment, regulation, or order may be made, any notice issued, form prescrihed, and act done which appears to a Secretary of State necessary or proper to be made, issued, preseribed, or done for the purpose of bringing this act into operation at the conimencement thereof.

* lart I.-Gexerai, LAW relatisg to Factorifs axd Work- [*719] sIIOPS.

\section{(1.) Sanitary Prorisions.}

3. A fictory and a workshop slatl he kept in a cleanly state and free from effuvia arising from any drain, privy, or other nuisance.

A factory or workship shall not be so overerowded while work is earried on therein as to be injurious to the health of the persons employed therein, and shall be ventilated in such a manner as to render harmless, sil far as is practicable, all the gases, vapours, dust, or other impurities generated in the course of the manufacturing process or handicraft carried on therein that may be injurious to heatth.

(s) Ante, p. 639.

( $t$ ) And see the Factory and Workshop Aet, 1883 ( $46 \& 47$ Viet. e. 53), post. 42 Mas. \& Sir. 
A factory or workshop in which there is a contravention of this section shall be deemed not to be kept in conformity with this act.

4. Where it appears to an inspector under this act that any act, neglect, or default in relation to any drain, watercloset, earthcloset, privy, ashpit, watersupply, nuisance, or other matter in a factory or workshop is punishable or remediable under the law relating to public health, but not under this act, that inspector shall give notice in writing of such act, neglect, or defanlt to the sanitary authority in whose district the factory or workshop is situate, and it shall be the duty of the sanitary anthority to make such inquiry into the subject of the notice, and take such action thereon, as to that authority may seem proper for the purpose of enforcing the law.

An inspector under this act may, for the purposes of this section, take with him into a factory or a workshop a medical officer of health, inspector of nuisances, or other officer of the sanitary authority.

\section{(2.) Safety.}

5. With respect to the fencing of machinery in a factory, the following provisions shall have effect :

(1.) Every hoist or teagle near to which any person is liable to pass or to be employed, and every fly-wheel directly connected with the steam or water or other mechanical power, whether in the engine house or not, and every part of a steam engine and water wheel, shall be securely fenced; and

(2.) Every wheel-race not otherwise secured shall be securely fenced close to the edge of the wheel-race; and

(3.) Every part of the mill gearing $(u)$ shall either be securcly fenced or be in such position or of such construction as to be equally safe to every person employed in the factory as it would be if it were securely fenced ; and

(4.) All fencing shall be constantly maintained in an efficient state while the parts required to be fenced are in motion or use for the purpose of any manufacturing process.

A factory in which there is a contravention of this section shall be deemed not to be kept in conformity with this act.

6. Where an inspector considers that in a factory any part of the machinery of any kind moved by steam, water, or other mechanical power, to which the foregoing provisions of this Act with respect to the fencing of machinery do not apply, is not securely fenced, and is so dangerous as to be likely to cause bodily injury to any person employed in the factory, the following provisions shall apply to the fencing of such machinery :

[*720] (1.) The inspector shall serve on the occupier of the factory a notice *requiring him to fence the part of the machinery which the inspector so deems to be dangerous :

(2.) The occupier, within seven days after the receipt of the notice, may serve on the inspector a requisition to refer the matter to arbitration; and thereupon the matter shall be referred to arbitration, and two skilled arbitrators shall be appointed, the one by the inspector and the other by the occupier; and the provisions of the Companies Clauses Consolidation Act, 1845, with respect to the settlement of disputes by arbitration shall, subject to the express provisions of this section, apply to the said arbitration, and the arbitrators or their umpire shall give the decision within twenty-one days after the last of the arbitrators, or, in the case of the umpire, after the umpire is appointed, or within such further time as the occupier and inspector, by writing, allow; and if the decision is not so given the matter shall be referred

(u) See post, sect. 96, and Holmes v. Clarke, 30 L. J., Exc. 135; 31 L. J., Exc.'356. 
to the arbitration of an umpire to be appointed by the judge of the county court within the jurisdiction of which the factory is situate:

(3.) If the arbitrators or their umpire decide that it is unnecessary or impossible to fence the machinery alleged in the notice to be dangerous, the notice shall be cancelled, and the occupier shall not be required to fence in pursuance thereof, and the expenses of the arbitration shall be paid as the expenses of the inspectors under this act :

(4.) If the occupier does not, within the said seven days, serve on the inspector a requisition to refer the matter to arbitration or does not appoint an arbitrator within seven dass after he served that requisition, or if neither the arbitrators nor the umpire decide that it is unnecessary or impossible to fence the machinery alleged in the notice to be dangerous, the occupier shall securely fence the said machinery in accordance with the notice, or with the award of the arbitrators or umpire if it modifies the notice, and the expenses of the arbitration shall be paid by the occupier, and shall be recoverable from him by the inspector in the county court:

(5.) Where the occupier of a factory fails to comply within a reasonable time with the requirements of this section as to securely fencing the said machinery in accordance with the notiee or award, or tails to keep the said machinery securely fenced in accordance therewit?, or fails constantly to maintain such fencing in an eflicient state while the machinery required to be fenced is in motion for the purpose of any manufacturing process, the factory shall be deemed not to be kept in conformity with this act:

(6.) For the purpose of this section and of any provisions of this act relating thereto, "machinery" shall be deemed to include any driving strap or band.

7. Where an inspector considers that in a factory or workshop a vat, pan, or other structure, which is used in the process or handicraft carried on in such factory or workshop, and near to or over which children or young persons are liable to pass or to be employed, is so dangerous, by reason of its being filled by hot liquid or molten metal or otherwise, as to be likely to be a cause of bodily injury to any child or young person eniployed in the factory or workshop, he shall serve on the occupier of the factory or workshop a notice requiring him to fence such vat, pan, or other structure.

The provisions of this act with respect to the fencing of machinery which an inspector considers not to be securely fenced and to be dangerous shall apply in like manner as if they were re-enacted in this section, with the substitution of the vat, pan, or other structure, for machinery, *and with the addition [*721] of workshop, and if the occupier of a factory or work-shop fails constantly to maintain the fencing required under this section in an efficient state, while such vat, pan, or other structure is so filled or otherwise dangerous as aforesaid, the factory or workshop shall be deemed not to be kept in conformity with this act.

8. Where an inspector observes in a factory that any grindstone, worked hy steam, water, or other mechanical power is in itself so fanlty, or is tixed in so faulty a manner as to be likely to cause bodily injury to the grinder using the same, he shall serve on the occupier of the factory a notice requiring him to replace such faulty grindstone, or to properly fix the grindstone fixed in the faulty manner.

The provisions of this act with respect to the fencing of machinery which an inspector considers not to be securely fenced and to be dangerous shall apply in like manner as if they were re-enacted in this section with the necessary modifications.

Where the occupier of a fitetory fails to keep the grindstone mentioned in the notice or award in such a state and fixed in snch manner as not to be dangerons, the factory shall be deemed not to be kept in eonformity with this act.

9. A child shall not be allowed to clean any part of the machinery in a factory while the same is in motion by the aid of steam, water, or other mechanical power. 
A young person or woman shall not be allowed to clean such part of the machinery in a factory as is mill-gearing while the same is in motion for the purpose of propelling any part of the manufacturing machinery.

A child, young person, or woman shall not be allowed to work between the fixed and traversing part of any self-acting machine while the machine is in motion by the action of steam, water, or other mechanical power.

A child, young person, or woman allowed to clean or to work in contravention of this section, shall be deemed to be employed contrary to the provisions of this act.

\section{(3.) Employment and Meal Hours.}

10. A child, young person, or woman shall not be employed in a factory or a workshop except during the period of employment hereinaf er mentioned.

11. With respect to the employment of young persons and women in a textile factory the following regulations shall be observed :

(1.) The period of employment, except on Saturday, shall either begin at six o'clock in the morning and end at six o'clock in the evening, or begin at seven o'clock in the morning and end at seven o'clock in the evening; and

(2.) The period of employment on Saturday shall begin either at six o'clock or at seven o'clock in the morning; and

(3.) Where the period of employment on Saturday begins at six o'clock in the morning, that period-

(a.) If not less than one hour is allowed for meals, shall end at one o'clock in the afternoon as regards employment in any manufacturing process, and at half-past one o'clock in the afternoon as regards employment for any purpose whatever; and

(b.) If less than one hour is allowed for meals, shall end at half an hour after noon as regards employment in any manufacturing process, and at one o'clock in the afternoon as regards employment for any purpose whatever; and

(4.) Where the period of employment on Saturday begins at seven o'clock in the morning, that period shall end at half-past one o'clock in the after-

[*722] noon as regards any manufacturing process, *and at two o'clock in the afternoon as regards employment for any purpose whatever; and

(5) There shall be allowed for meals during the said period of employment in the factory-

(a.) on every day except Saturday not less than two hours, of which one hour at the least, either at the same time or at different times, slall be before three o'clock in the afternoon; and

(b.) on Saturday not less than half an hour; and

(6.) A young person or woman shall not be employed continuously for more than four hours and a half, without an interval of at least half an hour for a meal.

12. With respect to the employment of children in a textile factory, the following regulations shall be observed-

(1.) Children shall not be employed except on the system either of employment in morning and afternoon sets, or of employment on alternate days only; and

(2.) The period of employment for a child in a morning set shall, except on Saturday, begin at the same hour as if the ehild were a young person, and end at one o'clock in the atternoon; or if the dinner time begins before one o'clock, at the beginning of dínner time; and

(3.) The period of employment for a child in an afternoon set shall, except on Saturday, hegin at one o'clock in the afternoon, or at any later hour at which the dinner time terminates, and end at the same hour as if the child were a young person $(x)$; and

(x) And see the Factory and Workshop Act, 1883 (46 \& 47 Vict. c. 53 , s. 14), post. 
(4.) The period of employment for any ehild on Saturday shall begin and end at the same hour as if the child were a young person; and

(5.) A child shall not be employed in two successive periods of seven days in a morning set, nor in two suecessive periods of seven days in an afternoon set; and a child shall not be employed on two successive Saturdays, nor on Saturday in any week if on any other day in the same week his period of employment has exceeded five hours and a half; and

(6.) When a child is employed on the alternate day system, the period of employment for such child, and the time allowed for meals, shall be the same as if the child were a young person; but the child shall not be employed on two successive days, and shall not be employed on the same day of the week in two successive weeks; and

(7.) A child shall not on either system be cmployed continuously for any longer period than he could be if he were a young person without an interval of at least half an hour for a meal.

13. With respect to the employment of young persons and women in a nontextile factory, and of young persons in a workshop, the following regulations shall be observed:

(1.) The period of employment, except on Saturday, shall (save as is in this act specially excepted) either begin at six o'clock in the morning and end at six o'clock in the evening, or begin at seven o'clock in the morning and end at seven o'clock in the evening; and

(2.) The period of employment on Saturday shall (save as is in this act speeially excepted) begin at six o'elock in the morning or at seven o'clock in the morning, and end at two o'clock in the afternoon; and

*(3.) There shall be allowed for meals during the said period of [* 723$] \mathrm{em}$ ployment in the factory or workshop-

(a.) on every day except Saturday not less than one hour and a half, of which one hour at the least, either at the same time or at different times shall be before three o'clock in the nfternoon; and

(b.) on Saturday not less than half an hour; and

(4.) A young person or a woman in a non-textile factory and a young person in a workshop shall not be employed eontinuously for more than five hours without an interval of at least half-an-hour for a meal:

14. With respect to the employment of ehildren in a non-textile factory and a workshop the following regulations shall be observed:

(1.) Children shall not be employed exeept either on the system of employment in morning and afternoon sets $(y)$, or (in a factory or workship in which not less than two hours are allowed for meals on every day except Saturday) on the system of employment on alternate days only; and

(2.) The period of enployment for a child in a morning set on every day, including Saturday, shall begin at six or seven o'clock in the morning and end at one o'elock in the atternoon, or, if the dinner time begins before one o'clock, at the beginning of dinner time; and

(3.) The period of cmployment for a ehild in un ufternoon set on every day, including Saturday, shall begin at one o'elock in the afternoon, or at any hour later than half-past twelve o'clock at which the dinner time terminates, and end on Satuday at two o'cloek in the aftermoon, and on any other day at six or seven o'clock in the evening, according as the period of employment for children in the morning set began at six or seven o'clock in the morning; and

(4.) A child shall not be employed in two snecessive periols of seven days in a morning set, nor in two suceessive periols of seven days in an afternoon set, and a child shall not be employed on Siturday in any week in the same set in which he has been employed on any other day of the same week; and 
(5.) When a child is employed on the aiternate day system-

(a.) The period of employment for such child shall, except on 'Saturday, either begin at six o'clock in the morning and end at six o'clock in the evening, or begin at seven o'clock in the morning and end at seven o'clock in the evening; and

(b.) The period of employment for such child shall on Saturday begin at six or scven o'clock in the morning, and end at two o'clock in the afternoon; and

(c.) There shall be allowed to such child for meals during the said period of employment not less, on any day except Saturday, than two hours, and on Saturday than half an hour; but

(d.) The child shall not be employed in any manner on two successive days, and shall not be employed on the same day of the week in two successive weeks; and

16.) A child shall not on either system be employed continiously for more than five hours without an interval of at least half an hour for a meal.

15. With respect to the employment of women in workshops, the following regulations shall be observed:

(1.) In a workshop which is condueted on the system of employing [*724] *therein children and young persons, or either of them, a woman shall not be employed except during the same period and subjeet to the same restrictious as if she were a young person; and the regulations of this act with respect to the employment of young persons in a workshop shall apply accordingly to the employment of women in that workshop; and

(2.) In a workshop which is conducted on the system of not employing therein eitler children or young persons-

(a.) The period of employment for a woman shall, except on Saturday, begin at six o'clock in the morning and end at nine o'clock in the evening, and shall on Saturday begin at six o'clock in morning and end at four o'clock in the afternoon; and

(b.) There shall be allowed to a woman for meals and absence from work during the period of employment not less, except on Saturday, than four hours and a half, and on Saturday than two hours and a half.

A workshop shall not be deemed to be conducted on the system of not employing therein either ehildren or young persons until the occupier has served on an inspector notice of his intention to conduct his workshop on that system.

16. Where persons are employed at home, that is to say, in a private house, room, or place which, though used as a dwelling, is by reason of the work carried on there a factory or workshop within the meaning of this act, and in which neither steam, water, nor other mechanical power is used in aid of the manufacturing process carried on there, and in which the only persons employed are members of the same family dwelling there, the foregoing regulations of this act with respect to the employment of children, young persons, and women, shall not apply to such factory or workshop, and in lieu thereof the following regulations shall be observed therein:

(1.) A child or young person shall not be employed in the factory or workshop except during the period of employment hereinatter mentioned; and

(2.) The period of employment for a young person shall, except on Saturday, begin at six o'clock in the morning and end at nine o'clock in the evening; and shall on Saturday begin at six o'elock in morning and end at four o'clock in the afternoon; and

(3.) There shall be allowed to every young person for meals and absence from work during the period of employment not less, except on Saturday, than four hours and a half, and on Saturday than two hours and a half; and

(4.) The period of employment for a child on every day either shall begin at six o'clock in the morning and end at one o'clock in the afternoon, or 
shall begin at one o'clock in the afternoon and end at eight o'clock in the evening, or on Saturday at fonr o'clock in the afternoon; and for the purposes of the provisions of this act respecting education such child shall be deemed, according to circumstances, to be employed in a morning or afternoon set; and

(5.) A child shall not be employed before the hour of one in the afternoon in two successive periods of seven days, nor after that hour in two suecessive periods of seven days; and a child shall not be employed on Saturday in any week before the hour of one in the afternoon, if on any other day in the same week he has been employed before that hour, nor after that hour if on any other day of the same week he has been employed after that lour; and

(6.) A child shall not be employed continuously for more than five hours without an interval of at least half an hour for a meal.

*17. With respect to meals the following regulations shall (save as is. [*\%25] in this act specially excepted) be observed in a factory and workshop:

(1) All children, young persons, and women employed therein shall have the times allowed for meals at the same hour of the day ; and

(2.) A child, young person, or woman shall not, during any part of the times allowed for meals in the factory or workshop, be employed in the factory or the workshop, or be allowed to remain in a room in which a manufacturing process or handicraft is then being carried on.

18. The period of employment on Saturday for a young person or woman in a non-textile factory or workshop may be of the same length as on any other day, if the period of employment of such young person or woman has not exceeded eight honrs on any day of the same week, and if notice has been affixed in the factory or workshop, and served on the inspector.

19. The occupier of a factory or workshop may from time to time tix within the limits allowed by this act, and shall (save as is in this act specially excepted) specify in a notice affixed in the factory or workshop, the period of employment, the times allowed for meals, and whether the children are employed on the system of morning and afternoon sets, or of alternate days.

The period of employment and the times allowed for meals in the factory or workshop shall be deemed to be the period and times specified in the notice affixed in the factory or workshop; and all the children in the factory or workshop shall be employed either on the system of morning and afternoon sets, or on the system of alternate days, according to the system for the time being specified in such notice :

Provided that a change in such period or times or system of employment shall not be made until after the oceupier has served on an inspector and affixed in the factory or workshop notice of his intention to make such change, and shall not be made oftener than once a quarter, unless for special cause allowed in writing by an inspector.

20. A child under the age of ten years shall not be employed in a factory or a workshop.

21. A child, young person, or woman, shall not (save as is in this act spe-eially excepted) be enployed on sunday in a factory or workshop.

\section{(4.) Holidays.}

22. The occupier of a factory or of a workshop shall (save as is in this act specially excepted) allow to every child, yolng person, and woman employed therein the following holidays; that is to say

-(1.) The whole of Christmas Day, and the whole cither of Gool Friday, or if it is so specified by the oceupier in the notice aflixed in the faetory or workshop, of the next public holiday under the Holidays lixtension Act, 1875 ; and in addition

(2.) Eight half holidays in every year, bnt a whole holiday may be allowed in lieu of any two such halif holidays; and

(3.) At least half of the said half holidays or whole holidays shall be allowed 
between the fifteenth day of March and the first day of October in erery year; and

(4.) Cessation from work shall not be deemed to be a half loliday or whole holiday, unless a notice of the half holiday or whole holiday has been affixed in the factory or workshop for at least the whole period of enployment of young persons and women on the last previous work day but one ; and

(5.) A half holiday shall comprise at least one-half of the period of employment for young persons and women on some day other than saturdiy.

[*-26] *A child, young person, or woman who-

(a.) on a whole holiday fixed by or in pursuance of this section for a fictory or workshop is employed in the factory or workshop; or

(b.) on a half holiday fixed in pursuance of this section for a factory or workshop is employed in the factory or workshop during the portion of the period of employment assigned for such half holiday,

shall be deemed to be employed contrary to the provisions of this act.

If in a factory or workshop such whole holidays or half holidays as required by this section are not fixed in conformity therewith, the occupier of the factory or workshop shall be liable to a fine not exceeding tive pounds.

\section{(5.) Educalion of Children.}

23. The parent of a child employed in a factory or in a workshop shall cause that child to attend some recognized efticient school (which school may be selected by such parent), as follows:-

(1.) The child, when employed in a morning or afternoon set, shall in every week, during any part of which he is so employed, be caused to attend on each work day for at least one attendance : and

2.) The child, when employed on the alternate day system, shall on each work day preceding each day of employment in the factory or workshop he caused to attend for at least two attendances;

(3.) An attendance for the purposes of this section shall be an attendance as defined for the time being by a Secretary of State with the consent of the Education Department, and be between the hours of eight in the morning and six in the evening.

Provided thist-

(a.) A child shall not be required by this act to attend school on Saturday or on any holiday or half holiday allowed under this act in the factory or workshop in which the child is employed; and

(b.) The non-attendance of the child shall be excused on every day on which he is certified by the teacher of the school to have been prevented from attending by sickness or other unavoidable cause, also when the school is closed during the ordinary holidays or for any other temporary cause; and

(c.) Where there is not within the distance of two miles, measured according to the nearest road, from the residence of the cliild a recognised efficient school which the child can attend, attendance at a sehosl temporarily approved in writing by an inspector nnder this act. although not a recognised efficient school, shall for the purposes of this act be deemed attendance at a recognised efficient school until such recognised efficient school as aforesaid is established, and with a view to such establishment the inspector shall immediately report to the Education Department every case of the approval of a school by him under this section.

A child who has not in any week attended school for all the attendances required by this section shall not be employed in the following week until he has attended school for the deficient number of attendances.

The Education Department shall from time to time, by the publication of lists or by notices or otherwise as they think expedient, provide for giving to all persons interested information of the schools in each school district which are recognised effieient schools. 
24. The oceupier of a factory or workshop in which a child is employed shall on Monday in every week (after the first week in which such child began to work therein), or on some other day appointed for that purpose *by an in- [*\%)7] spector, obtain from the teacher of the recognised efficient school attended by the child, a certificate (according to the preseribed form and directions) respecting the attendance of such child at school in accordance with this at.

The employment of a child without obtiaining sueh certificate as is recpuired by this section shall be deemed to be employment of a child contrary to the provisions of this act.

The occupier shall keep every such certificate for two months after the date thereof, if the child so long continnes to be employed in his factory or his workshop, and shall produce the same to an inspector when required during that period.

25. The board authority or persons who manage a recognized efficient school attended by a child employed in a factory or workshop, or some person anthorized by such board authority or person, may apply in writing to the occupier of the factory or workshop to pay a weekly sum specified in the application, not exceeding threepence and not exceeding one-twelfth part of the wayes of the child, and after that application the occupier, so long as he employs the child, shall be liable to pay to the applicants, while the child attends their school, the said weekly sum, and the sum may be reeovered as a debt, and the oceupier may deduet the sum so paid by him from the wages payable for the services of the child.

26. Wher a child of the age of thirteen years has obtained from a person anthorized by the Education IDepartment a certificate of having attained such standard of proficieney in reading, writing and arithmetic or such standard of previous due attendance at a certitied efficient school, as hereinafter mentioned, that child shall be deemed to be a young person for the purposes of this aet.

The standards of proficiency and due attendance for the purposes of this seetion shall be snch as may be from time to time fixed for the purposes of this act by a Secretary of State, with the consent of the Educational Department, and the standards so fixed shall be published in the Iondon Gazette, and slull not have effect until the expiration of at least six months after such publication.

Attendance at a certified day industrial sehool shall be deemed for the purposes of this scction to be attendance at a certified eflieient school.

\section{(6.) Certificutes of Fitncs; for Limployment.}

27. In a factory a child or a young person under the age of sixteen years shall not be employed for more than seven, or if the certifying surgeon for the district resides more than three miles from the factory, thirteen, work days, unless the occupier of the fuctory has obtained a certificate, in the prescribed form, of the fitness of such child or young person for employment in that factory.

A certificate of fitness for emplnyment for the purposes of this act shall be granted by the certifying surgeon for the district, and shall be to the efiect that he is satisfied, by the production of n certificate of birth or other sulficient evidence, that the person named in the ecrtilicate of titness is of the age therein specified, and has heen personally examined by him, and is not incapacitated lyy disease or bodily infirmity for working daily for the time allowed ly law in the factory named in the certificate.

28. In order to enable oceupiers of workshops to bet ter secure the observance of this act, and prevent the employment in their workshops of children and young persons nncter the age of sixteen years who are untitted for that cmployment, an occupier of a workshop is herehy authorized to obtain, if he thinks tit, from the certifying surgen for the district, certitieates of the fitness of children and of young persons under the age of sixteen years for employment in his workshop, in like manner as if that workshop were a fictory, and the certifying surgeon shall examine the chitdren and young persons, and grant certilicates accordingly. 
[*728] *29. Where an inspector is of opinion that a child or a young person nnder the age of sixteen years is 'hy disease or bodily infirmity incapacitated for working daily for the time allowed by law in the factory or workshop in which he is employed, he may serve written notice thereof on the occupier of the factory or workshop, requiring that the employment of such child or young person be discontinued from the period named therein, not being less than one nor more than seven days after the service of such notice, and the occupier shall not continue after the period named in such notice to employ such child or young person (notwithstanding a certificate of fitness has been previously obtained for such child or young person), unless the certifying surgeon for the district has, after the service of the notice, personally examined such child or young person, and has certified that such child or young person is not so incapacitated as aforesaid.

30. All factories and workshops in the occupation of the same occupier, and in the district of the same certifying surgeon, or any of them, may be named in the certificate of fitness for employment, if the surgeon is of opinion that he can truly give the certificate for employment therein.

The certificate of birth (which may be produced to a certifying surgeon) shall either be a certified copy of the entry in the register of births, kept in pursuance of the acts relating to the registration of births, of the birth of the child or young person (whether such copy be obtained in pursuance of the Elementary Education Act, 1876, or otherwise), or be a certificate from a local authority within the meaning of the Elementary Education Act, 1876, to the effect that it appears from the returns transmitted to such anthority in pursuance of the said act by the registrar of births and deaths that the child was born at the date named in the certificate.

Where a certificate of fitness for employment is to the cffect that the certifying surgeon has been satisfied of the age of a child or young person by evidence other than the production of a certificate of birth, an inspector may, by notice in writing, annul the surgeon's certificate, if he has reasonable cause to believe that the real agc of the child or young person named in it is less than that mentioned in the certificate, and thereupon that certificate shall be of no avail for the purposes of this act.

When a child becomes a young person a fresh certificate of fitness must be obtained.

The occupier shall, when required, produce to an inspector at the factory or workshop in whieh a child or young person is entployed, the eertificate of fitness of snch child or young person for employment, which he is required to obtain under this act.

\section{(7.) Accidents.}

31. Where there occurs in a factory or a workshop any accident which either-

(a.) canses loss of life to a person employed in the factory or in the workshop, or

(b.) causes bodily injury to a person employed in the factory or in the workshop, and is produced either by machinery moved by steam, water, or other mechanical power, or through a vat, pan, or other structure filled with hot liquid or molten metal or other substance, or by explosion, or by escape of gas, steam, or metal, and is of such a nature as to prevent the person injured by it from returning to his work in the factory or workshop within forty-eight hours after the occurrence of the accident,

written notice of the accident shall forth with be sent to the inspector and to the certifying surgeon for the district, stating the residence of the person killed or injured, or the place to which he may have been removed, and if any such notice is not sent the occupicr of the factory or workshop shall be liable to a fine not exceeding five pounds. Sce Lakeman v. Slephenson, 34 L. J., M. C. 54 ; 9 Best. \& S. 54 .

[*729] If any such accident as aforesaid oecurs to a person employed in an *iron 
mill or blast furnace, or other factory or workshop where the occupier is not the actual employer of the person killed or injured, the actual employer shall immediately report the same to the occupier, and in default shall be liable to a fine not exceeding fire pounds.

A notice of an accident, of which notice is required by section sixty-three of the Explosives Act, 1875 , to be sent to a government inspector, need not be sent to the certifying surgeon in pursuance of this section.

32 . Where a certifying surgeon receives in pursuance of this act notice of an accident in a factory or a workshop, he shall with the least possible delay proceed to the factory or workshop, and make a full investigation as to the nature and cause of the death or injury caused by that aceilent, and within the next twenty-four hours send to the inspeetor a report thereof:

The certifying surgeon, for the purpose only of an investigation under this section, shall have the same powers as an inspector, and shall also have power to enter any room in a building to which the person killed or injured has been removed.

There shall be paid to the said surgeon for the, investgation such fee, not exceeding ten or less than three shillings, as a secretary of state considers reasonable, which fee shall he paid as expenses incurred by a Secretary of State in the execution of this act.

\section{PART II.-Special Provisions relating to particulak Classes of FACTORIES ANI WORKSHOPS.}

\section{(1.) Special Provisions for Health in eertain Factories and Workshops.}

33. For the purpose of securing the observance of the requirements of this act as to eleanliness in every factory and workshop, all the inside walls of the rooms of a factory or workshop, and all the ceilings or tops of such rooms (whether such walls, ceilings, or tops be plastered or not), and all the passages and staircases of a factory or workshop, if they have not been painted with oil or varnished once at least within seven years, shall be limewashed once at least within every fourteen months, to date from period when last limewaslied; and if they have been so painterl or varnished shall be washed with hot water and soap once at least within every fourteen months, to date from period when last washed.

A factory or workshop in which there is a contravention of this section shall be deemed not to be kejt in conformity with this act.

Where it appears to a Secretary of State that in any class of fictories or workshops, or parts thereof; the regulations in this section are not required for the purpose of securing therein the observance of the requirements of this act as to cleanliness, or are by reason of special cireumstanees inapplicable, he may, if he thinks fit, by order made uncles this part of this act, gratut to such class of factories or workshops, or parts thereof, a special exception that the regulations in this section shatl not apply thereto.

34. Where a bakehouse is situate in any eity, town or place containing, according to the last published census for the time being, a population of more than five thousand persons, all the inside walls of the rooms of such bakehouse, and all the ceilings or.tops of such rooms (whether such walls, ceilings or tops be plastered or not), and all the passages and staircases of such bakehonse, shall either be painted with oil or varnished or be limewasherl, or he partly painted or varnished and partly limewashed; where painted with oil or varnished there shall be three coats of paint or varnish, and the paint or varnish shall be renewed once at least in every seven years, and shall be washed with hot water and soap once at least in every six montls; where limewashed the limewishing shall be renewed once at least in every six months.

$A$ hakelouse in which there is any contravention of this section shall be deemed not to be kept in conformity with this act.

*35. Where a bakehouse is situate in any eity, town, or place cont:uin-[*7:30] ing, aceording to the last published census for the time being, a $p^{x}$ pulation of more than five thousand persons, a place on the same level with the lakehouse, 
and forming part of the same building, shall not be used as a sleeping place, nnless it is constructed as follows ; that is to say,

unless it is effectually separated from the bakehouse, by a partition extending from the floor to the ceiling; and

unless there be an external glazed window of at leat nine superficial feet in area, of which at least four and a halt superficial feet are made to open for ventilation.

Any person who lets or occnpies or continues to let or knowingly suffers to be occupied any place contrary to this section slall be liable to a fine not exceeding, for the first offence, twenty shillings, and for every subsequent offence five pounds.

36. If in a factory or workshop where grinding, glazing or polishing, on a wheel, or any prociess is carried on, by which dust is generated and inhaled by the workers to an injurious extent, it appears to an inspector that such inhalation could be to a great extent prevented by the use of a fan or other mcchanical means, the inspector may direct a fan or other mechanical means of a proper construction for preventing such inhalation to be provided within a reasonable time; and if the same is not provided, maintained, and used, the factory or workshop shall be deemed not to be kept in conformity with this act.

37. A child, young person, or woman shall not be employed in any part of a factory in which wet-spinning is carried on, unless sufficient means be employed and continued for protecting the workers from being wetted, and where hot water is used, for preventing the escape of steam into the room occupied by the workers.

A factory in which there is a contrarention of this section shall be deemed not to be kept in conformity with this act.

\section{(2.) Special restriction as to Employment, Meals and Certificates of Fitness.}

38. A child or young person shall not, to the extent mentioned in the first schedule to this act, be employed in the factories or workshops or parts thereof named in that schedule.

Notice of the prohibition in this section shall be affixed in a factory or workshop to which it applies.

39. A child, or young person, or woman shall not be allowed to take a meal or to remain during the times allowed for meals in the parts of factories or workshops to which this section applies; and a child, young person, or woman allowed to take a meal or to remain in contravention of this section shall be, deemed to be employed contrary to the provisions of this act.

Notice of the prohibition in this section shall be affixed in a factory or workshop to which it applies.

This section applies to the parts of factories or workshops named in the second schedule to this act.

Where it appears to a Secretary of State that by reason of the natnre of the process in any class of factories or workshops or parts thereof not named in the said schedule, the taking of meals therein is especially injurious to health, he may, if he thinks fit, by order made under this part of this act extend the prohibition in this section to the said class of factories or workshops or parts thereof.

If the prohibition in this section is proved to the satisfaction of a Secretary of State to be no longer necessary for the protection of the health of children, young persons, and women in any class of factories or workshops or parts thereof to which the prohibition has been extended by an order, he may, by an order made under this part of this act, rescind the order of extension, withont prejudice nevertheless to the subsequent making of another order.

$\left[{ }^{*} 731\right] * 40$. In print works and bleaching and dyeing works the period of employment for a child, young person, and woman, and the times allowed for meals, shall be the same as if the said works were a textile factory, and the regulations of this act with respect to the employment of children, young persons. and women in a textile factory shall apply accordingly, as if print works and 
bleaching and dyeing works were textile factories; save that nothing in this section shall prevent the continuous employment of a child, young person, or woman in the said works without an interval of half an hour for a meal, for the period allowed by this act in a non-textile factory.

41. Where it appears to a Secretary of State that by reason of special circumstances affecting any class of workshops it is expedient for protecting the health of the children and of the young persons under the age of sixteen years employed therein, to extend thereto the prohibition in this section mentioned, he may, by order made under this part of this act, extend to such class of workshops the prohibition in this act of the employment of children and young persons under the age of sixteen years without a certificate of the fitness of such child or young person for employnent, and thereupon the provisions of this act with respect to certiticates of fitness for employment shall apply to the class of workshops named in the order in like manner as if they were factories.

If the prohibition is proved to the satisfaction of the Secretary of State to be no longer necessary for the protection of the health of the children and the young persons under the age of sixteen years employed in any class of workshops to which it has been extended under this section, he may by order mate under this part of this act rescind the order of extension, without prejudice nevertheless to the subsecuent making of another order.

\section{(3.) Special Laceptions relaxing General Law in certain Factories and Workshops.}

\section{(a.) Period of Employment.}

42. In the factories and workshops or parts thereof to which this exception applies the period of employment for young persons and women, if so fixed by the occupier and specified in the notice, may, except on Saturday, hegin at eight o'clock in the morning and end at eight o'clock in the evening, and on Saturday may begin at eight o'clock in the morning and end at four o'clock in the afternoon, or where it begins at seveu o'clock in the morning may end at three o'elock in the afternoon; and the period of employment for a child in a morning set may begin at the same hour, and the period of employment for a child in an afternoon set may end at the same hour.

This exception applies to the factories and workshops and parts thereof specified in Part One of the Third Schedule to this act.

Where it is proved to the satisfaction of a Secretary of State that the customs or exigencies of the trade carried on in any class of non-textile factories or workshops or parts thereof, either grenerally or when situate in any partieular locality, require the extension thereto of this exception, and that the extension can be makle without injury to the health of the children, young persons, and women aflected thereby, he may by order made under this part of this act extend this exception accordingly.

43. Where it is proved to the satisfaction of a Secretary of State that the enstoms or exigencies of the trade carried on in any class of non-textile factories or workshops or parts thereof, either generally or when situate in any particular locality, require that the special exception hereinafter in this section mentioned should be granted, and that such grant can be mikde without injury to the health of the ehildren, young persons, and women affected thereby, he may, by order made under this part of this act grant to such elass of factories or workshops or parts *thereof a special exception, that the period of em- [*73:2] ployment for young persons and women therein, if so fixed by the oceupier and specified in the notice, may on any day except Saturday begin at nine o'rlock in the morning and end at nine o'clock in the evening, and in such wase the period of employment for a child in a morning set shall begin at nine o'clock in the morning; and the period of employment for a child in an aftemoon set shall end at eight o'clock in the evening.

44. The regulations of this act with respeet to the employment of young persons in textile factories shall not prevent the employment, in the part of a textile fartory in which a machine for the manufacture of lace is moved by steam, water, or other mechanical power, of any male young person above the age of 
sixteen years between four o'clock in the morning and ten o'clock in the erening, if he is employed in accordance with the following conclitions; namely,

(a.) Where such young person is employed on any day before the beginning or after the end of the ordinary period of employment in the factory, there shall be allowed him for meals and alssence from work between the above-mentioned hours of four in the morning and ten in the evening not less than nine hours; and

(b.) Where such young person is employed on any day hefore the beginning of the ordinary period of employment in the factory, he shall not be employed on the same day after the end of that period; and

(c.) Where such young person is employed on any day after the end of the ordinary period of employment in the factory, he sliall not be employed next morning before the beginning of the ordinary period of employment.

For the purpose of this exception the ordinary period of employment in the factory means the period of employment for young persons under the age of sixteen years or women in the factory, or if none are employed means sucl period as can under this act be fixed for the employment of such young persons and women in the factory, and notice of such period shall be aflixed in the factory.

45. The regulations of this act with respect to the employment of young persons in non-textile factories or workshops shall not prevent the employment, in the part of a bakehouse in which the process of baking bread is carried on, of any male young person above the age of sixteen years between tive o'clock in the morning and nine o'clock in the evening, if he is employed in accordance with the following conditions ; namely,

(a.) Where such young person is employed on any day before the beginning or after the end of the ordinary period of employment in the bakehouse, there shall be allowed him for meals and absence from work between the above-mentioned hours of tive in the morning and nine in the evening not less than seven hours; and

(b.) Where such young person is employed on any day before the beginning of the ordinary period of employment in the bakehouse, he shall not be enployed aiter the end of that period on the same day; and

(c.) Where such young person is employed on any day after the end of the ordinary period of employment in the bakehonse, he shall not be employed next morning before the beginning of the ordinaryperiod of employment.

For the purpose of this exception the ordinary period of employment in the bakehonse means the period of employment for young persons under the age of sixteen years or women in the bakehouse, or if none are employed, means such period as can under this act be fixed for the employment of such young persons and women in the bakehouse, and notice of snch period shall be aftixed in the bakehouse.

[*733] Where it is proved to the satisfaction of a Secretary of State that the *exigencies of the trade carried on in bakehouses, either generally or when situate in any particular locality, require that the special exception hereafter in this section mentioned should be granted, and that such grant can be made without injury to the health of the male young persons affected therehy, he may hy order male under this part of this act grant to bakehouses, or to bakehouses situate in the said locality, a special exception permitting the employment of male young persons of sixteen years of age and upwards as if they were no longer young persons.

46. Where it is proved to the satisfaction of a Secretary of State that the customs or exigencies of the trade carried on in any class of non-textile factories or workshops, either generally or when situate in any particular locality, reqnire some other day in the reek to be substituted for Saturday, as regards the hour at which the period of emplorment for children, young persons, and women is required by this act to end on Saturday, he may by order made ander this part of this act grant to such class of factories or workshops a special exception, authorising the occupier of every such factory and workshop to substitute by a notice affixed in his factory or workshop some other day for Saturday, and : 
such case this act shall apply in such fuctory or workshop in like manner as if the substituted day were Saturday, and Saturday were an ordinary work day.

47. In the process of Turkey red dyeing, nothing in Part One of this act shall prevent the employment of young persons and women on sisturday until halfpast four o'eloek in the afternom, but the additional number of hours so worked shall be computed as part of the week's limit of work, whirh shall in no (ase? be excceded.

48. In any of the textile factories to which this exception applies, if the period of employment for young persons and women, as fixel by the occupier and specified in the notice, begins at the hour of seven in the morning, and the whole time between that hour and eight o'clock is allowed for meals, the rownlations of this act with respect to the employment of children, young persens, and women shall not prevent a child, young person, or woman, between the first day of November and the last day of March next following, being employed continuously, without an interval of at least half an hour for a meal, for the same period as if the factory were a non-textile factory.

This exception applies to the textile factories specified in l'art Seven of the Third Schedule of this act.

Where it is proved to the satisfaction of a Secretary of State that in any class of textile factories, either generally or when situate in any particular locality, the customary habits of the persons employed therein require the extension thereto of this exception, and that the manufacturing process carried on therein is of a healthy character, and the extension can be mate without injury to the health of the children, young persons and women afleeted thereby, he may by order made under this part of this act extend this exception accordingly.

49. Where it is proved to the satisfaction of a Secretary of State that the customs or exigencies of the trade carried on in any class of non-textile factories: or workshops, either generally or when situate in any particular locality, require that the special exception hereafter in this section mentioned should be granted, he may by order inale under this part of this act grant to such rlass of factories or workshops a special exception, anthorizing the occupier of any such factory or workshop to allow all or any of the half holitays, or whole holidays in lieu of them, on different lays to any of the children, young persons and women employed in his factory or workshop, or to any sets of such children, young persons and women, and not on the same lays.

50. Where the occupier of a factory or workshop is a person of the Jewish religion, the regulations of this aet witl respect to the employment of young persons and women shall not prevent him-

(1.) If he keeps his factory or workshop closed on Saturday until sun*set, from employing young persons and women on Saturlay [*734] from after sunset until nine o'clock in the evening; or.

(2.) If he keeps his factory or workshop closed on Saturiay both before and after sunset, from employing young persons and women one hour on every other day in the week (not being Sunday), in addition to the hours allowed by this act, so that such hour he at the beginning or end of the period of employment, and be not before six o'clock in the morning or after nine o'clock in the evening; or

(3.) If all the children, young persons and women in his factory or workshop are of the Jewish religion, from giving them, if so specified in a notire? affixed in the factory or workshop as by this act provilled, any two public holidays moler the Holidays Extension Act, 1875, in lien of Christmas Day and Good Friday, but in that case such factory or workshop shall not be open for trafie on Christmas bay or Good Friduy.

51. No penalty shall be incurred hy any person in resprect of any work done on Sunday in any fictory or workshop by a young persen or women of the Jewish religion, subject to the following (enditions:

(1.) The occupier of the factory or workshop shall be of the Jewish religion; and

(2.) The factory or workshop shall be elosed on saturdy and shall not. be open for traffic on Sunday; and 
(3.) The occupier shall not avail himself of the exception authorizing the employment of young persons and women on Saturday evening, or for an additional hour during any other day of the week.

Where the occupier avails himself of this exception, this act shall apply to the factory or workshop in like manner as if in the provisions thereof respecting Sunday the word Saturday were substituted for Sunday, and in the provisions thereof respecting Saturday the word Sunday, or, if the occupier so specify in the notice the word Friday, were substituted for Saturday.

\section{(b.) Meal Hours.}

52. The provisions of this act which require that all the children, young persons and women employed in a factory or workshop shall have the times allowed for meals at the same hour of the day shall not apply in the case mentioned in Part Two of the Third Schedule of this act.

The provisions of this act which require that,a child, young person, and woman shall not, during any part of the times allowed for meals in a factory or workshop, be employed in the factory or workshop, or be allowed to remain in a room in which a manufacturing process or handicraft is being carried on, shall not apply in the cases and to the extent mentioned in Part Two of the Third Schedule of this act.

Where it is proved to the satisfaction of a Secretary of State that in any class of factories or workshops or parts thereof it is necessary, by reason of the continuous nature of the process, or of special circumstances affecting such class, to extend thereto the exceptions in this section or either of them, and that snch extension can be made without injury to the health of the children, young persons and women affected thereby, he may by order made under this part of this act extend the same accordingly.

\section{(c.) Overtime (z).}

53. The regulations of this act with respect to the employment of young per[*735] sons and women shall not prevent the employment in the *factories and workshop or parts thereof to which this exception applies, of young persons and of women during a period of employment beginning at six o'clock in the morning and ending at eight o'clock in the evening, or beginning at seven o'clock in the morning and ending at nine o'elock in the evening; or beginning at eight o'clock in the morning and ending at ten o'clock in the evening, if they are employed in accordance with the following conditions; namely,

(1.) There shall be allowed to every such young person and woman for meals during the period of employment not less than two hours, of which half an hour shall be after five o'clock in evening; and

(2.) Any such young person or woman shall not be so employed on the whole for more than five days in any one week, nor for more than forty-eight. days in any twelve months.

This exception applies to the factories and workshops and parts thereof specified in Part Three of the Third Schedule to this act.

Where it is proved to the satisfaction of a Secretary of State that in any class of non-textile factories or workshops or parts thereof it is necessary, by reason of the material which is the subject of the manufacturing process or handicraft therein being liable to be spoiled by the weather, or by reason of press of work arising at certain recurring seasons of the year, or by reason of the liability of the business to a sudden press of orders arising from unforeseen events, to employ young persons and women in manner authorised by this exception, and that such employment will not injure the health of the young persons and women affected thereby, he may by order made under this part of this act extend this exception to such factories or workshops or parts thereof.

54. If in any factory or workshop or part thereof to which this exception applies, the process in which a child, young person, or woman is employed is in

(z) And see the Factory and Workshop Act, 1883 (46 \& 47 Vict. c. 53, s. 13), post. 
an incomplete state at the end of the period of employment of such child, young person, or woman, the provisions of this aet with respect to the period of employment shall not prevent such ehild, young person, or woman from being employed for a further period not exceeding thirty minutes :

Provided that such further periods, when added to the total n unber of hours of the periods of employment of such ehild, young person, or woman, in that week, do not raise that total above the number otherwise allowed under this act.

This exeeption applies to the factories and workshops speeified in P'art Four of the Third Schedule to this act.

Where it is proved to the satistaction of a Seeretary of State that in any class of non-textile factories or workshops or parts thereof the time for the completion of a process cannot by reason of the nature thercof be accurately fixed, and that the extension to such class of factories or work-shops or parts thereof of this exeeption can be made without injury to the health of the ehildren, young persons, and women affeeted thereby, he may by order made under this part of this act extend this exception accordingly.

55. Nothing in this act shall prevent the employment of young persons and women so far as is necessary for the purpose only of preventing any damage which may arise from spontaneous combustion in the process of Turkey red dyeing, or from any extraordinary atmospheric influence in the process of openair bleaching.

56. The regulations of this act with respect to the employment of young persons and women shall not prevent the employment in the factories and workshops and parts thereof to which this exception applies, of women during a period of employment beginning at six o'clock in the morning and ending at eight o'clock in the evening; or beginning at seven o'clock in the morning and ending at nine o'clock in *the evening, if they are employed in [*736] accordance with the following conditions; namely,

(1.) There shall be allowed to every such woman for meals during the period of employment not less than two hours, of which half an hour shall be after five o'elock in the evening; and

(2.) Any such woman shall not be so employed on the whole for more than five days in any one week, nor for more than ninety-six days in any twelve months $(a)$.

This exception applies to the factories and workshops and parts thereof specified in Part Five of the Third Sehednle to this act.

Where it is proved to the satisfaction of a Secretary of State that in any class of non-textile factories or workshops or parts thereof it is necessary, by reason of the perishable nature of the articles or materials which are the subject of the manufacturing process or liandieraft, to employ women in manner authorized by this exception, and that such employment will not injure the health of the women employed, he may by order made under this part of this act extend this exception to snch factories or workshops or parts thereot:

57. Where it appears to a Secretary of State that factories driven by water power are liable to be stopped by drought or flood, he may, hy order made under this part of this act, grant to sueh factories a special exception permitting the employment of young persons and women duriug a period of employment from six o'elock in the morning until seven o'elock in the afternoons on such conditions as he may think proper, but so as that no person shall be deprived of the meal hours by this act provided, nor be so employed on Sisturday, and that as regards factories liable to be stopped hy dronglit, such speeial exception shall not extend to more than ninety-six days in any period of twelve montlis, and as regards factories liable to be stopped by tloods, such special exception shall not extend to more than forty-eight days in any period of twolve montlis. This overtime shall not extend in any ease beyond the time already lost during the previous twelve months.

(1) And see the Factory and Workshop Act, 1883 (46 \& 47 Vict. c. i3, s. 13), post.

43 MAS. \& SER. 


\section{(d.) Nightwork.}

58. Nothing in this act shall prevent the employment, in factories and workslops to which this exception applies, of male young persons during the night, if they are employed in accordance with the following conditions :

(1.) The period of employment shall not exceed twelve consecutive hours, and shall begin and end at the hours specified in the notice in this act mentioned; and

(2.) The provisions of Part One of this act with respect to the allowance of times for meals to young persons during the period of employment shall be observed with the necessary modifications as to the hour at which the times allowed for meals are fixed; and

(3.) A male young person employed during any part of the night shall not be employed during any part of the twelve hours preceding or succeeding the period of employment; and

(4.) A male young person shall not be employed on more than six nights, or in the case of blast furnaces or paper mills seven nights, in any two weeks.

The provisions of this act with respect to the period of employment on Saturlay, and with respect to the allowance to young persons of eight half holi$\left[*_{737}\right]$ days in every year or of whole holidays in lieu of them, shall not *apply to a male young person employed in day and night turns in pursuance of this exception.

This exception applies to the factories and workshops specified in Part Six of the Third schedule to this act.

Where it is proved to the satisfaction of a Secretary of State that in any class of non-textile factories or workshops or parts thereof it is necessary, by reason of the nature of the business requiring the process to be carried on throughout the night, to employ male young persons of sixteen years of age or upwards at night, and that such employment will not injure the health of the male young persons employed, he nay by order made under this part of this act extend this exception to such factories or workshops or parts thereof, so far as regards young persons of the age of sixteen years or upwards.

59. In a factory or workshop in which the process of printing newspapers is carried on on not more than two nights in the week, nothing in this act shall prevent the employment of a male young person of sixteen years of age and upwards at night during not more than two nights in a week, as if he were no longer a young person.

60. In glass works nothing in this act shall prevent any malc young person from working according to the accustomed hours of the works, if he is employed in accordance with the following conditions; namely,

(1.) 'The total number of hours of the periods of employment shall not exceed sixty in any one week; and

(2.) The periods of employment for any such young person shall not exceed fourteen hours in four separate turns per week, or twelve hours in five separate turns per week, or ten hours in six separate turns per week, or any less number of lours in the accustomed number of separate turns per week, so that such number of turns do not exceed nine; and

(3.) Such young person shall not work in any turn without an interval of time not less than one full turn; and

(4.) There shall be allowed to such young person during each turn (so far as is practicable) the like times for meals as, are required by this act to be allowed in any other non-textile factory or workshop.

(4.) Special Exception for Domestic and certain other Factories and Workshops.

61. The provisions of this act which relate-

(1.) To the cleanliness (including limewashing, painting, varnishing, and washing) or to the freedom from efflavia, or to the overerowding, or ventilation of a factory or workshop; or

(2.) To all children, young persons, and women employed in a factory or (736) 
workshop having the times allowed for meals at the same hour of the day, or during any part of the times allowed for meals in a factory or workshop being employed in the factory or workshop or being allowed to remain in any room; or

(3.) To the affixing of any notice or abstract in a factory or workshop; or specifying any matter in the notice so affixed; or

(4.) To the allowance of any holidays to a child, young person, or woman; or

(5.) To the sending notice of accillents:

shall not apply-

(a.) Where persons are employed at home, that is to say, to a private house, room, or place which, though used as a dwelling, is by reason of the work carried on there a factory or workshop within the meaning of this act, and in which neither steam, water, nor other mechanical power is used, and in which the only persons employed are members of the same family dwelling there; or

*(b.) To a workshop which is conducted on the system of not employ- [*738] ing children or young persons therein, and the occupier of which has served on an inspector notice of his intention to conduct his workshod on that system.

And the provisions of this act with respect to certificates of fitness for employment shall apply to any such private house, room, or place as aforesaid, which by reason of the nature of the work carried on there is a factory, as if the same were a workshop within the meaning of this act, and not a factory.

Where the occupier of a workshop has served on an inspector notice of his intention to conduct that workshop on the system of not employing children or young persons therein, the workshop shall be deemed for all the purposes of this act to be conducted on the said system until the oceupier changes it, and no change shall be made until the oecupier has served on the inspector notice of his intention to change the system, and until the change a child or young person employed in the workshop shall be deemed to be employed contrary to the provisions of this act. A change in the said system shall not be made oftener than once a quarter, unless for special cause allowed in writing by an inspector.

Nothing in this section shall exempt a bakehonse from the provisions of this act with respect to cleanliness (including limewashing, painting, varnishing, and washing) or to freelom from effluvia.

62. The regulations of this act with respect to the employment of women shall not apply to flax scutch mills which are conducted on the system of not employing either clildren or young persons therein, and which are worked intermittently, and for periods only which do not exceed in the whole six months in any year. A flax scutch mill shall not be deemed to be conducted in the system of not employing therein either children or young persons until the occupier has served on an inspector notice of his intention to conduct such mill on that system.

\section{(5.) Supplemental as to Special Provisious.}

63. Where it appears to a Secretary of State that the adoption of any special means or provision for the cleanliness or ventilation of a factory or workshop is required for the protection of the health of any child, young person, or woman employed, in pursuance of an exception under this part of this act. either for a longer period than is otherwise allowed by this act, or at night, he may by order made under this part of this act direct that the adoption of such means or provision shall be a condition of such employment ; and if it appeass to a Serretary of State that the aloption of any such means or provision is no longer required, or is, having regard to all the circumstances, inexpedient, he may, by order made under this part of this act, reseind the order directing such adoption without prejudice to the subsequent naking of another orler.

64. Where an exception has been granted or extended under this part of this act by an orler of a Seeretary of State, and it appears to a secretary of State that such exception is injurious to the health of the ehildren, young persons, 
or women employed in, or is no longer necessary for the carrying on of the business in, the class of factories or workshops or parts thereof to which the said exception was so granted or extended, he may by an order made under this part of this act rescind the grant or extension, without prejudice to the subsequent making of another order.

65 . Where a Secretary of State has power to make an order under this part of this act, the following provisions shall apply to that order :

(1.) The order shatl be under the hand of the Secretary of State and shall be published in the London Gazette, and shall come into operation at the date of such publication in the London Gazette, or at any later date mentioned in the order :

(2.) The order may be temporary or permanent, conditional or unconditional, [*739] and whether extending a prohibition or exception *granting an exception, directing the adoption of any means or provisions, or rescinding a previous order, or effecting any other thing, may do so either wholly or partly :

(3.) The order shall be laid as soon as may be before both Honses of Parliament, and if either House of Parliament, within the next forty days after the sume has been so laid before such House, resolve that such order ought to be annulled, the same shall after the datc of such resolntion be of no effect, without prejudice to the validity of anything done in the meantime under such order or to the making of any new order :

(4.) The order, while it is in force, shall, so far as is consistent with the tenor thereof, apply as if it formed part of the enactment which provides for the extension or grant or otherwise for making the order.

66. An occupier of a factory or workshop, not less than seren days before he avails himself of any special exception under this part of this act, shall serve on an inspector, and (except in the case of a factory or workshop to which the provisions of this act with respect to the affixing of notices do not apply) affix in his factory or workshop notice of his intention so to avail himself, and whilst he avails himself of the exception shall keep the notice so affixed.

Before the service of such notice on the inspector the special exception shall not be deemed to apply to the factory or workshop, and atter the service of such notice on the inspector it shall not be competent in any proceeding under this act for the occupier to prove that such special exception does not apply to his factory or workshop, unless he has previonsly served on an inspector notice that he no longer intends to arail himself of sucli special exception.

The notice so served and aftixed shall specify the hours for the beginning and end of the period of employment, and the times to be allowed for meals to every child, young person, and woman where they differ from the ordinary hours or times.

An occupier of a factory or workshop shall enter in the preseribed register, and report to an inspector, the prescribed particulars respecting the employment of a child, young person, or women in pursuance of an exception, but such entry and report need not be made in the case of a factory or workshop to which the provisions of this act with respect to the affixing of notices do not apply, except so far as may be from time to time prescribed ly a secretary of State.

Where the occupier of a factory or workshop avails himself of an exception noder this part of this act, and a condition for availing himself of such exception (whether specified in this part of this act, or in an order of a Secretary of State made under this part of this act) is not observed in that factory or workshop, then

(1.) If such condition relates to the cleanliness, ventilation, or over-crowding of the factory or workshop, the factory or workshop shall be deemed not to be kept in conformity with this act; and

(2.) In any other case a child, voung person, or woman employed in the factory or workshop, in alleged pursuance of the said exception, shall be deemed to be employed contary to the provisions of this act. 


\section{Part III.-Adinistration, Penalties, and Legal Proceedrags:}

\section{(1.) Inspcction.}

67. A Secretary of State from time to time, with the approval of the Treasury as to numbers and salaries, may appoint such inspectors (under whatever title he may from time to time fix) and such clerks and servants as he may think necessary for the execution of this act, and may assign to *them their du- [*740] ties and award them their salaries, and may constitute a principal inspector with an office in London, and may regulate the cases and manner in which the inspectors, or any of them, are to execute and perform the powers and dinties of inspectors under this act, and may remove such inspectors, clerks, and servants.

The salaries of the inspectors, clerks, and servants, and the expenses incurred by them or by a Secretary of State in the execution of this act, shall be paid out of moneys provided by Parliament.

Notice of the appointment of every such inspector shall be pnblished in the London Gazette.

$A$ person who is the occupier of a factory or workshop, or is directly or indirectly interested therein or in any process or business carried on therein, or in a patent connected therewith, or is employed in or about a factory or workshop, shall not act as an inspector under this aet.

An inspector under this act shall not be liable to serve in any parochial or municipal office.

Such annual report of the proceedings of the inspectors as the Secretary of State from time to time directs shall be laid before both houses of Parliament.

A reference in this act to an inspector refers, unless it is otherwise expressed, to an inspector appointed in pursuanee of this section, and a notice or other document required by this act to be sent to an inspector shall be sent to such inspector as a Secretary of State from time to time directs, by declaration published in the London Gazette or otherwise as he thinks expedient for making the same krown to all persons interested.

68. An inspector under this act shall for the purpose of the execution of this act have power to do all or any of the following things; namely,

(1.) To enter, inspect, and examine at all reasonable times by day and night a fictory and a workshop and every part thereof when he has reasonible canse to believe that any person is employed therein, and to enter by day any place which he has reasonable cause to believe to be a factory or workshop; and

(2.) To take with him in either case a constable into a factory in which he has reasonable cause to apprehend any serious obstruction in the execution of his duty; and

(3.) To require the production of the registers, certificates, notices, and documents kept in pursuance of this act, and to inspect, examine, and copy the same; and

(4.) To make such examination and inquiry as may be necessary to ascertain whether the enactments for the time being in force relating to public health and the enactments of this act are complied with, so far as respects the factory or workshop and the persons employed therein; and

(5.) To enter any school in which he has reasonable ause to believe that chilltren employed in a factory or workshop are for the time being educated; and

(6.) To examine either alone or in the presence of any other person, as he thinks fit, with respect to matters under this act, every person whom he finds in a factory or workshop, or such a schonl as aforesaid, or whom he has reasonable cause to believe to be or to have been within the preceding two months employed in a factory or workshop. and to require such person to be so examined and to sign a decharation of the truth of the natters respecting which he is so examined; and

(7.) To excrise such other powers as mal be necessary for carrying this act into effect. 
The occupier of every factory and workshop, his agents and servants, shall furnish the means required by an inspector as necessary for an entry, inspection, examination, inquiry, or the exercise of his powers under this act in relation to such factory and workshop.

$[* 711] \quad *$ Every person who wilfully delays an inspector in the exercise of any power under this section, or who fails to conply with a requisition of an inspector in pursuance of this section, or to produce any certiticate or document which he is required by or in pursuance of this act to produce, or who conceals or prevents a child, young person, or woman from appearing before or being examined by an inspector, or attempts so to conceal or prevent a child, young person, or woman, shall be deemed to obstruct an inspector in the execution of his duties under this act: Provided always, that no one shall be required under this section to answer any question or to give any evidence tending to criminate himself.

Where an inspector is obstructed in the execution of his duties under this act, the person obstructing him shall be liable to a fine not exceeding five pounds; and where an inspector is so obstructed in a factory or workshop, the occupier of that factory or workshop shall be liable to a fine not exceeding five, or where the offence is committed at night, twenty pounds; and where an inspector is so obstructed in a factory or workshop within the meaning of sec. tion sixteen of this act, the occupier shall be liable to a fine not exceeding one, or where the offence is committed at night, five pounds.

69. An inspector before entering, in pursuance of the powers conferred by this act, without the consent of the occupier, any room or place actually used as a dwelling as well as a factory or workshop, shall, on an affidavit or statutory declaration of facts and reasons, obtain written authority so to do from a Secretary of State, or such warrant as is hereinafter mentioned from a justice of the peace.

The aftidavit or statuory declaration above mentioned may be inspected or produced in evidence in all respects the same as an information on oath before a justice.

A justice of the peace, if satisfied by information on oath that there is reasonable cause to suppose that any enactment of this act is contravened in any such room or place as aforesaid, may in his discretion grant a warrant under his hand authorising the inspector named therein at any time within the period named therein, but not exceeding one month from the date thereof, to enter, in pursuance of this act, the room or place named in the warrant, and exercise therein the powers of inspection and examination conferred by this act, and the fines and provisions of this act with respect to obstruction of an inspector shall apply accordingly.

70. Every inspector under this act shall be furnished with the prescribed certificate of his appointment, and on applying for admission to a factory or workshop shall, if required, produce to the occupier the said certificate.

Every person who forges or counterfeits any such certificate, or makes use of any forged, counterfeited, or false certificate, or personates the inspector named in any such certificate, or falsely pretends to be an inspector under this act, shall be liable to be imprisoned for a period not exceeding three months, with or without hard labour.

\section{(2.) Certifying Surgeons.}

71. Where there is no certifying surgeon resident within three miles of a factory or workshop, the poor law medical officer shall be for the time being the certifying surgeon under this act for such factory or workshop.

72. Subject to such regulations as may be from time to time made by a Secretary of State, an inspector may from time to time appoint a sufficient number of duly registered medical practitioners to be certifying surgcons for the purposes of this act, and may from time to time reroke any such appointment.

Every appointment and revocation of appointment of a certifying surgeon may be annulled by a Secretary of State upon appeal to him for that purpose.

A surgeon who is the occupier of a factory or workshop, or is directly or in- 
directly interested therein or in any process or business earried on *there- [*742] in or in a patent connected therewith, shall not be a certifying surgeon for that factory or workshop.

A Seeretary of State may from time to time makes rules for the guilance of certifying surgeons, and for the partieulars to be registered respecting their visits, and for the forms of certifieates and other doeuments to be used by them.

73. A certificate of fitness for employment shall not be granted for the purposes of this act, except upon personal examination of the person named therein.

A certifying surgeon shall not examine a child or young person for the purposes of a certifieate of fitness for employment, or sign any such certificate, elsewhere than at the factory or workshop where such child or young person is or is about to be employed, innless the number of children and young persons employed in that factory or workshop are less than five, or unless for some special reason allowed in writing by an inspector.

If a eertifying surgeon refuses to grant for any person examined by him a certificate of fitness for employment, he shall when required give in writing and sign the reasons for such refusal.

74. With respeet to the fees to be paid to eertifying surgeons in respeet of the examination of, and grant of certifieates of fitness for employment for, children and young persons in factories or workshops, the following provisions shall have effect :

(1.) The ocenpier may agree with the certifying surgeon as to the amount of such fees:

(2.) In the absence of any such agreement the fees shall be those named in the following seale :-

When the examination is at a factory or workshop not exceeding one mile from the surgeon's residence.

When the examination is at a factory or workshop more than one mile from the surgeon's residence.

When the examination is not at the factory or workshop, but at the residence of the surgeon, or at some place appointed by the surgeon for the purpose, and which place, as well as the day and hour, appointed for the purpose shall be pulblished in the prescribed manner.

2s. 6d. for eaeh visit and $6 d$. for each person after the first tive examined at that visit.

The above fees and an additional 6d. for each complete half mile over and above the mile.

6d. for each person examined.

(3.) The oceupier shall pay the fees on the completion of the examination, or if any certificates are granted at the time at whieh the surgeon signs the certificates, or at any other time directed by an inspector:

(4.) The oeeupier may deduet the fee or any part thereof, not exceeding in any case threepence, from the wages of the person for whom the certificate was granted :

(5.) A Seeretary of 'State'may from time to time, if he think it expedient, alter any fees fixed by this section.

\section{(3.) Miscellaneous.}

75. Every person shall, within one month after he begins to occupy a fisetory, serve on an inspeetor a written notice containing the name of the factory, the place where it is situate, the aldress to which he desires his letters to be atldressed, the nature of the work, the nature and amount of the moving power therein, and the name of the firm under which the *lusiness of the firk- [*-43] tory is to be carried on, and in default shall be liable to a tine not excecding five pounds.

76. Where an inspector. by notice in writing, nanes a public clock, or somo 
other clock open to public view, for the purpose of regulating the period o employment in a factory or workshop, the period of employment and times allowed for meals for ehildren, young persons, and women in that factory or workshop shall be regulated by that cloek, which shall be specitied in the notice affixed in the factory or workshop.

77. The occupier of every factory and workshop to which this section applies shall keep in the prescribed form and with the preseribed particulars registers of the children and youmg persons employed in that fictory or workshop, and of their employment, and of other matters under this act.

The occupier of a factory or workshop shall send to an inspector such extracts from any register kept in pursuance of this act as the inspector from time to time requires for the execution of his duties under this act.

This section applies to every factory and workshop in which a child or young person under the age of sixteen years is, for the time being prohibited under this act from being employed without a certificate of titness for employment.

Where by reason of the number of children and young persons enployed in a fictory or workshop to which this seetion does not for the time being apply, or otherwise, it seems expedient to a Secretary of State so to do, he may order the oceupier of that factory or workshop to keep a register under this seetion, with power to reseind such order, and while such order is in force this section shall apply to that factory or workshop.

In the event of a contravention of this section in a factory or workshop, the occupier of the factory or workshop shall be liable to a fine not exceeding forty shillings.

78. There shall be affixed at the entrance of a factory and a workshop, and in such other parts thereof as an inspector for the time being directs, and be constantly kept so aftixed in the preseribed form and in such position as to be easily read by the persons employed in the factory or workshop,-

(1.) The preseribed abstract of this act; and

(2.) A notice of the name and address of the preseribed inspector; and

(3.) A notice of the name and address of the certifying surgeon for the district; and

(4.) A notice of the clock (if any) by which the period of employment and times for meals in the factory or workshop are regulated; and

(5.) Every notice and document required by this act to be affixed in the factory or workshop.

In the event of a contravention of this section in a factory or workshop, the occupier of the fictory or workshop shall be liable to a fine not exceeding forty shillings.

79. Any notice, order, requisition, summons, and doenment under this act may be in writing or print, or partly in writing and partly in print.

Any notice, order, requisition, summons, and document required or authorised to be served or sent for the purposes of this act may be served and sent by delivering the same to or at the residence of the person on or to whom it is to be served or sent, or, where that person is the occupier of a factory or workshop, by delivering the same or a true copy thereof to his agent or to some person in such factory or workshop; it may also be served or sent hy post by a prepaid letter, and if served or sent by post shall be deemed to have been served and received respectively at the time when the letter eontaining the same would be delivered in the ordinary course of post, and in providing such service or sending it shall be sufficient to prove that it was properly addressed and put into the post; and where it is recuired to be served on or sent to the occupier of a factory or workshop, it shall be deemed to be properly addressed if ad$[* 744]$ dressed to the *oceupier of such faetory or workshop at the factory or workshop, with the addition of the proper postal address, but without naming the person who is the oceupies.

80. Any act for the time being in force relating to weights and measures $(b)$

(b) $41 \& 4:$ Viet. e. 49. ( $T$ (fi) 
shall extend to weights, measures, scales, balances, steelyards, and weighing machines used in a factory or workshop in checking or ascertaining the wages of any person employed therein, in like manner as if they were used in the sale of goods, and as if such factory or workshop were a place where goocls are kept for sale, and such act shall apply accordingly, and every inspector of, or other person authorised to inspect or examine, weights and measures, shall inspect, stamp, mark, search for, and examine the said weights and measures, scales, balances, steelyards, and weighing machines accordingly, and for that purpose shall have the same powers and duties as he has in relation to weights, measures, scaleś, balances, steelyards, and weighing machines used in the sale of goods.

\section{(4.) Fines.}

81. If a factory or workshop is not kept in eonformity with this act, the occupier thereof shall be liable to a tine not exeeding ten pounds.

The conrt of summary jurisdiction, in addition to or instead of inflicting such fine, may order certain means to be adopted by the occupier, within the time named in the order, for the purpose of bringing his factory or workshop into conformity with this act; the court may, upon application, enlarge the time so named, but if, after the expiration of the time as originally named or enlarged by subsequent order, the order is not complied with. the occupier shall be liable to a fine not exceeding one pound for every day that such non-compliance continues.

82. If any person is killed or suffers any bodily injury in consequenee of the occupier of a factory having neglected to fence any machinery required by or in pursuance of this act to be securely fenced, or having neglected to maintain such fencing, or in consequence of the occupier of a factory or workshop having neglected to fence any vat, pan, or other structure required by or in pursuance of this act to be securely fenced, or having neglected to maintain such fencing, the occupier of the factory or workshop shall be liable to a fine not exceeding one hundred pounds, the whole or any part of which may be applied for the benefit of the injured person or his family, or otherwise as a Secretary of State determines :

Provided that the occupier of a fictory shall not be liable to a fine under this section if an information against lim for not fencing the part of the machinery, or the vat, pan, or other structure, by which the death or bodily injury was inflicted, has been heard and dismissed previous to the time when the death or bodily injury was inflicted.

83. Where a child, young person, or woman is employed in a factory or workshop contrary to the provisions of this act, the occupier of the factory or workshop shall be liable to a fine not exceeding three, or if the oflence was committed during the night, five pounds for eaeh child, young person, or woman so employed ; and where a ehild, youngr person, or woman is so employed in a factory or workshop within the meaning of section sixteen of this act, the occupier shall be liable to a fine not exceeding one, or if the oflence was committed cluring the night, two ponnds for each child, young person, or woman so employed.

$\dot{A}$ child, young person, or womm who is not allowed times for meals and absence from work as required by this act, or during any part of the times allowed for meals and hlssence from work is, in eontravention of the provisions of this act, enployed in the factory or workshop or allowed *to remain [*-15] in any room, shall be deemed to be employed contrary to the provisions of this act.

84. The parent of a child or young person shall.-

(1.) If such ehild or young person is employed in a factory or workshop contrary to the provisions of this act, be liable to a fine not exceeding twenty shillings for each ofence, unless it appears to the court that such offence was eommitted witlont the consent, connivance, or wilful defunlt or such parents; and

(2.) If he neglects to cause such child to attend school in arordance with 
this Act, be liable to a fine not exceeding twenty shilling for each offence.

85. Every person who forges or counterfeits any certificate for the purposes of this act (for the forgery or counterfeiting of which no other punishment is provided), or who gives or signs any such certificate knowing the same to be false in any material particular, or who knowingly utters or makes use of any certificate so forged, counterfeited, or false as aforesaid, or who knowingly utters or makes use of as applying to any person a certificate which does not so apply, or who personates any person named in a certificate, or who wilfully connives at the forging, counterfeiting, giving, signing, uttering, making use, or personating as aforesaid, shall be liable to a tine not exceeding trenty pounds, or to imprisonment for a term not exceeding three months with or without liard labour.

Every person who wilfully makes a false entry in any register, notice, certificate, or document required by this act to be kept or served or sent, or who wilfully makes or signs a false declaration under this act, or who knowingly makes use of any such false entry or declaration, shall be liable to a fine not exceeding twenty pounds, or to an imprisonment for a term not exceeding three months with or without hard labour.

86. Where an offence for which the cccupier of a factory or workshop is liable under this act to a fine, has in fact been committed by some agent, servant, workman, or other person, such agent, servant, workman, or other person shall be liable to the same fine as if he were the occupier.

87. Where the occupier of a factory or workshop is charged with an offence against this act, he sliall be entitled upon information duly laid by him to have any other person whom he charges as the actual offender brought before the court at the time appointed for hearing the charge; and if, after the commission of the offence has been proved, the occupier of the factory or workshop proves to the satisfaction of the court that he had used due diligence to entorce the execution of the act, and that the said other person had committed the offence in question without his knowledge, consent or connivance, the other person shall be summarily convicted of such offence, and the occupier shall be exempt from any fine.

When it is made to appear to the satisfaction of an inspector at the time of discovering the offence, that the occupier of the factory or workshop had used all due diligence to enforce the execution of this act, and also by what person such offence had been committed, and also that it had been committed without the knowledge, consent or connivance of the occupier and in contravention of his orders, then the inspector shall proceed against the person whom he believes to be the actual offender in the first instance, without first proceding against the occupier of the factory or workshop.

88. A person shall not be liable in respect of a repetition of the same kind of offence from day to day to any larger amount of fines than the lighest fine fixed by this act for the offence, except-

(a.) where the repetition of the offence occurs after au information has been laid for the previous offence ; or

$[* 746] *(b$. $)$ where the offence is one of employing two or more children,. young persons or women contrary to the provisions of this act.

\section{(5.) Legal Proecedings.}

89. All offences under this act shall be prosecuted, and all fines under this act shall be recovered, on summary conviction before a court of summary jurisdiction in manner provided by the Summary Jurisdiction Acts.

A summary order may be made for the purposes of this act by a court of summary jurisdiction in manner provided by the Summary Jurisdiction Acts.

All fines imposed in pursuance of this act shall, save as otherwise expressly provided by this act, be paid into the Exchequer.

The court of summary jurisdiction, when hearing and deternining a case arising under this act, shall be constituted either of two or more justices of the 
peace sitting at some court or public place at which justices are for the time being accustomed to assemble for the purpose of holding petty sessions or of some magistrate or officer sitting alone or with others at some conrt or other place appointed for the publie administration of justice, and for the time being empowered by law to do alone any act anthorized to be done by more than one justice of the peace.

Where a proceeding is taken before a court of summary jurisoliction with respect to an offence against this act alleged to be eommitted in or with reference to a factory or workshop, the oceupier of that factory or workshop, and the father, son or brother of such occupier, shall not be qualified to act as a member of such court.

90. If any person feels aggrieved by a conviction or order made by a court of summary jurisdiction on determining an intormation or complaint uncler this act he may appeal therefrom ; subject, in England, to the conditions and regulations following :

(1.) The appeal shall be made to the next practicable court of general or quarter sessions [the rest or this sect. uars repealed by 47 \& 48 Vict. c. 43.]

91. The following provisions shall have effect with respeet to summary proceedings for offences and fines under this act :-

(1.) The information slall be laid within two months, or, whère the offence is punishable at discretion by imprisonment, or is a breach of the provisions of this act with respect to holidays, within three months after the commission of the oftence :

[Subseets. (2) and (3) were repealed by 47 \& 48 Iict. e. 43.]

(4.) It shall be sufficient to allege that a factory or workshop is a factory or workshop within the meaning of this act, without more:

(5.) It shall be suffieient to state the name of the ostensible occrpier of the factory or workshop or the title of the firm by which the oecupier employing persons in the factory or workshop is usually known :

(6). [The first part of this subsect. was repealed by 47 \& 48 I Iict. c. 43]. A conviction or order made by a court of summary jurisclietion against which a person is authorized by this act to appeal shallnot be removed by certiorari or otherwise, either at the instance of the crown or of any private person, int, a superior eourt, except for the purpose of the hearing and determination of a special case.

92. If a person is found in a factory, except at meal times, or while all the machinery of the factory is stopped, or for the sole purpose of bringing food to the persons employed in the factory between the hours of four and tive o'elock in the aftermoon, such persons shall, until the contrary is proved, be deemed for the purposes of this act to have been then employed in the factory;

Provirled that yards, playgrounds, and places open to the public view, * seh oolrooms, waiting rooms, and other rooms belonging to the factory $[* 747]$ in which no machinery is used or manufacturing process earried on, shall. not be taken to be any part of the factory within the meaning of this enactment ; and this enaetment shall not apply to a faetory or workshop to which the provisions of this act with respect to the affixing of notices do not apply.

Where a child or young person is, in the opinion of the court, nppurently of the age alleged by tho informant, it shall lie on the defendant to prove that the child or young person is not of that age.

A declaration in writing by a certifying surgeon for the district that he has personally examined a person employed in a factory or workshop in that district, and believes him to be under the age set forth in the deelaration, shall be admissible in evidence of the ange of that person.

A copy of a conviction for an offence against this act purporting to he certified under the hand of the elerk of the peace having the custody of sneh conviction to be a true copy shall be receivable as evidence, and every such clerk of the peace shall, upon the written request of an inspector and pilyment of a fee of one shilling, deliver to him a copy of the conviction so certified. 


\section{PART IV.-Definitions, SAVINGs, APplication to Scotlaxid AND} IRELAND, AND REPEAL.

\section{(1.) Definitions.}

93. The expression "textile factory" in this act means-

any premises wherein or within the close or curtilage of which steam, water, or other mechanical power is used to move or work any machinery employed in preparing, manufacturing, or finishing, or in any process incident to the manufacture of, cotton, wool, hair, silk, flax, hemp, jute, tow, china-grass, cocoa-nut fibre, or other like material, either separately or mixed together. or mixed witl any other material, or any fabric made thereof:

Provided that print works, bleaching and dyeing works, lace warehouses, paper mills, flax scuteh mills, rope works, and hat works shall not be deemed to be textile factories.

The expression "non-textile factory" in this act means-

(1.) any works, warehouses, furnaces, mills, foundries, or places named in Part One of the Fourth Schedule to this act,

(2.) also any prenises or places named in Part Two of the said schednle wherein, or within the close or curtilage or precincts of which, steam, water, or other mechanical power is used in aid of the manufacturing process carried on there,

(3.) also any premises wherein, or within the close or curtilage or precincts of which, any manual labour is exercised by way of trade or for purposes of gain in or incidental to the following purposes, or any of them; that is to say,

(a.) in or incidental to the making of any article or of part of any article, or

(b.) in or incidental to the altering, repairing, ornamenting, or finishing of any article, or

(c.) in or incidental to the adapting for sale of any article,

and wherein, or within the close or curtilage or precincts of which, steam, water, or other mechanical power is used in aid of the manufacturing process carried on there.

The expression "factory" in this act means textile factory and non-textile factory, or either of such descriptions of factories.

The expression "workshop" in this act means-

(1.) any premises or places named in Part Two of the Fonrth Schedule to this act, which are not a factory within the meaning of this act.

$\left[{ }^{*} ; 48\right] *(2$.$) also any premises, room, or place not being a factory within the$ meaning of this act, in which premises, room, or place, or within the close or curtilage or precincts of which premises, any manual labour is exercised by way of trade or for purposes of gain in or incidental to the following purposes or any of them; that is to say,

(a.) in or incidental to the making of any article or of part of any article, or

(b.) in or incidental to the altering, repairing, ornamenting, or finishing of any article, or

(c.) in or incidental to the adapting for sale of any article, and to which or over which premises, roon, or place the employer of the persons working therein has the right of access or control.

A part of a factory or workshop may for the purposes of this act be taken to be a separate factory or workshop; and a place solely used as a dwelling shall not be deemed to form part of the factory or workshop for the purposes of this act.

Where a place situate within the close, curtilage, or precincts forming a factory or workshop is solels used for some purpose other than the manufacturing process or handicraft earried on in the factory or workshop, such place shall not be deemed to form part of that factory or workshop for the purposes of this act, but shall, if otherwise it would be a factory or workshop, be deemed to be a separate factory or workshop, and be regulated accordingly. 
Any premises or place shall not be excluded from the definition of a factory or workshop by reason only that such premises or place are or is in the open air.

This act shall not apply to such workshops, other than bakelrouses, ats are conducted on the system of not employing any child, young person, or woman therein, but save as aforesaid applies to all factories and workshops as before defined, inclusive of factories and workshops belonging to the Crown; provided that in case of any public emergency a Secretary of State may exempt a factory or workshop belonging to the Crown from this act to the extent and during the period named by him.

The exercise by any child or young person in any recognised efficient school during a portion of the school hours of any manual labour for the purpose of instrueting such child or young person in any art or handieraft, shall not he deemed to be an exercise of manual labour for the purpose of gain within the meaning of this act.

94. A child, young person, or woman who works in a fictory or workshop, whether for wages or not, either in a manufacturing process or handieraft, or in cleaning any part of the factory or workshop used for any manufacturing process or handicraft, or in cleaning or oiling any part of the machinery, or in any other kind of work whatsoever incidental to or connected with the manufacturing process or handicraft, or connected with the article made or otherwise the subject of the manufacturing process or handicraft therein, shall, save as is otherwise provided by this act, be deemed to be employed therein within the meaning of this act.

For the purposes of this act an apprentice shall be deemed to work for hire.

95. The expression "certified eflicient school" in this act means a public elementary school within the meaning of the Elementary Education Acts, 1870 and 1873, and any workhouse school in England certified to be efticient by the Local Government Board, and also any elementary school which is not condueted for private profit and is open at all reasonable times to the inspection of her Majesty's inspectors of schools, and requires the like attendanee from its scholars as is required in a public elementary school, and keeps such registers of those attendances as may be for the time being required by the Education Department, and is *eertified by the Education Department to be an [* *49] efficient school ; and the expression "recognised efficient school" means a certitied efficient school as aloove defined, and also any school which the Education Department have not refused to take into consideration under the Elementary Education Act, $18 \% 0$, as a school giving efficient elementary edncation to and suitable for the children of a school district, and which is recognised for the time being by an inspector under this act as giving efficient elementary education, and the inspector shall immediately report to the Elucation Department every school so recognized by him.

96. In this act, unless the context otherwise requires, -

The expression "child" means a person under the age of fourteen years:

The cxpression "young person" means a person of the age of fourteen years and under the age of eighteen years:

The expression "woman" means a woman of eighteen years of age and upwards :

The expression "parent" means a parent or guardian of, or person having the legal eustody of, or the control over, or having direct benefit from the wages, of a child or young person :

The expression "Treasury" means the Commissioners of her Majesty's Treasury :

The expression "Secretary of State" means one of hel Majesty's Principal Secretaries of State:

The expression "Elucation Department" means the Lords of the Committee of the Privy Council on Elucation:

"The expression "sanitary authority" means an urban or rural sanitary authority within the meaning of the Public Health Act, 18\%5, and any commissions, hoard or vestry in the metropolis having the like powers as such urban sanitary authority : 
The expression "person" includes a body of persons corporate or unincorporate :

The expression "week" means the period between midnight on Saturday night and midnight on the succeeding Saturday night:

The expression " night" means the period between nine o'clock in the evening and six o'clock in the succeeding morning:

The expression "prescribed" means prescribed for the time being by a Secretary of State:

The expression "Summary Jurisdiction Acts" means the act of session of the elerenth and twelfth years of the reign of her present Majesty, chapter forty-three, intituled "An Act to facilitate the Performance of the Duties of Justices of the Peace out of Sessions within England and Wales with respect to Summary Convictions and Orders," and any acts amending the same $(c)$ :

The expression "court of summary jurisdiction" means any justice or justices of the peace, metropolitan police magistrate, stipendiary or other magistrate or officer, by whatever name called, to whom jurisdiction is given by the Summary Jurisdiction Acts or any acts therein referred to :

The expression "mill-gearing" comprehends erery shaft, whether upright, oblique or horizontal, and every wheel, drum or pulley by which the motion of the first moving power is communicated to any machine appertaining to a manufacturing process.

The factories and workshops named in the Fonrth Schedule to this act are in this act referred to by the names therein assigned to them.

\section{Special Exemption of certain Trades}

97. The exercise in a private house or private room by the family dwelling therein, or by any of them, of mannal labour by way of trade or for purposes $[* 750]$ of gain in or incidental to any of the handicrafts specified *in the fifth schedule to this act, shall not of itself constitute such house or room a workshop within the meaning of this act.

When it is proved to the satisfaction of a Secretary of State that by reason of the light character of the handicraft carried on in any private house or private room by the family dwelling therein, or by any of them, it is expedient to extend this section to that handicraft, he may by order extend the same.

The order shall be made in manner provided by Part Two of this act, and that part shall apply so far as circumstances admit as if the order were an order extending an exception.

98. The exercise in a private house or private room by the family dwelling therein, or by any of them, of manual labor for the purposes of gain in or incidental to some of the purposes in this act in that behalf mentioned, shall not of itself constitnte such house or room a workshop where the labour is exercised at irregular intervals, and does not furnish the whole or principal means of living to such family.

\section{(2.) Savings.}

99. Where in a factory the owner or hirer of a machine or implement mored by steam, water, or other mechanical power, in or about or in connexion with which machine or implement children, young persons, or women are employed, is some person other than the occupier of a factory, and such children, young persons, or women are in the employment and pay of the owner or hirer of such machine or implement, in any such case such owner or hirer shall, so far as respects any offence against this act which may be committed in relation to such children, young persons, or women, be dcemed to be the occupier of the factory.

100. Nothing in this act shall extend-

(c) See the Summary Jurisdiction Act, 1879, $42 \& 43$ Vict. c. 49. 
(1) To any young person, being a mechanie, artisan, or labourer, working only in repairing either the machinery in or any part of a factory or any part of a factory or workshop; or

(2.) To the process of gutting, salting, and packing fish immediately upon its arrrival in the fishing boats.

101. The provisions of section ninety-one of the Public Health Aet, 185, with respect to a factory, wokshop, or workplace not kept in a cleanly state or not rentilated, or overerowded, shall not apply to a factory or workshop which is subject to the provisions of this act relating to eleanliness, rentilittion, and overcrowding, but shall apply to every other factory, workshop and workplace.

It is hereby declared that the Public Health Act, 1875, shall apply to buildings in which persons are employed, whatever their number may be, in like manner as it applies to buikdings where more than twenty are employed.

102. Any enactment or document referring to the acts repealed by this act, or any of them, or to any enactment thereof, shall be construed to refer to this act and to the corresponding enactment thereof.

\section{(3.) Application of Act to Scotland and Ireland.}

103. The provisions of this act shall, in the case of a factory or workshop in Scotland or Ireland, in which a child under the age of ten years may lawfully be employed at the passing of this act, be modified as follows; that is to say,

(1.) Sliall apply during twelve months after the commencement of this act to children of the age of nine years and upwards, as if they were of the age of ten years; and

(2.) Shall not prevent a child who, before the commencement of this act, is lawfully employed in any factory or workshop as a child under the age of nine years, or any child who during the twelve months next after the commencement of this act is lawtilly *employed in [*751] any factory or workshop as a child under the age of ten years, from continuing to be employed in a factory or workshop in like manner as if the child were above the age of ten years; and

(3.) Shall apply during twelve months after the commencement of this act to children of the age of thirteen years and upwards as if they were young persons; and

(4.) Shall not prevent a child, who before the expiration of twelve months after the commencement of this act is lawfully employed in a factory or workshop as a young person, from continuing to be employed in a factory or workshop as a young person.

104. Where the age of any ehild is reguired to be ascertained or proved for the purposes of this act, ar for any purpose eonnected with the elementary edlucation or employment in labour of such child, any person, on presenting a written requisition in such form and containing such particulars as may be from time to time preseribed by a Seeretary of State, and on payment of such fee, not exceeding one shilling, as a Secretary of State from time to time fixes, shall be entitled to olstain-

(1.) In Scotlaud an extract under the hand of the registrar under the act of the seventeenth and eighteenth years of her present IIajesty, chapter eighty, and any acts amending the same, of the entry in the register kept under these acts; amd

(2.) In Ireland a certified copy under the hand of the registrar or superintendent registrar under the Registration of Births and Deaths (Ireland) Act of the entry in the register under that act of the birth of the child named in the requisition.

105. In the application of this act to Scotlanel-

(1.) The expression "certitied efficient school" means any pulblic or other elementary school under government inspection:

(2.) In lieu of Christmas Dity and either Good Friday or the next publie lohiday under the Holidays Extension Act, 1875, there shall be allowed as a. 
holiday to every child, young person, and woman employed in a factory or workshop the whole of two days separated from each other by an interval of not less than three months, one of which shall be a day set apart by the Church of Scotland for the observance of the sacramental fast in the parish in which the factory or workshop is situate, or some other day substituted for sucl day as aforesaid by the occupier specifying the same in the notice affixed in the factory or workshop:

(3.) The expression "sanitary authority" means the local authority under the Public Health (Scotland) Act, 1867 :

(4.) The expression "medical officer of health" means the medical officer under the Public Health (Scotland) Act, 1867, or where no such officer has been appointed, the medical officer appointod by the parochial board :

The expression "poor law medical officer" means the medical offcer appointed by the parochial board :

(5.) The expression "Companies Clauses Consolidation Act, 1845," means the Companies Clauses Consolidation (Scotland; Act, 1845:

(6.) The expression "Summary Jurisdiction Acts" means the Summary Procedure Act, 1864, and any Acts amending the same :

(7.) The expression "court of summary jurisdiction" means the sheriff of the county or any of his substitutes :

(8.) The expression "Education Department" means the Lords of the Committee of the Privy Council appointed by her Majesty on Education in Scotland :

(9.) The expression " county court" means the sheriff court :

(10.) All matters required by this Act to be published in the London

[*752] *Gazette shall (if they relate exclusively to Scotland), instead of being published in the London Gazette, be published in the Edinburgh Gazette only :

(11.) The expression "information" means petition or complaint :

(12.) The expression "informant" means petitioner, pursuer, or complainer:

13. The expression "defendant" means defender or respondent :

14. The expression "clerk of the peace" means sheriff clerk :

(15.) All offences under this Act shall be prosecuted and all penalties under this act shall be recovered under the provisions of the Summary Jurisdiction Acts at the instance of the procurator fiscal or of an inspector under this act:

(16.) The court may make, and may also from time to time alter or vary, summary orders under this act on petition by such procurator fiscal or inspector presented in common form :

(17.) All fines under this act in default of payment, and all orders made under this act failing compliance, may. be enforced by imprisonment for a term to be specified in the order or conviction, but not exceeding three months:

(18.) It shall be no objection to the competency of an inspector to gire evidence as a witness in any prosecution for offences under this act, that such prosecution is brought at the instance of such inspector :

(19.) Every person convicted of an offence under this act shall be liable in the reasonable eosts and charges of such conviction :

(20.) All penalties imposed and recovered under this act shall be paid to the clerk of the court, and by him accounted for and paid to the Queen's and Lord Treasurer's Remembrancer, on behalf of her Majesty's Exchequer, and shall be carried to the Consolidated Fund :

(21.) All jurisdictions, powers, and authorities necessary for the purposes of this section are conferred on the sheriffs and their substitutes:

(22.) Any person may appeal from any order or conviction under this act to the Court of Justiciary, under and in terms of the act of the twentieth year of the reign of his Majesty King George the Second, chapter 43, or under any enactment amending that act, or applying or incorporating its provisions, or any of them, with regard to appeals, or to the 
Conrt of Justieiary at Edinburgh under and in terms of the Summary Prosecutions Appeal (Scotland) Act, 1875.

106. In the application of this act to Ireland-

(1.) The expression "certified efficient school" means any national school, or any school recognized by the Lord Lientenant and Privy Council as affording sufficient means of literary education for the purposes of this act :

(2.) In lieu of any two half-holidays allowed under the provisions of subsection (2) in section twenty-two of this act, there shall be allowed as a holiday to every child, young person, and woman employed in a factory or workshop the whole ef the 17th day of March : Provided, that when this date falls on a Sunday, this sub-section shall have no effect as regards such clate:

(3.) The expression "sanitary authority" means an urban or rural sanitary anthority within the meaning of the Public Health (Ireland) Act, 1874 , and any act amending the same :

(4.) The expression "medical officer of health" means the medieal sanitary officer of the sanitary district:

The expression "poor law medical officer" means the dispensary doctor:

(5.) Any act authorised to be done or consent required to be given by * the Education Department under this act shall be done and [*753] given by the Lord Lieutenant or Lords Justices of Ireland, acting by and with the advice of the Privy Council in Ireland:

(6.) The expression "county court" means the civil bill court :

(7.) The expression "Summary Jurisdiction Acts" means, within the police district of Dublin metropolis, the acts regulating the powers and duties of justices of the peace for such district, or of the police of such district, and elsewhere in Ireland the Petty Sessions (Ireland) Act, 1851, and any act amending the same:

(8.) A court of summary jurisdiction when hearing and determining an information or complaint in any matter arising under this act shall be constituted within the police district of Dublin metropolis of one of the divisional justices of that district sitting at a police court within the district, and elsewhere of a stipendiary magistrate sitting alone, or with others, or of two or more justices of the peace sitting in petty sessions at a place appointed for holding petty sessions:

(9.) Appeals from a court of summary jurisdiction shall lie in the manner and subject to the conditions and regulations prescribed in the twentyfourth section of the Petty Sessions (Ireland) Act, 1851, and any acts amending the same:

(10.) All fines imposed under this act shall, save as is otherwise expressly provided by this act, be applied in the manner directed by the Fines Act (Ireland), 1851, and any act amending the same:

(11.) The provisions of section nineteen of the Public Health Act, 1866, or of any enactment substituted for that section, with respeet to any factory, workshop, or workplace not kept in a eleanly state, or not ventilated, or overcrowded, shall not apply to any factory or workshop which is subject to the provisions of this act with respect to cleanliness, ventilation, and overerowding, but shall apply to every other factory, workshop, and workplace:

It is hereby declared that the Sanitary Acts within the meaning of the Public Health (Ireland) Aet, 1874, shall apply to buildings in which persons are employed, whatever their number may be, in like manner as they apply to buildings where moro than twenty persons are employed :

(12.) All matters required by this aet to be published in the Iondon Gazette shall. if they relate exclusively to Ireland, instead of being published in the London Gazette, be published in the Dublin Gazette only. 


\section{(4.) Repeal.}

107. The acts specified in the sixth schedule to this act are hereby repealed from and after the commencement of this act to the extent in the third column of that schedule mentioned:

Provided that-

(1.) All notices affixed in the factory in parsuance of the acts hereby repealed shall, so far as they are in accordance with the provisions of this act, be deemed to have been aftixed in pursuance of this act; and

(2.) All inspectors, sub-inspectors, officers, clerks, and servants appointed in pursuance of the acts hereby repealed shall continue in office and shall be subject to removal and have the same powers and duties as if they had been appointed in pursuance of this act; and

(3.) All certifying surgeons appointed in pursuance of any act hereby rcpealed shall be deemed to have been appointed in pursuance of this act; and

[*754] *(4.) All surgical certificates granted in pursuance of any act hereby repealed shall have effect as certificates of fitness for employment granted in pursuance of this act, and all registers kept in pursuance of any act hereby repealed shall, until otherwise directed by a Secretary of State, be deemed to be the registers required by this act; and

(5.) Any order made by a Secretary of State in pursuance of any enactment hereby repealed for granting any permission or relaxation to any factories or workshops may, if the Secretary of State so direct, continue in force for a period not exceeding three months ofter the commencement of this act; and

(6.) The standard of proficiency fixed by the Education Department in pursuance of any enactment hereby repealed shall be deemed to have been fixed in pursuance of this act; and

(7.) A child exempted by section eight of the Elementary Education Aet 1876 , from the provisions of section twelve of the Factory Act, 1874, by reason of his having attained the age of eleven years before the 1st day of January, 1877, shall, on attaining the age of thirteen years, be deemed to be a young person within the meaning of this act:

(8.) This repeal shall not affect-

(a.) Anything duly done or suffered under any enactment hereby repealed ; or

(b.) Any obligation or liability incurred under any enactment hereby repealed; or

(c.) Any penalty or punishment incurred in respect of any offenee committed against an enactment hereby repealed ; or

(d.) Any legal proceeding or remedy in respect of any such obligation, liability, penalty, or pnnishment as aforesaid, and any such legal proceeding and remedy may be carried on as if this act had not passed.

\section{SCHEDULES.}

\section{FIRST SCHEDULE.}

\section{Spectal Provisions for Health.}

Factories and Workshops in which the Employment of Young Persons and Children is restricted.

1. In a part of a factory or workshop in which there is carried onthe process of silvering of mirrors by the mercurial proeess; or the process of making white lead,

a young person or child shall not be employed. 
2. In the part of a factory in which the process of melting or annealing glaw is carried on a ehild or female young person shall not be employed.

3 . In a factory or workshop in which there is carried on-

(a.) the making or finishing of bricks or tiles not being ornamental tiles; or

(b.) the making or finishing of salt,

a girl under the age of sixteen years shall not be employed.

4. In a part of a factory or workshop in which there is carried on-

(a.) any dry grinding in the metal trade, or

(b.) the dipping of lucifer matches,

a child shall not be employed.

5. In any grinding in the metal trades other than dry grinding or in fustian cutting a ehild under the age of eleven years shall not be employed.

${ }^{*}$ SE CON D SCH E DULE.

SPECIAI, RESTRICTIONS.

Places forbidden for Meals.

The prohibition on a ehild, young person or woman taking a meal or remaining during the times allowed for meals in certain parts of factories or workshops applies to the parts of factories and workshops following; that is to say,

(1.) In the case of glass works, to any part in which the materials are mixed; and

(2.) In the ease of glass works where flint glass is made, to any part in which the work of grinding, cutting or polishing is carried on ; and

(3.) In the case of lucifer-match works, to any part in which any manufacturing process or handieraft (exeept that of cutting the wood) is usually carried on ; and

(4.) In the ease of earthenware works, to any part known or used as dippers' house, dippers' drying room or china scouring room.

\section{TH I RD SCHEIULE.}

\section{Speciat, Fxceptions.}

PART ONE.-Period of Employment.

The exception respecting the employment of children, young persons and women hetween the hours of eight in the morning and eight in the evening, and on Saturday between the hours of eight in the morning and four in the afternoon or between the hours of seven in the morning and three in the afternoon, applies to any factory or workshop or part thereof in whieh any of the following manufacturing processes or handierafts are carried on ; that is to say,

(a.) Iithographic printing :

(b.) Turkey red dyeing:

(c.) The making of any article of wearing apparel :

(d.) The making of furniture hangings:

(e.) Artificial flower making :

f.) Bon-bon and Christmas present making:

(g.) Valentine making:

(h.) Fancy box making :

(i.) Envelope making:

(k.) Almanae making :

(1.) Playing card making :

(m.) Machine ruling : 
(n.) Biscuit making :

(o.) Firewood cutting :

(p.) Job dyeing : or

(q.) Aërated water making; and also to

(r.) Bookbinding works :

(s.) Letterpress printing works : and

(t.) A part of a factory or workshop which is a warehouse not used for any manufacturing process or handicraft, and in which persons are solely employed in polishing, cleaning, wrapping or packing up goods.

\section{PART Tivo.-Meal Hours.}

[*756] *The cases in which the provisions of this act as to meal times being allowed at the same hour of the day are not to apply are-

(1.) The case of children, young persons and women employed in the follow ing factories; that is to say,

Blast furnaces,

Iron mills,

Paper mills,

Glass works, and

Letterpress printing works ; and

(2.) The case of male young persons employed in that part of any print works or bleaching and dyeing works in which the process of dyeing or open-air bleaching is carried on.

The cases in which and the extent to which the provisions of this act as to a child, young person or woman during the times allowed for meals being employed or being allowed to remain in a room in which a manufacturing process or handicraft is being carried on, are not to apply are,-

(1.) The case of ehildren, young persons and women employed in the follow ing factories; that is to say,

Iron mills,

Paper mills,

Glass works (save as otherwise provided by this act), and

Ietter-press printing works ; and

(2.) The case of a male young person employed in that part of any print works or bleaching and dyeing works in which the process of dyeing or open-air bleaching is carried on, to this extent, that the said provisions shall not prevent him, during the times allowed for meals to any other young person or to any child or woman, from being employed or being allowed to remain in any room in which any manufacturing process is carried on, and shall not prevent, during the times allowed for meals to such male young person, any other young person or any child or woman from being employed in the factory or allowed to remain in any room in which any manufacturing process is carried on.

\section{PART ThreE.-Overtime.}

The exception with respect to the employment of young persons and women for forty-eight days in any twelve months during a period of employment, beginning at six or seven o'clock in the morning and ending at eight or nine o'clock in the evening, or beginning at eight o'clock in the morning and ending at ten o'clock in the evening: applies to each of the factories and workshops, and parts thereof, following ; that is to say,

(1.) Where the material which is the subject of the manufacturing process or handicraft is liable to be spoiled by weather ; namely,

(a.) Flax scutch mills; and

(b.) A factory or workshop or part thereof in which is carried on the making or finishing of bricks or tiles not being ornamental tiles; and

(c.) The part of rope works in which is carried on the open-air process ; and 
(d.). The part of bleaching and dyeing works in which is carried on open-air bleaching or Turkey red dyeing; and

(e.) A factory or workshop or part thereof in which is carried on glue making; and

*(2.) Where press of work arises at certain recurring seasons of the [*757j year; namely,

(f.) Letterpress printing works;

(g.) Bookbinding works; and

a factory, workshop, or part thereof in which is carried on the manufacturing process or handicraft of -

(h.) Lithographic printing; or

(i.) Machine ruling; or

(k.) Firewood cutting; or

(1.) Bon-bon and Christmas present making; or

(m.) Almanac making; or

(n.) Valentine making; or

(o.) Envelope making; or

(p.) Aërated water making; or

(q.) Playing card making; and

(3.) Where the business is liable to sudden press of orders arising from unforeseen events; namely,

a factory or workshop, or part thereof, in which is carried on the manufacturing process or handieraft of-

(r.) The making up of any article of wearing apparel; or

(s.) 'The making up of furniture hangings; or

(t.) Artificial flower making; or

(u.) Fancy box making; or

(v.) Biscuit making; or

(w.) Job dyeing; and also,

(x.) A part of a factory or workshop which is a warehouse not used for any manufacturing process or handicraft, and in which persons are solely employed in polishing, cleaning, wrapping. or packing up goods.

Provided that the said exception shall not apply-

(a.) Where persons are employed at home, that is to say, to a private lousc, room, or place which, though used as a dwelling, is by reason of the work carried on there a factory or workshop within the meaning of this act, and in which neither steam, water, nor other mechanical power is used, and in which the only persons employed are members of the same fimily dwelling there; or

(b.) To a workshop or part thereof which is conducted on the system of not employing any child or young person therein.

\section{PART FOER.-Additional Half Hour.}

The exception with respect to the employment of a child, young person, or woman for a further period of thirty minutes where the process is in an ineonplete state applies to the factories following; (that is to say),

(a.) Bleaching and dyeing works;

(b.) Print works;

(c.) Iron mills in which male young persons are not employed during any part of the night;

(d.) Foundries in which male young persons are not employed during any part of the night; and

(e.) Paper mills in which male young persons are not employed during any part of the night.

\section{PART Five-Overlime for Perishable Articles.}

The exception with respect to the employment of women for ninety-six days in any twelve months during a period of employment beginning at wix or seven 
[*758] o'clock in the morning and ending at eight or nine o'clock in *the evening applies to a factory or workshop or part thereof in which any of the following processes is carried on; namely,

The process of making preserves from fruit,

The process of preserving or curing fish, or

The process of making condensed milk.

\section{PART Six.-Night Work.}

The exception with respect to the employment of male young persons during the night applies to the factories following; (that is to say,)
(a.) Blast furnaces,
(b.) Iron mills,
(c.) Letterpress printing works, and
(d.) Paper mills.

\section{Part Seven.-Spell.}

The exception respecting the continuous employment in certain textile factories during the winter months of children, young persons, and women without an interval of at least half an hour for a meal for the same period as in a non-textile factory, applies to textile factories solely used for-

(a.) The making of elastic web; or

(b.) The making of ribbon; or

(c.) The making of trimming.

\section{FOURTH SCHEDULE.}

\section{List of Factories and Workshops.}

\section{PART ONE.-Non-Textile Factories.}

(1.) "Print works," that is to say, any premises in which any persons are employed to print figures, patterns, or designs upon any cotton, linen, woollen, worsted, or silken yarn, or upon any woven or felted fabric not being paper;

(2.) "Bleaching and dyeing works," that is to say, any premises in which the processes of bleaching, beetling, dyeing, calendering, finishing, hooking, lapping, and making up and packing any yarn or cloth of any material, or the dressing or finishing of lace, or any one or more of such processes, or any process incidental thereto, are or is carried on;

(3.) "Earthen ware works," that is to say, any place in which persons work for hire in making or assisting in making, finishing, or assisting in finishing, earthenware of any description, except bricks and tiles not being ornamental tiles;

(4.) "Lucifer-match works," that is to say, any place in which persons work for hire in making lncifer matches, or in mixing the chemical materials for making them, or in any process incidental to making lucifer matches, except the cutting of the wood;

(5.) "Percnssion-cap works," that is to say, any place in which persons work for live in making percussion caps, or in mixing or storing the chemical materials for making them, or in any process incidental to making percussion caps;

(6.) "Cartridge works," that is to say, any place in which persons work for hire in making cartridges, or in any process incidental to making cartridges, except the manufacture of the paper or other material that is used in making the cases of the cartridges;

[*759] *(7) "Paper-staining works," that is to say, any place in which persons work for hire in printing a pattern in colours upon sheets of paper, either 
by blocks applicd by hand, or by rollers worked by steam, water, or other mechanical power;

(8.) "Fustian-cutting works," that is to say, any place in whieh persons work for hive in fustian cutting;

(9.) "Blast furnaces," that is to say, any blast furnace or other furnace or premises in or on which the process of smelting or otherwise obtaining any metals from the ores is carried on;

(10.) "Copper mills";

11.) "Iron mills," that is to say, any mill, forge, or other premises in or on which any process is carried on for converting iron into malleable iron, steel, or tin plate, or for otherwise making or converting steel;

(12.) "Foundries," that is to say, iron foundries, copper foundries, brass foundries, ant other premises or places in which the process of founding or casting any metal is carried on; except any premises or places in which such process is carried on by not more than five persons and as subsidiary to the repair and completion of some other work;

(13.) "Metal and india-rubber works," that is to say, any premises in which steam, water, or other mechanical power is used for moving machinery cmployed in the manufacture of machinery, or in the manufacture of any article of metal not being machinery, or in the manufacture of india-rubber or guttar percha, or of articles made wholly or partially of india-rubber or gutta-percha;

(14.) "Paper mills," that is to say, any jrenises in which the manufacture of paper is carried on;

(15.) "Glass works," that is to say, any premises in which the manufacture of glass is carried on:

(16.) "Tobacco factories," that is to say, any premises in which the manufacture of tobacco is carried on;

(17.) "Letter-press printing works," that is to say, any premises in which process of letter-press printing is carried on;

(18.) "Bookbinding works," that is to say, any premises in which the process of bookbinding is carried on;

(19.) "Flax scutch mills."

\section{PAir Two.-Non-Textile Factories and Workshops.}

(20.) "Iat works," that is to say, any premises in which the manufacture of hats or any process incidental to their manufactnre is carried on;

(21.) "Rope works," that is to say, any premises heing a ropery, ropewalk, or rope work, in which is auricd on the laying or twisting or other process of preparing or finisluing the lines, twines, cords, or ropes, and in which machinery moved by steam, water, or other meclianical power is not used for drawing or spinning the fihres of flax, hemp, jute or tow, and which has no internal communication with any buildings or premises joining or forming part of u textile tactory, "except such communication as is necessary for the transwission of poiver;

(2:.) "Bakehouses," that is to say, any places in which are baked lorend, biscuits, or confectionery from the baking or selling of which a profit is de rived;

(2:3.) "Lace warehonses," that is to say, any premises, room, or place not included in bleacling and dycing works as hercinbefore defined, in which persons are employed upon any minufacturing proxess or handionat in relation ta lace, subsequent to the making of lace upon a lace machine mover by steam, water, or othel mechanical power;

(24.) "Shiphuilding yarls," that is to say, any prenises in which any slips, boats, or vessels used in navigation are made, finished, or repaired;

"(25.) "Quarries," that is to say, any place, not being a mine, in [*760] which persons work in retting slate, stone, coprolites, or other minerals;

(26.) "Pit-banks," that is to say, any place ahove ground adjacent to a shan of a mine, in which plice the employment of women is not regulated by the 
Coal Mines Regalation Act, 18\%2 (c), or the Metalliferous Mines Regulation Act, $1872(d)$, whether such place does or does not form part of the mine within the meaning of those acts.

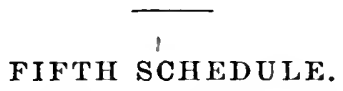

\author{
SPECIAL Exemptions. \\ Straw plaiting, \\ Pillow-lace making. \\ Glove making.
}

\title{
SIXTH SCHEDULE.
}

Acts repealed.

\begin{tabular}{|c|c|c|}
\hline $\begin{array}{l}\text { Session and } \\
\text { Chapter. }\end{array}$ & Title of Act. & Extent of Repeal. \\
\hline 42 Geo. 3, c. 73. & $\begin{array}{l}\text { An act for the preservation of the } \\
\text { health and morals of apprentices } \\
\text { and others employed in cotton } \\
\text { and other mills and cotton and } \\
\text { other factories. }\end{array}$ & The whole act. \\
\hline $\begin{array}{l}3 \text { \& } 4 \text { Will. } 4, \\
\text { c. } 103 \text {. }\end{array}$ & $\begin{array}{l}\text { An act to regulate the labonr of } \\
\text { children and young persons in } \\
\text { the mills and factories of the } \\
\text { United Kingdom. }\end{array}$ & The whole ant. \\
\hline 7 \& 8 Vict. c. 15. & $\begin{array}{l}\text { An act to amend the laws relating } \\
\text { to labour in factories. }\end{array}$ & The whole art. \\
\hline $9 \& 10$ Vict. c. 40. & $\begin{array}{l}\text { An act to declare certain rope- } \\
\text { works not within the operation } \\
\text { of the Factory Acts. }\end{array}$ & The whole art. \\
\hline $\begin{array}{l}13 \& 14 \text { Vict. } \\
\text { c. } 54 .\end{array}$ & $\begin{array}{l}\text { An act to amend the acts relating } \\
\text { to labour in factories. }\end{array}$ & The whole act. \\
\hline $\begin{array}{l}16 \& 17 \text { Vict. } \\
\text { c. } 104 .\end{array}$ & $\begin{array}{l}\text { An act further to regulate the ent- } \\
\text { ployment of children in fac- } \\
\text { ries. }\end{array}$ & The whole ast. \\
\hline $\begin{array}{l}19 \underset{20}{\&} 20 \text { Vict. } \\
\text { e. } 38 .\end{array}$ & The Factory Act, $1856 . . . .$. & The whole ast. \\
\hline $\begin{array}{l}24 \& 25 \text { Vict. } \\
\text { c. } 117 \text {. }\end{array}$ & $\begin{array}{l}\text { An act to place the employnent of } \\
\text { women, young persons, youths, } \\
\text { and children in lace factories } \\
\text { under the regulations of the Fac- } \\
\text { tories Acts. }\end{array}$ & The whole art. \\
\hline $\begin{array}{l}26 \& 27 \text { Vict. } \\
\text { c. } 40 .\end{array}$ & $\begin{array}{l}\text { The Bakehouse Regulation Act, } \\
1863 .\end{array}$ & The whole act. \\
\hline $\begin{array}{l}{[* \% 61] * 27 \& 28} \\
\text { Vict. c. } 48 .\end{array}$ & $\begin{array}{l}\text { The Factory Acts Extension Act, } \\
1864 \text {. }\end{array}$ & The whole act. \\
\hline
\end{tabular}

(c) Ante, p. 641 .

(d) Ante, p. 673. 


\begin{tabular}{|c|c|c|}
\hline $\begin{array}{l}\text { Session and } \\
\text { Chapter. }\end{array}$ & Title of Act. & Extent of Repeal. \\
\hline $\begin{array}{l}29 \& 30 \text { Viet. c. } \\
90 .\end{array}$ & The Sanitary Aet, 1866 . . . . & $\begin{array}{l}\text { The following words } \\
\text { (so far as unrepealed) } \\
\text { in section nineteen, } \\
\text { "not alrealy under } \\
\text { "the operition of } \\
\text { "any general act } \\
\text { "for the regulation: } \\
\text { "of factories., or } \\
\text { "bakehouses." }\end{array}$ \\
\hline $\begin{array}{l}30 \& 31 \text { Viet. e. } \\
103 .\end{array}$ & $\begin{array}{l}\text { The Factory Acts Extension Act, } \\
\text { 1867. }\end{array}$ & The whole act. \\
\hline $\begin{array}{l}30 \& 31 \text { Viet. } c . \\
146 .\end{array}$ & The Workshop Regulation Act, 1867. & The whole act. \\
\hline $\begin{array}{l}33 \text { \& } 34 \text { Viet. c. } \\
62 .\end{array}$ & $\begin{array}{l}\text { The Fictory and Workshop Act, } \\
1870 .\end{array}$ & The whole act. \\
\hline $\begin{array}{l}34 \text { \& } 35 \text { Viet. e. } \\
19 .\end{array}$ & $\begin{array}{l}\text { An act for exempting persons pro- } \\
\text { fessing the Jewish religion from } \\
\text { penalties in respect of young per- } \\
\text { sons and females professing the } \\
\text { said religion working on Sundays. }\end{array}$ & The whole act. \\
\hline $\begin{array}{l}34 \& 35 \text { Vict. e. } \\
104 .\end{array}$ & $\begin{array}{l}\text { The Factory and Workshop Act, } \\
1871 \text {. }\end{array}$ & The whole act. \\
\hline $\begin{array}{l}37 \& 38 \text { Vict. c. } \\
44 .\end{array}$ & The Factory Act, 1874 . . . . . & \\
\hline $\begin{array}{l}38 \text { \& } 39 \text { Viet. c. } \\
55 .\end{array}$ & The Public Health Act, 1875 . . . & $\begin{array}{l}\text { The following words } \\
\text { in section four, } \\
\text { "more than twen- } \\
\text { "ty," and the } \\
\text { words "at one } \\
\text { "time," and the } \\
\text { following words in } \\
\text { section ninety-one. } \\
\text { "not already under } \\
\text { "the operation of } \\
\text { "any general act } \\
\text { "for the regulation } \\
\text { "of factories or } \\
\text { "bakehouses." }\end{array}$ \\
\hline $\begin{array}{l}39 \& 40 \text { Viet. e. } \\
79 .\end{array}$ & $\begin{array}{l}\text { The Elementary Education Act, } \\
\text { 1876. }\end{array}$ & $\begin{array}{l}\text { Section eight and the: } \\
\text { following words in } \\
\text { section forty-eight, } \\
\text { "the Wuctory Acts, } \\
\text { "1833 to } 1874 \text {, :s } \\
\text { "amended by this } \\
\text { "act, and includes } \\
\text { "the Workshop } \\
\text { "Acts, 1867to 1871, } \\
\text { "as umended by } \\
\text { "this act, and". }\end{array}$ \\
\hline
\end{tabular}




\section{[*762] *An Act to regulate the Employment of Children in places of public amusement in certain cases. [24th July, 1879.]}

Whereas it is expedient to regulate the employment of children in places of public amusement in certain cases:

Be it therefore enacted by, \&c., \&c., as follows :

1. This act may be cited as the Children's Dangerous Performances Act, 1879

2. 'This act slall not come into operation until the first day of January, 1880 , which date is hereinafter referred to as the commencement of this act.

3. From and atter the commencement of this act, any person who shall cause any child uncler the sige of fourteen years to take part in any public exhibition or performance whereby, in the opinion of a court of summary jurisdiction, the life or limbs of such child shall be endangered, and the parent or guardian, or any person having the custody, of such child, who shall aid or abet the same, shall severally be guilty of an offence against this act, and shall on summary conviction be liable for each offence to a penalty not exceeding ten pounds.

And where in the course of a public exhibition or performance, which in its nature is dangerous to the life or limb of a child under such age as aforesaid taking part therein, any accident causing actual bodily harm occurs to any such ehild, the employer of such child shall be liable to be indicted as having committed an assault; and the court before whom such employer is convicted on indictment shall have the power of awarding compensation not exceeding twenty pounds, to be paid by such employer to the child, or to some person named by the court on behalf of the child, for the bodily harm so occasioned; provided that no person slall be punished twice for the same offence.

4. Whenever any person is charged with an offence against this act in respect of a child who in the opinion of the court trying the case is apparently of the age alleged by the informant, it shall lie on the person charged to prove that the child is not of that age.

5. Every offence against this act in respect of which the person committing it is liable as above mentioned to a penalty not exeeding ten pounds shall be prosecuted and the penalty recovered with costs in a summary manner, as follows:

In England, in accordance with the provisions of the act eleventl and twelfth Victoria, chapter forty-three, intituled "An Act to facilitate the performance of the duties of justices of the peace ont of sessions within England and Wales with respect to summary convictions and orders," and of any act or acts amending the same $(d)$; and the court of summary jurisdiction when hearing and determining an information in respect of any offence under this act shall be constituted either of two or more justices of the peace in petty sessions, sitting at a place appointed for the holding of petty sessions, or some magistrate or officer sitting alone or with others at some court or other place appointed for the administration of justice for the time being empowered by law to do alone any act authorised to be done by more than one justice of the peace:

In Scotland, in accordance with the provisions of the Summary Procednre Act, 1861, and of any act or acts amending the same; and

In Ireland, within the poliec district of Dublin metropolis in accordance with the provisions of the acts regulating the powers and duties of justices of the peace for.such district, or of the police of such district, and elsewhere in Ireland in aceordance with the provisions of the Petty Sessions (Ireland) Act, 1851, and any act amending or affecting the same.

(d) See the Summary Jurisdiction Act, 1879, 42 \& 43 Vict. c. 49. 


\section{An Act to extend and regulate the Liability of Employers to make Compensation for Personal Injuries suffered by Workmen in their service. \\ [7th September, 1880.]}

Be it enacted by, \&c., \&c., as follows:-

1. Where after the commencement of this act personal injury is caused to a workman $(e)$.

(1.) By reason of any defect in the condition of the ways $(f)$, works, machinery $(g)$, or plantconneeted with or used in the business of the employer $(h)$; or

(2. By reason of the negligence of any person in the service of the employer who has any superintendence $(i)$ entrusted to him whilst in the exercise of such superintendence $(k)$; or

(3.) By reason of the negligence of any person in the service of the employer to whose orders or directions the workman at the time of the injury was bound to conform $(l)$, and did conform, where such injury resulted from his having so conformed; or

(4.) By reason of the act or omission of any person in the service of the employer done or made in obedience to the rules or brelaws of the employer, or in obedience to particular instructions given by any person delegated with the authority of the employer in that behalf $(m)$; or

(5.) By reason of the negligence of any person in the service of the ${ }^{*}$ ent- [*764]

(c) Sec post, sect. 8 . It has been decided in England that an omnibus conductor is not within the act (dissenting from the Scotch case of Wilson v. The Glasgow Tramways and Omnibus Co., Sess. Cas., 4th Ser. vol. 5, 981); Morgan v. General Omnibus Co., 12 Q. B. Div. 201 ; affd. 53 L. J., C. L. 352. Morgan v. (iencral Omnibus Co. is also reported $13 \mathrm{Q}$. B. D. 8.?. In Leceh v. Gartside, 5: I. T., N. S. 427, an overlooker of loons onc-half of whose time was taken up in manual labour, was held to be a workman within the act.

(f) A temporary obstruction is not a defect in the condition of a way, MI'Giffen v. I'almer's Ship Building Co., 52 I. J., C. L. 25; 10 Q. B. D. 5.

(g) This applies to a case where the machine, though not defective in its construction, was under the circumstances in which it was used calculated to cause injury to those using it. Heske v. Samuclson, 12 Q. 13. D. 30 ; 53 L. J., C. I. 45. And see Cripps v. Judge, 13 Q. B. Div. 583 ; 53 L. J., C. I. 517.

(h) Sce sect. 2, subsect. 1 .

(i) Sec sect. 8.

(k) It has been held that a "gangway man" whose duties were to give the word when certain sacks were to be loisted by a steam crane from a barge alongside, and lowered into a vessel, was a fellow labourer, and not a person who had superintendence entrusted to him. Shaffers v. The General Stcam Navigation Co., 52 L. J., C. L. $260 ; 10$ Q. B. D. 356. See also Robins v. Cubitt, 46 J. T., N.S. 535. But an employer may be liable although the superintendent is voluntarily assisting in manual labour. Osbornc v. Jackson, 11 Q. B. D. 619. See also Morrison v. Bairl, 10 C. of S. Cas. 271 (Se.).

( $l$ ) If the orders were such that the plaintiff was not bound to conform, he conld not recover against the employer. Bunker v. The Midland Raihoay Co., 47 I. T., N. S. 476 , ante, p. 235. See also Millward v. Same Co., 14 Q. B. D. 68, Van-boy and Carman. $\Lambda$ lso reported in 54 L. J., C. L. $202 ; 52$ L. T., N. S. 25i). And see Stuart v. Evans, 49 L. T., N. S. 138, that the defence of contributory negligence is not done awaty with by the act.

(m) Sce sect. 2, subsect. 2 . 
ployer who has the charge or control of any signal, points $(n)$, locomotive engine $(o)$, or train upon a railway $(p)$,

The term railway includes a temporary tramway used by a contractor. Doughty v. Firbank, 52 L. J., C. L. $480 ; 10$ Q. B. D. 358.

the workman, or in case the injury results in death, the legal personal representatives of the workmen, and any persons entitled in case of death, shall have the same right of compensation and remedies against the employer as if the workman had not been a workman of nor in the service of the employer, nor engaged in his work.

2. A workman shall not be entitled under this act to any right of compensation or remedy against the employer in any of the following cases; that is to say,

(1.) Under sub-section one of section one, unless the defect therein mentioned arose from, or had not been discovered or remedied owing to the negligence of the employer, or of some person in the service of the employer; and entrusted by him with the duty of seeing that the ways, works, machinery, or plant were in proper condition.

(2.) Under sub-section four of section one, unless the injury resulted from some impropriety or defect in the rules, byelaws, or instructions therein mentioned; provided that where a rule or byelaw has beelı approved or has been accepted as a proper rule or byelaw by one of her Majesty's Principal Secretaries of State, or by the Board of Trade or any other department of the Government, under or by virtue of any act of parliament, it shall not be deemed for the purposes of this act to be an improper or defective rule or byelaw.

(3.) In any case where the workmen knew of the defect or negligence which caused his injury, and failed within a reasonable time to give, or cause to be given, information thereof to the employer or some person superior to himself in the service of the employer, unless he was aware that the employer of such superior already knew of the said defect or negligence.

3. The amount of compensation recorerable under this act shall not exceed such sum as may be found to be equivalent to the estimated earnings, during the three years preceding the injury, of a person in the same grade employed during those years in the like employment and in the district in which the workman is employed at the time of the injury.

4. An action for the recovery under this act of compensation for an injury shall not be maintainable unless notice $(q)$ that injury has been sustained is given within six weeks, and the action is commenced within six months from [*765] the occurrence of the accident causing the injury, or, in "case of death, within twelve months from the time of death: Provided always, that in case of death the want of such notice shall be no bar to the maintenance of such action if the judge shall be of opinion that there was reasonable excuse for such want of notice.

5. There shall be deducted from any compensation awarded to any work-

(n) It was the duty of F., a workman employed in the signal department of the defendants' railway, to clean, oil, and adjust the points and wires of the locking apparatus at various places along the line, and to do slight repairs, and hè was, with others, subject to the orders of an inspector who was responsible for the points and locking gear, which were moved by men in signal boxes, being kept in proper condition. It was held that there was evidence to go to the jury that F. had " charge or control" of the points. Gibbs v. Great Western Railway Co., 11 Q. B. Div. 22 ; 12 Q. B. Div. 208 ; 53 L. J., C. L. 543.

(o) A steam crane fixed on a movable truck is not a locomotive engine. Murphy v. Wilson, 52 L. J., C. L. 524.

(p) A man working a capstan whereby he conld put a train of trucks in motion was held to be in "charge or control of a train upon a railway." Cox r. Great Western Railway Co., 9 Q. B. D. 106.

(q) See as to this notice, sect. 7. 
man, or representatives of a workman, or persons claiming by, under, or through a workman in respect of any cause of action arising under this act, any penalty or part of a penalty which may have been paid in pursuance of any other act of parliament to such workman, representatives, or persons in respect of the same canse of action; and where an action has been brought nnder this act by any workman, or the representatives of any workman, or any persons elaiming by, under, or through such workman, for compensation in respect of any cause of action arising nnder this act, and payment has not previously been made of any penalty or part of a penalty under any other act of parliament in respect of the same cause of action, such workman, representatives, or person shall not be entitled thereafter to receive any penalty or part of a penalty under any other act of parliament in respect of the same cause of action.

6.-(1.) Every action for recovery of compensation under this act shall be brought in a county court, but may, upon the application of either plaintiff or defendant, be removed into a superior court in like manner and upon the same conditions as an action commenced in a county court may by law be removed $(r)$.

(2.) Upon the trial of any such action in a county court before the judge withont a jury one or more assessors may be appointed for the purpose of ascertaining the amount of compensation.

(3.) For the purpose of regulating the conditions and mode of appointment and remuneration of such assessors, and all matters of procedure relating to their duties, and also for the purpose of consolidating any actions under this act in a county court, and otherwise preventing multiplicity of such actions, rules and regulations may be made, varied, and repealed from time to time in the sane manner as rules and regulations for regulating the practice and procedure in other actions in county courts $(s)$.

"County', court" shall, with respect to Scotland, mean the "Sherift's Court," and shall, with respect to Ireland, mean the "Civil Bill Court."

In Scotland any action under this act may be removed to the Court of Sessions at the instance of either party, in the manner provided by, and subject to the conditions prescribed by, section nine of the Sheriff Courts (Scotland) Act, $1877(t)$.

In Scotland the sheriff may conjoin actions arising out of the same oceurrence or cause of action, though at the iustance of different parties and in respect of different injuries.

7. Notice in respect of an injury under this act $(u)$ shall give the name $*_{a u d}$ address of the person injured, and shall state in ordinary language [*766] the cause of the injury and the date at which it was sustained, and shall bo served on the employer, or, if there is more than one employer, upon one of such employers.

The notice may be served by delivering the same to or at the residence or place of business of the person on whom it is to be served.

The notice may also be served by post by a registered letter addressed to the person on whom it is to be served at his last known place of residence or place of business; and, if served by post, shall be deemed to have been served at

(r) See Munday v. Thames Iron Works, de. Co., 52 L. J., C. L. 119 ; 10 Q. B. I). 59.

(*) See rules, post, p. 766 .

(t) $40 \& 41$ Vict. c. 50.

(u) See sect. 4. Notice under this act must be in writing, although the employer was present when the accident happened. Moyle v. Jenkins, 51 L. I., C. I. $113 ; 8$ Q. P. D. 116; Keen v. Millwall Dock Co., 51 T. J., C. L. $277 ; 8$ Q. B. D. 482. The notice need only state cause of injury, not cause of action. Clarkson v. Musgrave, 51 L. J., C. L., 526; 9 Q. B. D. 386 . And an omission to state cause of injury, is a "defect" which does not render the notice invalid. Stone v. Hydle, 51 L. J., C. L. 452 ; 9 Q. B. D. 76. Even an omission of the date of the injury has been held not to invalidate the notice where the defendant was not prejudiced, and it was not done for the purpose of misleading. Carter v. Drysdale, 12 Q. B. D. 91 ; 53 L. J., C. L. 557. 
the time when a letter containing the same would be delivered in the ordinary course of post ; and, in proving the service of such notice, it shall be sufficient to prove that the notice was properly addressed and registered.

Where the employer is a body of persons corporate or unincorporate the notice shall be served by delivering the same at or by sending it by post in a registered letter addressed to the office, or, if there be more than one office, any one of the offices of such body.

A notice under this section shall not be deemed invalid by reason of any defect or inaccuracy therein, unless the judge who tries the action arising from the injury mentioned in the notice shall be of opinion that the defendant in the action is prejudiced in his defence by such defect or inagcuracy, and that the defect or inacenracy was for the purpose of misleading.

8. For the purposes of this act, unless the context otherwise requires,-

The expression "person who has superintendence entrusted to him" means

a person whose sole or principal duty is that of superintendence, and who is not ordinarily engaged in manual labour:

The expression "employer" includes a body of persons corporate or unincorporate :

The expression "workman" means a railway servant $(x)$ and any person to whom the Employers and Workmen Act, $1875(y)$, applies.

9. This act shall not come into operation until the 1st day of January, 1881, which date is in this act referred to as the commencement of this act.

10. This act may be cited as the Employers' Liability Act, 18=0, and shall continue in force till the 31st day of December, 1887, and to the end of the then next session of parliament, and no longer, unless parliament shall otherwise determine, and all actions commenced under this act before that period shall be continued as if the said act had not expired.

\section{- \\ THE COUNTY COURT RULES, 1880.}

1. These rules may be cited as the County Court Rules, 1880 , or each rule may be cited as if it had been one of the county Court kules, 1875, and had been numbered therein by the number of the order and rule placed in the margin opposite each of these rules.

2. An order and rule referred to by number in these rules shall mean the order and rule so numbered in the County Court Rules, 1875.

\section{*ORDER XXXIXb.}

\section{The Employers' Liability ACt, 1880.}

\section{Service of Summons.}

13. A snmmons in an action brouglit under the provisions of the Employers: Liability Act, 1880, where it is to be served in the home district, sluall be delivered to the bailiff thirty-two clear days at least, and where it is to be served in a foreign district, thirty-five clear days before the return day, but it shall in either case be served thirty clear days before the return day thereof.

14. Particulars of demand shall be filed br the plaintiff at the time of the entry of the plaint, whatever the amount claimed may be; and a copy thereof shall be forthwith sent to the judge. 346.

(x) General manager. Conway v. Belfast, \&c. Railway Co., Ir. Rep. 11 C. L.

(y) 38 \& 39 Vict. c. 90 , ante, p. 698. 
15. The particulars of demand shall state in ordinary language the eause of the injury, and the date at which it was sustained, and the anount of compensation claimed, and where the action is brought by more than one plaintiff, the amount of compensation elaimed by each plaintiff, and where the injury of which the plaintiff complains shatl have arisen hy reason of the act or omission of any person in the service of the defendant, the partieulars shall give the name and description of such person.

Jury.

16. Notice of a demand for a jury shall be given in writing to the registrar of the court tifteen elear days at least before the return day, and the summonses to the intended jurors shall be delivered to the bailiff forthwith.

\section{Assessors.}

17. Any person who shall, as hereinafter provided, be appointed by tho jndge to act as an assessor in the action, shall be qualified so to act.

18. Where no demand for a jury shall have been madde, a party who desires assessors to be appointed shall, ten clear days at least before the return day, file an application aecording to the form in the schedule, stating the number of assessors he proposes to be appointed, and the names, addresses, and occupations of the persons who may have expressed their willingness in writing to act as assessors. If the applicant has obtained the eonsent of the other party to the persons named being appointed, he shall file such consent with his application.

19. Where the application for the appointnent of assessors has been made by one party to an action only, the registrar shal! forward the applieation so made to the other party, who may then either file an application for asseisors, or file objections to one or more of the persons proposed.

20. Where separate applieations are filed by the parties, no objection to the persons proposed shall be marle by either party, but the julge may appoint from the persons named in each application one or more assessor or assessors, provided that the same number of assessors be appointed from the names given in such applications respectively.

21. The applieations for the appointment of assessors, together with any objections made to the persons proposed, shall be forwarded by the registrar to the judge.

22 . Where the judge shall grant the application for the apprintment of assessors he shall appoint such of the persons proposed for assessors an he may think fit, subject to the provisions hereinbefore or hereinafter contained in this order.

*23. In any aetion where no demand for a jury has been mite, and [*\%68.] an application for the appointment of assessors has been filed, the judge may, either before or at the return day, nominate one or more additional persons to act as assessor or assessors in the action. Where no application for assessors has been made, the judge may, if he think fit, appoint any one or more persons to act as assessor or assessors in the action before or at the return day.

24. If at the time and place appointed for the trial all or any of the assessors appointed shall not attend, the judge may either proceed to try the action with the assistance of sueh of the assessors, if any, as shall attend, or he may adjourn the trial generally, or upon any terms which he may think fit, or he may appoint auy person who may be available and who is willing to act. and who is not objected to or who if objected to is objected to on some insuflicient gronnd, or the judge may try the action without assessors if he shall think tit.

2i. Every person nominated as an assessor shall receive for each day's attendance in every action the sum of two guineas, together with such further sum, if any, for his expenses as the judge may order.

26. Every person requiring the julge to be assisted by assessors shall, at the time of filing his application deposit with the registrar the sum of two gnineas for each assessor proposed, and such payments shall be considered as costs in 
the action, unless otherwise ordered by the judge. Provided that where a person proposed as an assessor shall have in writing inforned the registrar that he does not require his remuneration to be so deposited, 10 deposit in respect of such person shall be rectuired.

27. Where an action shall be tried by the judge with the assistance of any assessors in addition to or independently of any assessors proposed by the parties the remuneration of such assessors shall be borne by the parties, or either of them, as the judge shall direct.

23. If after an assessor has been appointed the action shall not be tried, the judge shall have power to make an allowance to him in respect of any expense or tronble which he may have incurred by reason of his appointment, and direct the payment to be made ont of the sum deposited for his remuneration.

29. The assessors shall sit in court with the jndge, and assist lim when required with their opinion and special knowledge for the purpose of ascertaining the amount of compensation, if any, which the plaintiff shall be entitled to recover.

\section{Consolidations of Actions or Stay of Proccedings.}

30. Where several actions shall be brought under this act against a defendant in the same court in respect of the same negligence, act, or omission, the defendant shall be at liberty to apply to the judge that the said actions shall be consolidated.

31. Applications for consolidation of actions shall be made upon notice to the plaintiff's affected by such consolidation.

32. In case several actions shall be hrought under this act against a defendant in the same court in respect of the same necrligence, act. or omission, the defendant may, on filing an undertaking to be bound so far as his liability for such negligence, act, or omission is concerned by the decision in such one of the said actions as may be selected by the judge apply to the judge for an order to stay the proceedings in the actions other than in the one so selected, until judgment is given in such selected action.

[*69] *333. Applications for stay of proccedings shall be made upon notice to the plaintiffs affected by stay of proceedings or ex parte.

34. Upon the hearing of any application for consolidation of actions or for stay of proceedings, the judge shall have power to impose such terms and conditions and make such order in the matter as may be just.

35. If any order shall be made by a judge upon an ex parte application to staly proceedings, it shall be competent to the plaintiffs affected by such order to apply to the judge, upon notice or ex parte, to vary or discharge the order so made, and upon such last-mentioned application such order shall be made as the judge shall think fit, and the judge shall have power to dispose of the costs occasioned by such order or orders as he may deem right.

36 . In case a verdict in the selected action shall be given against the defendant, the plaintiffs in the action stayed shall be at liberty to proceed for the purpose of ascertaining and recovering their damages and costs.

37. A defendant may admit the truth in the plaintiff's particnlars in the actions of any statement of his liability for such negligence, act, or omission, and thereupon the provisions of Order XII. rule 3, shall apply.

Where two or more persons are joined as plaintiffs under Order V. rule 1, and the negligence, act, or omission, which is the cause of action shall be proved, the judgment shall be for all the plaintiffs, but the amount of compensation, if any, that each plaintiff is entitled to shall be separately found and set forth in the judgment, and the amount of costs awarded in the action shall be ordered to be paid to such person and in such manner as the court may think fit.

Should the defendant fail to pay the several amounts of compensation and the costs awarded in the action, execution against his goods may issue as in an ordinary action, and shonld the procecds of the execution be insufficient, after deducting all costs, to pay the whole of the amounts awarded, a dividend shall be paid to each plaintiff, calculated upon the proportion of the amount which 
shall have been awarded to the respective plaintiffs to the total amount realised after the deduction of all the costs of the action as aforesaid.

\section{SCHEDULE.}

\section{Application for Assessors.}

The Employers Liability Act, 1880.

In the County Court of holden at

$$
\text { Between plaintiff, }
$$

The plaintiff [or defendant] applies to have an assessor [or assessors] appointed to assist the court in ascertaining the amonnt of compensation to be awarded to the plaintiff, should the judgment be in his favour; and he submits the names of the following persons, who have expressed their willingness in writing to act as assessors, should they be appointed.

(Here set out the names, addresses, and occupations of the persons above referred to.)

${ }^{*}+$ The defendant [or plaintiff] consents to the appointment of any of [*770] the persons above named to act as assessors in this action, as appears by his consent thereto filed herewith.

I appoint

$$
\text { Appointment by Judge. }
$$

$$
\text { Plaintiff [or Defendant]. }
$$

$$
\text { E. F. }
$$

to be assessors in this action.

tWhere the other party does not consent, or where the other party has filed an application for the appointment of assessors, strike this paragraph out.

We, John Bury Dasent, Rupert Alfred Kettle, Alfred Martinean, Henry J. Stonor, and James Motteram, being judges of county conrts appointed to frame rules and orders for regulating the practice of the courts, and forms of proceedings therein, under the 32nd section of "The County Courts Act, 1856," have by virtue of the powers vested in us thereby and of all other powers enabling us in this behalf, framed the foregoing rules and forms, and we do hereby certify the same to the Lord Chancellor accordingly.
J. B. DAsent.
RUPERT KETTIF.
A. Martineau.
H. J. Stoxor.
J. MotTeraM.

I approve of these rules and forms to come into force in all county courts on the 1st day of Jannary, 1881.

27 th December, 1880.

SELBORNE, C. 
45 VICT. c. 3.

\section{An Act to amend the Law relating to the use of Gumpowder in Slate Mines. [29th March, 1882.].}

Be it enacted by, \&c., \&c., as follows :

1. This act may be eited as the Slate Mines (Gunpowder) Act, 1882.

2. (1.) It shall be lawful for one of her Majesty's Principal Secretaries of State, if he shall think fit, from time to time, on the applieation of the owner, agent, or manager of any slate mine, to exempt such mine from the general rule contained in sub-section two of section twenty-three of the Metalliferous Mines Regulation Act, $187_{2}(z)$, with respect to the use of gnnpowder or other explosive substances, or any portion of such rule.

(2.) The application shall be transmitted by the owner, agent, or manager to the inspector of the district, and the requirements of sections twenty-four and twenty-eight of the Metalliferous Mines Regulation Act, $1872(a)$, as to the posting of any proposed special rule shall extend to any such application . Provided that the exemption shall not come into force until granted by the Secretary of State.

[*771] *(3.) The Secretary of State may at any time revoke such exemption, but such revocation shall not come into force until written or printed notice thereof has been posted up at the mine for twenty-four hours.

(4.) A list of the exemptions granted or revoked under this act shall be set forth by the inspector of the district in his annual report.

\section{$46 \& 47$ VICT. c. 31.}

\section{An Act to prohibit the Payment of Wages to Workmen in Public- houses and certain other places. [20th August, 1883.]}

Whereas by the Coal Mines Regulation Act, $18 \% 2(b)$, and the Metalliferous Mines Regulation Act, $1872(c)$, the payment in public-houscs, beershops, or other places in the said acts mentioned of wages to persons employed in or about any mines to which the said acts apply is prohibited, and it is expedient to extend sucl prohibition to the payment in public-houses, beershops, and other places in England and Scotland of wages to all workmen as defined by this act:

Be it therefore enacted by, \&c., \&c., as follows:

1. This act may be cited as the Payment of Wages in Public-houses Prohibition Act, 1883.

2. In this act the expression "workman" means any person who is a labourer, servant in husbandry, journeyman, artificer, handicraftsman, or is otherwise engaged in manual labour, whether under the age of twenty-one years or above that age, but does not include a domestic or menial servant, nor any person employed in or about any mine to which the Coal Mines Regulation Act, 1872, or the Metalliferous Mines Regulation Act, 1872, applies :

3. From and after the passing of this act no wages shall be paid to any workman at or within any public-house, beershop, or place for the sale of any spirits, wine, cyder, or other spirituous or fermented liquor, or any office, garden, or place belonging thereto or occupied therewith, save and except such wages as are paid by the resident owner or ocenpier of such public-house, beershop, or place to any workman bonâ fide employed by him.

(z) Ante, p. 681.

(a) Ante, pp. 683, 684. (b) Ante, p. 645.

(c) Ante, p. 674 . 
Every person who contrarenes or fails to comply with or permits any person to eontravene or fail to comply with this act shall be guilty of an offence against this act.

And in the event of any wages being paid by any person in eontravention of the provisions of this aet for or on behalf of any employer, such employer sliall himself be guilty of an offenee against this act, unless he prove that he had taken all reasonable means in his power for enforeing the provisions of this act and to prevent such contravention.

4. Every person who is guilty of an offence against this act shall be liable to a penalty not exceeding ten pounds for each offence; and all offenees against this act may be prosecuted and all penalties under this act may be recovered by any person summarily in England in the manner provided by the Summary Jurisdiction Aets, and in Scotland in the manner provided by the Summary Jurisdiction (Scotland) Aets, 1864 and 1881.

5. This act shall not apply to Ireland.

*46 \& 47 VIст. с. 53.

\section{An Act to amend the Law relating to certain Factories and Work- shops $(d)$. [25th August, 1883.]}

Be it enacted by, \&c., \&c., as follows:

1. This act may be eited as the Factory and Workshop Act, 1883.

\section{White Lcad Factories.}

2. After the 31st day of December, 1883 , it shall not be lawful to carry on a white lead factory unless such factory is certified by an inspector to be in conformity with this act.

3.-(1.) A white lead factory shall not be certified to be in conformity with this act unless the scheduled conditions, that is to say, the conditions specified in the schedule to this act, as amended by any order of a Secretary of State under this section, and including any eonditions added by any such order, have been complied with.

(2.) A Sccretary of State may at any time, by writing under his hand, revoke, alter, add to, or modify all or any of the conditions specified in the schednle to this act.

4. Within a reasonable time after written application in that behalf, adlressed to the chief inspector of factories by the occupier of any white lead factory, such faetory shall be inspected by an inspector, and if he finds that the seheduled conditions have been complied with he shall certify to a Secretary of State that the factory is in conformity with this act; and a copy of the certifieate, signed by the inspector, shall be forthwith given to the oceupier.

5 . If at any time after a white lead factory has been certified to be in conformity with this act it appears to an inspector that the faetory is not kept in eonformity with this act, he shall forthwith give notice to the ocenpier specifying in what respects defanlt is made; and unless the default is within a reasonable time after the notice remedied to the satisfaction of an inspector, a Secretary of State may, if he sees fit, withdraw the certificate until the defult is remedied.

6. The occupier of a white lead factory which after the 31st day of December, 1883 , is carried on without a certificate under this act shall, for every day 718

(d) See the Factory and Workshop Act, $1878,41 \& 42$ Vict. c. 16, ante, p. 
during which it is so carried on, be liable on summary conviction to a fine not exceeding two pounds.

7. (1.) There shall be established not later than the 1st day of January, 1884, in every white lead factory, such special rules for the guidance of the persons employed therein as may appear best calculated to enforce the use by them of the requirements provided under this act, and generally to prevent injury to health in the conrse of their employment.

(2.) Such special rules when established shall be observed in and abont the factory as if they were enacted in this act.

(3.) If any person who is bound to observe the special rules established for any white lead factory acts in contravention of or fails to comply with any of such special rules he shall be liable on summary conviction to a fine not exceeding two pounds; and the occnpier of such factory shall also be liable on summary conviction to a fine not exceeding five pounds, unless he proves that he lad taken all reasonable means, by publishing and to the best of his power enforeing the said rules, to prevent such contravention or non-compliance.

$\left[{ }^{*}\right.$-773] *8. (1.) The gccupier of every white lead factory shall frame and transmit to the chief inspector, for approval by a Secretary of State, special rules for such factory within three months after the passing of ths act, or within three months after the opening for work of any white lead factory not opened for work before the passing of this act.

$(2$.$) The proposed special rules, together with a printed notice specifying$ that any objection to such rules on the ground of anything contained therein or omitted therefrom may be sent by any of the persons employed in the factory to the chief inspector, shall, during not less than two weeks before such rules are transmitted to the chief inspector, be posted up in like manner as is provided in this act respecting the publication of special rules for the-information of persons employed in the factory; and a certificate that such rules and notice have been so posted up shall be sent to the chief inspector, with the rules signed by the person sending the same.

(3.) The Secretary of State may approve such rules either with or without any omission, alteration or addition, and on his approval being signified in such manner as he may think fit the special rules as approved may be establisher. But no such omission, alteration or addition shall be made without sufficient notice to the occupier to enable him to state his objections, if any, thereto.

9. (1.) After special rules are established under this act in any white lead factory, the occupier of such factory may from time to time propose in writing to the chief inspector, for the approval of a Secretary of State any amendment of such rules or any new special rnles, and the prorisions of this aet with respect to the original special rules shall apply to all such amendments and new rules in like manner, as near as may be, as they apply to the original rnles.

(2.) A Secretary of State may at any time propose to the occupier of any white lead factory any new special rules or any amenclments to the special rules; and such new rules or amendments shall, as settled after time given for consideration of the objections, if any, of the occupier, be established as from a date to be fixed by a Secretary of State and specified therein.

10. If the occupier of any white lead factory to which this act applies makes any false statement with respect to the posting up of the special rules and notices, he slall be liable on summary conviction to a fine not exceeding twenty pounds; and if special rules for any white lead factory are not transmitted within the time limited by this act to the chief inspector, for the approval of a Secretary of State, such Secretary may by writing under his hand establish for that fuctory such special rules as he may see fit, to come into operation as from a late to be fixed by him and specified therein.

11. (1.) Printed copies of all special rules for the time being in force in any white lead factory under this act shall be kept posted up in legible characters in conspicuous places in the factory where they may be conveniently read by the persons employed. 
(2.) A printed copy of such rules shall be given by the occupier to any person affeeted thereby on his or her application.

(3.) If the oceupier of any white lead factory fails to comply with any provision of this section, he shall be liable on summary convietion to a fine not exceeding ten pounds.

12. Every person, who pulls down, injures, or defaces any proposed special rules, notice, or special rules when posted up in pursuance of the provisions of this act with respect to special rules, or any notice posted up in pursuance of the special rules, shall be liable on summary conviction to a fine not exceeding five pounds.

* Explanation of certain Provisions of Factory, dec. Act, 1878.

13. It is hereby declared that-

(a.) Section fifty-three of the Factory and Workshop Act, 1878 (e), only authorises overtime employment of young persons or women to take place in any factory or workshop on forty-eight days in the whole, in any twelve months; and that in reckoning such period of forty-eight days, every day on which any young person or woman has been employed overtime is to be taken into aceount; and that

(b.) Section fifty-six $(f)$ of the said act only authorises overtime employment of women to take place in any factory or workshop on ninety-six days in the whole in any twelve months, and that in reckoning such period of ninety-six days, every day on which any woman has been employed overtime is to be taken into account.

14. Notwithstanding anything in section twelve or section fourteen of the Factory and Workshop Aet, $1878(g)$, the period of employment for a child in an afternoon set in a factory or workshop, where the dinner time does not begin before two o'elock in the afternoon, may begin at noon; provided that in such ease the period of employment in the morning set shall end at noon.

\section{Bakehouses.}

15. It shall not be lawful to let or suffer to be occupied as a bakehouse, or to occupy as a bakehouse, any room or place which was not so let or oceupied before the first day of June, 1883, unless the following regulations are complied with :-

(i.) No watereloset, eartheloset, privy, or ashpit shall be within or conmmunicate directly with the bakehouse;

(ii.) Any cistern for supplying water to the bakehouse shall be separate and distinet from any eistern for supplying water to a watereloset ;

(iii.) No drain or pipe for earrying of 'foecal or sewage matter shall have an opening within the bakeliouse.

Any person who lets or suffers to be oceupied or who oceupies any room or place as a bakehouse in eontravention of this section shall be liable, on summary convietion, to a fine not exeeeding forty shillings, and to a further fine not execeding five shillings for every day during which any room or place is so ocenpied after a conviction under this section.

16. Where a court of summary jurisdiction is satisfied on the prosecution of an inspeetor or a local authority that any room or place used as a bakehouse (whether the same was or was not so nsed before the passing of this aet) is in such a state as to be on sanitary grounds unfit for use or occupation as a bakehouse, the occupier of the bakehouse shall be liable, on summary conviction, to a fine not exceeding forty shillings, and on a second or any subsequent conviction, not exceeding five pounds.

The court of summary jurisdiction, in addition to or instead of inflicting such fine, may order means to be adopted by the ocenpier, within the time named in the order, for the purpose of removing the ground of complaint.

(e) Ante, p. 734 .

(f) Ante, p. 735 . (g) Ante, p. 722. 
The court may, upon application, enlarge the time so named, but if, after the time as originally named or enlarged by subsequent order, the order isrnot com[*775] plied with, the occupier shall be *liable to a fine not exceeding one pound for every day that such non-compliance continues.

17. (1.) As respect every retail bakehouse, the provisions of this part of this act and of sections three, thirty-three, thirty-four, and thirty-five of the Factory and Workshop Act, $1878(h)$ (which relate to cleanliness, rentilation, overcrowding, and other sanitary conditions), shall be enforced by the local authority of the district in which the retail bakehouse is situate, and not by an inspector under the Factory and Workshop Act, 1878; and for the purposes of this section the medical officer of health of the local authority shall liare and exercise all such powers of entry, inspection, taking legal proceedings and otherwise, as an inspector under the Factory and Workshop Act, 1878.

(2.) If any child, young person, or woman is employed in any retail bakehouse, and the medical officer of the local authority becomes aware thereof, he shall forthwith give written notice thereof to the factory inspector for the district.

(3.) An inspector under the Factory and Workshop Act, 1878, shall not, as respects any retail bakehouse, exercise the powers of entry and inspection conferred by that act, unless he has notice or reasonable cause to believe that a child, young person, or woman is employed therein.

18. This act shall be construed as one with the Factory and Workshop Act, 1878; and in this act, unless the context otherwise requires,-

The expression "white lead factory" includes every factory and workshop in which the manufacture of white lead is carried on.

The expression "retail bakchouse" means any bakehouse or place, the bread, biscuit, or confectionery baked in which are not sold wholesale but by retail in some shop or place occupied together with such bakehouse.

The expression "local authority" means, as respects the city of London and the liberties thereof, the commissioners of sewers; as respects the parishes and districts mentioned in the Schedules $A$. and $B$. annexed to the Metropolis Management Act, 1855 , and any parish to which the said act may be extended by Order in Council in manner in the said act provided, the vestries and district boards elected under the said act; and as respects any urban sanitary district, the urban sanitary authority, and as respects any rural sanitary district, the rural sanitary authority within the meaning of the Public Health Act, 1875.

\section{Application of Act to Scotland and Ireland.}

19. In the application of this act to Scotland the expression "local authority" means the local authority within the meaning of the Public Health (Scotland) Act, 1867 .

20. In the application of this act to Ireland the expression "local authority" means, as regards any urban sanitary district, the nrban sanitary authority, and as regards any rural sanitary district the rural sanitary authority, within the meaning of the Public Health (Ireland) Act, 1878.

(h) Ante, pp. 719, 729. 


\section{Conditions of obtaining Certificate.}

(1) The stacks and stoves in the factory must be efficiently rentilated.

(2.) There must be provided for the use of the persons employed in the factory sufficient means of frequently washing hands and feet with a sufficient supply of hot and cold water, soap, towels, and brushes.

(3.) There must be provided in addition, for the use of women employed in the factory, sufficient baths, with a sufficient supply of hot and cold water, soap, towels, and brushes.

(4.) There must be provided for the use of the persons employed in the factory, (but not in any part of the factory where any work is carried on) a proper room for meals.

(5.) There must be provided for every person working at any tank an overall suit with head covering, and for every person working at any white-bed a rcspirator or covering for the mouth and nostrils and head covering, and for every person working at any dry stove or rollers an overall suit with head covering, and a respirator or covering for the mouth and nostrils.

(6.) There must be accessible to all persons employed in the factory a sufficient supply of acidulated drink. 



\section{N D E X.}

** The figures refer to the * pages between brackets $\left[{ }^{*}\right]$.

ACCIDENTS,

in coal mines, notice to be given to inspector of district, 653 .

in metalliferous mines, 675 .

- in faetories, notice of, to be given to inspector and certifying surgeon, 728 . except in eertain cases, 737 .

ACCOUNT,

servant bound to account to master, 135.

when action for, lies in equity by servant against master, 75.

passing money in, when equivalent to payment, 396 .

public officers of company keeping frandulent, punishment of, 412.

falsification of accounts with intent to defraud, 531.

\section{ACTION BY}

Master v. Servant,

for refusing to serve, 131 .

leaving too soon, 131.

gross negligence, 133.

indemnity from eonsequences of servant's negligence, 134.

not aecounting, 135 .

fraud or misfeasance, 133.

specific performance, or injunction to compel performance of con-

tract of service will not lie, 132.

not for aceident, 133.

or soliciting future custom from master's customers, 134.

or for money paid according to orders, 137.

for money had and received, 135 .

servant eannot set up jus tertii, 137.

presumption of payment from conrse of dealing, 137.

after conviction for embezzlement, 529 .

Master v. 'Third Person,

for enticing away servant, 156.

harbouring servant, 160.

servant's earnings, 161.

personal injuries to servant, 172.

seduction of female servant or child, 174 .

Servant v, Master,

for refusing to receive him, 182.

injunetion will not lie to compel master to retain servant, 185.

wrongful discharge, 188.

wages in such case, 190.

wages, 196. And see Wagrs.

not supplying food and medicine, 228 .

indemnity from consequences of obeying master's orders, 233. breach of statutory regulations, 215 . 


\section{[The paging refers to the $\left[{ }^{*}\right]$ pages.]}

ACTION BY-contimued.

Servant v. Third Person

for loss of his luggage, where master paid carriage, $416, \mathrm{n} .(x)$.

Third Person v. Master,

upon contracts of servant, 271 .

when made in servant's name, 291.

warranty of servant, $28 \%$.

for torts of servant, 322 .

Third Person v. Servant,

upon contracts made in his master's behalf, 383 .

bills of exchange, 386 .

for money paid to servant on account of his master, 392 .

if paid over to his master, 395.

if paid by mistake and not paid over, 399 .

for money given to servant by master to be paid to third person, 402 .

for money obtained wrongfully by servant, 397 .

for torts of servant, 415 .

misfeasance or nonfeasance, 415.

frand, 421 .

ADMISSION,

of liability, effect of when made by master, 275 .

not always an estoppel, 275 .

by servant when not binding on master, 288 .

AFFIDAVITS,

on return to habeas corpus, 543 .

in support of rule to remove conviction under Truck Act, how intituled $605, \mathrm{n} .(u)$.

AGENT. See Servant.

signature of agreement by, 49.

effect of direction by testator to employ a particular agent, 575 .

AGRICULTURAL GANGS ACT, 1867 . . 630.

APPORTIONMENT,

act docs not apply to cases of hiring and service, 219 .

APPRENTICE,

contract of hiring and service by, 2 .

infant may bind himself, or take, 12 .

not liable on covenants, $12, \mathrm{n} .(\mathrm{m})$.

power of master to correct, 138.

not discharge, 139, n. $(e)$.

disputes between, and their masters, 699 .

on servant, 78.

parish apprentices, 15, n. (b).

bound to sea service, $15, \mathrm{n} .(b)$.

to watermen, \&c., on the Thames, 15, n. (b).

under General Merchant Seamen's Act, 15, n. (b).

to chimney-swceps, $15, \mathrm{n}$. (b).

servant inducing apprentice to leave master, liable to action, 134.

neglecting to supply with sufficient food, 229 .

is a servant within statutes of embezzlement, 502 .

deemed to work for hire within Factory Acts, 748 .

iurisdiction of justices in disputes between master and, 699 . 


\section{[The paging refers to the [*] pages.]}

ARBITRATION,

of disputes between masters and workmen, 544 .

what disputes may be referred, 544 .

appointment of referees, 545 .

meetings and proceedings of arbitrators, 546 .

arrest and commitment of refractory witnesses, 547.

award, how enforced, 551.

under Masters and Workmen Act, 1872 . . 553.

Coal Mines Regulation Act, 1872 . 657.

Metalliferous Nines Regulation Act, 1872 . 679.

\section{ARTIFICEI,}

who is, within Truek Act, 53.

ASSAULT,

by master on servant, 138.

by servant on master, 472 .

in pursuance of eonspiracy to raise wages, $4 \pi 2$.

to obtain possession of master's property, 472, n. (e).

ASSESSORS, under Employers' Liability Aet, 1880 . . 767.

\section{ASSIGNEES,}

of insolvent or bankrupt not entitled to wages of his personal labour, 35 . entitled to stipulated penalty for not employing bankrupt, 36 .

ASSISTANT OVERSÉR,

appointed by Poor Law Commissioners, or Poor Law Board, is to be deemed servant of inhabitants, $506,50 \%$.

ATTACHMENT OF WAGES, Abolition Act, 1870 . . 633.

ATTORNEY,

to corporation can only be appointed by deed, except in London, 22 .

AUPITOR,

appointed by testator cannot be removed by trustees, 577 .

AUTHOR,

within Dramatie Copyright Aet, who is, 166.

of articles in periodicals, \&c., 168.

composer of music, employed by manager of theatre, 169 .

of photographs, who is, 167.

AUTHORITY. And see LIABILITY.

of servant, rule as to extent of, implied, 275.

AWARD. See Airbitration.

form of, when disputes referred to arbitration, 550,600 . performance of, how enforced, 551.

\section{BAKEHOUSES,}

within Fastory and Workshop Act, 1878 . . 759.

limewashing, \&e. interior of, 729 .

sleeping places near, 730 .

law as to retail, to be enforced by local authorities, 775 .

definition of retail, 775 .

regulations for new, 774 . 


\section{BANKRUPT,}

contracts of hiring by, 35 .

may sue for wages for his own personal labour, $\dot{35}$.

but not for liquidated damages on breach of contract to employ, 36 . when liable to pay wages after bankruptcy, 36, 211 .

servant convicted liable to be made bankrupt after eonviction, 386 .

\section{BANKRUPTCY OF MASTER,}

when a discharge of apprenticeship indentures, $2, \mathrm{n} .(d)$.

provisions of Bankrupt Act for wages of clerks and servants, labourers, and workmen, 210.

practice previous to 6 Geo. 4 , c. 16, s. 48 . . 211 .

service, to come within the act, must be under a contract, 213 .

what contracts within the act, 213 .

not within it, 214 .

out of what money wages to be paid, 217 .

where dispute referred to arbitration under 5 Geo. 4, c. 96 . . 549.

BILL OF EXCHANGE,

liability of servant upon, when drawu on behalf of master, 386 . master on, when drawn by servant, 287 .

after discharge, 305.

\section{BLAST FURNACES,} within Factory and Workshop Act, 1878 . . 759 .

BLEACHING AND DYEING WORKS, within Factory and Workshop Act, 1878 . . 758.

\section{BOARD WAGES,}

domestic servant not entitled to, when discharged with a month's wages, 92, n. $(r)$.

BOARDING-HOUSE KEEPER,

liability of, for servants' acts, 360 .

\section{BOOKBINDING WORKS,}

within Factory and Workshop Act, 1878 . . 759.

BOOKS,

property in master, 132.

\section{BROKER,}

book-keeper and Secretary of Joint Stock Company acting as, without licence, 406.

BURGLARY, by servant in master's house, 472 .

CAB DRIVER, servant of proprietor, 283.

\section{CARRIER,}

liable for acts of servant, 325 .

by land or water, limitation of liability, $325, \mathrm{n} .(b)$. felonious act, ibid.

liable to servant for loss of his luggage, though master paid the fare, 416 , n. $(x)$.

who was bailec, not a servant, 510 .

CARTRIDGE WORKS, within Factory and Workshop Act, 1878 . . 758. 
[The paging refers to the [*] pages.]

CERTIFICATE. See BANKRUPT.

of third person when necessary to entitle servant to wages, 204 .

CHARACTER, 426. And sce SEDUction.

master not bound to give discharged servant any, 426 .

when he does, communication privileged, 427 .

no action lics for false character unless maliciously given, 427 .

mere falsehood not sufficient to sustain action, 427.

nor that facts consistent with malice, 430 .

cases showing malice, 430.

facts not showing malice, 439 .

part privileged, part not, 442.

privileged threefold,

1. Communications made in discharge of public duty, 444. in course of jndicial proceedings, 444 .

2. In discharge of private duty, 447 .

master to friend of servant, $447-449$.

other servants, 449 .

tenant to landlord respecting his servant, 450 .

stranger to master, 451.

directors' report, 452.

anditors' report, 453.

discussion as to conduct of trustee of charity, 454.

3. Cases in which interest is concerned, 455 .

complaints made to master with a view to redress, 457.

where communication is priviliged, presence of third party does not make

it less so, 459 .

when not privileged, 461. And see SIANDER.

making indorsement upon servant's written character, 467.

liability consequent on giving false character, 467 .

personating master, 468 .

punishment of scrvant offering himself with false character, 469.

CHASTISEMENT,

of servant, 138 .

CHILDREN. Sce INFANT.

COAL MINES REGUTATION ACT, 1872 . 641.

inspection of, 654 .

notice to be given to inspector of district of accidents in, 653 .

COHABITATION, 。

agreement for service and, void, 47.

and not for service, 86 .

COIN,

and bank notes, may be described as money in indictments, 526 .

COLLABORATEURS,

who are, 252.

COLIECTOR,

of poor rates appointed by Poor Law Commissioners, or Poor Law Board, servant of inhabitants, 506.

\section{COMBINATION,}

amongst masters and workmen, 560 .

bond illegal, 104. 
[The paging refers to the [*] pages.]

COMMERCIAL TRAVELLER,

what notice entitled to, 95 .

not bound to take ont a hawker's licence, 406 .

employed by several persons, servant of each, 509 .

\section{COMMISSION,}

remuneration of servant by, does not make hin a partner, 60 .

bill in equity will not lie for an account, 78.

distinction between traveller and commission agent, 509 .

agreement by third person to give servant commission, a corrupt bargain, 60, n. (e).

COMMissioners. See Public OfFicers.

when liable for acts of persons obeying their orders, 378 .

\section{COMPANY,}

public officers of, appropriating property of company, punishment of, 412.

COMPULSORY,

liability of master when bound to employ particular persons, 361 .

\section{CONCILIATION,}

The Councils of Conciliation Act, 1867 . . 556.

\section{CONDITIONAL,}

hiring not less yearly because, 86 .

\section{CONSIDERATION,}

must appear in contracts of hiring within Statute of Frauds, 44.

when necessary to support agrecments in restraint of trade, 109, 119. courts will not inquire into adequacy of, 46, 119.

must not be illegal, 46 .

\section{CONSPIRACY AND PROTECTION OF PROPERTY ACT, 1875 . . 560.}

\section{CONSPIRACY,}

to persuade workmen to leave master, 156.

to depart from service no good reason for dischaging servant, unless acted on, 183.

what is $a, 561$.

\section{CONTRACT,}

liability of master upon contract of servant, 271 .

servant upon contract entered into for his master, 383.

\section{CONTRACT OF HIRING AND SERVICE,}

parties to the contract, 1 .

servant must be sui juris, or hiring would not confer a settlement, 1.

by married women, 4 .

infants, 11.

lunatics, 15 .

partners, 16.

corporations, 22 .

bankrupts and insolvents, 35 .

requisites of, at common law, 37 .

writing, when necessary-Statute of Frauds, 37.

in cases under 4 Geo. 4, c, 34 . 42 .

stamp, 49. 
[The paging refers to the [*] pages.]

\section{CONTRACT OF HIRING AND SERVICE-continued.}

interpretation of,

parol evidence, when admissible to explain written contract, 54 .

Partnership Act, 1865. . 60.

partner or servant, inter se, 61.

in criminal cases, 67 .

as regards third persons, 69.

apprentice or servant, 78 .

tenant or servant, 80 .

effect of general hiring, 84 .

master may not be bound to find employment, though bound to pay wages, 98.

courts disposed to imply contract to find work, 101.

agreements in restraint of trade in, 103.

general restraint, 103.

partial restraint upheld in some cases, 109.

hoiv distance measured, 114.

what reasonable, 115.

partly good and partly bad, 122.

injunction to enforce, 124 .

\section{CONTRACTOR,}

person employing, not generally liable for acts of his servants, 352 .

but may render himself liable, 357 .

head contractor not liable to sub-contractor's workmen for injuries, 246. not a workman or labourer within the Truck Act, 607, n. (a).

\section{CONTRIBUTORY NEGLIGENCE,}

effect of, in civil cases, 344 .

criminal cases, 414.

\section{CONVICT,}

contract of hiring by wife of, 7 .

\section{CONVICTION,}

of servant, when exemption of master, 320 .

if frandulent, quashed, $3: 0$.

under Truck Act, 606 .

\section{COPPER MILLS,}

within Factory and Workshop Act, 1878, 759.

\section{COPYRIGHT,}

in periodicals, \&e., in proprietor, not author employed to write, 168.

CORONER, provisions as to inquests on deaths from accidents in coal mines, 658.

in metalliferous mines, 680 .

\section{CORPORATION,}

servants to, in general, must be appointed by deed, 22.

so attorneys, except in Iondon, 22 .

exception in cases of inferior servants, 25 .

trading corporations, 29.

uncer Companies Clauses Consolidation Act, 34.

Joint Stock Companies Acts, 24.

power to appoint servants without seal only applies to ordinary servants, 34. 
WThe paging refers to the $[*]$ pages.]

CORPORATION-continued.

liable in tort for acts of servant, though not appointed by deed, 26, 327, 328.

\section{CORRECTION,}

of servant by master, 138.

COUNCILS OF CONCILIATION ACT, 1867 . . 556.

\section{CRIMINAL,}

responsibility of master for acts of servant, 306 .

of servant for acts done by command of master, 404 .

contributory negligence no answer in criminal cases, 414.

And see OFFENCES.

\section{CUSTOM,}

evidence of, admissible to explain contract, 54 .

\section{CUSTOMERS,}

contract not to solicit master's, 121.

servant not liable for solicing future business from master's, 134 .

\section{CUSTOMS,}

bond by infant servant of, $14, \mathrm{n} .(y)$.

DAMAGES,

in action for wrongful discharge, 194.

seduction, 181.

\section{DEATH,}

of master, discharges servant, 217 .

revocation of servant's authority to pledge master's credit, 305 .

servant not liable for goods obtained on master's credit after his death, 385 .

of servant, 226 .

\section{DEBAUCHING,}

female servant, 174. And see Seductions.

DEED,

hiring by, Statute of Frauds does not apply to, 41 .

DEFAMATION, 426.

DELEGATUS NON POTEST DELEGARE, employment of servants is no violation of this rule, 299.

\section{DELIVERY,}

to servant, when delivery to master, 392 .

\section{DEPUTY,} ministerial public officer may appoint, judicial may not, 3 .

\section{DEPUTY CLERK OF PEACE}

liability of, for negligence of assistant, 378, n. $(p)$

wreporting conduct of tradesmen to finance committee, 437. 
[The paging refers to the [*] pages.]

DISCHARGE,

of servant, what causes will justify, 139.

wilful disobedience of lawful orders, 140.

gross moral misconduct, embezzlement, \&c., 143.

habitual negligence in business, \&c., 144.

incompetence, or permanent disability from illness, 151.

wages on. See WAGES.

DISCOVERY,

in action for libel, $427, \mathrm{n} .(f)$.

\section{DISTANCE,}

how measured in construing contracts in restraint of trade, 114.

\section{DOMESTIC SERVANTS,}

entitled to month's warning or month's wages, 92 .

not board wages on discharge, $92, \mathrm{n} .(r)$.

who are "servants on domestic establishment," 568 .

not within The Councils of Conciliation Act, 1867 . . 559.

Employers and Workmen Act, 1875 . . 701.

Truck Act, 205, 607.

act for prohibition of payment of wages in a publichouse, 771 .

\section{DROVER,}

by trade, is not a servant, 493,503 .

but a bailee, 493 .

embezzlement by, 503 .

\section{DRUNKENNESS,}

discharge of servant for, 144, 147.

\section{DUTY,}

of servant to master, and master's remedies, 130.

when enforced by statute, 407 .

of master to servant, and servant's remedies, 182.

$$
\text { to indemnify servant, } 233 \text {. }
$$

as to character, 426.

food, 229 .

medicine, 230 .

wages, 197.

\section{DYERS,}

iourneymen and servants dyeing goods for their own profit without master's consent, 597.

\section{EARNINGS,}

of wife deserted by husband, order for protection of, 10 .

of servants, master entitled to, 162.

\section{EARTHENWARE,}

manufacture of, except bricks and tiles not being ornamental tiles, within Factory and Workshop Act, 1878 . . 758.

\section{EDUCATION,}

of children in factories and workshops, 726 .

\section{ELECTION,}

to charge servant, creditor cannot afterwards clarge master, 246. 46 MAS. \& SER. 


\section{EMBEZZLEMENT,}

by clerks and servants, 479 . And see LARCENY.

distinction between larceny and, 479 .

person indicted for one may be convicted of the other, 479, 528 .

may be dealt with summarily, 501 .

servant misappropriating property which has never been in master's posses-

sion, embezzlement, 497, 498.

pnnishment of, 500 .

same as for larceny by servant, 496,501 .

what must concur to constitute the offence, 501 .

who is a servant within the statute, 502 .

who is not, 507.

servant receiving money without anthority to do so not within the old acts.

511.

aliter, if employed to receive it, though on one occasion only, 513.

or from particular class of customers, 514 .

but may now be convicted of embezzlement, 528 .

conviction for, on indictment for larceny, 529.

stealing money received from master, larceny, 517.

from master's agent to be paid to master, embezzlement, 518 .

of change by servant sent to get change, 518 .

refusal to account must be shown, 519 .

omission to account not sufficient, 520,

even after promise to do so, 521 .

unless wilful, 520 .

leaving situation and absconding, evidence of embezzlement, 520.

claim of right to money no embezzlement, 521.

some specific sum must be proved, 521 .

no objection that master had no right to money, if received for him, 524 .

aliter, clerk of illegal society, 525.

receipt need not be stamped, to prove embezzlement, 525 .

indictment, 526,

particulars, 527.

after trial for, master may sue servant, 529.

or make servant bankrupt, 530 .

or his executors, 530 .

if servant go abroad, right to sue before trial depends on lex fori, 530 .

by persons employed in public service or by police, 532 .

by servants of the Bank of England or Ireland, 534 .

by servants of the Post Office, 535 .

of postage of letters, 537 .

who is a servant of Post Office, 537.

what is a "post letter," 538.

EMPLOYERS AND WORKMEN ACT, 1875 . . 698. rules thereunder, 704 .

EMPLOYERS LIABILITY ACT, 1880 . . 269, 763.

County Court Rules under, 766.

ENTICING,

servant from master, action, for, 156.

ENTRY,

by deceased clerk in master's book, how far evidence, 290 .

\section{EVIDENCE,}

parol, when admissible to explain contract, 54.

entry by deceased servant, 290 . 


\section{[The paging refers to the [*] pages.]}

EVIDENCE-continued.

of acting as servant when sufficient, $1, \mathrm{n} .(a)$.

EXCEPTIVE HIRING,

not yearly hiring, if express, 88.

aliter, if merely implied by custom, 89.

\section{EXCUSE,}

what is a lawful excuse for servant absenting himself from service, 459.

\section{EXECUTंORS,}

of master liable to pay servant's wages, 219 .

of servant not liable on contracts for personal services, 224.

\section{FACTORS,}

clerks assisting masters in obtaining for their use advances on property of principal, punishment of, 412 .

\section{FACTORY AND WORKSHOP ACT, 1878 . . 718.}

trades to which Act of 1878 applies, 758.

\section{FALSE CHARACTER,}

consequence of giving, 467 .

uttering forged testimonial, forgery at common law, 468 , n. (s).

servant offering himself with, 469 .

\section{FAISE PRETENCES,}

by guilty master by means of innocent servant, 308 .

obtaining goods from servant by, is taking from master, $395, \mathrm{n}$. (8).

\section{FALSIFICATION OF ACCOUNTS ACT, 1875 . . 531.}

FAN,

provision with respect to use of, in workshops where grinding, glazing or polishing on a wheel is carried on, or where dust generated, 730 .

\section{FARM BAILIFF,}

implied authority of, 301.

what warning entitled to, 95 .

entitled to legacy as a servant, 567.

FEES,

under 5 Geo. 4, c. 96 . . 552.

\section{FELLOW-WORKMEN,} who are, 252.

FELONIOUS ACT, of carricr's servant, 263, n. (i).

Felory. See Larceny, Stealing, \&c.

\section{FERRY,}

master liable for invasion of, by servant, 328 .

\section{FIDELITY,}

bonds given to partners, effect of change of firm, \&c. on, 19. 


\section{[The paging refers to the [*] pages.]}

FIRE,

liability of master for fire caused by negligence of servant, 324 . servant for negligently firing master's house, 474 . wilfully doing so, $474, \mathrm{n}$. $(n)$

FLAX SCUTCH MILLS,

within Factory and Workshop Act, 1878 . 759.

FOOD,

liability of master to supply, 229.

FOREMAN,

is fellow-servant, not deputy master, 257, 763.

\section{FORGED CHARACTER, 469.}

\section{FORGERY,}

by master, by means of innocent servant, 307 .

servant intrusted with money to pay bill, forging receipt, 518 , n. $(f)$.

blank cheque, filling it up with too large a sum, 287.

of certificates under Factory and Workshop Act, 1878 . 745.

\section{FOUNDRIES,}

within Factory and Workshop Act, 1878 . 759.

FRAMES, not belonging to workmen, not liable to be seized for rent, 615 . obliterating marks on, 615 .

FRAMEWORK KNITTERS, hiring frames and refusing to return, or injuring them, $28 \mathrm{Geo} .3$, c. 55 . destroying them, $i b$., and $24 \& 25$ Vict, c. 97, s. 14 .

FRAUD,

liability of master for servant's fraud, 328,343 . servant to master for fraud, 133.

for his own fraud, 421.

FRAUDS, STATUTE OF,

what contracts of hiring and service are within, 37 .

requisites of - consideration must anpear, 43.

signature, 48 .

FKAUDULENT,

conviction of servant quashed, 320 .

FURIOUS DRIVING,

drivers injuring persons by, 413.

FUSTIAN CUTTING WORKS, within Factory and Workshop Act, 1878 . 759.

GAME, unqualified servant sporting with master, 405.

licensed sporting in master's absence, 405.

\section{GARDENER,}

is a menial servant, 93 . 
[The paging refers to the [*] pages.]

GAS,

breach of contract by persons employed in supply of, 561.

GENERAL HIRING,

effect of, 84 .

GLASS WORKS, within Factory and Workshop Act, 1878 . 759.

GLAZING, on a wheel, provision with respect to use of fan to protect workmen from dust, 730.

GLOVE MAKING, in private house, or room, exempt from Factory and Workshop Act, 1878, 749,760 .

GOVERNESS,

what notice entitled to, 95 .

GRATUITY,

no action lies for, unless part of remuneration, 202.

GRINDING,

on a wheel, provisions with respect to use of fan to protect workmen from dust, 730

\section{GRINDSTONES,}

penalty on not fixing securely, 721.

GUARANTEE,

to firm, ceases on change of firm, 20 .

GUNPOWDER, use of, in coal mines, 680 .

metalliferous mines, 681. slate mines, 770 .

GUTTA PERCHA WORKS, within Factory and Workshop Act, 1878 . 759.

MABEAS CORPUS, for servant convicted under 4 Geo. 4, c. 34 . 543 .

\section{IARBOURING,}

a servant, 160 .

\section{HARDWARE,}

Truck Act applies to manufactures of, 607 .

HAWKERS' ACT,

traveller not within, 406.

HIRING. See Contract.

hours of work limited, hiring not yearly, 89.

HOLIDAYS,

in factories and workshops, 725 .

in sets on different days, 733 . 
INDEX.

\section{[The paging refers to the [*] pages.]}

HUNTSMAN, only entitled to month's notice, 93.

\section{HUSBANDRY,}

servant in, not within Truck Act, 607.

Councils of Conciliation Act, 1867 . . 559.

Agricultural Gangs Act, 1867 . .630.

ILLEGALITY, parol evidence admissible to show, $47, \mathrm{n} .(u)$.

\section{ILLNESS,}

temporary, no suspension of wages nnder permanent contract, 132, 153.

permanent, when answer to action by master, 132, 226 .

ground of discharge, 154, 226.

parish liable to find medicine, 231.

\section{IMMIORALITY,}

when gronnd of discharge, 143.

IMPLIED AUTHORITY,

of servant in cases of contract, 275 ,

IMPLIED CONTRACT,

Statute of Frauds does not apply to, 41.

when contract for hiring implied, 86 . yearly hiring, 84 .

to pay wages. See Wages.

\section{INDEMNITY,}

how far master bound to indemnify his servant, 233.

servant his master, 134.

INDIA RUBBER WORKS,

within Factory and Workshop Act, 1878 . . 759.

\section{INDICTMENT,}

will not lie for enticing away servants, 156 .

will for conspiracy, 156.

for embezzlement, 526 .

three counts, when advisable, 528 .

of master for stealing by hands of servant, 309 .

for receiving stolen goods, 308 .

for nuisance committed by servant, $\mathbf{3 1 7}$.

of servant for larceny, 495 .

INFANT. And see APPRENTICE.

liable upon eontracts beneficial to him, 11 .

what contracts of hiring are beneficial to him, 12 .

for necessaries, 12 .

livery for servant to officer in the army necessaries, 12.

may recover wages in county court and City of London Court, 14.

give bond under Customs Regulation Act, 14, n. $(y)$.

proceed under 5 Geo. 4. c. 96 , in name of parent, \&c., 550.

within Employers and Workmen Act, 1875 . .14, 701.

Employers Liability Act 1880 . . 766.

not within Councils of Conciliation Act, 1867 . . 15, 558.

statutes for protection of, $15, \mathrm{n}$. (b).

power of master to chastise, 138. 
[The paging refers to the [*] pages.]

INFANT-continued.

employment of, in coal mines, $15, \mathrm{n} .(b), 642$.

in metalliferous mines, 673 .

in factories and workshops, 15, n. (b), 721.

in husbandry, $15, \mathrm{n} .(\mathrm{b}), 630$.

in bakehouses, 775 .

in places of public amusement, 762 .

INFORMATION,

for penalties against master for act of servant, 312 .

INJUNCTION,

not granted to enforce contract of hiring, 132, 185.

to restrain breach of covenant in restraint of trade, 124. master from dismissing servant, refused, 185. printing, \&c., notices warning workmen not to work, 563.

INNKEEPER,

liable for refusal by servant to receive guest, 319 .

lien of, on masters property left with him by clerk, 271, n. (a).

INSOLVENTS,

contracts of hiring by, 35 .

INSPECTORS,

of factories, 739.

bakehouses, 775 .

coal mines, 654 .

metalliferous mines, 677 .

INVENTION,

of servant, when master may take out patent for, 164, 165.

IRON MILLS,

within Factory and Workshop Act, 1878 . . 759 .

JAPANNED GOODS,

Truck Act applies to manufacturers of, 607 .

JOB,

servant hired by, within Bankrupt Act, 210, 216.

not yearly servant, 87 .

with carriage, not servant of hirer so as to render him liable, 350 .

nor within $7 \& 8$ Geo. 4 , e. 29 , s. 46 . 351 , n. (z).

nor entitled to legacy as servant, 566 .

JUDGE,

cannot appoint deputy unless empowered by act of parliament, 4 .

JUS TERTII,

when servant may set up, in opposition to master, 135.

carrier may, 136 , n. $(h)$.

JUSTICES OF THE PEACE,

jurisdiction of, in disputes between masters and servants, 542 .

who are "workmen," 701.

employers and workmen, 609 .

menial servants not, 701 .

proceedings before, not to be deemed criminal procecdings, 699, 700 .

power to order payment of wages, 699 .

arbitration of disputes by, 544 .

master not to act on such arbitration as, 549. 


\section{[The paging refers to the [*] pages.]}

\section{TABOURERS,}

agreements for hire of, exempt from stamp, 49.

recovery of wages in case of bankruptcy of master, 210 .

who are within Stamp and Truck Acts, $49,51,607$, n. (a).

\section{LACE,}

warehouses, not textile factories within Factory and Workshop Ac7, 1878, 747.

non-textile factories within Factory and Workshop Act, 1878, 759.

pillow-lace making in private house, or room, exempt, 749, 760.

LACE TRADE,

Truck Act applies to, 607.

\section{LAPSE OF TIME,}

presumption of payment of wages from, 209

presumption of revocation of servant's authority from, 305 .

LARCENY BY SERVANTS. And see Embezzlement; SteaIing.

distinction between larceny and embezzlement, 479.

what is larceny, $479, \mathrm{n}$. (c).

at common law, 480 .

where servant has bare custody, 480 .

other cases,

taking goods out of master's possession, though constructive only, 485.

offering master his own goods for sale, 488.

giving away master's property, 486.

appropriating property found in master's house, 486.

where master parts with possession as well as custody, felonious intent at

time of receipt necessary to constitute larceny, 492 .

punishment of larceny by servants, 496 .

who is servant, 497.

prosecutor when bound to elect where single taking charged, 495.

three larcenies in six months, 495 .

servant indicted for, may be convicted of simple larceny, 407,495 .

emberzlement, 529.

summary conviction for, under Summary Jurisdiction Act, 1879 . . 497.

IEGACY,

by master to servant, 565 .

what servants entitled to, 565 .

how far satisfaction of wages, 220 .

LETTER PRESS PRINTING WORKS, within Factory and Workshop Act, 1878 • . 759.

LIABILITY. And see ACTION.

of master to indemnify servant, 233.

one servant for injuries caused by fellow-servant, 236 .

of master to third person for acts of servant, 271 .

upon contracts, 271.

although servant incapable of contracting for himself, 271.

express authority to servant in writing, 272.

writing should be inspected, 298 .

letters of instruction need not, 273, 298. verbal, 273.

implied authority, extent of, 275.

cannot be extended to collateral transactions, 287.

nor is it increased by emergency, 290. 
[The paging refers to the [*] pages.]

LIABILITY-continued. termination of, by notice, 304 .

death of master, 305 .

lapse of time, 305 .

master not bound if servant had no authority to pledge his credit, 299.

nor if credit given to servant, 303.

effect of private orders to servant on master's liability, 291.

distinction between general and special agent, 292 .

implied general authority cannot be limited by private orders, 293.

effect of notice of private orders, 296.

where servant special agent, his authority must be inquired into, 296.

so where parties have notice that he is special agent, 297 .

servant without precise authority has all usual powers, 282.

warranty by servant entrusted to sell, 282.

of master for torts of servant,

criminalter,

master not generally liable, 306 .

exceptions in cases of express orders, 306.

implied orders, 310 .

libel, 310.

actions for penalties, 311 .

informations for penalties, 312 .

indictments for nuisances, 317 .

master only liable for breach by servant of public duty binding on master, 321.

civiliter,

master generally liable for torts of servant in course of his employment, 322 .

although he do not immediately appoint the servant, 331 .

or servant's act not necessary to perform his orders, 334 .

and for all consequences, 339 .

and though damage immediatcly caused by stranger, 338 .

but not if servant go beyond scope of his employment, 339 .

nor if person injured might, by care, have avoided consequences of servant's negligence, 334 .

for which purpose servant of person injured is identified with him, 346 . driver of public conveyance with passenger, 347 .

aliter, if person injured incapable of exercising care, 349.

nor for acts of another person's servant, as in case of hired carriage, 350 . or where contractor employed, 352 .

thougl in such cases he may make himself liable, 357.

nor where bound by law to employ particular servant, 361 .

aliter, if he have power of selection, 365.

of employer of person doing an unlawful act, 344, 356.

of master for tresspass of servant, 367 .

if command express, master liable whether present or not, $\mathbf{3 6 7}$.

so if trespass necessary consequence of obeying express command, 368 . or if done in pursuance of general orders, 369 .

or for the benefit of, and adopted by master, 369 .

if trespass committed by servant without master's orders, master may

be liable if present, 370 .

master not liable in trespass if his will do not concur in servant's act, 371.

master liable in trespass for act of one not his servant, 375 .

public oflicers not liable for inferior oflicers, 376 .

liable for their own servants, 378.

master not liable to one servant for negligence of another, 381 .

of servant to indennify master from consequences of his negligence, 134. . 


\section{[The paging refers to the [*] pages.]}

\section{LIABILITY-continued.}

of servant to third person for acts done on behalf of his master, 383 .

servant not generally liable upon contracts, 383 .

but may be, 383 .

low to avoid liability, 385 .

clerk signing master s name not liable upon the instrument, 385,392 .

servant, where he is liable, paról evidence not admissible to discharge lim, 388.

not generally liable to third person for money paid to him on account of his master, 392 .

where he has paid it over, 395 .

when passing money in account is equivalent to pay. ment, 396.

but may be, if he obtain the money wrongfully, 397 .

or by trespass or otlier tort, 398 .

or if money paid by mistake, and not paid over, 399 .

when liable to third persons for money given to him by his master to be paid to them, 402 .

of servant in cases of tort,

criminaliter,

servant liable for acts mala in se, 404.

aliter, in some cases of mala prohibita, 404.

servant liable for breach of duty to master, which involves breach of public duty, 407 .

in cases of mere omission, 400.

civiliter, nuisance, 409.

servant liable for misfeasance, 415 .

fraud to master, 133.

fraud to third persons, 421 .

not for nonfeasance, 415 .

injuries to fellow-servant, 244, n. $(d), 268$.

nor where act did not amount to conversion, 419 .

subordinate public officers liable for misfeasance, 422 .

ministerial public officers liable for negligence, 423.

LibEL. See Character; Siander.

corporation liable for, punisherl by servant, 27 .

owner of newspaper, when liable to information for libel published by his servant, 310 .

LIMITATIONS,

Statute of, no bar to suit against confidential agent, 530 .

acknowledgment by clerk will not bar, 272, n. (d).

\section{LIQUIDATED DAMAGES, OR PENALTY, 123.}

\section{LIVERY,}

infant master, when liable to pay for, 12.

master not liable to pay for, when fraudulently returned to tailor by servant, 300 .

property in, is in master who provided it, $189, \mathrm{n} .(u)$.

\section{LODGING-HOUSE KEEPER,}

liability of, for negligence of servants, 360 .

\section{LUCIFER MATCH WORKS,}

within Factory and Workshop Act, 1878 . . 759. 
[The paging refers to the [*] pages.]

LUNATICS,

contracts of hiring and service by, 15 .

MACHINERY,

daily inspection of, in coal mines, 662 .

fencing of, in factories, 719 .

penal compensation toperson injured by want of, 744 .

in coal mines, 662 .

in metalliferous mines, 683 .

Magistrate. See Justice of the Peace.

MAINTENANCE,

in what cases master is entitled to maintain litigation by his servant, 155, n. (i).

MALICE, express malice mnst be proved in actions of slander, \&c., for character given to servants, 428 .

what is evidence of, 430 .

MALICIOUS PROSECUTION, action against corporation for, 26.

\section{MARINERS,}

agreement between masters, \&c., frce from stamp duty, 50 . firemen and stokers are within exemption, 51.

MARRIED WOMEN, cannot take apprentice, 4 .

contracts of hiring by, 4 .

liability of lusband on such contracts, 4 .

powel of hushand to take advantage of such contracts, 7 .

their power in equity, 8 .

payment of wages to, 7 .

earnings of, if married after 1st January, 1883 . . 9.

deserted by husband, 10.

complainant in cases under 5 Geo. 4, c. 96 . 550 .

MASTER,

who may be, generally, 1 .

infant, livery for servants of, 11.

lunatic, 15.

partners, 16.

corporations, 22.

bankrupt or insolvent, 35 .

rights of, against servant, 131.

third person, 155. And see Action.

semble, cannot chastise servant of full age, 138.

may dismiss him for wilful disobedience, 139 .

gross moral misconduct, 143.

habitual negligence in business, 144.

incompetence or permanent disability, 151.

liability of master to servant, or for his acts. See ACtion; LidBritr.

\section{MATERIALS,}

workmen embezzling, 579, 589.

not returning remains of, 585 . 


\section{[The paging refers to the [*] pages.]}

MATERIALS-continued.

receivers of embezzled, $581-590$.

search warrant for embezzled, 585, 593.

mode of proceeding by justices against persons suspected of having em.

bezzled, or received embezzled materials, 592 .

search warrant in such cases, 593.

owners of, may enter shops, \&c., of workmen, 596 .

\section{MEDICINE,}

master not bound to find, for servant, 230 .

but may render himself liable by conduct, 232 .

parish liable, 231, 233.

quære, whether master bound to supply medicine as necessary food, 232 .

agreement to supply not within Truck Act, 608 .

MENIAL SERVANT,

contract of hiring free from stamp, 49.

who are within rule as to, 93 .

entitled to month's notice or month's wages, 92 .

not within Employers' and Workmen Act, 1875 . . 701.

Truck Act, 607.

\section{MERCHANT SERVICE,}

apprentices in, $15, \mathrm{n}$. (b).

agreements between masters and mariners in, free from stamp, 50 .

\section{MESSMAN,}

to regiment, as to stamping agreement for hire of, 53.

discharge of, 142 .

METALLIFEROUS MINES REGULATION ACT, 1872 • 673.

METROPOLITAN BUILDING ACT, penalty on workmen violating, 414.

\section{MILITIAMEN,}

contracts of hiring and service by, 2.

MINES (COAL),

employment of women and children in, $15, \mathrm{n} .(b), 642$

frauds by persons employed in, 488 , n. $(n)$.

inspection of, 654 .

on behalf of workmen, 663 .

fencing abandoned, 654-676.

places not in use, 659 .

old shafts and entrances, 661, 682 . machinery, 662, 683 .

\section{MINES (METALLIFEROUS), 673,}

\section{MINING AGENT,}

extent of authority of, 301.

MISAPPROPRIATION,

by servants of master's property, act for summary punishment of, 625 .

\section{MISCONDUCT,}

discharge of servant for, 220 . 
[The paging refers to the [*] pages.]

MIXED CONTRACTS,

for hire of labour and something else, how far within exemption in Stamp Act, 52.

MONEY ORDER,

fraudulent issue of, by officers of Post Office, 540.

MURDER,

of master by servant, 471 .

third person by master by innocent servant, 307 .

\section{NEGLIGENCE. See ACtion; IiABILITY.}

\section{NOTICE,}

what notice domestic servant entitled to, 92 .

to other yearly servants, 93,95 .

of termination of servant's authority to contract, 304 .

NUISANCE,

liability of master to action for, for nuisance committed by servant, 322 . to indictment for, 317 .

servant, 409 ,

owners of real property, though committed by person not their servant, 366.

OATH,

administering, not to work under certain prices, unlawful, 564 .

\section{OFFENCES,}

by servants against master, 471 .

murder of master, 471 .

assault on master, 472 .

burglary in master's house, 472 .

firing master's house by negligence, 474 .

stealing in master's dwelling-house to the value of $5 l$., 476 .

shop, warchouse or counting-house, 475.

stealing or destroying goods in process of manufacture, 478.

larceny and embezzlement, 479.

falsification of aecounts with intent to defrand, 531 .

by public servants or police, 532 .

servants of Bank of England or Ireland, 534.

Post Office, 535.

OFFICER,

ministerial, may appoint deputy, judicial cannot, 3.

\section{OVERSEERS,}

accountant and treasurer to, is a scrvant within the statutes against embezzlement, 503 .

OVERTIME,

in factories, 734.

OWNER,

of mine not to act as justice in proceedings nnder Coal Mines Regulation Act, 1872 . . 667.

no corresponding provision in Metalliferous Mines Regulation Act, 1872 . 688. 
OWNER-continued.

may be a witness where charged with breach by another person of Mines Regulation Act, 1872 . . 667. of Metalliferons Mines Regulation Act, 1872 . . 686.

“PAPER MILLS" AND "PAPER STAINING WORKS," within Factory and Workshop Act, 1878 . . 759 .

PAROL EVIDENCE, admissibility of, to apply contract, 54.

to explain contract, 56,58 , not to add to, or contradict contract, $56,59$.

PARTICULARS, .

of plaintiff's demand in action for wages, 196, $\mathbf{n},(d)$. running down case, 323 , n. $(q)$. of charges of embezzlement, order for, when granted, 527.

PARTNER,

power of hiring and dismissing servants, 16.

or servant under contract, 59 .

liability of, for injuries to servant throngh negligence of co-partner, 17 effect of dissolution of firm on contracts of hiring, 18 .

change of firm on fidelity bond or guarantee, 19, 20.

considered principal in arbitration cases under 5 Geo. 4, c. 96.549 .

PATENT,

when master may take out, for invention of servant, 164, 165.

PAYMENT,

presumption of, by servant to master, 137.

of servant's wages, presumption of, 209 .

earnings to master, good, 163.

to servant, payment to master, when, 280,392 .

PENALTY,

liability of master to action for, for acts of servant, 311.

or liquidated damages, 123.

information for, 312

injunction refused, after payment of, 127.

PERCUSSION CAP WORKS,

within Factory and Workshop Act, 1878 . . 758.

\section{PERSONATING}

master, and giving false character, 468.

\section{PHOTOGRAPHS}

firm not "authors" of, within Copyright of Works of Art Act, 167.

PHYSIC, 230. And see Medicine.

PICKETING, 693, n. $(f)$.

PIECEWORK, stipulation for will not render express yearly hiring less so, 87.

PILOT,

liability of owner obliged to employ, 361 . 
[The paging refers to the ["] pages.]

PIT BANKS,

within Factory and Workshop Act, 1878 . . 760.

\section{POLICE}

superintendent of, servant to chief constable, 507 .

embezzlement by, 532 .

POOR RATE,

servant occupying master's house not liable to, 81 .

POST OFFICE,

embezzlement by servants of, 535 .

what is a "post letter," 538 .

officers of, issuing post-office order frandulently, 540 .

PRESUMPTIVE AGENCY, of servant, extended to stranger in counting-house, 279 .

PRINT WORKS, within Factory and Workshop Act, $18 \% 8$. 758 .

PRIVATE ORDERS,

to servant, effect of, 293.

PRIVILEGED COMMUNICATION, 426. See Character.

\section{PROCURATION,}

making or accepting bills, \&c., by, without authority, felony, 412.

eivil liability of clerk signing by, 388 .

PRODCCTION,

of master's books, order for, refused, 223, n (c).

PROTECTION,

of deserted wife's earnings, order for, 10.

PUBLIC BODY, when acting for profit, liable for acts of serrant, 381 .

PUBLIC-HOUSE.

wages not to be paid in, $205,645,674,771$.

PUBI.IC OFFICERS AND SERVANTS, not responsible for acts of subordinate, $3 \% 6$. responsible for their own servants, 378 . suhordinates responsible for their own acts, 422 . ministerial liable for negligence, 423 . offences by, 532 .

may appoint deputy, 3.

QUARRIES,

within Factory and Workshop Act, 1878 . 760.

QUICQUID acquiritur servo acquiritur domino, 162. 


\section{[The paging refors to the [*] pages.]}

RAILWAY COMPANY. See CoRPoration.

power of secretary, of intended, to bind members of provisional committee, 302. station masters and other servants, 290.

indictment of, for servants obstructing highway, 318.

held not liable in trespass for driver running over sheep on line, 373.

for arrest of passenger by officer not authorized to do it, 327, 375 . servants and persons employed on, punishment of, 409.

\section{RATIFICATION,}

by master of contract made by servant, 273 .

must be of entire contract, 275 .

\section{RECEIPT,}

by master of servant's wages, 161 .

by servant, receipt by master, when, 392 .

servant forging, 518 , n. $(f)$.

stamped, not necessary to prove embezzlement, 525 .

RECEIVER,

of property embezzled, indictment of, 525 .

\section{RECORDS}

clerks of courts uttering false copies of certificates of, 541 .

REGISTER,

of parish servants under $16 \ldots 623$.

RELATIONSHIP, created by contract, 59 .

\section{REMEDIES,}

for servant wrongfully discharged, 188, 196.

\section{REMOVAL,}

mere power of, apart from power of selection, will not render person who has it responsible for acts of persons who are not his servants, 323, n. $(p)$.

\section{RESIDENCE,}

of child with parent, when service may be inferred from, 177.

RESPONDEAT SUPERIOR, 137, 322, n. (m).

\section{ROBBERY,}

of master by servant will justify his discharge, 143.

servant, servant not responsible to master for, 133.

and see Larceny; Stealing.

\section{ROPEWORKS,}

within Factory and Workshop Act, 1878 . . 759.

\section{SCHOOLMASTER,}

injunction granted to restrain discharge of, 185, n. (i).

\section{SCIENTER,}

in actions for enticing away and harbouring servants, 158.

how far knowledge of servant is knowledge of master, $324, \mathrm{n} .(u)$.

\section{SECRET,}

of trade, contract not to use, valid, 122. 
[The paging refers to the ["] pages.]

SEDUCTION,

of artificers from their employ to go abroad-statutes repealed, 156, n. (q).

of daughter or servant, 174 .

who may bring action for, 175 .

form of aetion, 176.

eamnot be brought in County Court, 178-179.

what loss of serviee sufficient to support, 176.

of daughter residing with parent, $17 \%$.

out in serviee, parent eannot sue for, 178.

danghter or servant a good witness, 179.

evidence of general good character, 180 .

promise of marriage, 180.

defence-pleas, 180.

evidenee, 180.

damages, 181 .

\section{SERVANT,}

duties of, 131.

rights of, 182.

liability of, 383 . See Liability.

offences by, against master, 471. And see OFFexces.

or agent, 508 .

or apprentice, 78 .

or partner, 59.

or tenant, 80.

\section{SET-OFF,}

by servant of wages dne to him on discharge, against claim for money had and reeeived to use of his master, 187.

by master against claim for wages, what may be, 208 .

SETTLEMENT,

by hiring and service, servant must be sui juris to gain, 2 .

abolished, $2, \mathrm{n}(b)$.

\section{SHERIFF,}

liability of, for negligence in executing writs, 423 .

aets of his bailiff, $306, \mathrm{n}$. $(a)$.

SHIPBUIY.DING YARDS,

within Factory and Workshop Act, 1878 . . 759.

\section{SIIIPOWNER,}

not liable to seaman, if ship not seaworthy, 245 .

SIGNATURE, when necessary, 37 .

what suficient to satisfy Statute of Frauds, 48.

SLANDER. See Character.

general rules in, 461 .

imputations on servants affeeting them in their sitnations, 462 .

unless eonnected with occupation or imputing general disability will not support action, 463.

special damage, 463 .

SLATE MINES,

Act relating to use of gunpowder in, $\mathbf{7 7 0}$.

\section{SOLDIER,}

contract of hiring and service by, 2 .

wages of servint enlisting as, 223 .

47 MAS. \& SER. 
[The prging refers to the [*] pages.]

SPECIAL CONSTABLES,

to keep order among workmen, expense of thrown on company carrying on works, 321.

STAMP,

when necessary, 49.

not in criminal proceedings, 53,525 .

exemptions in favour of labourers, \&c. and menial servants, 49.

seamen, 50.

poor children apprenticed by parish, 50 .

mixed contracts for labour and something more, 52 .

proceedings under 5 Geo. 4, c. 96, exempt from, 552.

STATUTE,

who entitled to protection given by, $379, \mathrm{n} .(x)$.

STATUTE FAIRS,

urigin of, xlvii.

STEALING. And see LARCENy.

master stealing by hands of servant, 309 .

in a dwelling-house to the value of $5 l$. or more, 476 .

in a shop, warehouse or counting-house, 475.

soliciting servant to steal his master's goods, misdemeanor, $480, \mathrm{n} .(h)$.

STEAM WHISTLES,

use of, in manufactories, 641 .

STEVEDORE,

master of general ship, not liable for careless stowage by, 352, n. (b).i

\section{STOKERS,}

on board a ship are labourers, not mariners, 51.

\section{STOLEN GOODS,}

receiving by master by hands of servant, 308 .

STRAW PLAITING,

in private house, or room, exempt from Factory and Workshop Act, 1878, 749,760 .

STREET KEEPER, appointed by commissioners, how to recover salary, 379 , n. $(u)$.

STRIKES, 560.

SUNDAY, contract of hiring made on, valid, 47.

\section{SURGEON,}

certifying under Factory Acts, 741.

SURVEYOR,

of highways not liable, 305 . 
[The paging refers to the [*] pages.]

TAX,

on male sezvants, 632 .

TENANT, servant is not, 80.

TICKETS OF WORK, by manufacturers generally, 550 .

in the manufacture of hosiery, 618. silk weavers, 621 .

TOBACCO FACTORIES, within Factory and Workshop Aet, 1878 . 759.

TOOLS, embezzlement of, 596.

TORTS. See Action; Liability.

TRADE, contracts in restraint of, 103. And see CoNTrACT. how distance measured, 114. not to use particular secret valid, 122 . not to solicit certain eustomers valid, 121 . mode of securing performance of, 123 .

what is " carrying on," 122. statutes for protection of masters, p. xli.

TRADES UNION ACTS, 1871 and $1876 \ldots 634,715$. rules of, void if in restraint of trade, 108 .

but that will not prevent prosecution of servent for embezzlement, 502 , n. $(q)$.

TRADING COMPANY, when bound to have authorized officer on the spot, 34 .

TRAVELLER, distinetion between traveller and commission agent, 509 .

TRUCK ACT, 603. And see WAGEs.

does not apply to domestic servants, $205,607$.

TRUST,

direetion in will to employ particular servant does not ereate a trust in his favor, 575 .

TURNPIKE TRUSTEES,

how far liable for acts of servants, 378 .

TUTOR,

what notiee to quit, entitled to, 95 .

USER,

by master of goods obtained by servant on master's eredit, effect of, 303 .

(801) 
INDEX.

[The paging refers to the [*] pages.]

VENTILATION,

of coal mines, 659 .

metalliferons mines, 681 .

factories and workshops, 719 .

where dust generated and inhaled, 730 .

provisions of Public Health Act, 1866, not to apply to factories and work. shops subject to Factory and workshop Act, 1878 . 753 .

\section{VOLUNTEER,}

assisting servant, cannot recover against master for negligence of servant, 217.

\section{VOLUNTEER CORPS,}

contract of hiring and service by members of, 2 .

VOTE,

when servant entitled to, 84 . And see ADDExDA.

\section{WAGES,}

when master bound to pay, though no work found for servant, 99 .

when servant entitled to, 197 .

$$
\text { discharged wrongfully, } 196 .
$$

for misconduct, 220 .

increased, not due withont agreement to pay them, 198.

on dissolution of special contract of hiring, 199.

where amount left to employer's generosity, '200.

certificate of third person, 204 .

gratuity at end of year, 20 ?.

in case of bankruptey of master, 210 . See BANKRUPTCY.

winding up of company, 211,217 .

company in liquidation, 224 ,

death of master, 217.

servant, 226 .

default of servant, 220.

when to sue in County Court, 207.

or proceed before justices, 208,699 .

payment of, in goods-Truck Act, 205.

not in a public-house or beershop, 205, 645, 674, 771.

set-off by master against, 208.

presumption of payment of, from course of business or lapse of time, 209.

legacy to servapt, how far satisfaction of, 220 .

right of master to sue for servant's wages, 161.

payment to master, answer to action by servant, 163 .

left in master's hands, interest, 220 .

attachment of, 633 .

in case of servant enlisting, 223 .

due to workmen or apprentices, powers of justices in respect of,' 699 .

rate of, cannot be made by justices without consent, 545 .

WARNING,

what warning domestic and other serrants entitled to, 92.

WARRANTY. And see LiabIIITY.

liability of master upon warranty of servant, 282,294 .

if part of transaction of sale, 286 .

serrant upon implied warranty that he had power to contract in his master's name, 392. 
[The paging refers to the $\left[{ }^{*}\right]$ pages.]

WATER,

breach of eontract by persons employed in supply of, 561 .

WEEKLY HIRING,

what is, 89 .

servant under, entitled to legacy left to servants, 570 .

but not to legacy of year's wages, 569 .

WESTMINSTER BRIDGE,

punishment of servants wilfully injuring, 413 .

WHITE LEAD FACTORIES,

Act relating to, 7\%2.

WIII. And see LEGACY.

direction in, to employ particular servant or agent, 575 .

WITNESS,

servant formerly not admissible for master in action against him for servant's negligence, 135.

\section{WORK,}

how far master bound to find, 98 .

WORKMEN,

wages of, on bankruptcy of master, 210 .

recovery of, not exceeding $10 l$, before justices, 699 .

WRITTEN CONTRACT,

of hiring when necessary, $3 \%$.

WRONGFUL, DISCHARGE,

remedies of servant for, 188, 196.

YEARLY HIRING,

wliat is, 84 .

when contract for indefinite time is, 86 .

presumption of, when exeluded, 87 .

effect of, when it may be terminated, 91.

THE FND. 
\# 





\section{PLEASE DO NOT REMOVE CARDS OR SLIPS FROM THIS POCKET}

\section{UNIVERSITY OF TORONTO LIBRARY}

Law

Smith, Charles Manley

Eng

A treatise on the law of S644t.2 master and servant 
